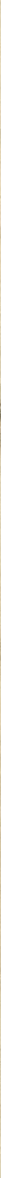




\section{$a 02$}

\section{تون حقون حفيون}

* $1001,80 \quad-125$

$$
\text { Gs. }
$$
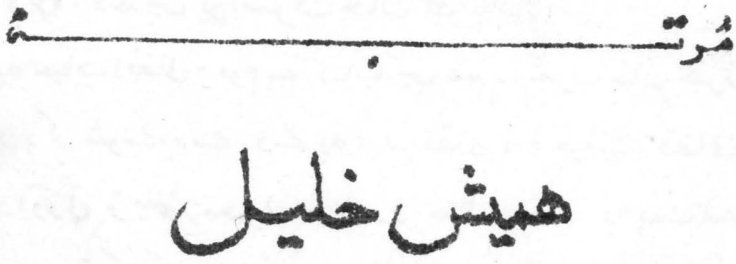

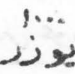

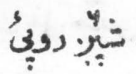

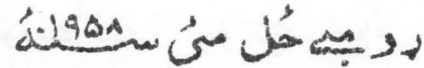

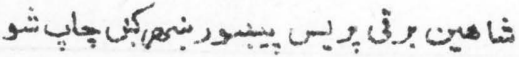


903

مُقِانَ

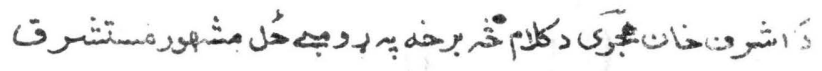

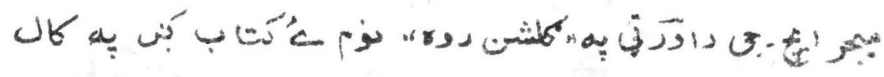

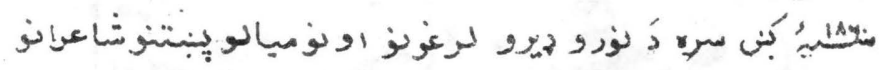

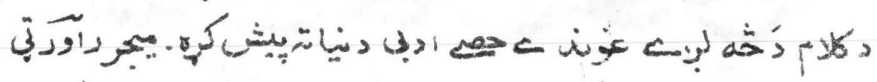

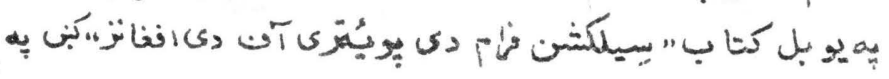

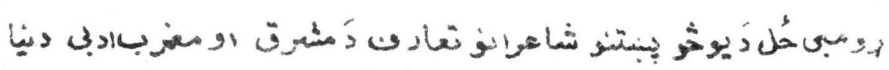

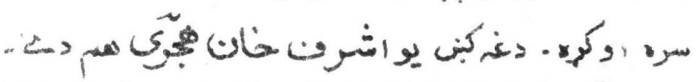

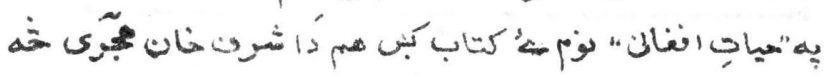

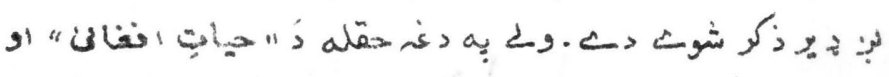

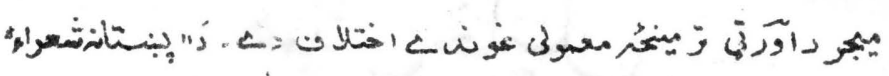

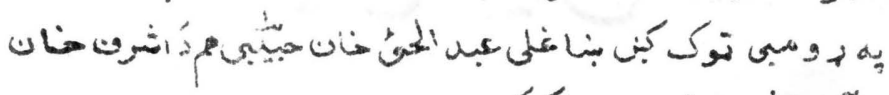

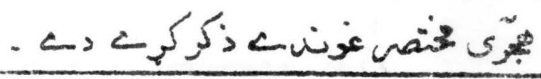

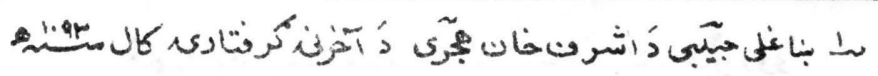

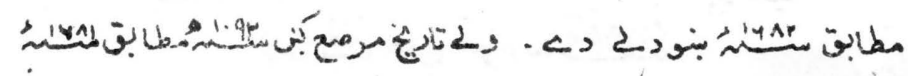

(2) 


\section{$9.4 \div$}

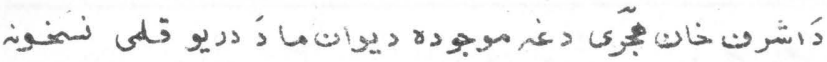

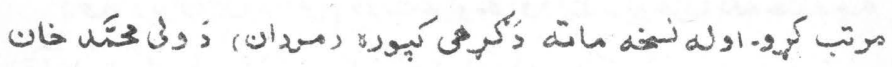

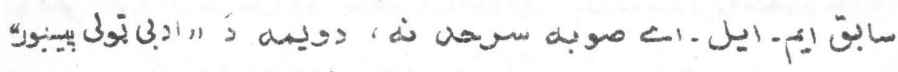

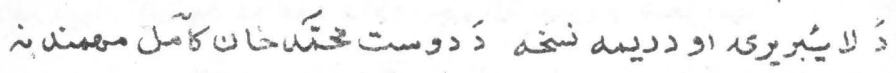

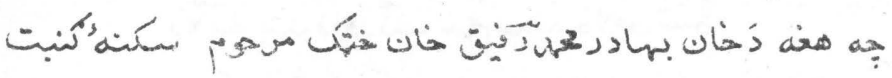

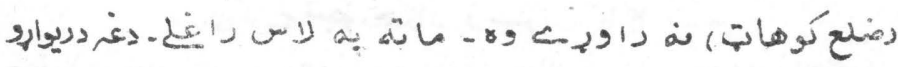
ain j

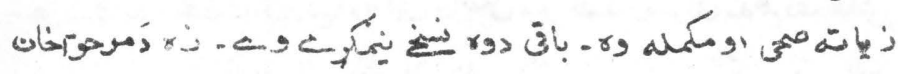

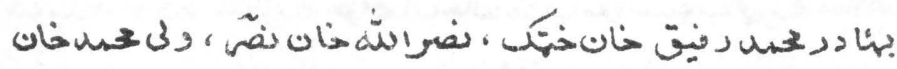

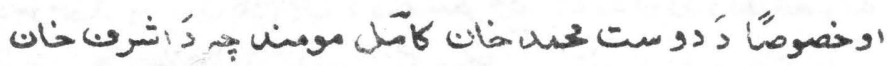

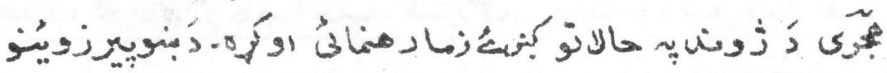
-

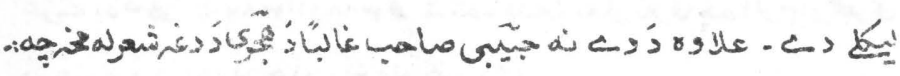

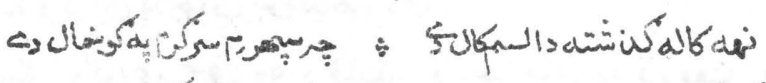

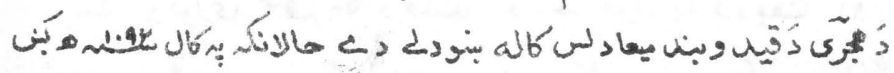

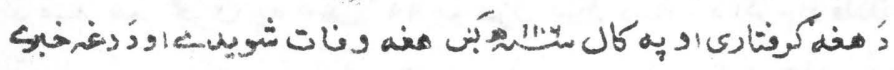

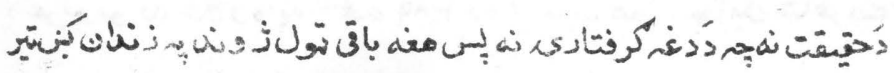

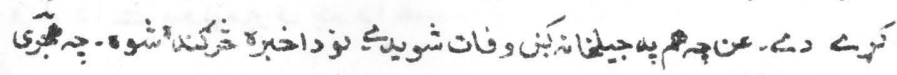

- 92 viris

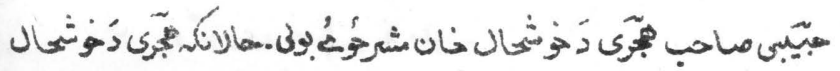

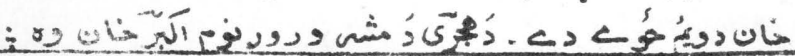


(4) $a 0^{*}$

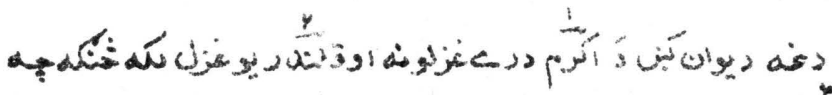

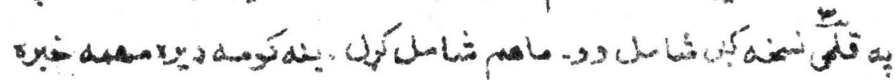

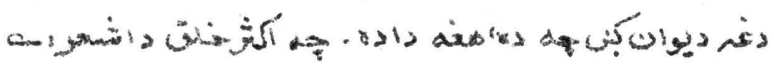

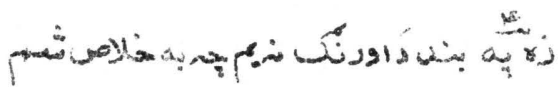

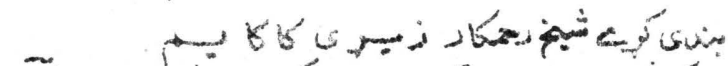

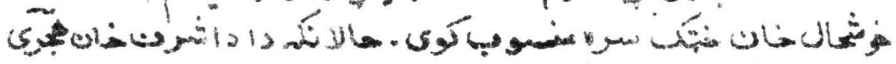

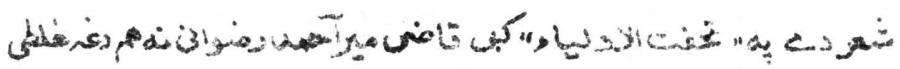
ثويس

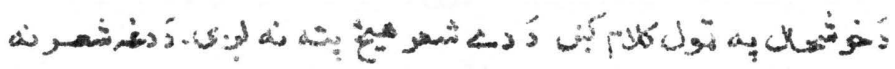

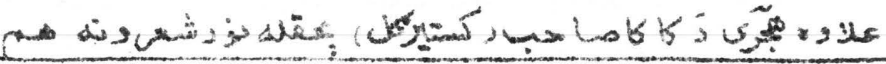

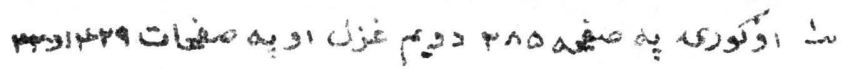

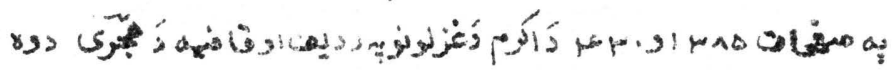
غن

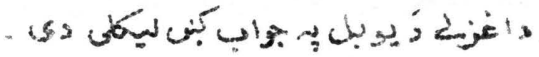

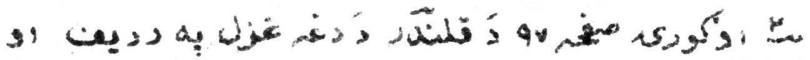

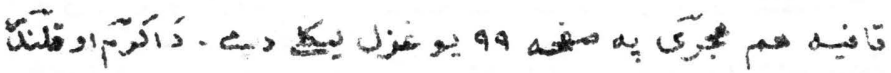

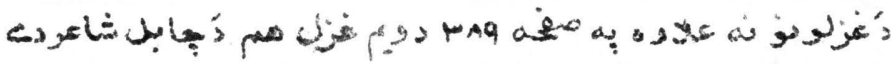

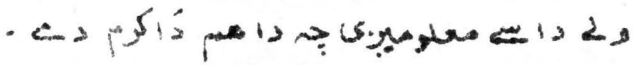

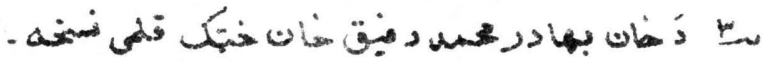

- H. A a (4) 


\section{is 906}

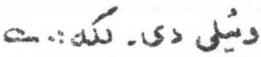

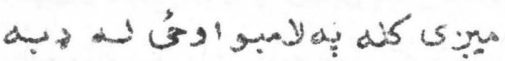

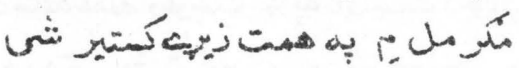

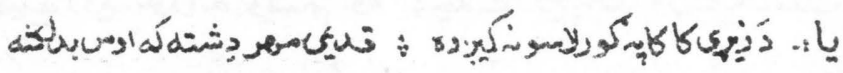

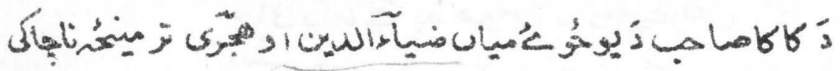

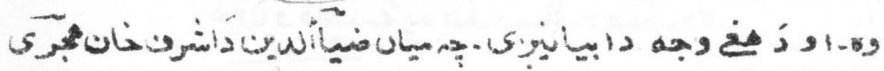

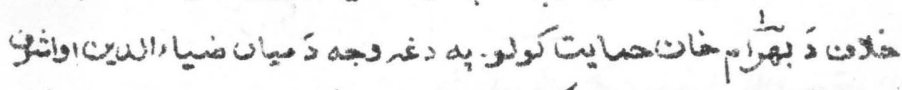

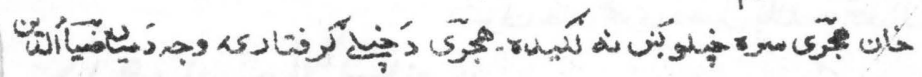

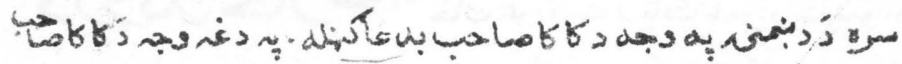

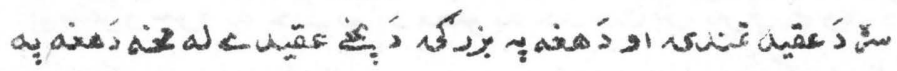

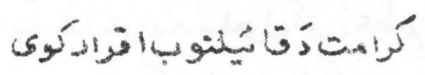

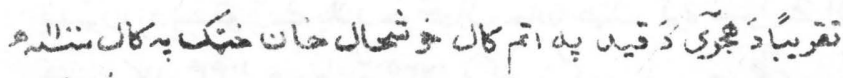

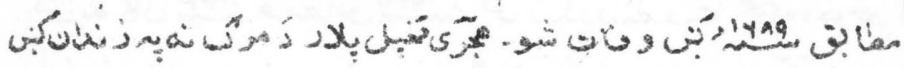

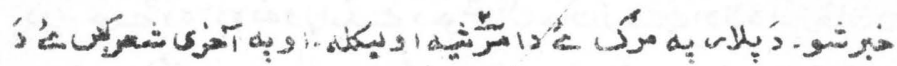

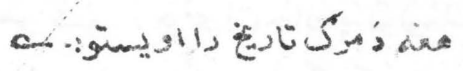

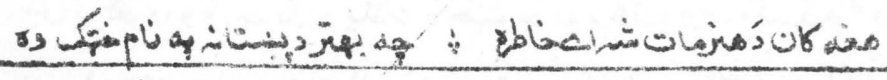

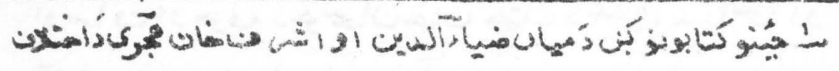

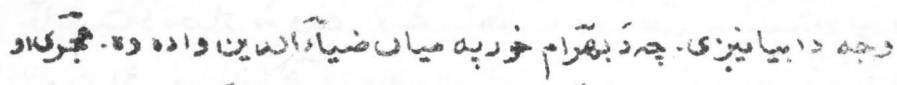

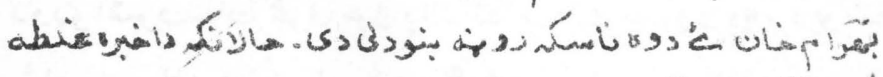

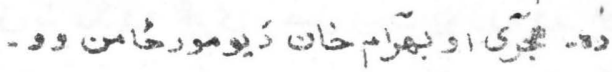
- a 
?. 907

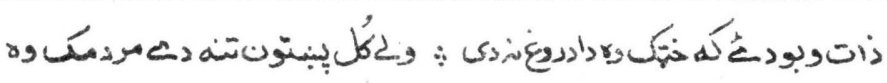

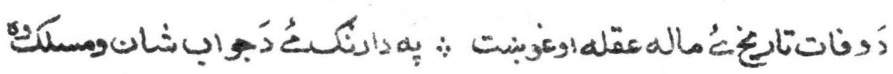

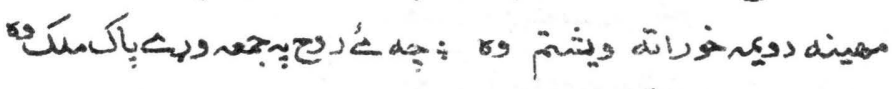
خاكة

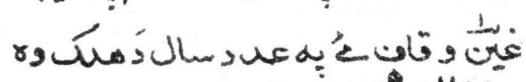

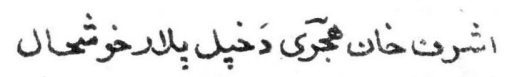

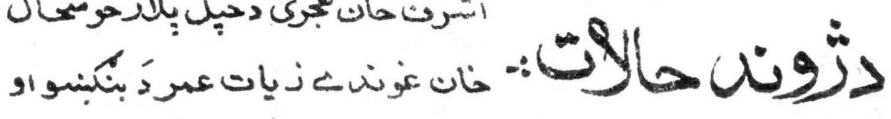

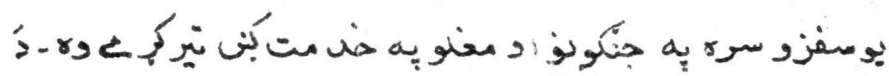

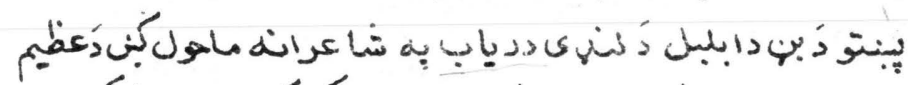

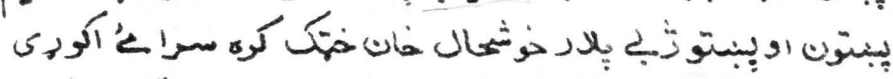

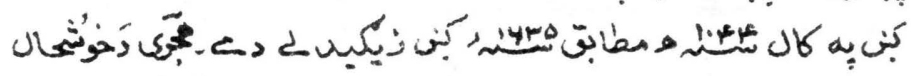

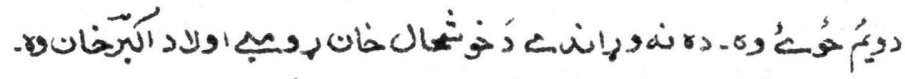

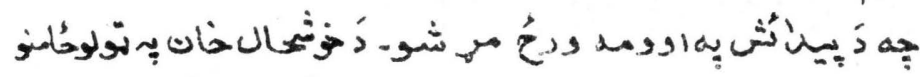

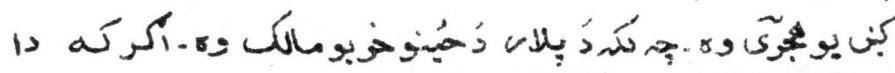

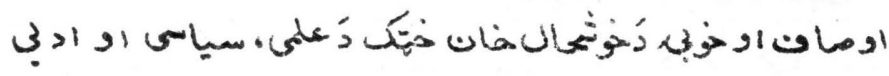

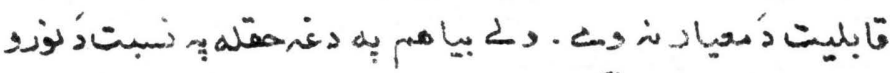

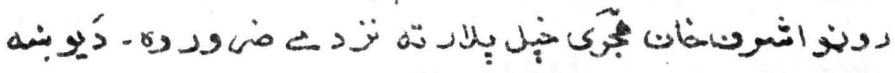

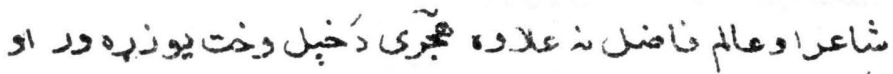

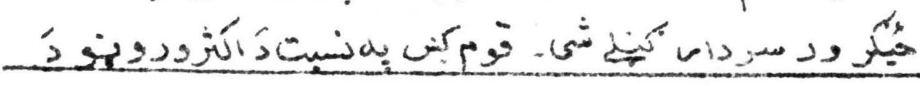

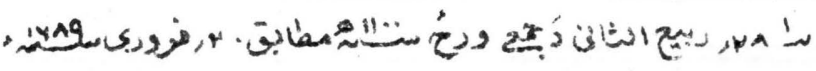




\section{$008 \mathrm{~T}$}

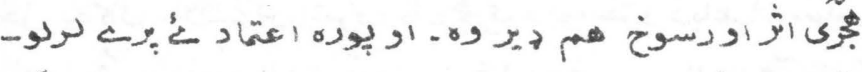

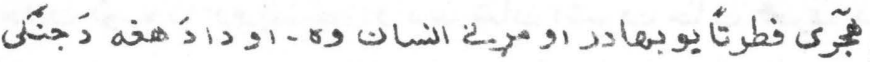

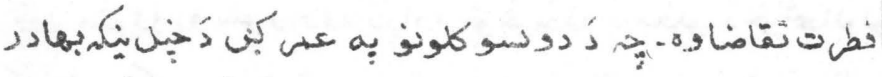

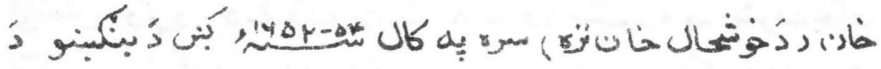

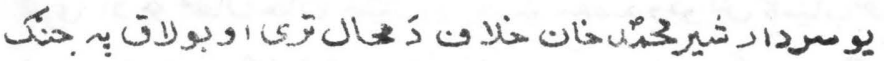

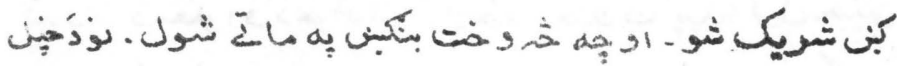

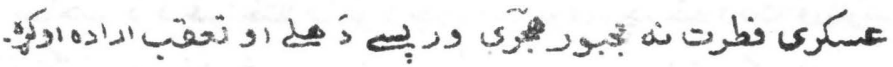

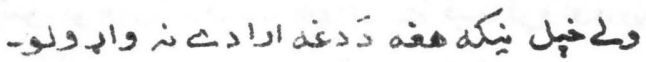

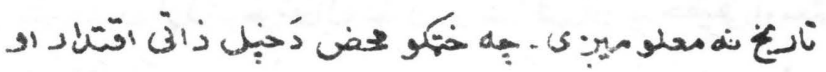

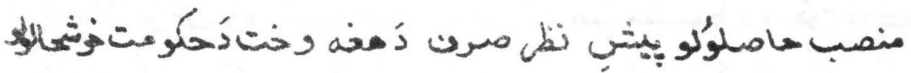

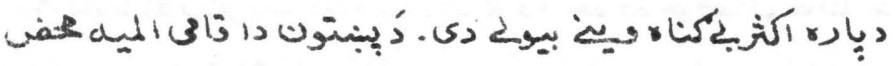

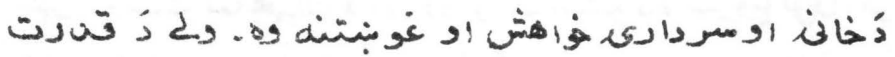

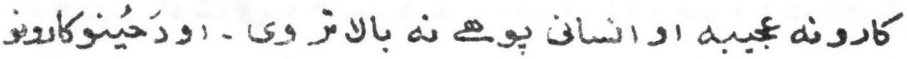

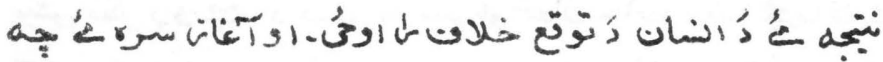

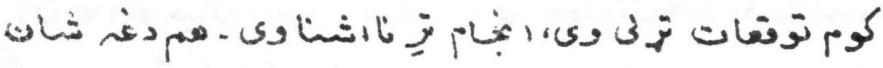

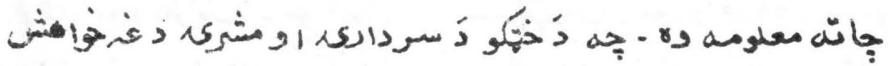

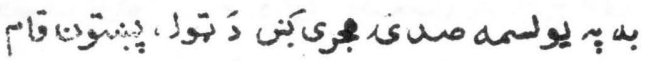

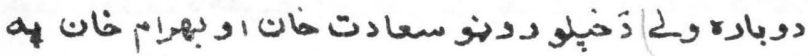

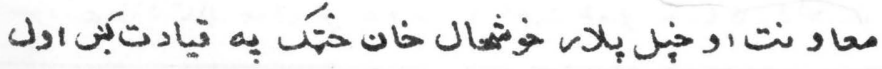




\section{¿1009}

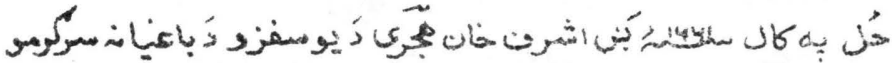

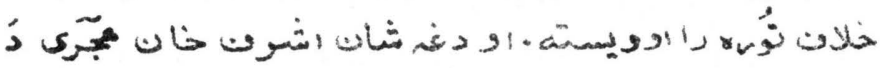

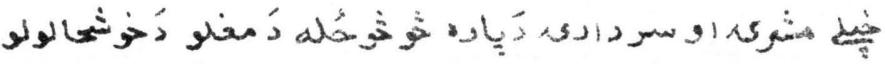

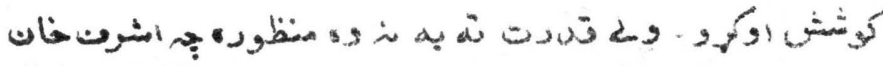

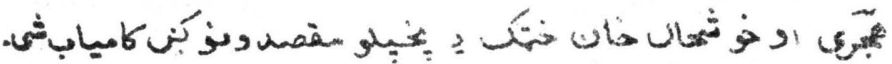

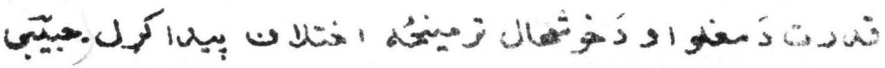

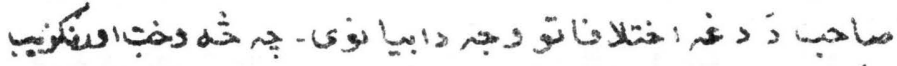

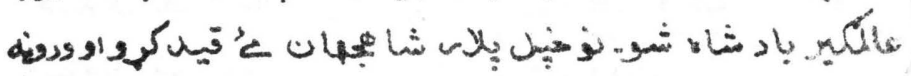

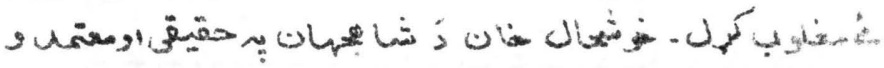

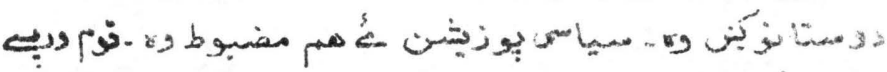

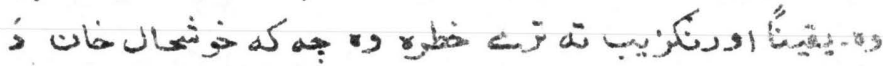

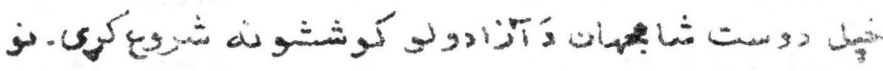

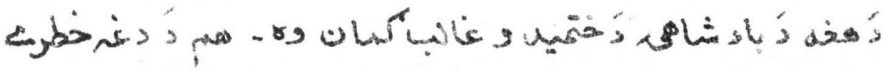

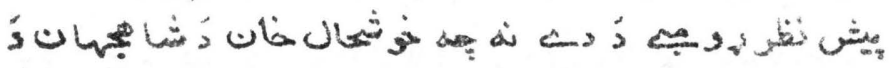

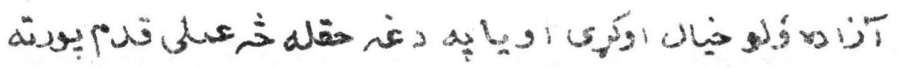

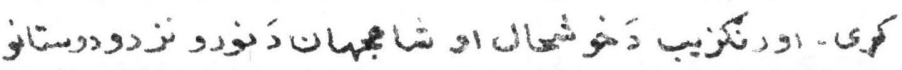

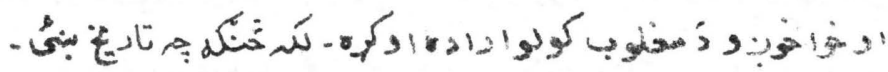

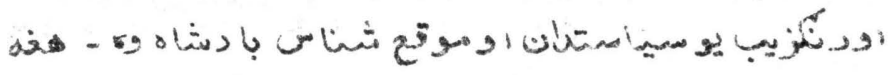

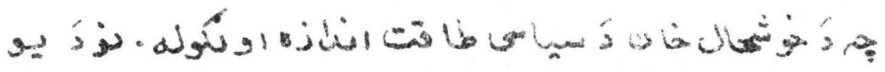

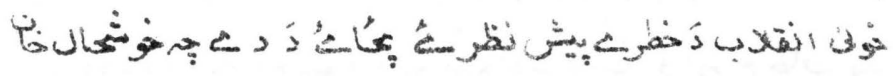

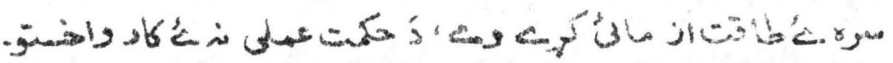




\section{$=a 10$}

مئس

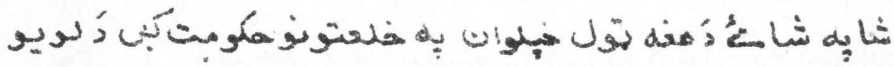

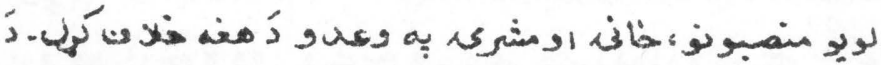

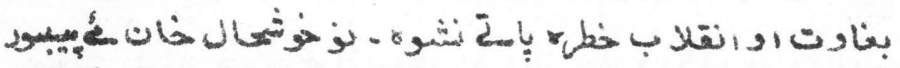

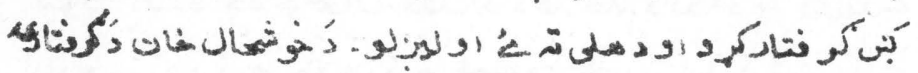

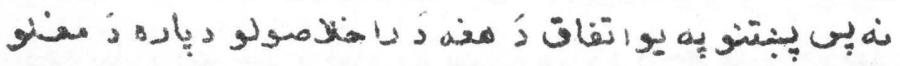

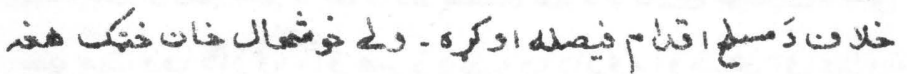

$$
\text { - drir }
$$

و

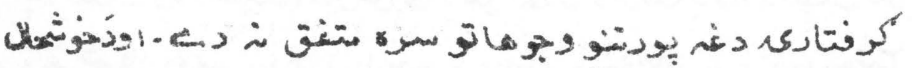

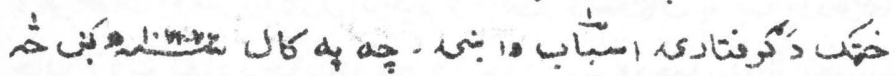
ule jig igla

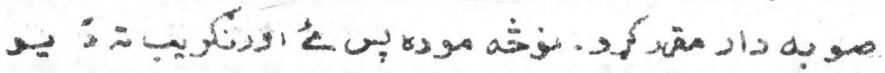

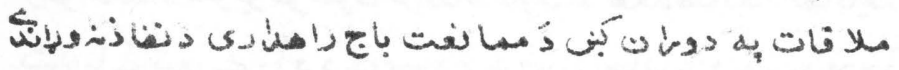
'

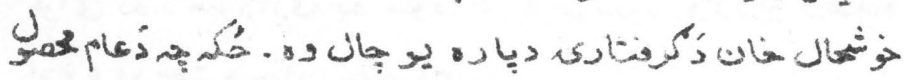

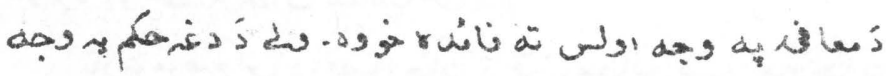

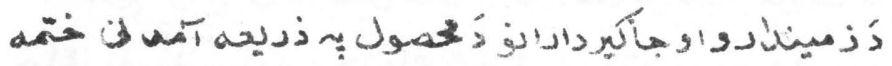
تسوبه

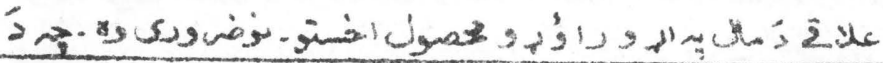

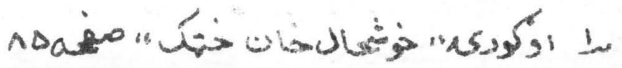




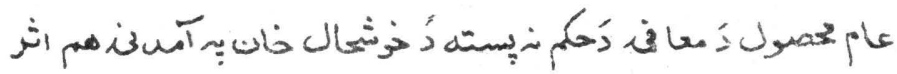

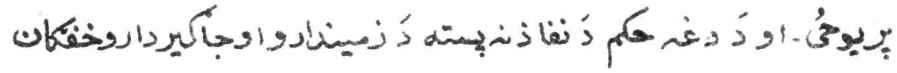

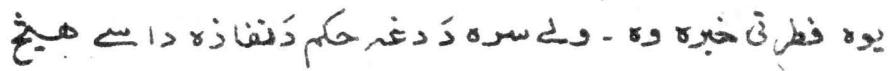

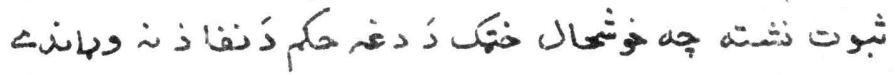

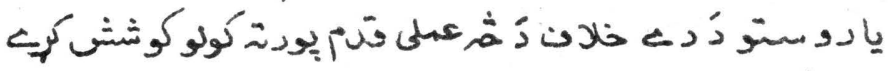

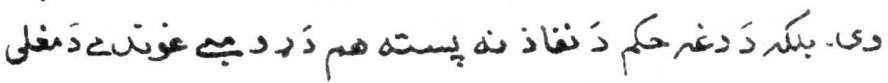

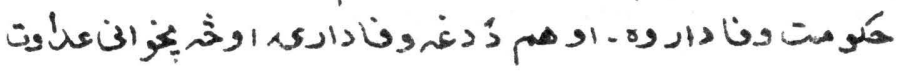

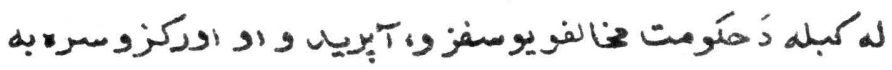

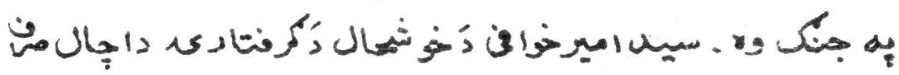

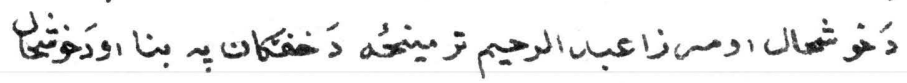

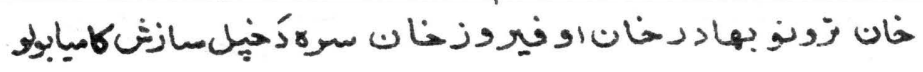

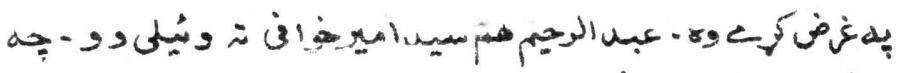

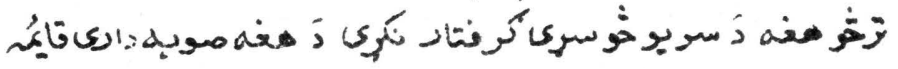

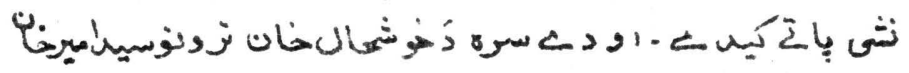

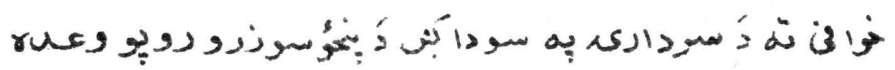

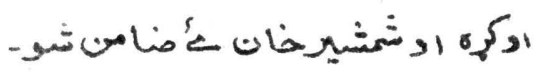

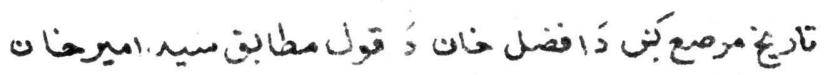

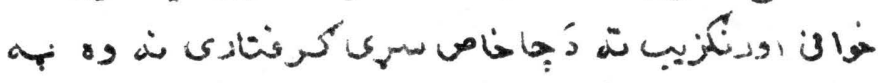

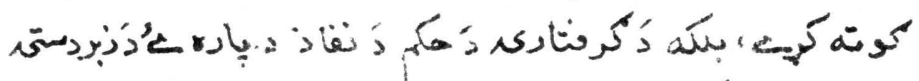

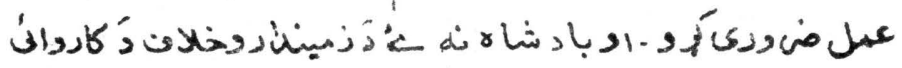

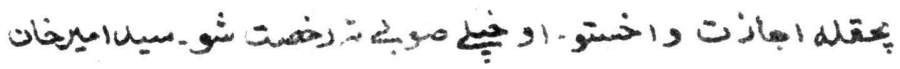




\section{$\div a 12$}

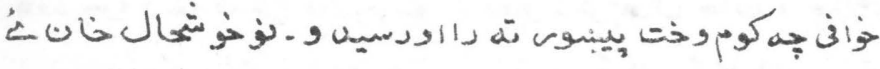

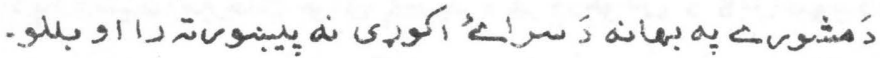

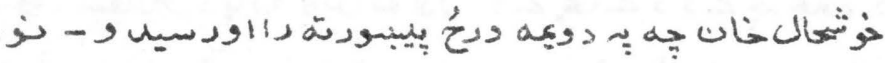

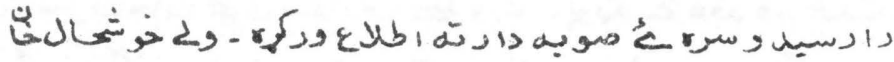

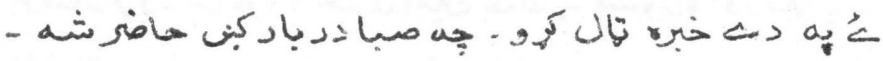

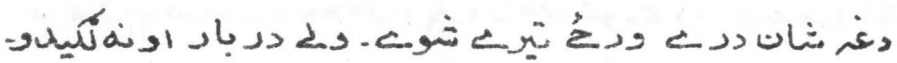

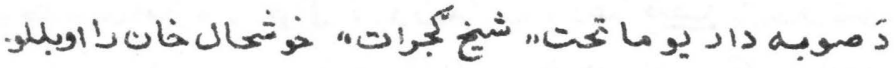

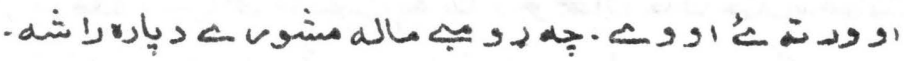

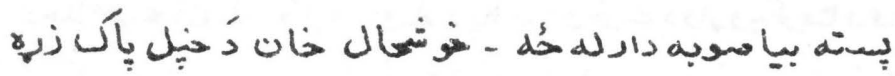

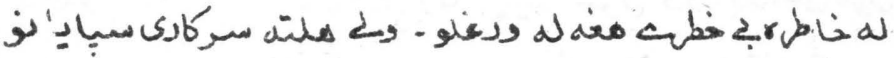

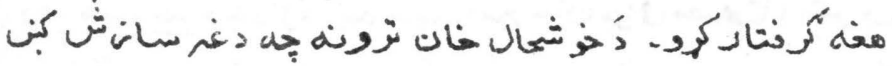

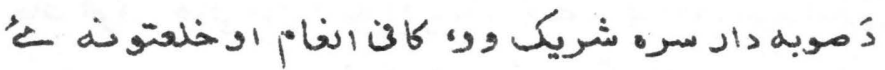

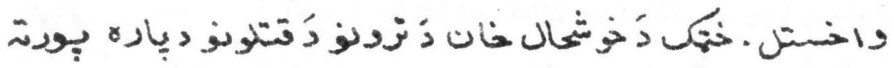

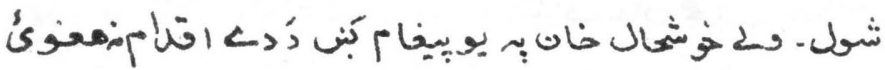

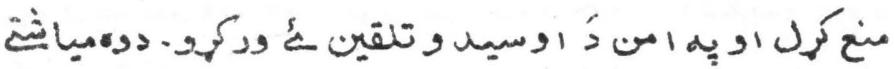

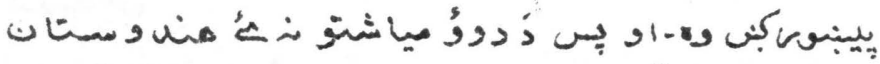
-

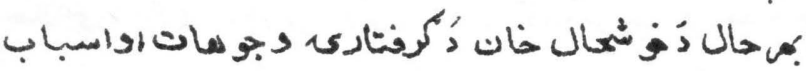

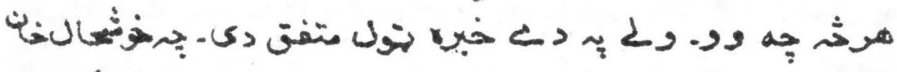

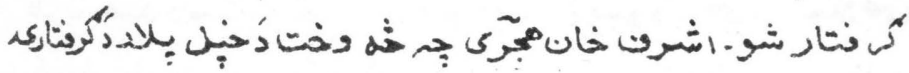

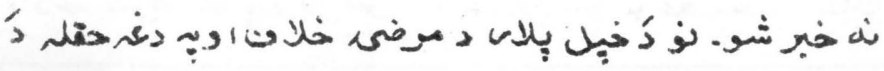




\section{413}

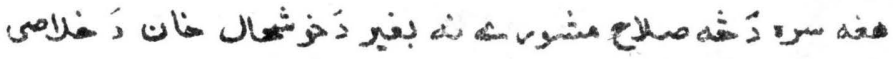

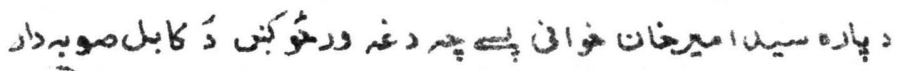

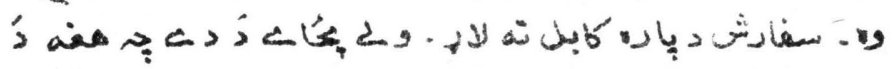

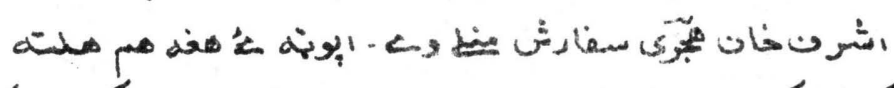

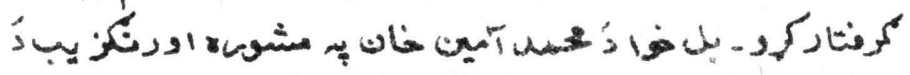

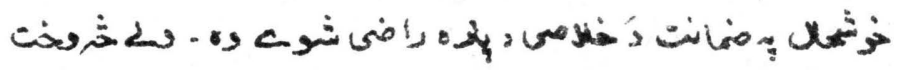

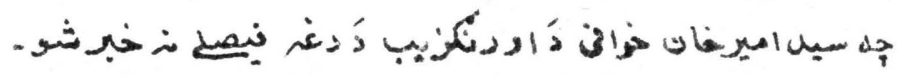

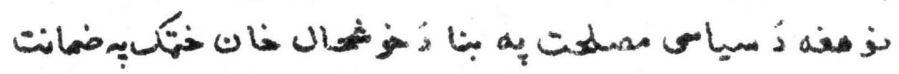

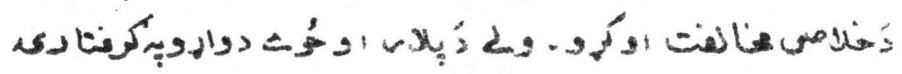

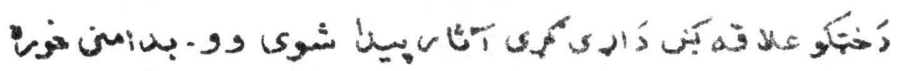

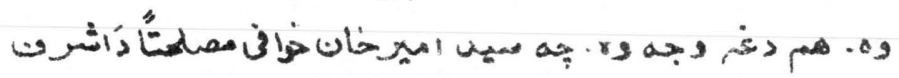

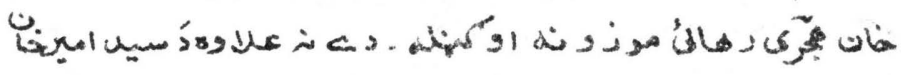

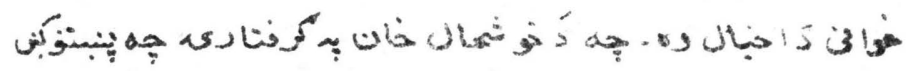

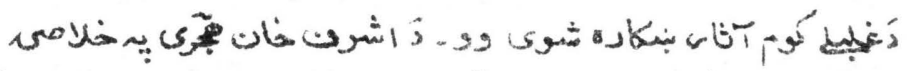

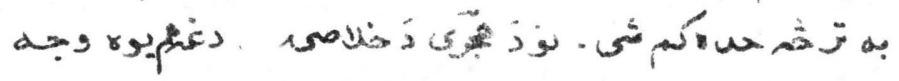

$$
-4=0
$$

is

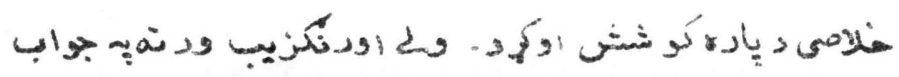

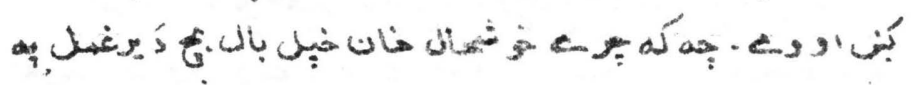
طولى هi

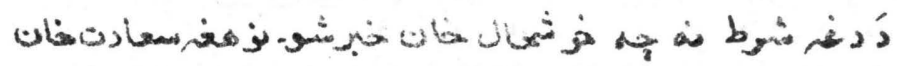




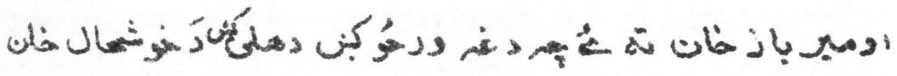

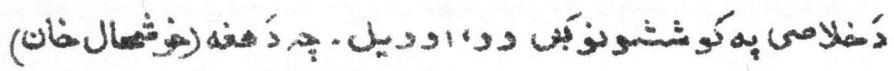

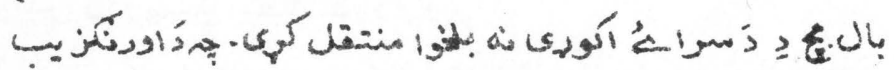

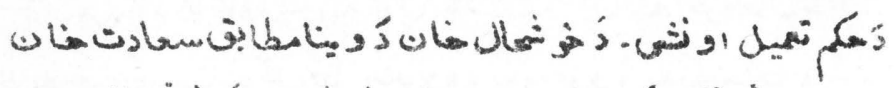

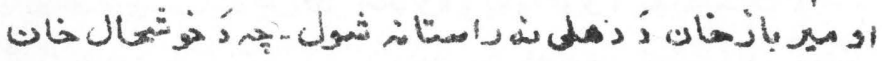

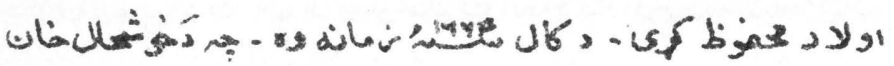

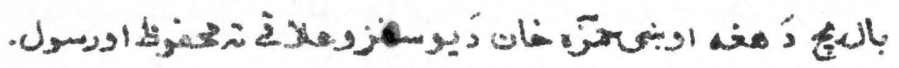

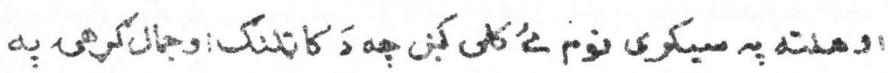

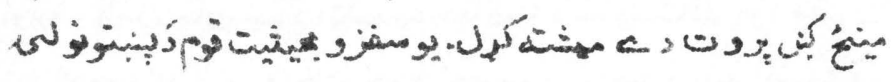

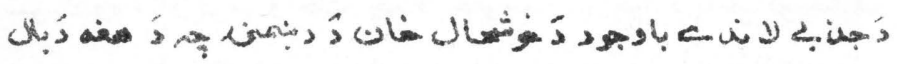

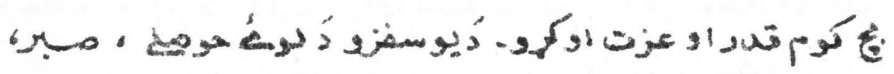

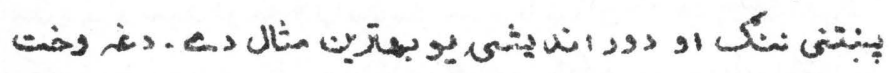

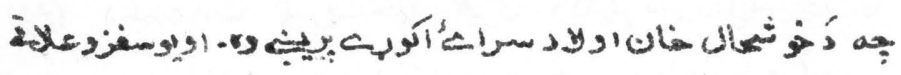

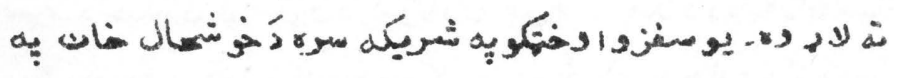

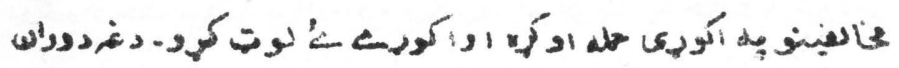

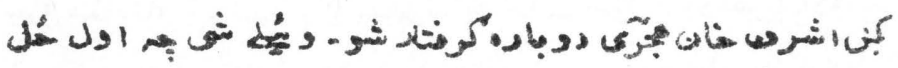

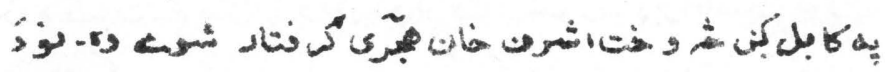

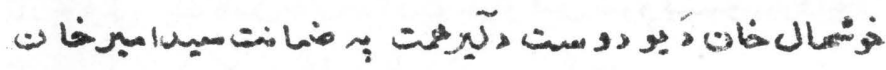

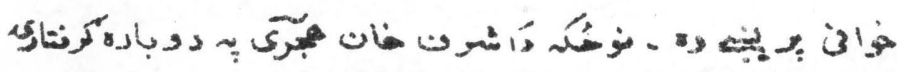

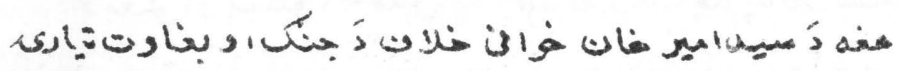

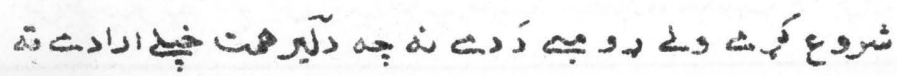




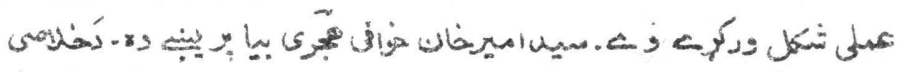

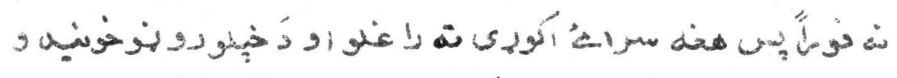

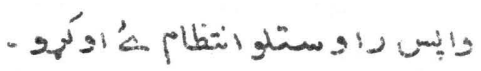

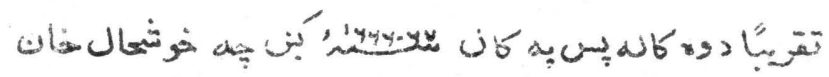

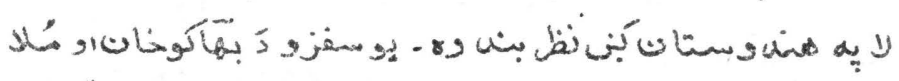

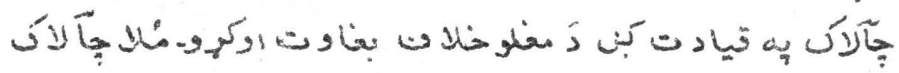

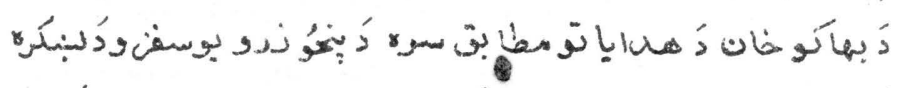

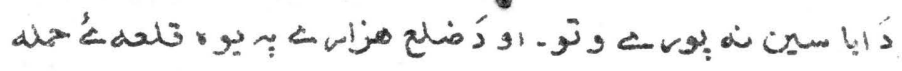

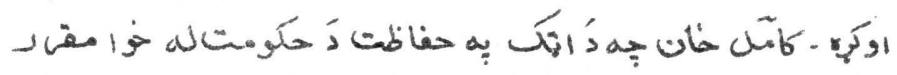

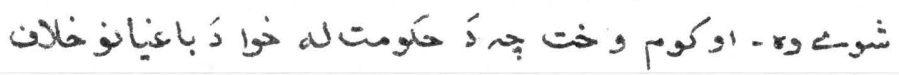

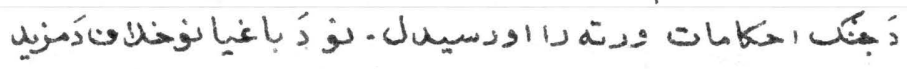

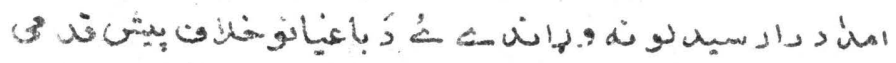

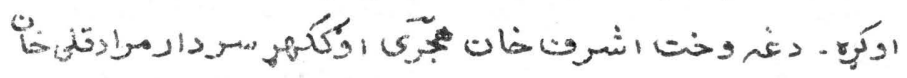

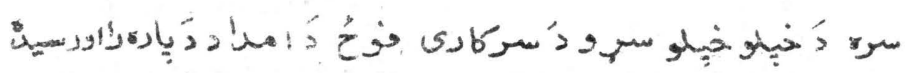

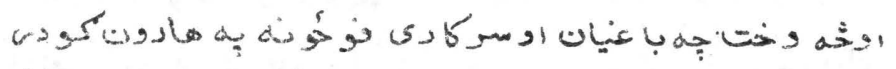

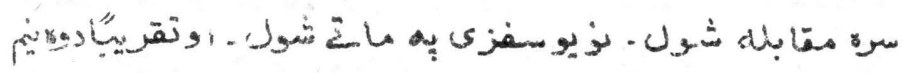

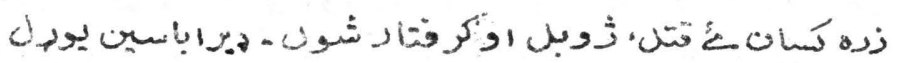

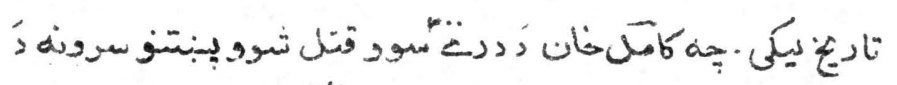

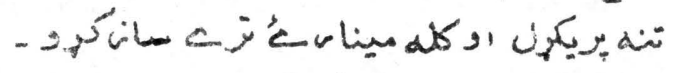

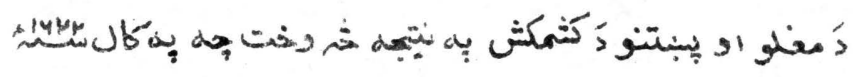

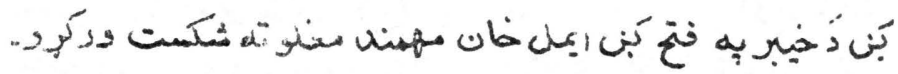




\section{i 216}

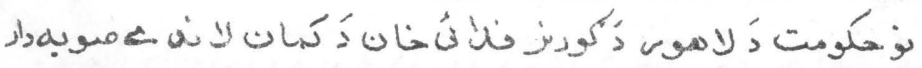

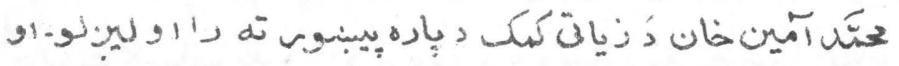

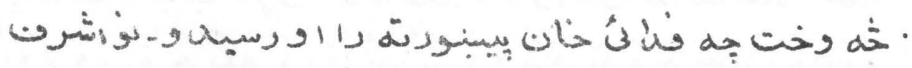

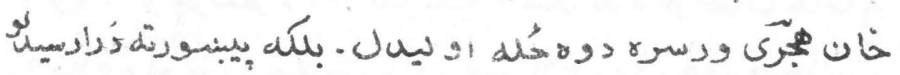

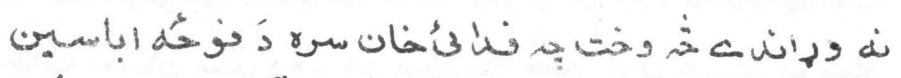

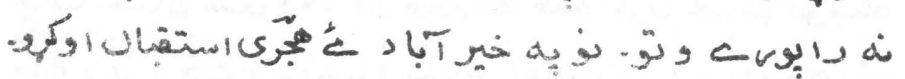

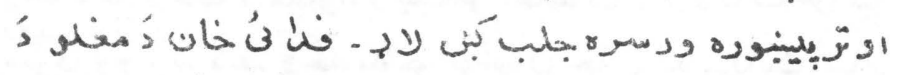

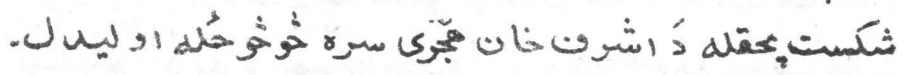

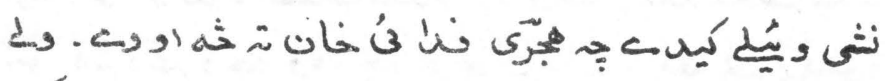

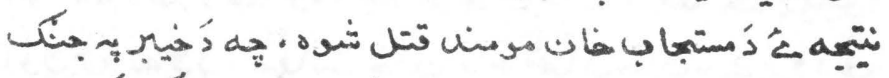

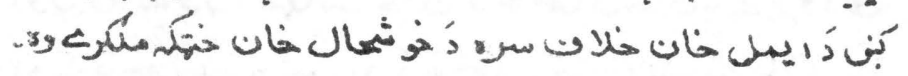

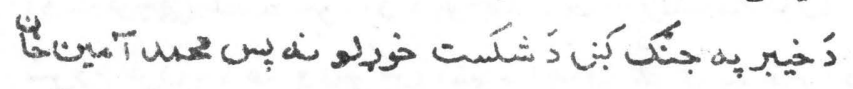

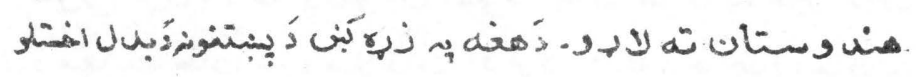

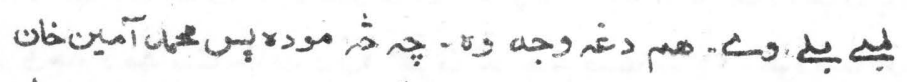

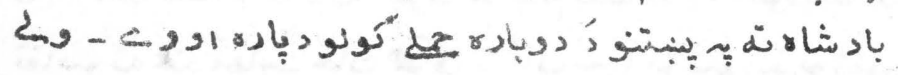

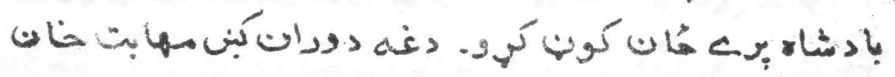

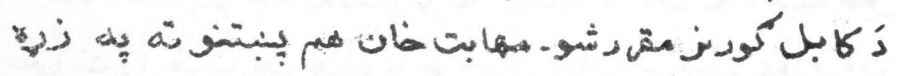

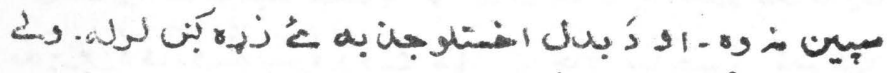

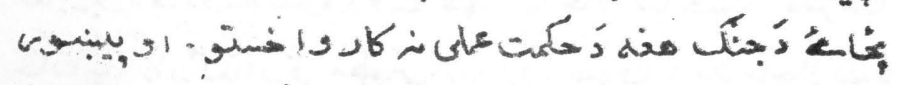

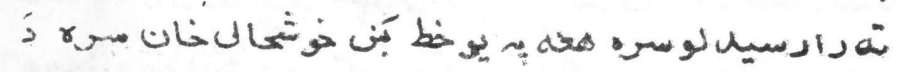

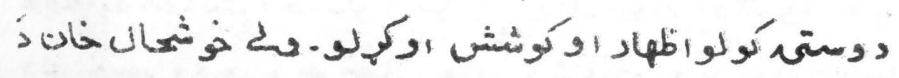




\section{6}

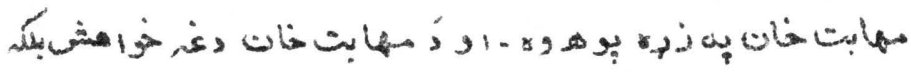

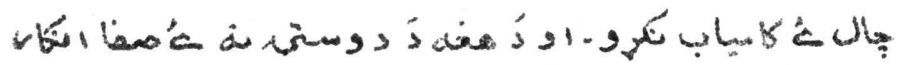

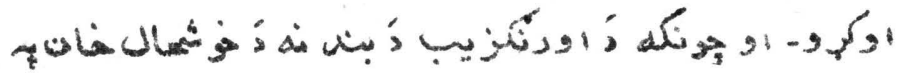

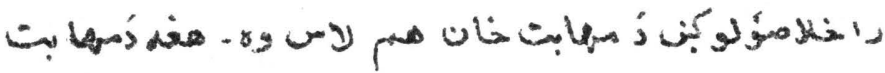
.

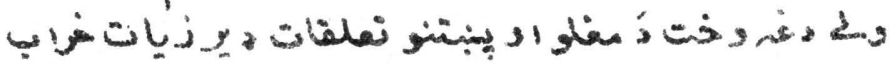

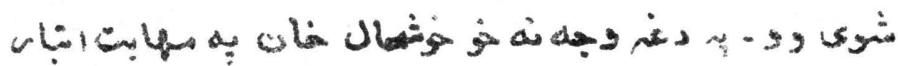

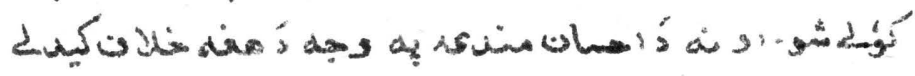

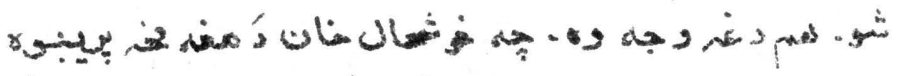

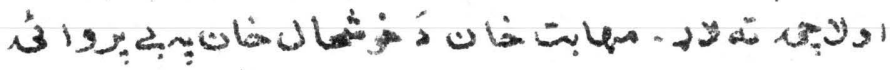

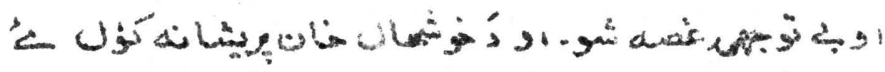

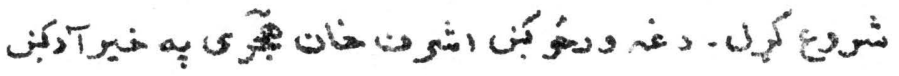

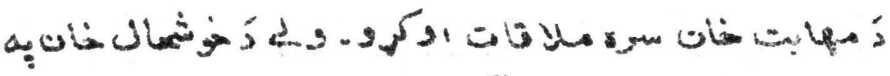

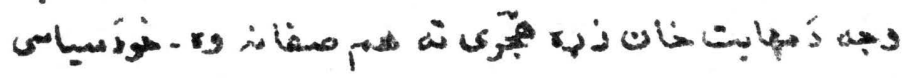

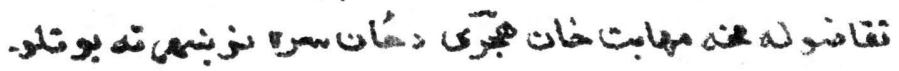

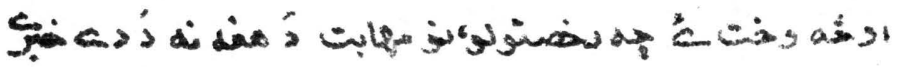

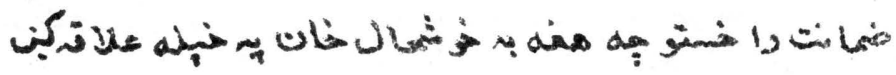
أنه

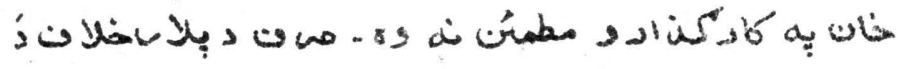

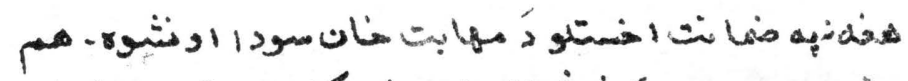

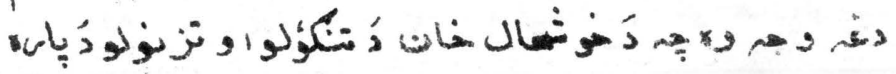




\section{i al 8}

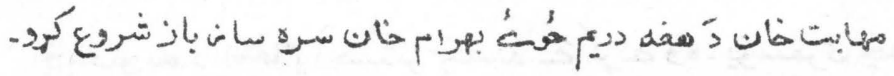

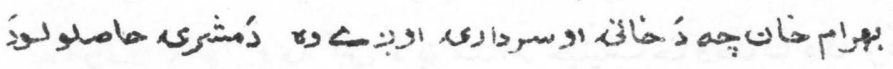

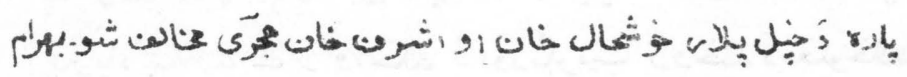

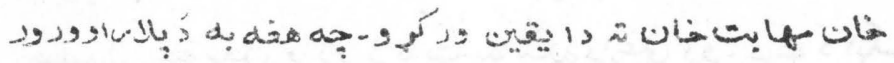

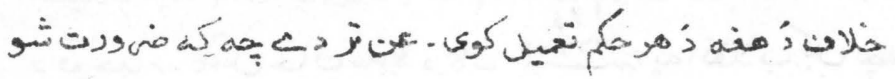

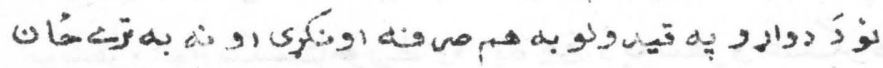

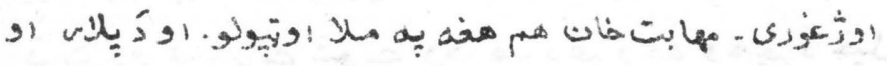

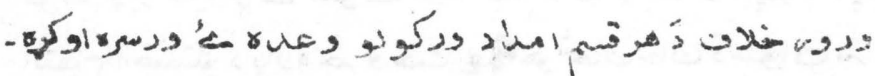

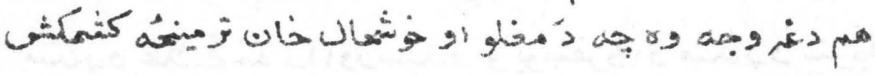

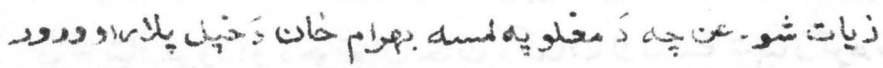

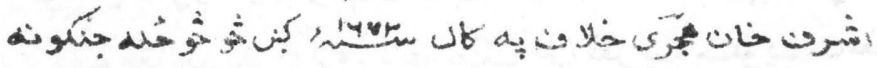

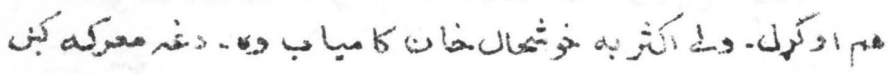

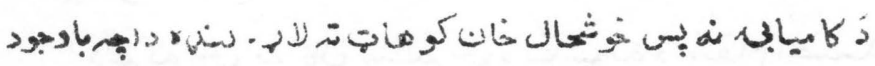

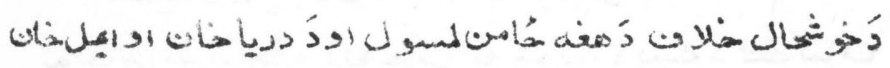

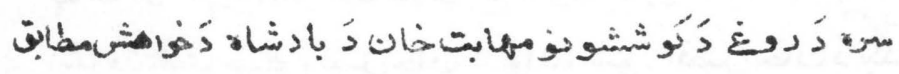

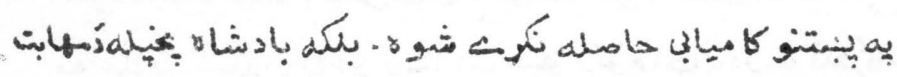

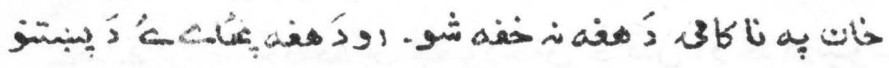

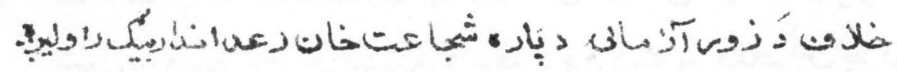

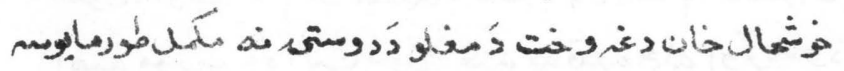

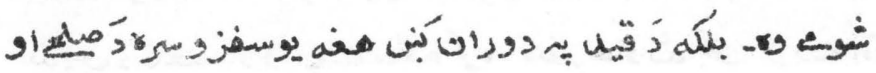

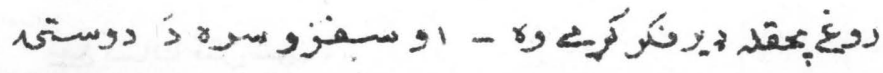




\section{balq}

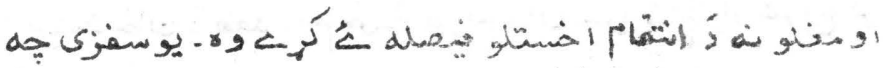

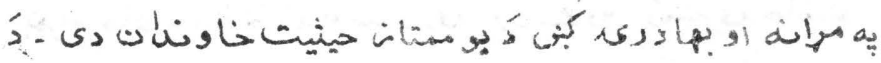

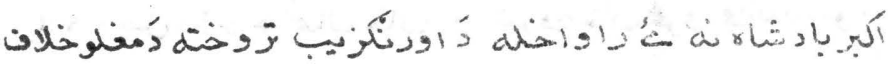

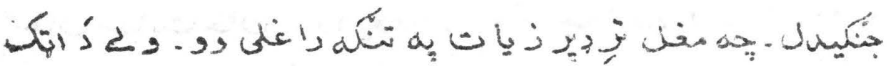

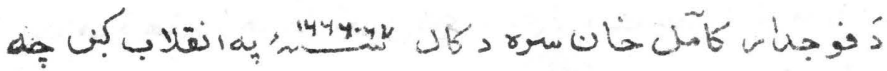

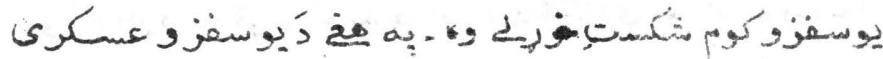

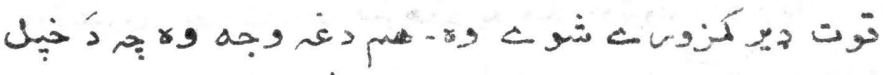

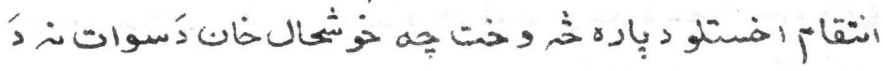

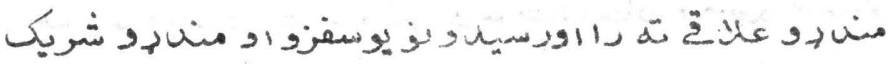

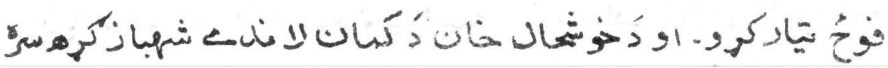

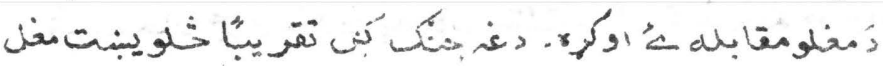

- in

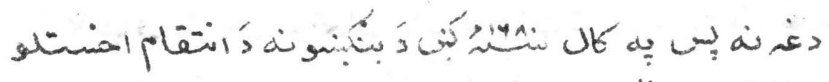

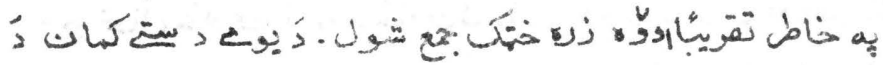

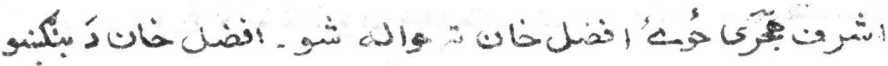

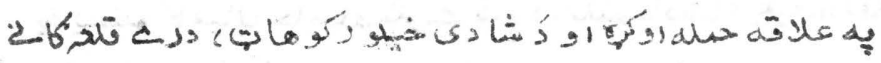
2

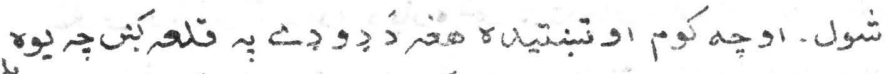

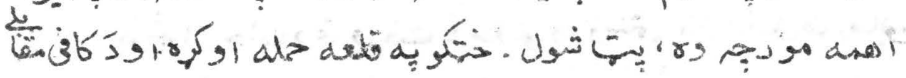

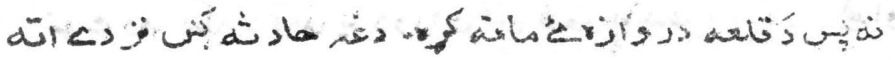

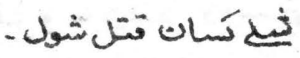




\section{ba20}

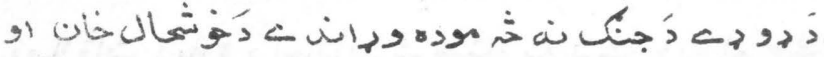

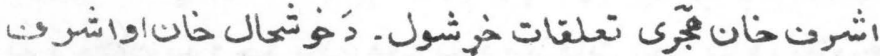

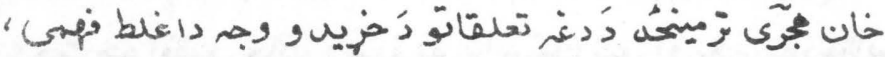

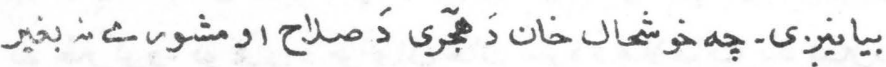

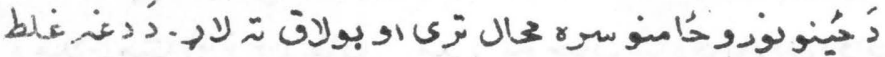
:

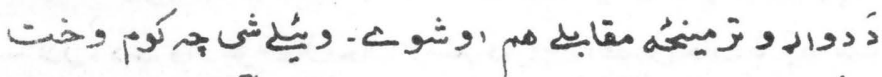

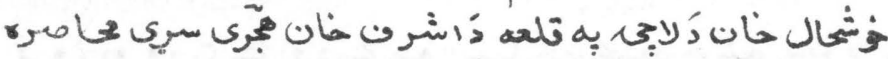

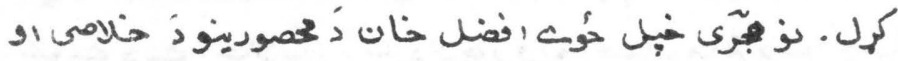

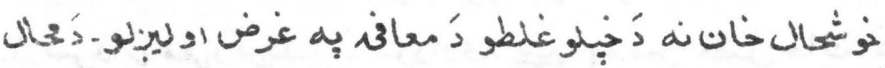
وئ

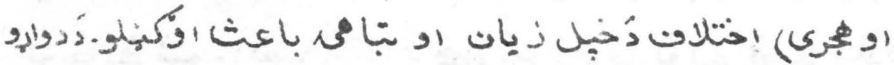

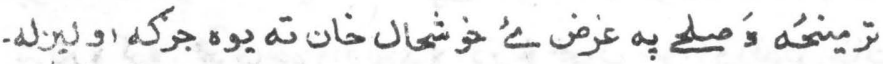

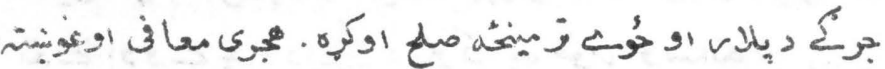
in

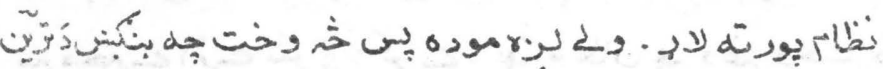

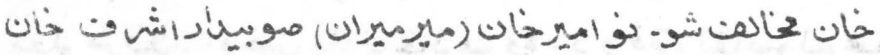

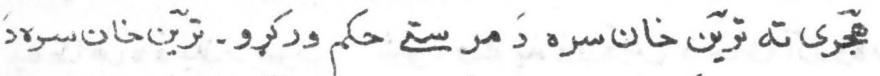

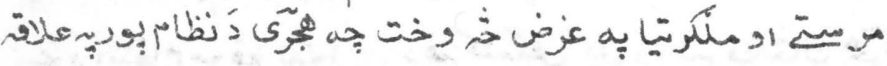

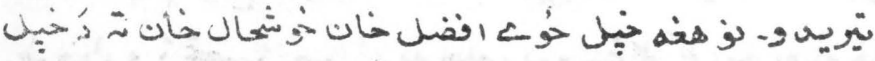

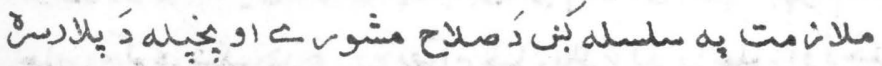




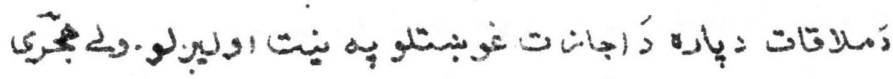

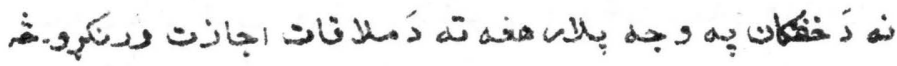

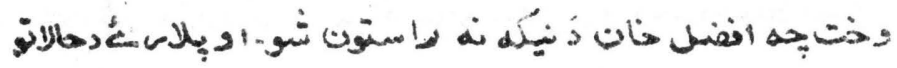

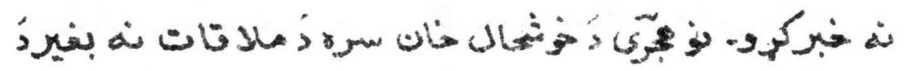

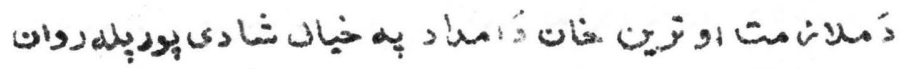

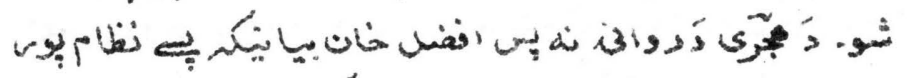

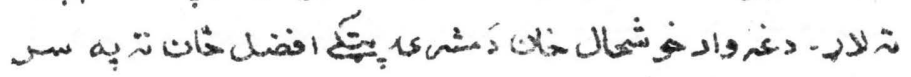

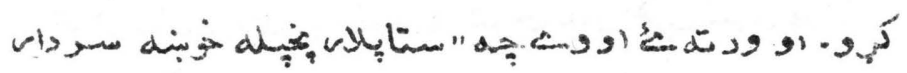

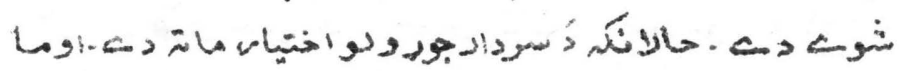

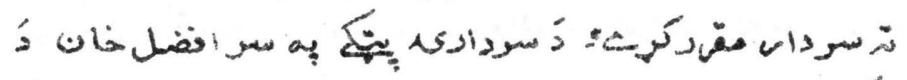

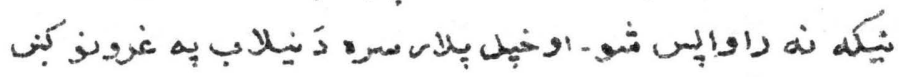

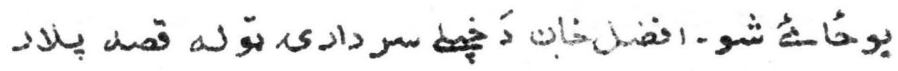

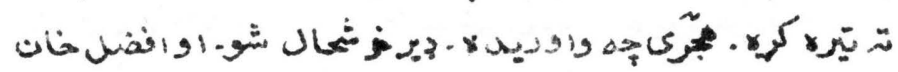

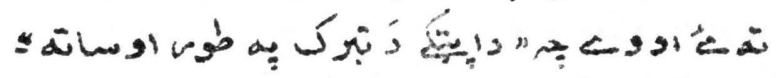

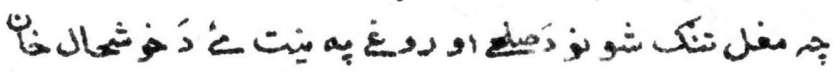

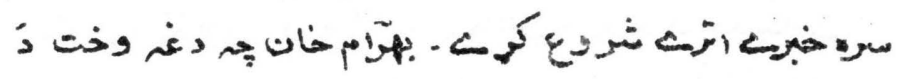

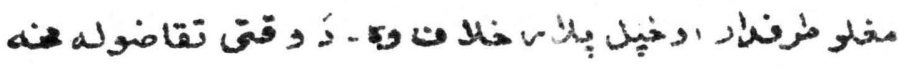

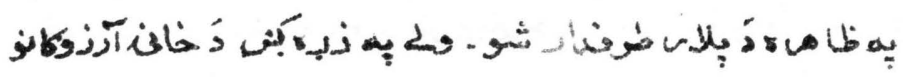

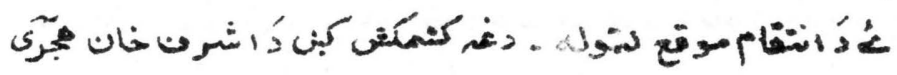

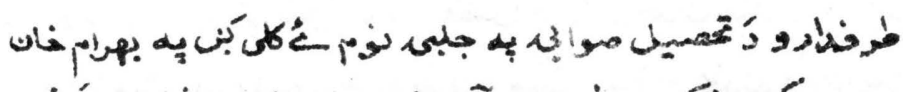

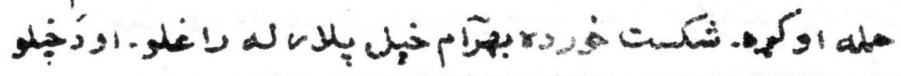




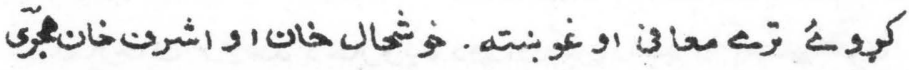

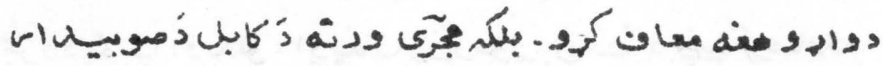

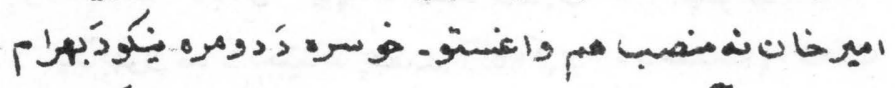

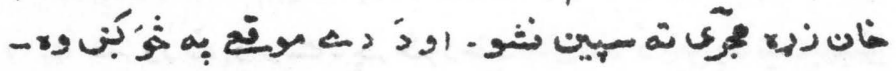

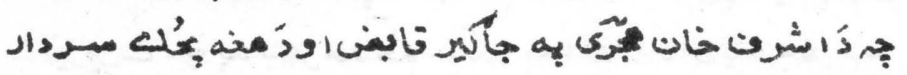

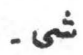

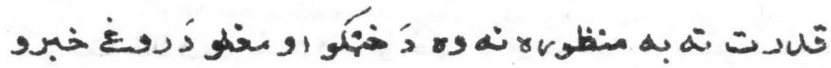

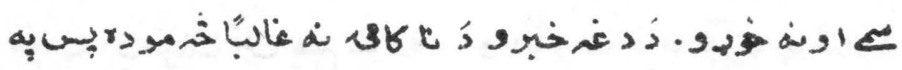

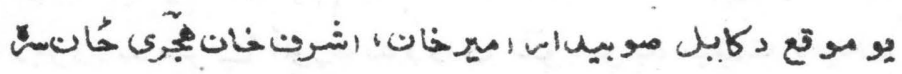

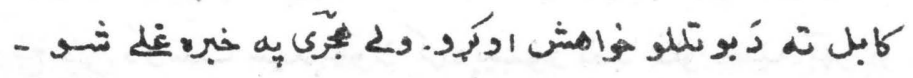

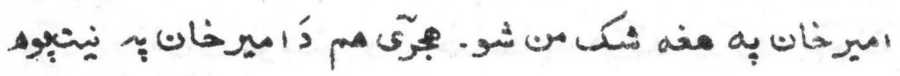

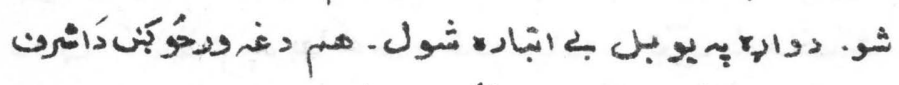

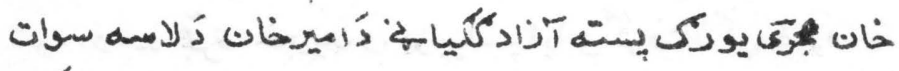

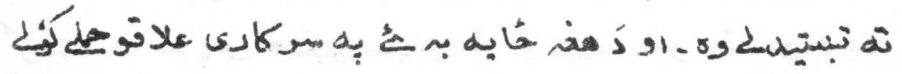

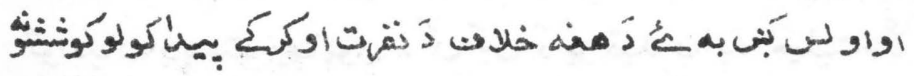

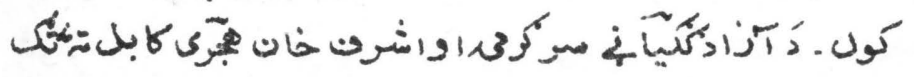

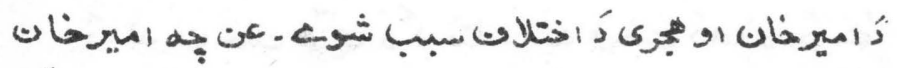

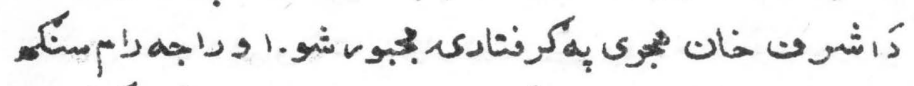
Ca

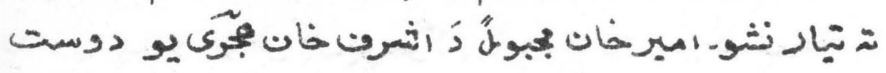

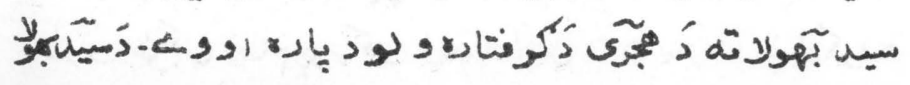




\section{\&923}

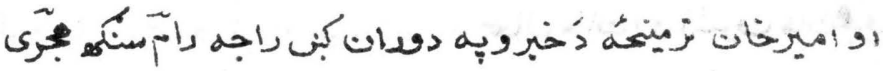

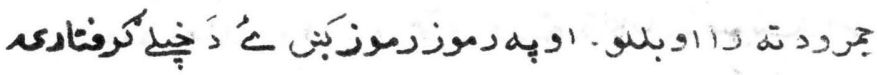

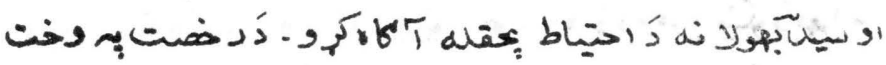

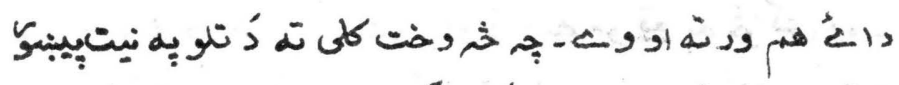

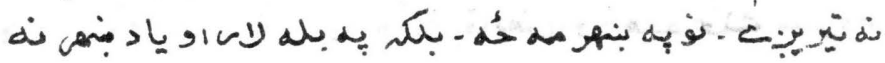

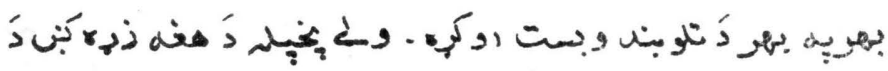

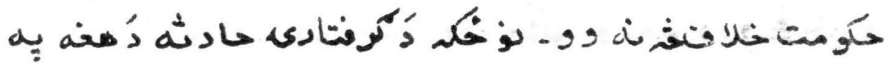

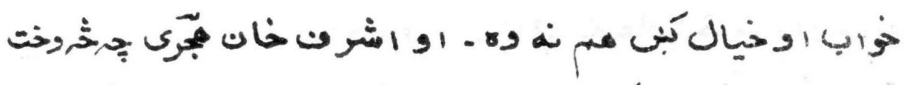

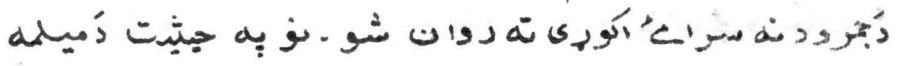

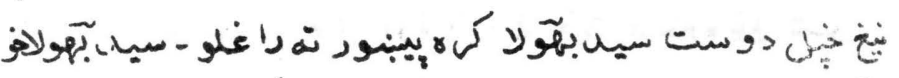

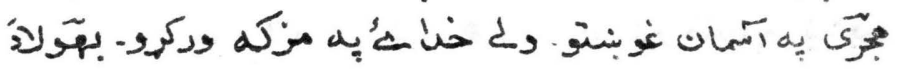

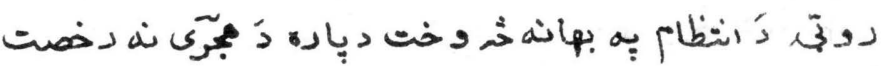

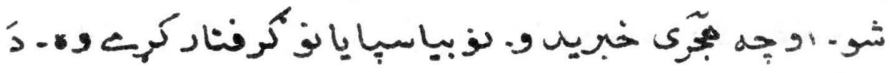

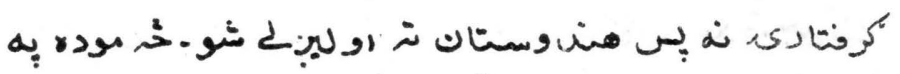

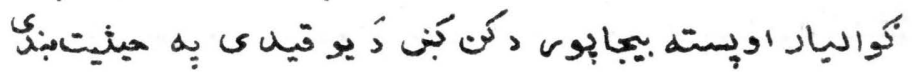
شَو - ـ

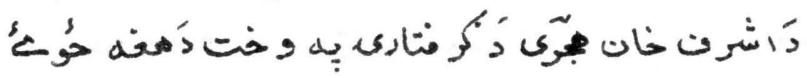

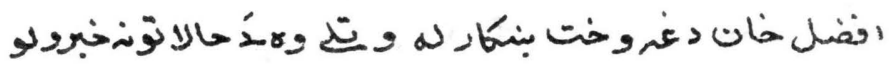

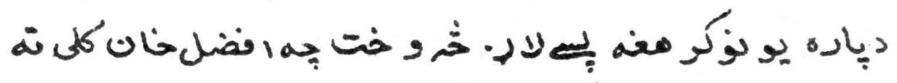

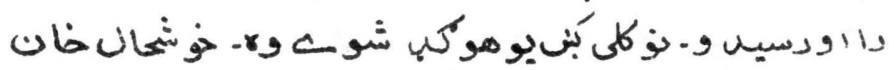

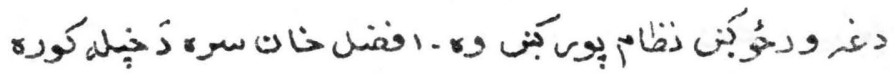




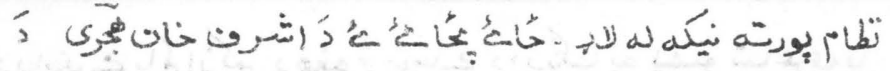

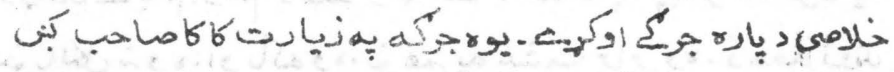

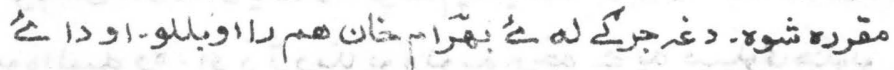

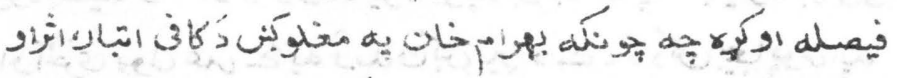

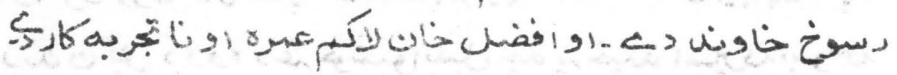

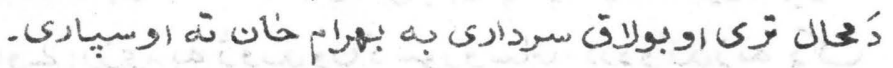

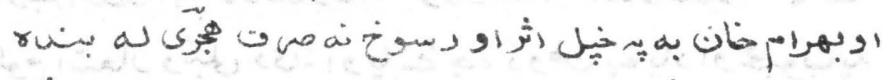

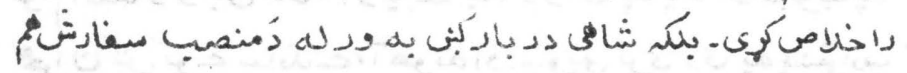

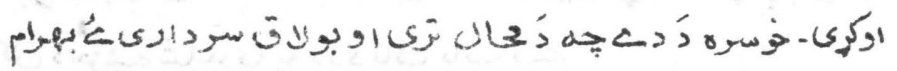

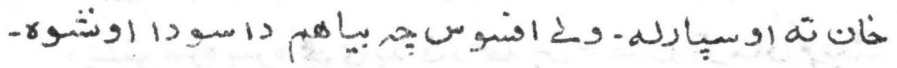

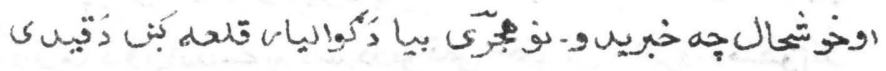

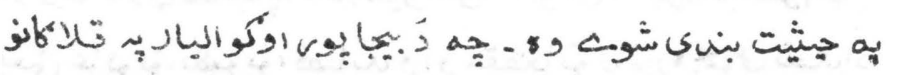

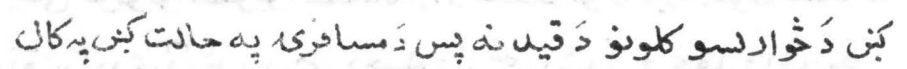

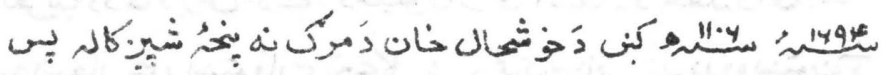
ونات شتو

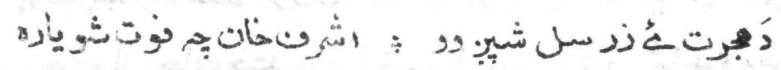

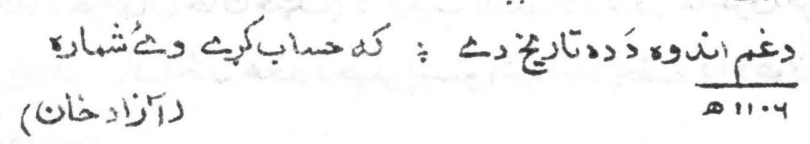

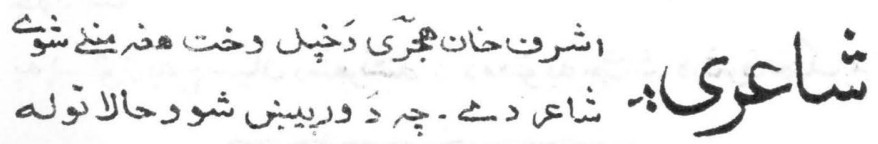

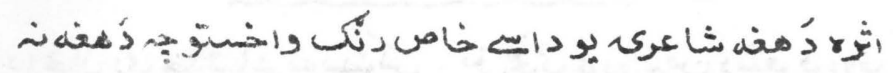




\section{5}

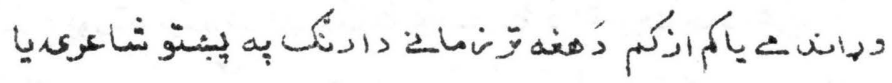

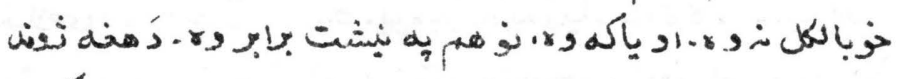

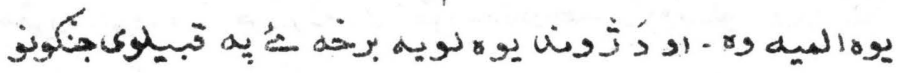

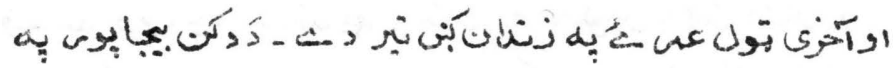

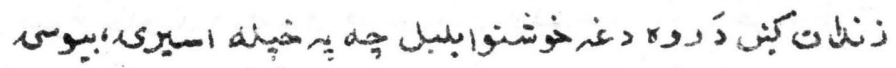

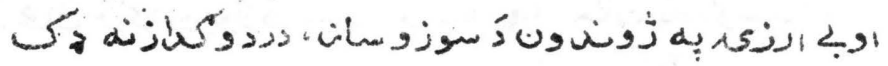

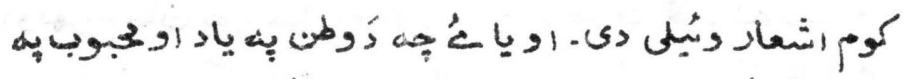

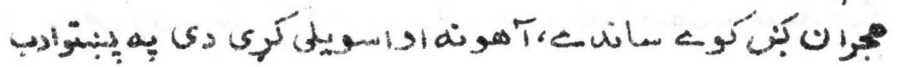

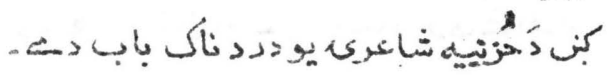

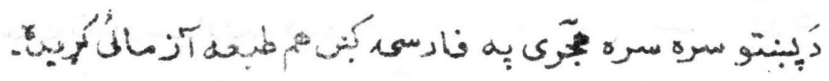

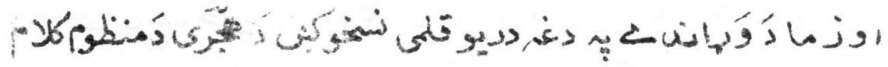

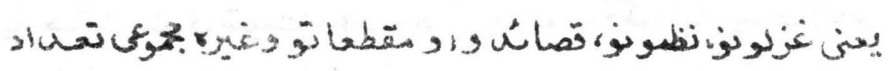

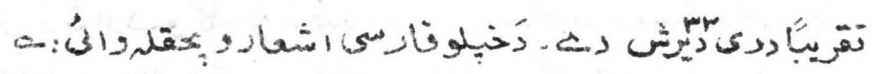

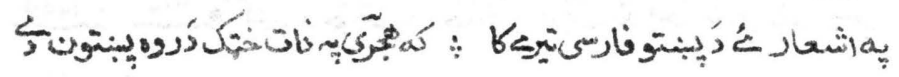

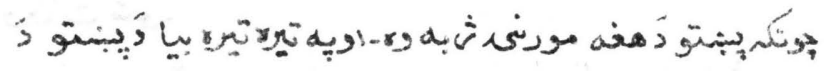

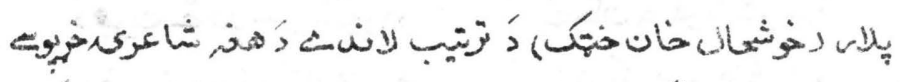

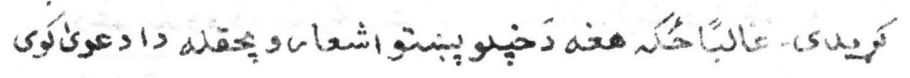

$$
\text { - }
$$

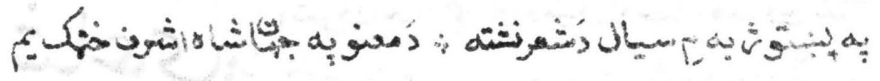

1) 
s) 926

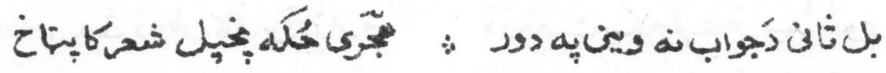

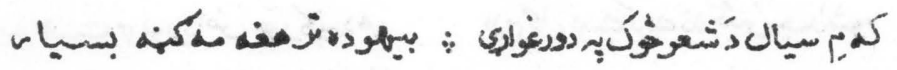

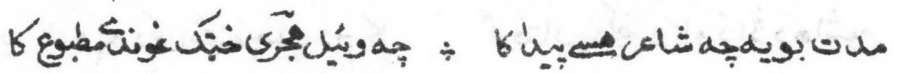

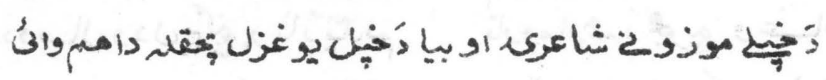

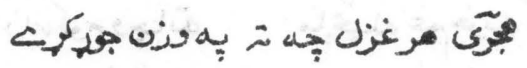

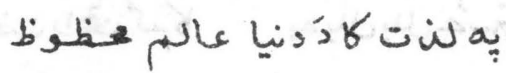

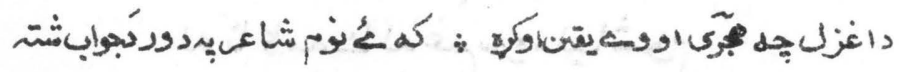

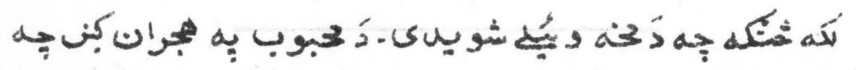

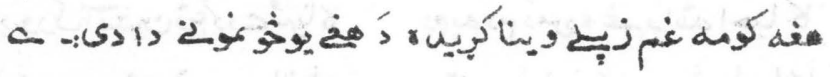

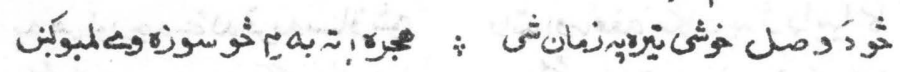

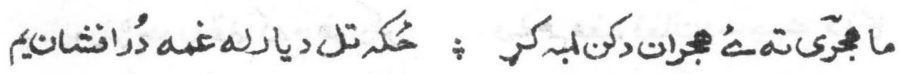

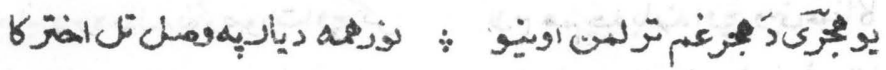

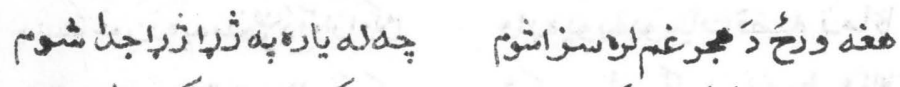

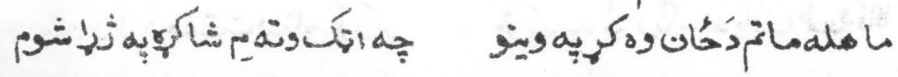




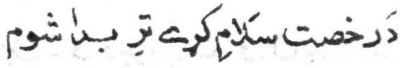

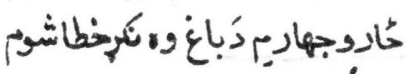

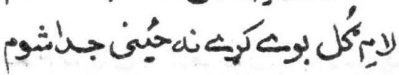

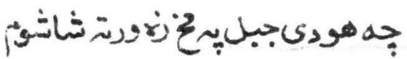

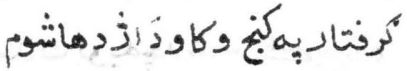

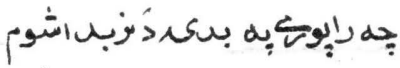

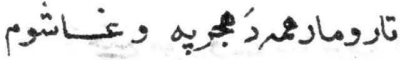

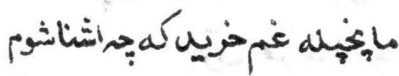

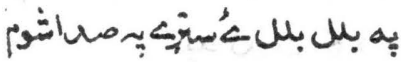

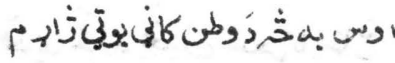

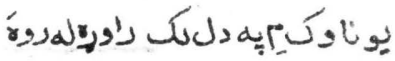

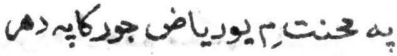

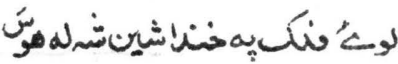

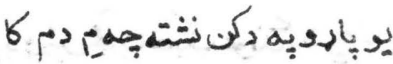

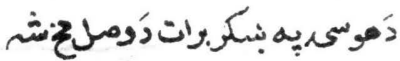

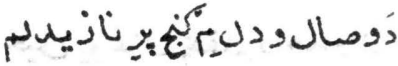

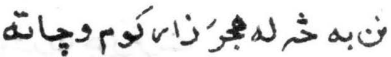

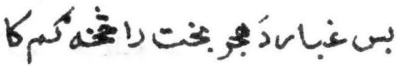

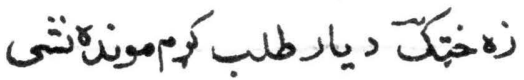

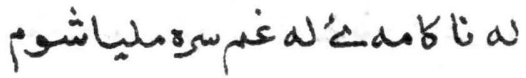

ك"

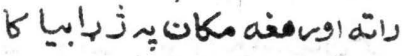

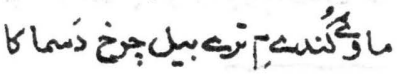

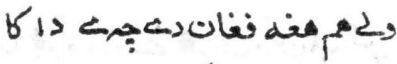

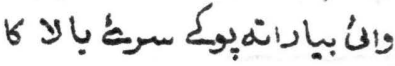

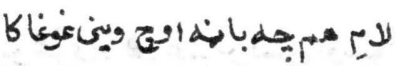

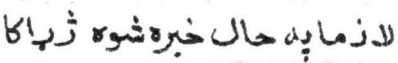
والجهيوبهيوبيات فضيه زماكان

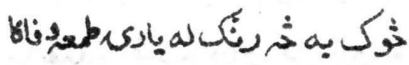

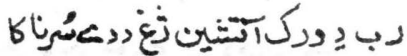

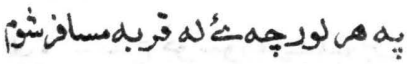

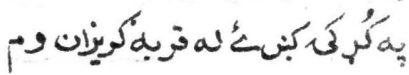

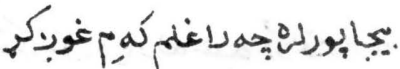

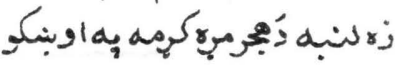

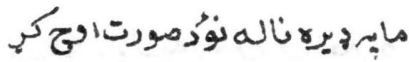

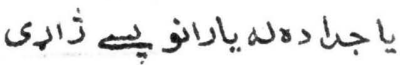

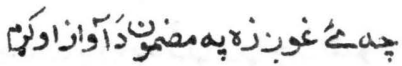

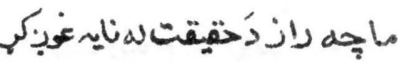


$J 928$

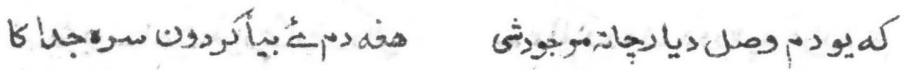

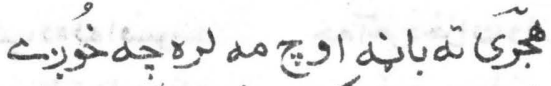

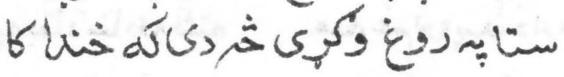

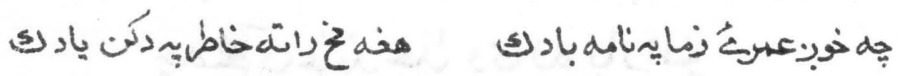

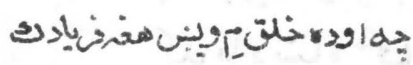

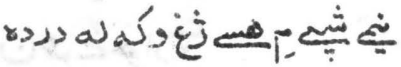

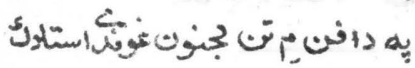

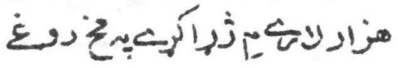

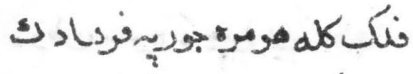

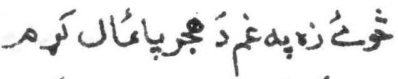

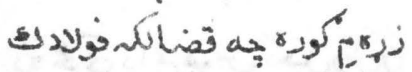

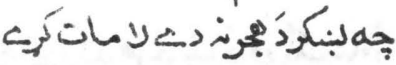

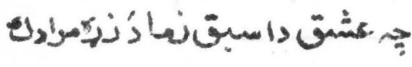

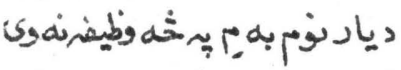

ك,

ك'وصال

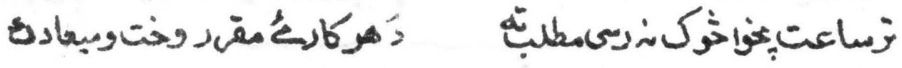

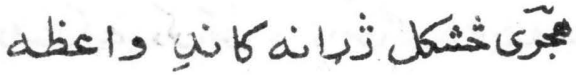

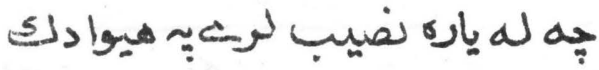

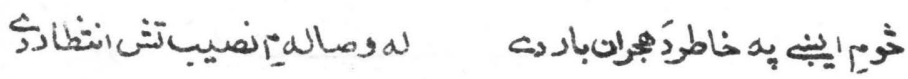

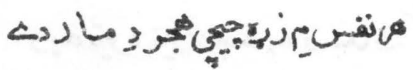

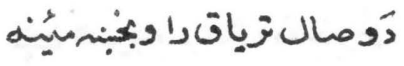

خدرديه

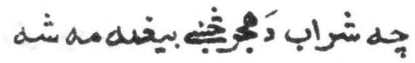

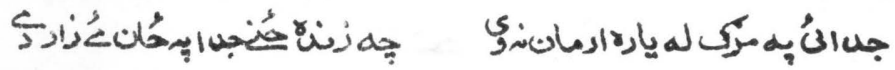

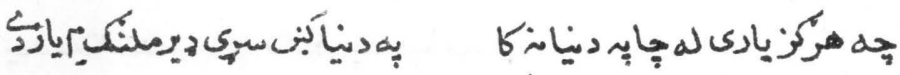

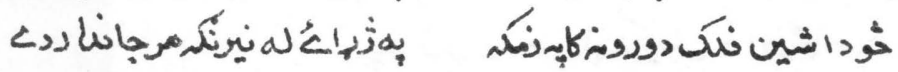


$929 r$

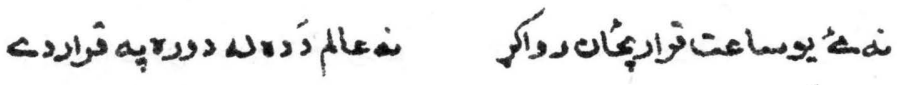

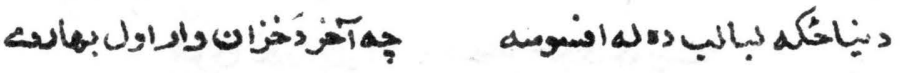

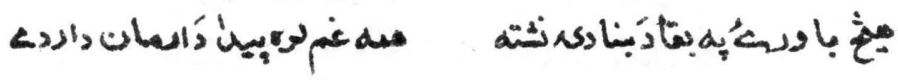

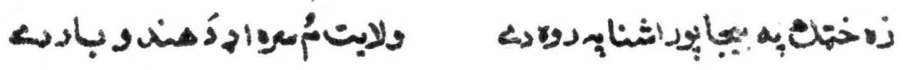

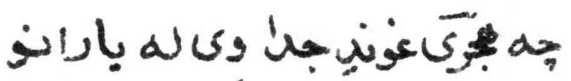

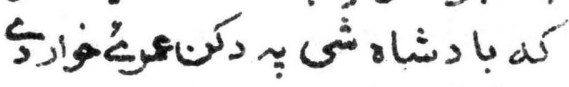

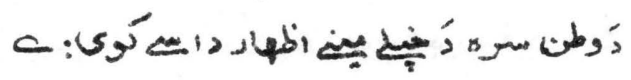

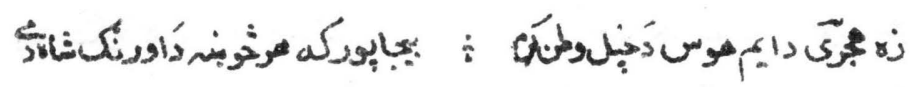

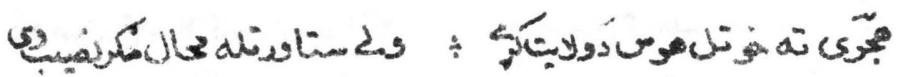

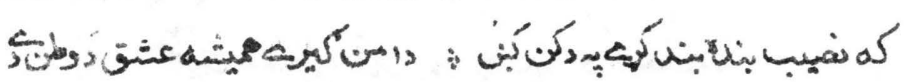

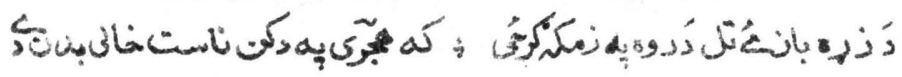

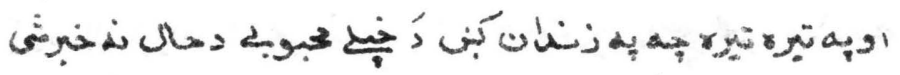

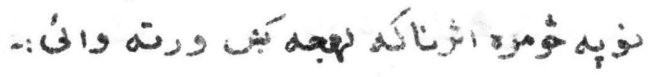
$a$

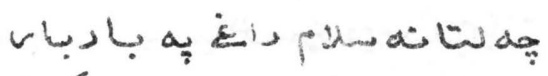

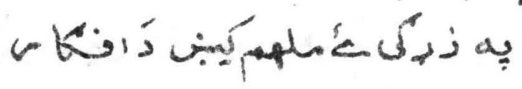


$-a 30$

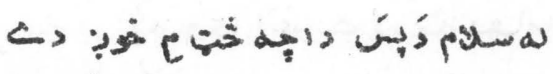


2 ت

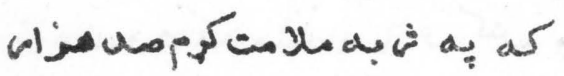

به ؤريسّة

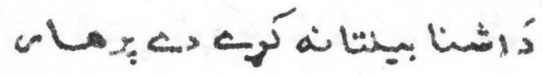

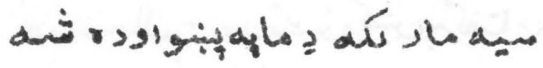

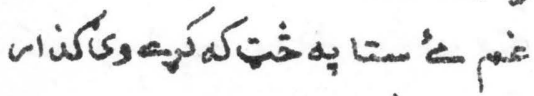

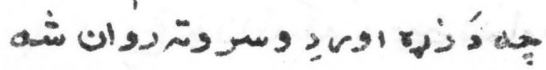

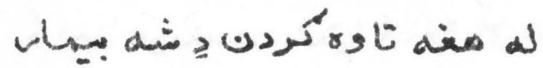

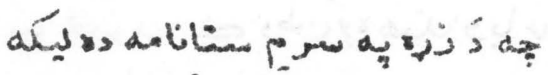

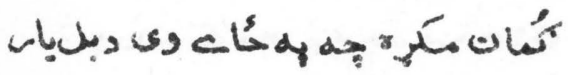

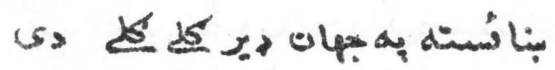

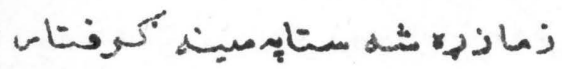

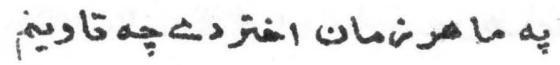

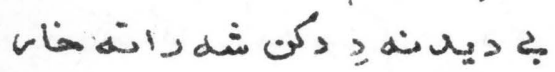

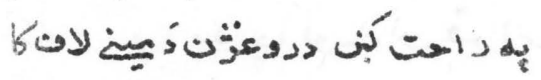

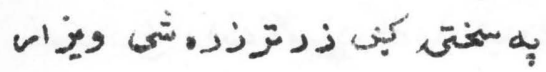

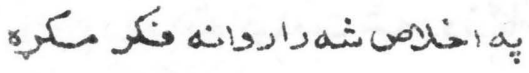

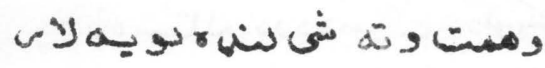

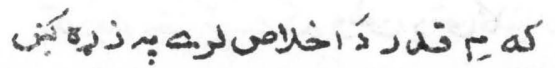


a31:

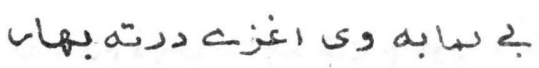

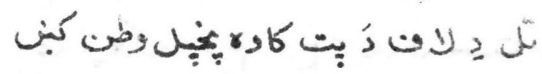

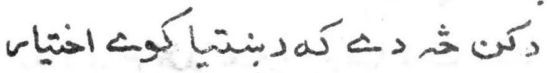

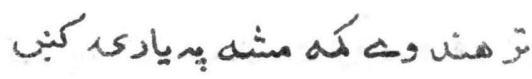

لأحة

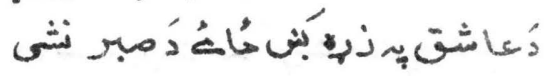

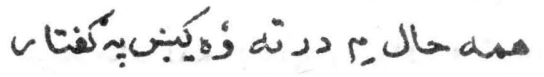

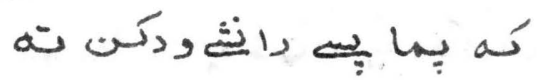

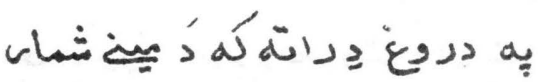

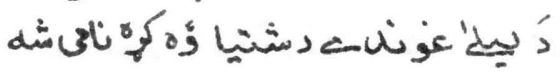

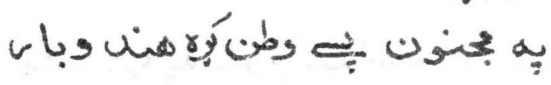

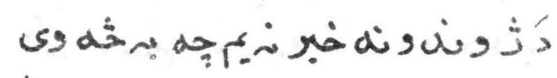

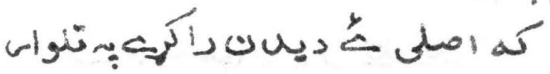

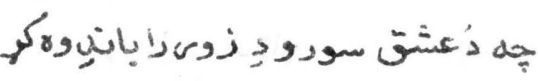

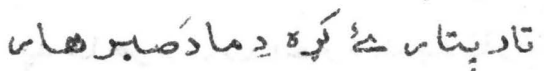

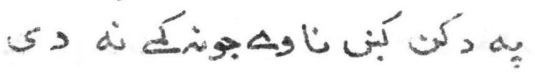

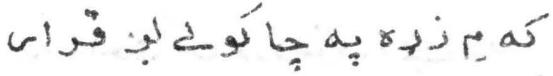

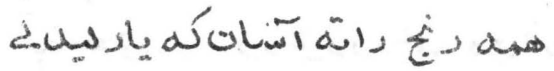

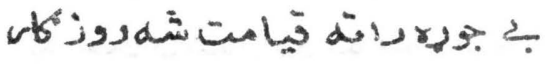

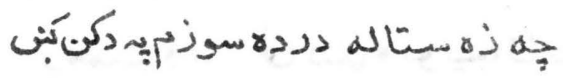

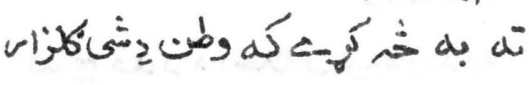


$\checkmark a 32$

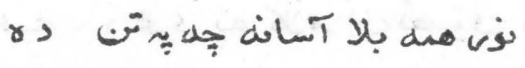

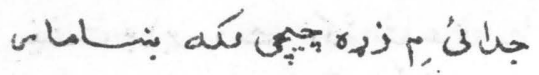

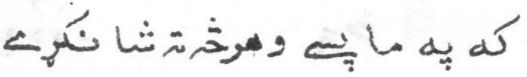

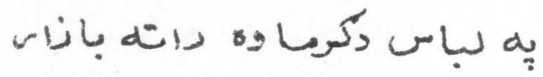

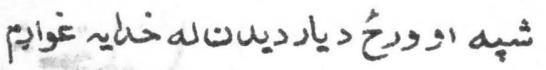

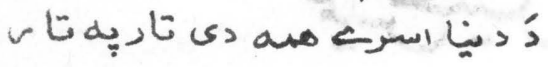

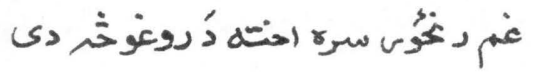

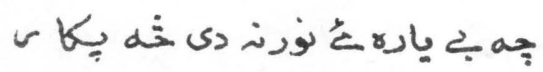

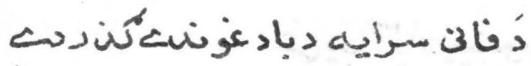

هن

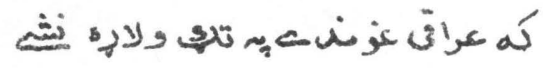

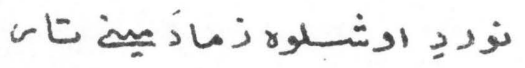

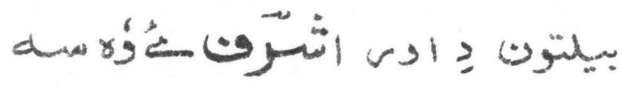

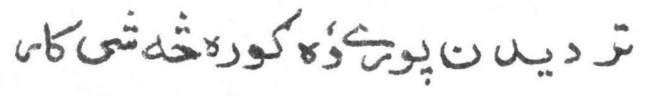

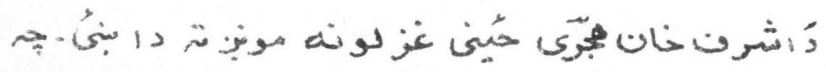

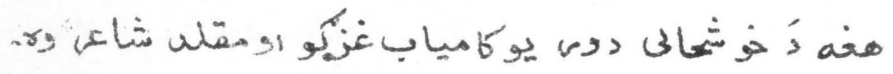

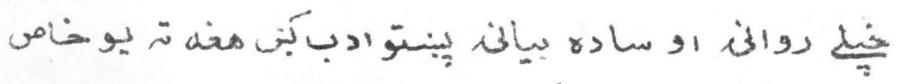

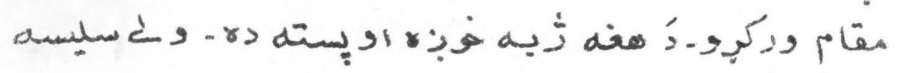

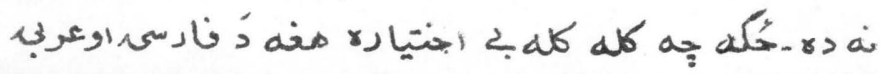


s 433

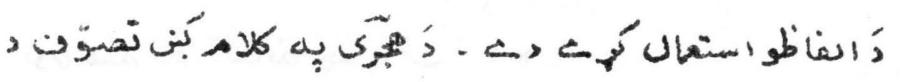

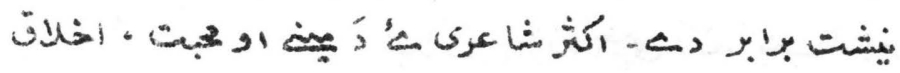

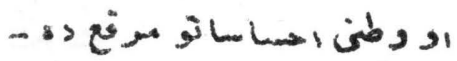

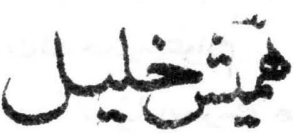

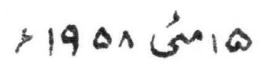

غن

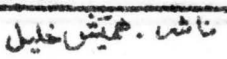




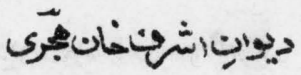

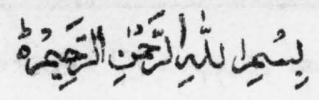

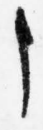

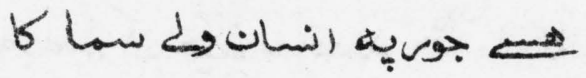

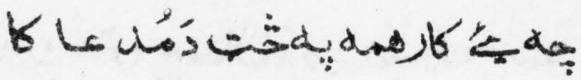

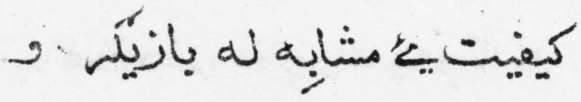

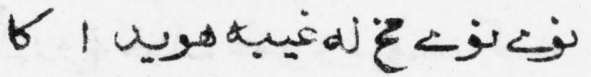

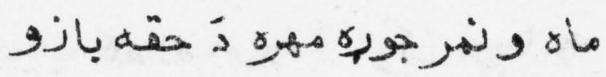

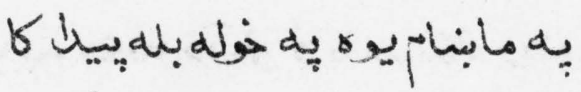

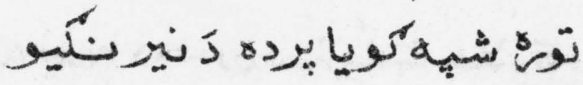

و كهباته

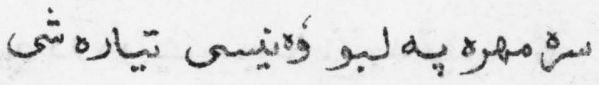

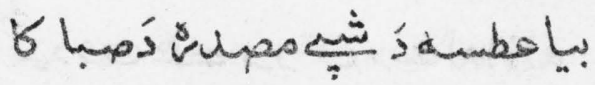

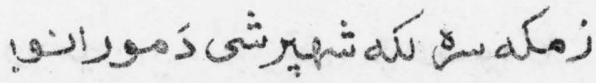




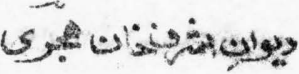

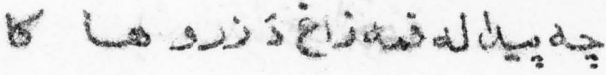

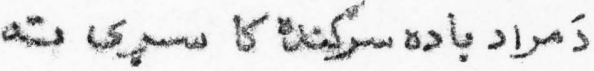

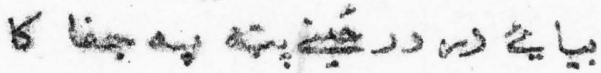

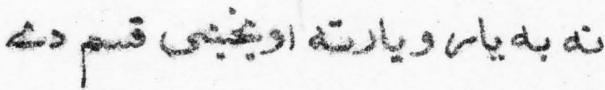

5 Lä dupha

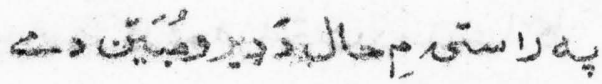

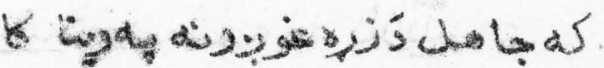

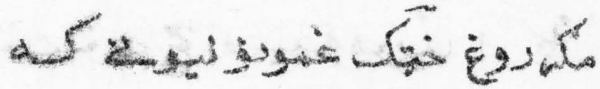

$6 \operatorname{loc} 5$ s

dos jom bs gis als dit.

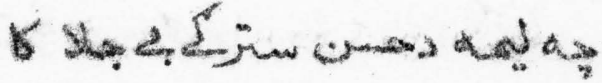

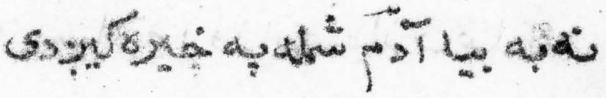

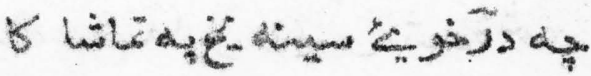

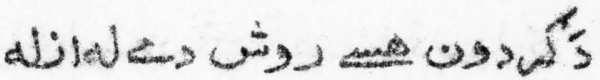

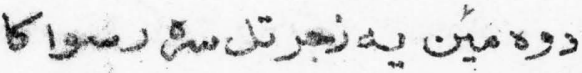




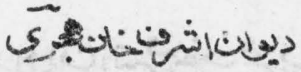

o

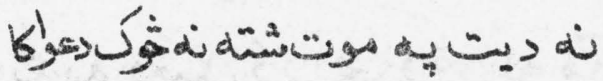

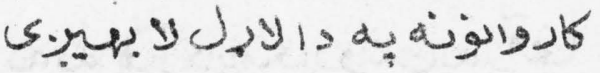

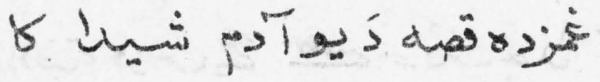

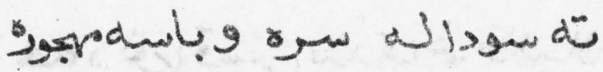

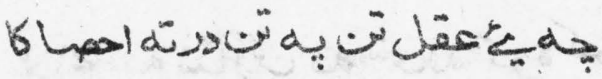

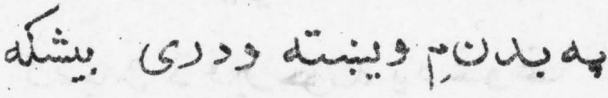

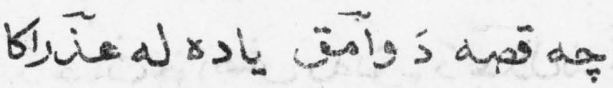

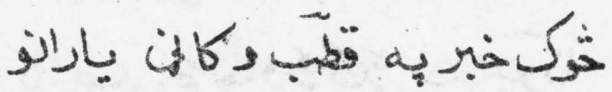

كاos

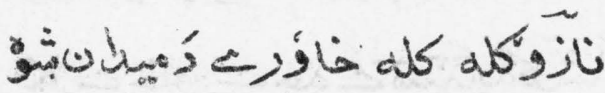

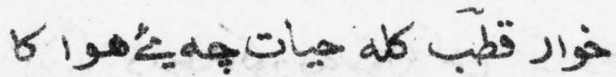

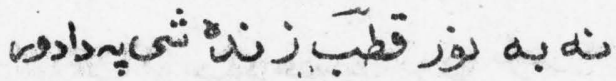

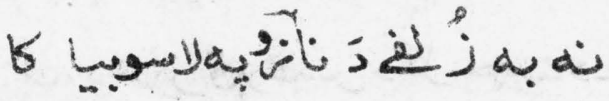

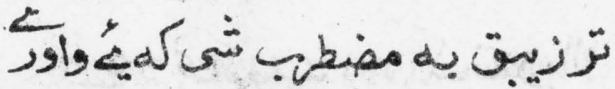




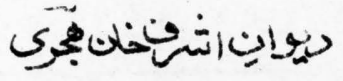

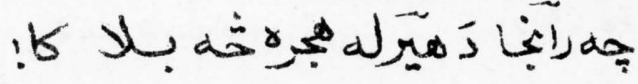

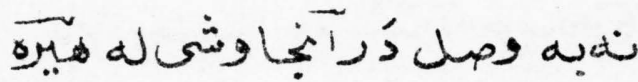

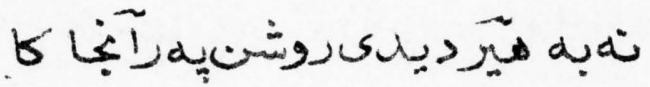

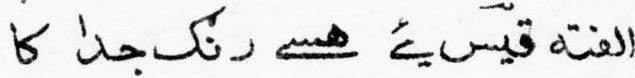

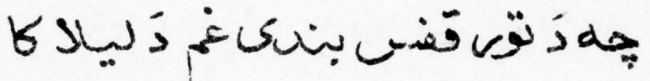

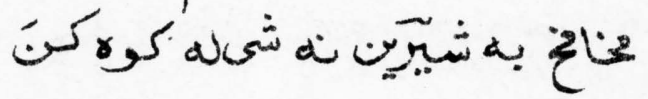

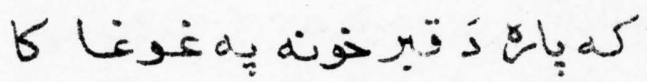

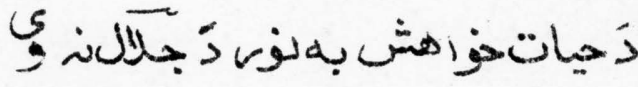

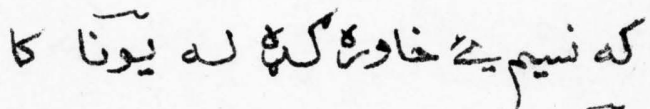

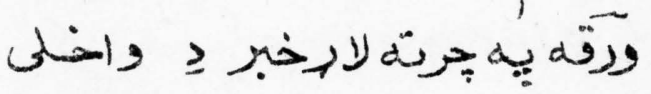

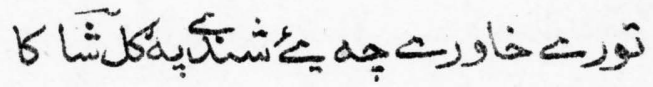

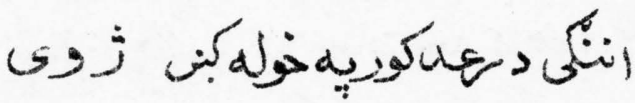

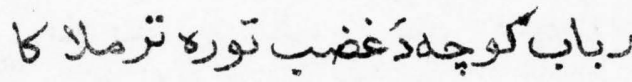

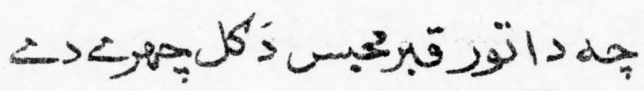

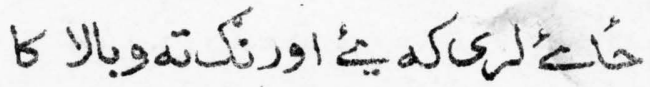




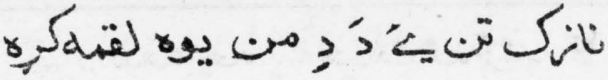

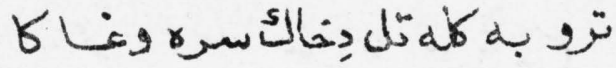

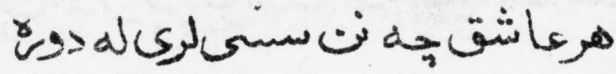

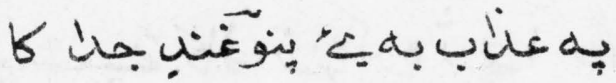

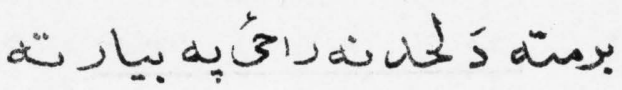

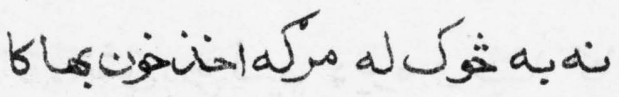

年

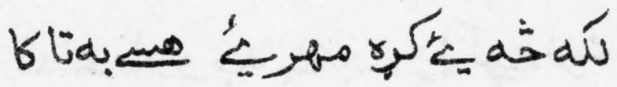

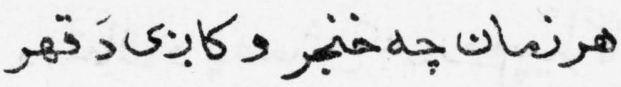

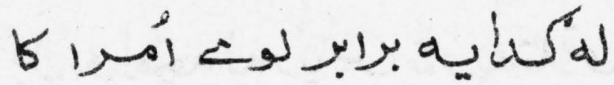

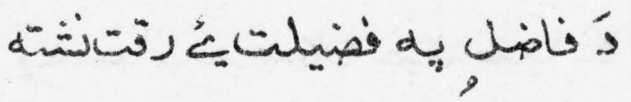

ك

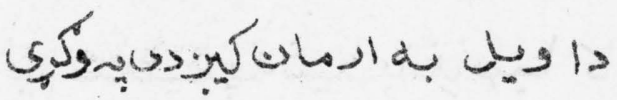

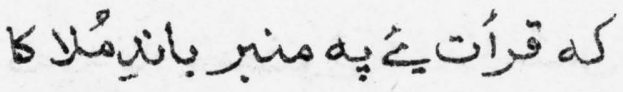

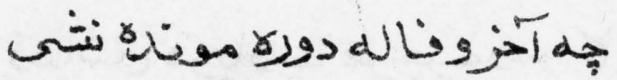




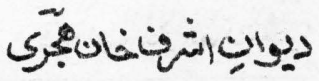

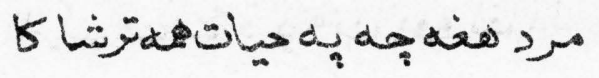

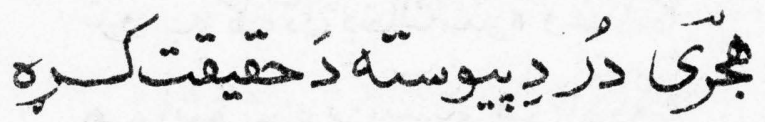

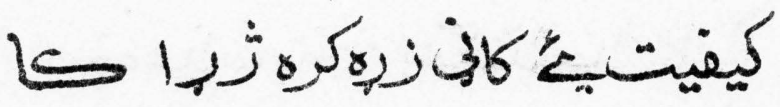

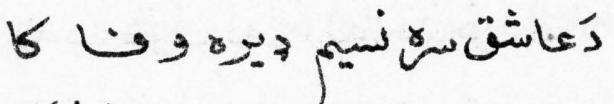

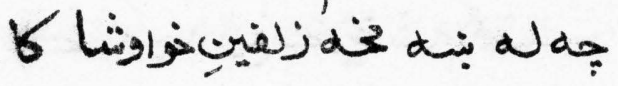
$\Delta \leqslant \begin{cases}0 \\ 4\end{cases}$ |

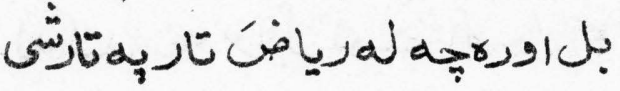

6 Lisdar

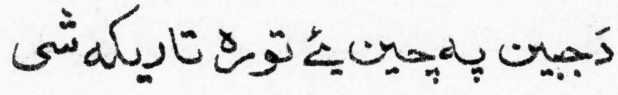

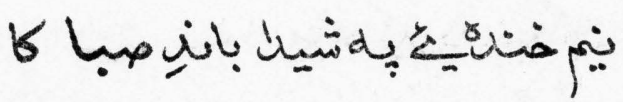

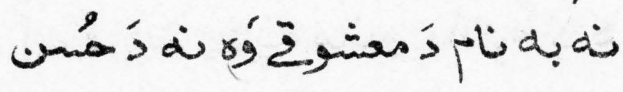

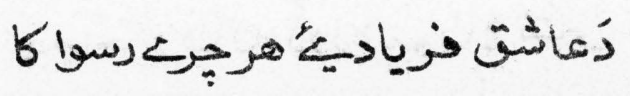




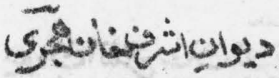

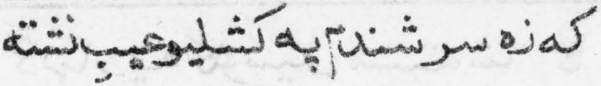

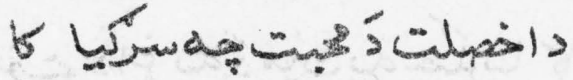

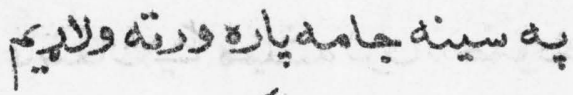

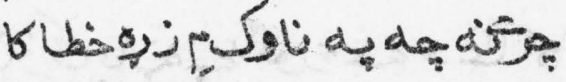

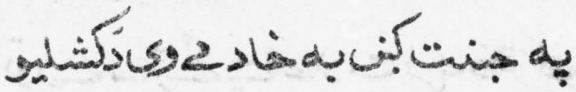

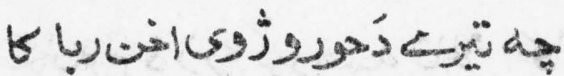

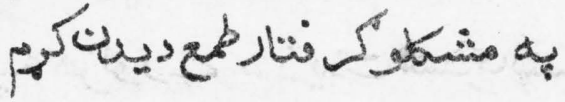

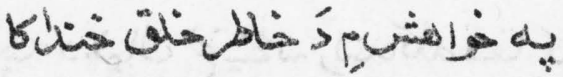

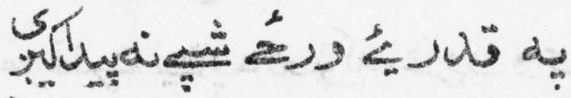

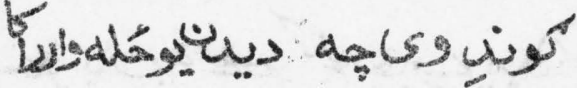

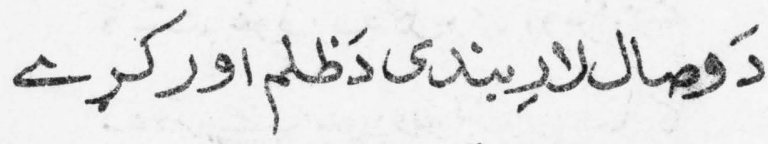

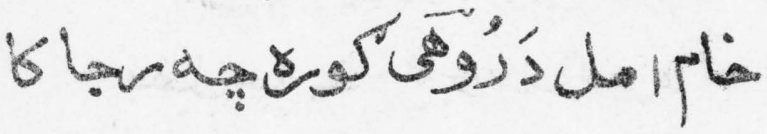




\section{>يوابِانشتنانهي}

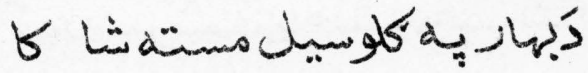

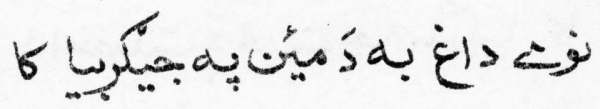

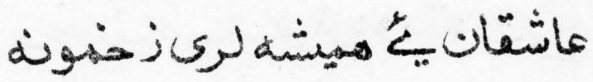

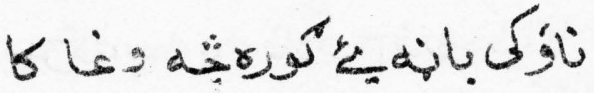

توند

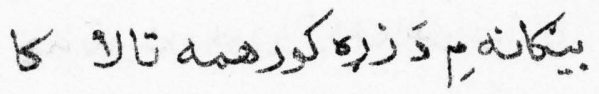

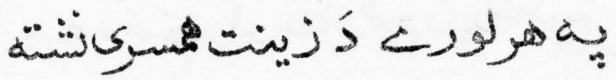

جها

مرئل

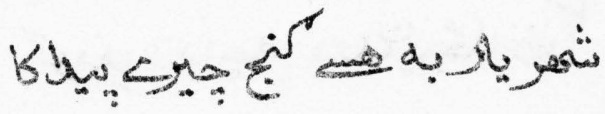

ك́

6 كLidy

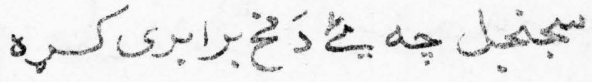

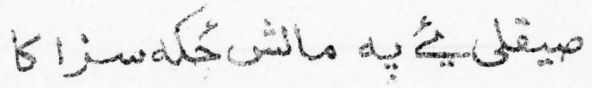

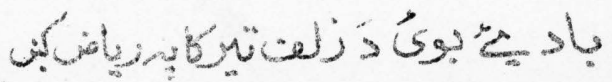




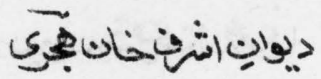

$$
\begin{aligned}
& \text { ا }
\end{aligned}
$$

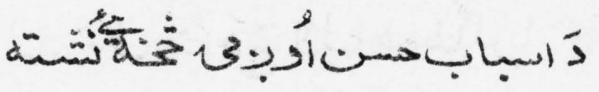

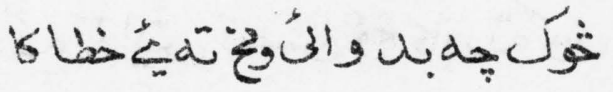

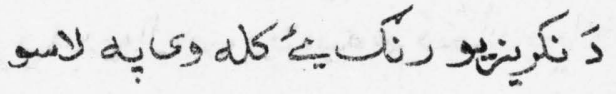

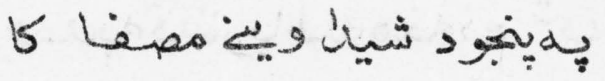

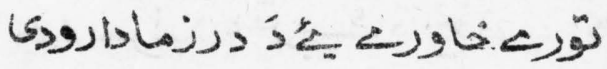

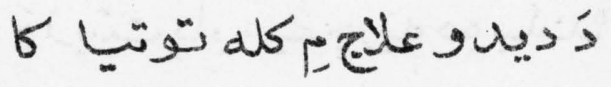

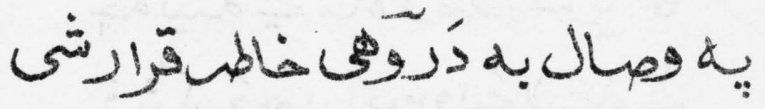

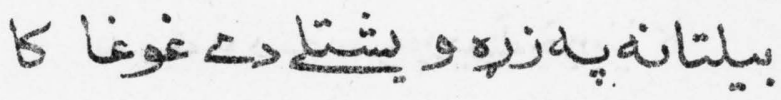




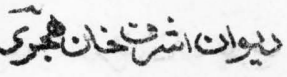

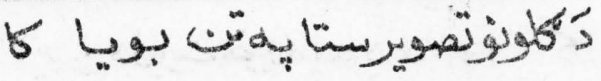

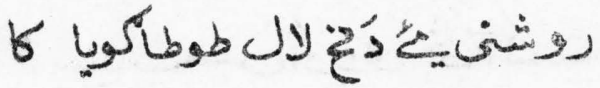

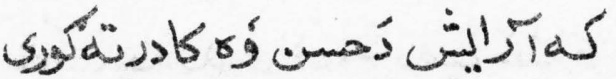

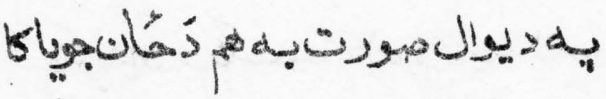

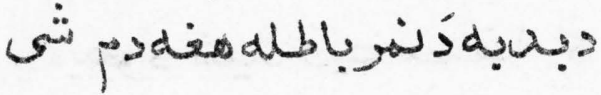

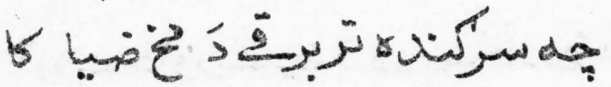

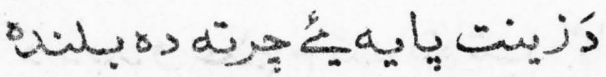

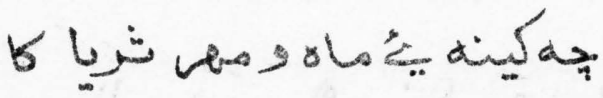

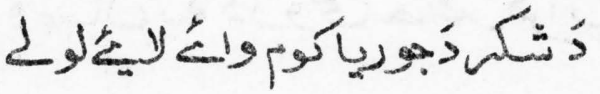

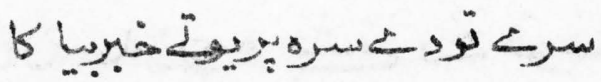

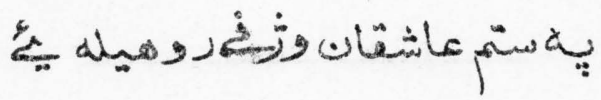

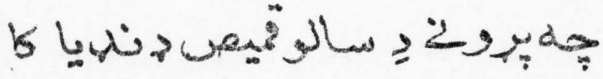

به بـ

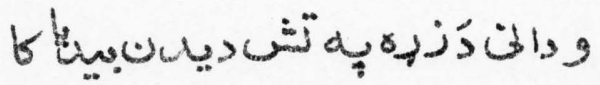

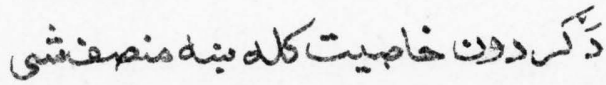




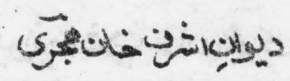

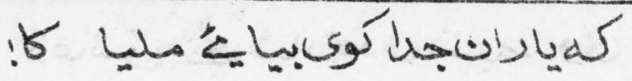

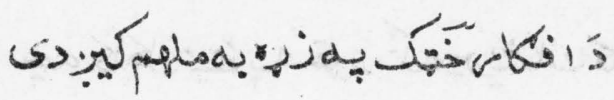

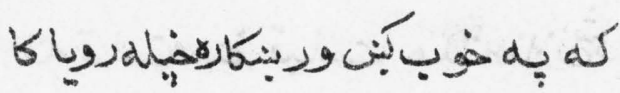

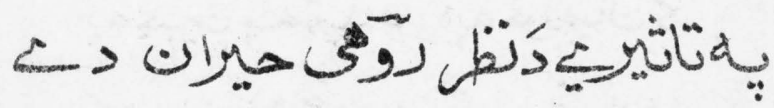

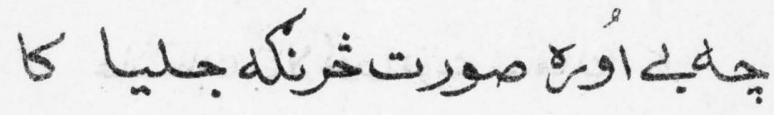

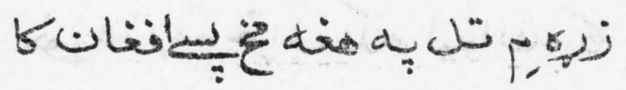

ك

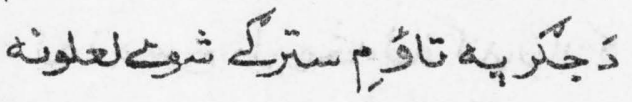

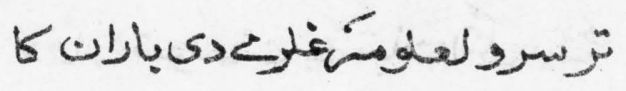

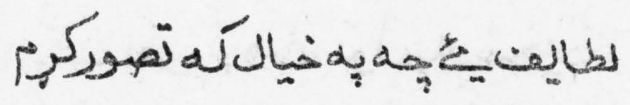

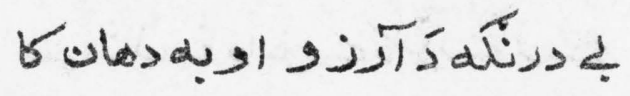

نازكَّ人

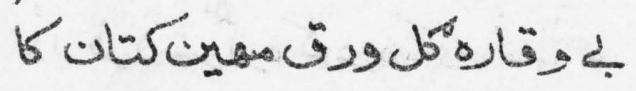

II 


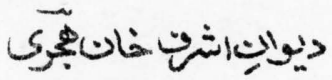

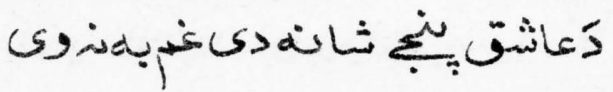

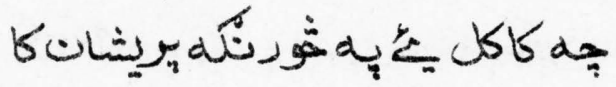

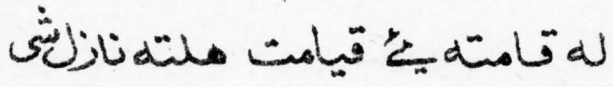

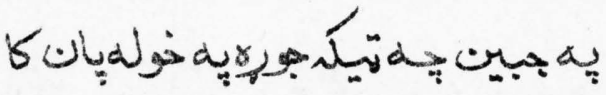

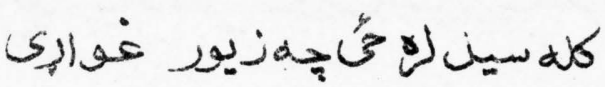

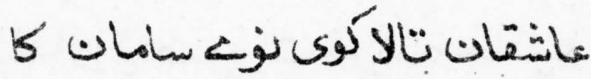

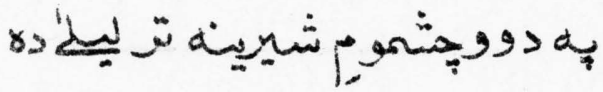

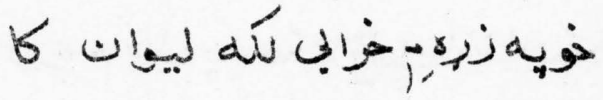

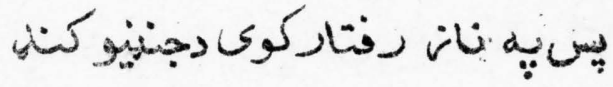

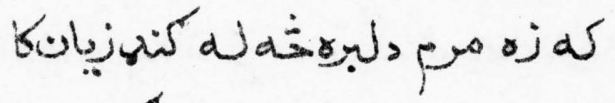

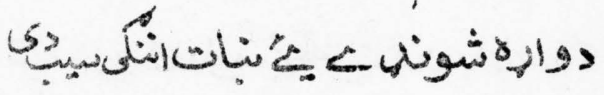

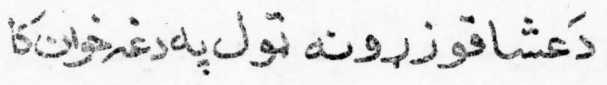
نا

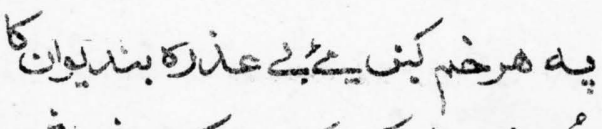

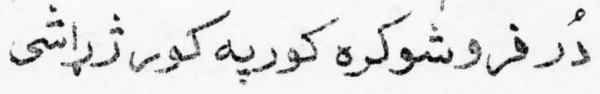




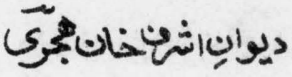

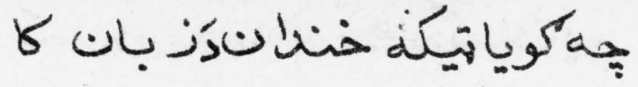

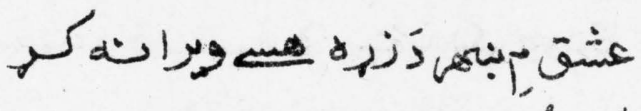

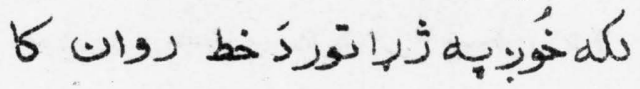

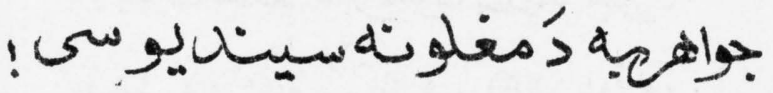

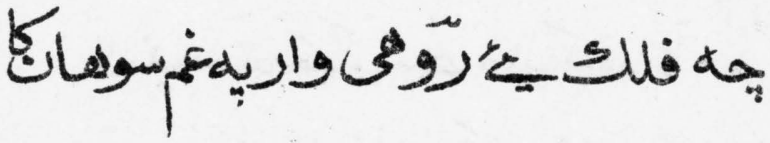

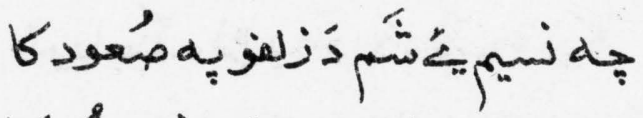

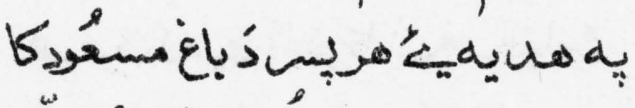

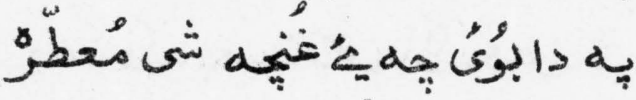

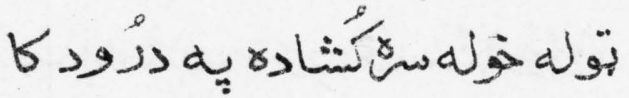

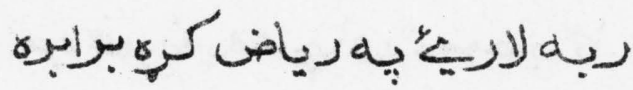
جه هركل

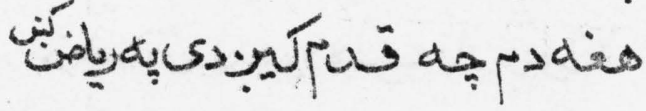

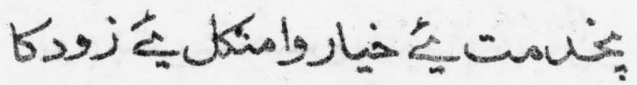




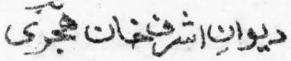

moiblis

$8^{\circ}$

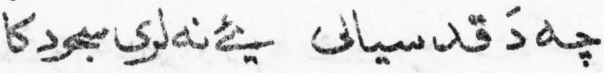

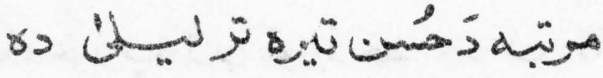

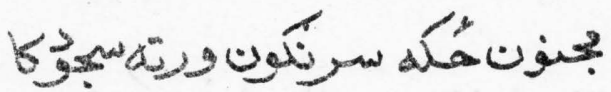

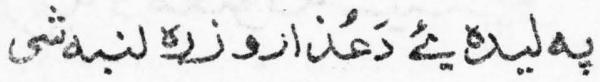

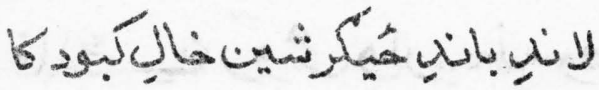
توزينيّن

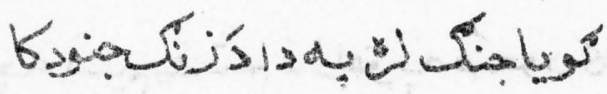

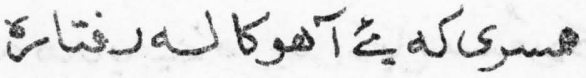
S>95

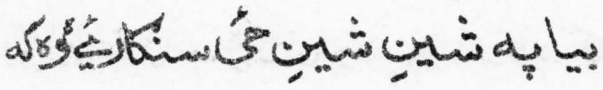

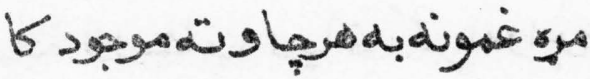
Sadch ك́

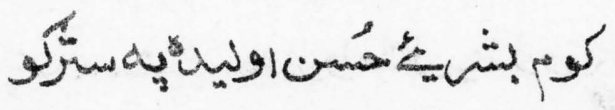




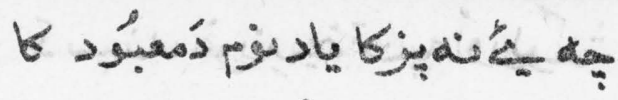

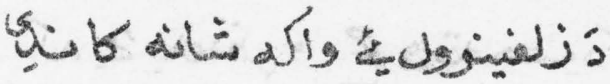

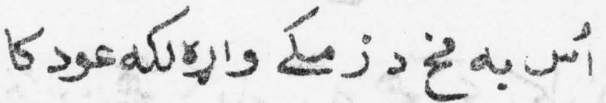

Gojdio a rbig a

$6,9+2 k$ da

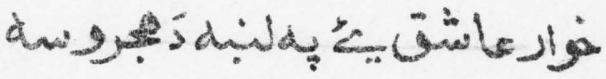

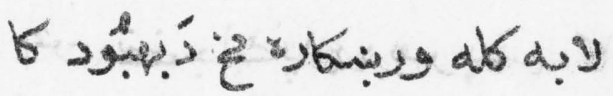

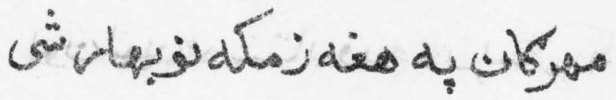

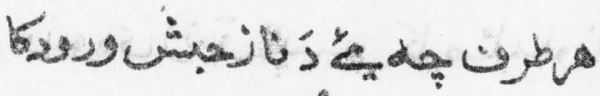

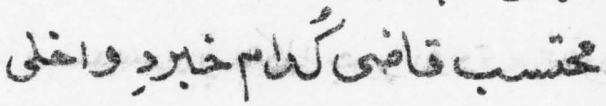

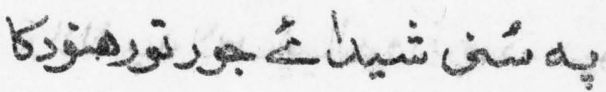

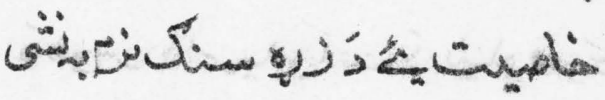

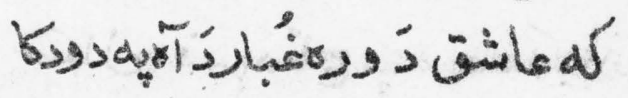

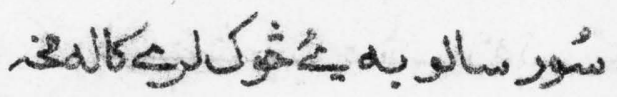

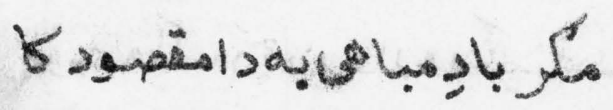




\section{ديوانِ}

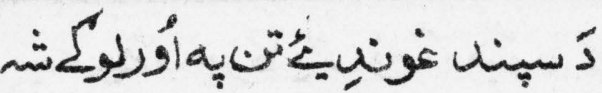

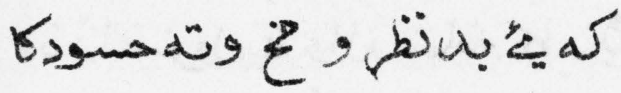

subcstar a

$6>$ ga

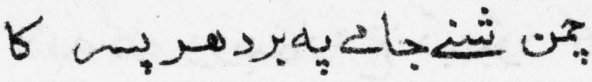

لونولة

2112

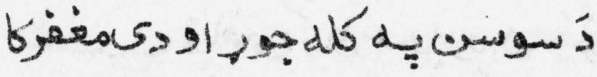

هـ

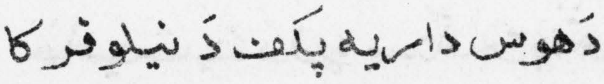

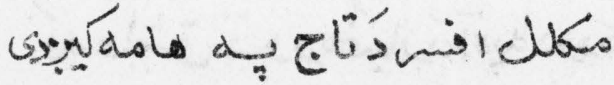

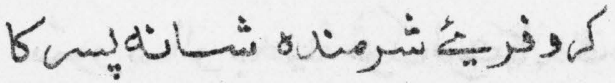

Gdifisall 


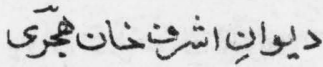

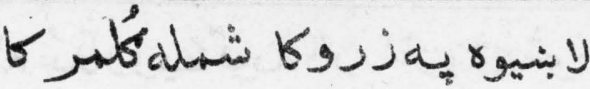

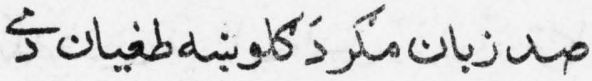

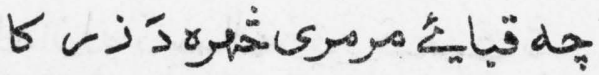

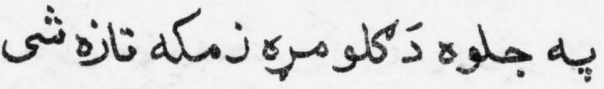

كل عالمي عله نوروزهكروفركا

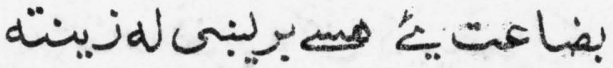

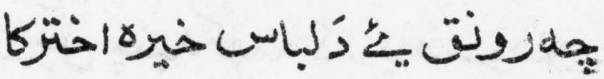

دضياتيخله

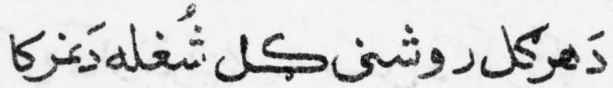

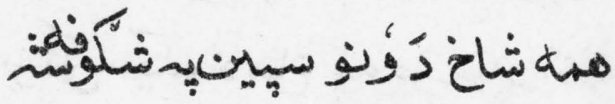

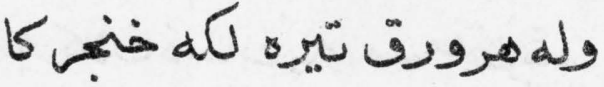

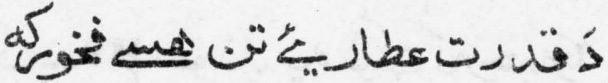

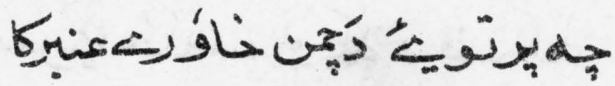

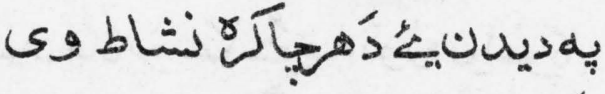

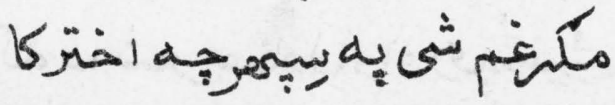




\section{بوابن}

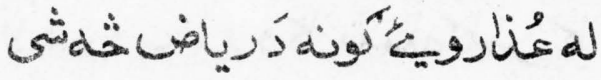

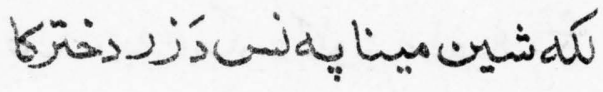
-

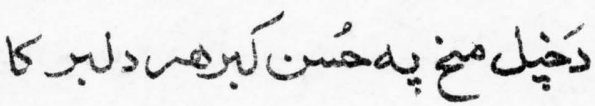

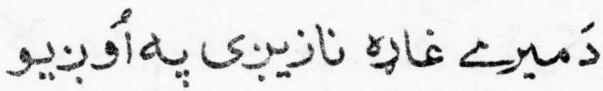

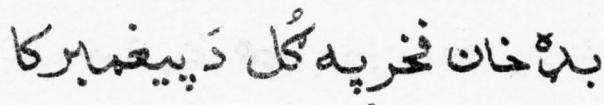

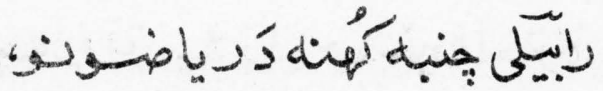

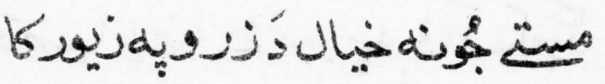

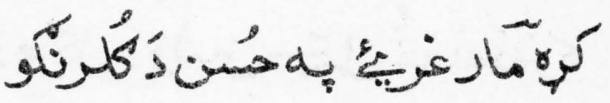

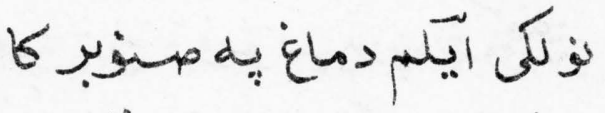

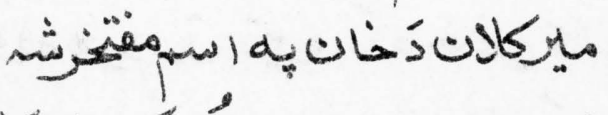
د بنه a

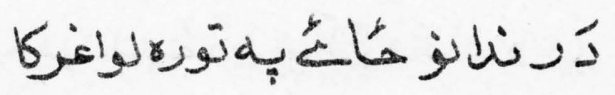

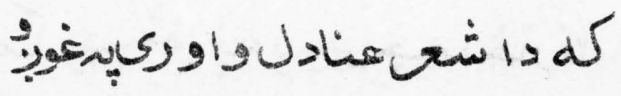




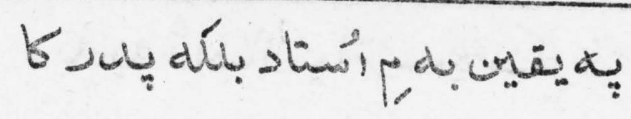

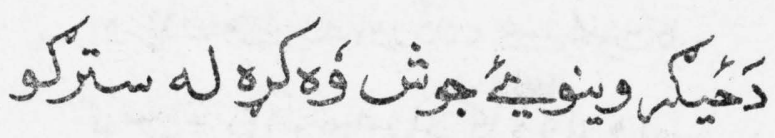

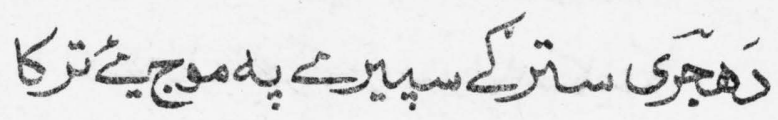

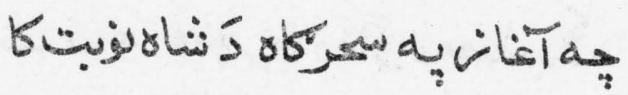

رابه ياد ذَهن

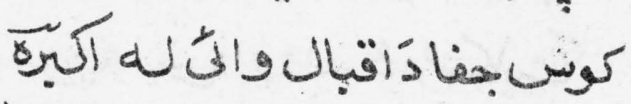

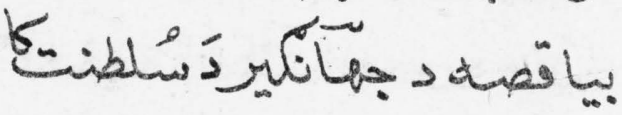

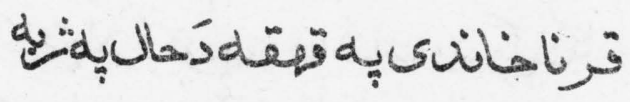

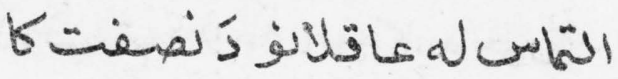

.

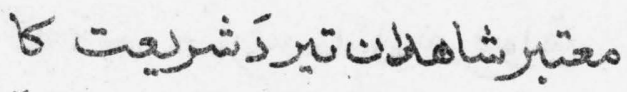

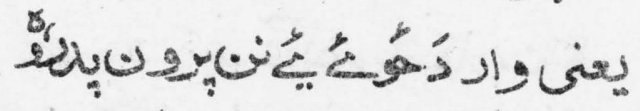

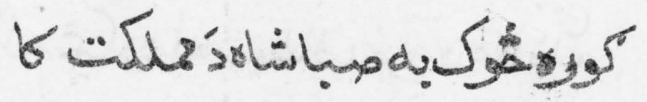




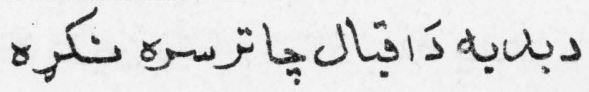

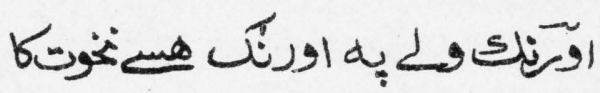

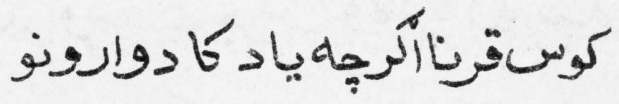

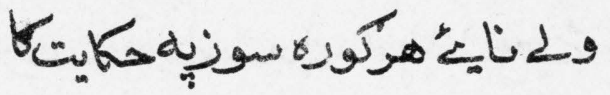

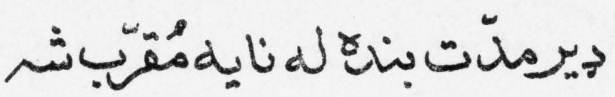

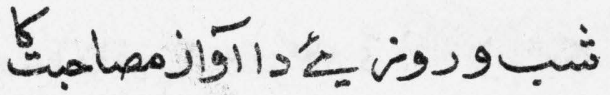

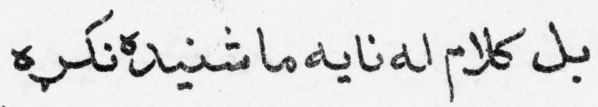

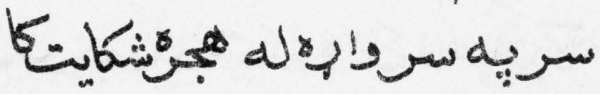

كأك

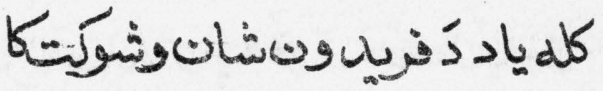

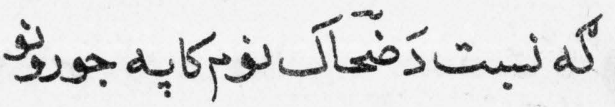

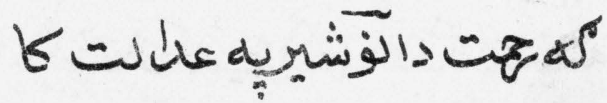

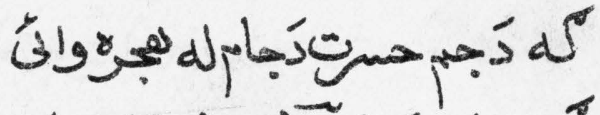

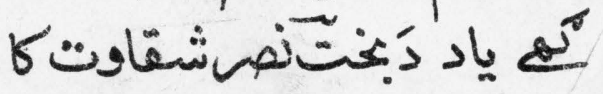

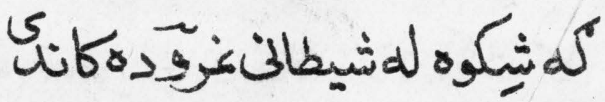




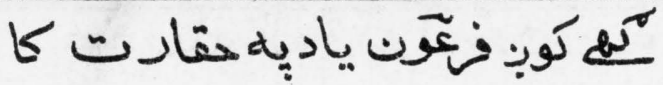
r) sevalseg alvitrabjá

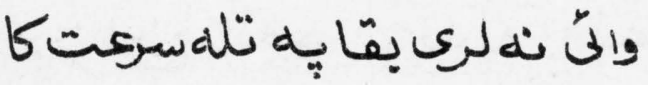

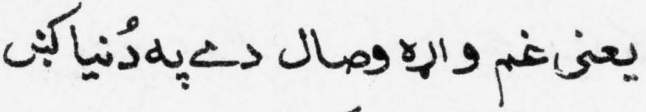

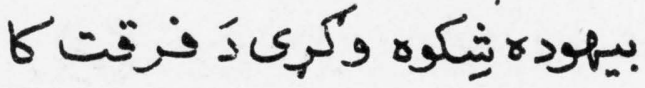

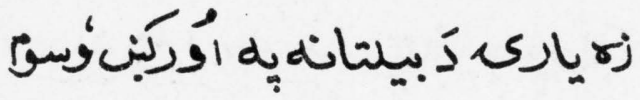

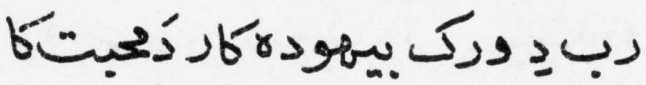

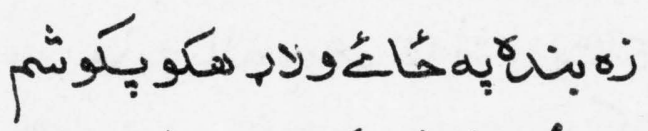
جهُ

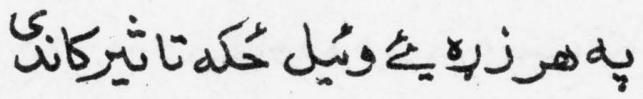
جها

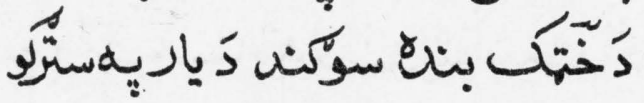

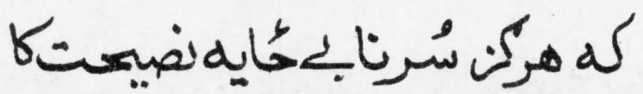

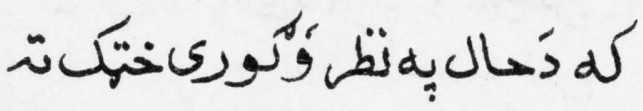

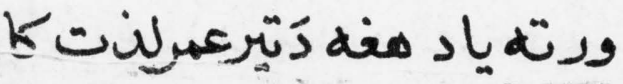




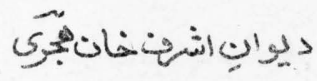

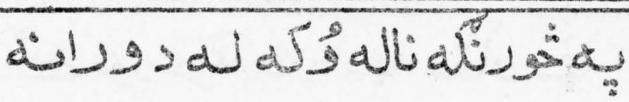

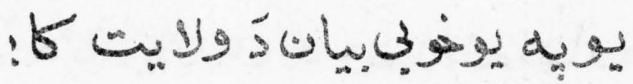

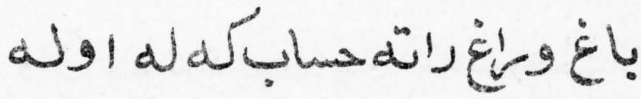

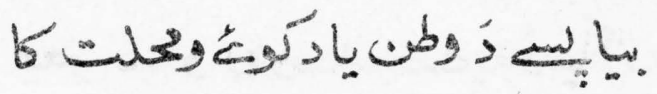

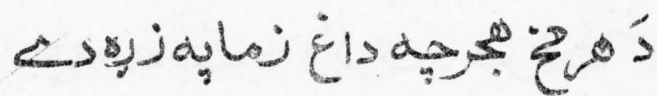

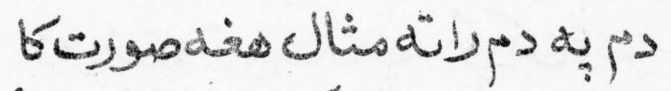

ssis

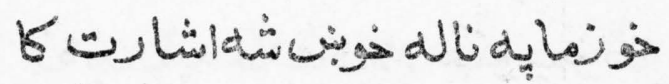

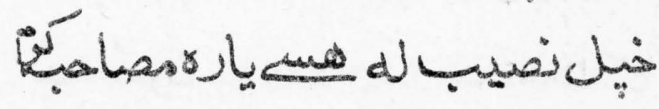

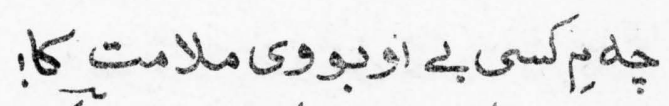

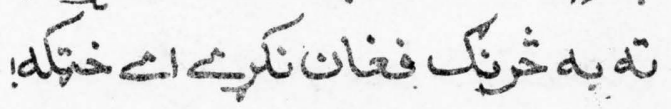

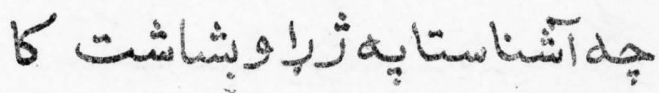

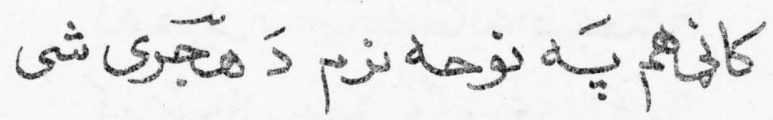

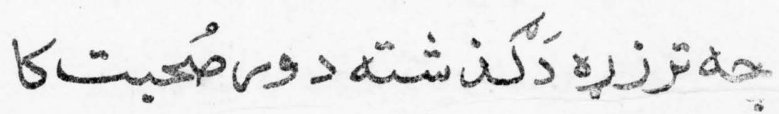




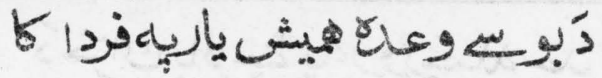

KLiglad

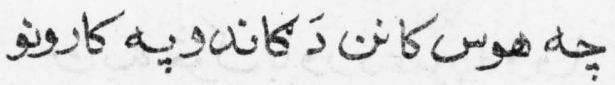

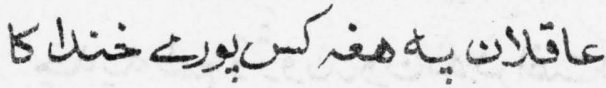

'sididos

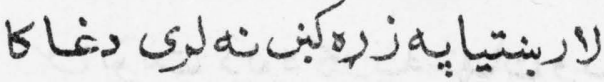

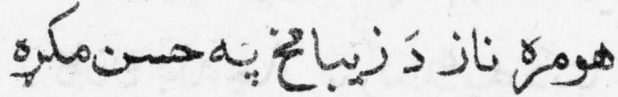

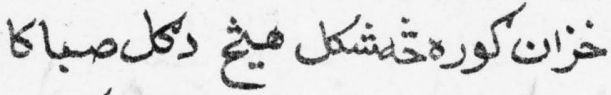



زيانة

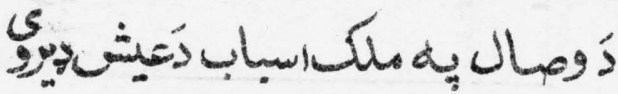

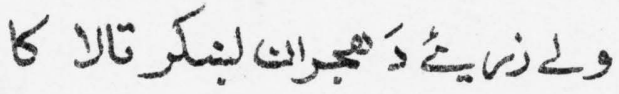

ركل

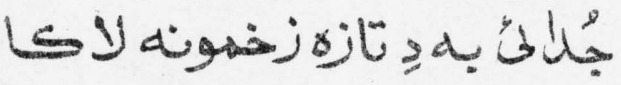

ك- 


\section{ديوالِيشتحناشهي}

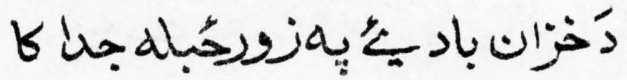

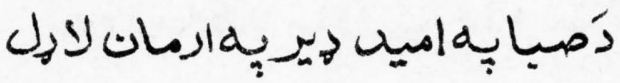

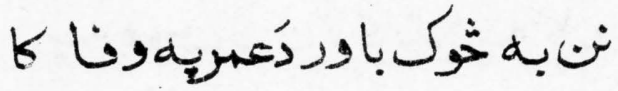

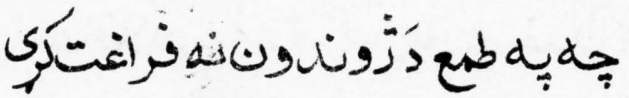

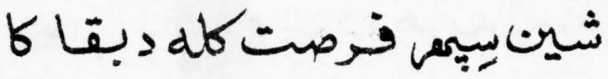

نت نوبت دُيوهكاريه جهات وينم

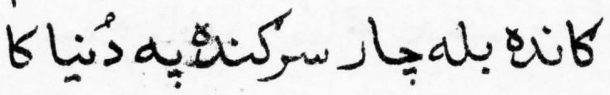

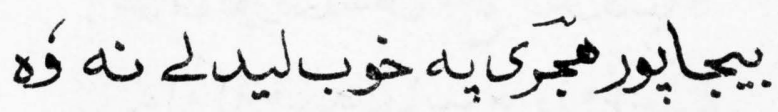

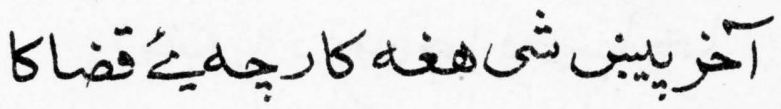




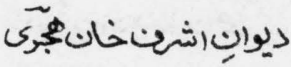

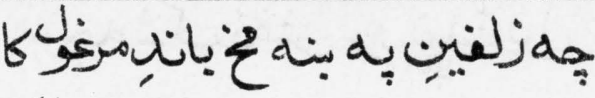

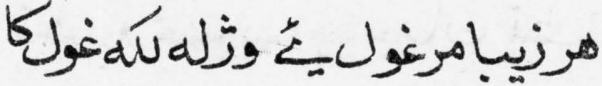

هرجها

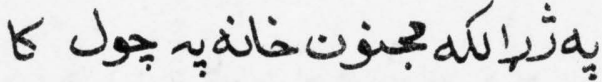

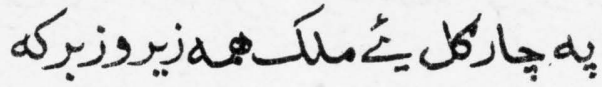

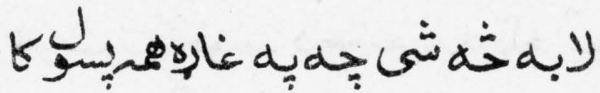

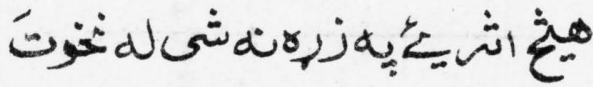

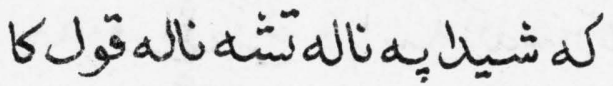

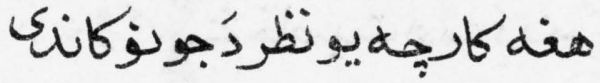

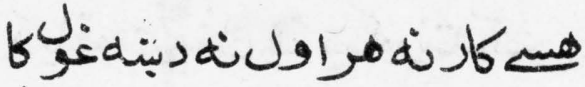

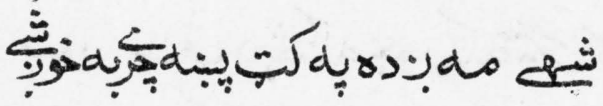

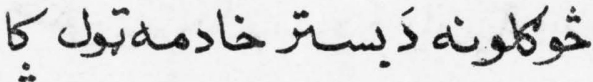

شتى

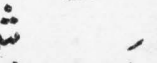

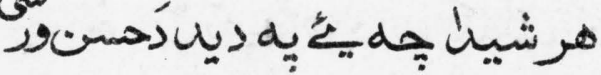

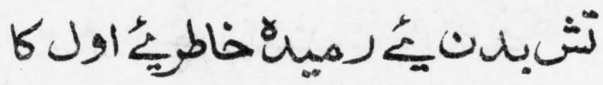

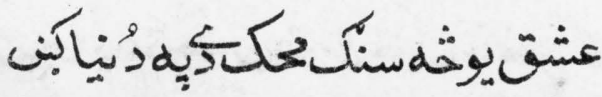




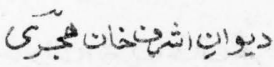

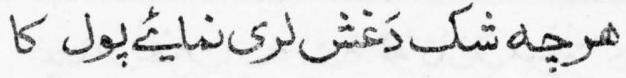

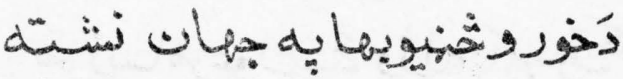

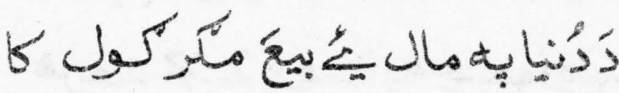

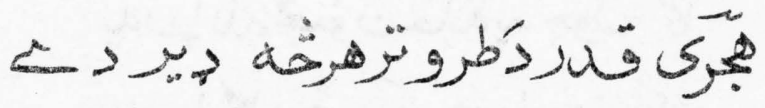

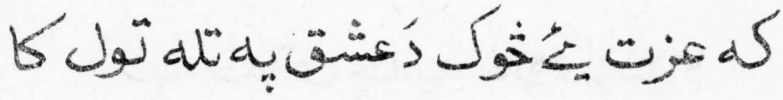

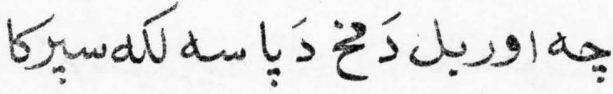

د'

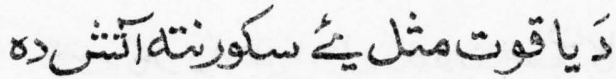

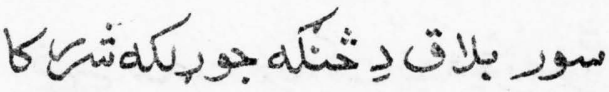

:

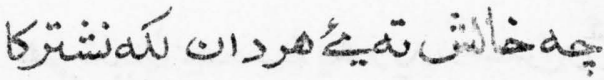

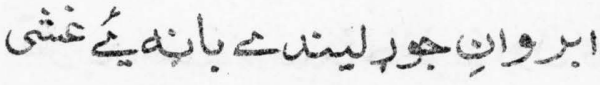

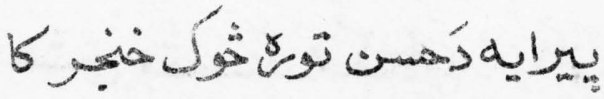




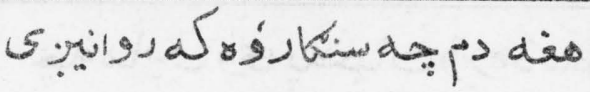

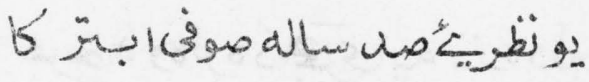

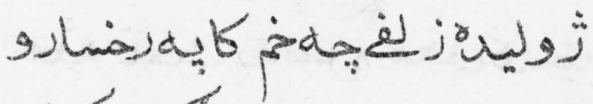

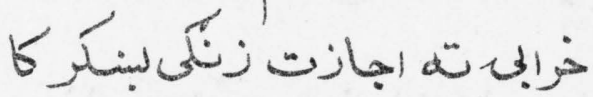

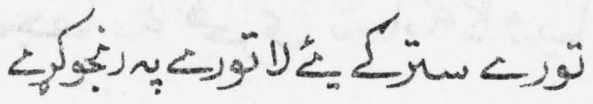

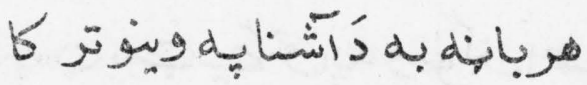

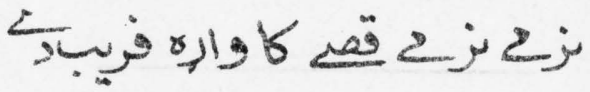

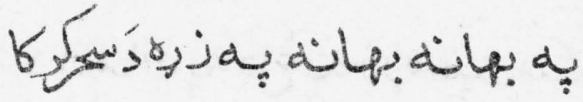

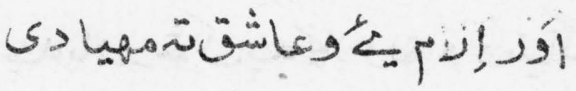

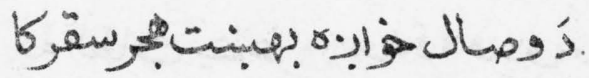

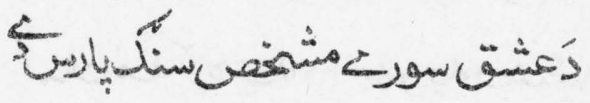

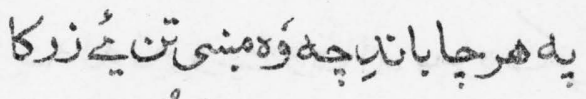

(5)

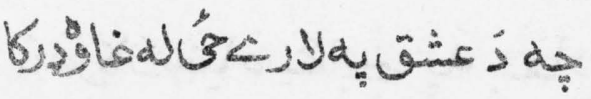

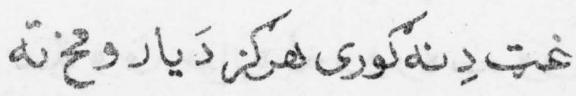




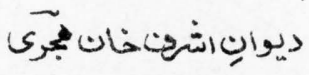

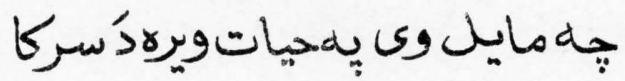

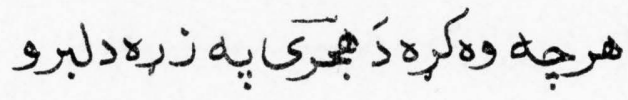

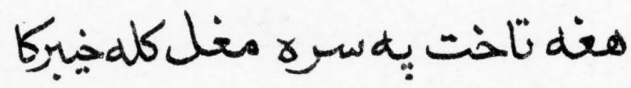

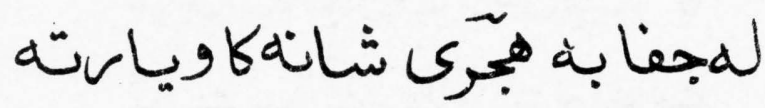

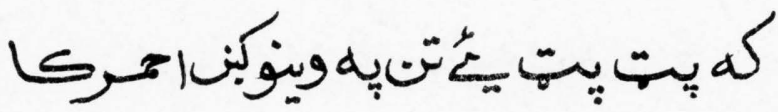

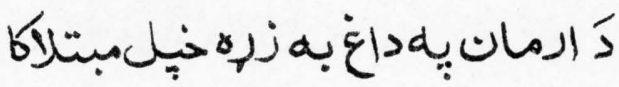

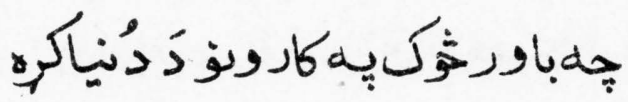

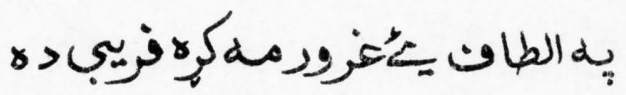

كُ

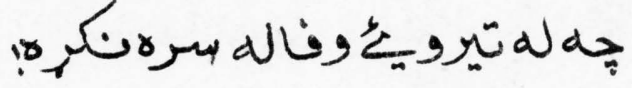

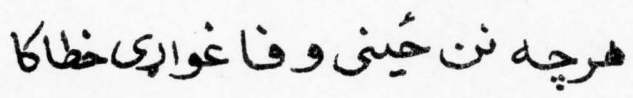

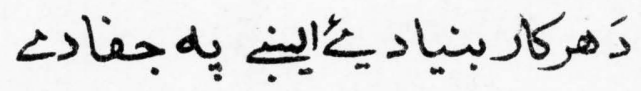

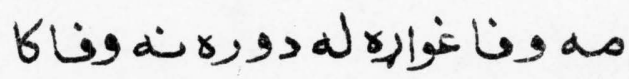




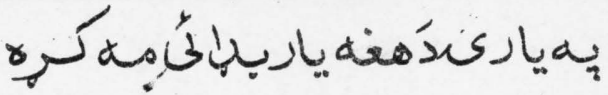

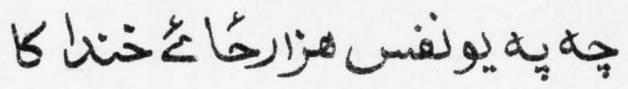

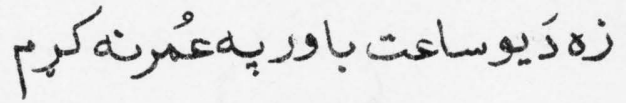

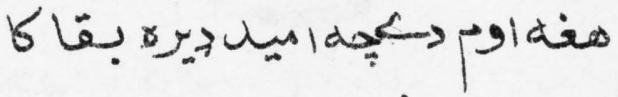

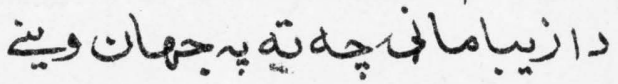

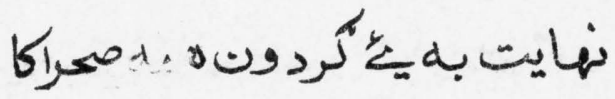

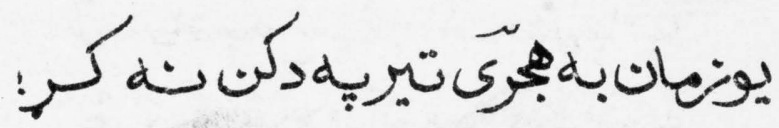

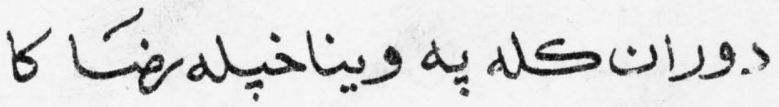




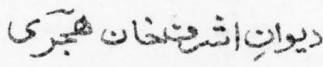

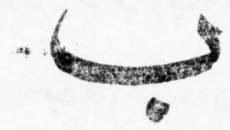

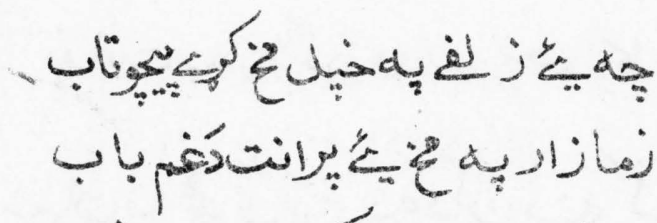

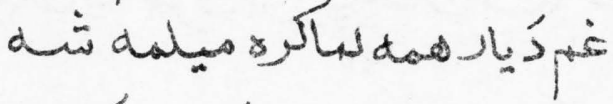

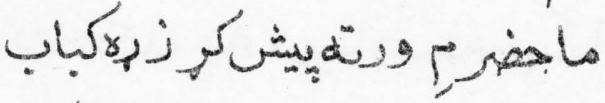

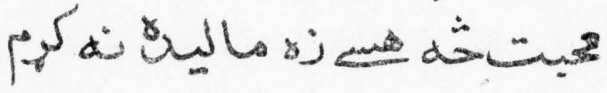

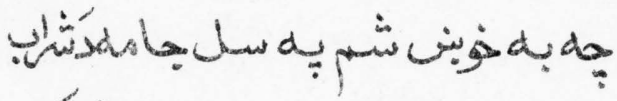

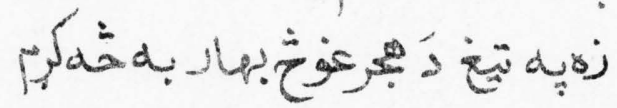
زبر

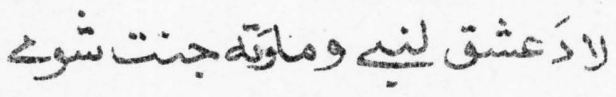
بأيأ 


\section{دانِ}

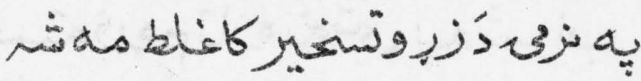

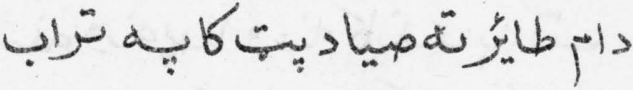

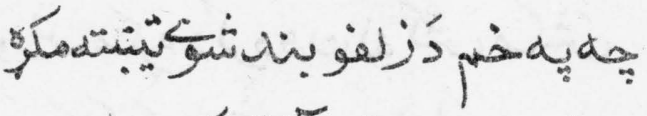

$\because$ S

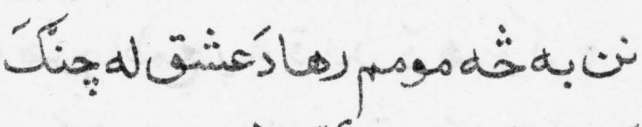

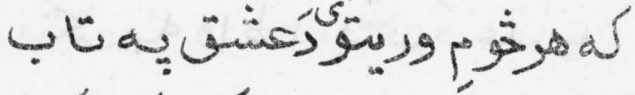

r

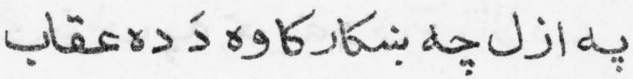

is

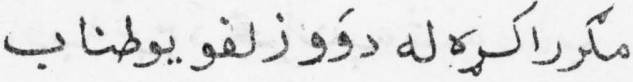

هـ ش

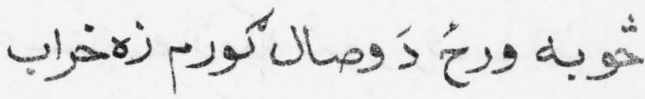

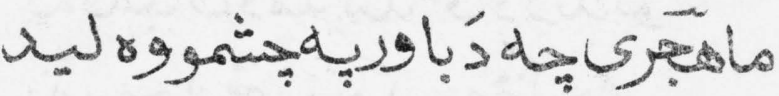

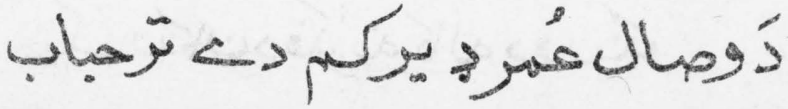




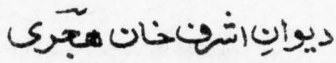

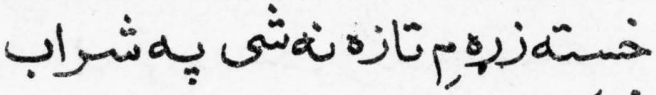

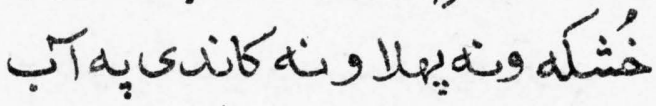

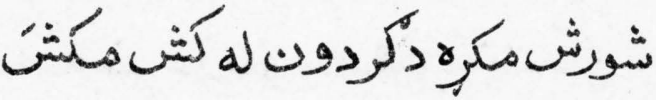

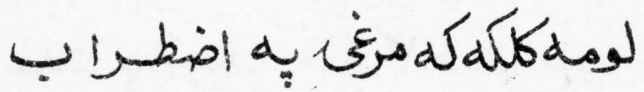

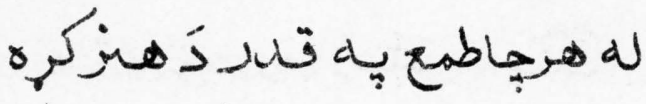

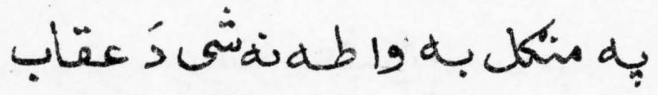

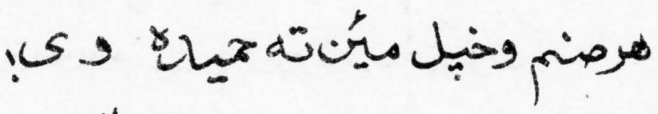

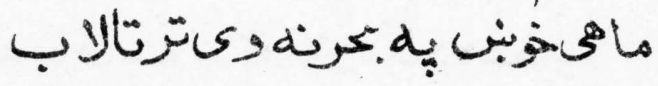

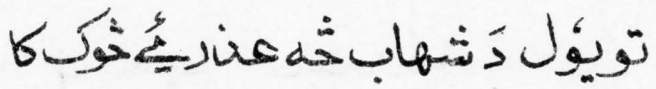

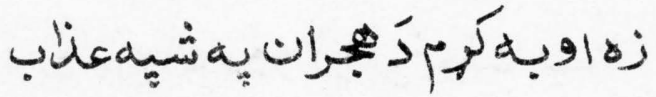

كأسارية

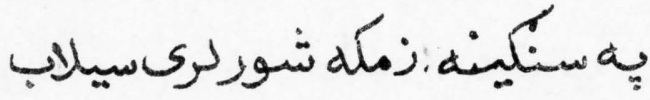

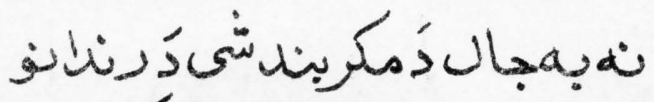

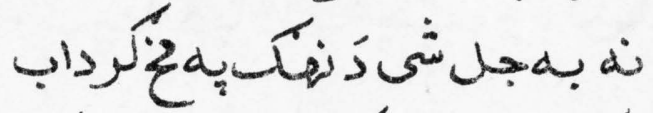

يك رنكالن 


\section{ديواثِ اثنتنان يجرى}

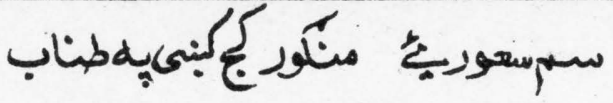

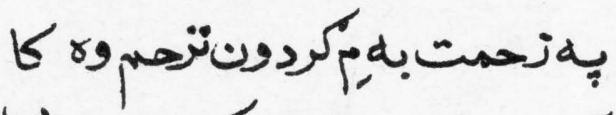

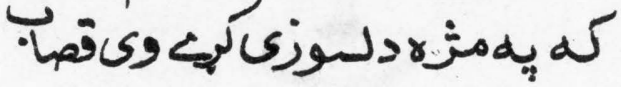

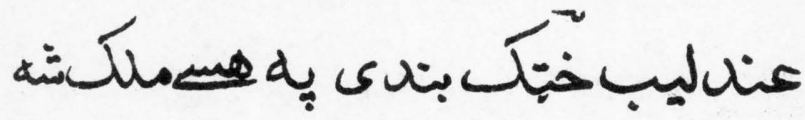

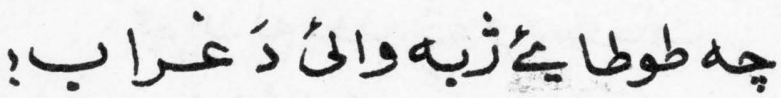




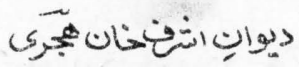

\section{6}

S'

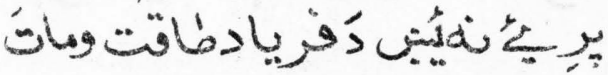

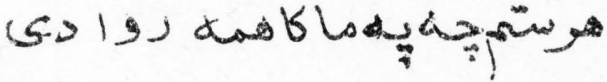

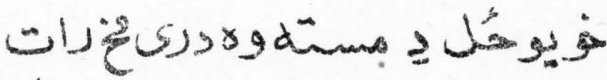

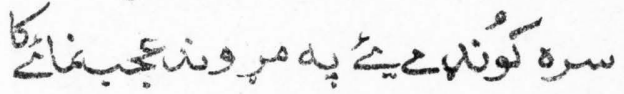

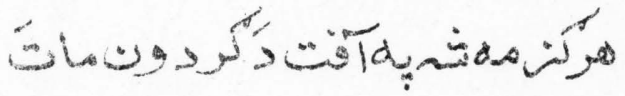

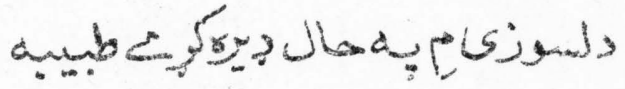

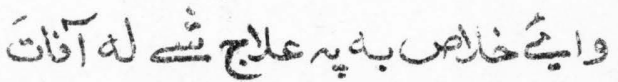

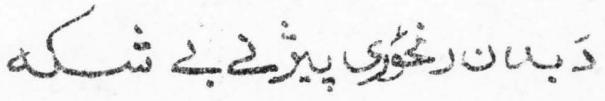

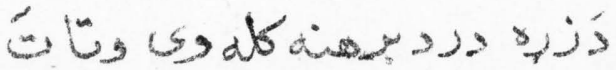


ديوانِانترونانهيجي

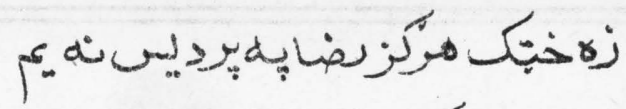

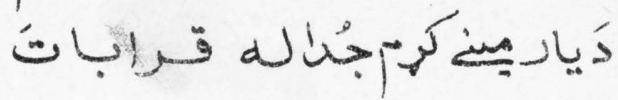

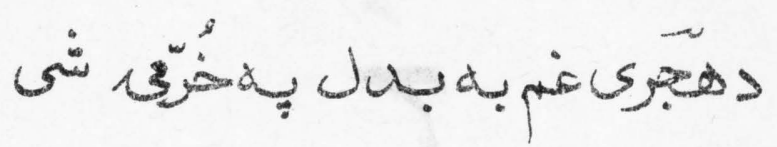

كرئه

No 


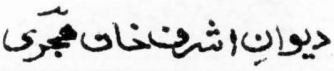

\section{5}

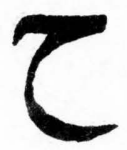

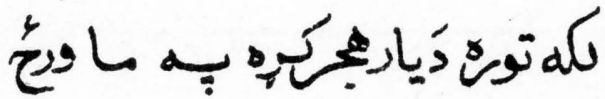

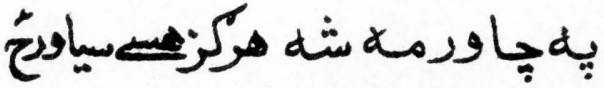

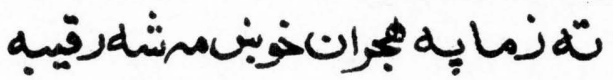

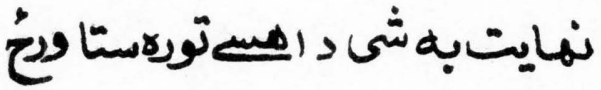

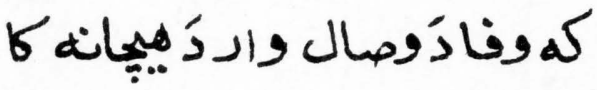

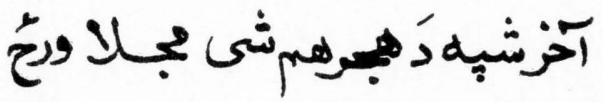

دَشبابِدَبهارورِّرَّكوبنه وره

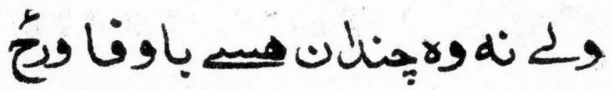

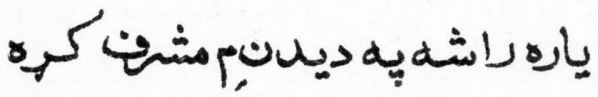

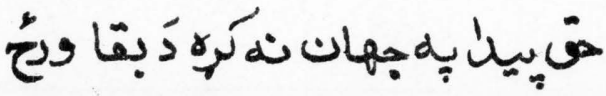




\section{ديوانِاشخنانهري}

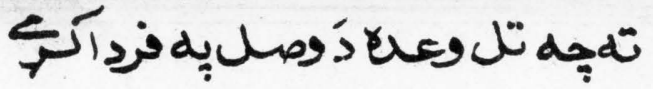

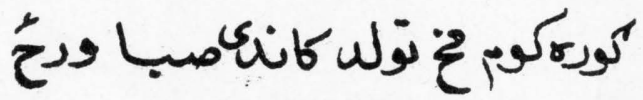

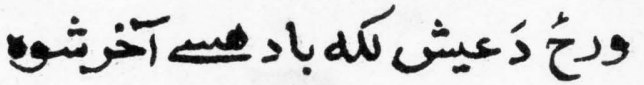

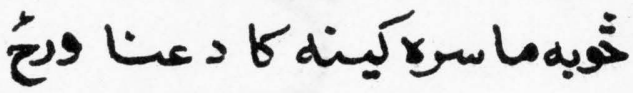

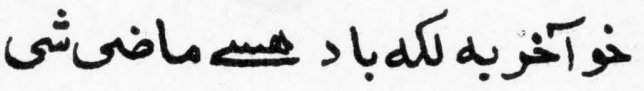

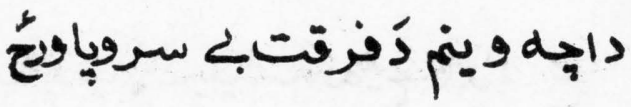

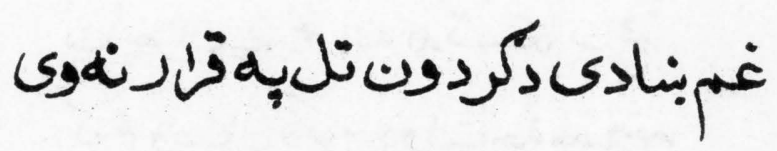

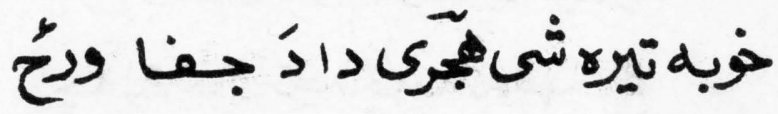




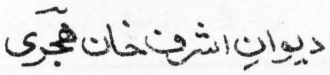

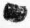

Axtragy

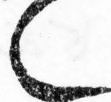

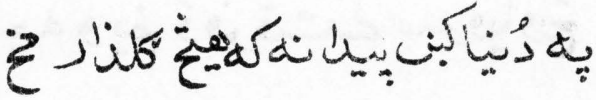

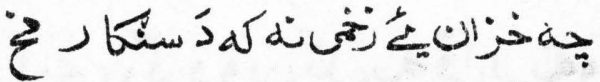

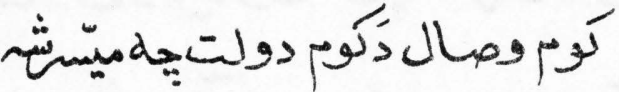

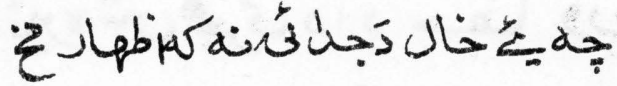

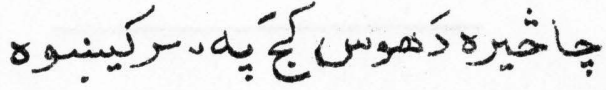

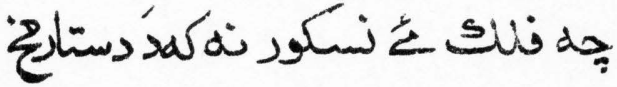

جاه معيوبئه خط وخال دَفنانيوي

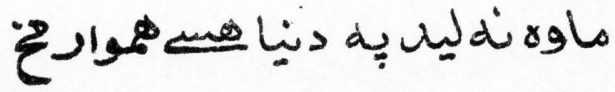

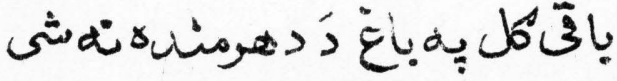

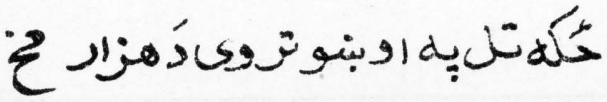


useovirim)

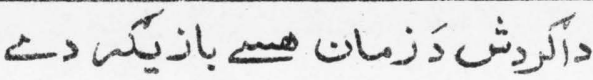

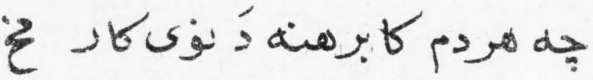

Koic

¿

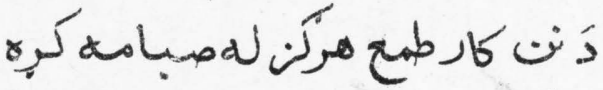

\& o

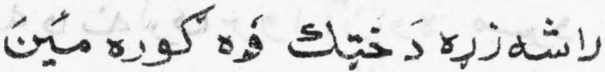

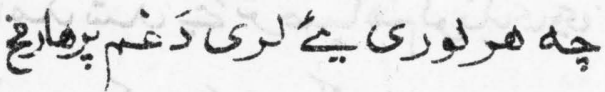

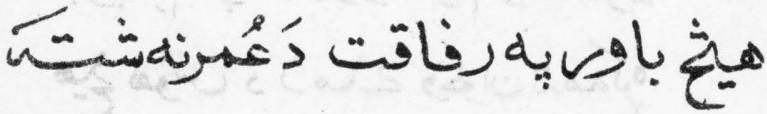

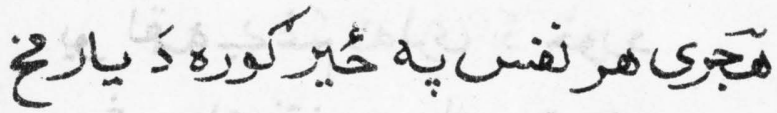


ديوانِاشعنخانتهجرى

غي بنادى دَجبان بادكيه ياكرد

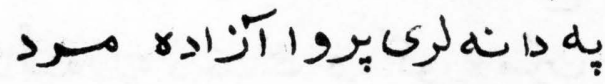

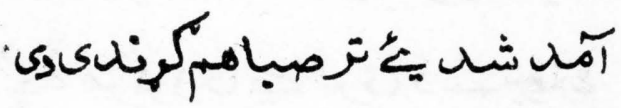

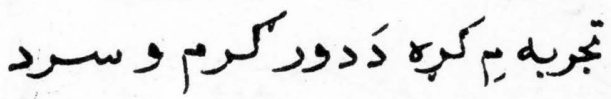

هيخ هوس دَ ذمالح وخوات تخمهكج

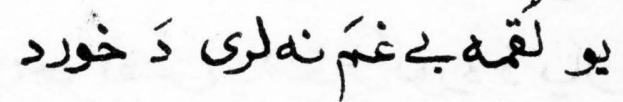

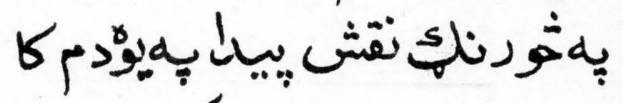

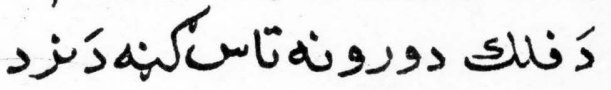

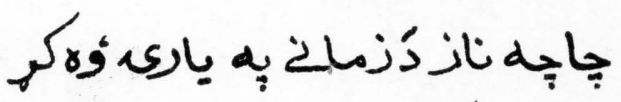

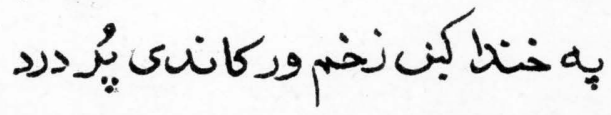

F. 


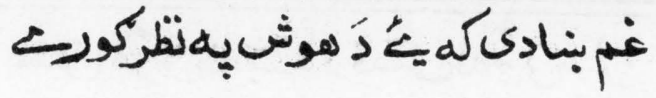

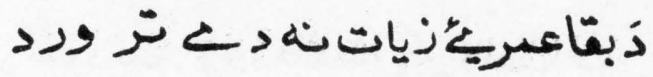

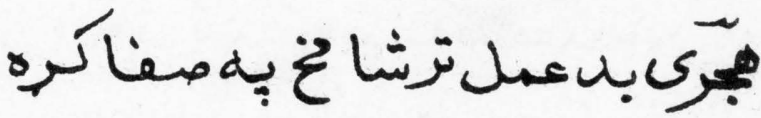

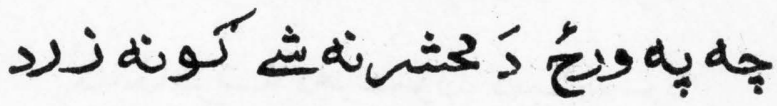

هورَزمه شتهستالمحبه ذريو ذماسرد

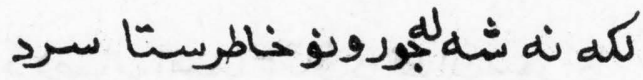

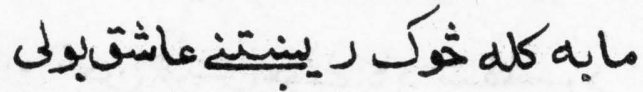

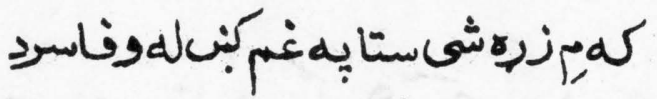

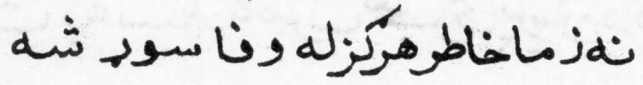

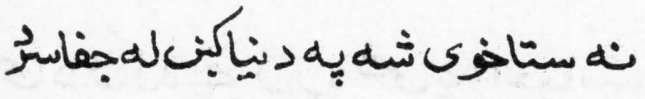

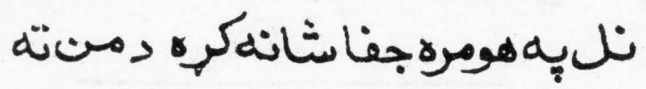

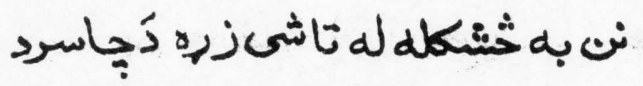

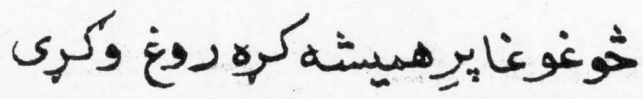




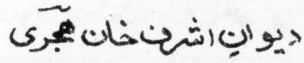

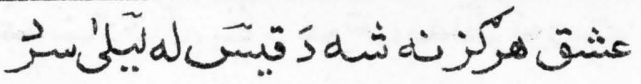

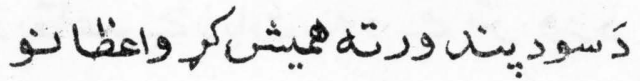

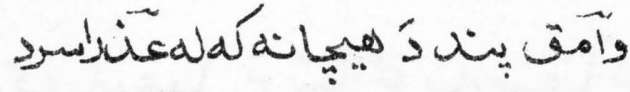



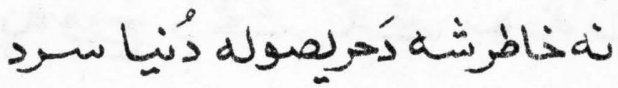

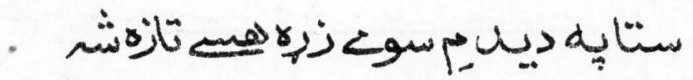

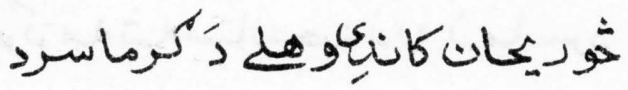

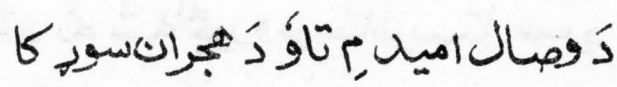

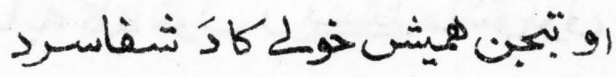

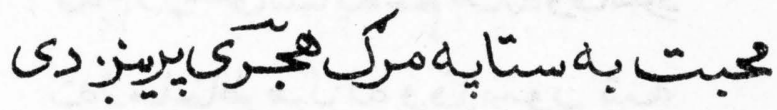

لباسى 


\section{$\checkmark$}

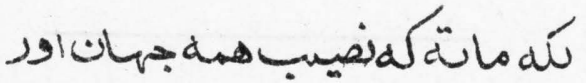

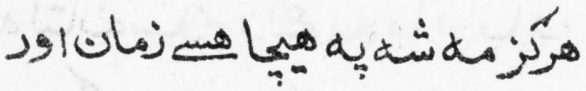

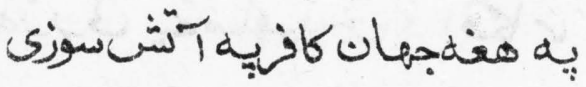

مجربل

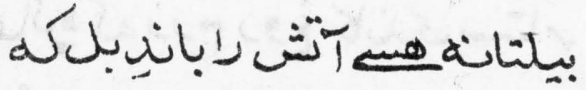

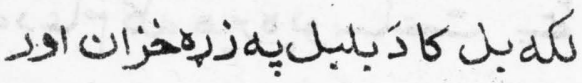

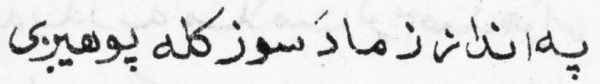

جاجيجا

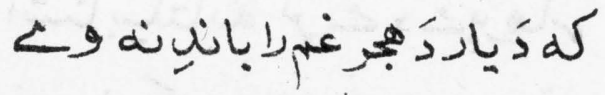

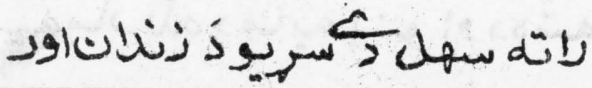




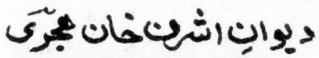

جورهومرطفيان وركر 3 سر الن

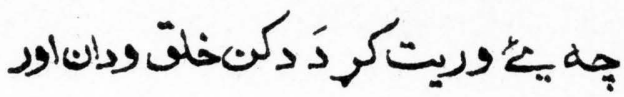

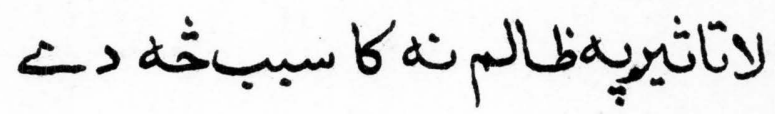

رَهجرى يمه هر سكرلولن د هان هاوى

جه لثانهسلام راغ به بار بار،

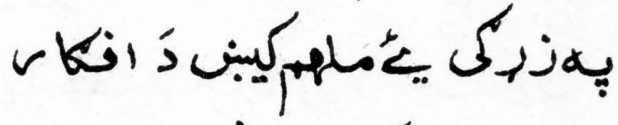

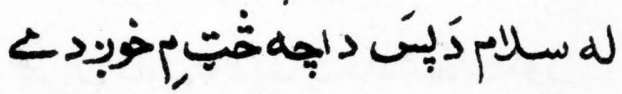

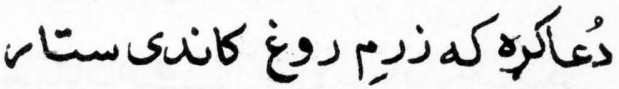

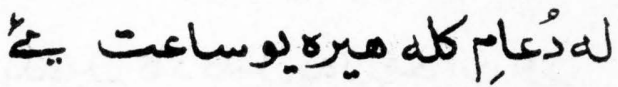

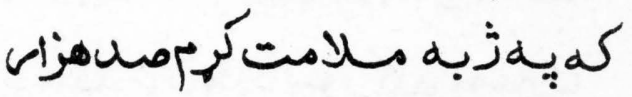

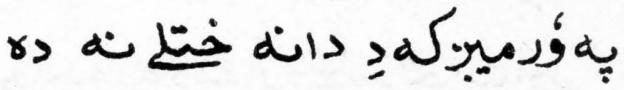

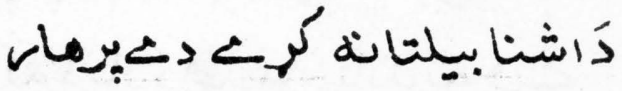

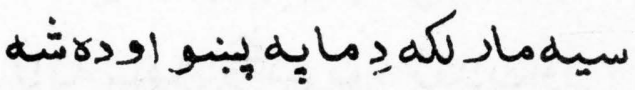




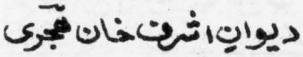

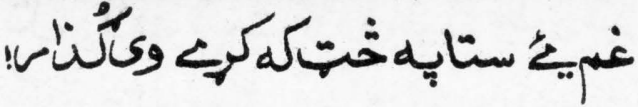

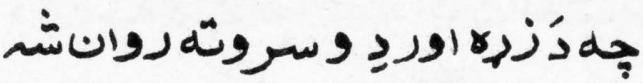

له هنه تاوككودت دِ شه بيهال

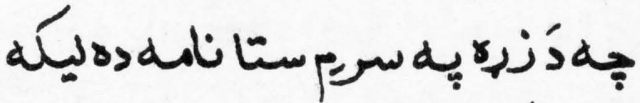

كانمكر

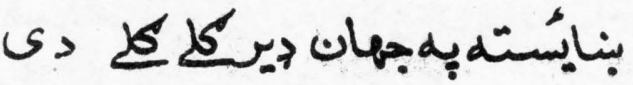

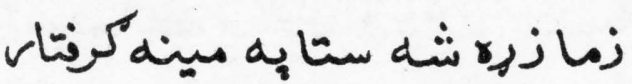

يماهرزاتاضتز

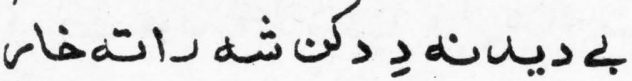

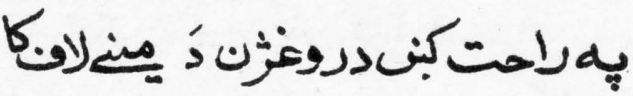

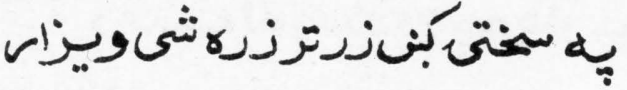

بهاخلاصشهراروانه فكرمكري

و همت وتهشى لنهُ لويه لام

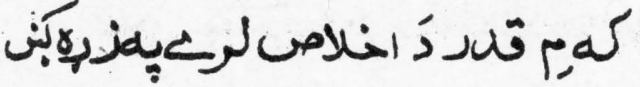

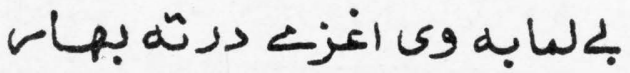




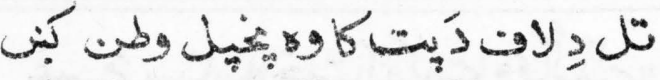

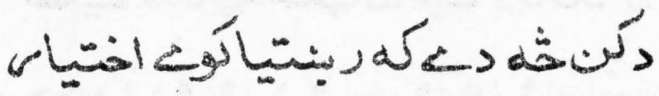

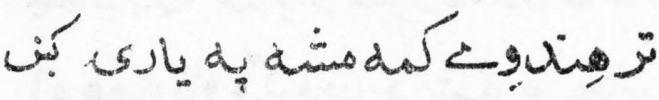

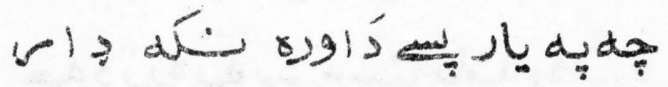

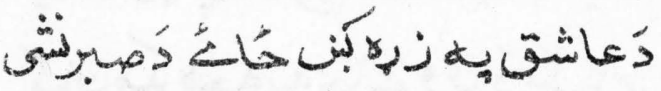

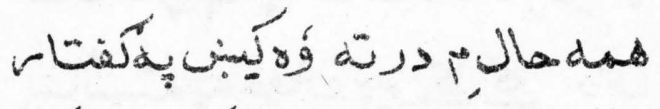

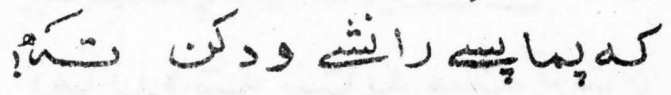
به درونة

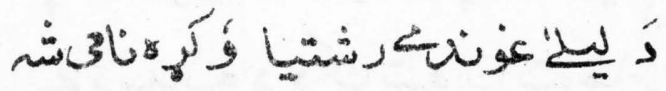

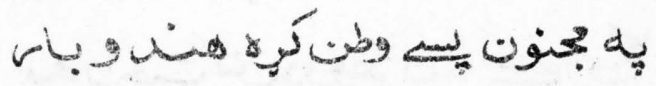
غد

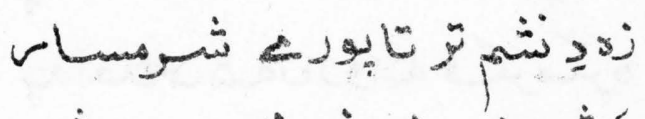

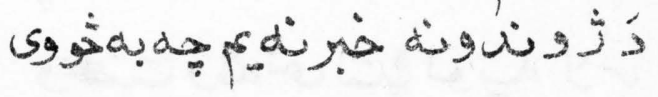
كأملفي

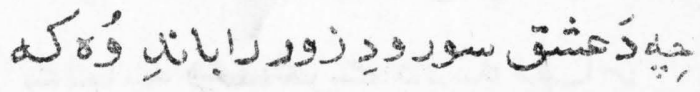




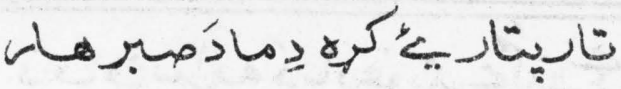

ئa

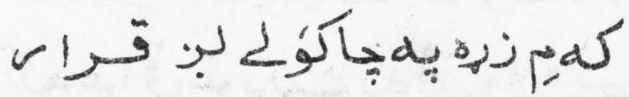

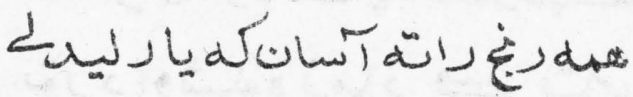

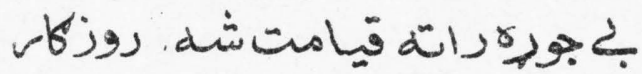

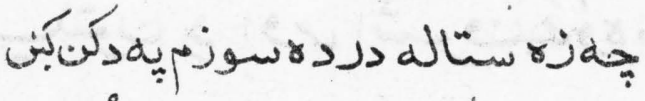

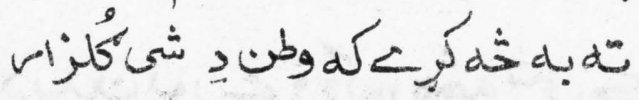

ن

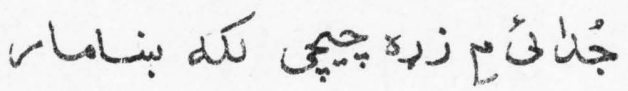

$\Delta$ -

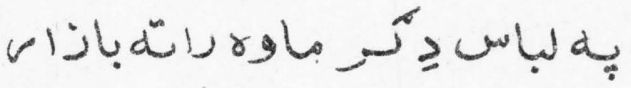

شيه 19

رَزتئاس

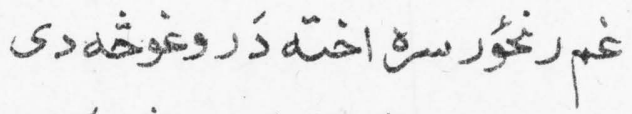

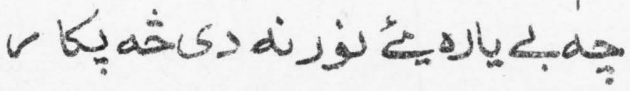




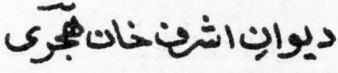

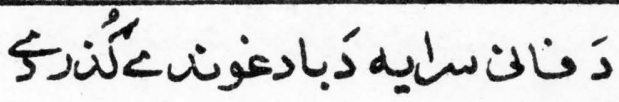

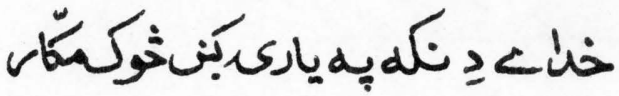

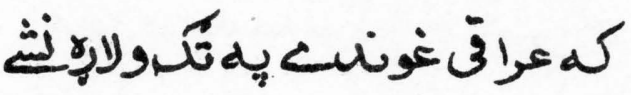

نورجِ اوشلؤه زماد' هين ئل

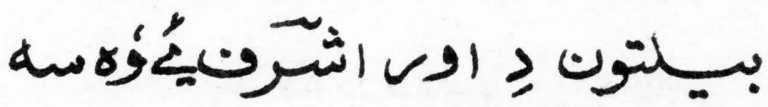

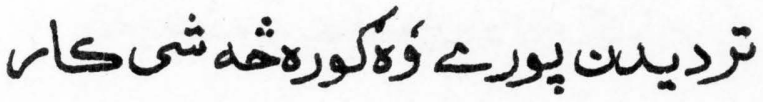




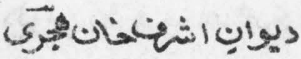

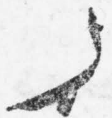

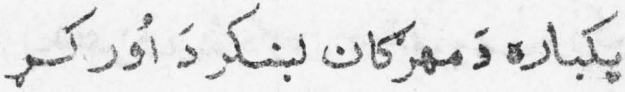

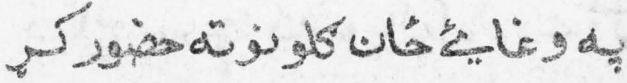

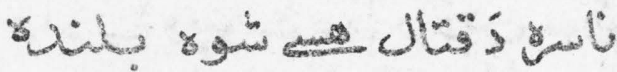

.

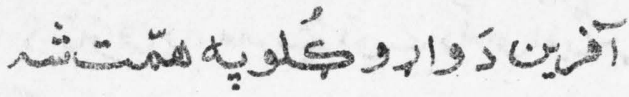

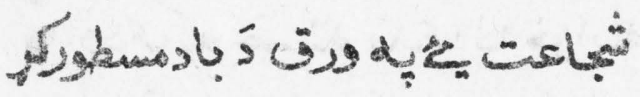

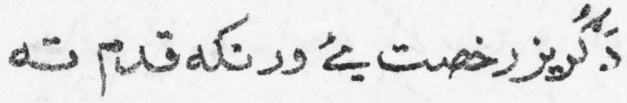

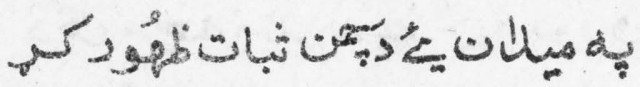

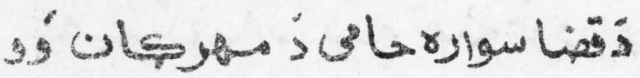

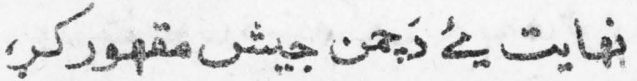




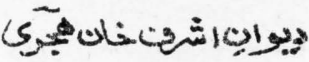

r

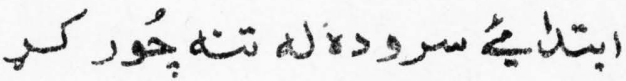

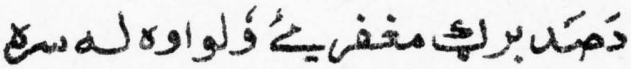

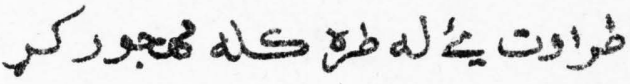

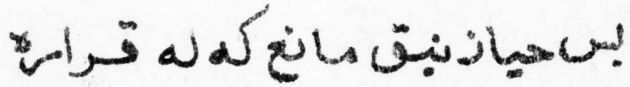

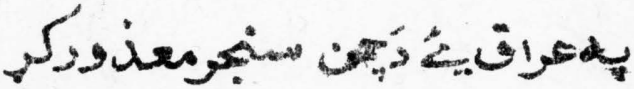

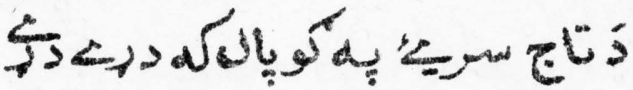

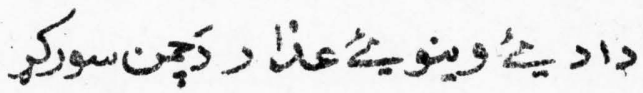
ه

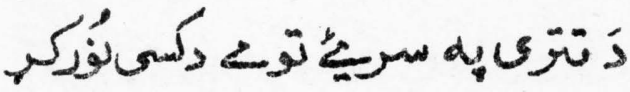

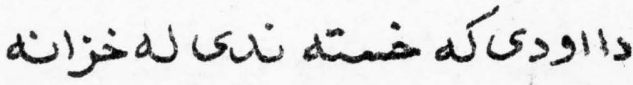

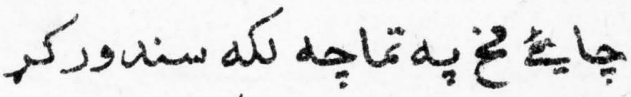

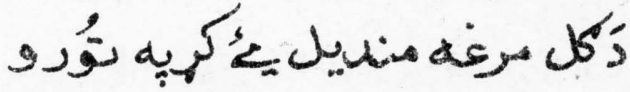
S.

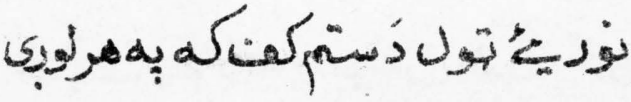




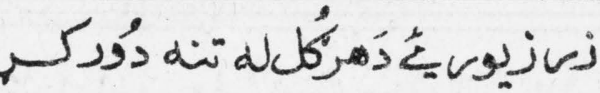

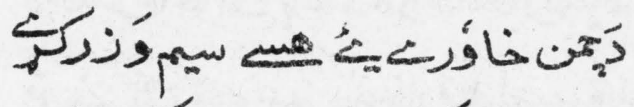

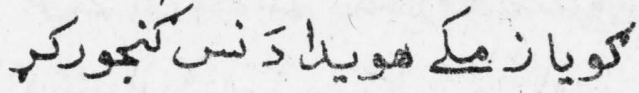

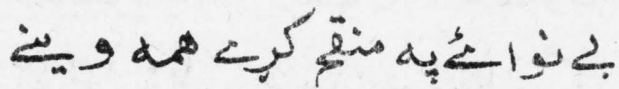

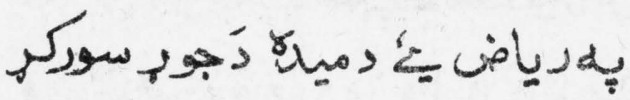

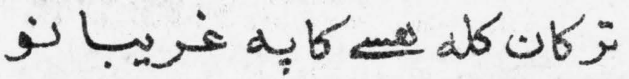

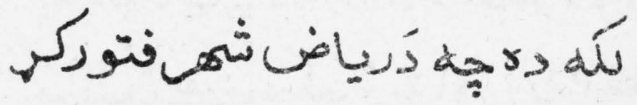

ثن

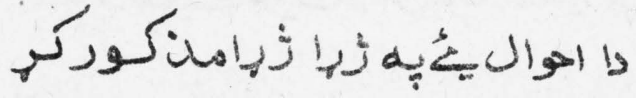

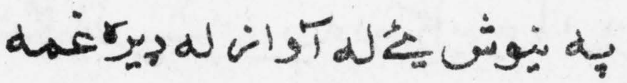

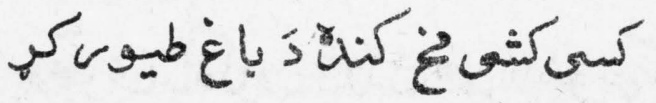

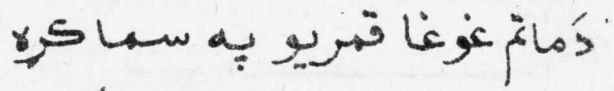

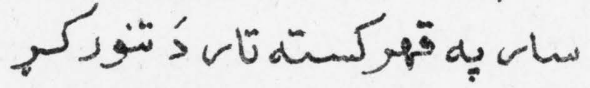

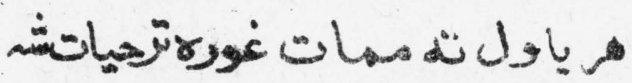

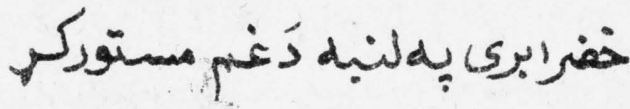




\section{ديوانِ}

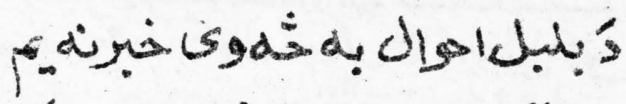

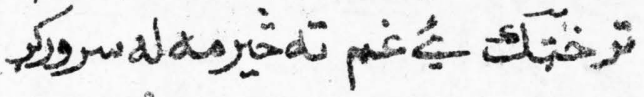



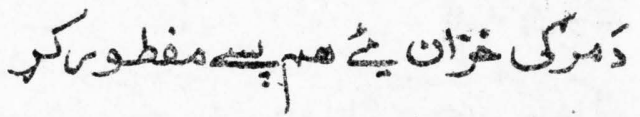

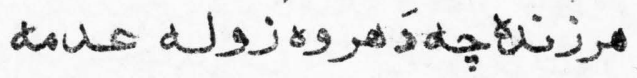

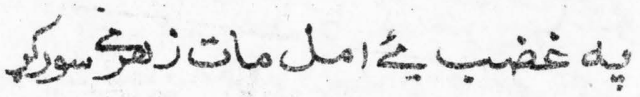

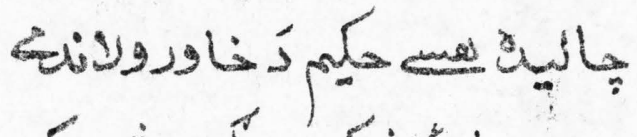

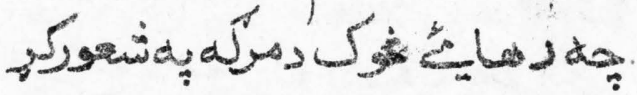

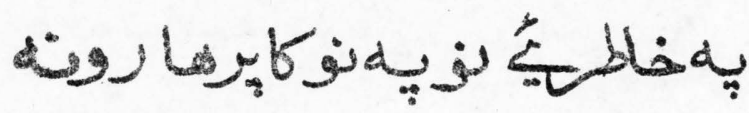

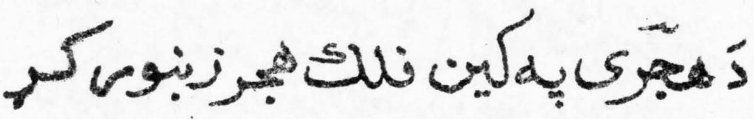




\section{حيواني اشتصنان}

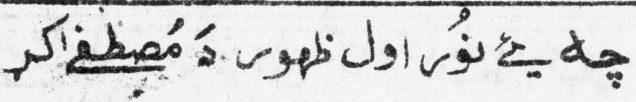

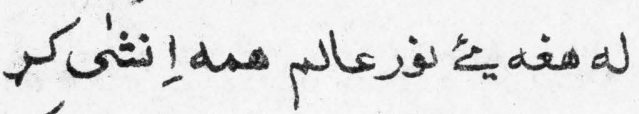

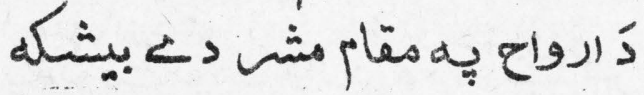

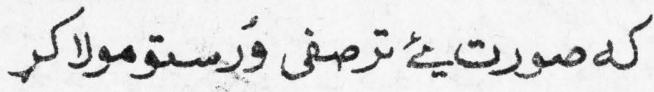

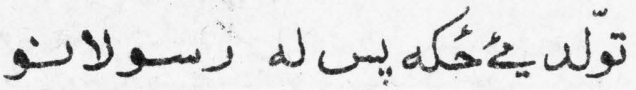
جه

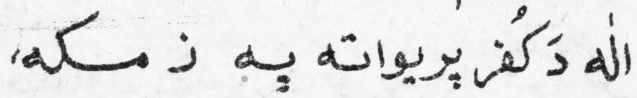
جهإ

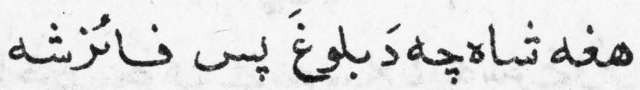

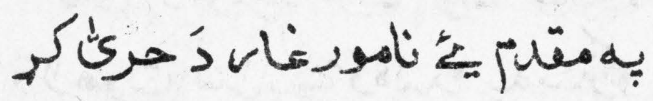

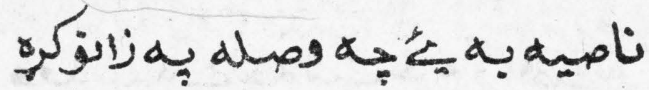

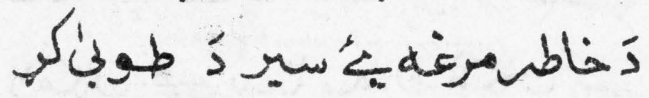

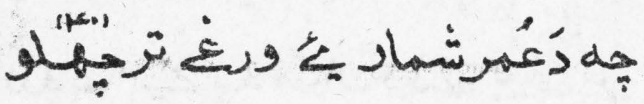

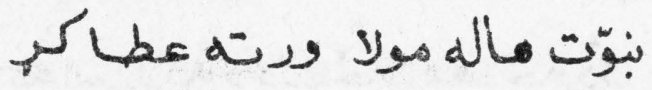

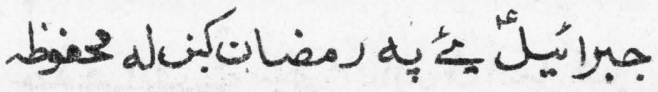




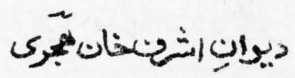

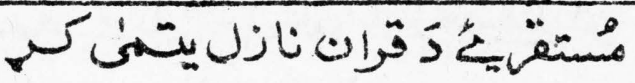

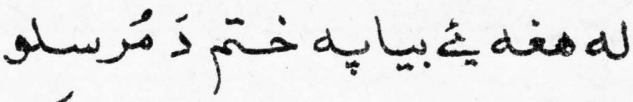

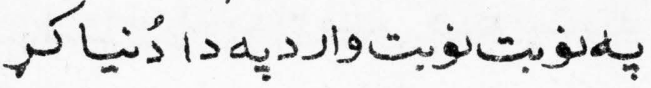

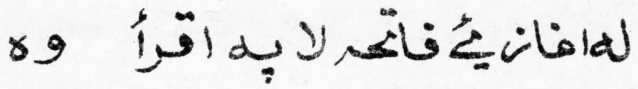

5 كإل

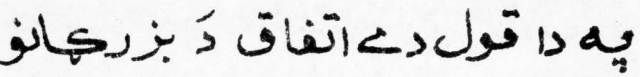

جاول

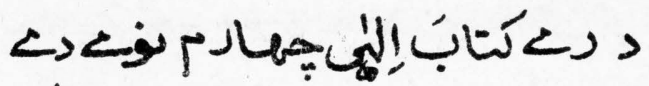

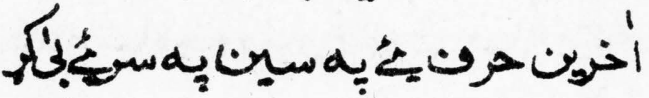

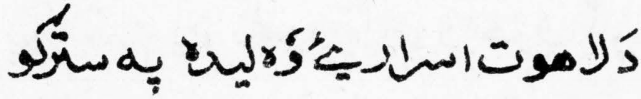

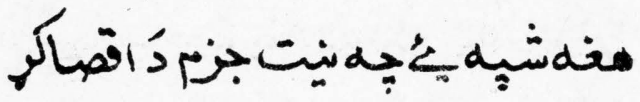

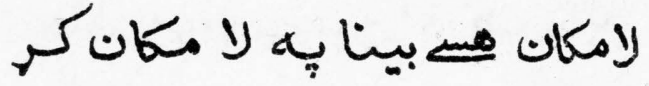

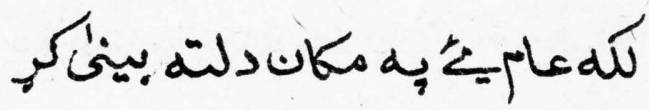

ئ

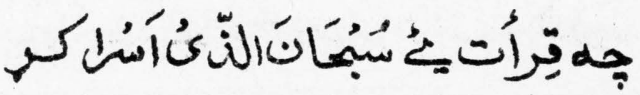




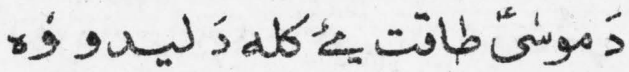

هid

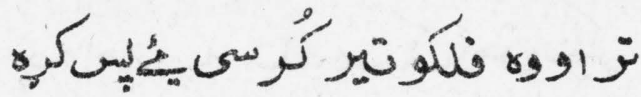

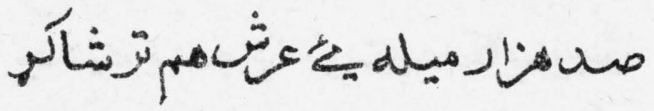

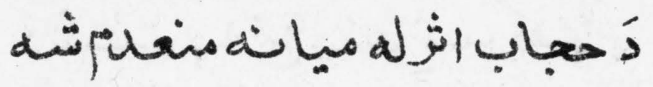

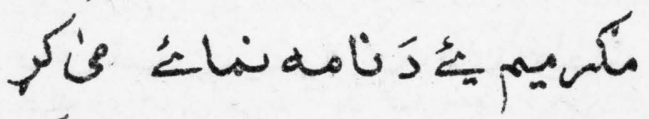

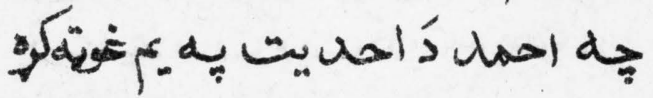

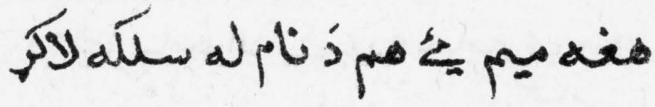

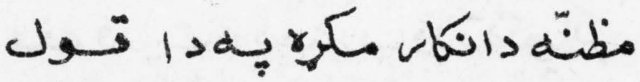

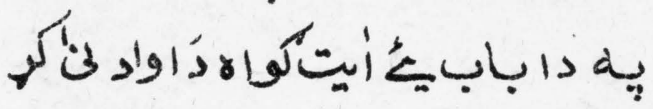

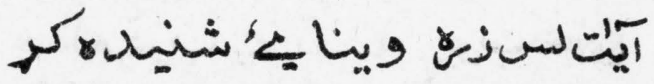
يه هويو يمُرسول قبلت د دينى'كل

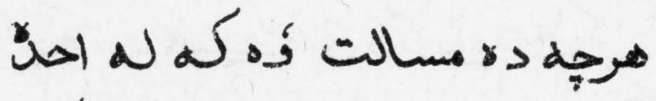

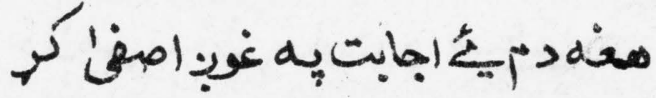

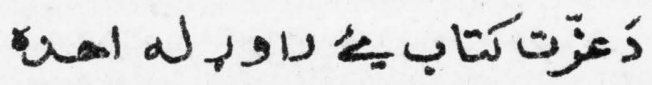




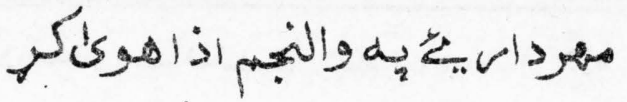

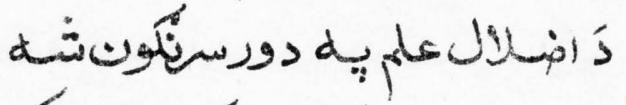

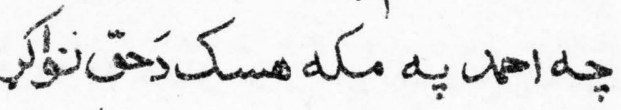

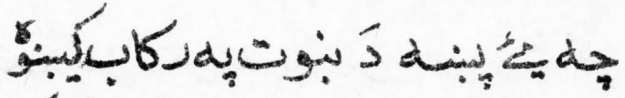

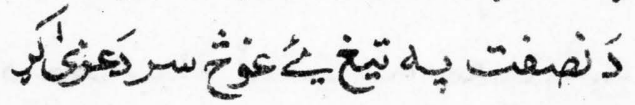

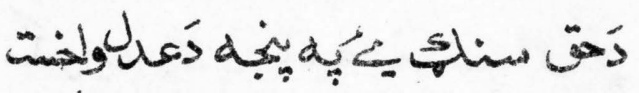

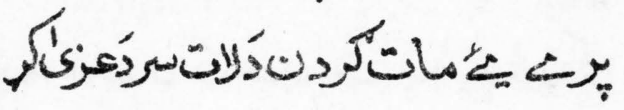

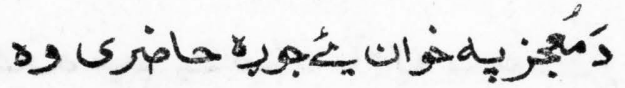

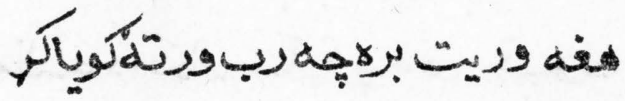

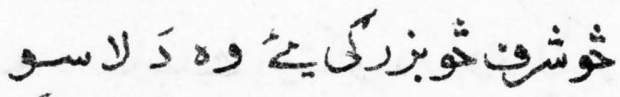
Ślás

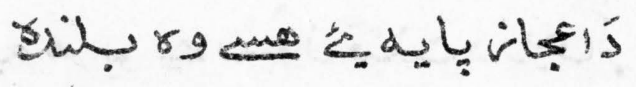

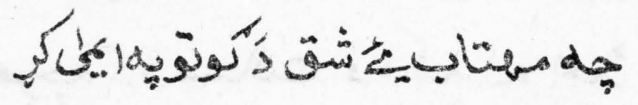

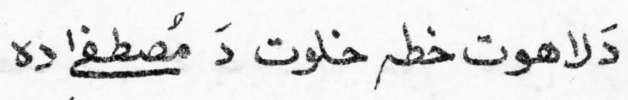

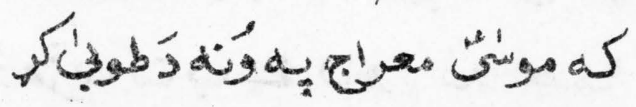




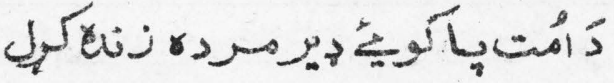

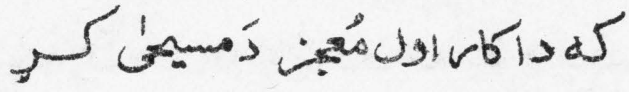

نه

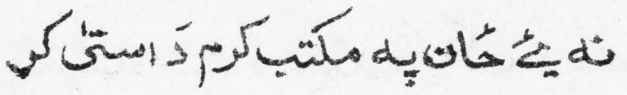

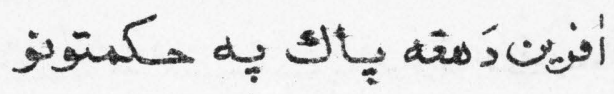

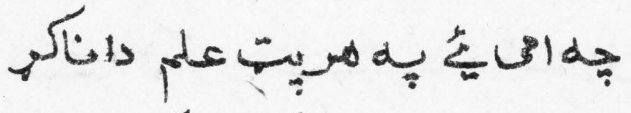

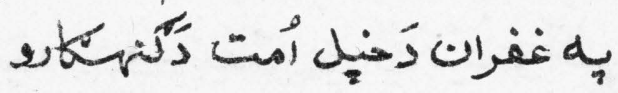

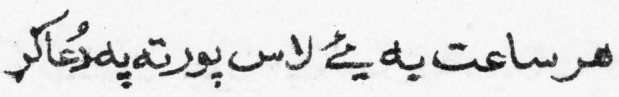

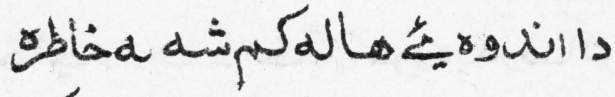

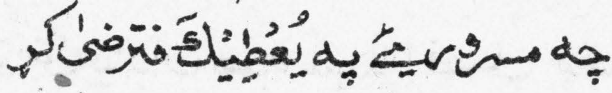
Sَّur

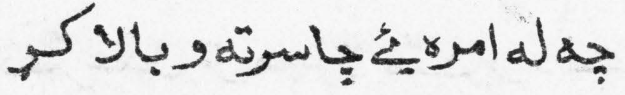

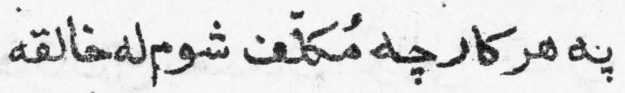

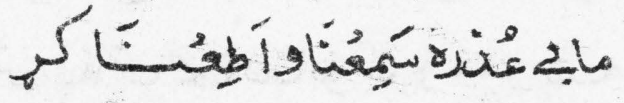

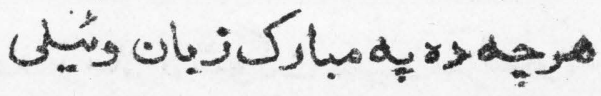




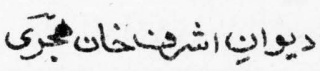

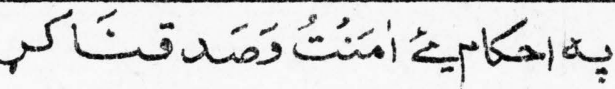

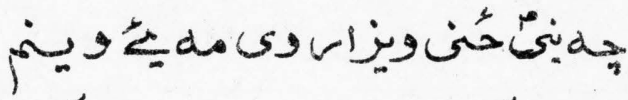

Fi,

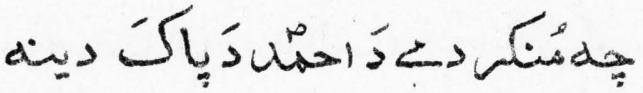

تورتماتِ

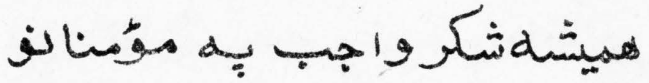

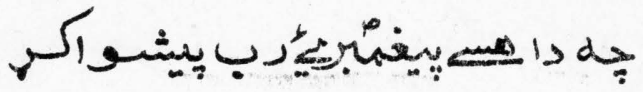

كَ.

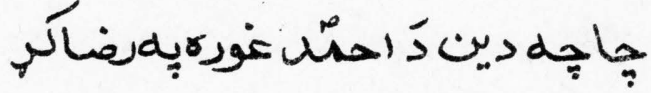

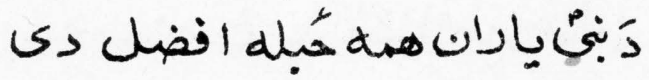

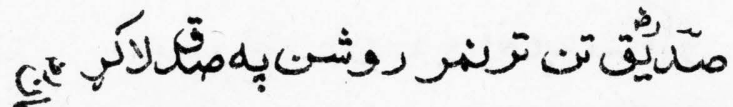

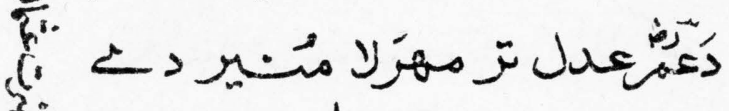

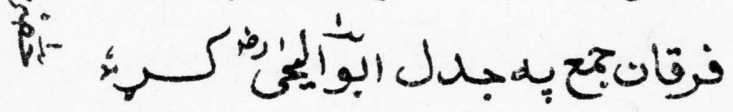

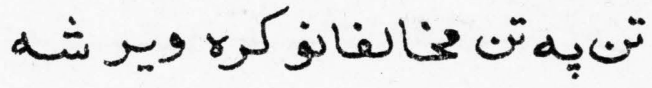

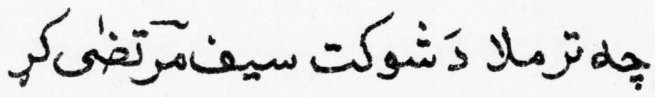




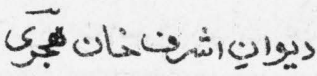

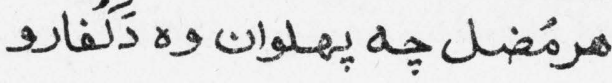

توكياك

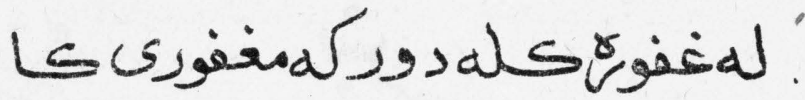

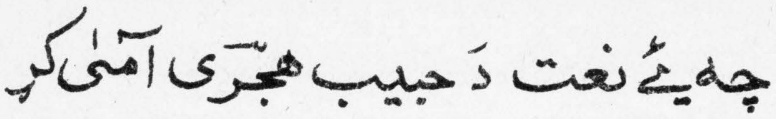




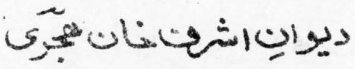

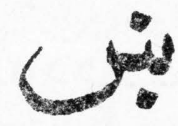

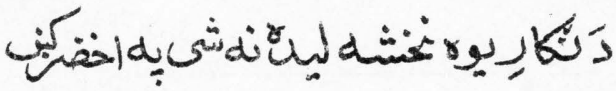

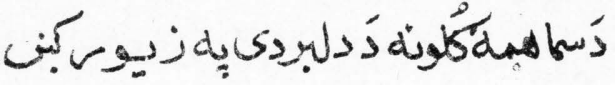

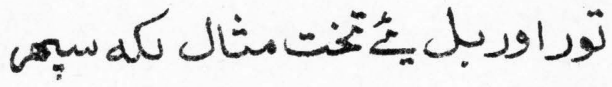

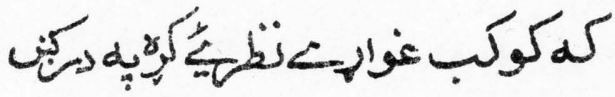

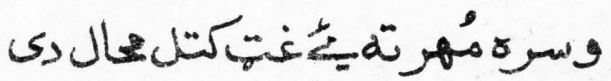

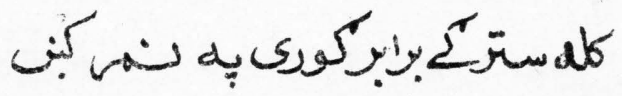

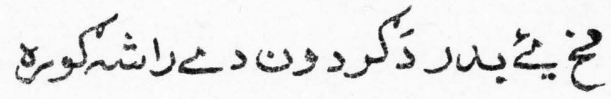

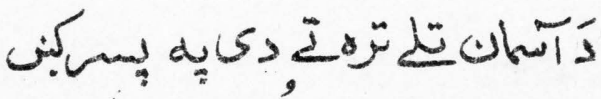

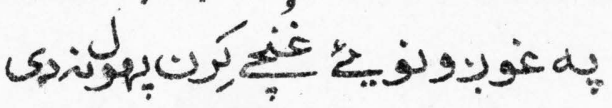

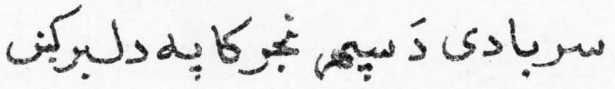




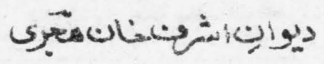

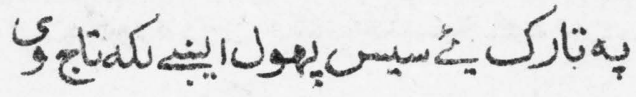

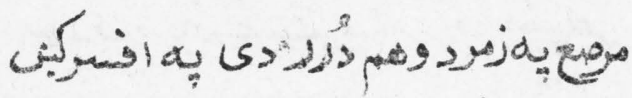

اهنت

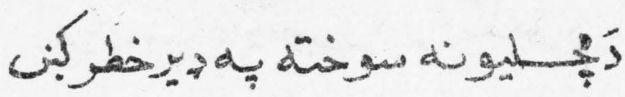

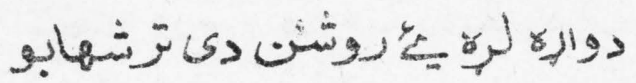

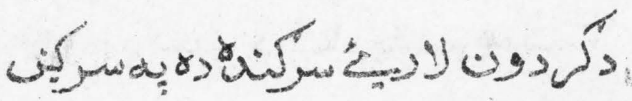

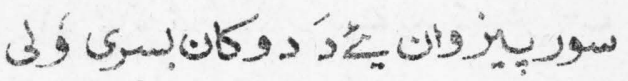

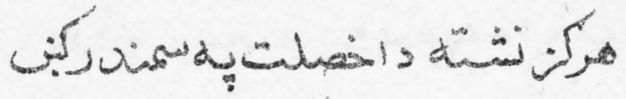

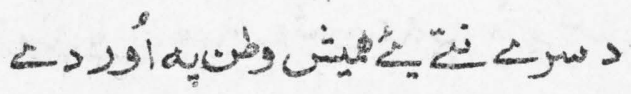

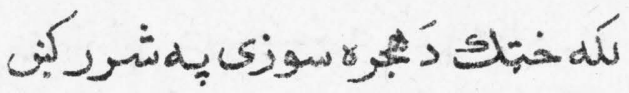

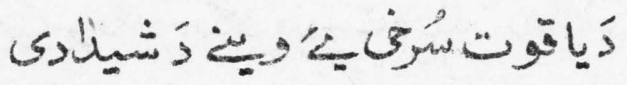

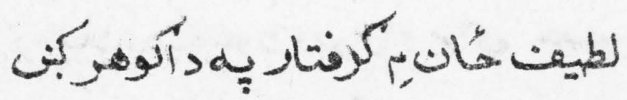

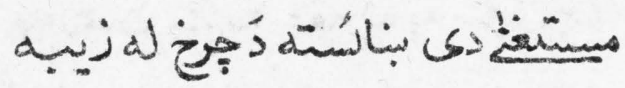

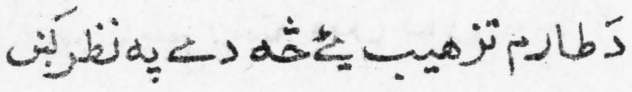

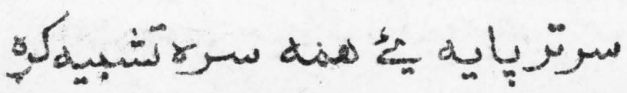




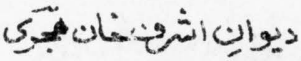

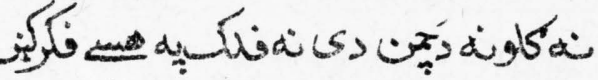

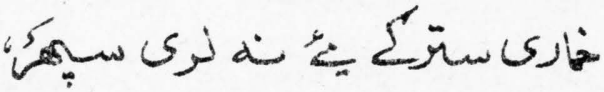

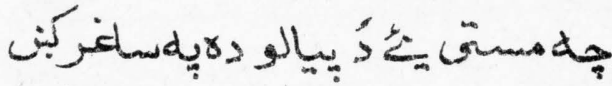

دَميَت هينة

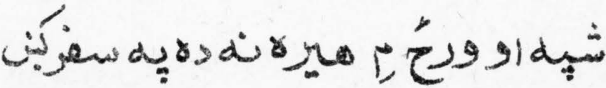

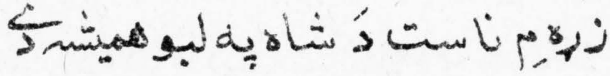

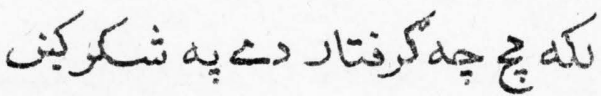

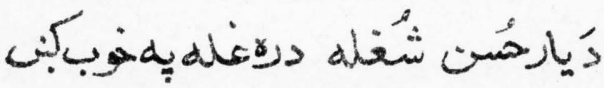

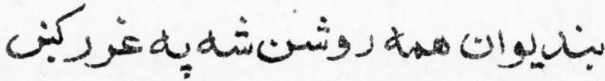

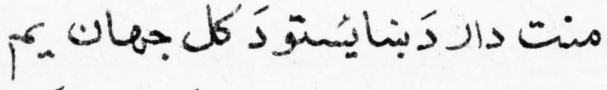

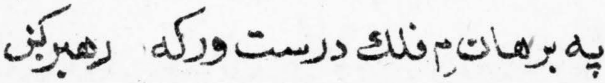

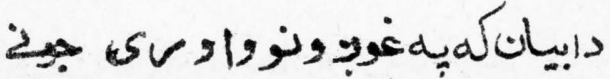

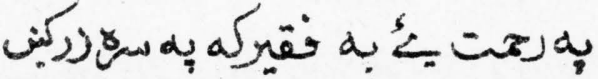

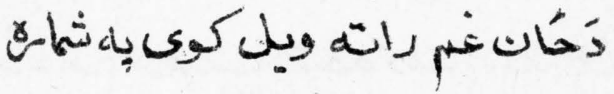

كونله طوطا r 


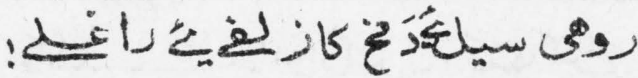

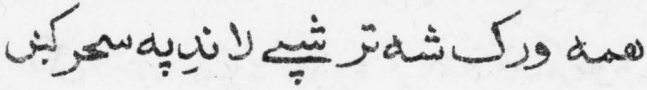

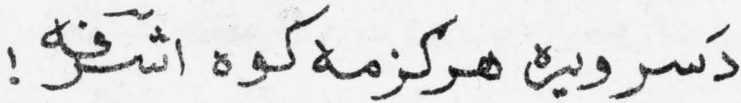

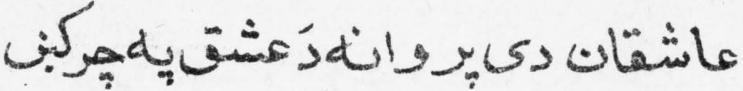

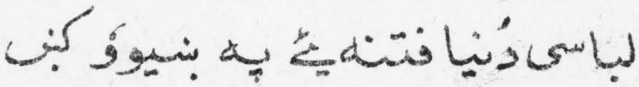

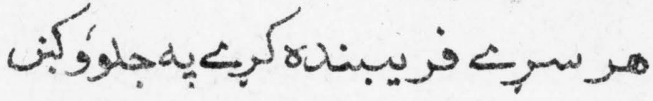

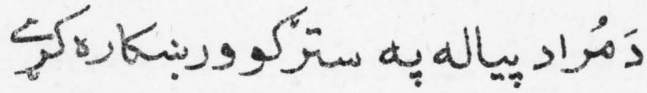

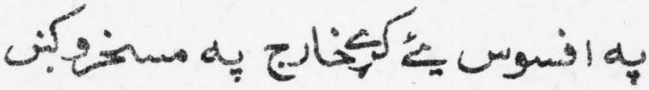

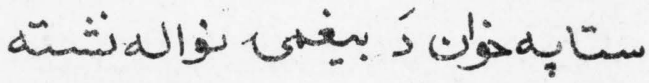

هيوتارخه

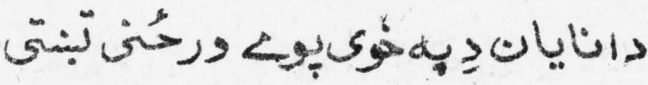

دنمت هوس يبروبت وينميه خروكنب

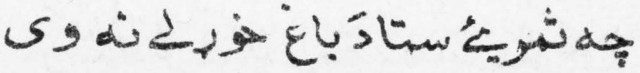




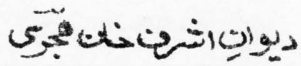

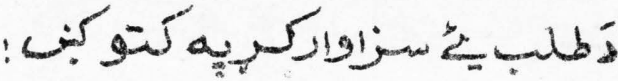

socisida

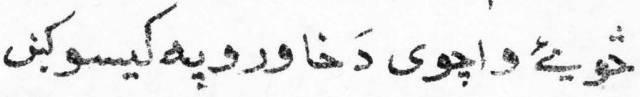

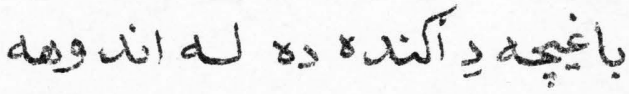

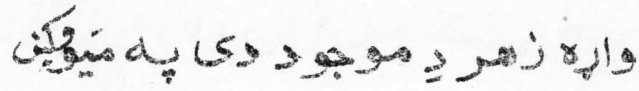

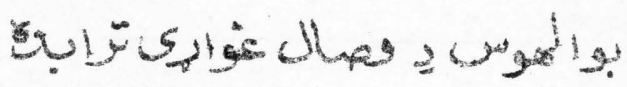

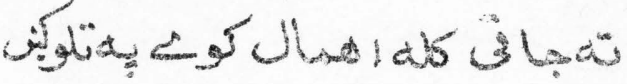

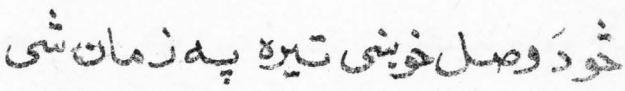

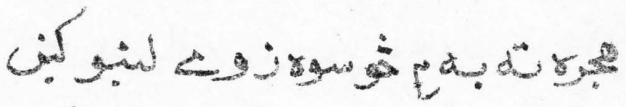

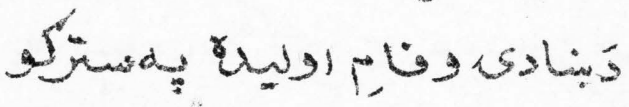

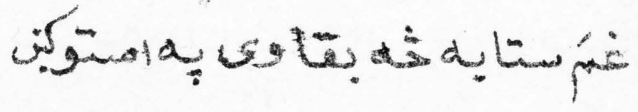

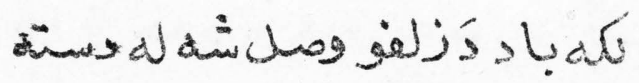

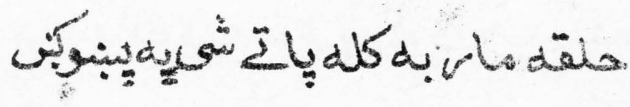

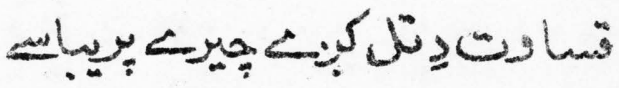

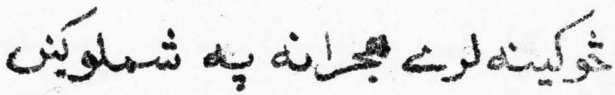




\section{ديوانباشهن}

طراركىٍ برهنه وارهة تألّدى

طُرُهه داجه بيا

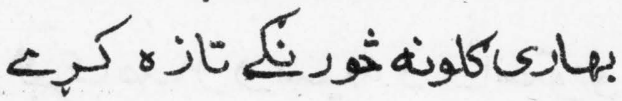

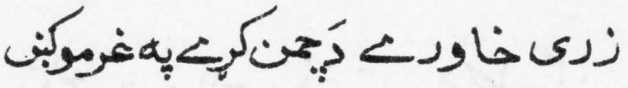

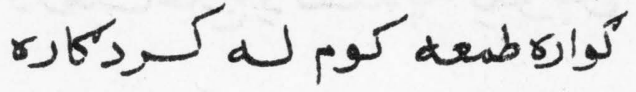

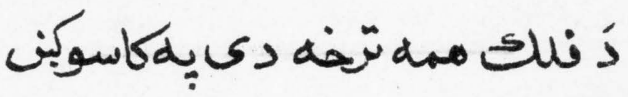

عارفان

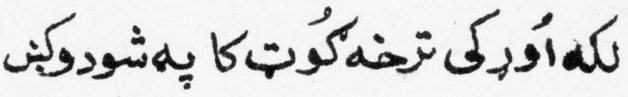

ذى ذيات

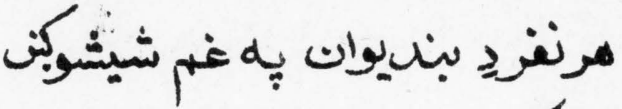

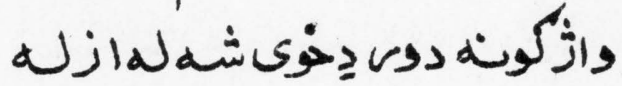

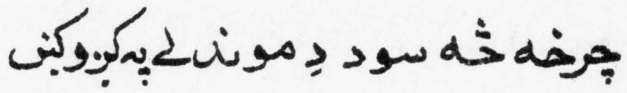

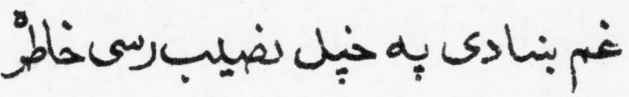

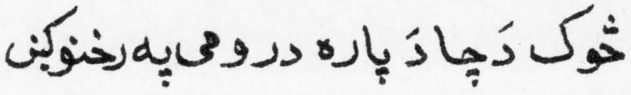

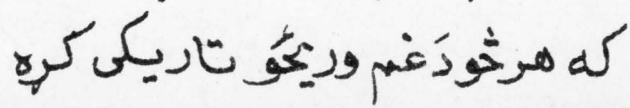




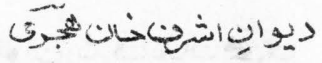

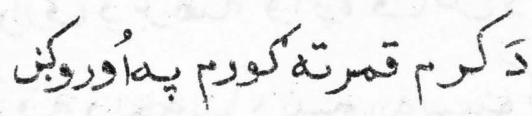

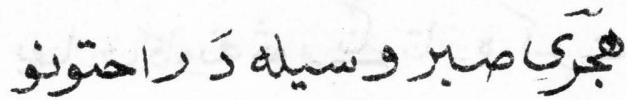

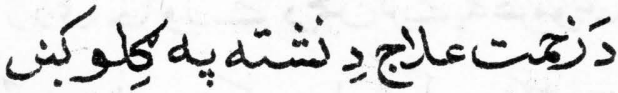




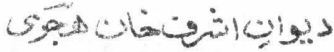

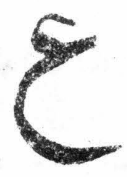

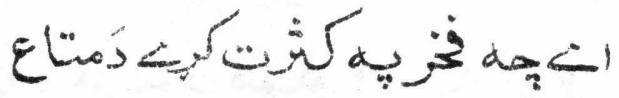

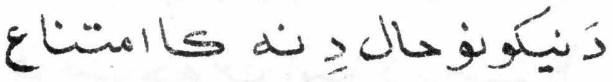

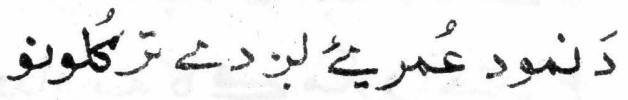

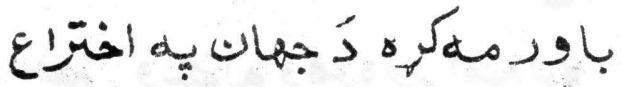

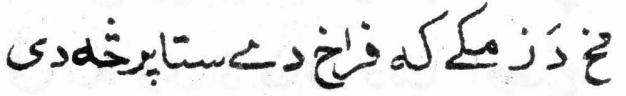

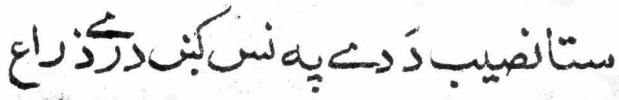

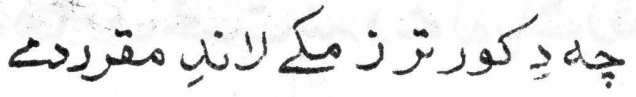

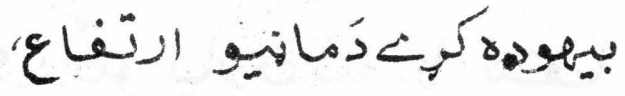

خوره عشهت تَمست دَ ناخبيرو

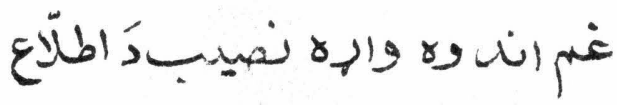




\section{ديوانِانتروناش دتجرى}

s)

Elaina

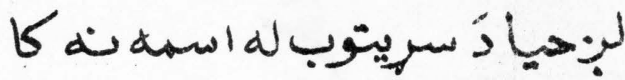

يويه بل خولة كئهى كله سباع

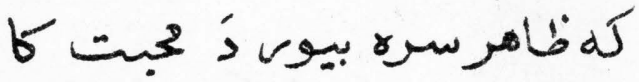

زرودَ هوسريى مملفو وى بـه نزاع

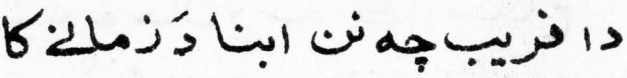

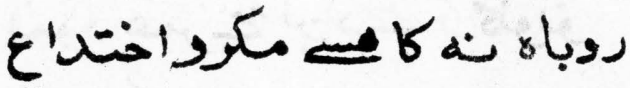

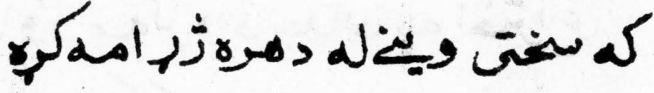

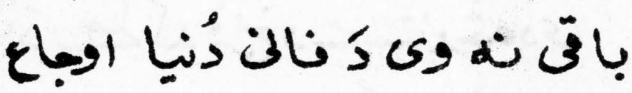

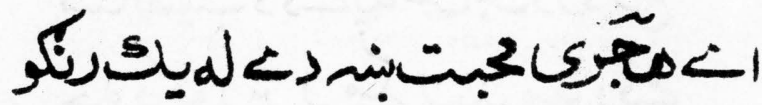

دَدورنكو يارى ند كارنتفاع 


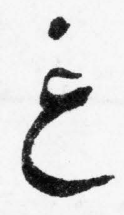

هميشه ٍِ يار زماوى بهُهُنياروغ

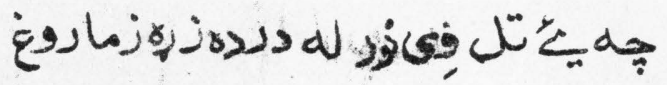

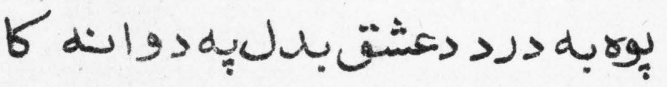

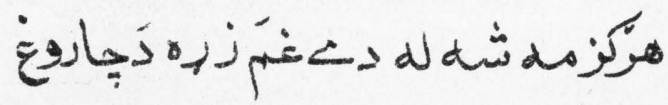

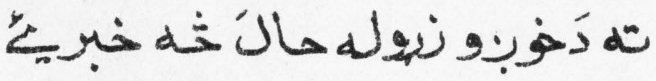

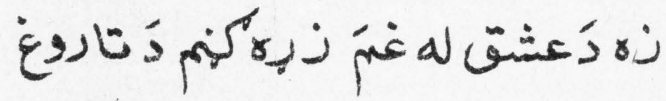

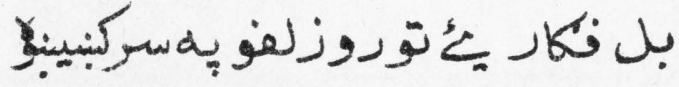

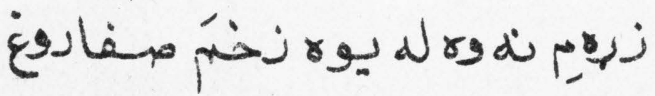

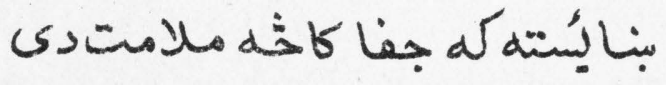

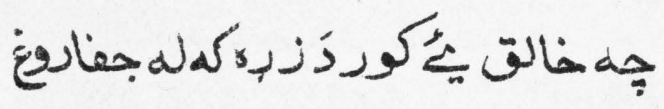




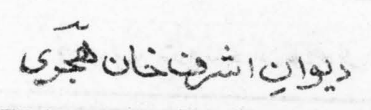

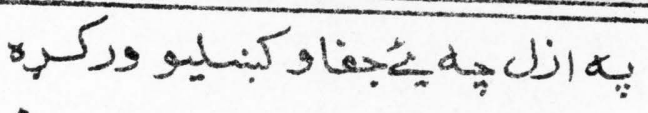

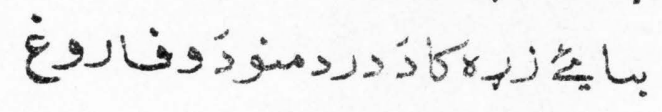

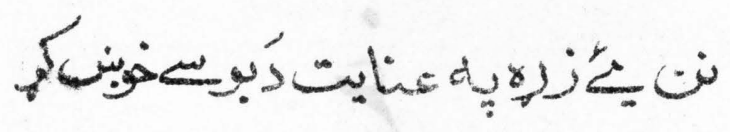

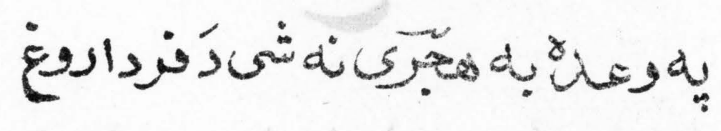

v. 


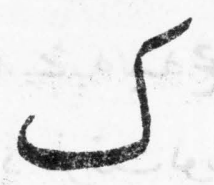

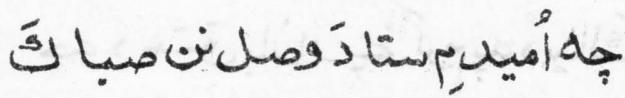

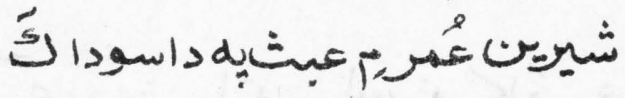

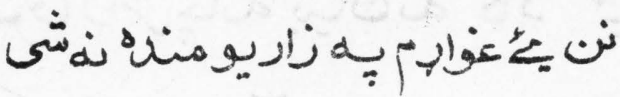

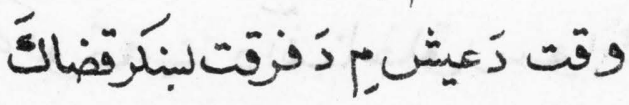

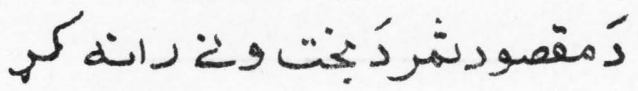

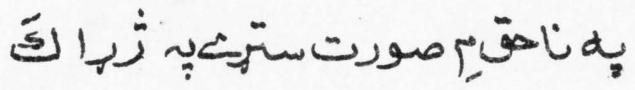

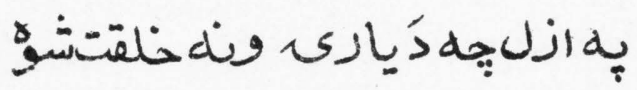

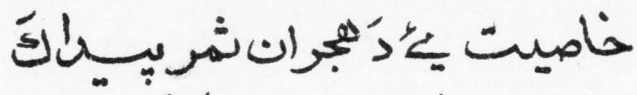

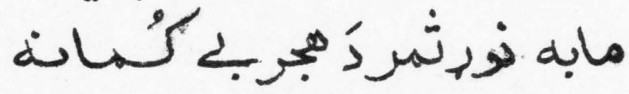

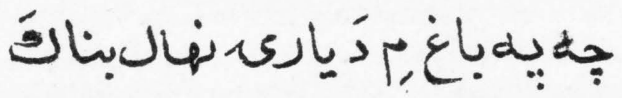




\section{دبوانِانشعنان هجميى}

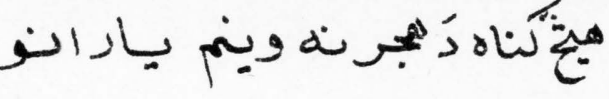

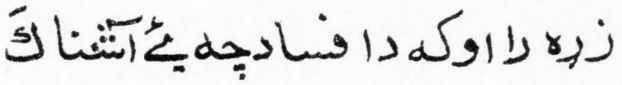

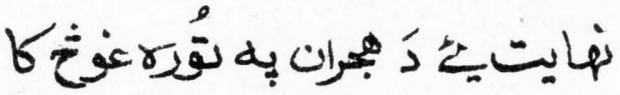

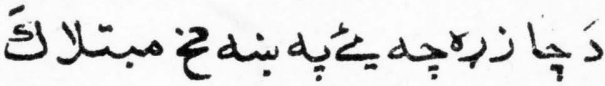

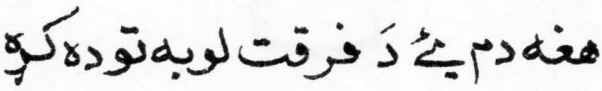

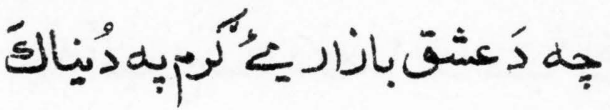

هِرى رانجاته بيانه كادً مين

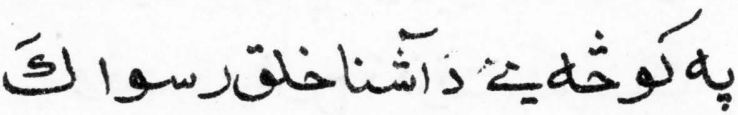




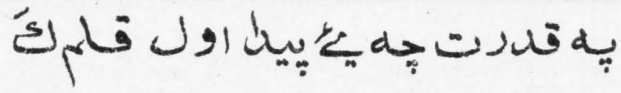

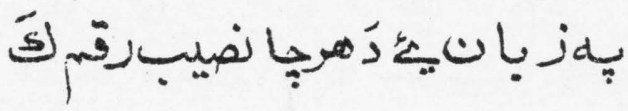

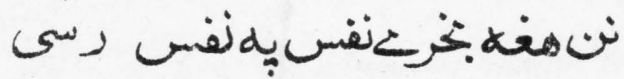

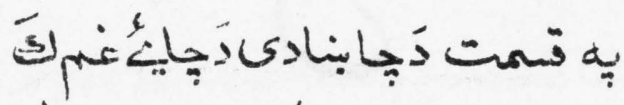

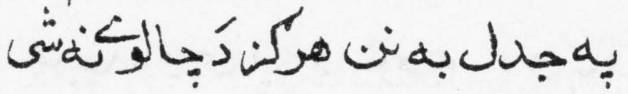

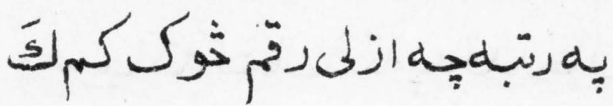

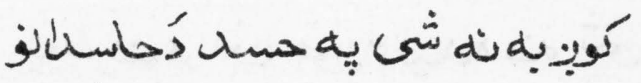

5)

مرك بح

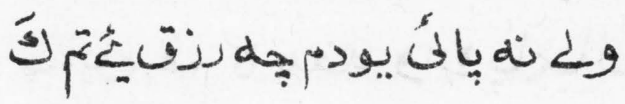

دَقضارضاحارج كاله.

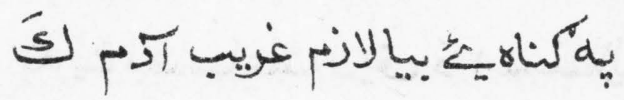

ك

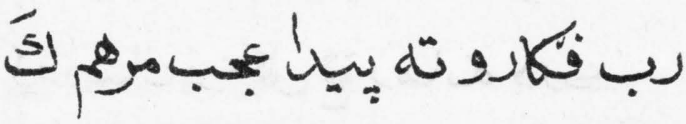




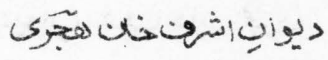<smiles>CCCCC</smiles>

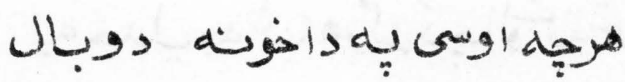

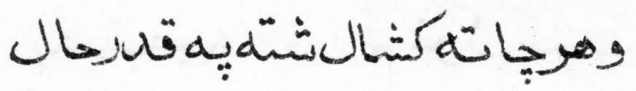

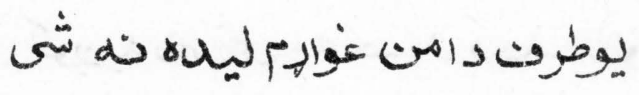

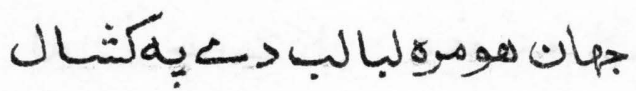

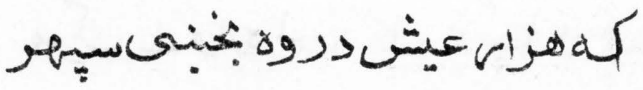

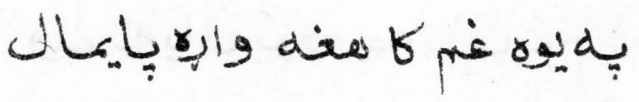

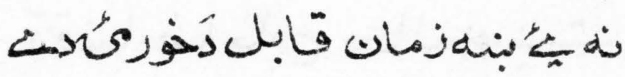

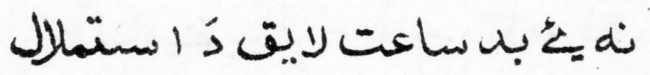
يمان

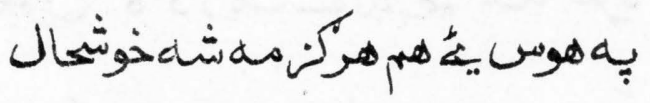

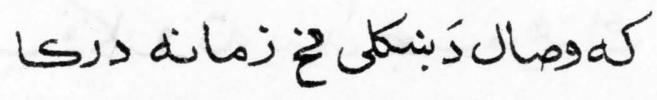
$v$ 


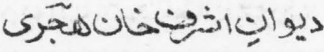

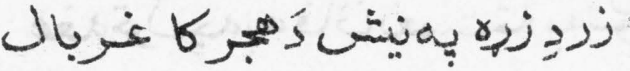

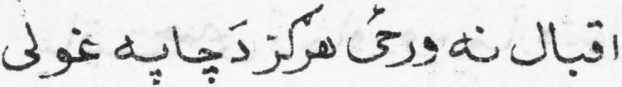

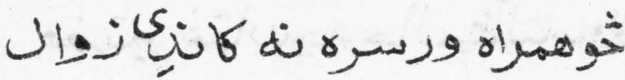

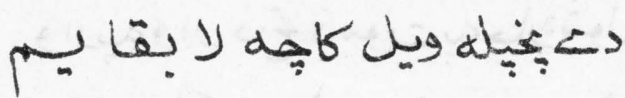

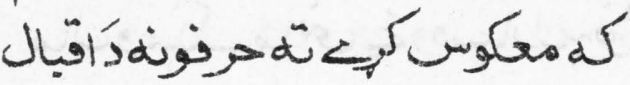

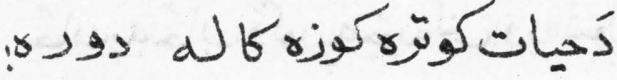

لl

ا إن

Jl2 28 rin a s.

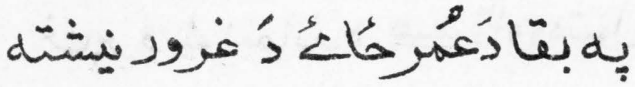

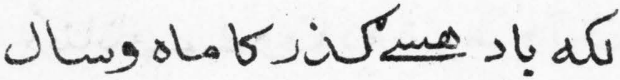

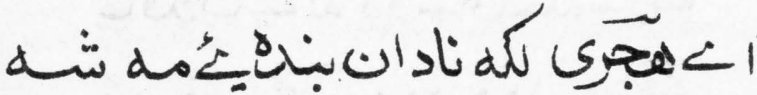

غنم بنادى دُجمانه خوبدعلا خيال 
ديواتِانَحنفانهتجرى

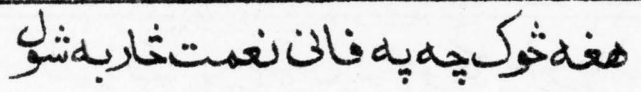

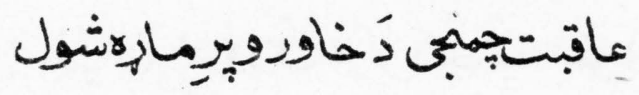

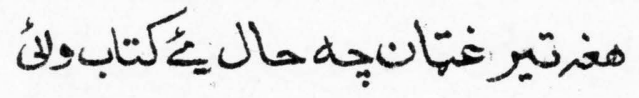

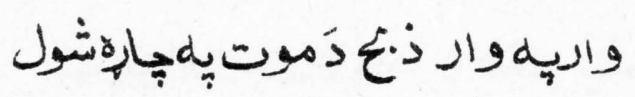

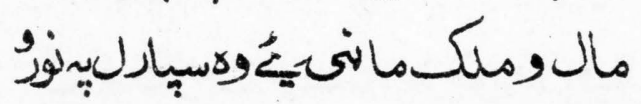

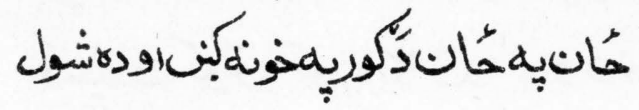
دَدينابِتش لباس بجب مغروبه وو

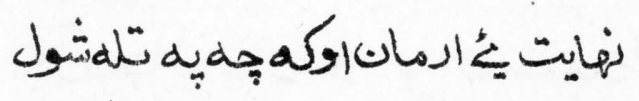

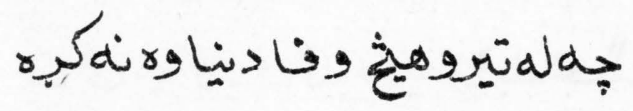

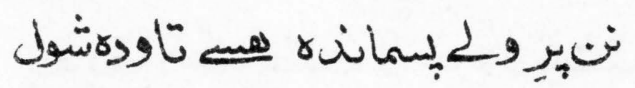

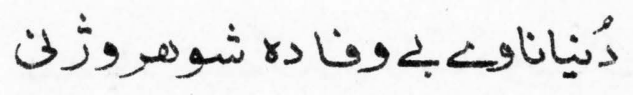

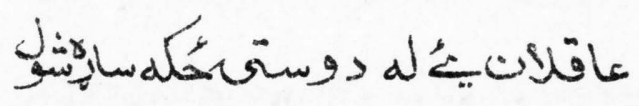

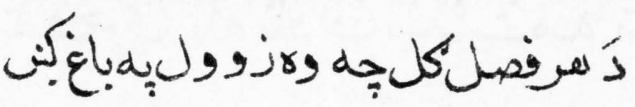
بيا همب لهيد دَخزاتِيهوارخوارنشول

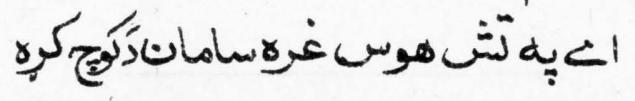

vy 


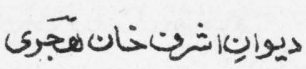

خيل همزولى درته

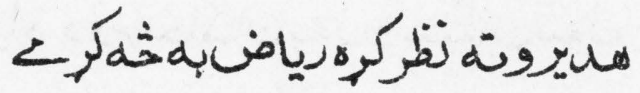

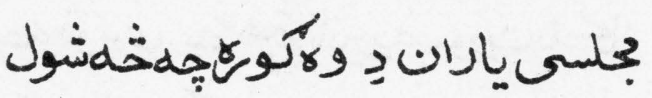

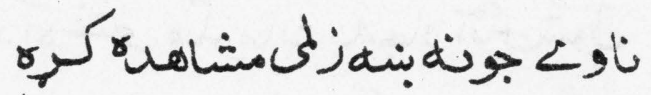

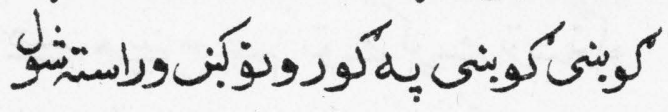

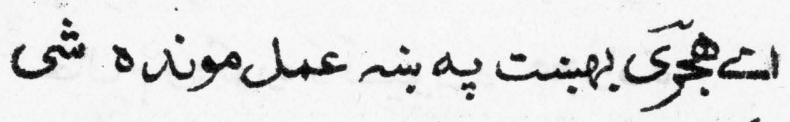

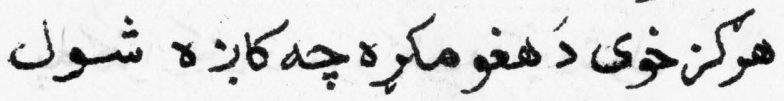

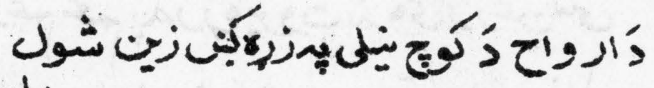

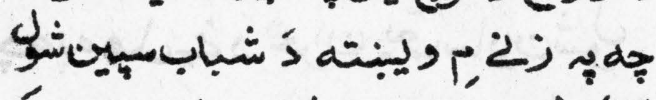

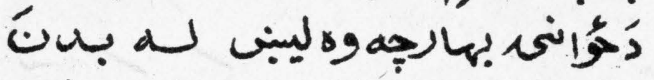

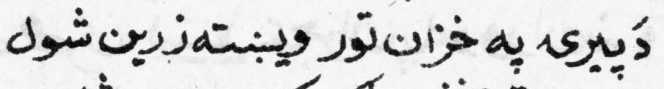

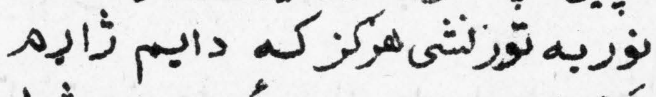

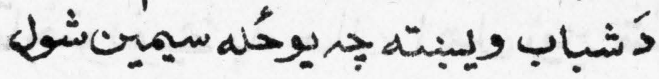

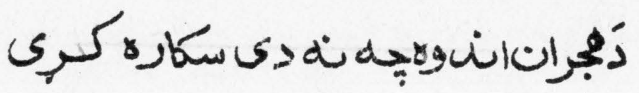

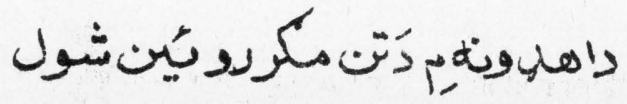




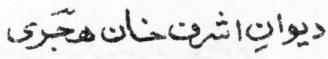

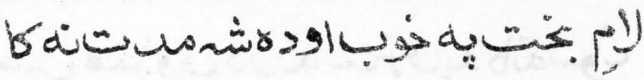

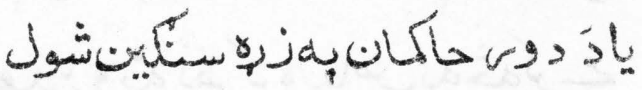

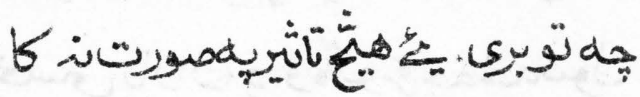

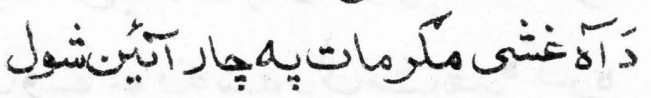

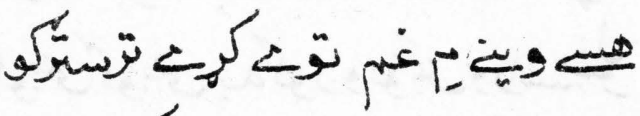

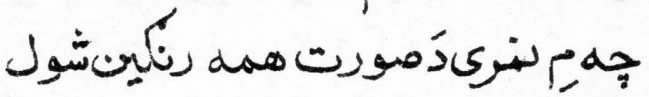

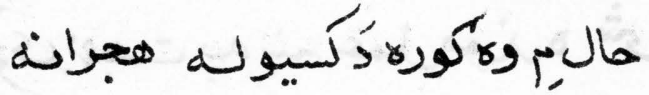

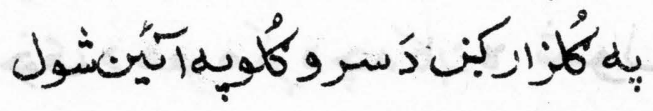

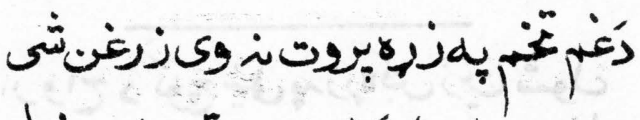

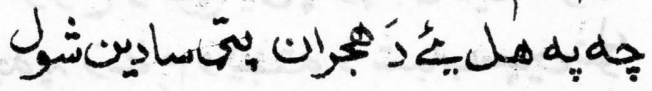

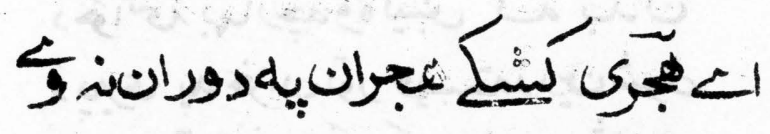

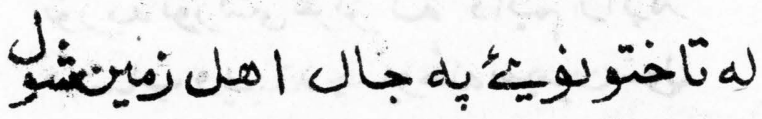




\section{r}

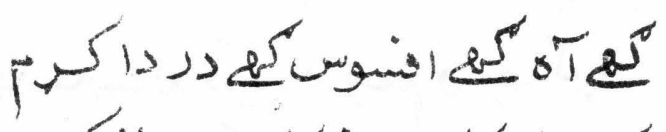

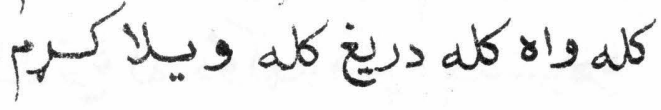

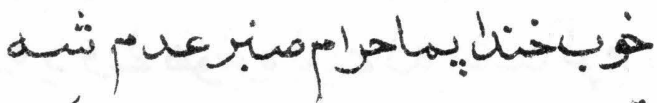

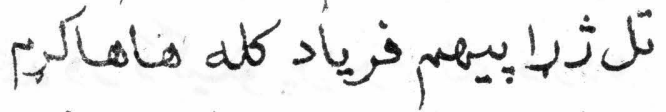

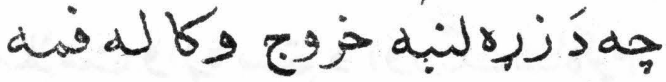

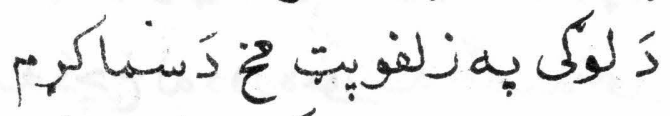

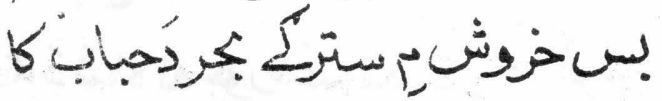

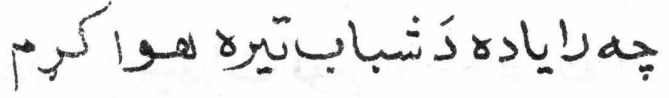

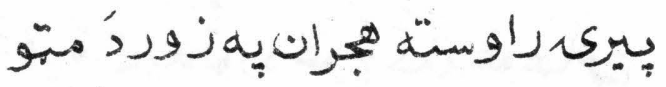

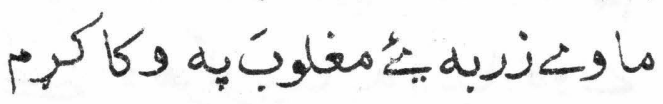




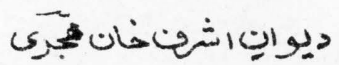

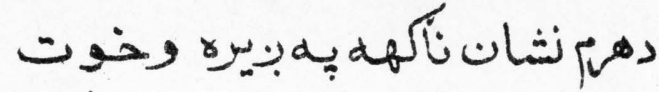

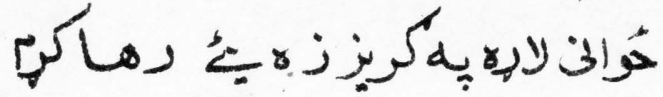

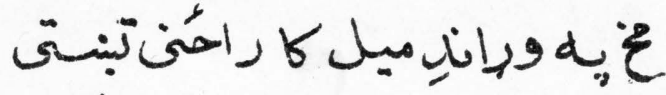

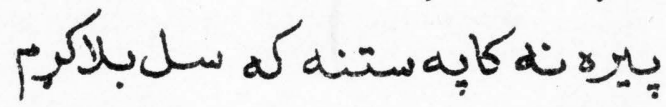

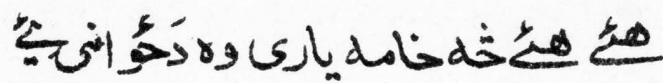

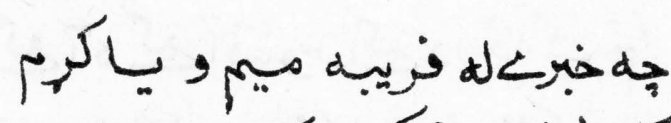

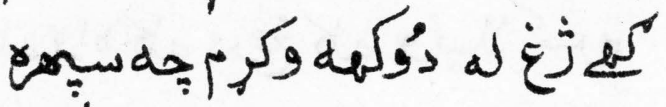

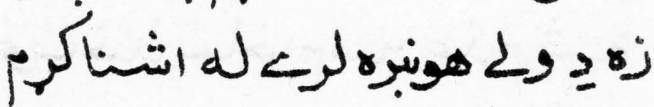

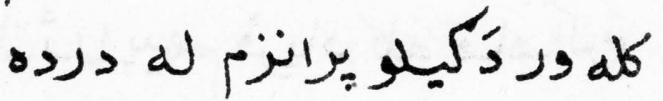

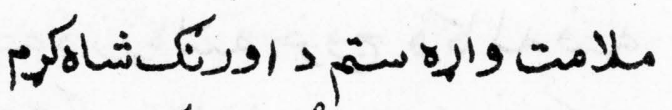

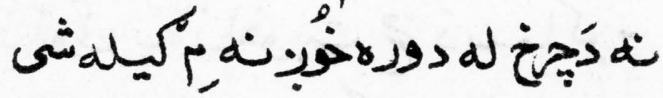

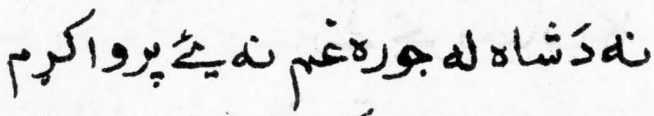

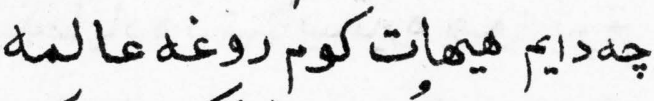

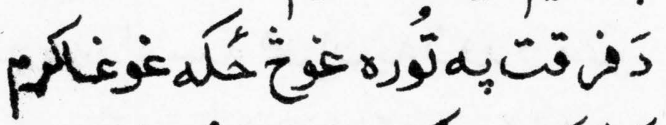

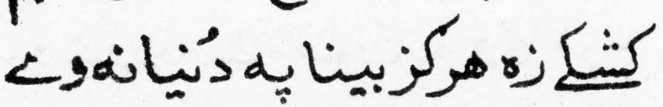




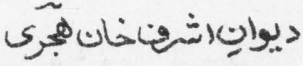

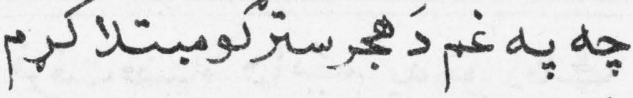

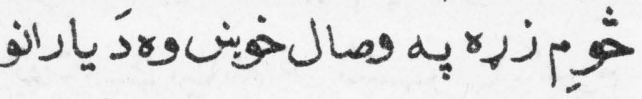

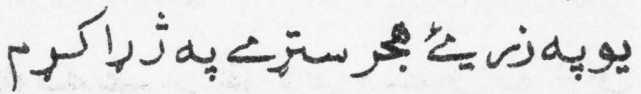

كهبيأوكسى هركزَخَجاو

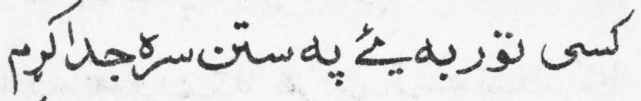

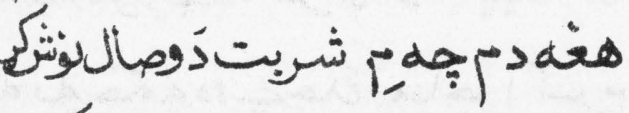

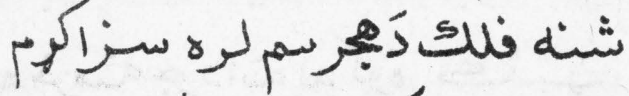

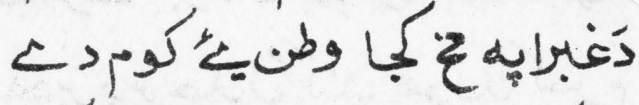

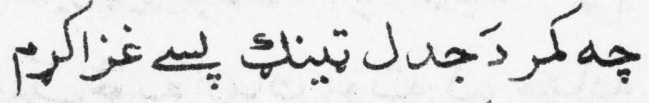

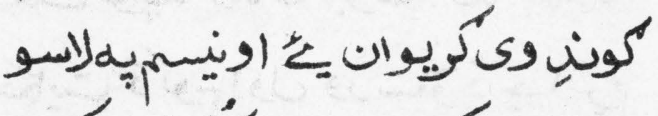

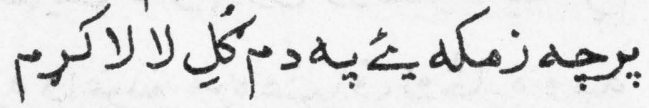

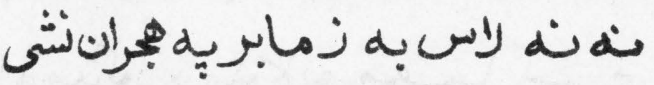

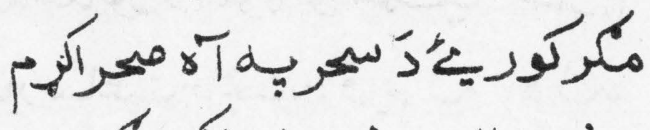

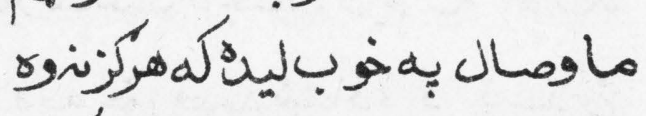

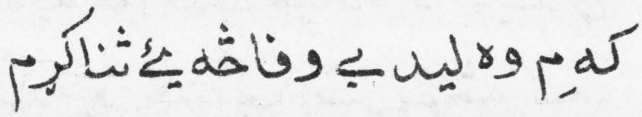




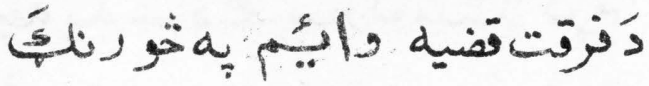

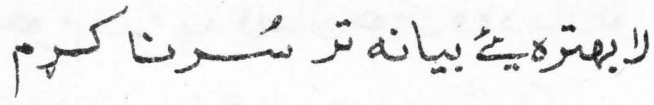

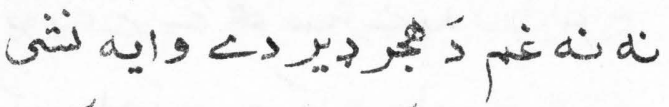

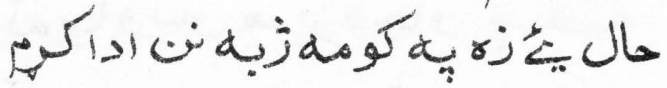
كانه

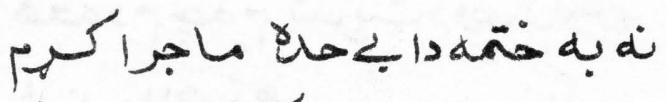

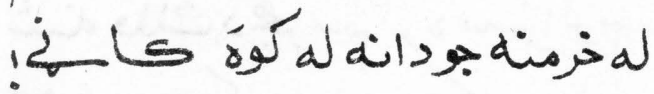

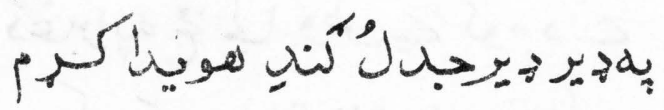

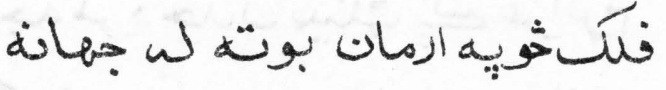

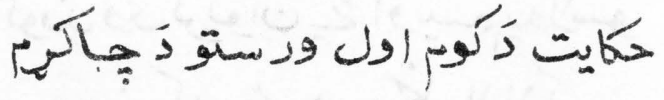

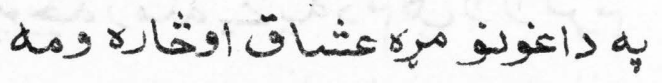

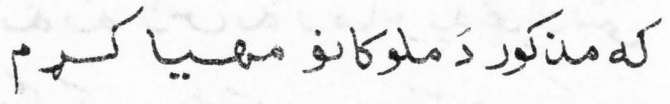

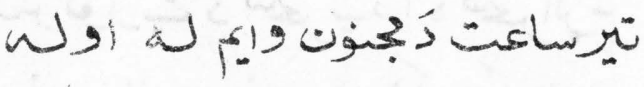

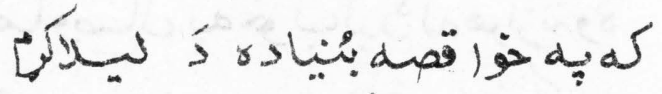

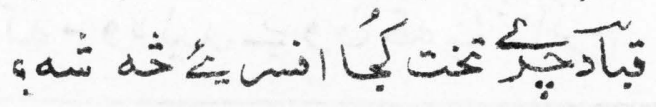




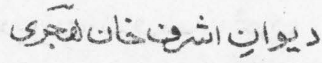

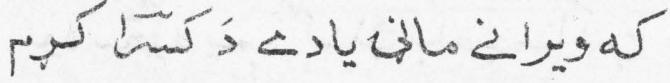

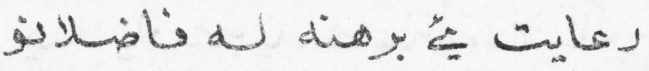

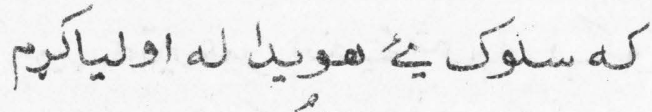

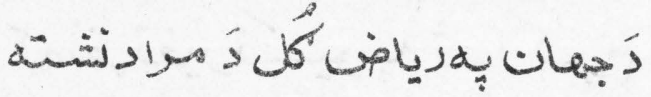

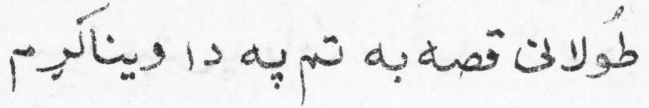

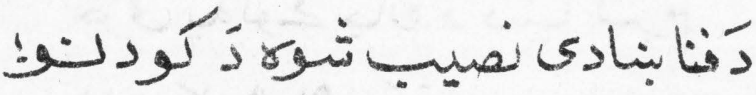

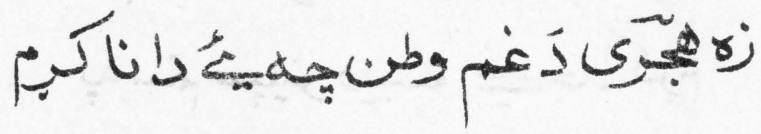




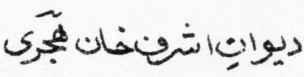

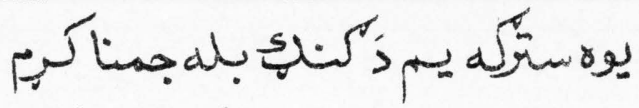

جه لإيا

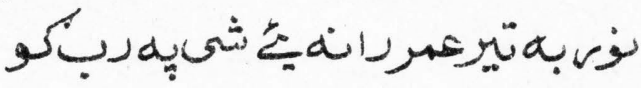

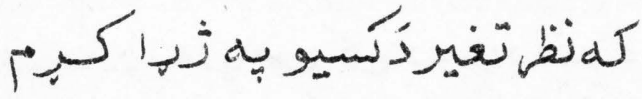

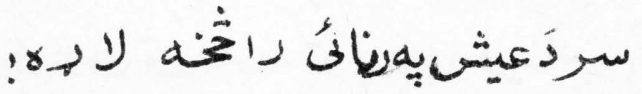

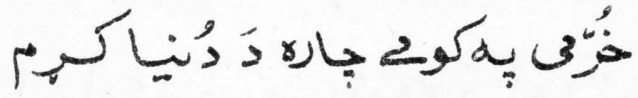

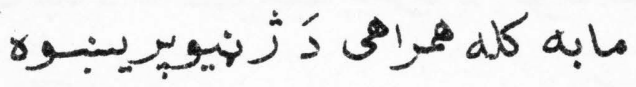

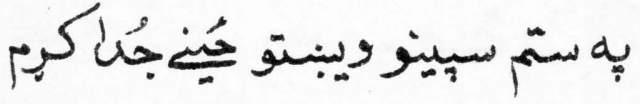

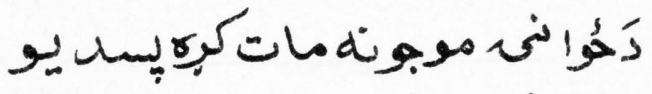

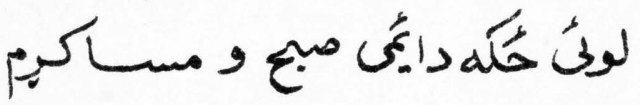

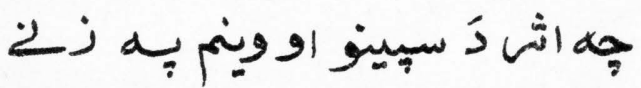

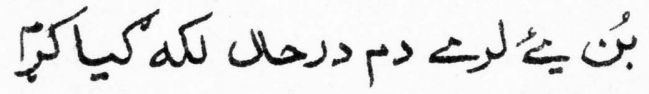

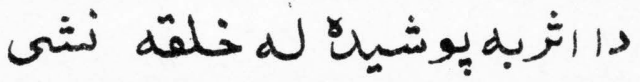

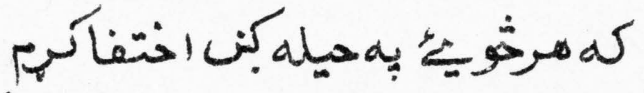

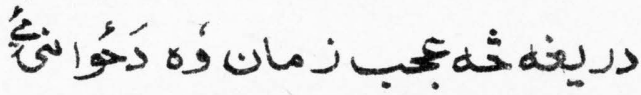




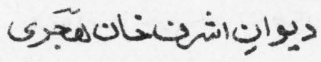

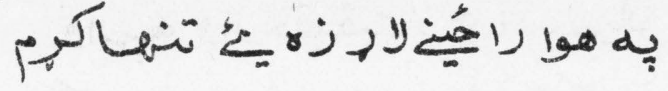

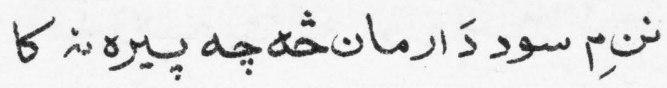

كميوكت به بل وهم له غيه

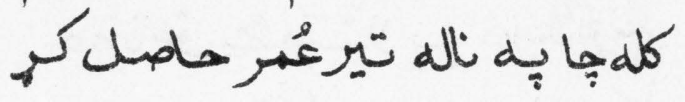

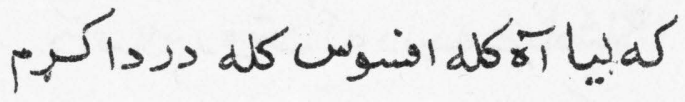

كينيت دُعمريو به يو بنطاره شَه

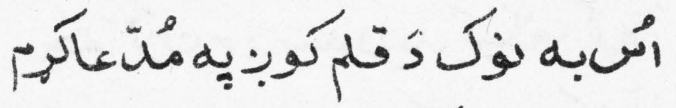

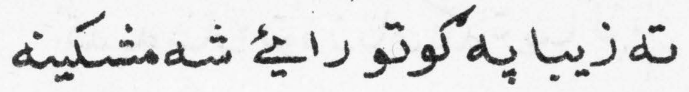

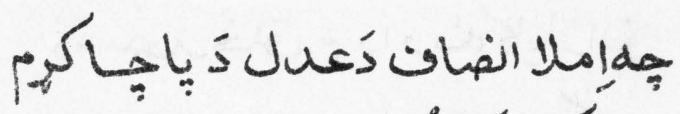

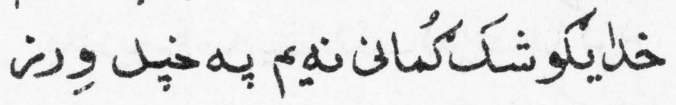

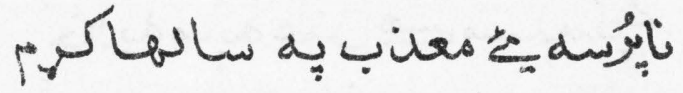

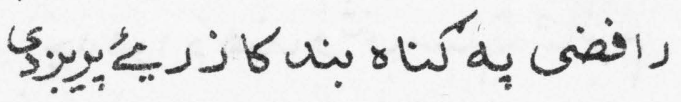

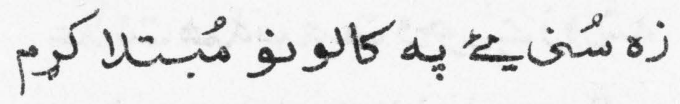

زئر

يه 


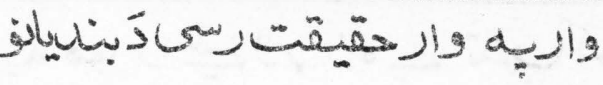

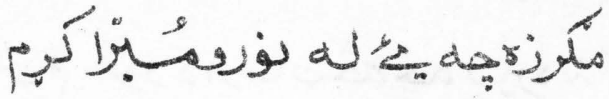

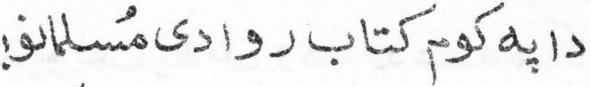

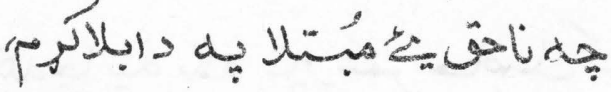

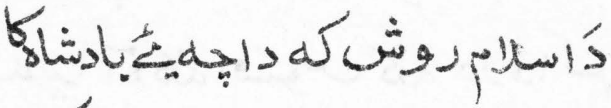

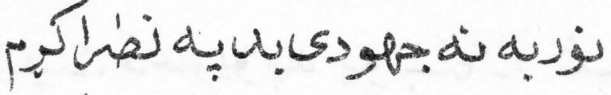

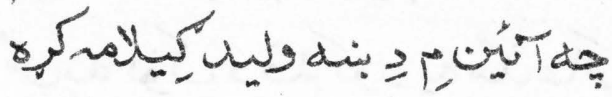

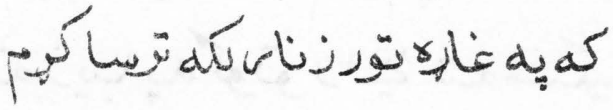

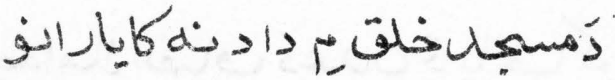

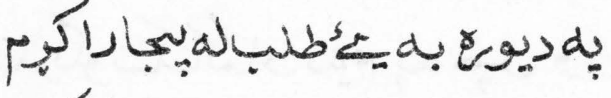

خ

|

على

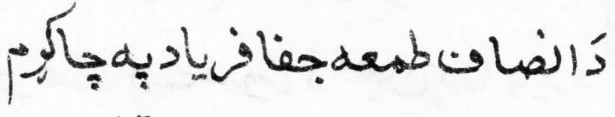

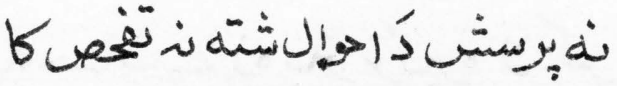




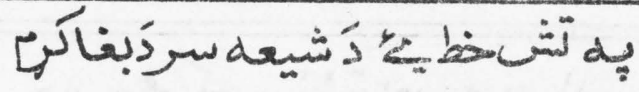

S

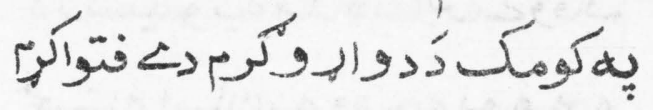

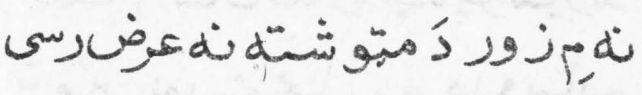

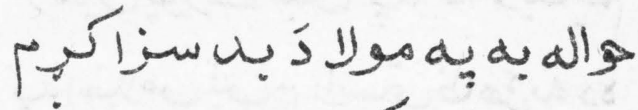

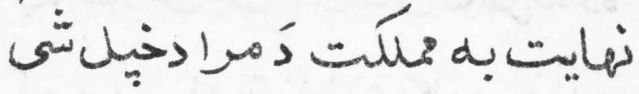

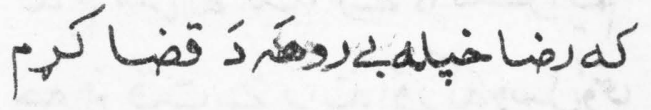

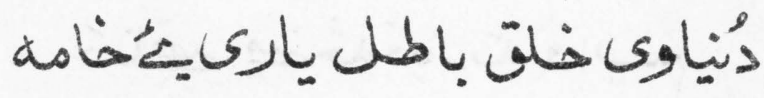

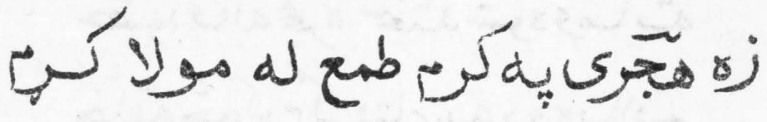




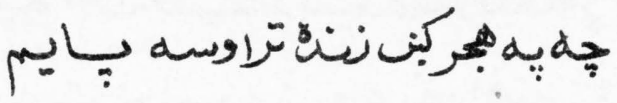

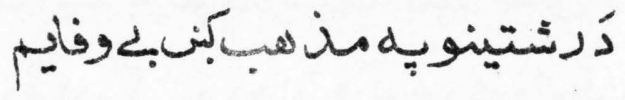

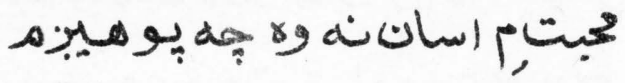

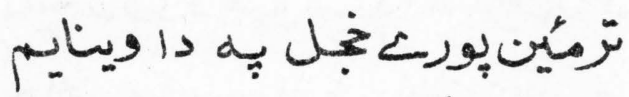

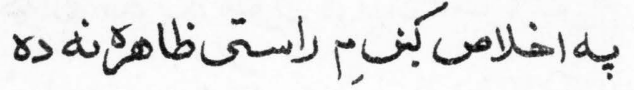

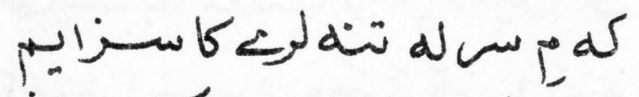

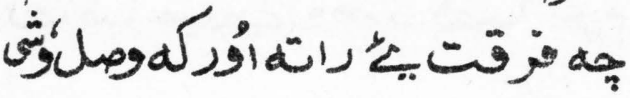

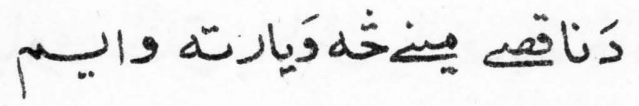

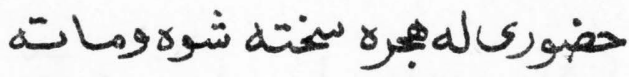

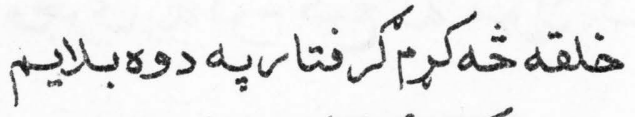

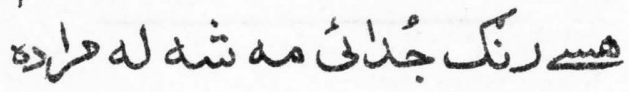

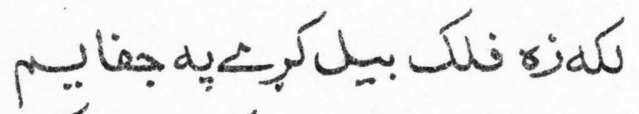

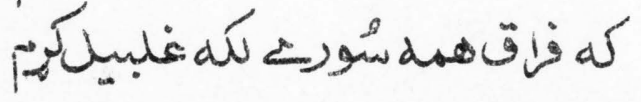

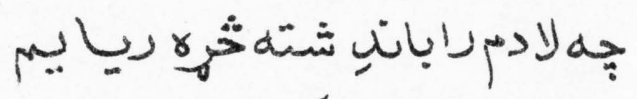

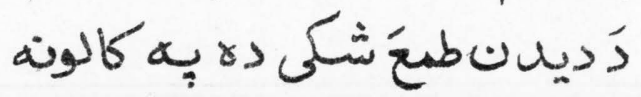


ديوانِاشنحنانهريتى

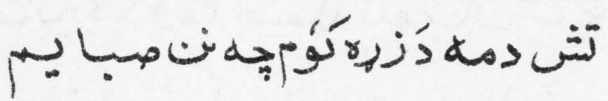

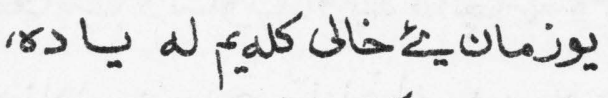

بل يه خوب كبن يه دغرسودوسودايسم

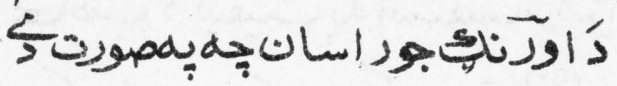

به فزياد دُوقتونو له غوتفابه

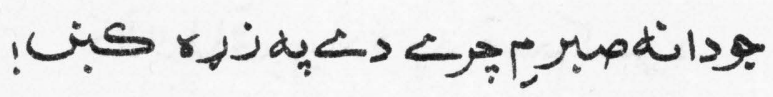

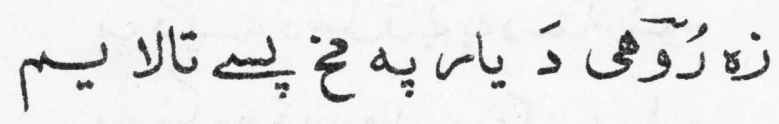

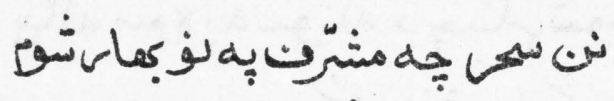

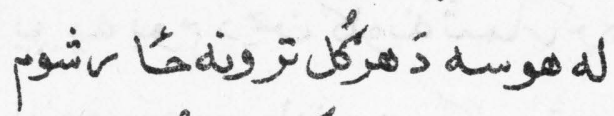

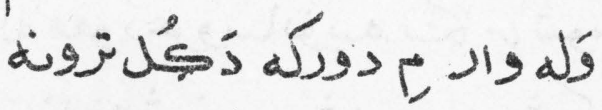

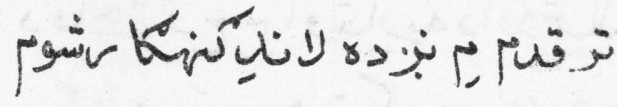

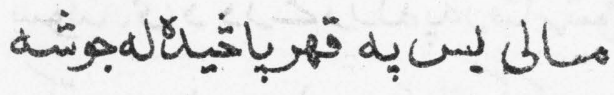

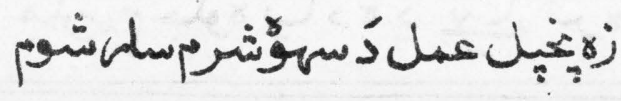

19 


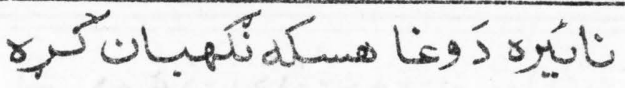

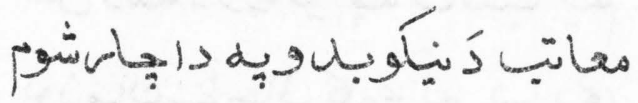

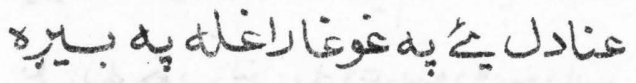

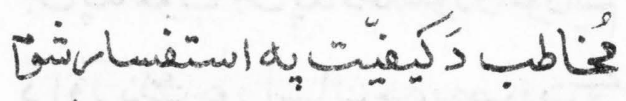

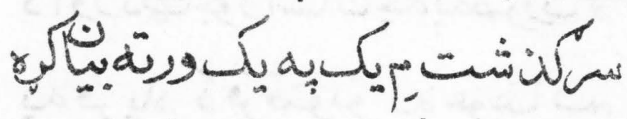

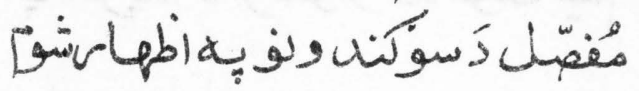

\&

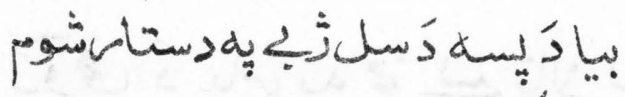

S

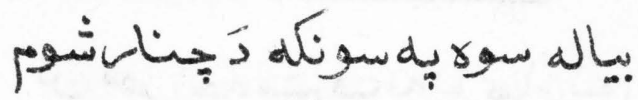

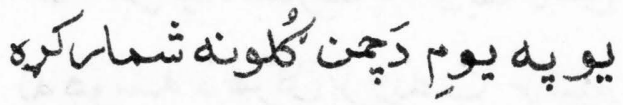

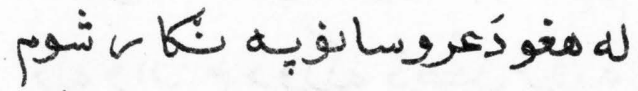

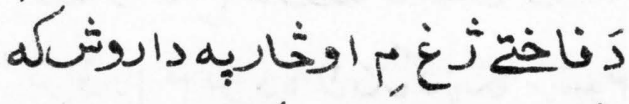

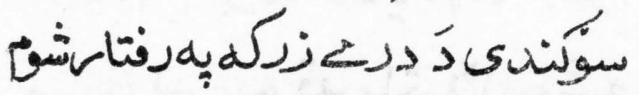

ك 


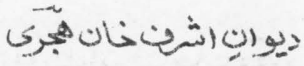

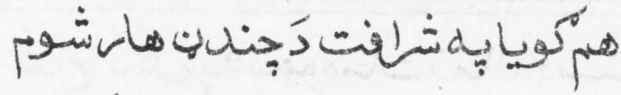

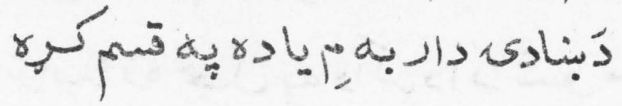

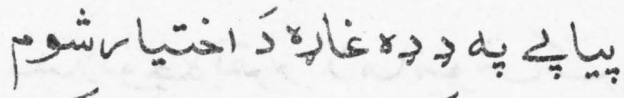

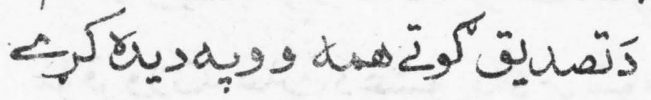

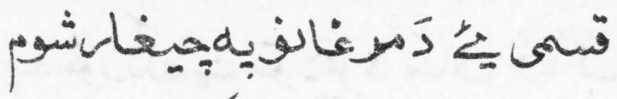

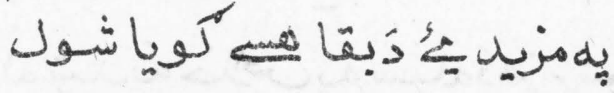

جهلهان

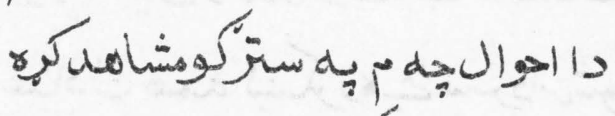

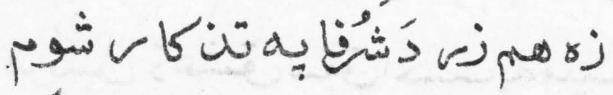

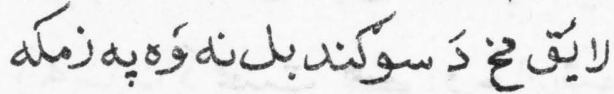

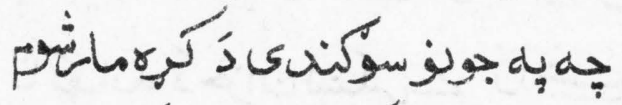

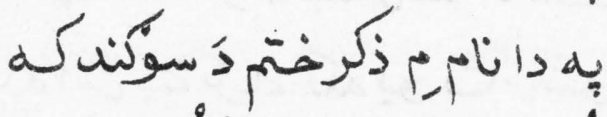

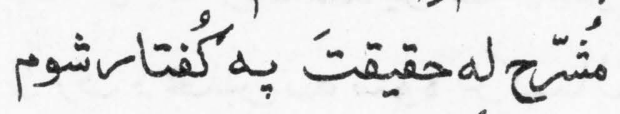

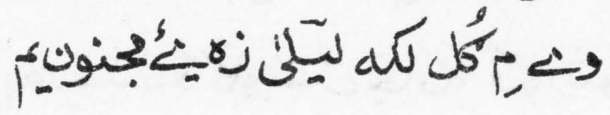

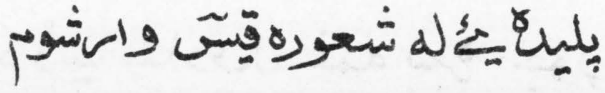


ديوابِاشرتخانهجِي

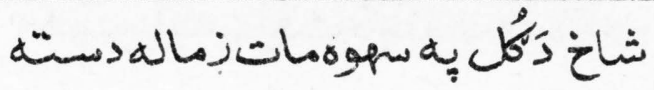

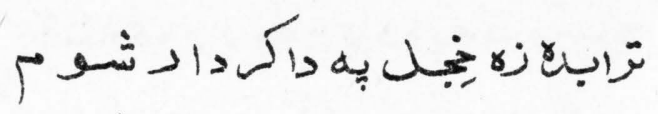

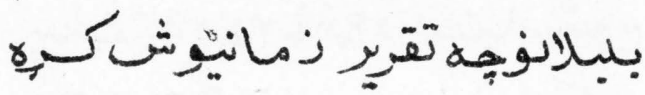

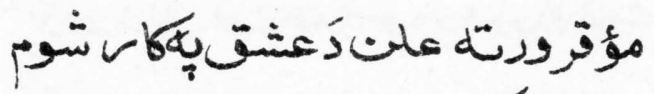

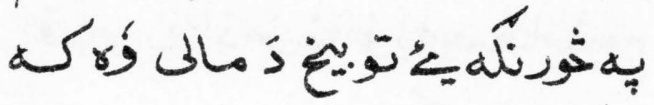

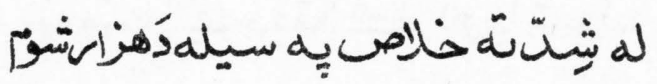

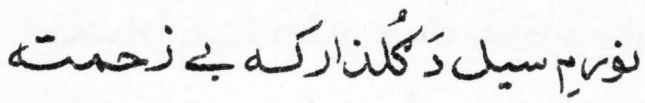

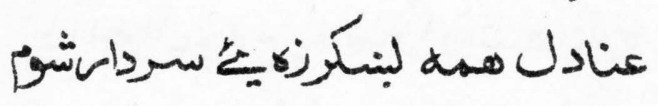

هربُبل دُعشتق سبت اخستبهمينه

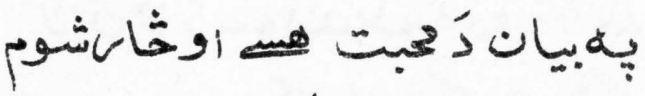

Lاثِ

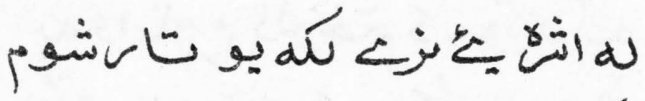

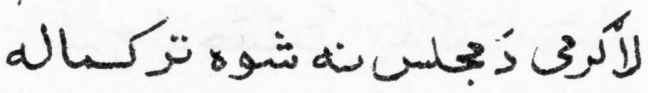

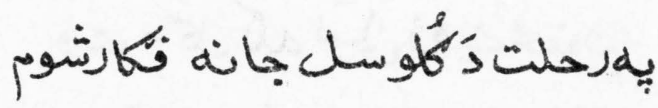

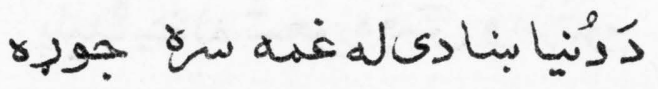

$9 r$ 


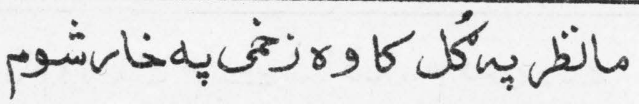

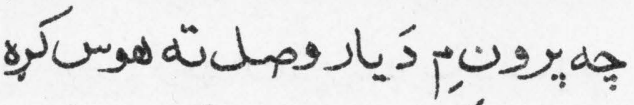

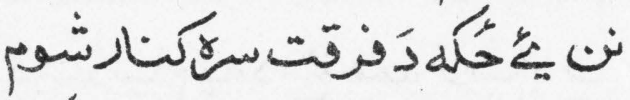

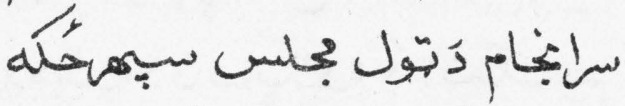

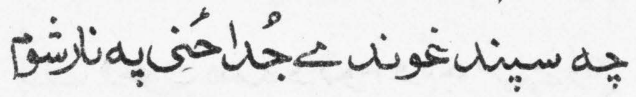

عنادلوقية غره اونيولم تاوه

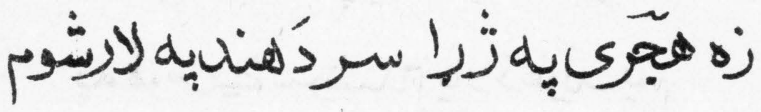

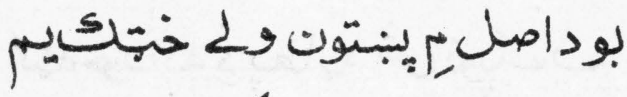

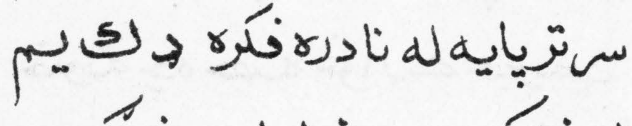

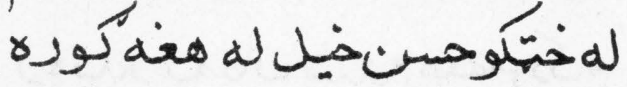

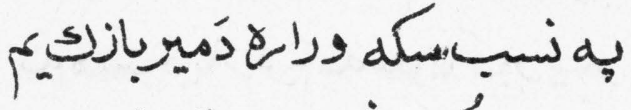

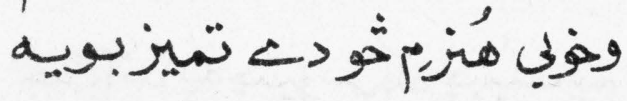

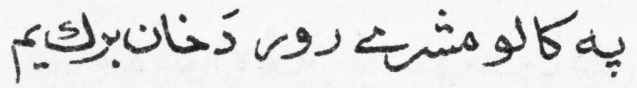




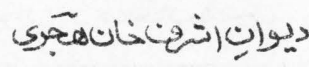

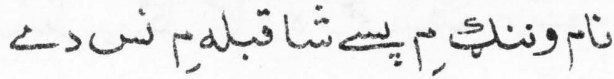

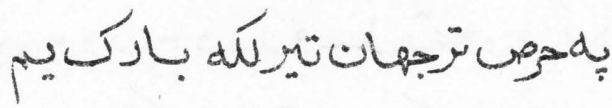

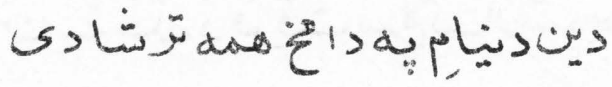

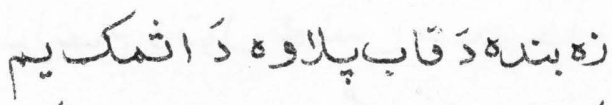

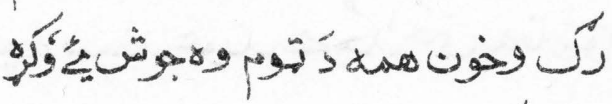

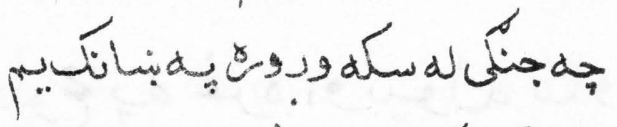

d,

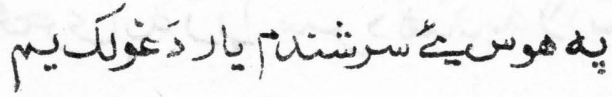

40.

مـ

م

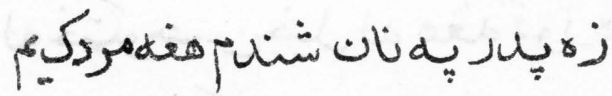

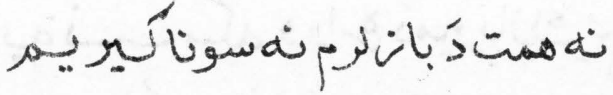

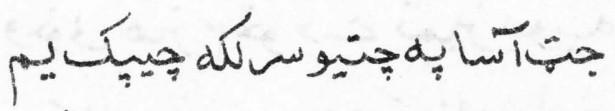

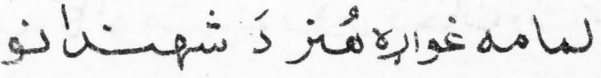




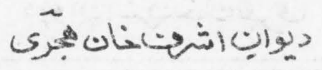

كalid

كَبنو

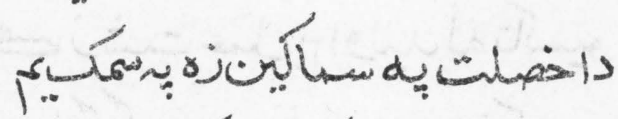

$\Leftrightarrow$

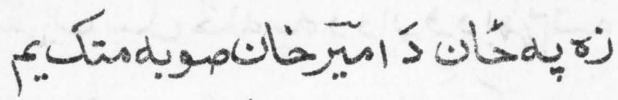

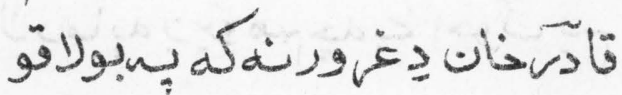

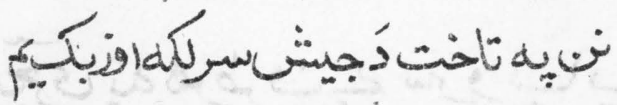

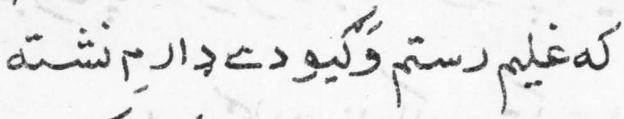

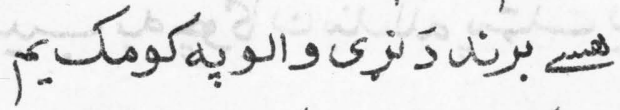

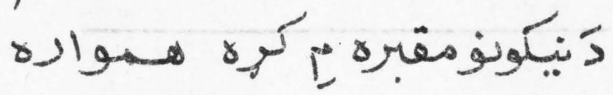

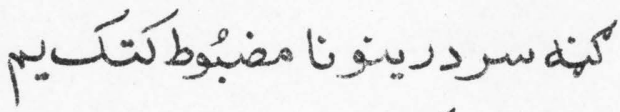

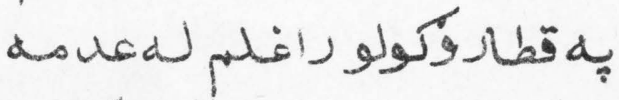

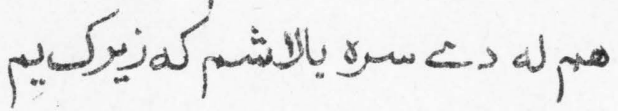

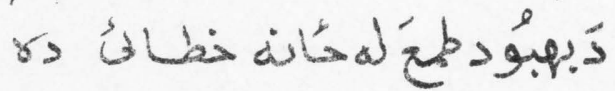

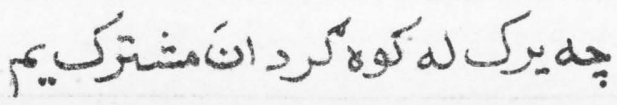

90 


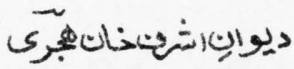

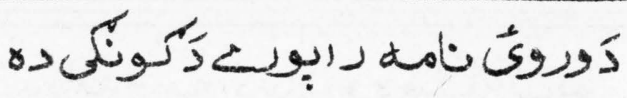

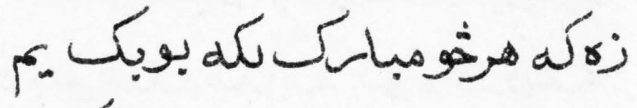

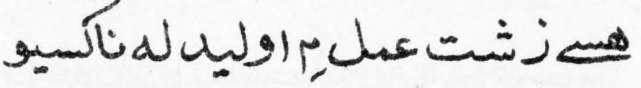

$$
\begin{aligned}
& \text { f. }
\end{aligned}
$$

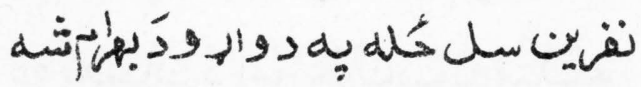

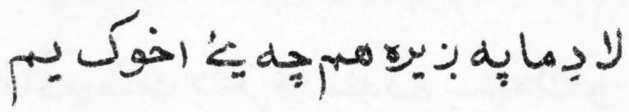

$$
\begin{aligned}
& \text { a. }
\end{aligned}
$$

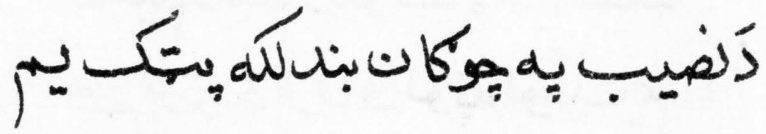




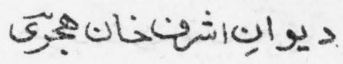

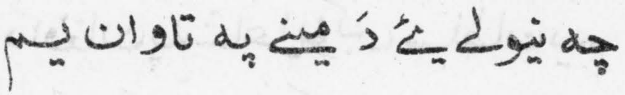

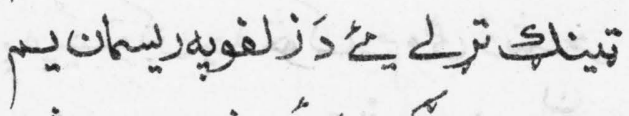

جه

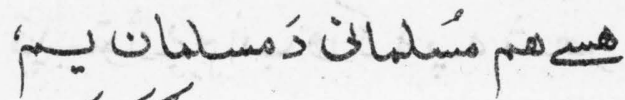

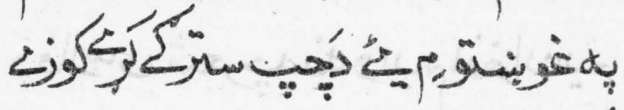

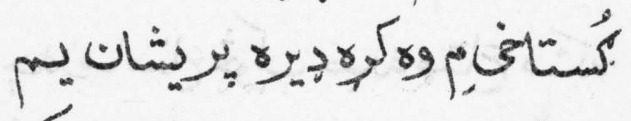

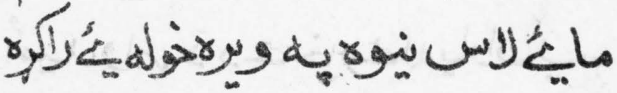

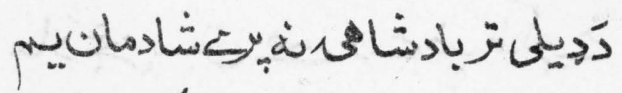

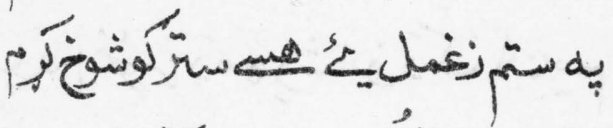

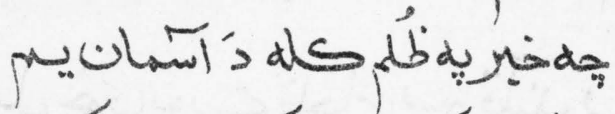

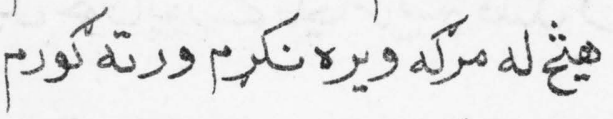

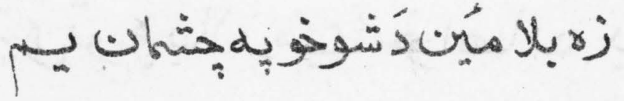

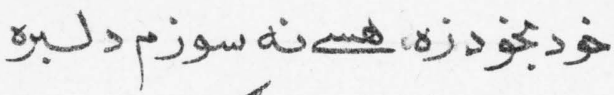

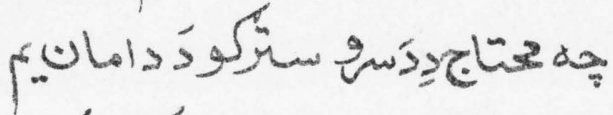

تو 


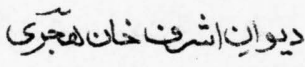

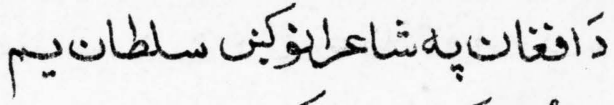

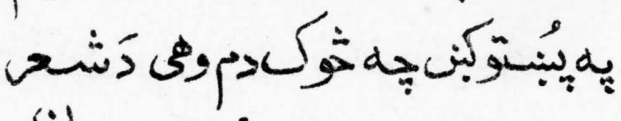

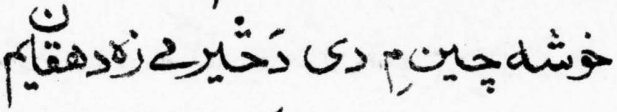

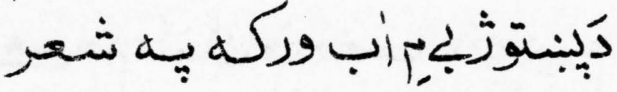

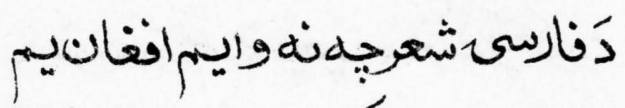

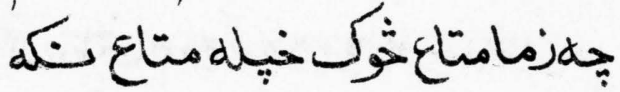

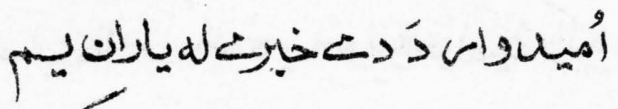



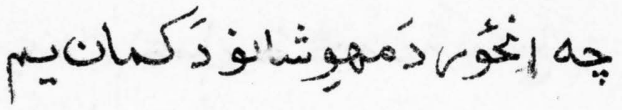

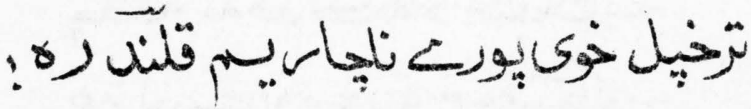

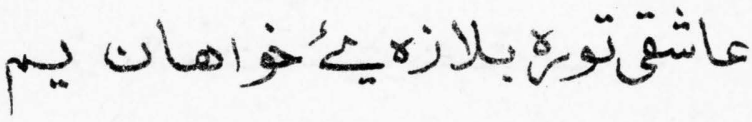




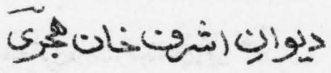

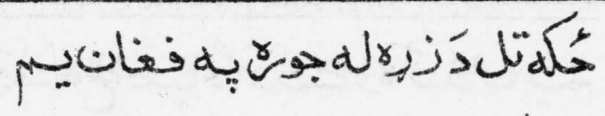

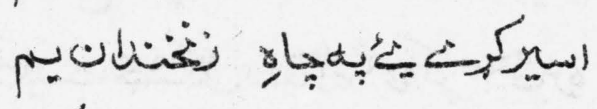

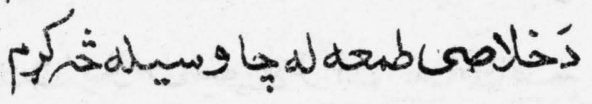

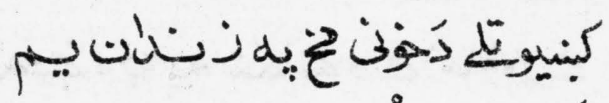

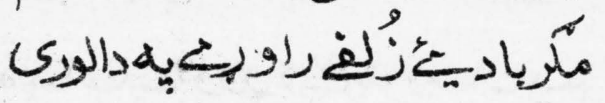

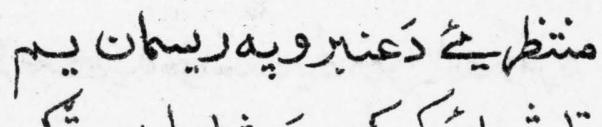

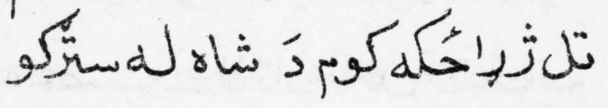

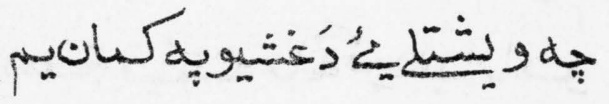
Lو

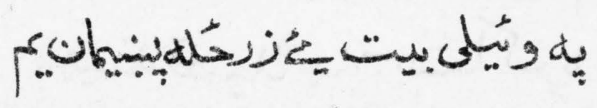

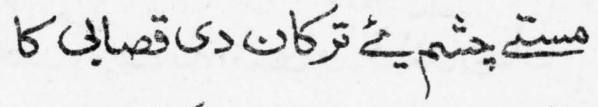
حناع

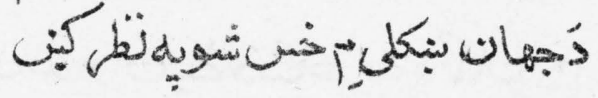

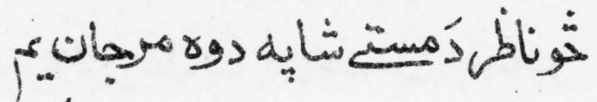

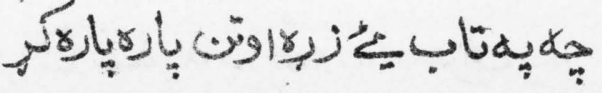




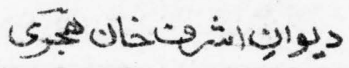

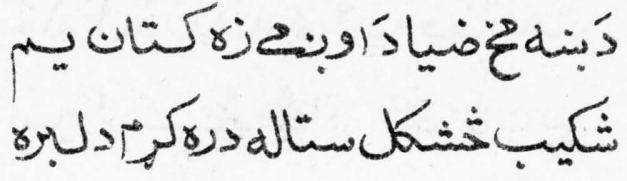

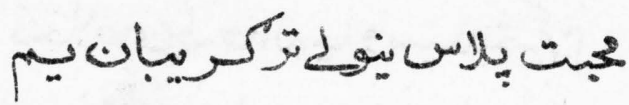

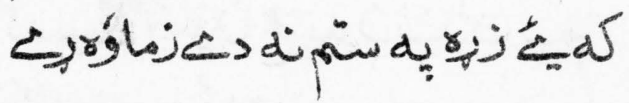

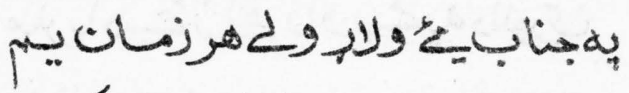

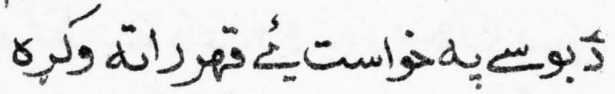

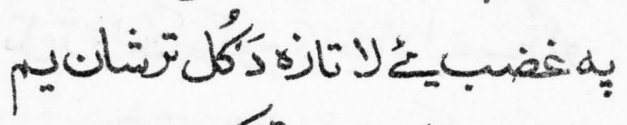

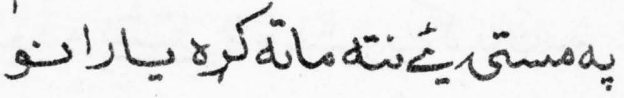

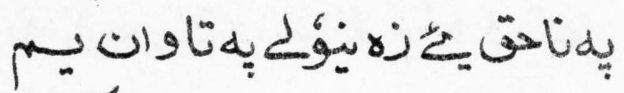

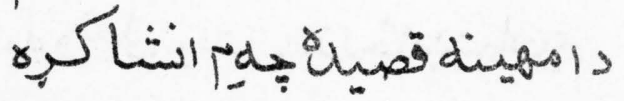

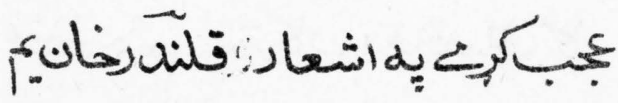

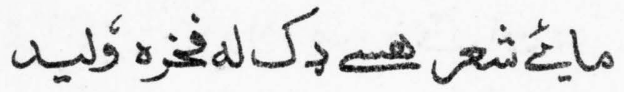

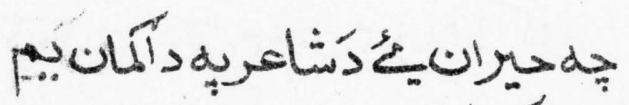

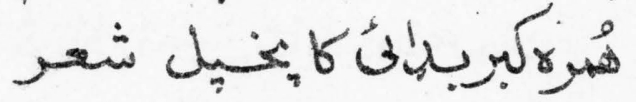

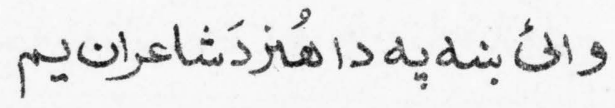




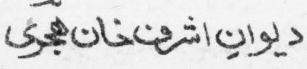

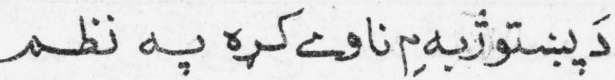

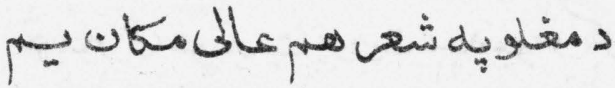

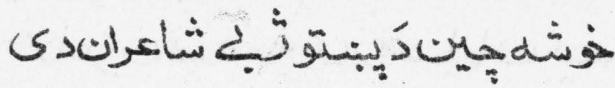

زئ

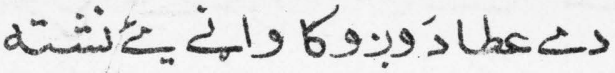

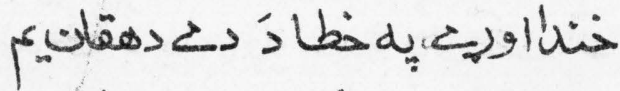
W

rolsdئه

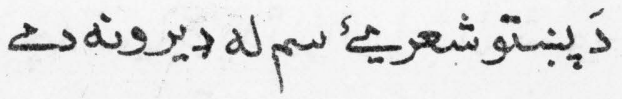

polra sogyzis gliós

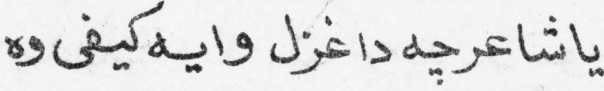

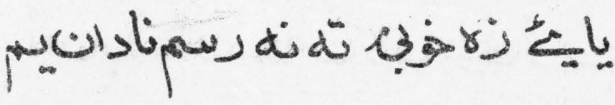

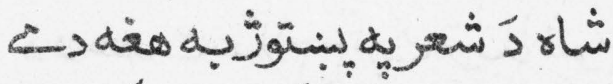

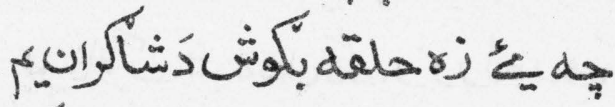

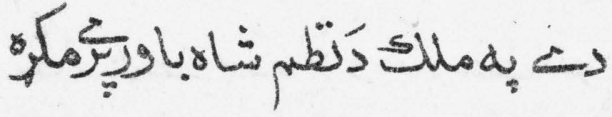




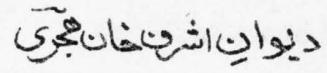

كمتر

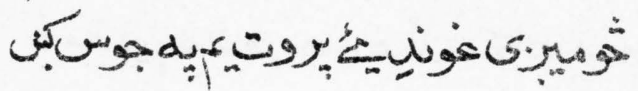

شايعران

ما

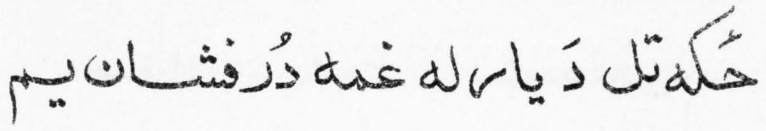

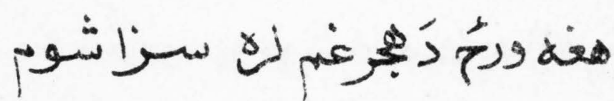

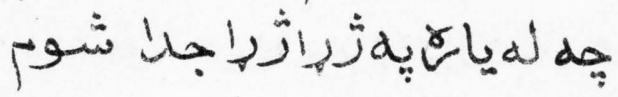

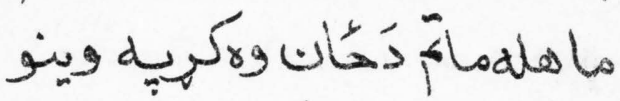

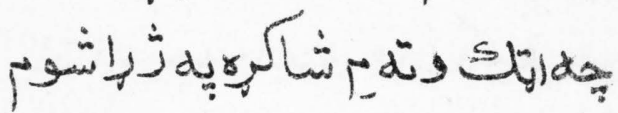

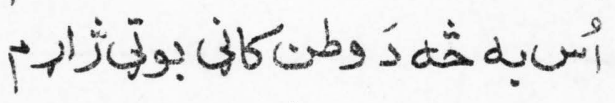

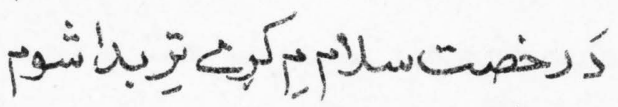

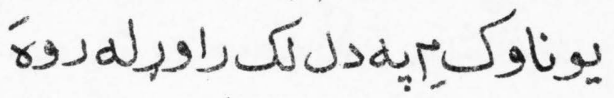

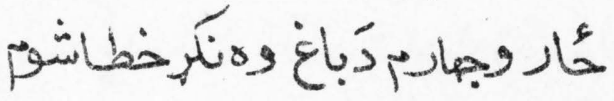


يوإِانثن خان هجرى

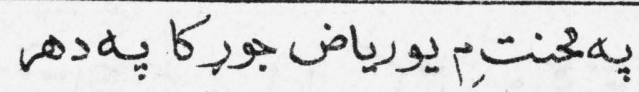

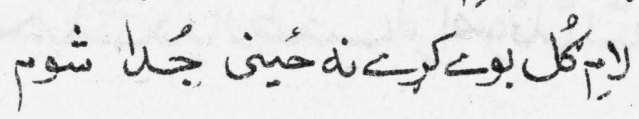

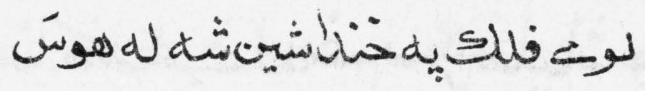

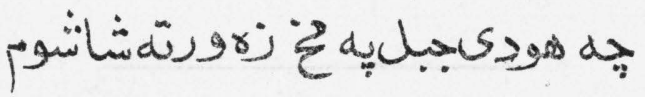

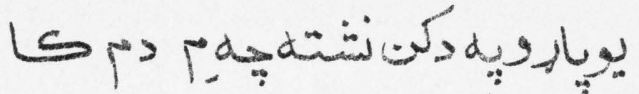

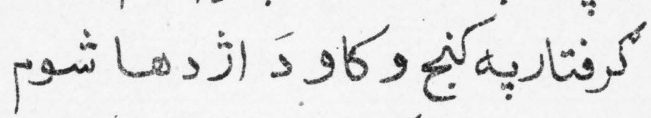

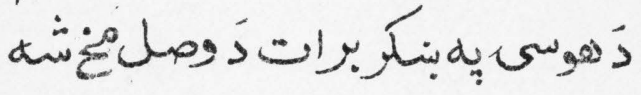

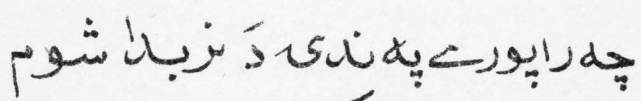

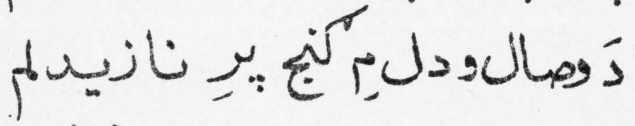

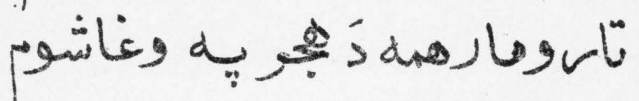

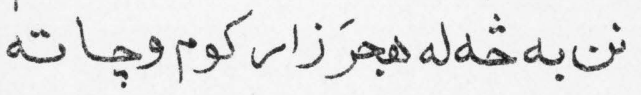

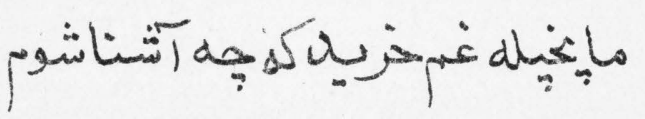

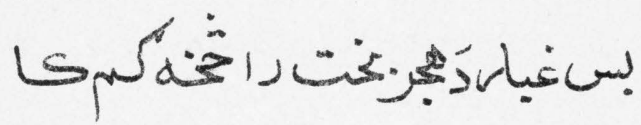

ئ

1.4 


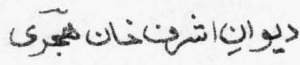

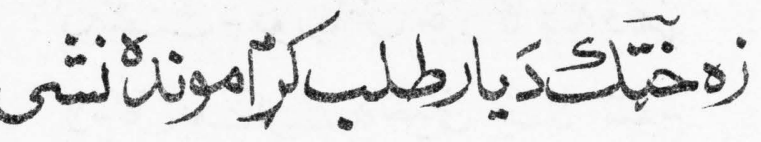

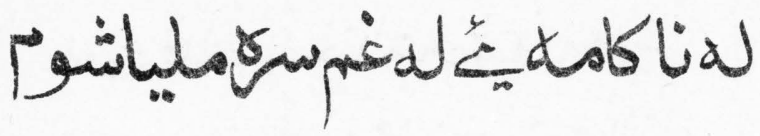




\section{ديوانِنشتصنانهُري}

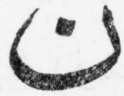

جرية ؤلاره هغغه بنه مينتياران

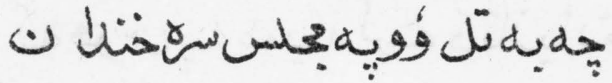

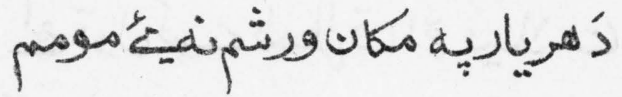

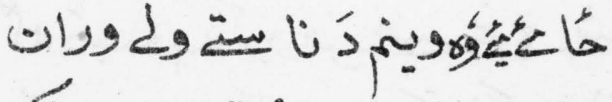

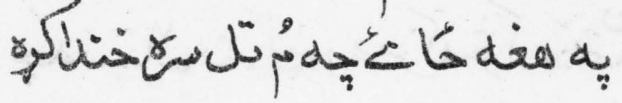

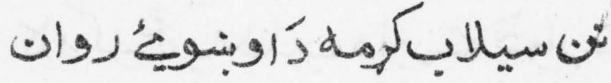

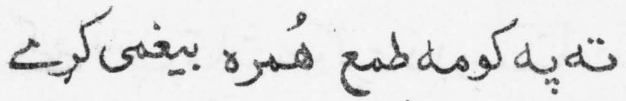

جل

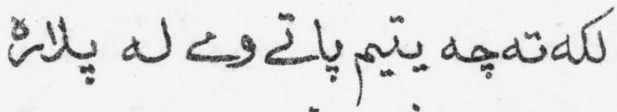

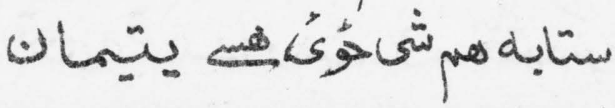




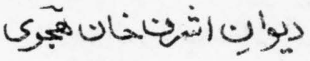

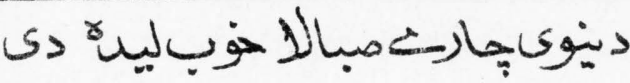

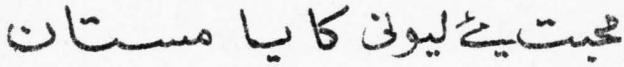

تابه

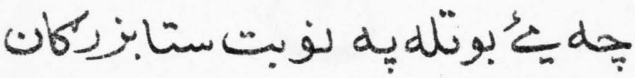

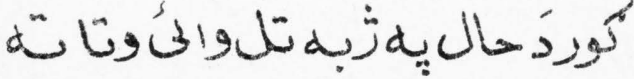

ينأُ

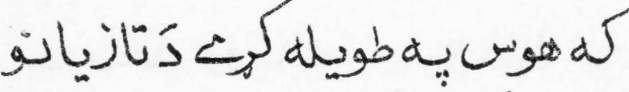

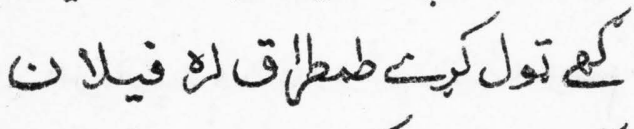

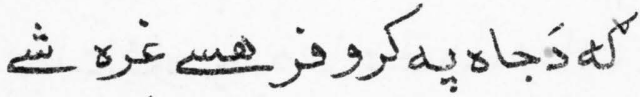

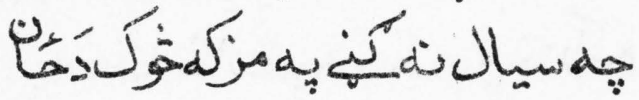

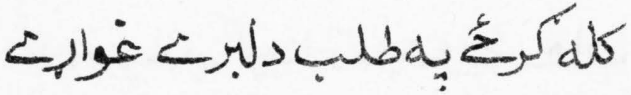

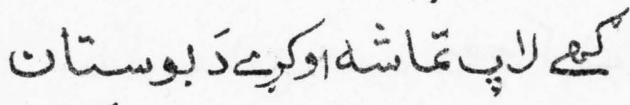

ثويله

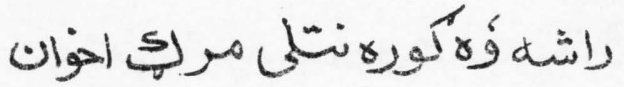

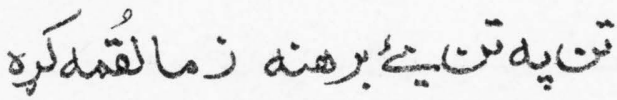




\section{ديوانِ|ثرتنانهُرى}

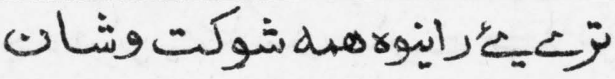

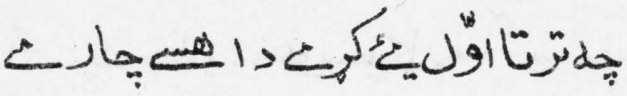

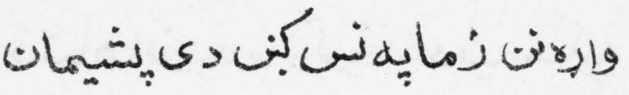

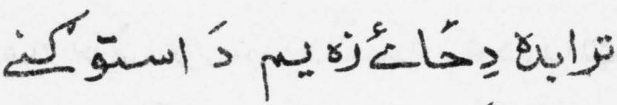

Uhin in

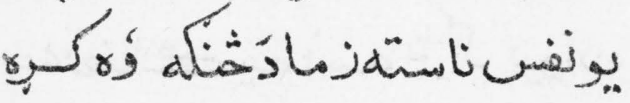

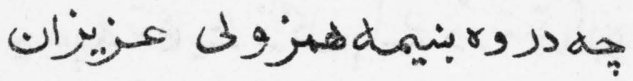

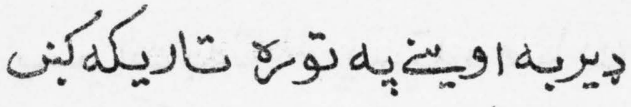

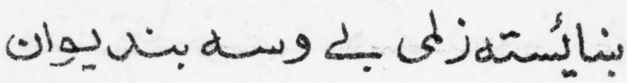

يو

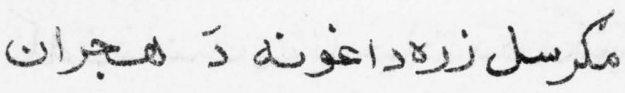

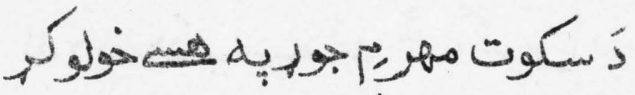

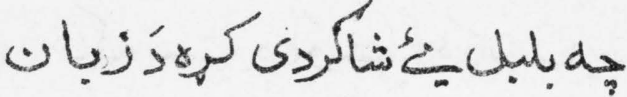

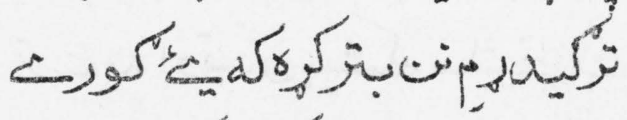

(4) 


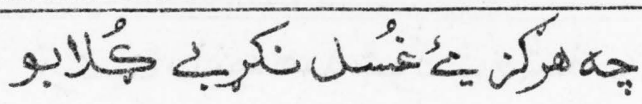

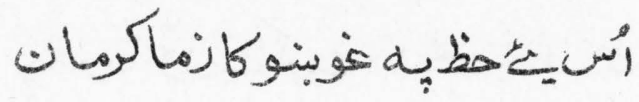

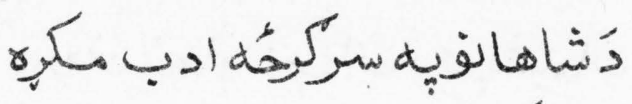
هبرتز

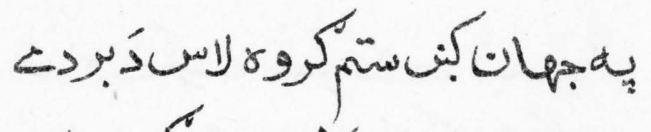

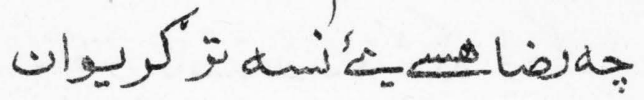

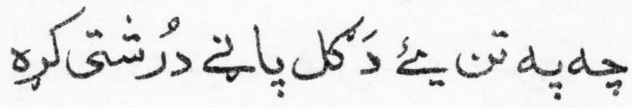

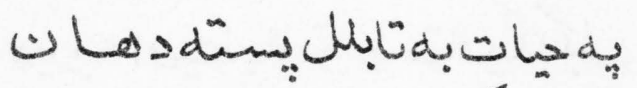

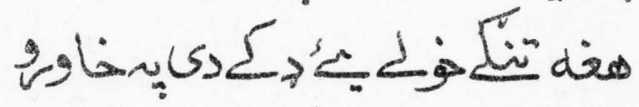

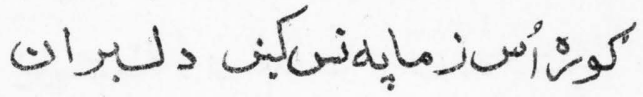

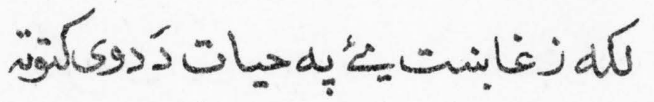
هان

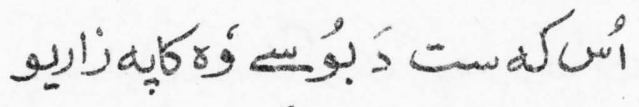

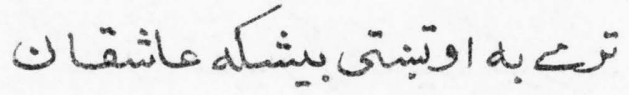
له 


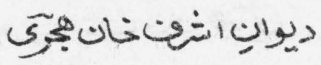

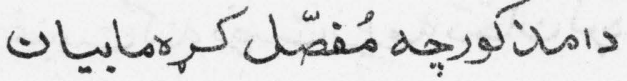
ونّ culsis

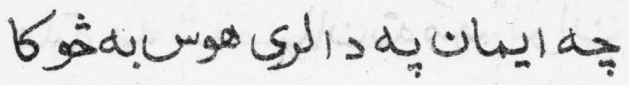
vir $\rightarrow$ or

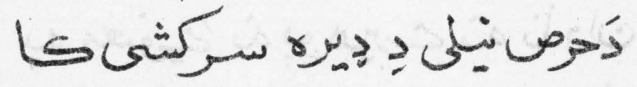

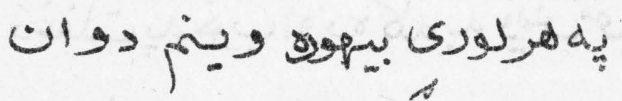

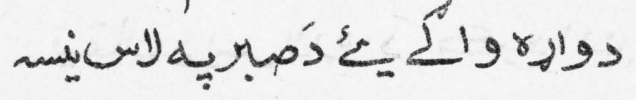

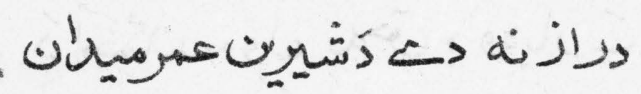

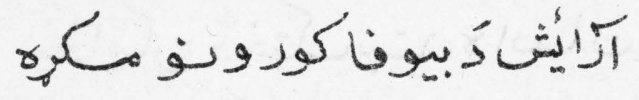

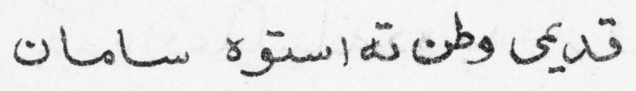

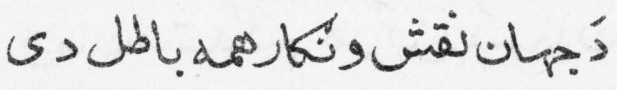

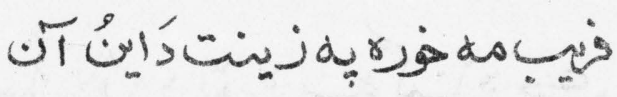

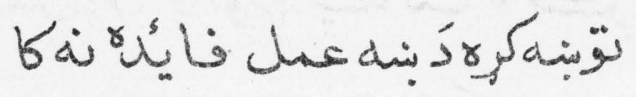

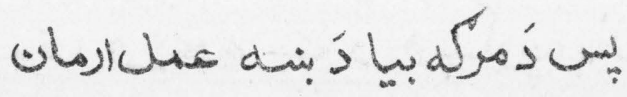


ديوايِنانشنان هيرتى

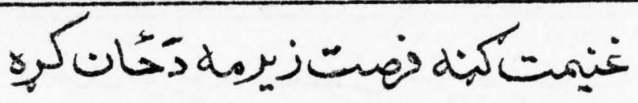

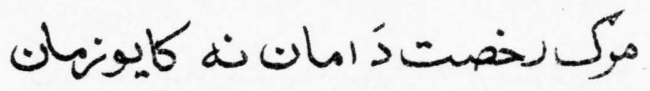

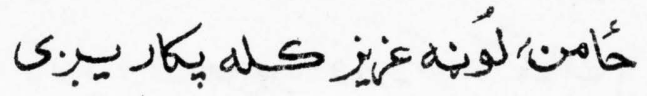

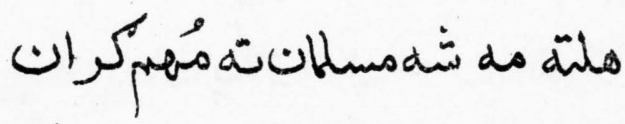

دَهويارموت جهب به تاخبر كا

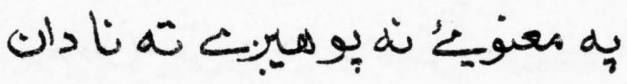

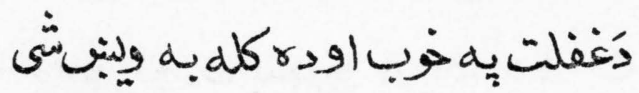

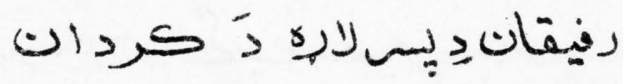

دأكئمارسول بهن

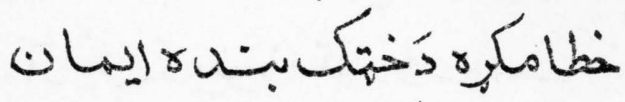

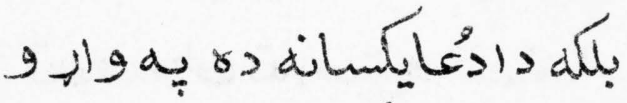

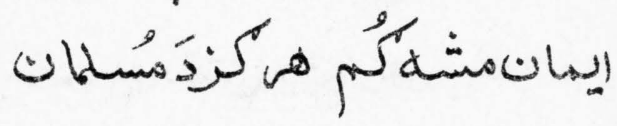

كعلئيح

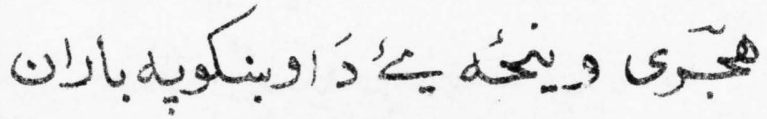




\section{ديوانِ اشحتخانهي}

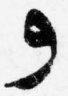

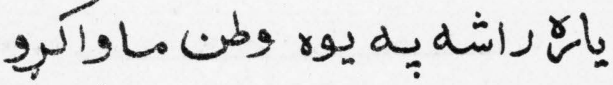

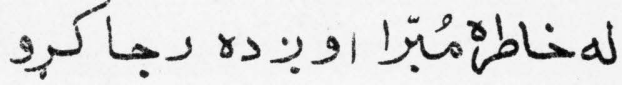

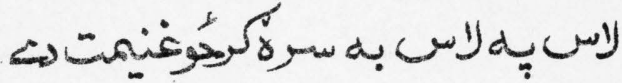

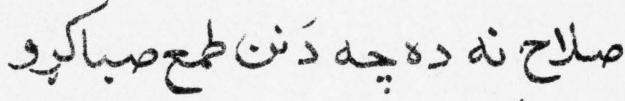

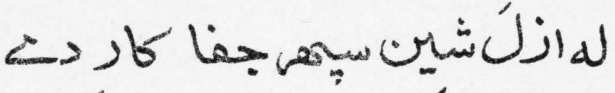

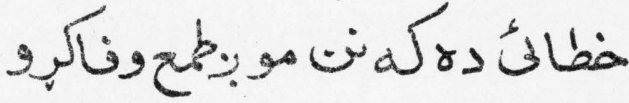

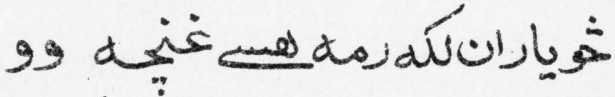

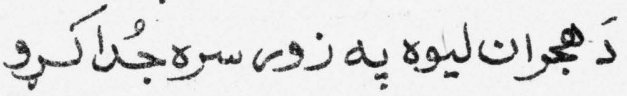

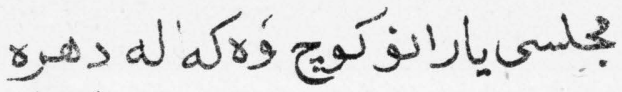

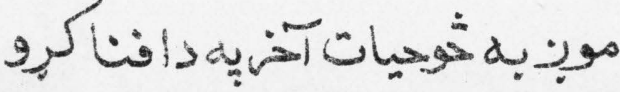


ديوانِانشنحنان لهبرى

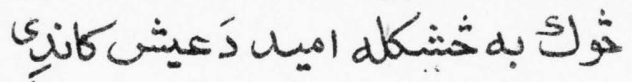

يل

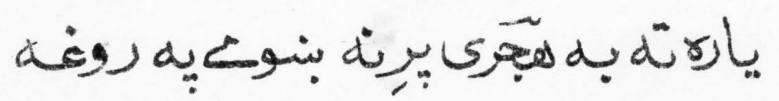

يه ستم سليبل جورد' باد شَالكرو 


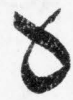

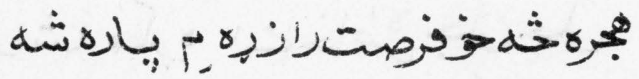

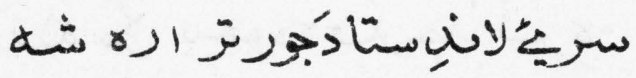

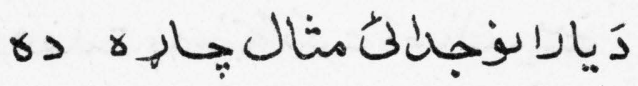

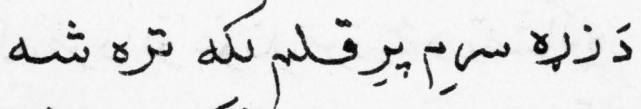

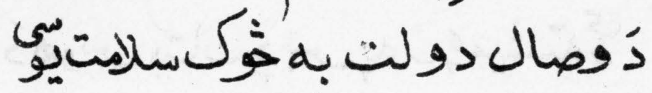

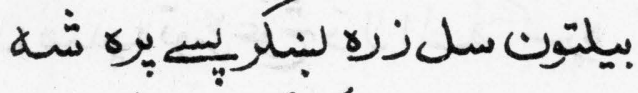

راشه يوحُل ختجكك لوريه دكتكبنى

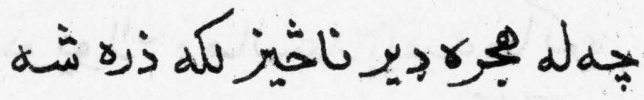

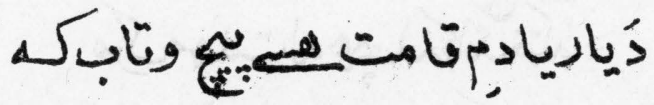

بهد دار كارمثال دُزلفوبيه طرهشه 


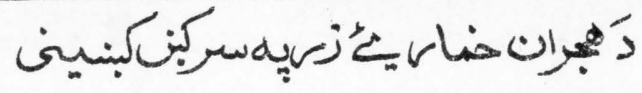

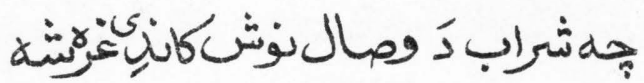

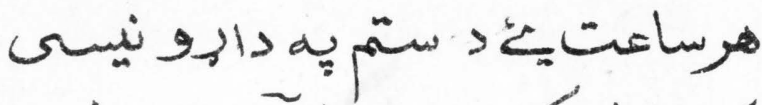

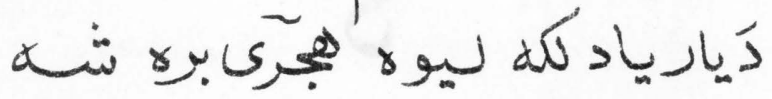

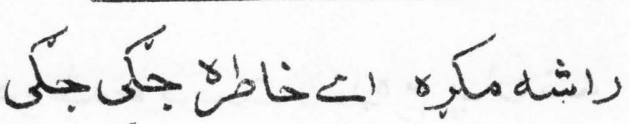

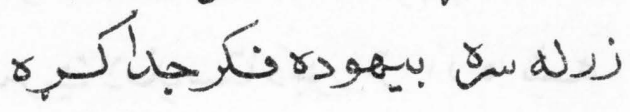

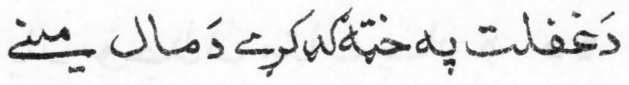

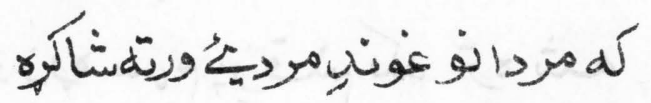

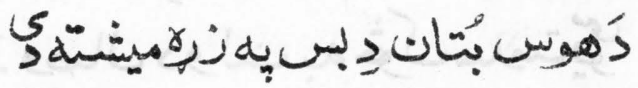

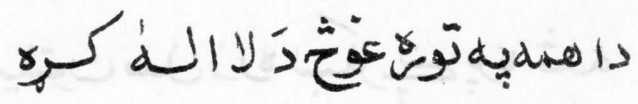

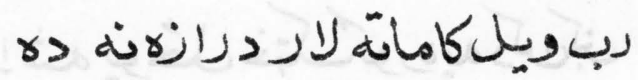

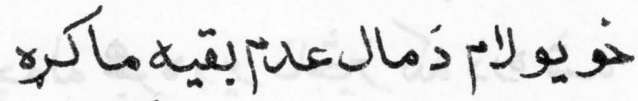

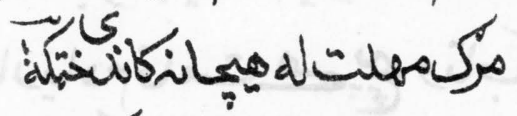

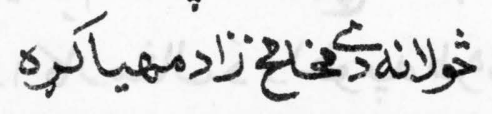




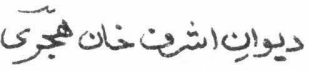

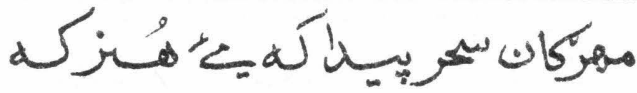

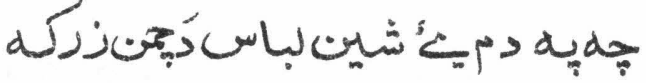

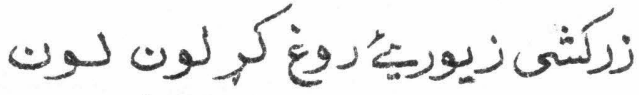

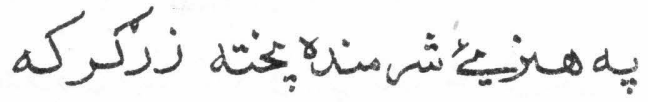

نَيجن بونه

هراعضايحمنفريه بل زيوركه

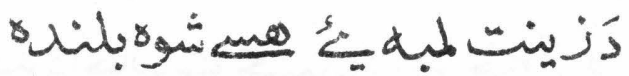

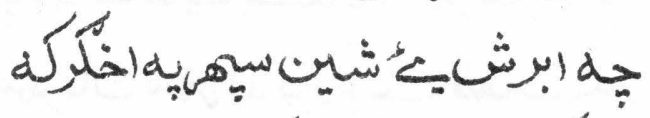

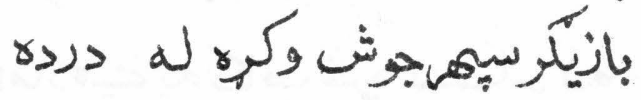

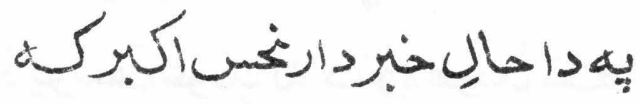

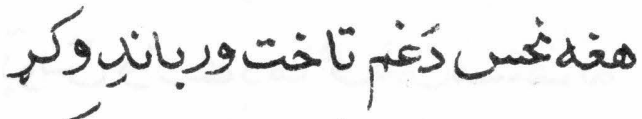

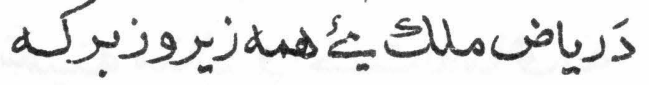

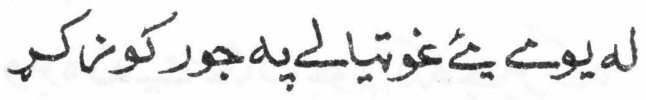

له

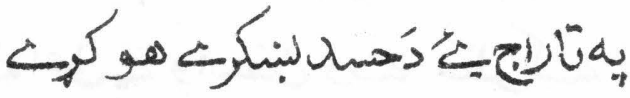




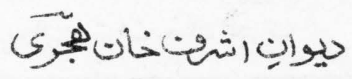

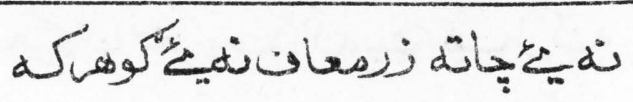

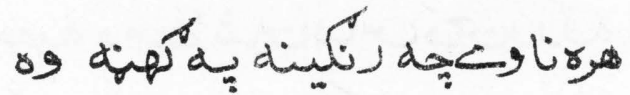

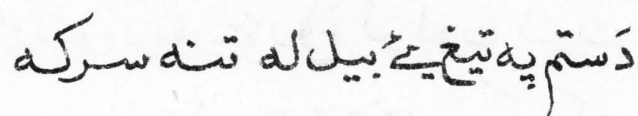

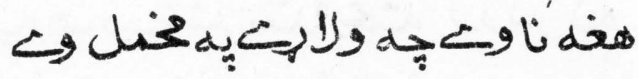

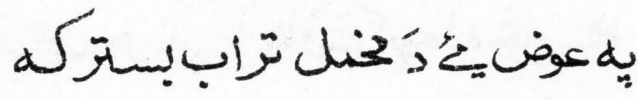

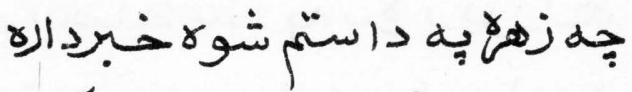

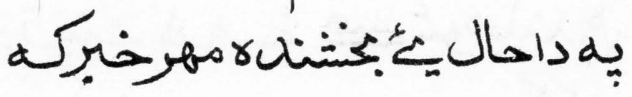

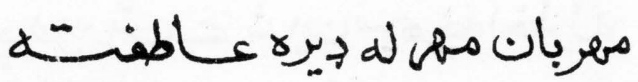

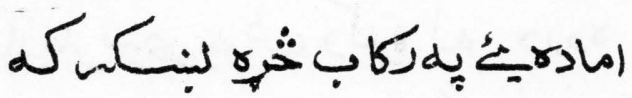

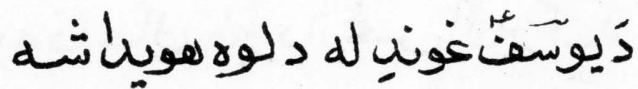

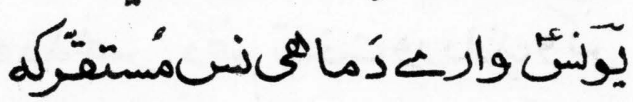

شمينه منالِ واخست لهمانهنه

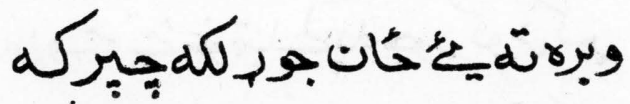

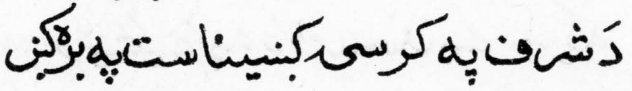

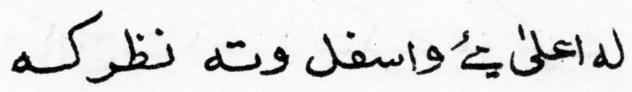

114 


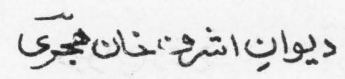

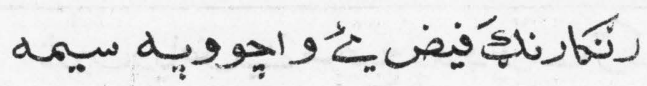

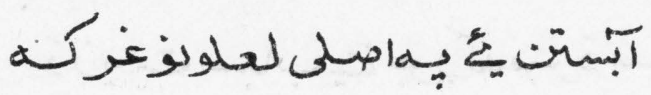

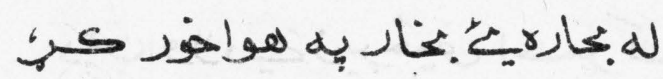

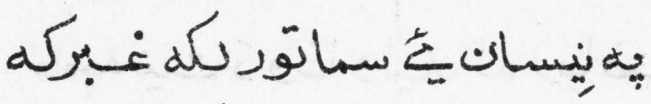

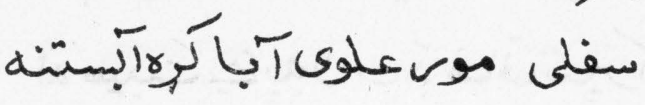

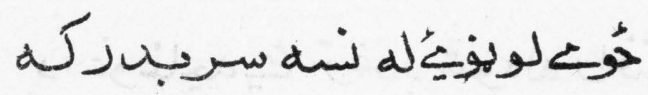

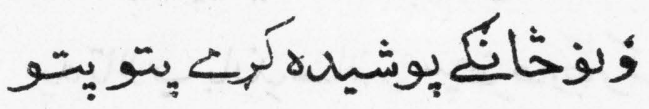

دهربرَك شكل ججنوت لَه نشتركَه

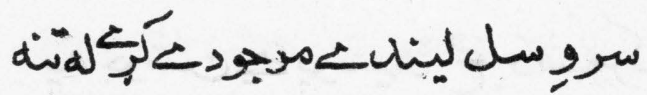

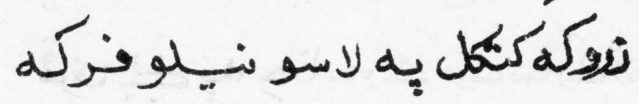

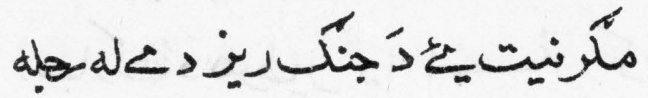

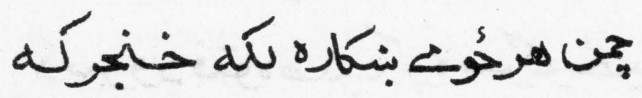

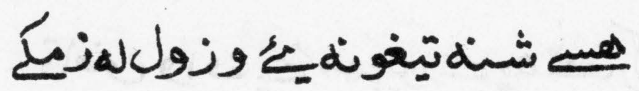

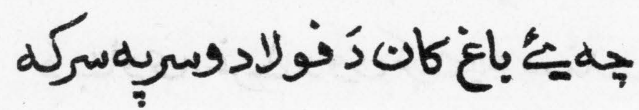

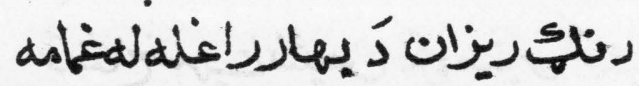

IIV 


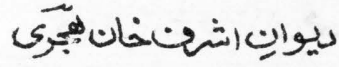

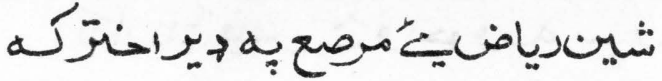

دَزينت اسبابِ

كَّتهن

مأهذه

هـ

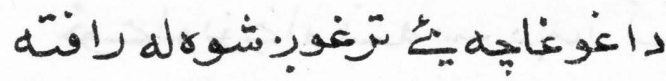

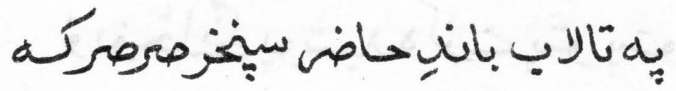

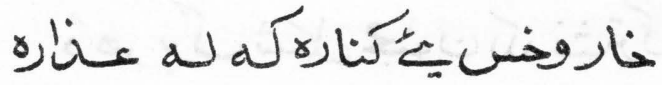

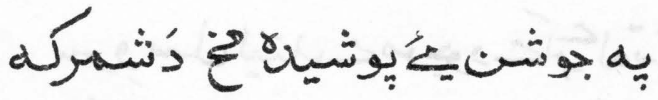

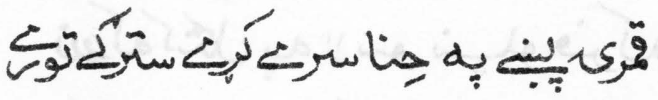

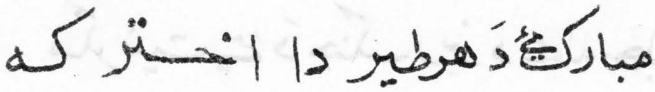

足

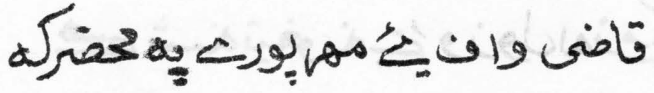

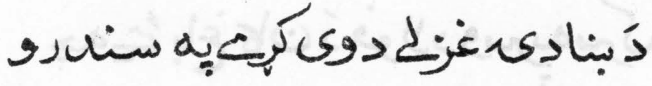

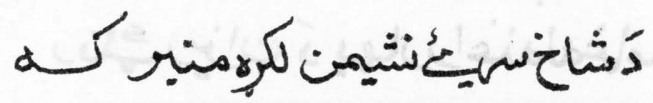




\section{ليوانِاشعتخان}

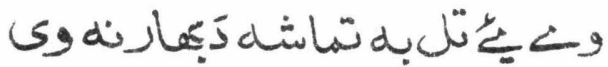

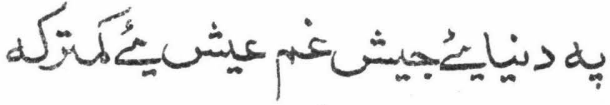

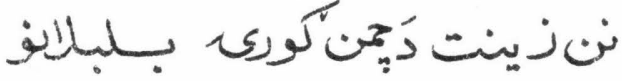

جهن

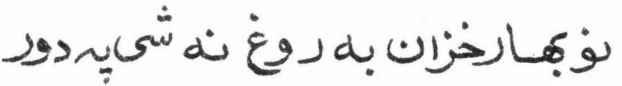

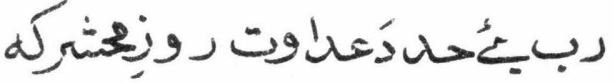

دَهرشىعمربهاردنيا د رياضف ده

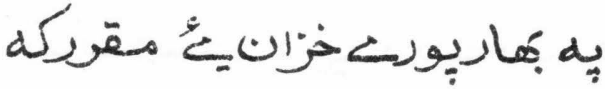

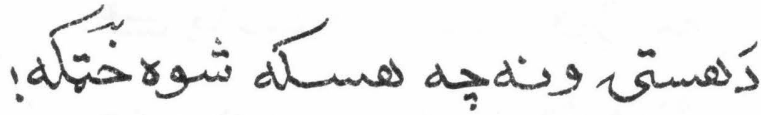

هر 


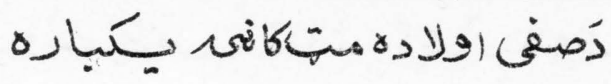

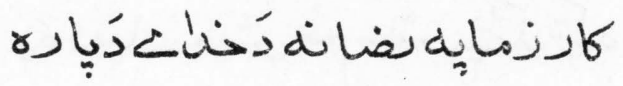

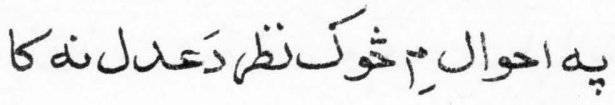

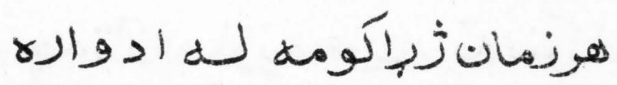

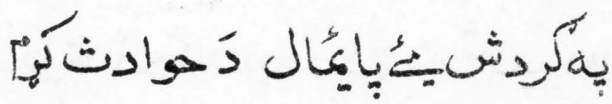

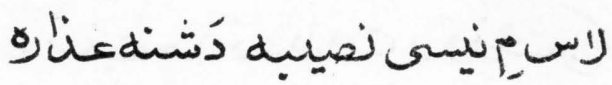

جه

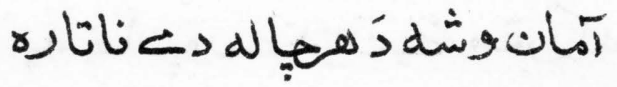

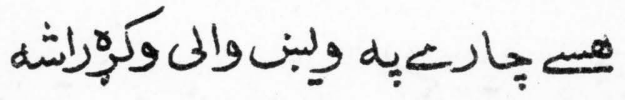

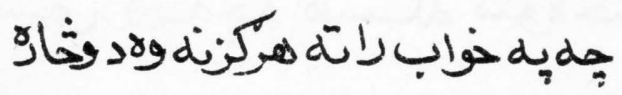

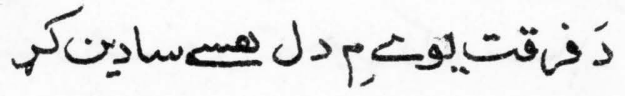

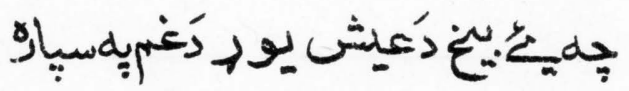

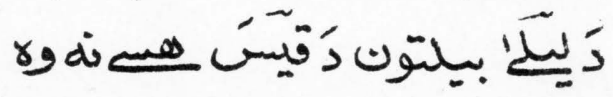

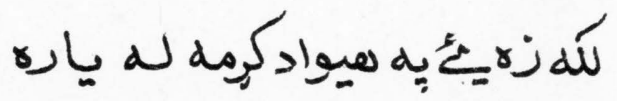

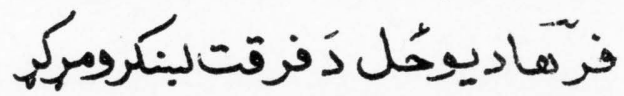


مابح دوده هركفن وزّنت دوبارة

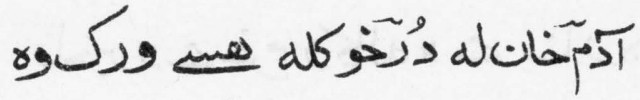
كارة

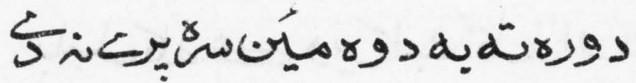

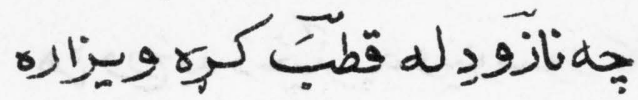

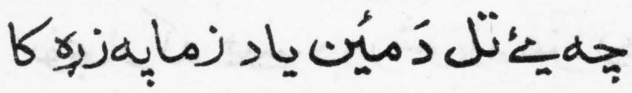

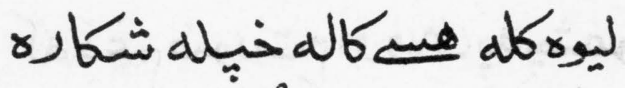

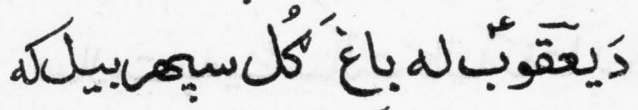

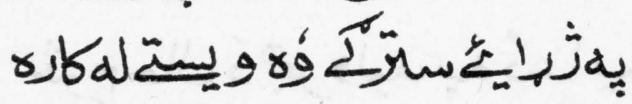

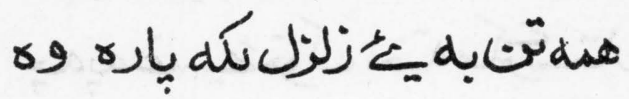

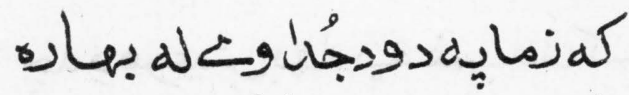

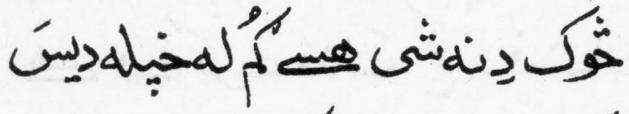

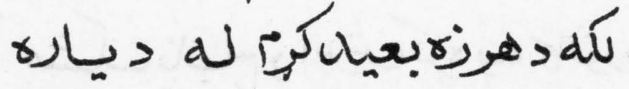

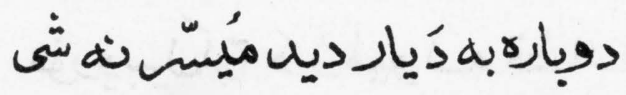

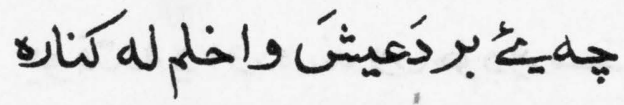




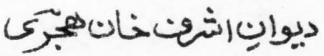

دياروصل يمأوردَفرقتبلكر

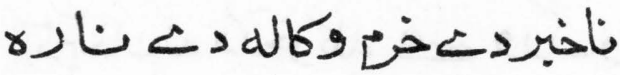

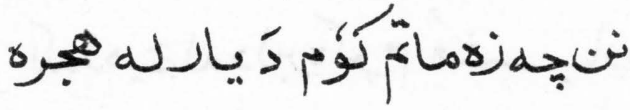

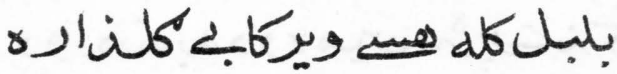

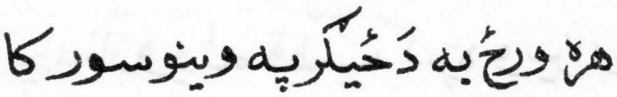

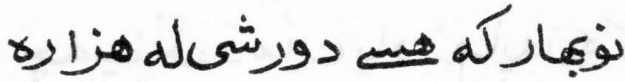

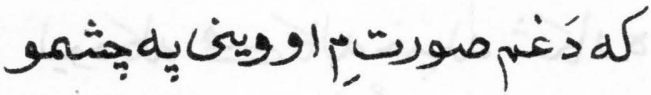

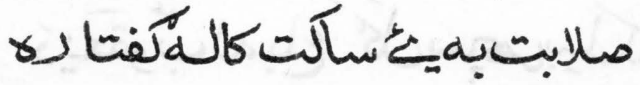

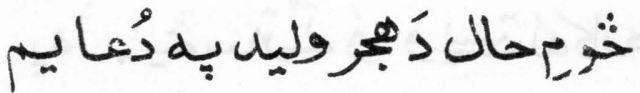

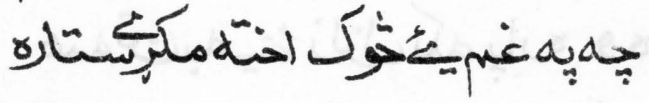

جه

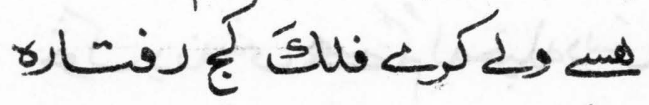

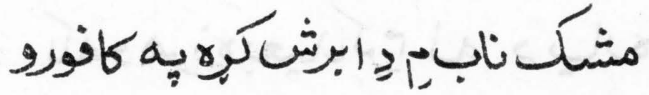

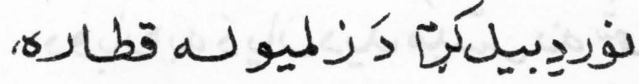

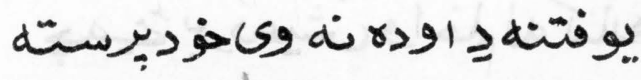




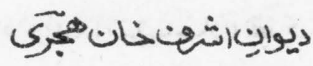

ช)

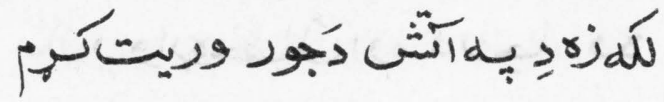

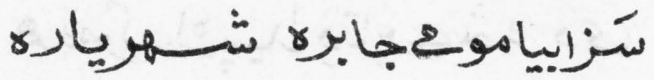

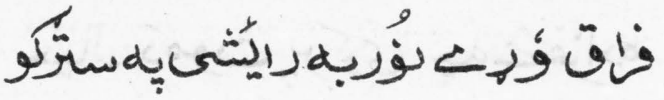

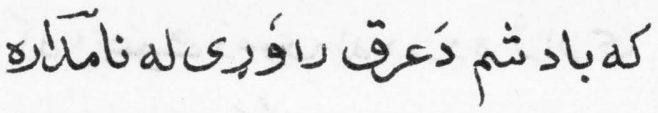

جه كُلكَّتَت

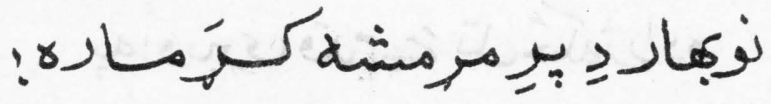

$\gamma>\operatorname{lol}^{2}$

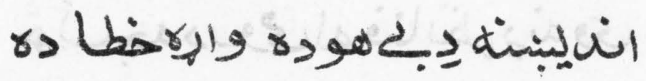

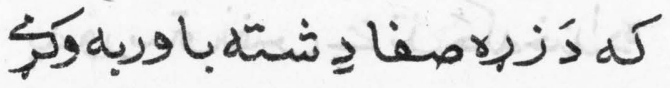

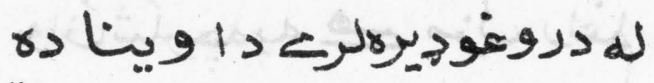

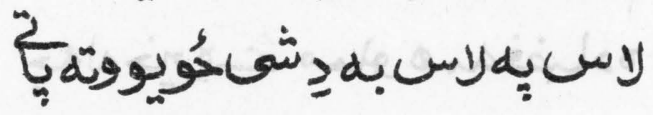

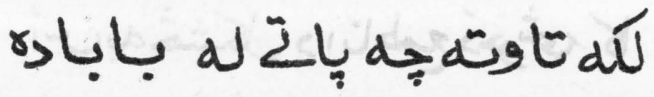




\section{ليوانِ اشتهنانهيجى}

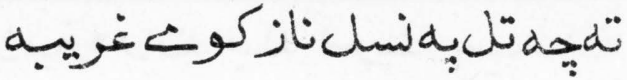

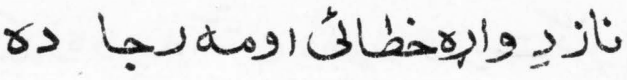

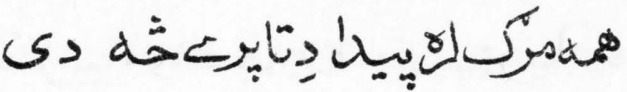

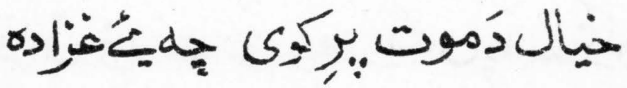

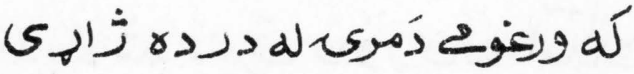

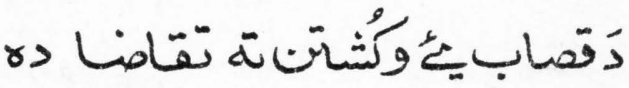

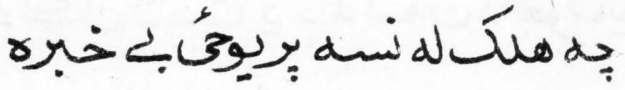

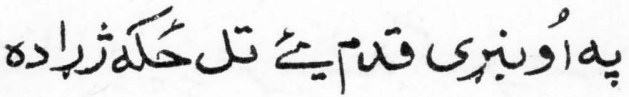

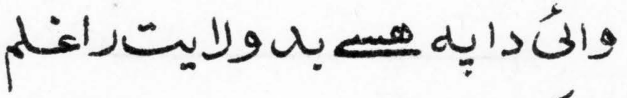

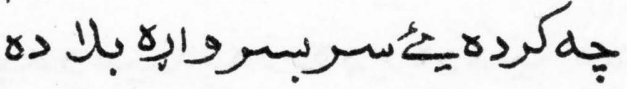

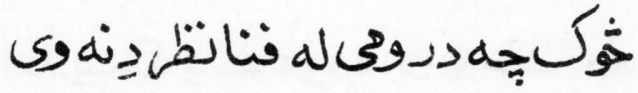

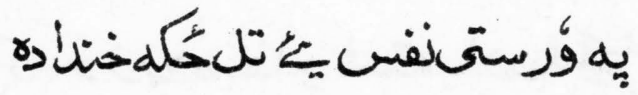

والثئشكرجهيه هيم مزل راغنم

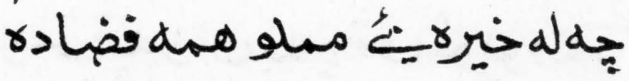

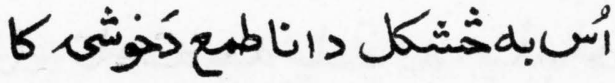




\section{ديوإناشنتخانهيمري}

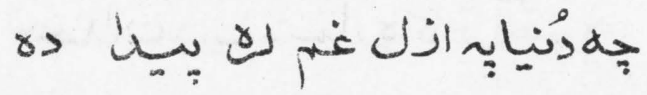

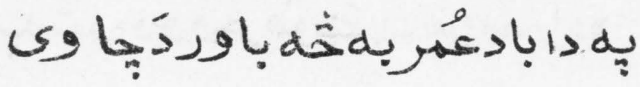

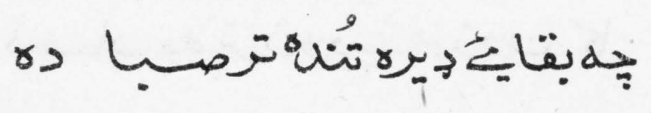

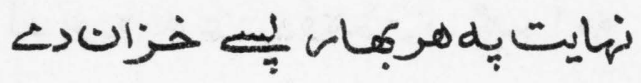

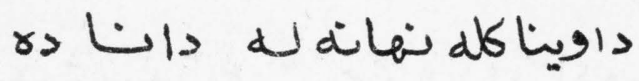

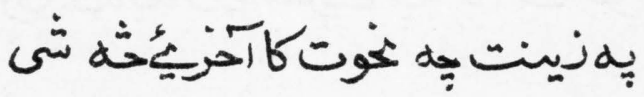

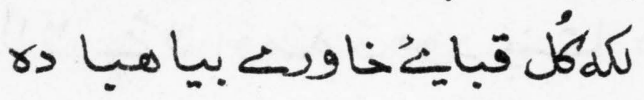

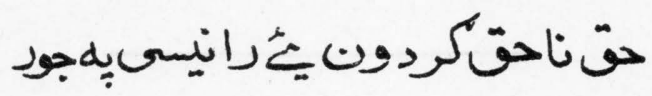

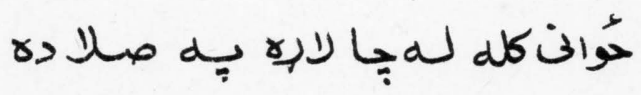

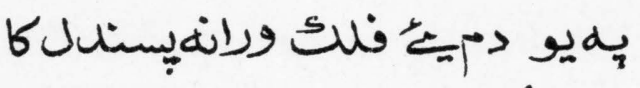

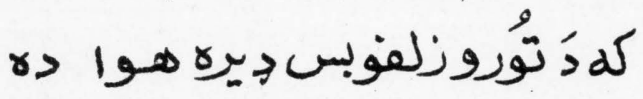

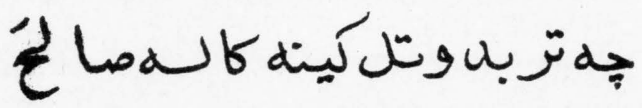

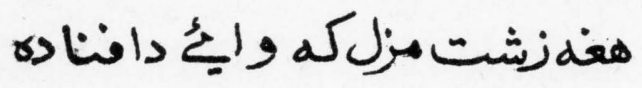

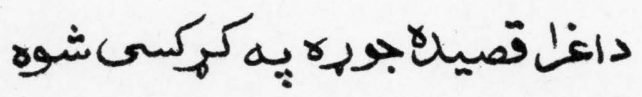

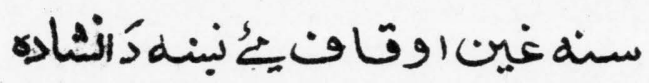




\section{دئى}

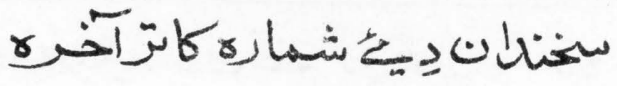

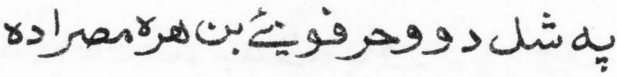

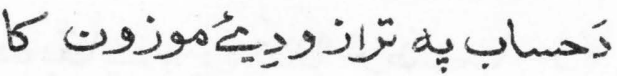

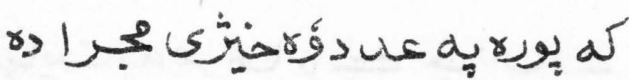

rs. L

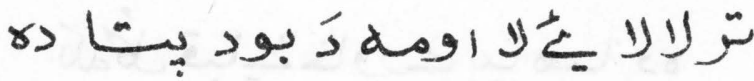


موح>

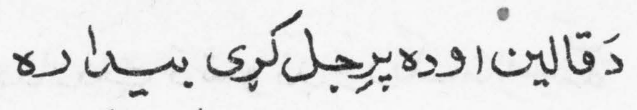

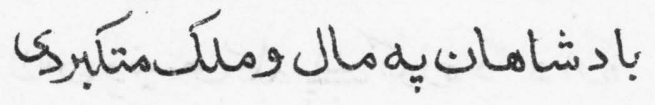

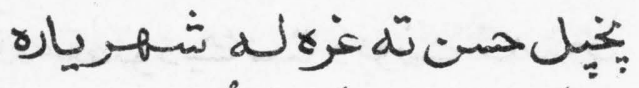

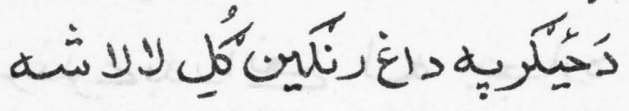

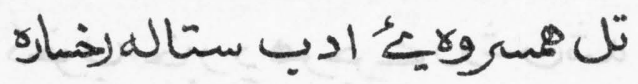

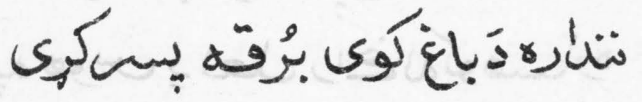

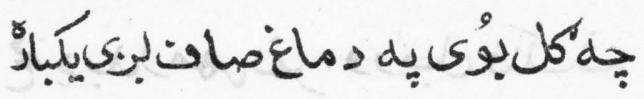

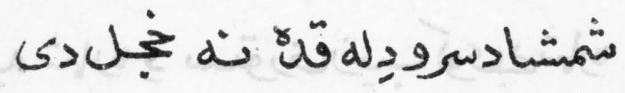

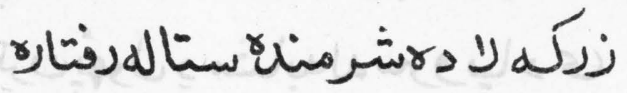

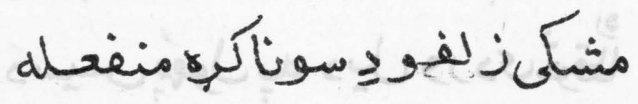

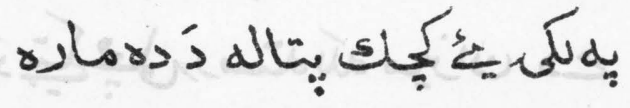

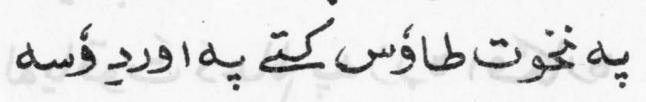

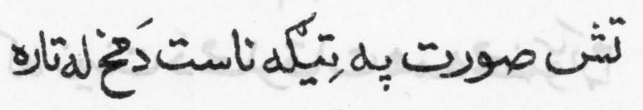

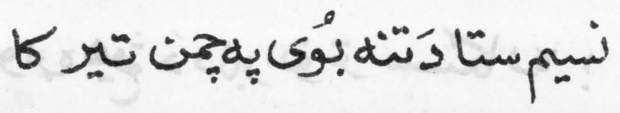




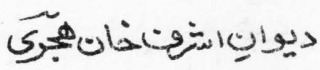

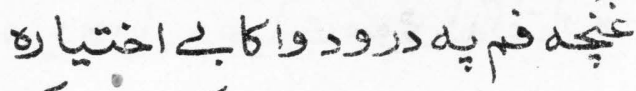

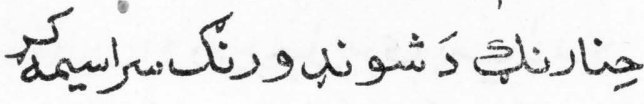

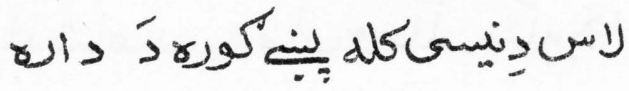

كمةمقصوحِ

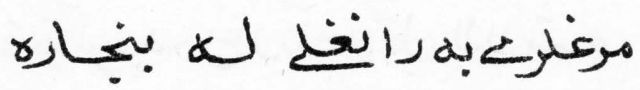

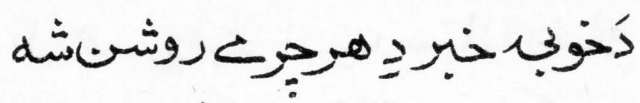

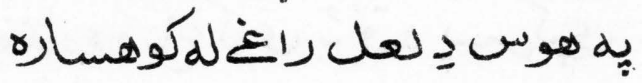

عُ

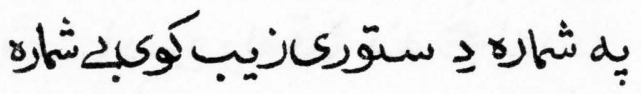

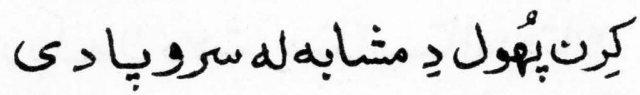

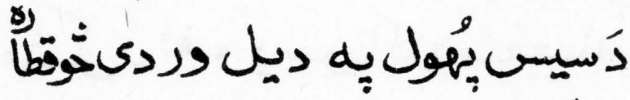

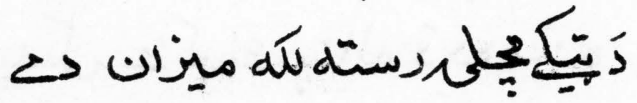

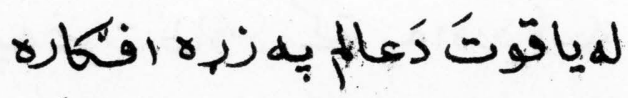

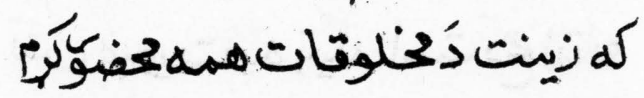

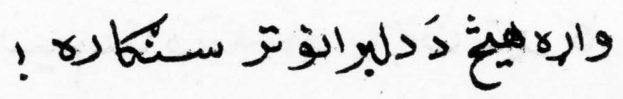




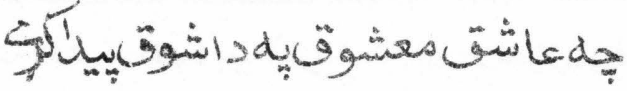

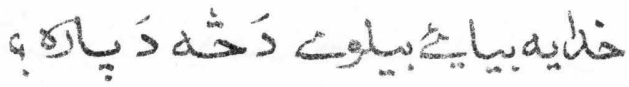

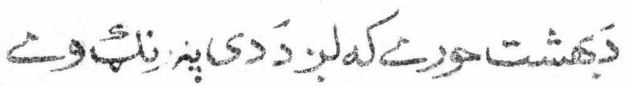

بنائسنة

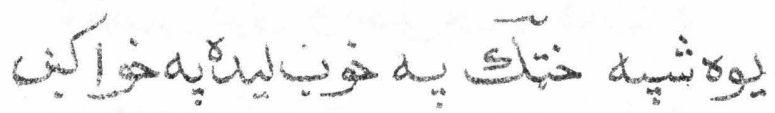

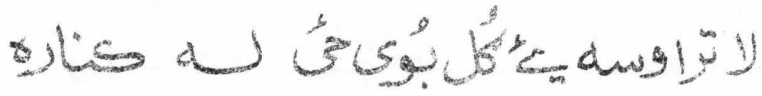

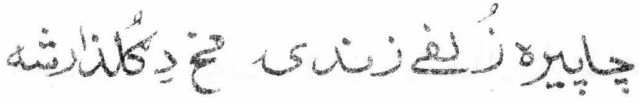
ماكُونة

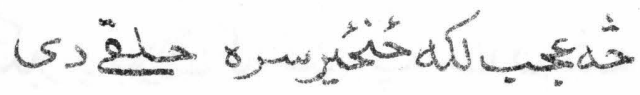

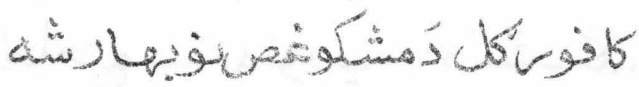
— S S

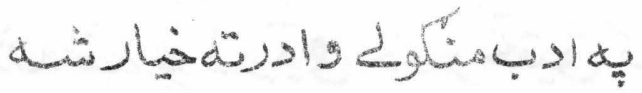

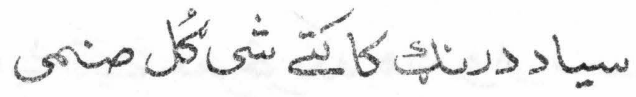




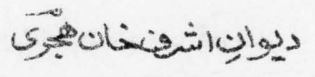

ت

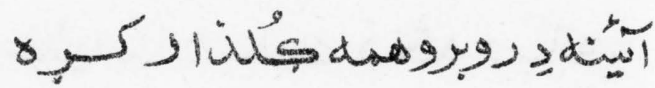

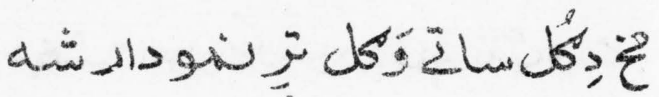
كونة

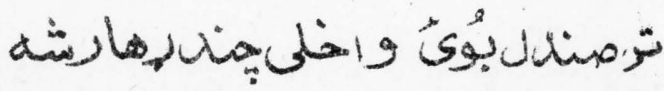

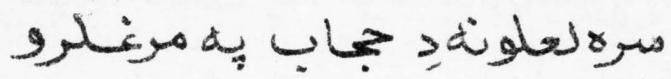

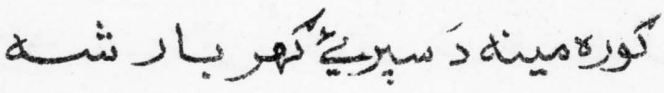

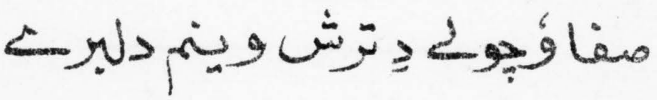

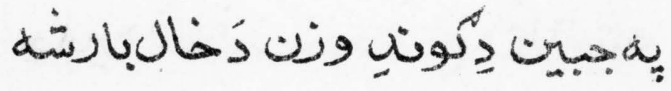
pow

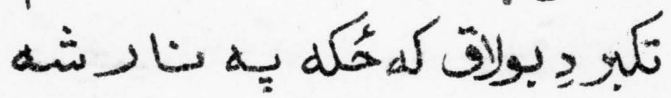

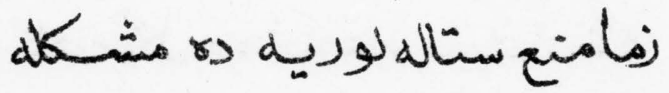

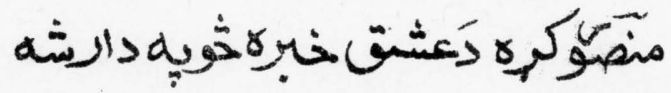
家

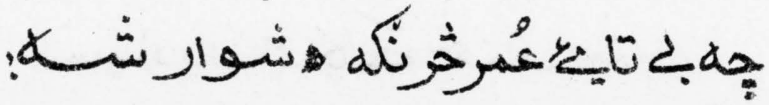




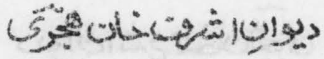

هululis's \&

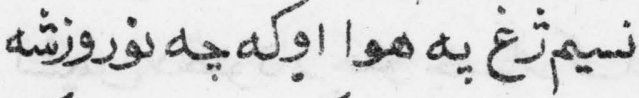

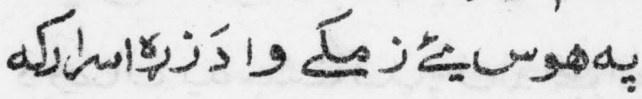

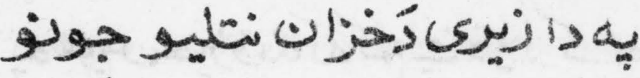

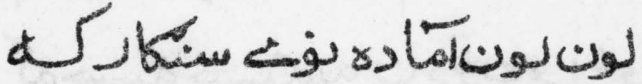

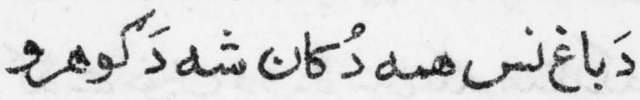

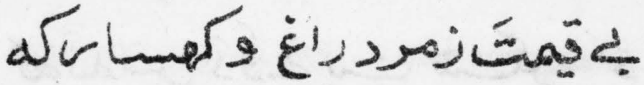

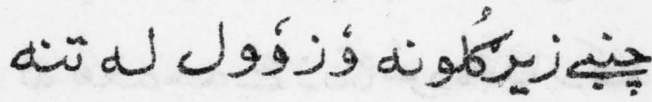

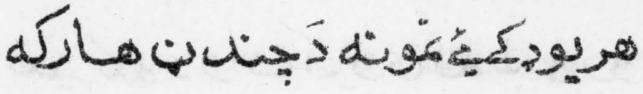

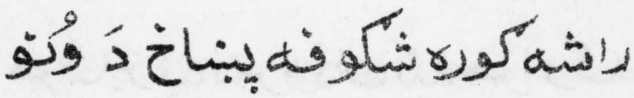

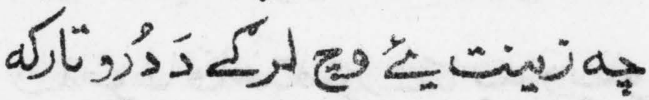

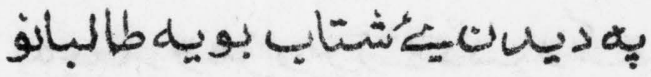

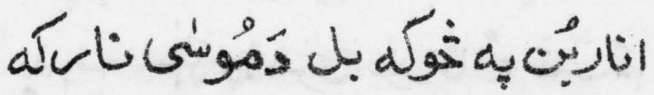

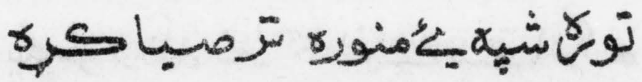




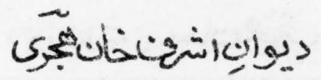

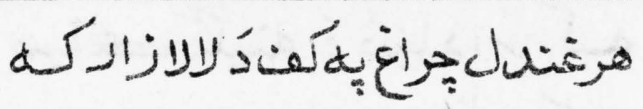

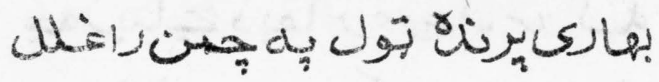

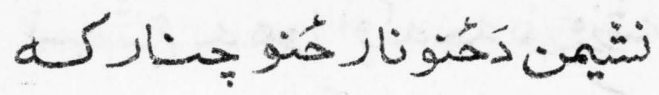

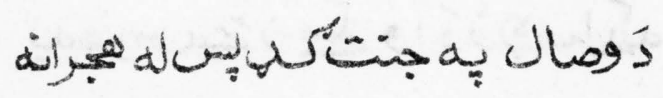

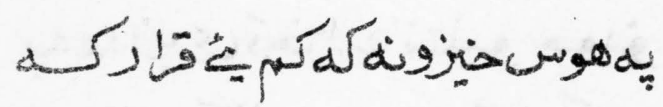

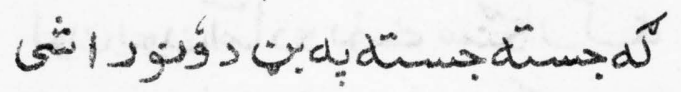

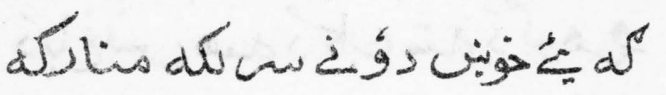

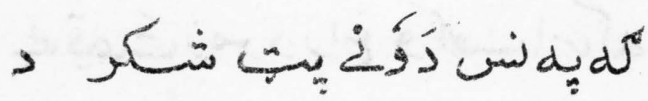

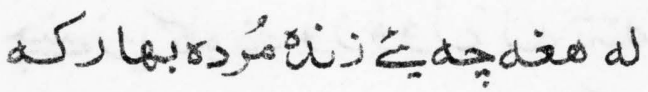

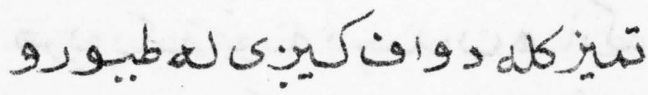

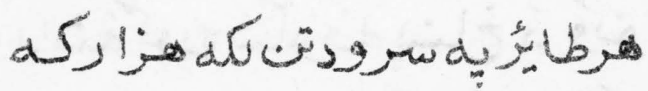

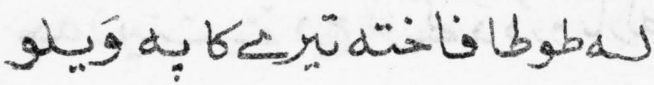

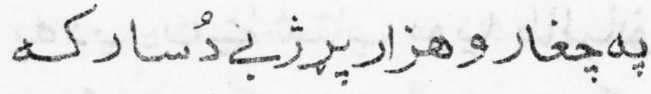

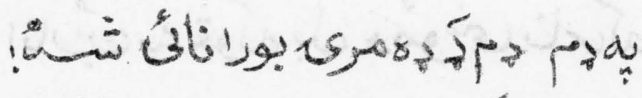

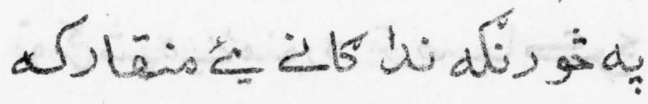


ديوالِِاشعنخانهُري

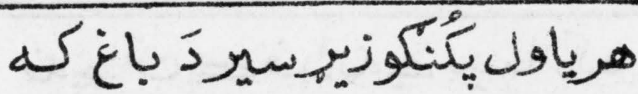

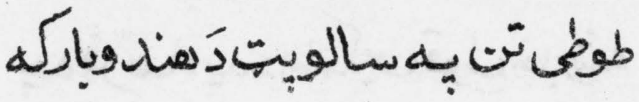

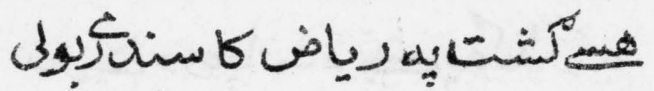

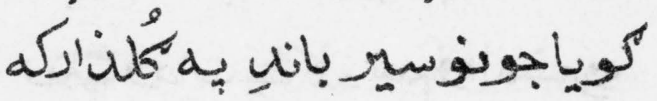

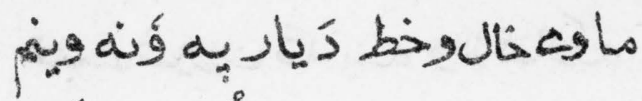

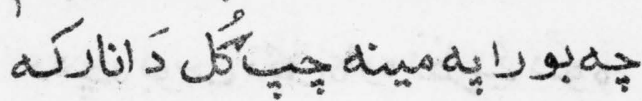

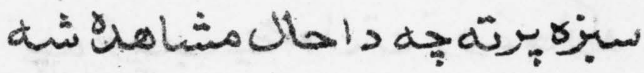

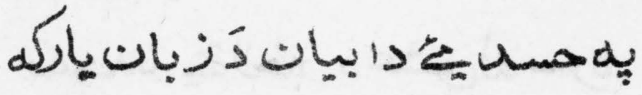

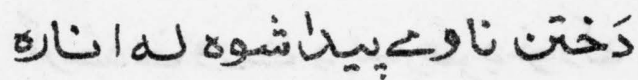

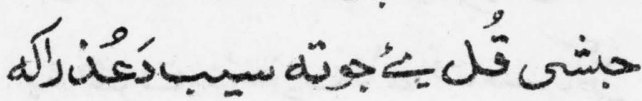

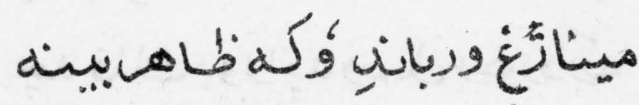

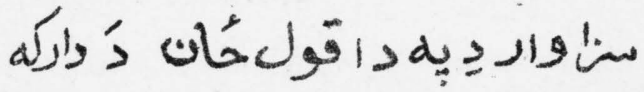

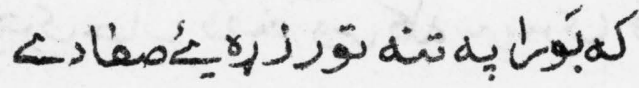

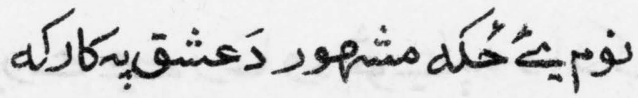

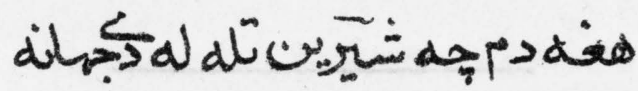

IrT 
(5)

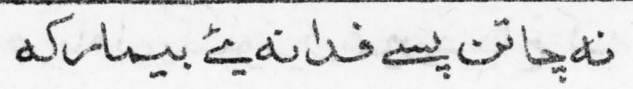

جه

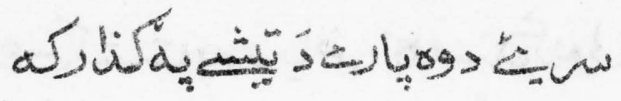

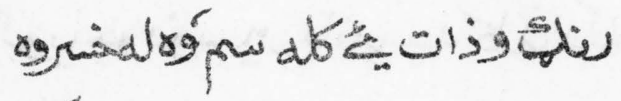

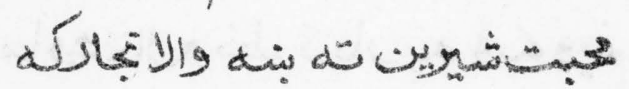

هُ

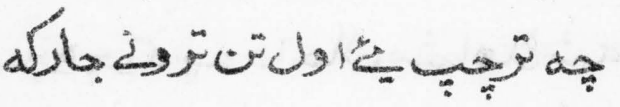

كَّة

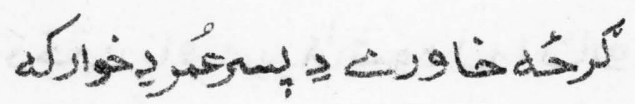

ئ

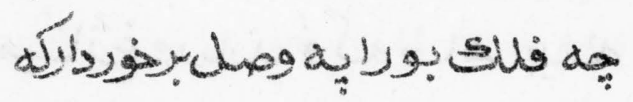

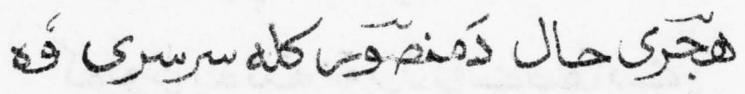

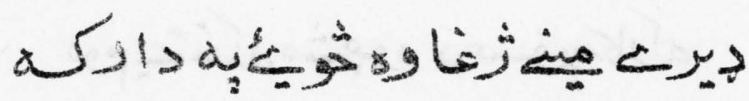

$1 \omega p$ 
nivh

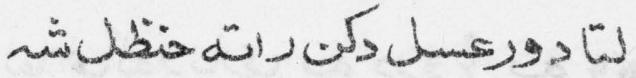

d

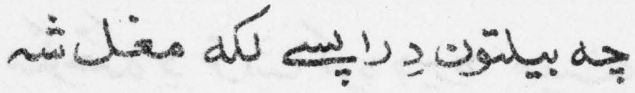

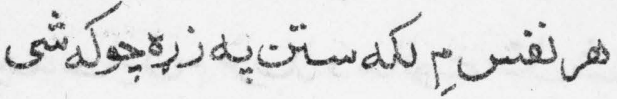

ثن

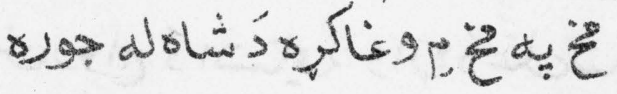

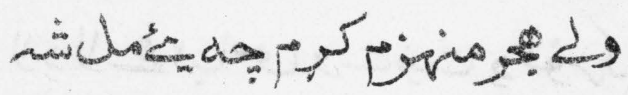

x, d d d a

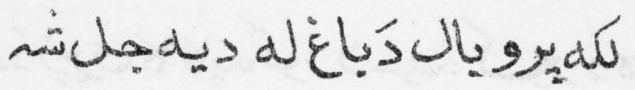

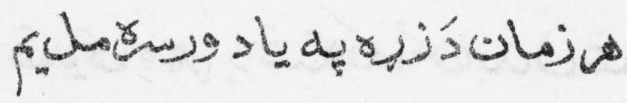

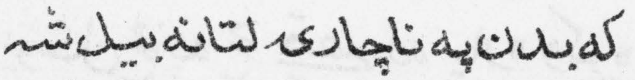

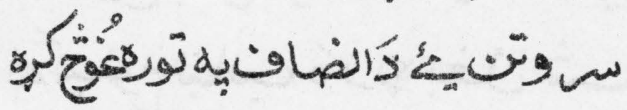

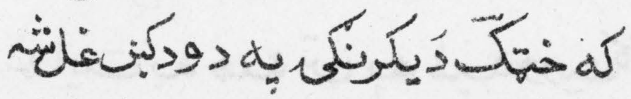

3,50 d d 


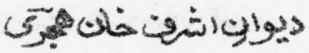

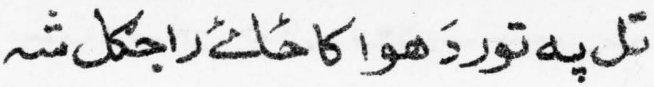

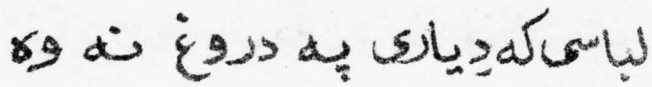

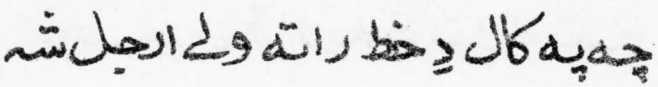

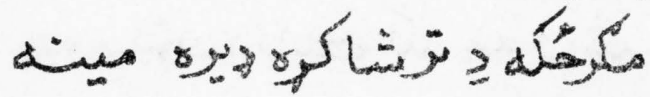

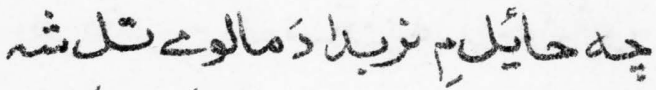

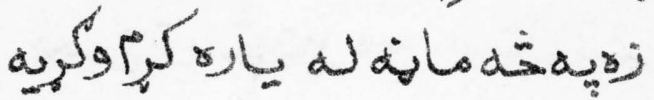

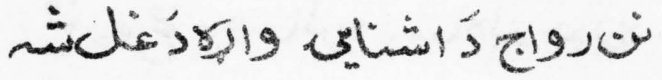

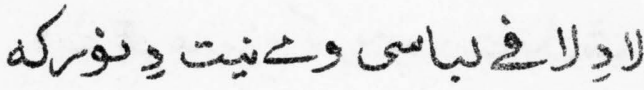

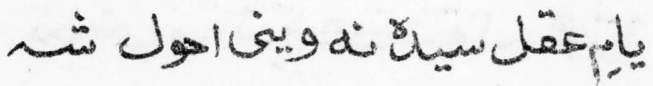

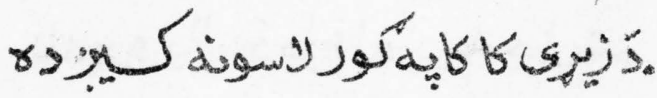

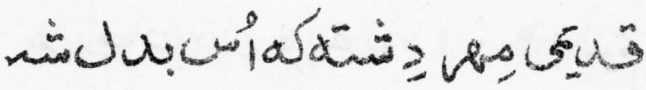

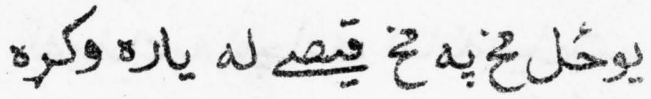

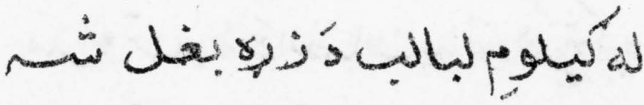

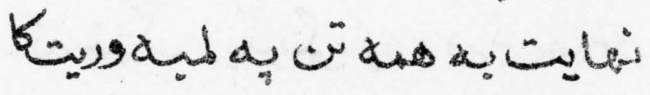

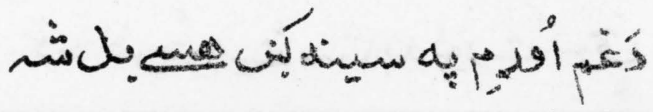


ذوبرة

بـ

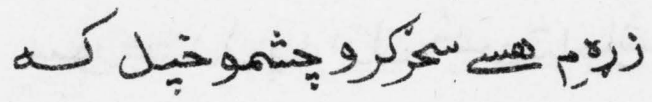

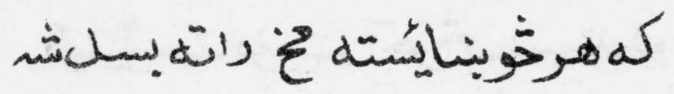

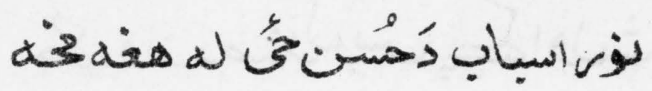

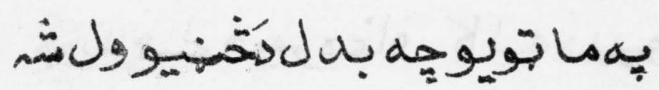

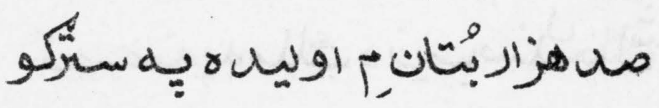

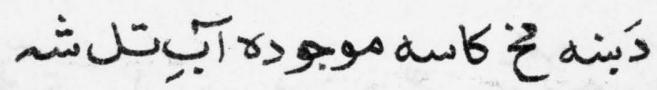

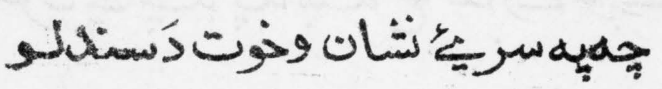

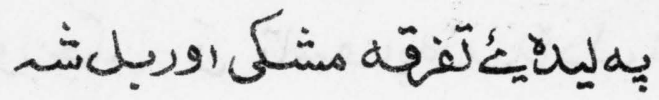

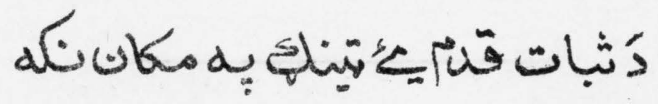

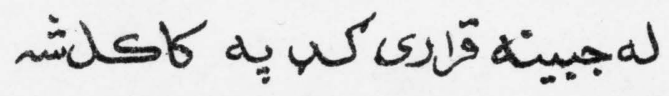

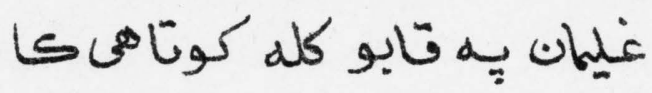

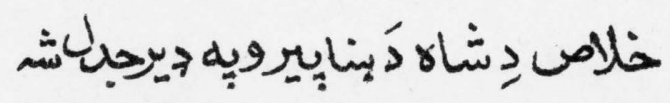

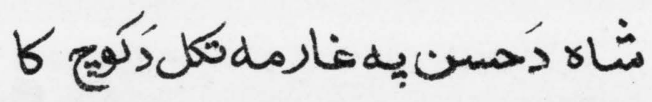




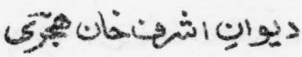

به山

سلم

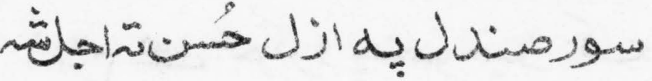

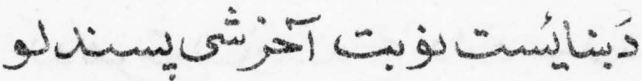

ش

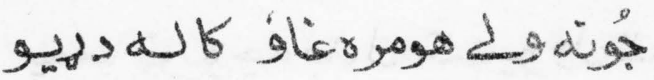

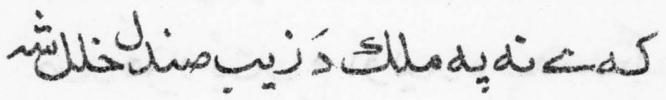

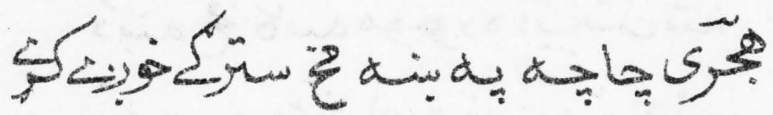

هو 


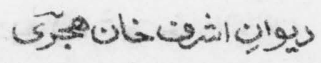

هั

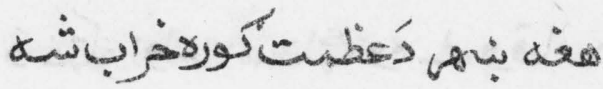

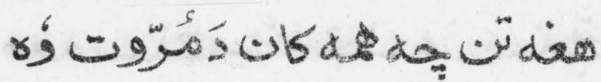

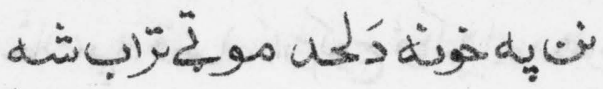

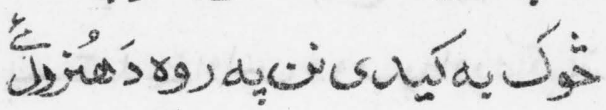

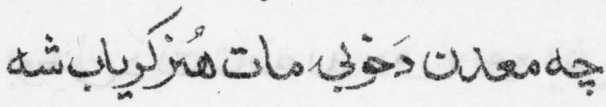

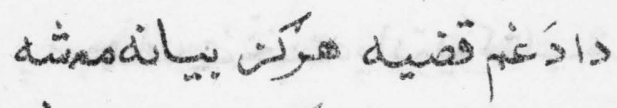

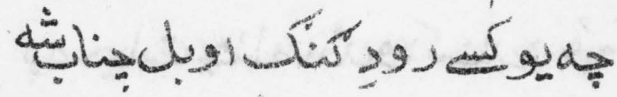

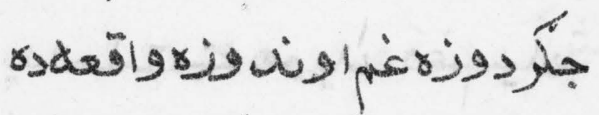

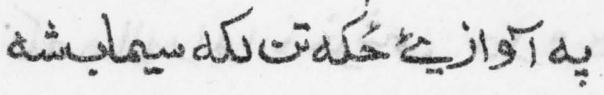

م Lُ

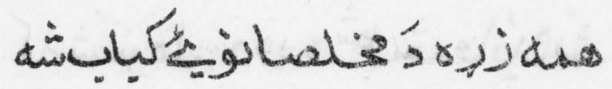

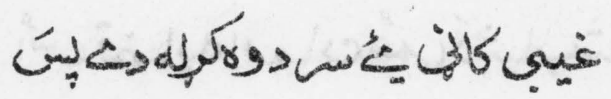

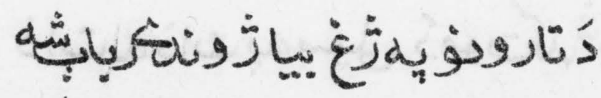

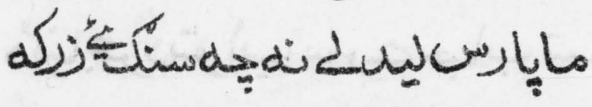

गएक 


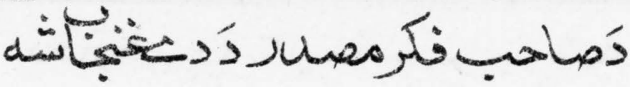

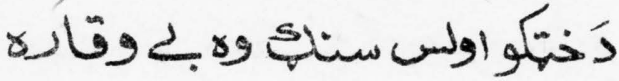

出

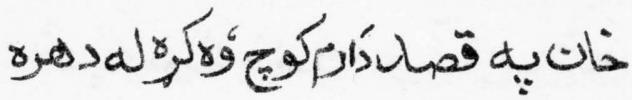

يستحته

.

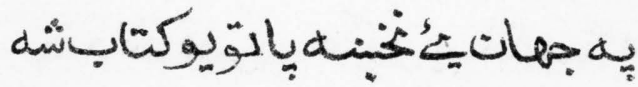

مو9 r r

ئرة

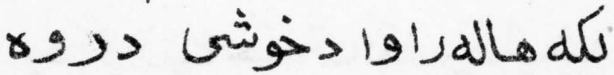

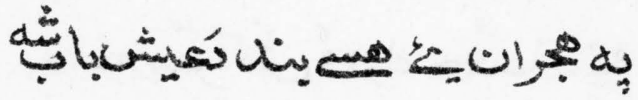

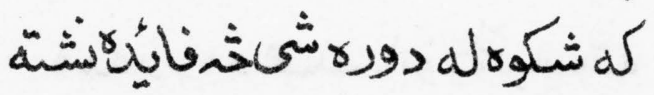

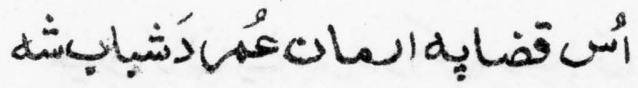

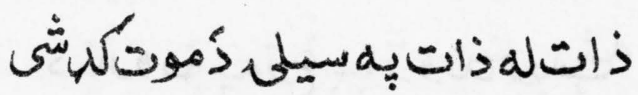

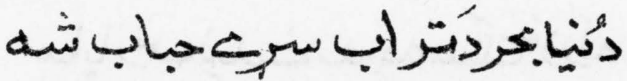




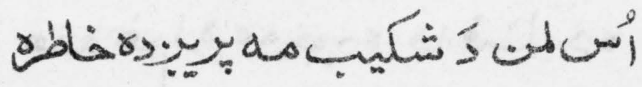

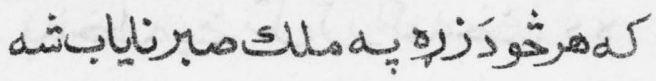

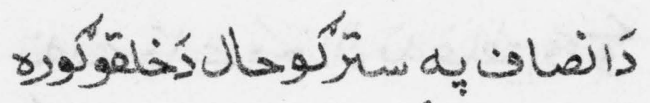

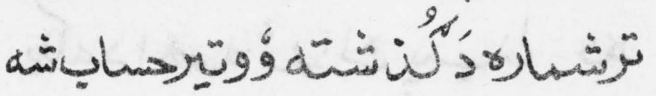

هو

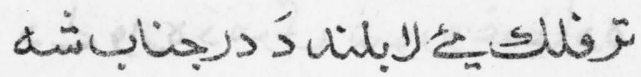

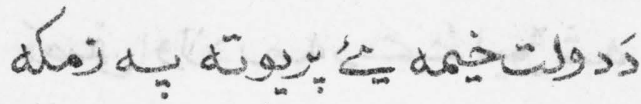

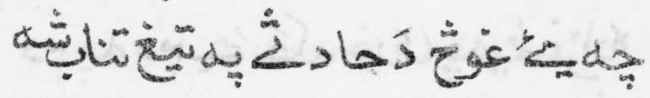

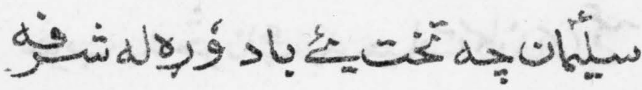

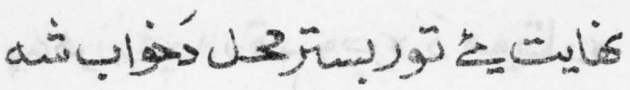

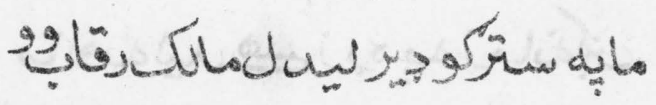

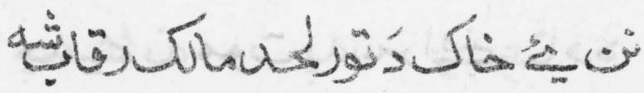

rg:es rul d a

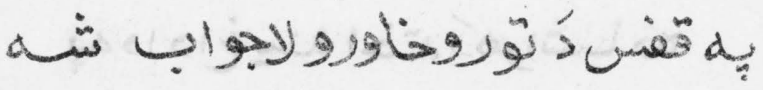




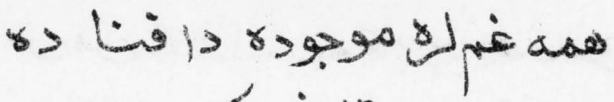
rs Uads Srgebled lliśs Lud

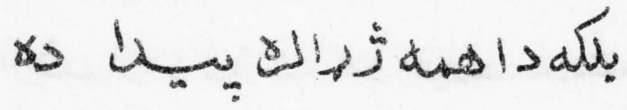

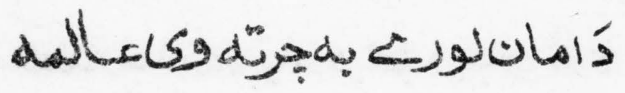

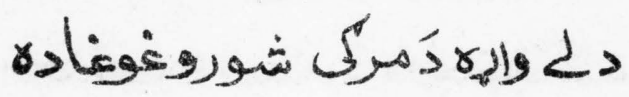

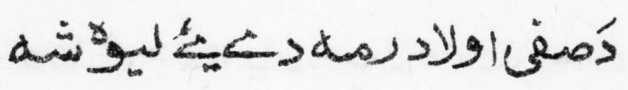

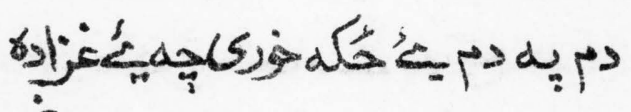

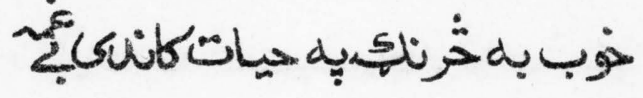

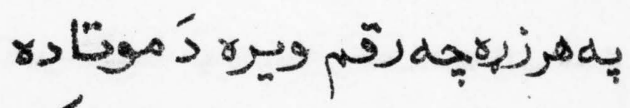

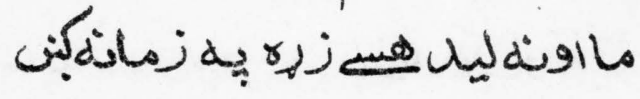

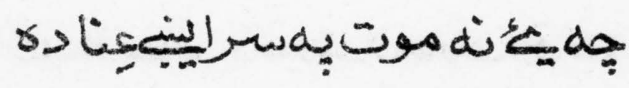

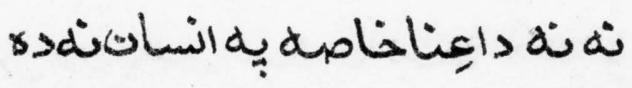

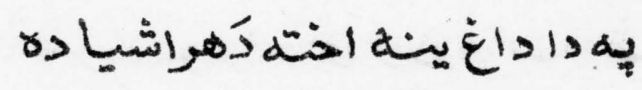

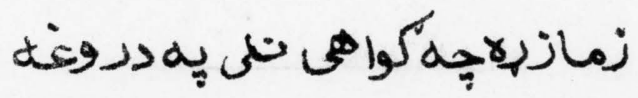




\section{5.}

r >

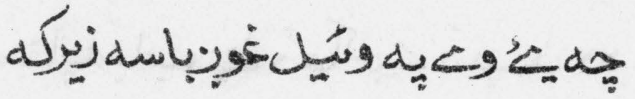

ج

ئيك

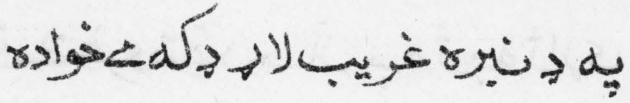

مساوشئه

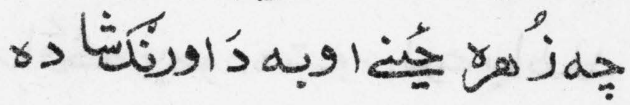

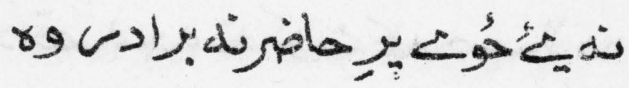

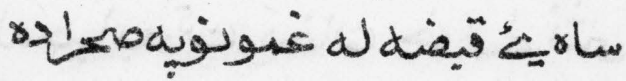

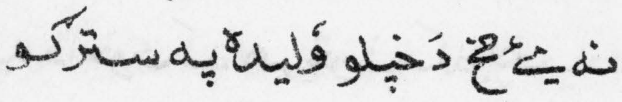

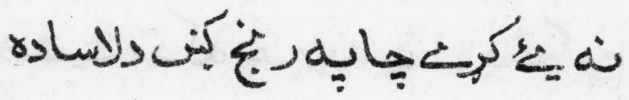

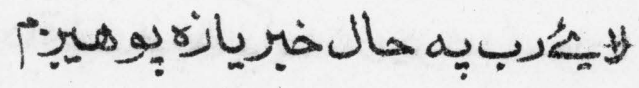

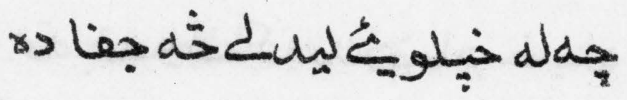

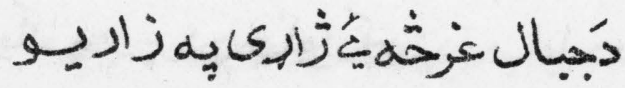

s' 


\section{ديوانِاشنحخانهيجي}

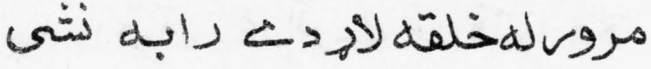
ستابه بابِ

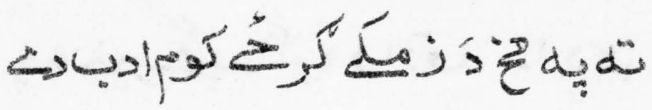

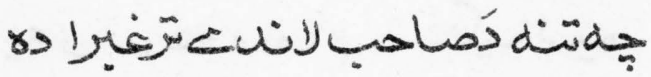

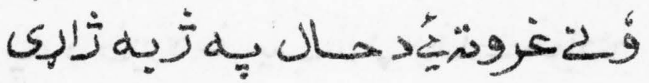
> L

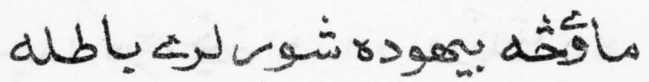
آ

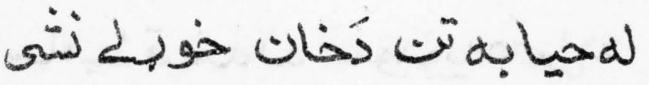

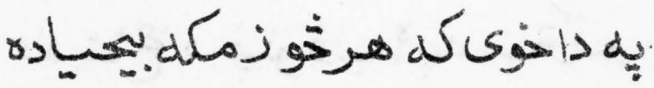

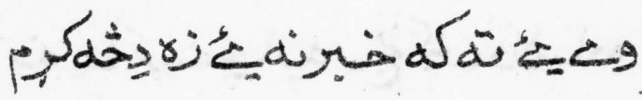

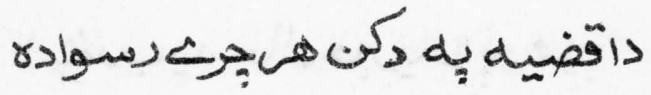

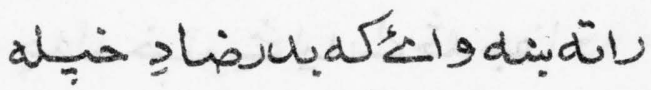

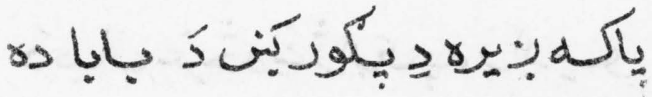

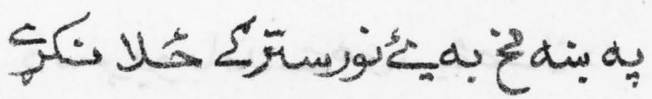


يوانِ اشتحتخان هبرى

8

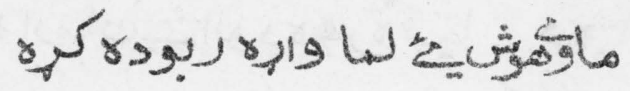

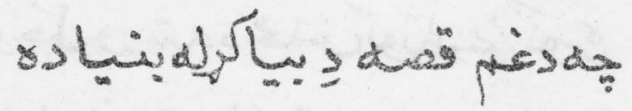

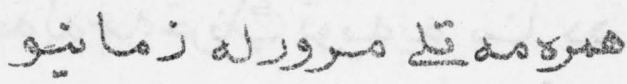

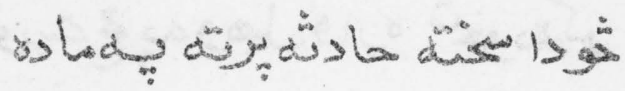

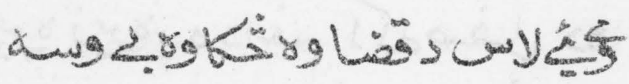

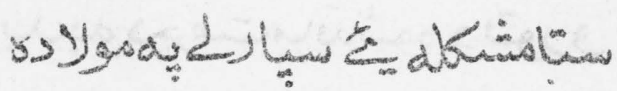

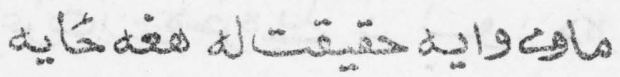

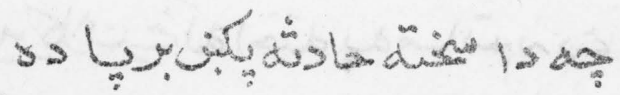

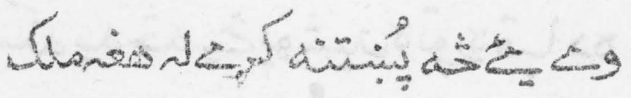

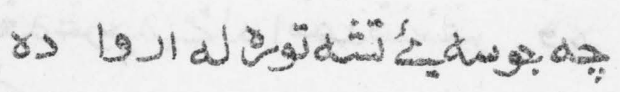

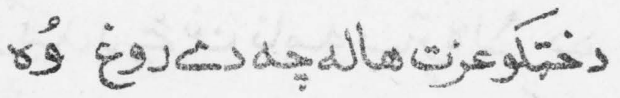

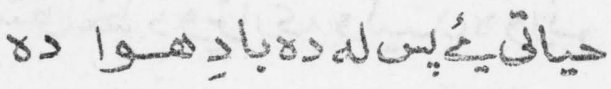

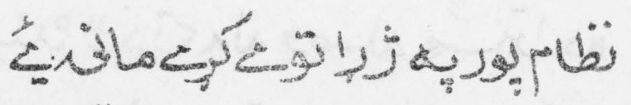

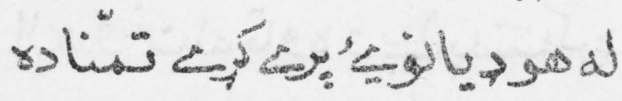

$=$ 


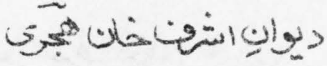

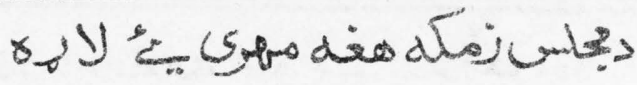

r) L

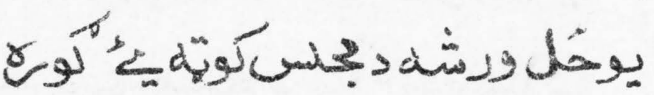

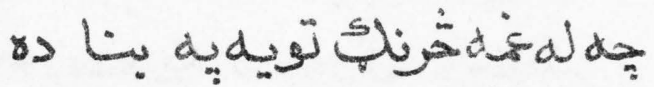

كryos

ه) $\underbrace{1}_{g}$

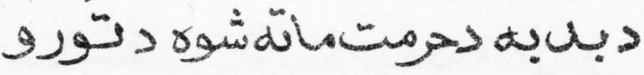

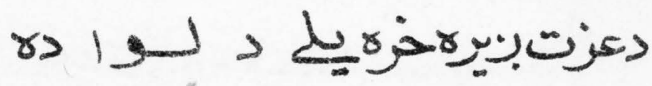

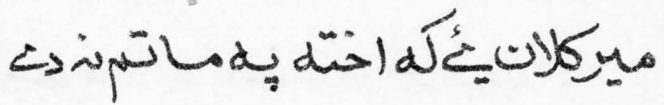

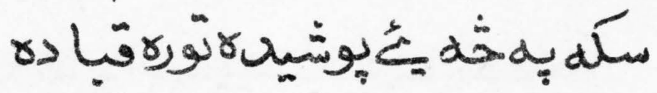

$\gamma$ ro

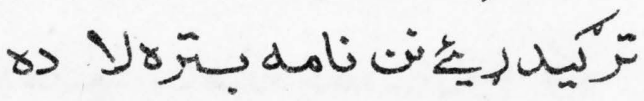

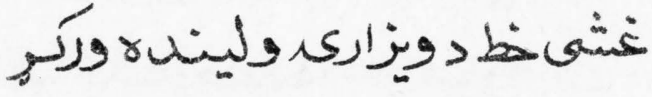

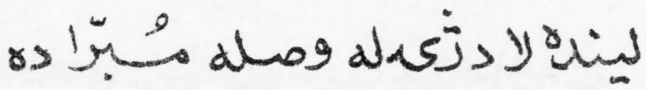

ه 


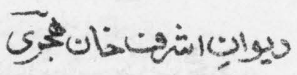

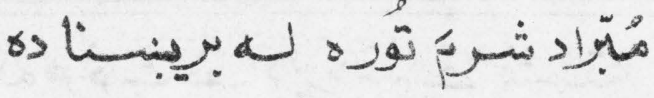

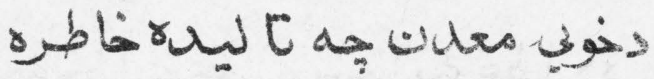

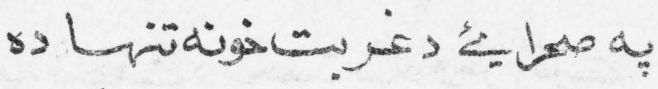



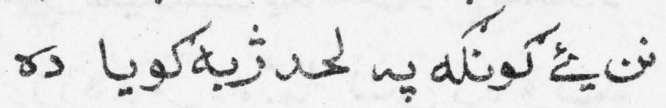

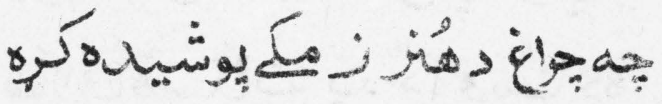

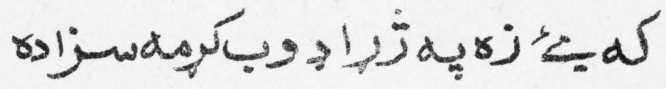

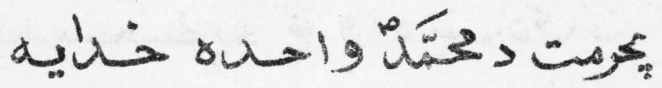

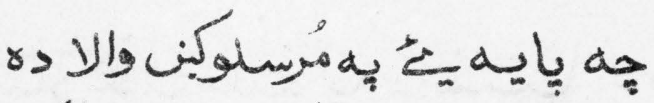

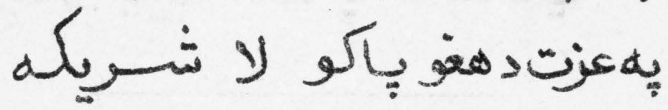

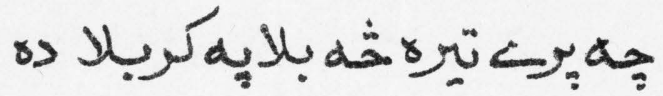

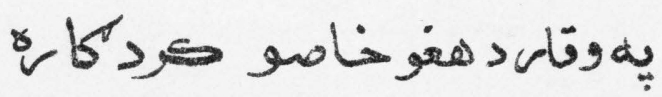

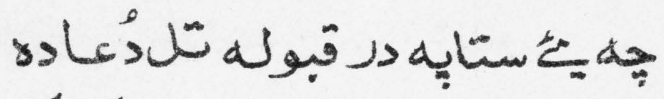

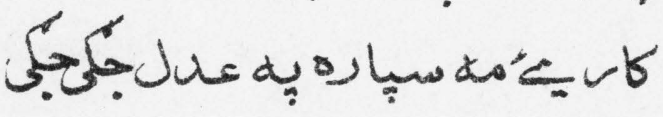

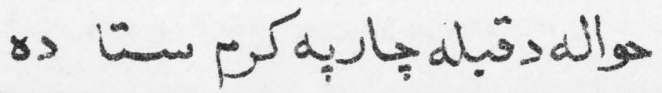




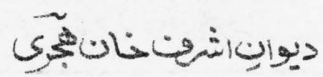

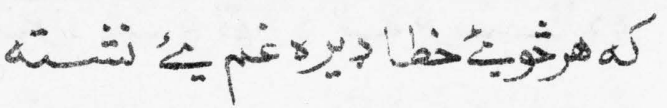

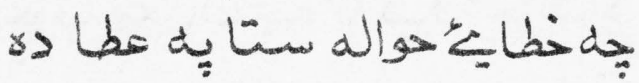

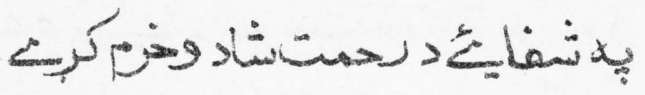

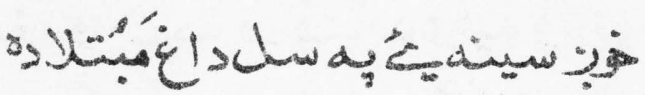

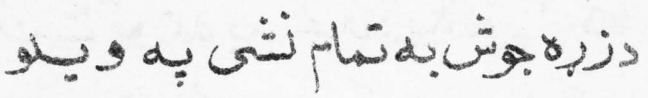

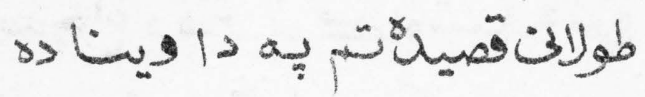

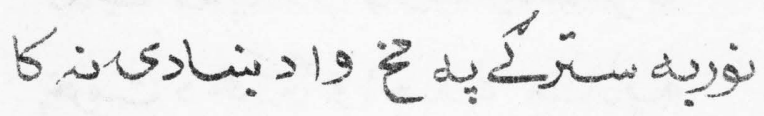

ه كن

$\mid C A$ 


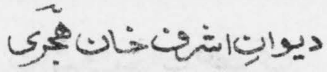

بيا

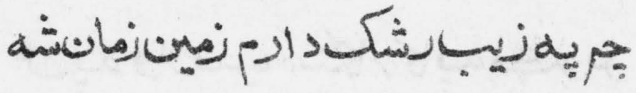

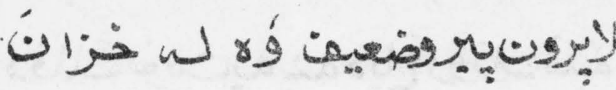

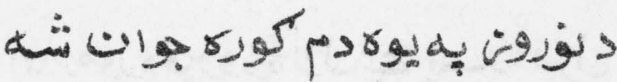

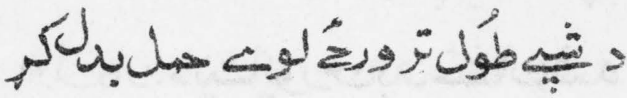

نُو

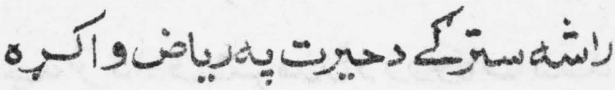

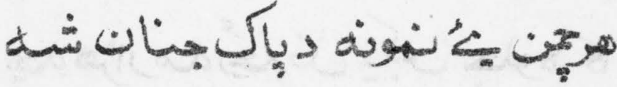

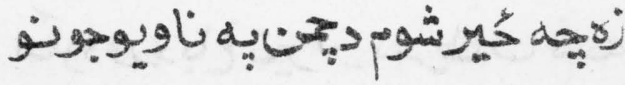

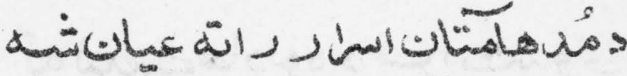

?

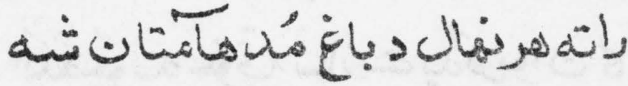

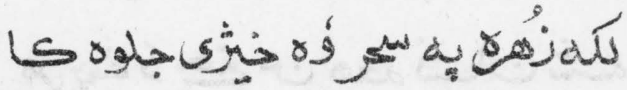

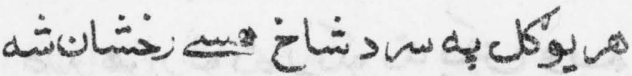

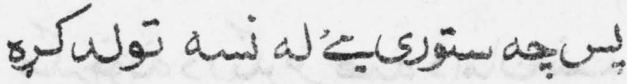




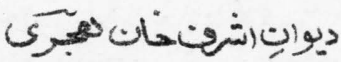

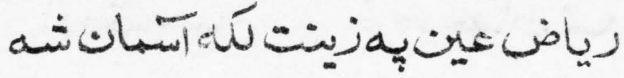

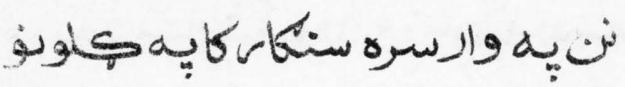

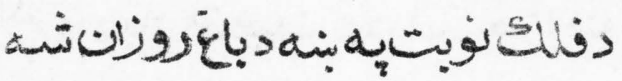

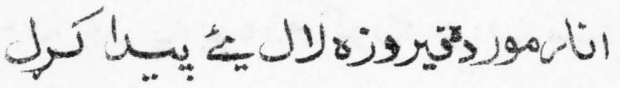

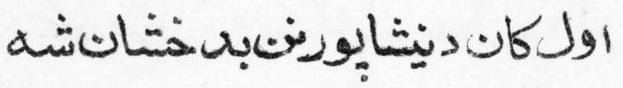

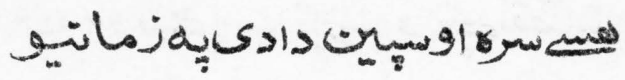

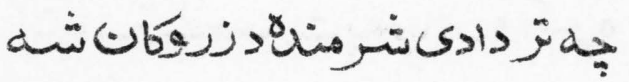
Krola

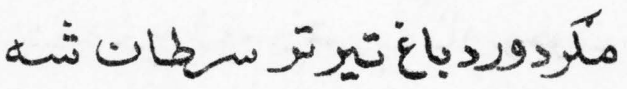

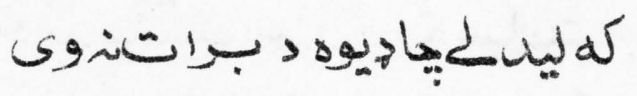

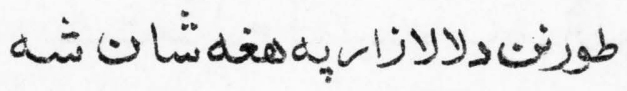

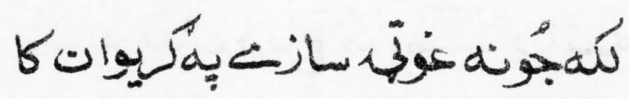

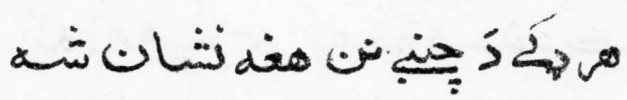

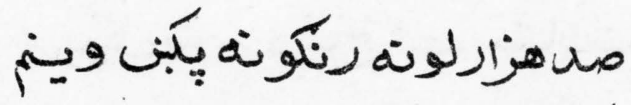

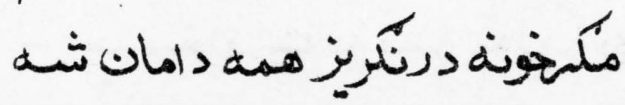




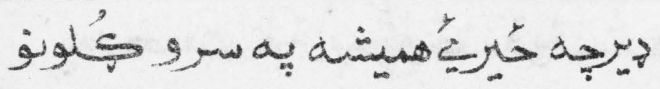

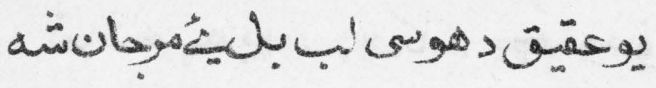

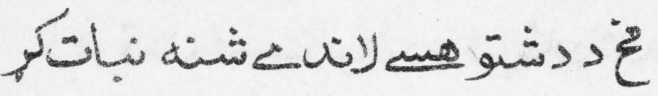

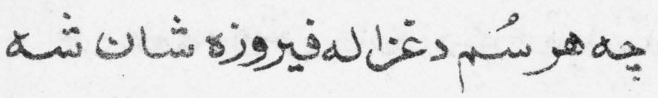

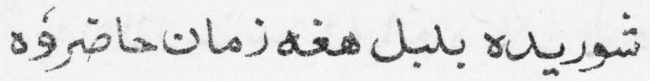

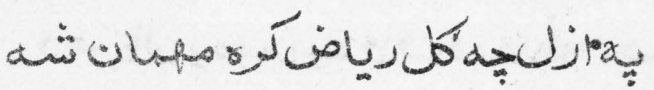

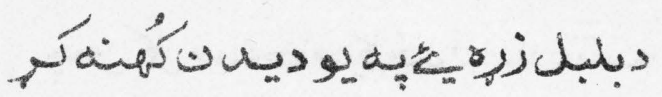

من

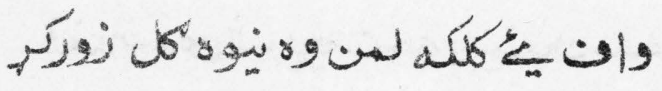

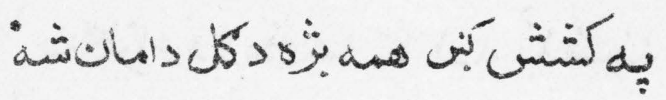

L. rg folis brjlios

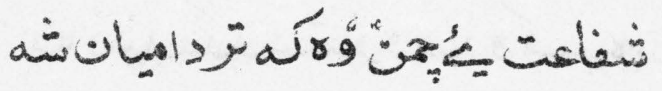

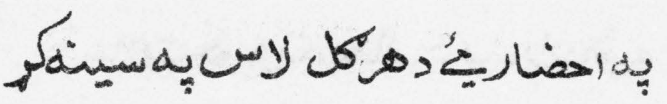

هن

disls d) 


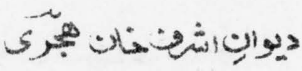

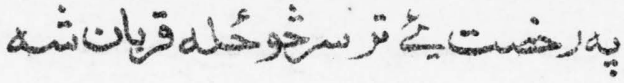

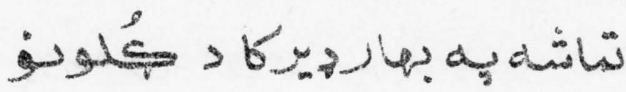

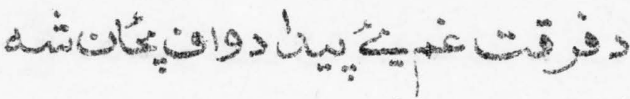

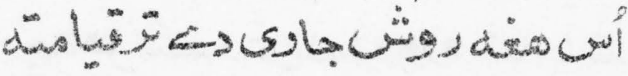

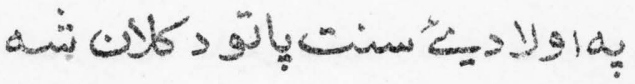

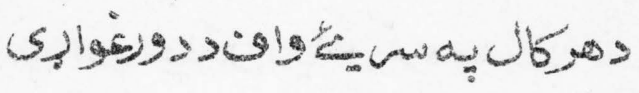

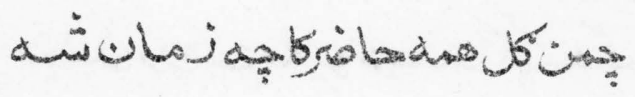

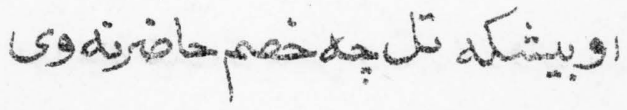

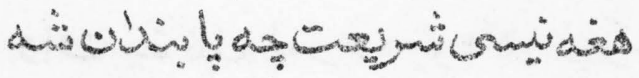

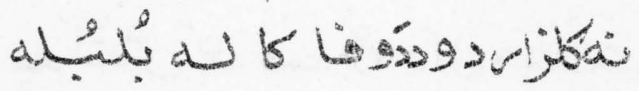

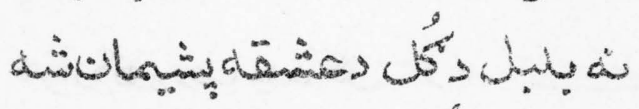

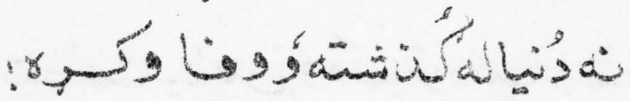
药 كرة

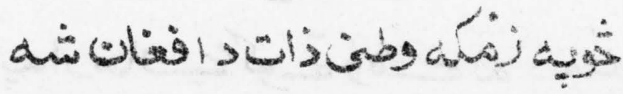




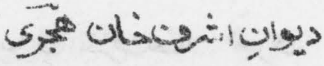

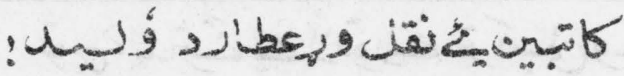

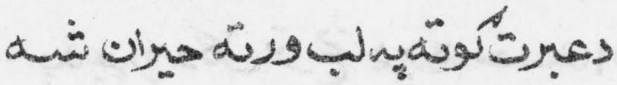

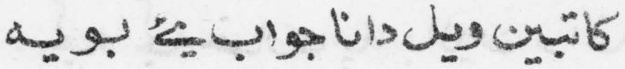

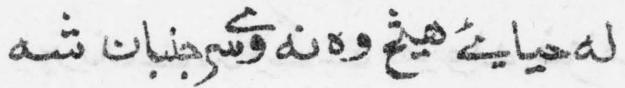

g.

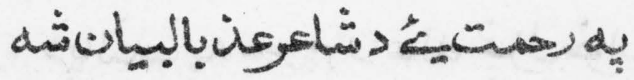

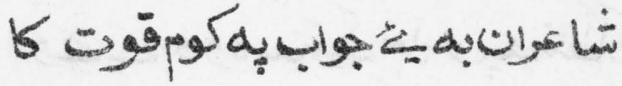

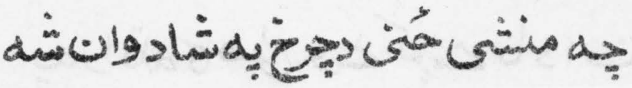

:

aivijand is apis al cress

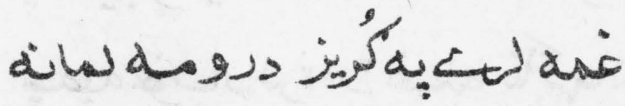

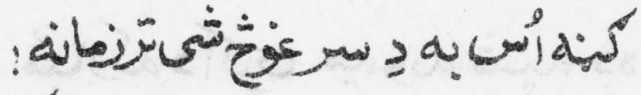

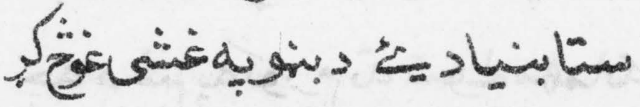

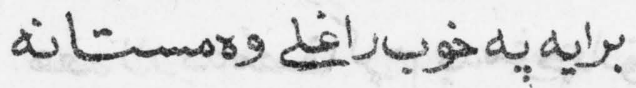




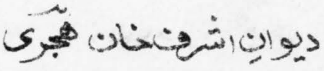

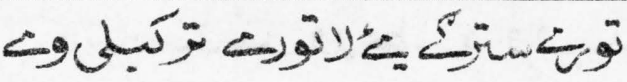

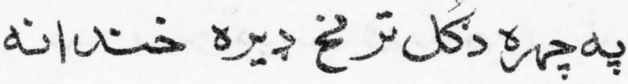

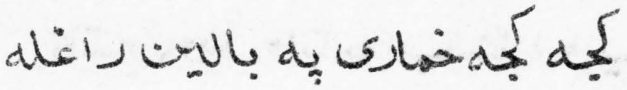

بران

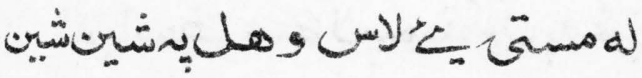

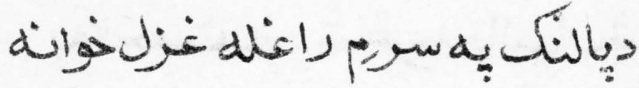

8ك

d إن إن

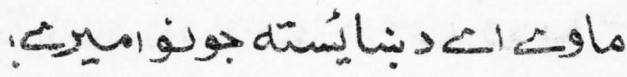

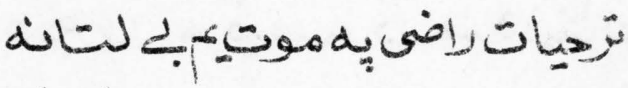

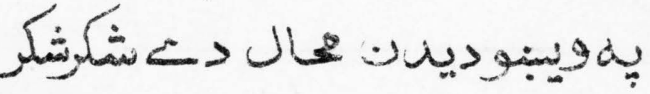

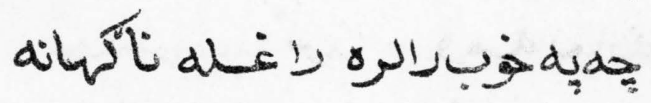

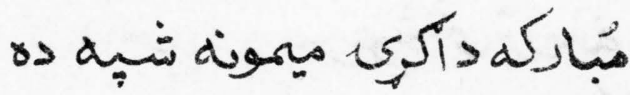

جه

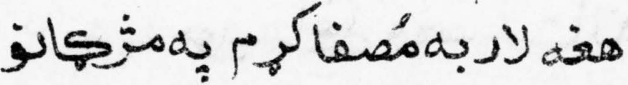




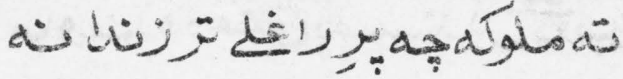

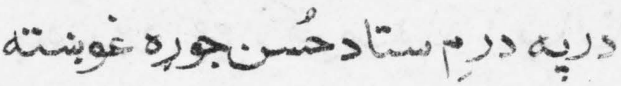

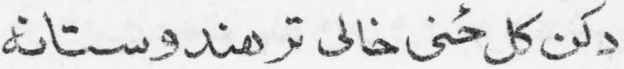

oـ 5 a

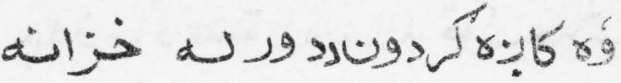

ك ru

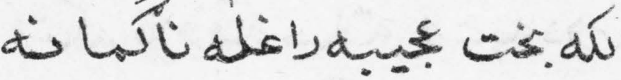

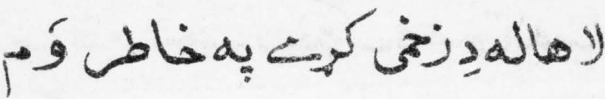

dus a jós

مimad a

diblisalis

Es is

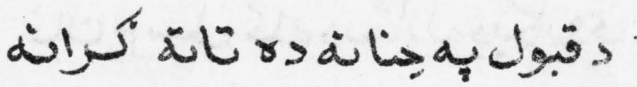

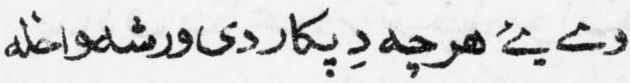

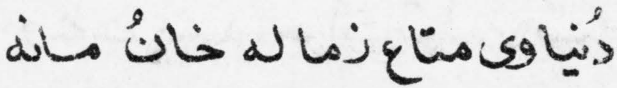




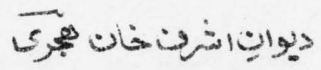

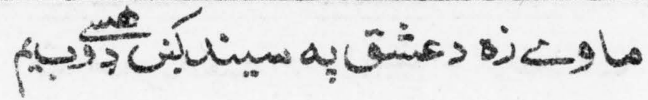
¿ s

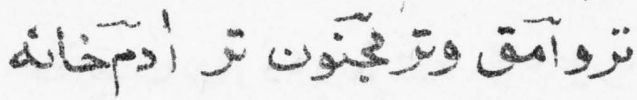

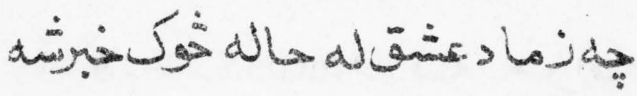

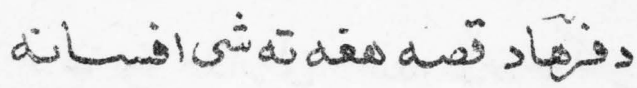
v9suc du

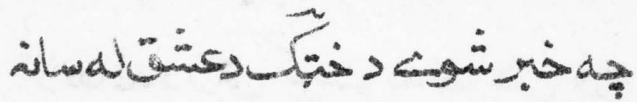

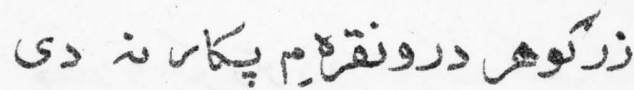

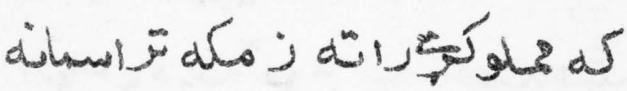

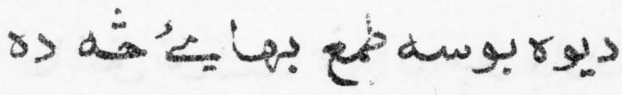

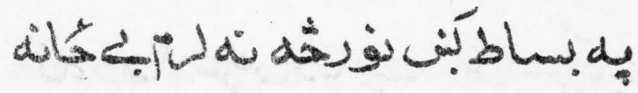

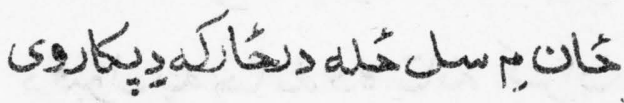

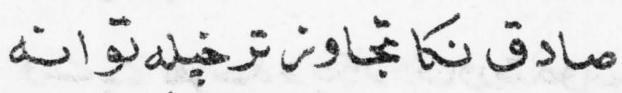
in 


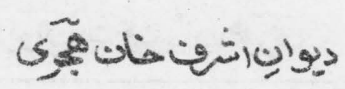

d.

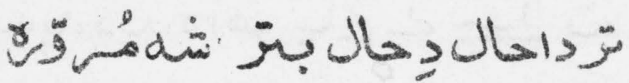
زمأله

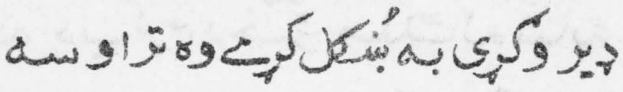

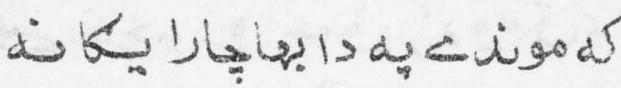

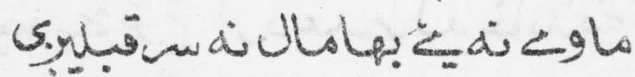

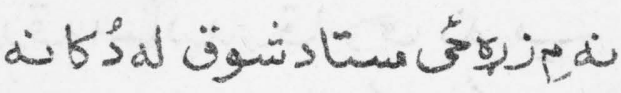

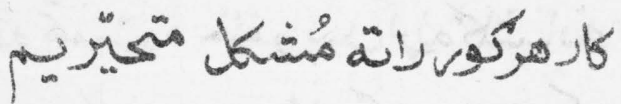
dن بs

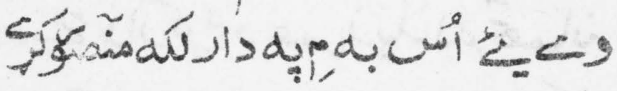

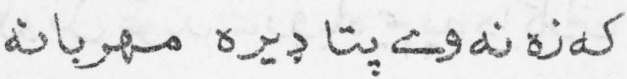

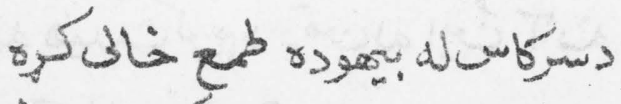

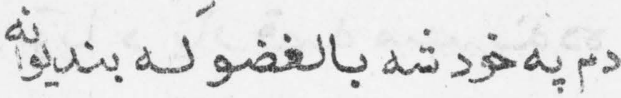


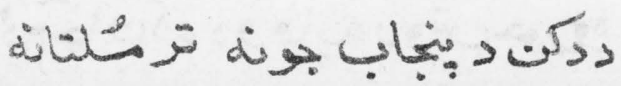

$10 \mathrm{~V}$ 


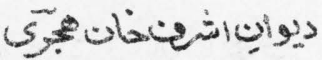

b(3)

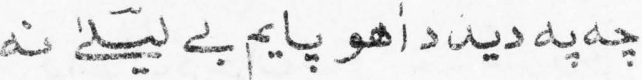

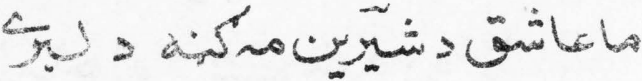

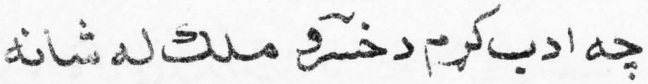

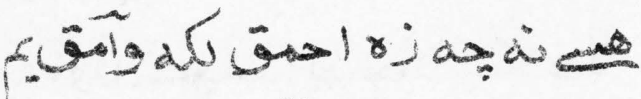

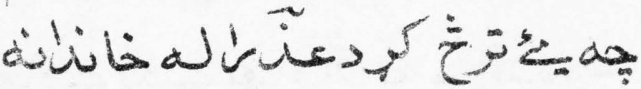

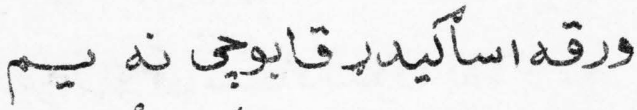

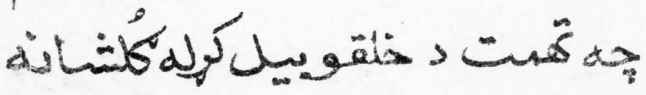

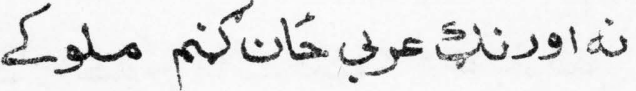

il.

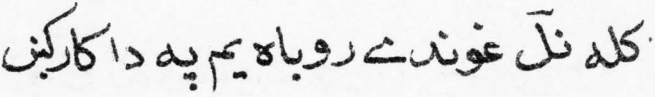

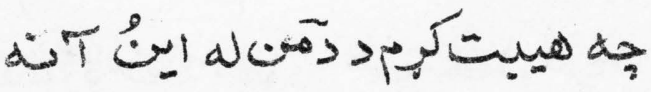

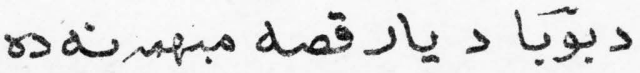

diliged

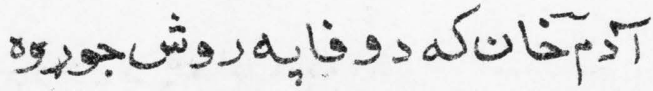




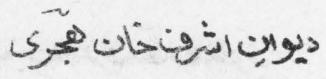

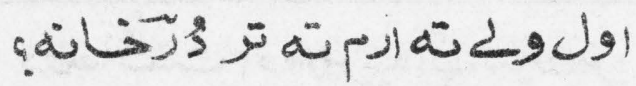

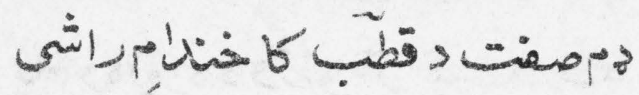

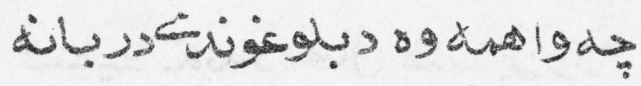

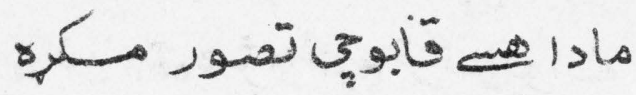

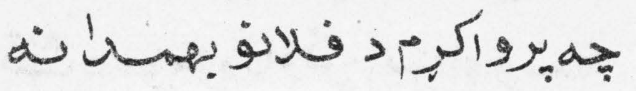
r

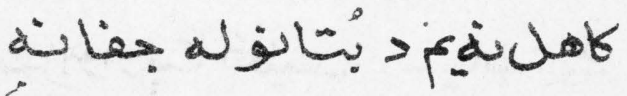

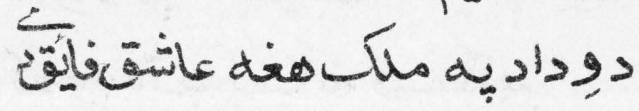

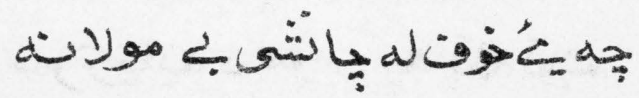

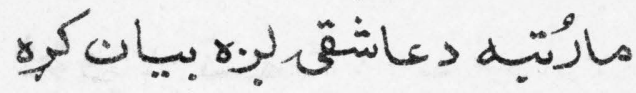

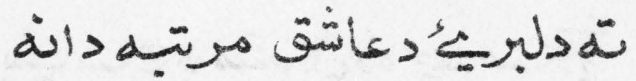
gisadw lashorinj

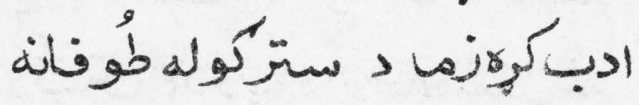

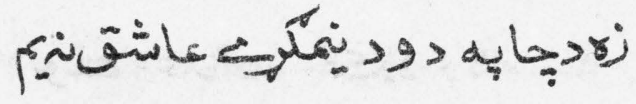

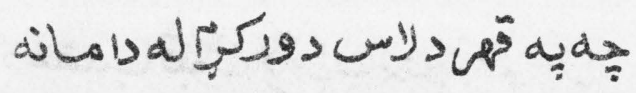

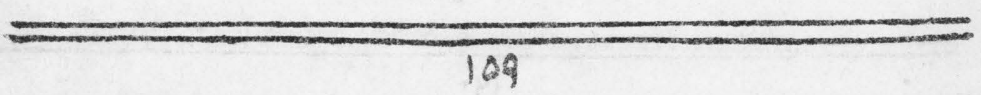




\section{ज̆}

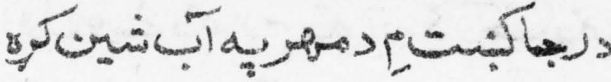

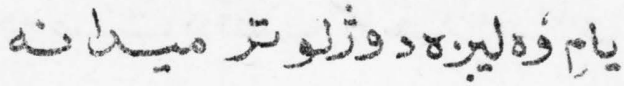

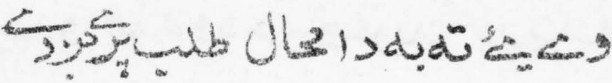

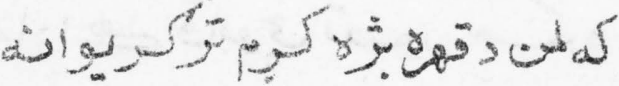

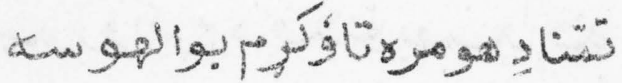

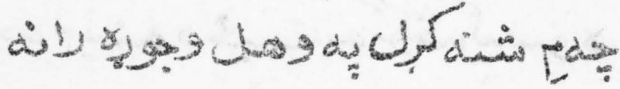

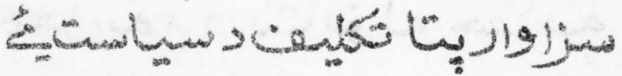

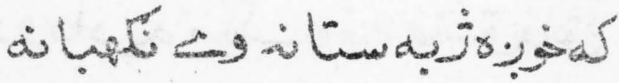

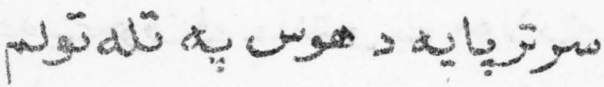

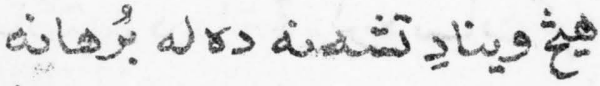

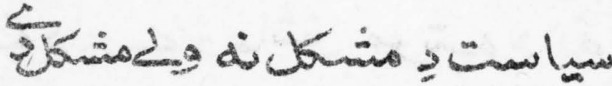

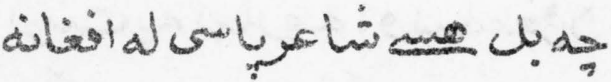

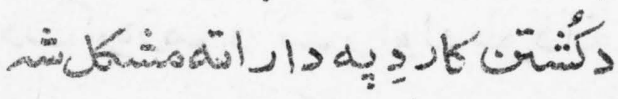

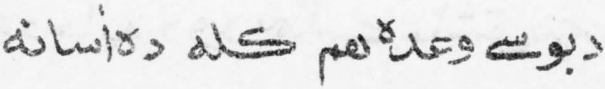

(1) 


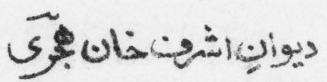

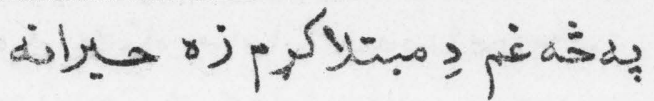

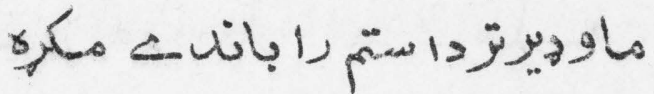

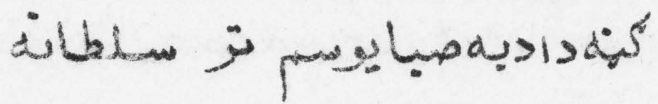

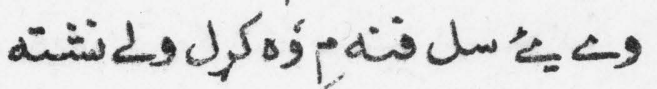

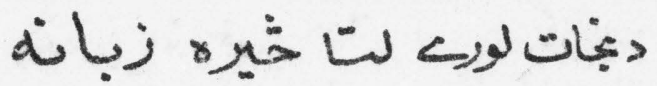

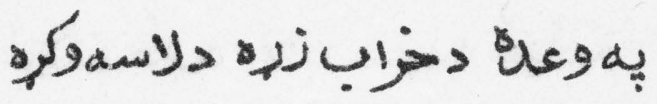

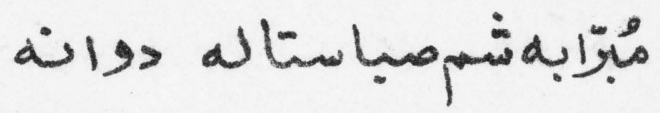

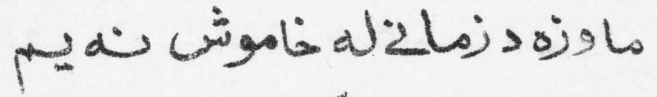

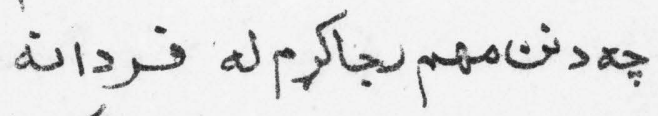

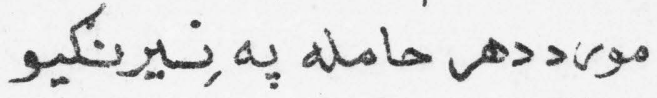

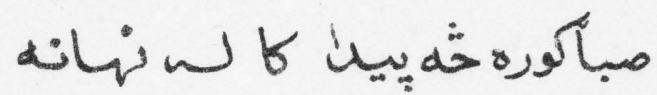

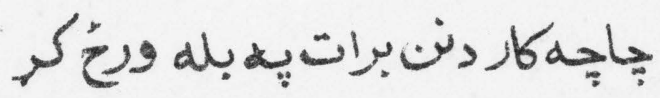

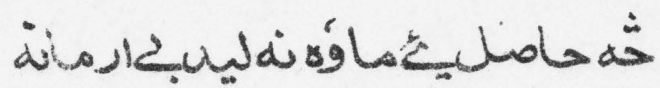

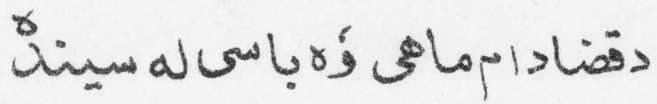

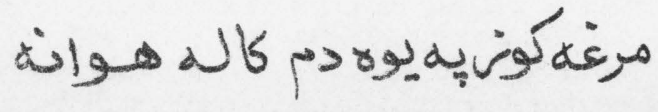

$14 \mid$ 


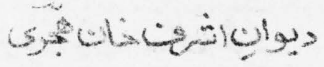

و

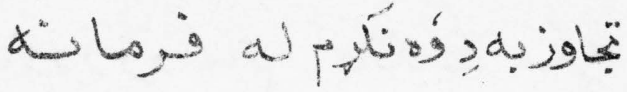

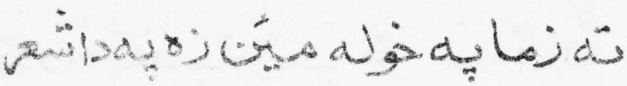
alol

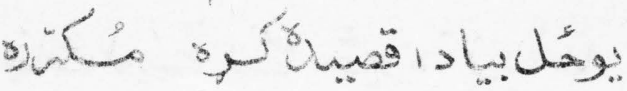

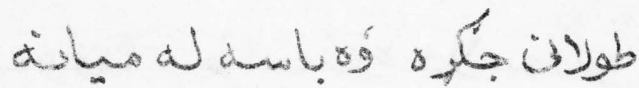
.

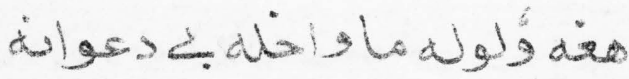

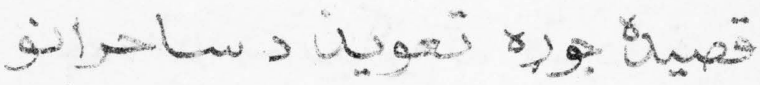
d L ب ب

iat 


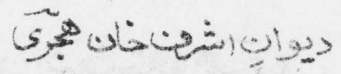

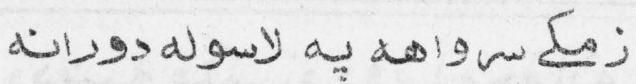

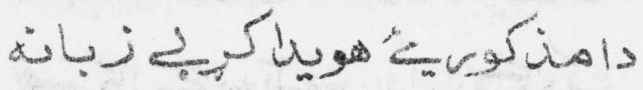

ئه

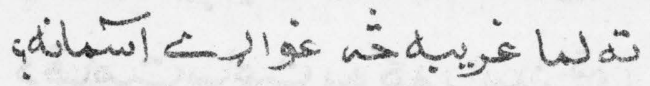

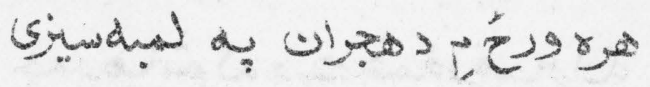

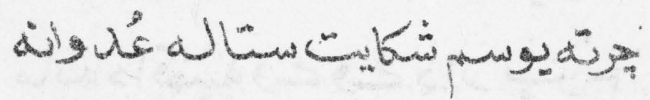

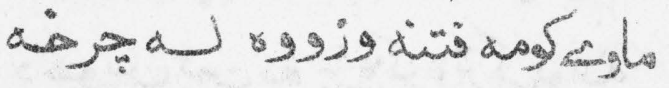

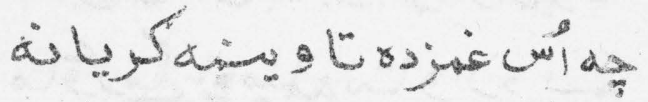

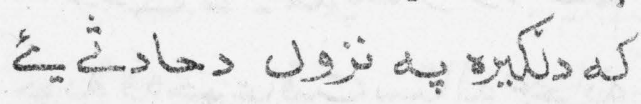

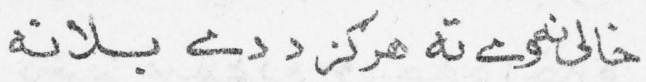

3! ك

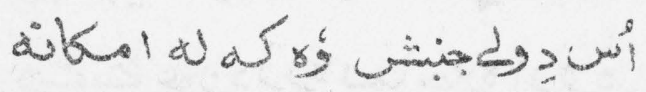

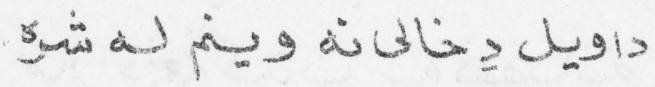

نl jo

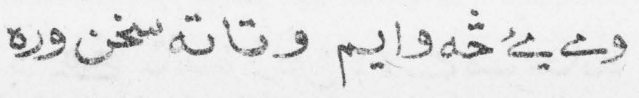

IबT 


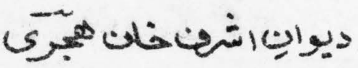

دوبنه فلكس

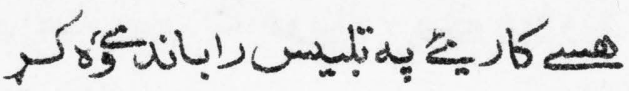

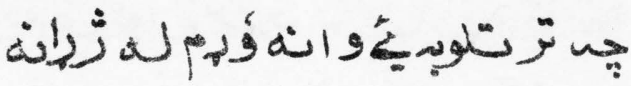

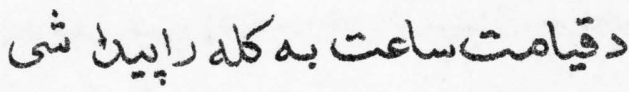

جل

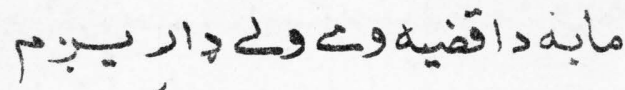

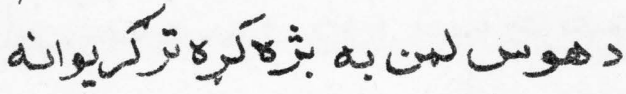

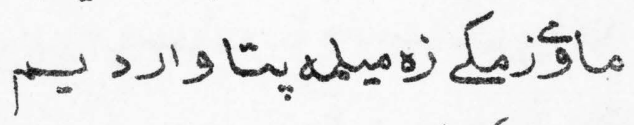

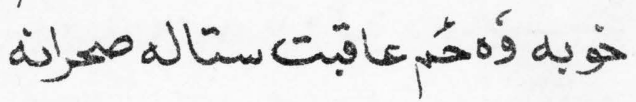

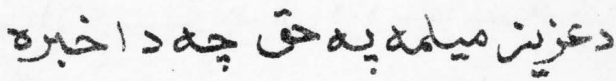

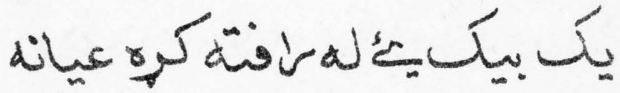

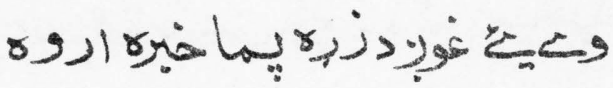

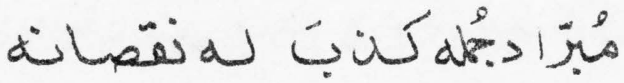
$x>$ ل ز ن 


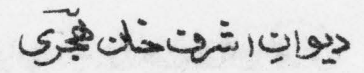

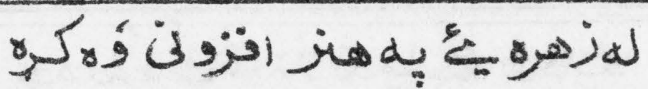

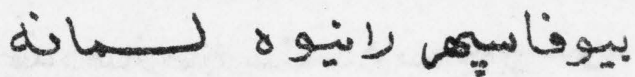

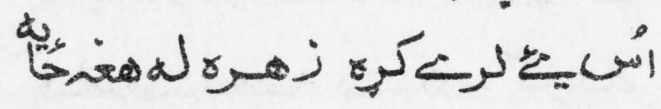

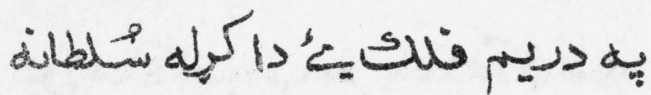

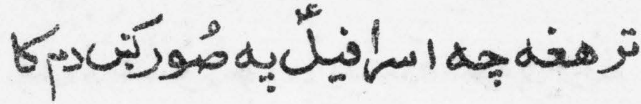

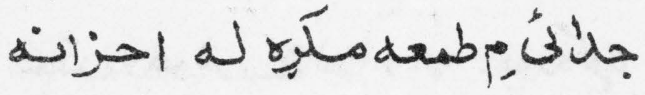

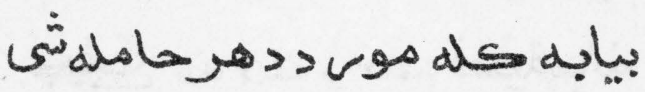

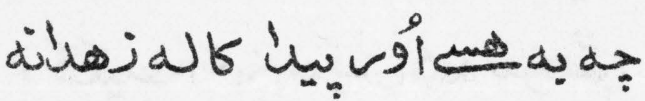

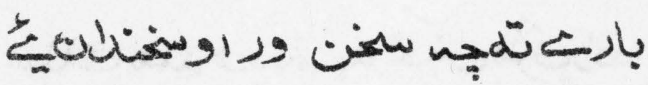

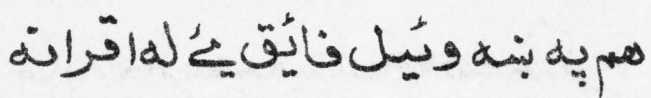
المب داروبم تَّه دى لراته وايبة

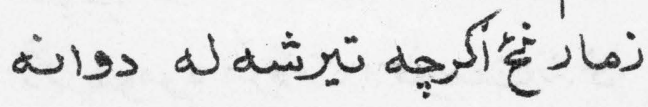

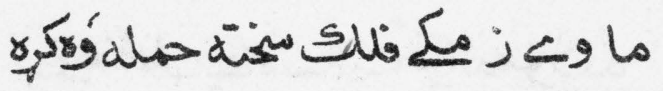

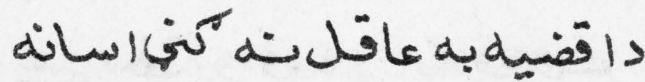

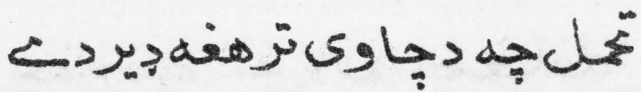




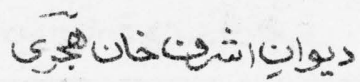

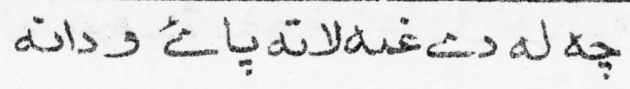

هن و

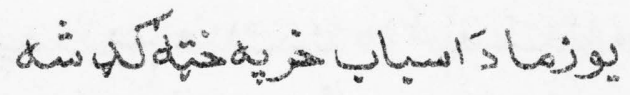

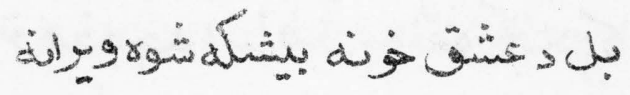

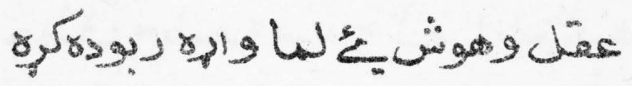

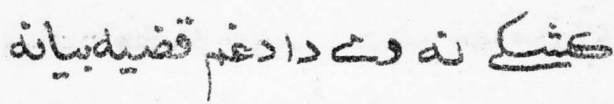

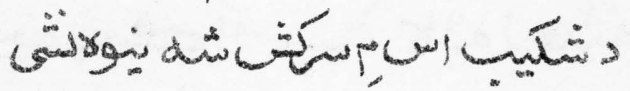
ماله

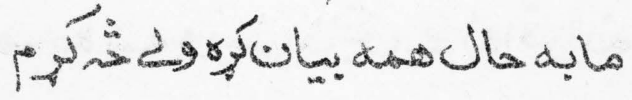

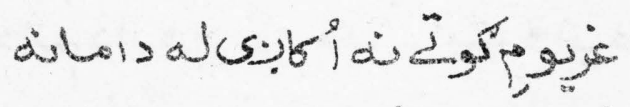

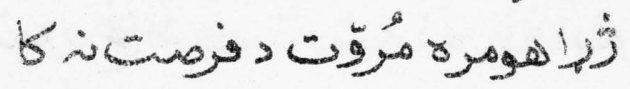

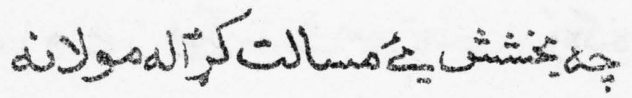

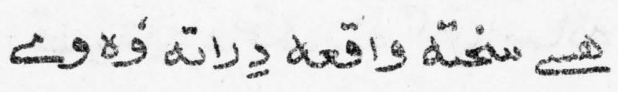

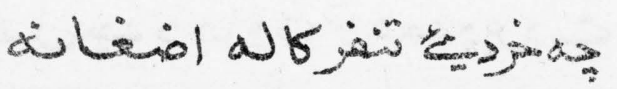




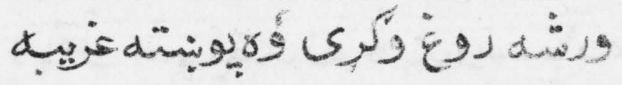

:

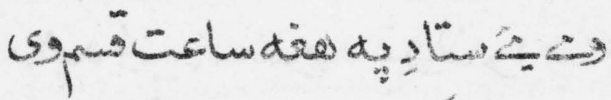

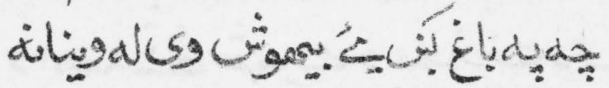

जو

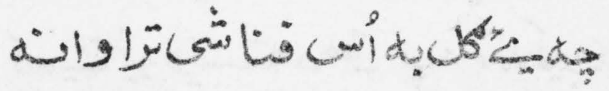
ه نائن rك

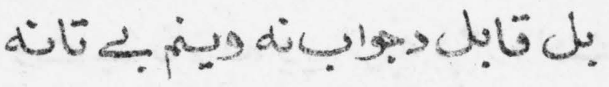

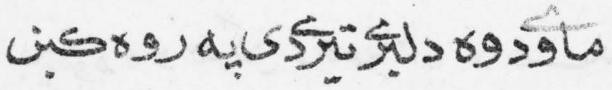
هو

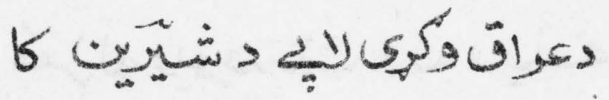

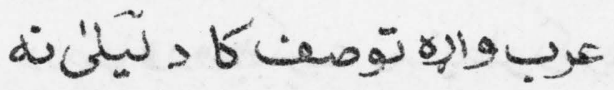

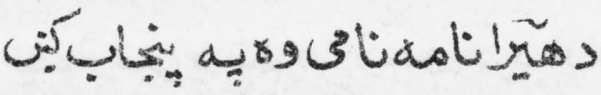




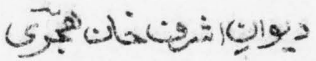

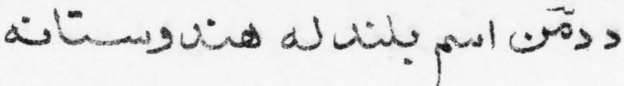

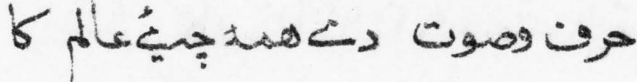

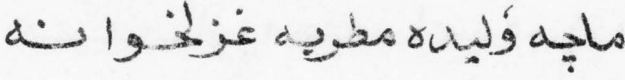

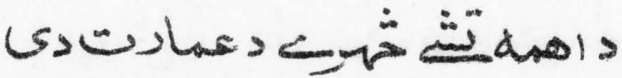
s

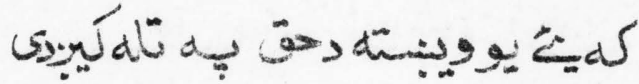

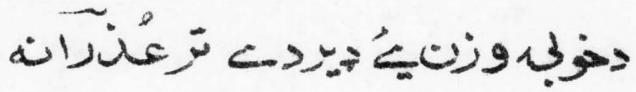
a

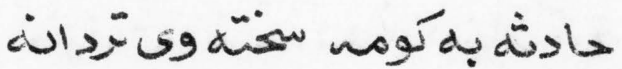
-

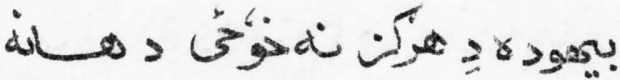

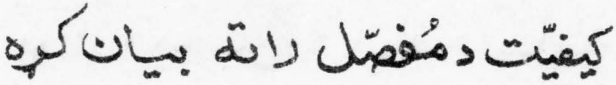

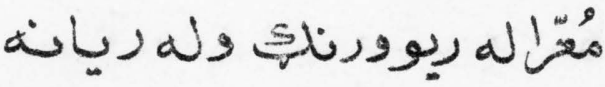

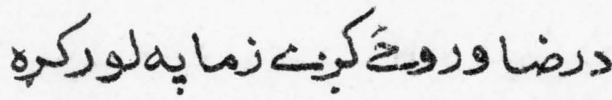

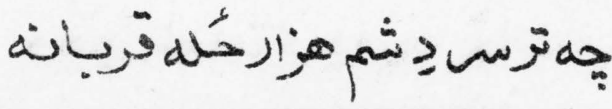




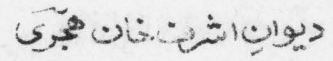

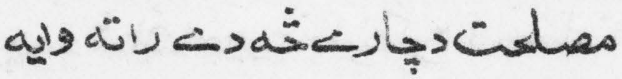

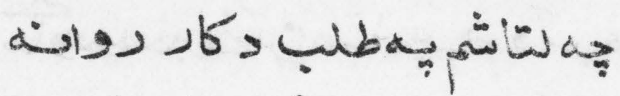

مأو

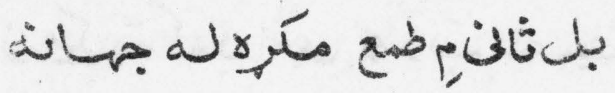

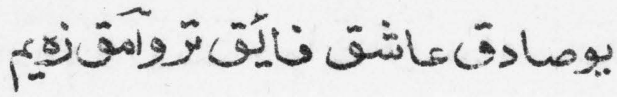

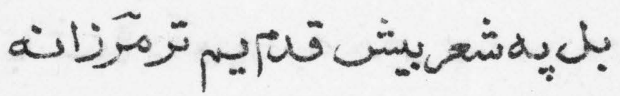

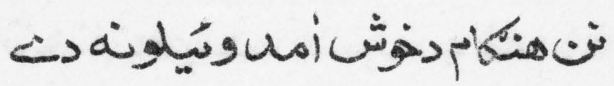

نان

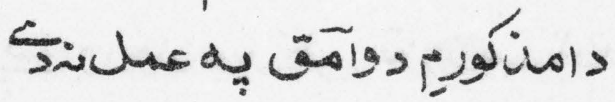

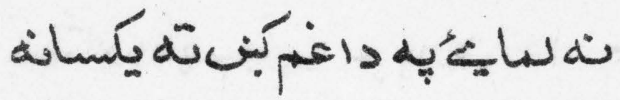

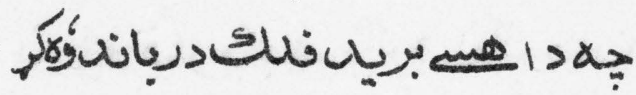

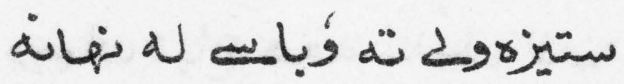

كيمت

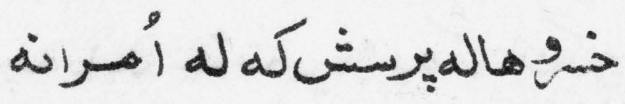

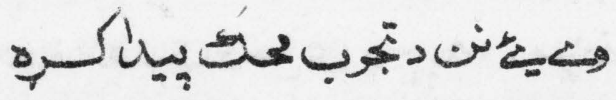

149 


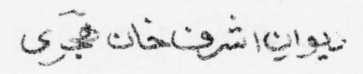

代卓

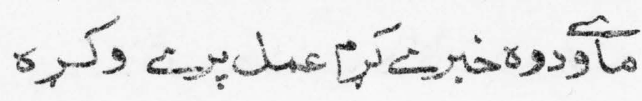

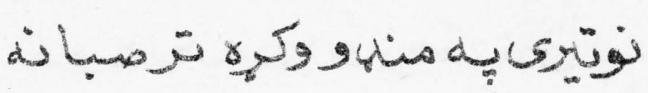

ز

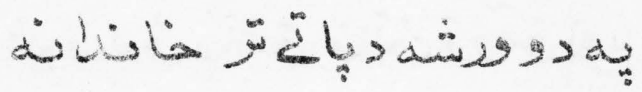

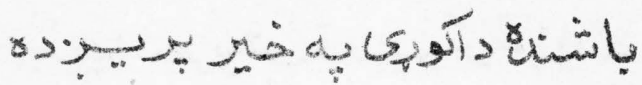

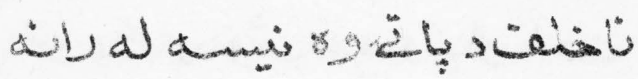

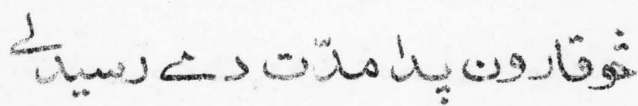

远

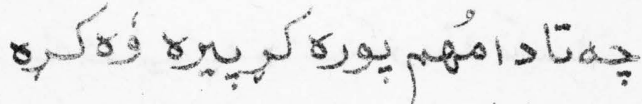

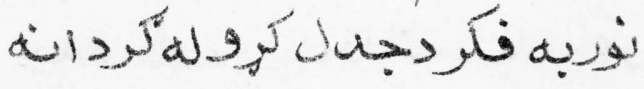

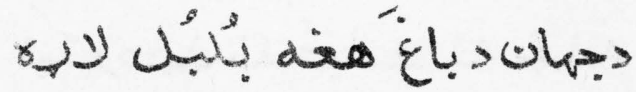

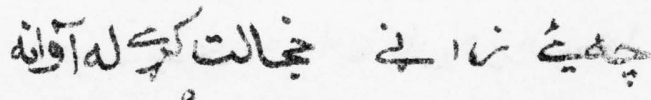

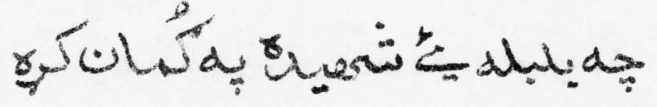

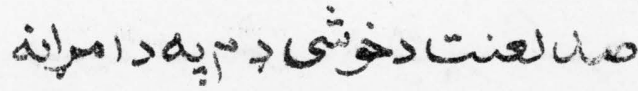

Iv 


\section{cs:ulis}

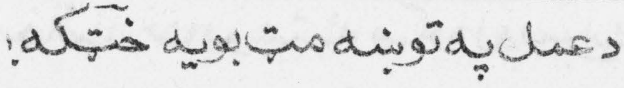

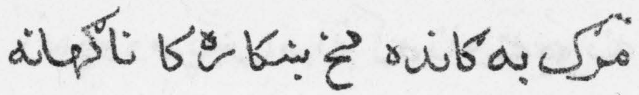

هان

نे حله

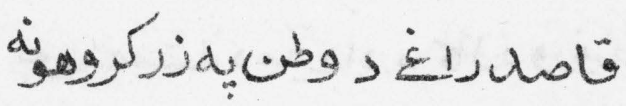

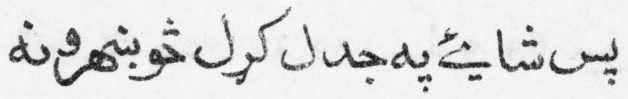

s.



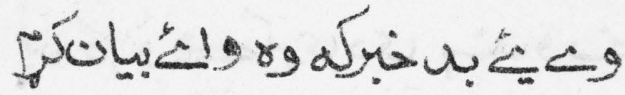

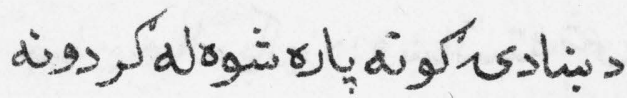

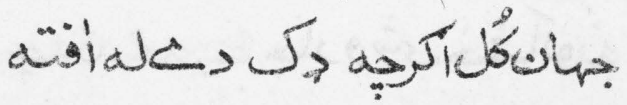

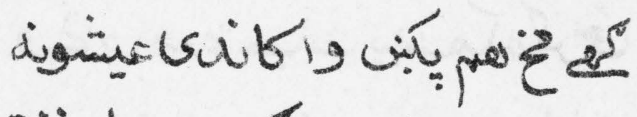

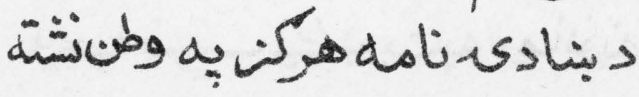

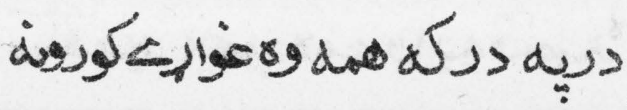


خاصس نت بيوبنتهنه مكوهل لهسرايه

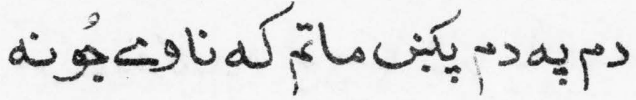

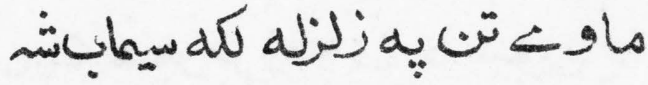

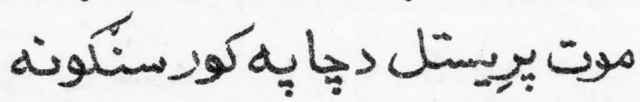

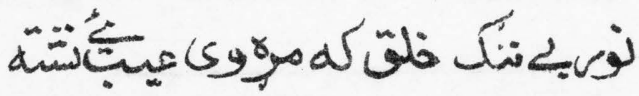

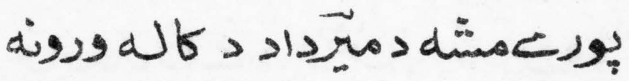

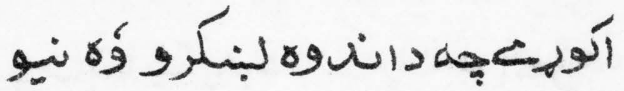

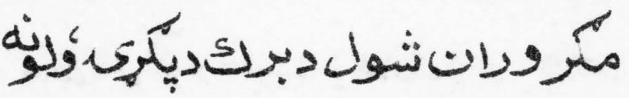
ون

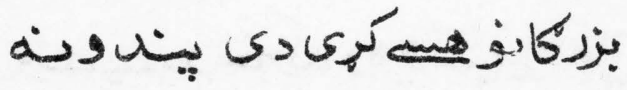

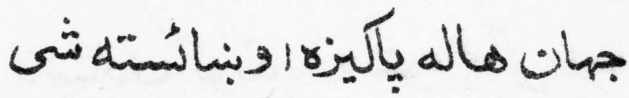

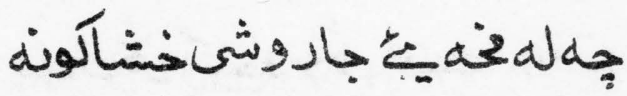

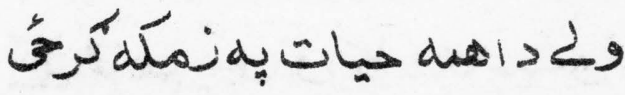

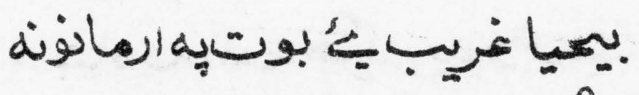

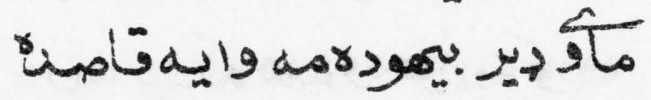




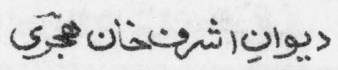

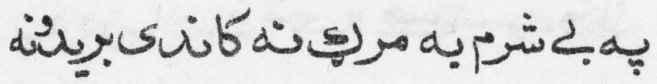

وضكيثة

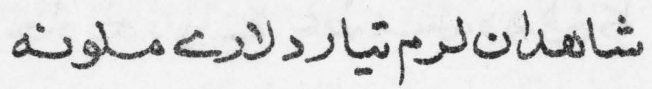

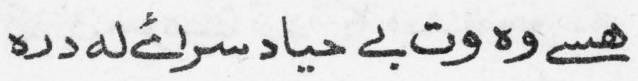

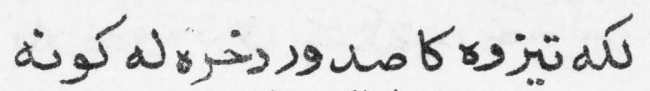

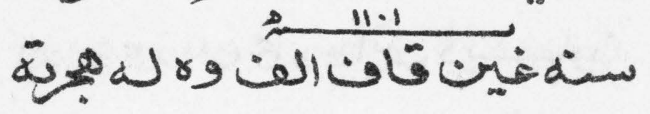

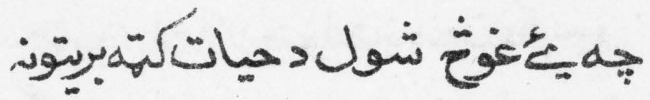

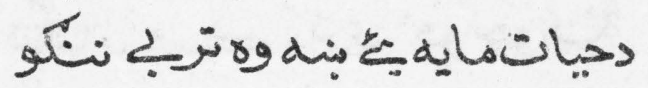

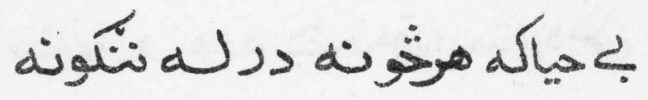

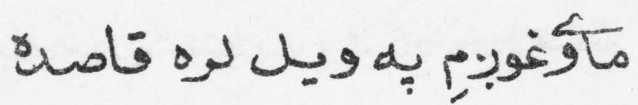

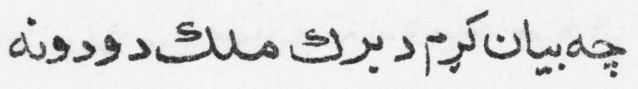

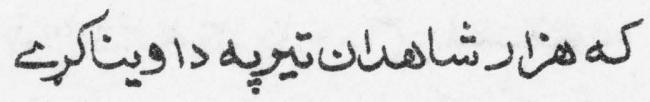

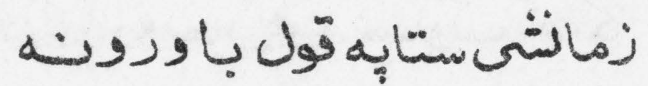

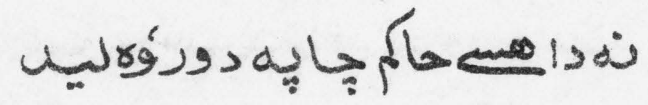

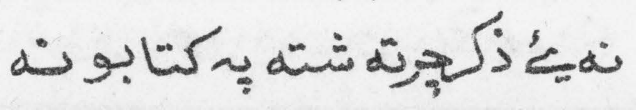

IVT 


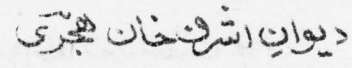

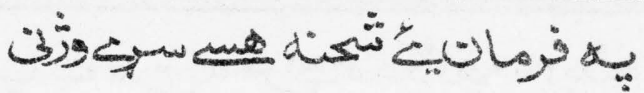

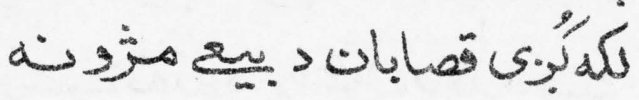

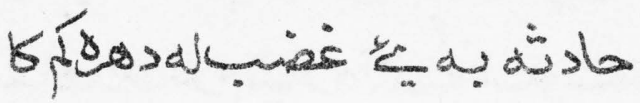

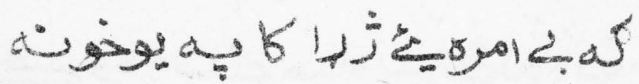

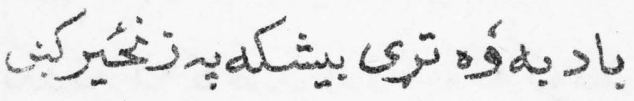

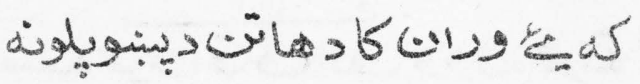

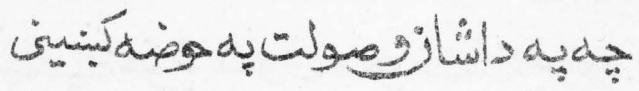

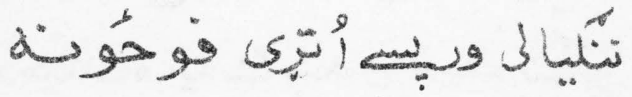

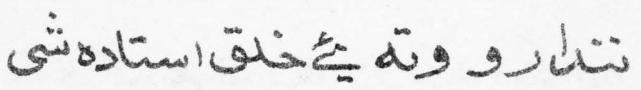

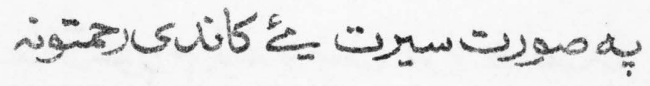

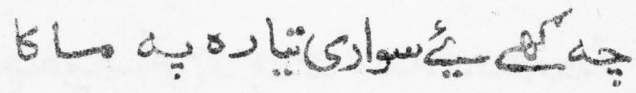

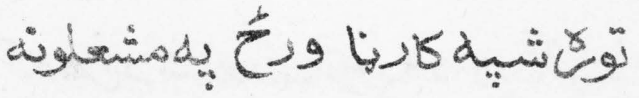

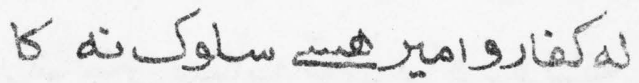

更و

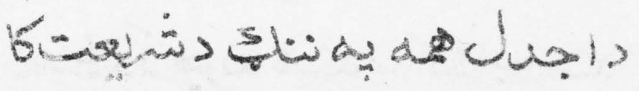

IV 
s:

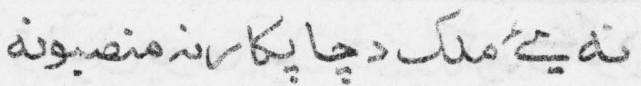
SE

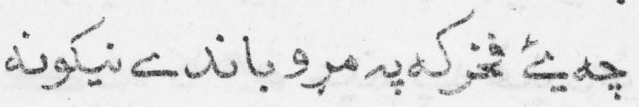
aish

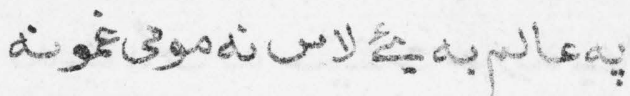
Bulsodg a a بy

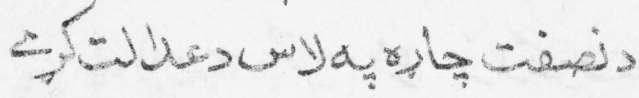
بكون

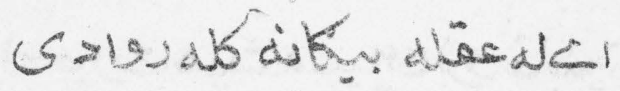

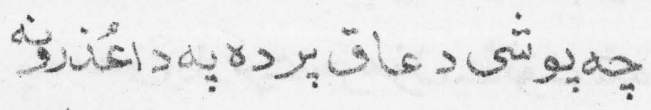
د

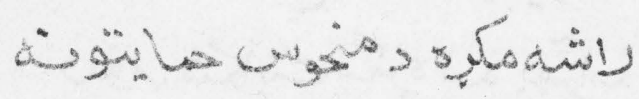

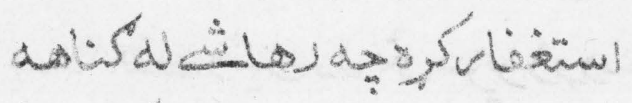

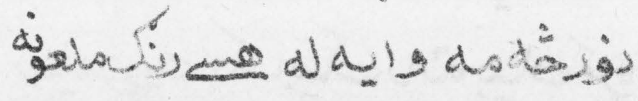




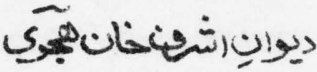

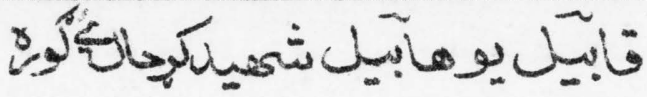

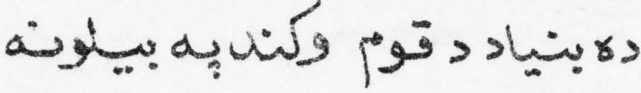

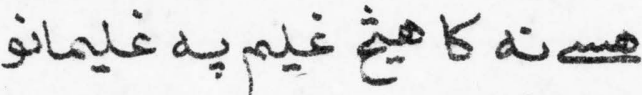

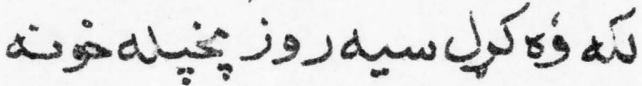

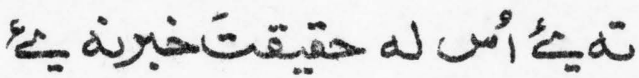

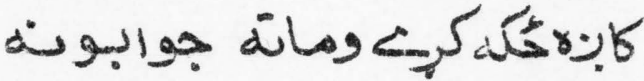

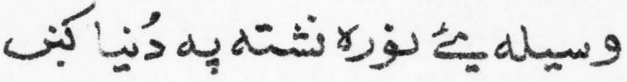

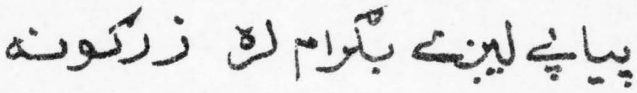

us

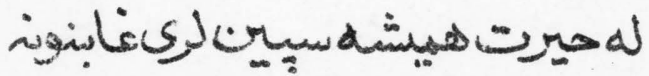

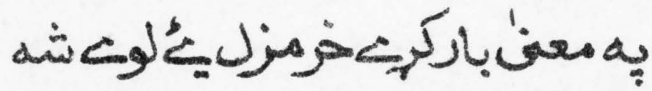

iوز a

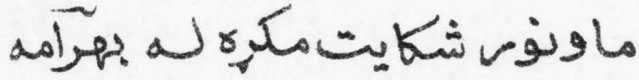

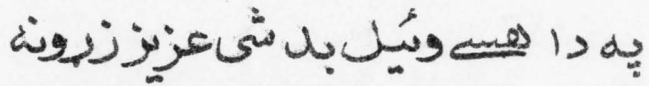

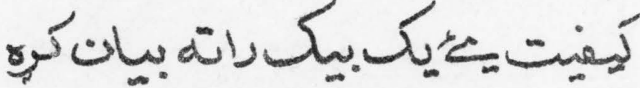




\section{ديوانِاشتهنحان هُريَ}

يגوطن كنى عزيزات لرمبمتزوبك

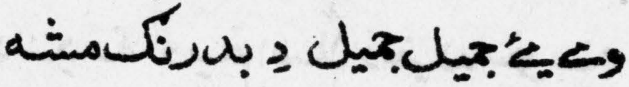

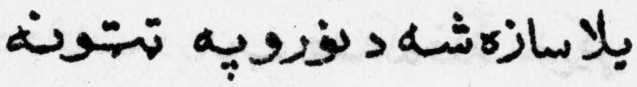

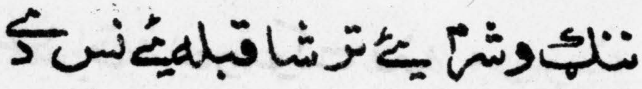
بaمطلب بيسجارباسى زيرحزينة

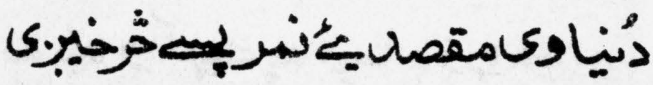

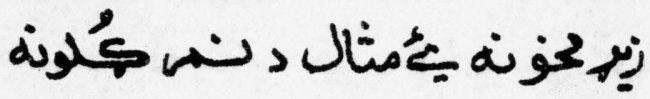

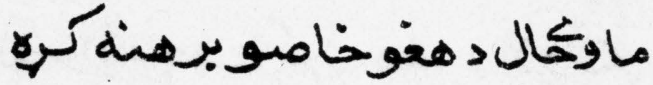

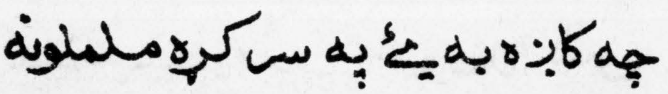

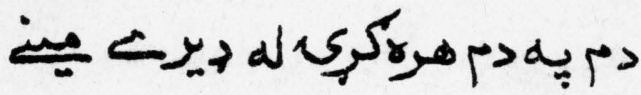

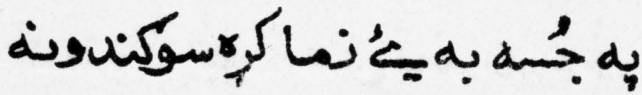

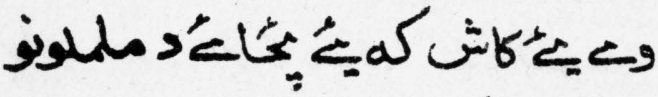

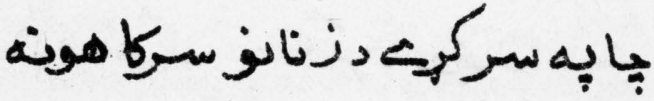

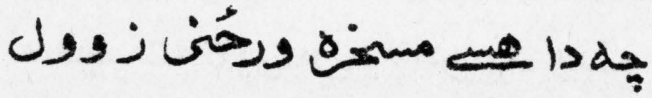
كيرخزد هغو مينل وبوده كســونة 


\section{ليوانِ اشُبنهانهجريَ}

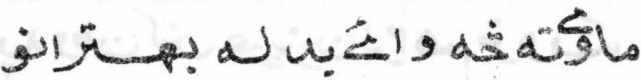
من

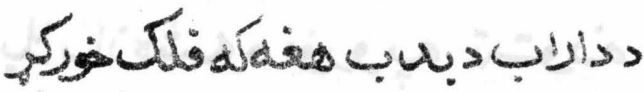

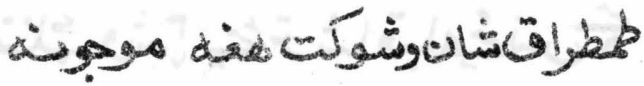

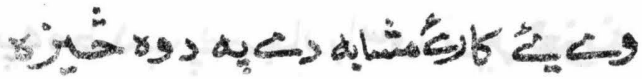

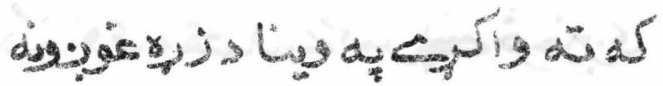

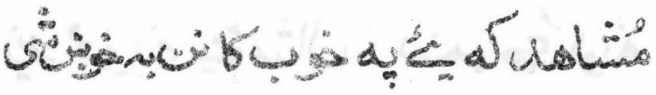

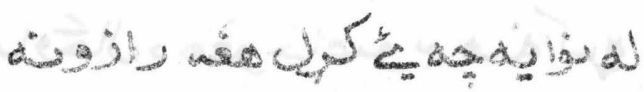

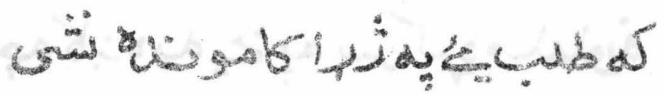

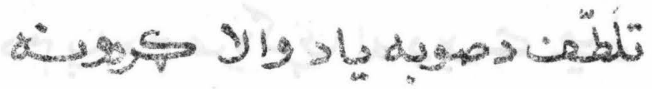
ssunis to

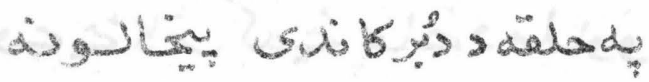

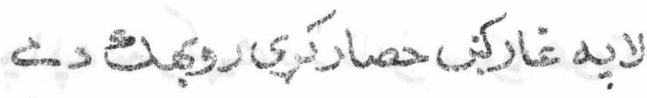

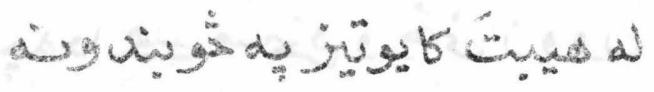

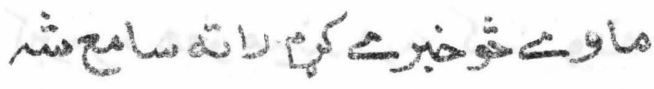




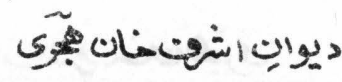

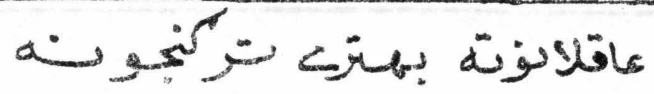

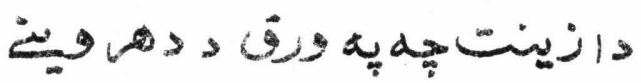

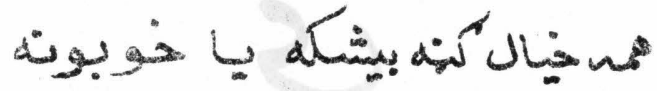

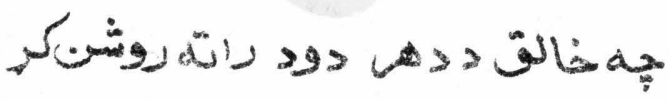

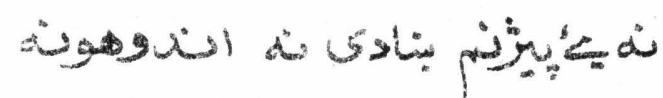

Lئن

远

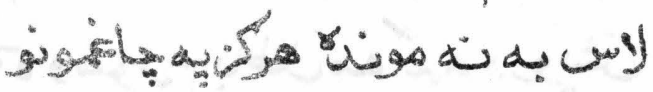

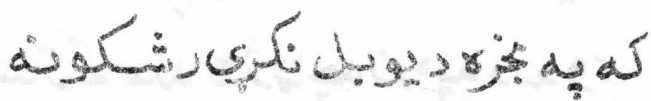

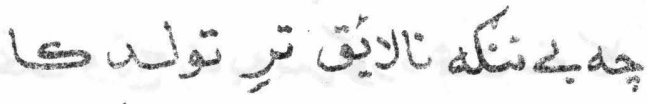

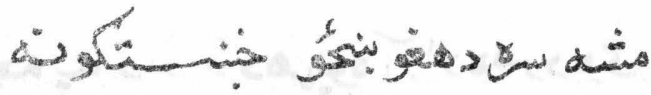

(c)

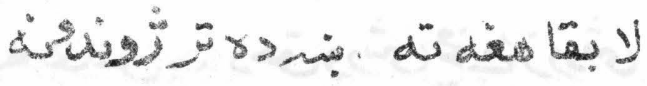

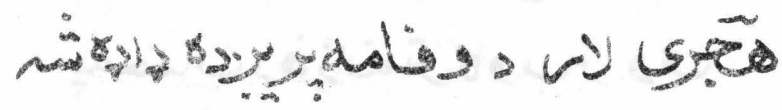

هن

189 
ديوالِنتهنه

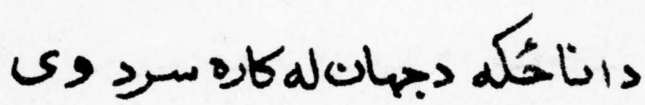

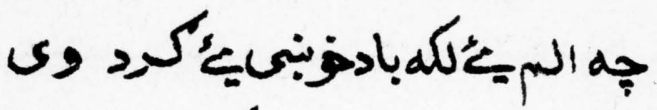

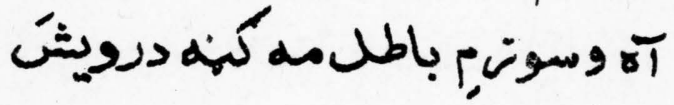

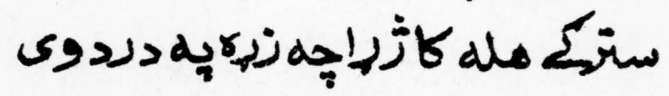

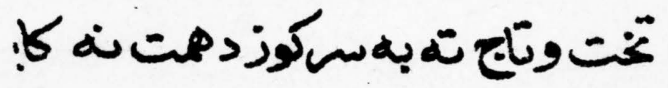

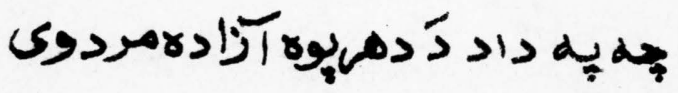

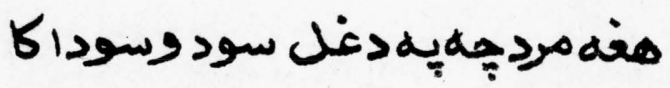

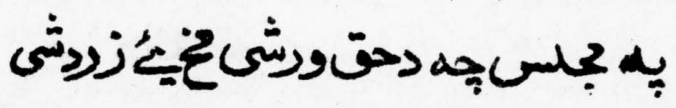
يه محسب دوزانغ تركاوبز وى

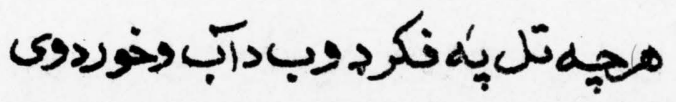

in. 


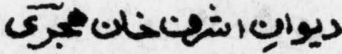

كردنا خلاك جكلمسرحدانه

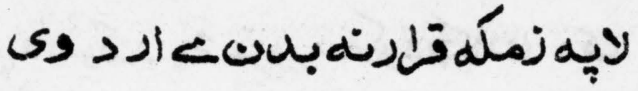

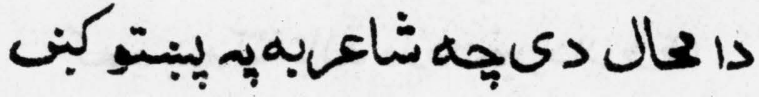

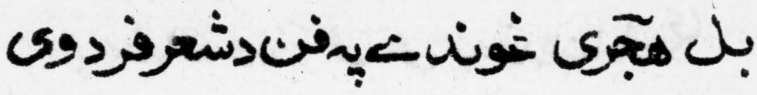

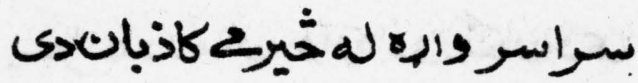

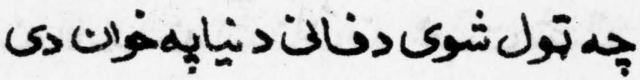

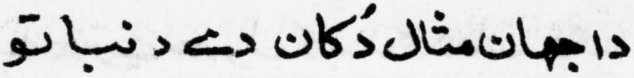

كإِ

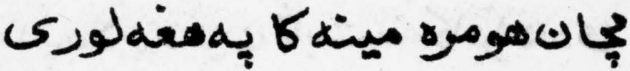

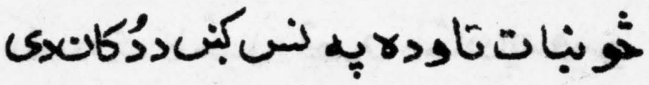

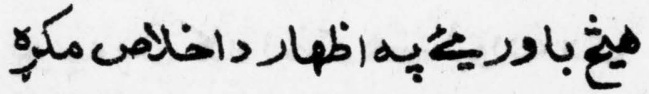

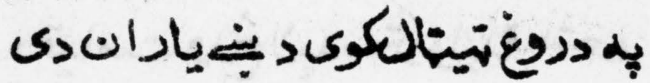

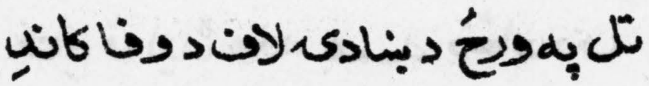

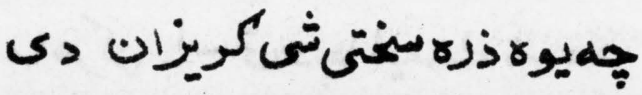




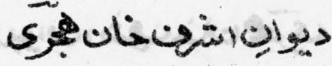

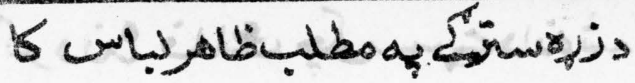

cs UbFrgas

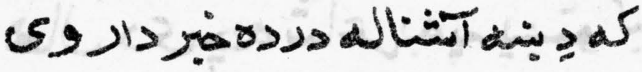

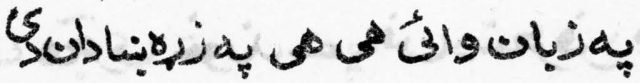

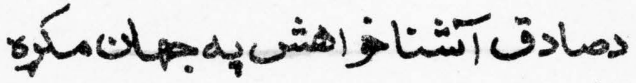

يسراندمالب واريا دورنكاندى

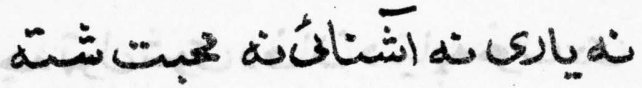

يه ئزيُحصول كابناله دنان دى

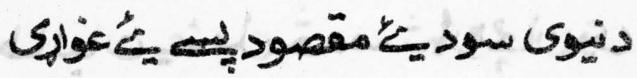

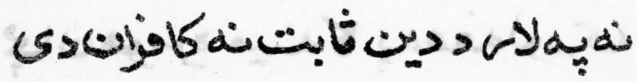

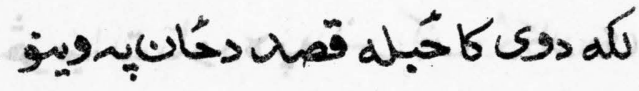

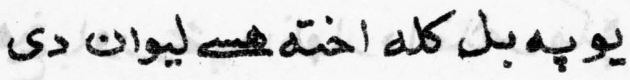

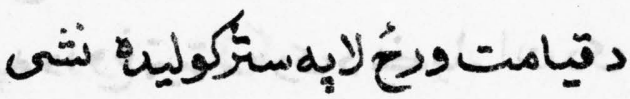

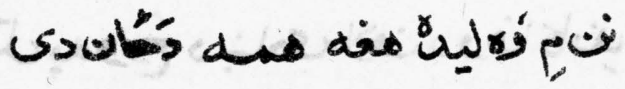

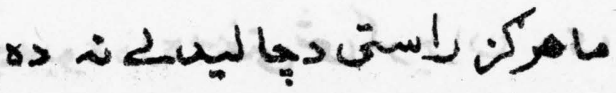


يوانيانهنان

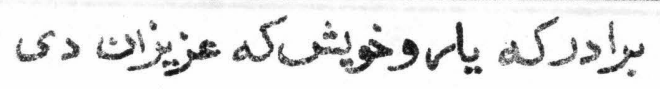

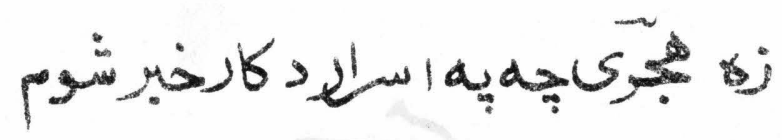

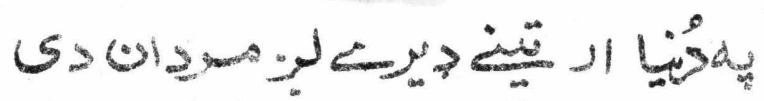

Apr 


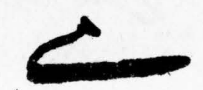

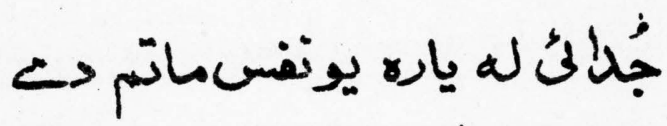

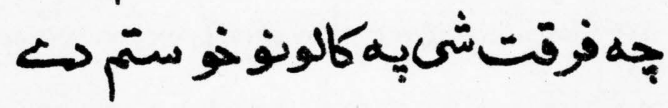

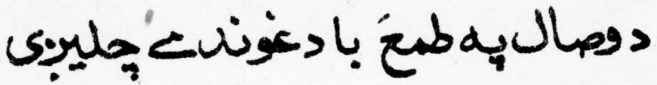

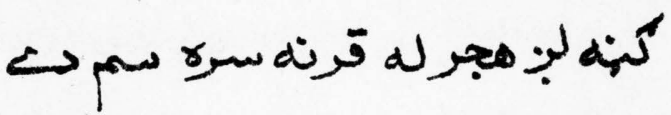

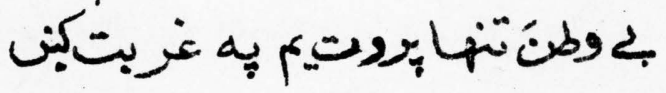

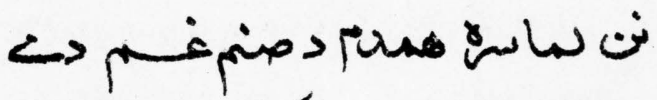

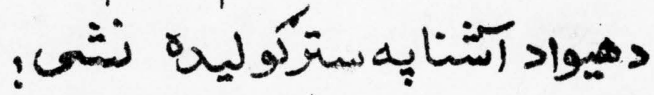

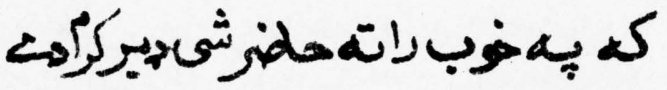

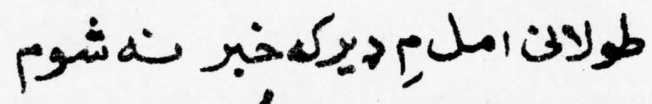

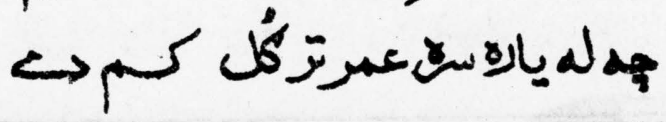




\section{جيوالِِ اتشهنتلن مجرى}

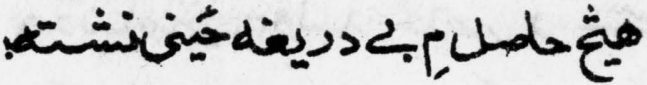

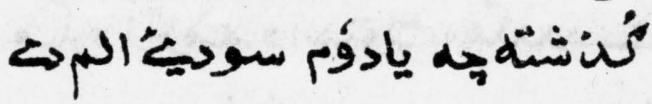

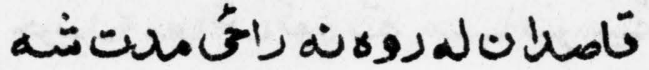

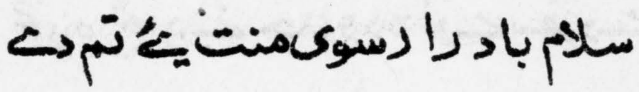

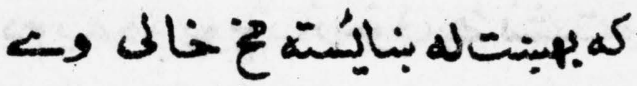

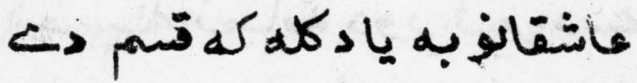

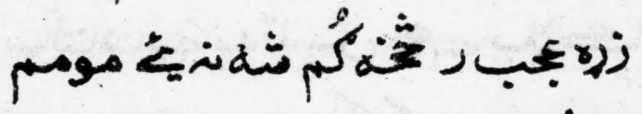

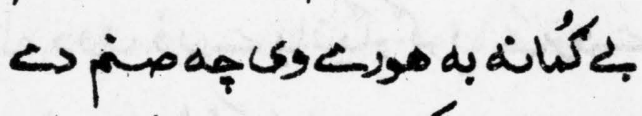

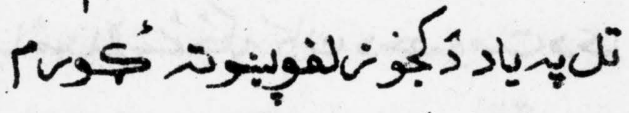

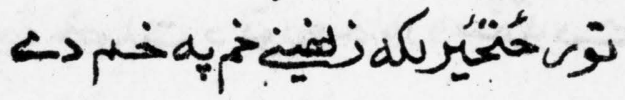
جه د دورخبحك كله تاصدراؤهى

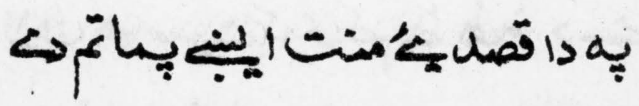
'́

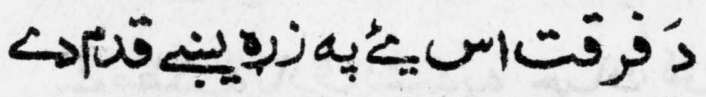


يوايناشهنخانئى

- > S

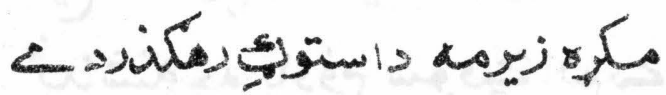

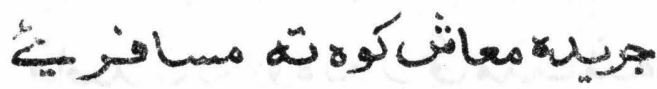

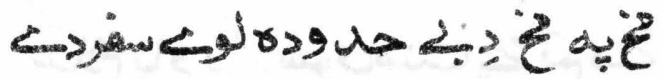

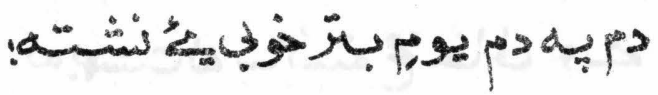

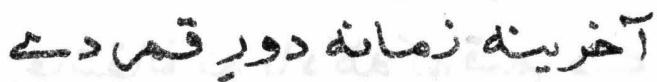

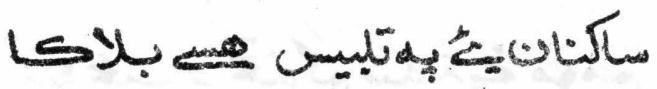

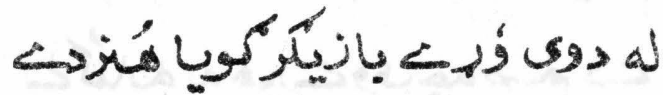
باش

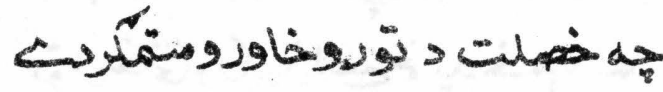

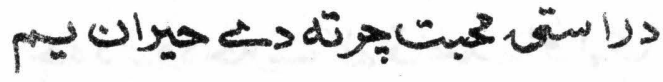

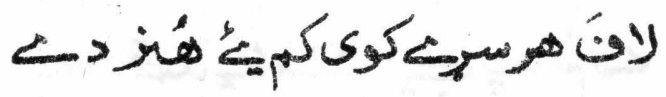

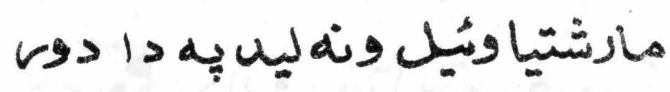

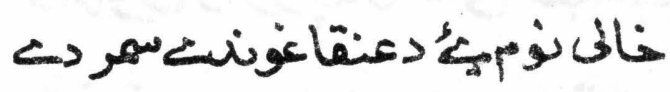

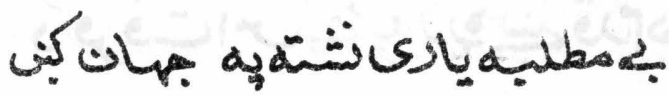

IAY 


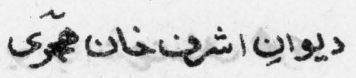

$\Leftrightarrow$

K

$\Leftrightarrow,-1,0$.

ق

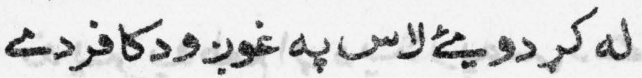

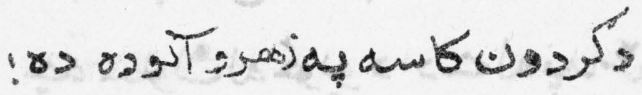

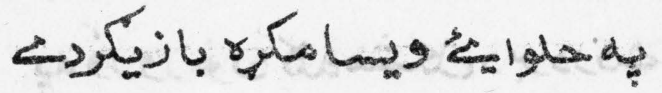

هوروت

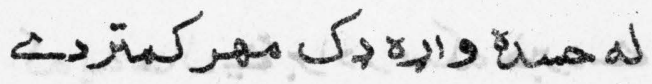

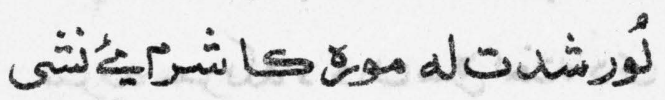

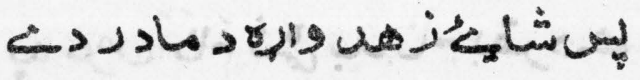

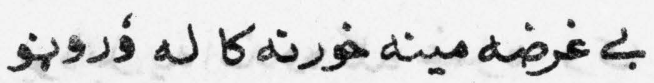

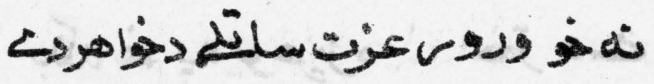

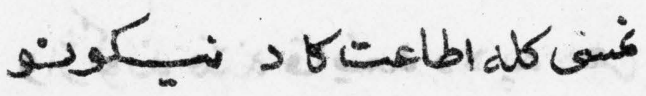

1 


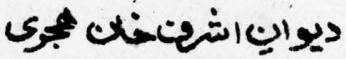

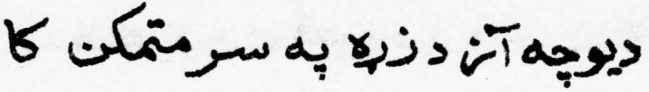

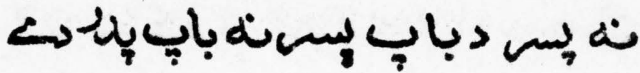

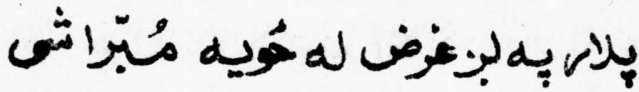

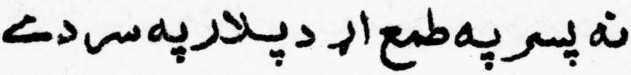

كuplesp

يه ؤرور

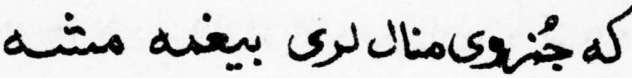

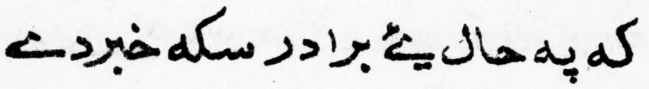

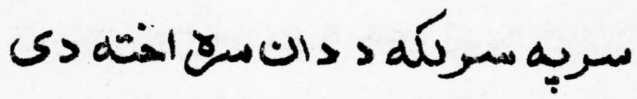

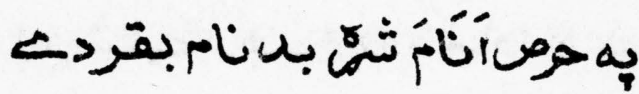

s)

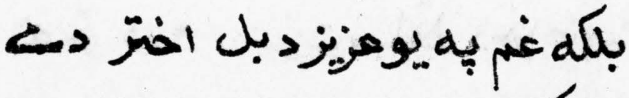

وازئ

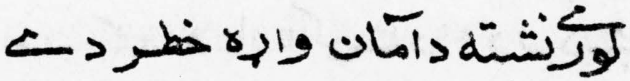




\section{يوإِانهنهانهبرى}

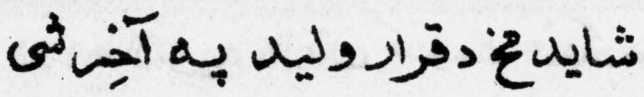

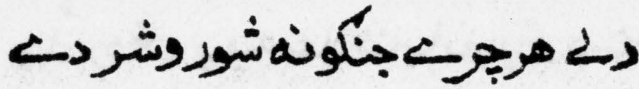

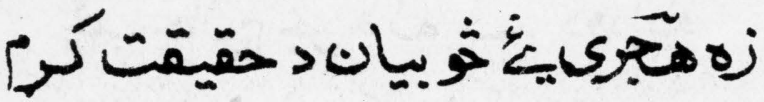

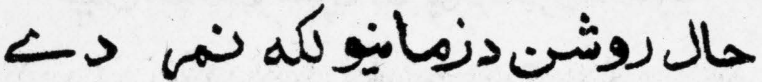

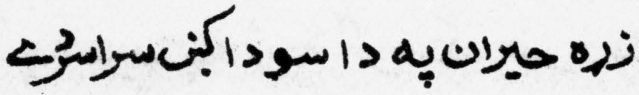

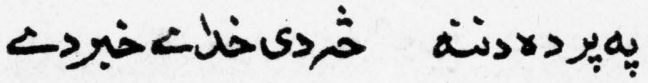

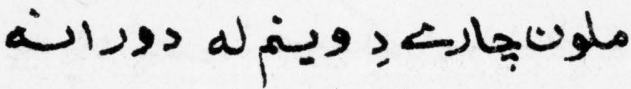

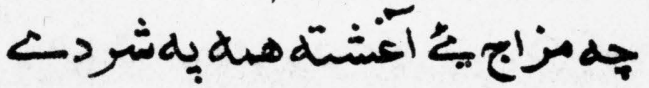

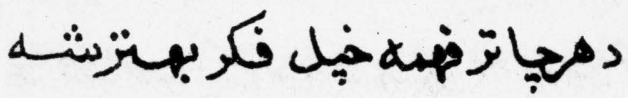

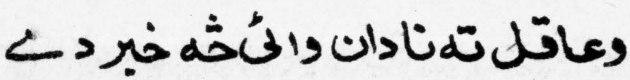

sا

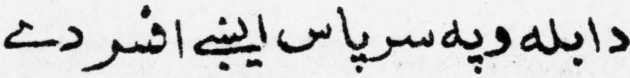

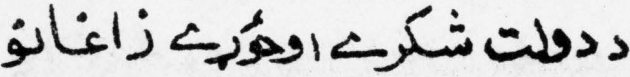

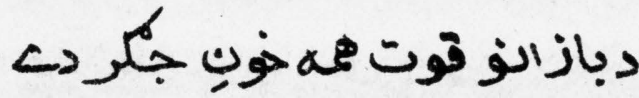




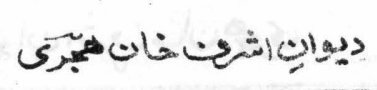

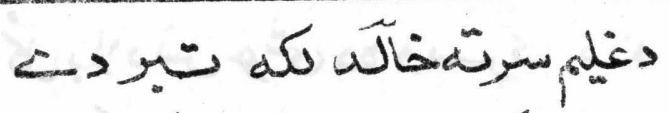

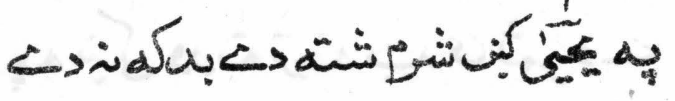

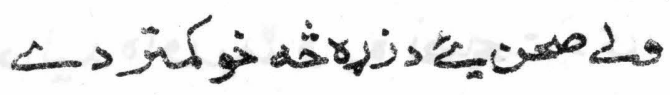

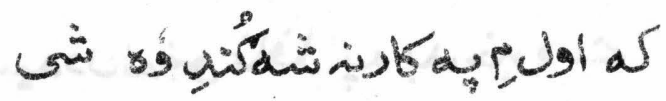

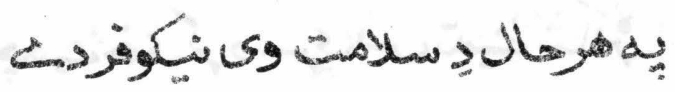
| Som 9 د

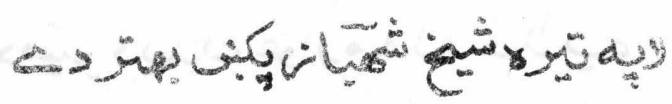
' L ل

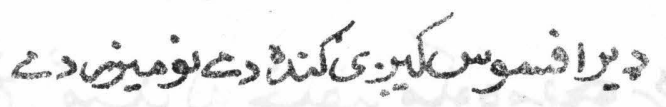
دات

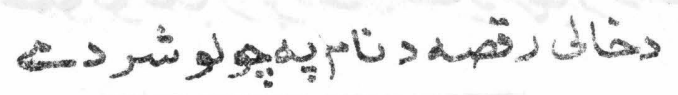

$19 !$ 
جيجانِن انتهنهانهميى

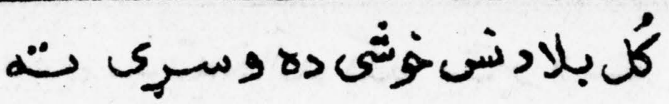

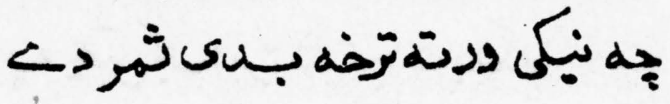

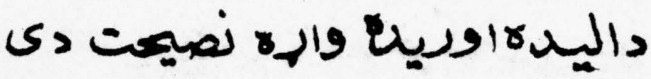

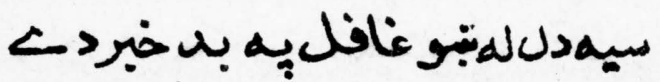

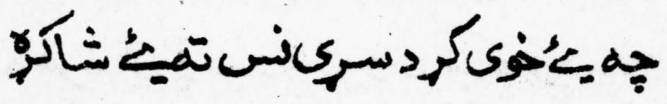

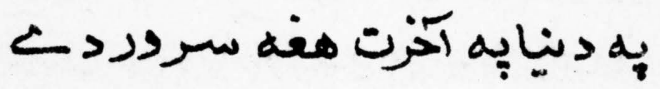

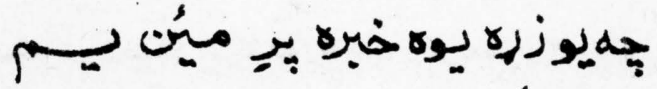

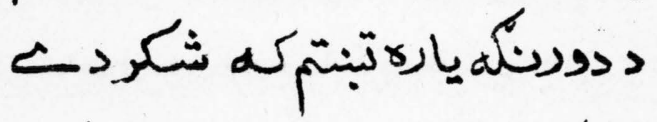

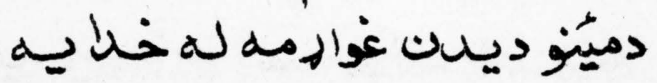

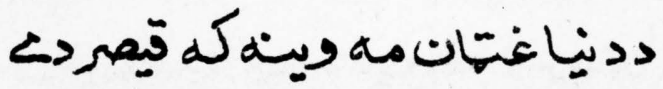

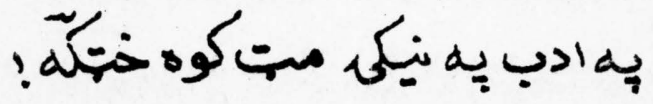

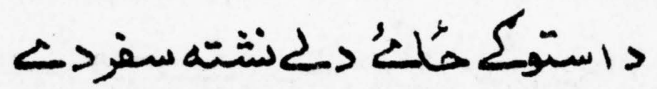

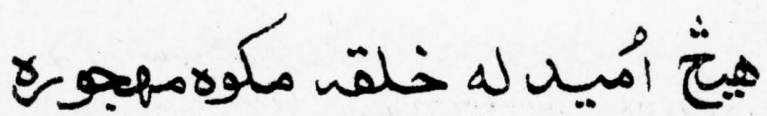

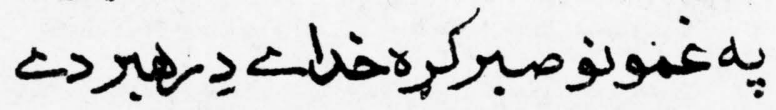

19 


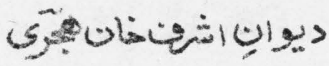

سونة

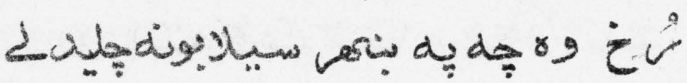

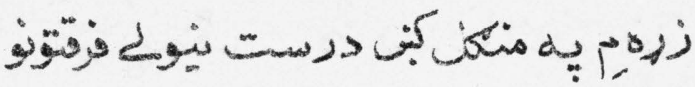

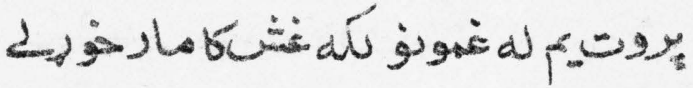

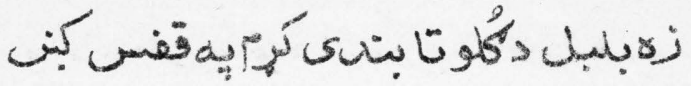

S

مركمة ثقلو

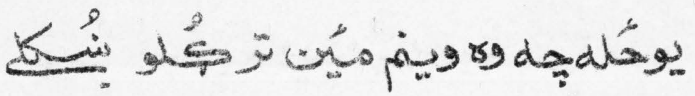

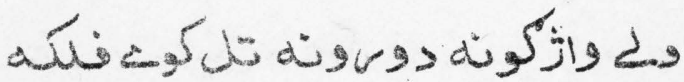

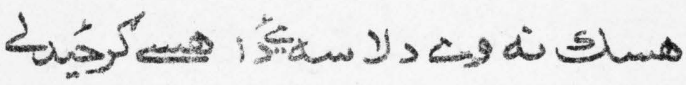

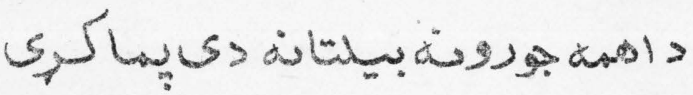

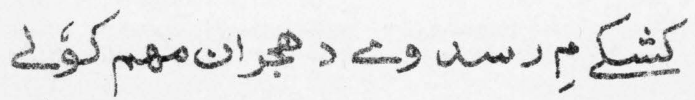

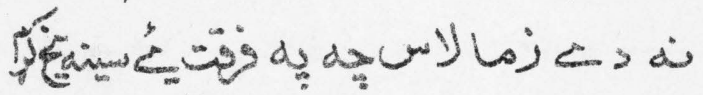

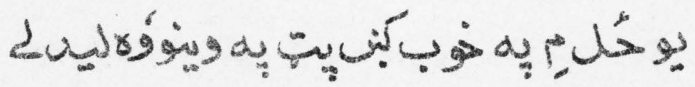

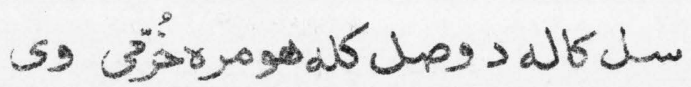




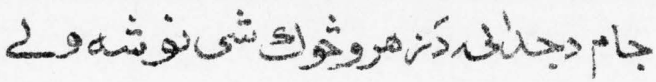

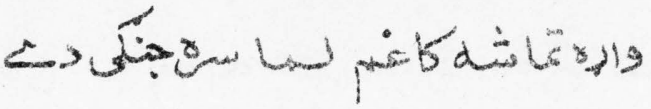
¿ل

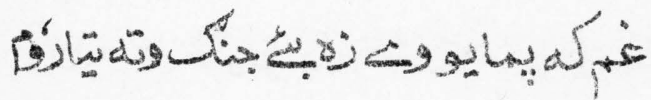

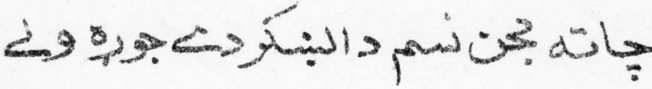
[T Lوندs

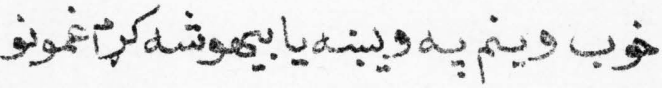

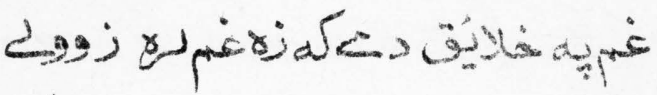

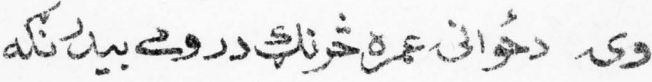
L

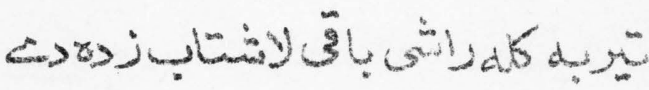

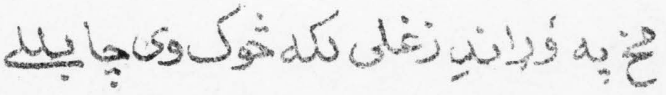

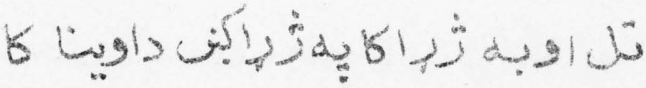

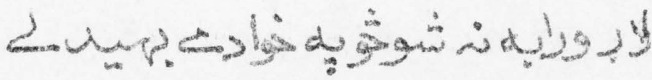




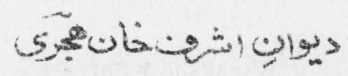

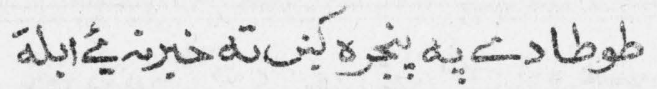

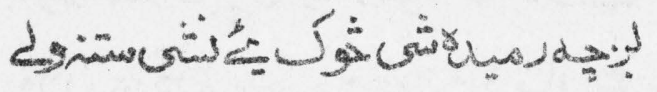
كوم كis

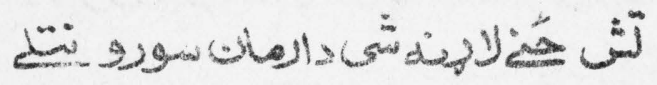

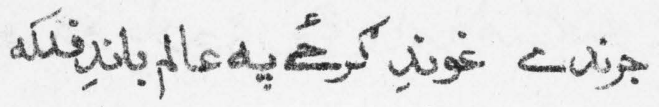
يانة

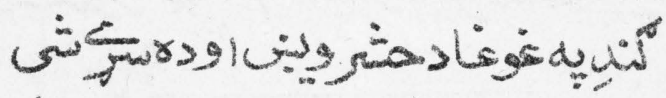

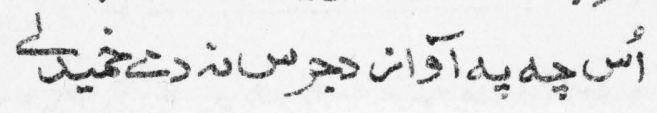

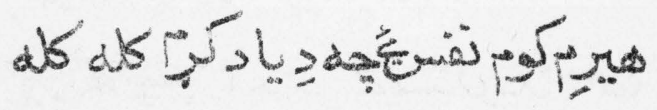

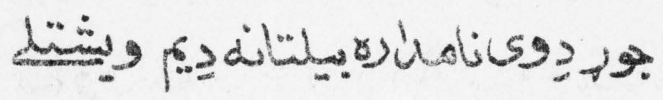

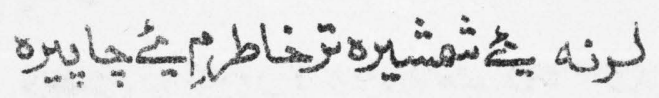

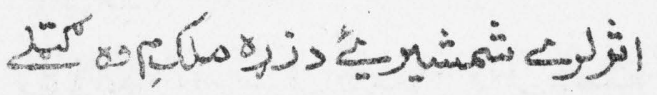
dالم

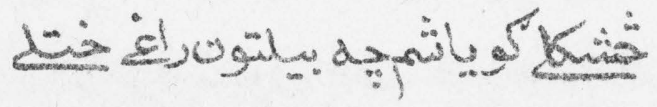
Lئ 


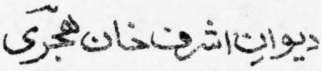

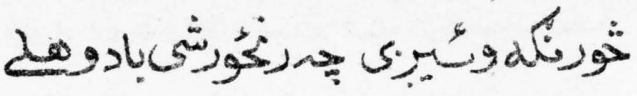

ولإبر

تئis

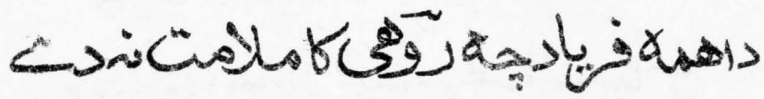

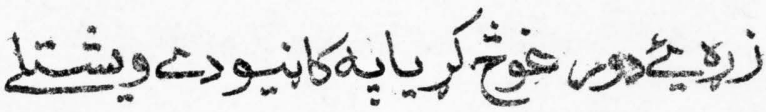

Gơnd

ज

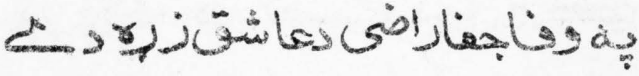

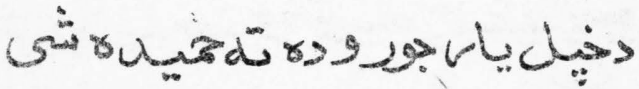

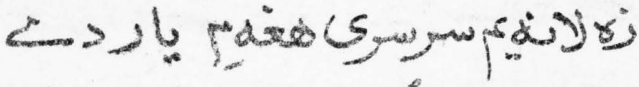

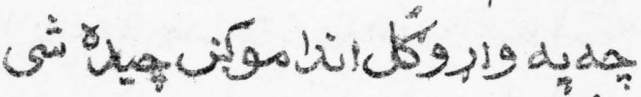

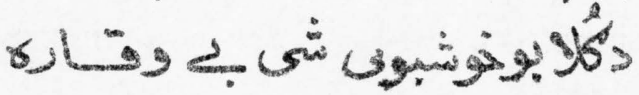

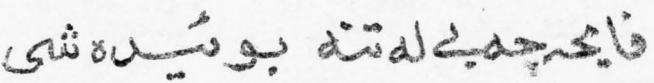




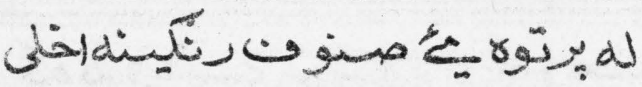

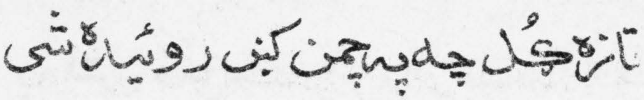

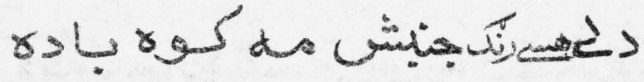

(

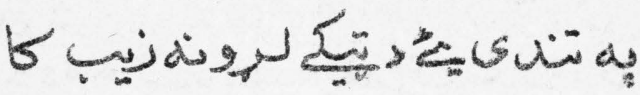

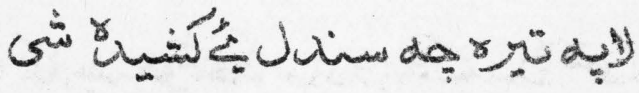

تّنة

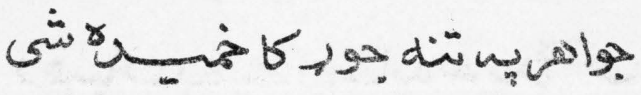

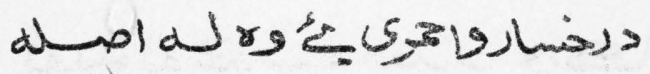

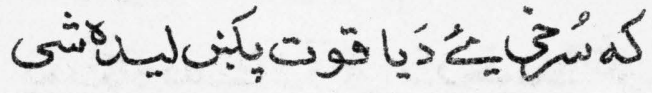

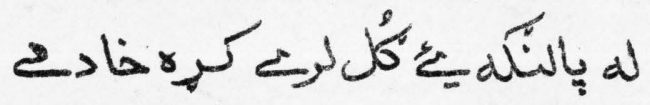

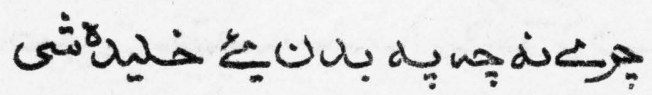

جإيسرة

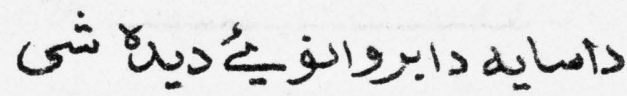




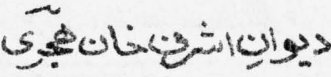

N⿴囗大

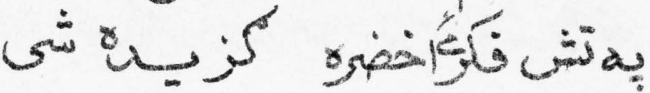

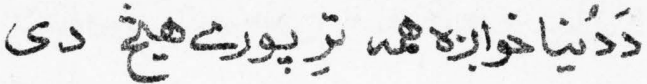

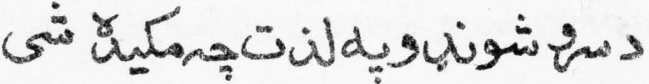

csobionsuds allows

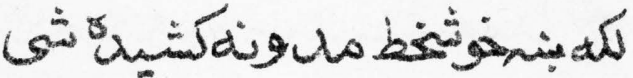

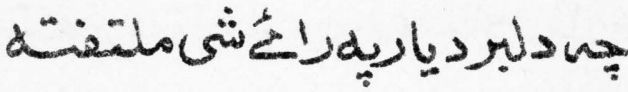

(5)

Lesus wis alus

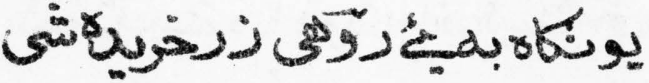

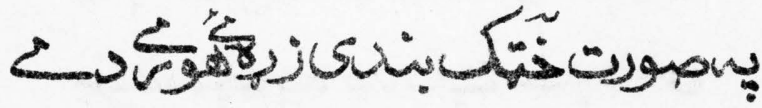

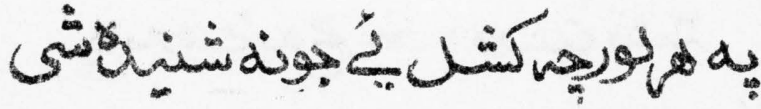




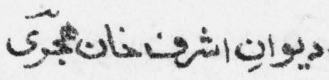

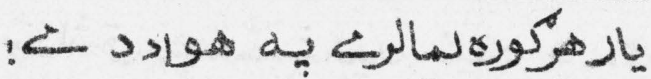
فو

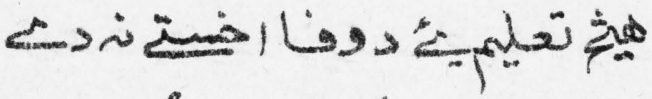

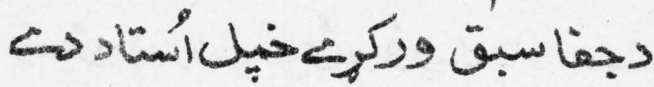

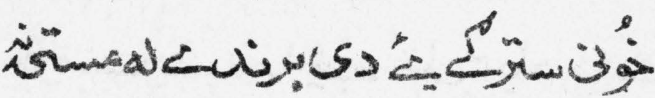
L

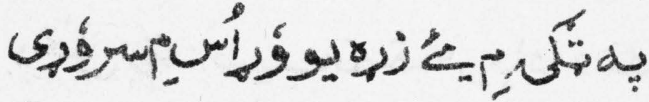

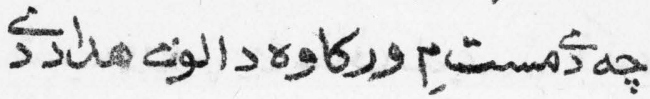

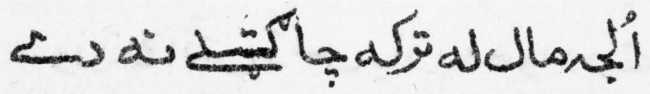
$\Leftrightarrow$

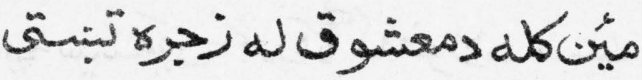

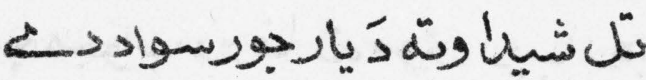

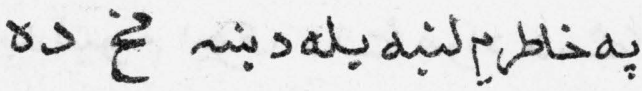

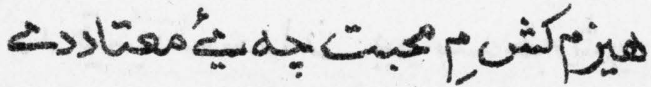

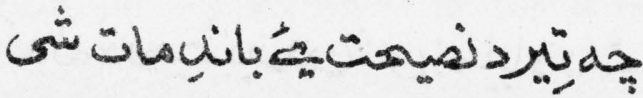




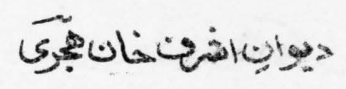

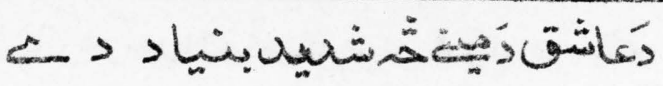

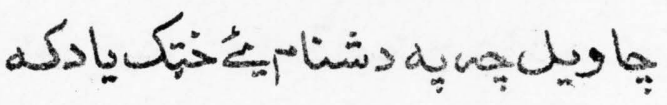

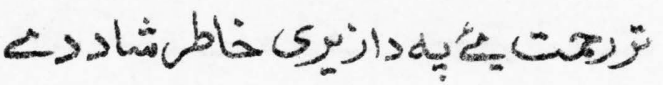

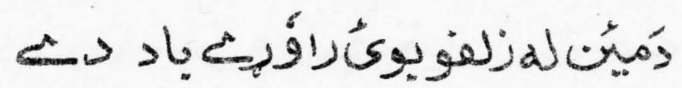

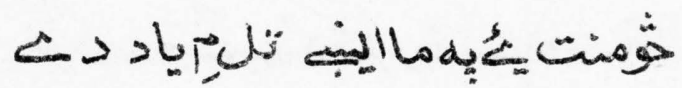

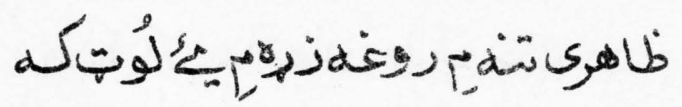

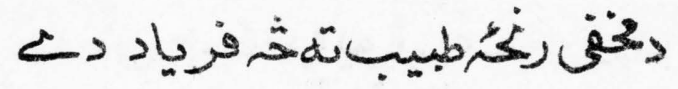

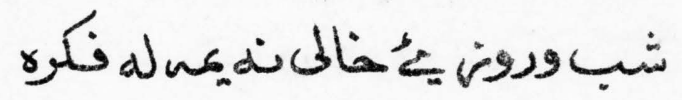

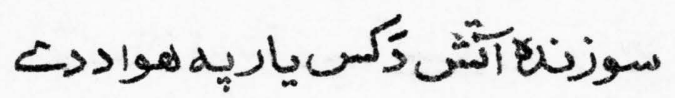

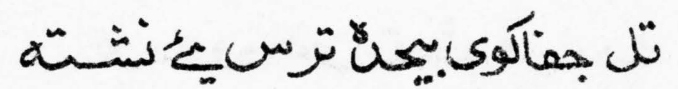

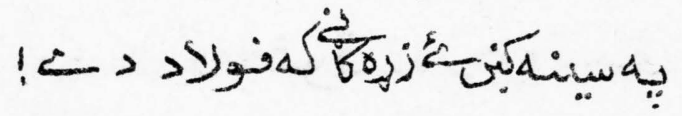

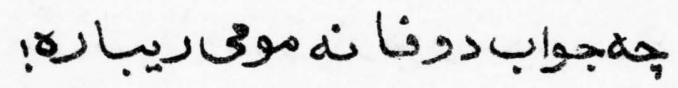

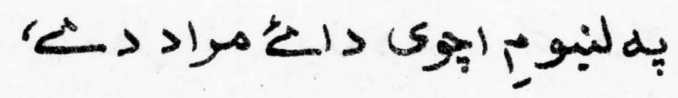

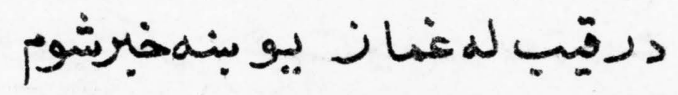

كل 


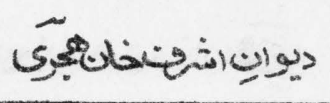

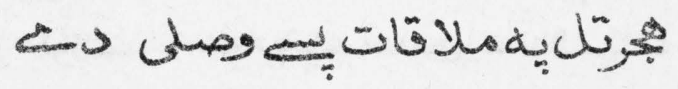

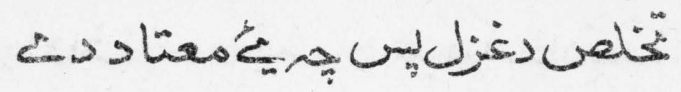
ل)

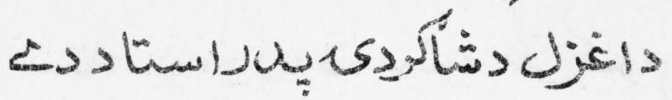

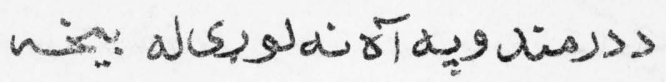

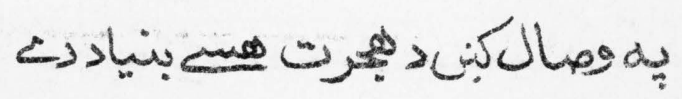

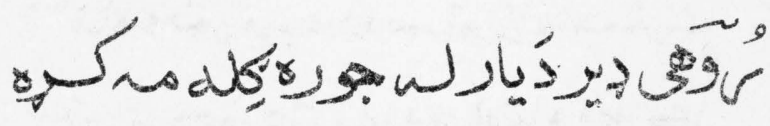

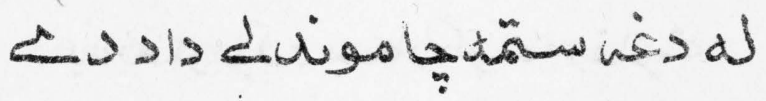

ثونس

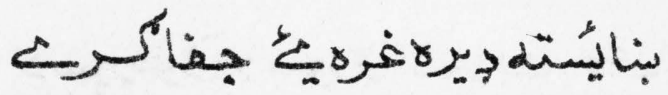

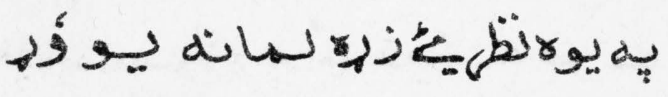

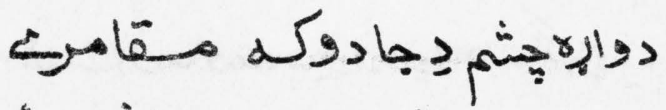

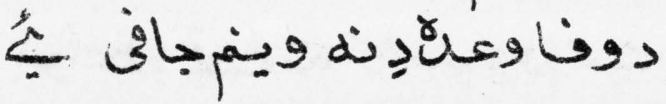

$r-1$ 


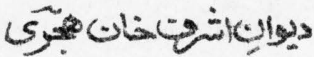

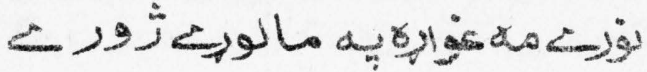

úcis $2 r u$ J

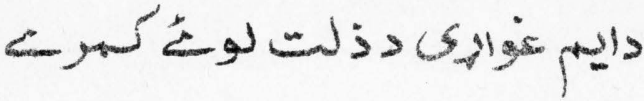

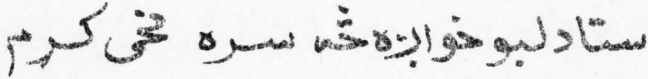

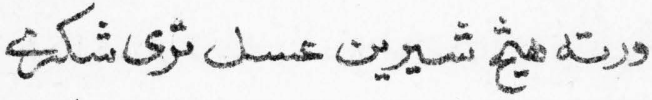

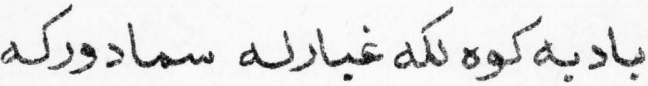
\& Le 29 distigsdañ

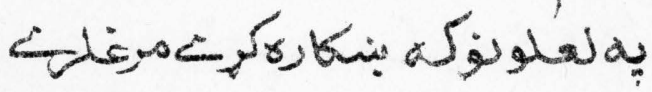

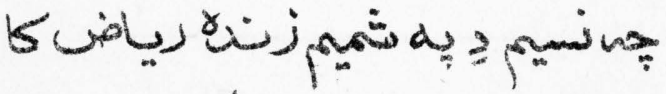

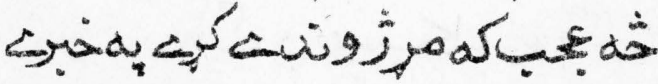

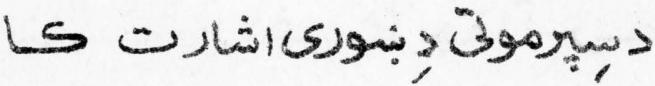

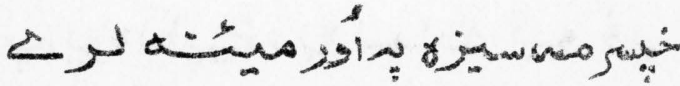
ب⿻上丨

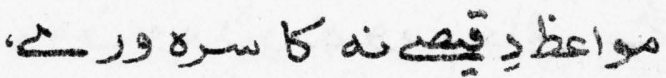




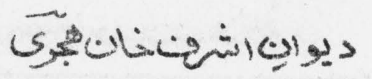

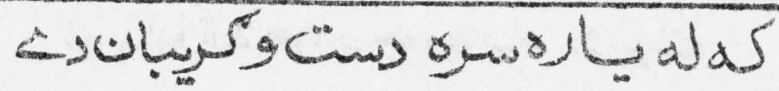

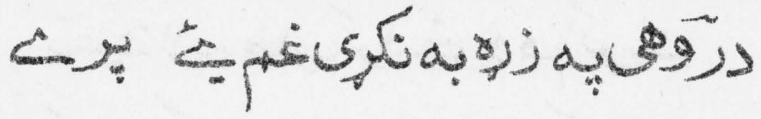

زرجها

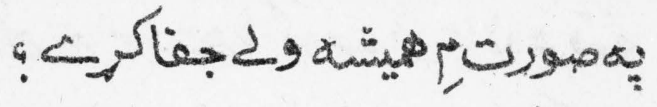

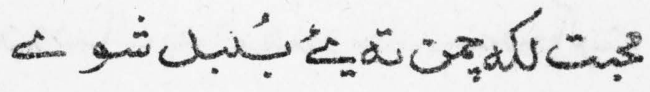

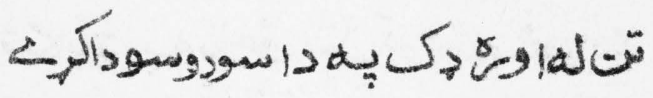

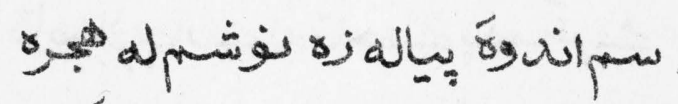

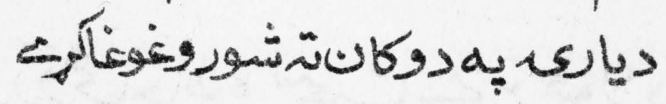

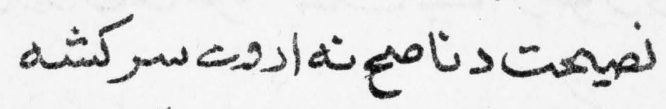

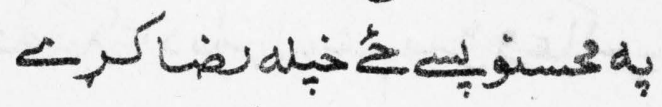

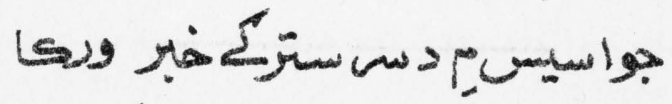

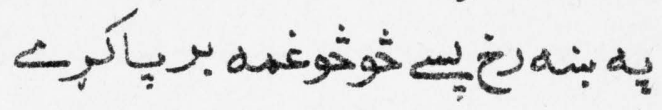

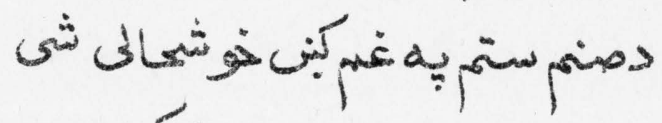

ي

$r o r$ 


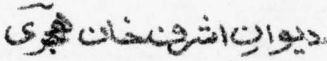

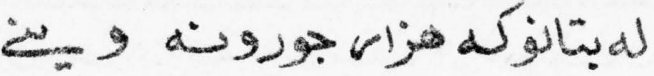

250

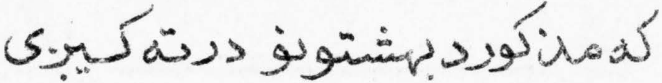

Es



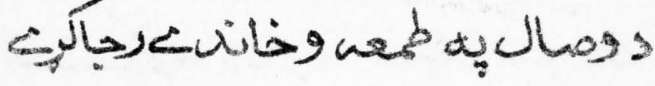

:

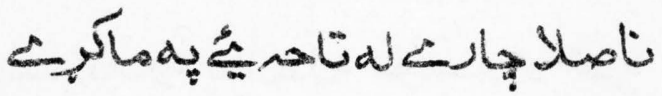

6)

 


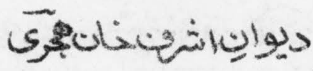

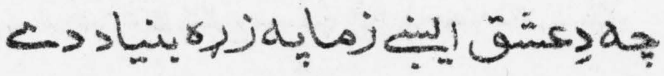

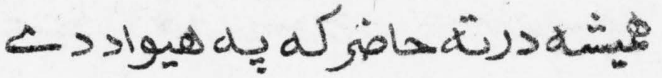
-rucgir

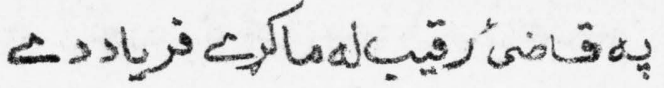

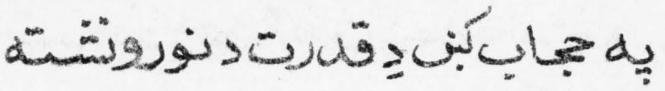

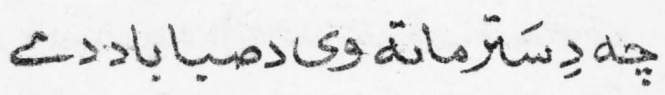

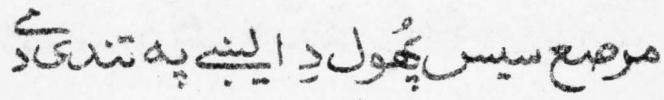

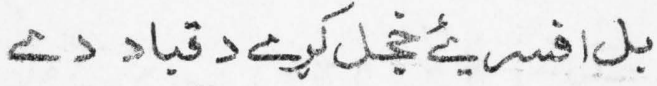
rs $\Leftrightarrow$

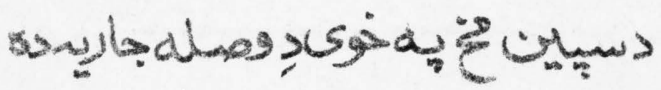

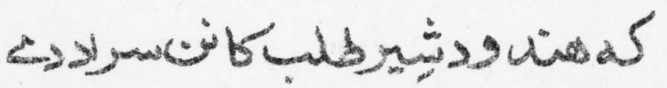

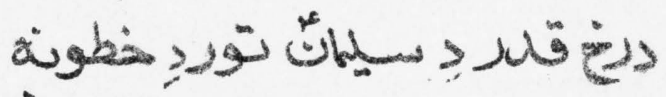
ياهير

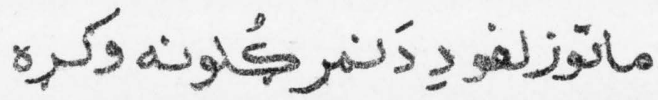




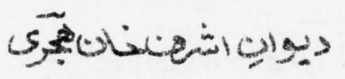

-

Prid ( )

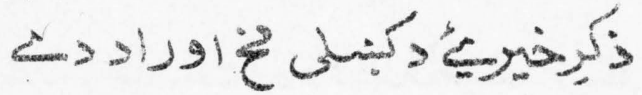

ش

$\Leftrightarrow$ m

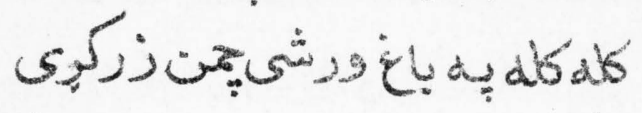

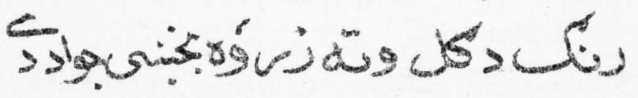

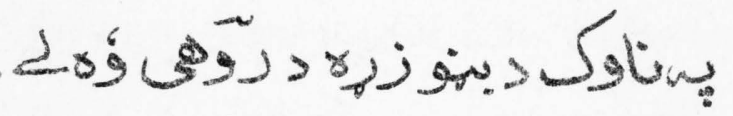

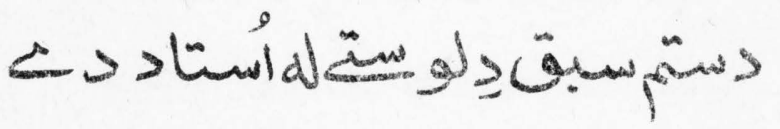




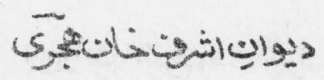

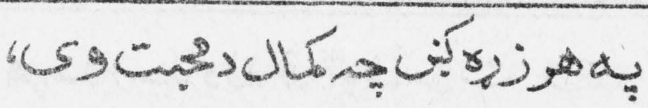

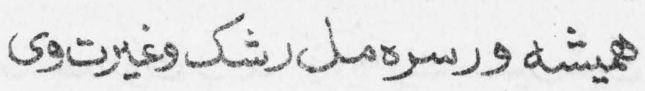

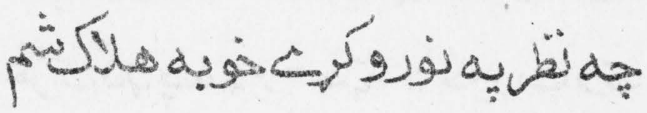

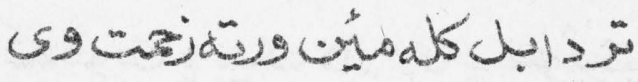

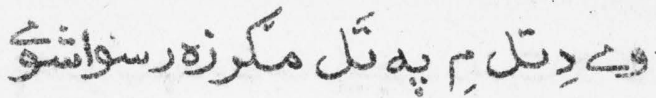

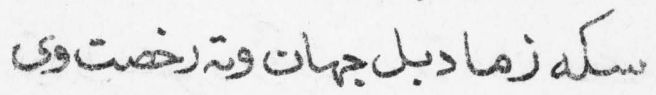

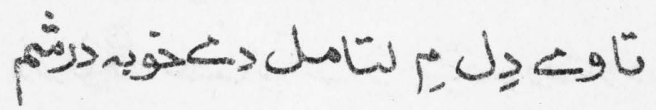

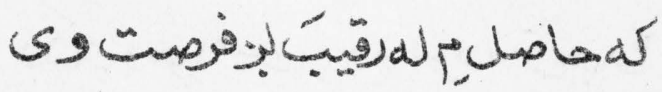

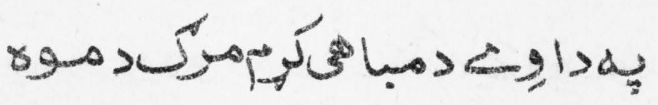

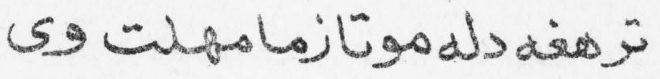

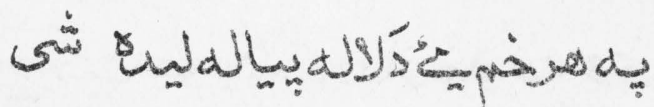

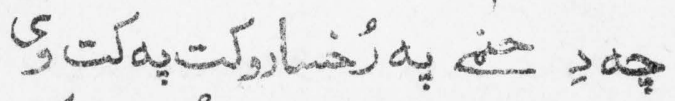

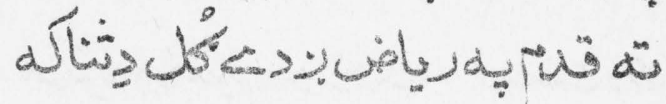

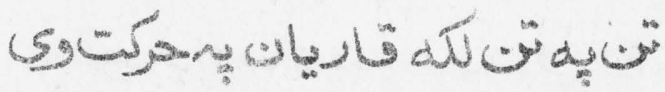

كLمق 


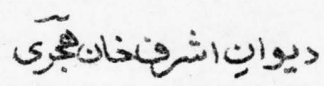

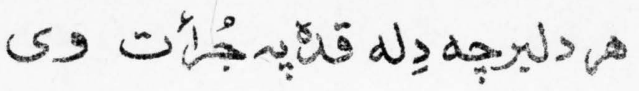
ن

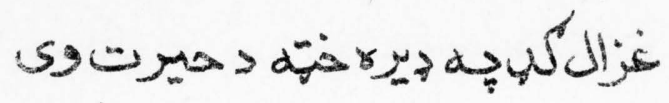
كان

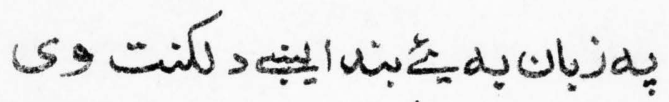

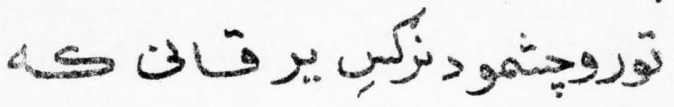

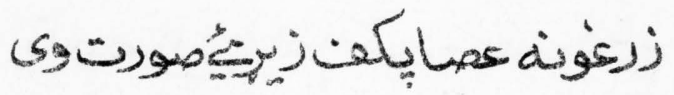
كان

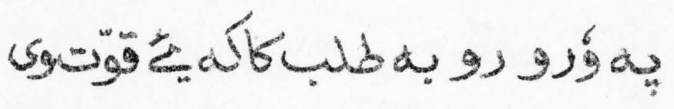

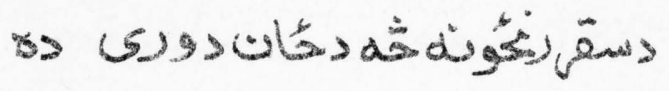

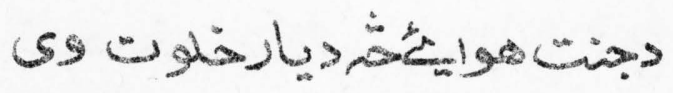
SDL

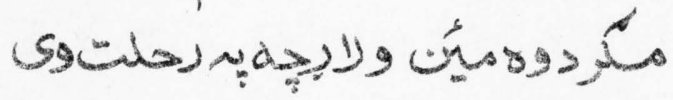

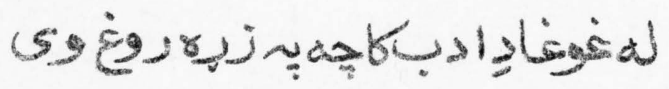

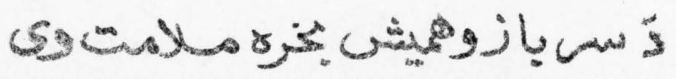

$p-\pi$ 


\section{s.}

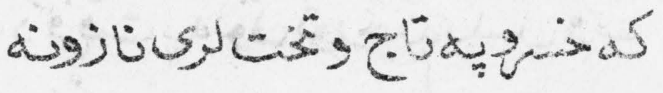

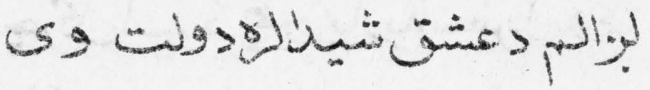

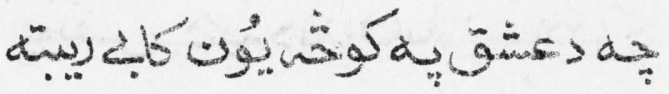

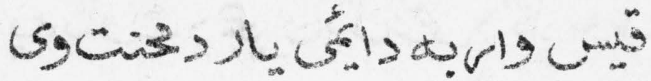

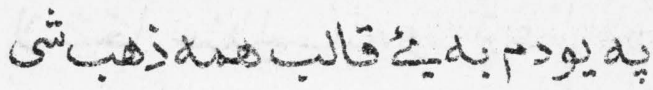

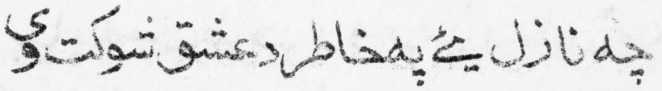

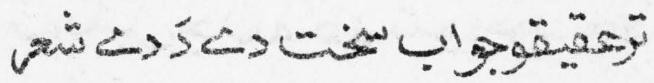

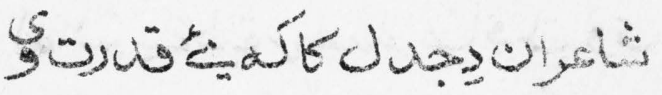

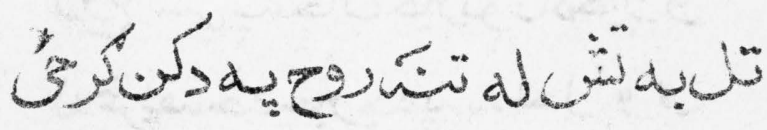

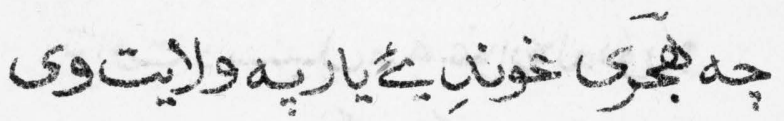


s's

جربكل

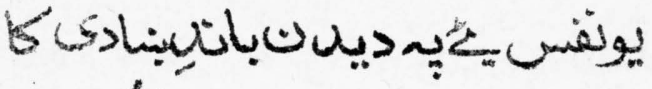

بs

a licو 5 gö

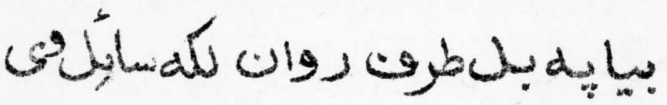

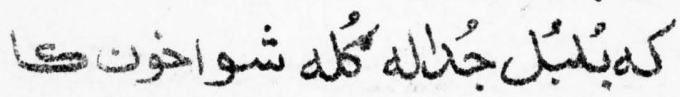

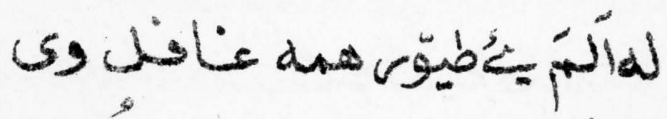

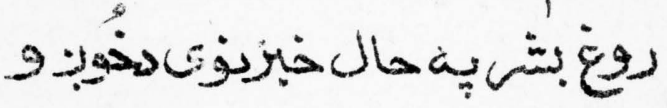

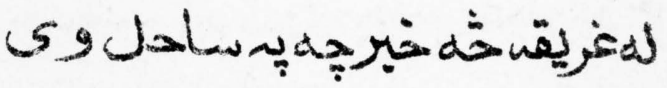

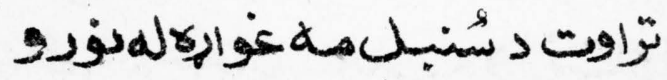

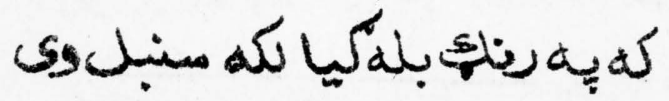

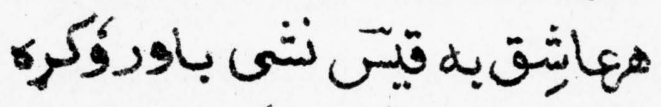

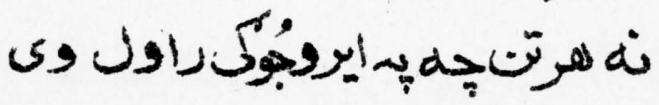

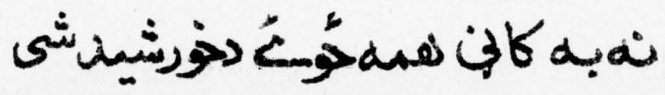




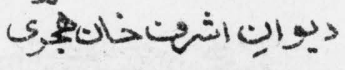

هان

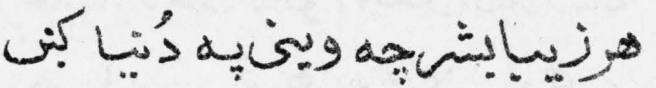

:

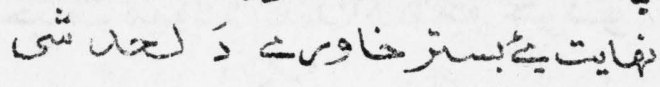

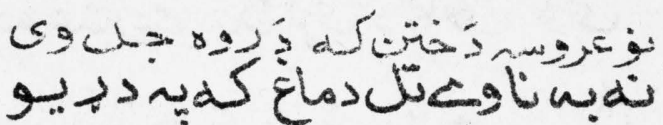

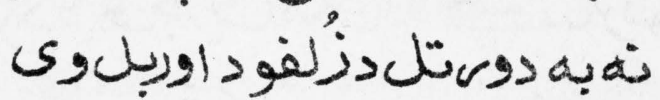

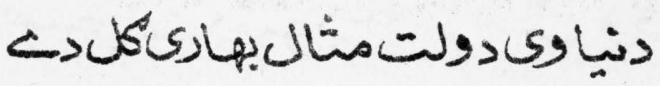

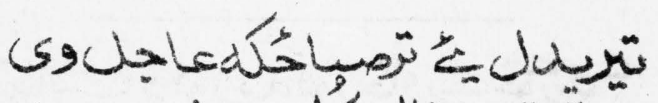

s)

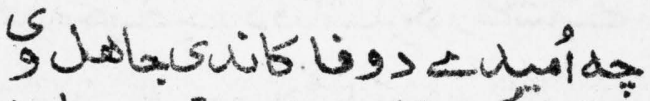

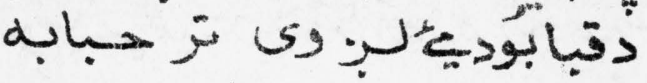

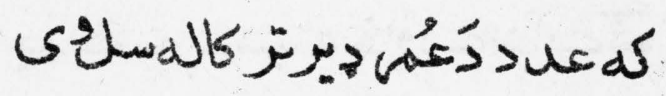

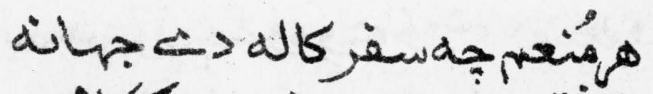

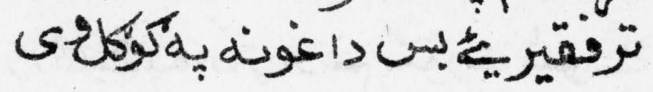

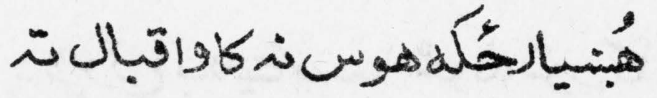

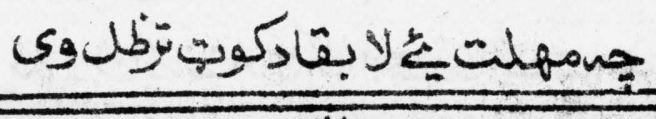

जा 


\section{(5)}

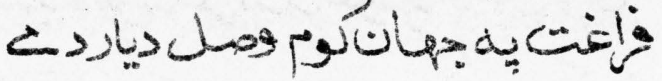

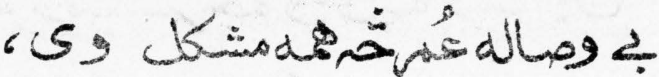

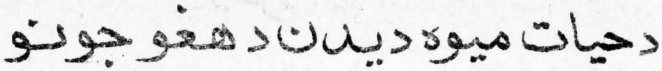

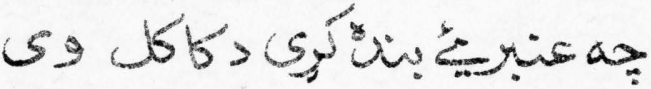

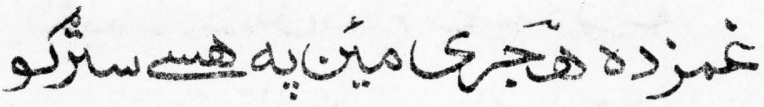

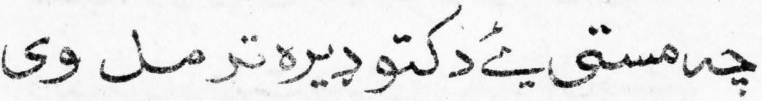

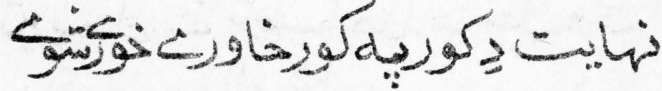

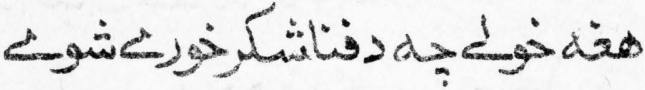

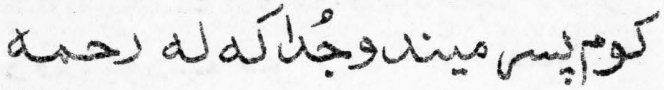

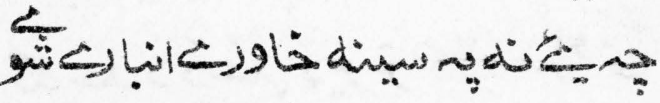

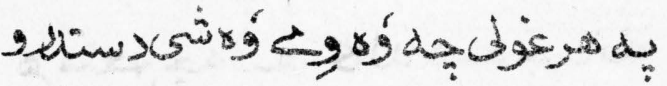

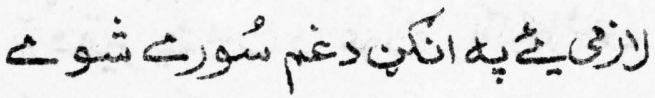

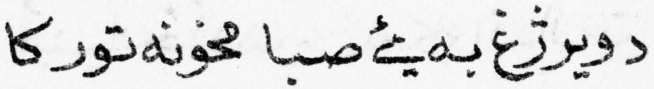

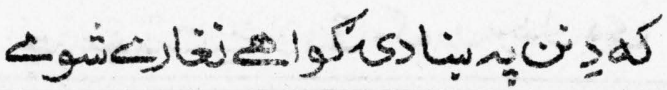




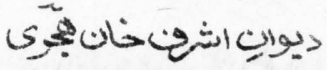

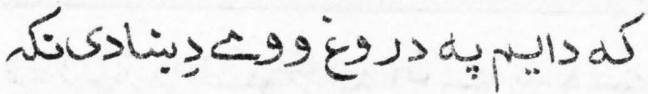

蓆

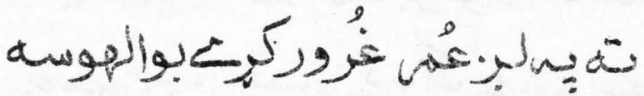

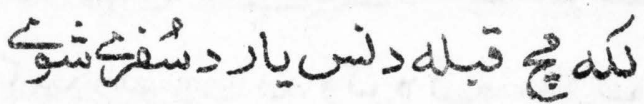

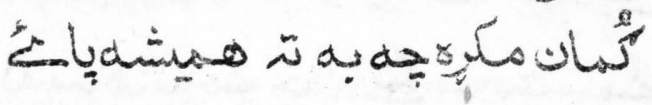

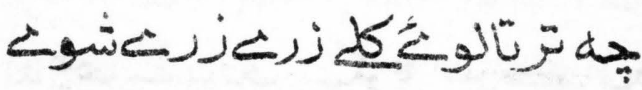

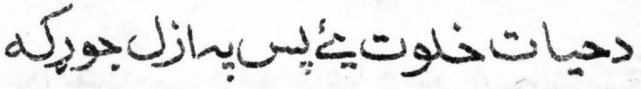

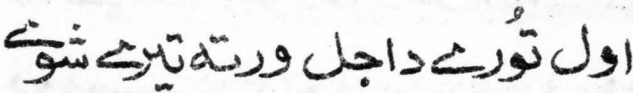

Lun

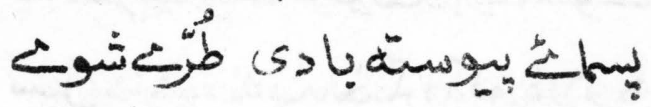

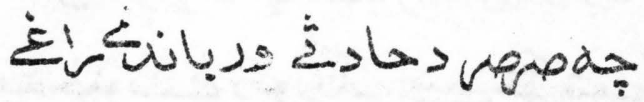

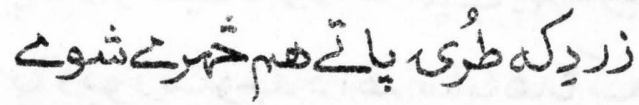

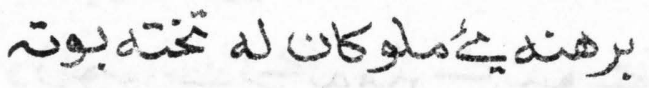

Sicy

> 


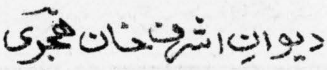

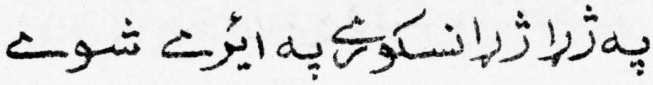

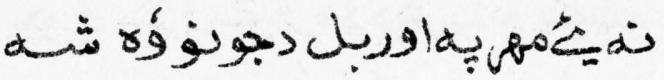

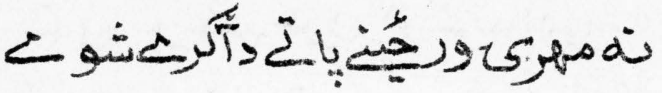

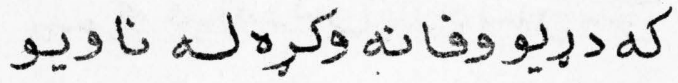

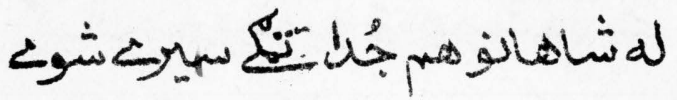

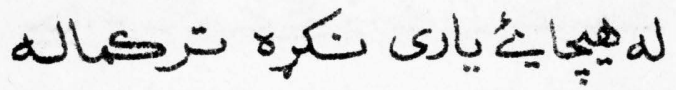

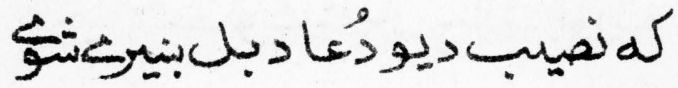

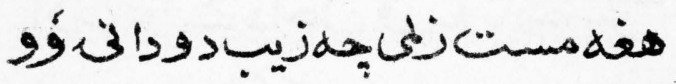

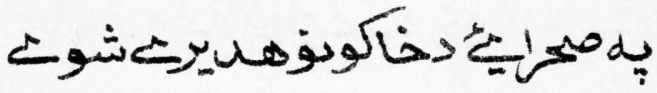

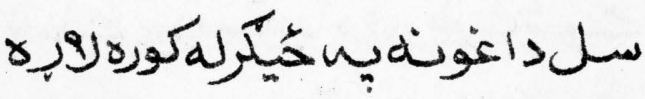

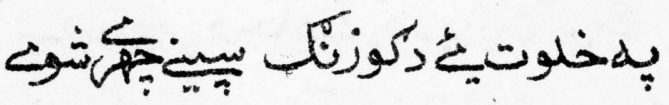

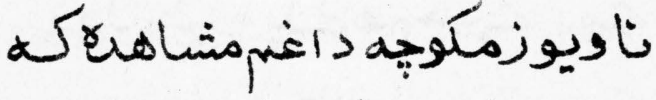

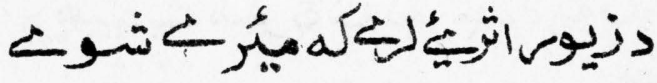

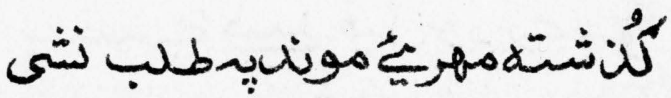

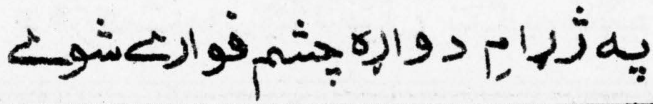




\section{يوإِ}

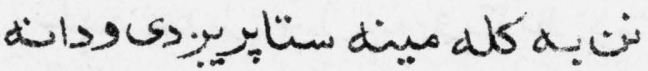

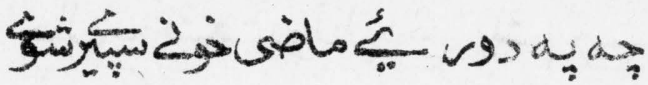

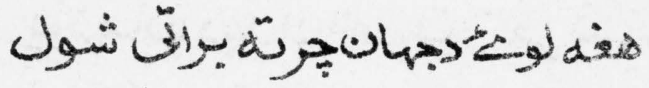

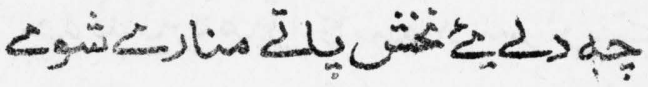

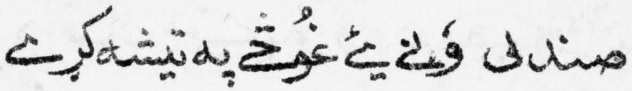

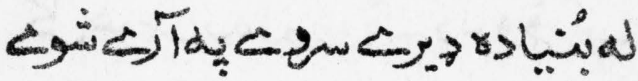

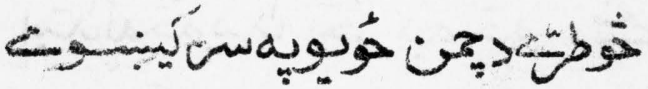

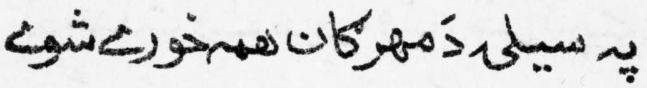

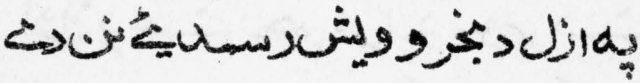

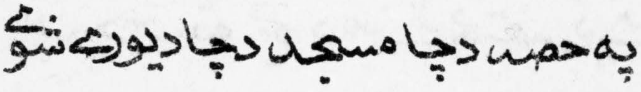

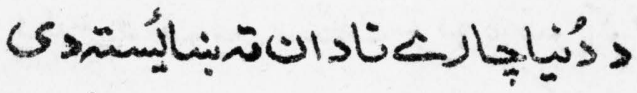

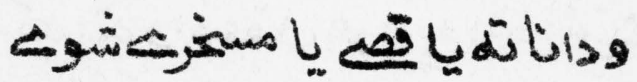

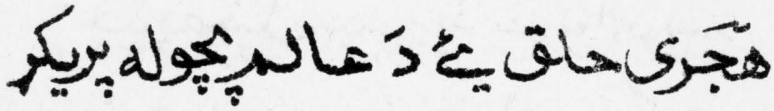

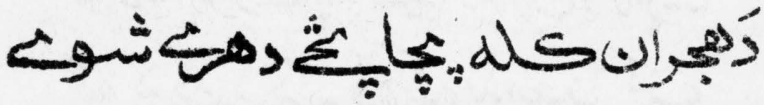




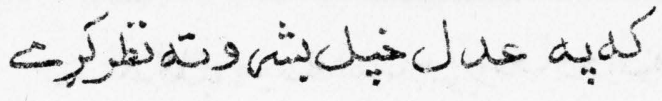
حال بة كثتهن يونة

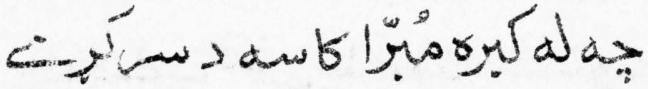

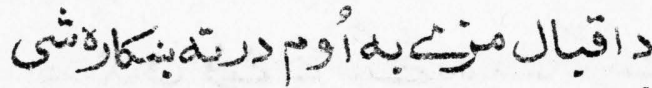

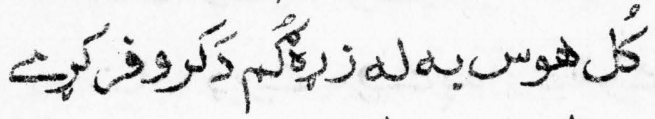

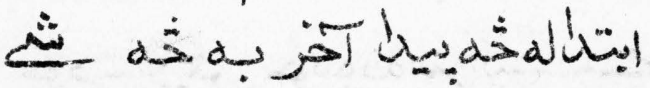

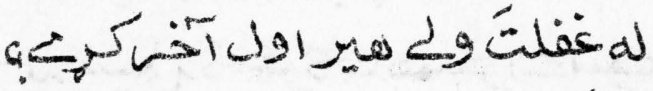

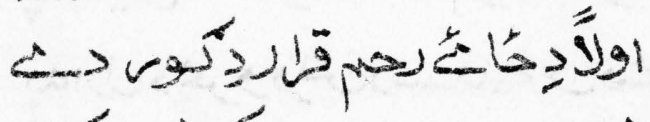
ن

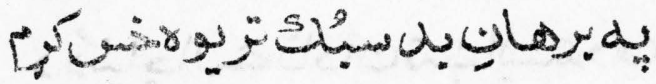

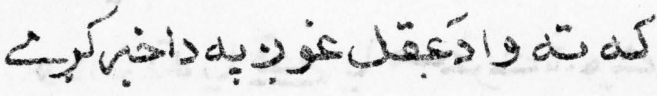

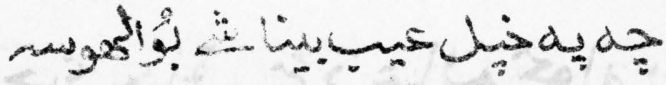

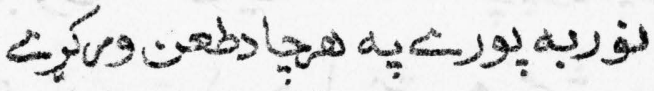

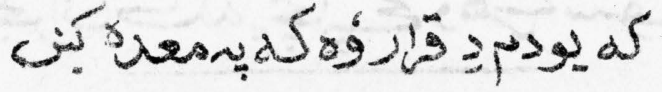




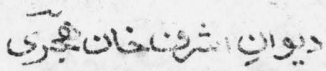

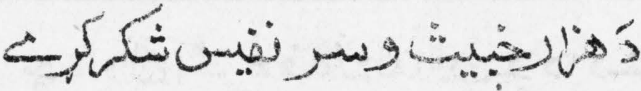

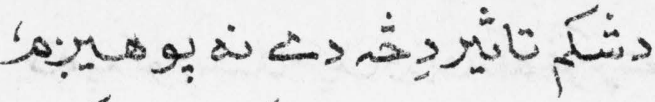

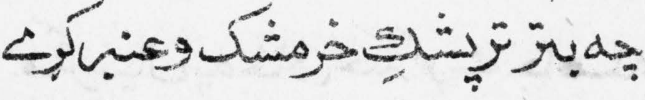

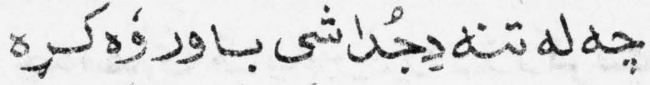

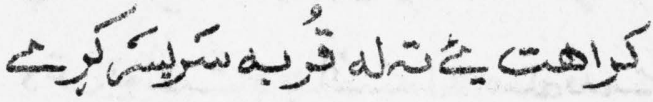

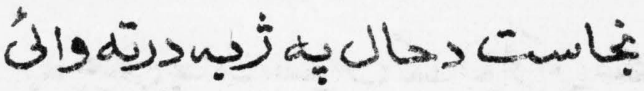

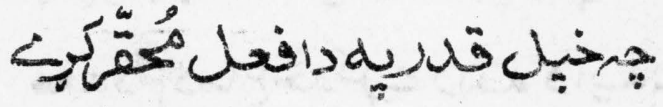

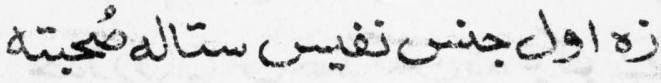
ترابن

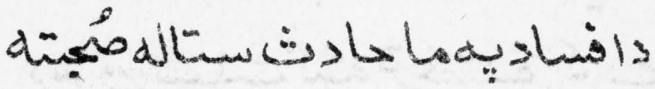

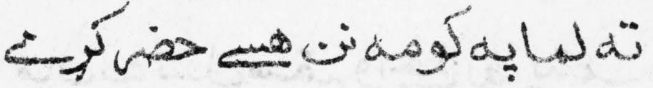

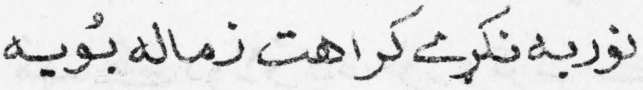

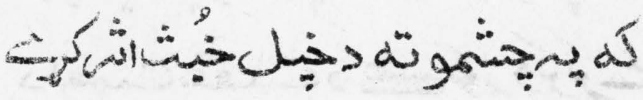

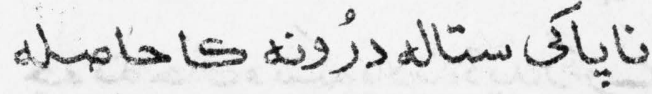

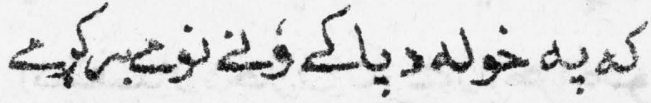




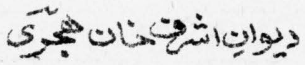

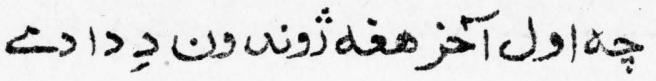

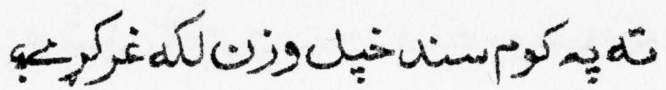

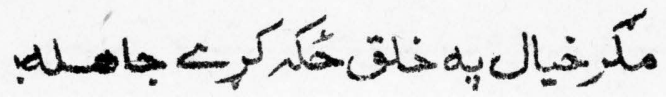

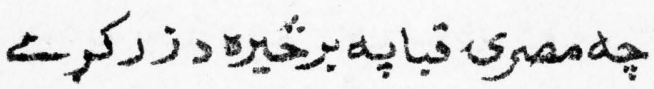

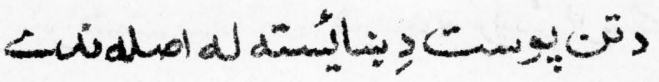

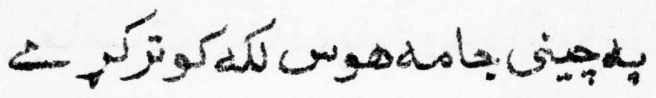

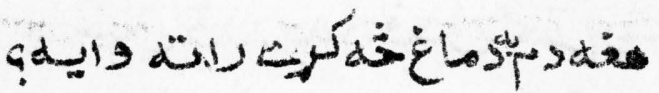

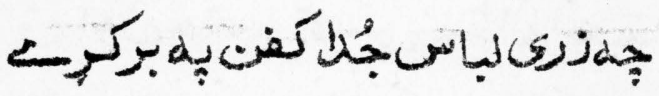

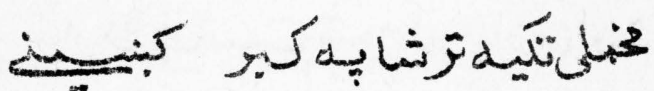

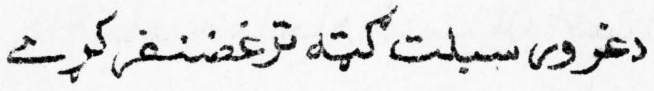

مأبه

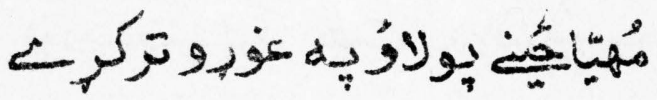

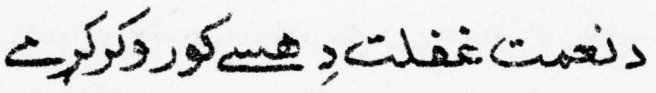

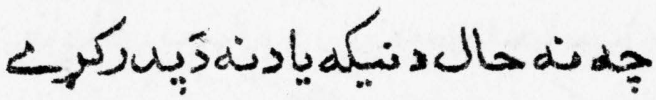

|

rin 


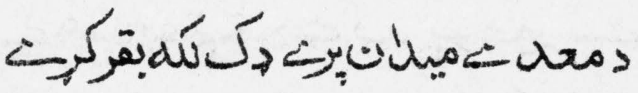

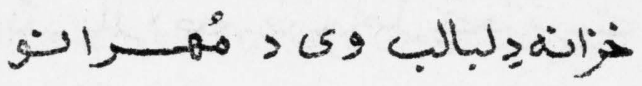

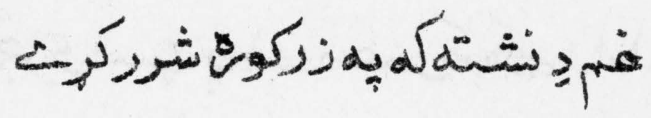

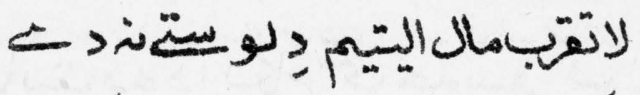

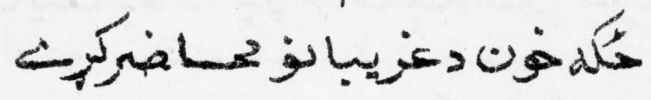

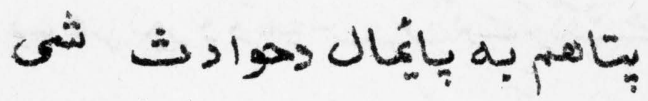

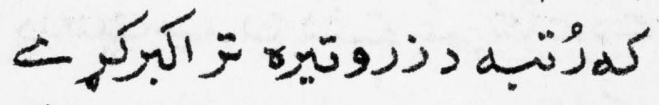

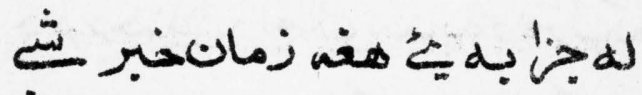

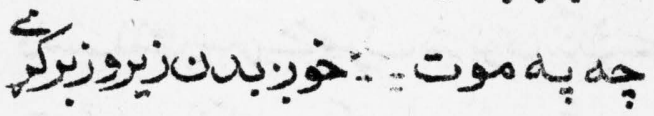

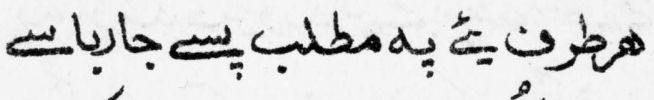

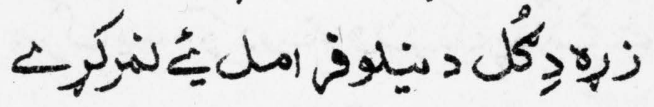

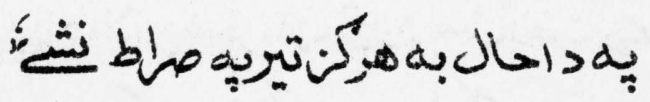

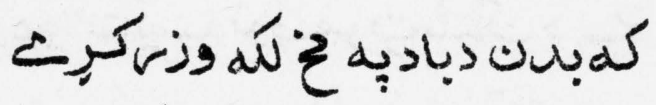

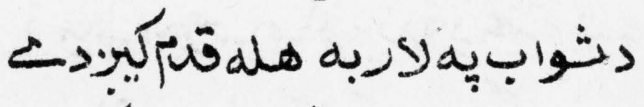

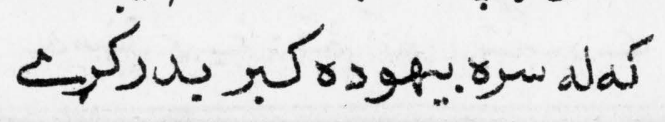




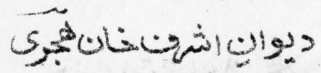

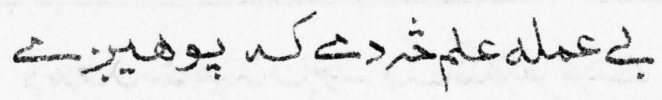

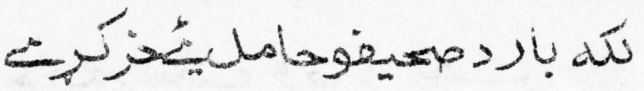

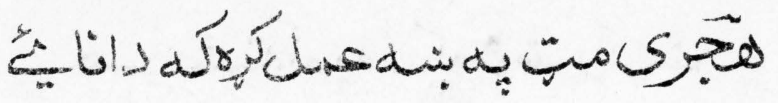

ن

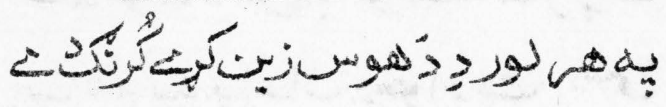

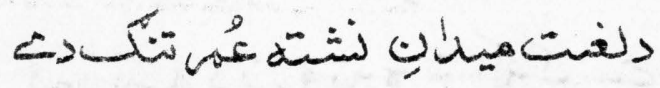

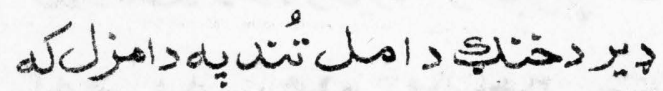

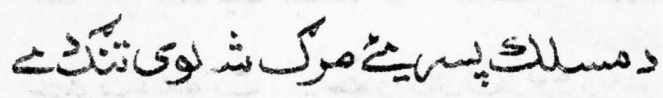

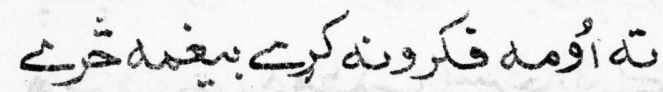

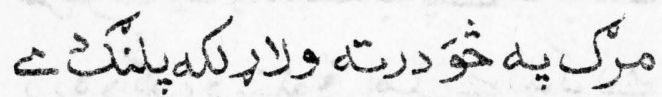

يه الأربه

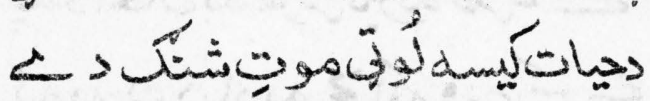

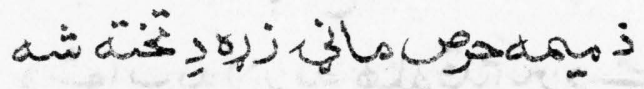

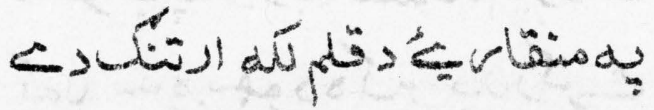




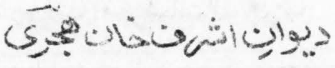

r) 58 rod

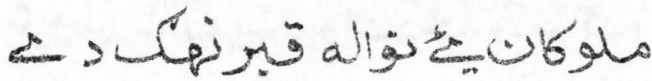

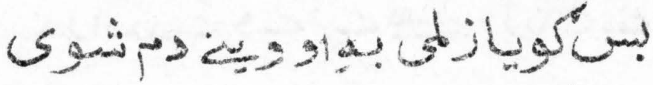

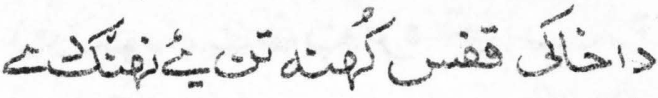

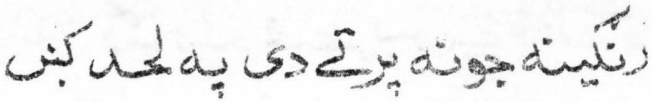

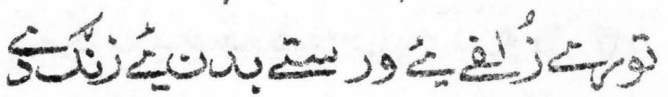

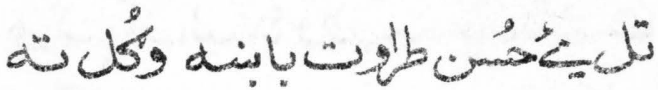

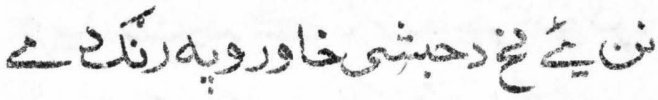

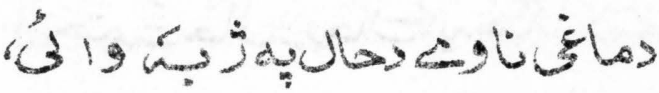

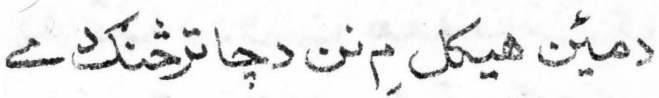

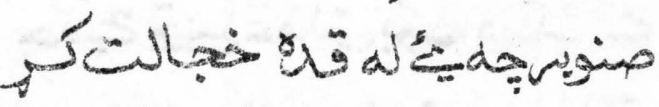

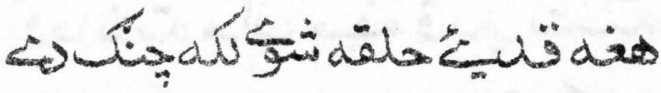

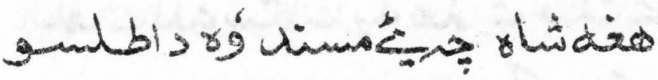
$\therefore$. orsaldiñ

$$
\text { FH }
$$




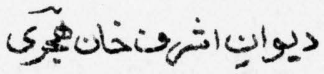

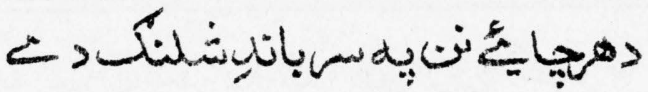

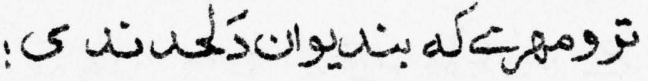

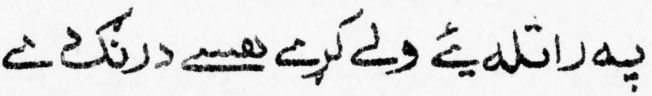

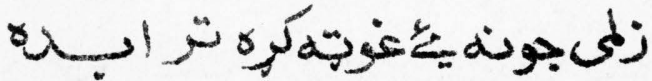

I.

bن

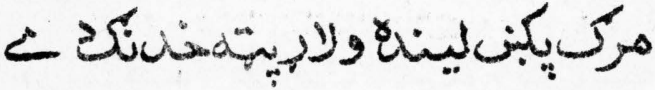

؛

Com

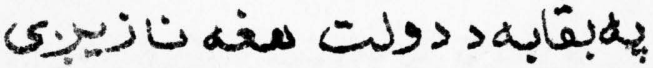

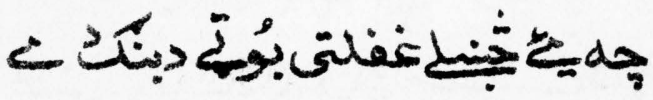

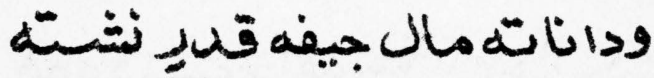

ع

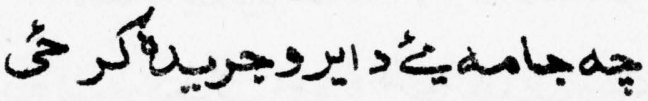

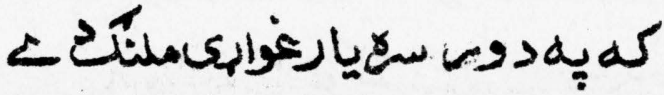




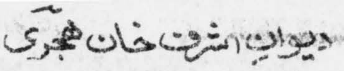

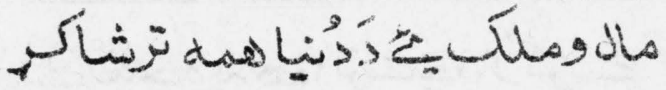

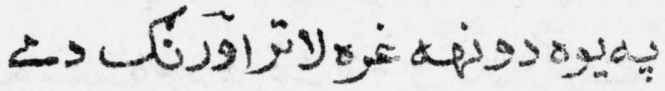

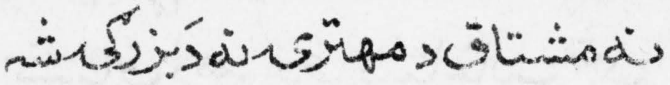

-

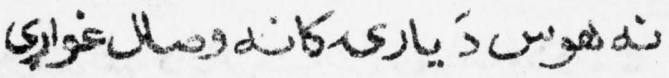

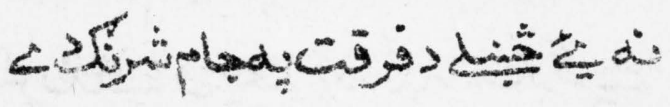

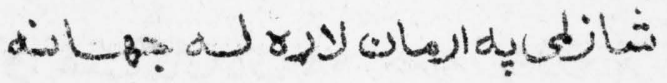

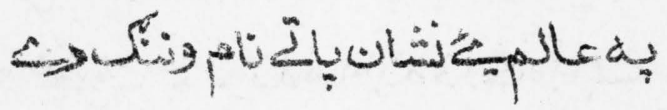

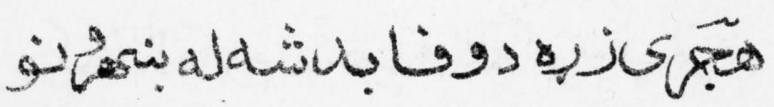

: 


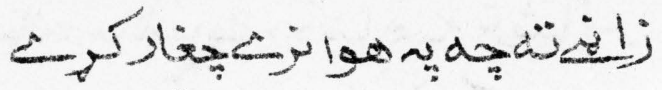

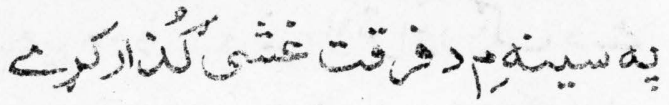

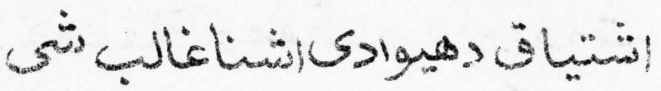

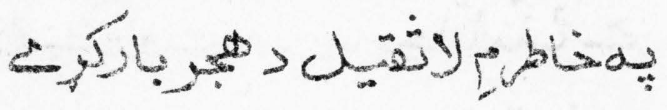

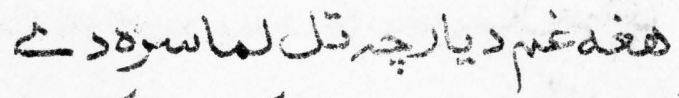

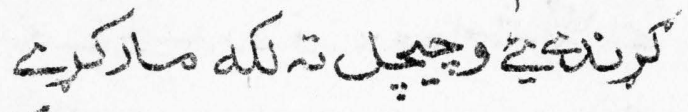

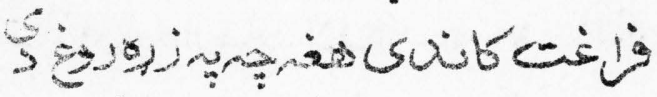

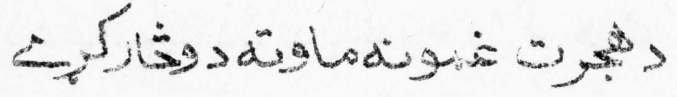

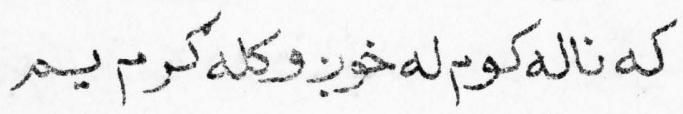

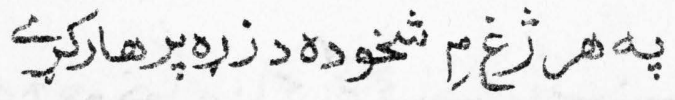

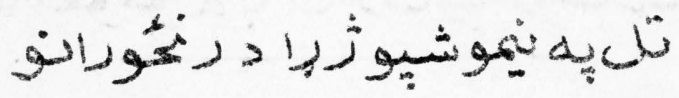

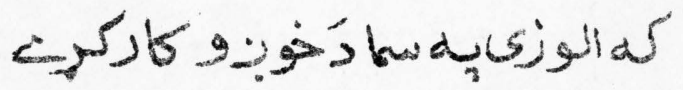

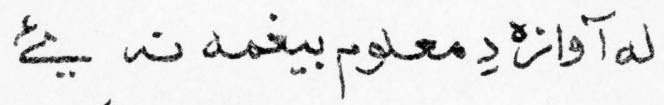
ك

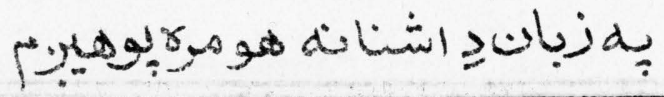




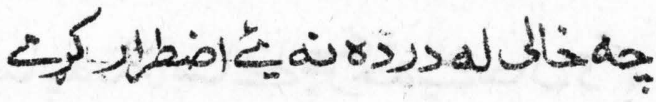
يأt

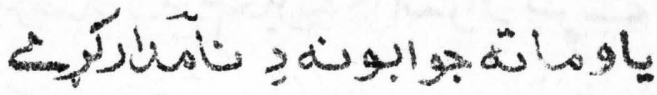
H 

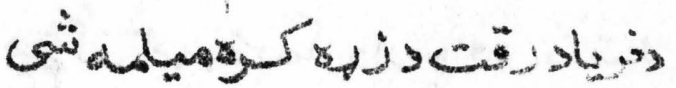

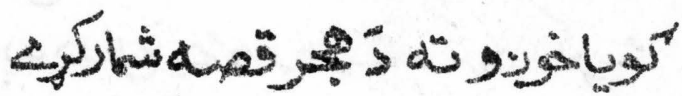

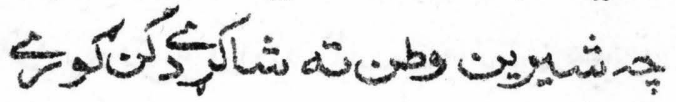

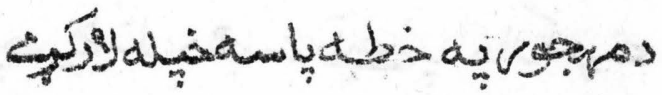

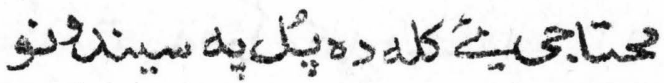

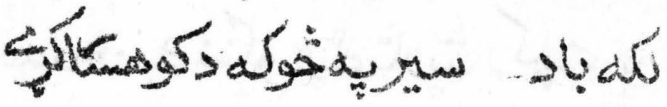

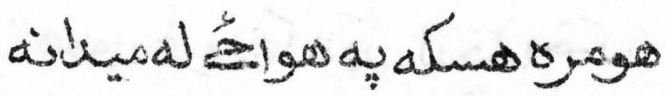

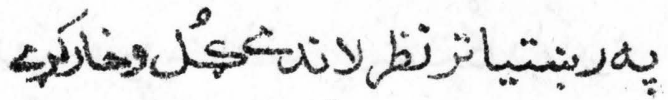

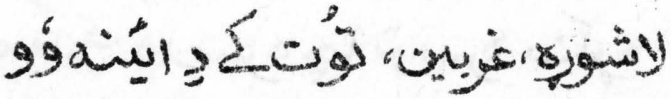

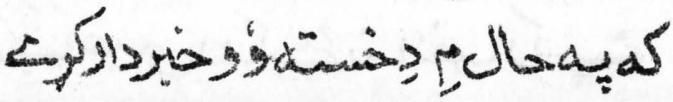




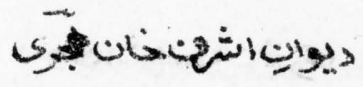

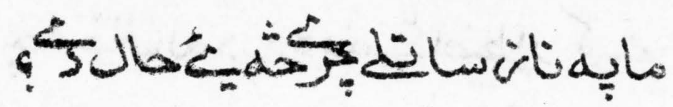

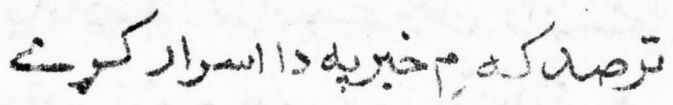

ar.

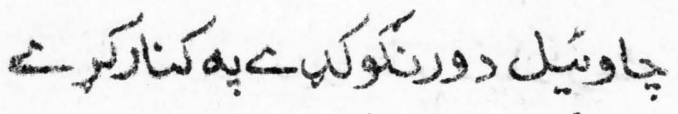

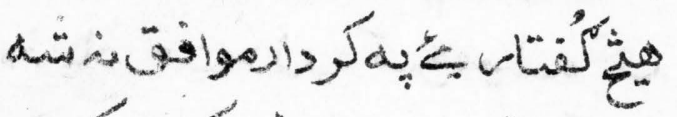

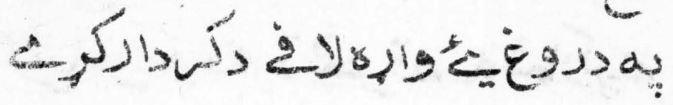

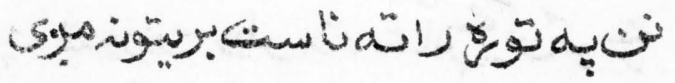

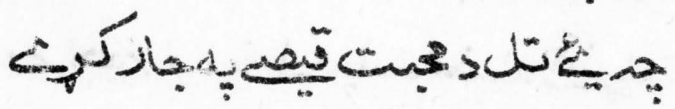

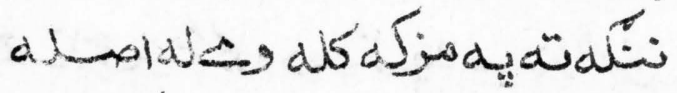

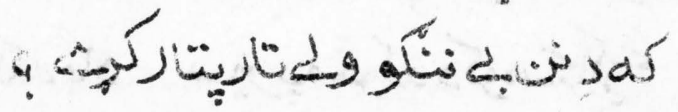

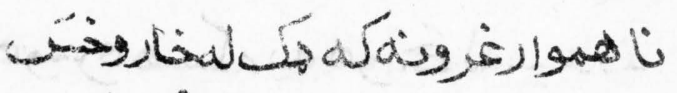

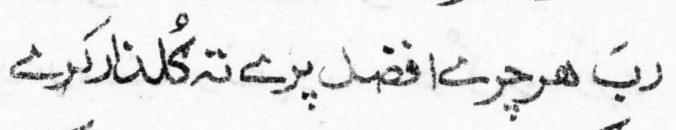

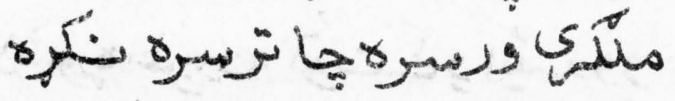

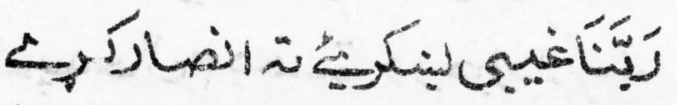

Fry 


$$
\begin{aligned}
& \text { مَّد }
\end{aligned}
$$

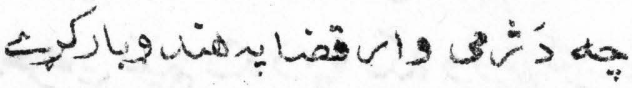

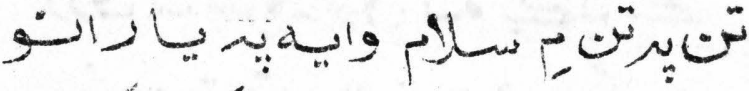

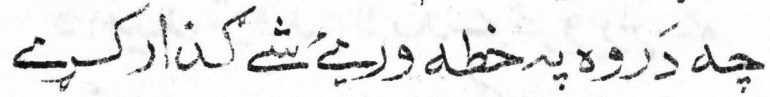

s

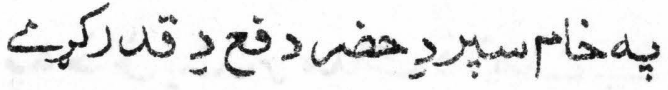

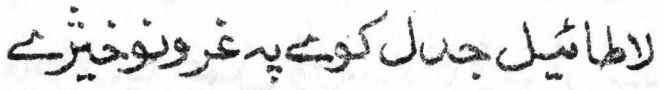

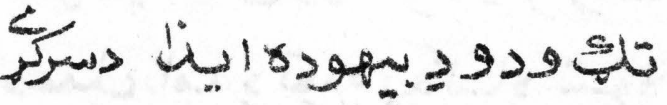

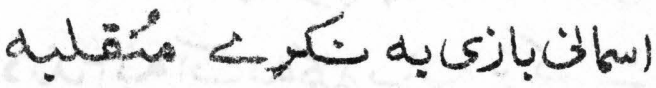

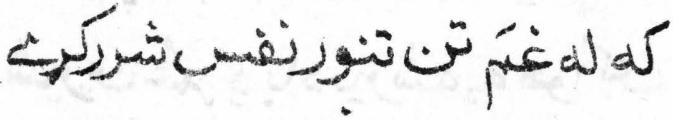
نَّل Sر

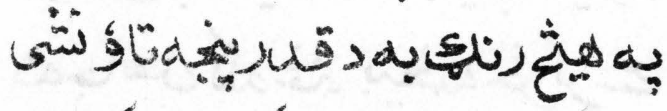

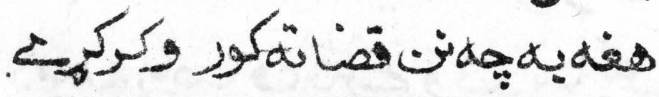




\section{s.}

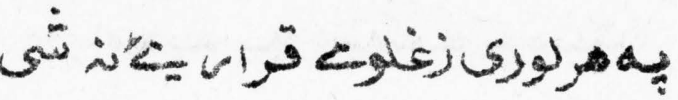

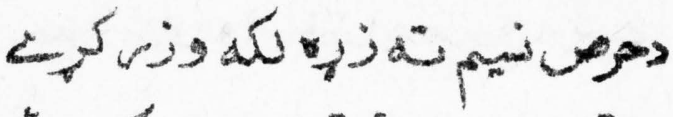

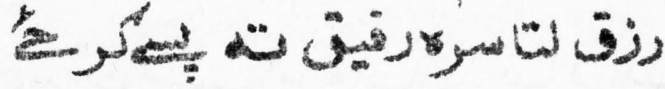

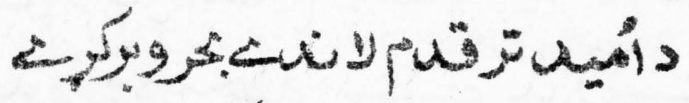

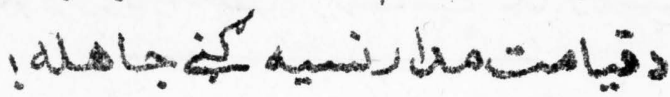

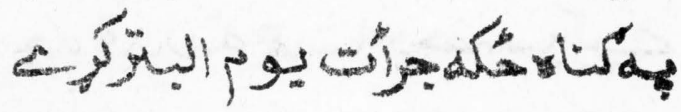

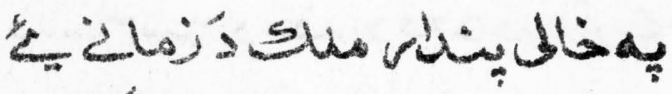

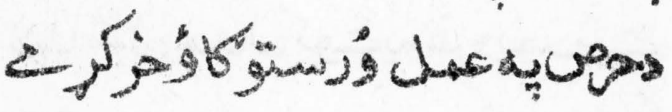

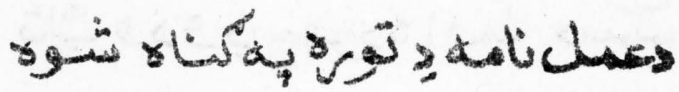


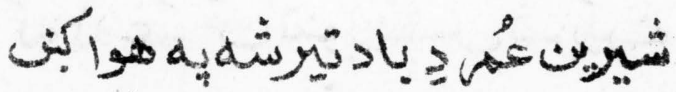

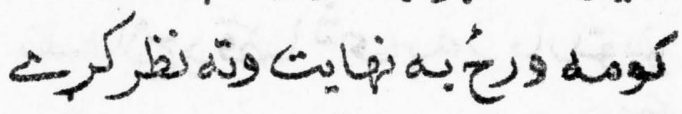

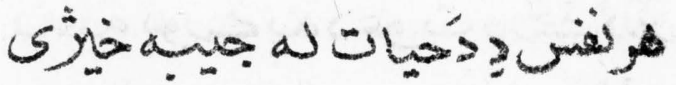

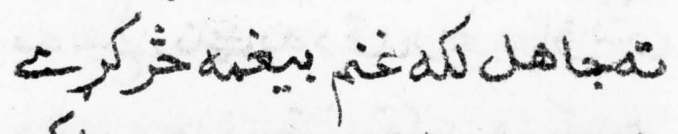

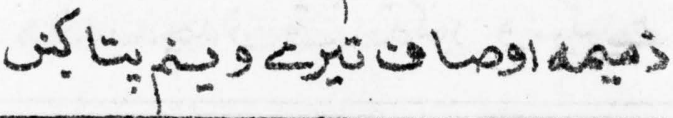




\section{5.}

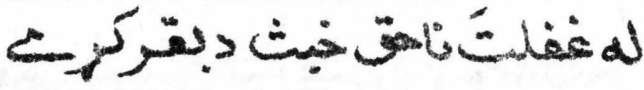

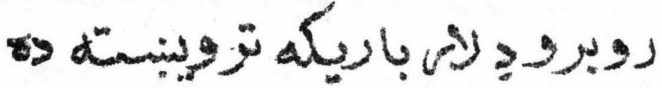

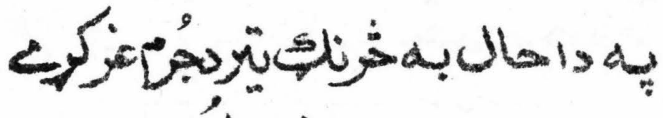

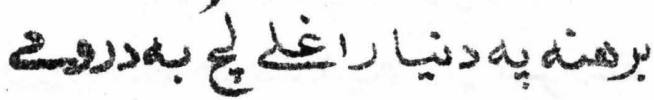

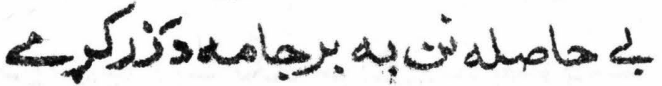

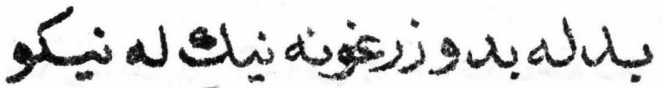

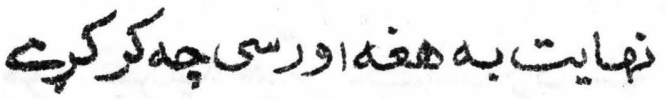

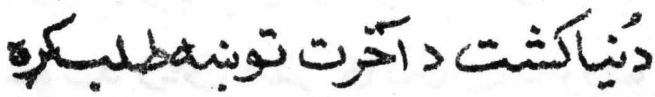

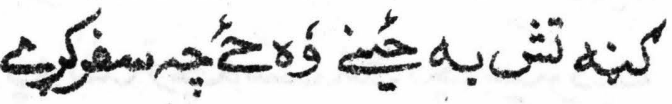

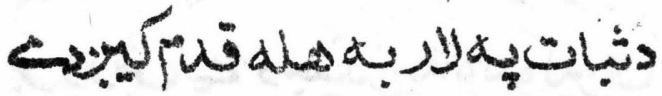

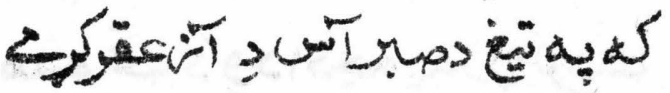

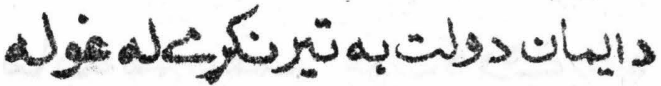

مكرسموريس

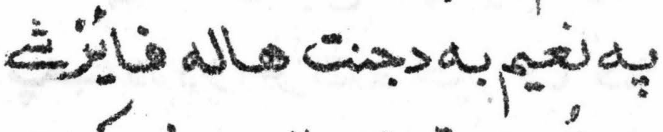

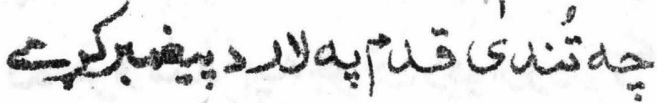




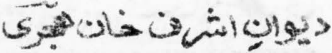

- J divin

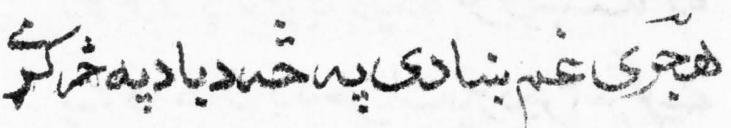
$\Leftrightarrow$

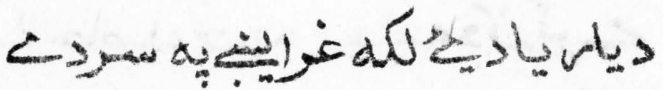
سكا

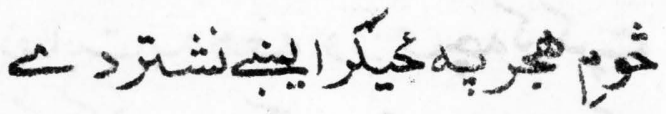

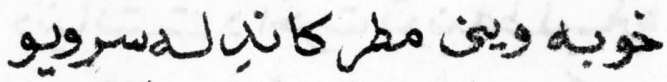
$\Leftrightarrow$

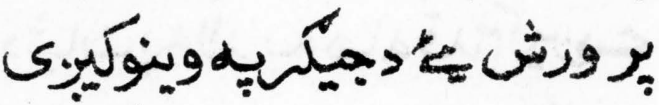

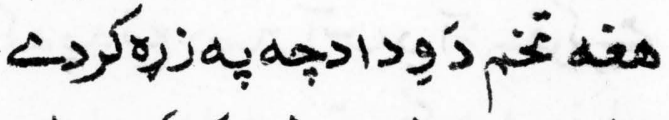

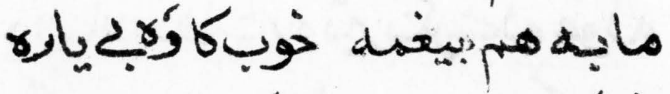

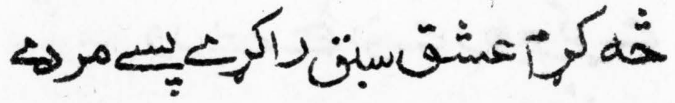

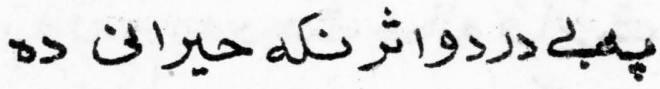
لهزروشهميه بوش ديوارودرك 


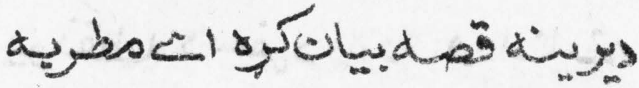

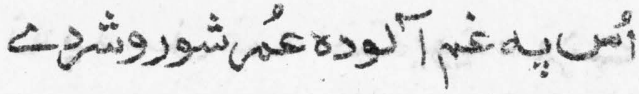

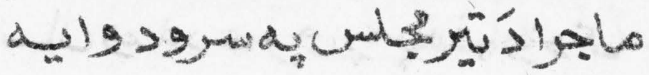

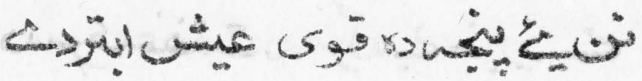
r)

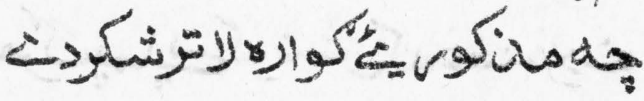

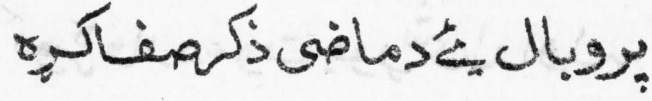

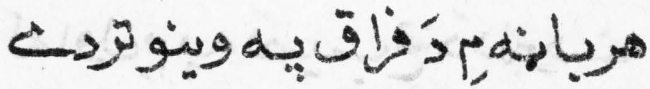

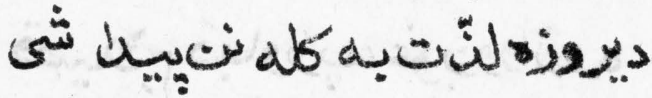

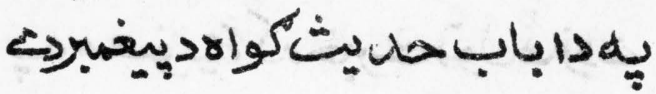

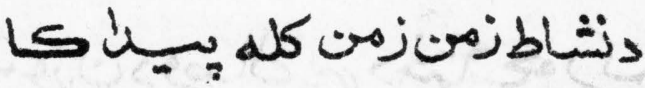

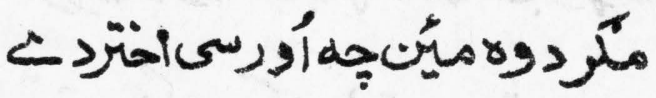

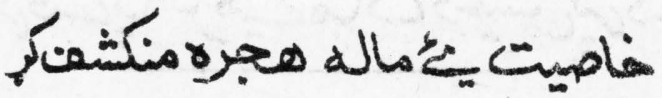

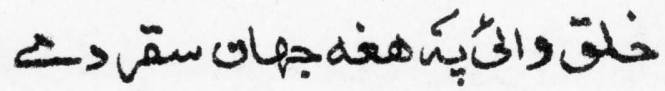




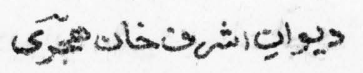

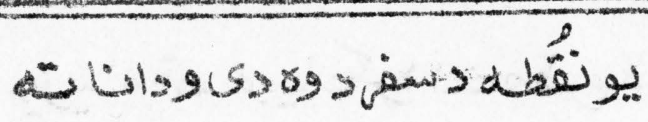

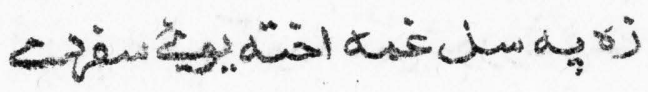

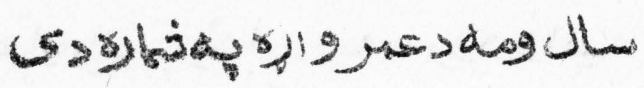

< 2 خ

L

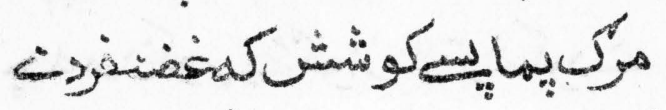

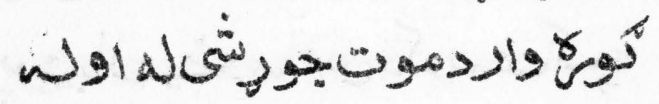

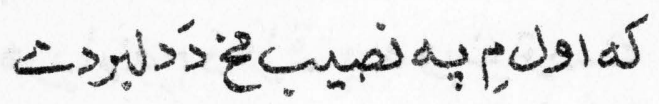

كوانو

criolu

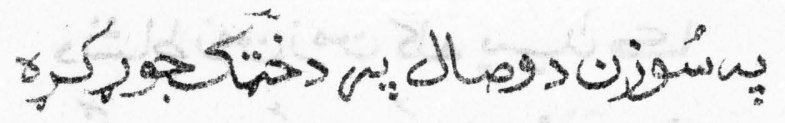

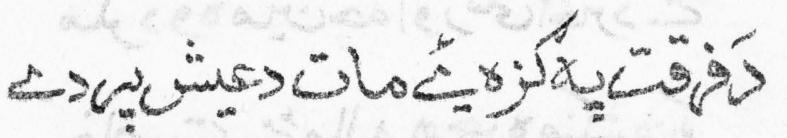




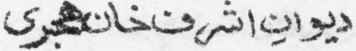

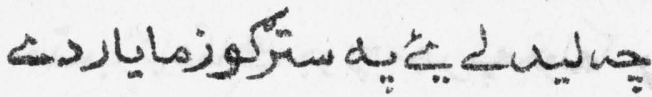

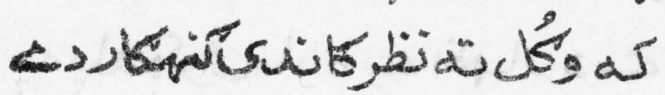

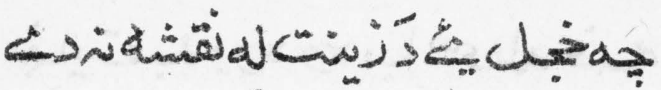

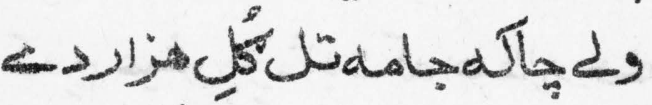

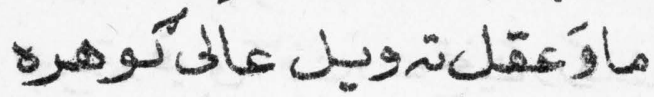

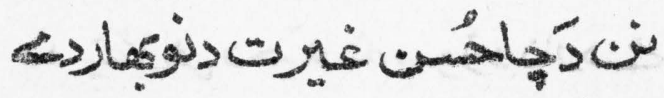

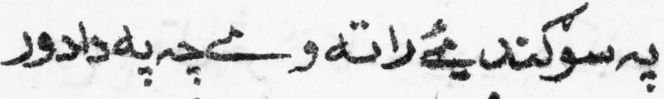

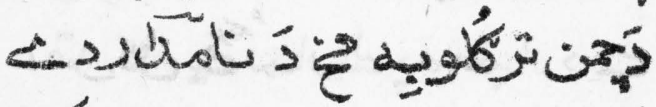

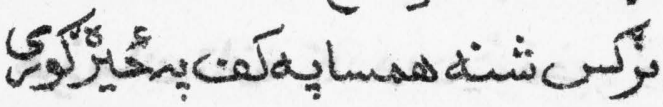

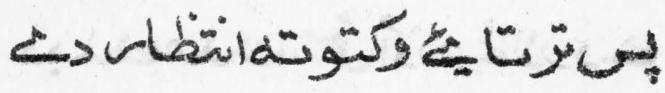

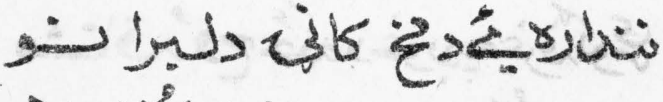

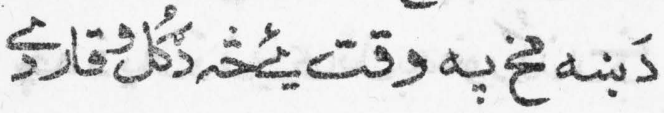
d is is

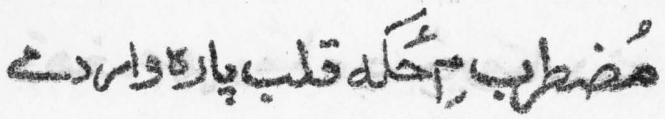




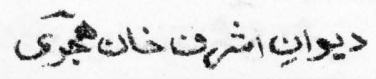

مaloه

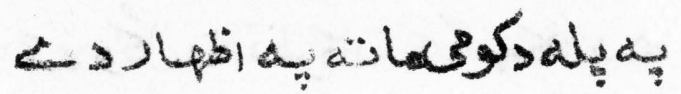

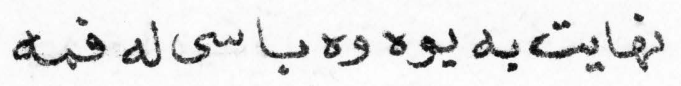

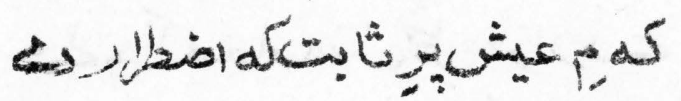
نو $\stackrel{2}{2}$

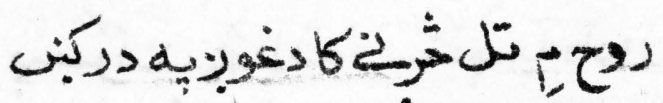

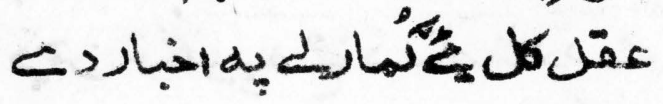

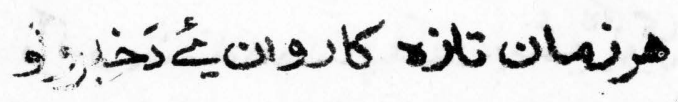

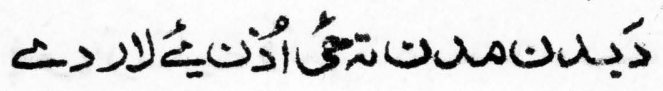

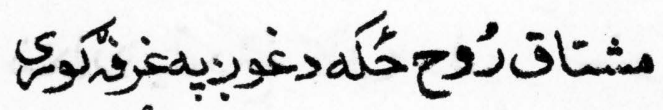

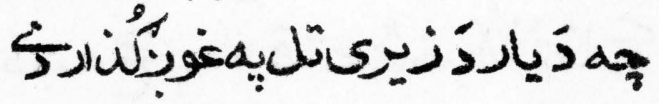

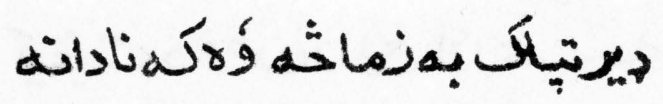
'sخ 


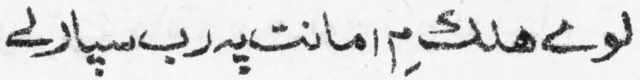

Fustives sllis som

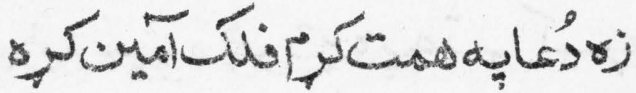

تكّة

ه

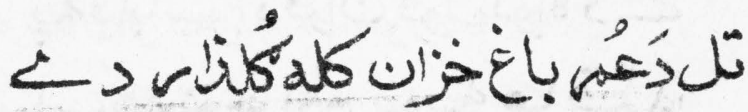

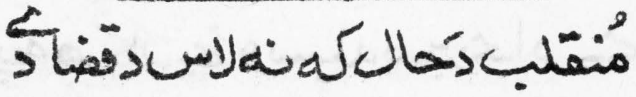

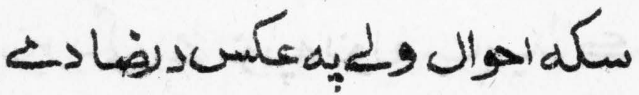

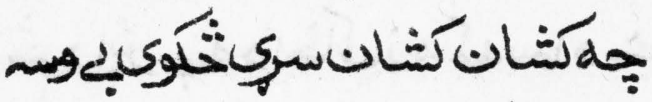

دابهو

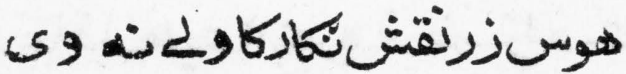

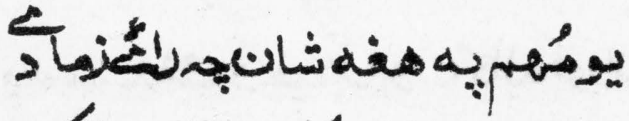

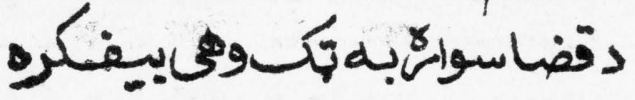

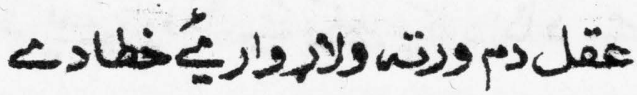




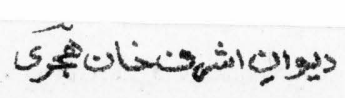

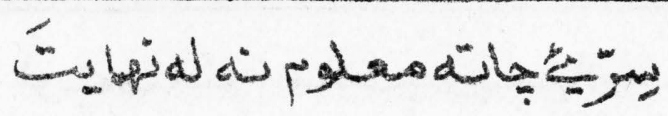

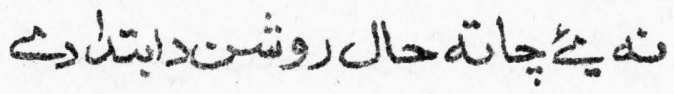

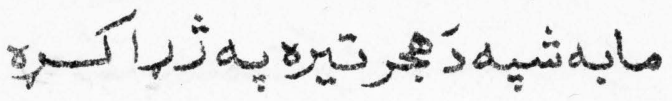

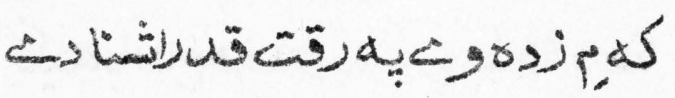

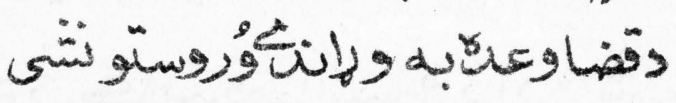

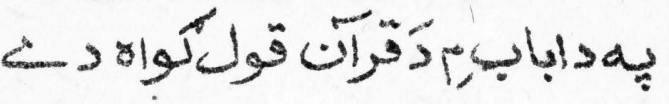

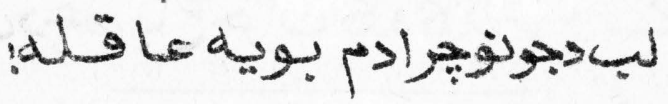

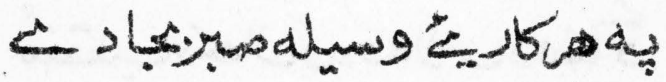

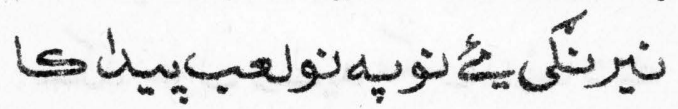

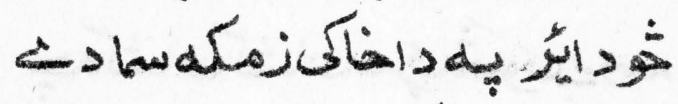
(ابلهان

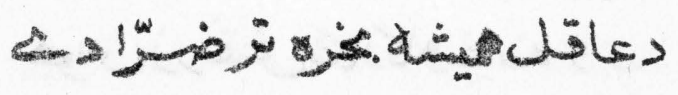

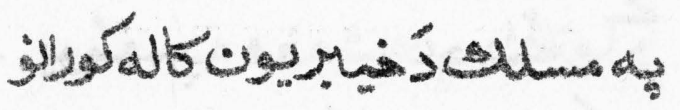

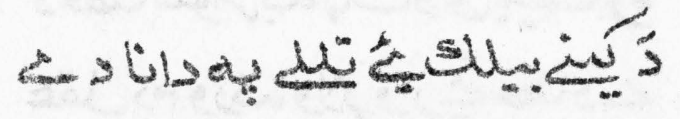

Prom 


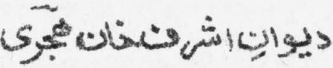

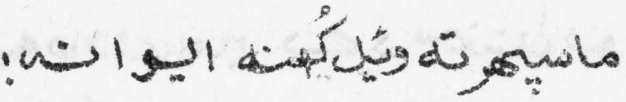

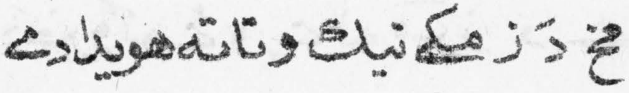

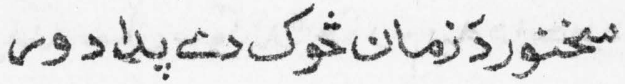

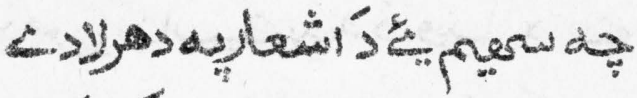

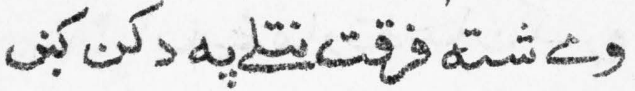

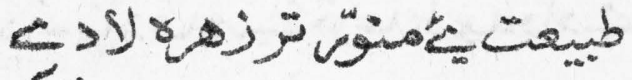
5و

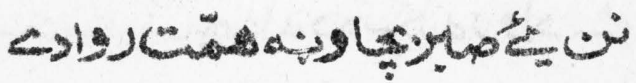

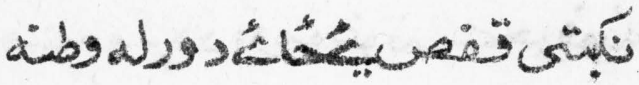

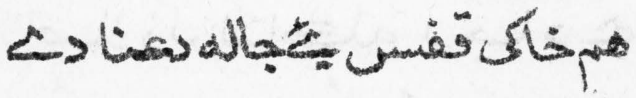

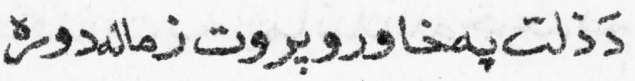
$\therefore$ L lo

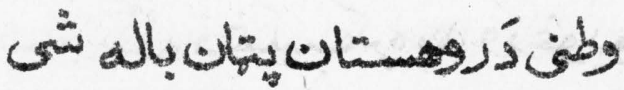

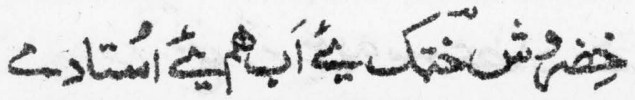




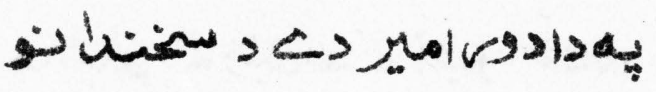
L

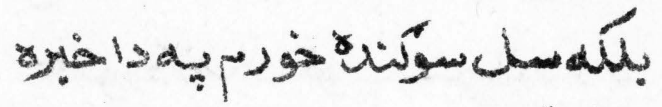

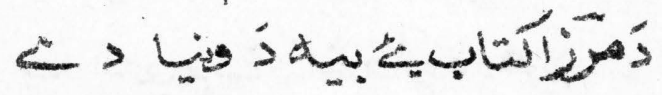

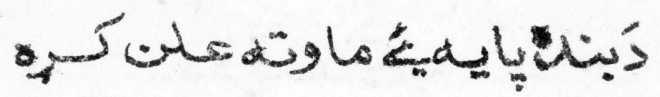

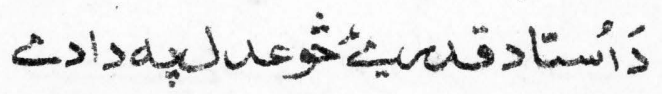

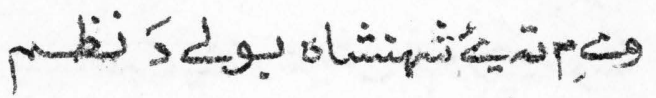

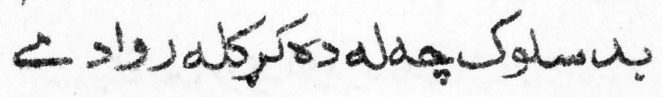

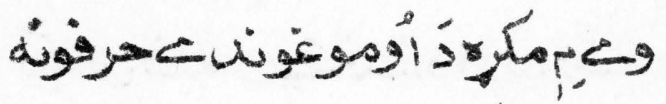

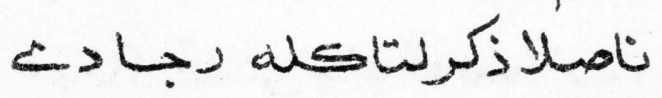

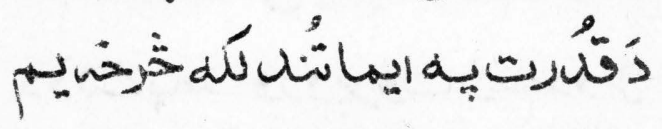

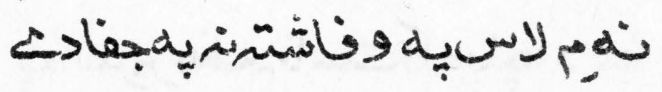

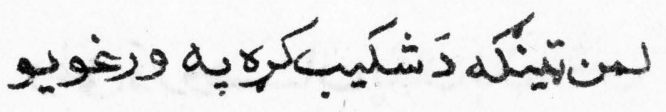

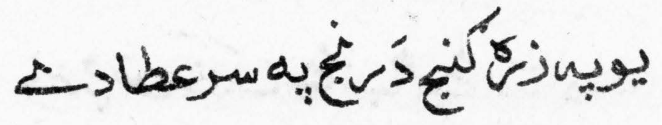




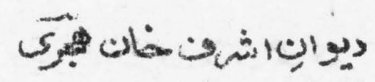

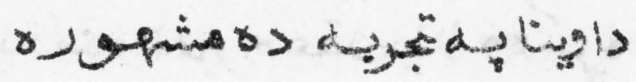

Stopakles Ulajejoide

a.jo nJo:

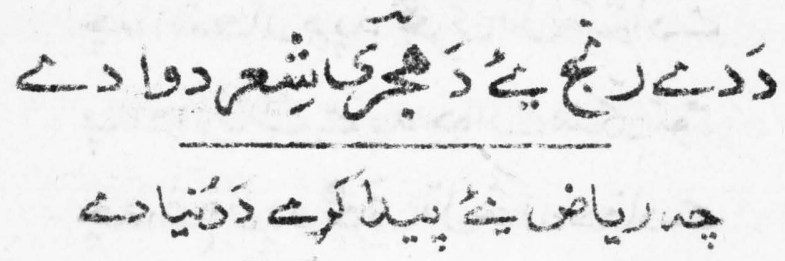

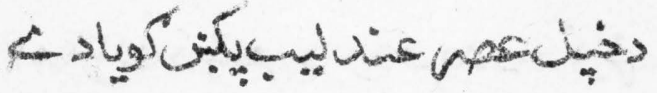

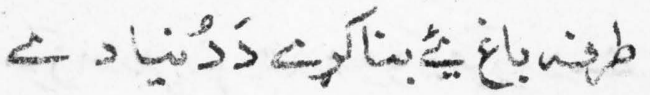

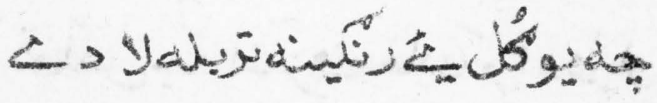

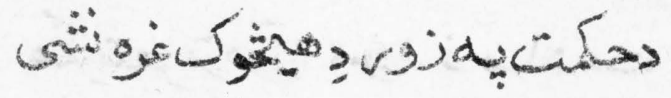

$[$ IL

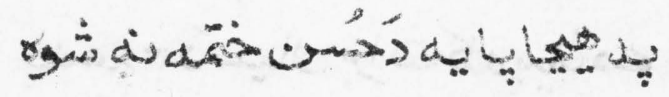

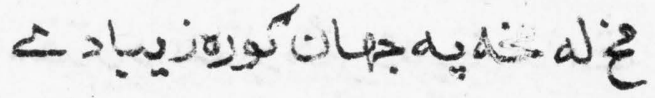

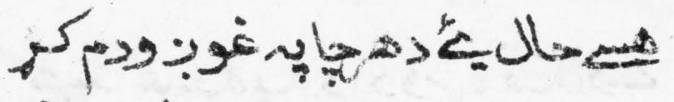

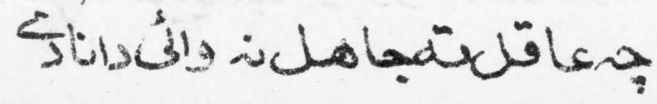

rra 
به

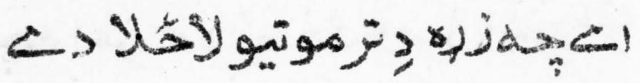

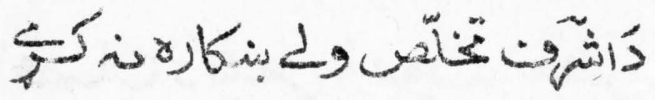

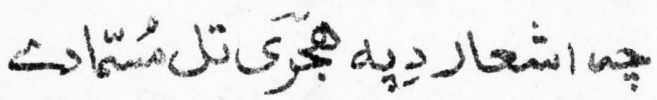
به $C l 0$ ab

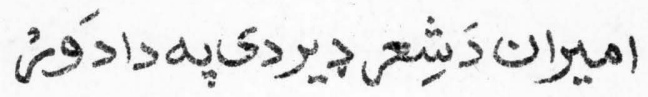

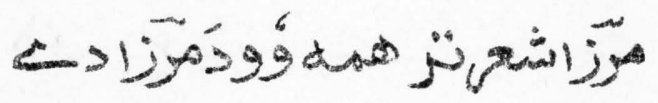

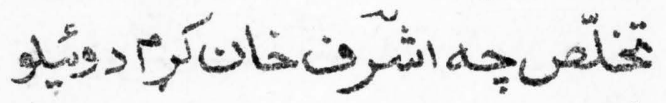

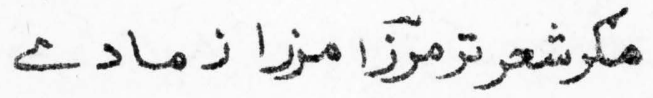
وبع

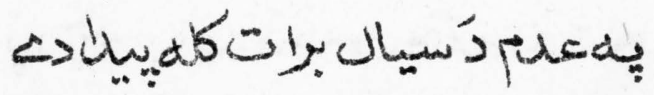

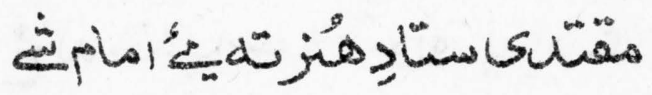

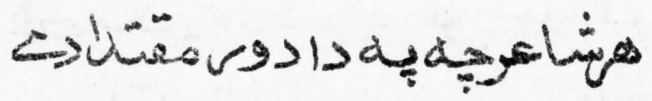




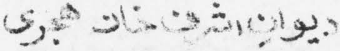

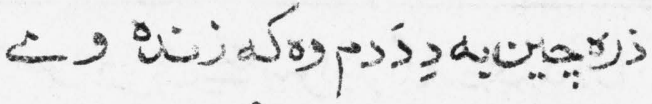

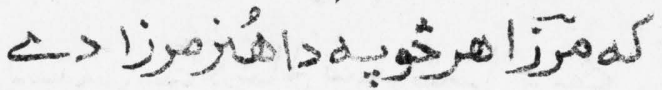

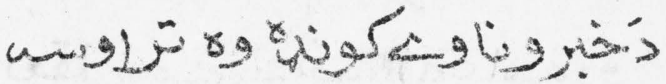

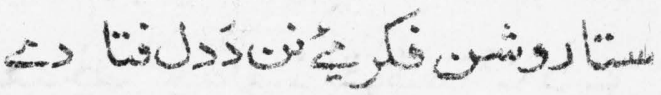

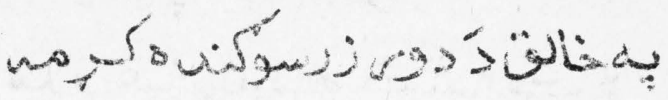

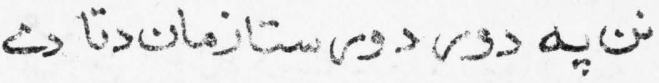

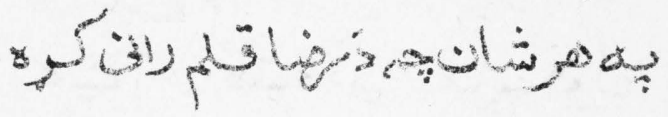

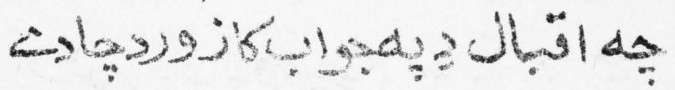

$<\therefore i n=3050$

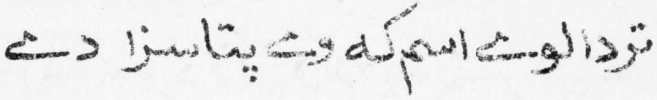

Lujs 999 grandisto

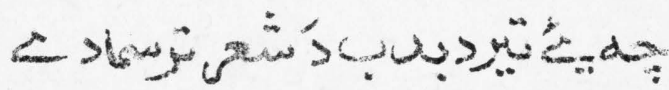

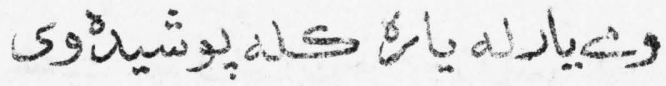

$\Leftrightarrow \rightarrow 45$ a 


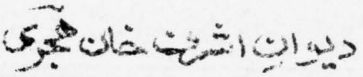

خاص

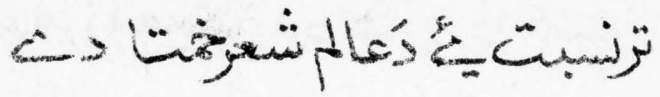

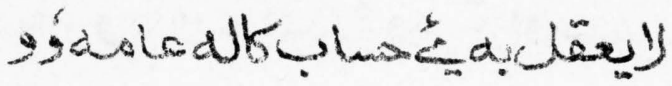

$\Delta$ A

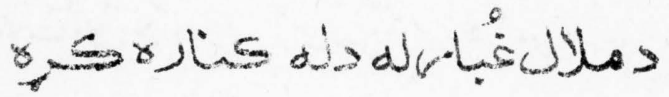

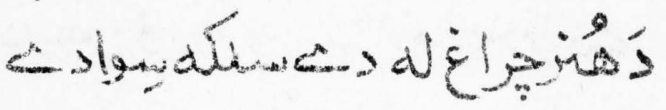

gو

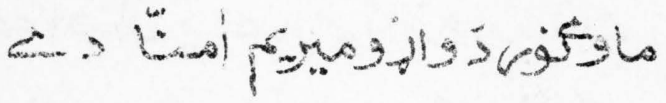

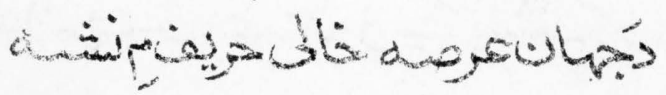

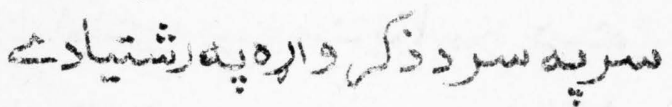

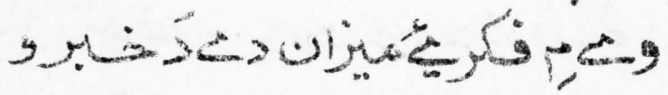

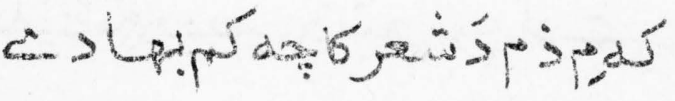

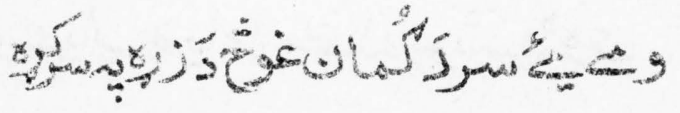

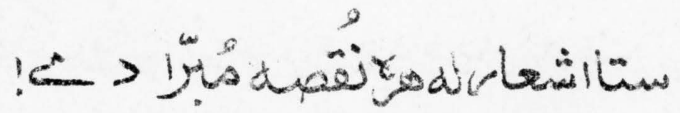

ris 


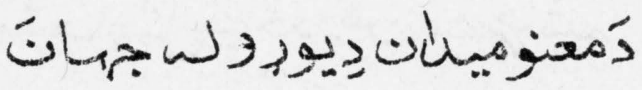

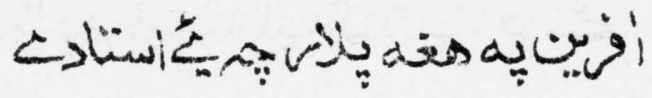

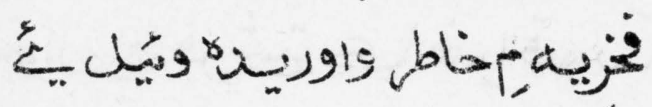
خو

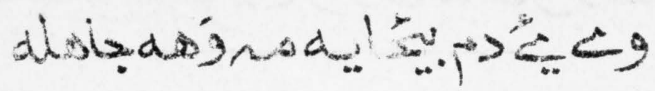

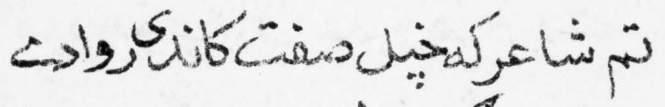
ن $\Leftrightarrow$ يهان خ地 له

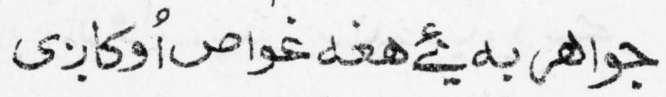

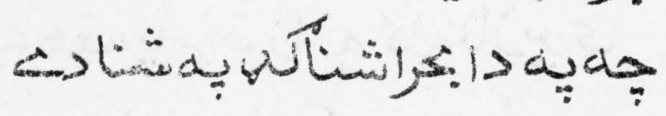

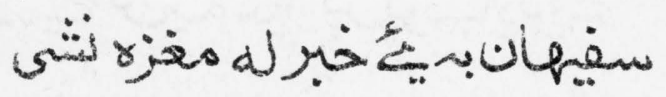

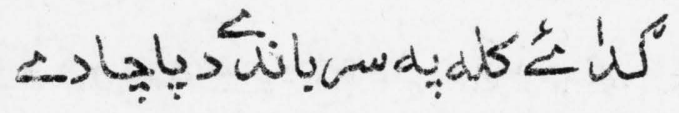




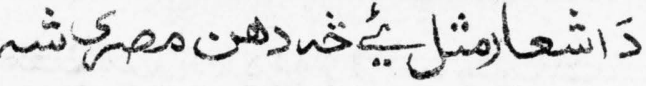

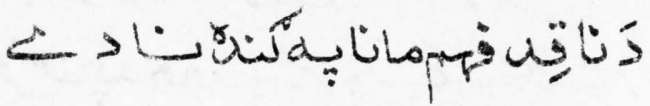

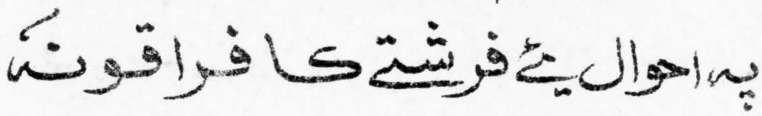

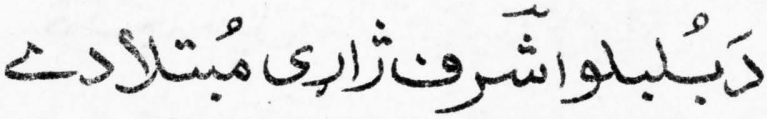

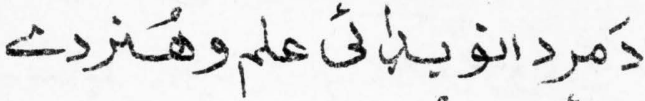

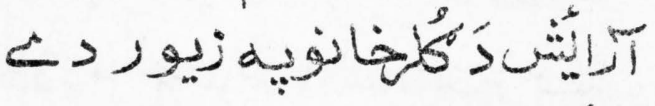

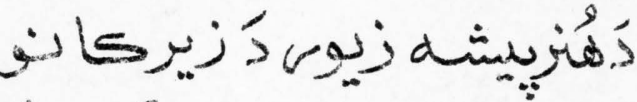
S

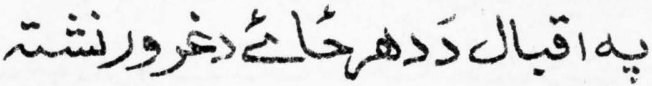

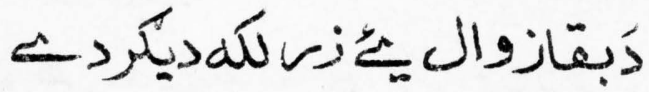

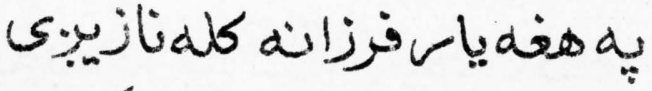
:

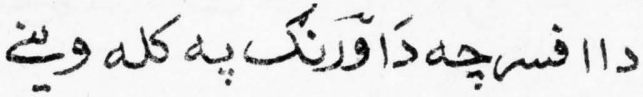

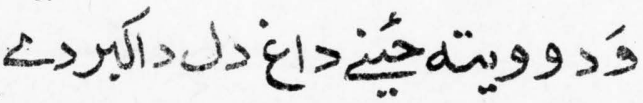




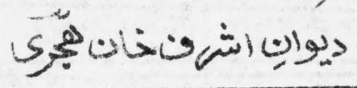

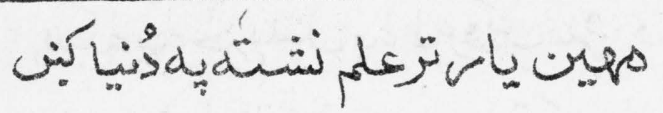

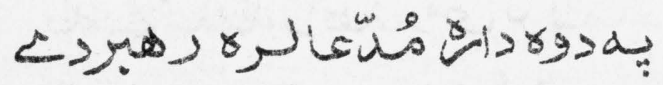

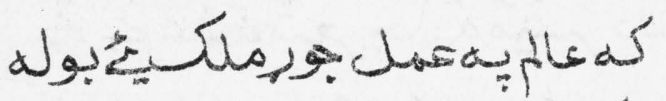

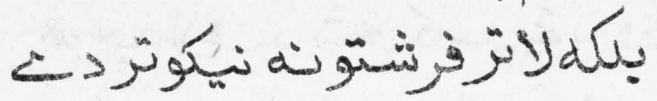

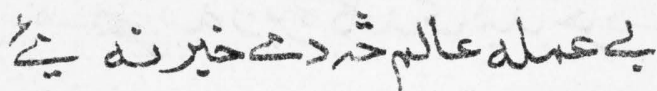

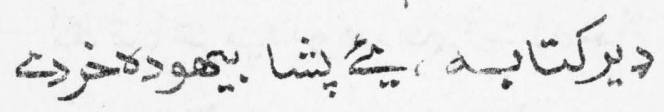

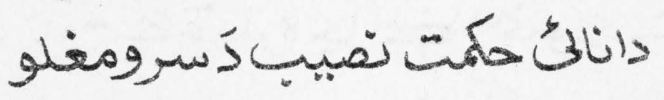

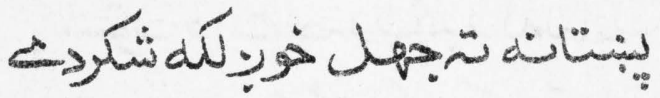

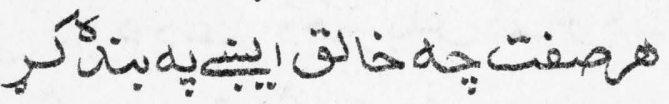

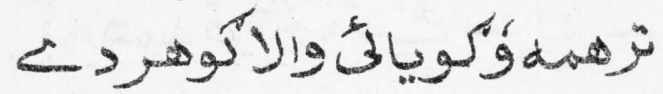

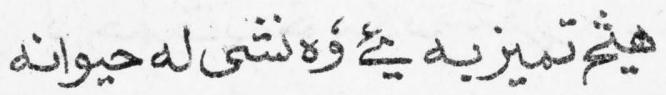

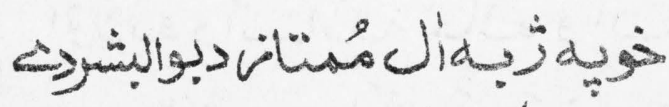

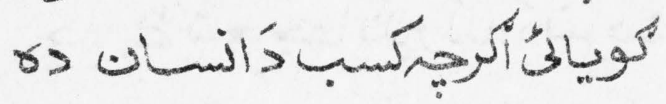
$\Leftrightarrow$ و

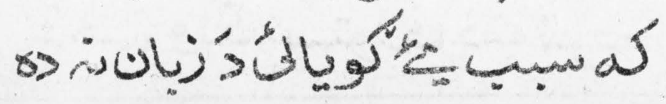




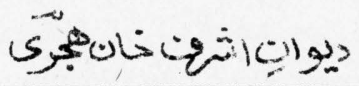

$\Leftrightarrow$ نس

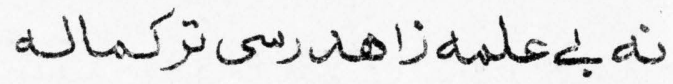

$\Leftrightarrow$ viñoula

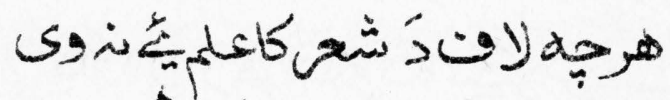

$\Leftrightarrow$

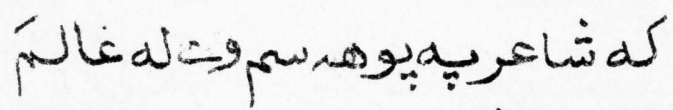

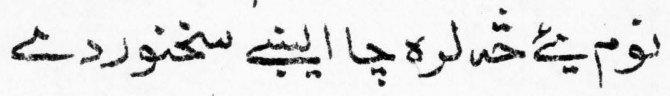

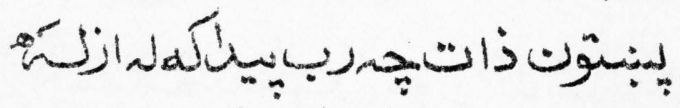

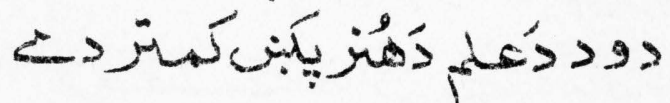

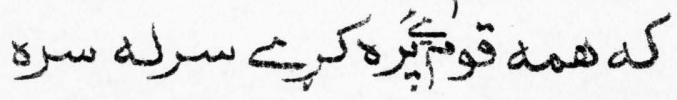

$\Leftrightarrow 200$ do

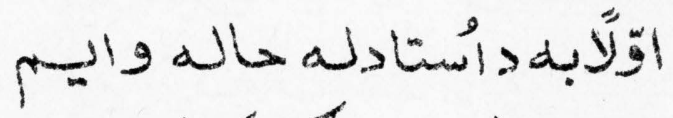

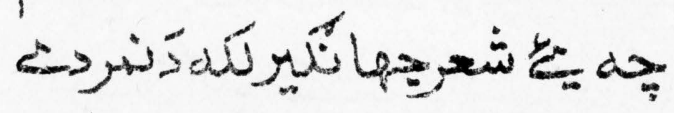

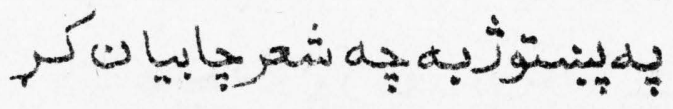

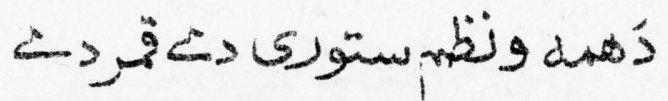




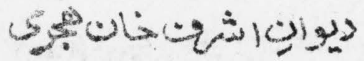

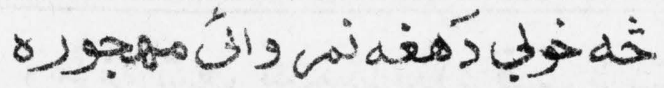

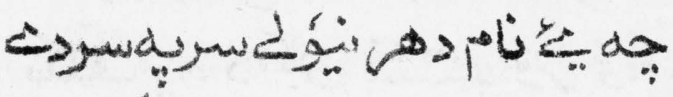

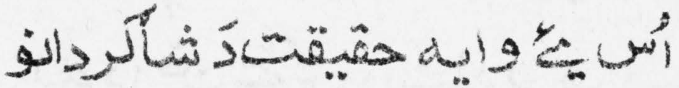

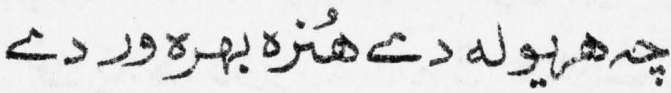

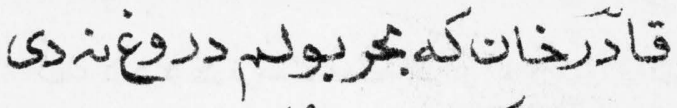

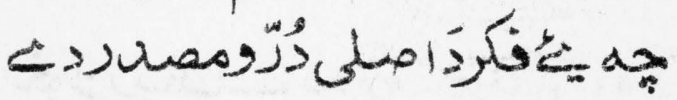

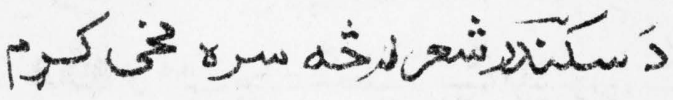

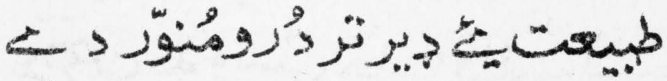

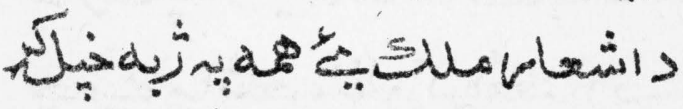
$\Rightarrow$ به نامن $\Leftrightarrow$ ڤ 6وان C2

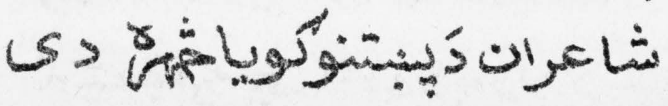


15.

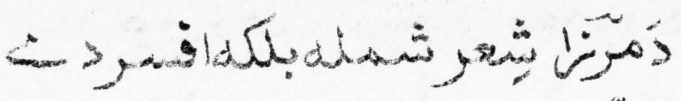

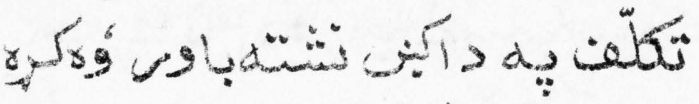

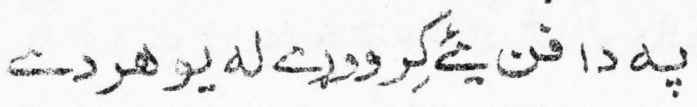

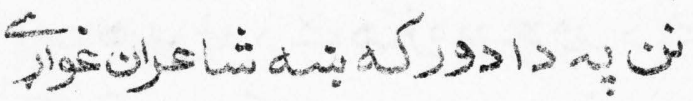

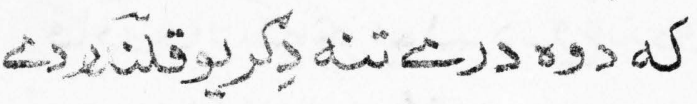
is

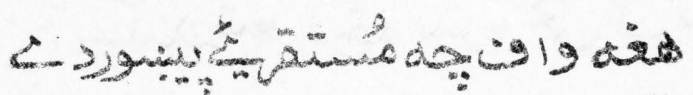

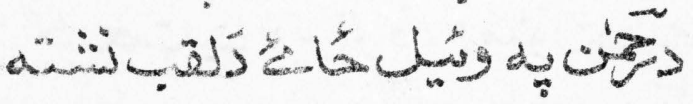

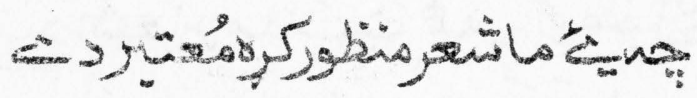

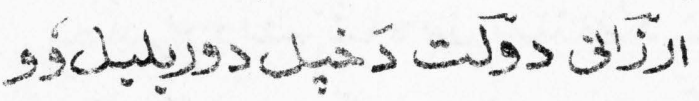
20 فر

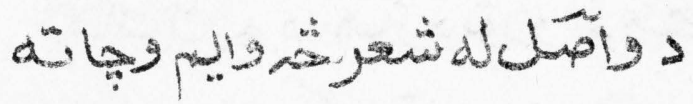

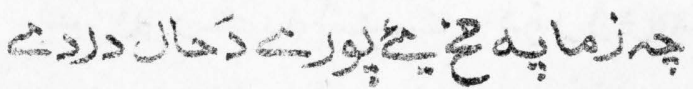
discosing

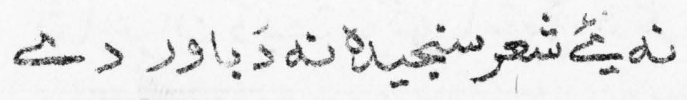


تمل

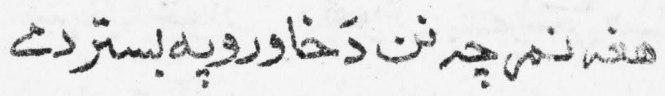

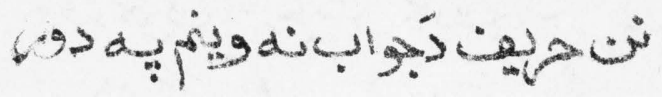

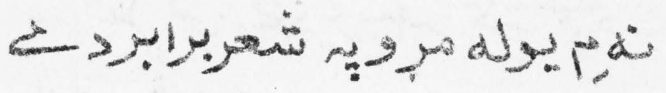

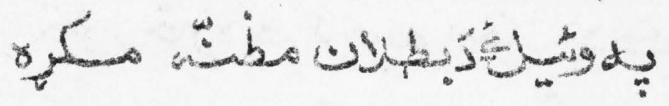

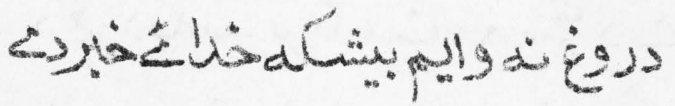

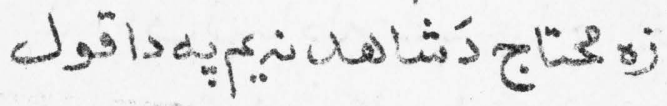
L

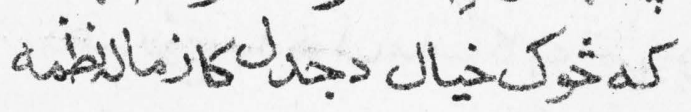

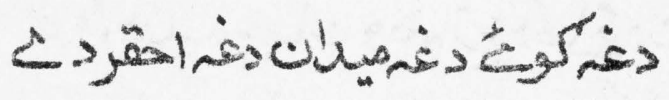

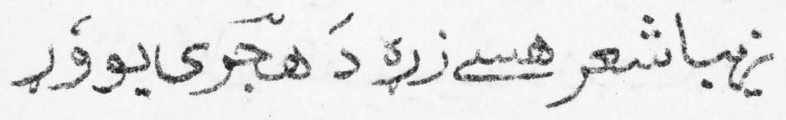

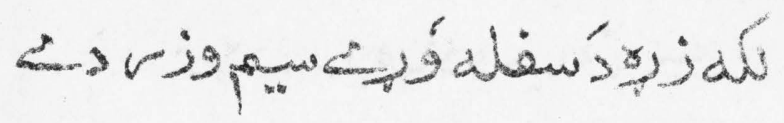




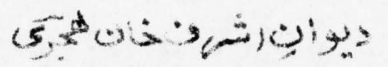

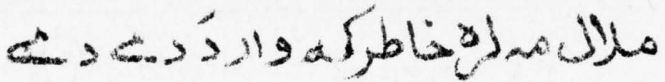

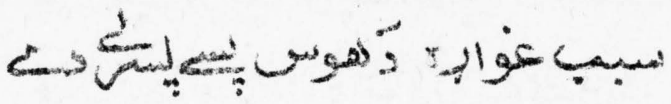

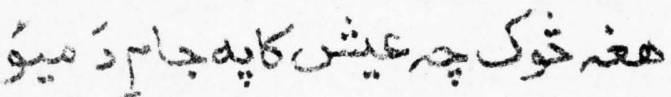

$\Delta$

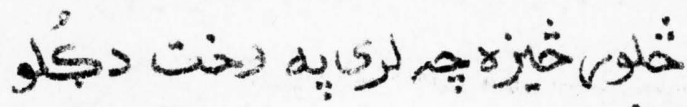

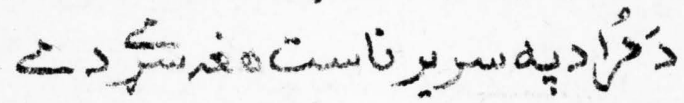

To

ar

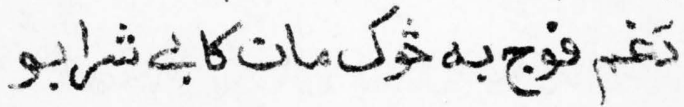

c.

ث

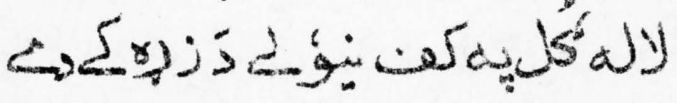

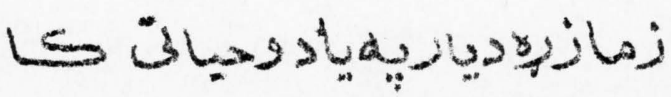

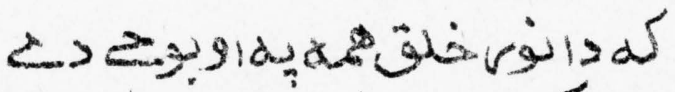

in

pa. 


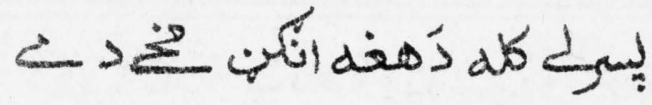

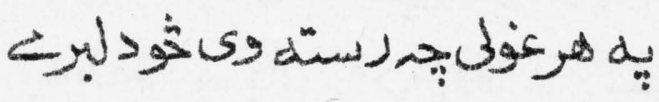

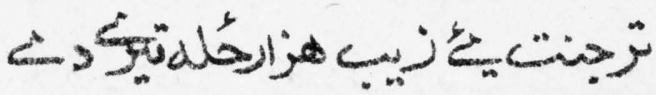
كيه

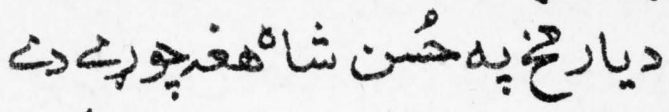

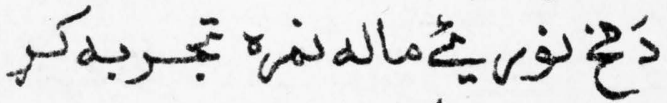

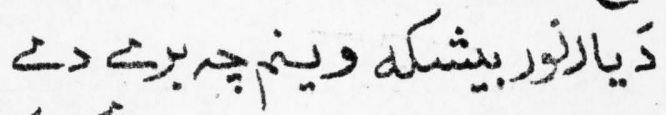

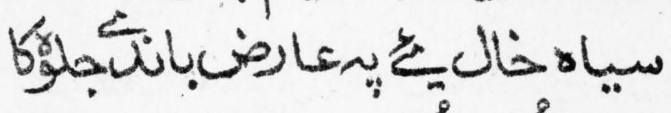

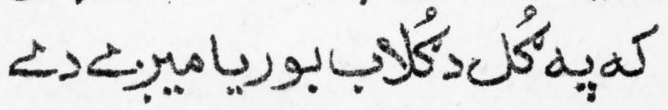

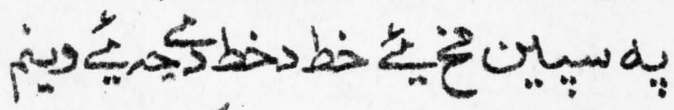

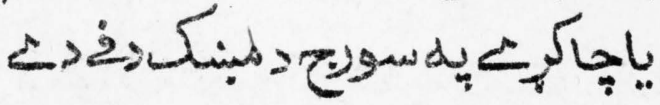

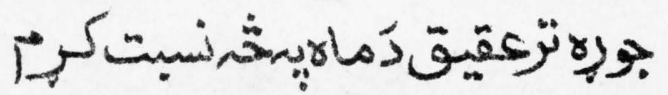

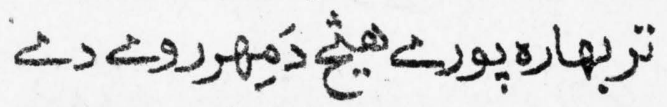

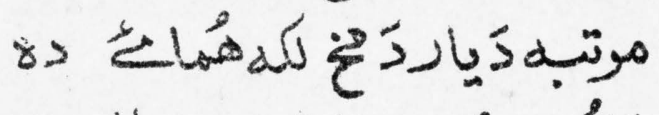

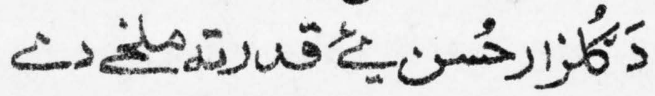




\section{ك)}

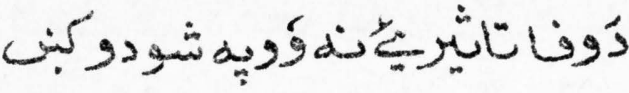

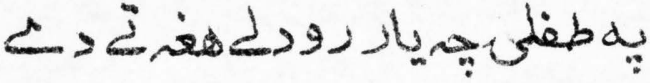

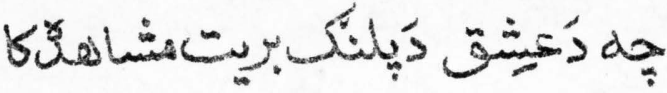

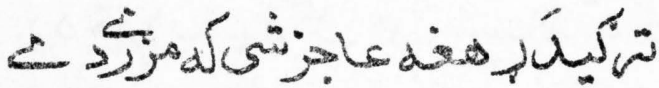

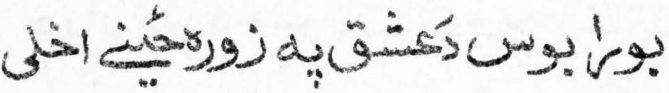

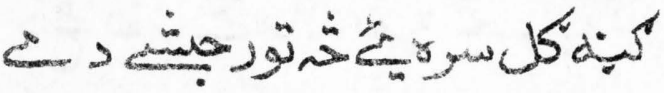

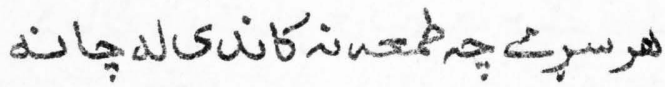

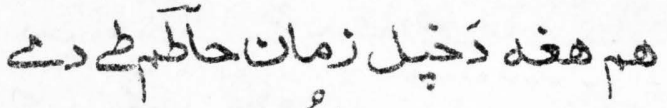

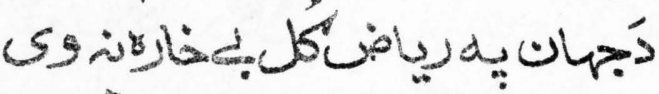

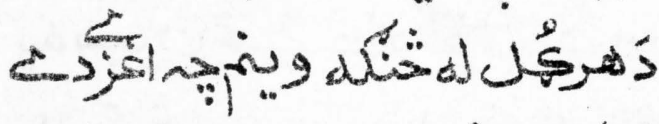

ذَّاو

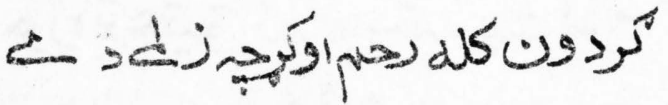

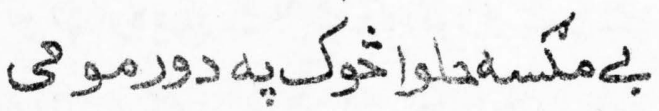

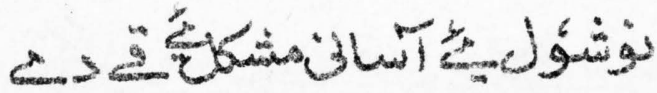


ه

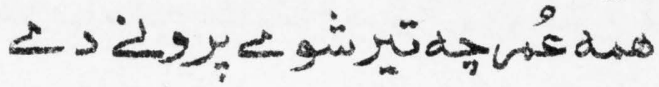

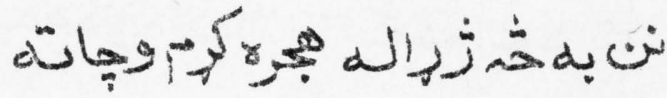

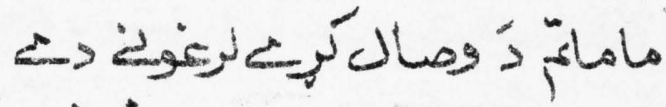

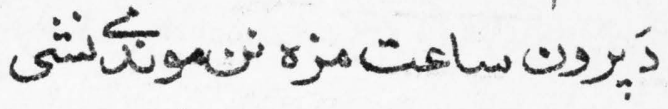

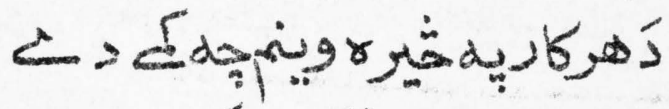

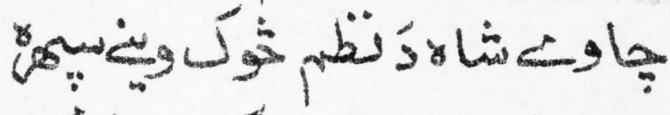

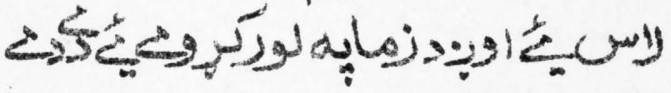

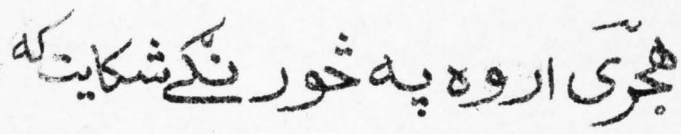

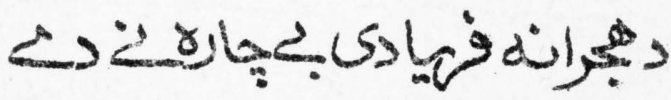


rar 


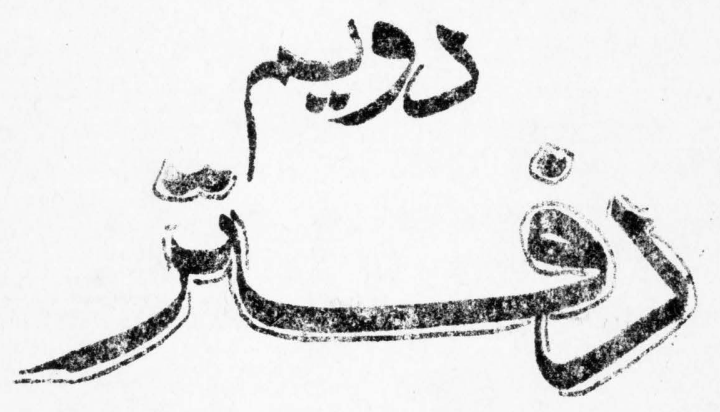

ros 
(

$12 k$ 
bL ن

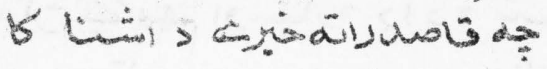
P91 949 a

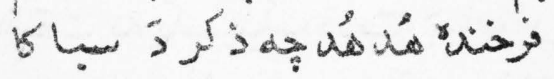

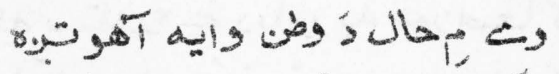

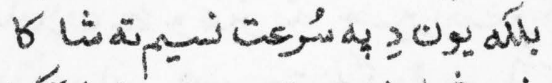
كrij; $\rightarrow$ o b إنه

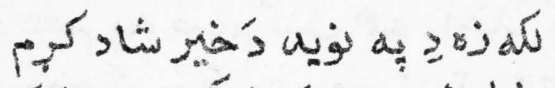

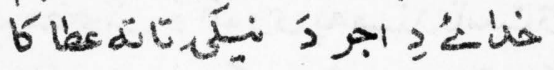

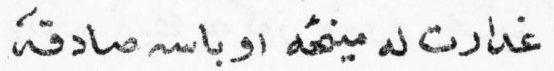
b

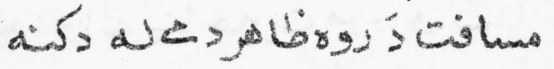

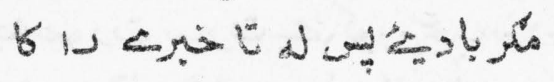
and 202190 .

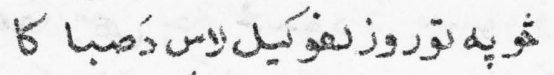

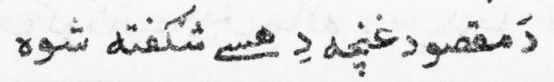




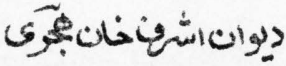

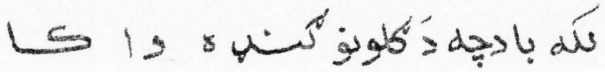

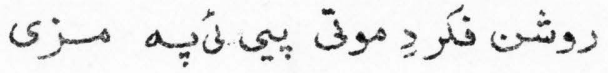

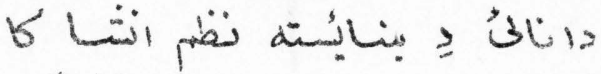
كم 6 las" d كأ إن

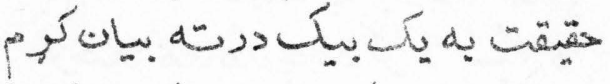

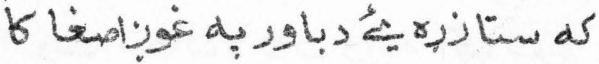

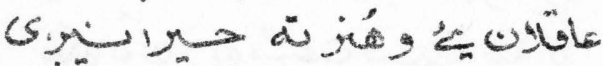
6 هos

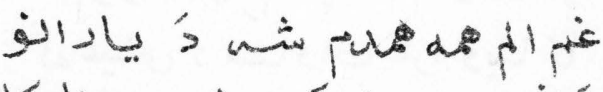

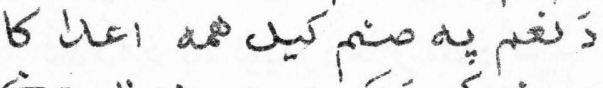

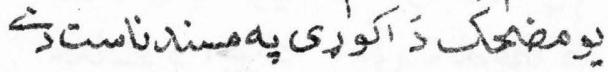

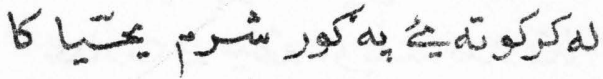

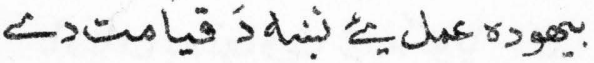

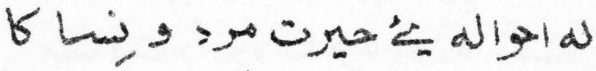
$\Leftrightarrow$ iن

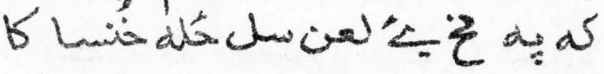

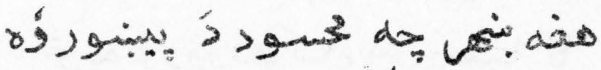
6 ن 


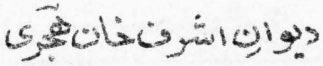

6 L S s rس

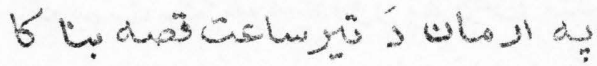

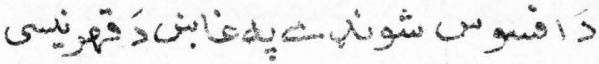

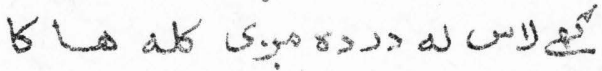

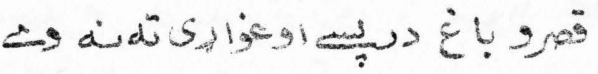

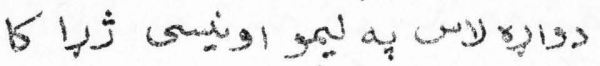
شه شه

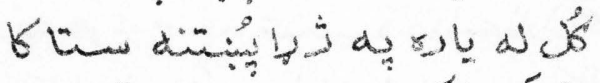

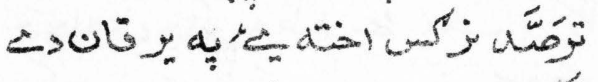
ك أكا

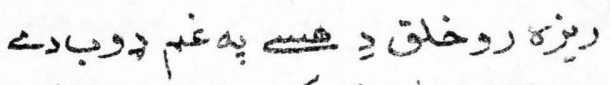

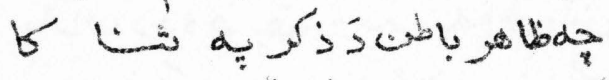
تص كابن

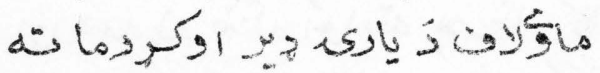

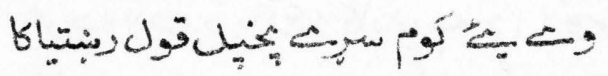

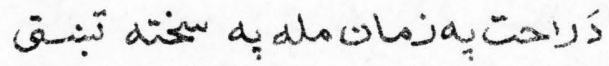

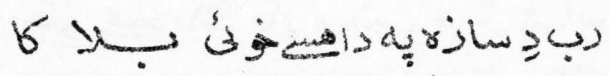
تئم

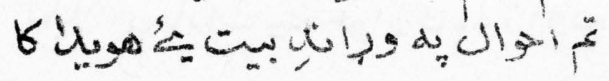




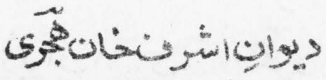

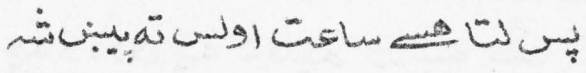

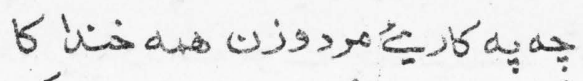

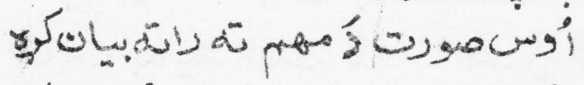
غ

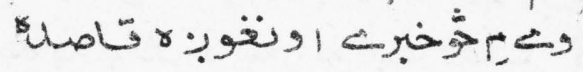

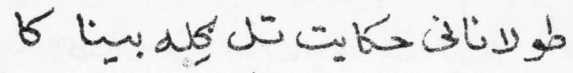
ज) نd كانة

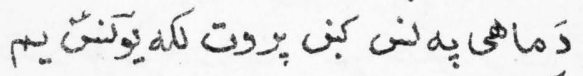

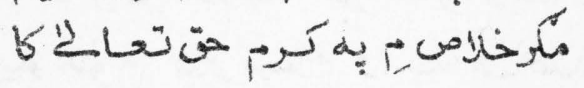

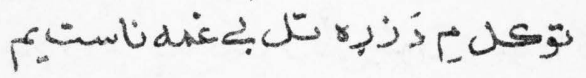

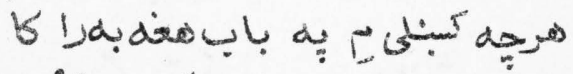
وزئ وز 19

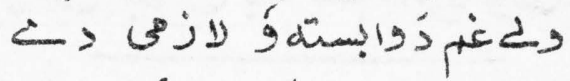

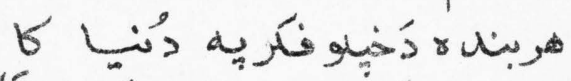

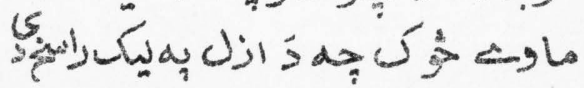
كانها

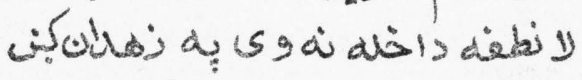

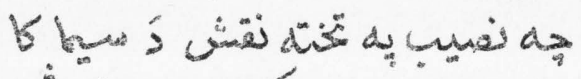
نه 


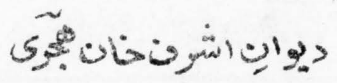

كأنه

ش

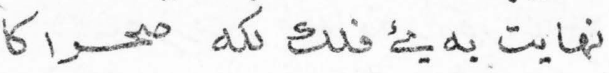

S.ب.

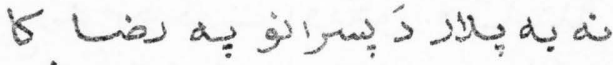

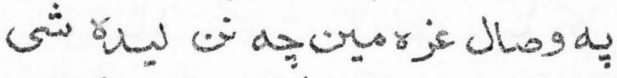

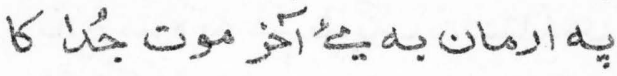

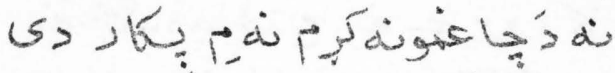

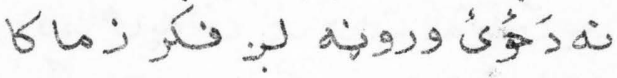

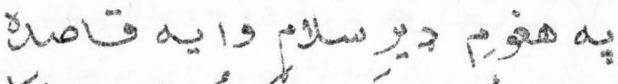

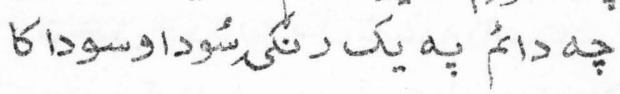

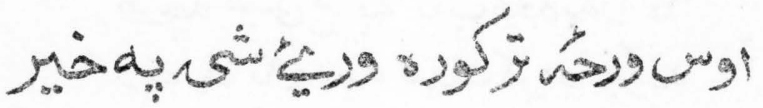

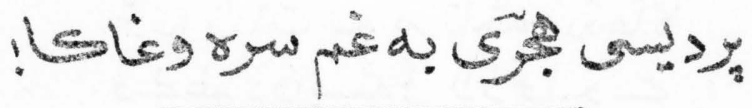


يوإِاشرونانهري

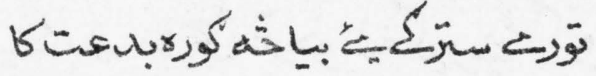

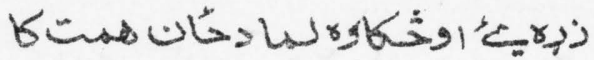

كميه

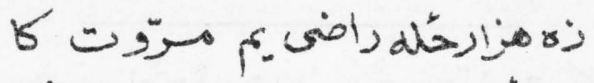

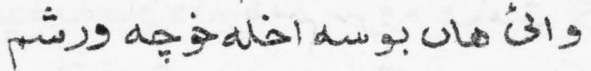

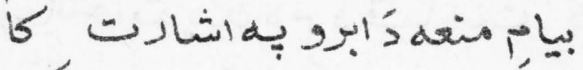

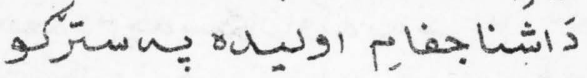
وناد

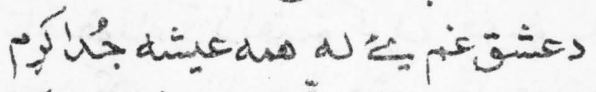

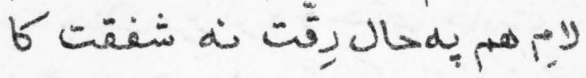
林

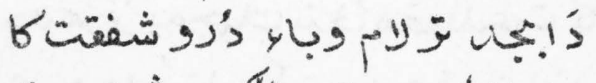

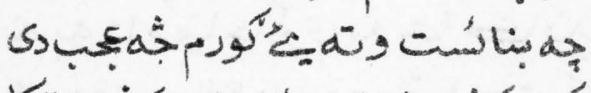

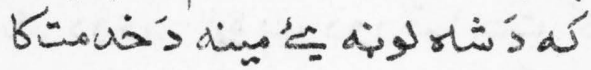

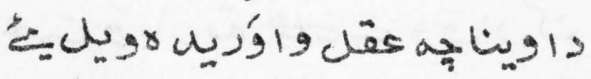

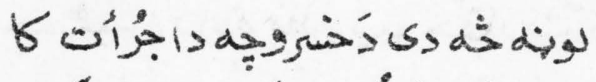

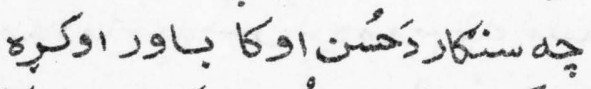

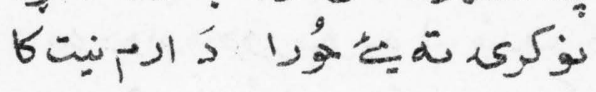

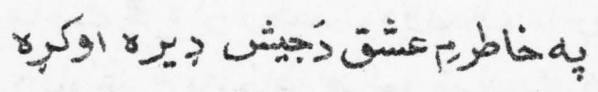

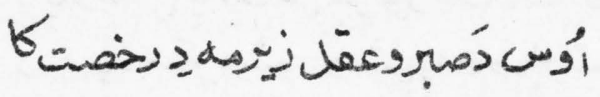




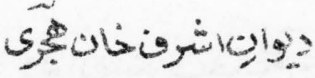

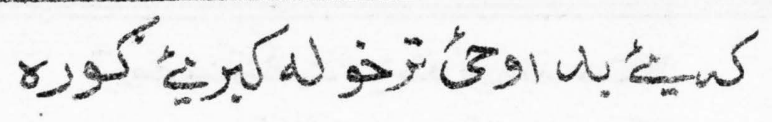

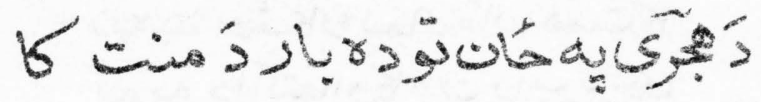

6 ك 6 ك

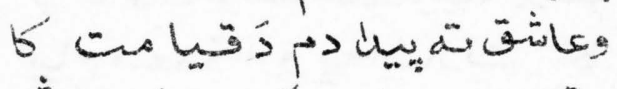

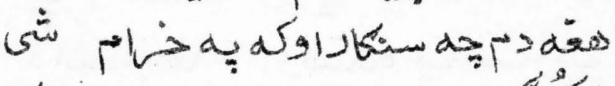
كأن تاصفونة

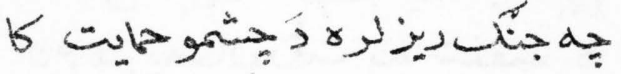

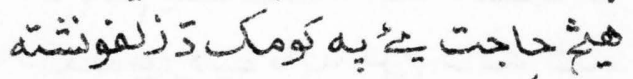

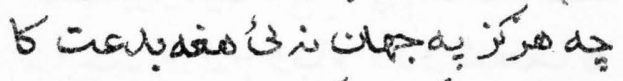
ULs

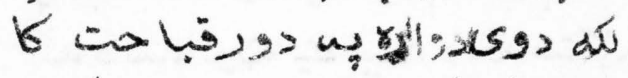
مرك

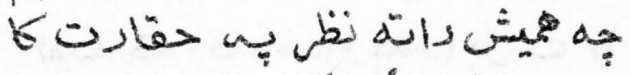

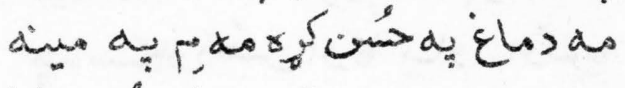

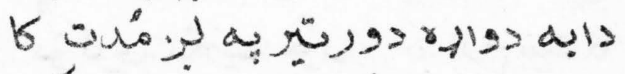
ه

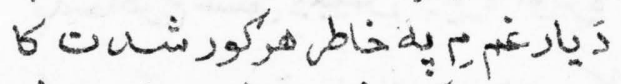
 


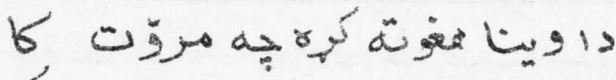

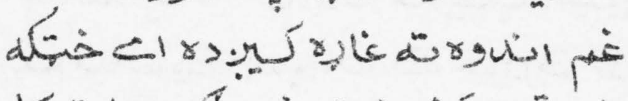

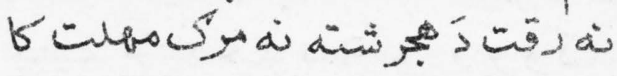

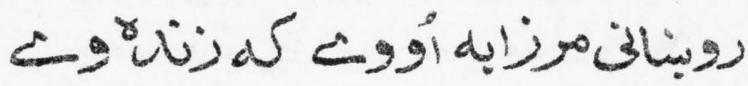

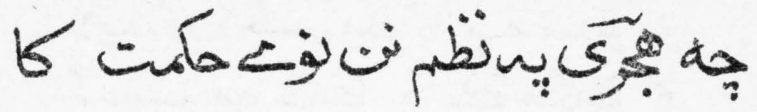

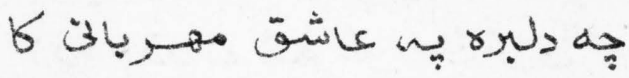

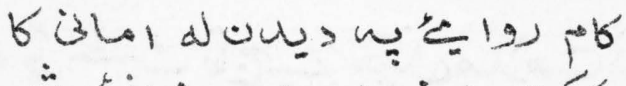

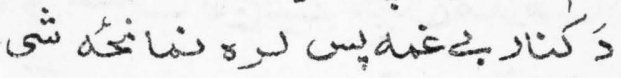

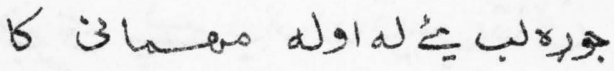

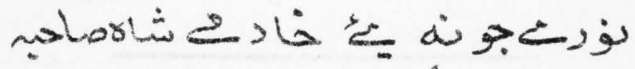

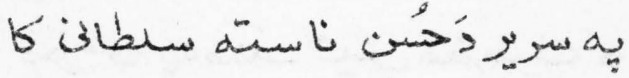

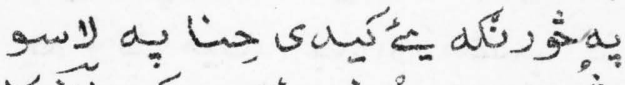

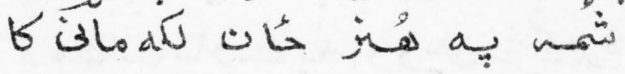

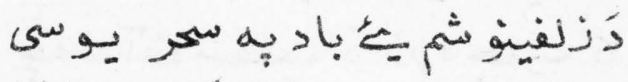

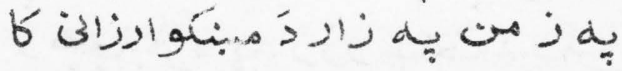

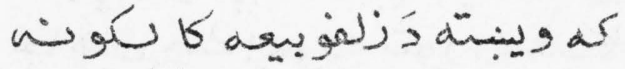
كانها

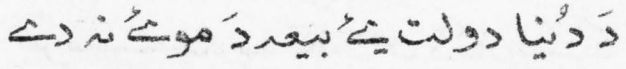

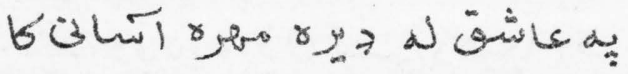


كا

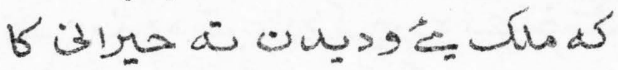

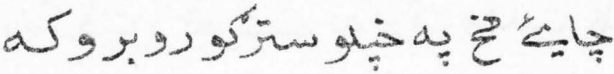
كنهان

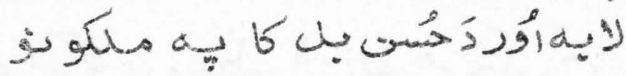

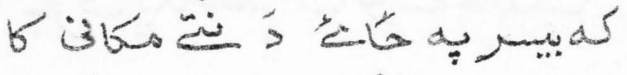

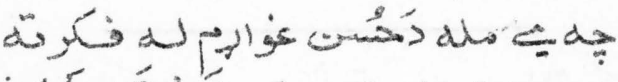

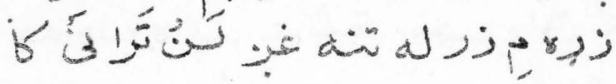

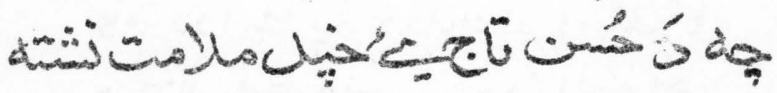
5 ibs.

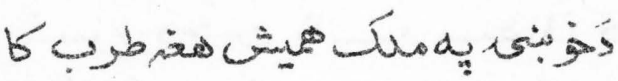

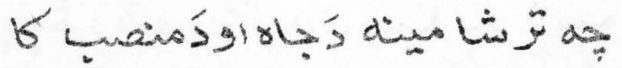
و كابه r

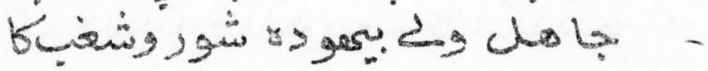

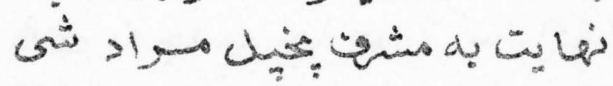

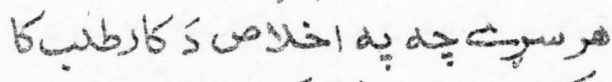
(s) 


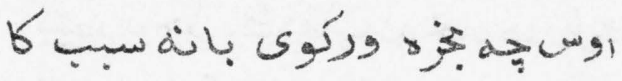

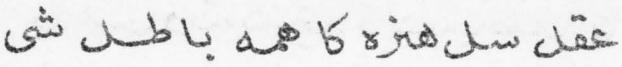

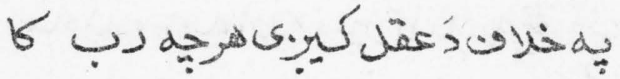

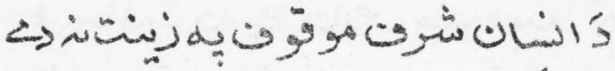
Kب إنها

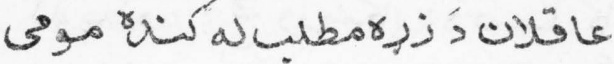

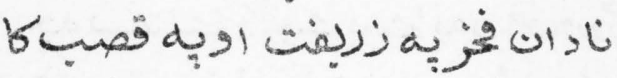

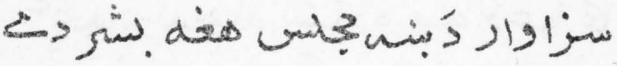

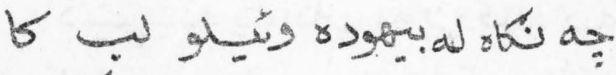

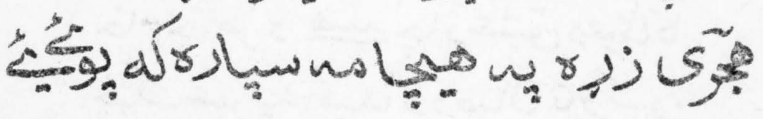

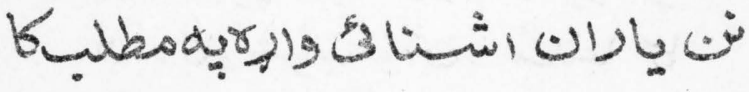

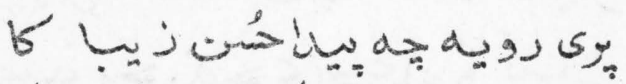

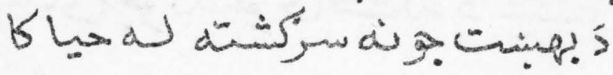

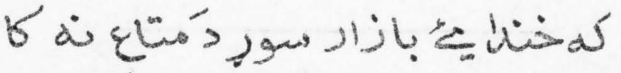

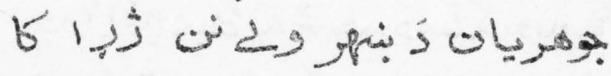

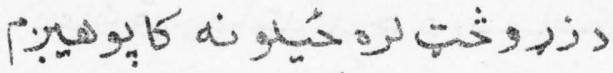

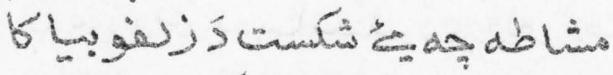

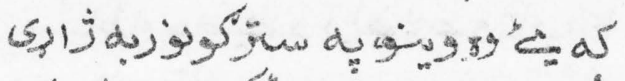

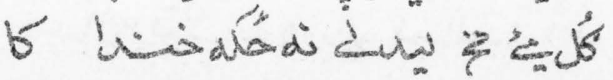




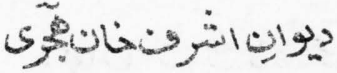

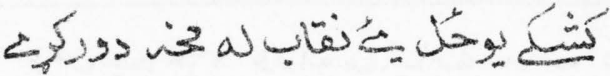

كانها:

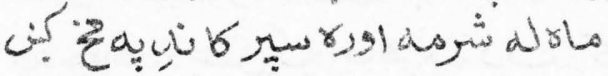

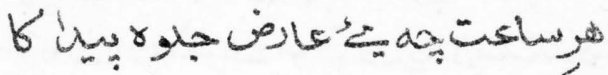

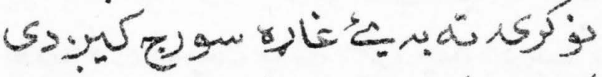

كأهن

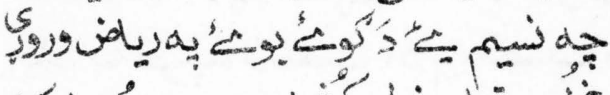

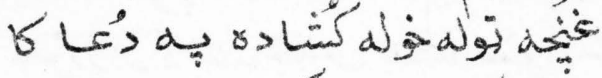

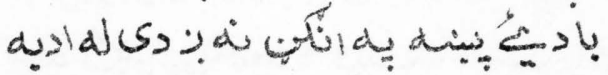

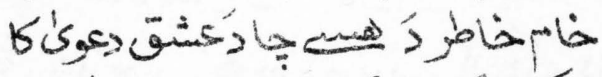

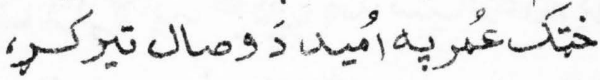

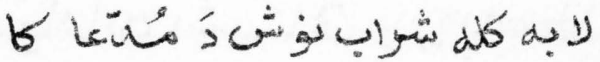

من

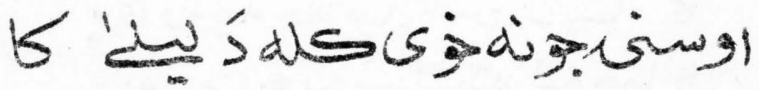

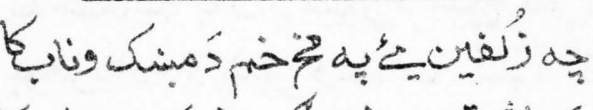

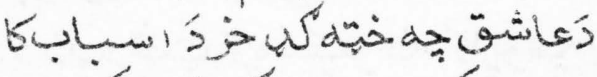

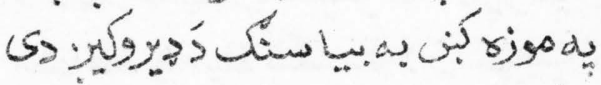

butis

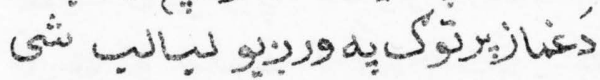




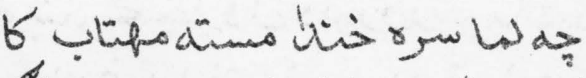
9)

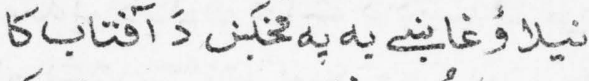

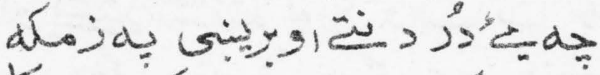

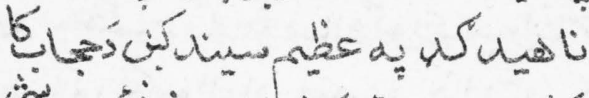
كر هرسيرة

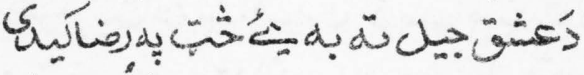
64 كأن كسينا

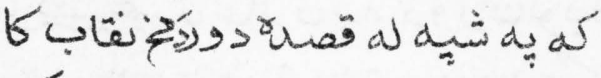

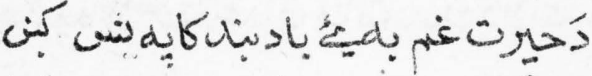

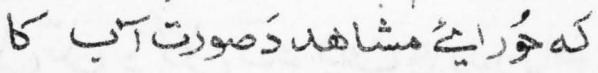

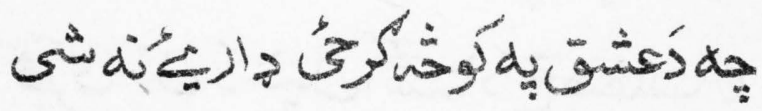

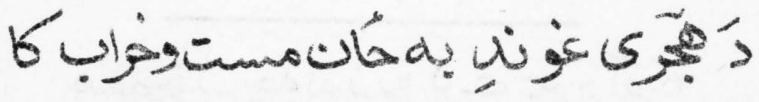




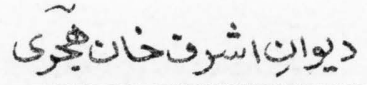

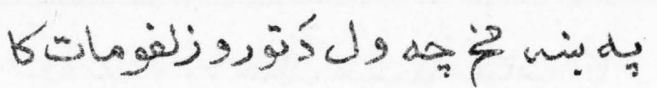

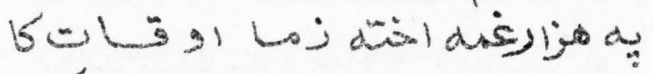

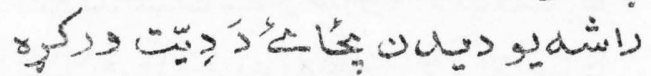

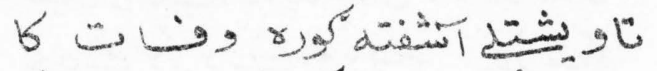

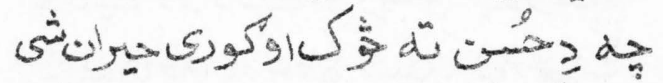

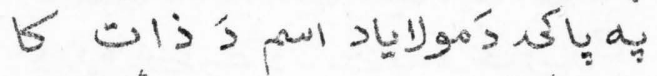

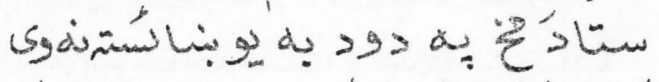

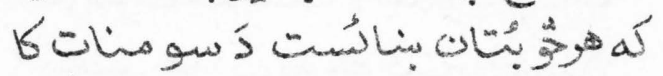
هي هوساعته

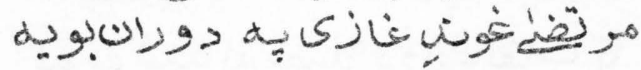

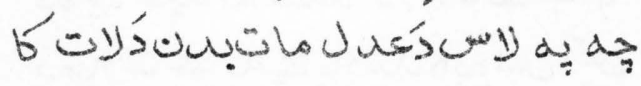

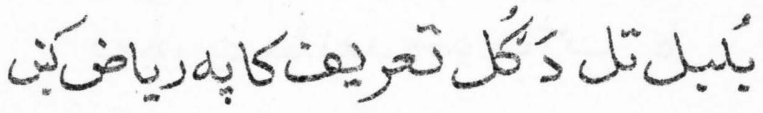

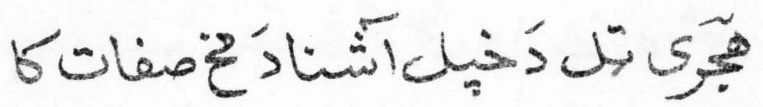

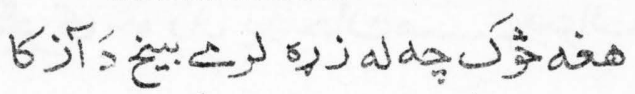

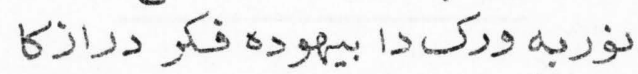

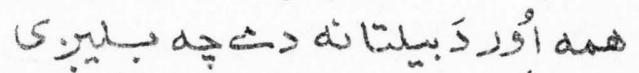

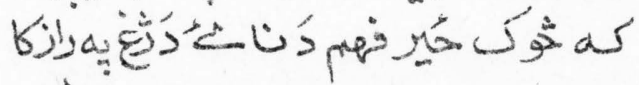

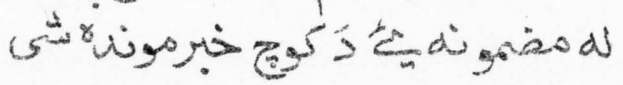




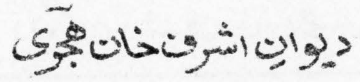

نام

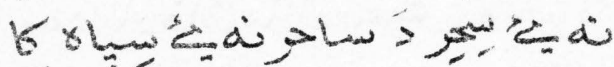

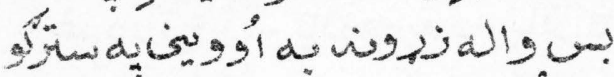

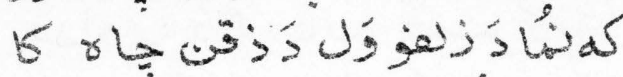

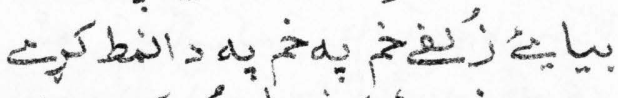

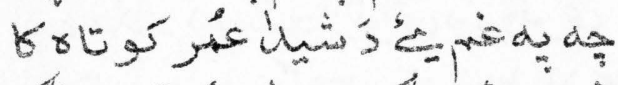

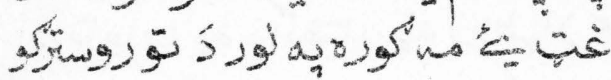

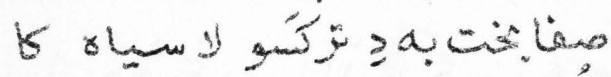
جاهن 6 نا

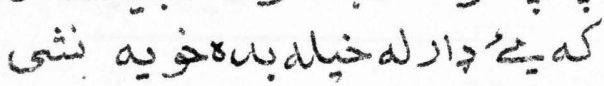

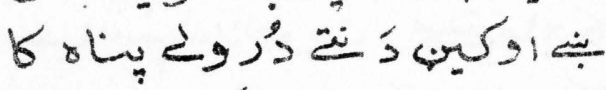

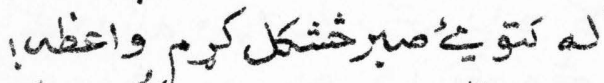

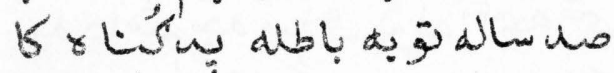

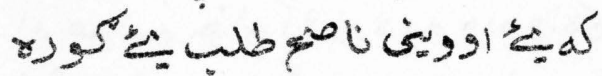

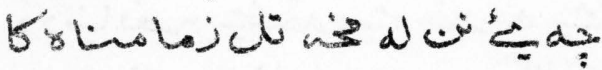

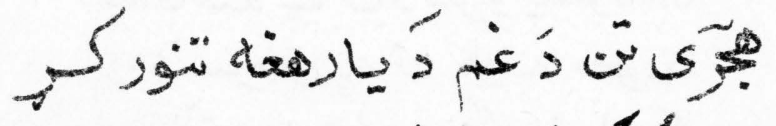

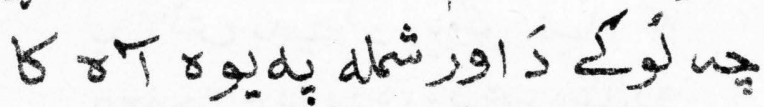

FV 


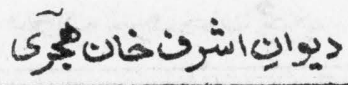

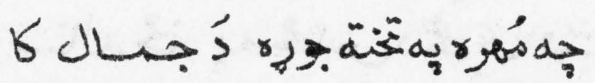

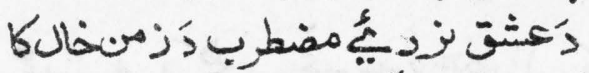

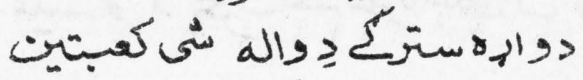

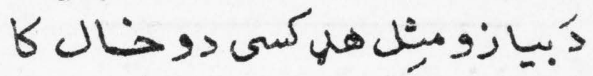

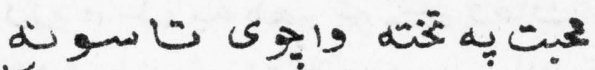

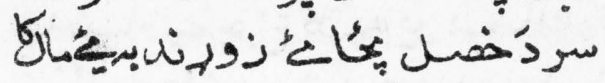

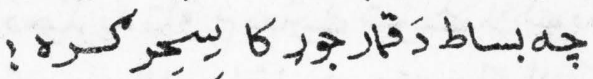

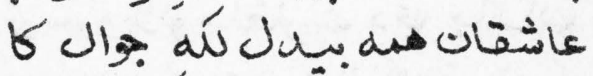

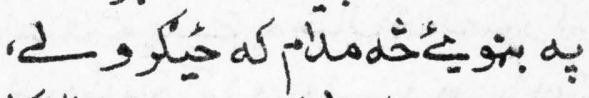

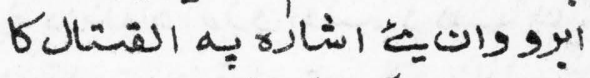

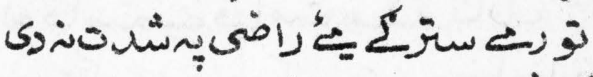

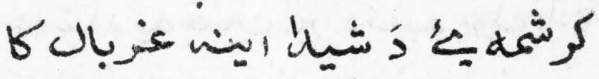

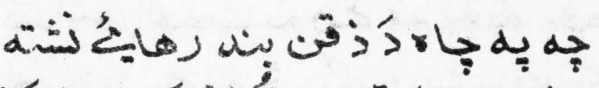

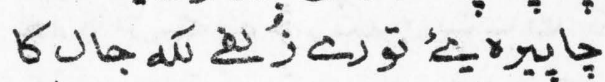
كَّ تَّبث

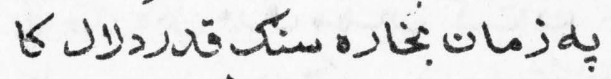
كان

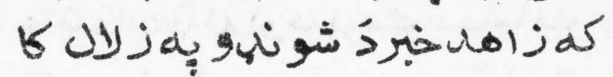

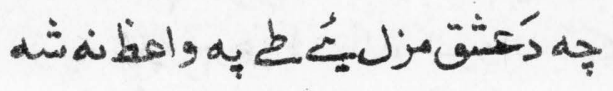

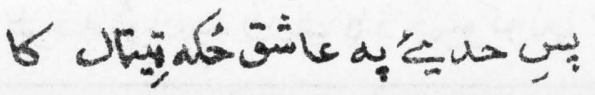

phu 
ديوانِشرفخانجيجي

ستال كائسة

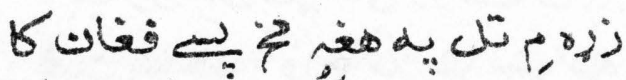

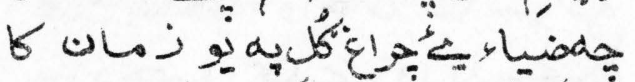

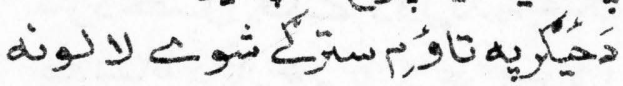

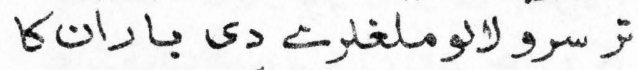

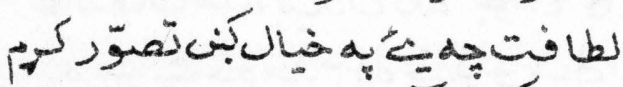

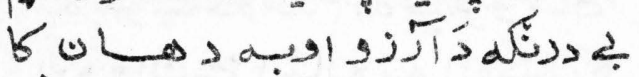

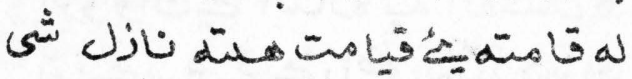

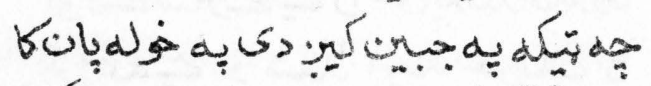

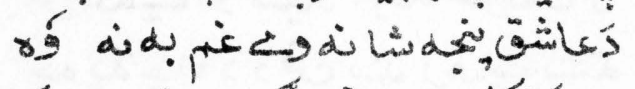

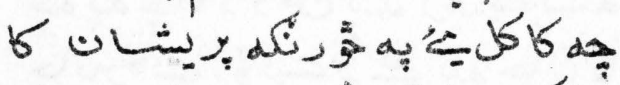
بونة

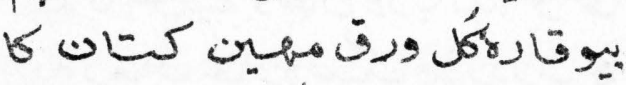

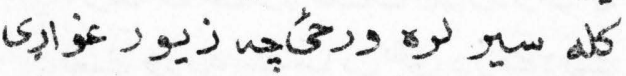

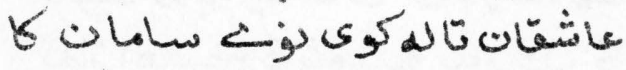

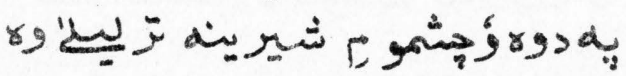

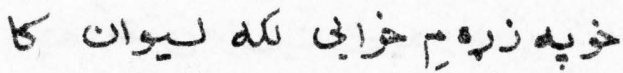

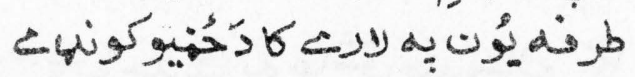

pre 
ديوانِاشرقنان بهري

كوزة

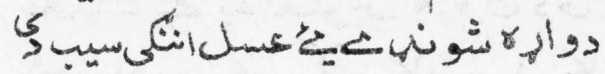

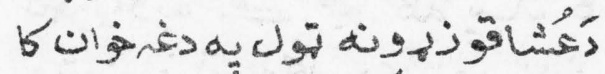

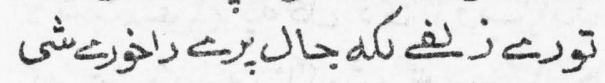

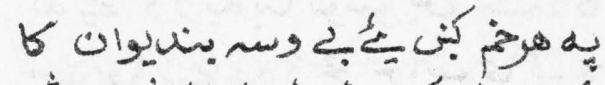

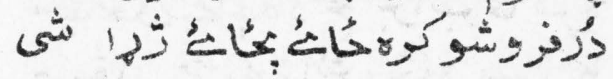

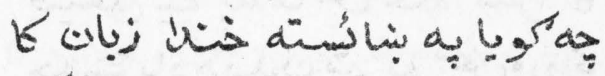

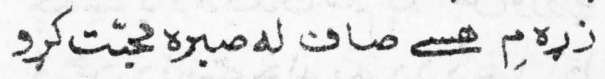

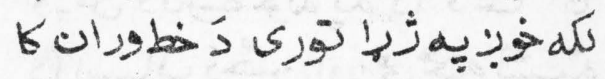

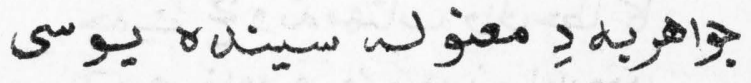

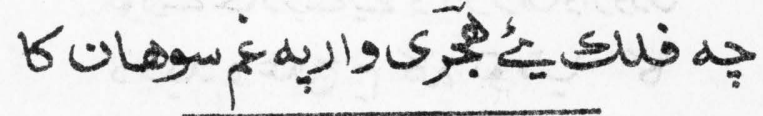

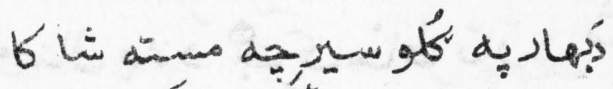
نأو

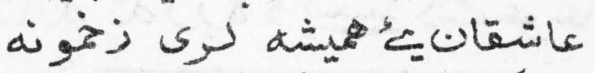

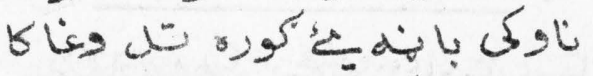

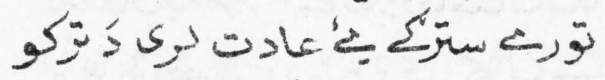

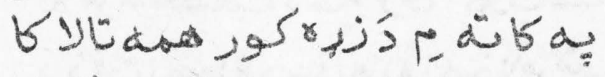

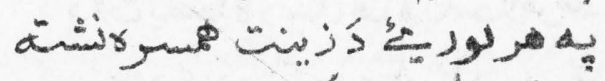
ك أlis 
حيوانِشرنخان هجمَىى

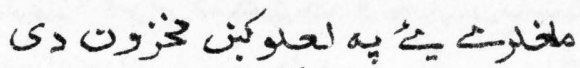

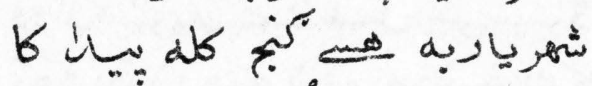

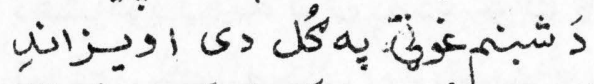

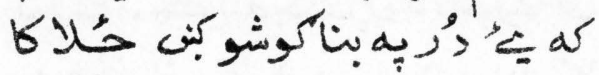
سمبنه

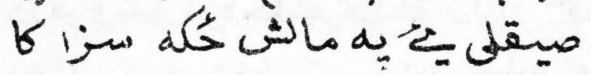

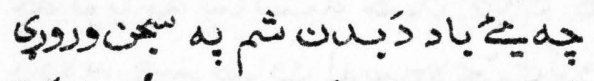

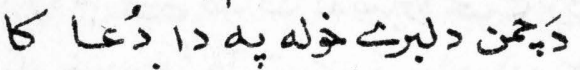

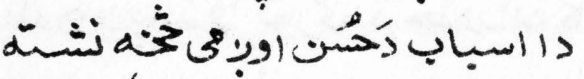

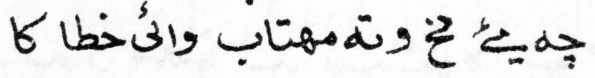

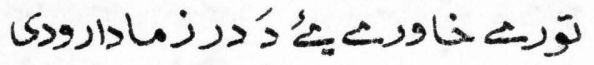

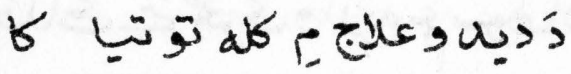

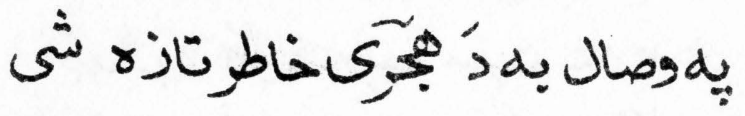
كأن

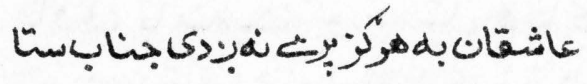

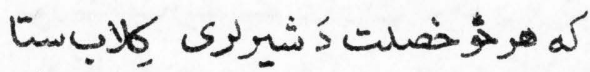

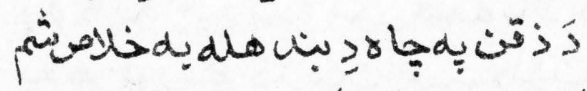

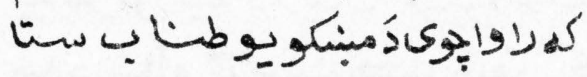

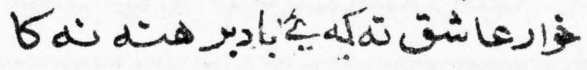

pvy 


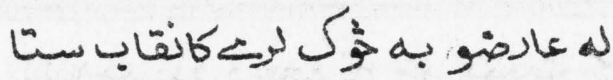

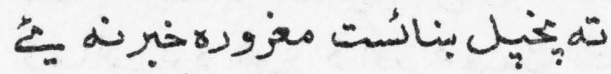

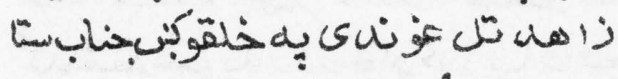

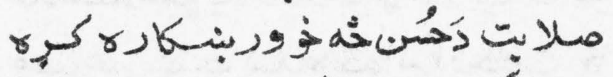

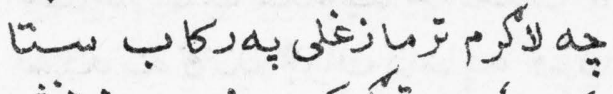

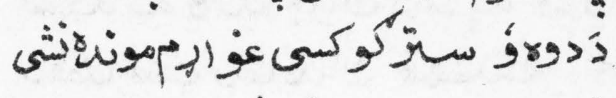

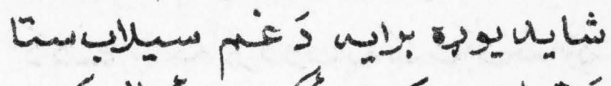

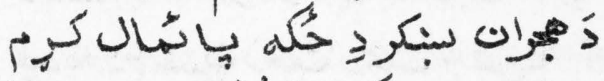

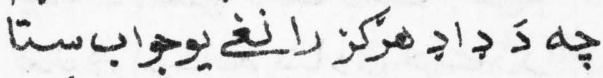

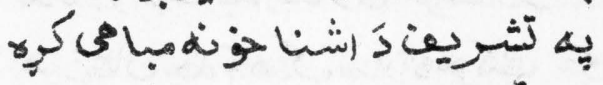

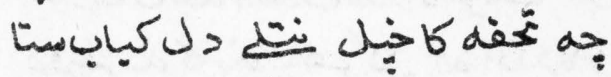

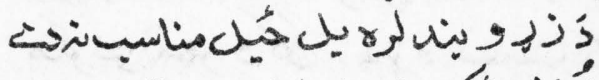

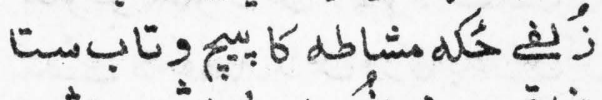

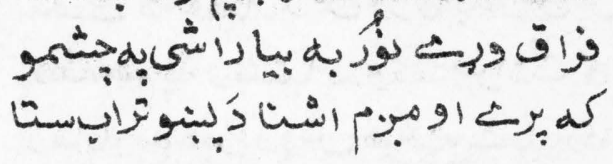

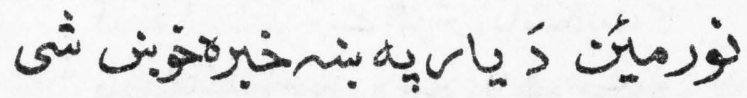

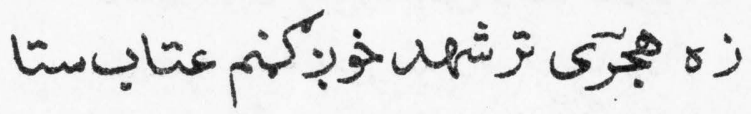




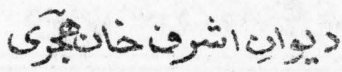

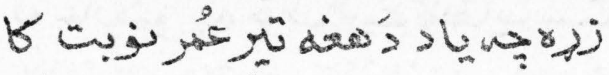

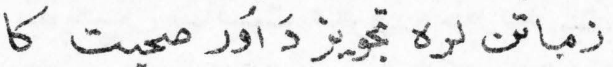

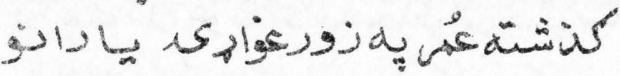

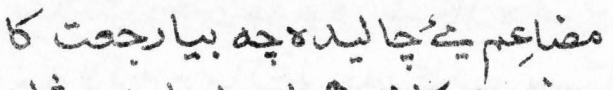

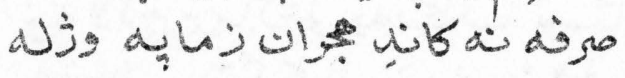

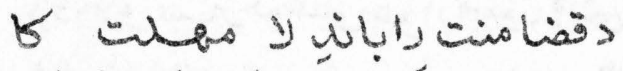
دا lك

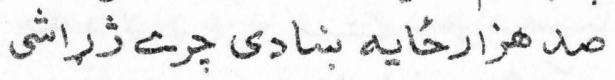

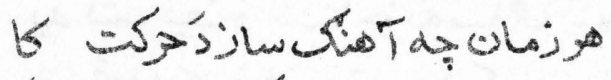

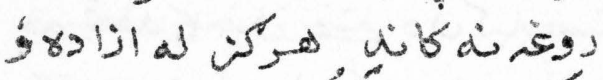

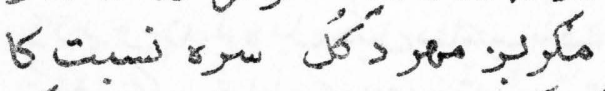

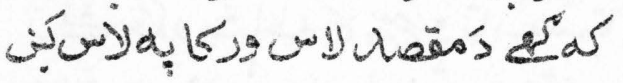

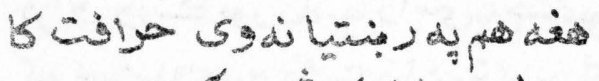

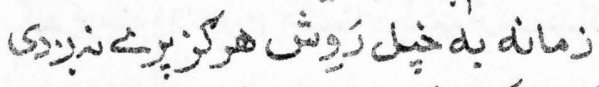

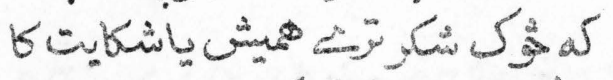

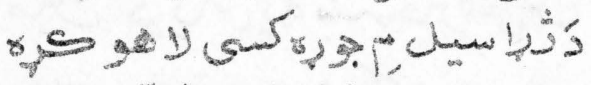

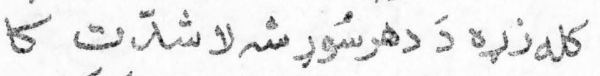

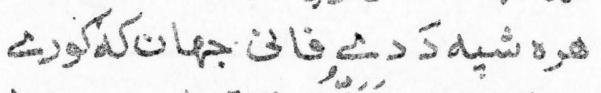
6 ك

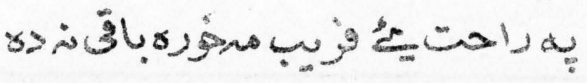




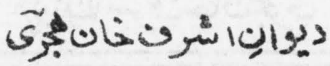

ك كاه

تن

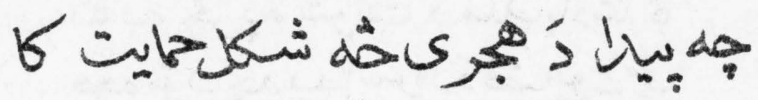

كنيل

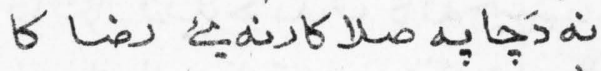

ها

ها

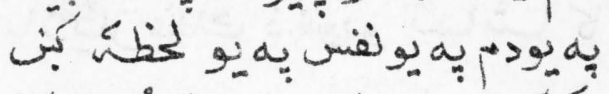

ك أن's

كَ

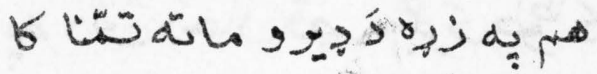

جئز

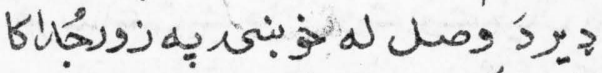

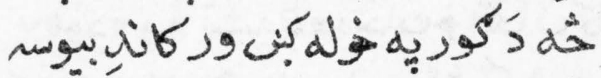

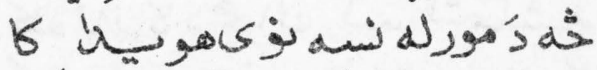

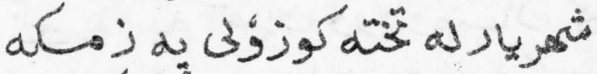

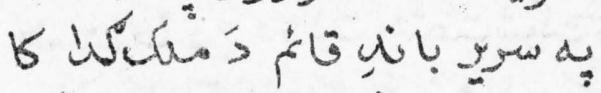

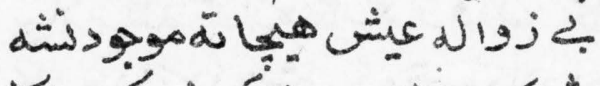

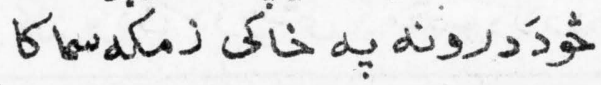




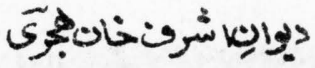

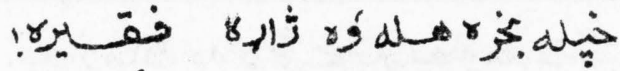

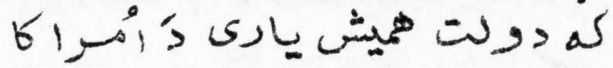

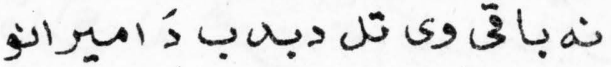

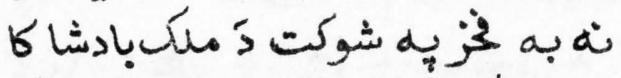

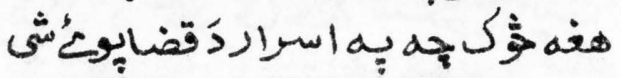

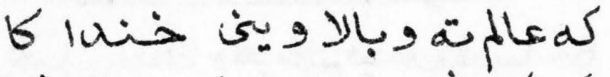

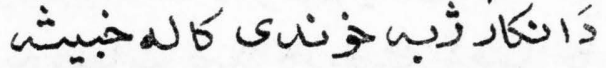

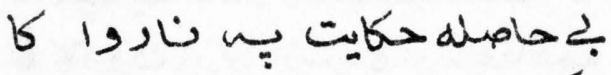

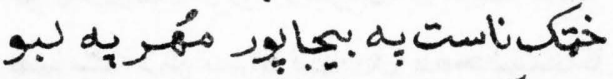

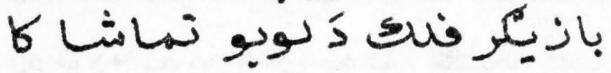

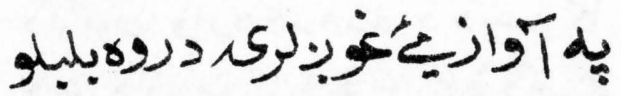
:

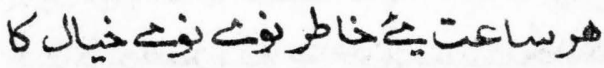

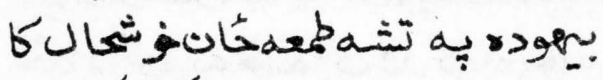

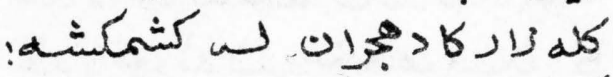

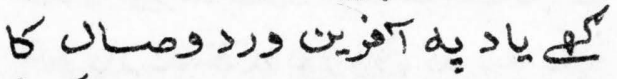

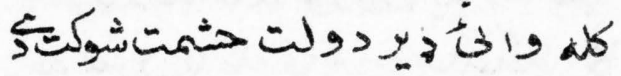

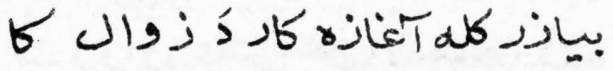
كله وانأدرويثى دُمقضود لادردها 
لا لاعقل د5 هرجِ

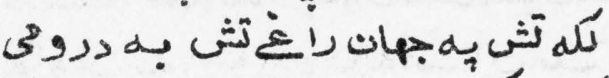

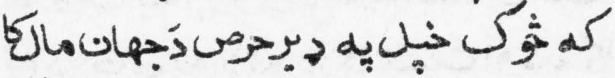

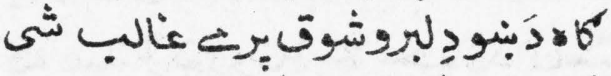

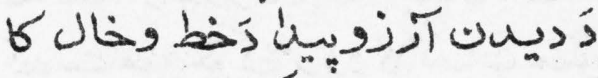

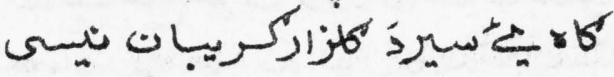

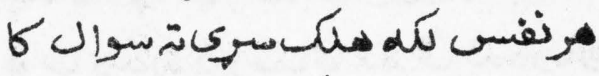

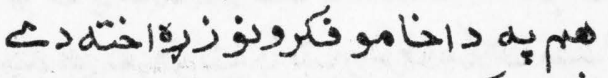

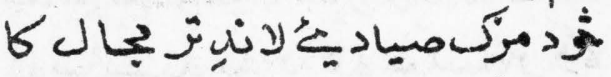

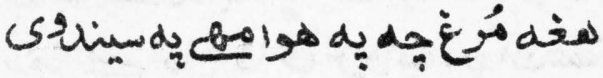

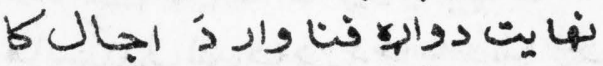

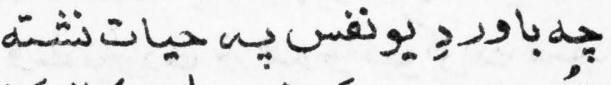

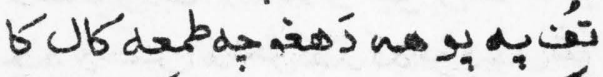

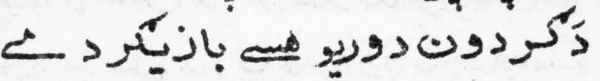

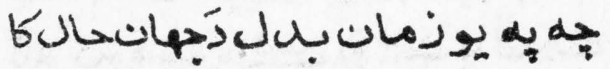

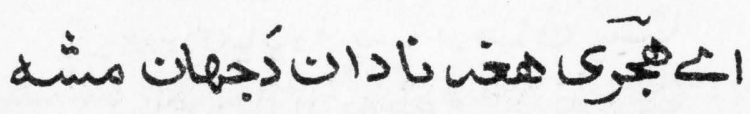

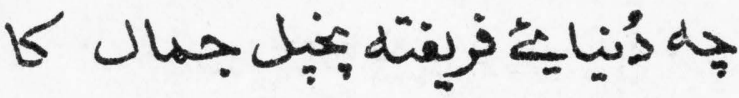




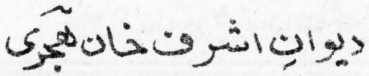

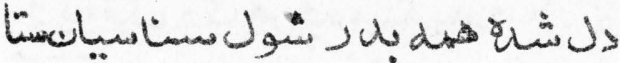

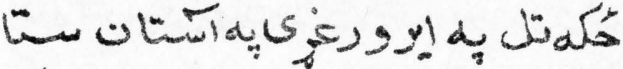

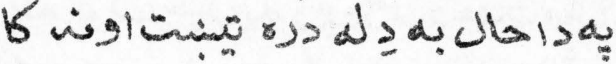

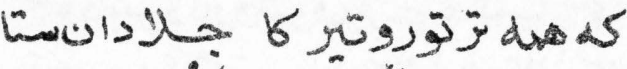

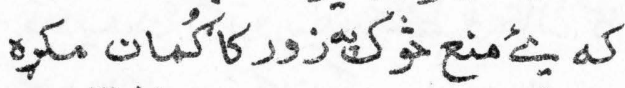

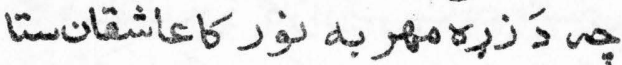

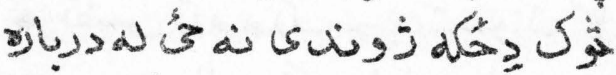

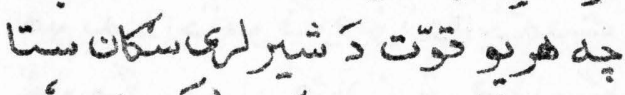

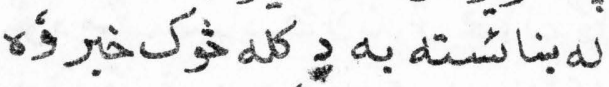


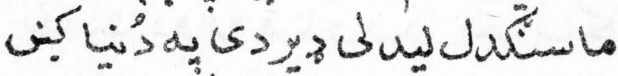

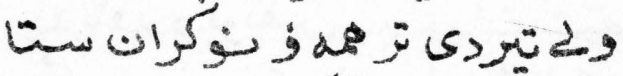

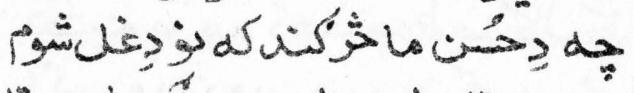

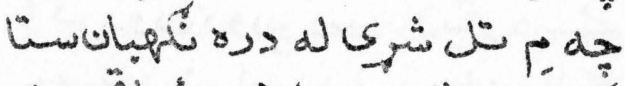

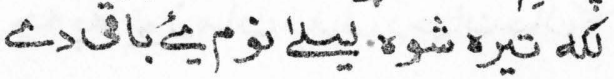

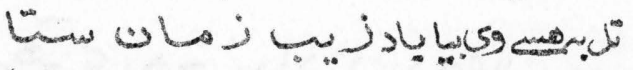

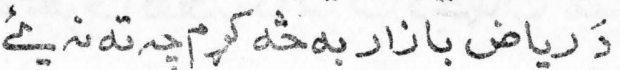

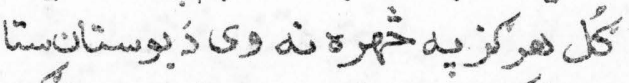

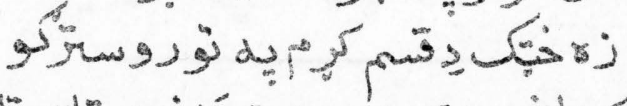

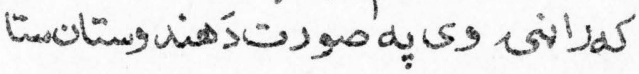
dithal 
يوانِاشرتخالهجري

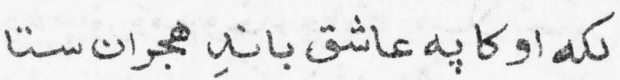

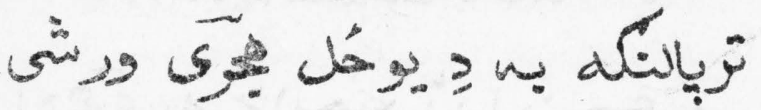

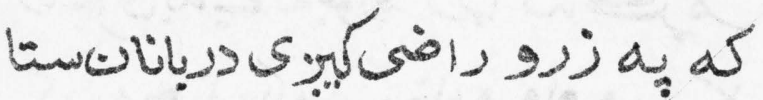

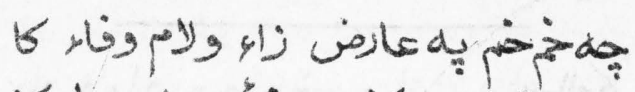

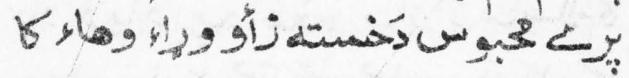

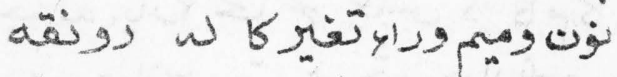
ك

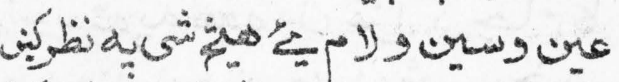

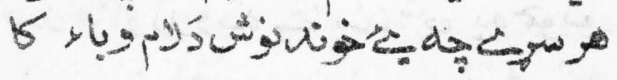

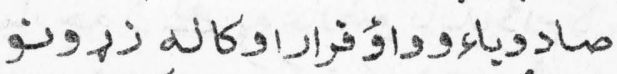

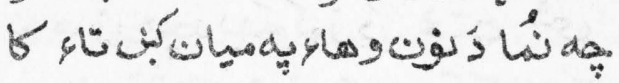

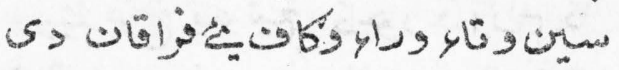

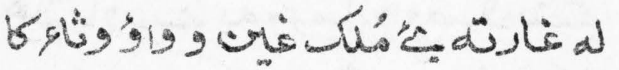

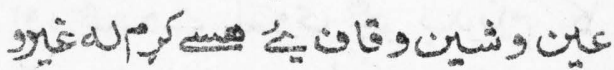

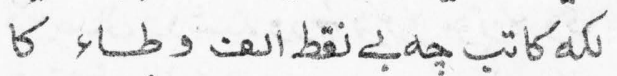

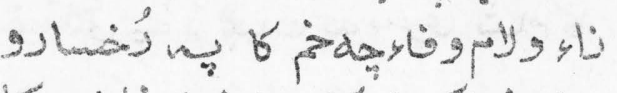

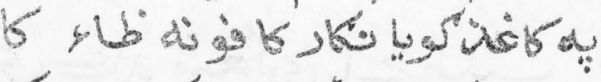

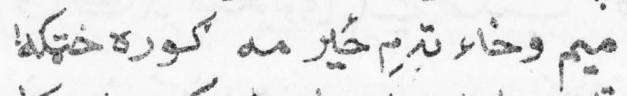

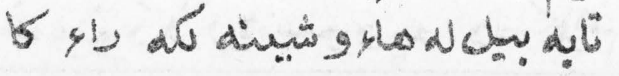

PAtw 


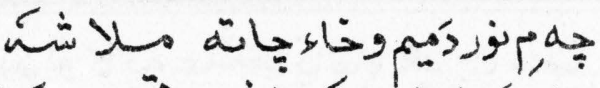

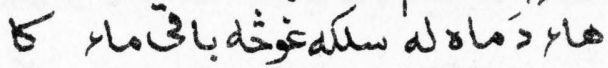

of

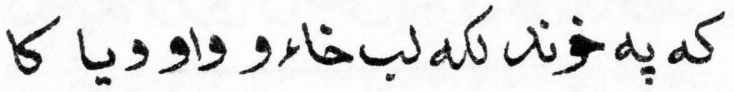

باد

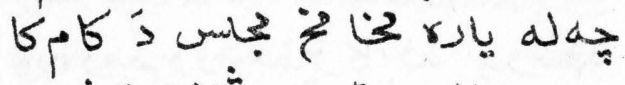

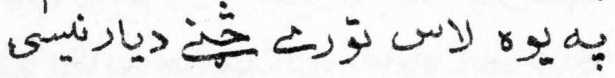

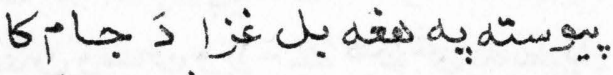

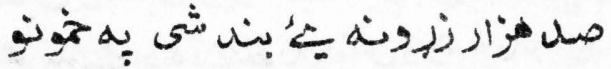

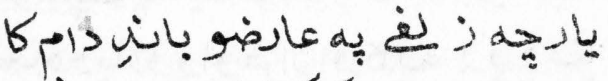

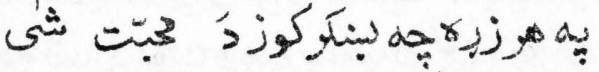

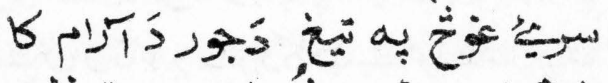

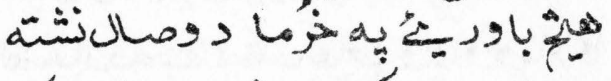

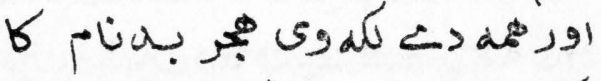

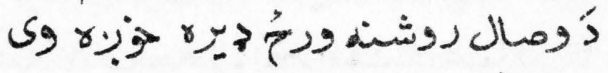

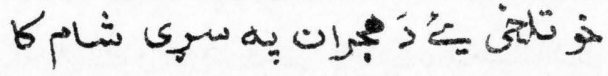

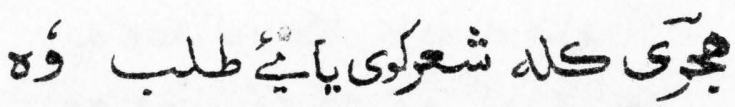

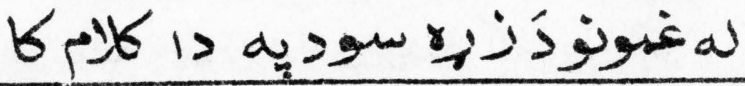




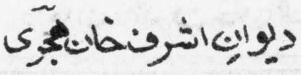

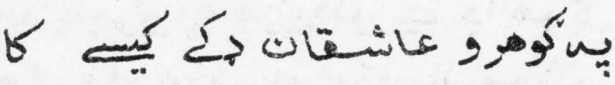

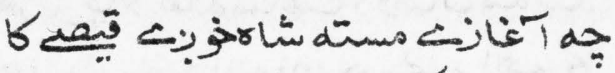

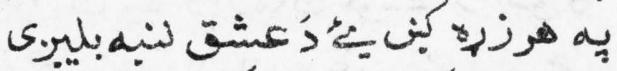

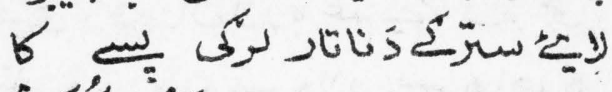

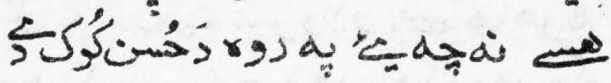

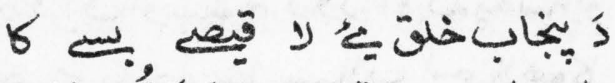

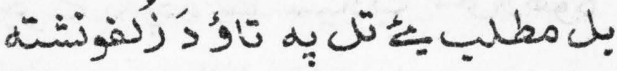

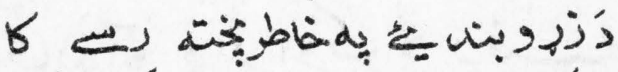

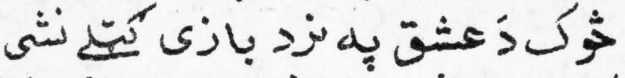

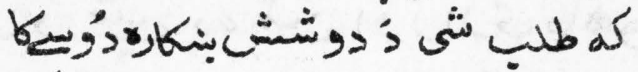

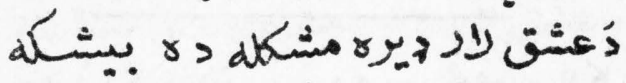

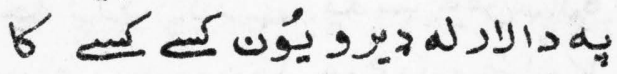

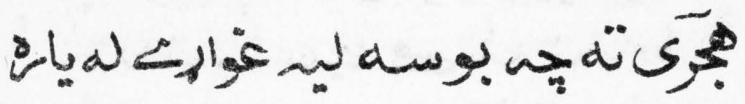

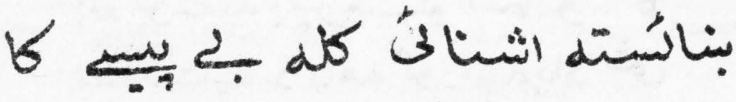

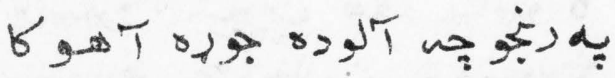

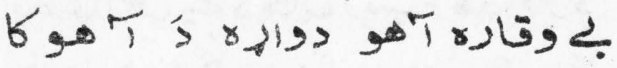

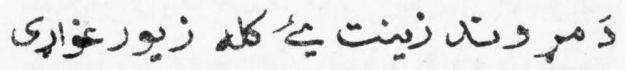

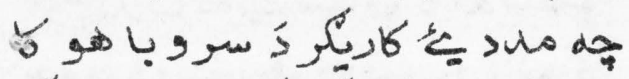

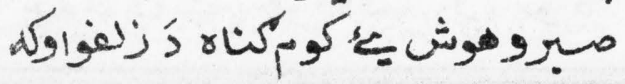




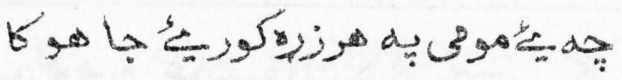

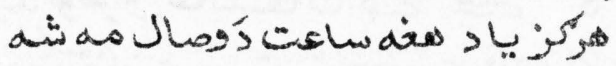

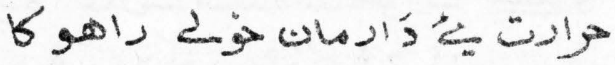
3 كام

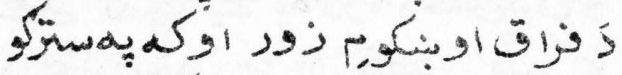
جر

:

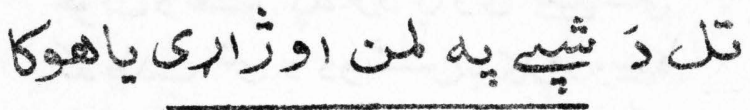

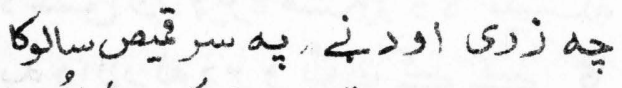

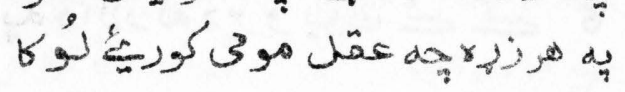

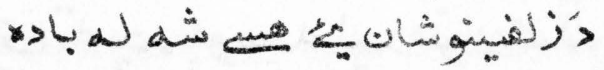

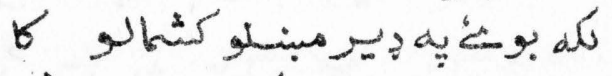

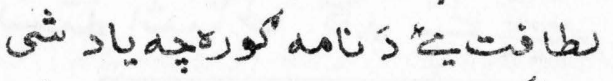

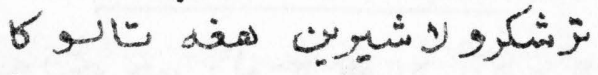

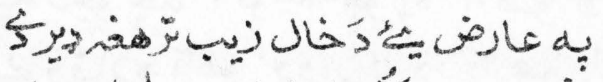

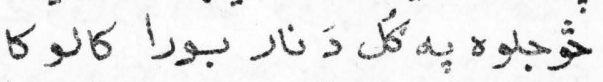

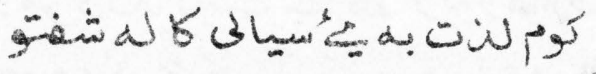

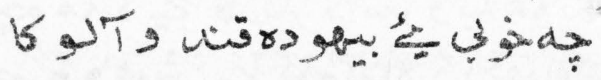


يوارِاشروتحانجئري

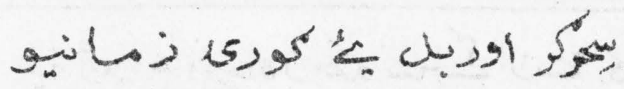

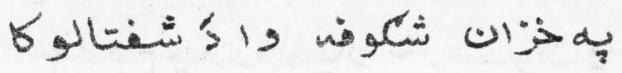

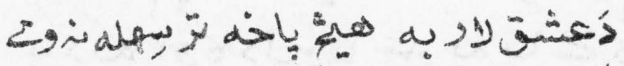

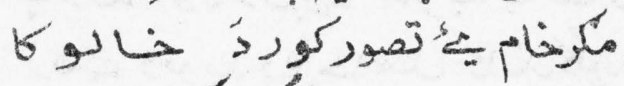

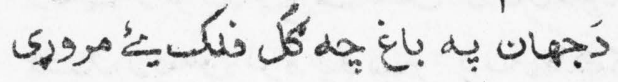
به sمان

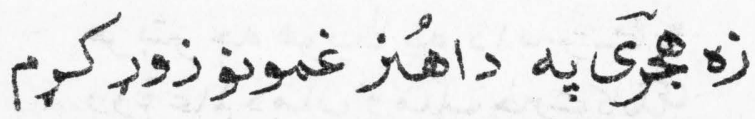

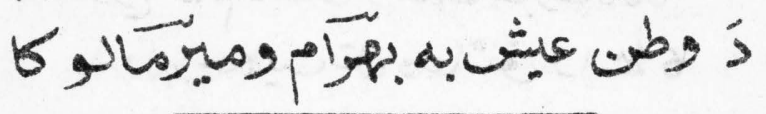

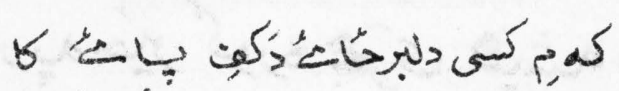

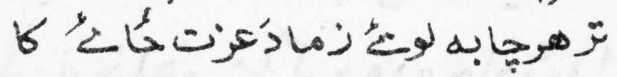

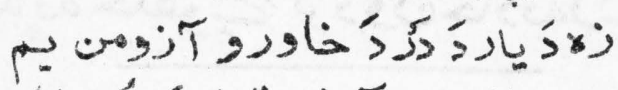

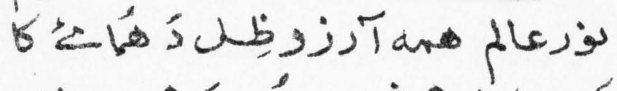

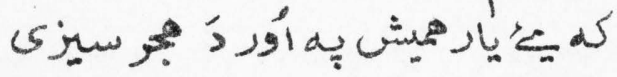

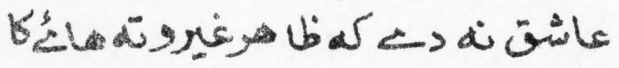

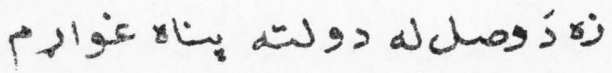
r承 دَوبال

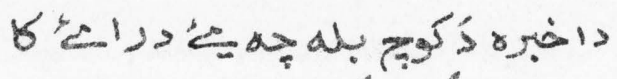

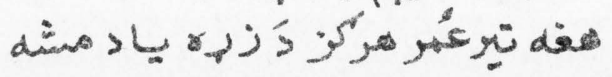

KAV 


\section{ديوانِاشرونخانجزى}

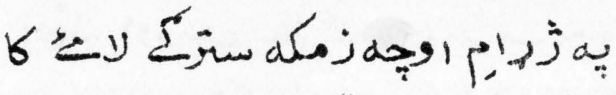

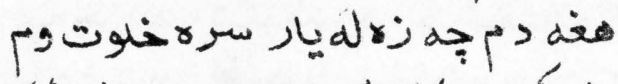

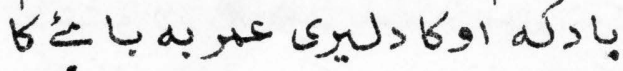

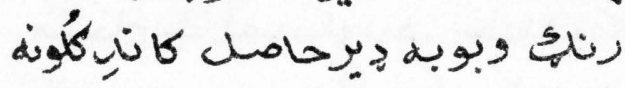

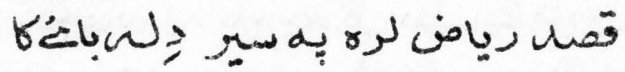

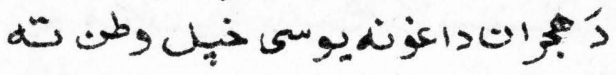

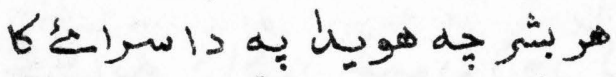

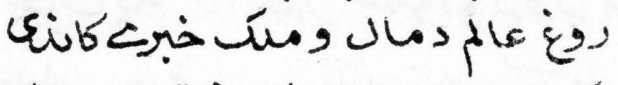

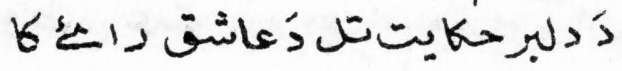

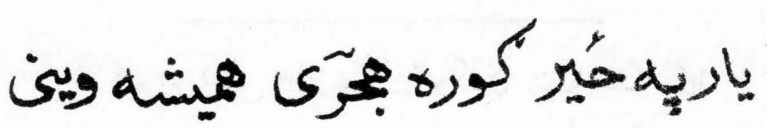

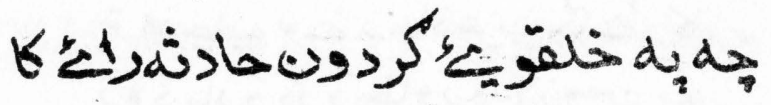




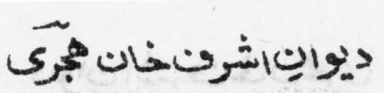

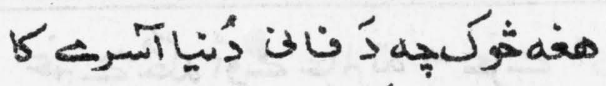

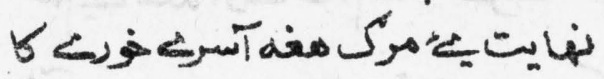

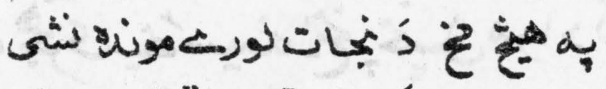

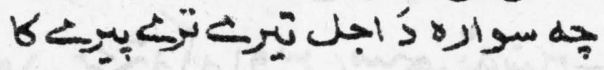

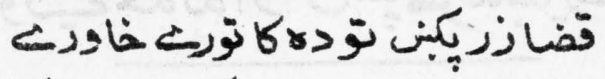

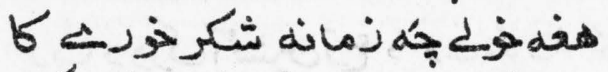

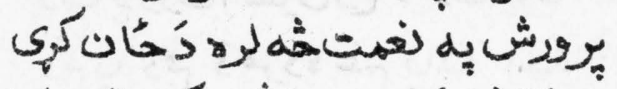

كا

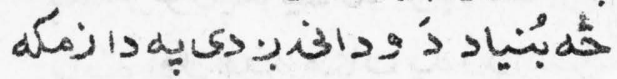

bs

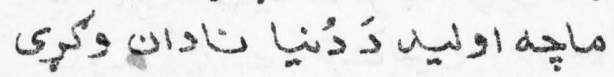

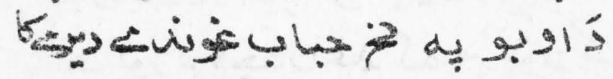

كَر

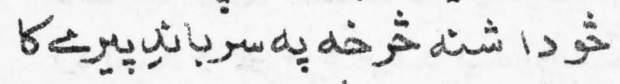

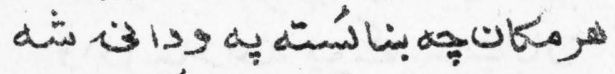

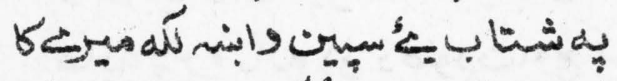

'

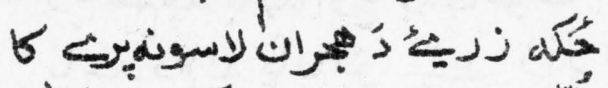

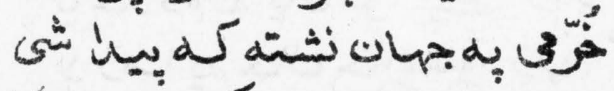

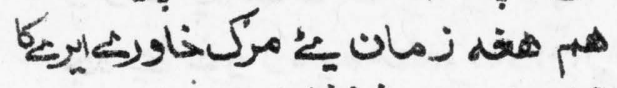

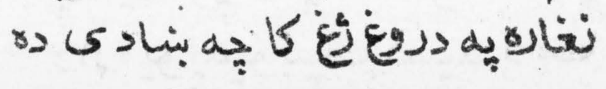

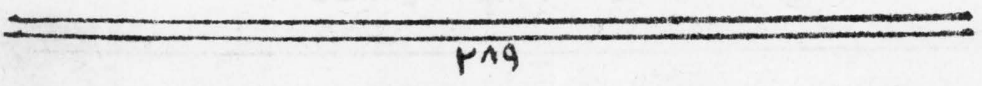




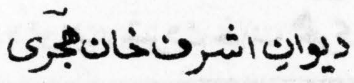

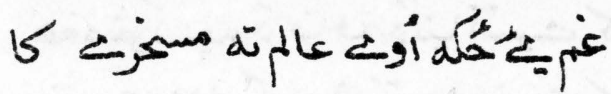

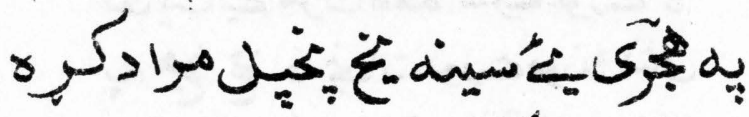

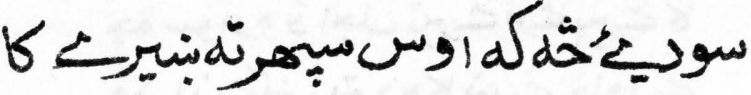

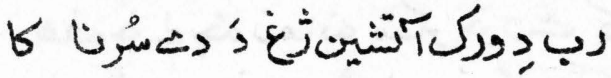

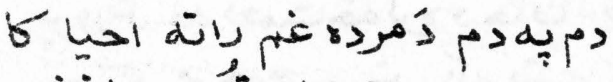

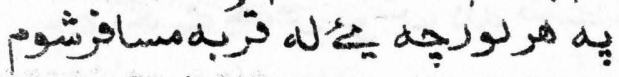

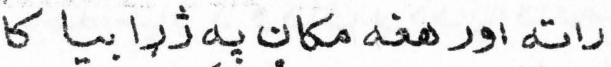

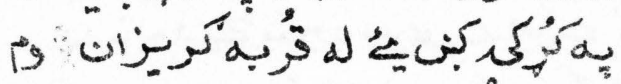

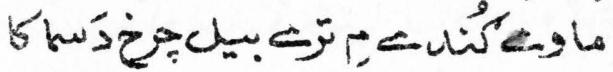

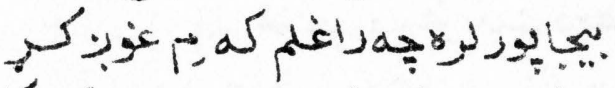

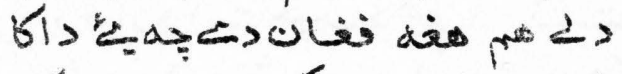

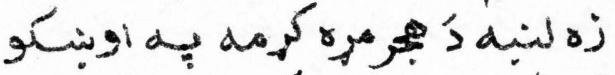

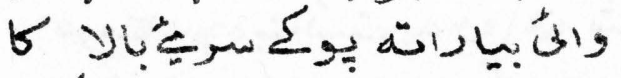

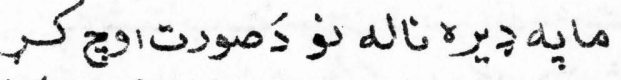

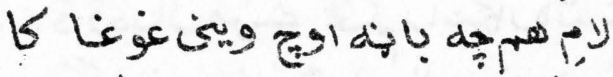

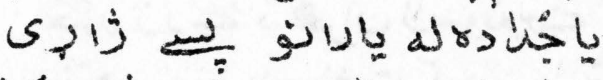

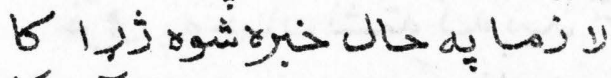

وله

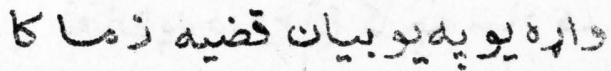




\section{ديوإِن اشرنخانبري}

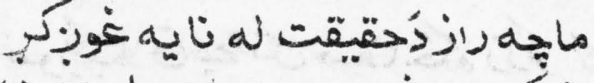

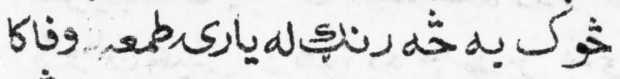

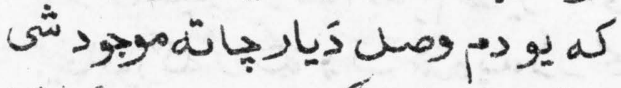

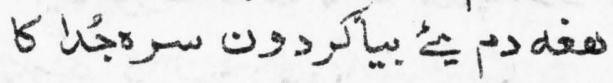

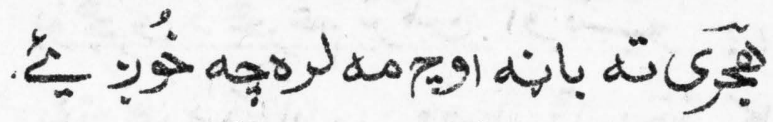

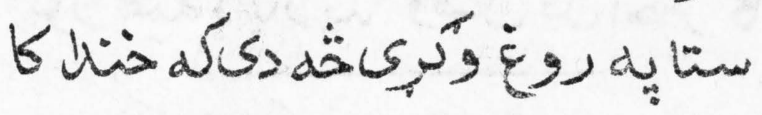

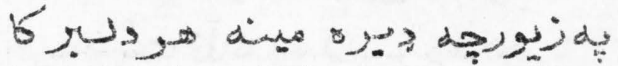

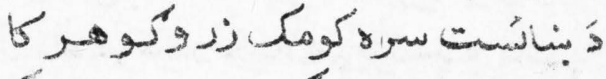
.

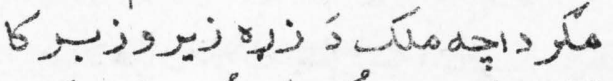

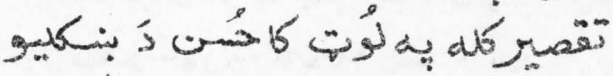

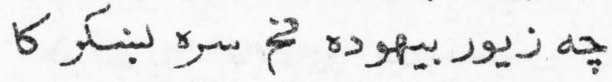

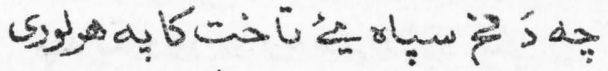

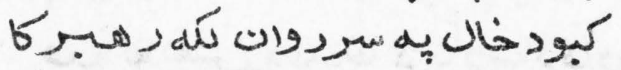

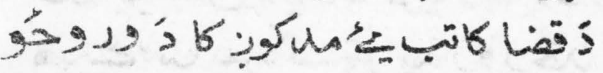

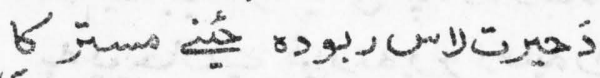
管

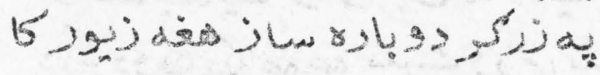

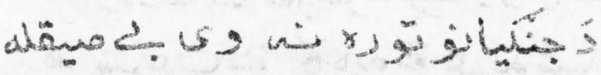




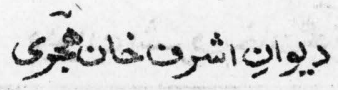

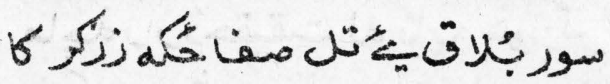

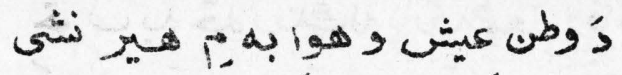

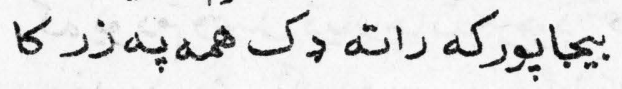

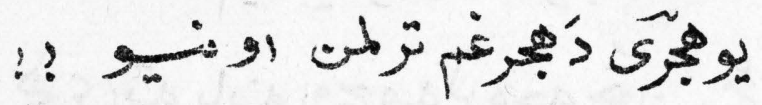

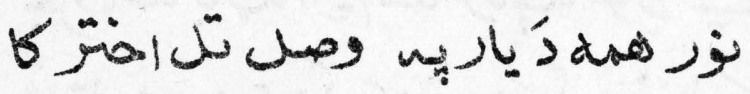

فكبـ

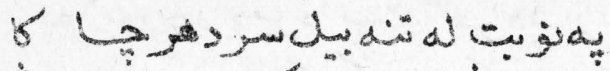

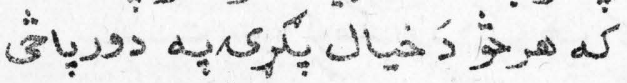

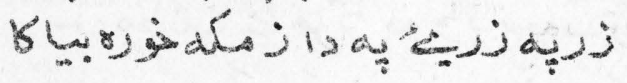

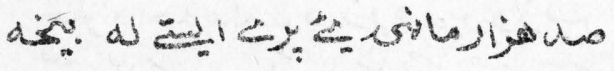
لابه

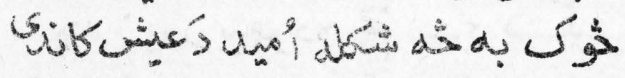

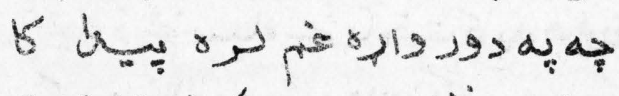

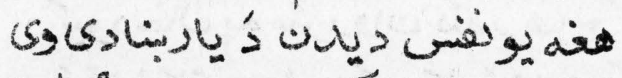

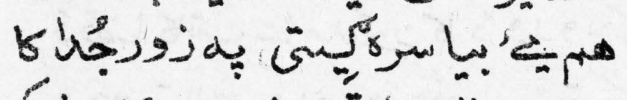

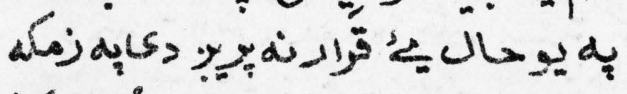

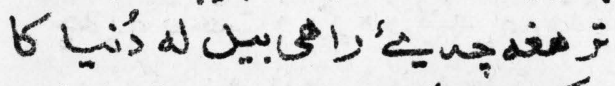

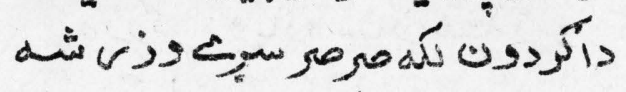
هرساعت 


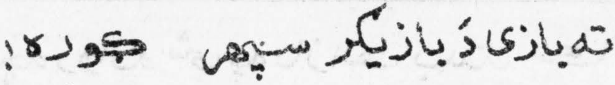

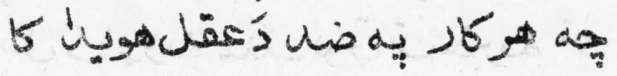

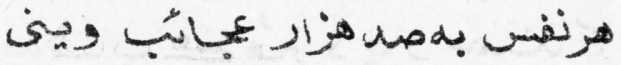

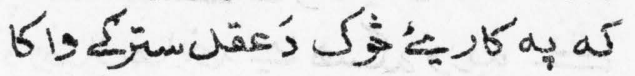

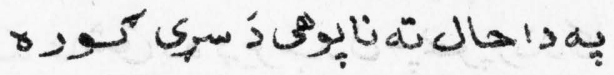

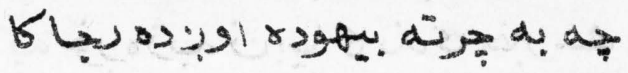

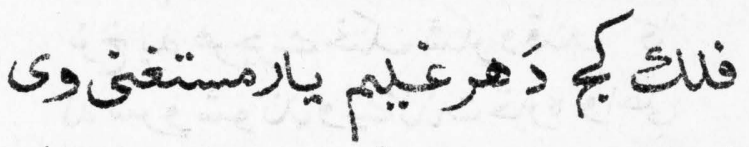

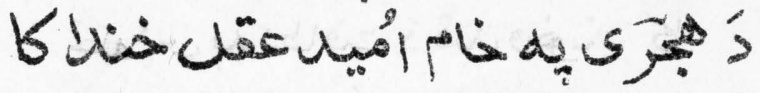

كابنه

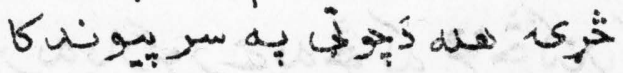

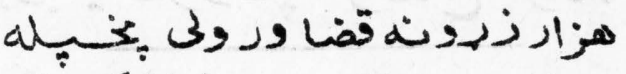

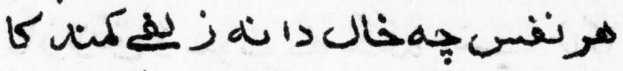

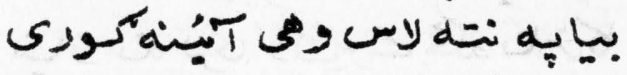

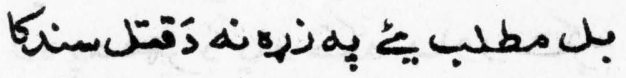

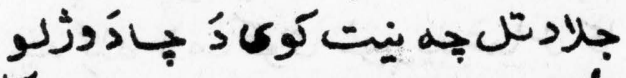

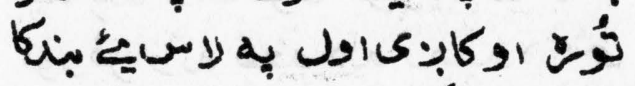

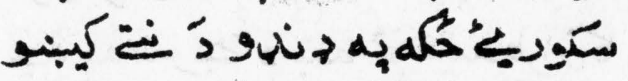

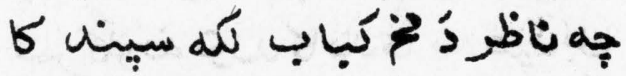

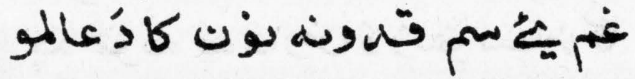


5 لج

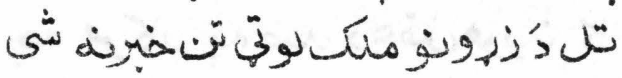

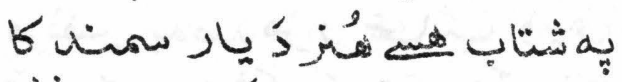

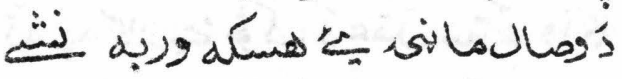

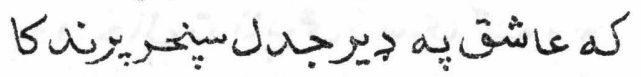

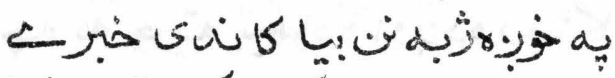

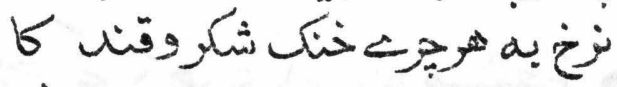

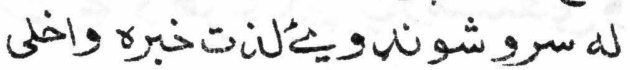

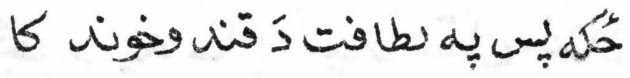

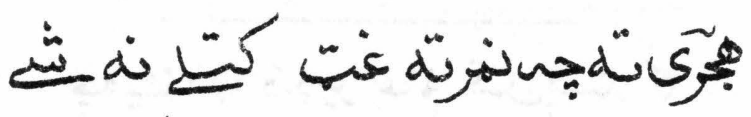
كسنا

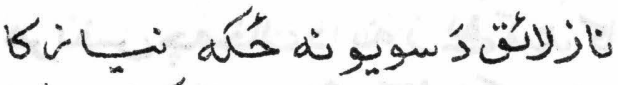

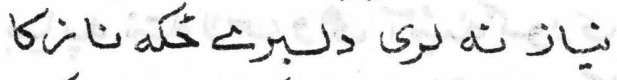

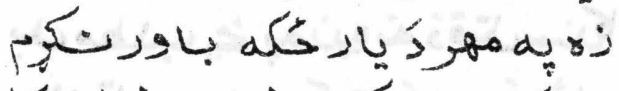

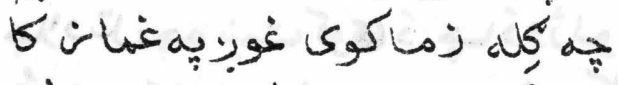

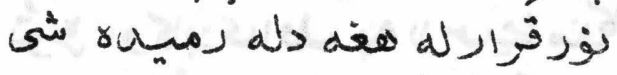

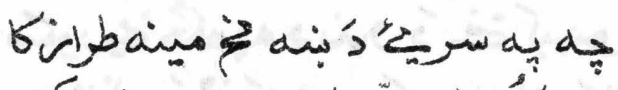

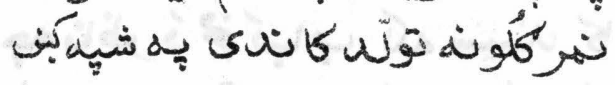

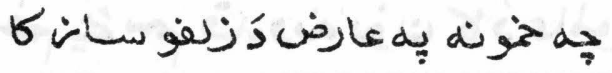


ديوالِِاشرتخانإُجرى

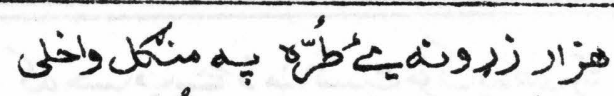

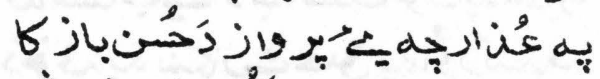

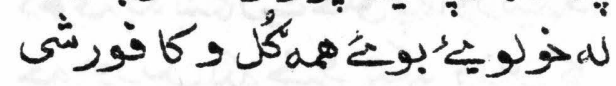

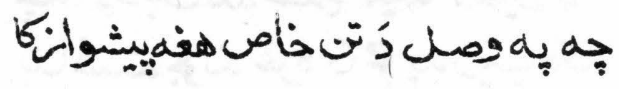

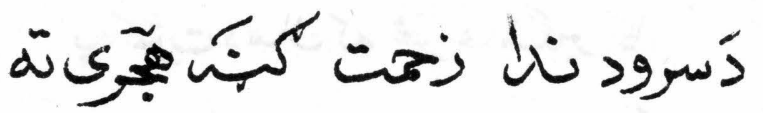

هil

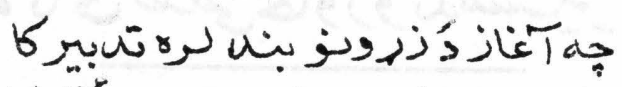

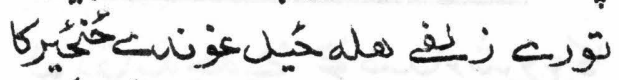

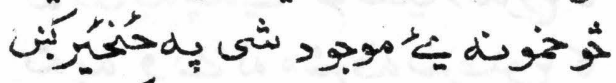

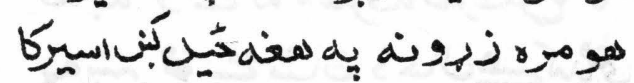

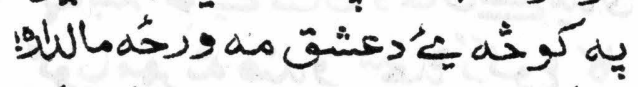

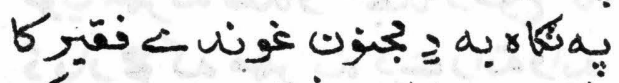

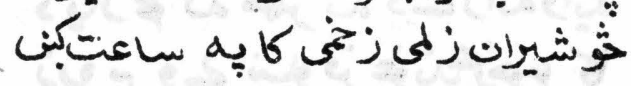

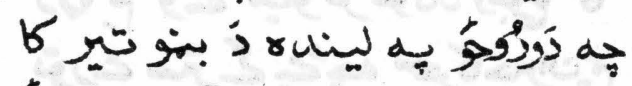
بها

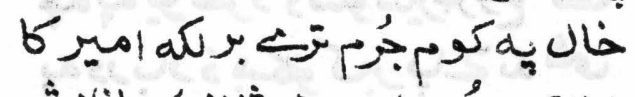

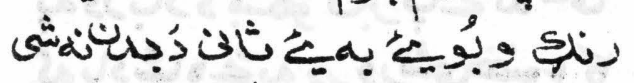

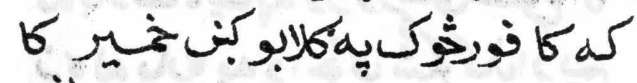

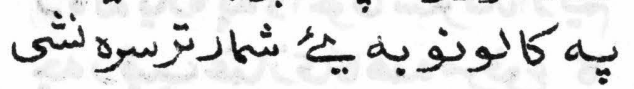




\section{ديوانِاشرنخانجري}

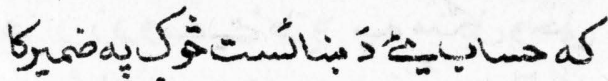

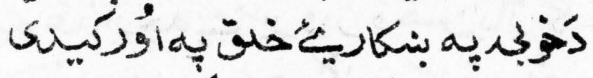

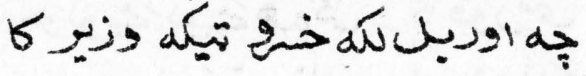

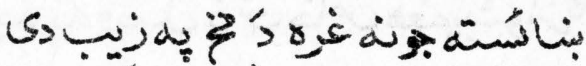

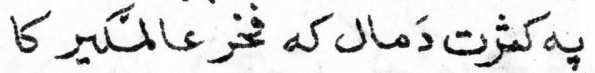

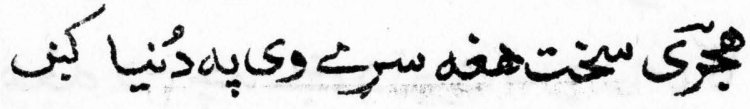
جه نا

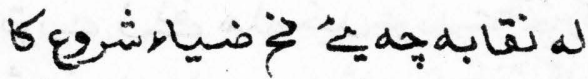

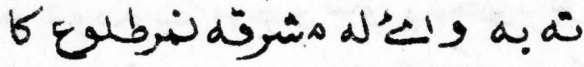

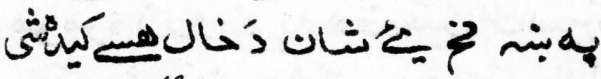

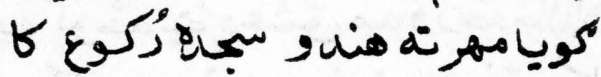

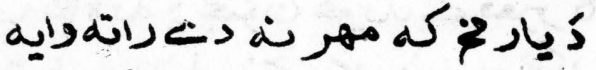

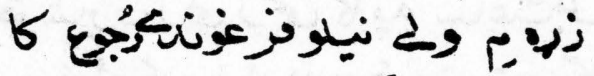

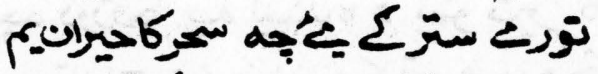

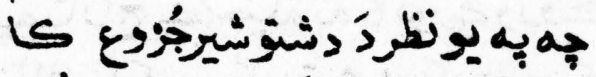

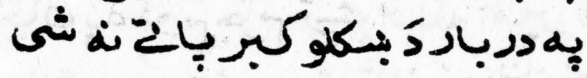

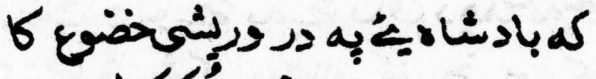

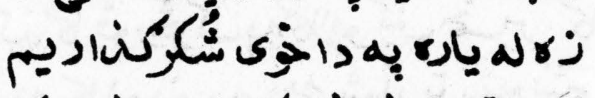

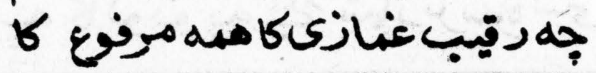




\section{حيواتِ اشروتخانجِرى}

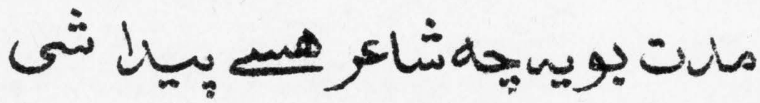

ك

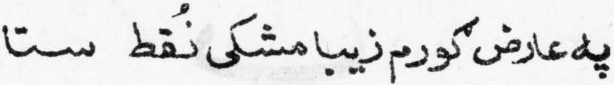

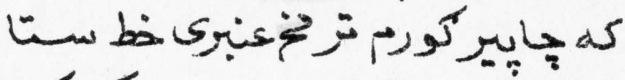

هإ

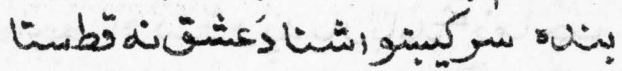

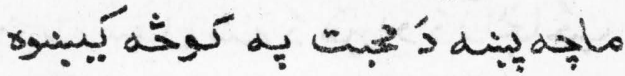

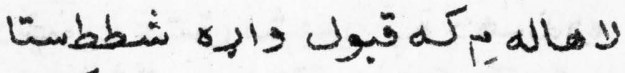

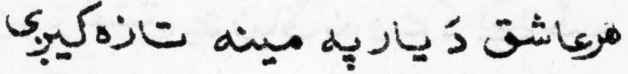

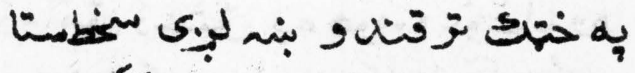

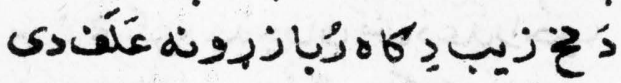

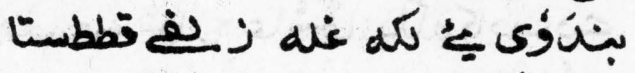

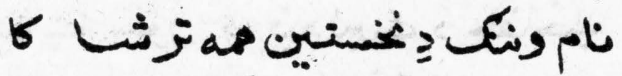

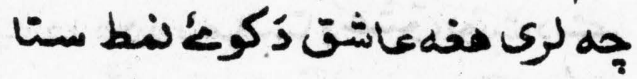

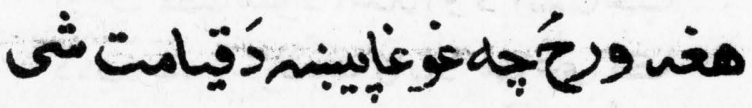

' 


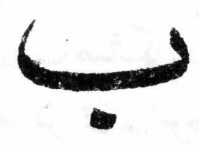

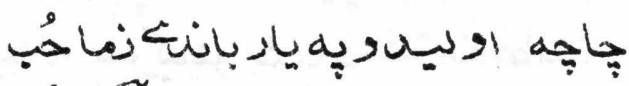

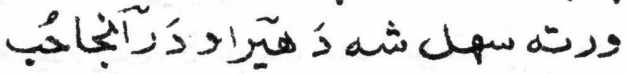

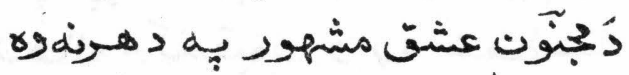

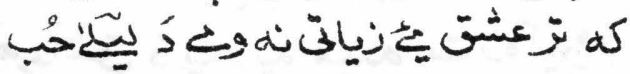

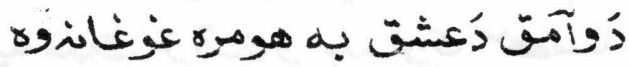

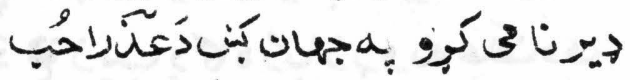

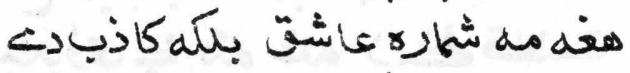

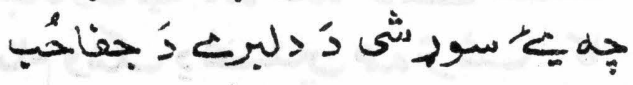
رها

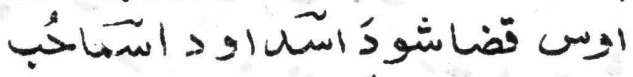

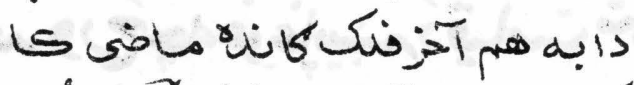

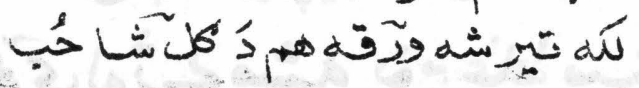

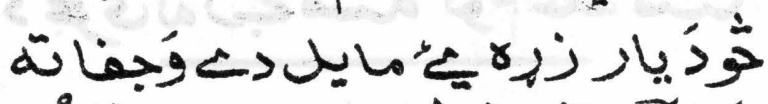

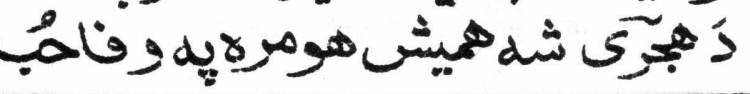




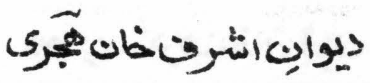

جهابز

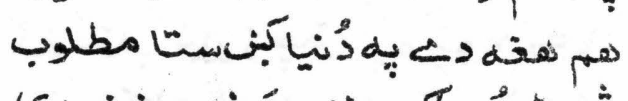

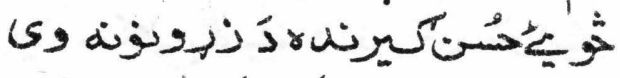

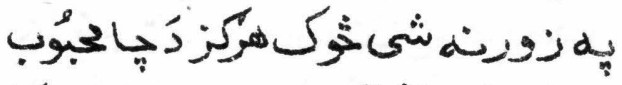

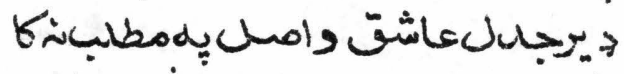

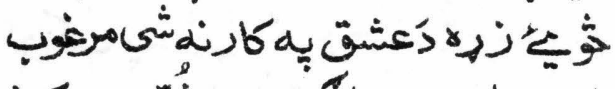

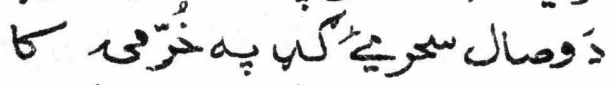

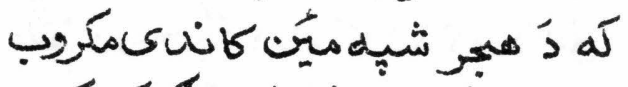

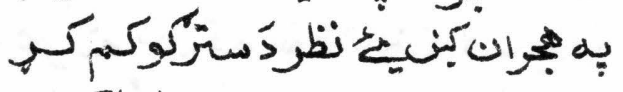

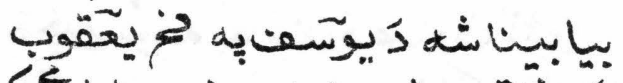

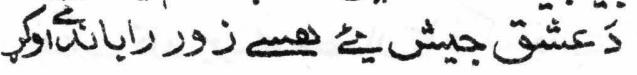

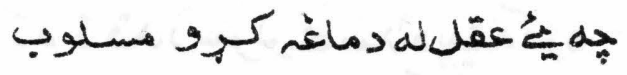

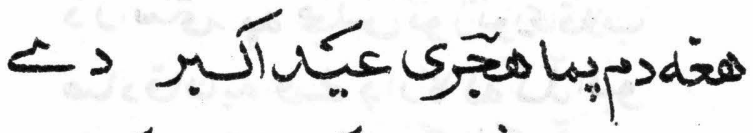
جه نازل شَى به دكم ديارمكتّوب

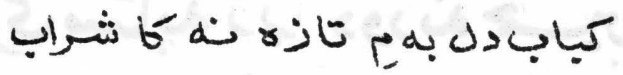

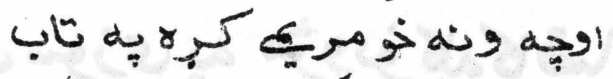

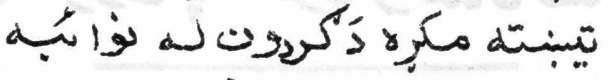

المر

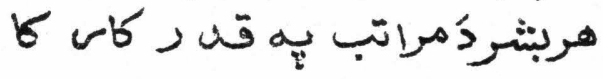




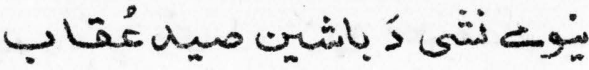

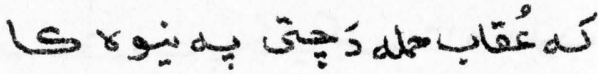

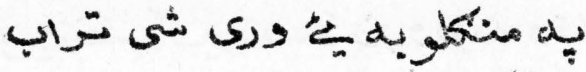

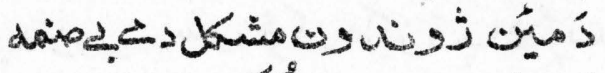

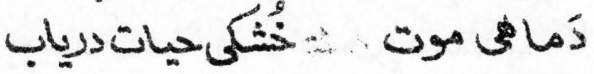

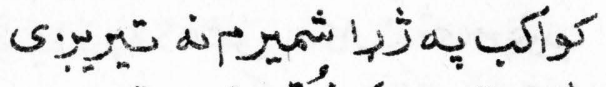

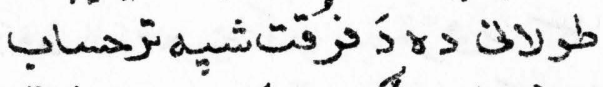

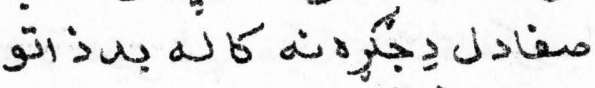

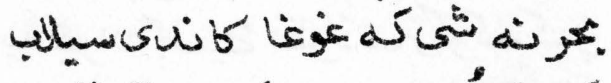

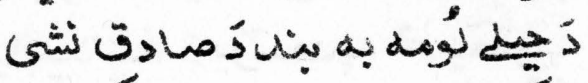

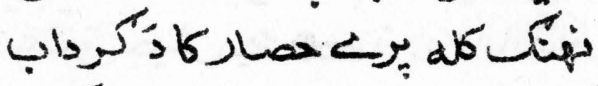

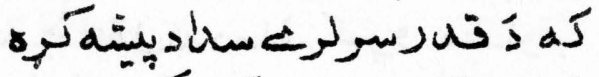

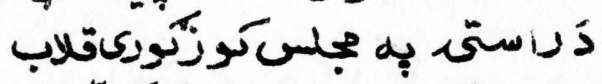

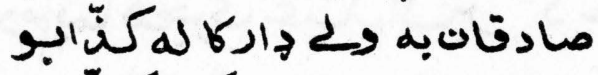

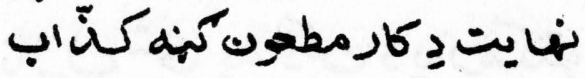

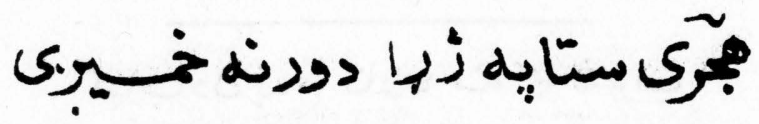
دل سوزى يه مزّونز كلهكاثضاب 


\section{ديوانِاشرتخانهُرى}

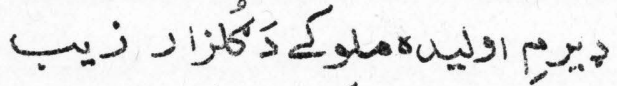

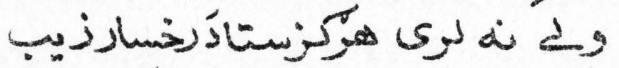

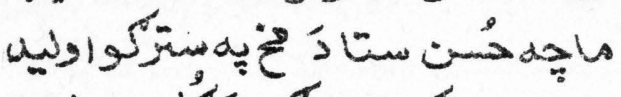

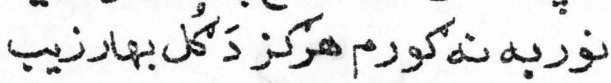

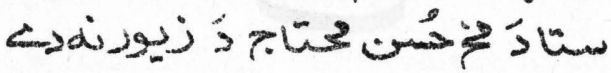

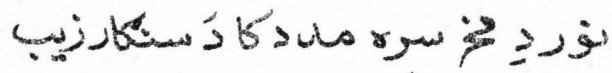

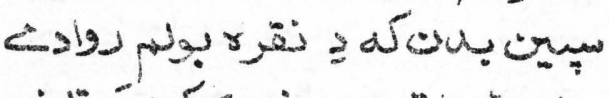

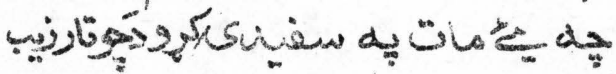

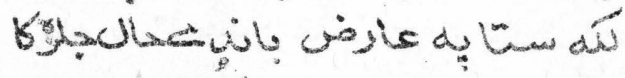
بـ

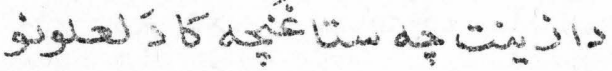
بل

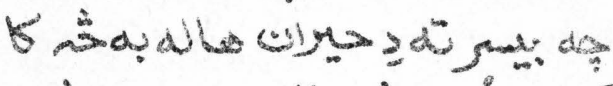

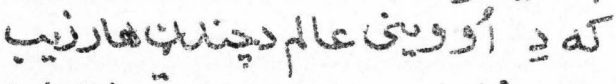

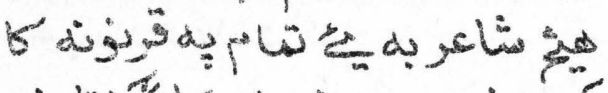

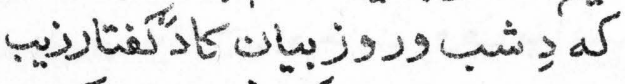

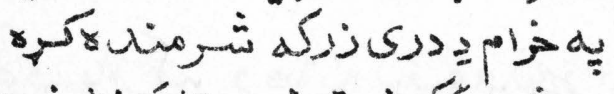

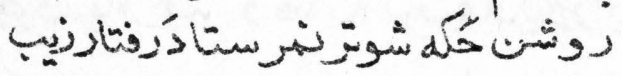

زهج

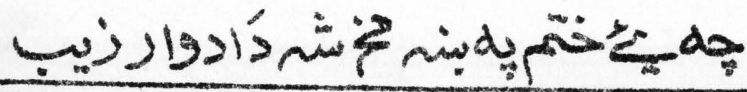




\section{ديوانِاشرتخانبِي}

\section{$\infty$}

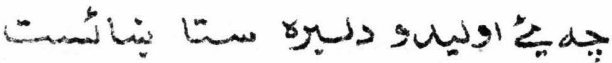

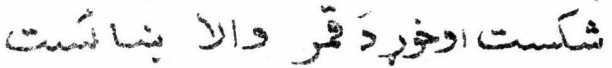

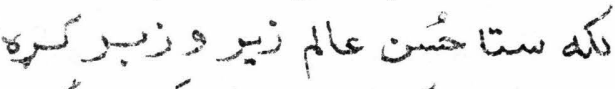

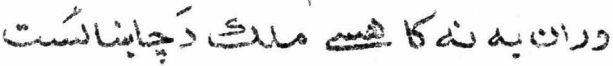

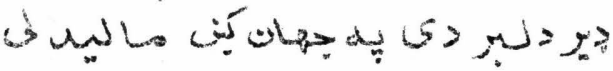

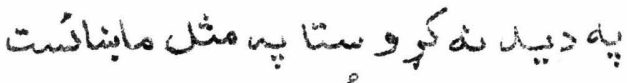
جه

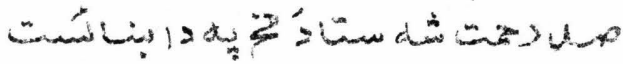

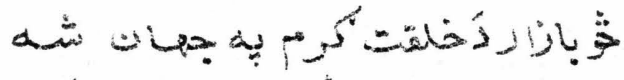

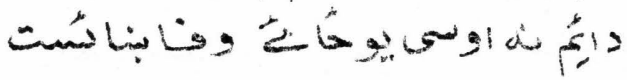

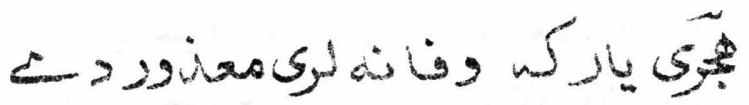

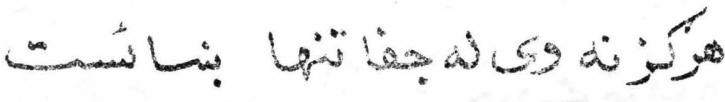




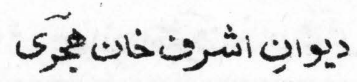

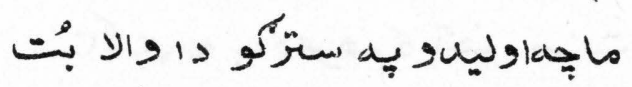

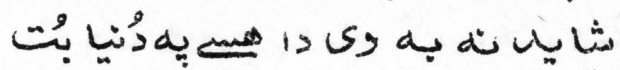

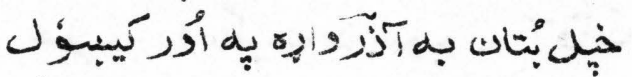
به زورنا

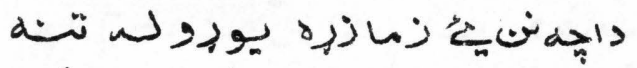

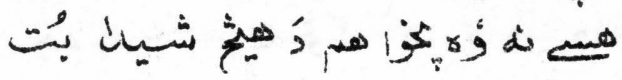

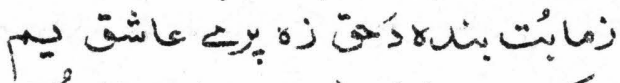

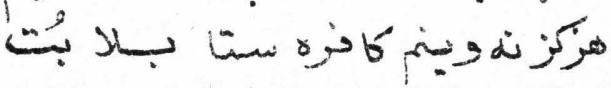

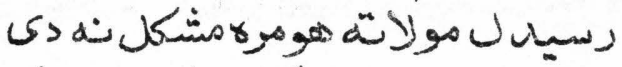

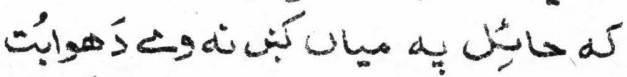

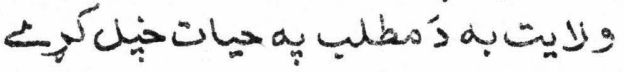

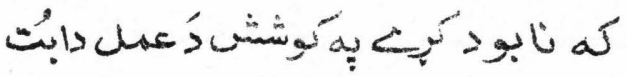

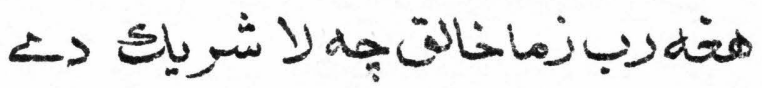


كأق E ت

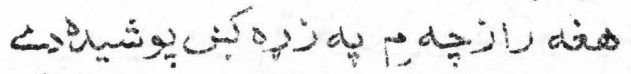

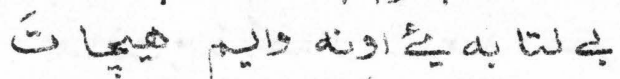

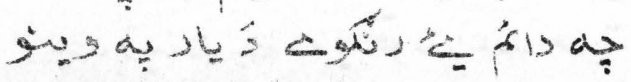




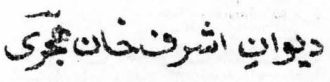

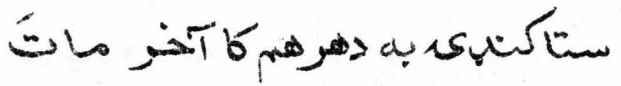

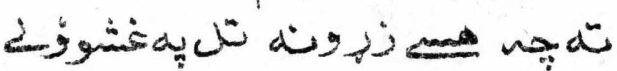

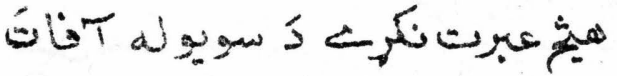

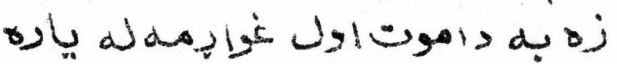

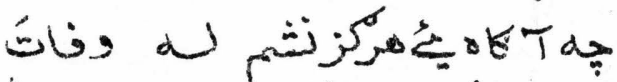
جها جه

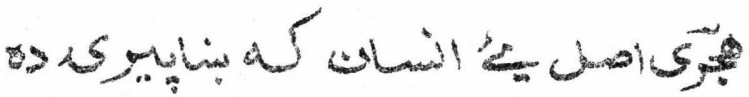

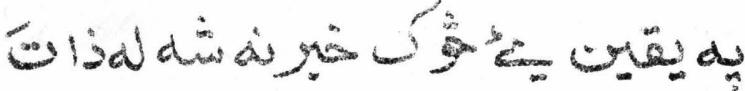

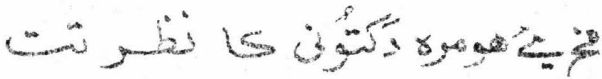

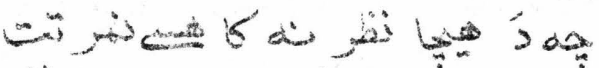

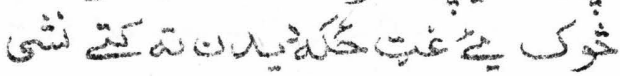

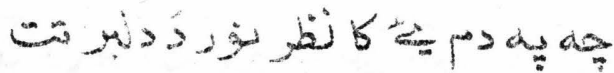

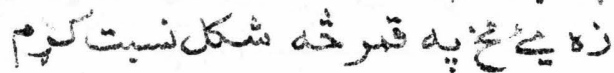

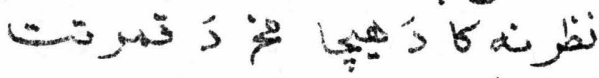

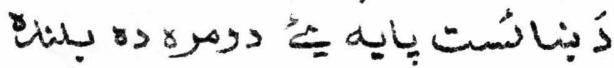

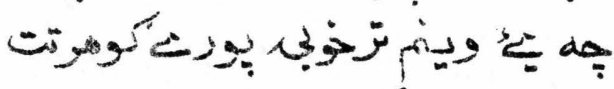

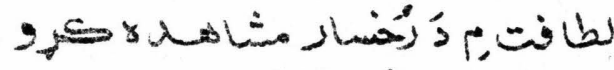

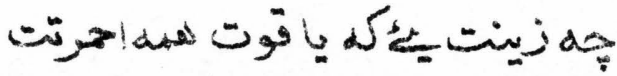




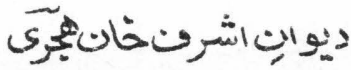

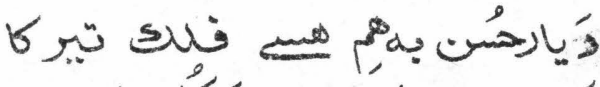

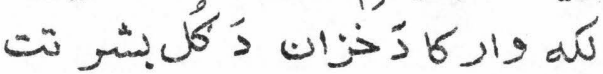

هرساعت

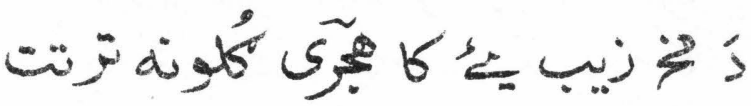

تز

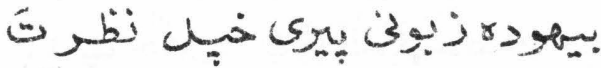

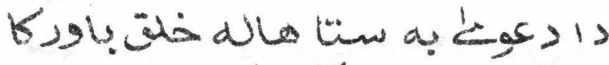

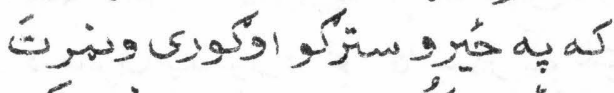

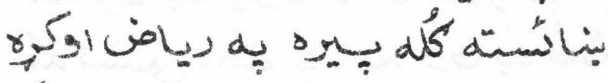

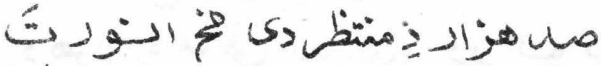

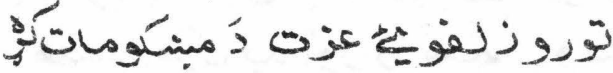

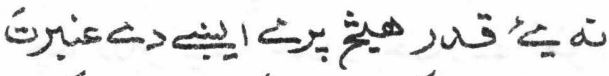

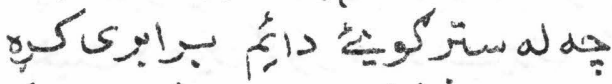

بنه به رئه

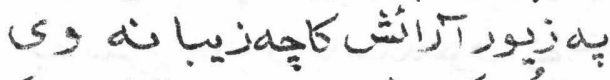

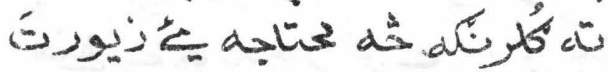

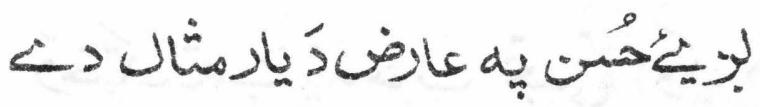

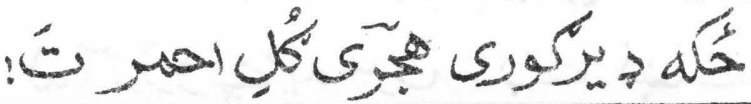




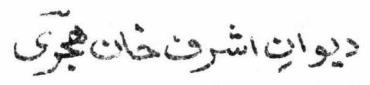

:

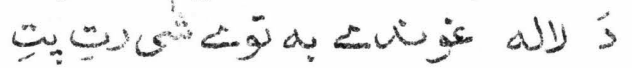

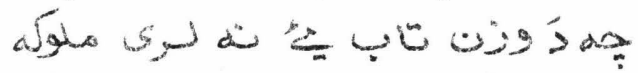
بوان

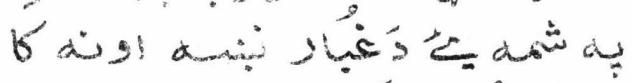

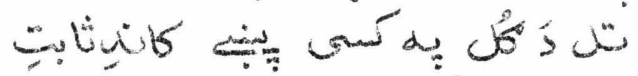

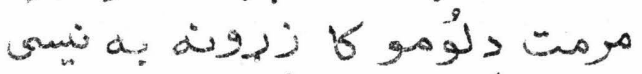
بيا

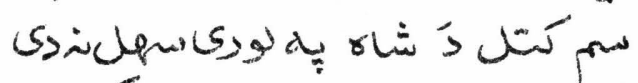

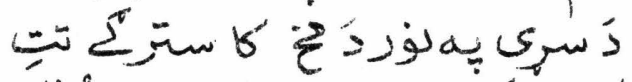

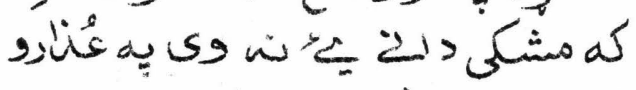

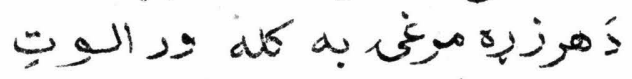

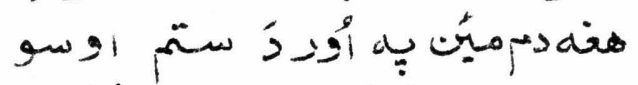

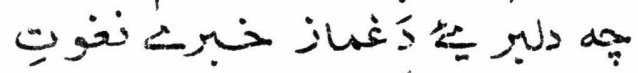

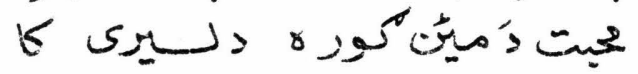

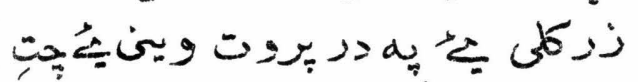

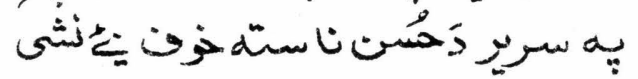

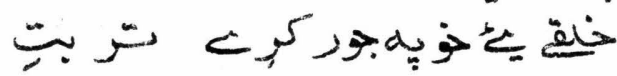

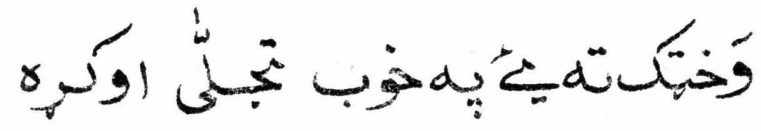

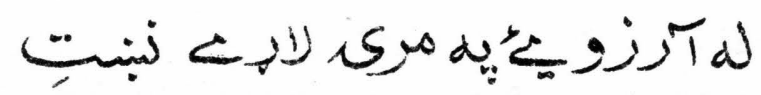




\section{1}

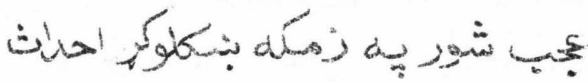

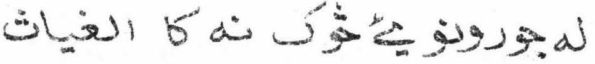

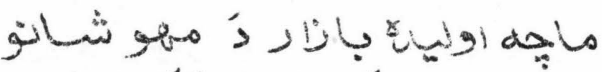

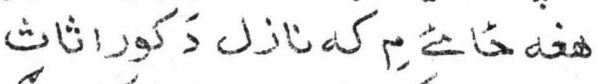
ن نَ

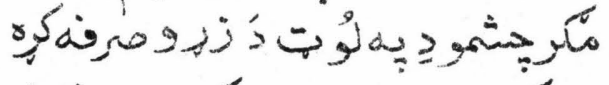

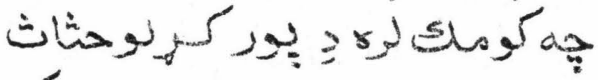

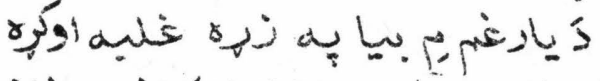
مطرب بو

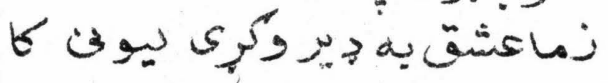

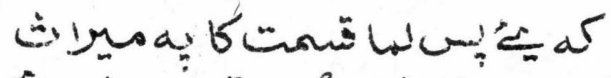

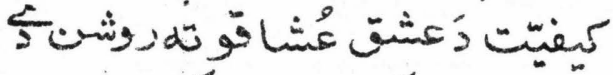

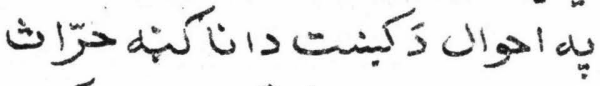
زم 
ديوإِاشرتخانهُ

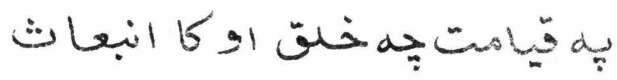

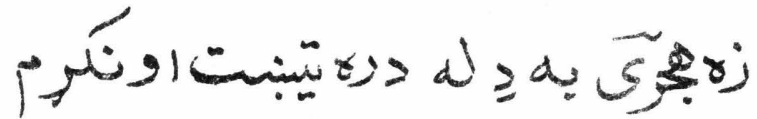

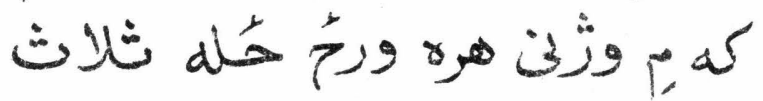

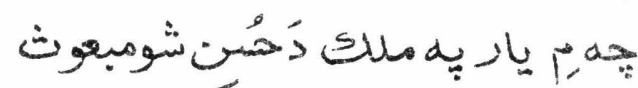

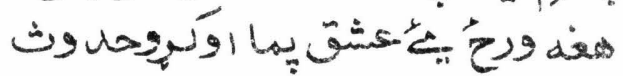

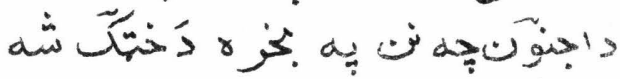

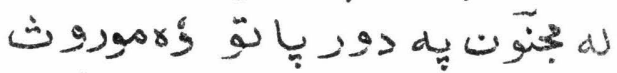

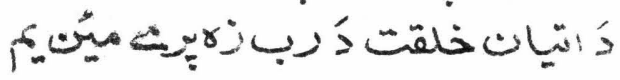

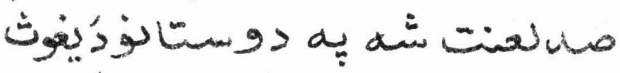

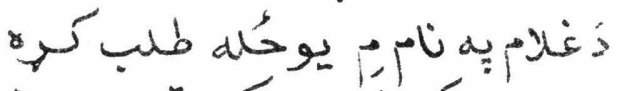

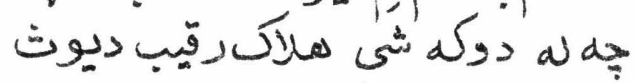

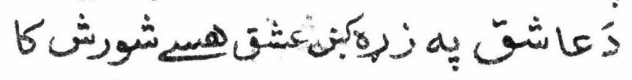

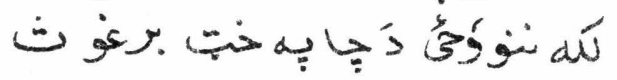

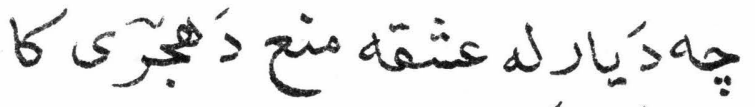

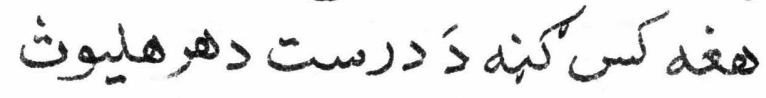

$\mu \cdot \wedge$ 


\section{حيوانِاشرتخانجيجرى}

زكاكهاوكرم سئا له جورك شاغنيات

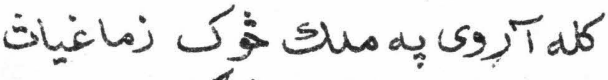

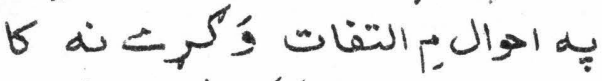

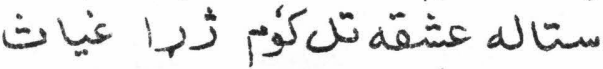

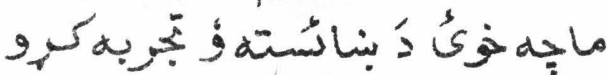

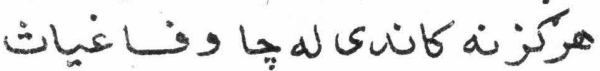

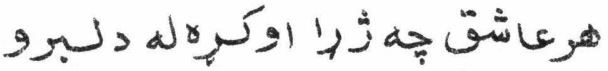

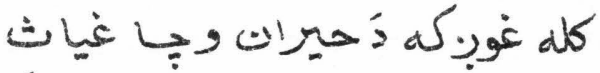

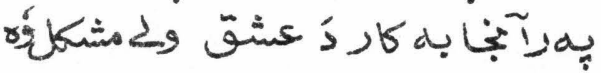

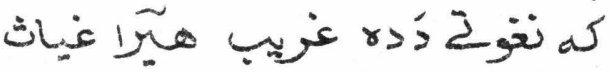

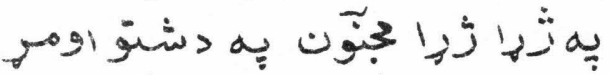

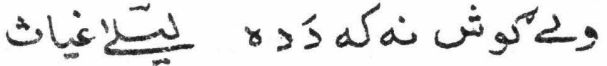

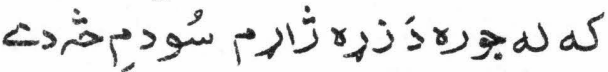

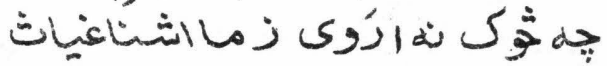

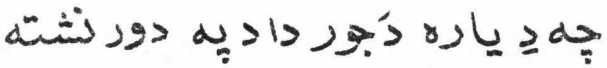

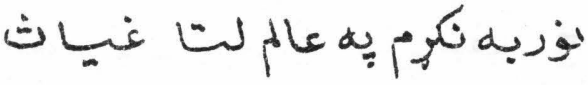

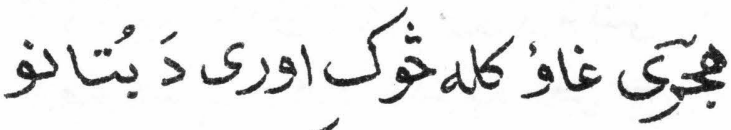

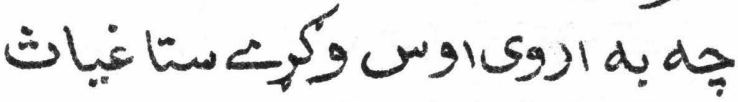




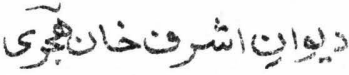

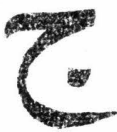

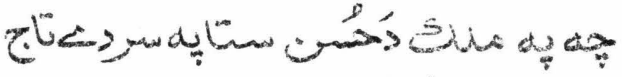

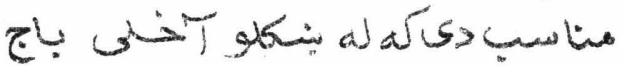

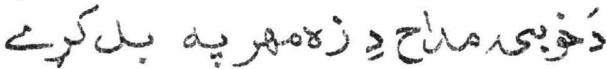
टla' l 6 L 6 , cos

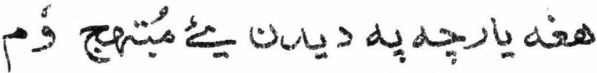
بـ

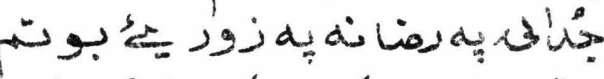

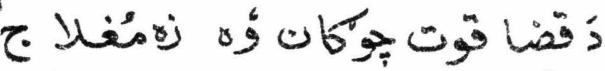
S'

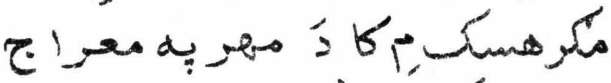
L C. .

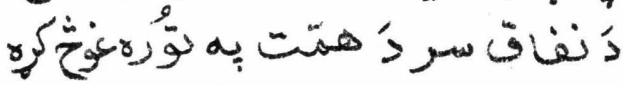




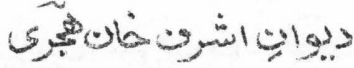

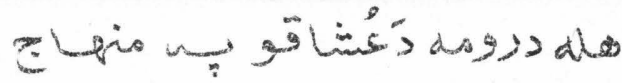

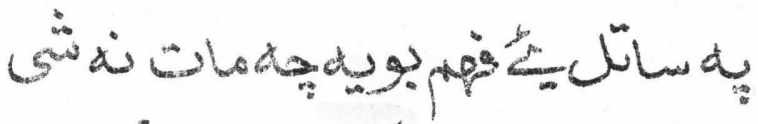
CLدj

تأجه كشق بئ

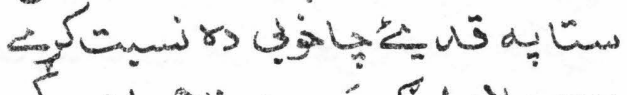
ह

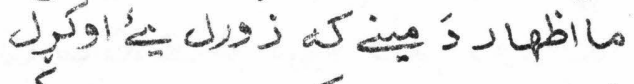

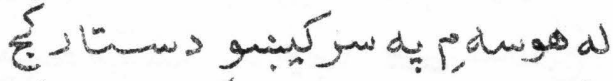
bأن

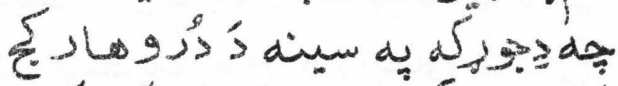

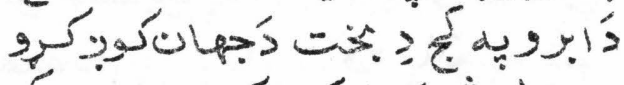

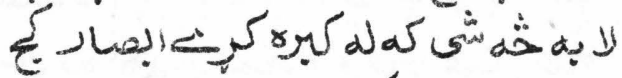

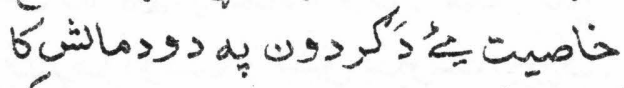

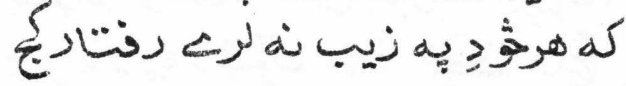

פ ₹ 


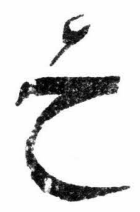

هُ

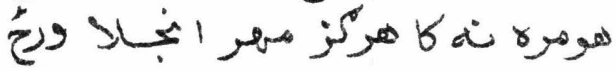

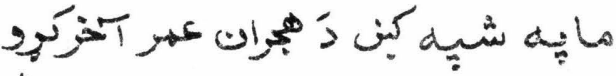

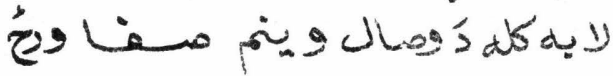

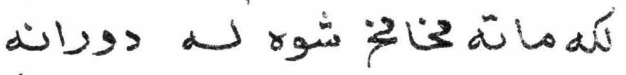

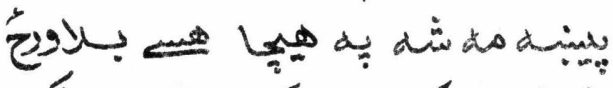

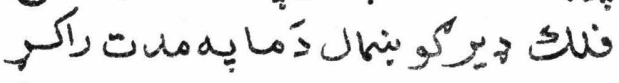

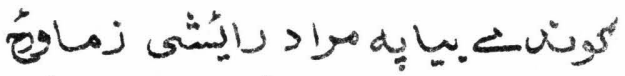
هنه حنز

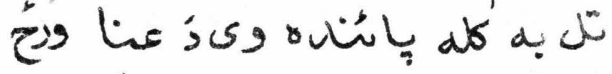

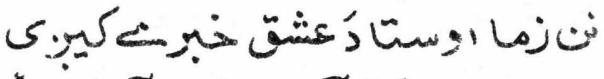

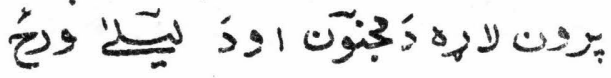

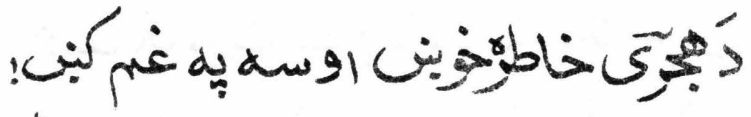
نهايت به 


\section{ديوانِ اشرتخانبهُى}

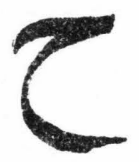

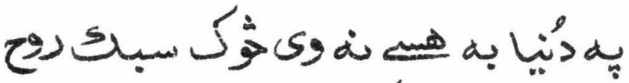

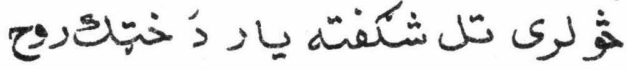

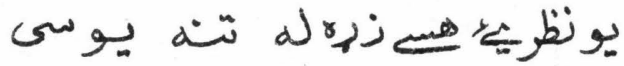

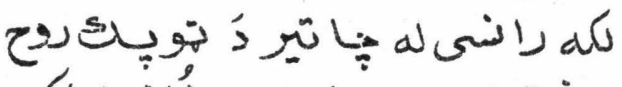

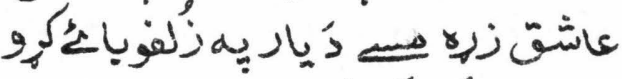

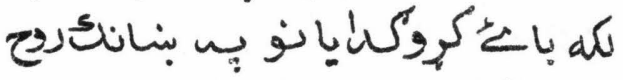

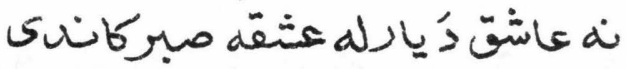

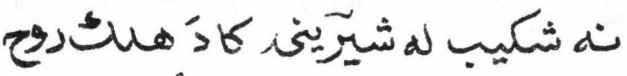

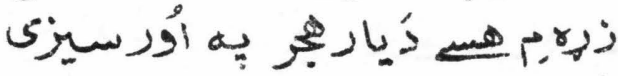

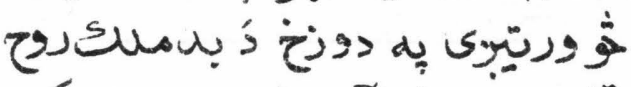

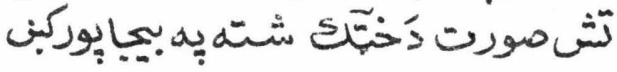

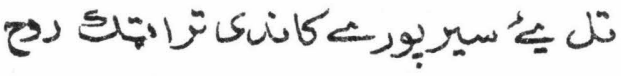

J لم

نه 


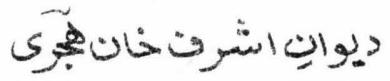

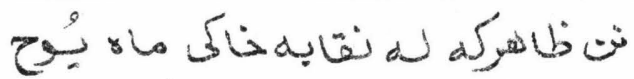

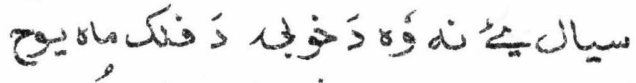

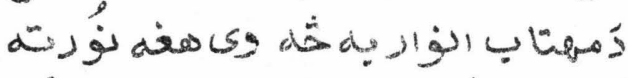
جه

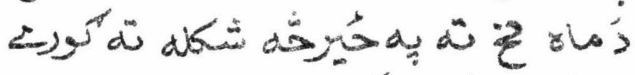

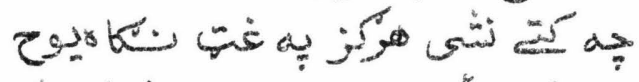
جن

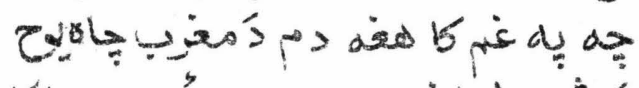

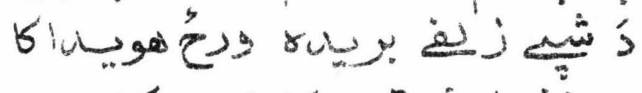

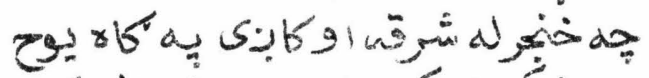

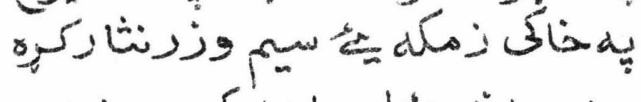
جله روانه

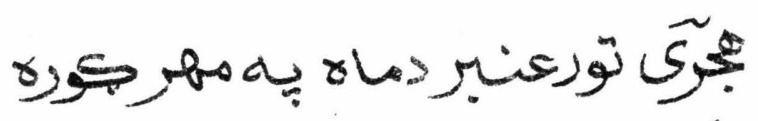

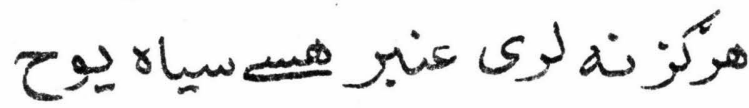




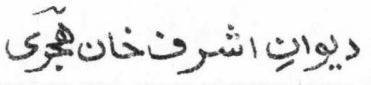

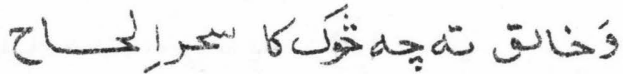

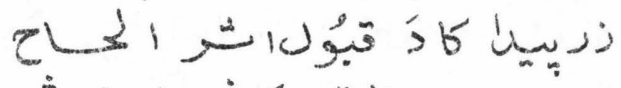

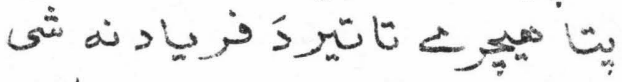

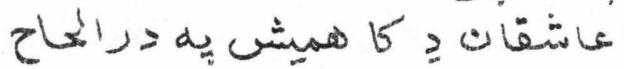

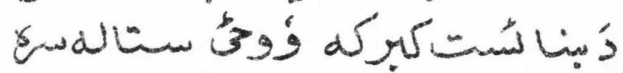

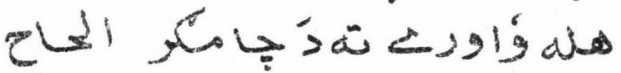

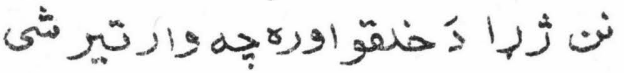

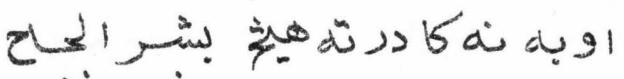

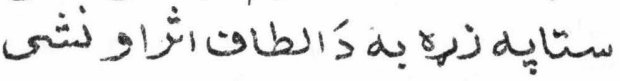

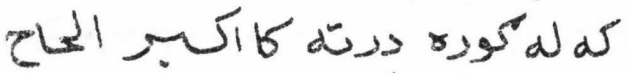

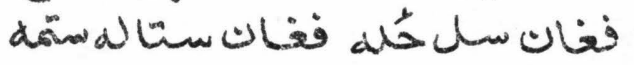

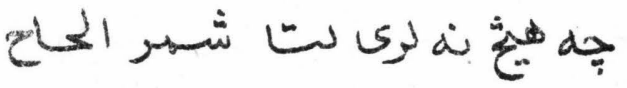

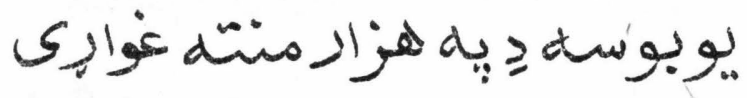

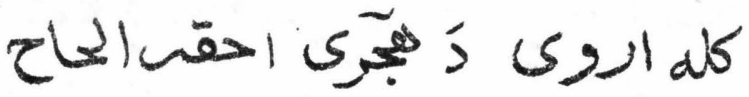

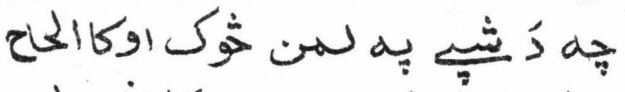

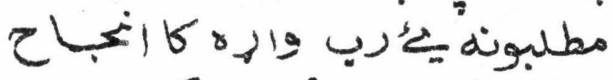

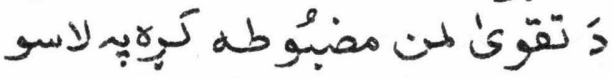
كه بكارج

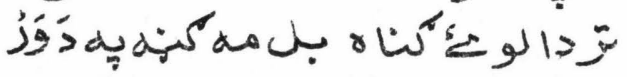




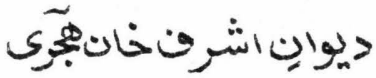

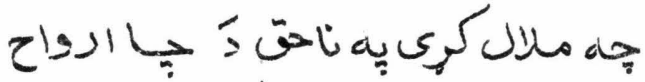

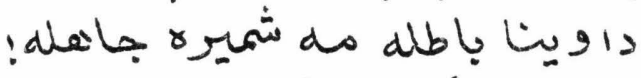

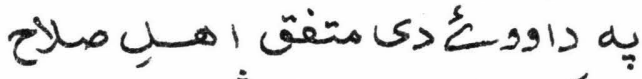

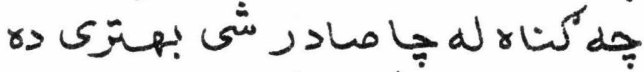

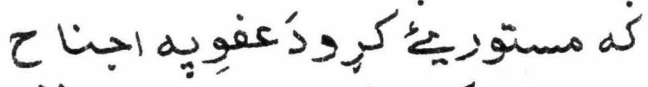

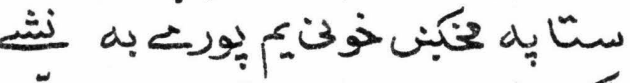

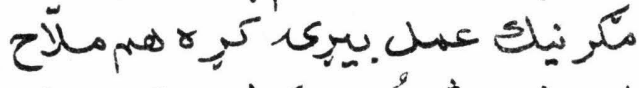

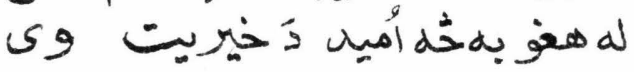

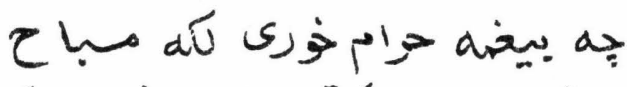

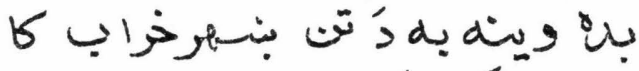

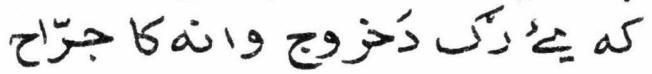

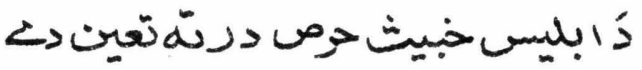

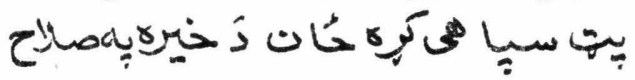

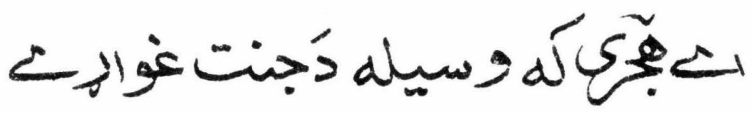

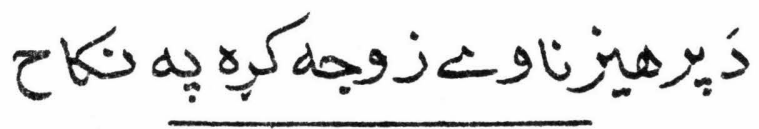




\section{$\dot{\tau}$}

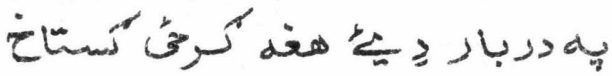

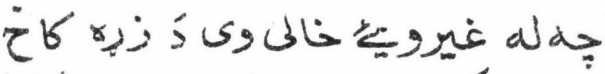

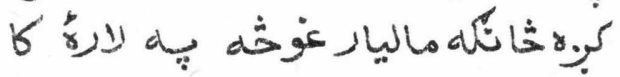

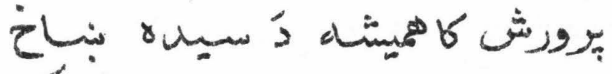

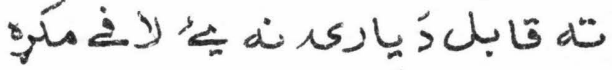

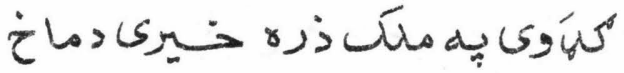

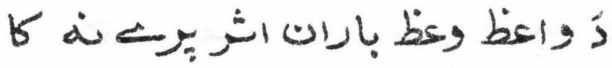

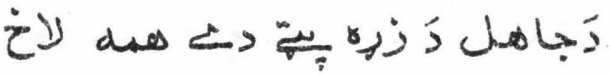

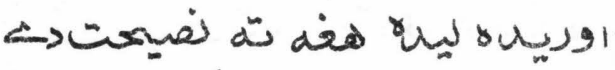

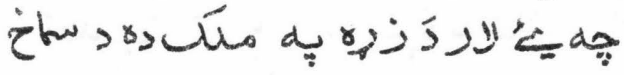
كا

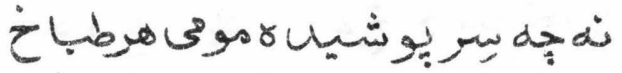

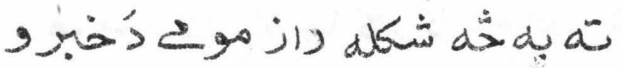

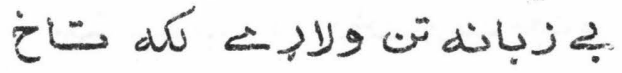




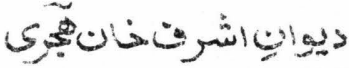

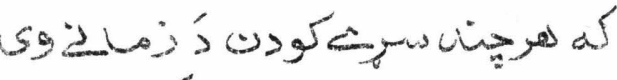

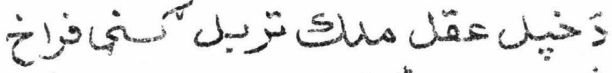

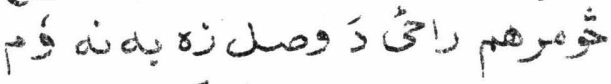

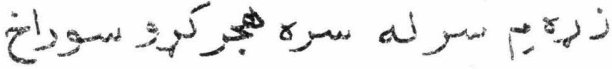

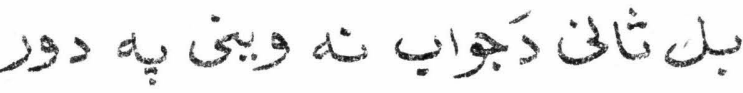

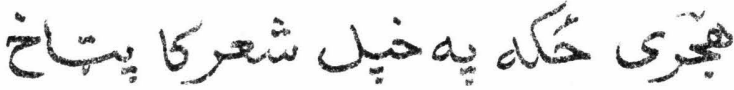

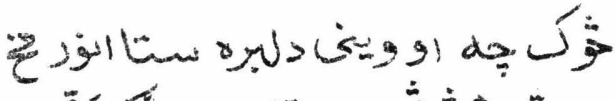

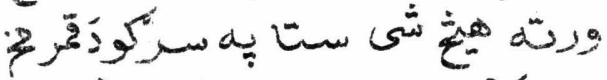

نسار

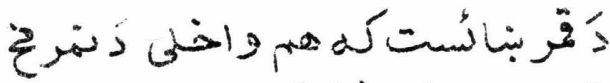

U

نه

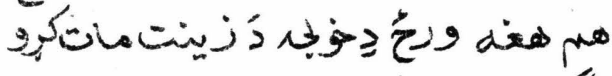

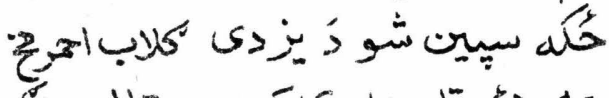

جه ئه

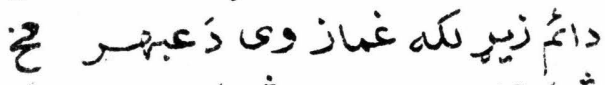

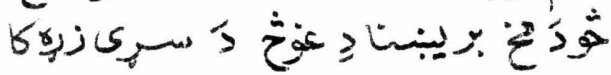

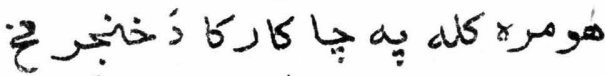

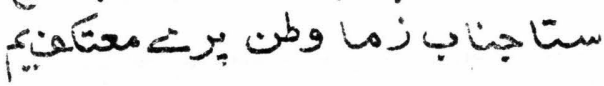




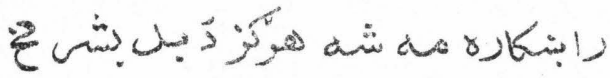

s s

ن

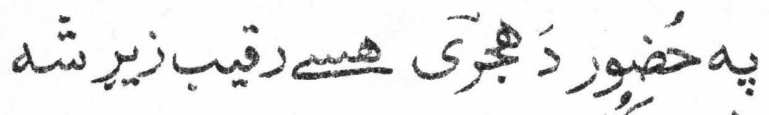
206

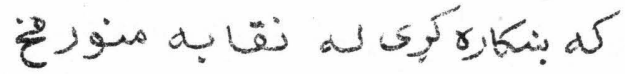

قال

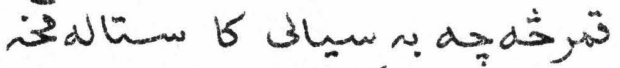

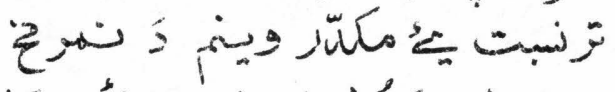

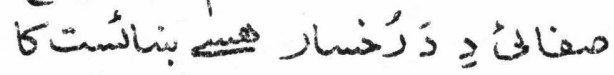

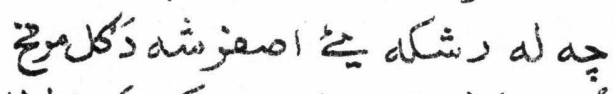

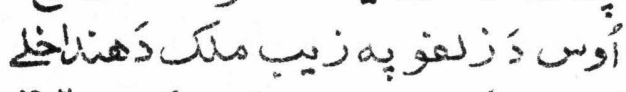

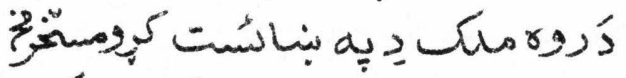

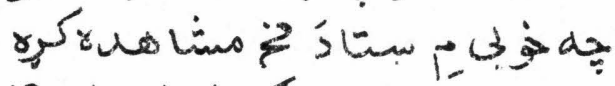

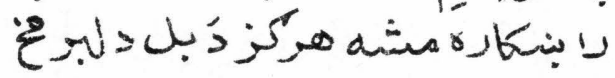

كَ'بتيب

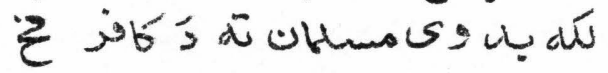

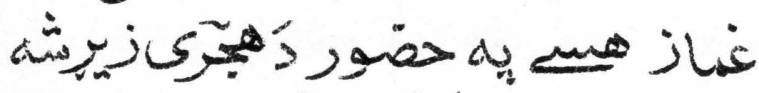
ن 


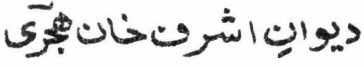

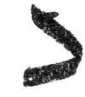

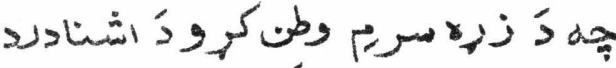

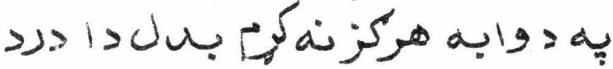

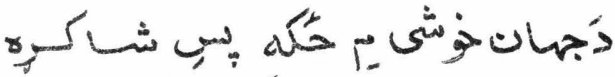
د

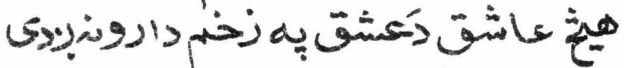

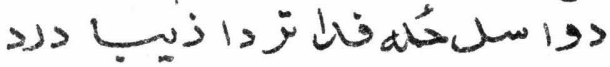

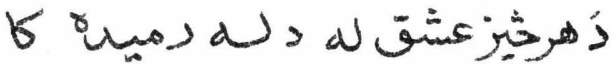

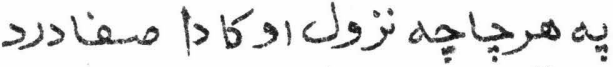

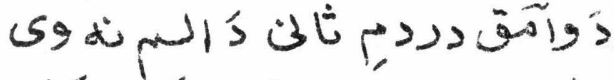

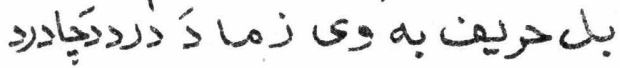

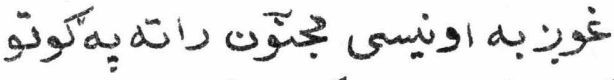

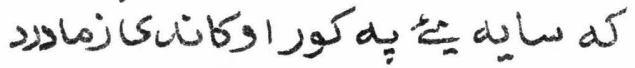

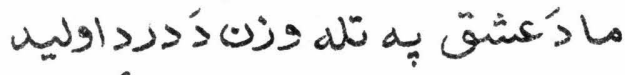

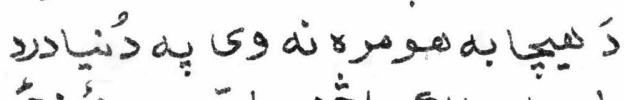

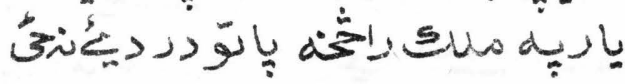




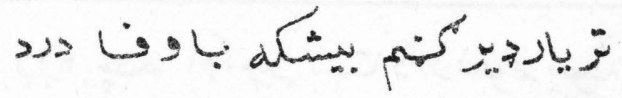

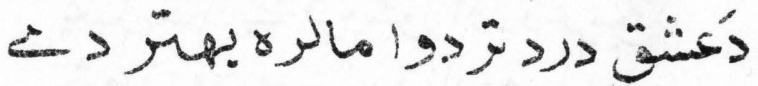

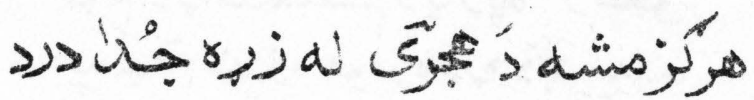

يا بيتحِن ؤه

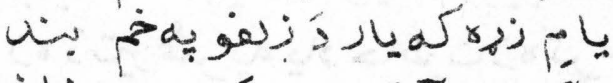

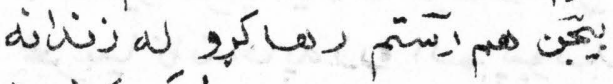

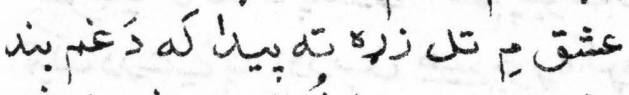

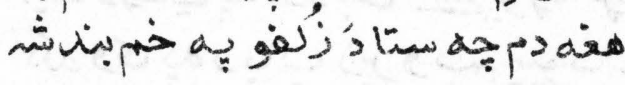

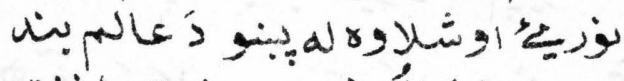

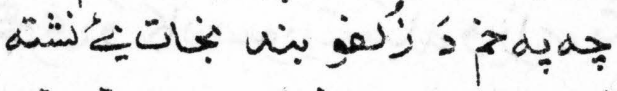

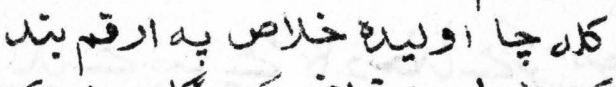

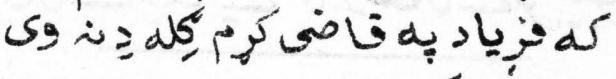

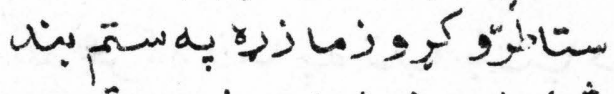

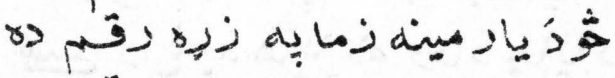

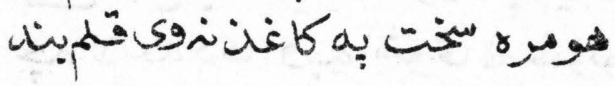

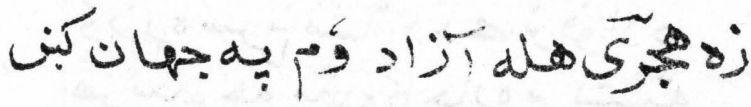

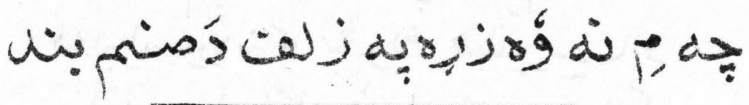




\section{>يوانِ}

ل ن زو

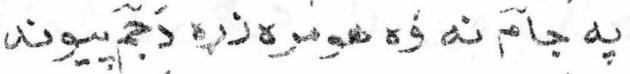

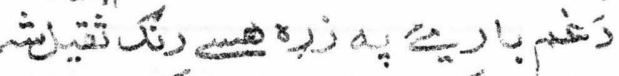

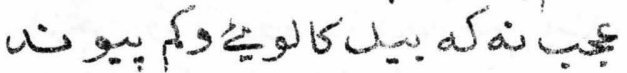

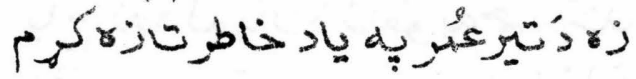

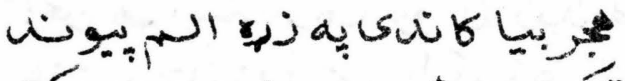
تئست لك ه U.

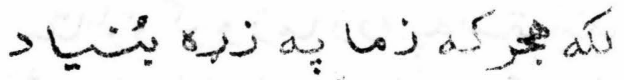
هي جه لإنة

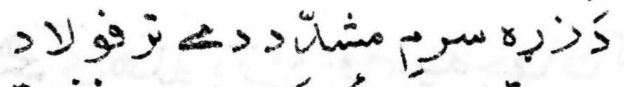

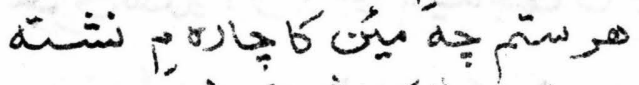

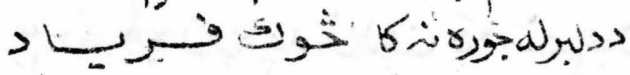

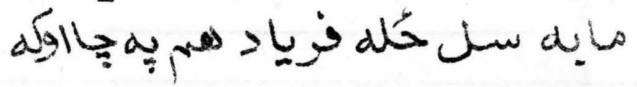




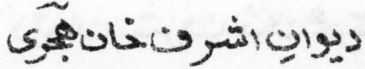

sists alcos's

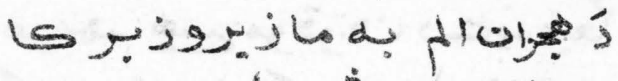

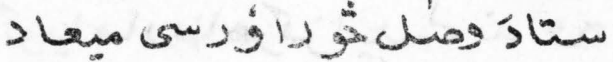

oy y y

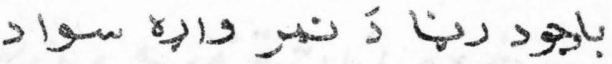

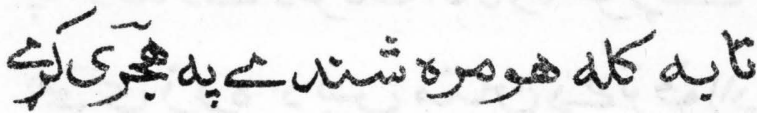

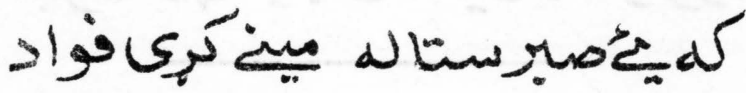

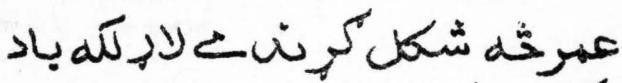

كئل

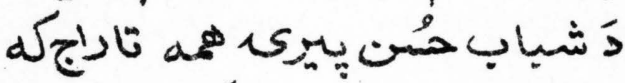

造

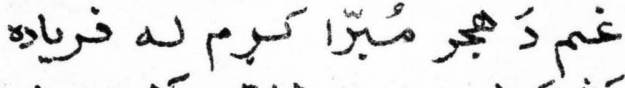

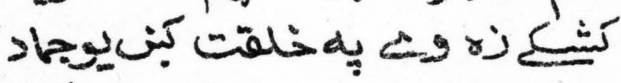

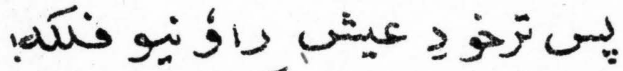

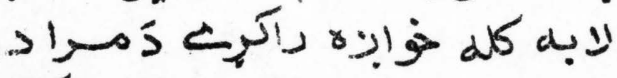

:

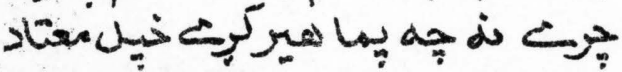

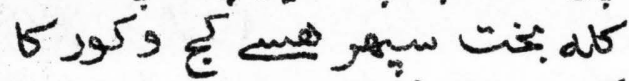

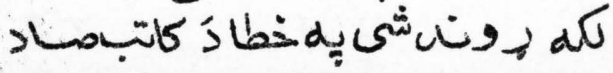




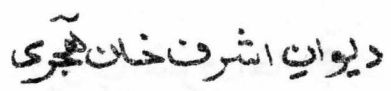

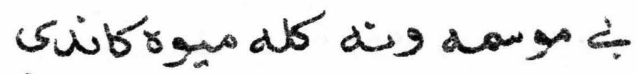

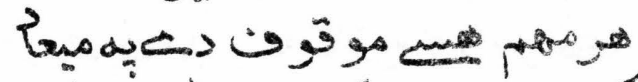
كو

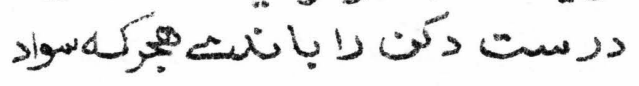

L جهان

لإن

$\mu \mu k$ 


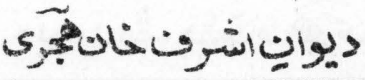

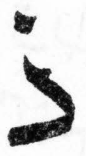

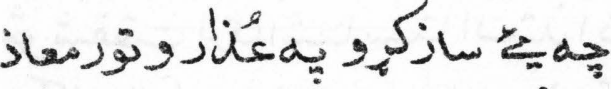

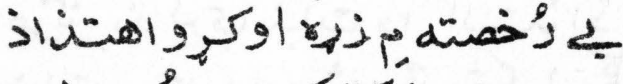

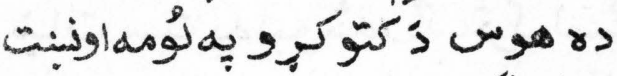

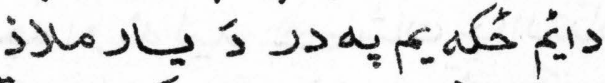

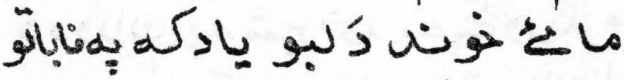

دارل

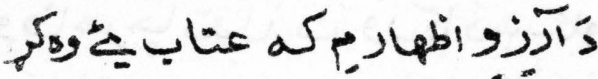

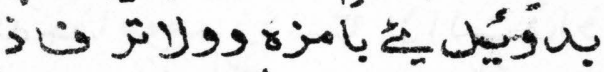

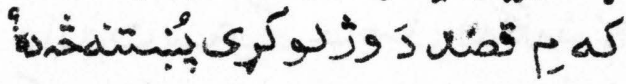

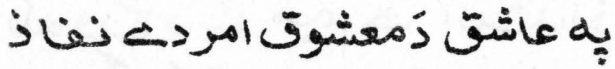

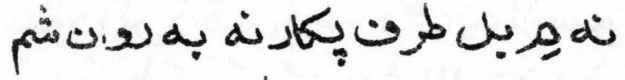

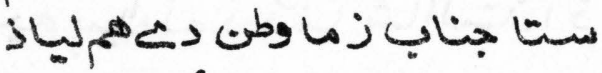

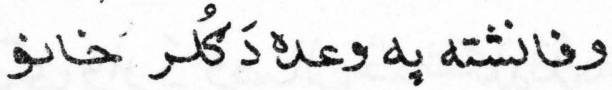

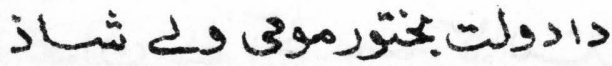




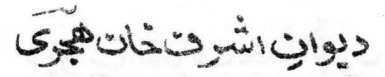

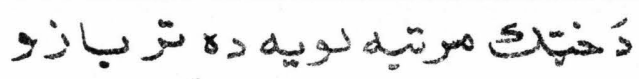

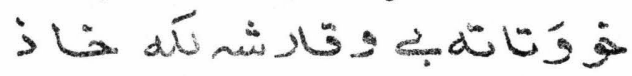

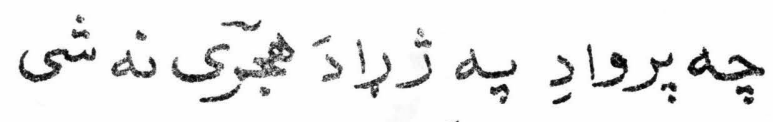
زيه

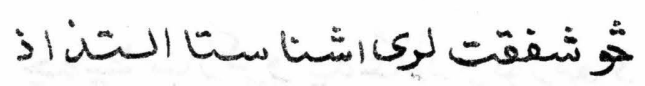

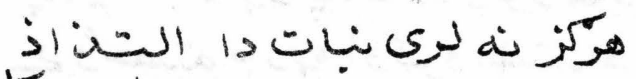

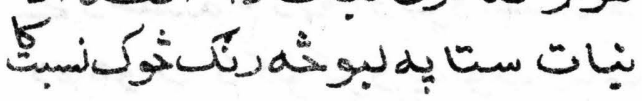

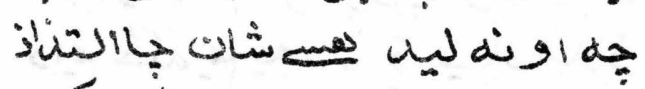

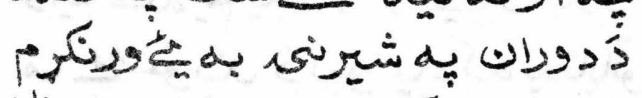

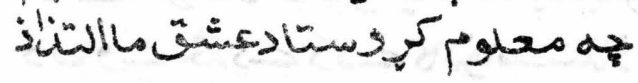

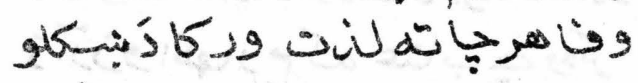

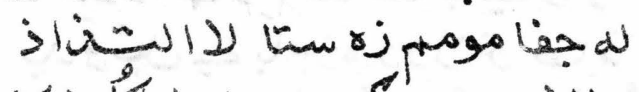

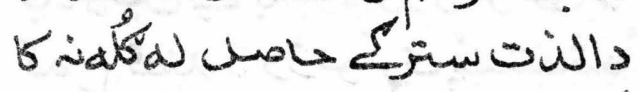

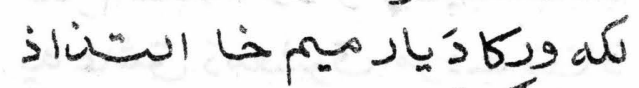

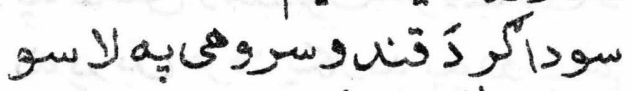
>

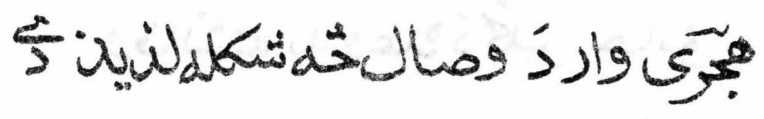
ذإن 
ديوانِاشربتخانهيجرى

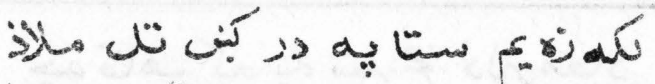

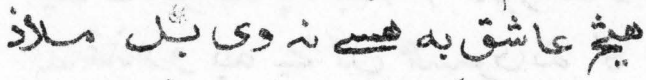
r)

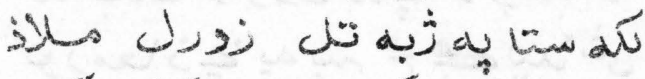

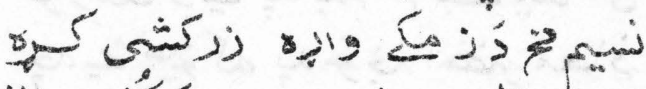

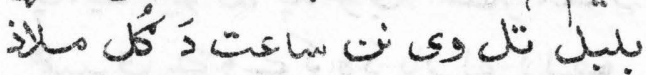

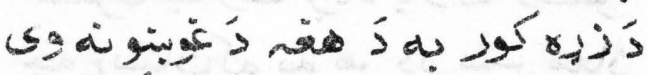

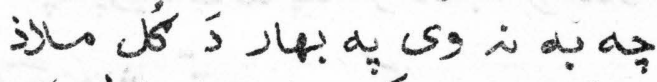

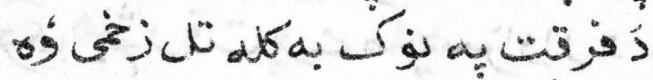
كأك

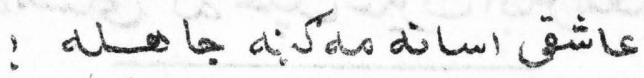

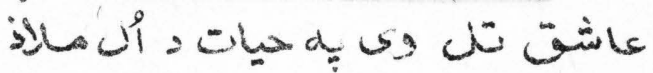

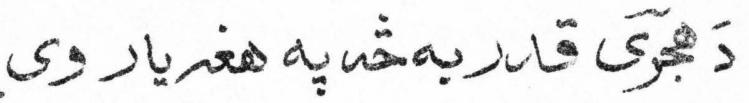

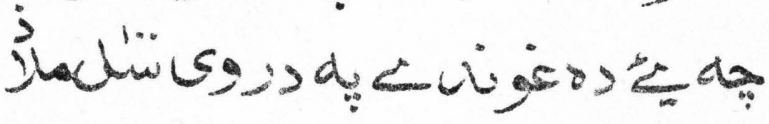

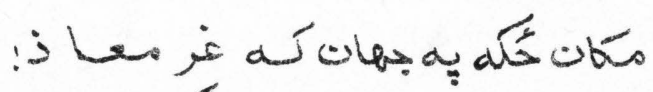
ذيا

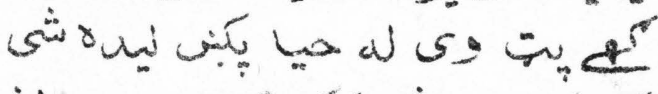

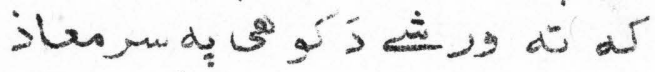

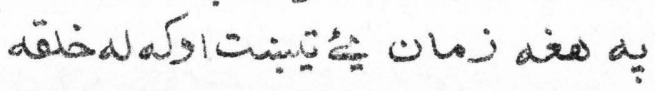

pM 


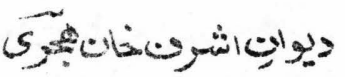

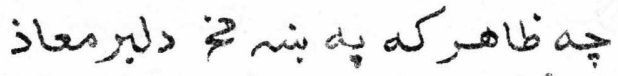

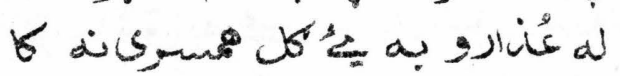

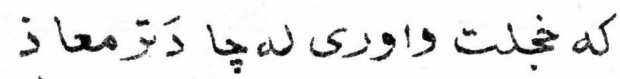

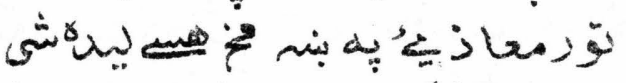
ileo

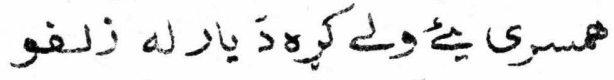

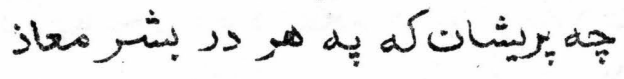
L بهمستى كم خيل غيرت ابتريكان

rkn 


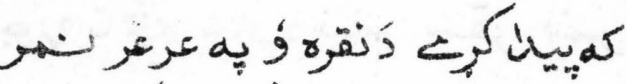

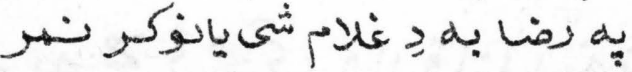

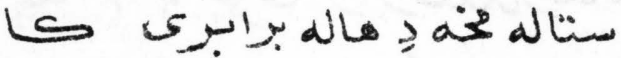

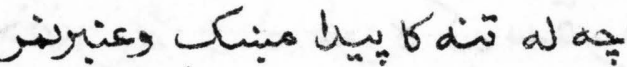

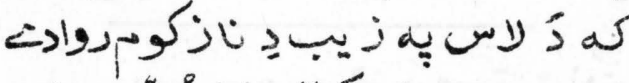

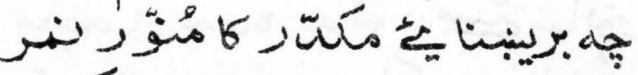

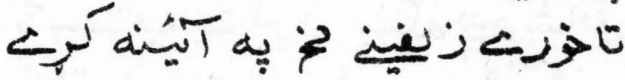

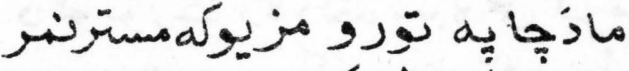

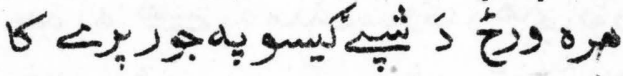

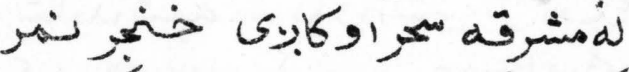
digs

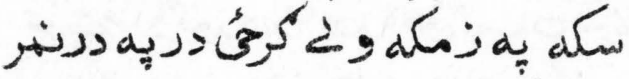

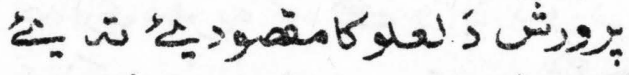
- ن

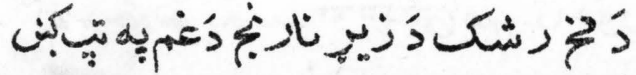




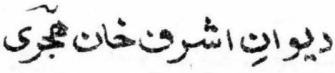

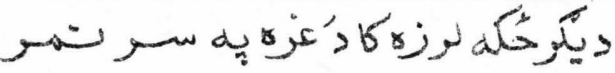

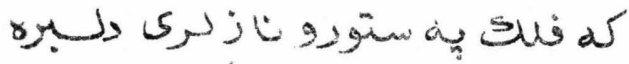

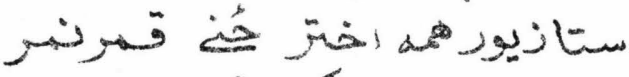

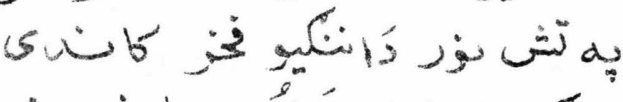

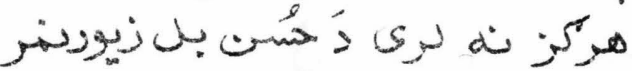

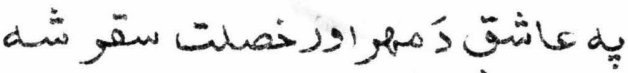

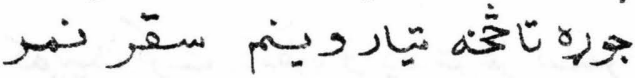

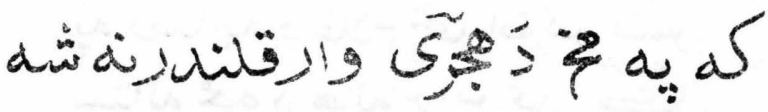

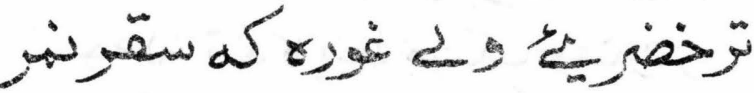

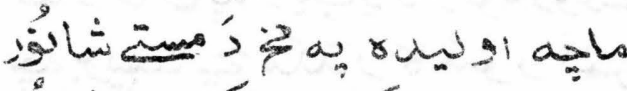

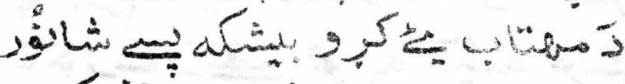
3'

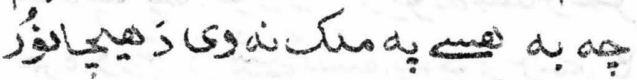

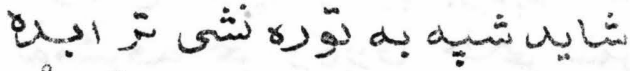
كأن ك

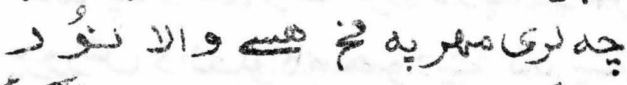

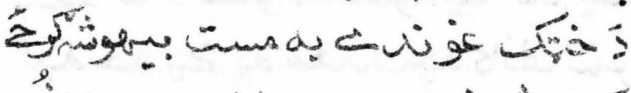

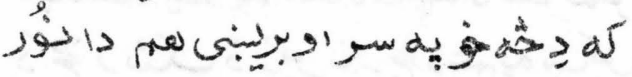




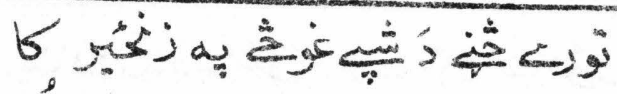

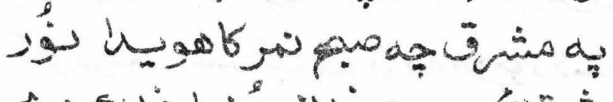

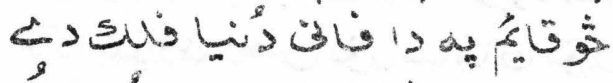

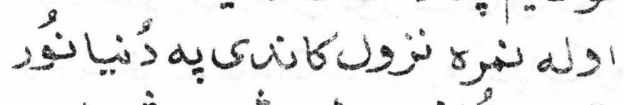

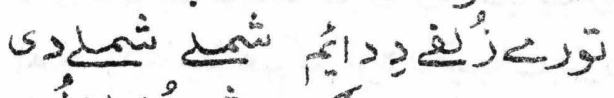

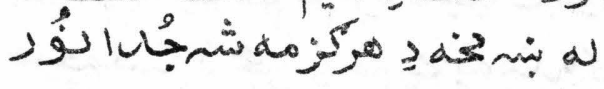

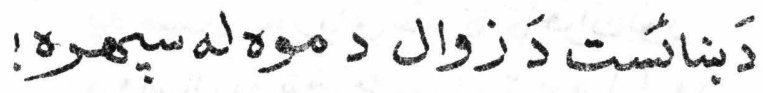
若

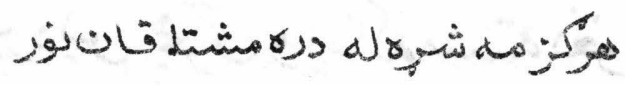

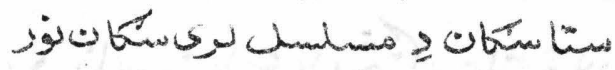

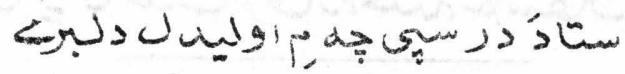

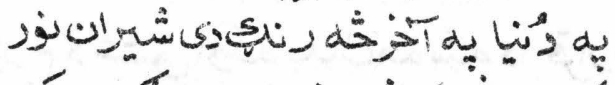

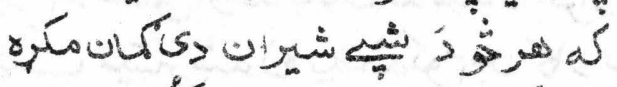

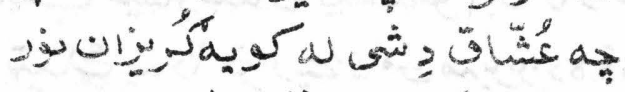

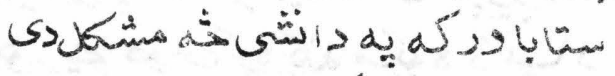

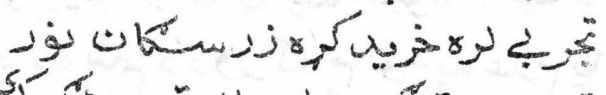

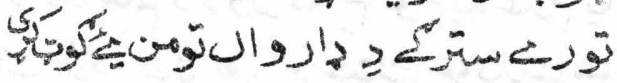

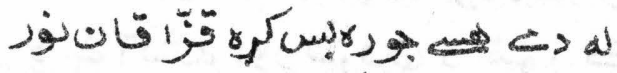

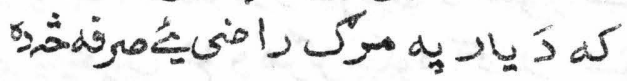




\section{حيوانِ اشرونخانمئى}

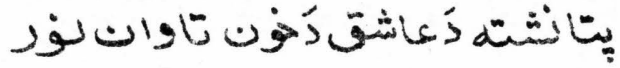

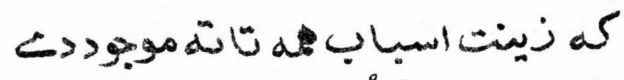

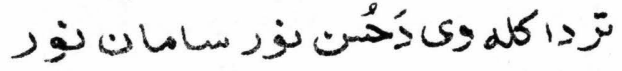

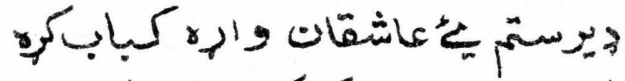

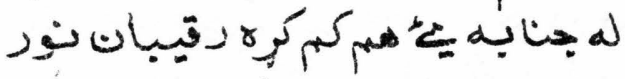

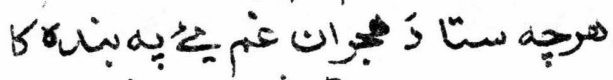

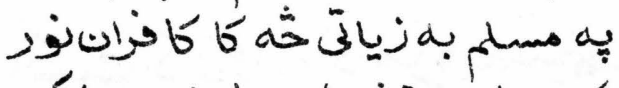

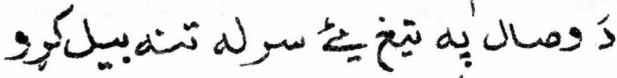

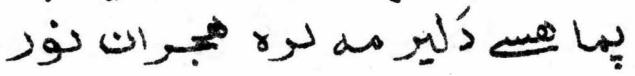

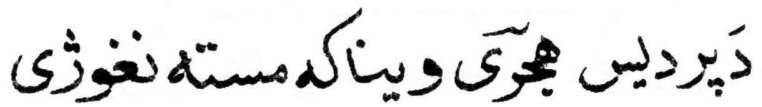

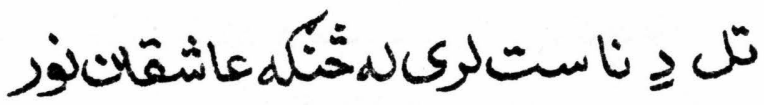

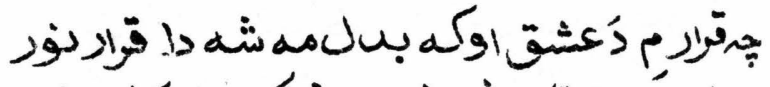

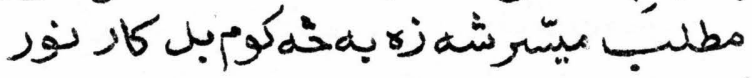

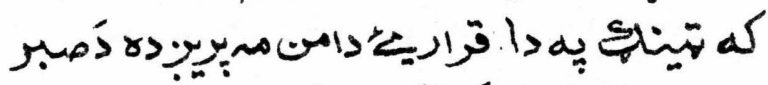

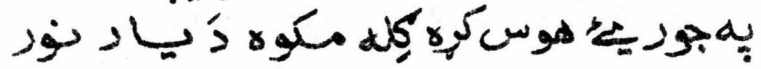

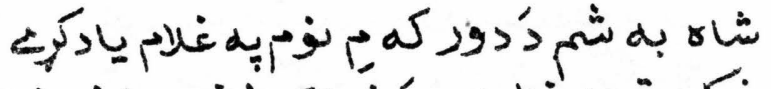

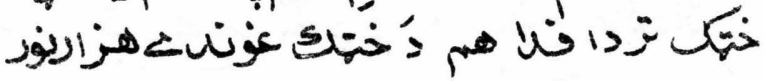

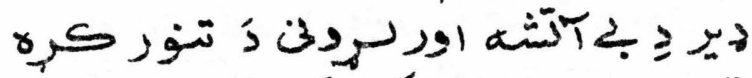

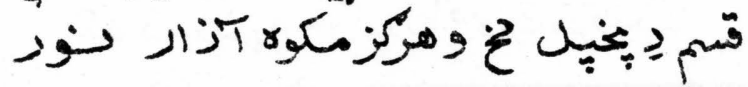




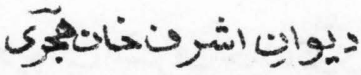

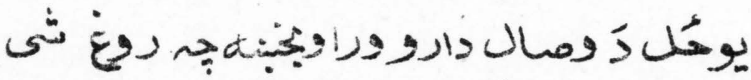

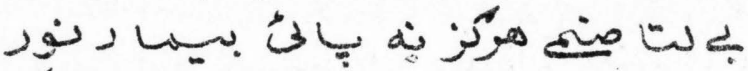

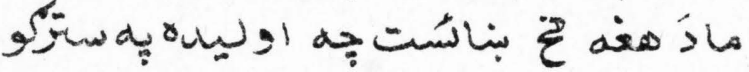

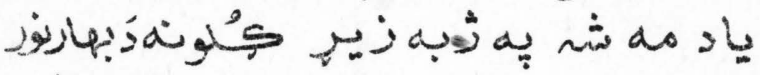
"

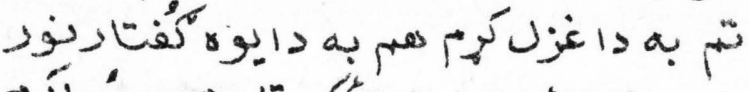

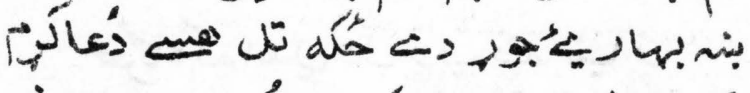

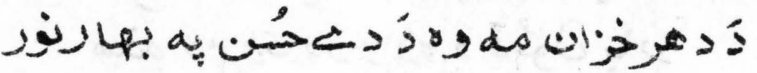

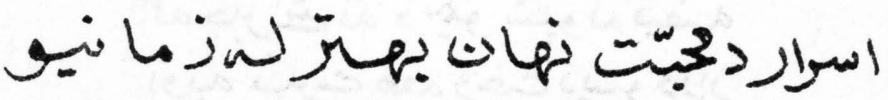

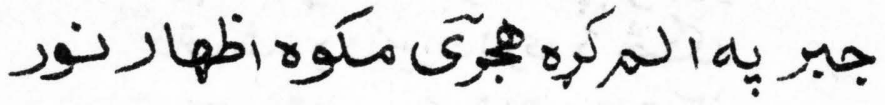




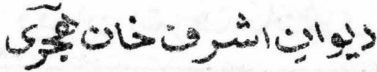

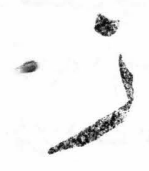

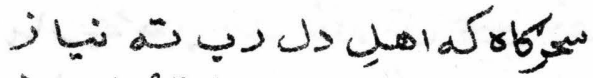

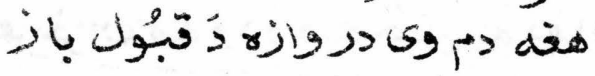

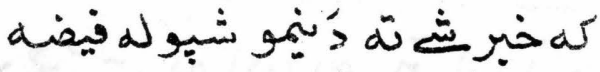

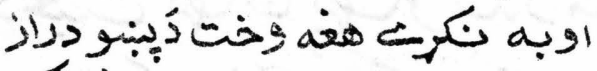
دَت شاه

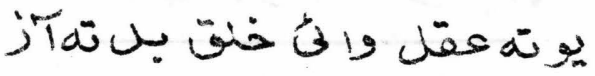
دا

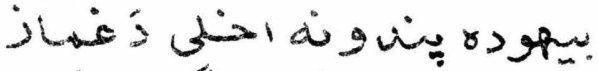

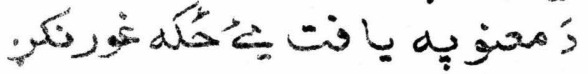

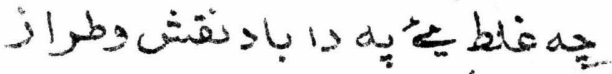
كأن

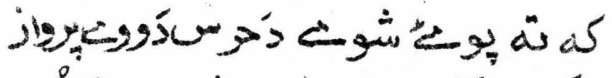

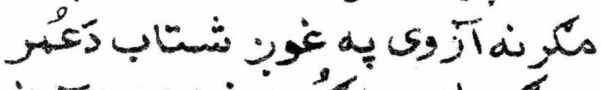
جهم يال هرن نه 


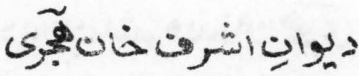

يوساعت ككه باد تيرشّ بل بأنان

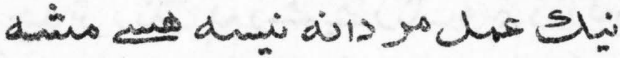

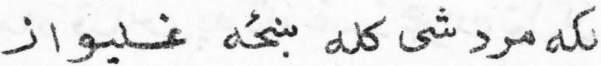

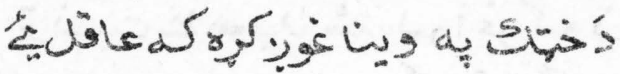

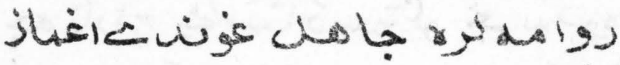

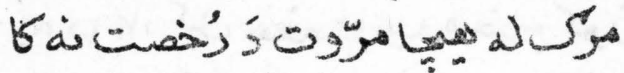

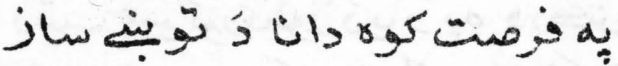

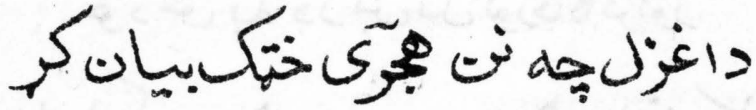
سوتز يايه حقيقت

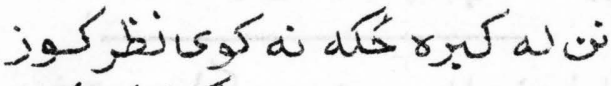

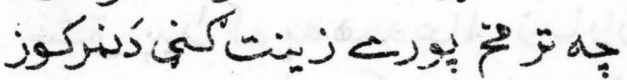

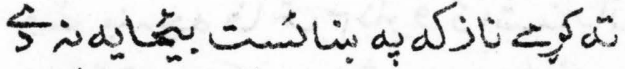

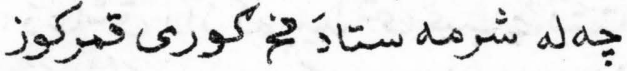

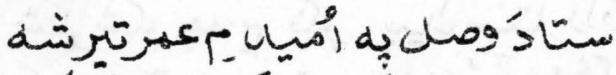

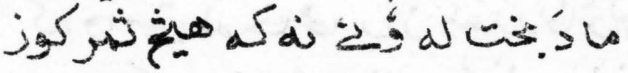

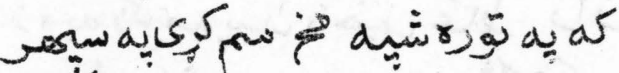

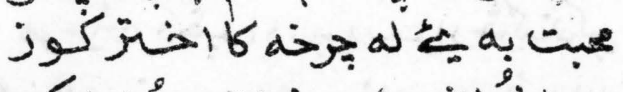

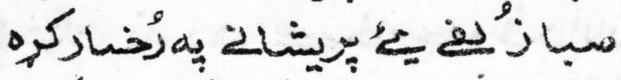
جه لم لزخه به دُنياكنىشى عنبركوز 


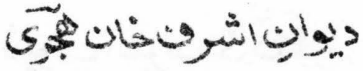

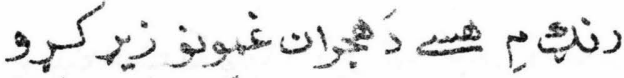

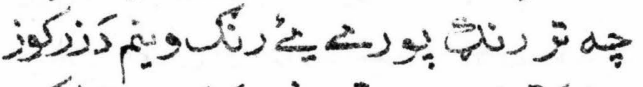

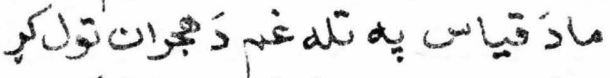
تز 希

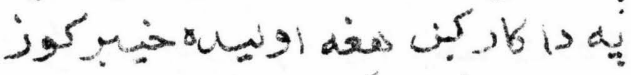

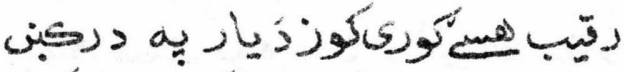

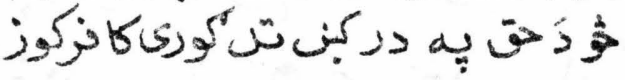

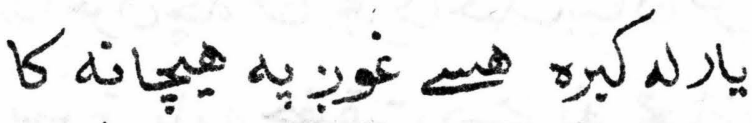

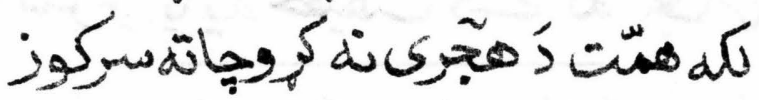

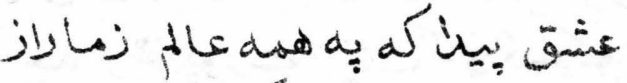

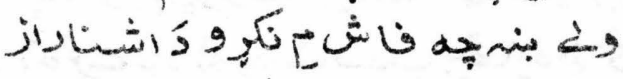

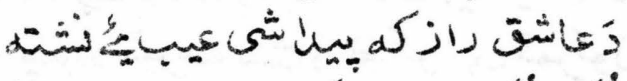

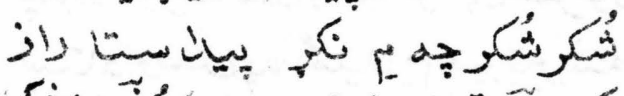

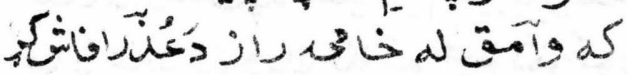
j1)

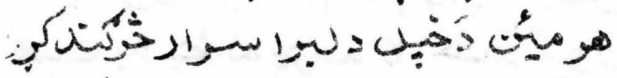

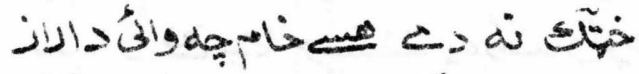

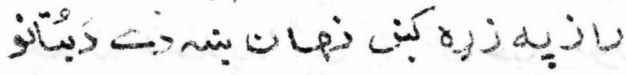




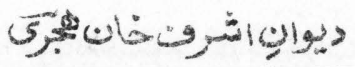

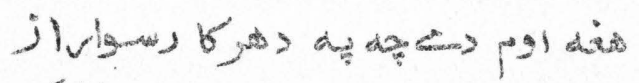

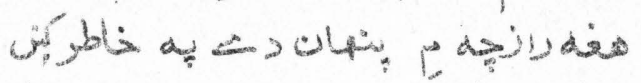

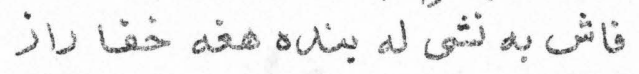

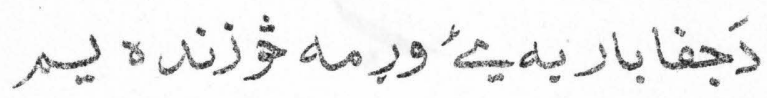

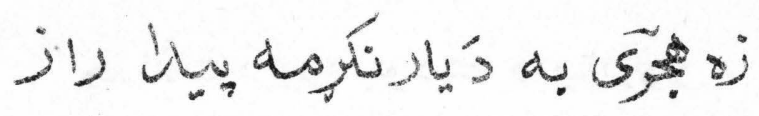




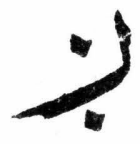

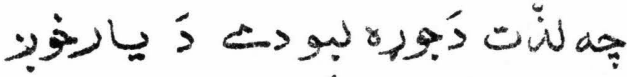

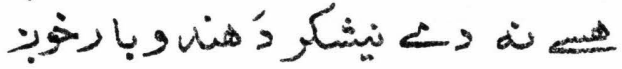

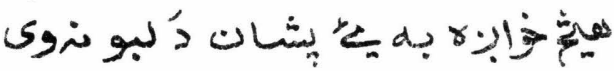

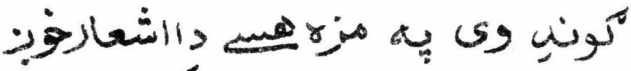

زربه زيريت

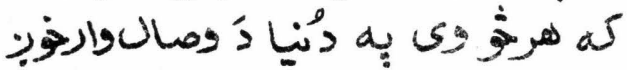

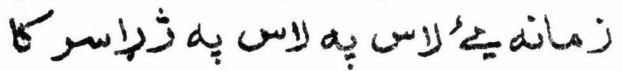

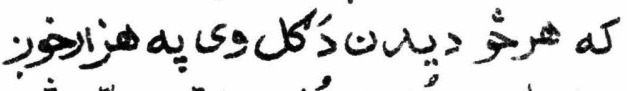

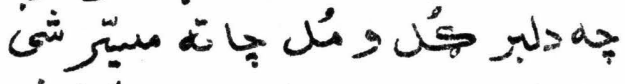

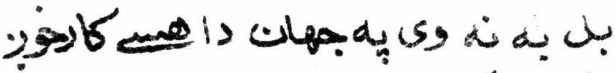

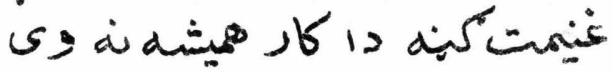

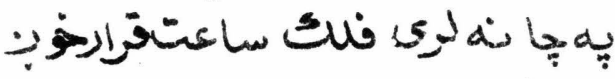

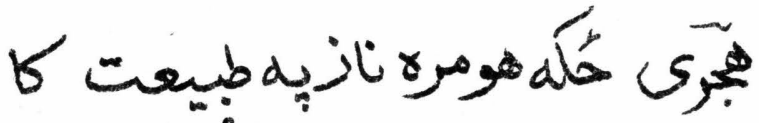

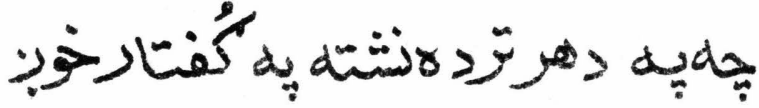




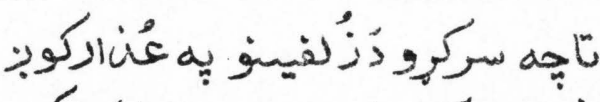

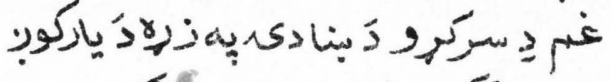

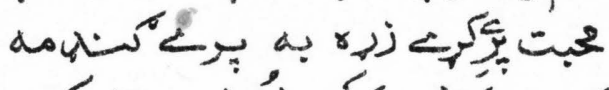

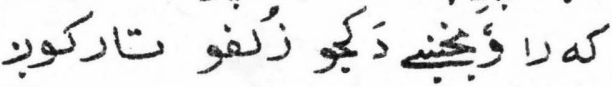

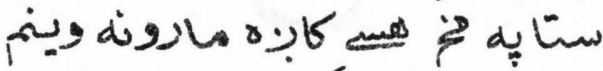

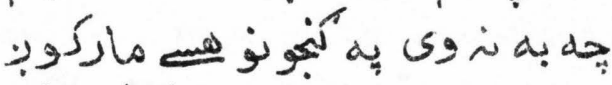

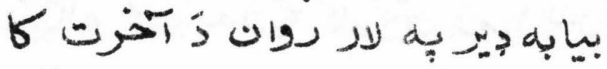

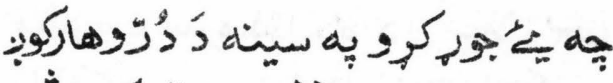

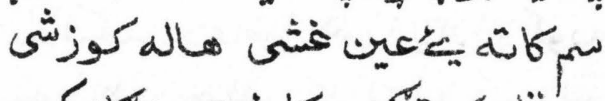

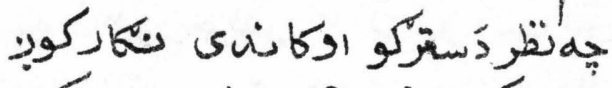

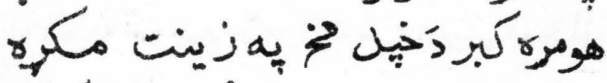

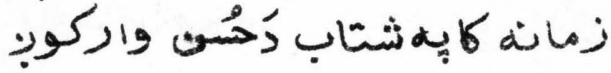

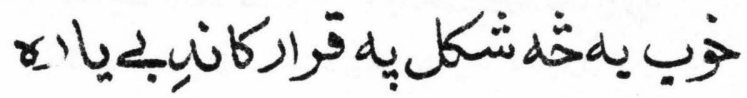

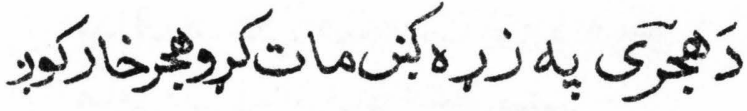




\section{$\cos ^{4}$}

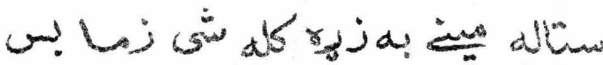

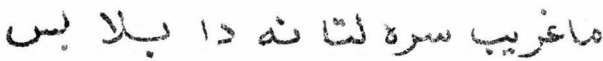

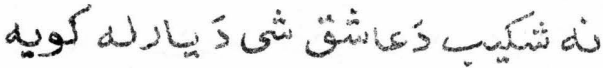

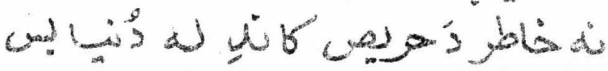

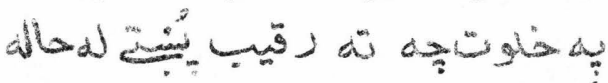

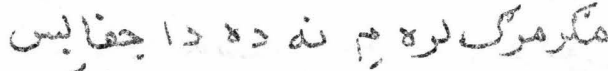

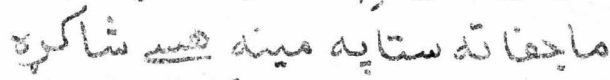

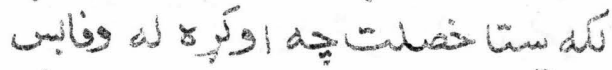

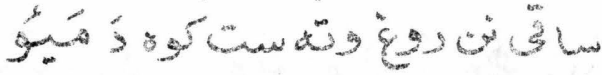

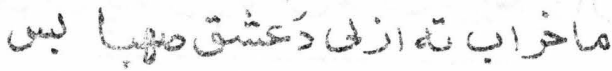

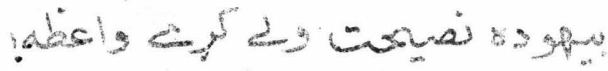

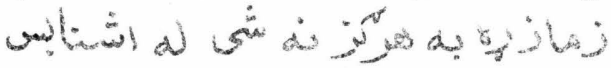

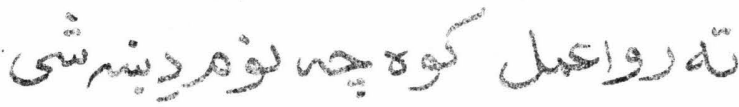

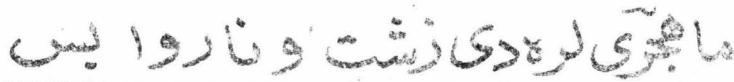




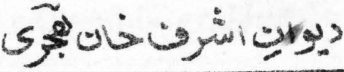

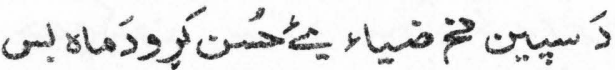

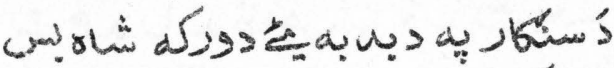

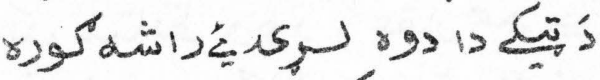

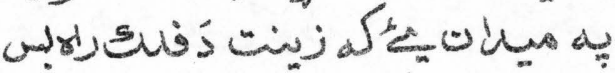

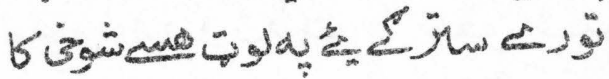

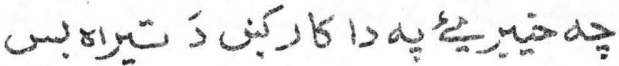

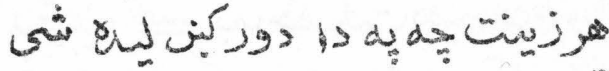

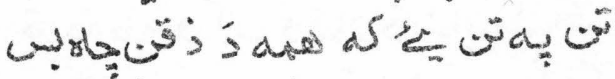
أونا

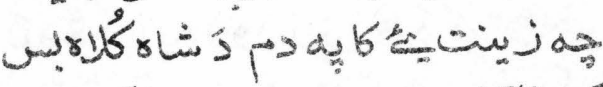

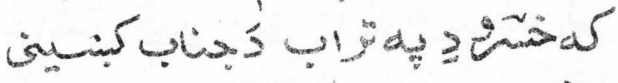

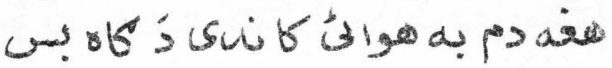
条 بن

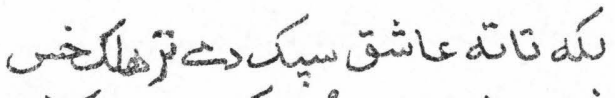

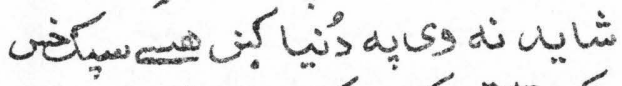

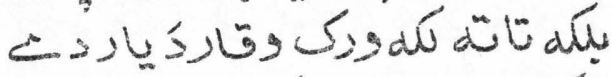

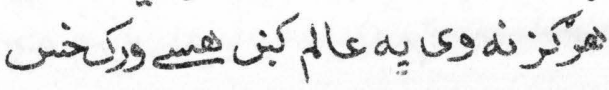




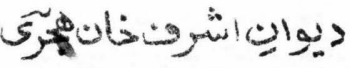

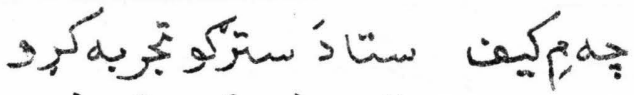

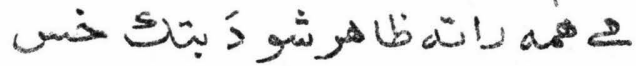

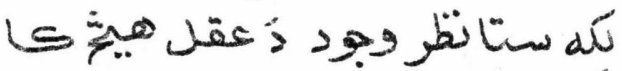

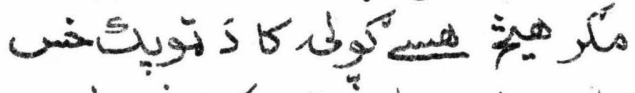

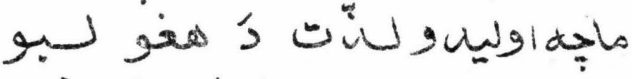

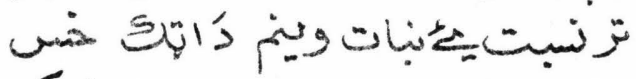

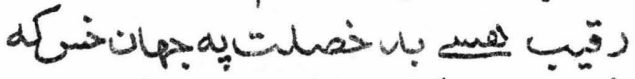

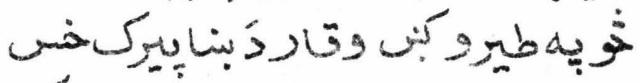

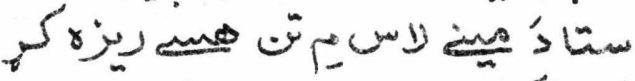

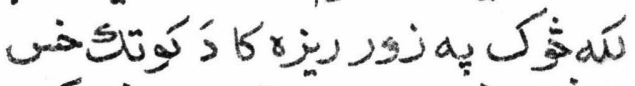

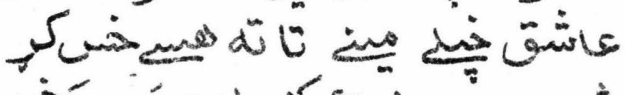

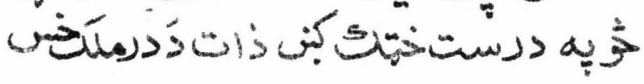

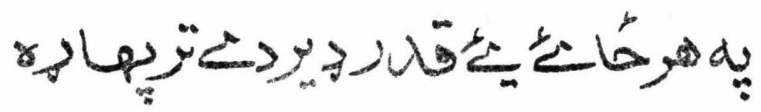

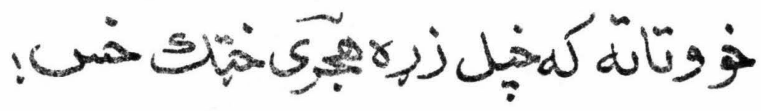

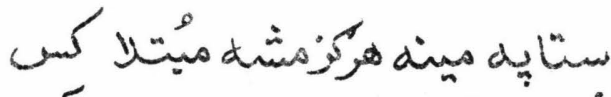

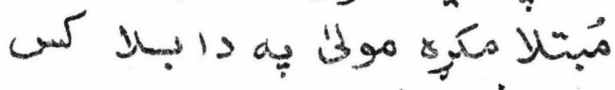

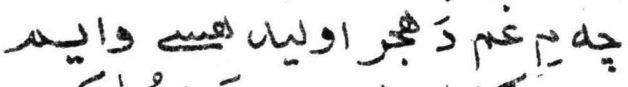

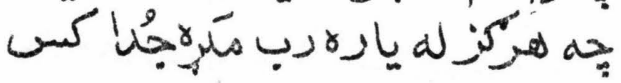




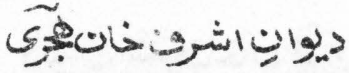

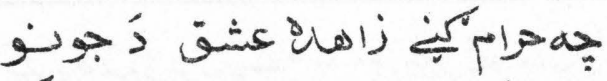

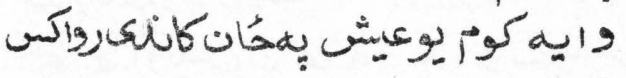

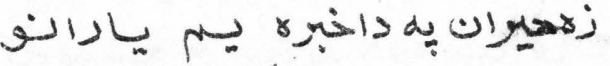

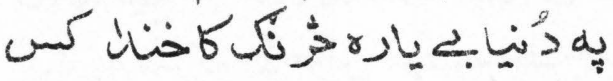

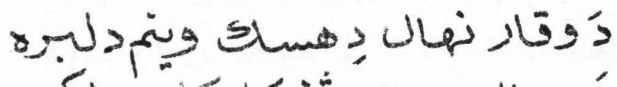

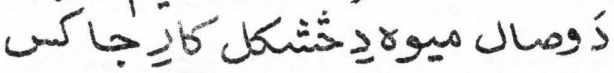

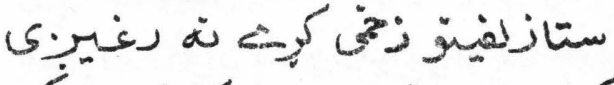

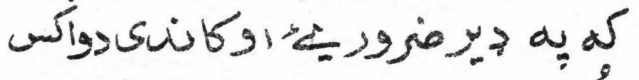

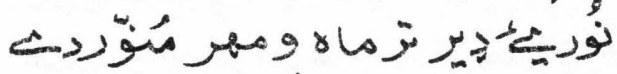

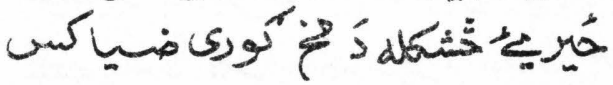

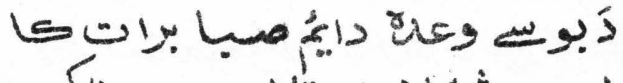

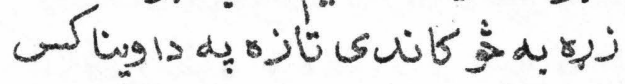

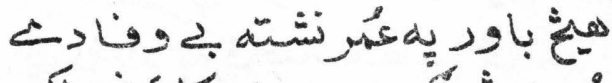

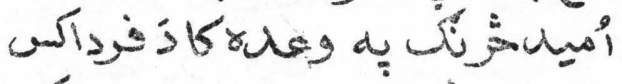

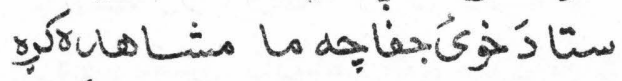

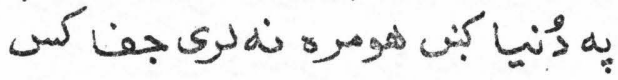

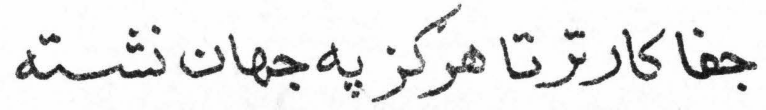

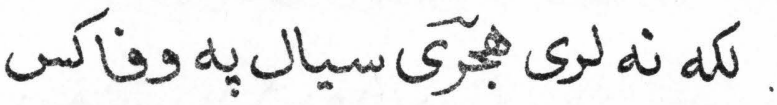




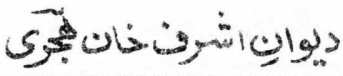

جه ية

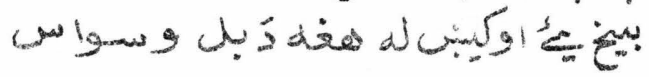

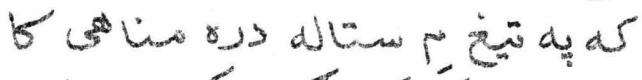

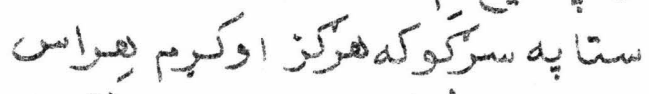

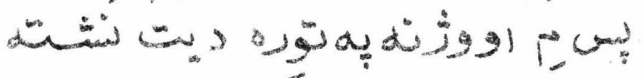

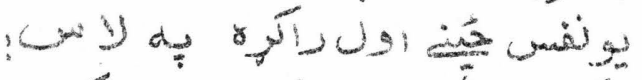
هن

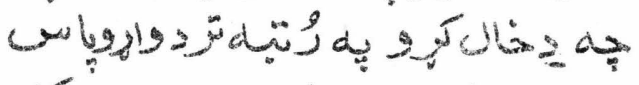

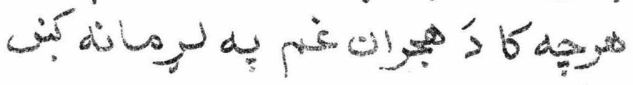

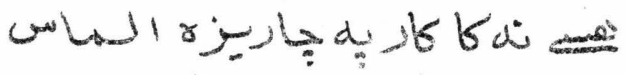

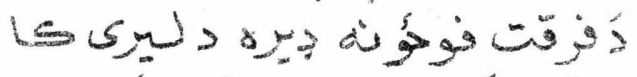

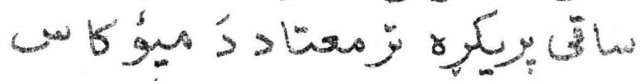

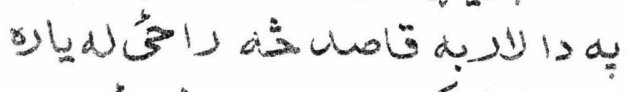
لج

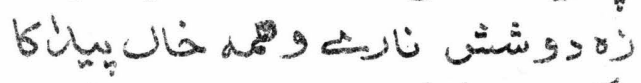

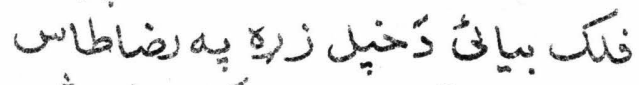

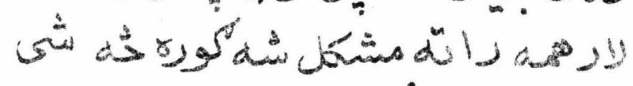

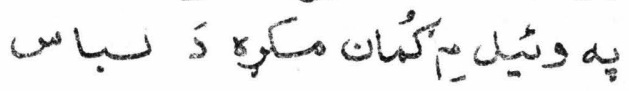
6inds

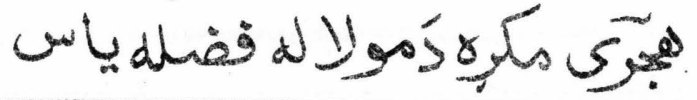




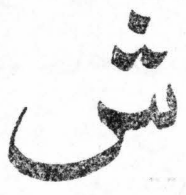

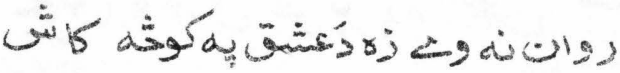

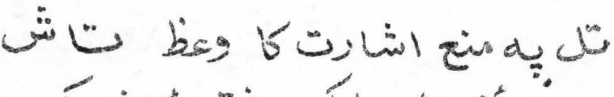

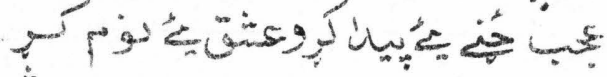

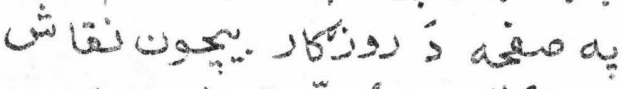

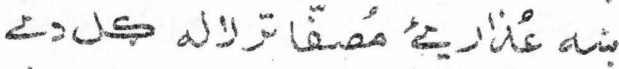

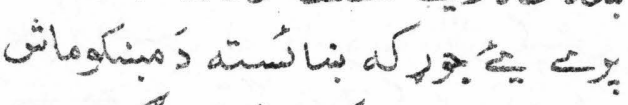

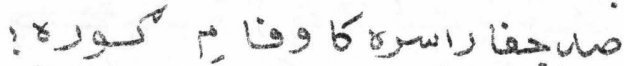

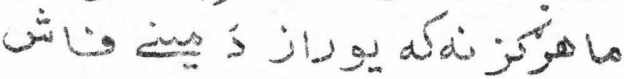

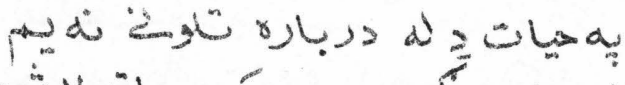

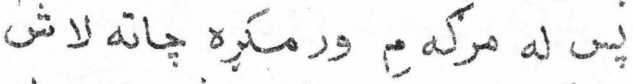

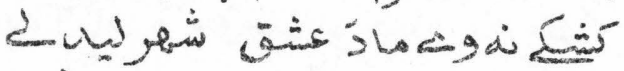

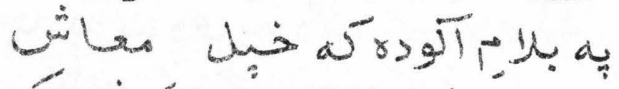

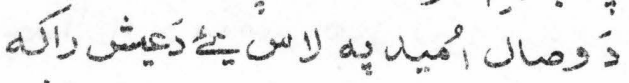

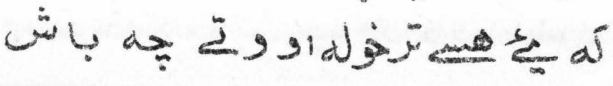




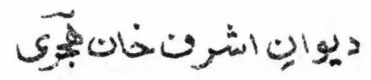

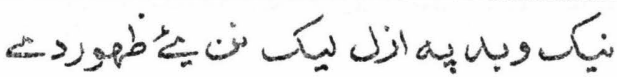
:

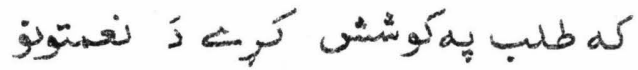

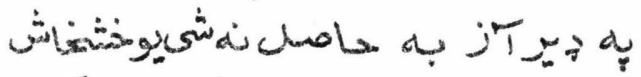

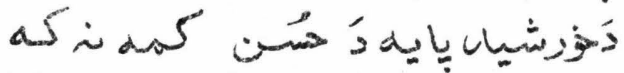

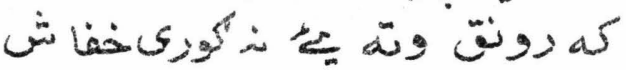

سن

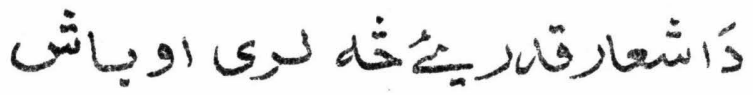

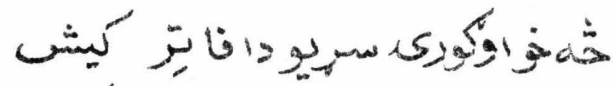
جها

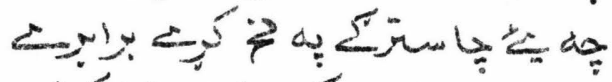

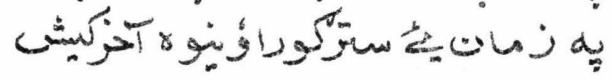
ज

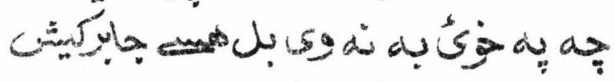
LS

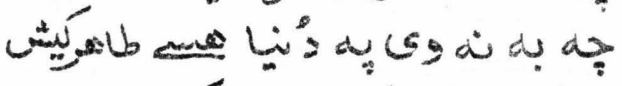

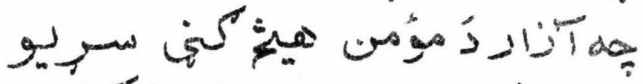

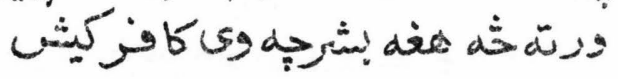




\section{ديوانِ اشتروبنابهيجى}

دَ

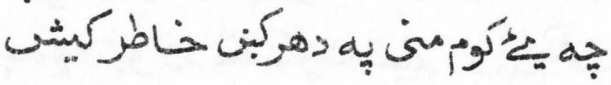

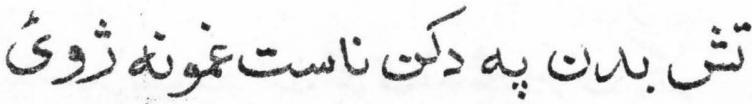

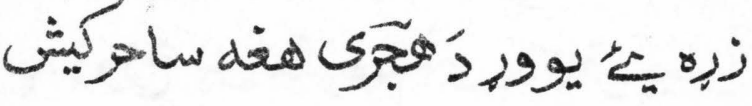

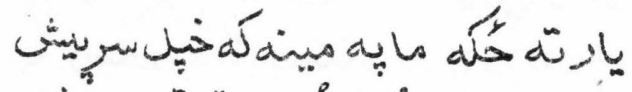

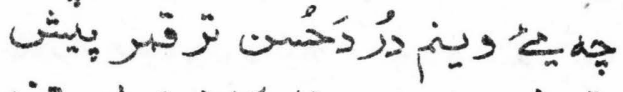

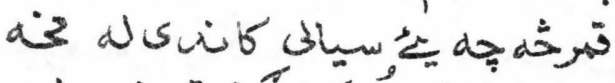

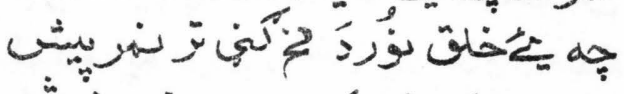

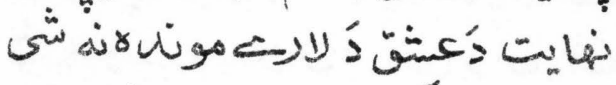

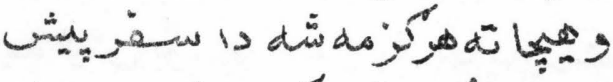

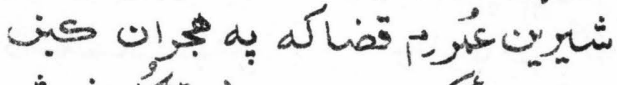

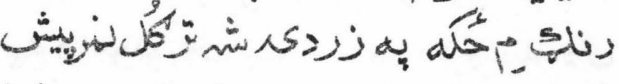

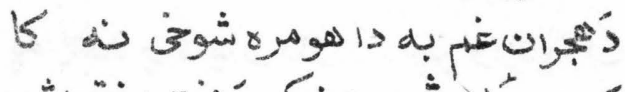

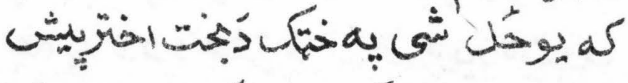

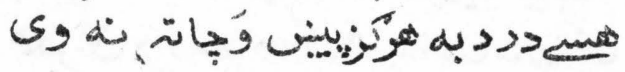
جه ديار ياد ئودانة

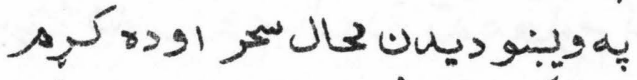

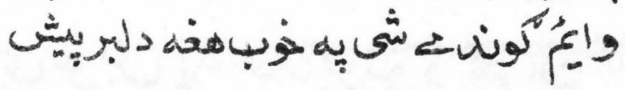




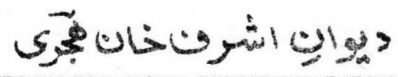

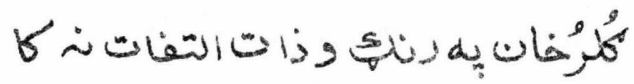

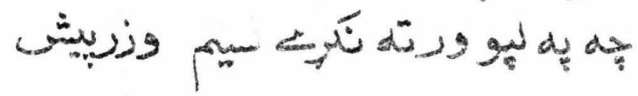

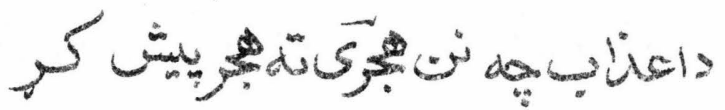

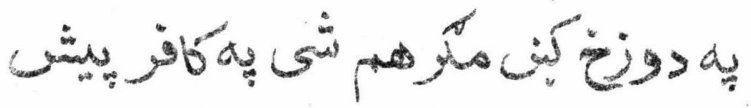

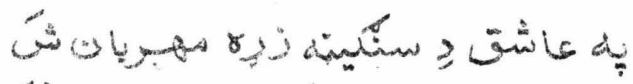

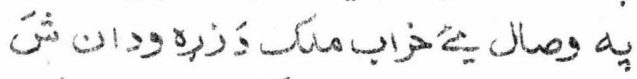
ش

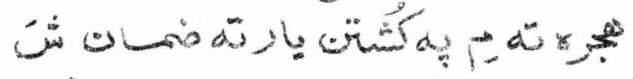

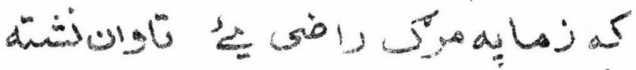

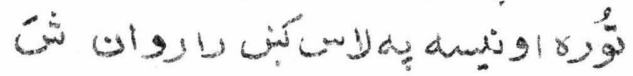

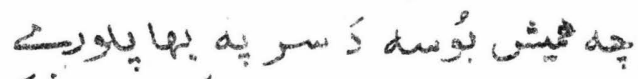

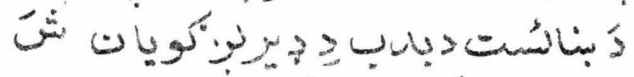

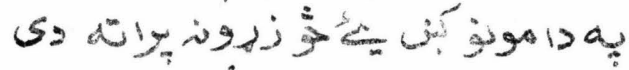

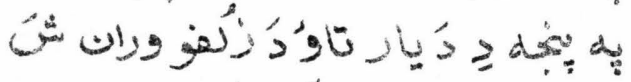

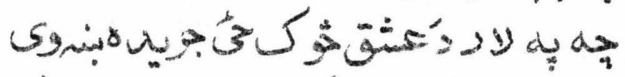

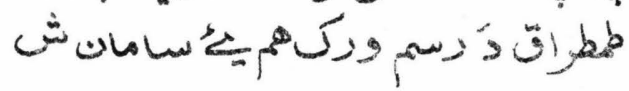

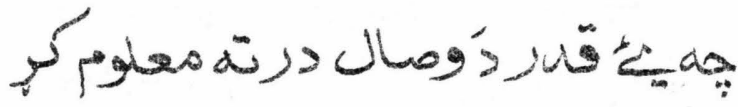

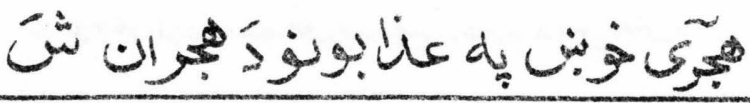




\section{6}

كن

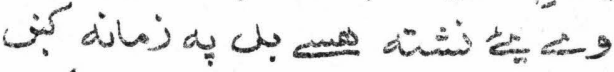

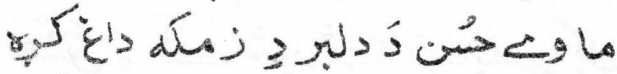

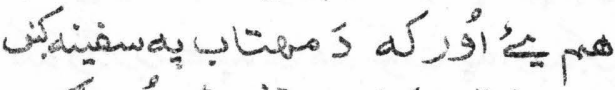

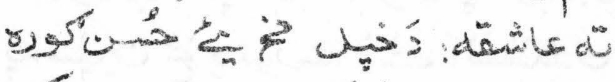

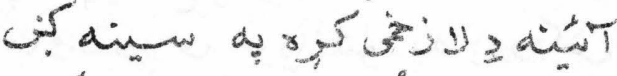

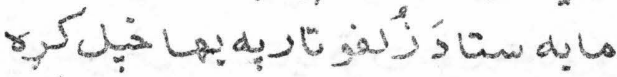
L ril

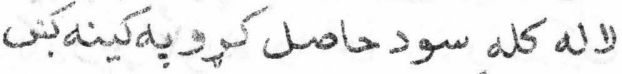

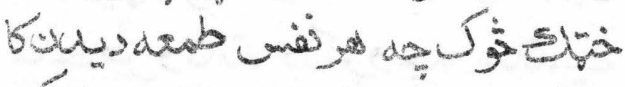

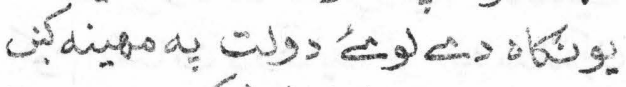

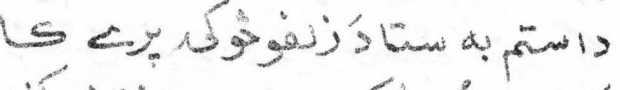

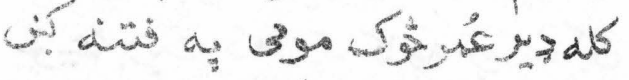

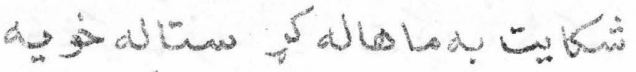

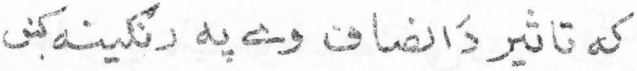




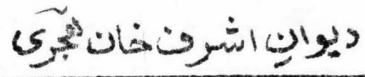

له خزبون لهو

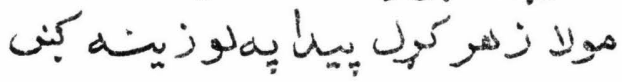

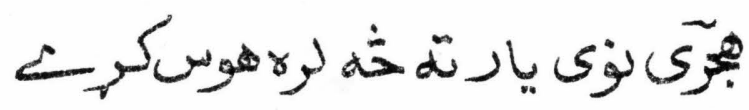

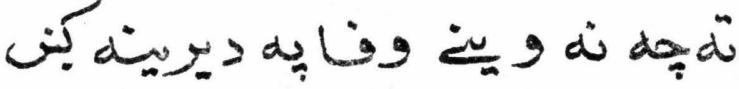

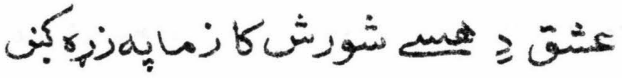

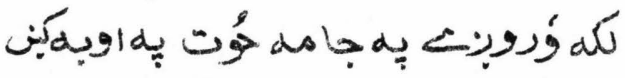

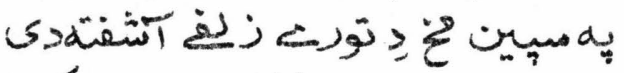

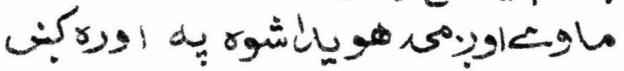

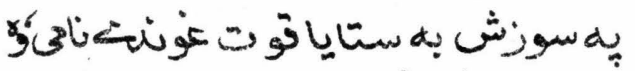

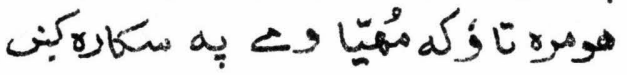

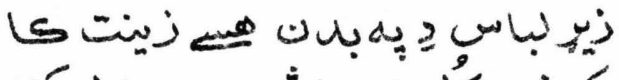

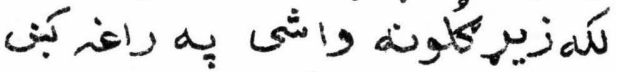

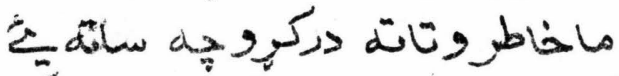

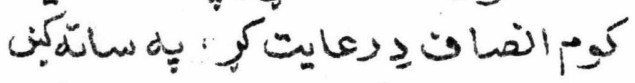

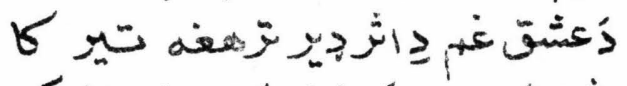

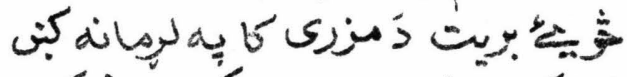

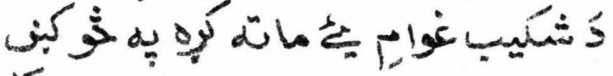

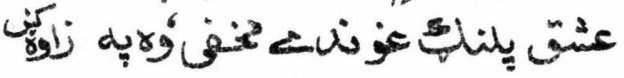




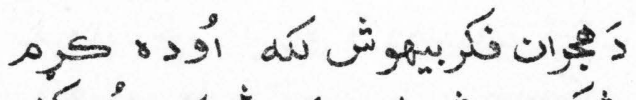

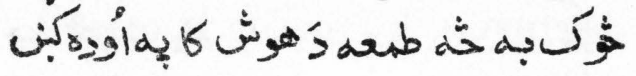

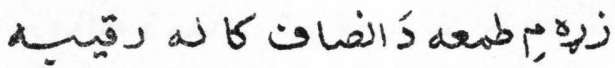

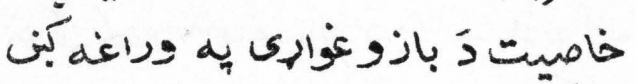

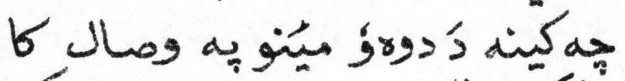

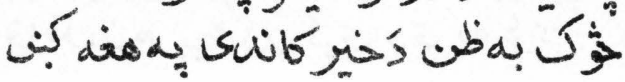

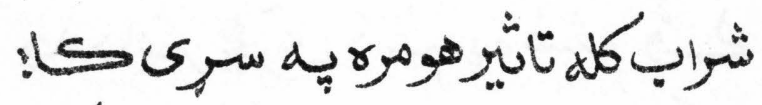

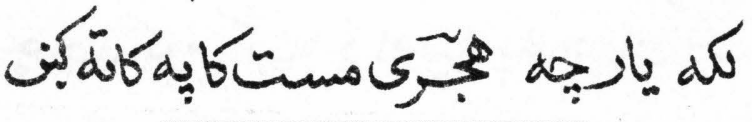

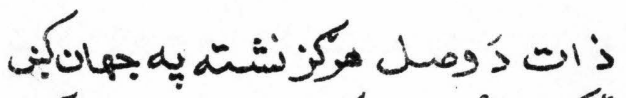

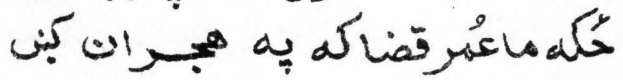

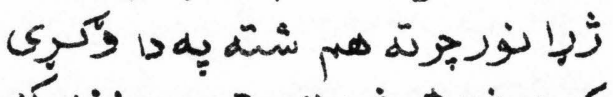

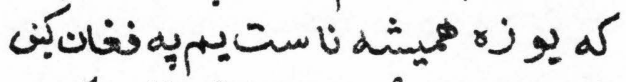

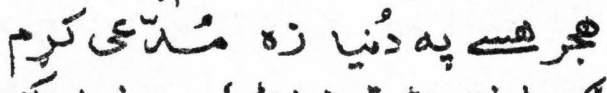

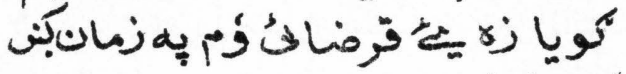

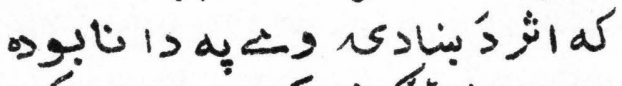

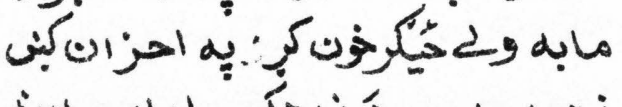

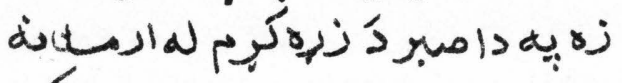

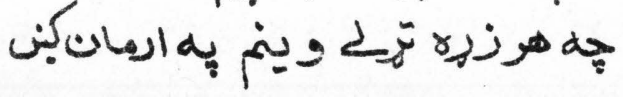




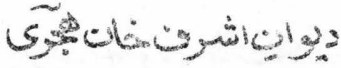

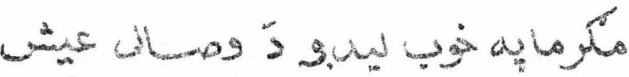

ن

b

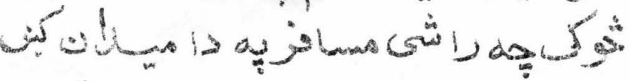

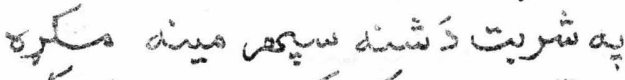
قاتل

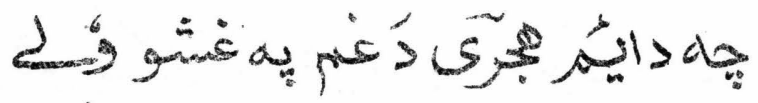

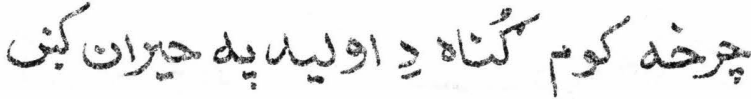

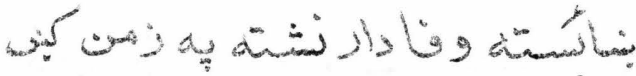

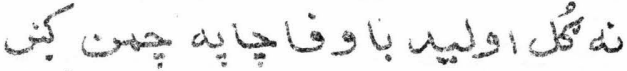

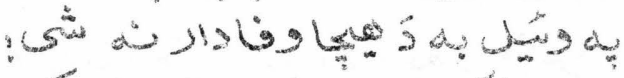

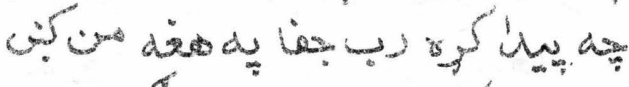

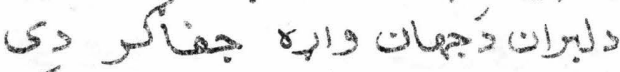

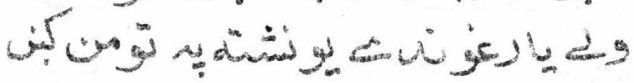

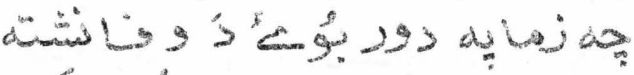
6.

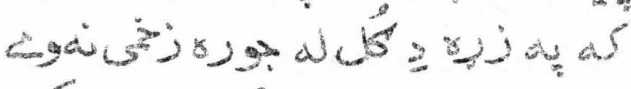
ن ك. 


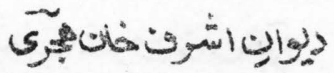

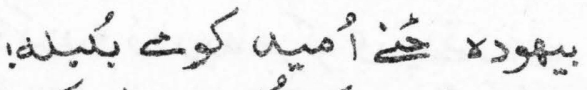

كبن

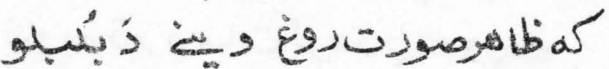

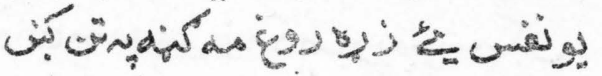

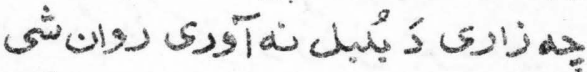

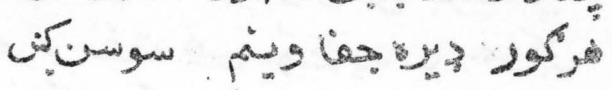

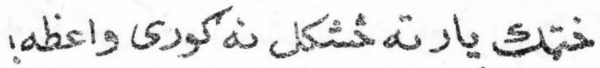

جه

$\angle 34$ rogstog

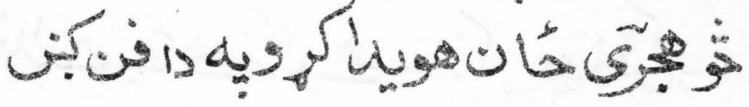

سماد

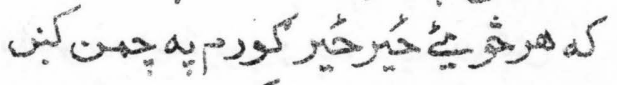

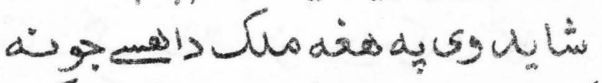

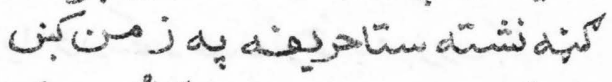

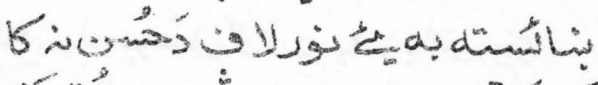

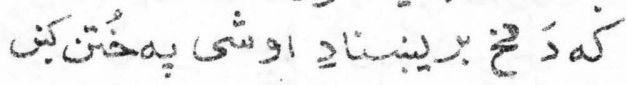

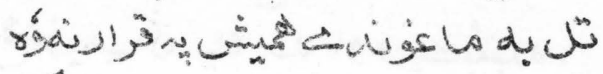

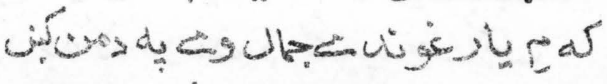




\section{ديوانِانـرتخانهئى}

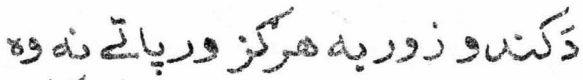

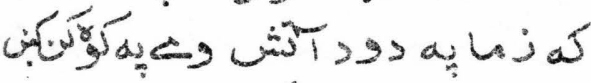

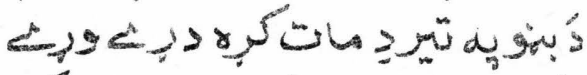

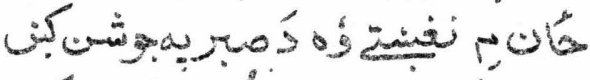

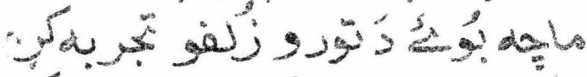

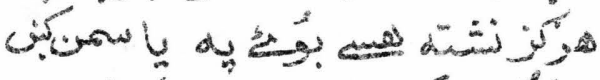

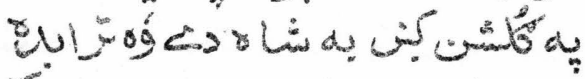

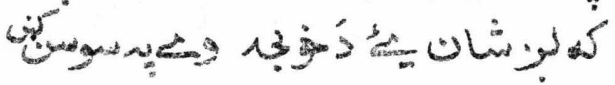

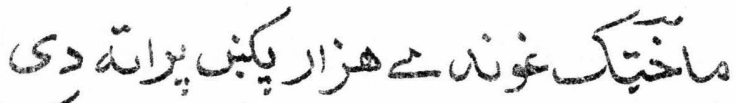

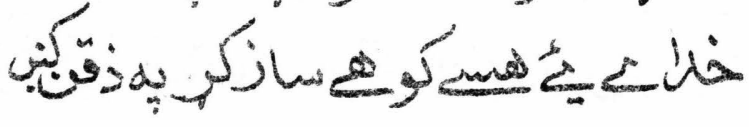

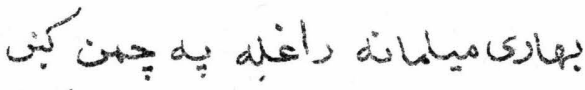

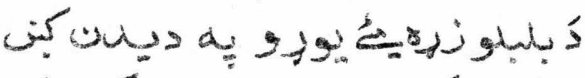

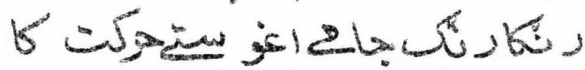

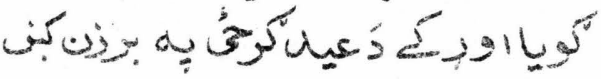

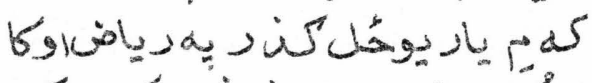

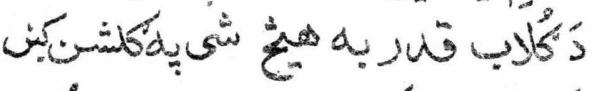
䒠

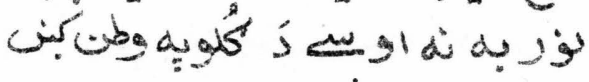




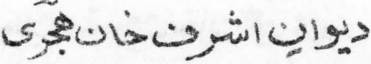

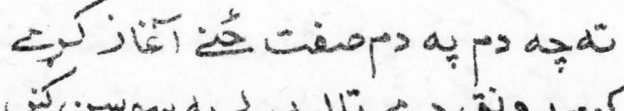

كو رونت

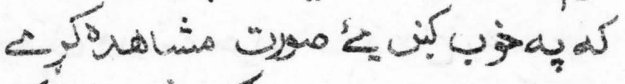

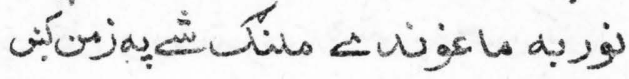

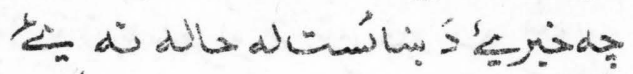

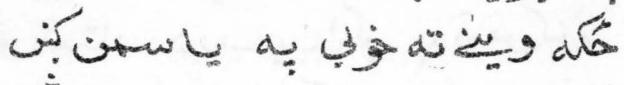

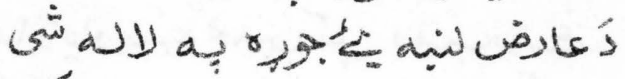

ن

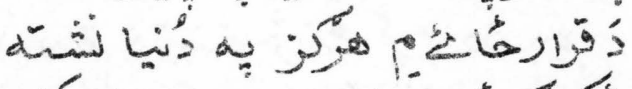

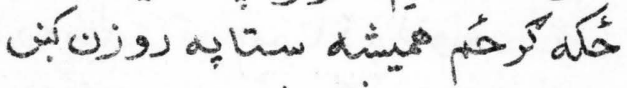

ज.

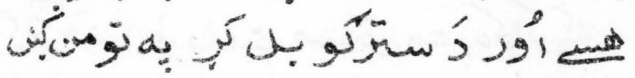

ls يونة

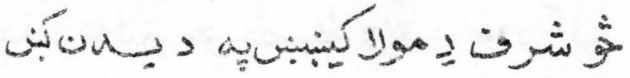

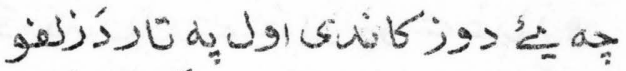

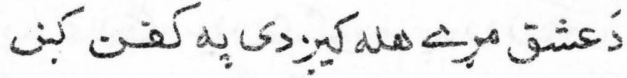

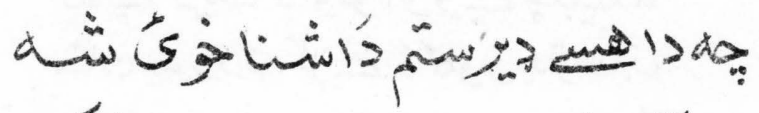
Ś 


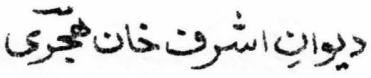

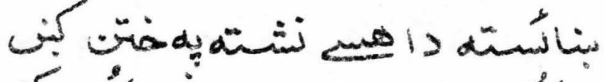

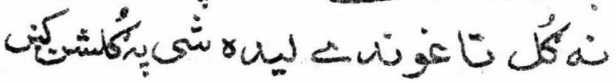

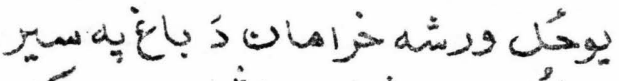
تونة

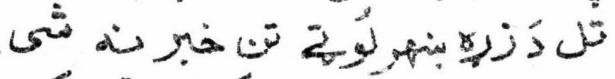

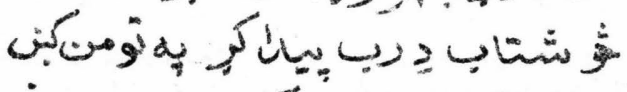

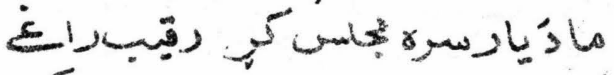

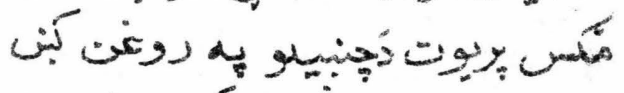
زمله

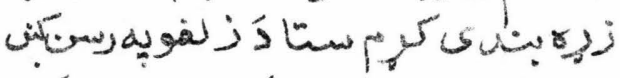

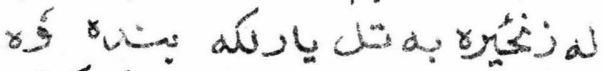

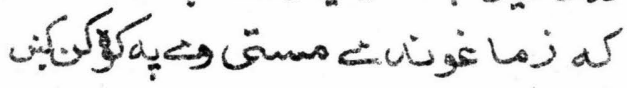

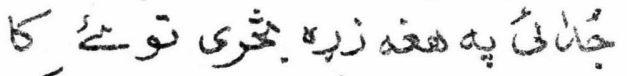

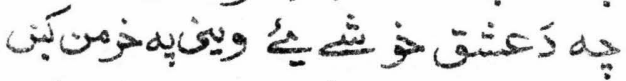

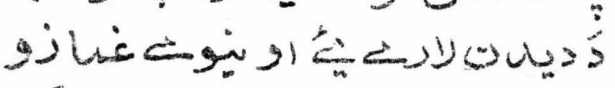

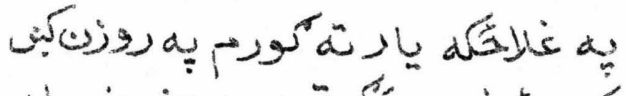

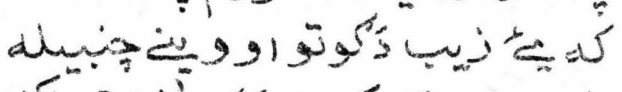

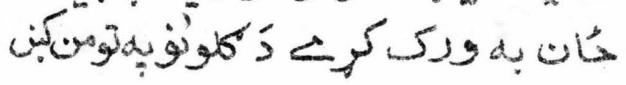

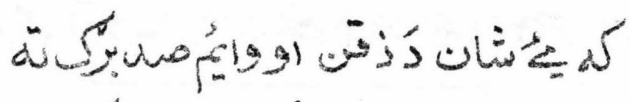

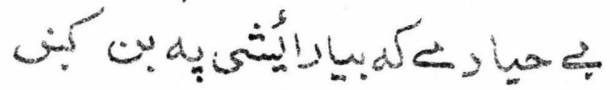




\section{ديوانِ}

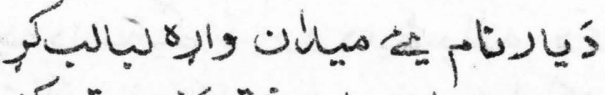

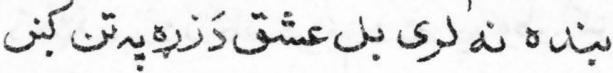

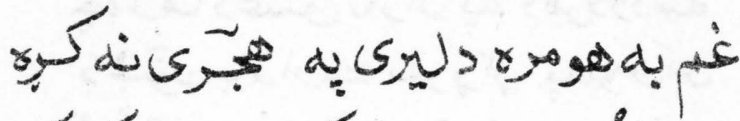

كميوئكل

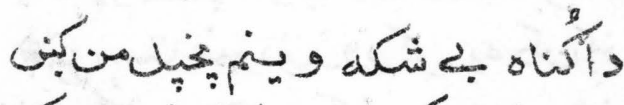

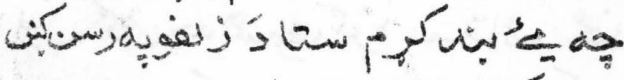

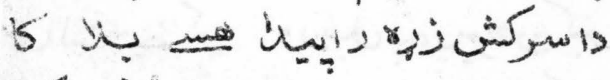

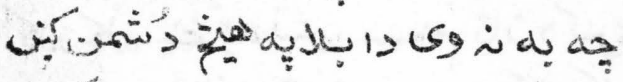

أنها

|

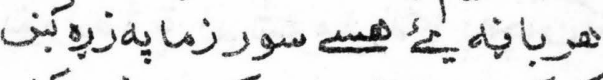

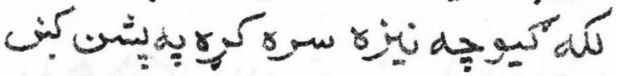

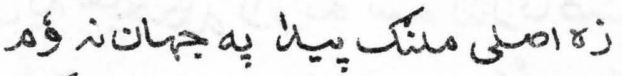

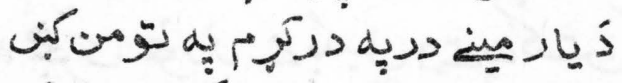

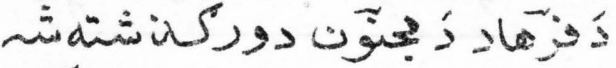

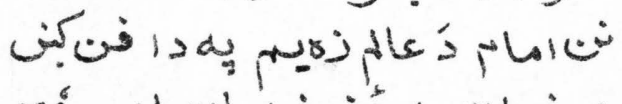

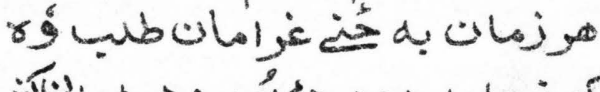

كمانمانيه 


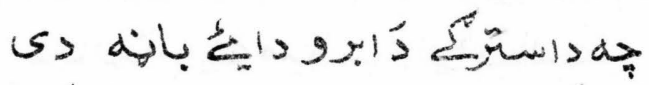

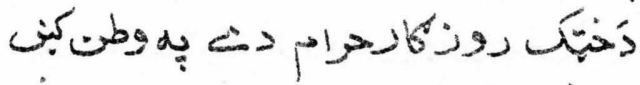

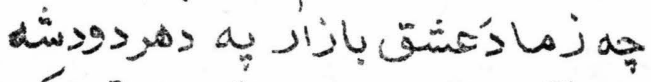

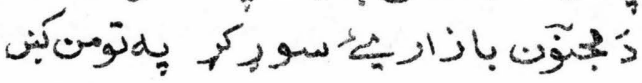

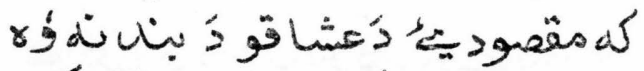

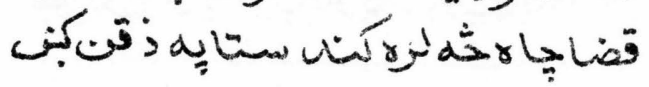

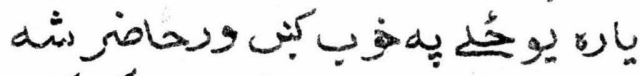

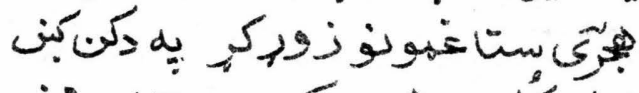

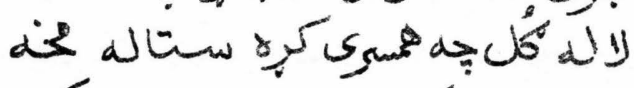

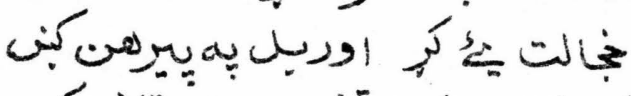

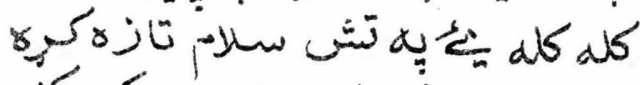

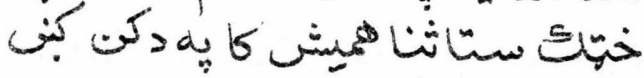

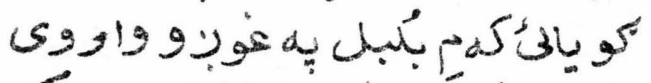

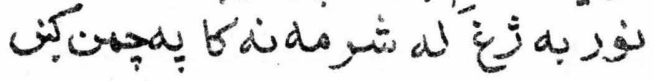

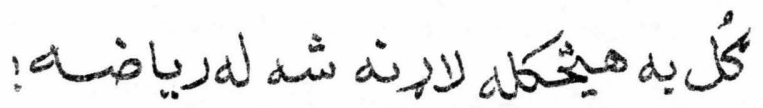

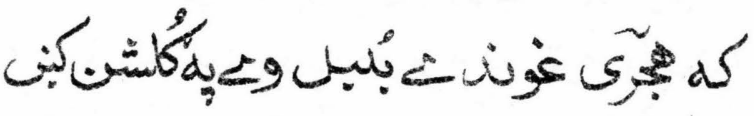




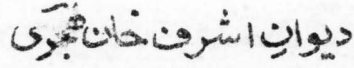

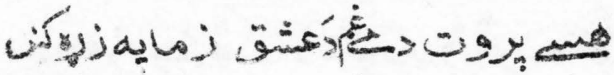

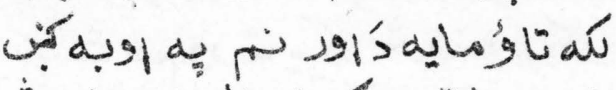

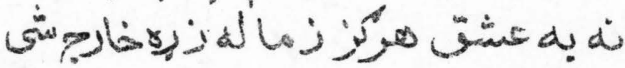

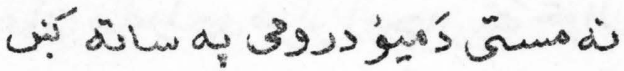
Lir

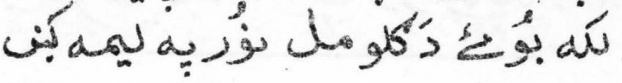

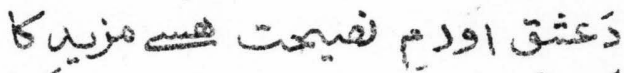

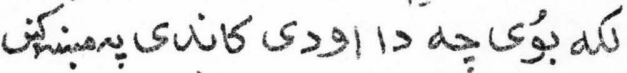

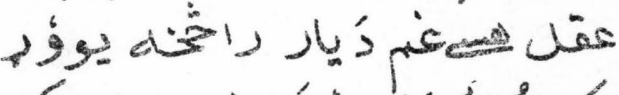

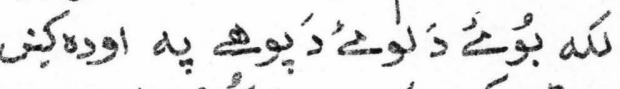

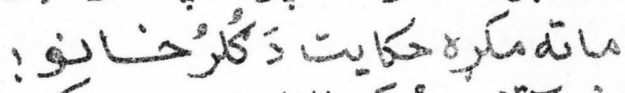
落 لجه

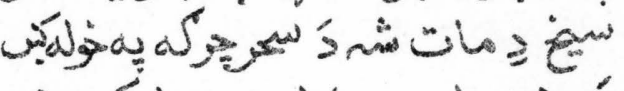

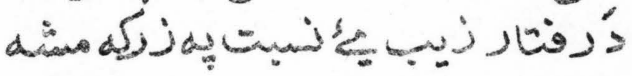

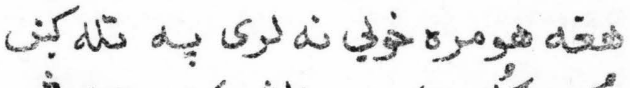

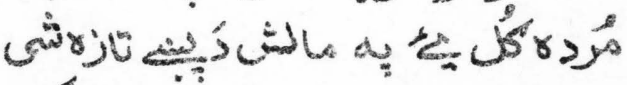

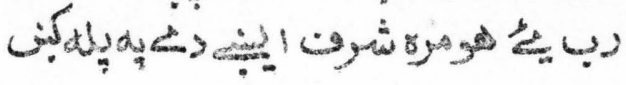
ؤن ن 


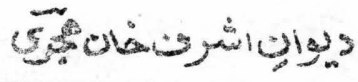

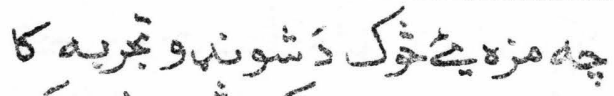

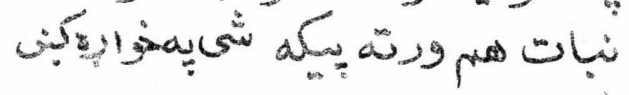

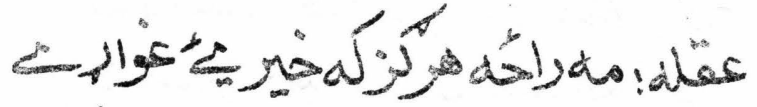
يار

pas. 


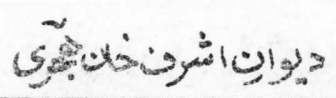

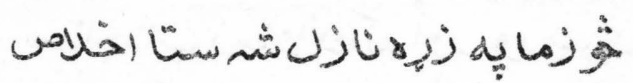

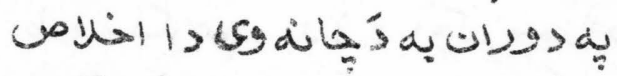
جه

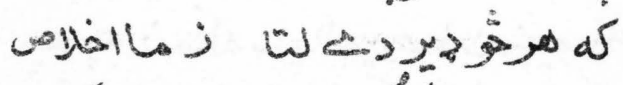

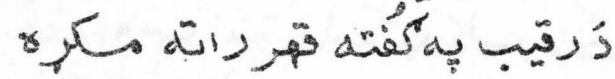

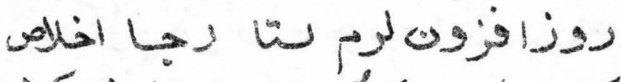

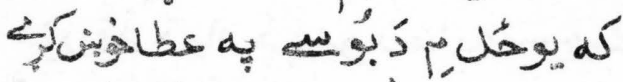

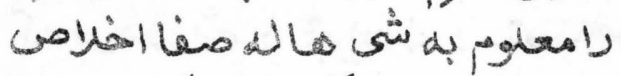

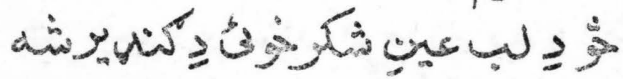

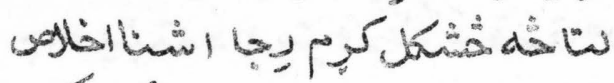
و

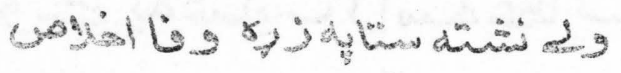

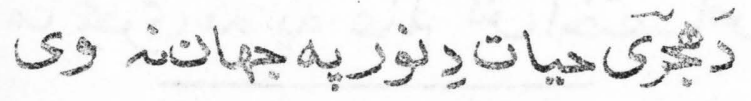

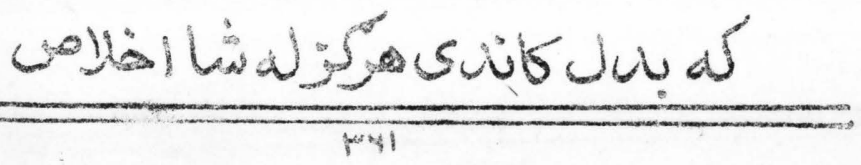




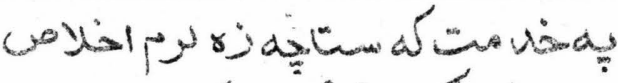

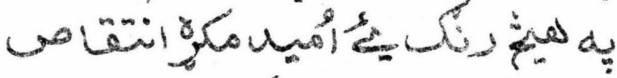
كنة

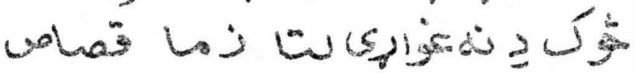

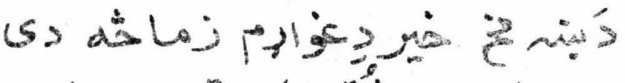

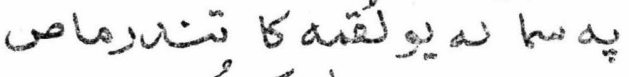

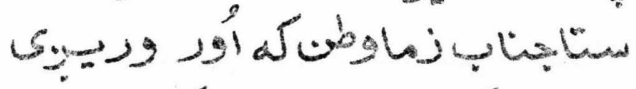
ص نو Mوئون

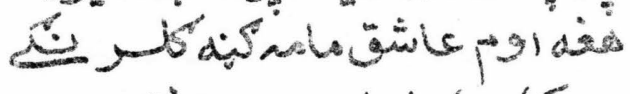

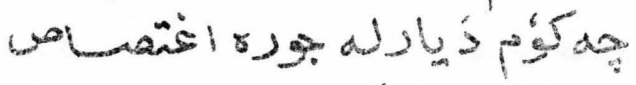

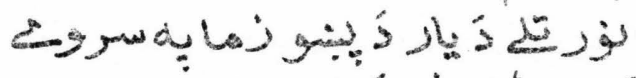

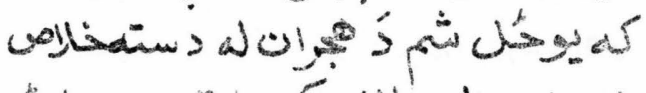

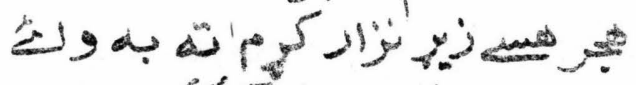

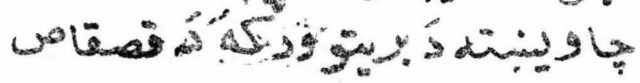

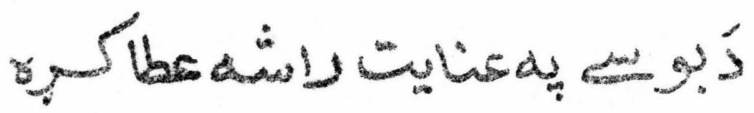

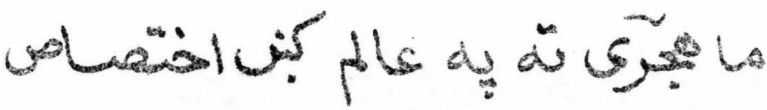




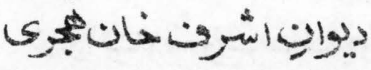

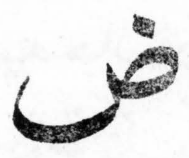

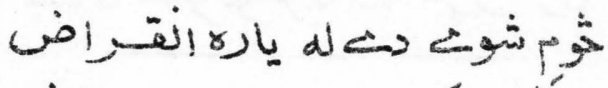

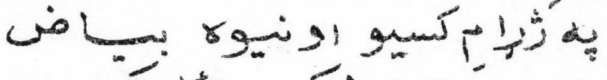
كز

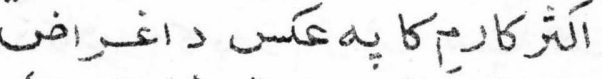

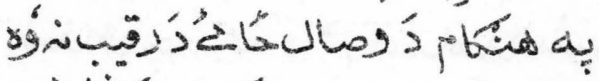
. جان

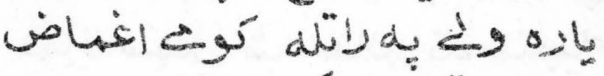
هان

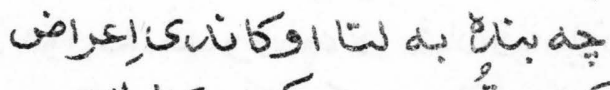

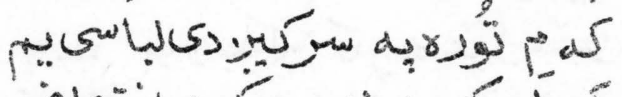

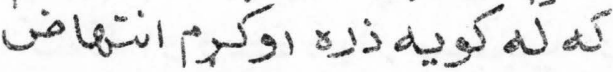

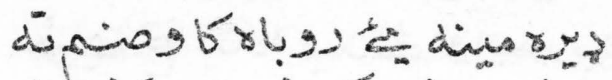

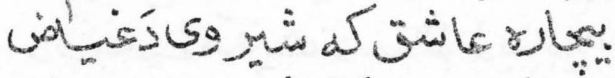

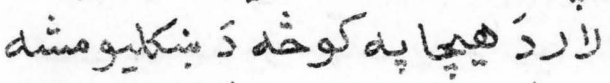

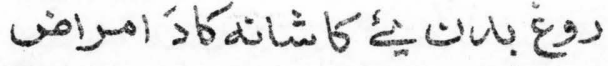




\section{حيوالِباشترهنان}

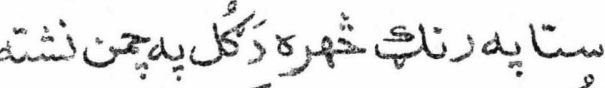

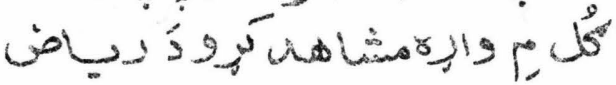

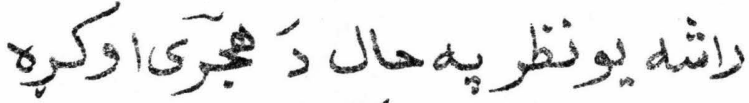

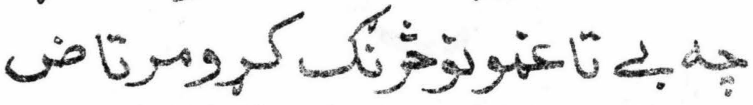

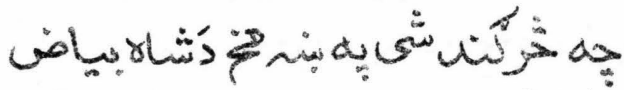

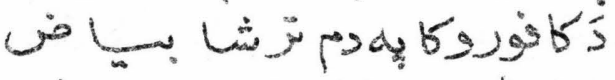

مفأئحة

ضإنس

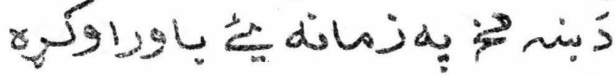

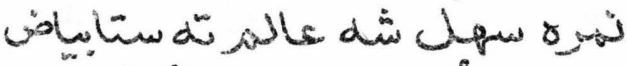
نه

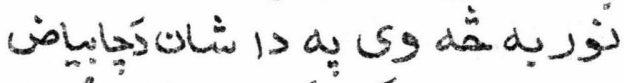
تجنَ كماتهاه 界

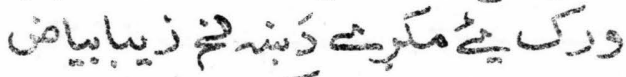
هائ

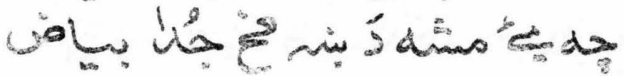




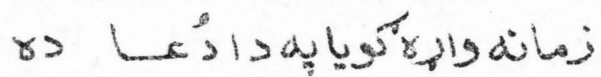
ضان

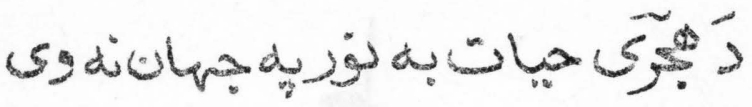

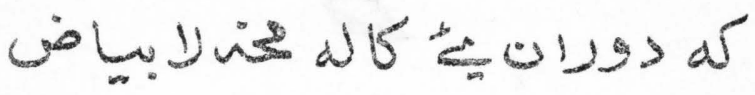

wyo 


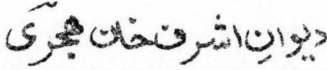

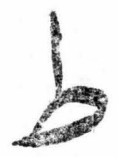

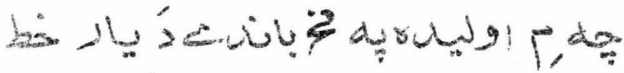
管

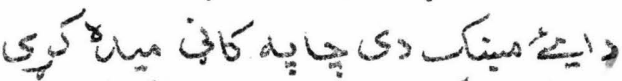

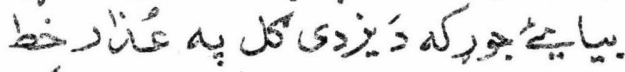

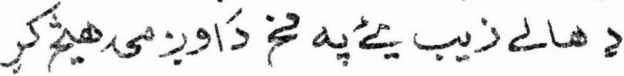

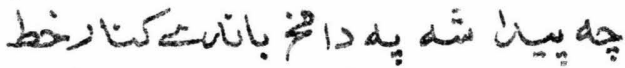

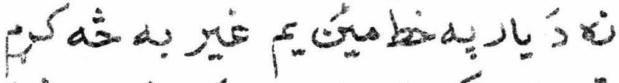

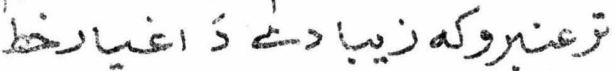

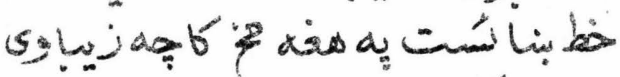

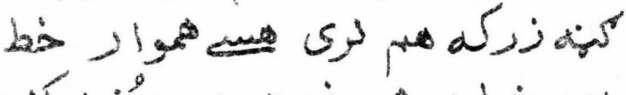

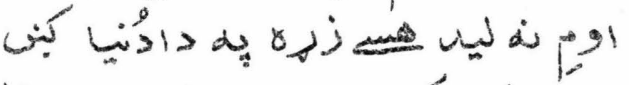
苑

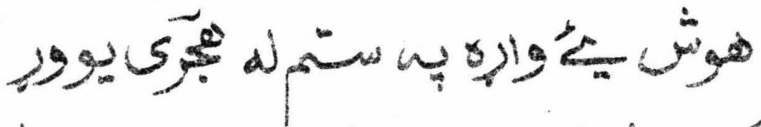

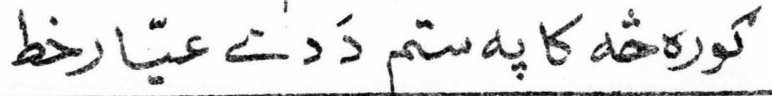




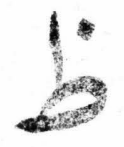

定

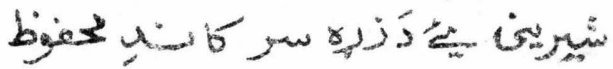
sga d و 管 定

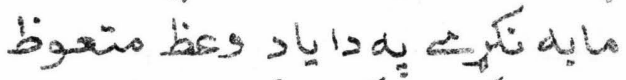
我若

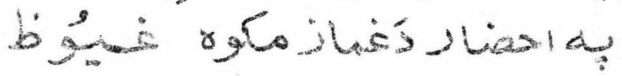

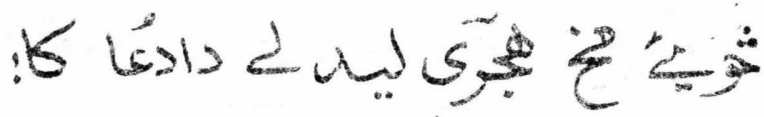

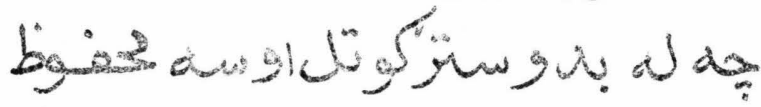


blisuctr

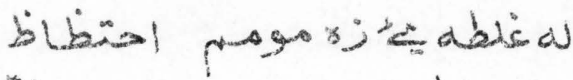

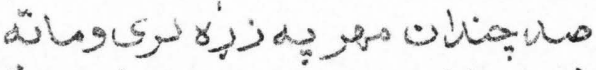

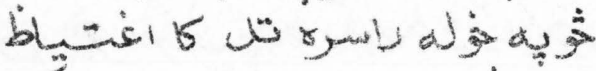

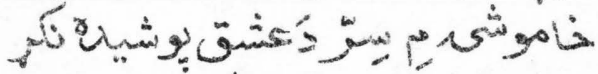
دأنة

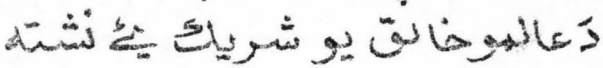

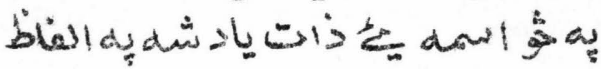

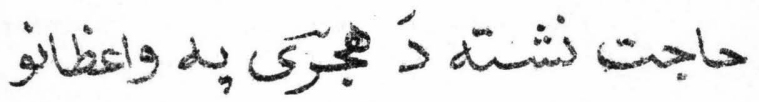

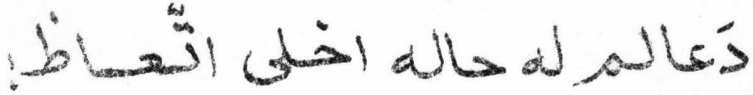

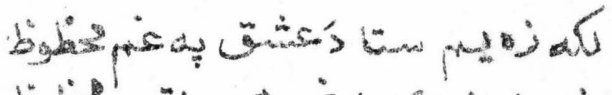
年

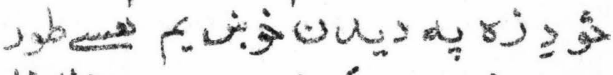

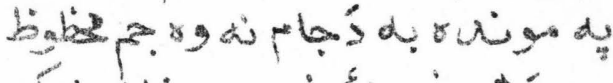

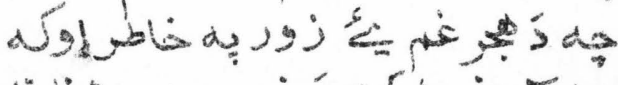

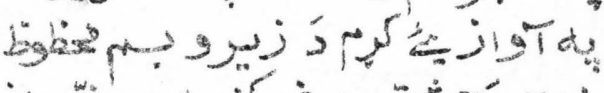

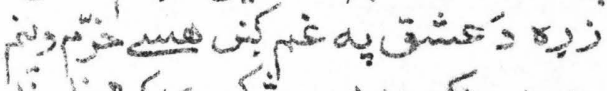

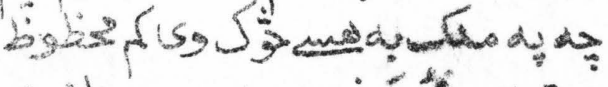

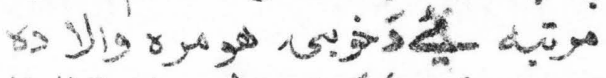
bis 


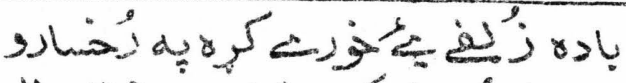

bو

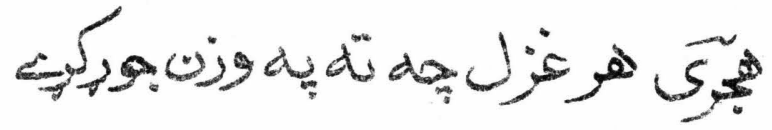

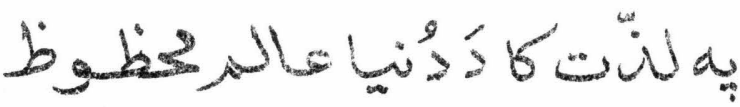




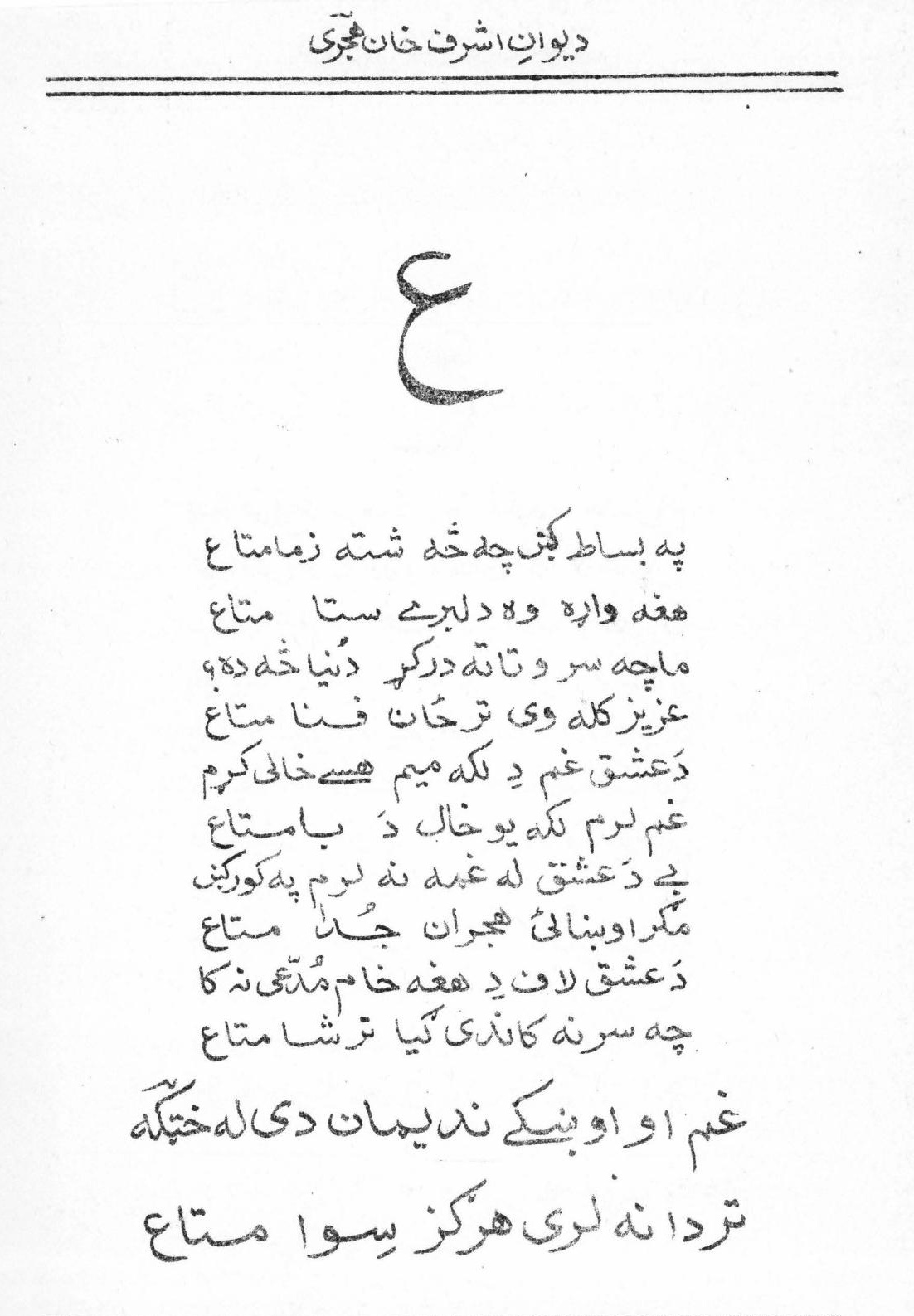




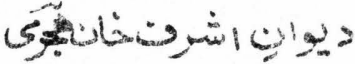

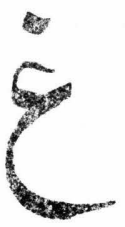

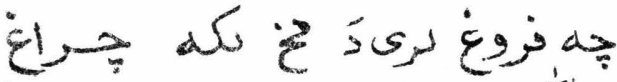

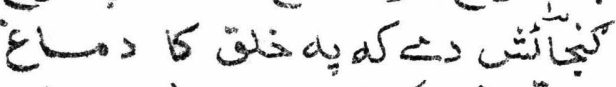

كأس

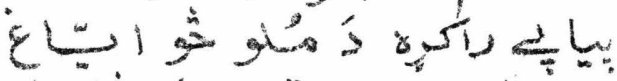

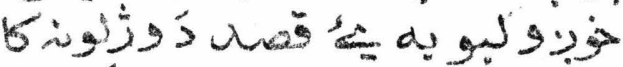

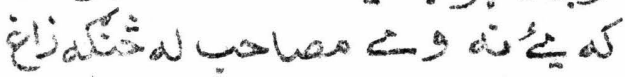

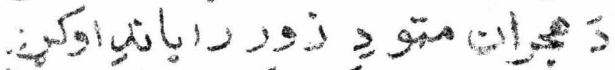

و و

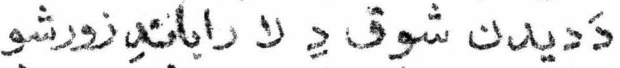

E E

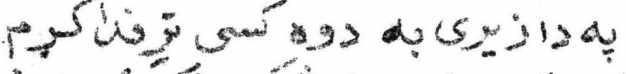

"É

مأ

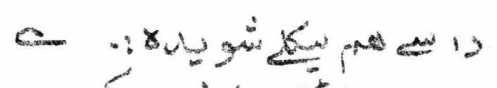

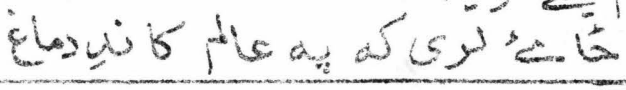




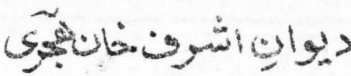

ك

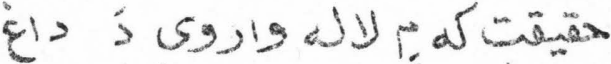

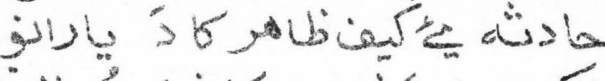
¿עom

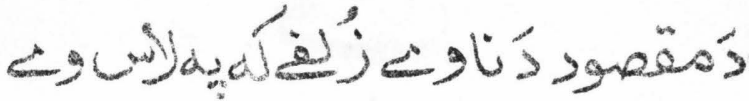

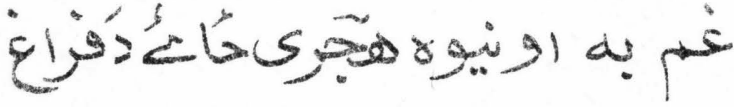




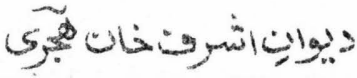

\section{$(2$}

نو بهار

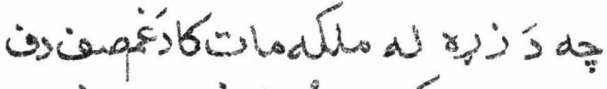

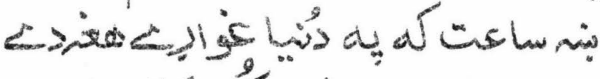

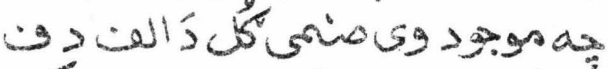

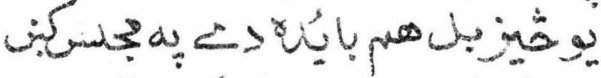
isien 6 amit al a

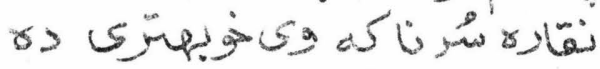

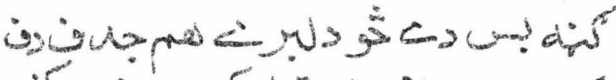
ن

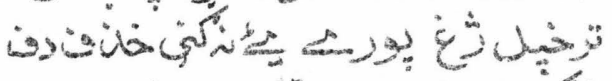

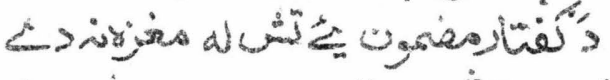

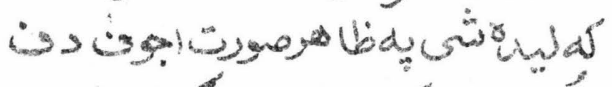

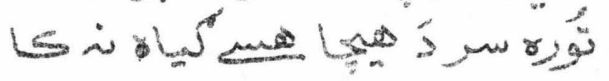

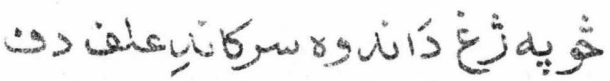




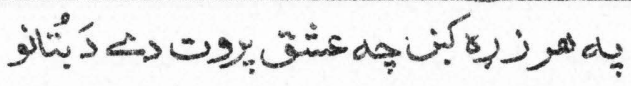

لإيخد

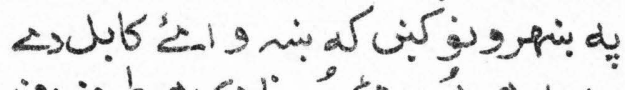

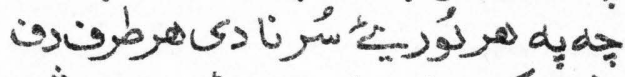

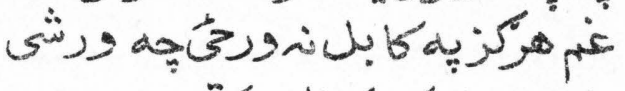

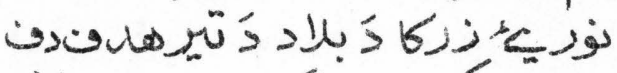

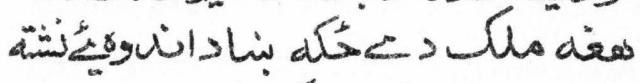

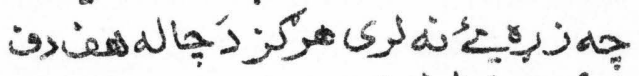

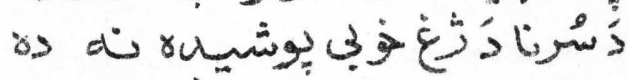

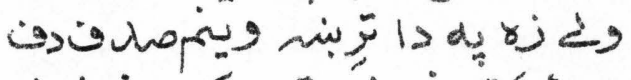

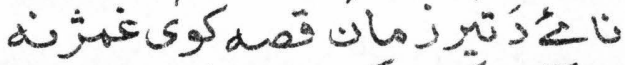
ئل

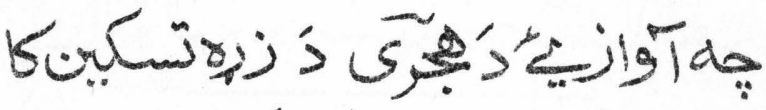

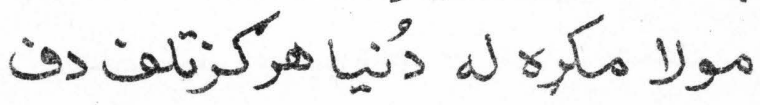

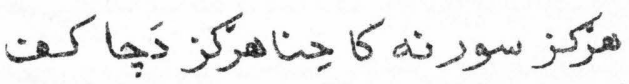

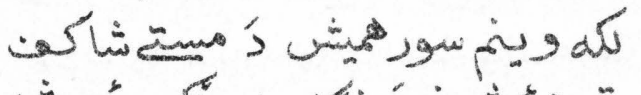

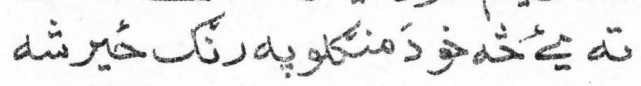

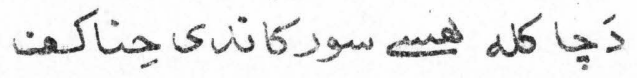
|

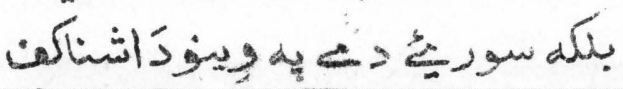




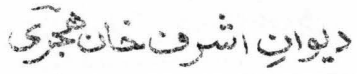

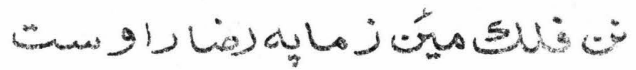

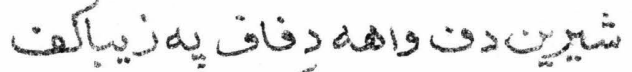
Lijslods 管

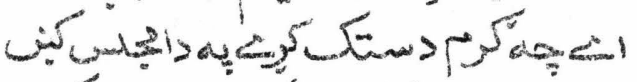

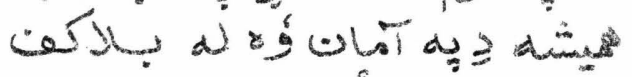

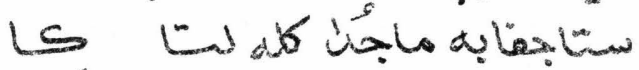
国

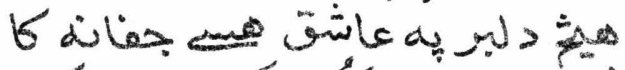

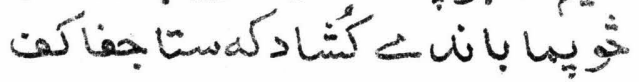

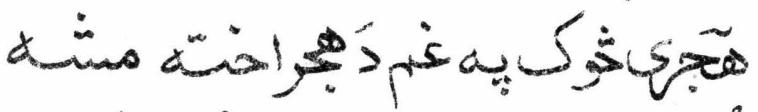

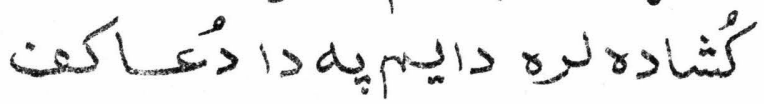

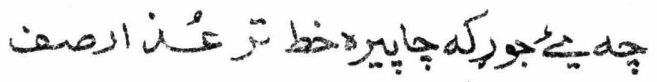
غن

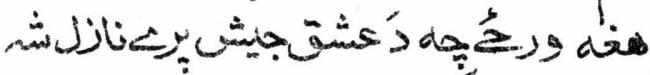

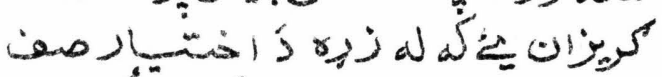

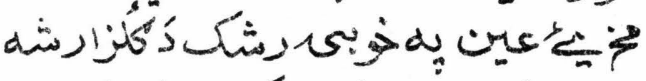

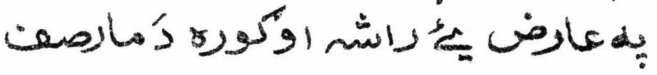

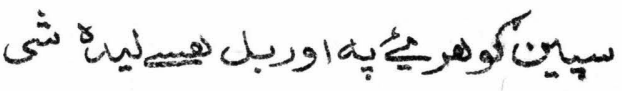

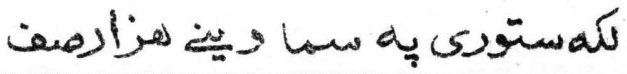
rivy 


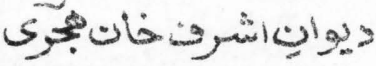

خاطنه

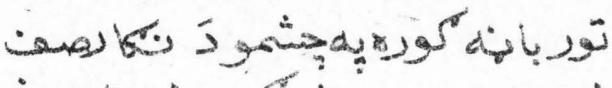

زئم

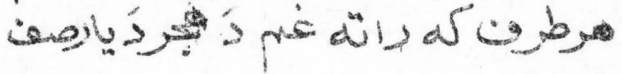

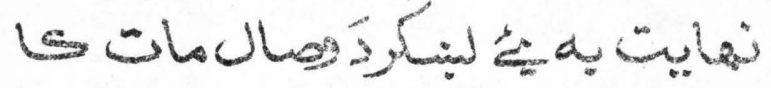

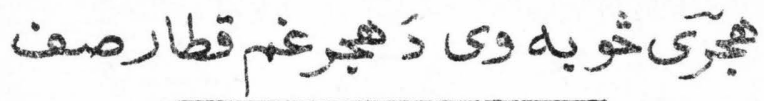

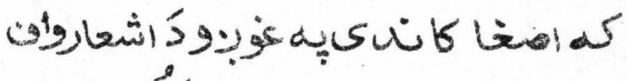

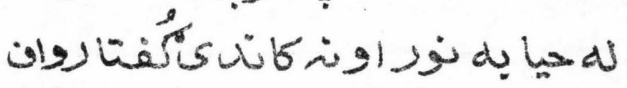

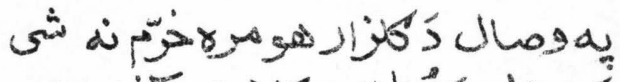

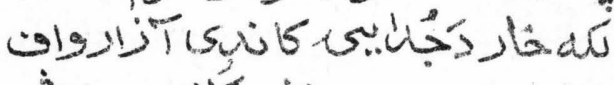

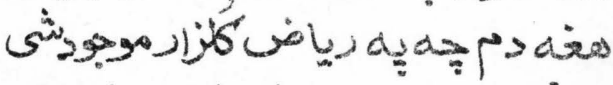

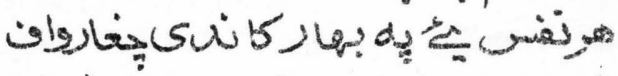

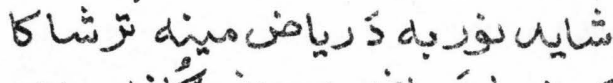

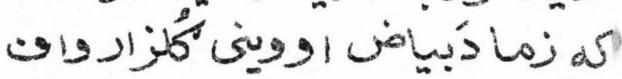

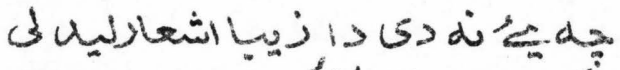

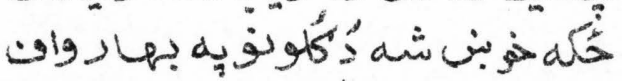

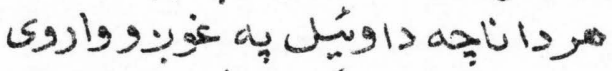

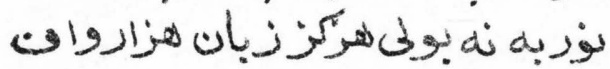

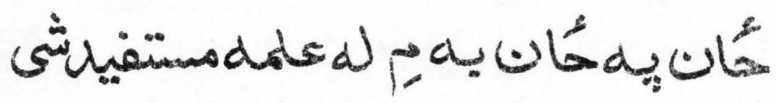

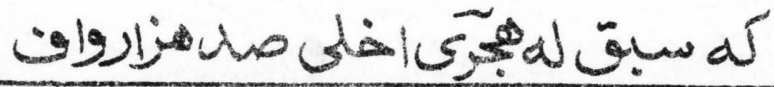




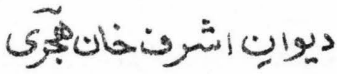

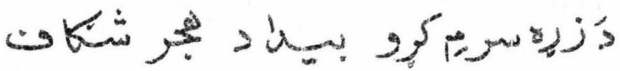

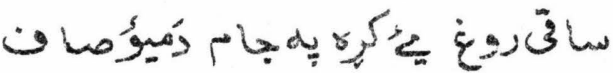

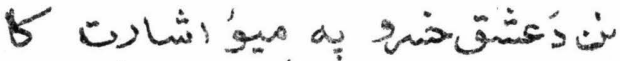

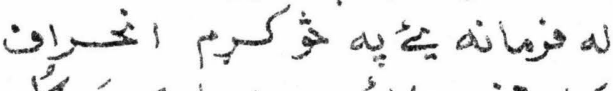

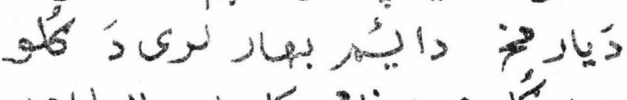

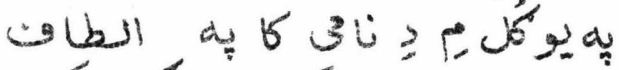
نيسال

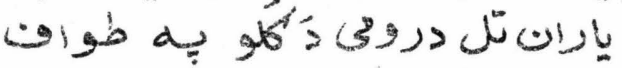

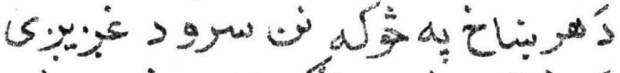

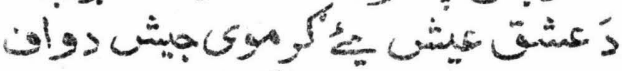

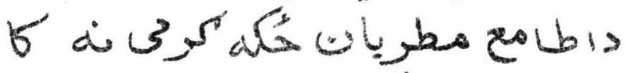

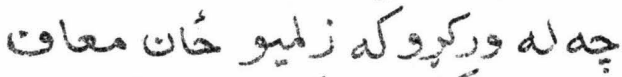

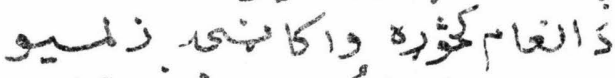

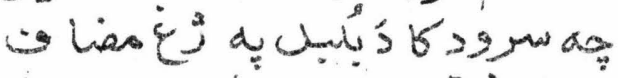

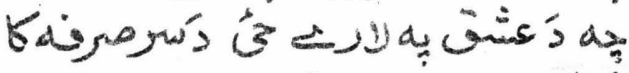
Lلا لا

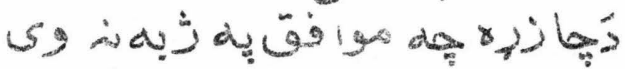

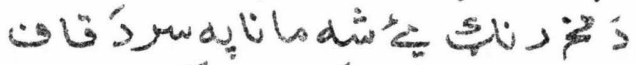

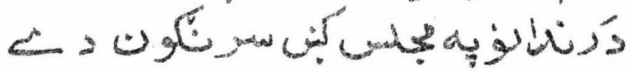

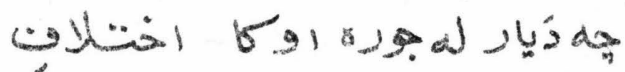

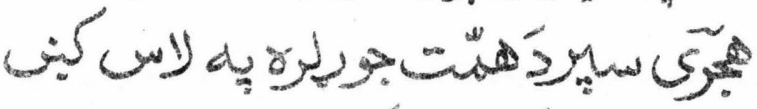

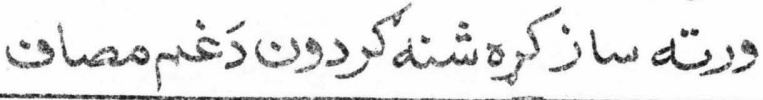




\section{aㅏ잉 \\ C}

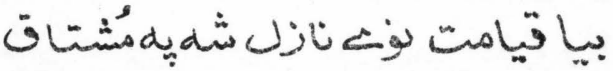

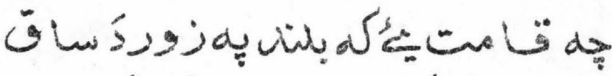

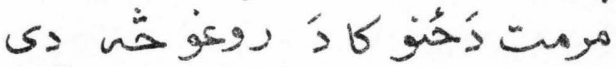

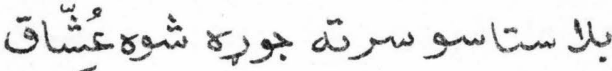

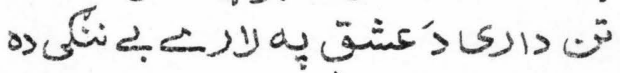

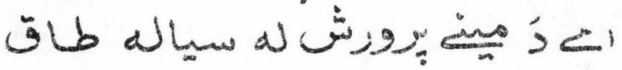

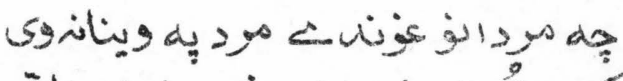

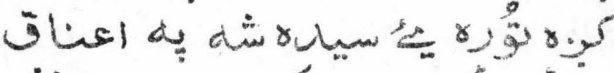

ئئ

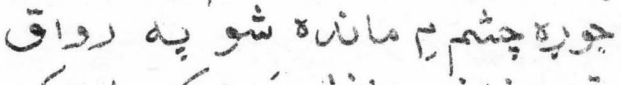

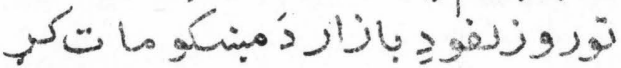

زيما جز

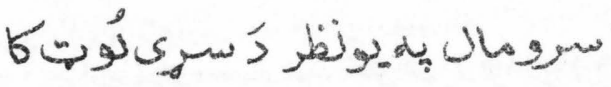

 


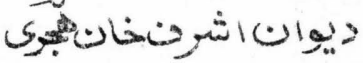

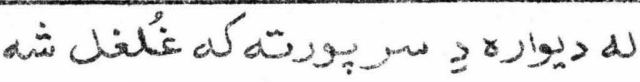

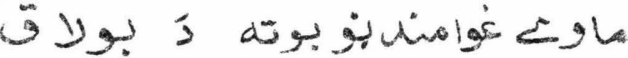

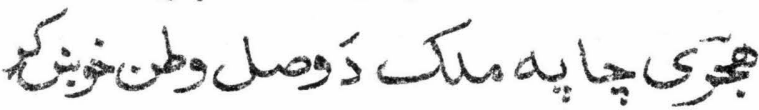

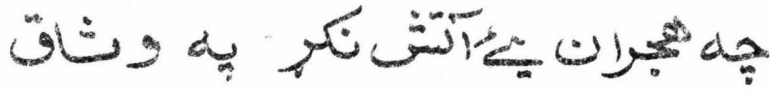

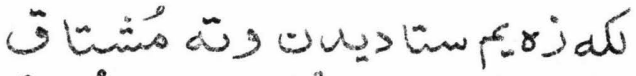

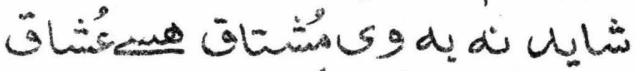

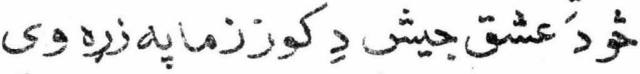

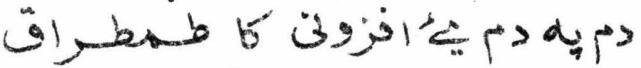

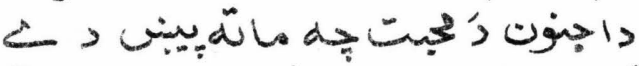

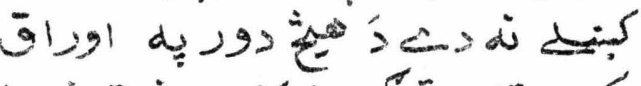

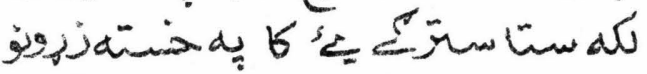

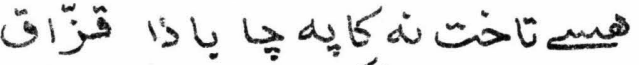

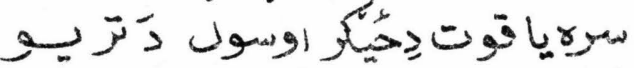

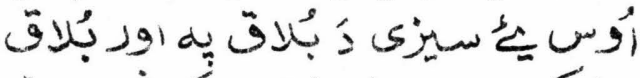
هخه

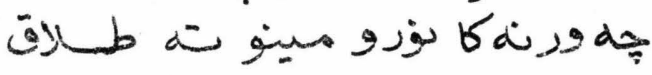

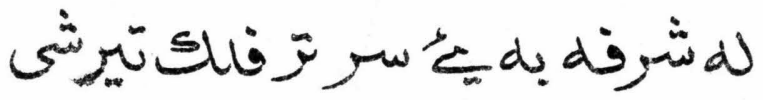
كأل 


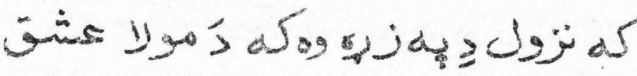

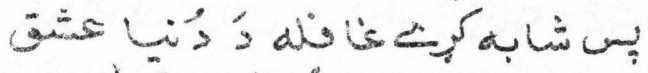

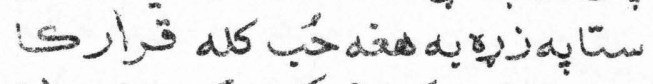

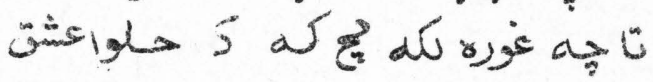

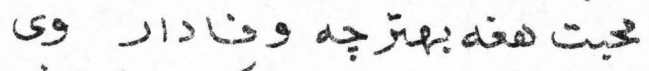

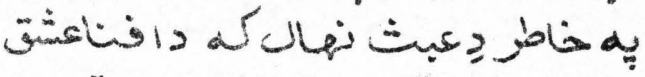

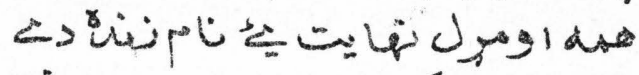

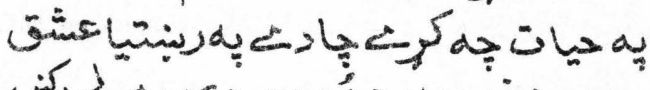

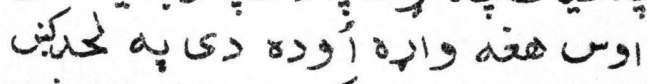

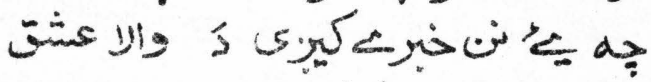

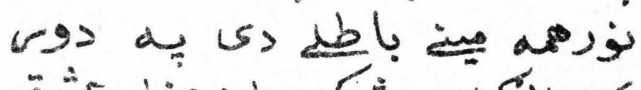
كاك

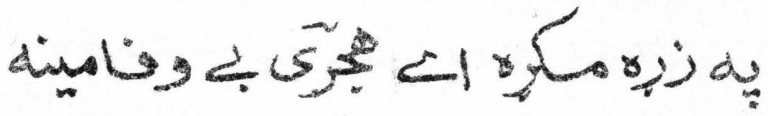

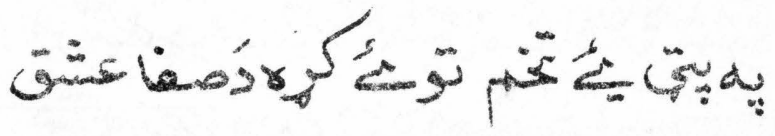

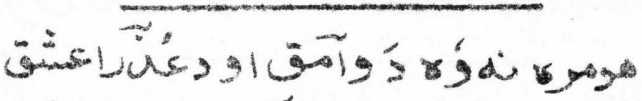

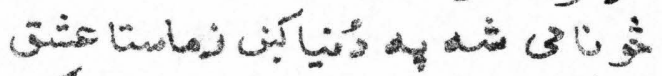


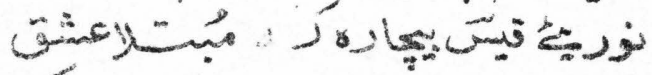

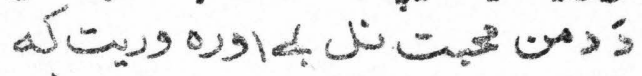

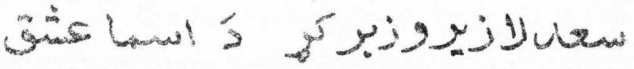




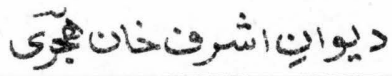

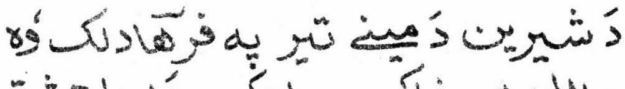

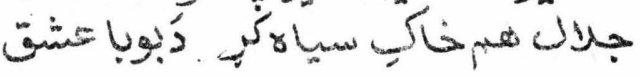

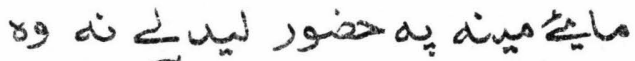

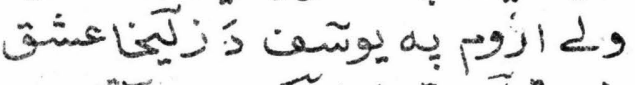

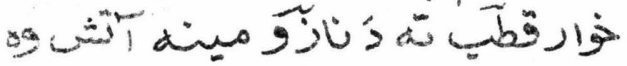

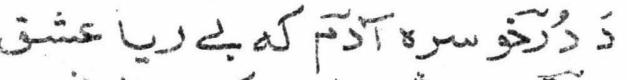

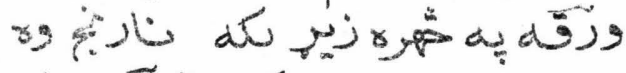

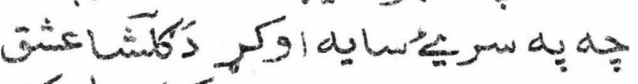

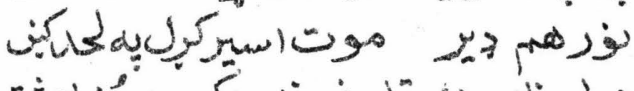
و 若

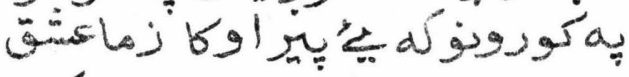

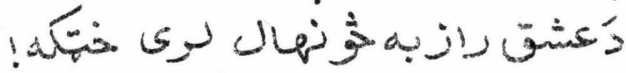

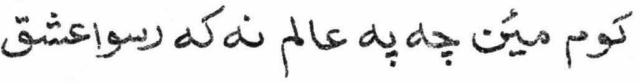

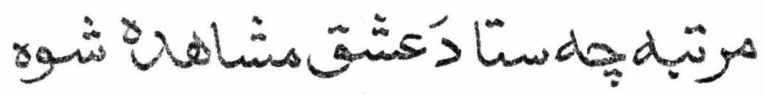

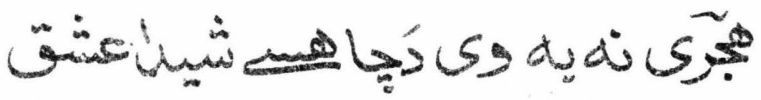

年

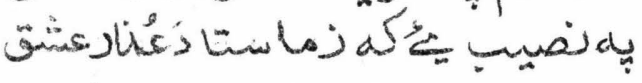
ك́ ها. 


\section{حيوانِاشِرن خان}

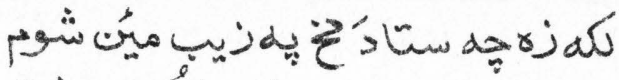

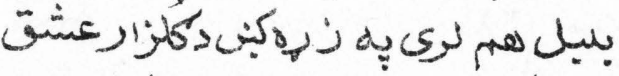

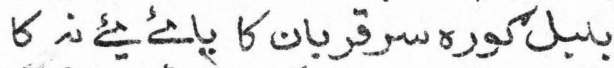

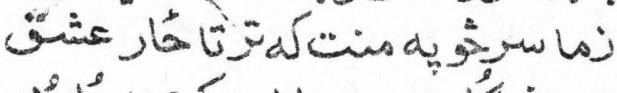

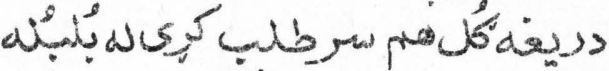

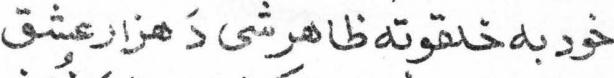

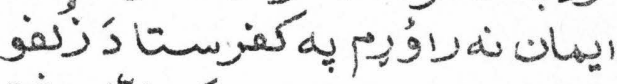

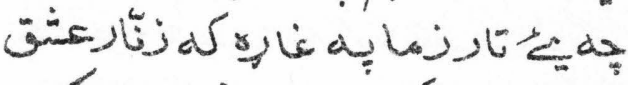

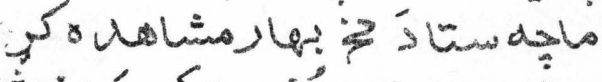

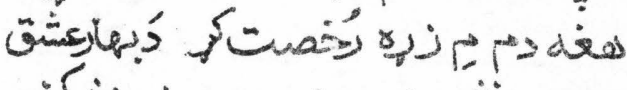

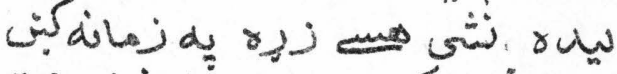

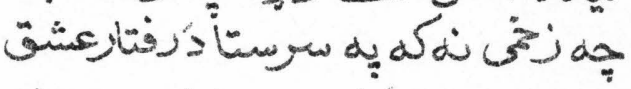

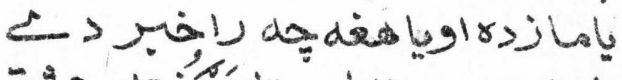

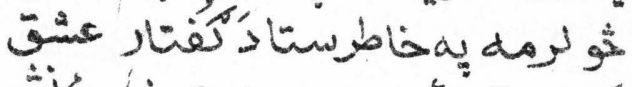

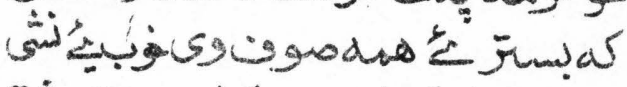
جه

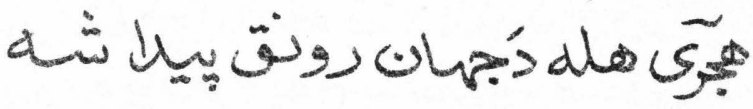

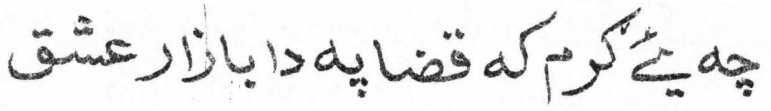




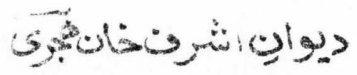

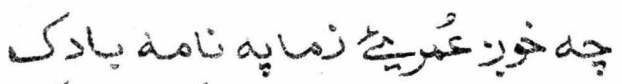
Sاك

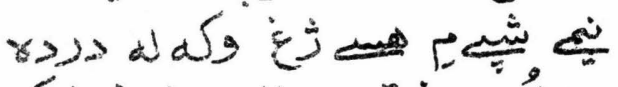
كان E

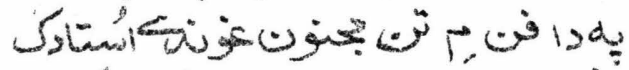

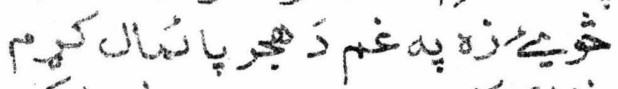

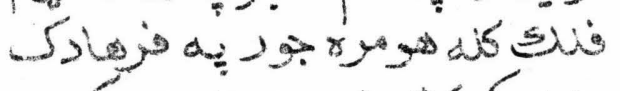

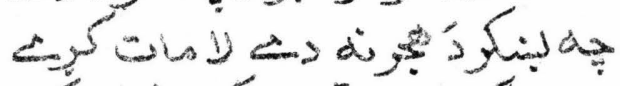

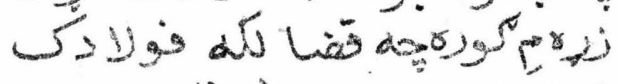

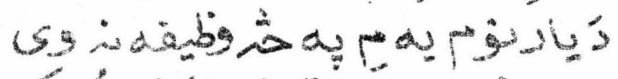
Solyosicoj

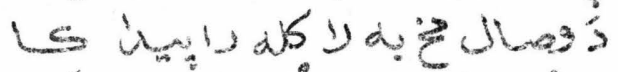

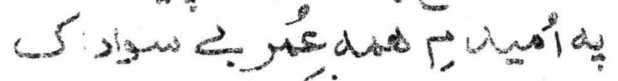
لز

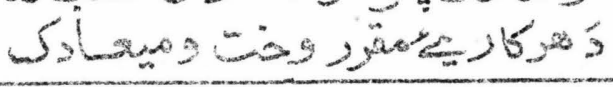


ديوانِاشرق خانئيح

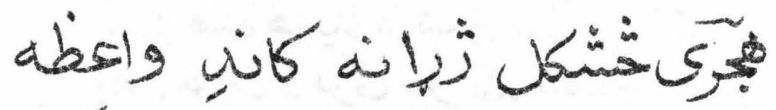

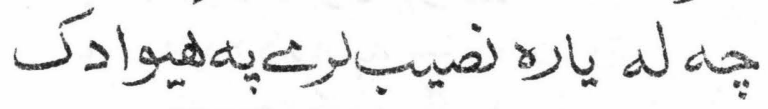

次

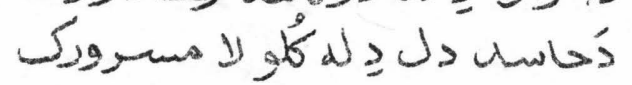

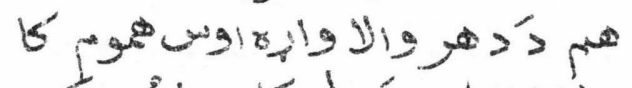



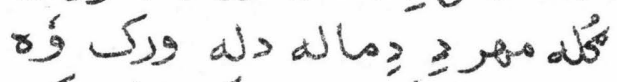

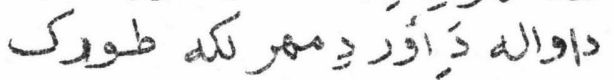

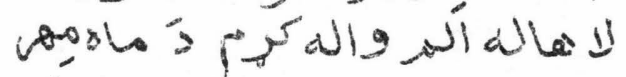

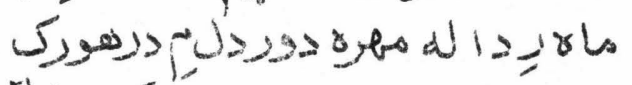

صن

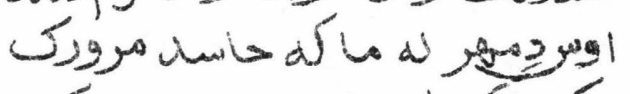

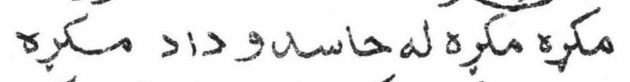

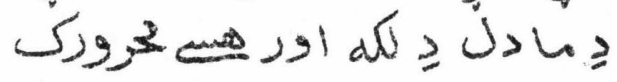

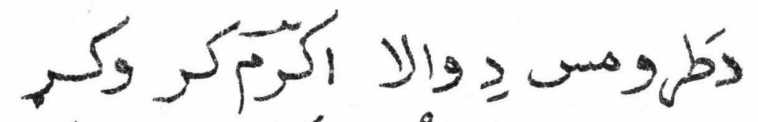

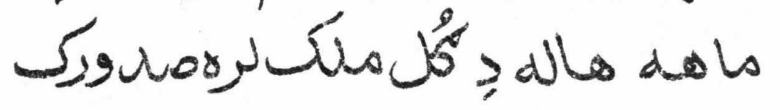

$\wedge \Delta$ 


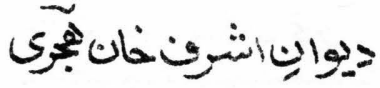

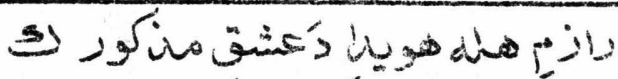

s)

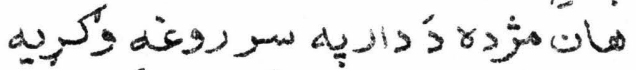

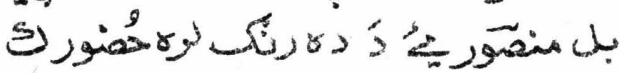

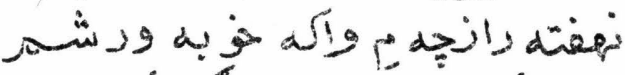

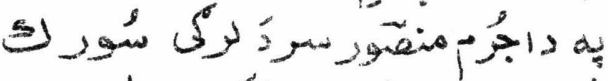

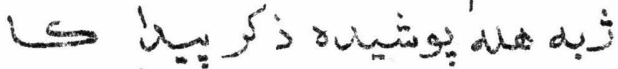

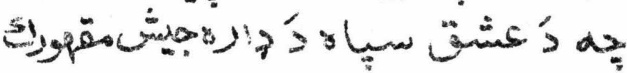

تو

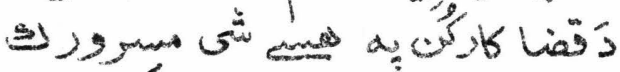

范

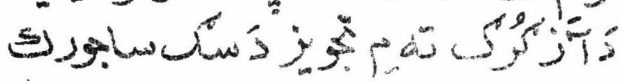

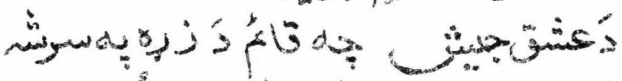

S)

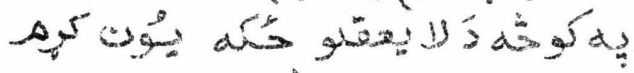

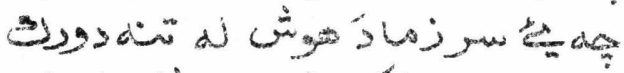

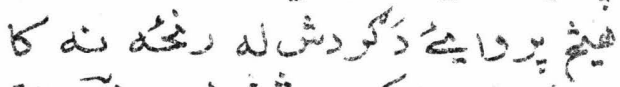

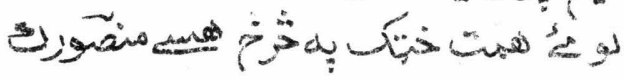

فا

S

ray 


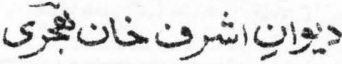

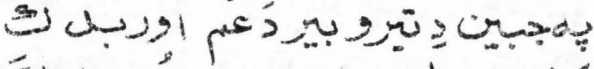

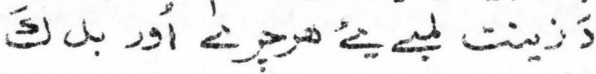

罗

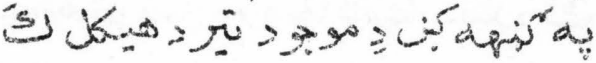

6 난

scla ¿

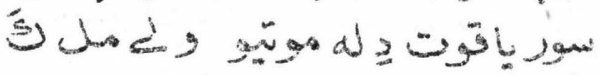

دَ"

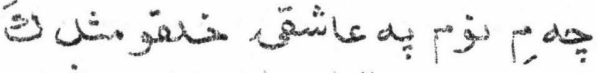

ك

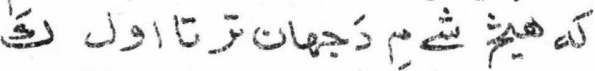

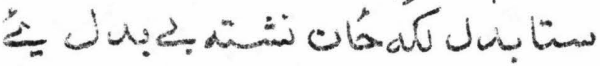

s dur a d

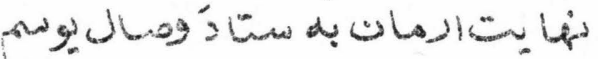

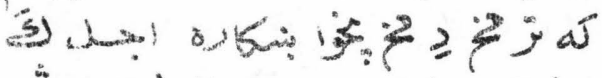

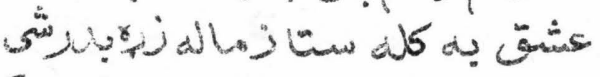

到U

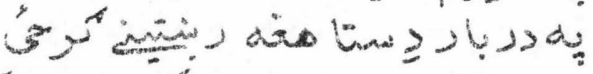

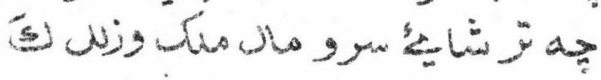
ش

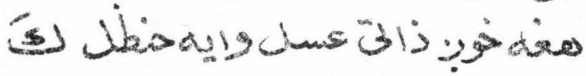




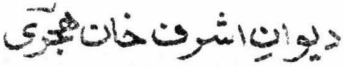

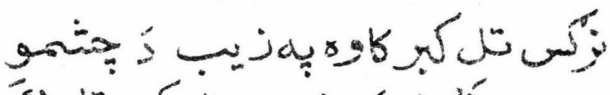

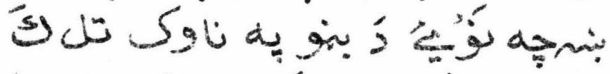

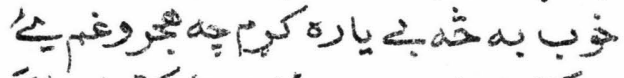

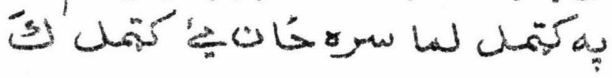

يمحيا

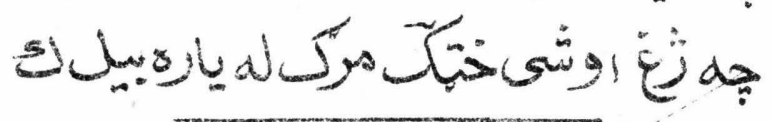

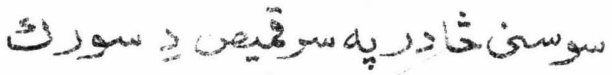

s)

管

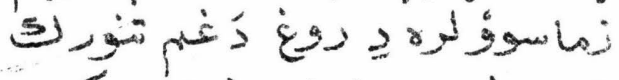

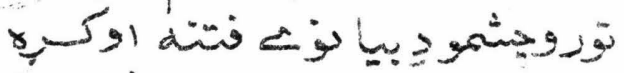

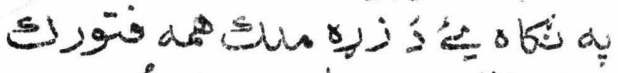

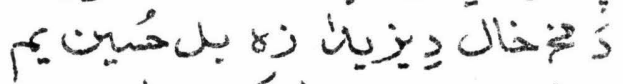

s)

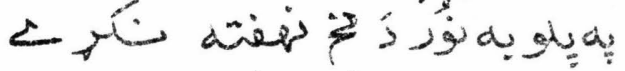

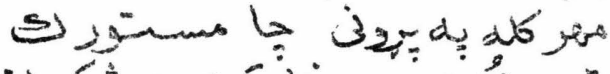

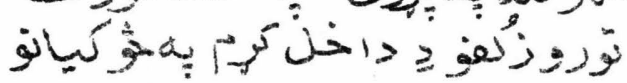

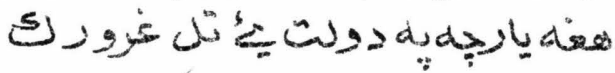

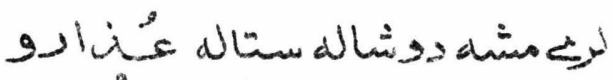

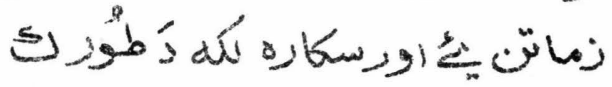




\section{(}

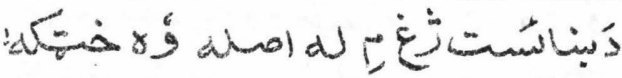

5)

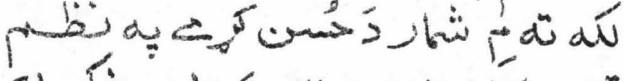

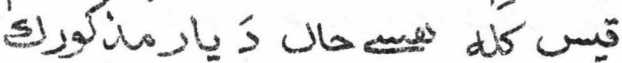
Pوكن : 5)

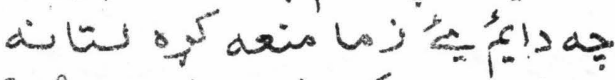

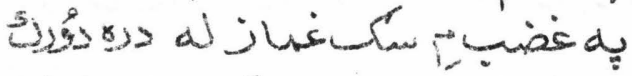

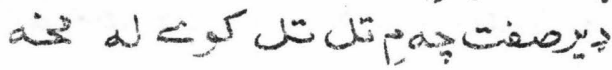

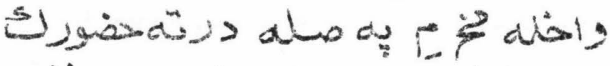

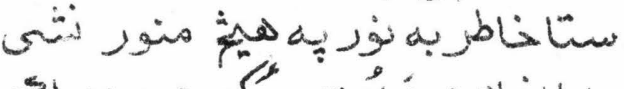

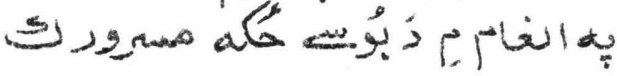

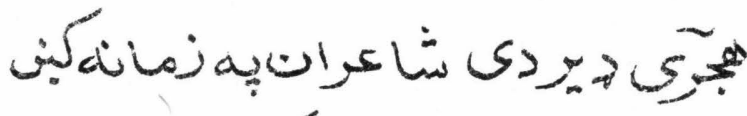

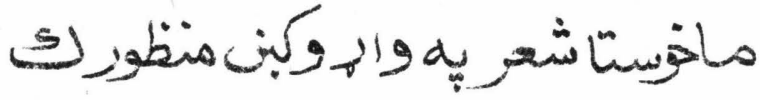

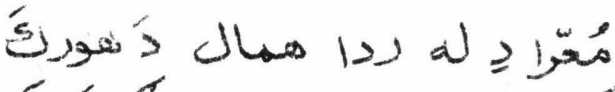

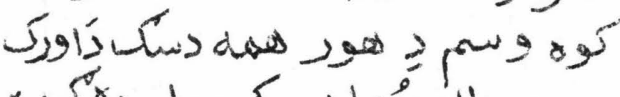

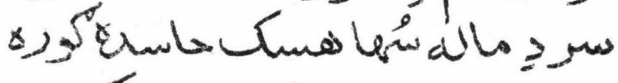

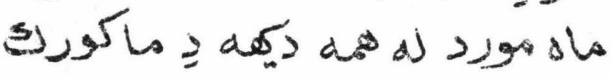

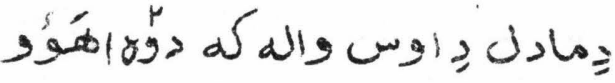

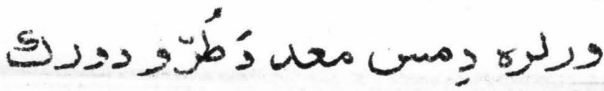




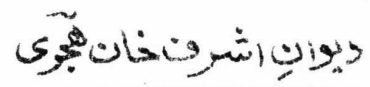

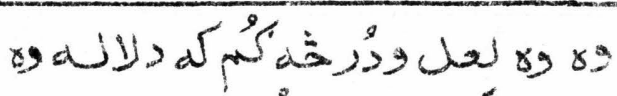

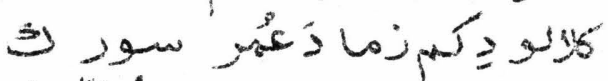

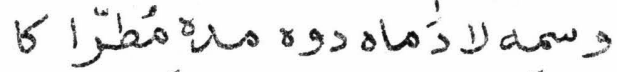

od

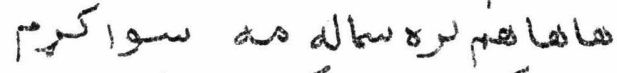

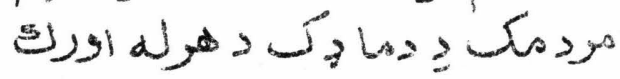

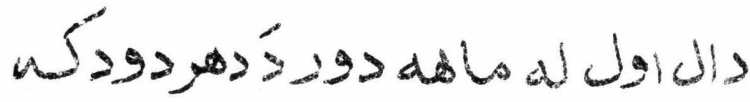

Si dos 
يوالِِانرينحانجزي

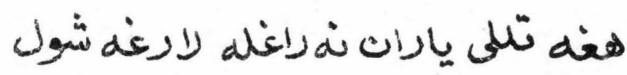

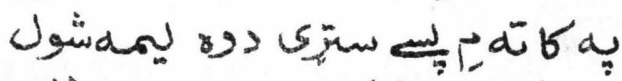

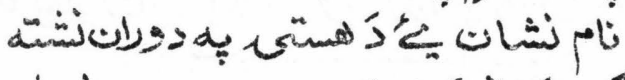

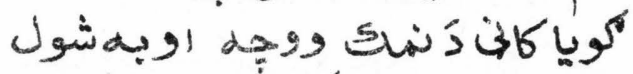

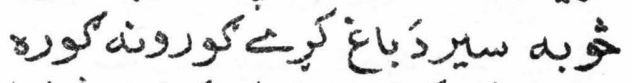

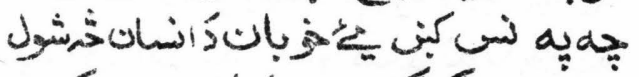

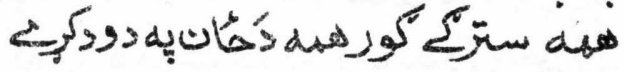

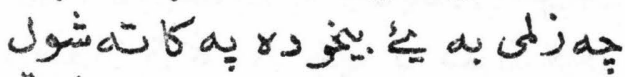

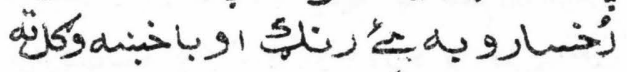

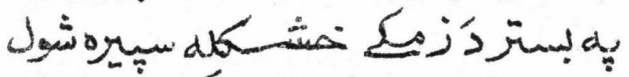

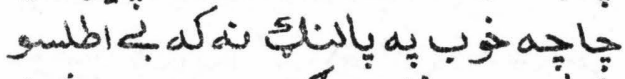

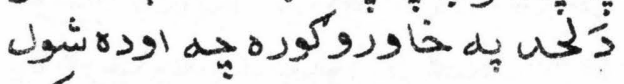

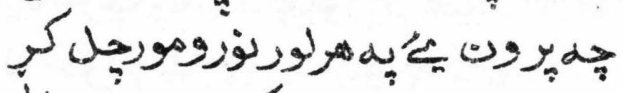

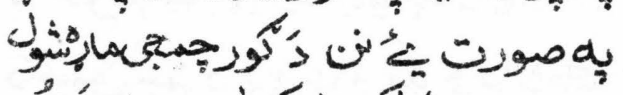

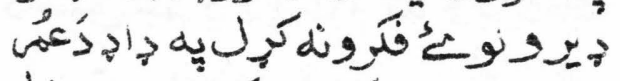

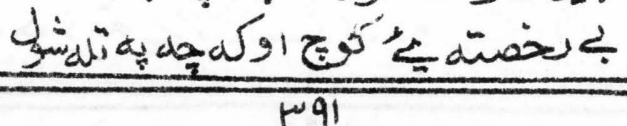




\section{يوانِ}

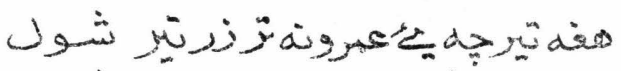

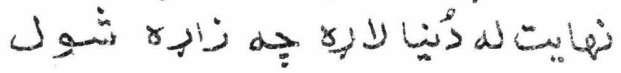

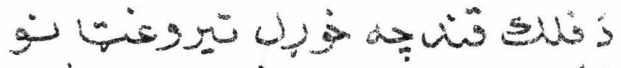

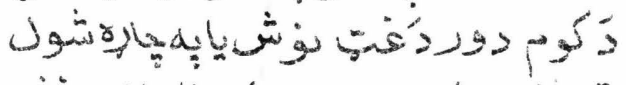

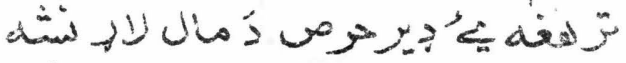

هو

كأن

لج

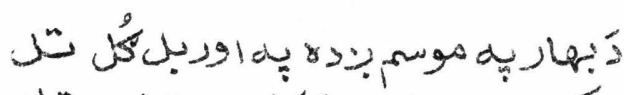

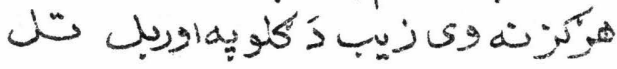

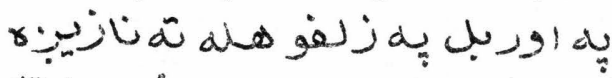

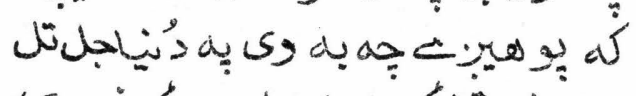

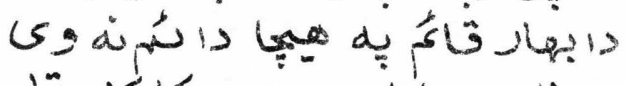

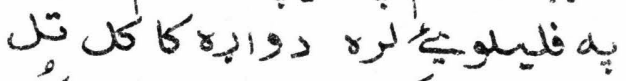

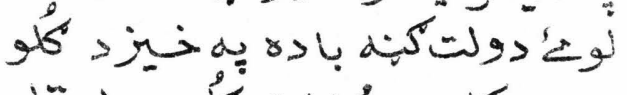

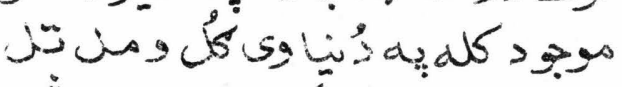

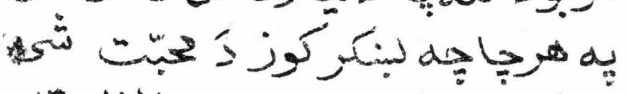

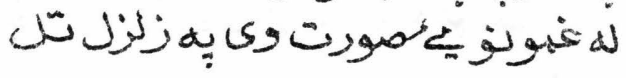

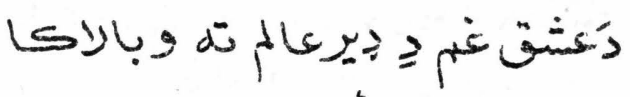

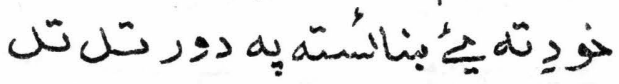




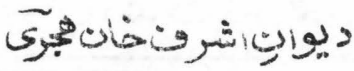

كل

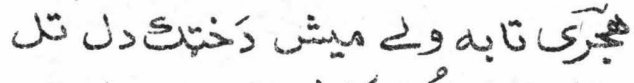

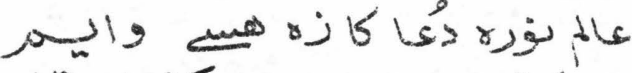

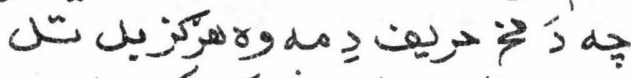
ب

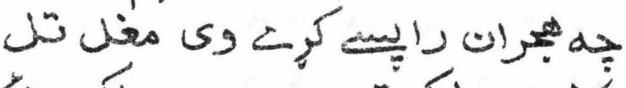

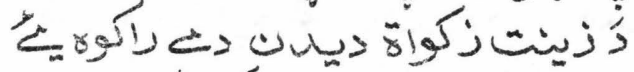

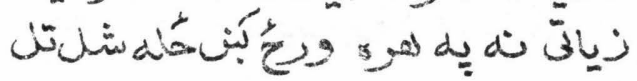

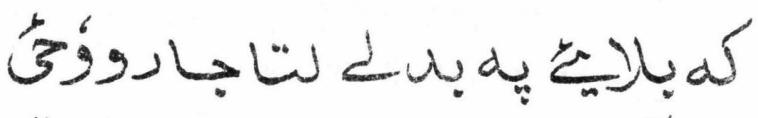

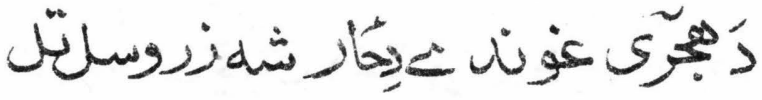

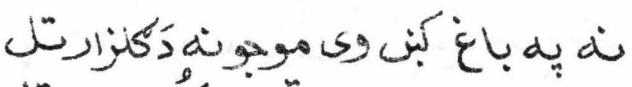

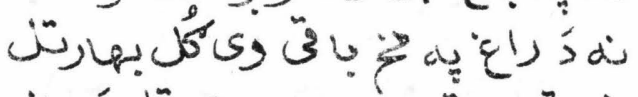

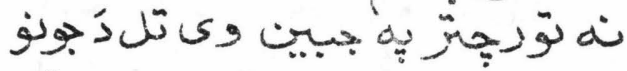
نة نه

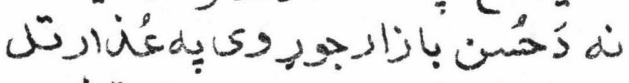

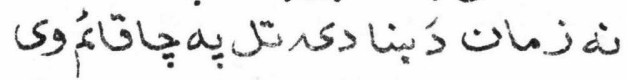

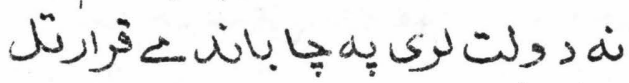

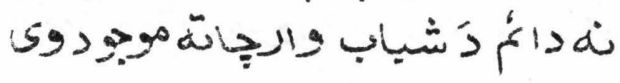

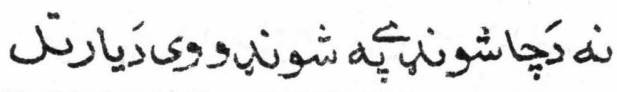




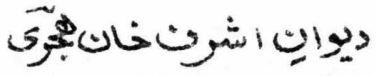

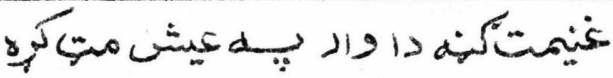

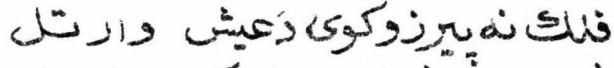

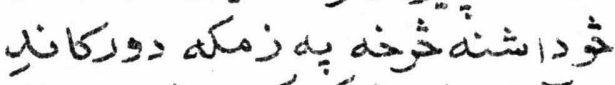

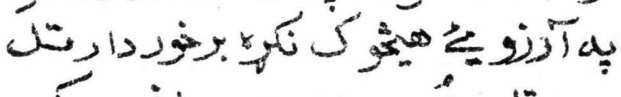

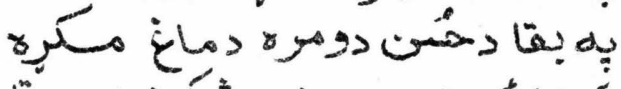

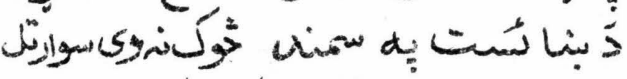

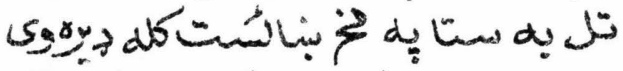

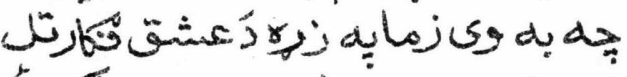
كله

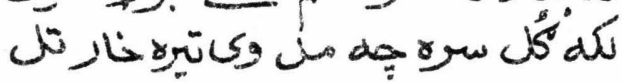

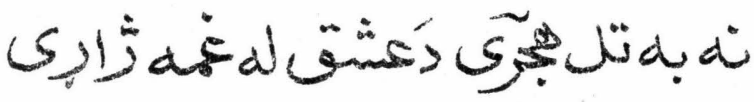

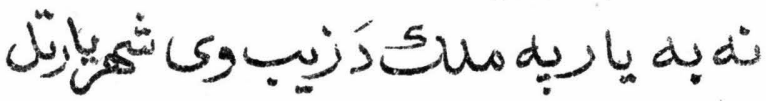

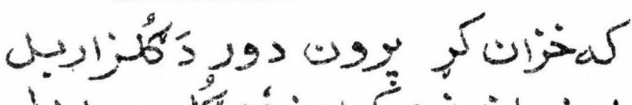

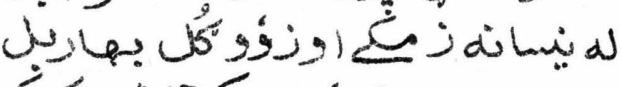

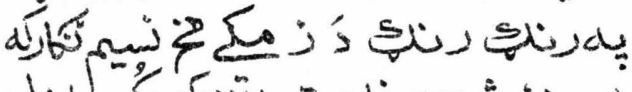

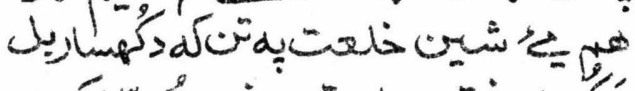

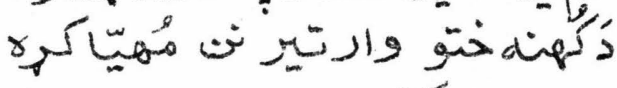

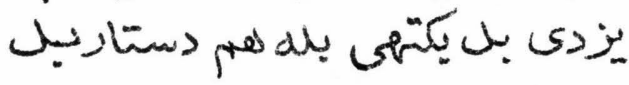

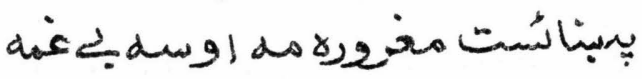

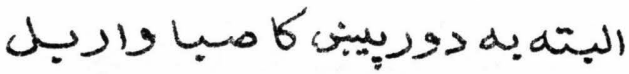




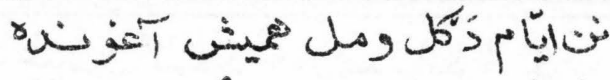

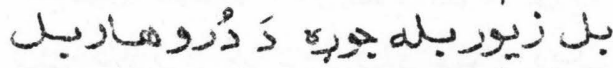

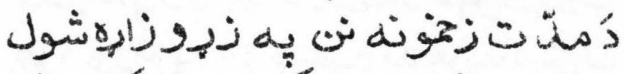

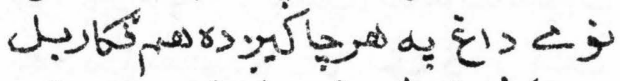

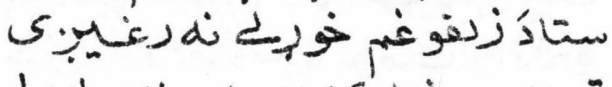
ل

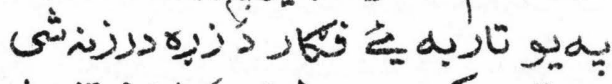

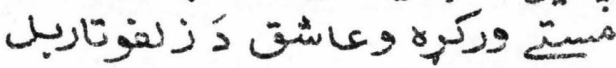

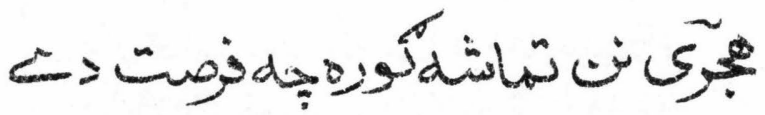

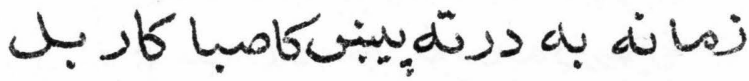

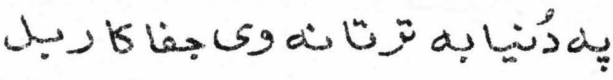

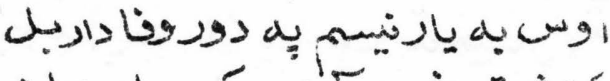

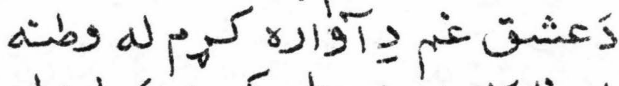

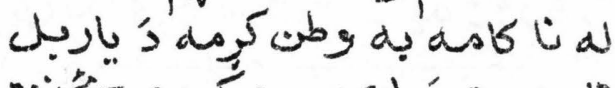

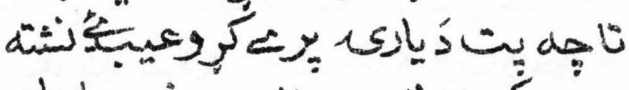

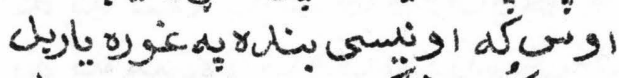

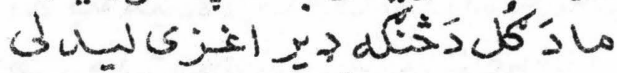

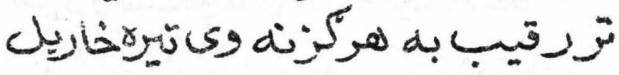

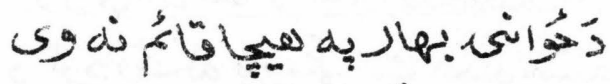

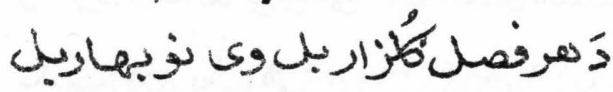


كون

زريه ذركانس

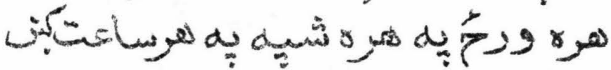

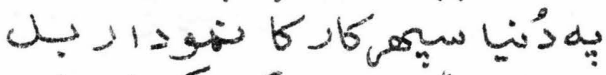

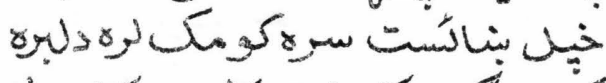

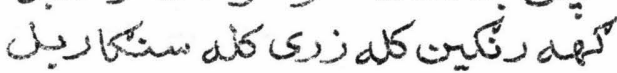

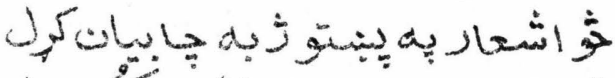

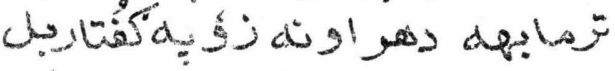

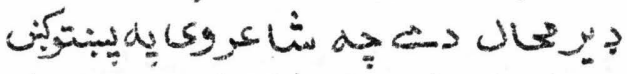

لمان

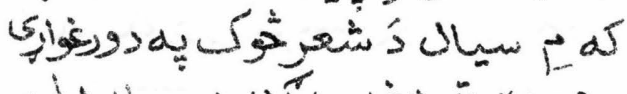

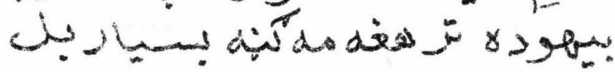

"

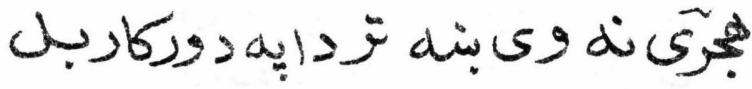

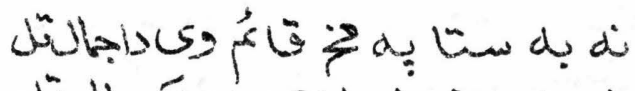

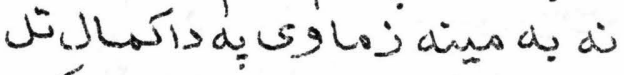

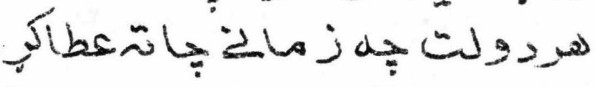

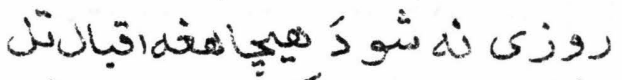

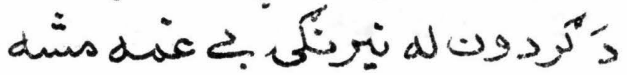

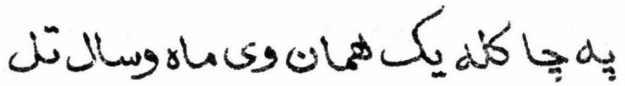




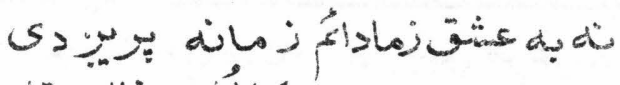

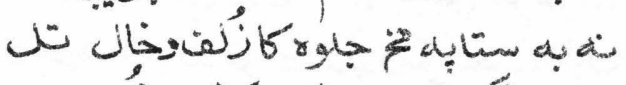

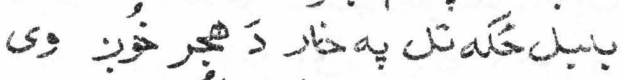
زبه

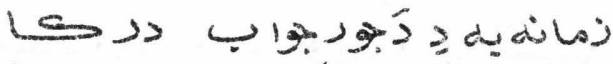

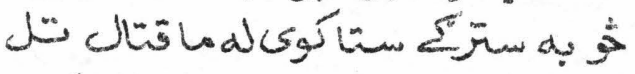

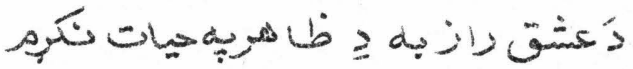

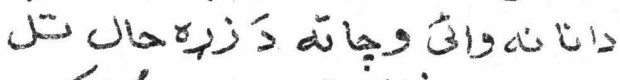

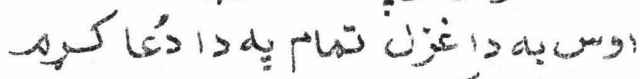
ل أل

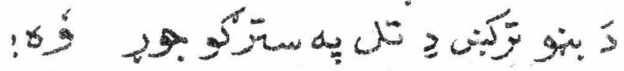

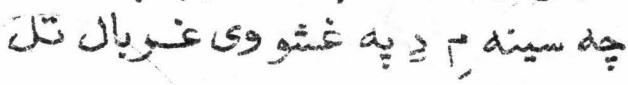

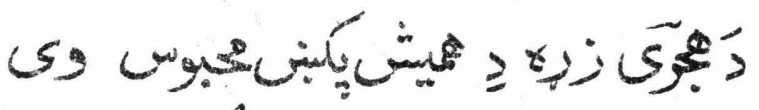

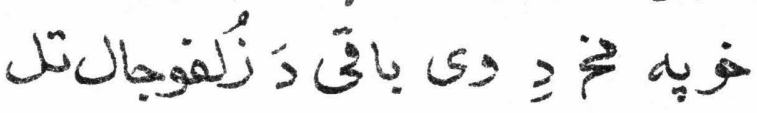

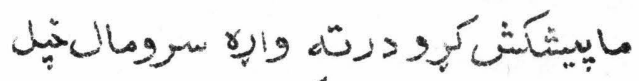

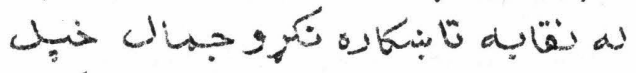

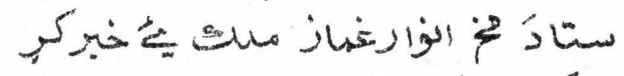

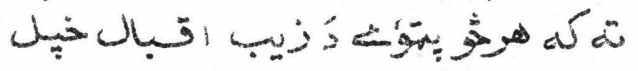

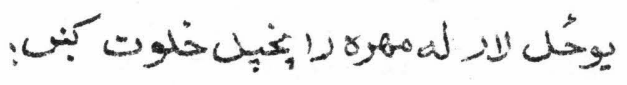
家 


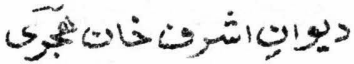

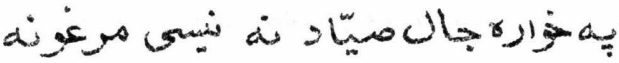

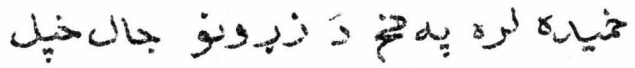
3و

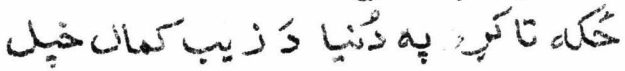
ستابا وركل

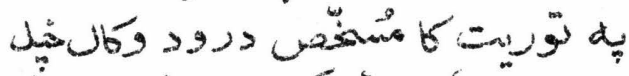
كأنو

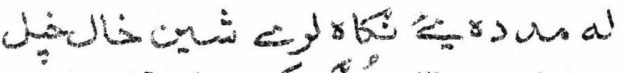

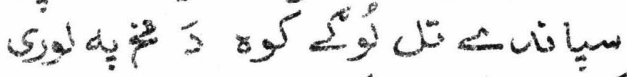

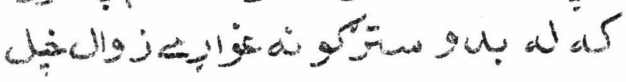

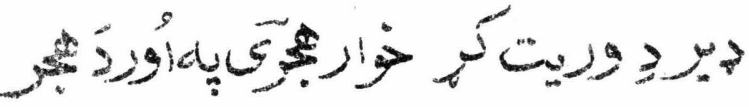

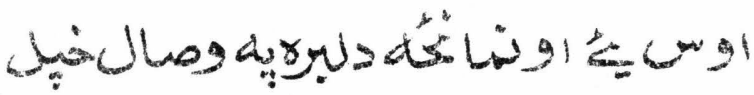

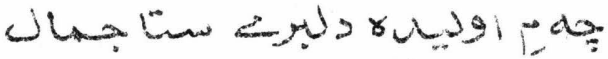

$$
\begin{aligned}
& \text { لها }
\end{aligned}
$$

20 Uh 5'

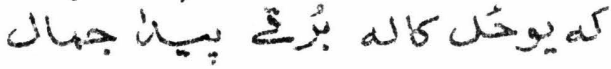
خ

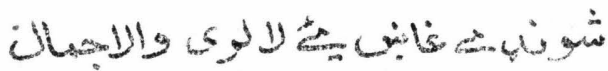


حيوابِاشرتخانجئى

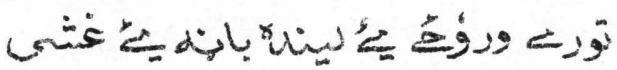

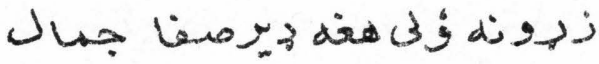

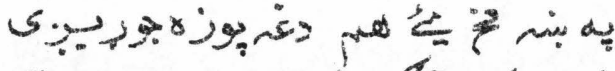

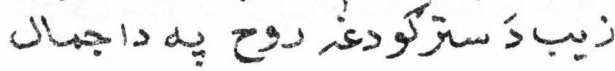

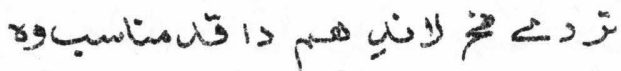

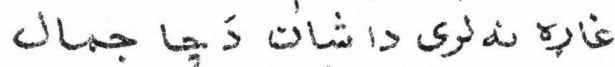

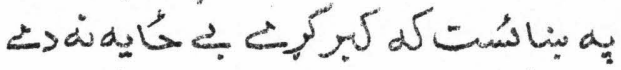

Ch جله

$\Leftrightarrow$ d du d

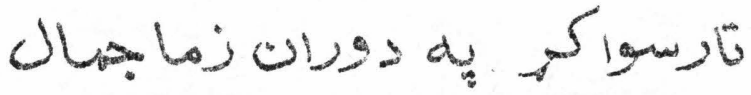

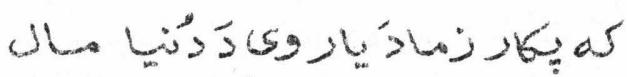

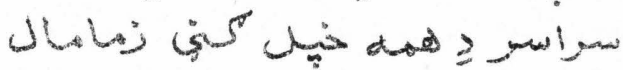

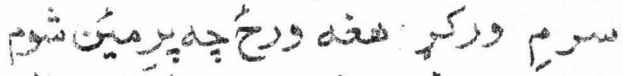

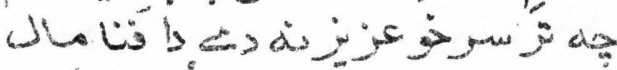

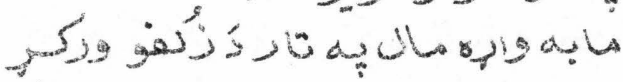

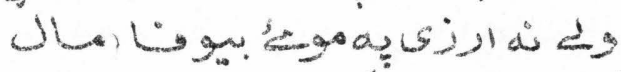

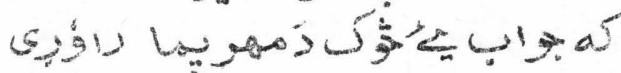

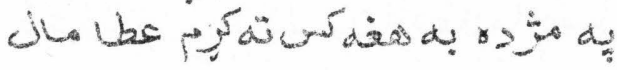

SCL

U.

एव9 


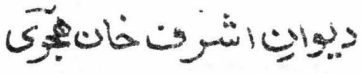

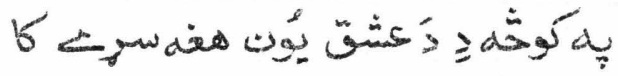

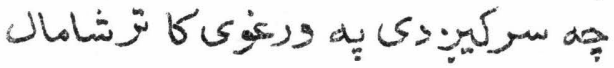

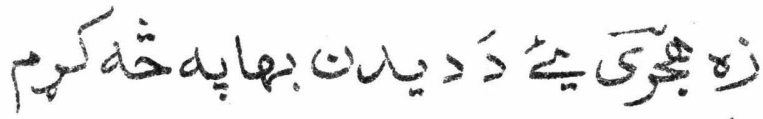

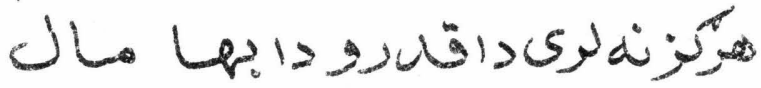

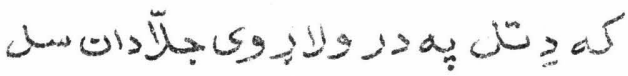

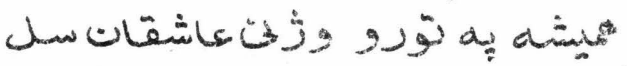
v> $>$ >

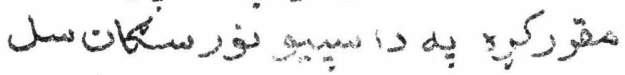
مزئان

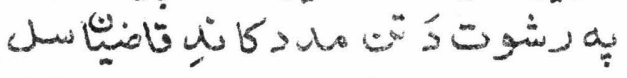

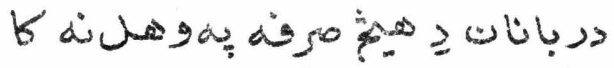

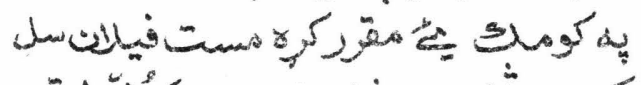
كَ

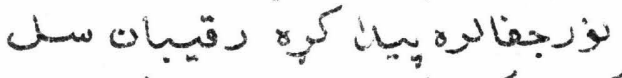

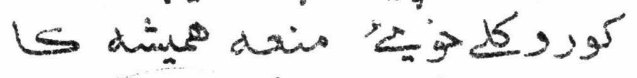

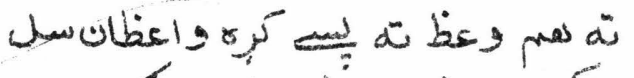

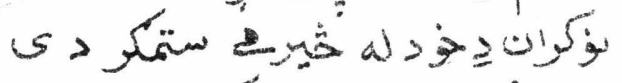

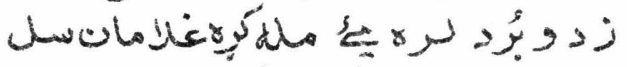

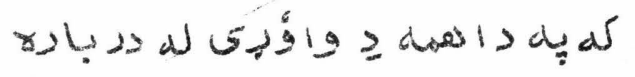

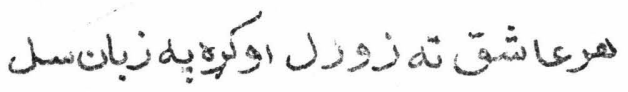


كله

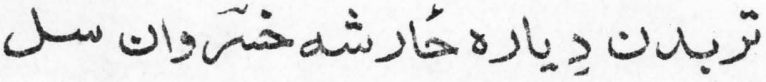

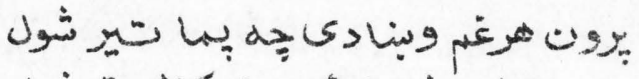

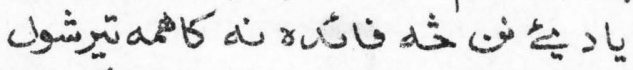

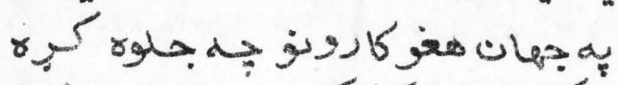

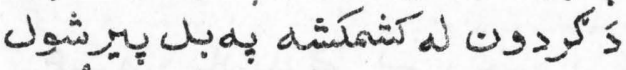

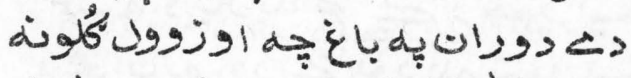
وإرهنج

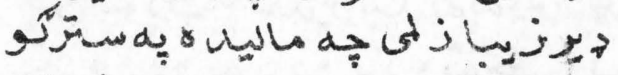

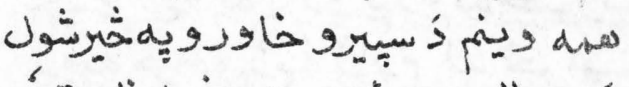

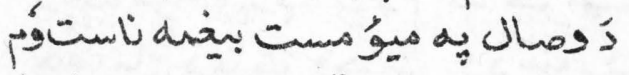

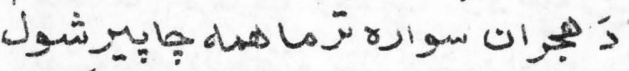

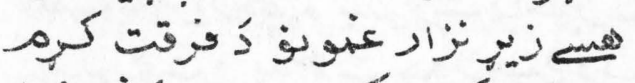

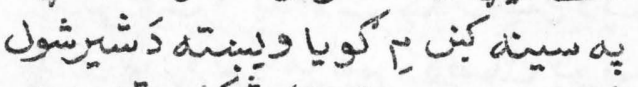

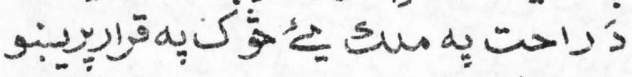

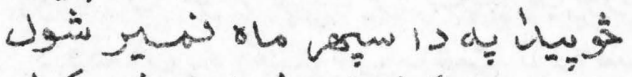

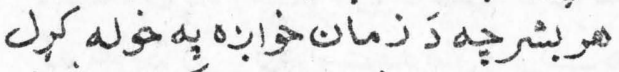

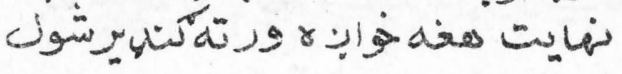

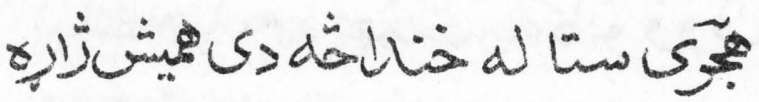
: 


\section{$\Gamma$}

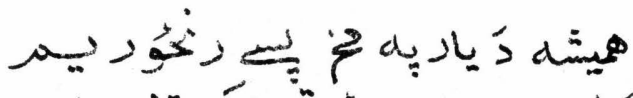

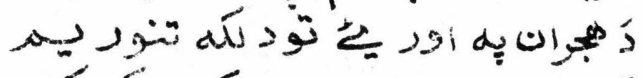

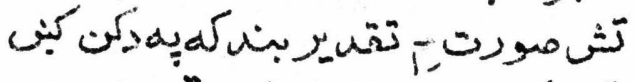

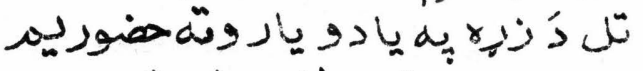
زها

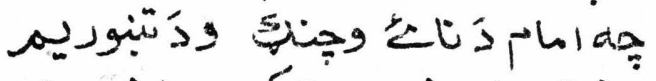

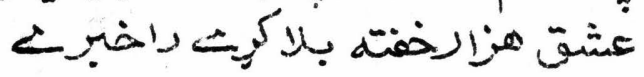

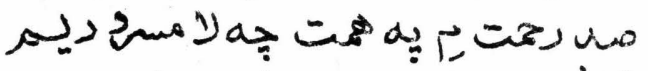

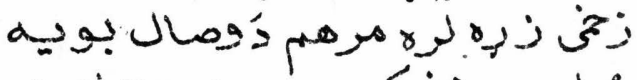

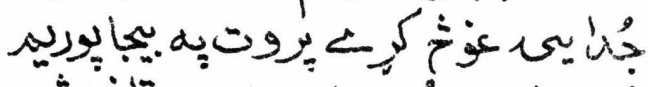

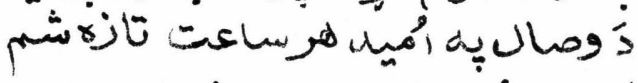

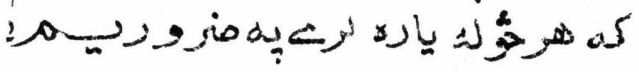

:

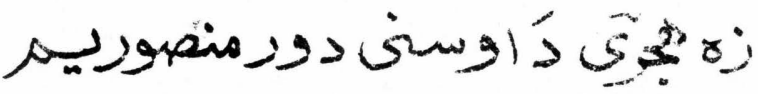




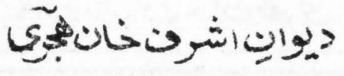

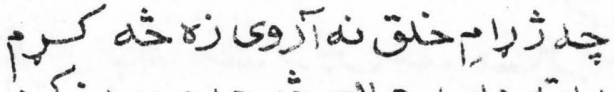

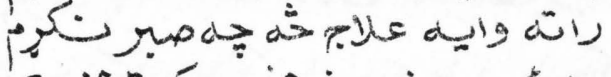
ن

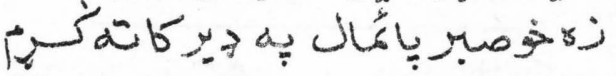

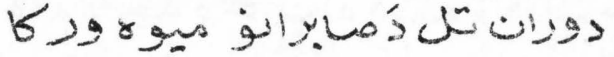

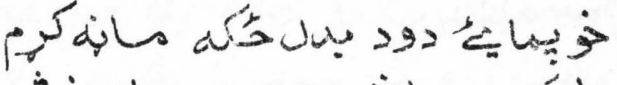

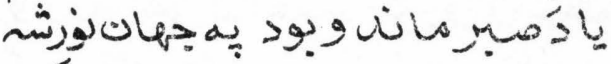

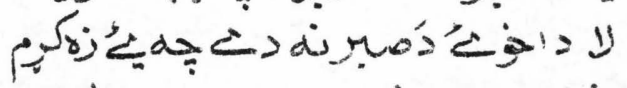

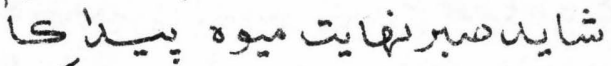

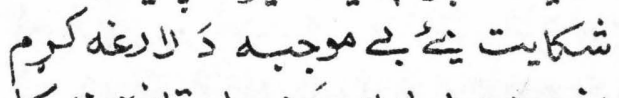

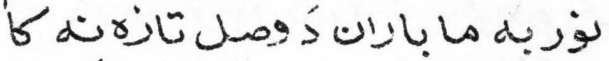

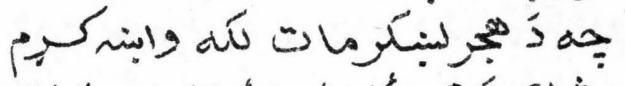

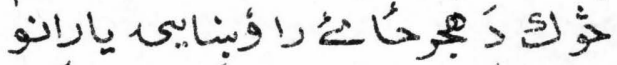

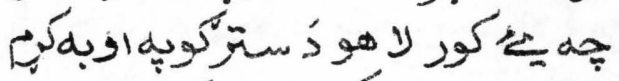

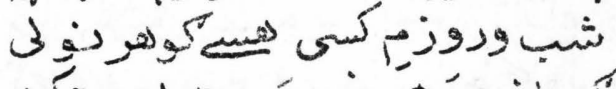

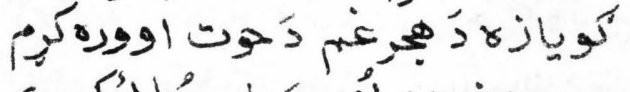

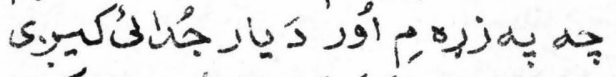
ونئه

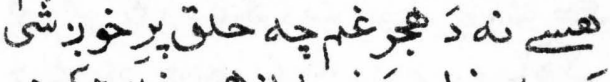

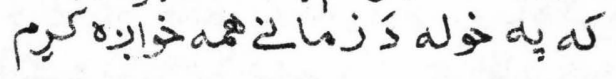

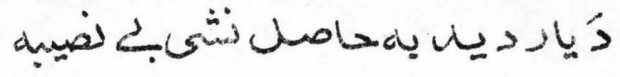

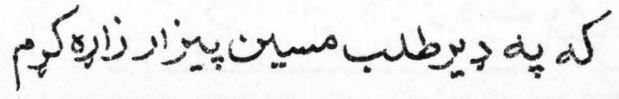




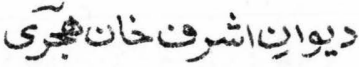

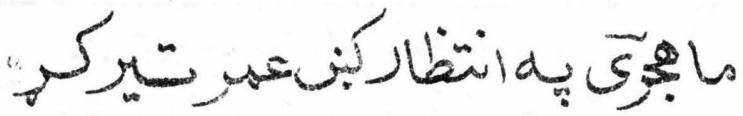

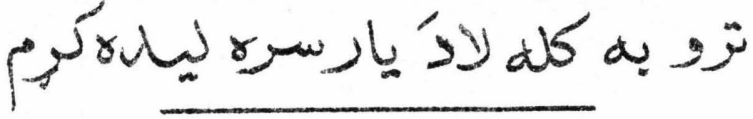

ه

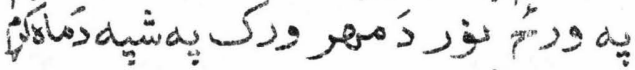

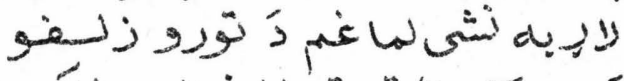

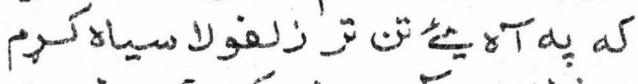
य,

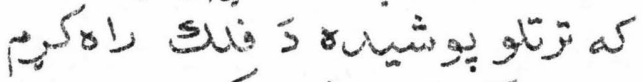
زله

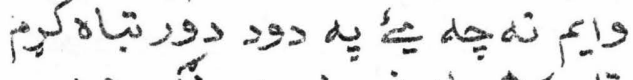

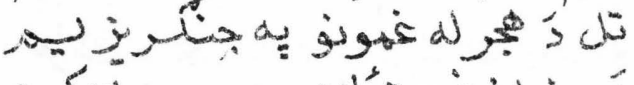

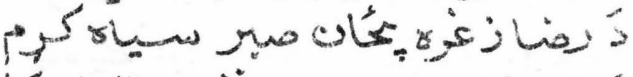

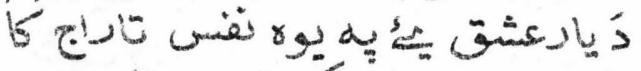

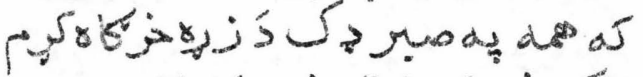

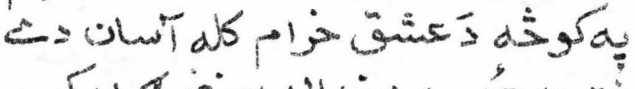
ز Le و ز

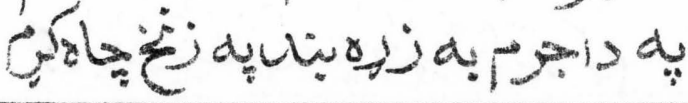




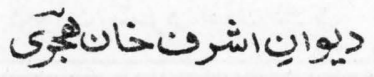

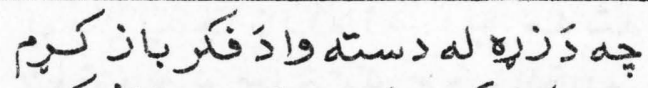

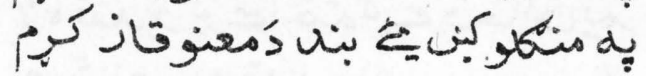
لز

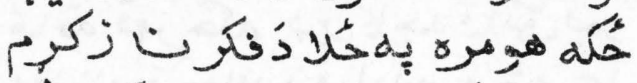

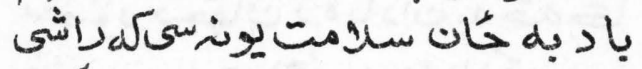

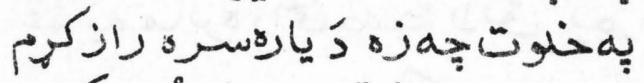

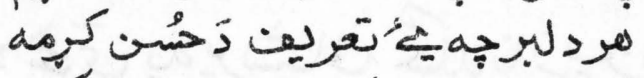

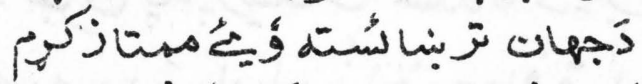

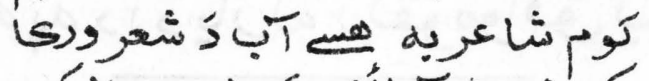

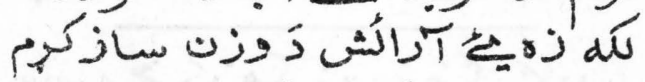

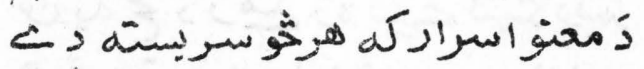
زريه زيرئية

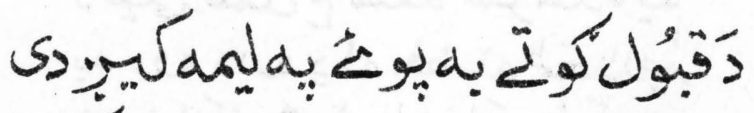

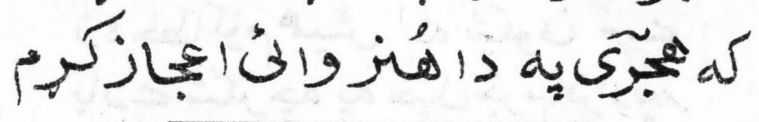

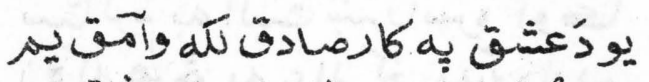

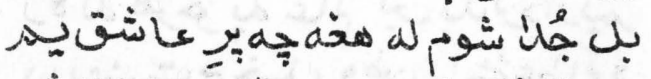

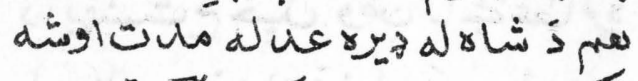

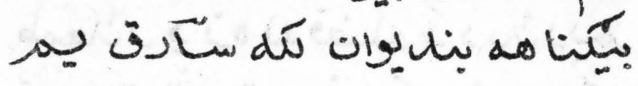

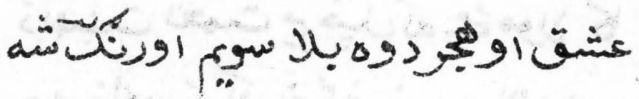

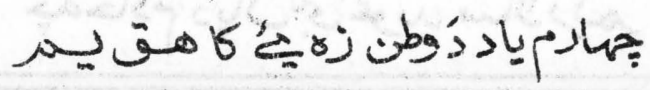


يوبا لا به

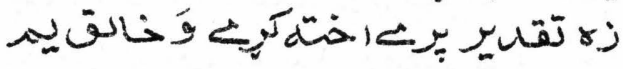

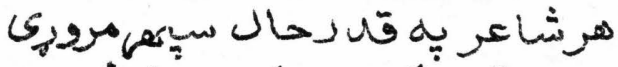

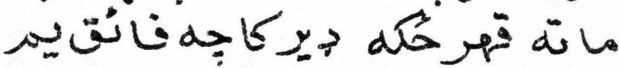

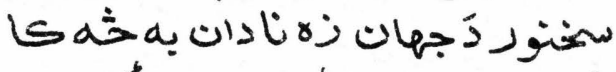

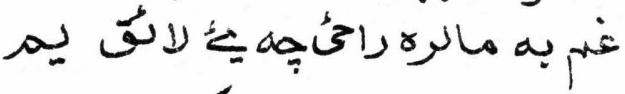

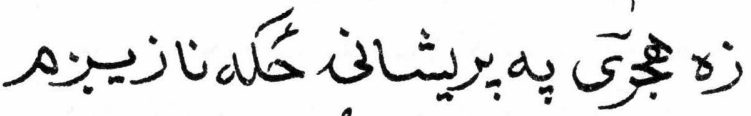

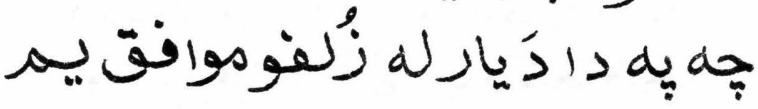

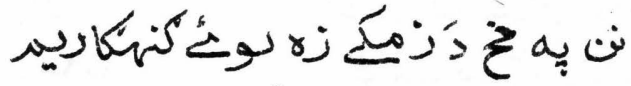

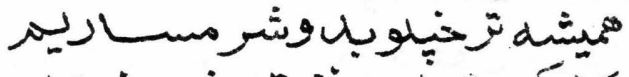

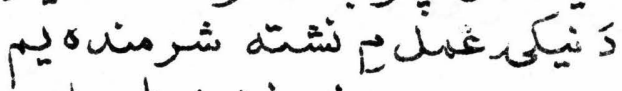
به

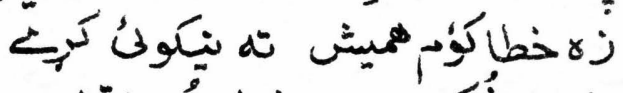

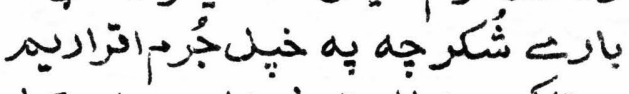

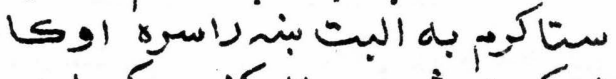

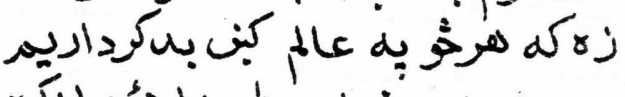

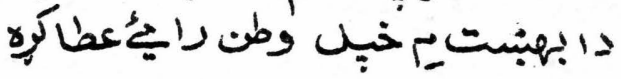

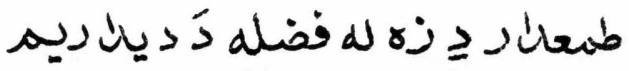

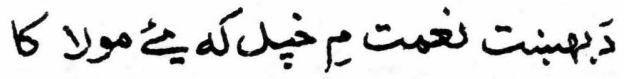

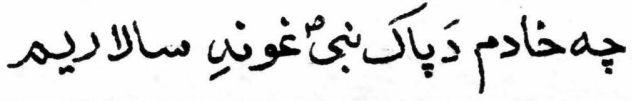




\section{ديوانِاشروفانجيُّي}

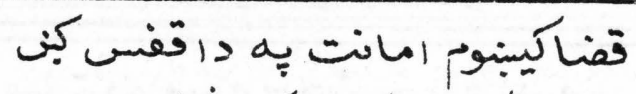

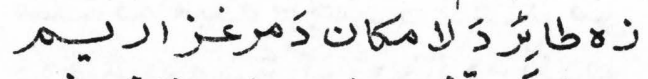

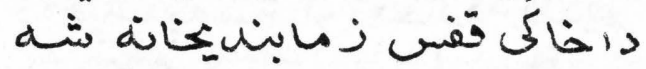

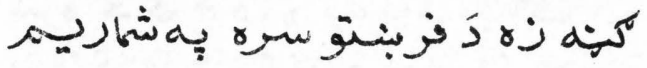

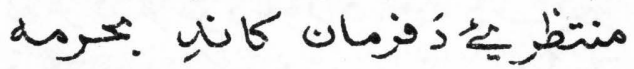

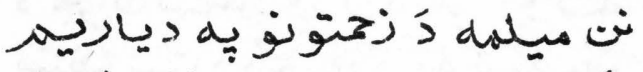

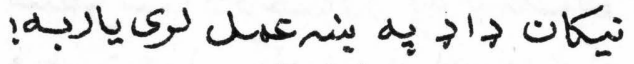

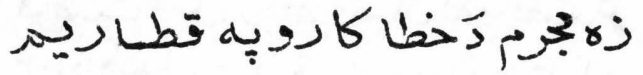

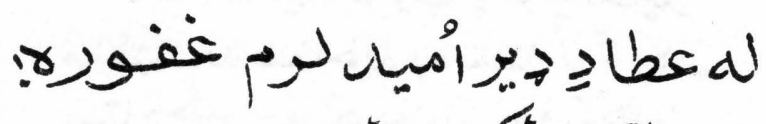

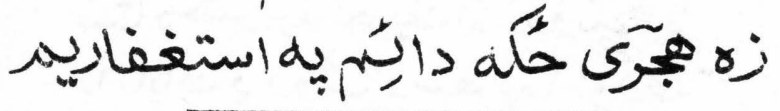

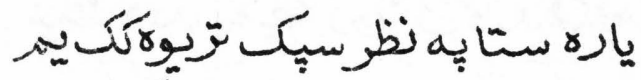

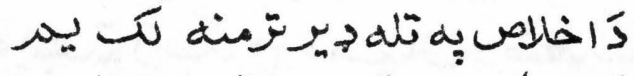

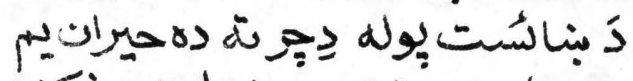

هن

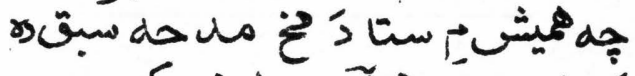

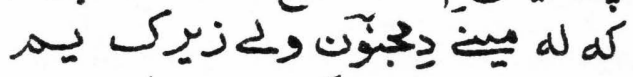

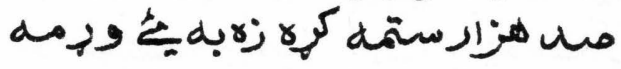

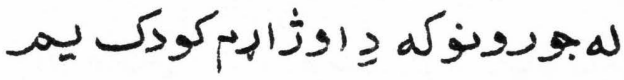

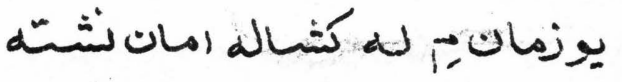

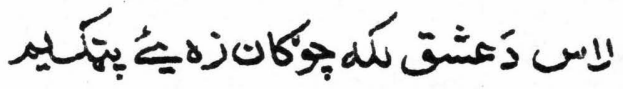


مستانة مينه

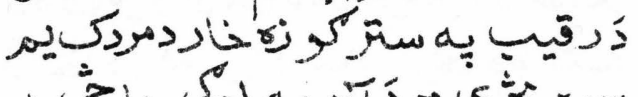

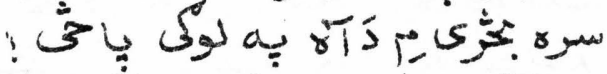

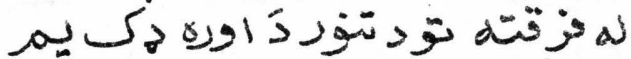

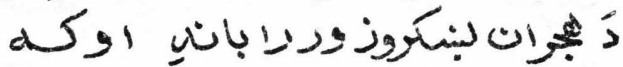

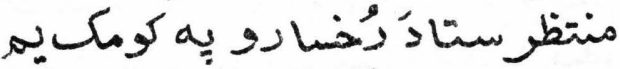

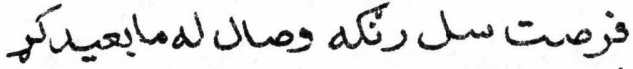

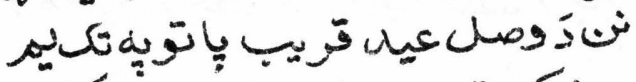

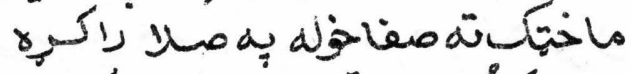

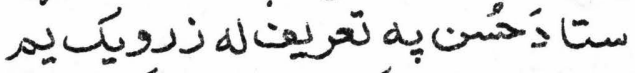

، نايان

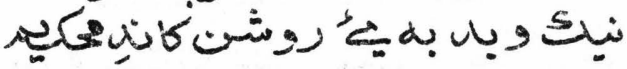

بيه

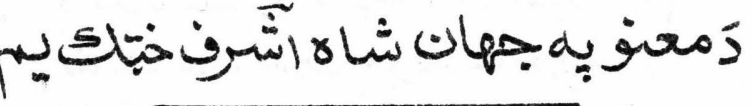




\section{ديوانِانشوقنانهيج}

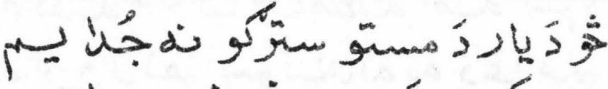

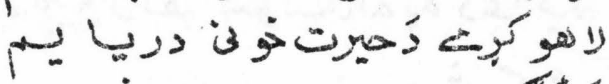

$?$

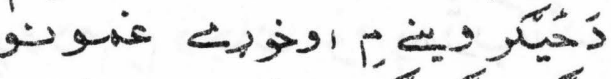

$\pi$

西

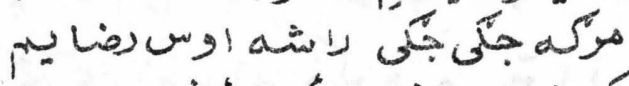

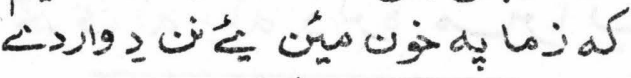

it.

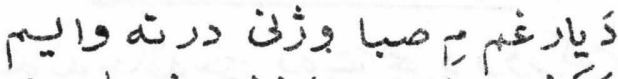

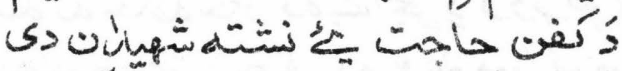

ti.

(1)

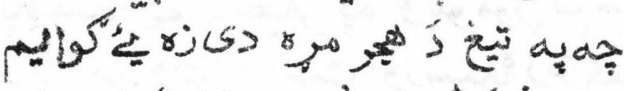
يه

6

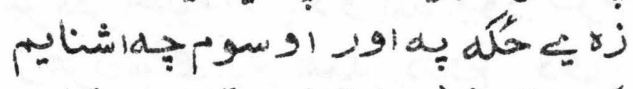

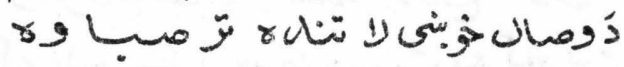

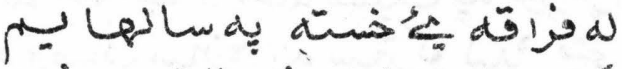

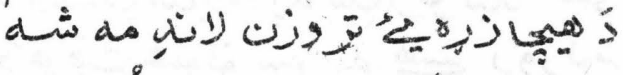

$\xi$

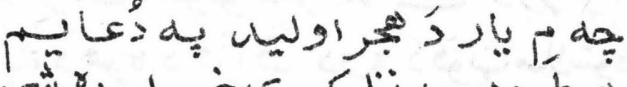

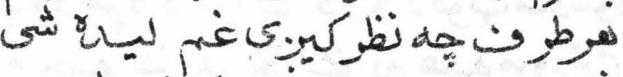
is

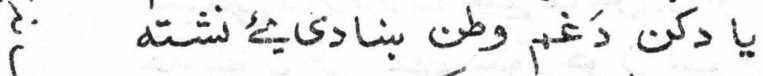

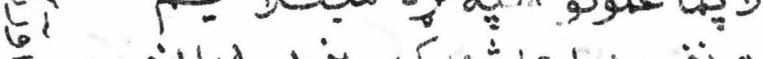

不

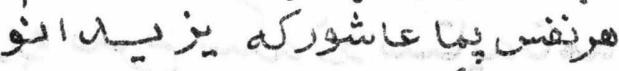

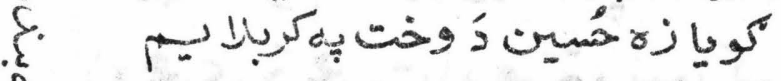

st

x.

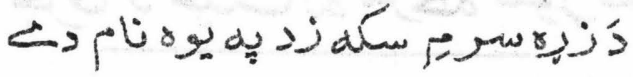

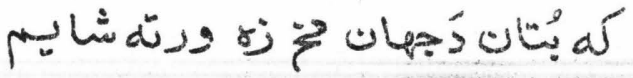




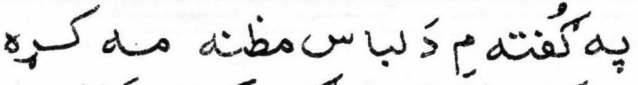

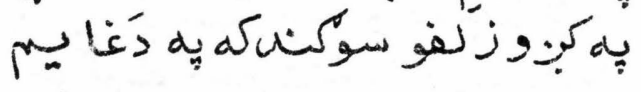

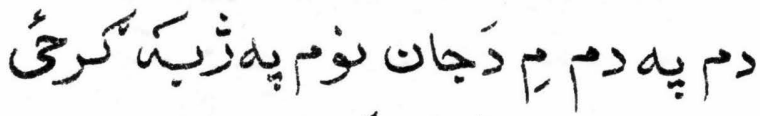

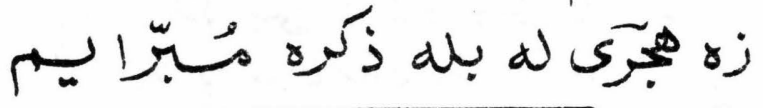

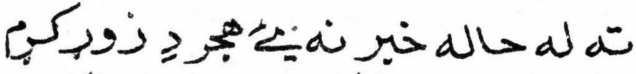

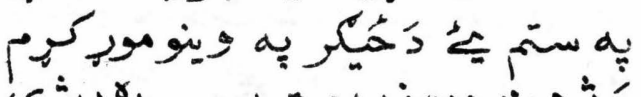

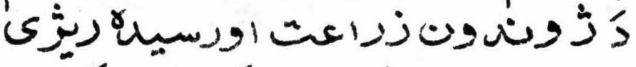

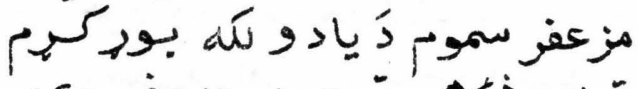

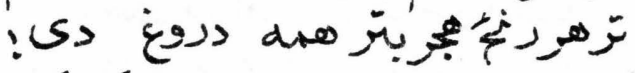

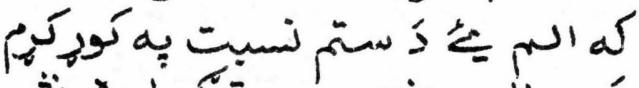

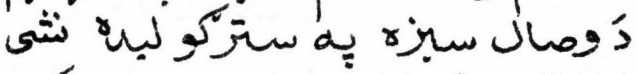

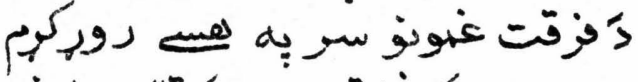

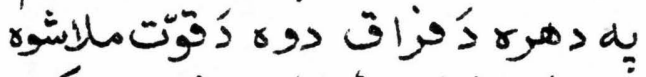

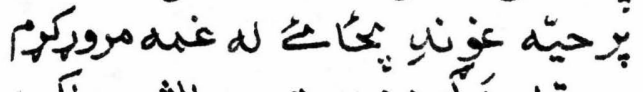

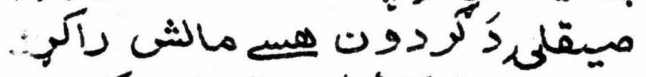

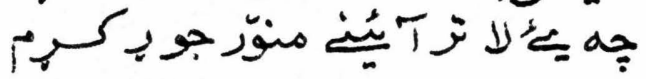

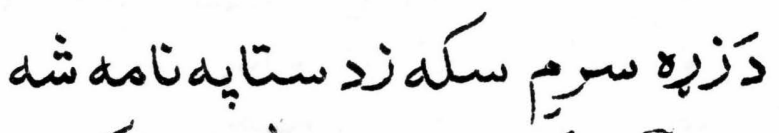

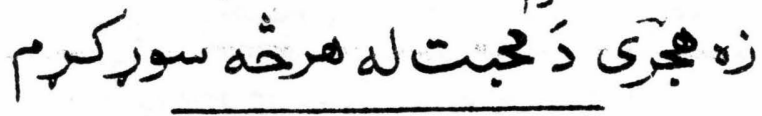




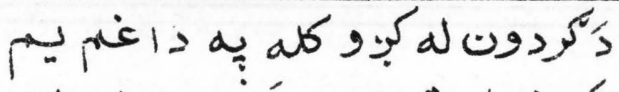

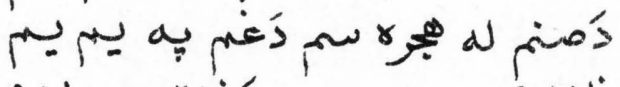

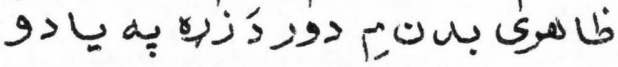

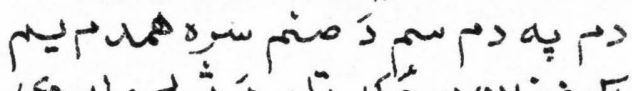

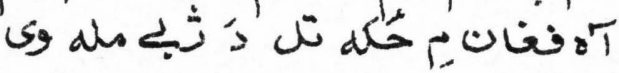

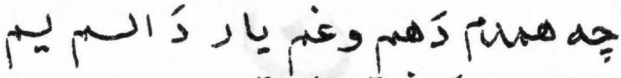

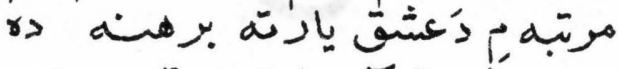

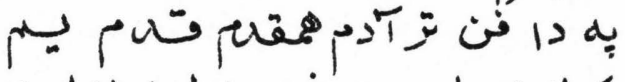

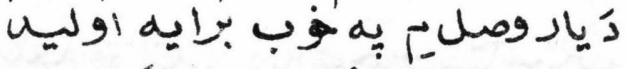

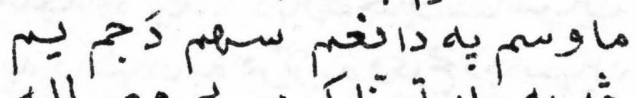

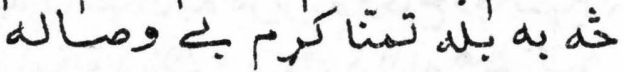

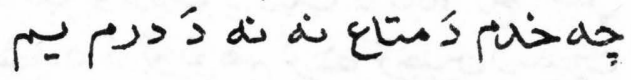
زَج

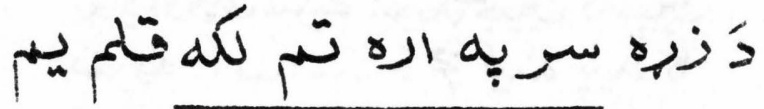




\section{حيوانِ اشرقخانجيجى}

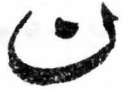

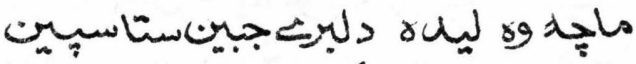

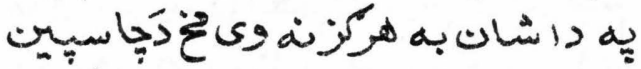

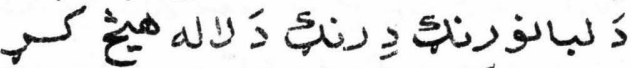

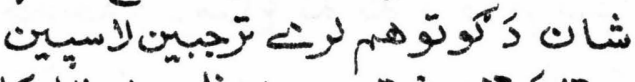

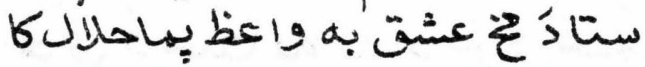

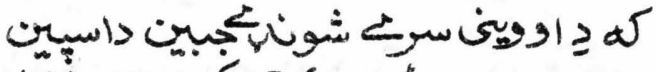

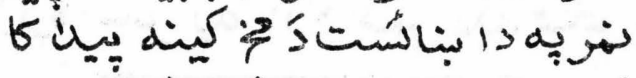

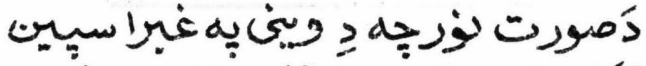

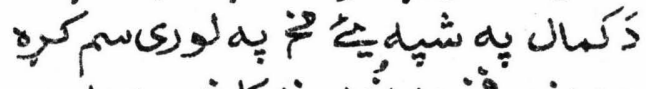

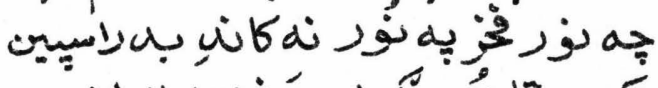

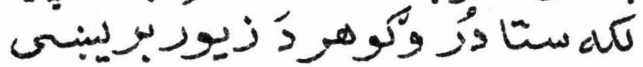

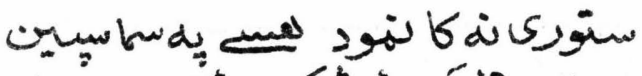

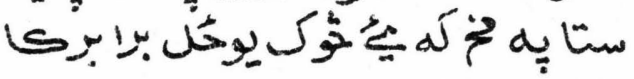

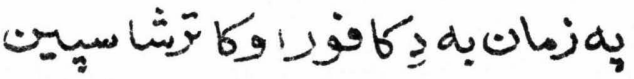




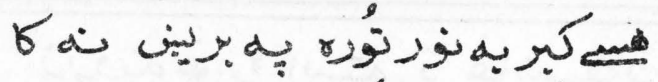

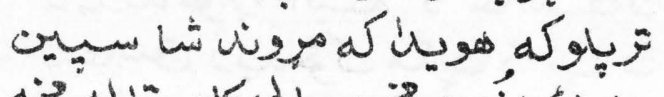

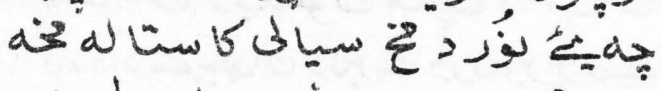

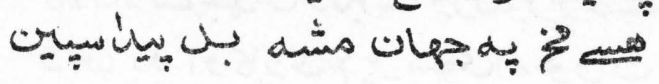

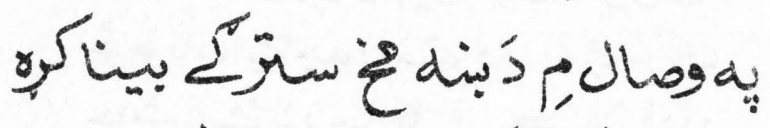

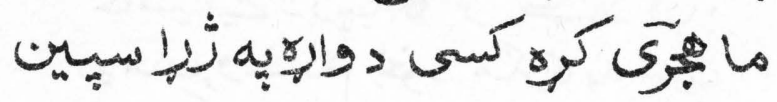

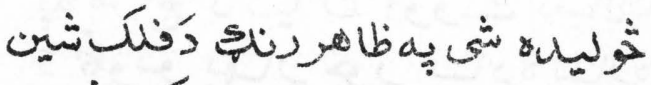

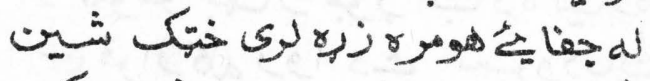

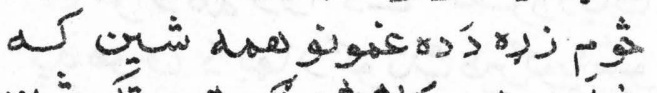

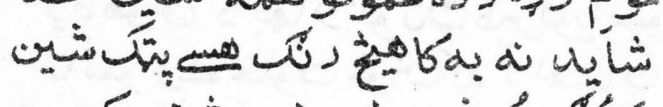

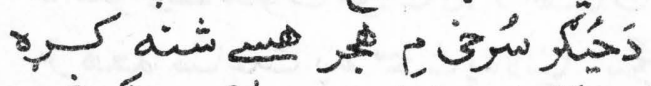
جاج

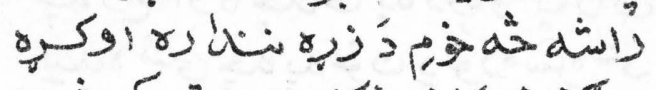

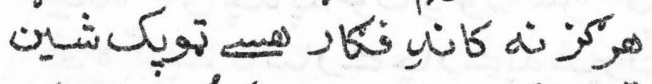

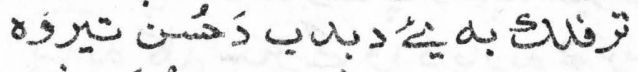

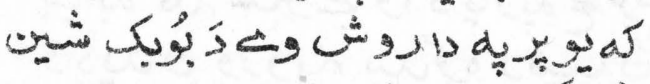

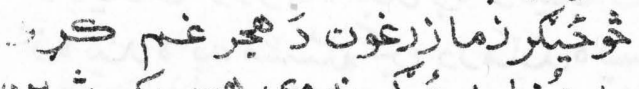

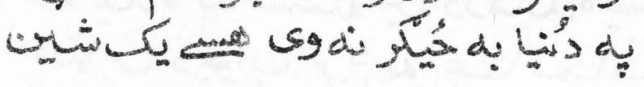

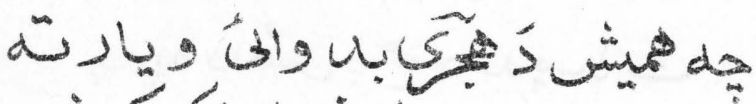
焉 


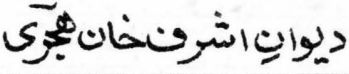

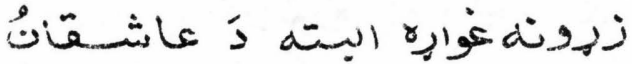

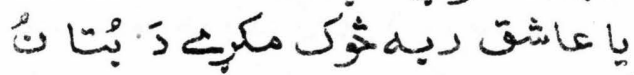

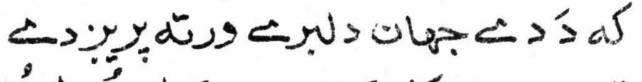

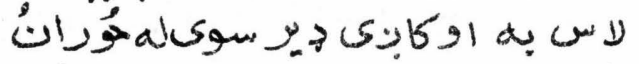

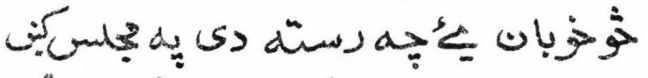

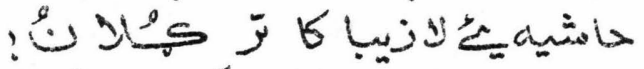

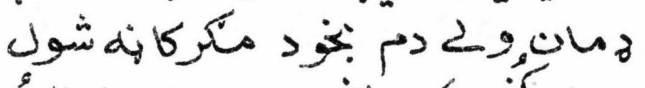

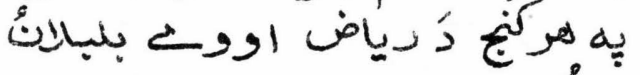

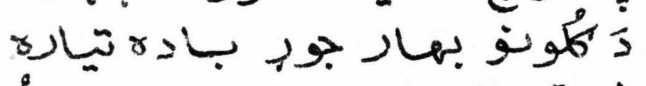

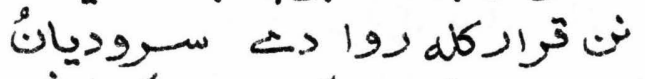

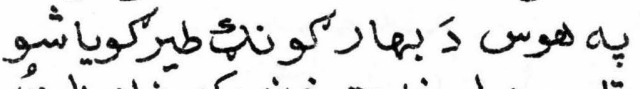

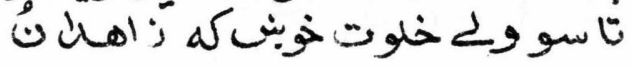

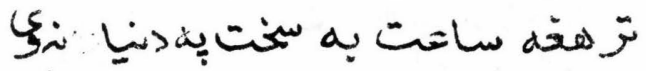

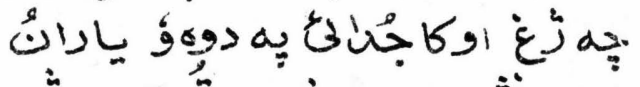

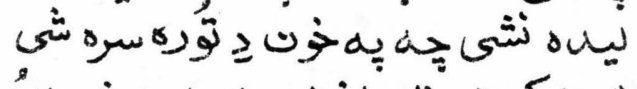

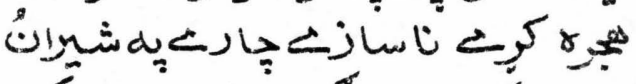

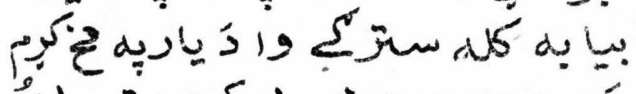

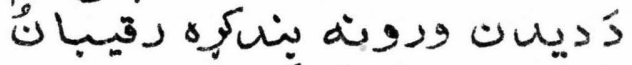

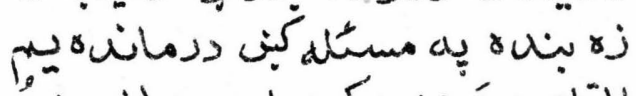

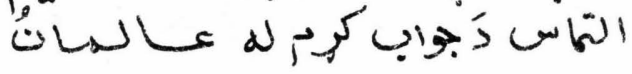

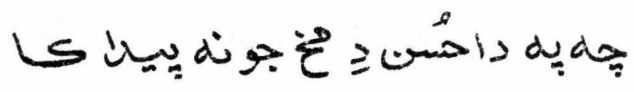

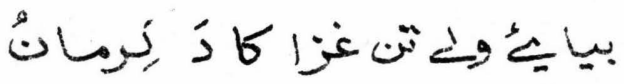


ديوابِشرنخانهُجي

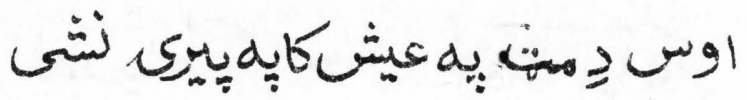

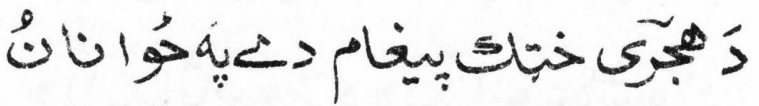

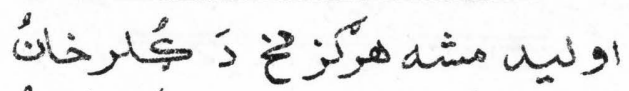

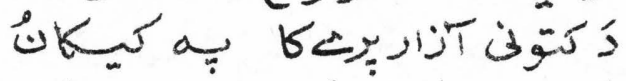

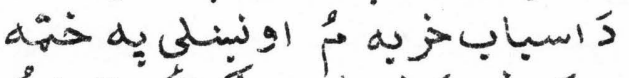

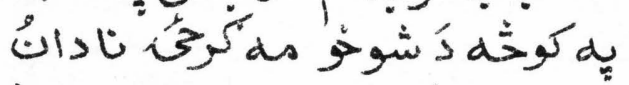

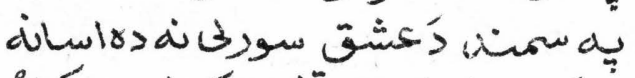

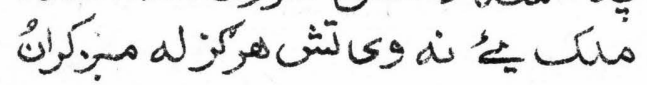

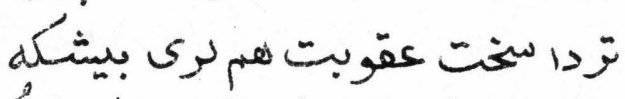

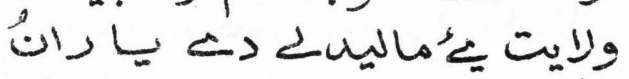

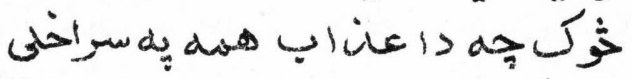

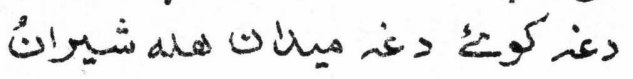

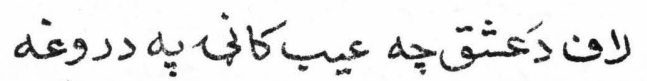

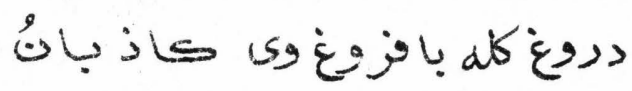

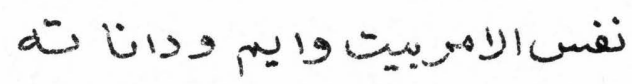

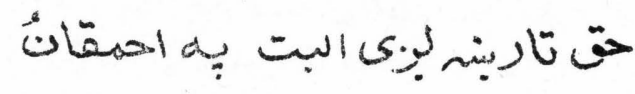

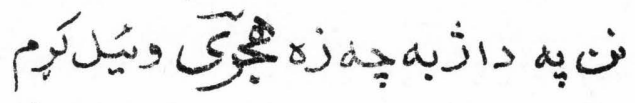

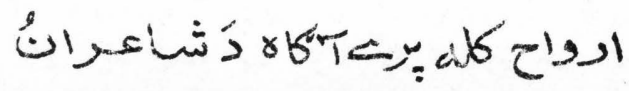

No 


\section{ديوانِاشرقخانجيجي}

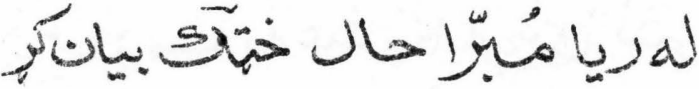

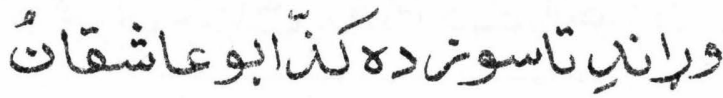




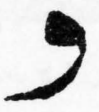

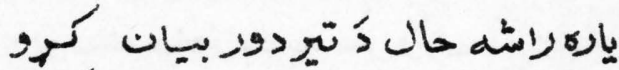

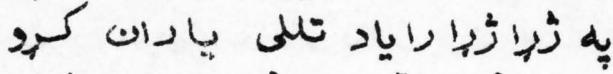

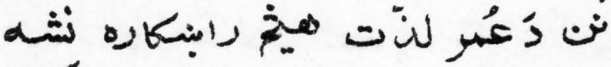

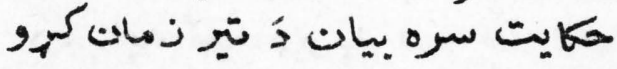

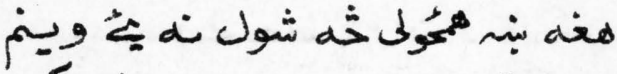

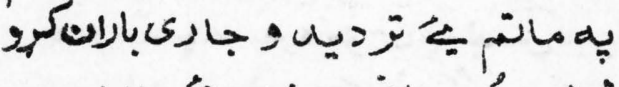

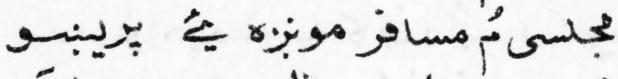

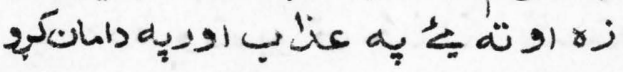

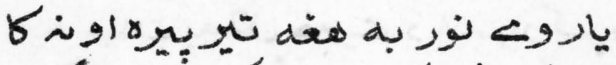

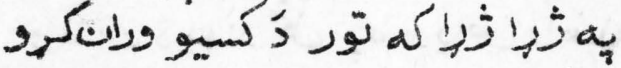

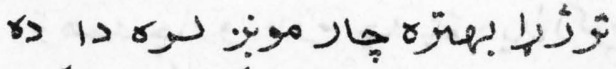

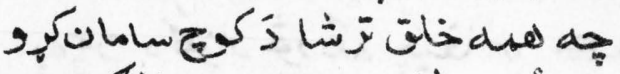

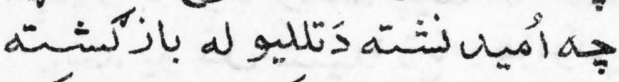

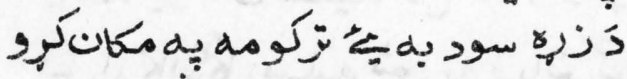

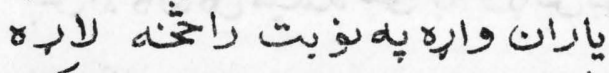

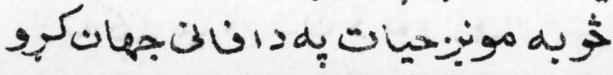




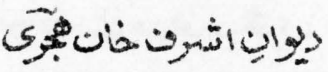

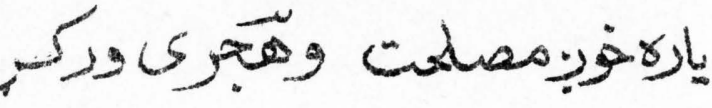

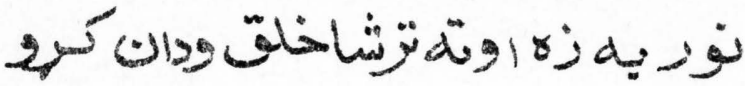

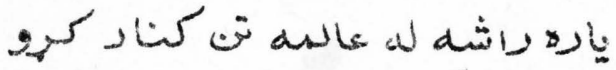

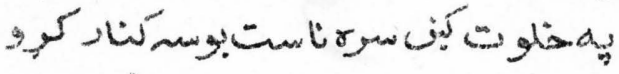

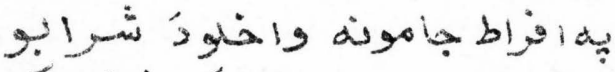

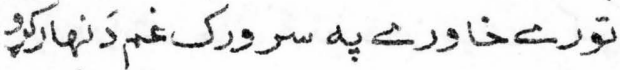

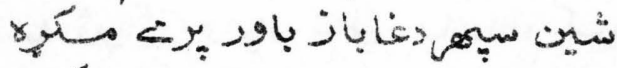

دئه

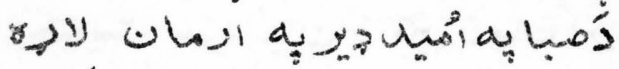

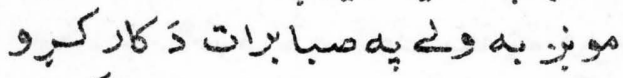

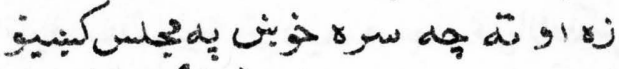

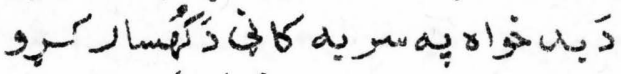

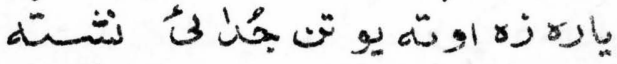

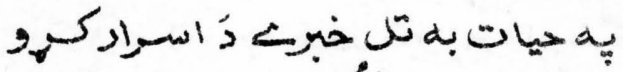

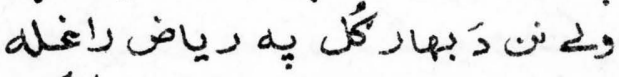

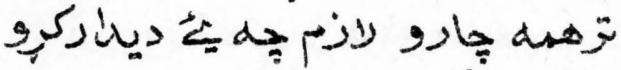

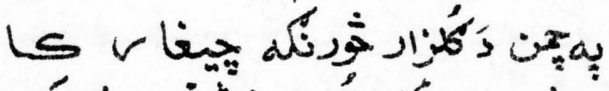

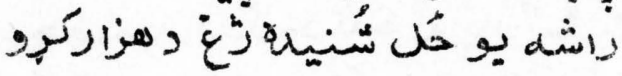

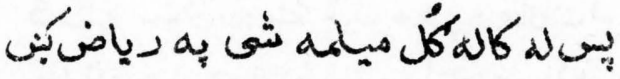

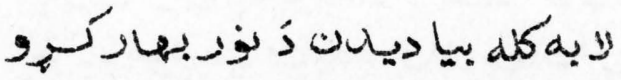




\section{ديوانوناشرنهانجزي}

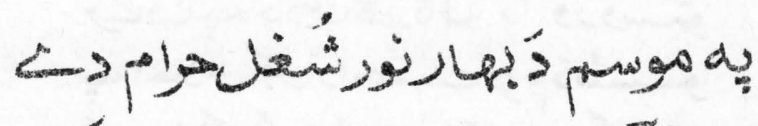
زه

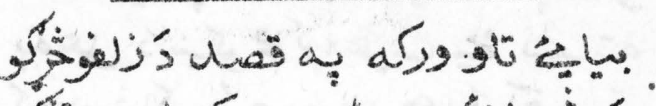

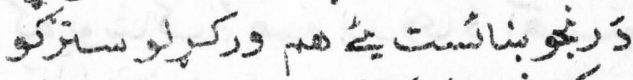

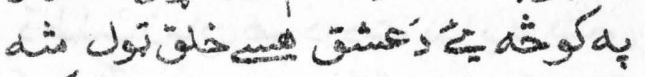
ده

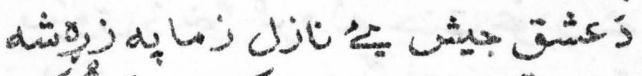

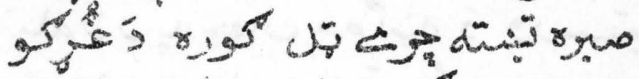

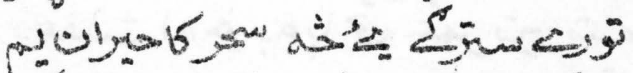

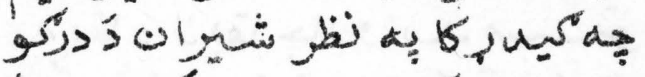

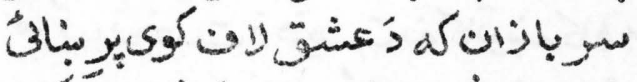

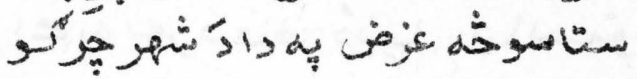

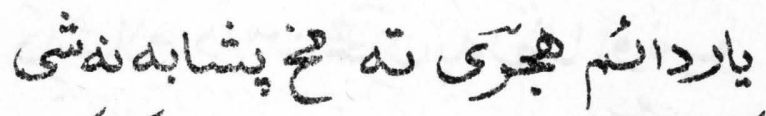
ك́ 


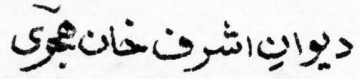

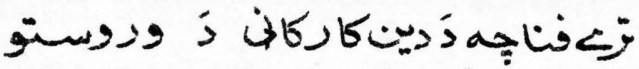

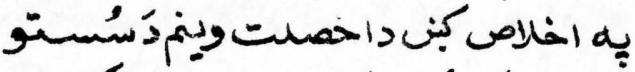

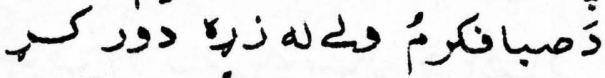

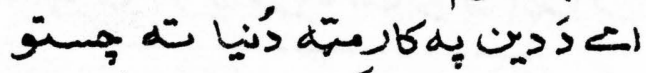

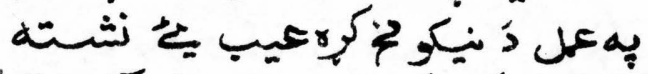

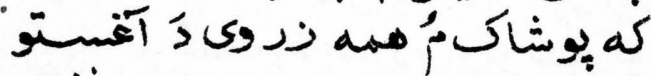

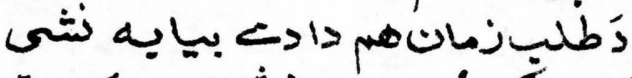

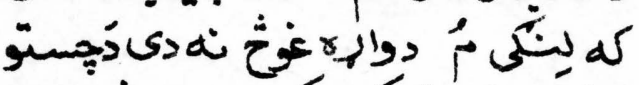

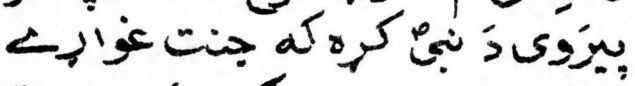

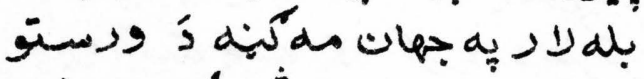

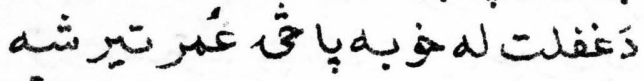

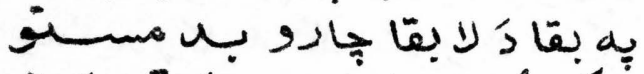

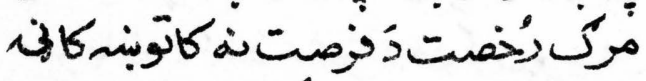

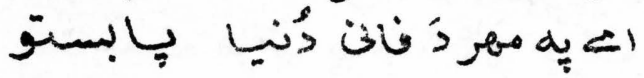

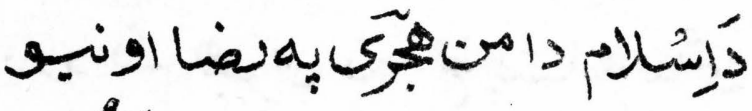

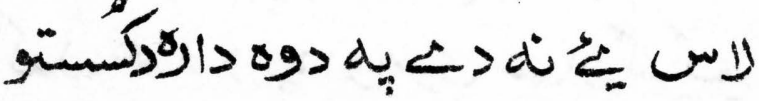

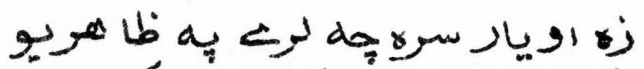

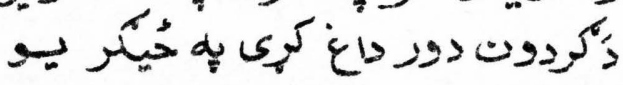

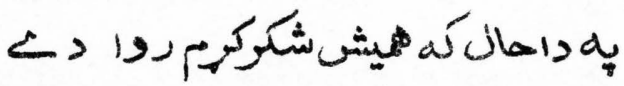

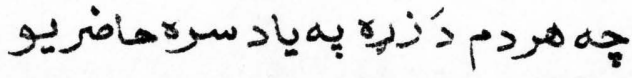




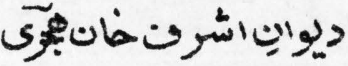

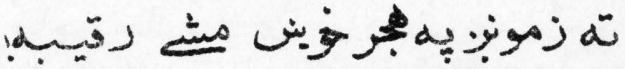

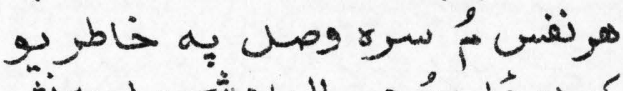

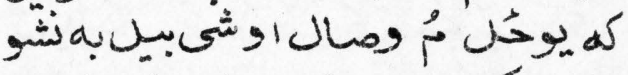

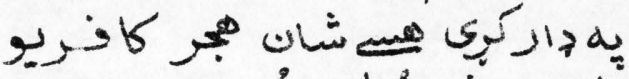

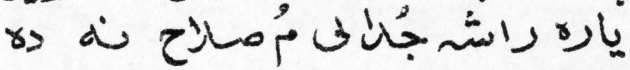

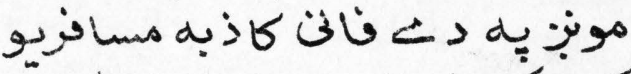

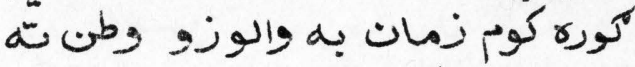

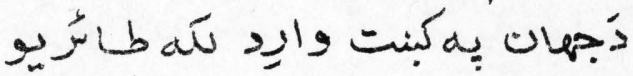

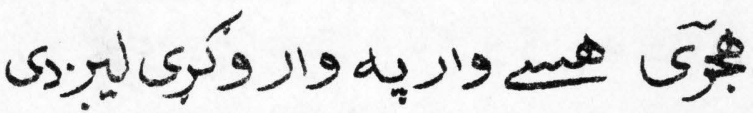

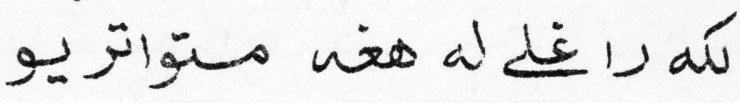

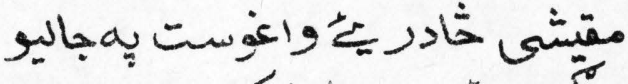

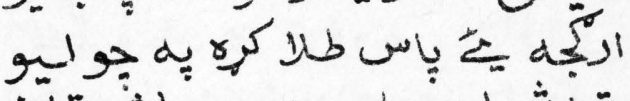

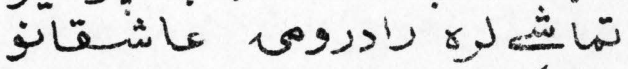

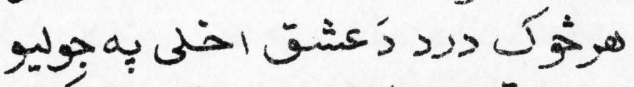

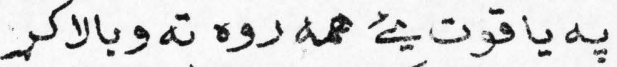

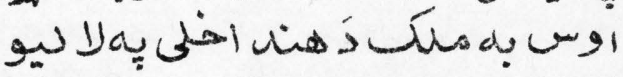
كَ

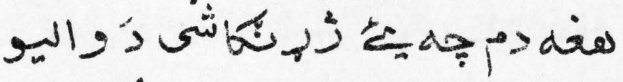

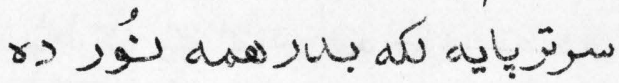
هيخ 


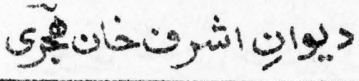

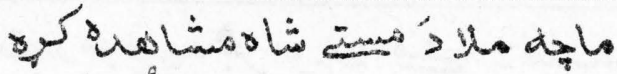

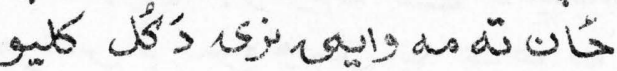

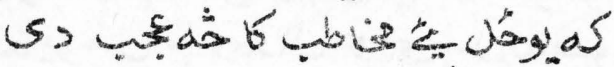

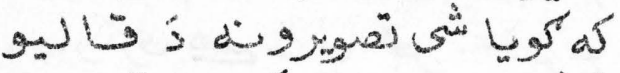

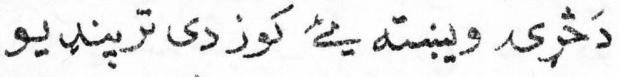

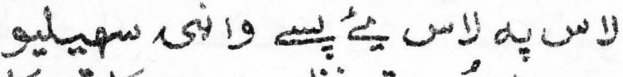

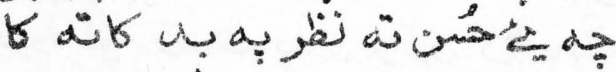

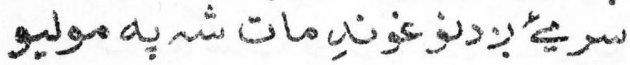

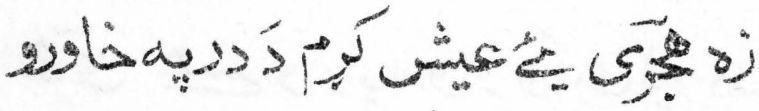

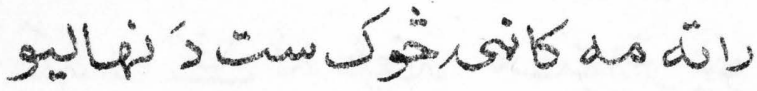

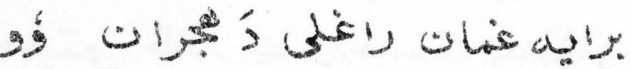

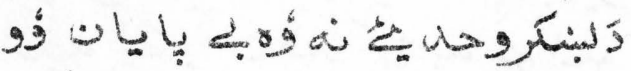

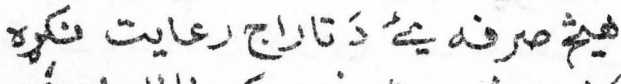

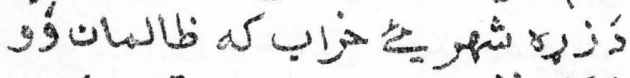

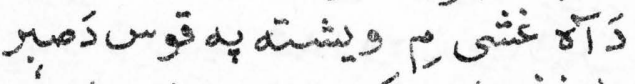
9 ؤبا

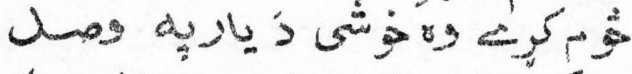

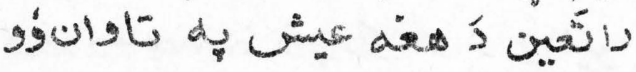

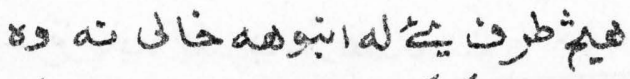

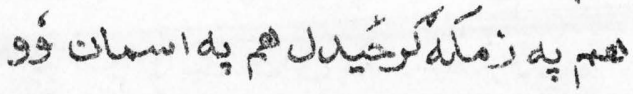




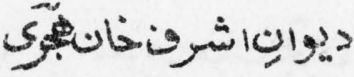

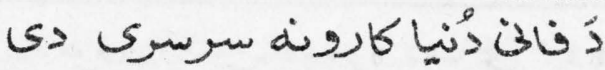

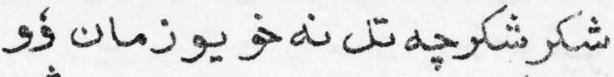

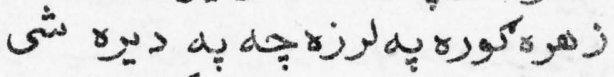

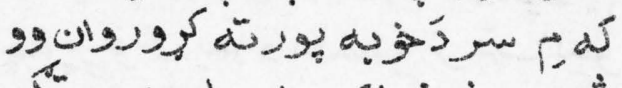
جأ

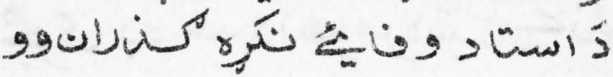

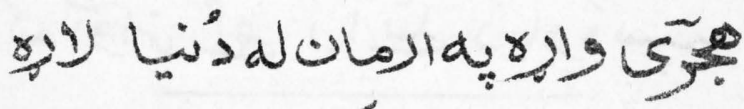

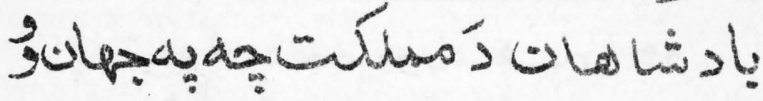

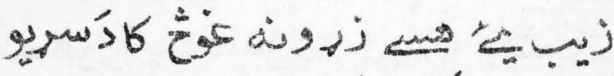

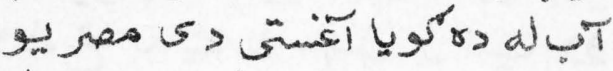

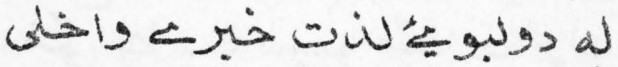

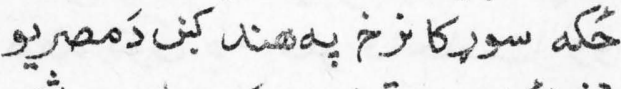

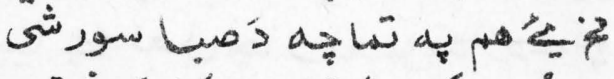
1)

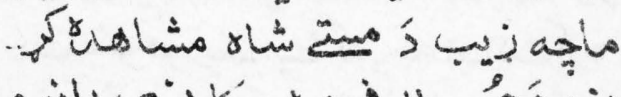

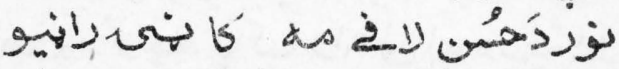

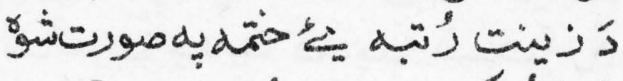

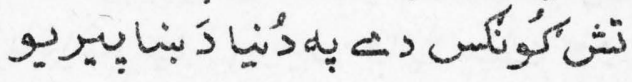

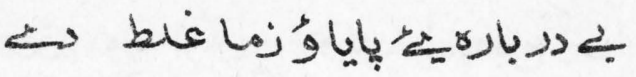
هيات كلم وى 


\section{يوانِاشرفخانهِيح}

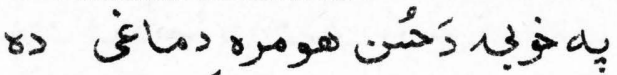

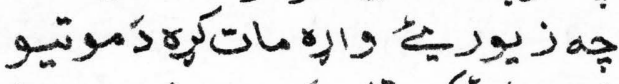

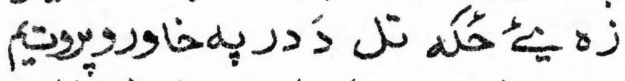

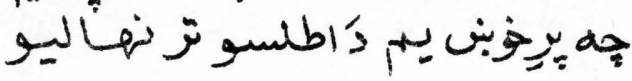

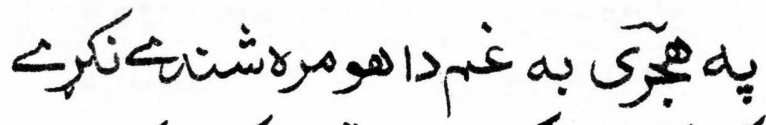

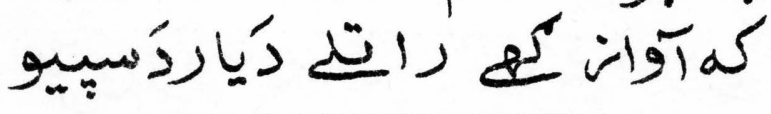

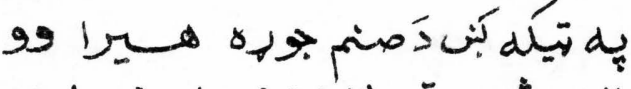

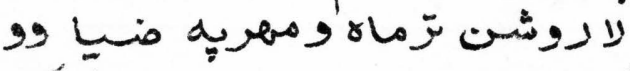

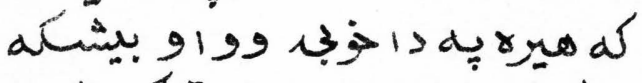

99 وأن

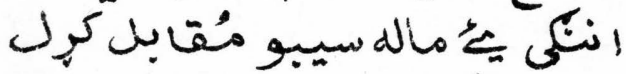

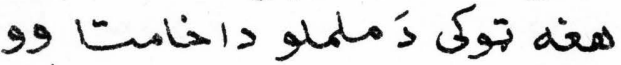

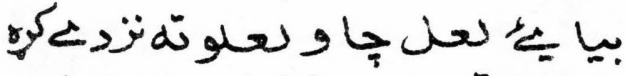

دَ هخه فيمت خوشته > البه بها

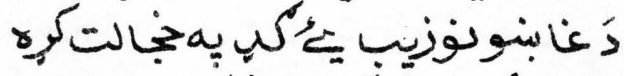

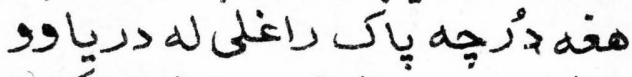

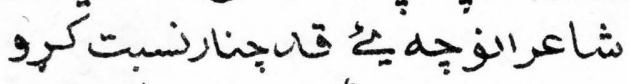

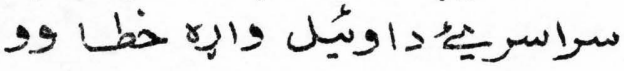

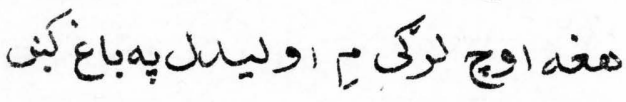

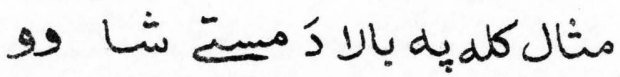




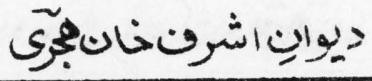

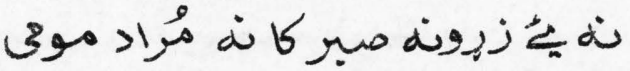

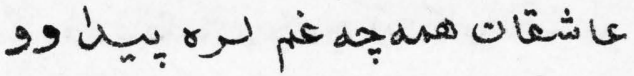

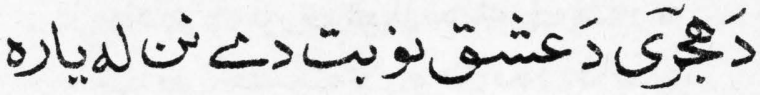

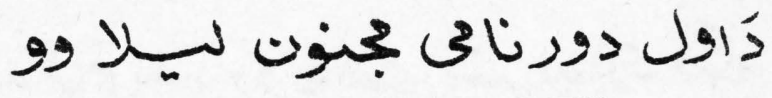

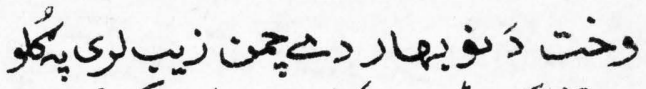

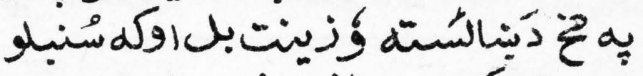

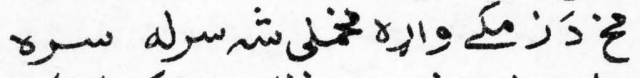

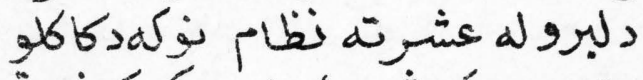

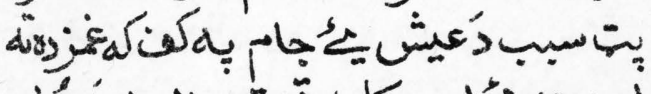

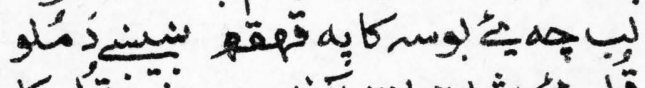

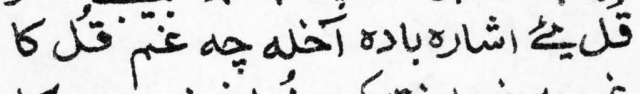

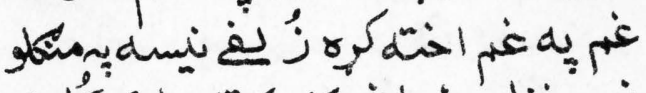

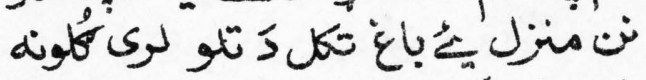

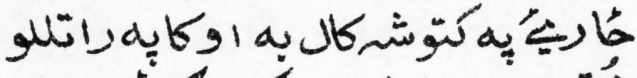

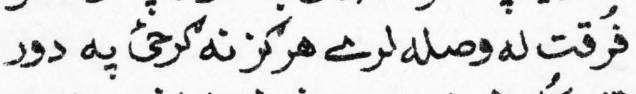

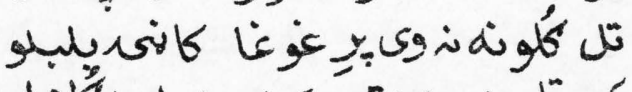

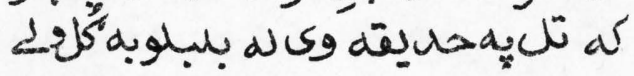

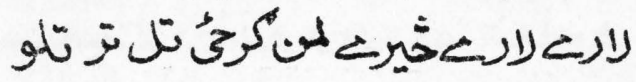

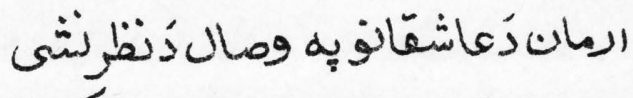

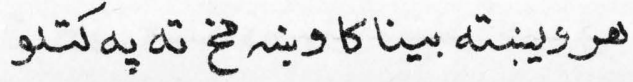




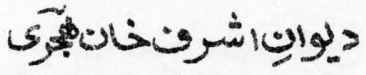

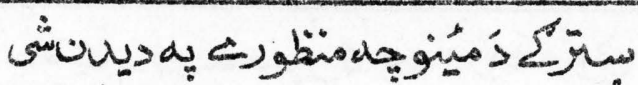

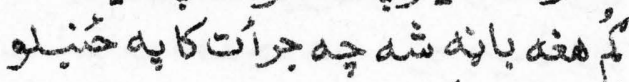

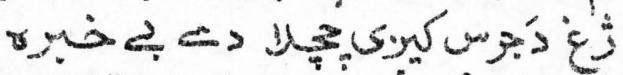
然

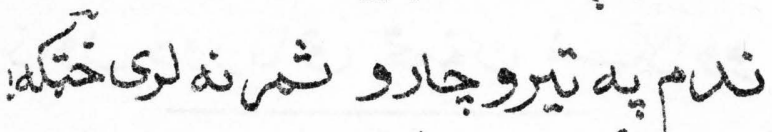

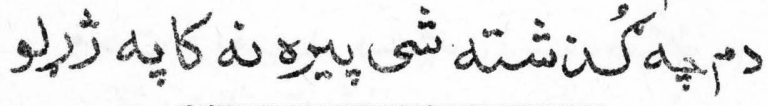

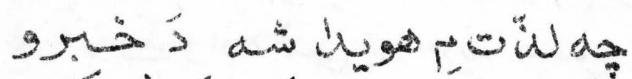

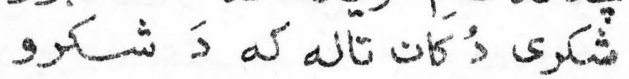

"

و

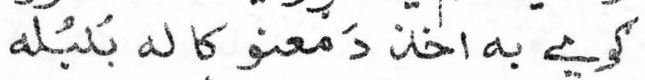

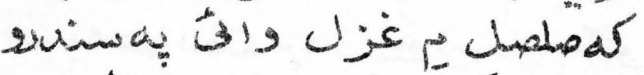

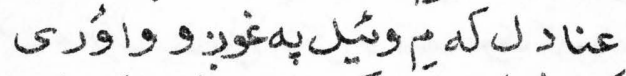

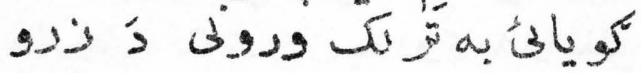

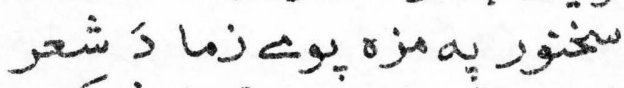

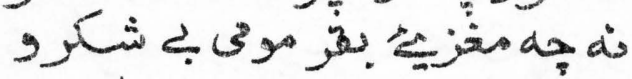

A

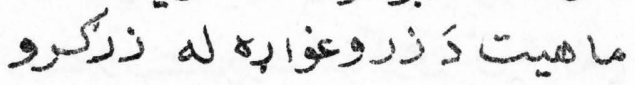

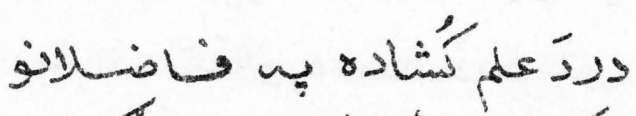

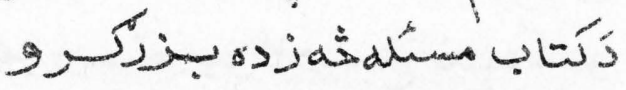

pry 


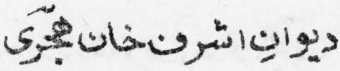

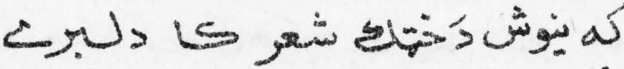

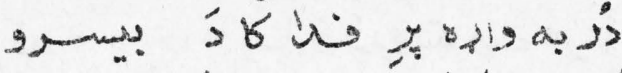

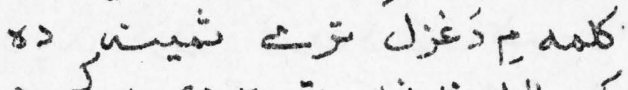

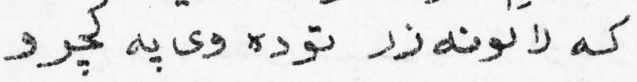

2.

'

象

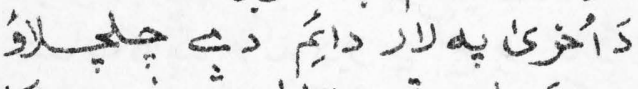
جها

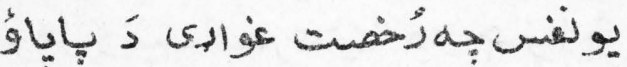

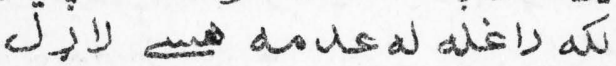

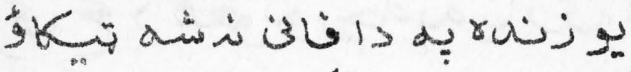

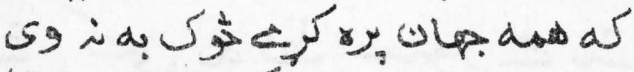

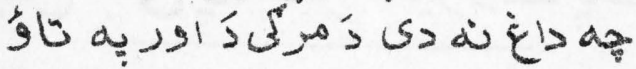

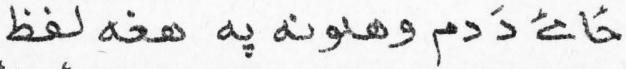

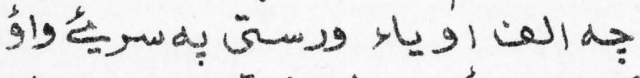

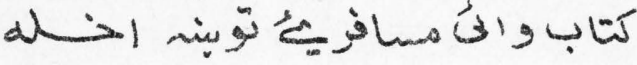

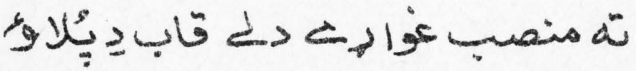

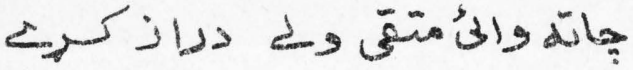
وان 


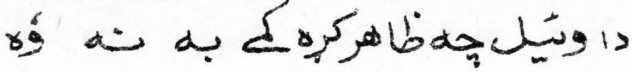

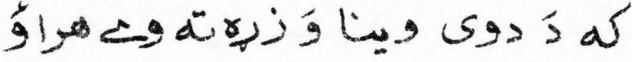

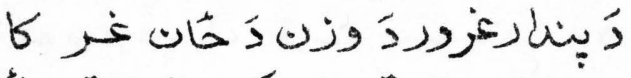

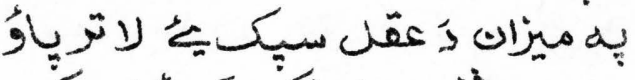

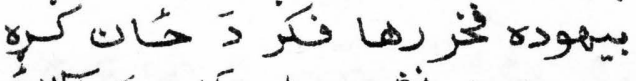

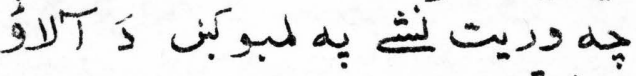
ذَّزَ

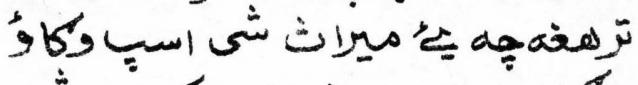

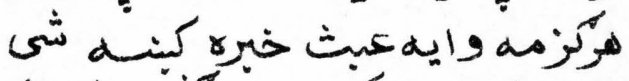
و

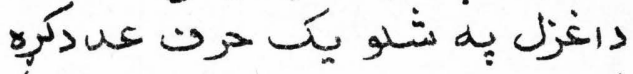

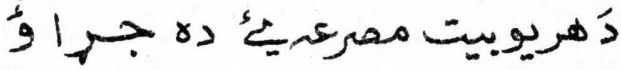

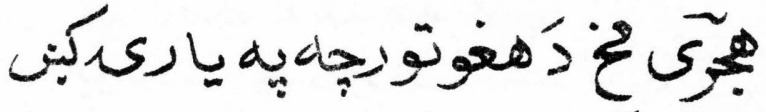

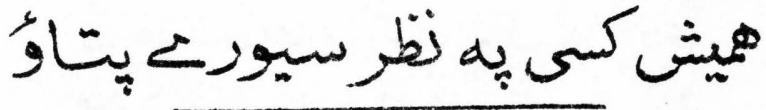




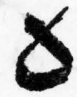

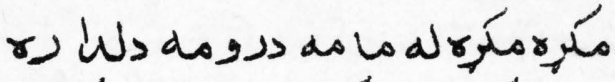

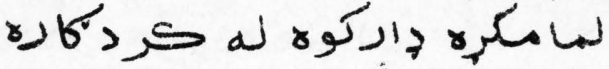

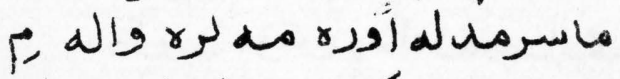

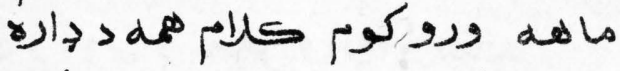

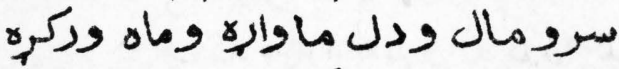

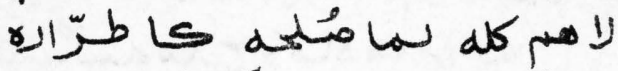

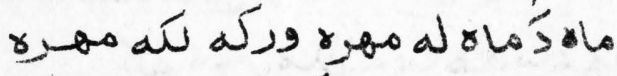

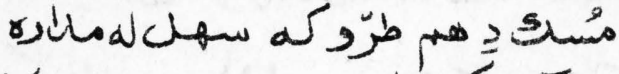
هر آد

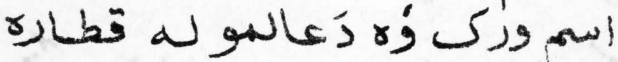

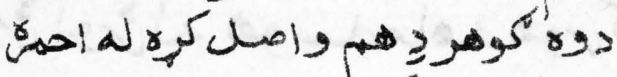

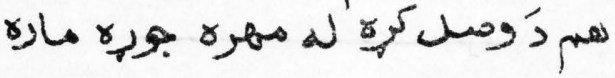

r lis r r sugunasodps

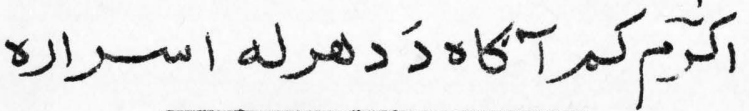


6 6 ك د,

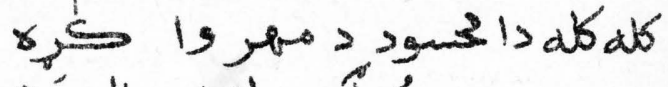
r

نو

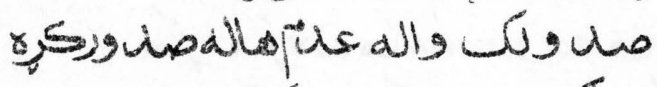
كو

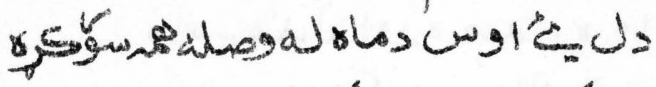

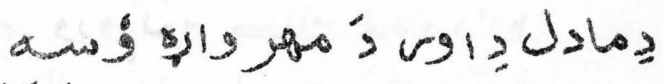
ا

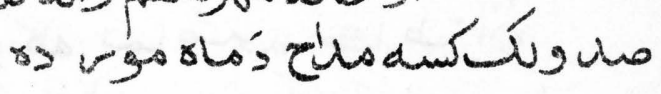

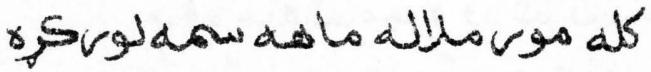

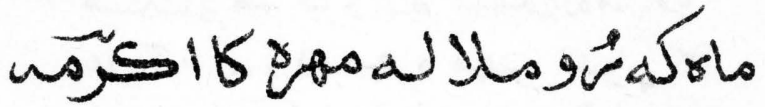

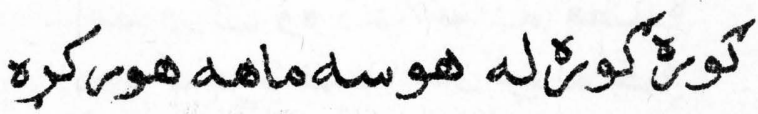




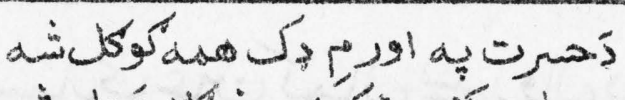

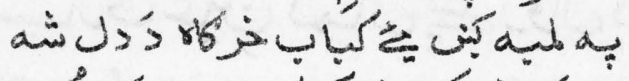
vis sإ

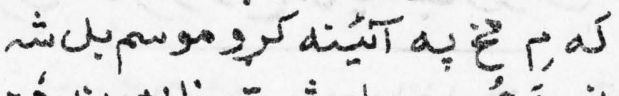

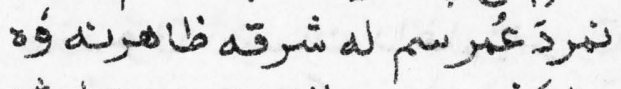

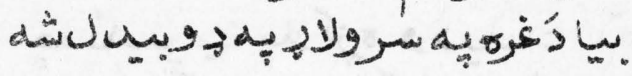

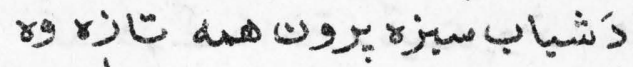

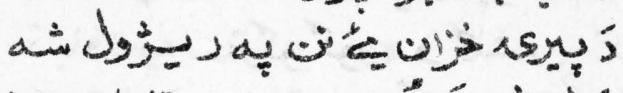

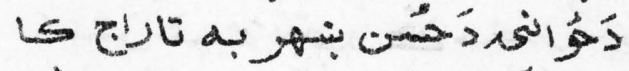
جن

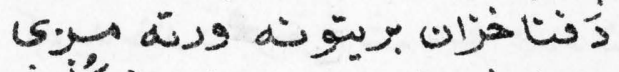
جه زئر 's

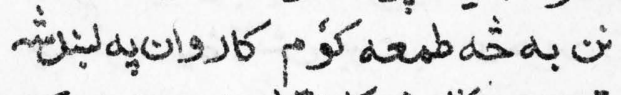
sو

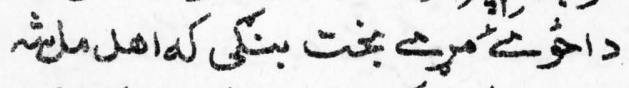

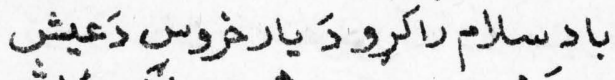

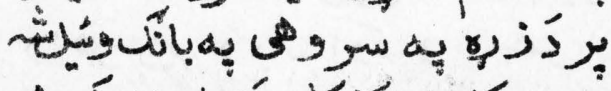

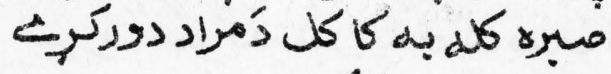
ك́

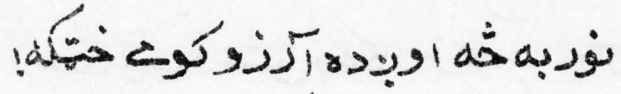

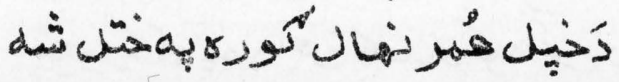




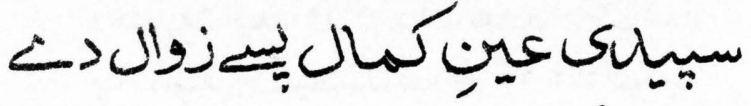

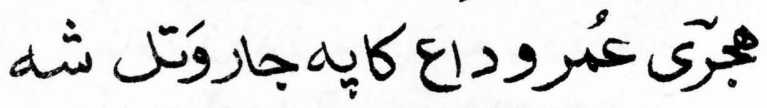

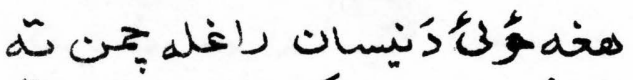

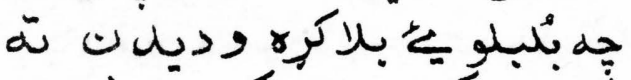

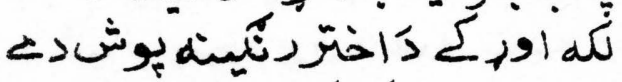

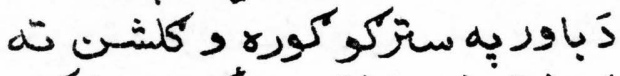

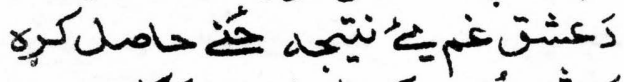

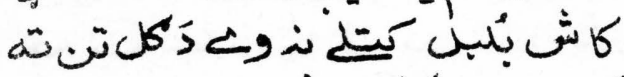

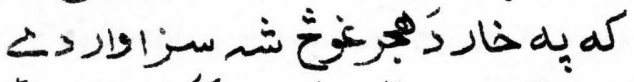

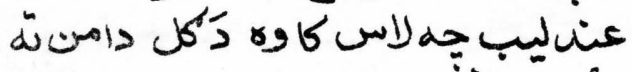

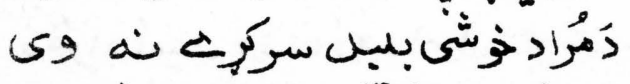

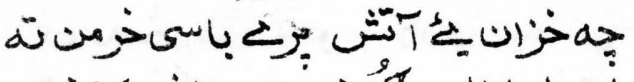

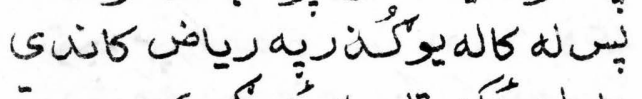

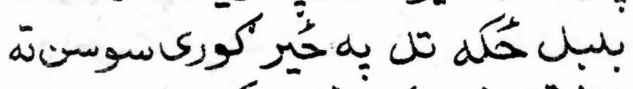

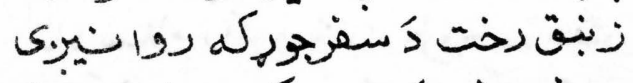

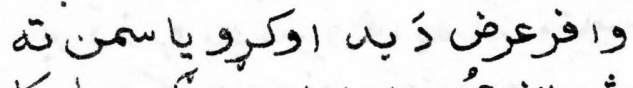

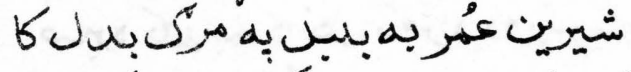

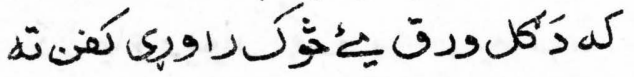

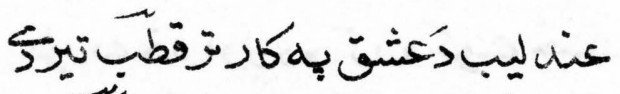

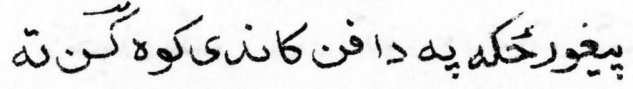




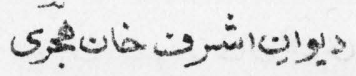

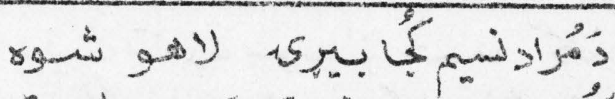
ث

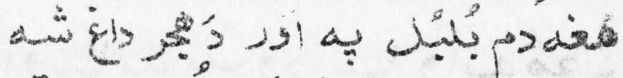

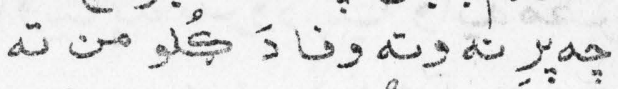

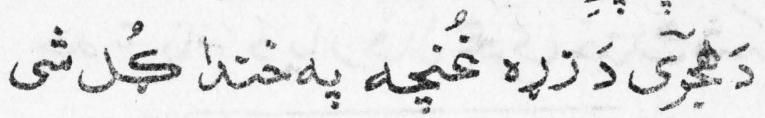

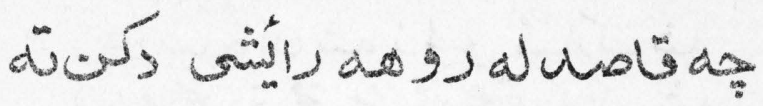

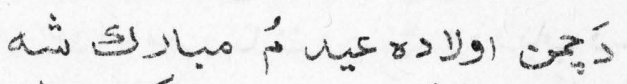
ن

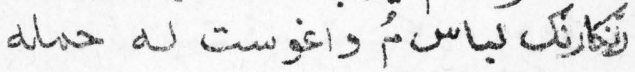

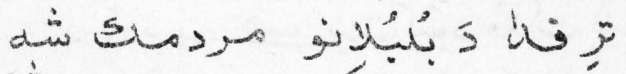
كاند

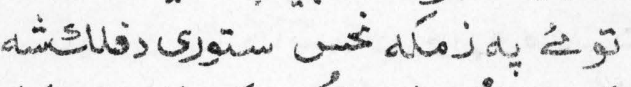

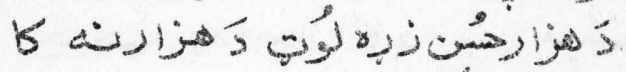

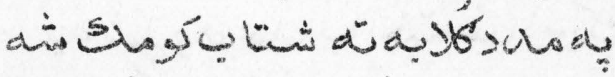

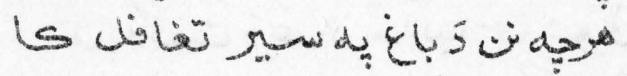
كَ"

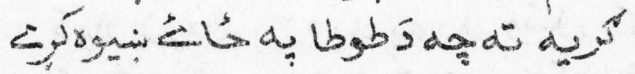

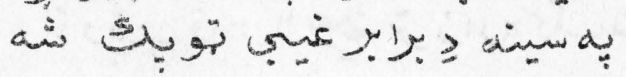
a

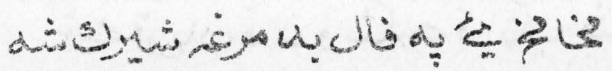

WN 


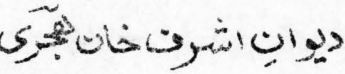

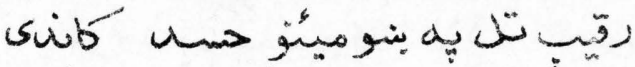

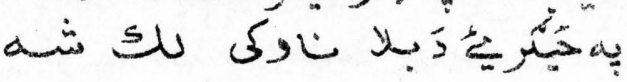

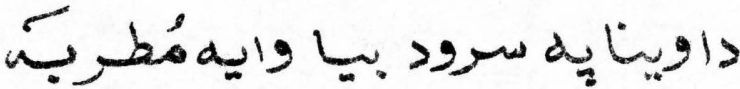

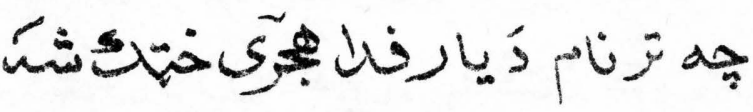

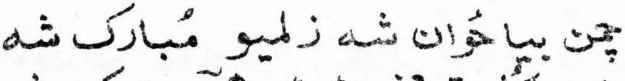
部 نَ

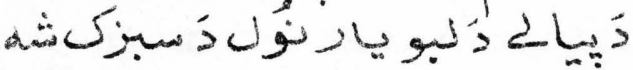

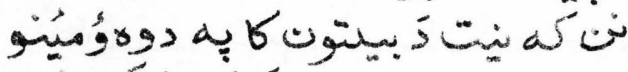

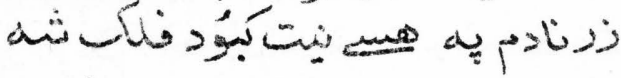

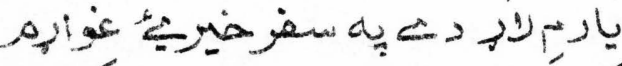

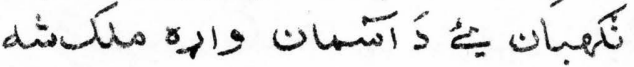

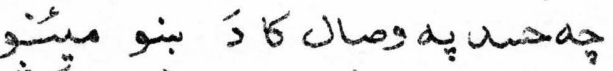

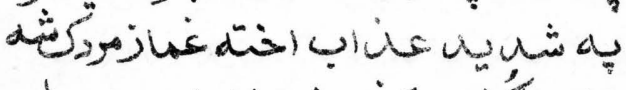

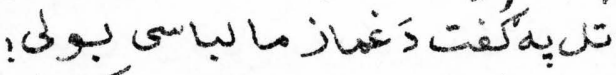

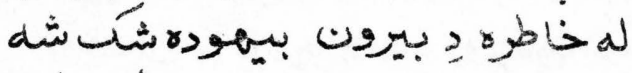

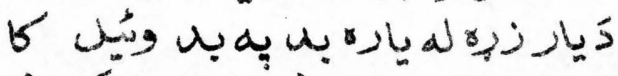

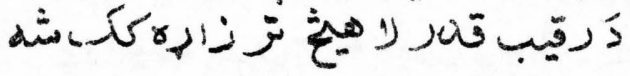

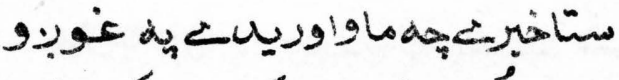

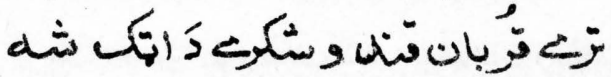


يوارِ

تريانه بوزئ

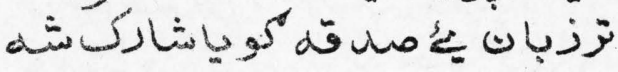

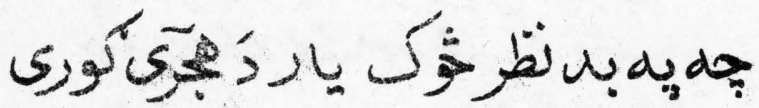

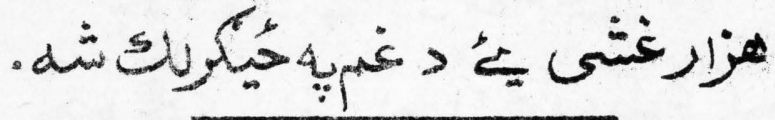

ǵ

ذان

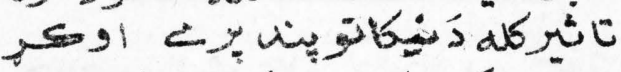

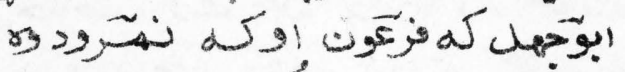

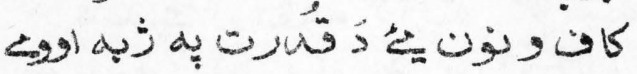

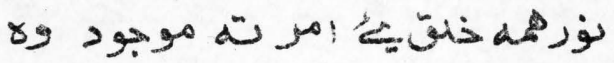

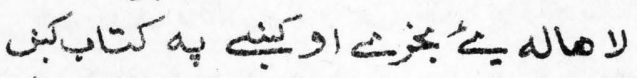

جا

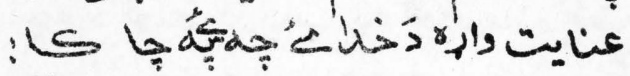

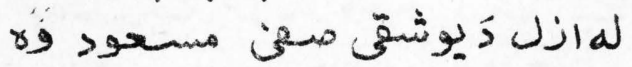

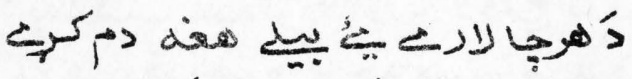

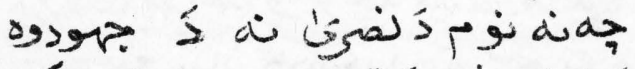

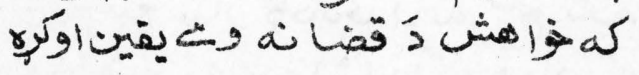

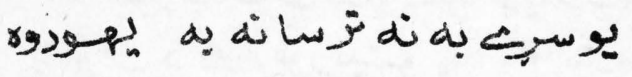

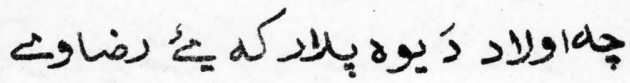

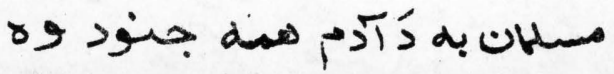

SHA 


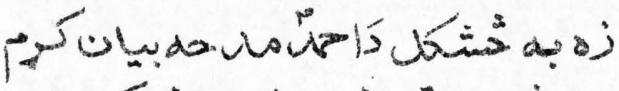

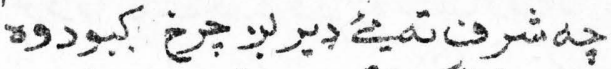

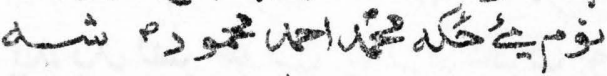

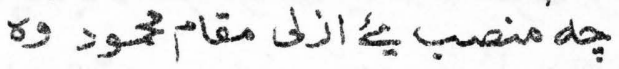

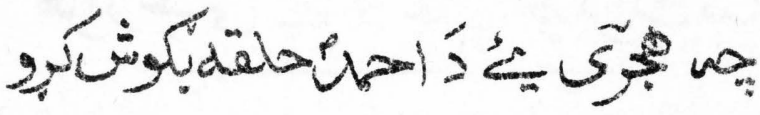

3390005 sos

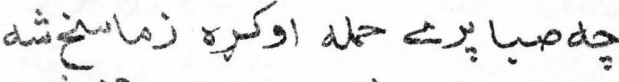

ش

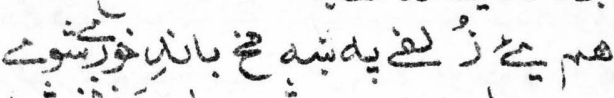

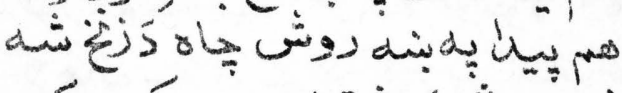

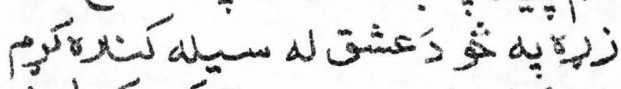

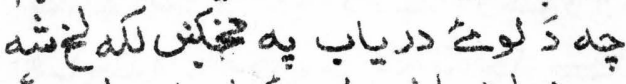
"

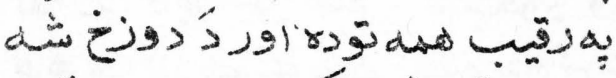
ك ش

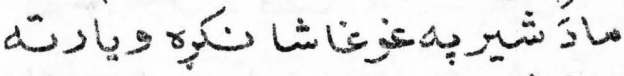

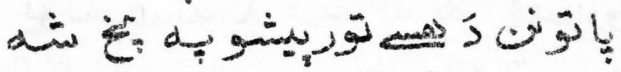

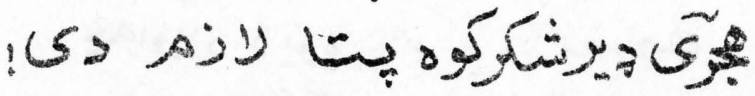
an 


\section{ديوإِاشرونخانبركي}

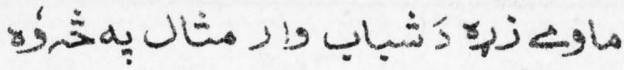

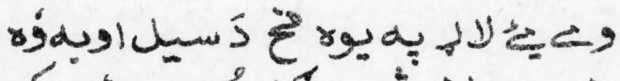

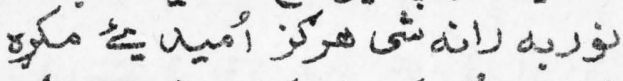

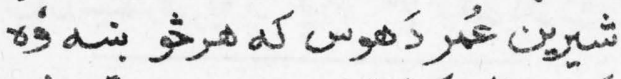

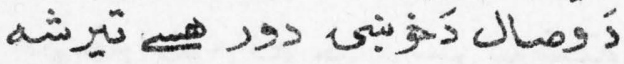

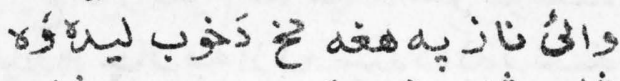

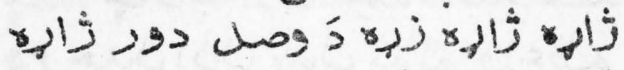

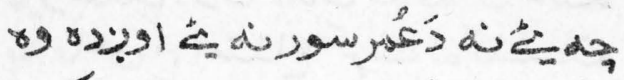
كايجه 放

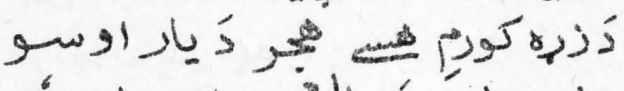

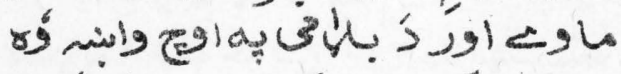
مونة

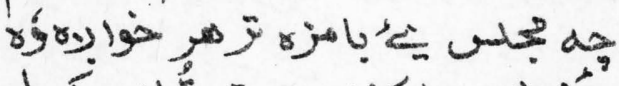

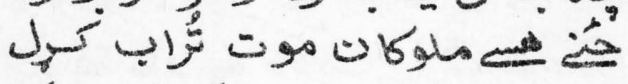

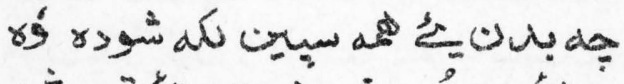

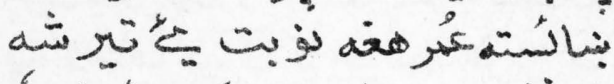

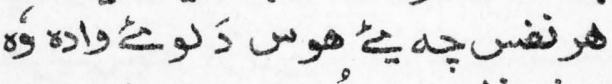

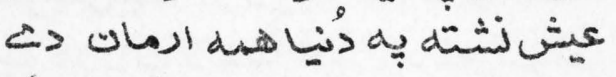

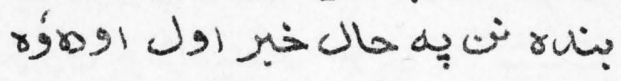
$\Leftrightarrow$ ماكَ

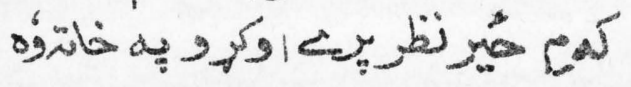




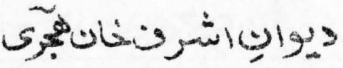

هin 09 r.9120\% d.

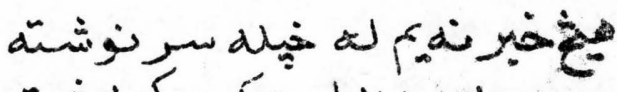

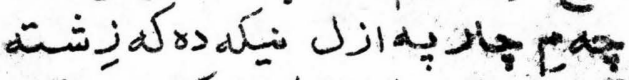

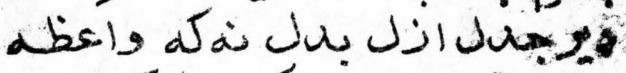

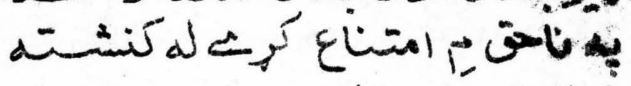

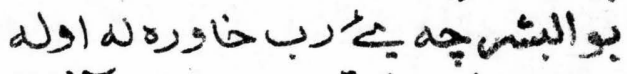

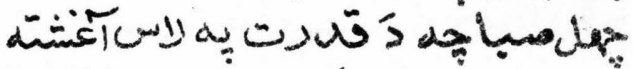
قهان

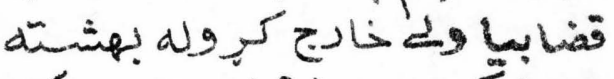

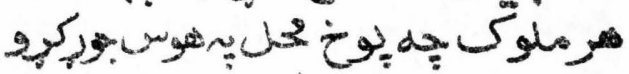

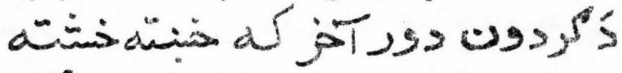

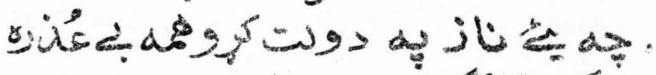

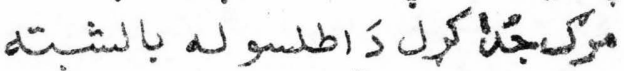

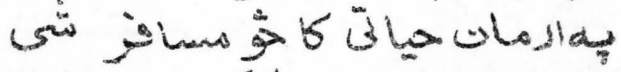

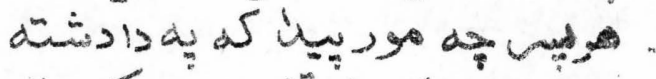

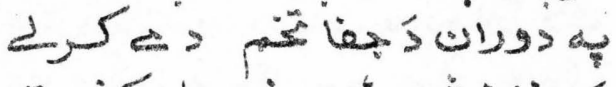
a

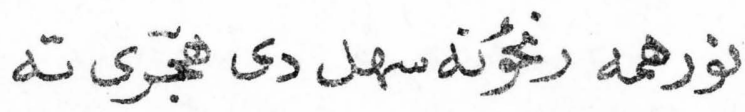

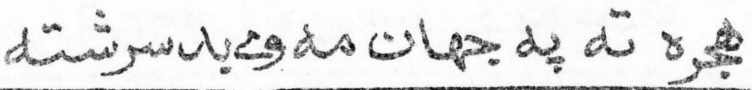




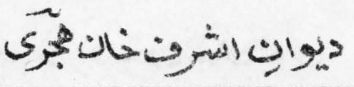

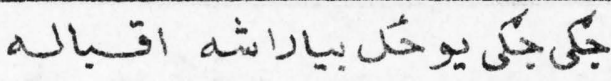

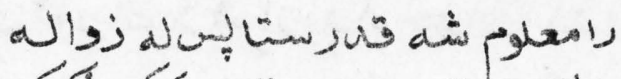

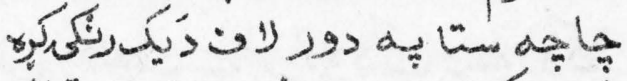

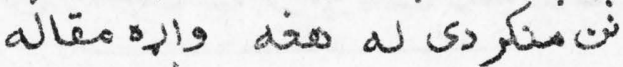

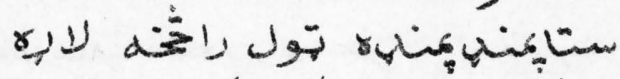

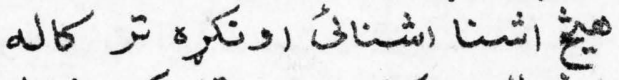

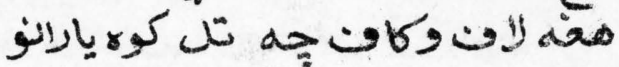

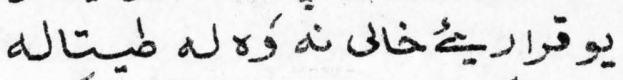

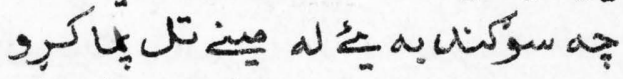

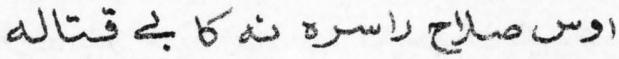

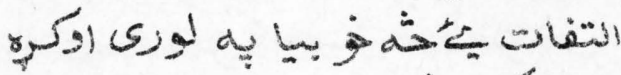

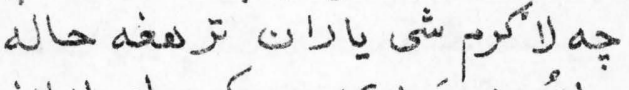

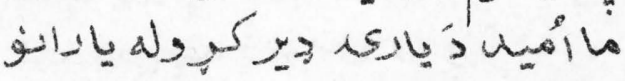

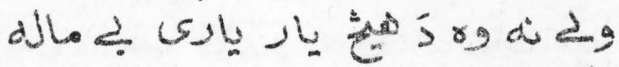

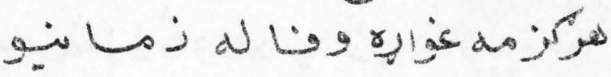
ل

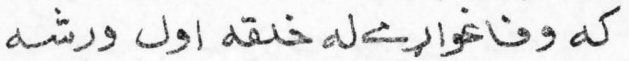

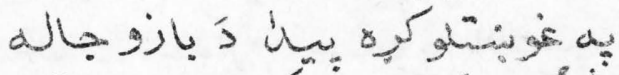

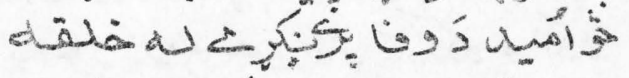

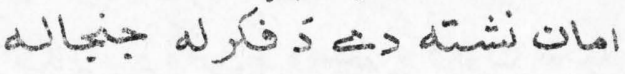

(s) له 


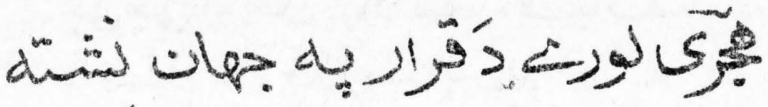

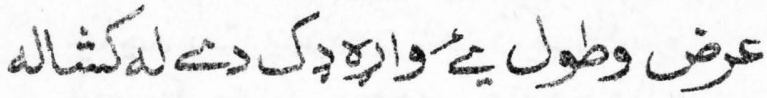

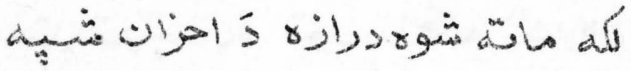

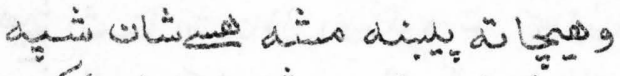

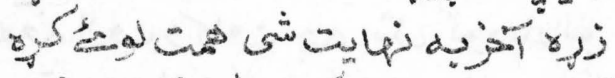

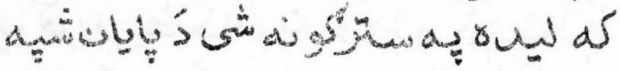

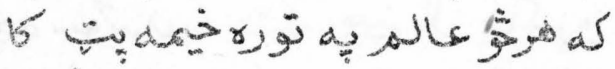

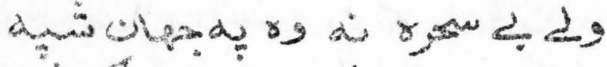

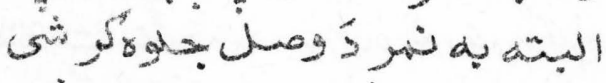

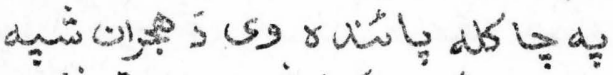

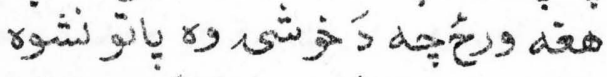

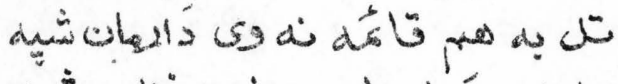

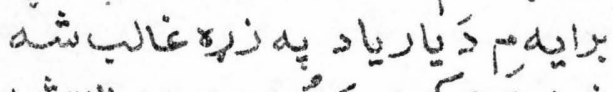

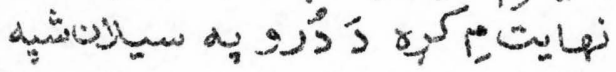

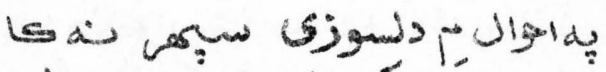

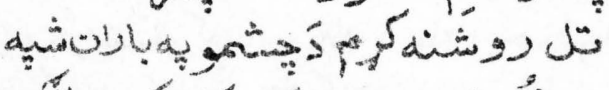

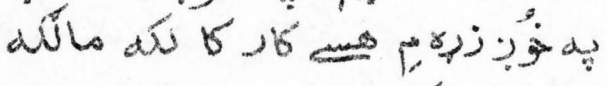

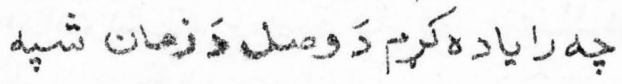

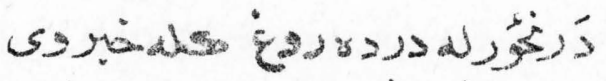

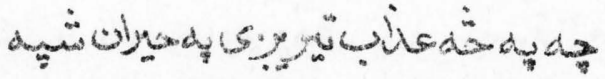




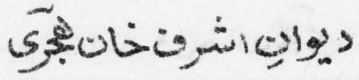

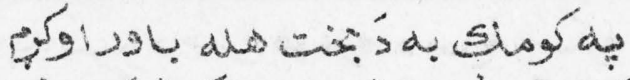

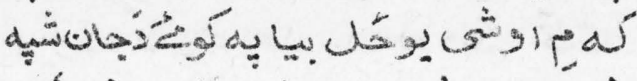

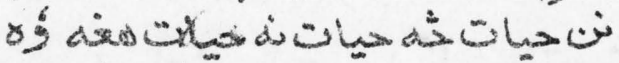

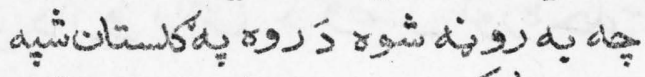
بن

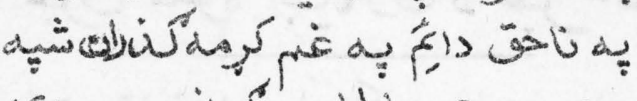
ज)

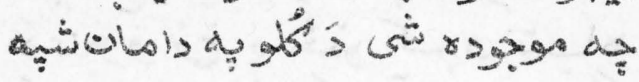

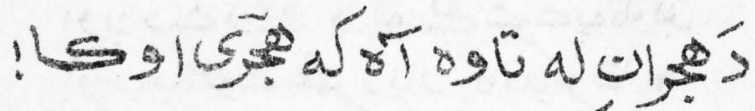

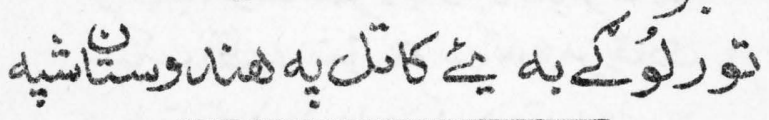

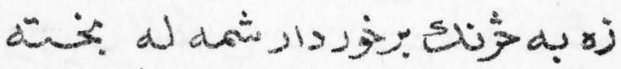

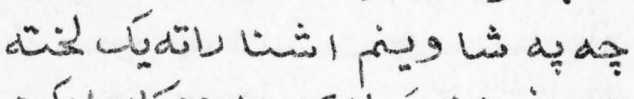

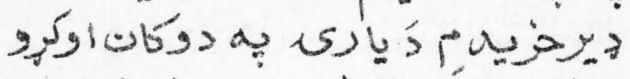
ماند حان جه

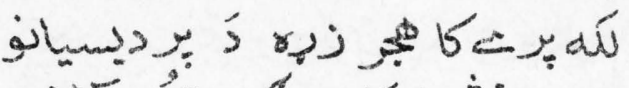

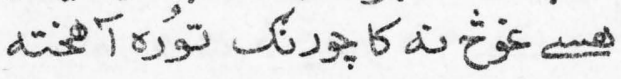

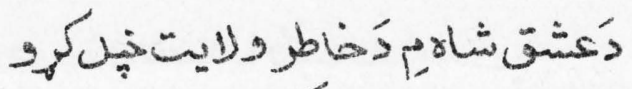

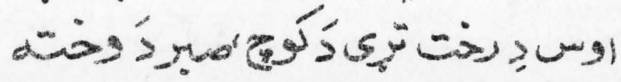




\section{ديوانِاشرونانئيجي}

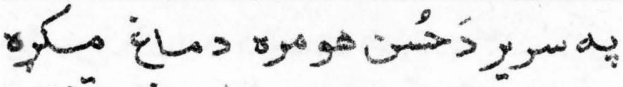

年

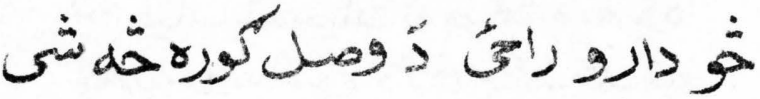

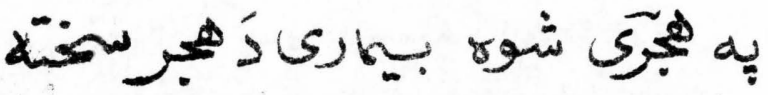

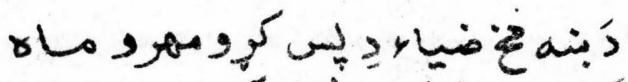

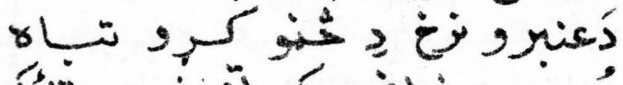

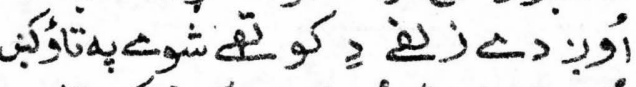

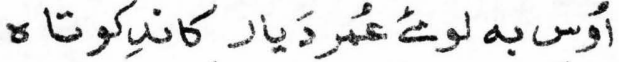

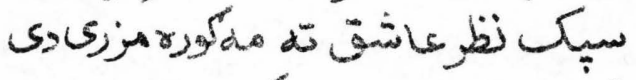

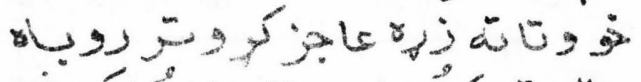

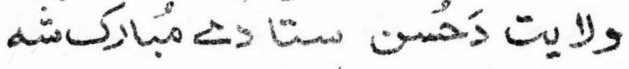

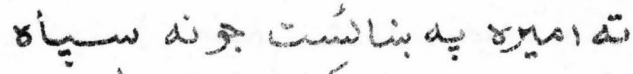

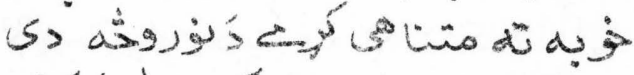

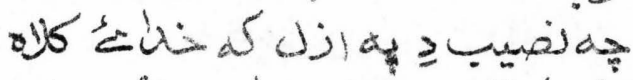

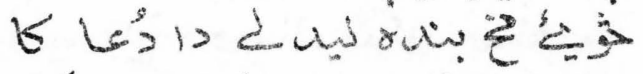

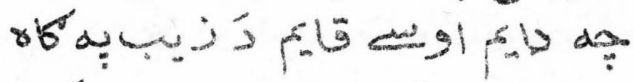
阝 لا

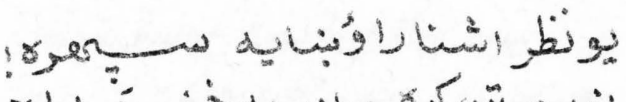
كون 


\section{ديوانِاشرنخانهُري}

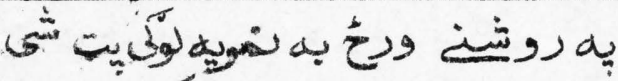

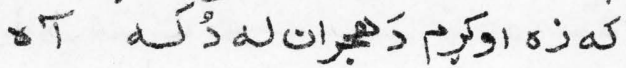

هو

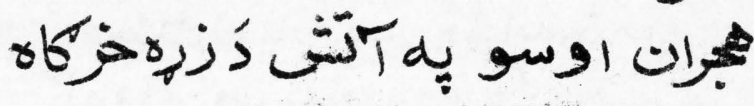

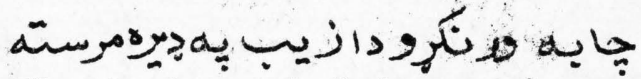

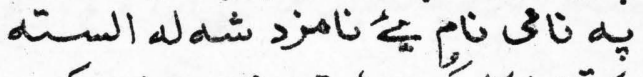

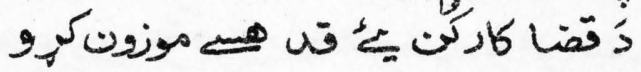

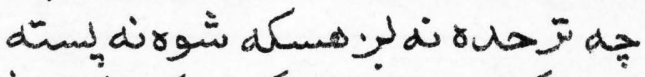

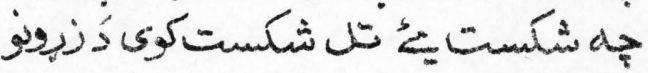

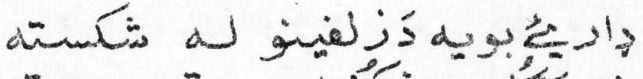

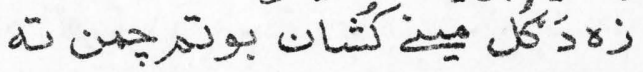

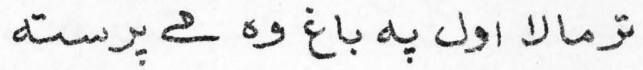

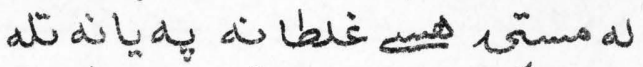

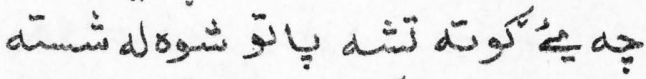

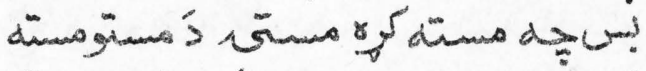

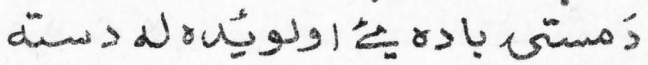

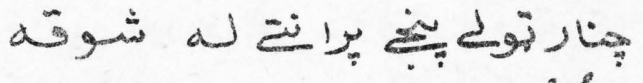

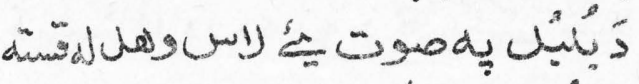

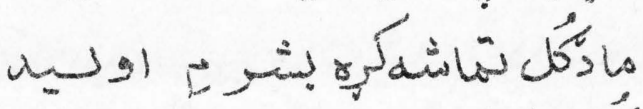
كُّل 


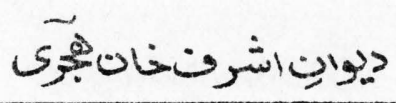

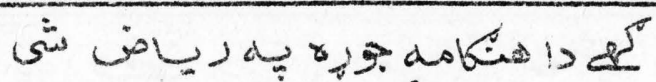

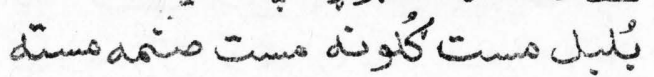

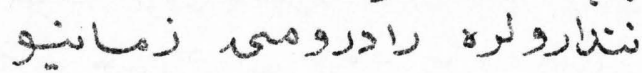

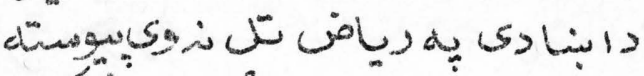

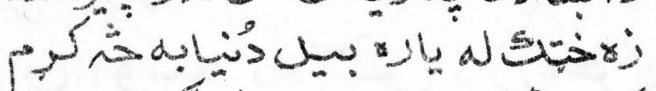

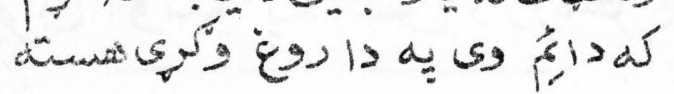

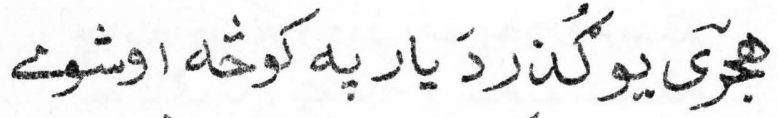
d

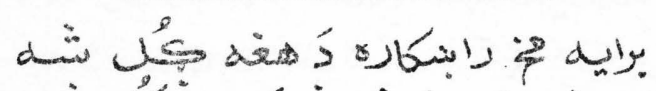

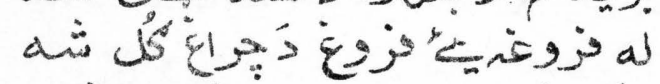

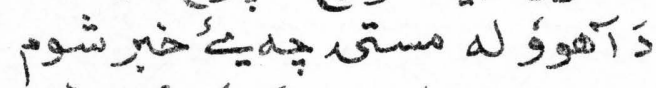

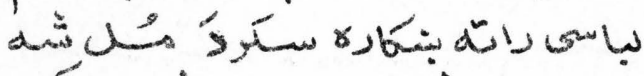

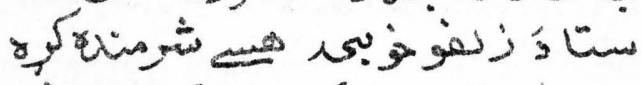

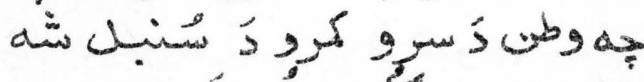

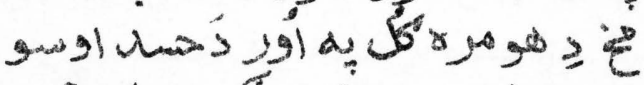

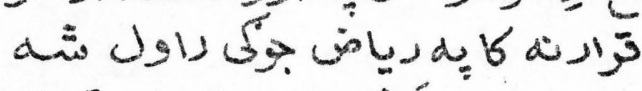

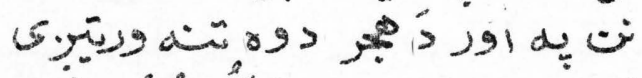
完

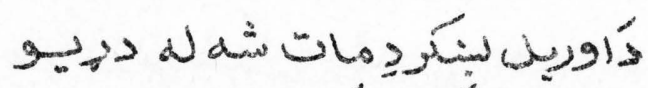

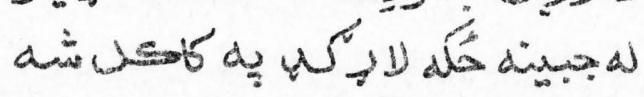




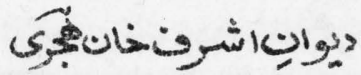

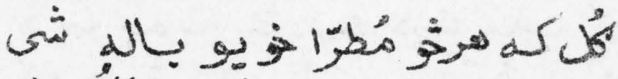

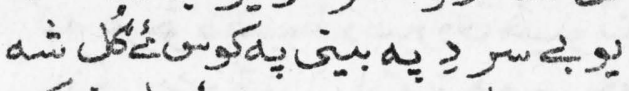

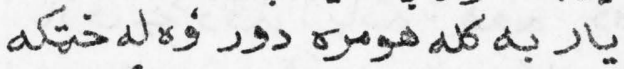

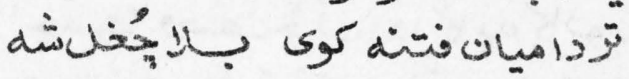

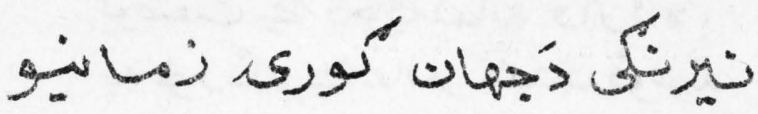
3.

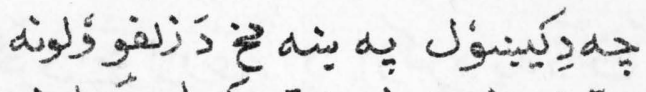

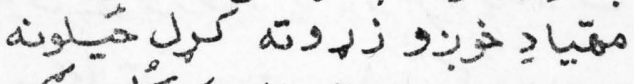
يه

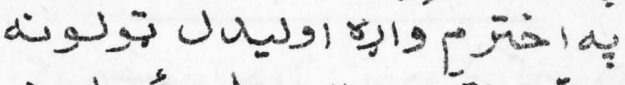

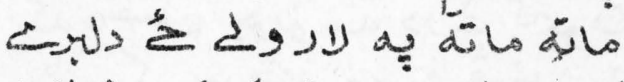

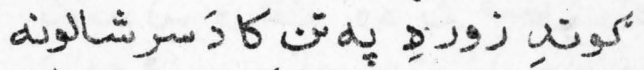

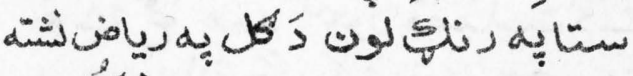

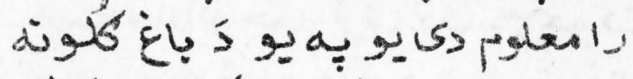

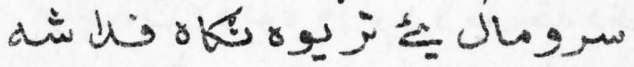

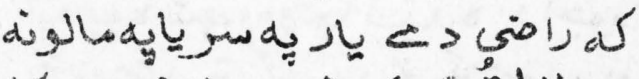

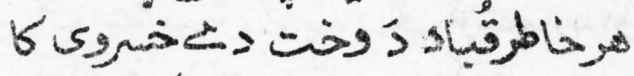

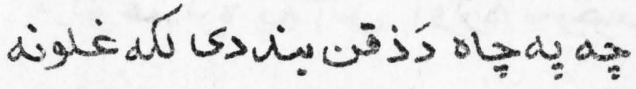

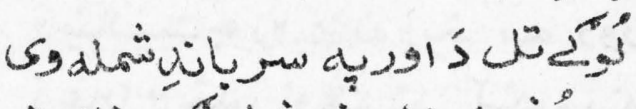

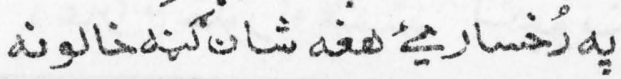




\section{حيوانِاشرتخانهيَي}

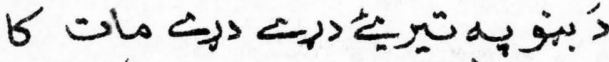

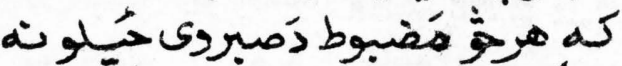

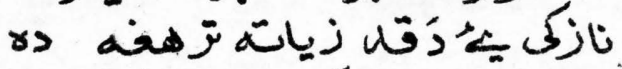

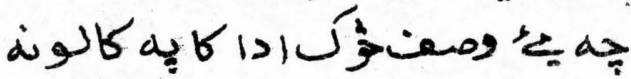

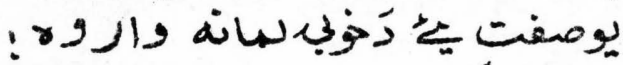

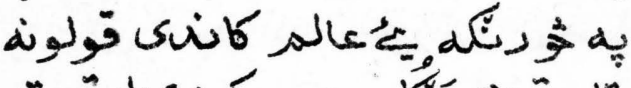

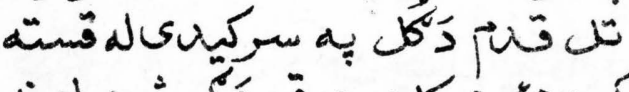

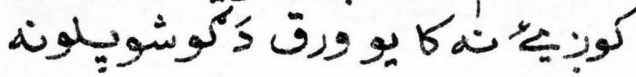

جز

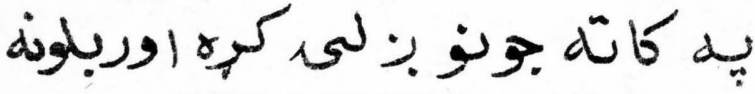

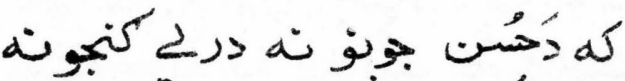

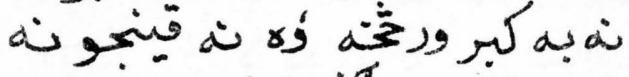

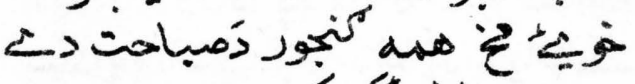

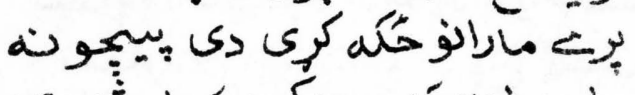

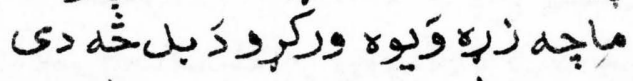

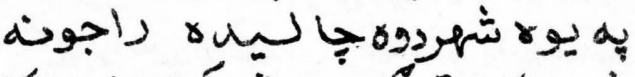

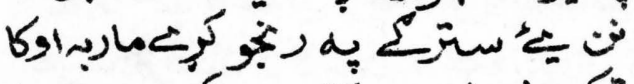

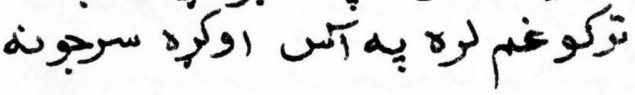

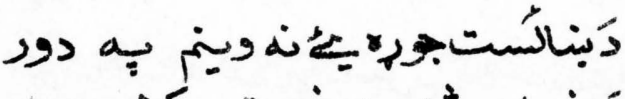

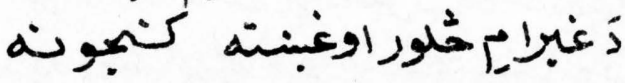




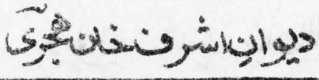

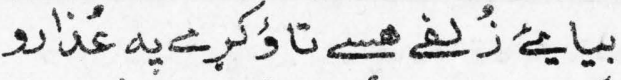

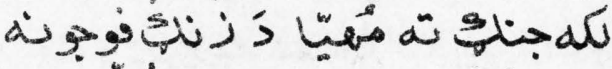

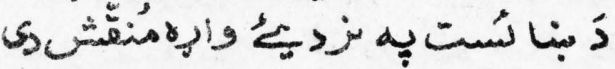

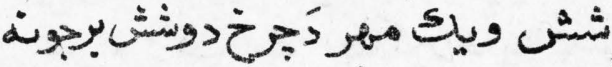

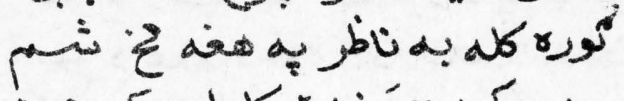

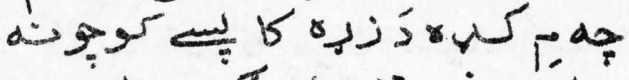

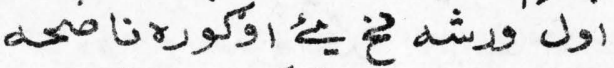

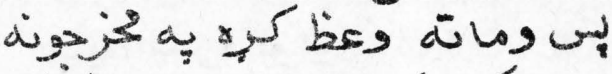
هـ

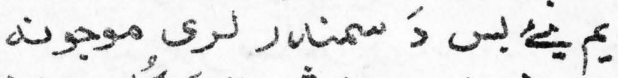

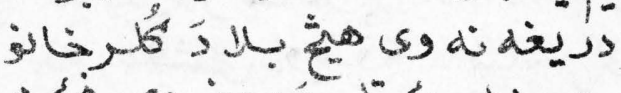

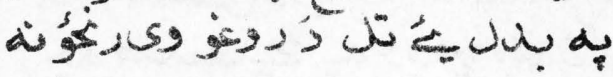

0)

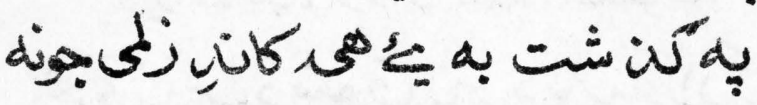

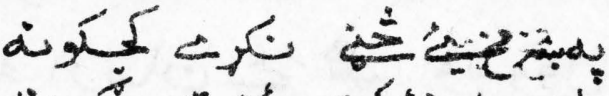

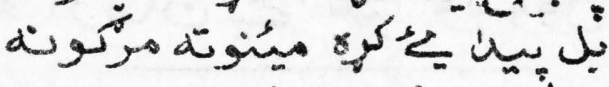

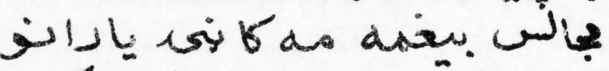

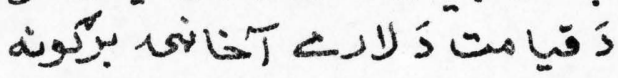

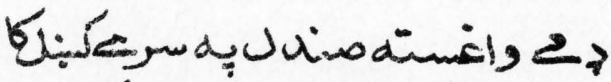

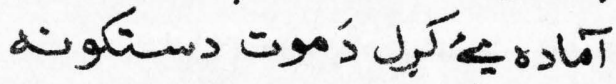




\section{S:}

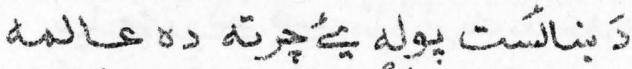
¿

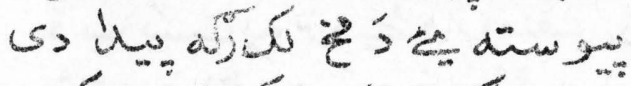

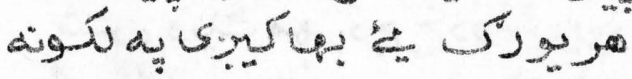

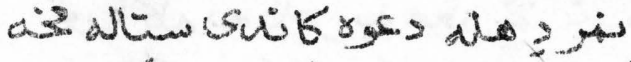

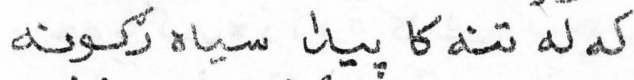

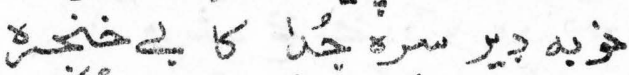

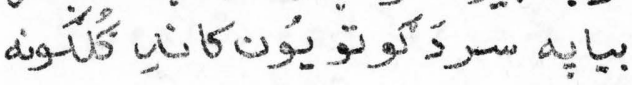
x)

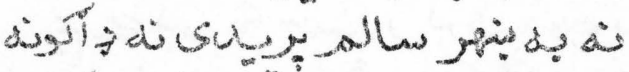

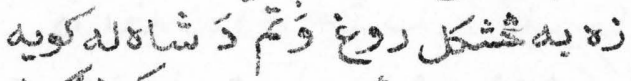

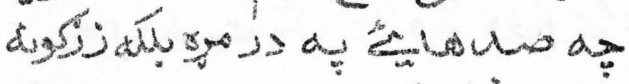
s9 d"

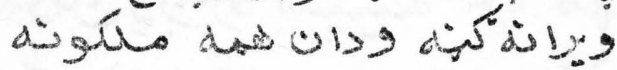

SDd

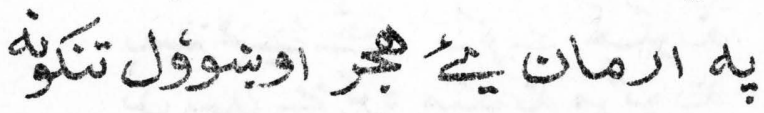




\section{ديوانِاشتوتخانهيمي}

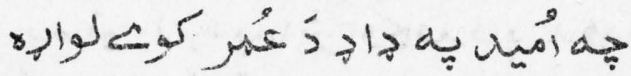

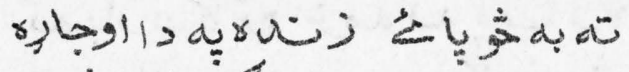
به

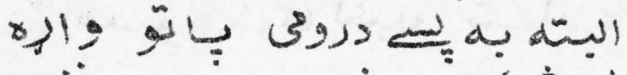

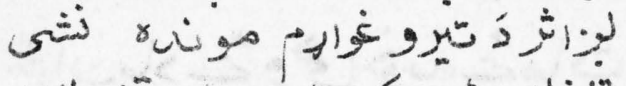

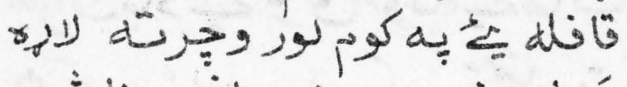

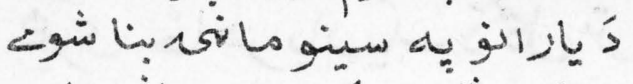

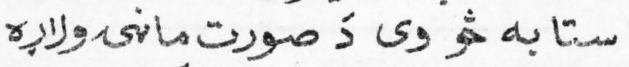

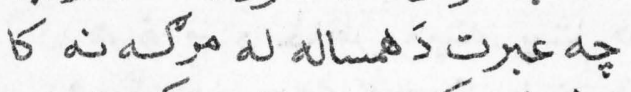

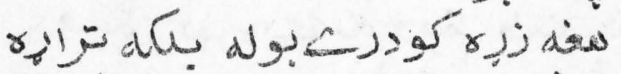
هائه

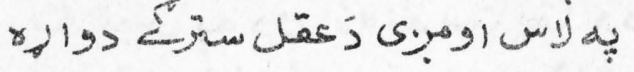

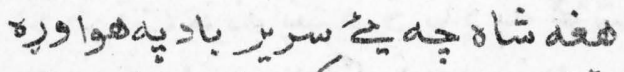

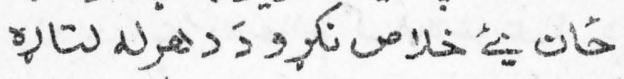

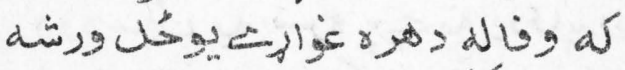

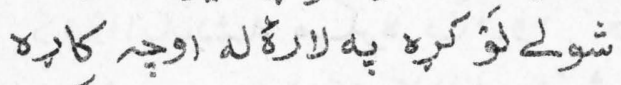
20 ته

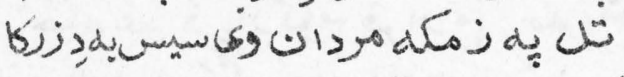

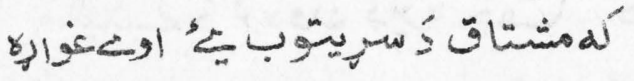

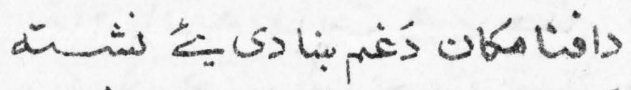

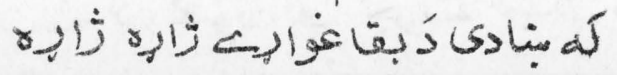




\section{حيوانِاشرِتخانهُري}

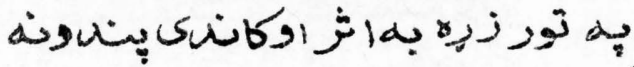

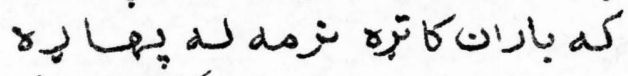

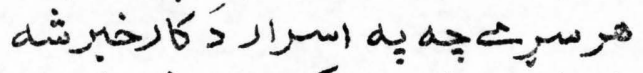

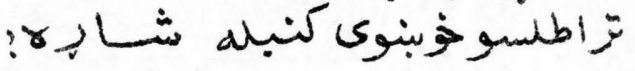

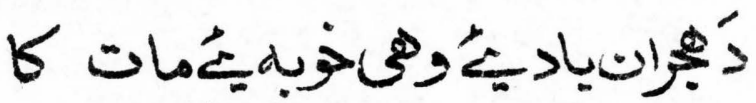
ز'

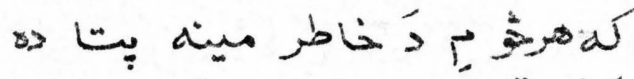

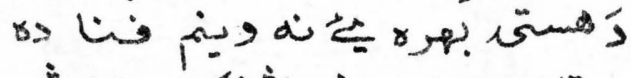

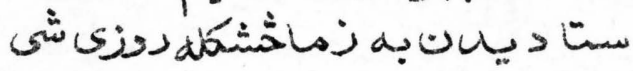

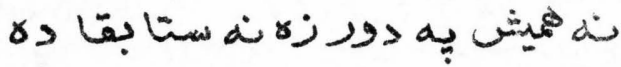

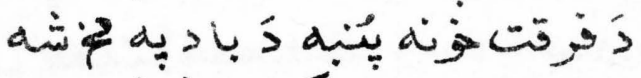

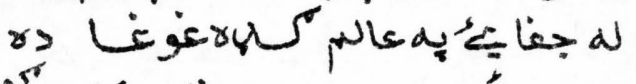

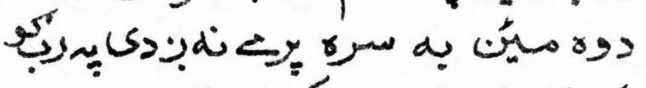

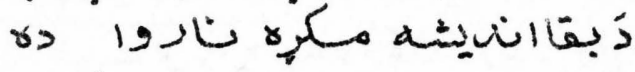

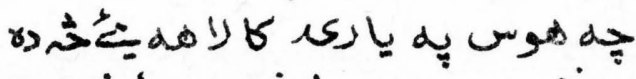

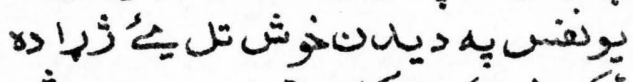

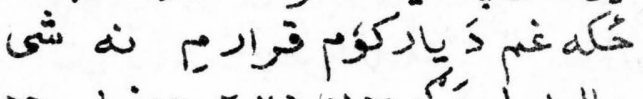

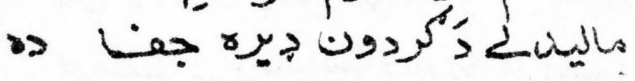

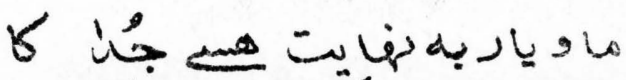

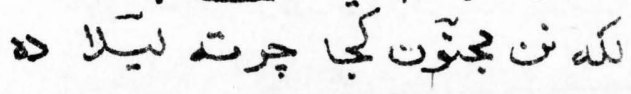




\section{يولانشرونانجئرى}

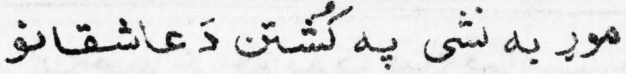

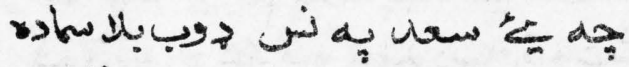

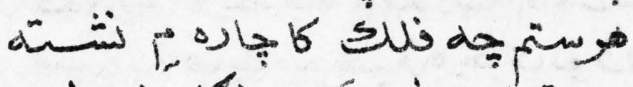

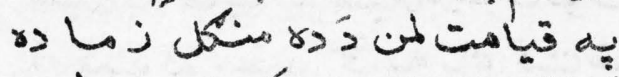

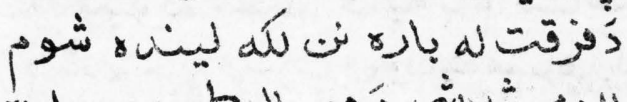
ها

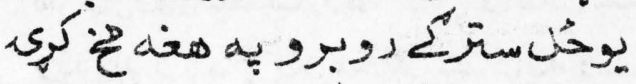

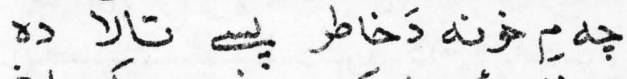

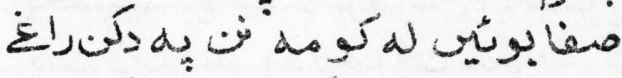

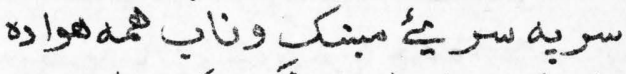

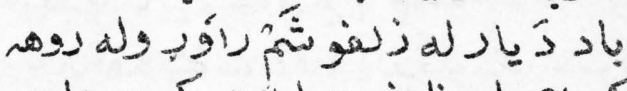

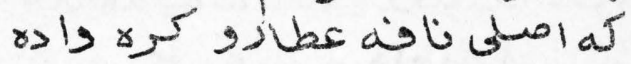

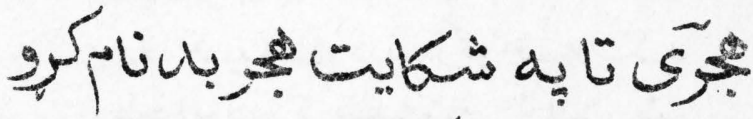
r) U. 


\section{حيوانِاشرينخانجمَي}

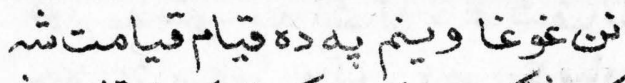

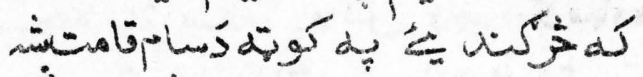

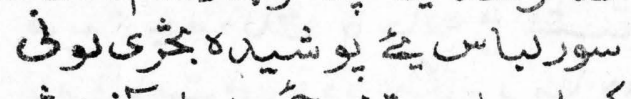

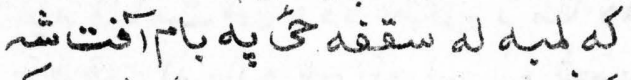

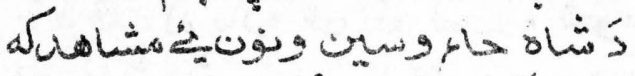

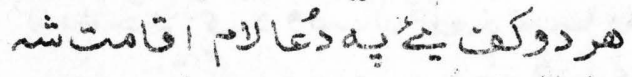
وله

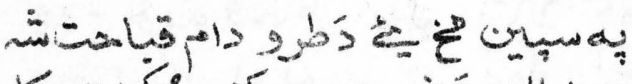

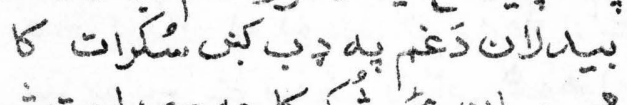

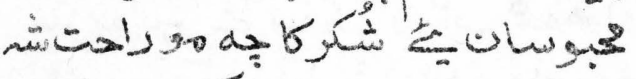

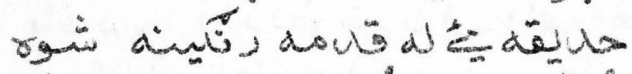

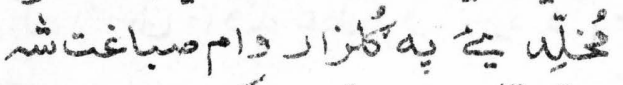
دوتى تل به

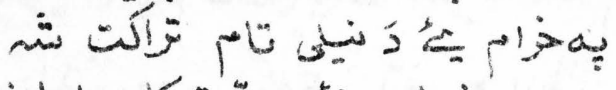

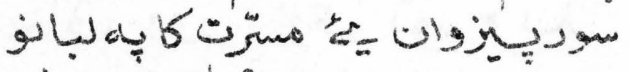

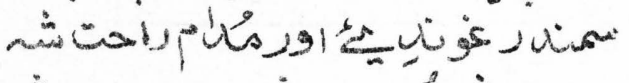

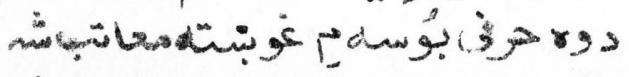

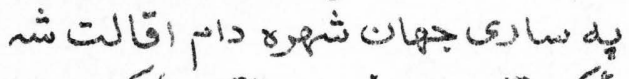

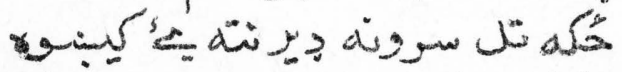

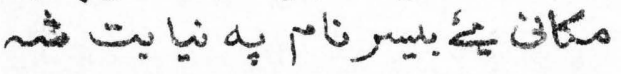

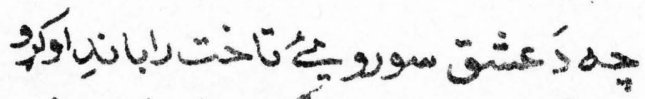

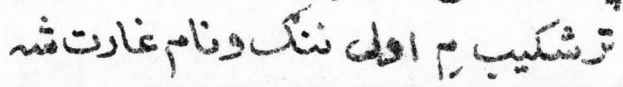




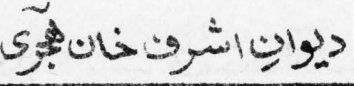

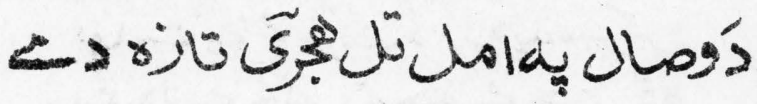

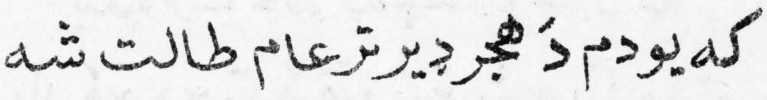

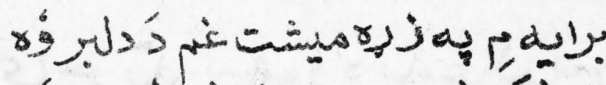

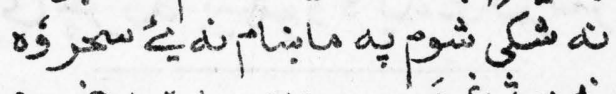
نه

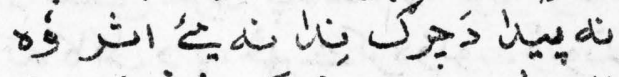
لا

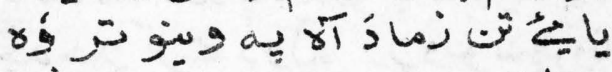
تِ

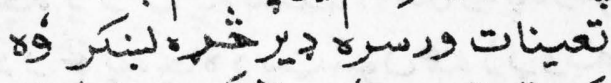

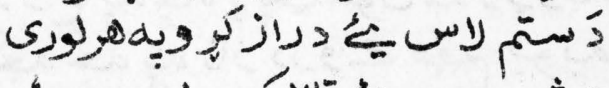

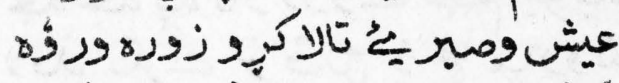

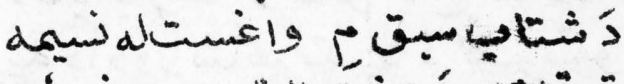

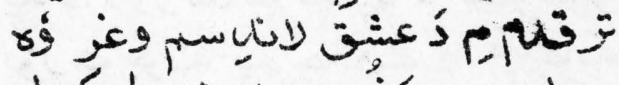

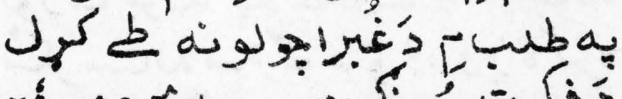

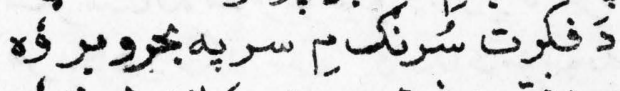

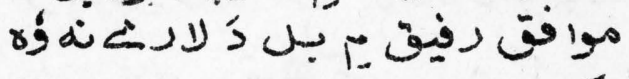

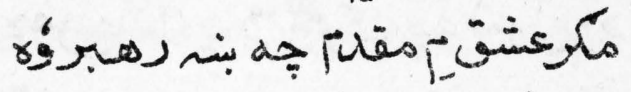

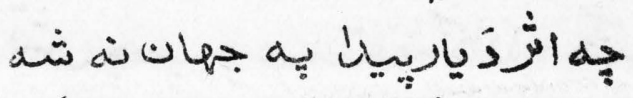

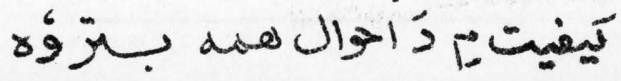




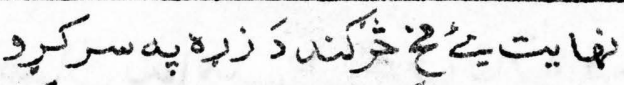

की

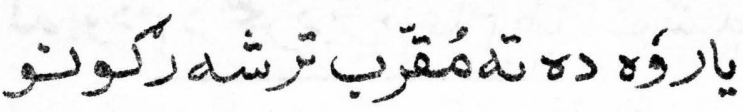

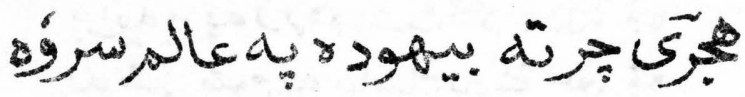

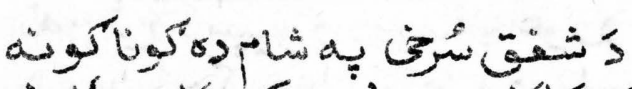

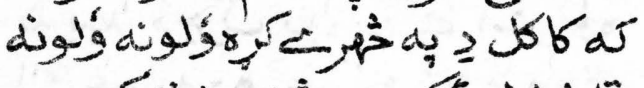
ها

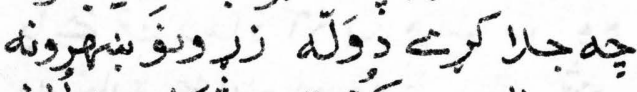

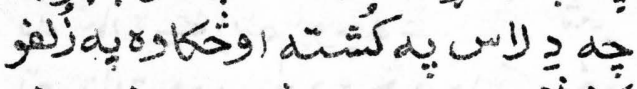

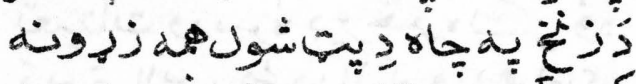
كأل

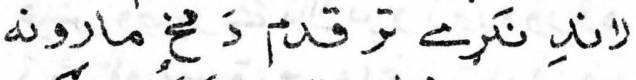

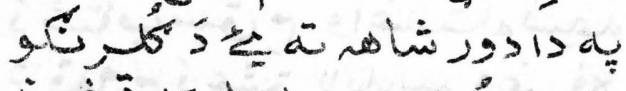
ن

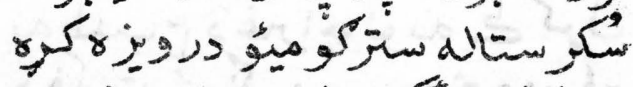
هرئان

s).ب.

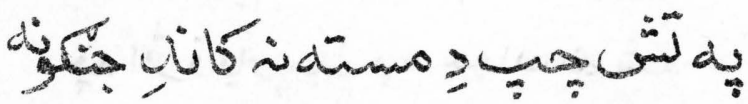




\section{ديوانِاشرقخانهُيَّي}

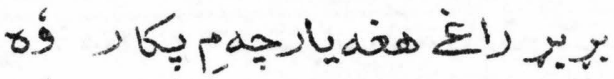

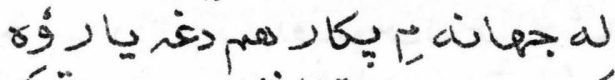

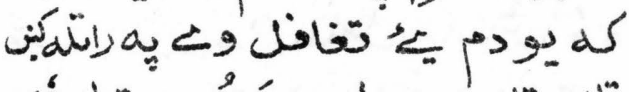

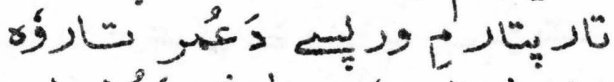

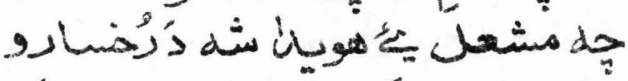

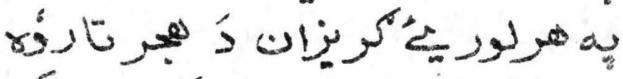

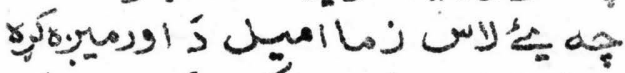

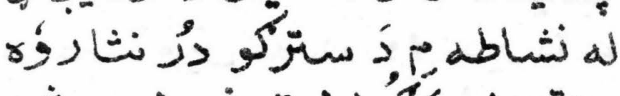

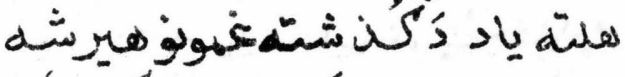

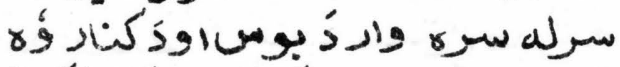

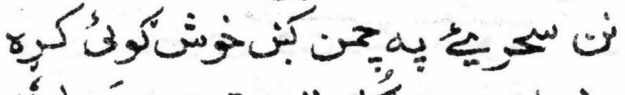

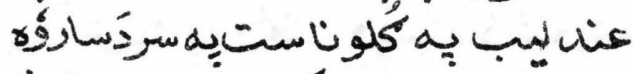

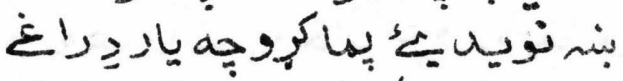

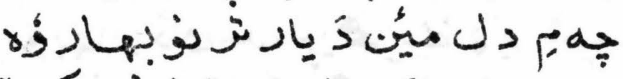

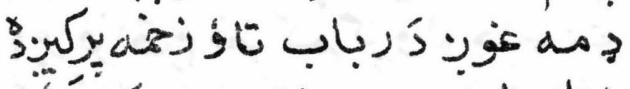

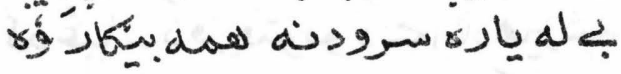

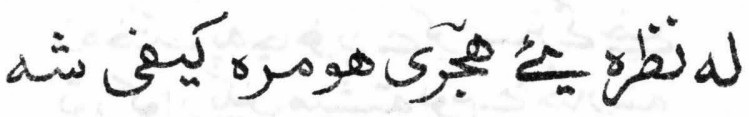

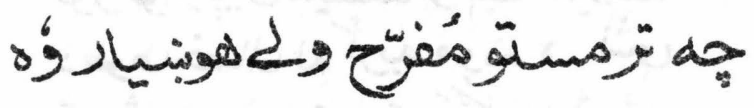




\section{حيوانِ اشرقخانهُمي}

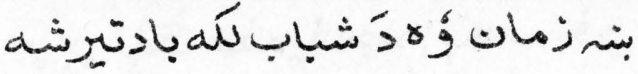

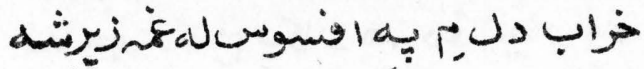

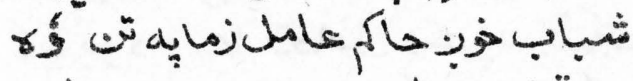

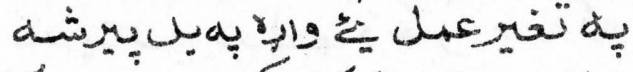

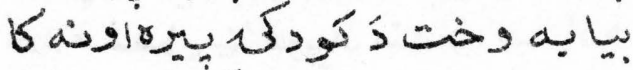

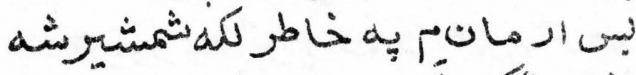

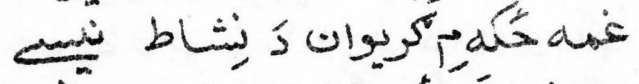

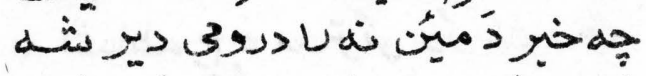

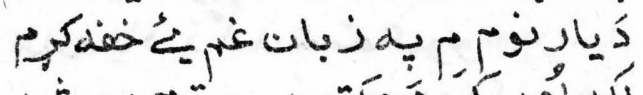

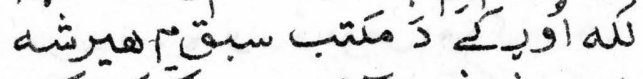

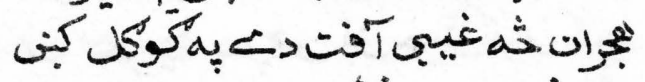

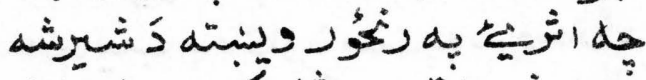

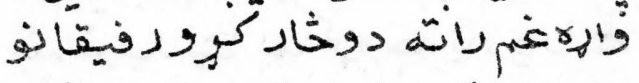

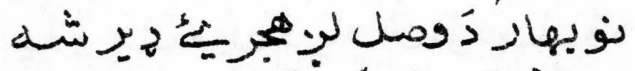

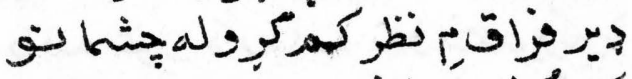

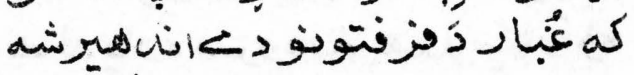

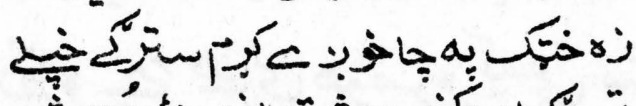

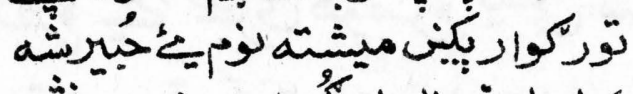

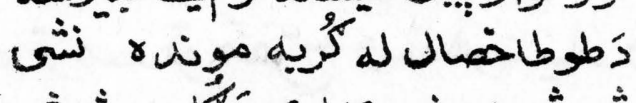

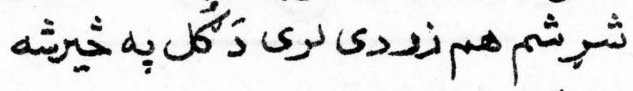

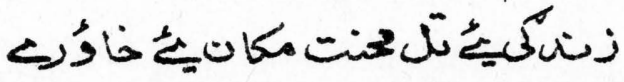

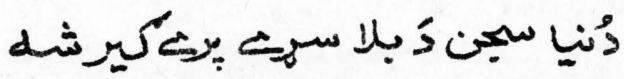




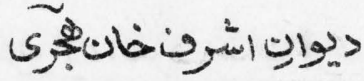

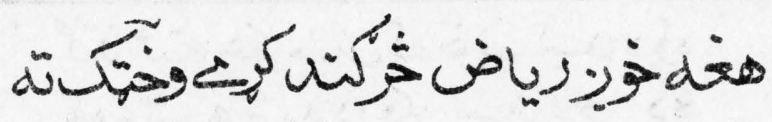

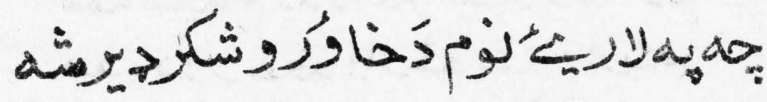

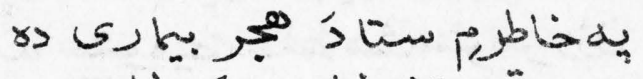

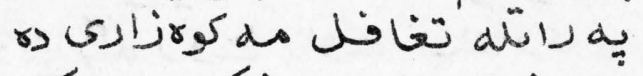

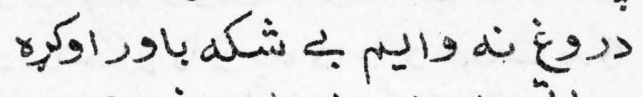

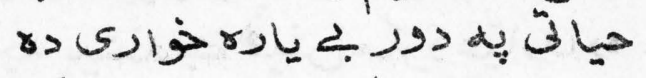

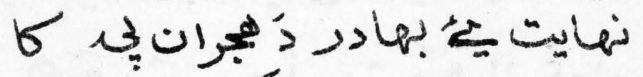

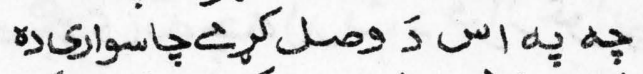

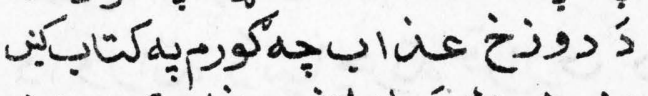
d

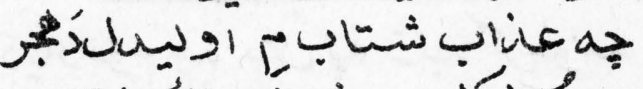

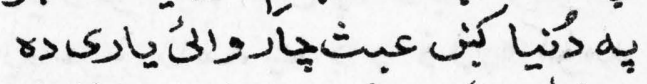

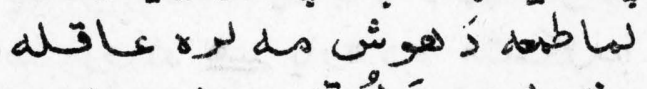

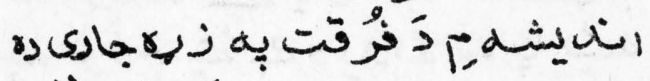

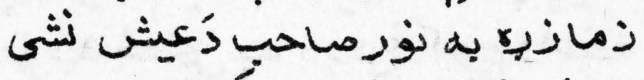

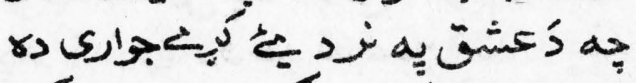

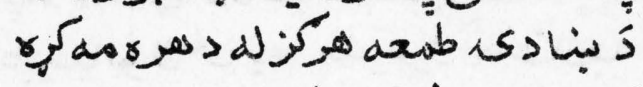

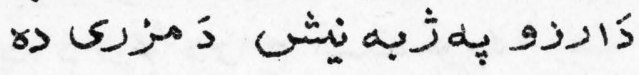

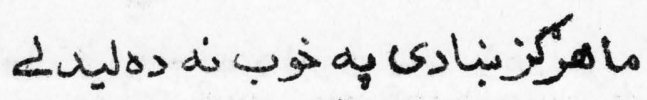

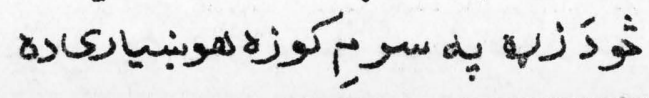


ديوابِ اشرتشانهيجى

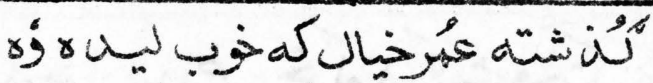

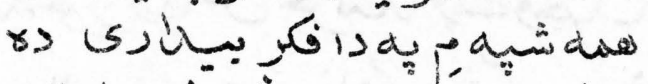

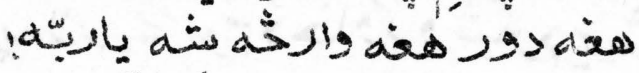

ه به

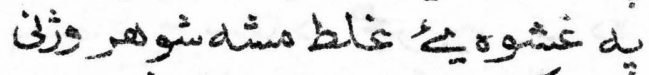

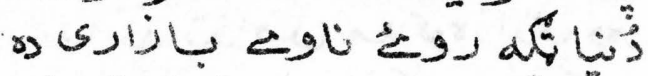

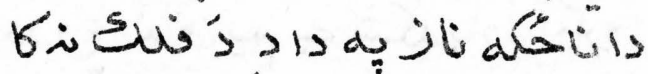

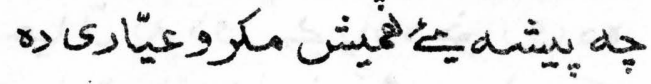

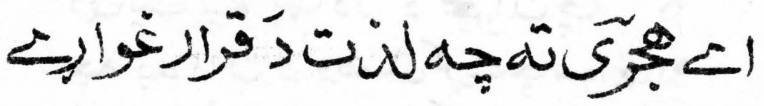

ه

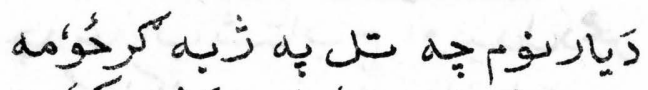

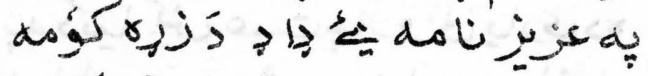

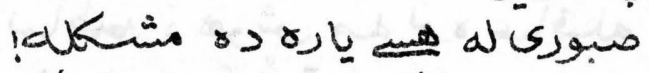

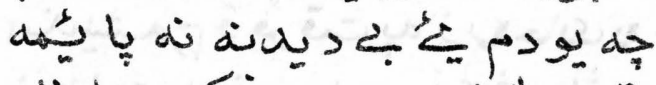

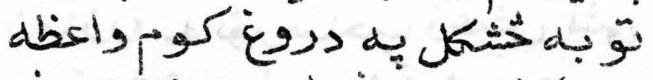

定

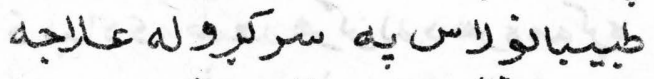

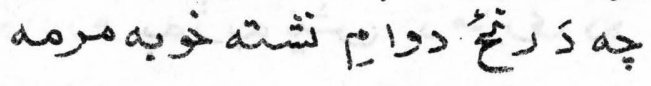

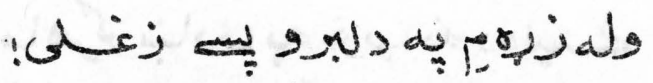

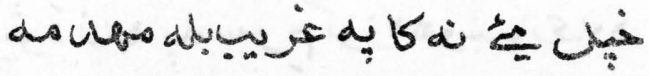

paA 
苗

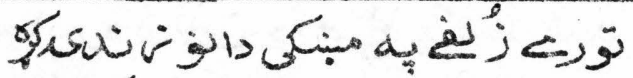

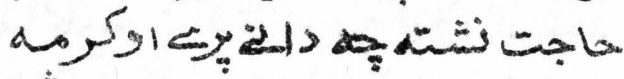

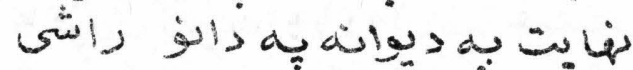

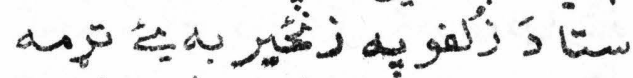

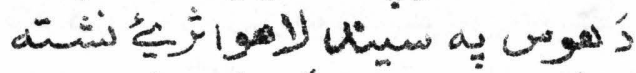

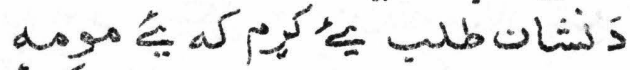

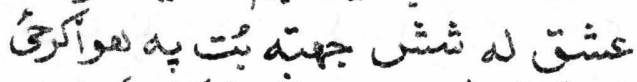

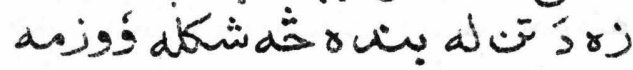

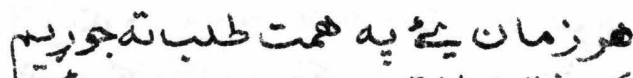

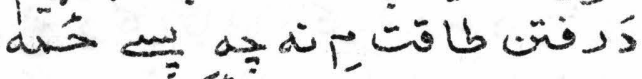

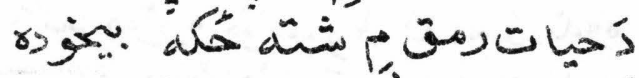

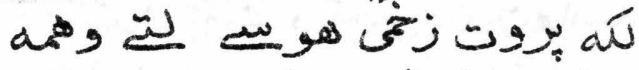

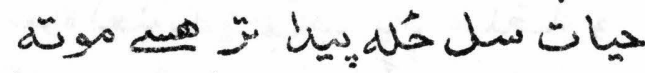

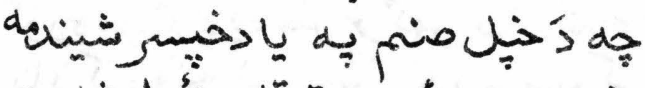

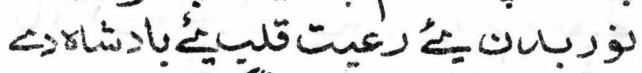

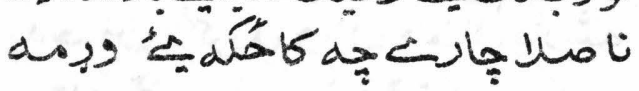

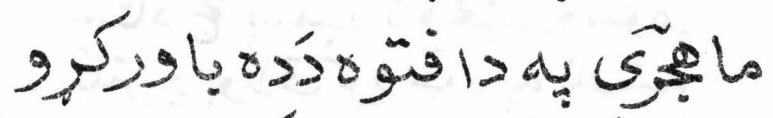

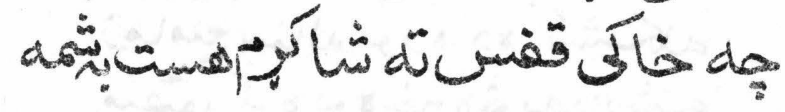




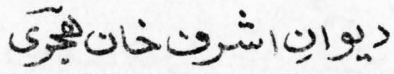

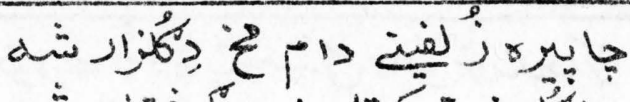

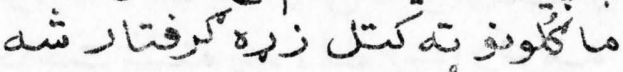

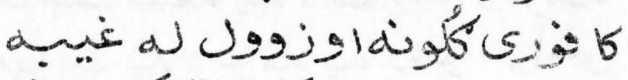

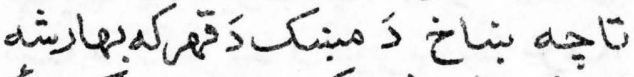


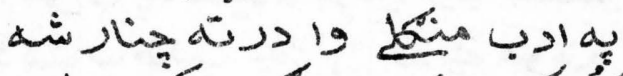

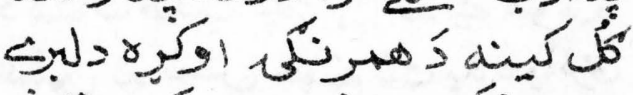

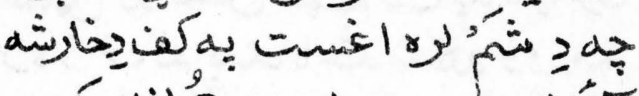
Tَّ 莫

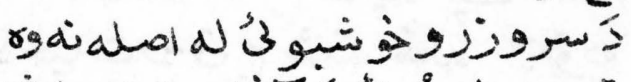

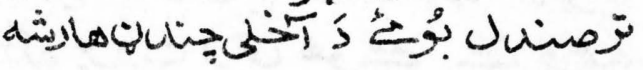

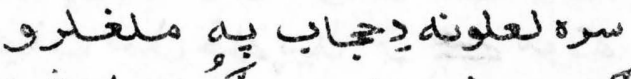

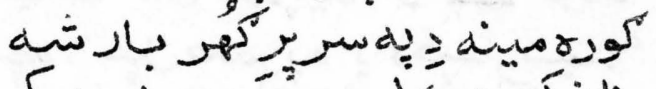

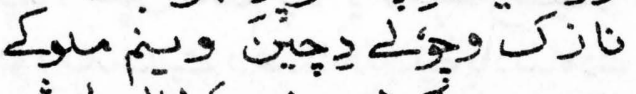

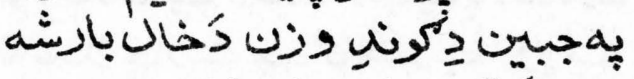

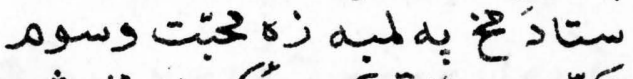

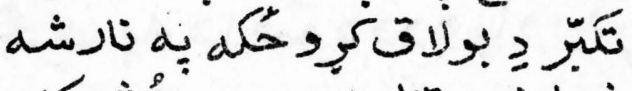

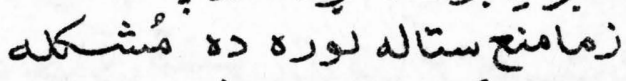

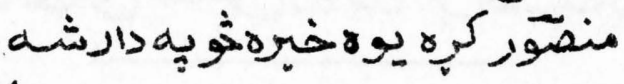

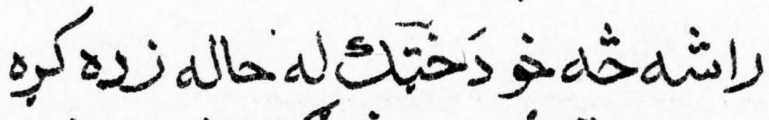

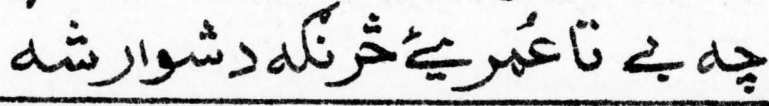




\section{ديوابِاشرنخانئيحي}

د r) ᄂi

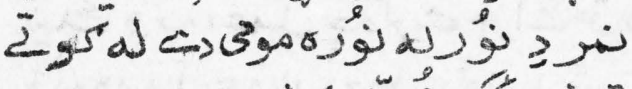

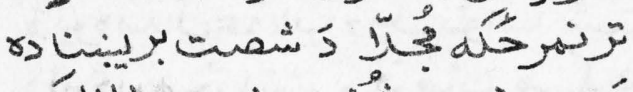

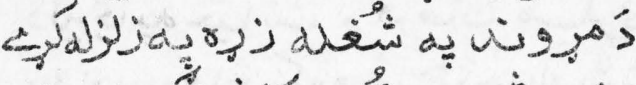

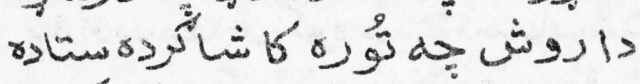

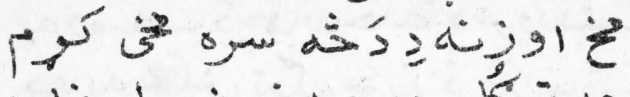

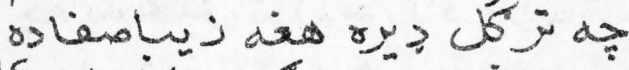
S rادئل

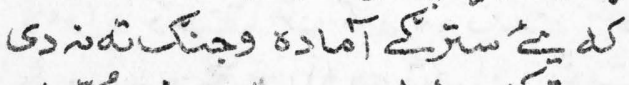

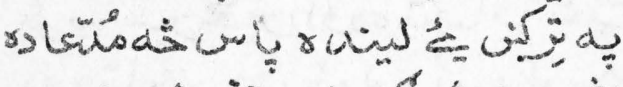
$\Leftrightarrow 4$ 年

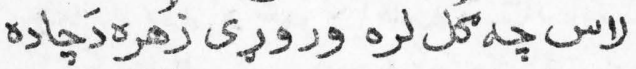

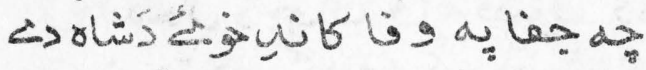

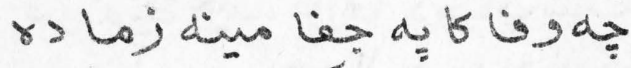
كأو ช بن

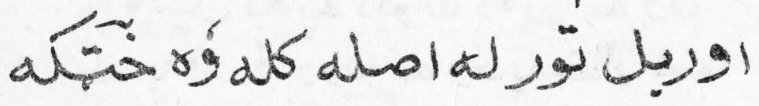

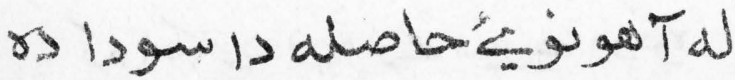




\section{اليوانِ اشترتخانجميكي}

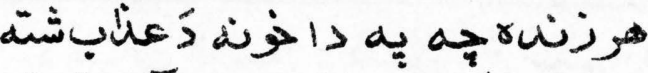

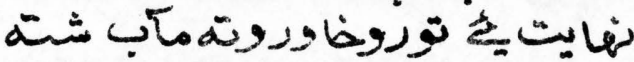

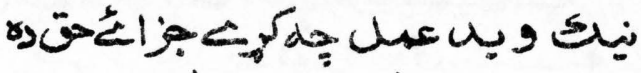
دَيولبهل

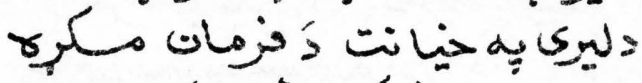

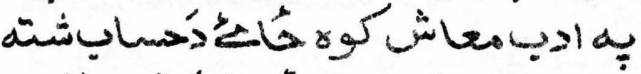

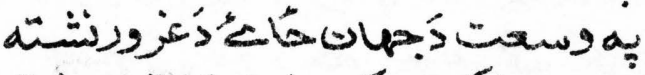

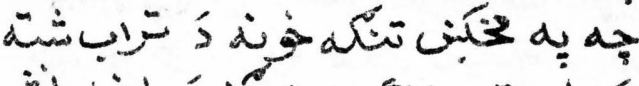

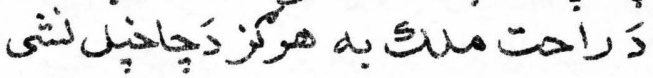

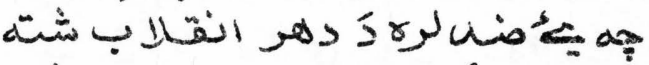
داملد

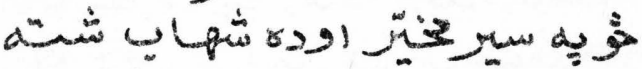

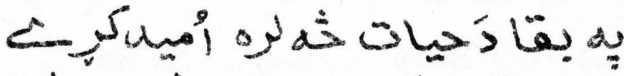

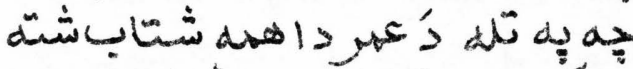

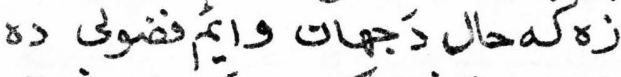

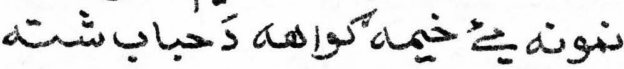

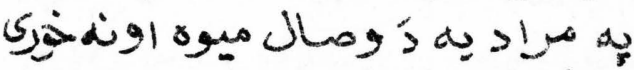

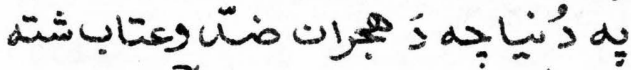
كا وبئل يه يه ديواته

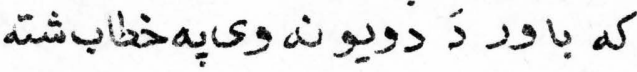

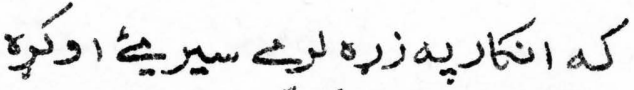

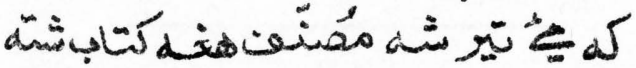


5

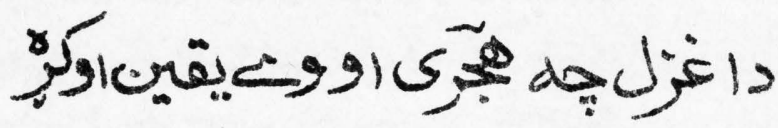

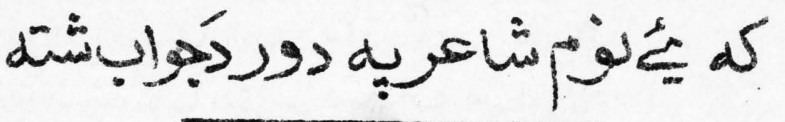




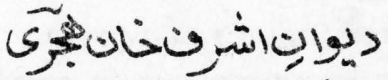

\section{$\checkmark$}

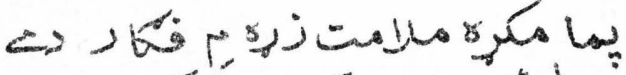
L

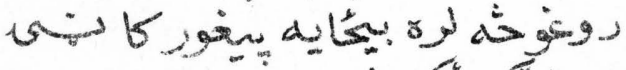

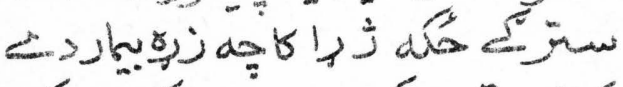
دأنا ته به

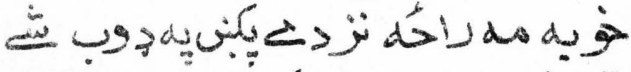
توبها تينّان

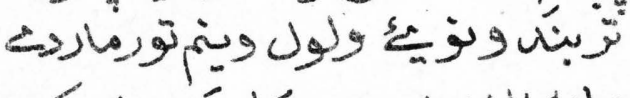

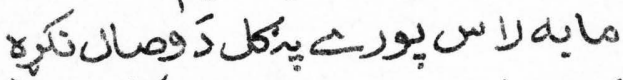

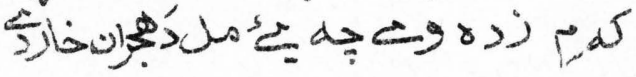

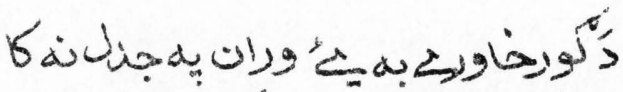

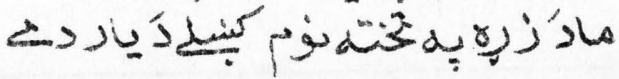




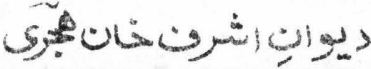

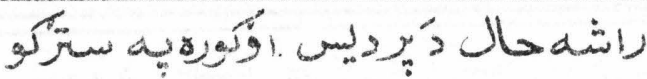

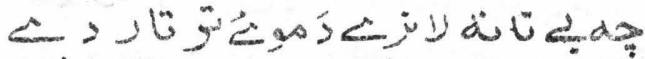

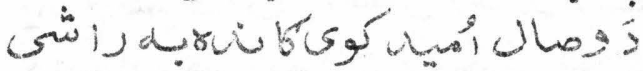

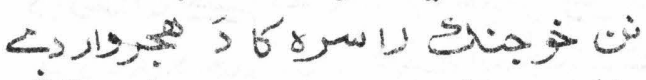
ن

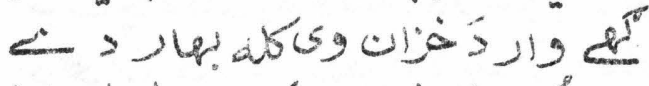
بيه

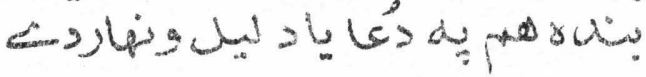

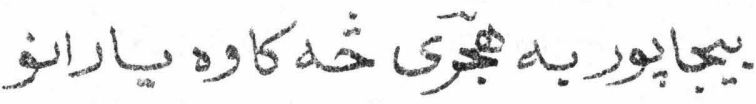

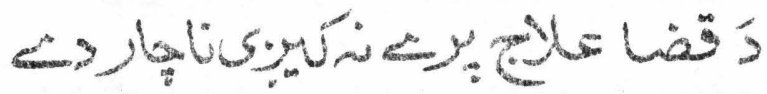
$\therefore$ s)

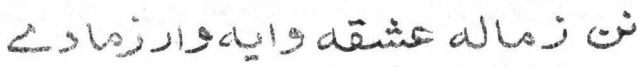
و

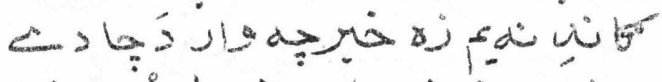
سل أنو L 2 s كأ

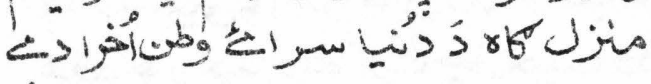

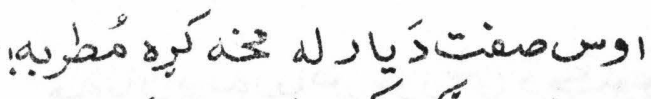

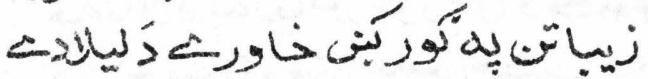




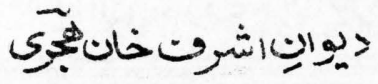

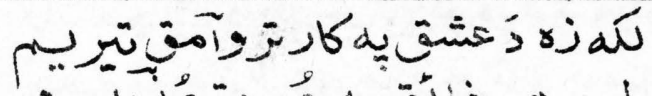

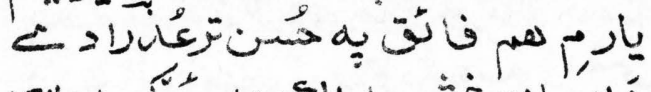

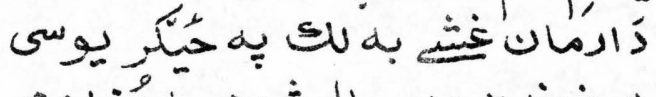

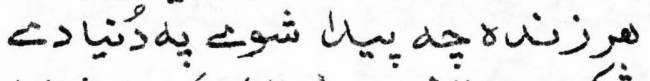
كو

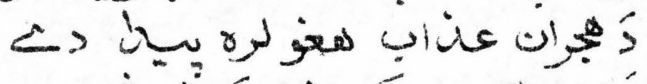
كَ c) 政

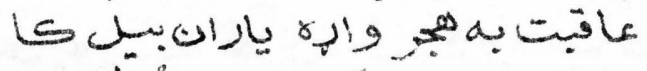

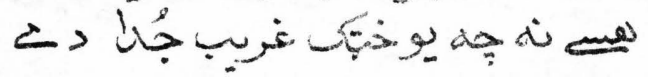

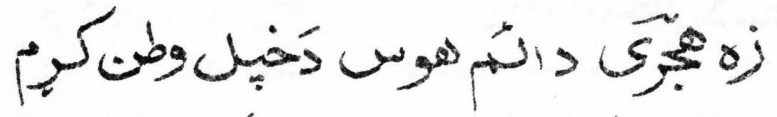

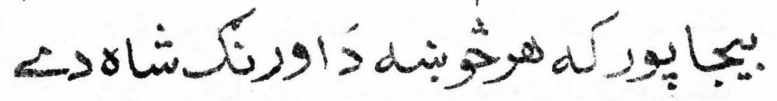

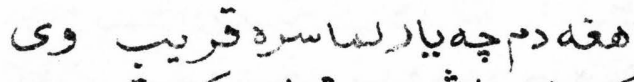

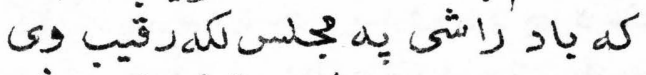

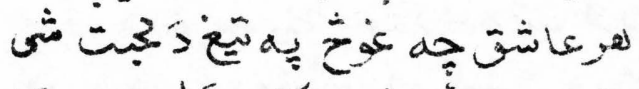

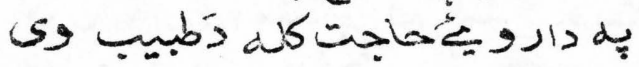

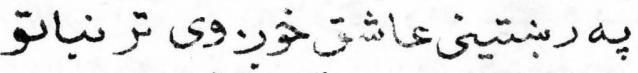

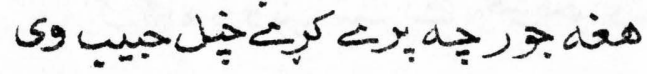

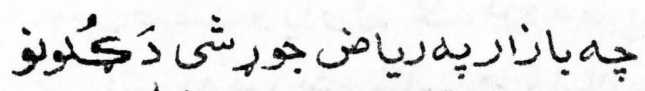

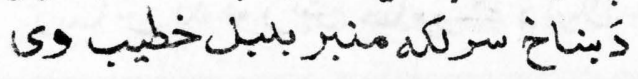




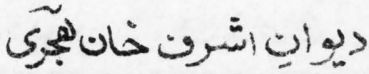

وئرة

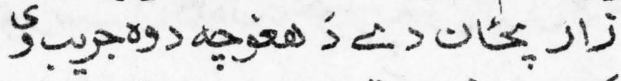

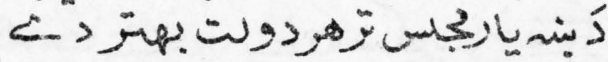

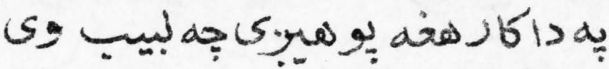

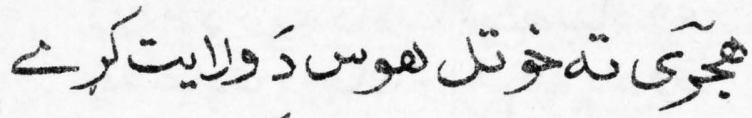

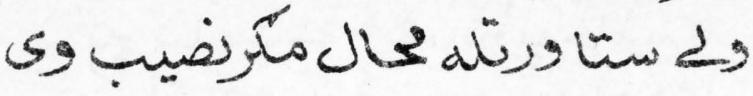

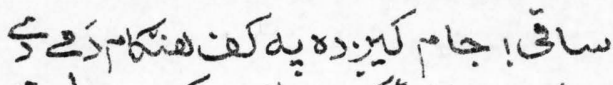

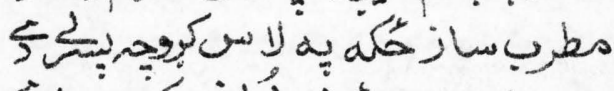

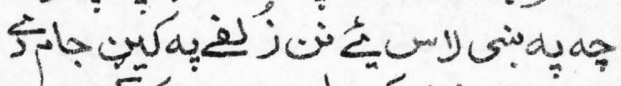

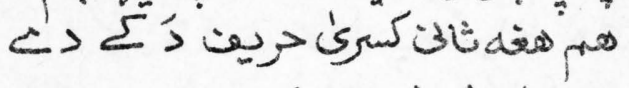

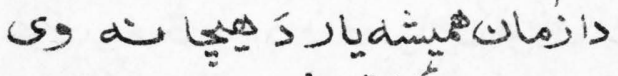

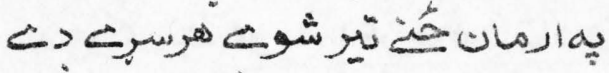
كا

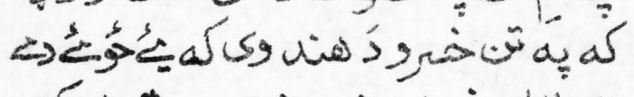

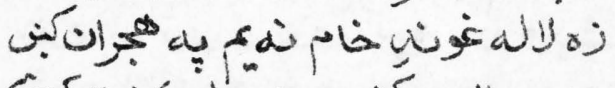

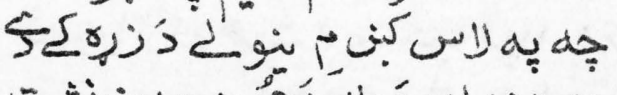

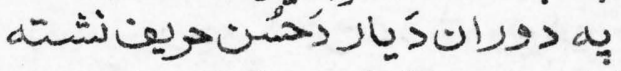

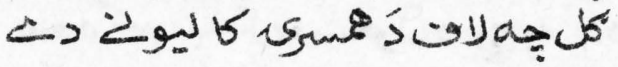

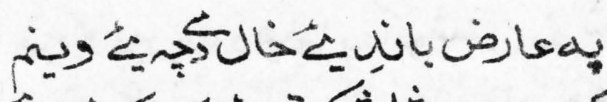
家 


\section{يوإِاشرتخانهرى}

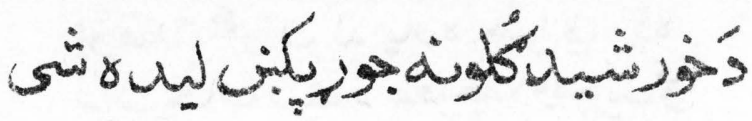

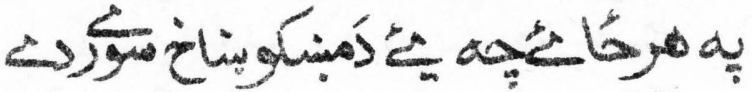

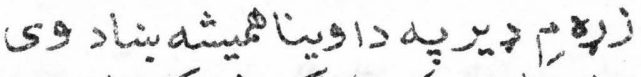

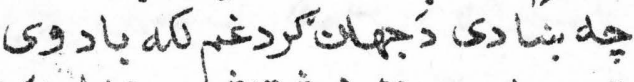

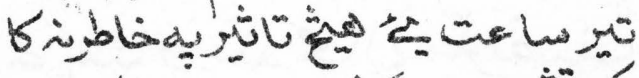

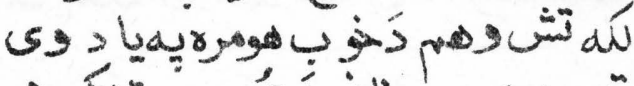

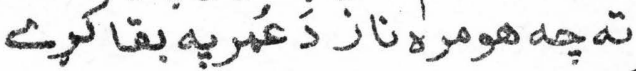

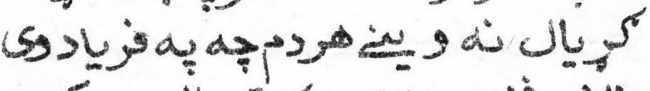

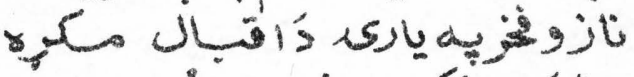

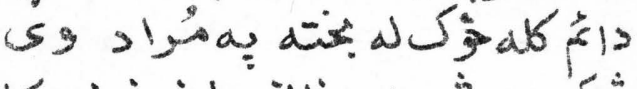

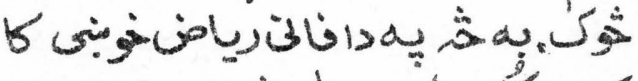

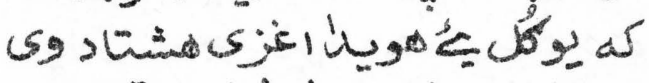

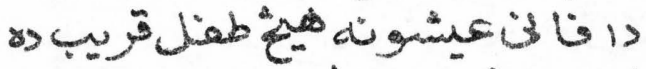

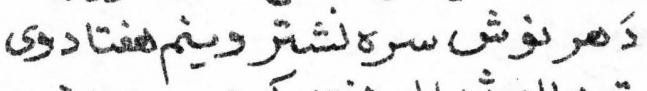

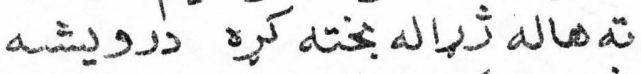

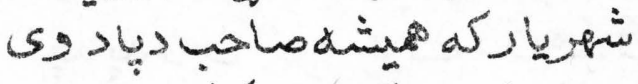

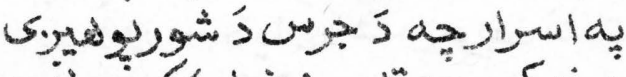

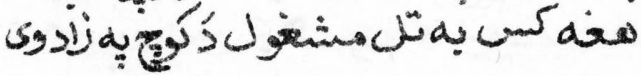

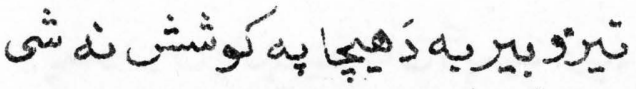

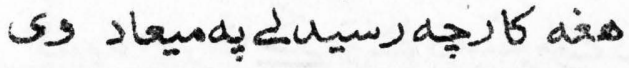


ك

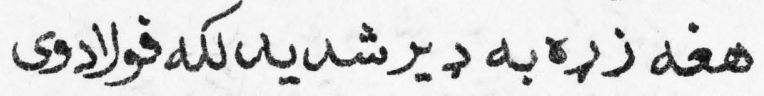

جه هيشهاتِ

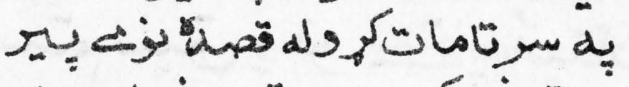

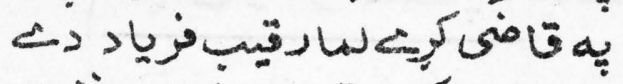

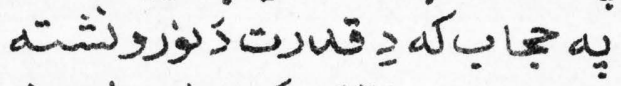
جه

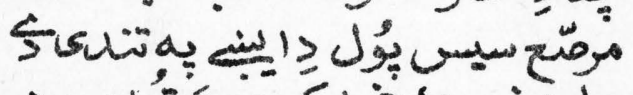

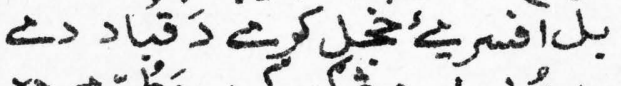
هيه

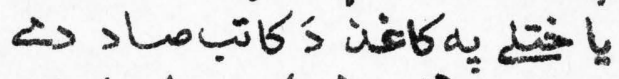

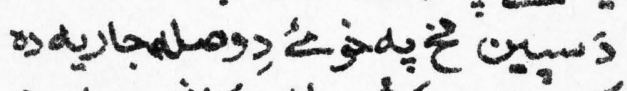
Mإنس

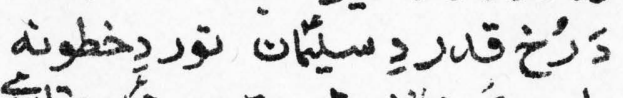

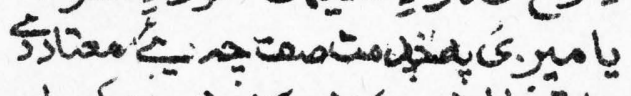

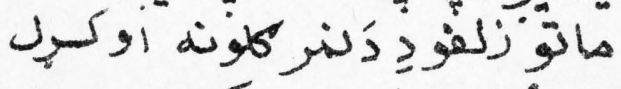

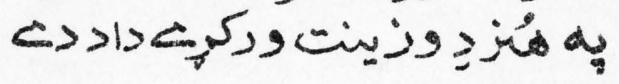

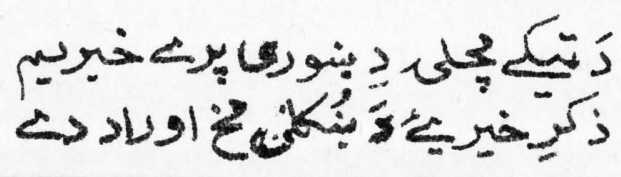




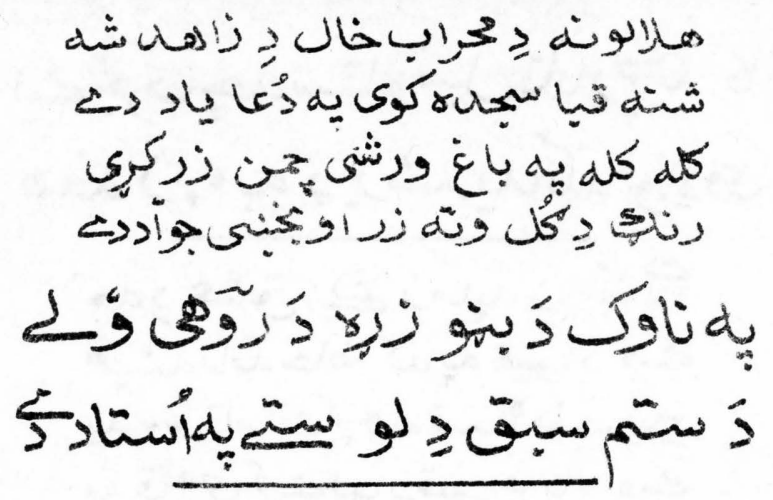




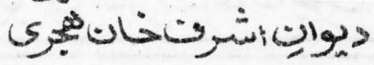

ئماه

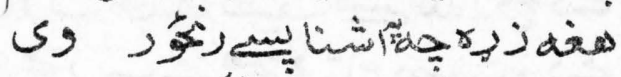

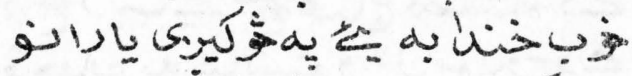
(19)

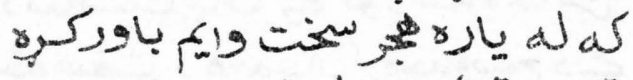
تل شايل

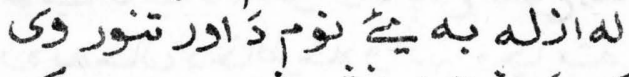

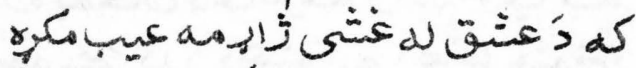

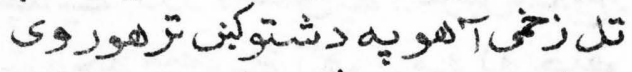

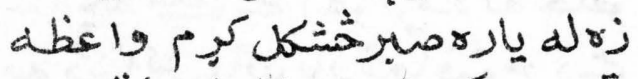

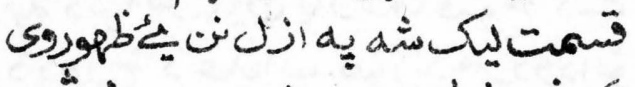

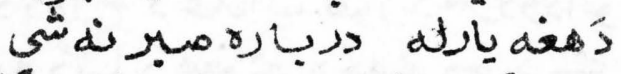

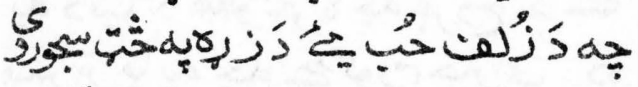

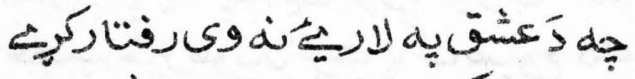
जgyiasaid وكن

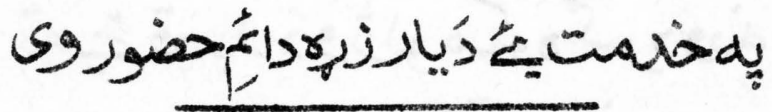




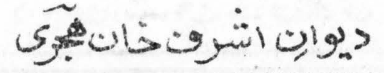

ع

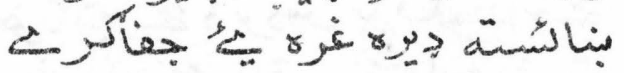

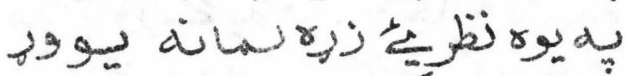

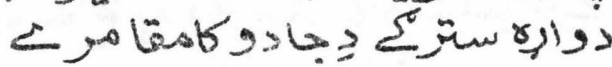

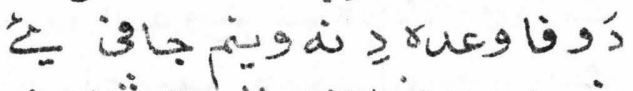

نو

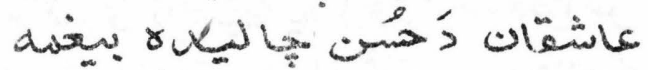

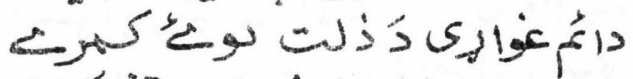

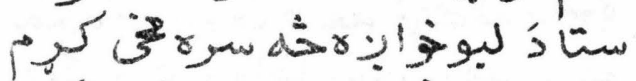

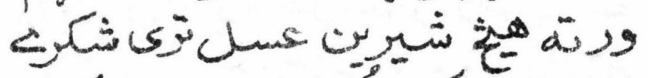

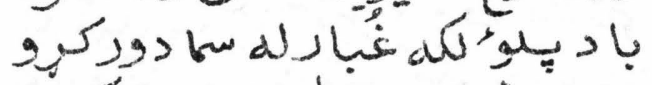

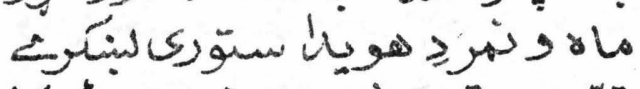

تبّتم

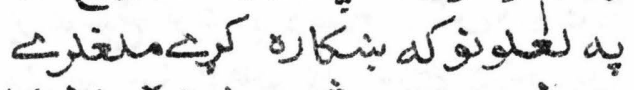

حئ

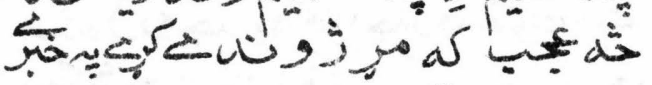

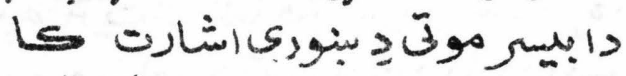

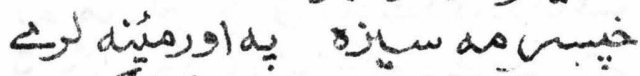

هو

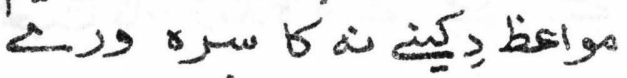

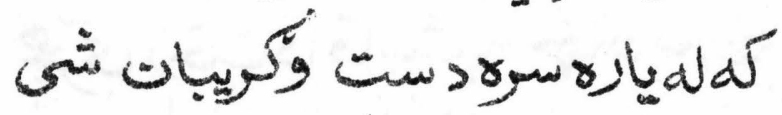

كَ 


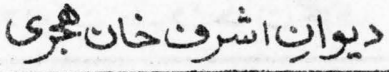

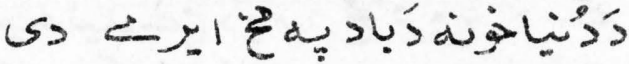

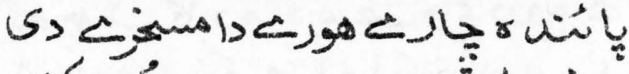
|

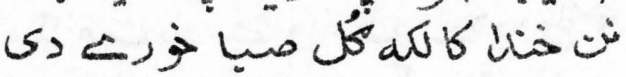

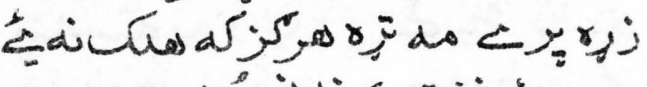

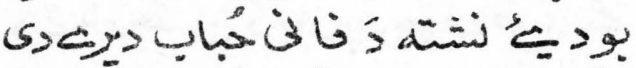

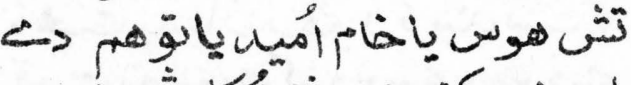

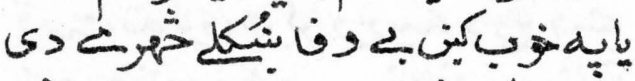
جِ

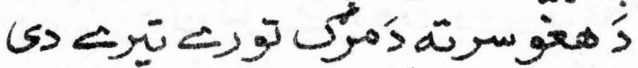

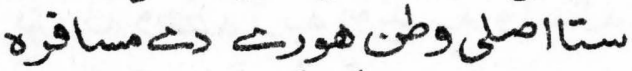
بهن

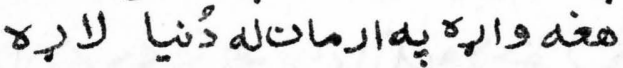

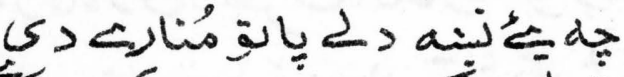

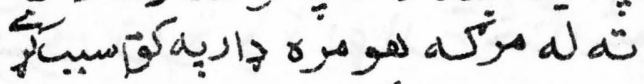

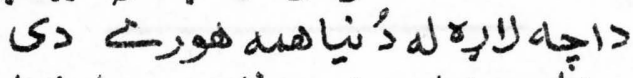

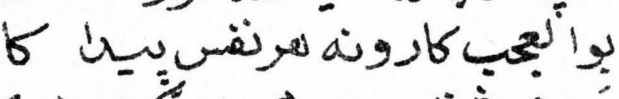
خِ

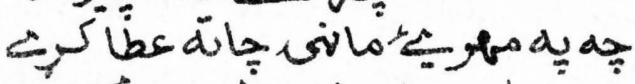

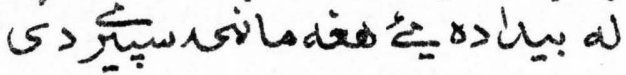

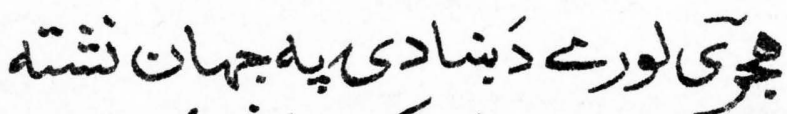

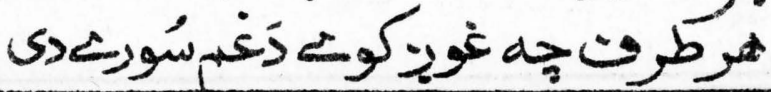


ديوانِاشرقخانهُجي

جه $\Leftrightarrow$ بهان 这

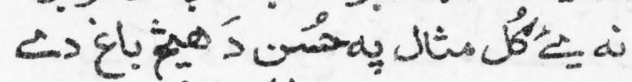

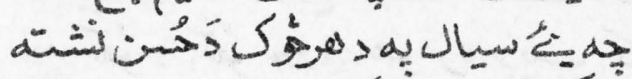
2 ن

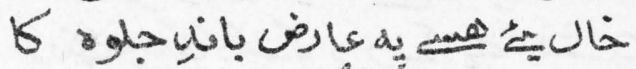

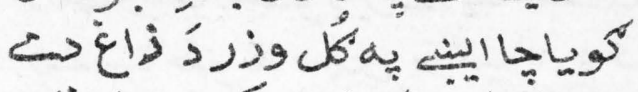

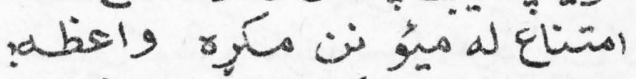
$\Leftrightarrow$ ' ز

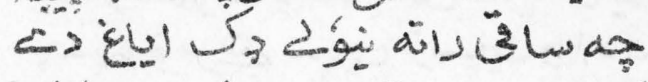
كردون غنيمتاكنه

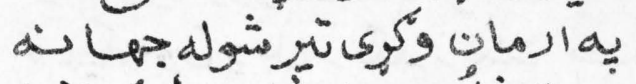

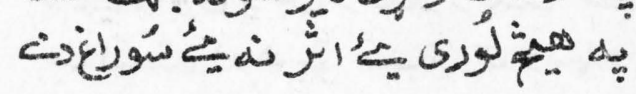

هره

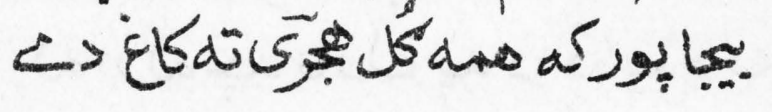

frv 


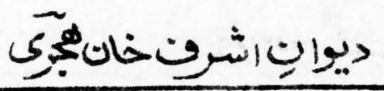

(5)

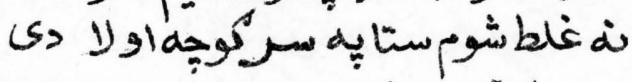

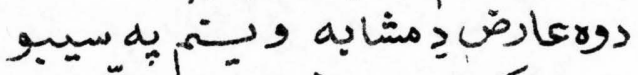

نة

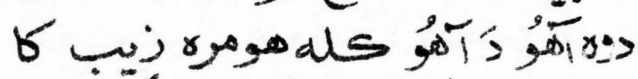

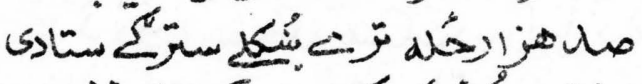

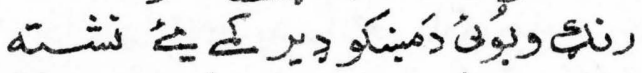

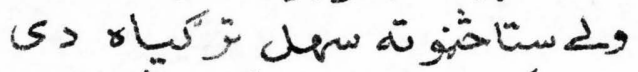

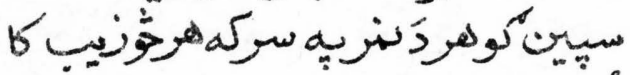

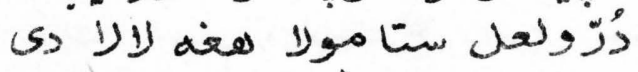

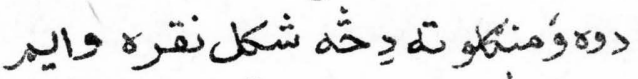

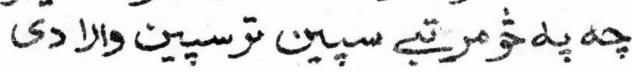

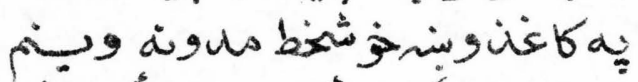

تز

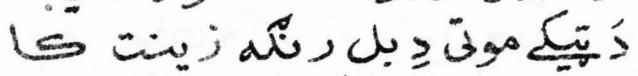

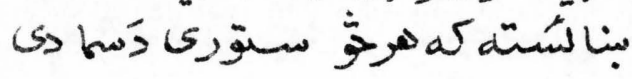

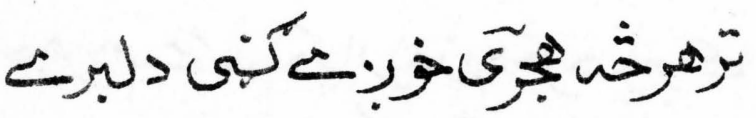

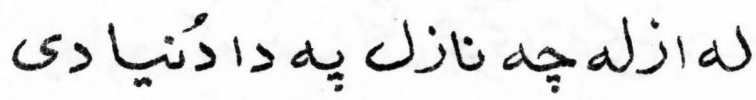

F्VN 


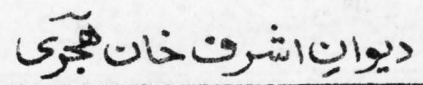

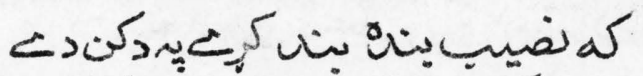

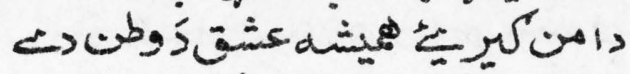

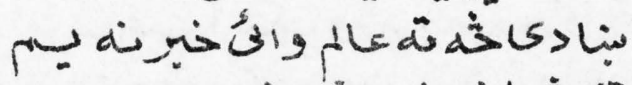

$\Leftrightarrow$

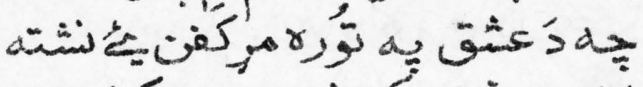

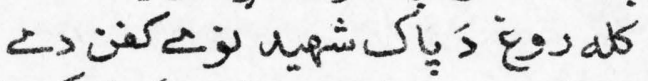

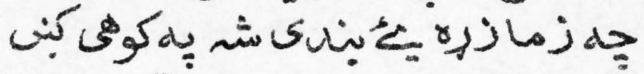

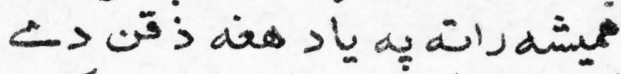

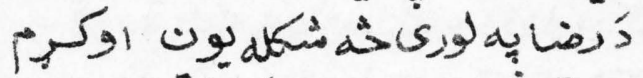

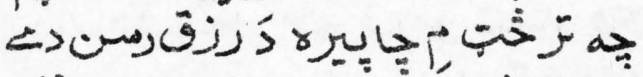

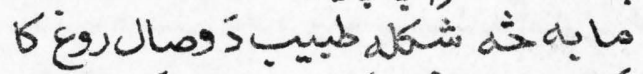

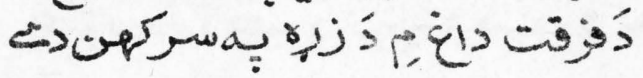

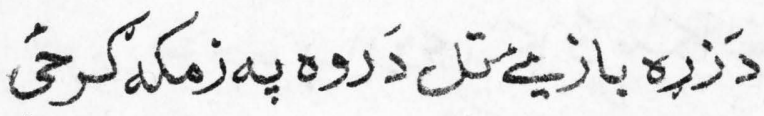

Sc

pus 


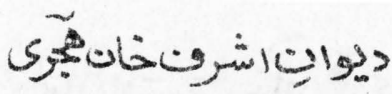

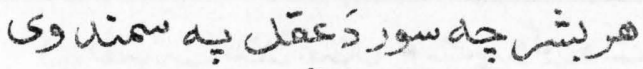
هو تو

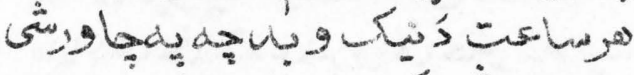

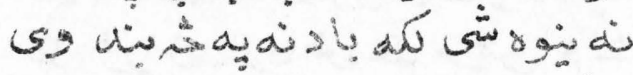

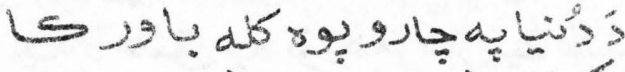
59 inس alisig a squis

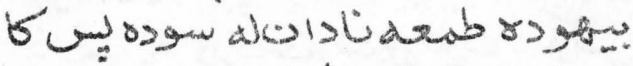

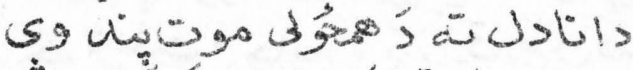

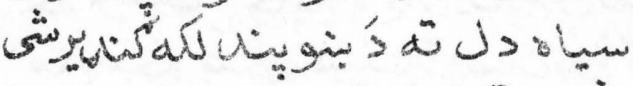

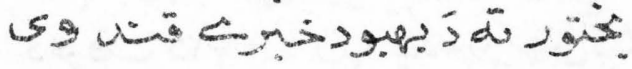

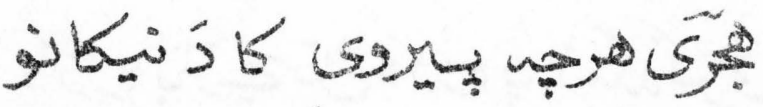

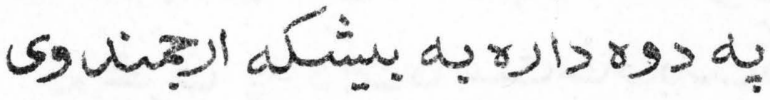


ديوانِاشرت خانجيَى

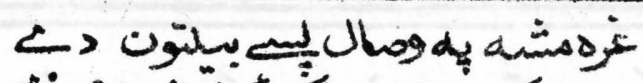

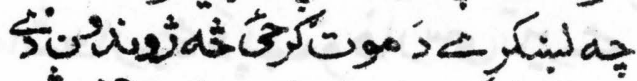

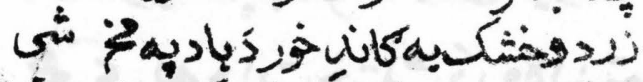

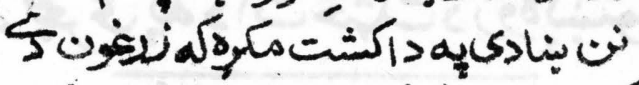

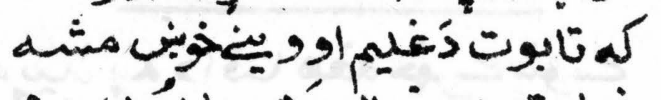

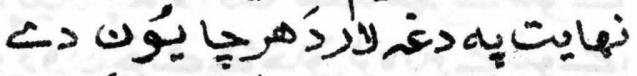

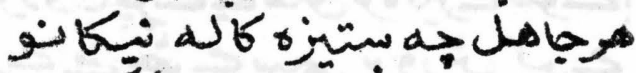

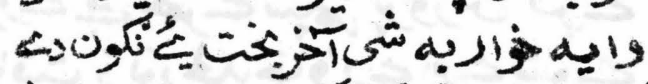

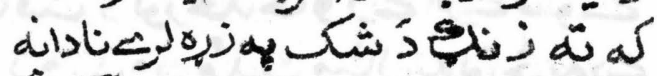

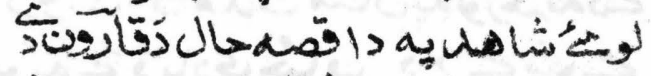

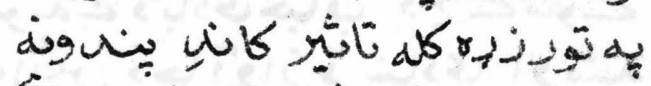

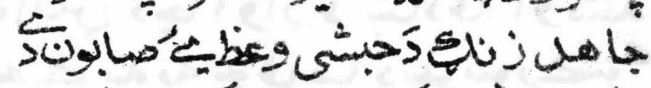
كا A

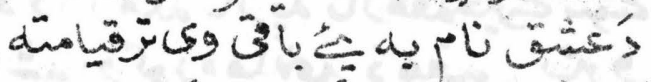

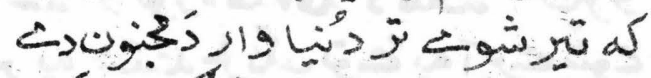

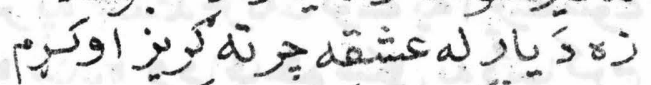

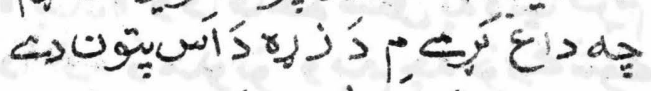
هن

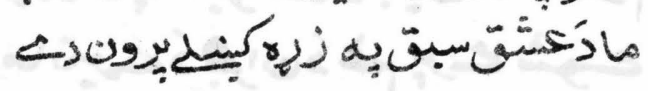

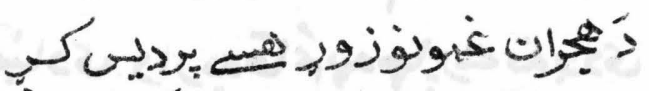

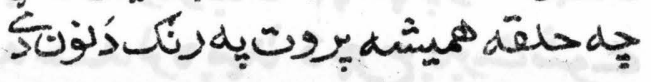




\section{ديوإِنشرتخانجُري}

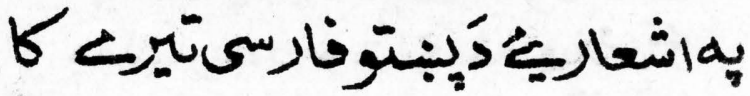

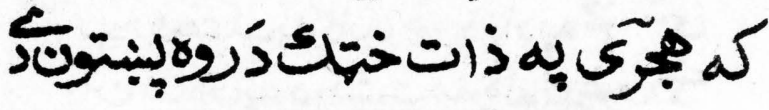
جهائنا ك

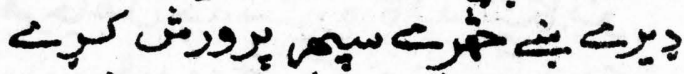

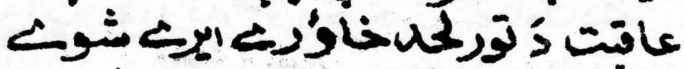

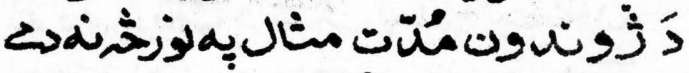

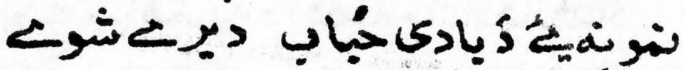

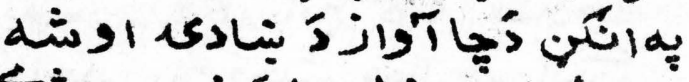

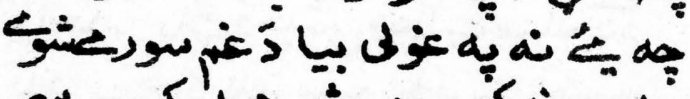

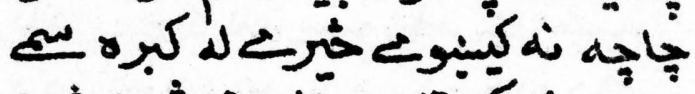

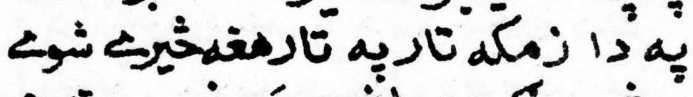

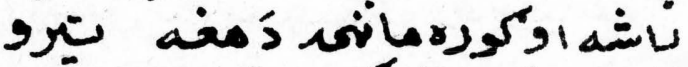

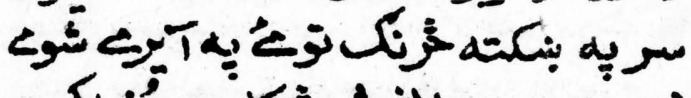

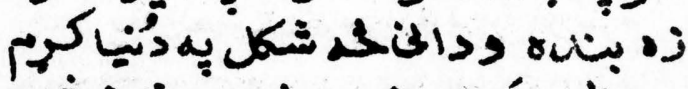

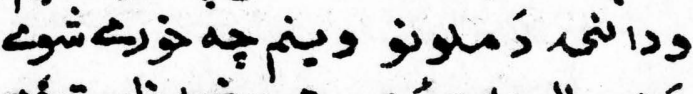

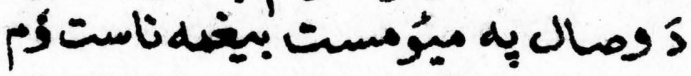

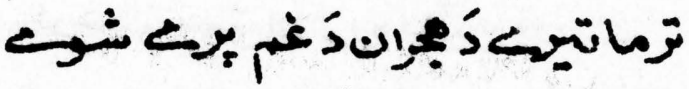

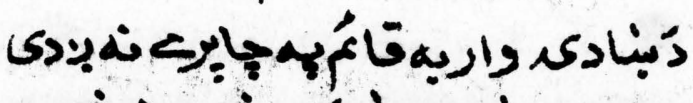

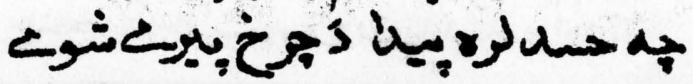




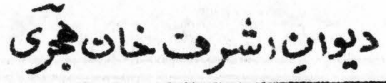

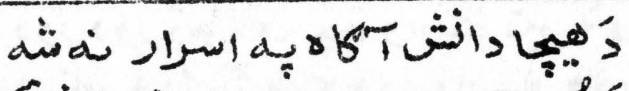

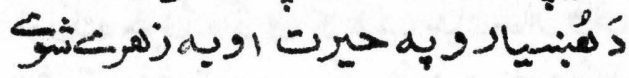

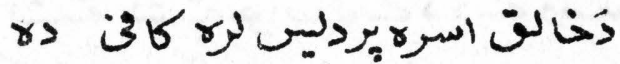

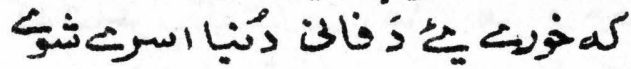

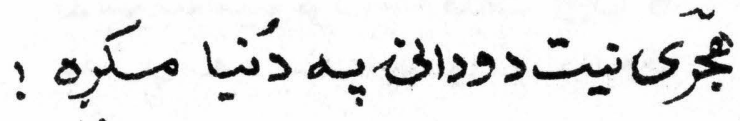

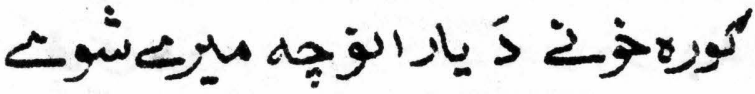

به

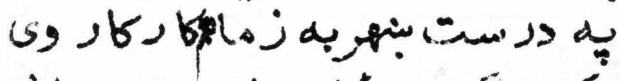

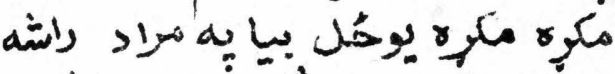

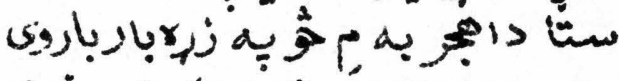

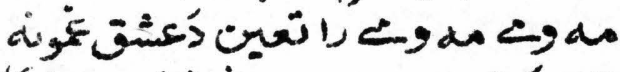

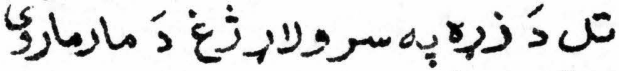

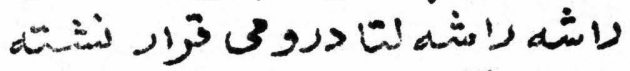

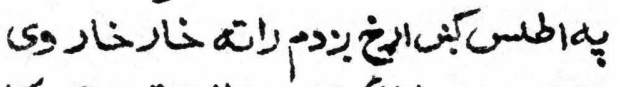
$\checkmark 2$ ح

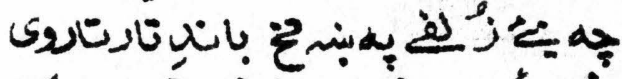

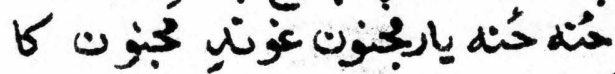

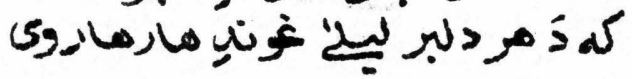

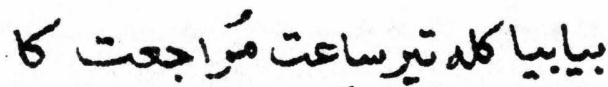

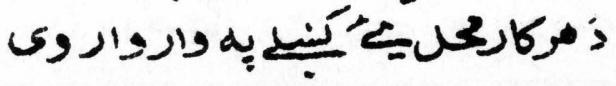




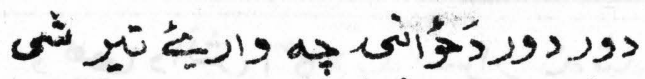

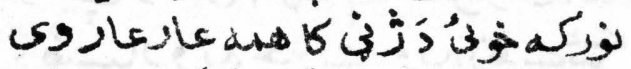

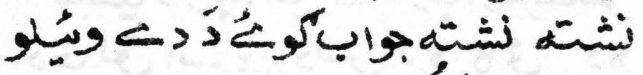

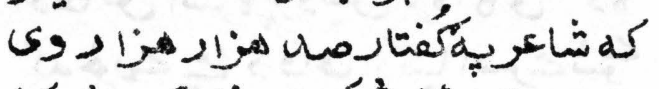

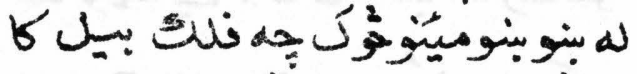

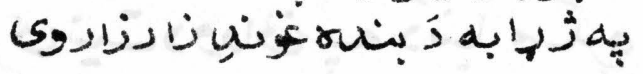

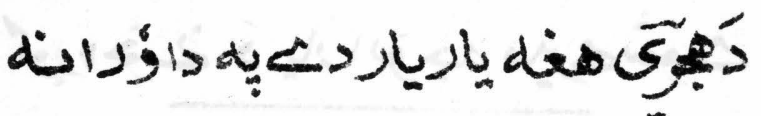

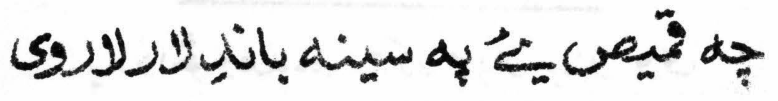

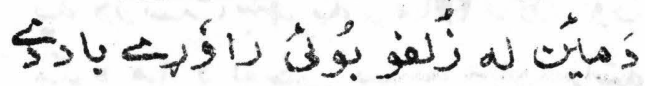
$\Leftrightarrow$ ثاثيت

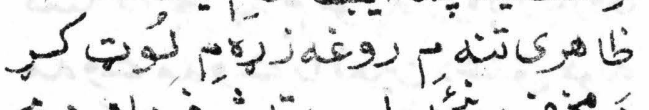

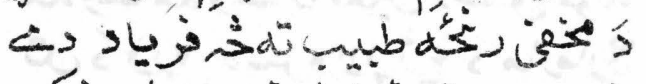

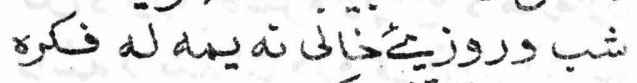

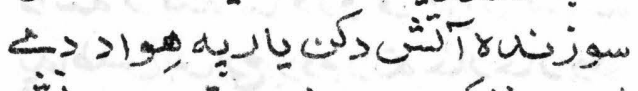

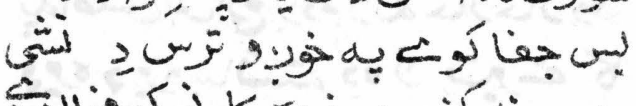

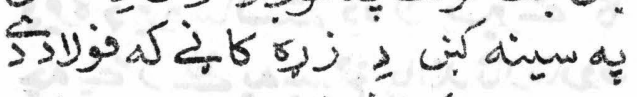

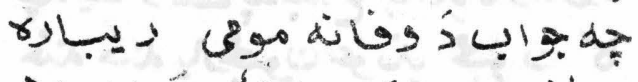

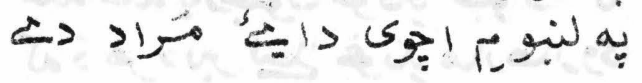

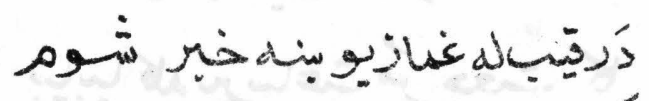

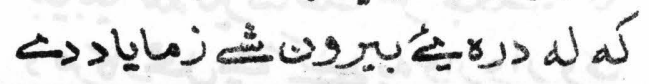




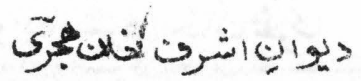

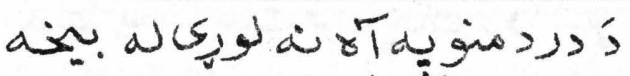

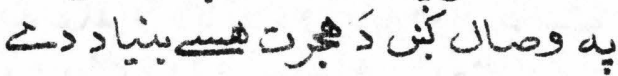
هن

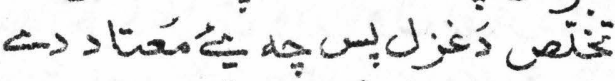
$r=$ طب

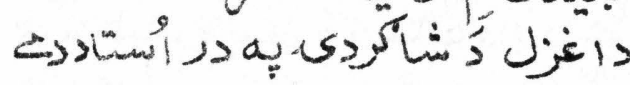

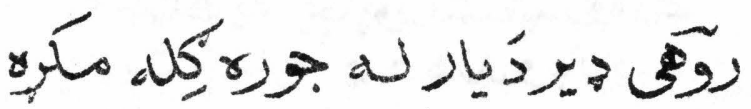

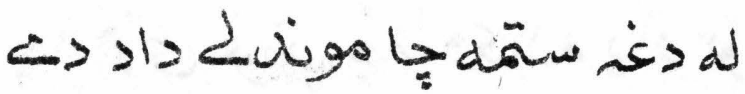

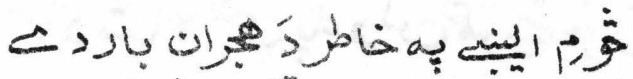

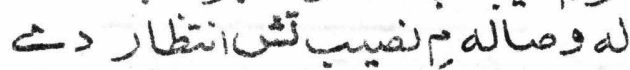

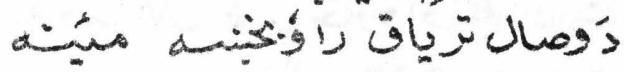

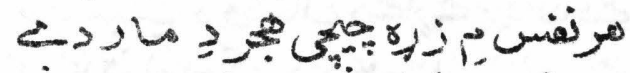

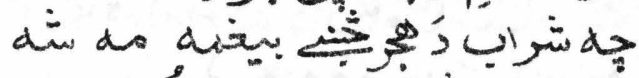

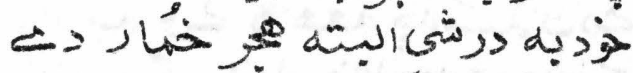

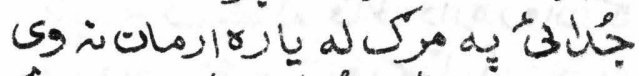

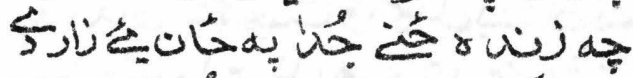

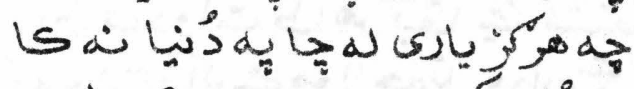
ट خو

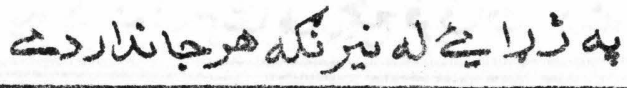


يوبِِاشروتخانهيجى

كأن

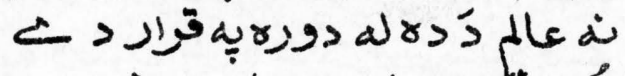

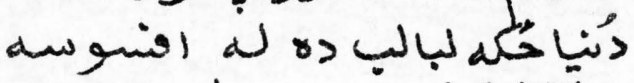

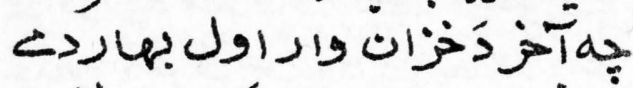

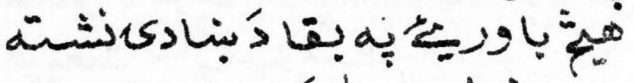

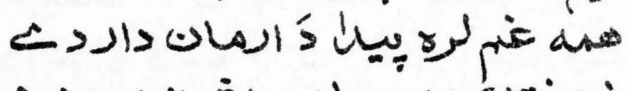

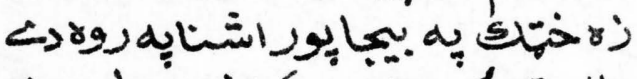

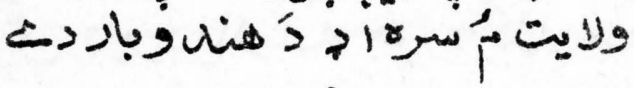

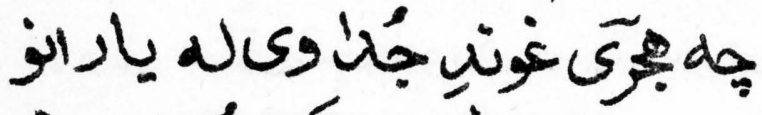

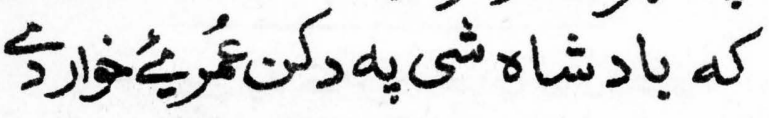

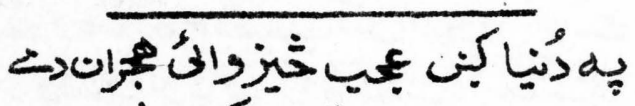

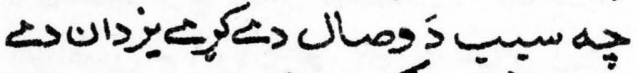

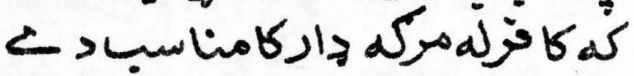
كاد بله

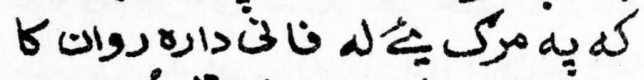

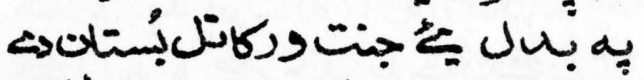

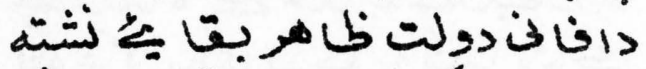

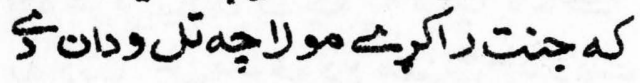

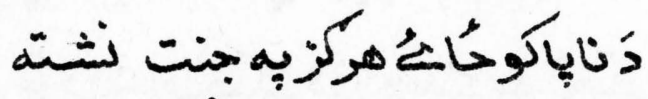


pay 
ديوانِ شرن خانجيجى

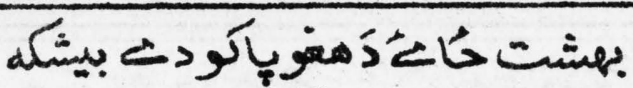

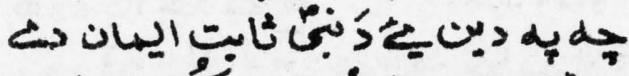

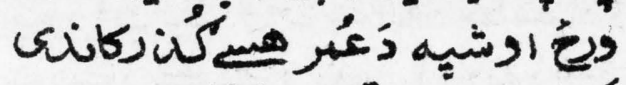

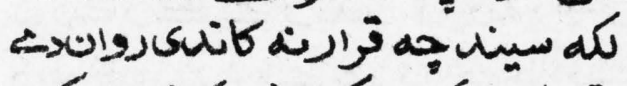

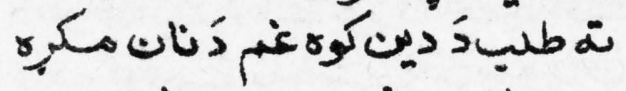
دِّ

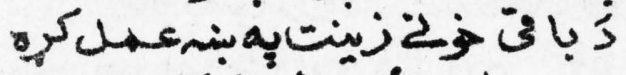

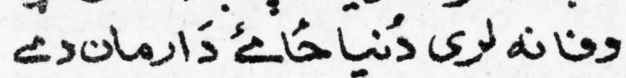

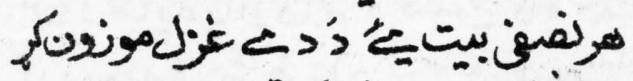

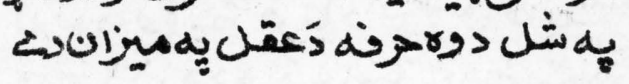

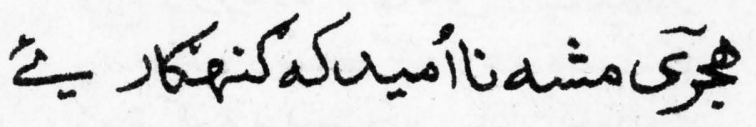

البتdبه النام

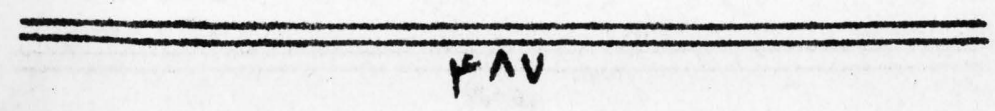




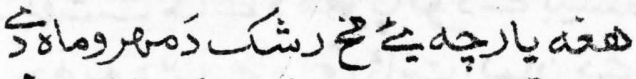

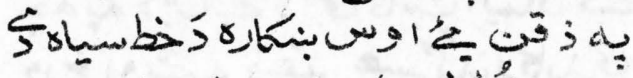

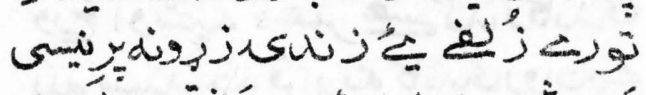

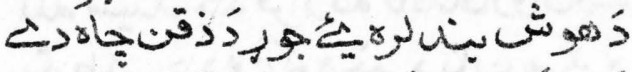

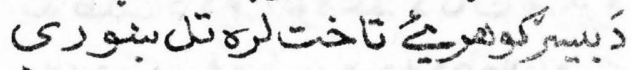
خ (s) O

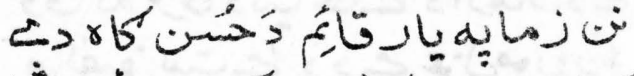

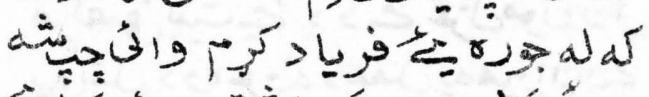

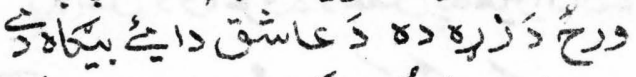

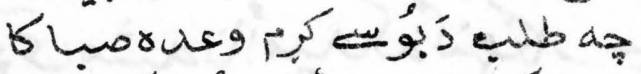

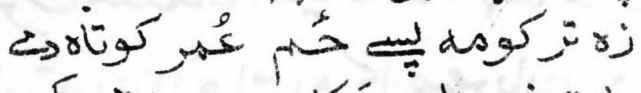

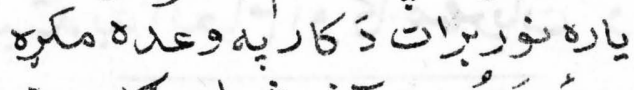
ورلا 先

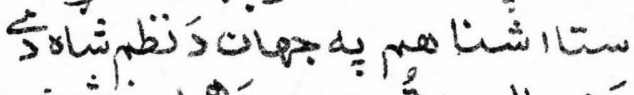

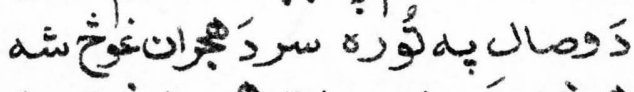

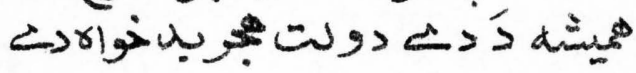

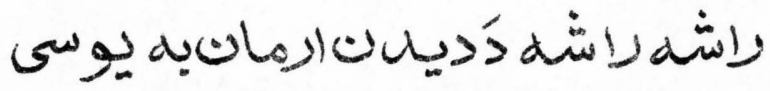

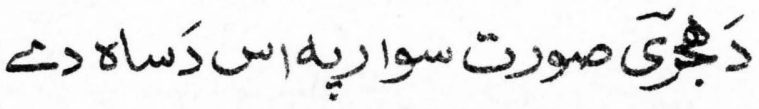




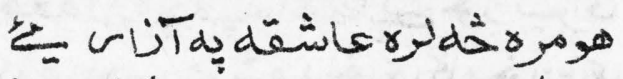
جِ

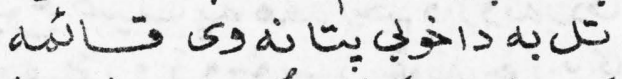

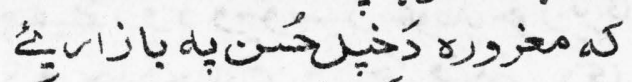

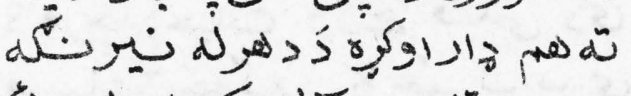
定

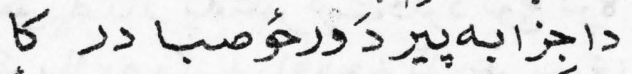

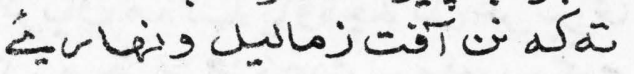

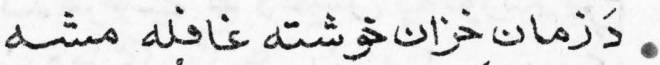

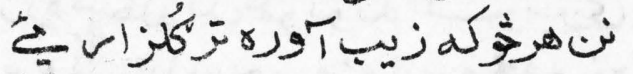

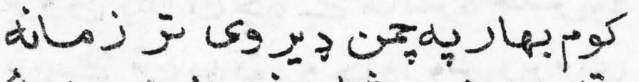

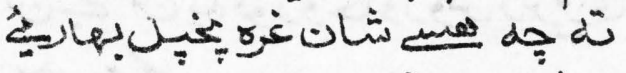

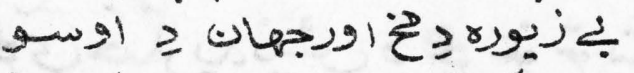

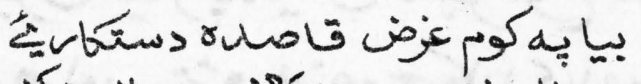

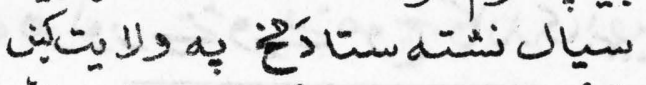

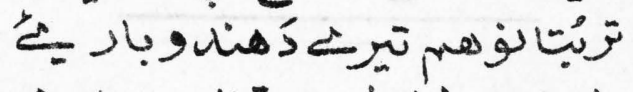

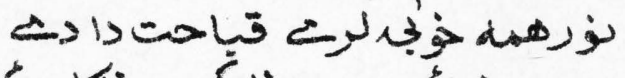

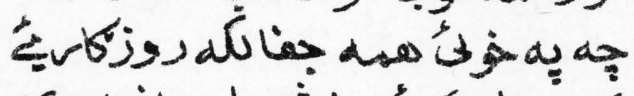

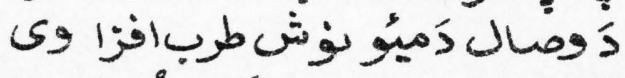

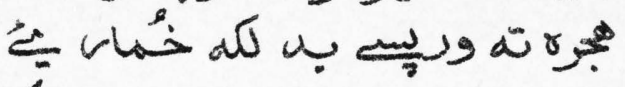

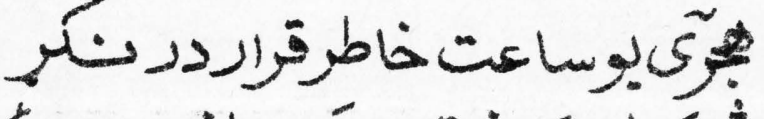

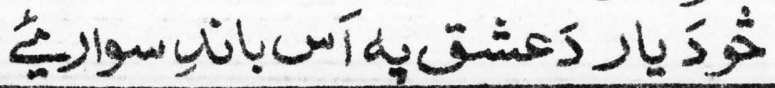


هن

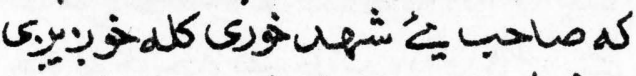

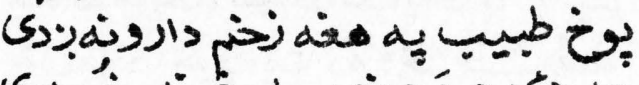

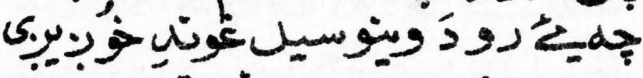

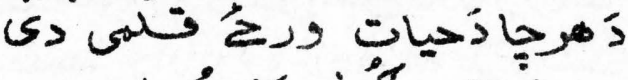

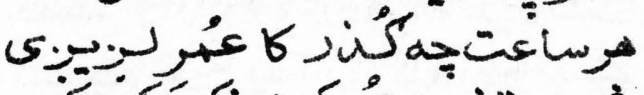

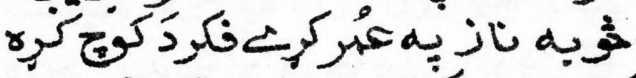

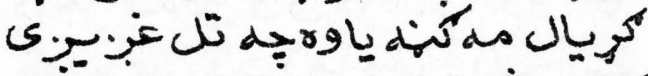

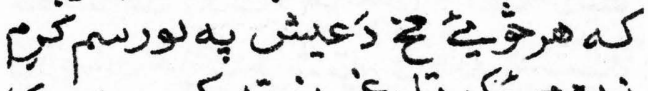

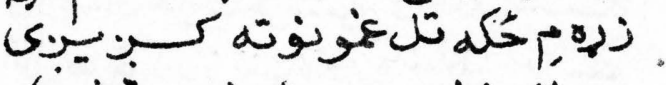

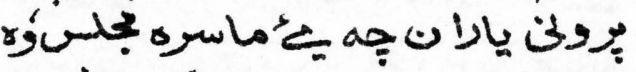

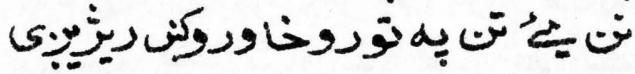

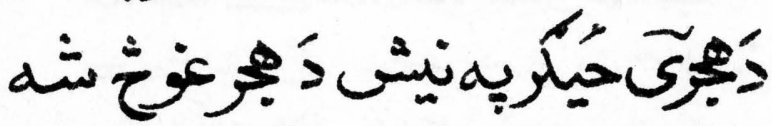

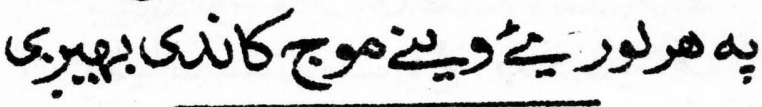


>وانِ اشرتخاتهُوى

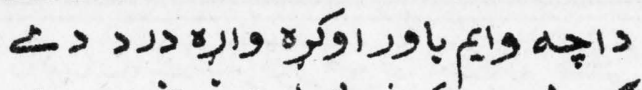

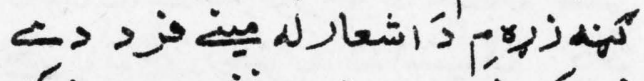

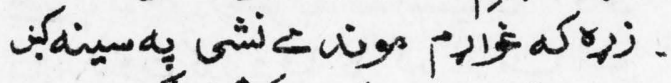

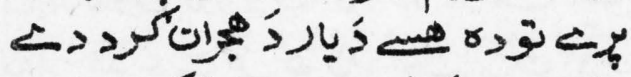

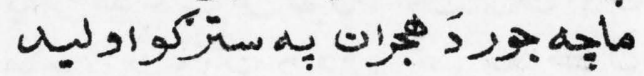

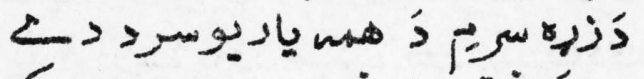

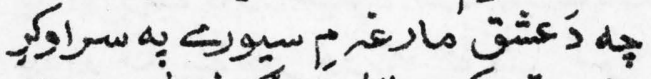

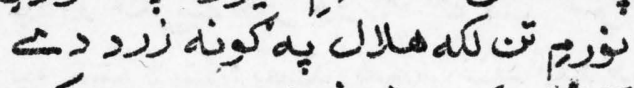

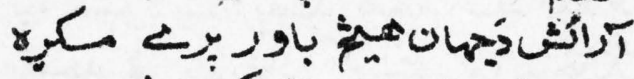
جا ك)

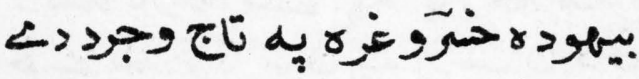

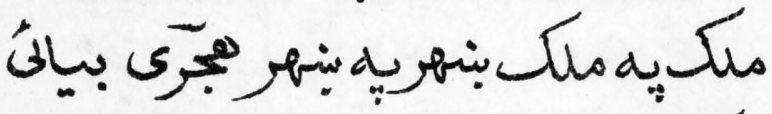
يّم

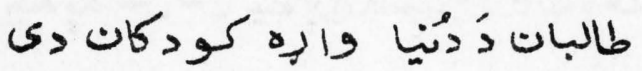

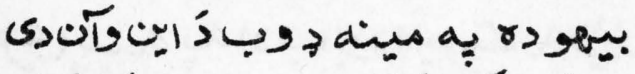

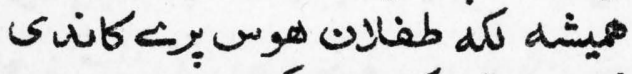

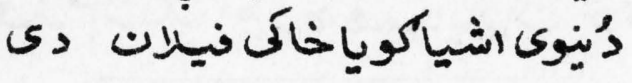

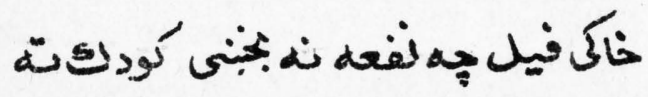
يَ

एवा 


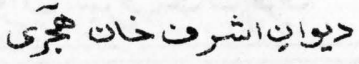

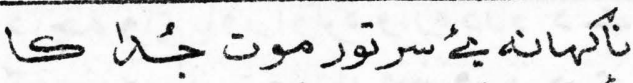

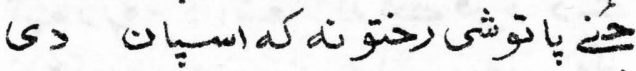

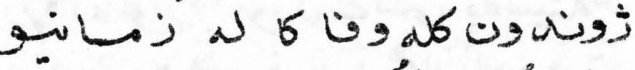

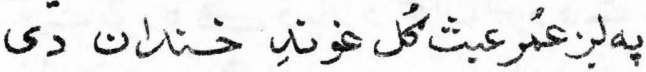

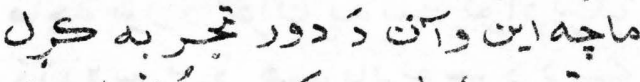

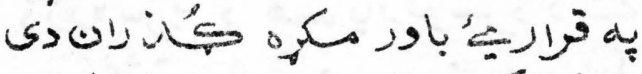

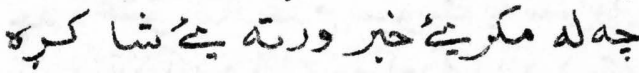

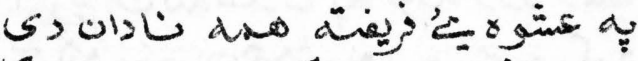

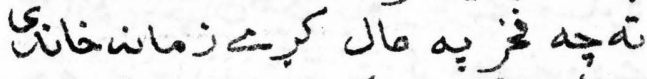

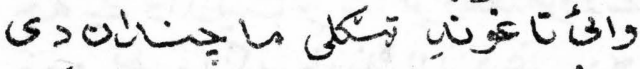

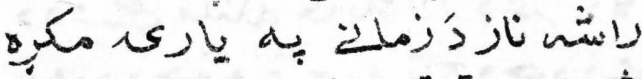

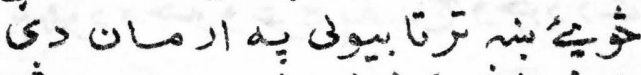

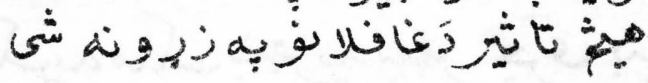

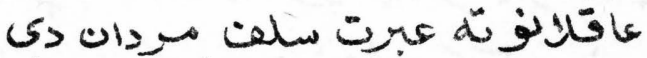

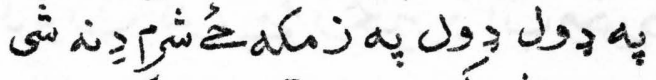
جه

若 s) - 
يوانِاشرتخخانجيَ

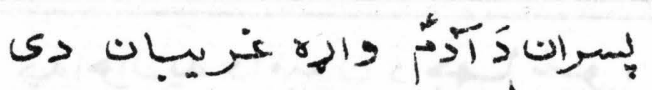

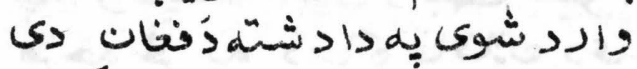

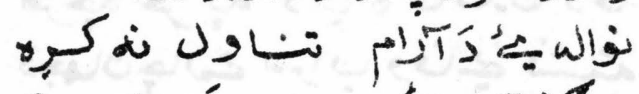

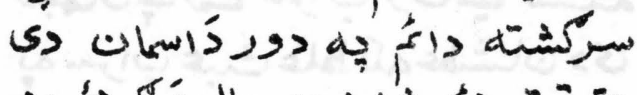

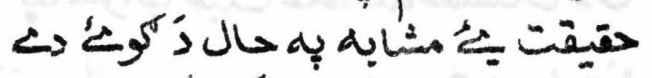
s)

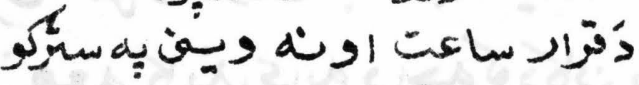

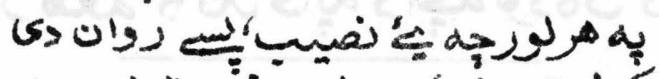

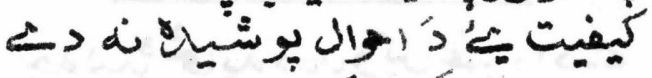

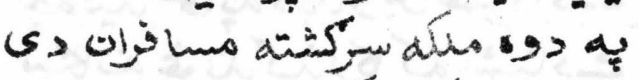

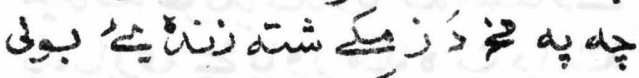
هنd تصبرتز

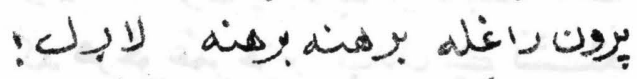

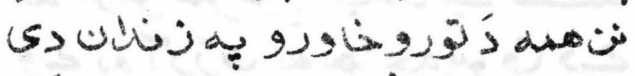

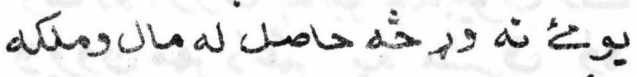

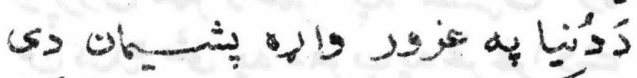
كن

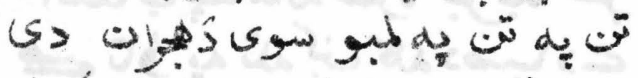

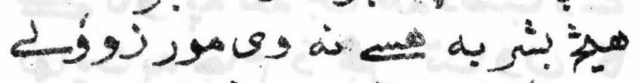
جنه

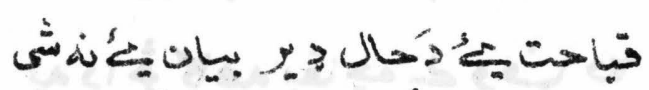

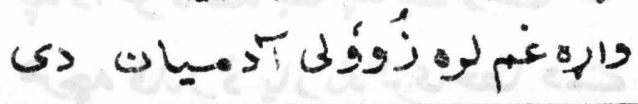




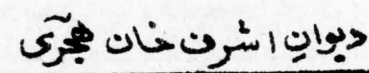

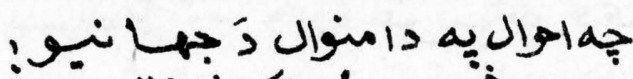

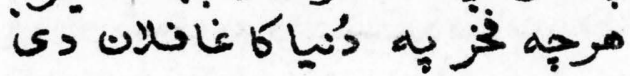

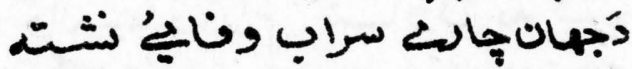

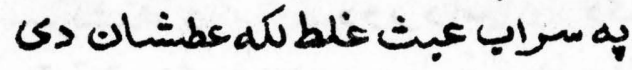

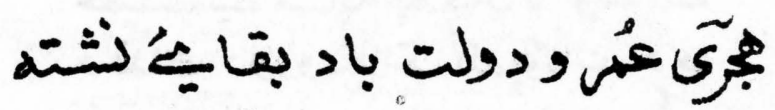

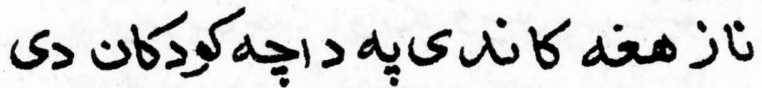

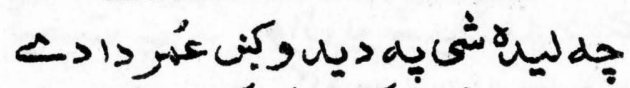

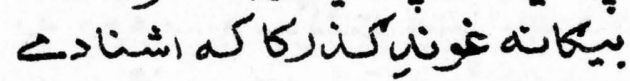

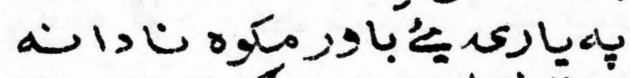

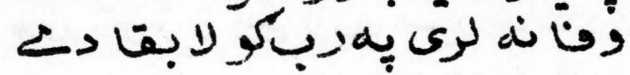

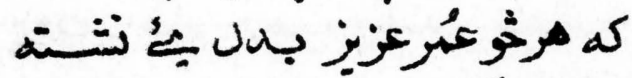

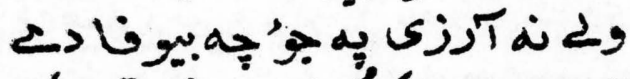

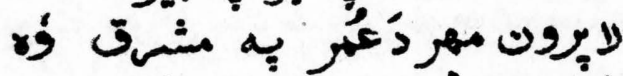

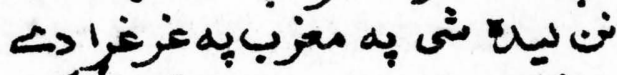

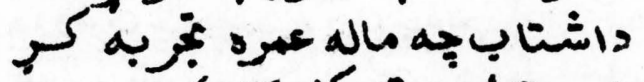

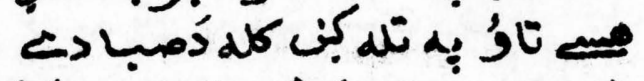

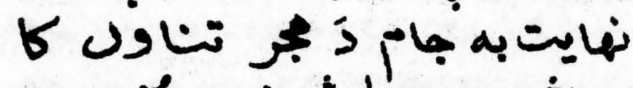

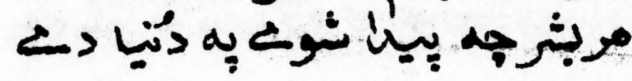

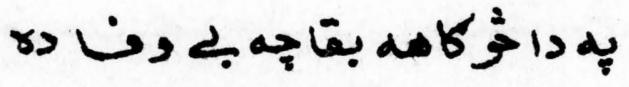

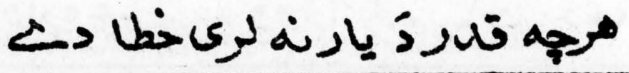




\section{ديوانِاشرتخانجئى}

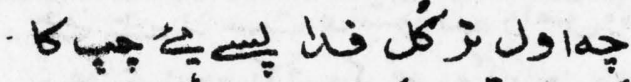

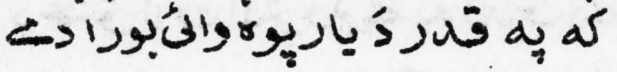

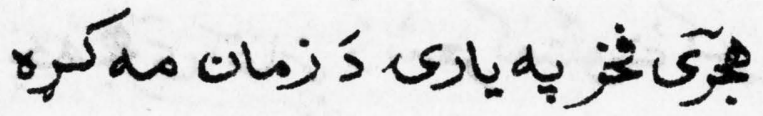

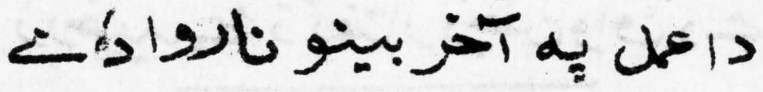

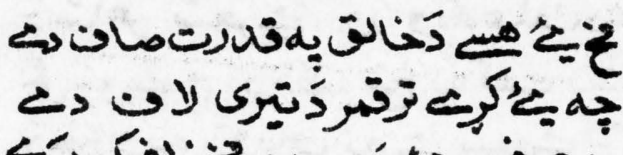
بَّهف

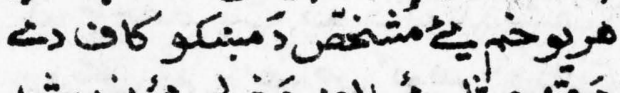

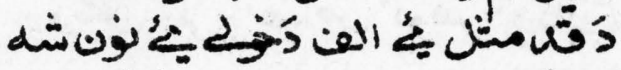
د

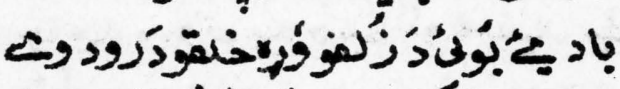

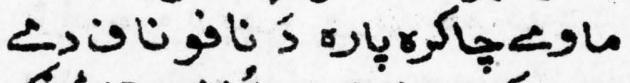

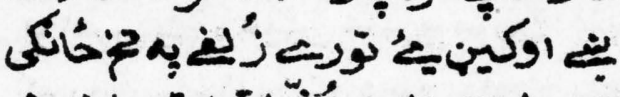

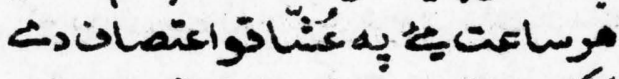

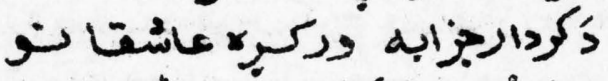

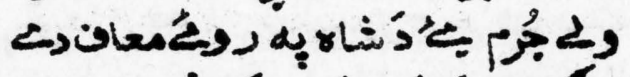

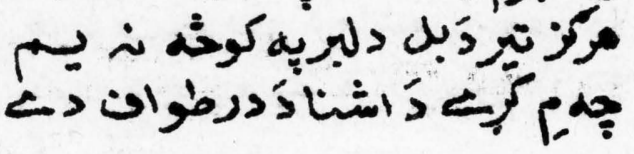

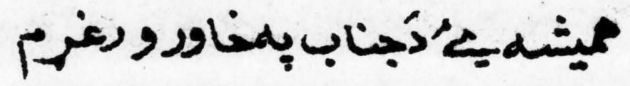

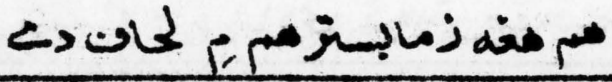


ديوانِ اشرتخالهُوَى

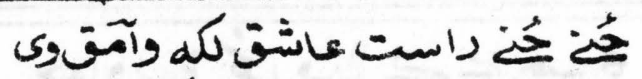

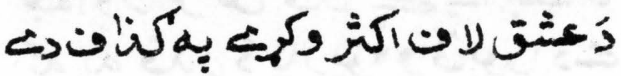

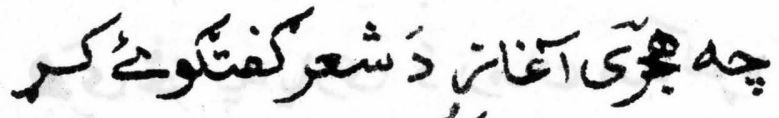

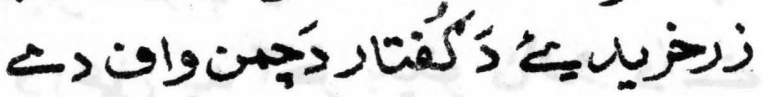

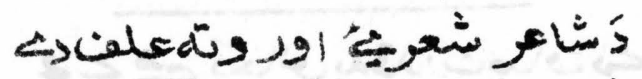

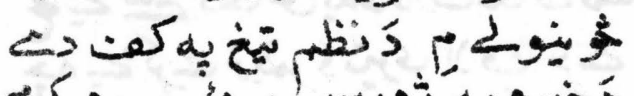

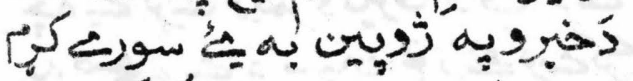
رو

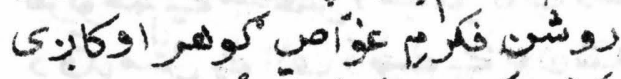

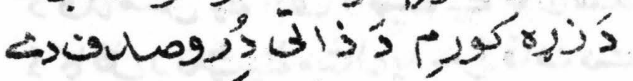

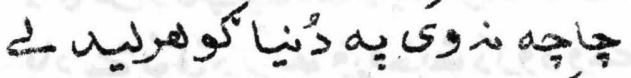

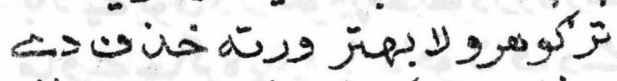

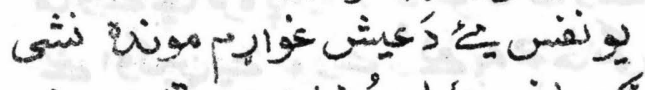

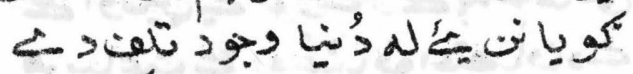

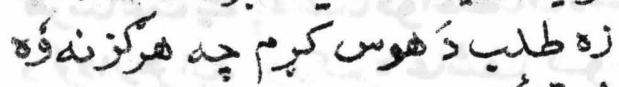

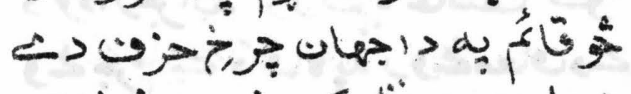

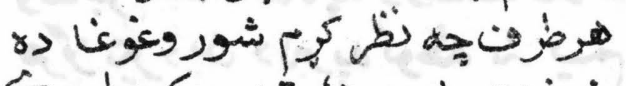

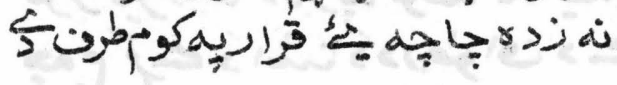

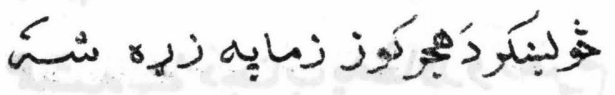

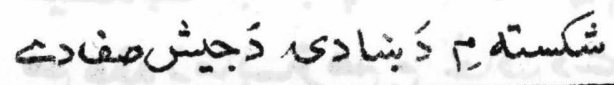




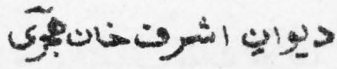

ركئه

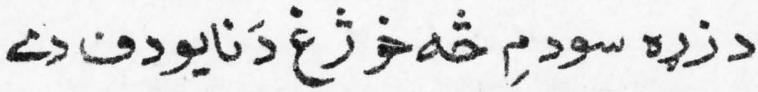

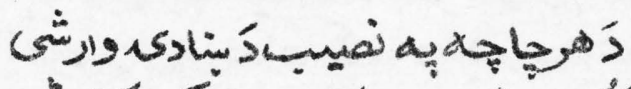

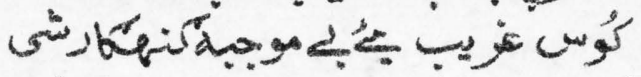

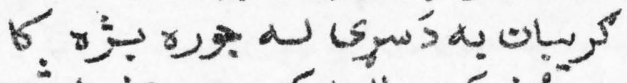

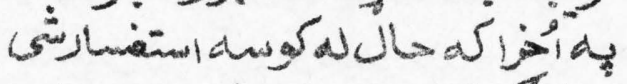

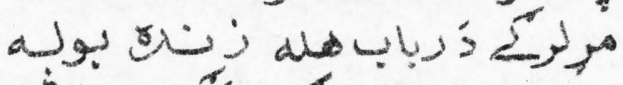
若

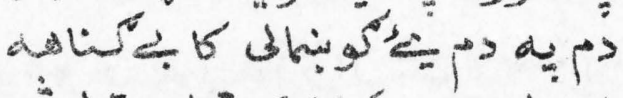

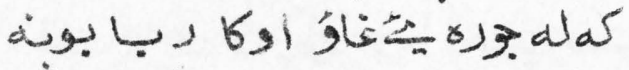

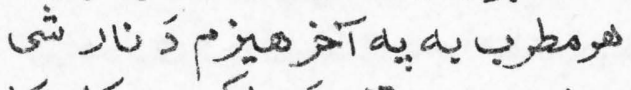

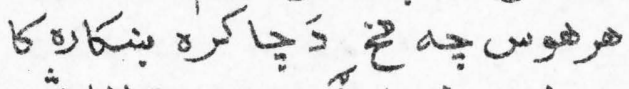

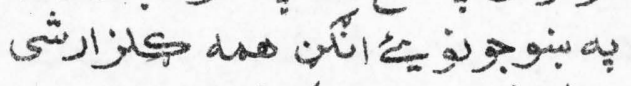

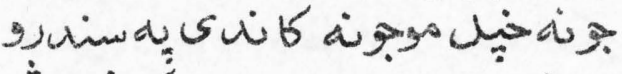

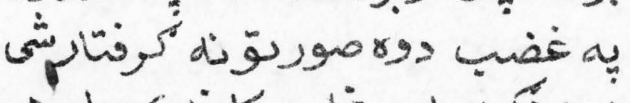

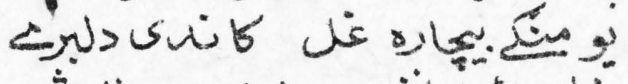

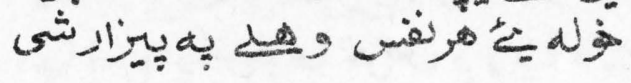

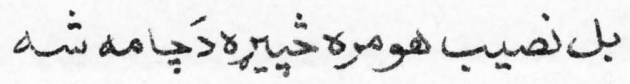

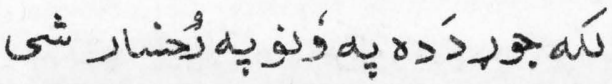




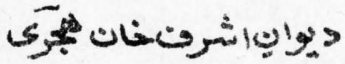

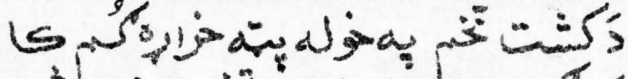

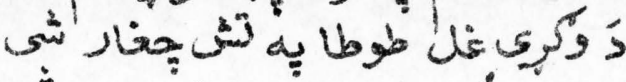

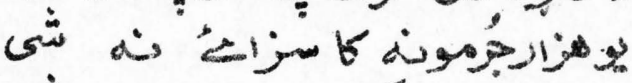

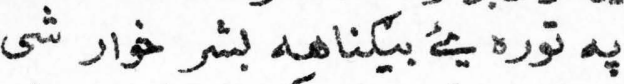

dus alrs a

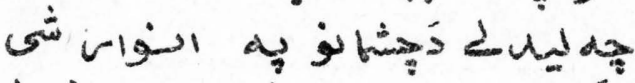

Liوئ

ها

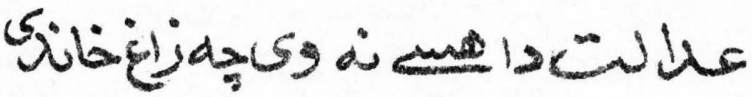

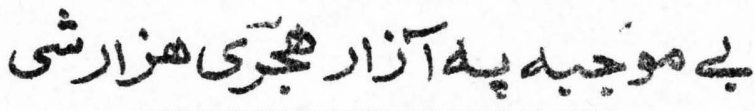

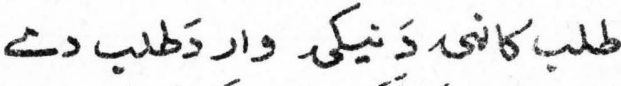

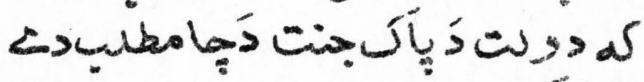

ل

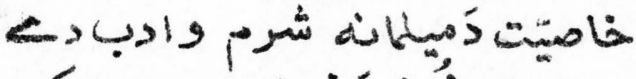

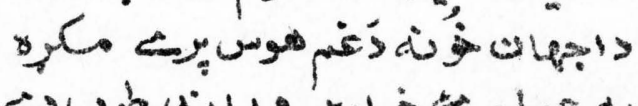

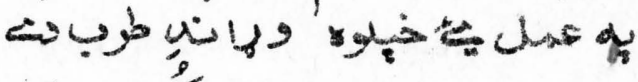

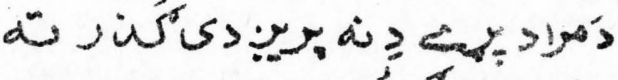

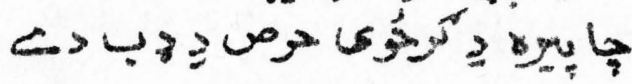

20

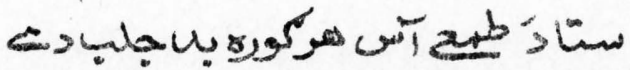




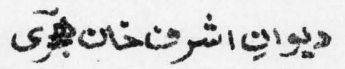

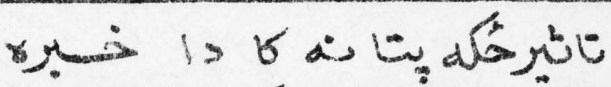

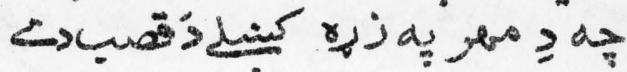

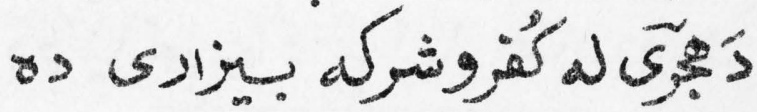

$\Leftrightarrow$ ب⿱宀

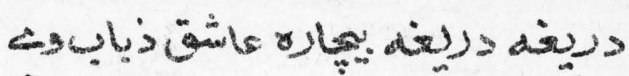

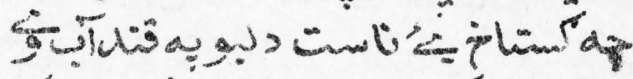
نا 20

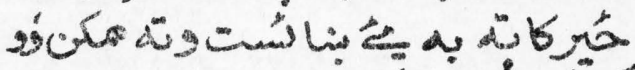

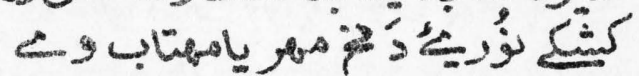

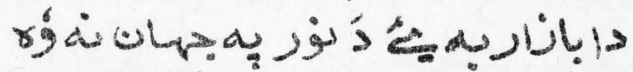
كوبان

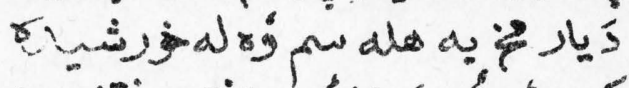

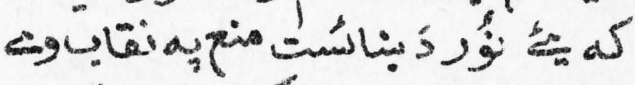
L

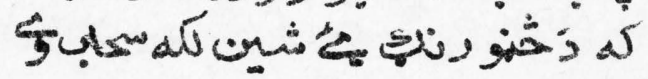

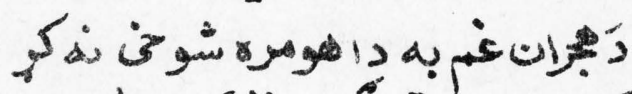

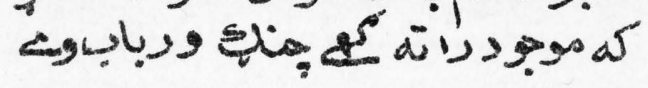

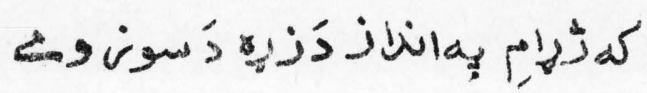

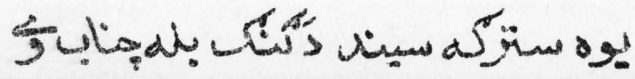

म99 
>

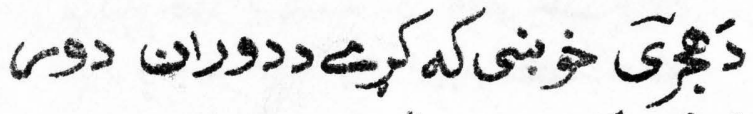

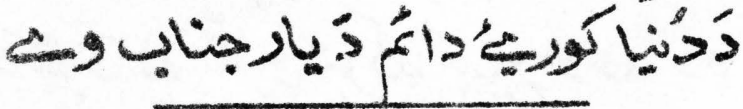

(S) LUS

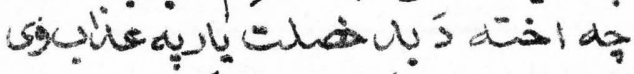

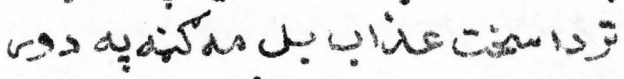

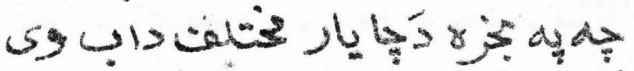

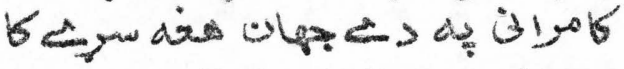

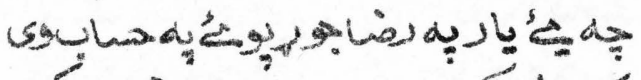
6 . 65 sly 65 is uxis iol y a dists

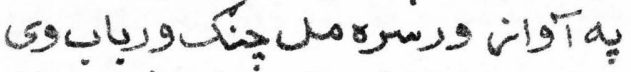

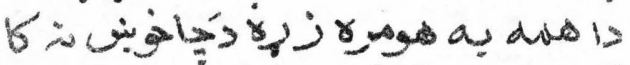

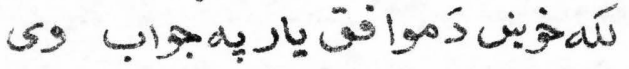

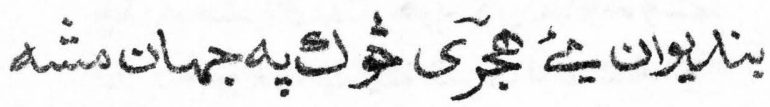

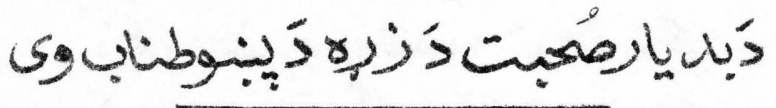




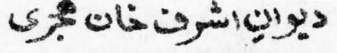

ज) ن - ن

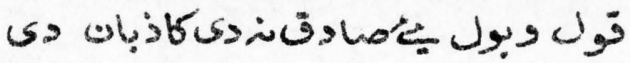

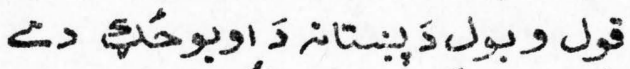

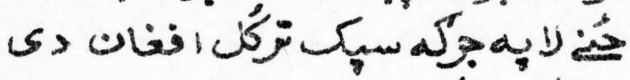

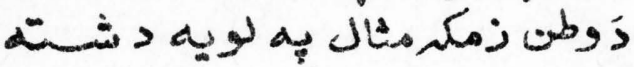

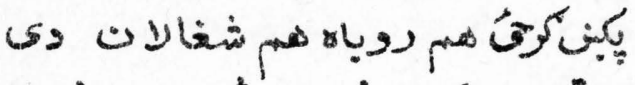

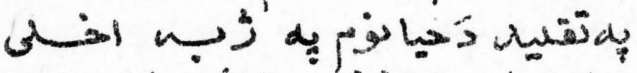

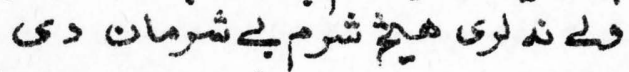

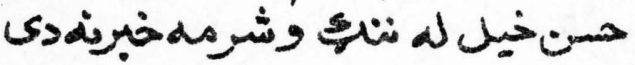

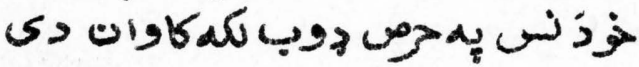

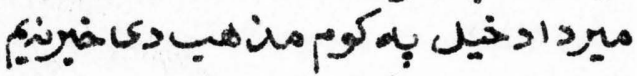

(5) نे

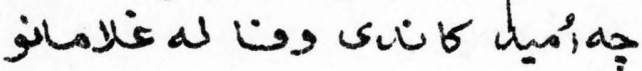

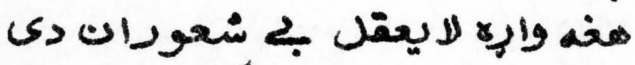

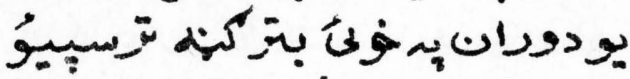

S) بل

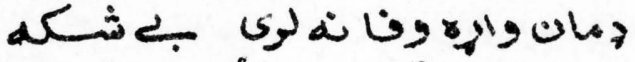

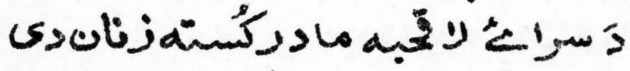

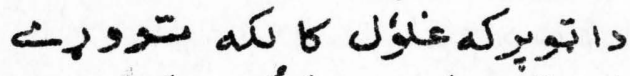

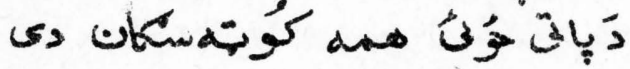

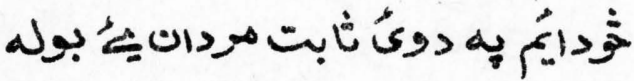

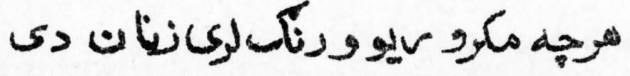

$\Delta \cdot T$ 


\section{ديوإِاشرنحان}

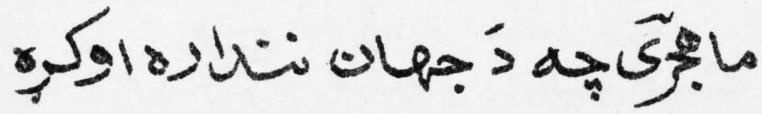

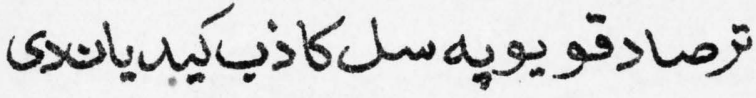

$\Leftrightarrow$ مشتمانف

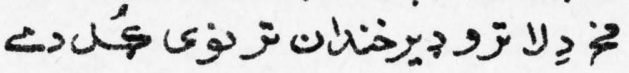

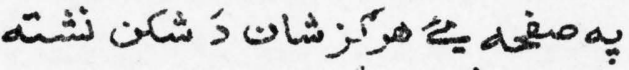

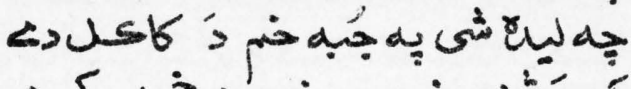
كن

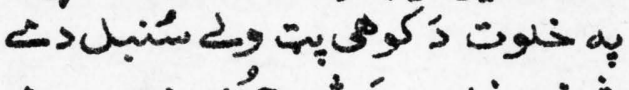

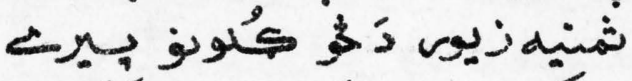

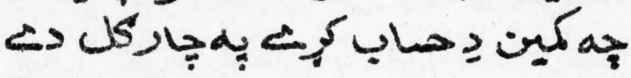

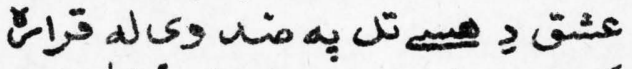

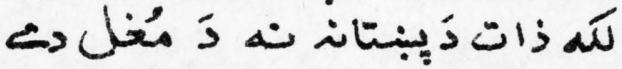

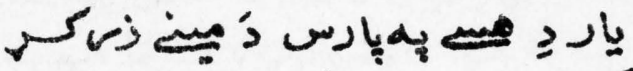

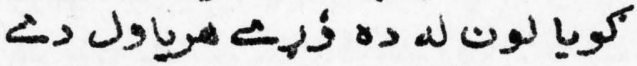

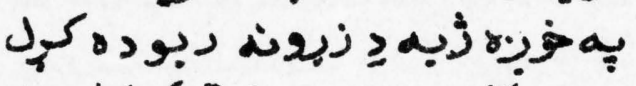
به

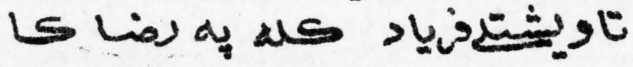

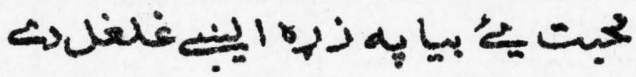

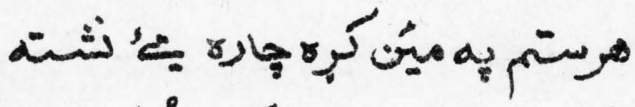

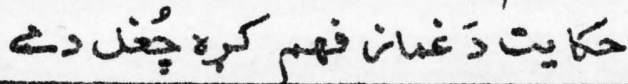

$$
\text { s.r }
$$




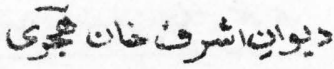

C

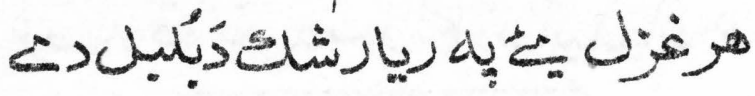

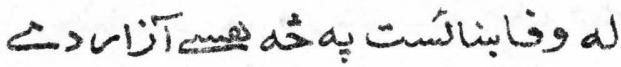
حهن

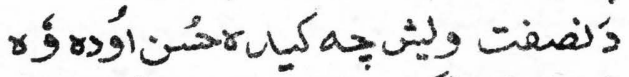

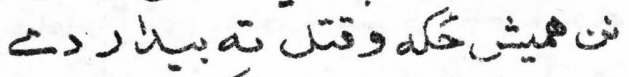

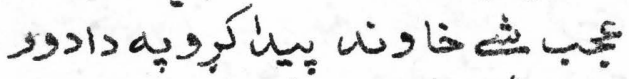

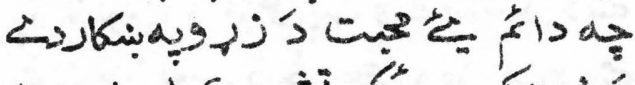

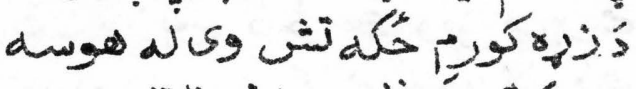

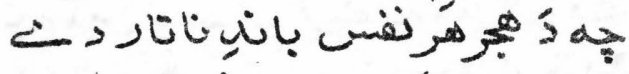

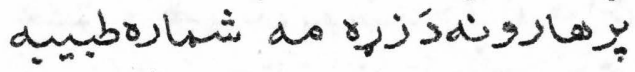

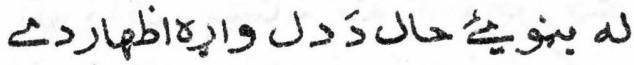

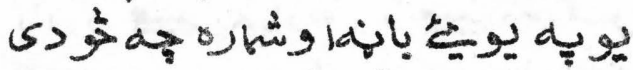

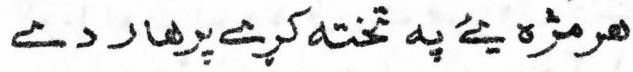
3,

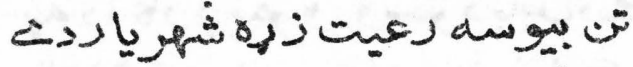

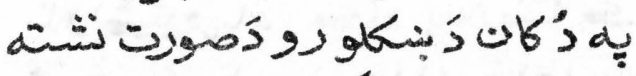
¿رirsplacs

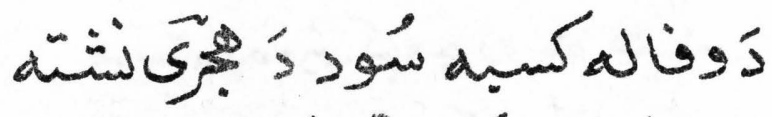

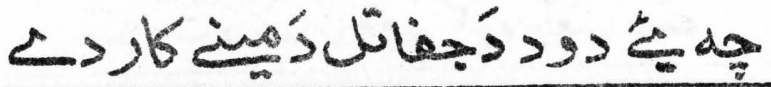




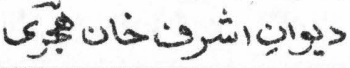

تز

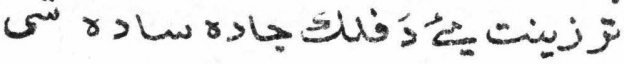

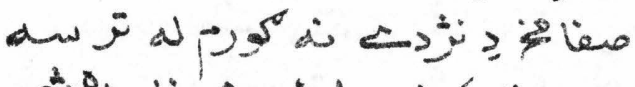
.

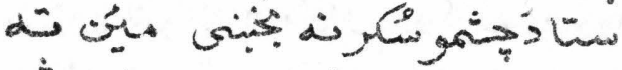

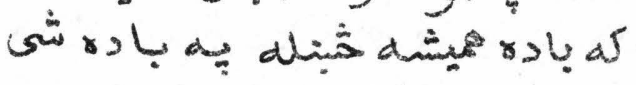

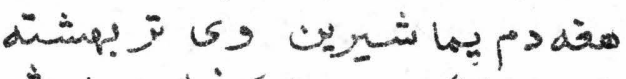

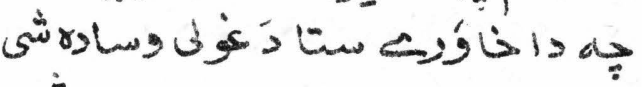

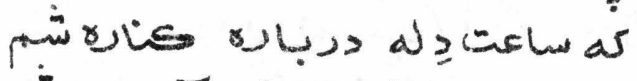

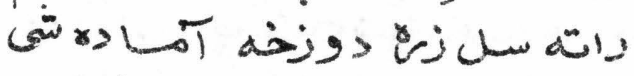

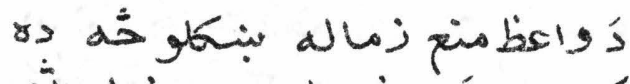

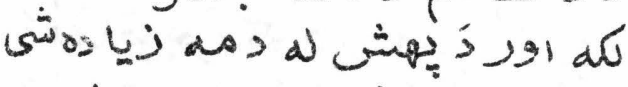

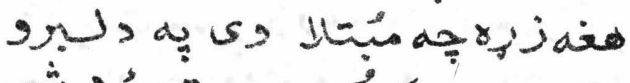

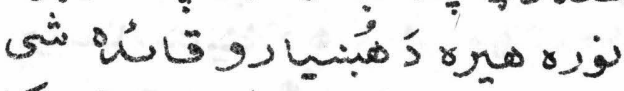

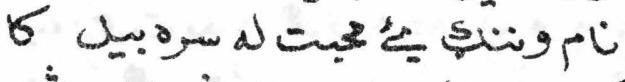

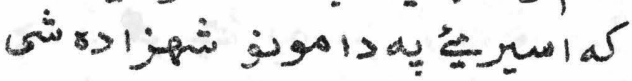
ل

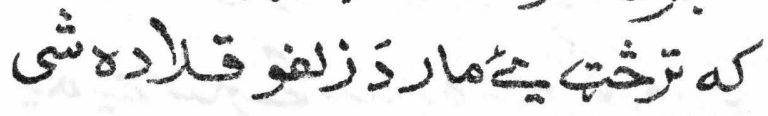




\section{ديواتِ اشرت شاث جبريكا}

(s) ind de

जo

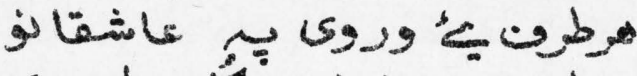

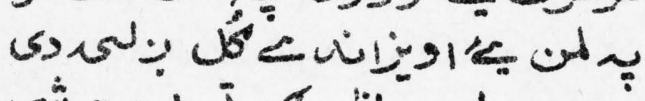

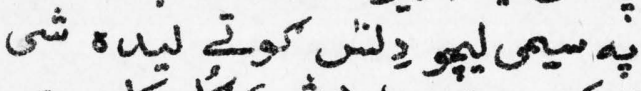
ज)

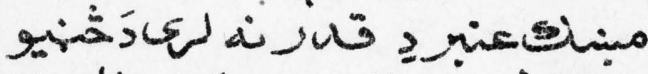
Sod

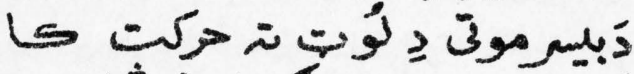
v)

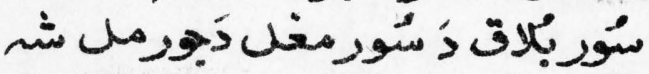

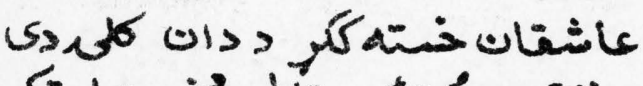

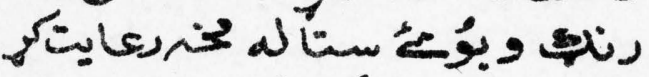

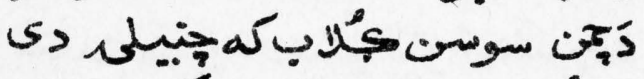

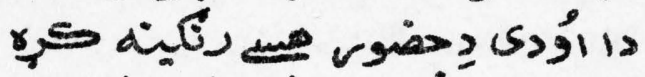

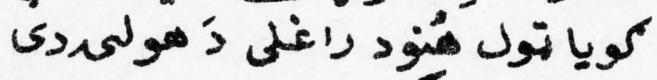

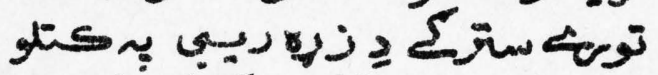

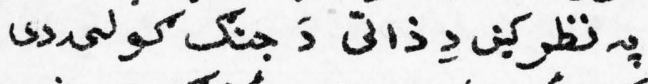

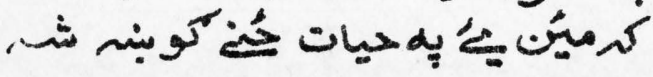
(5)

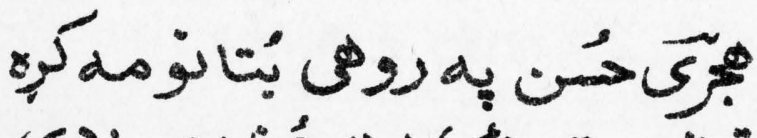
जifnow dis 


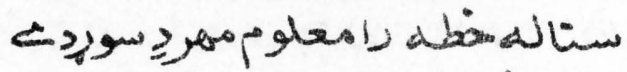

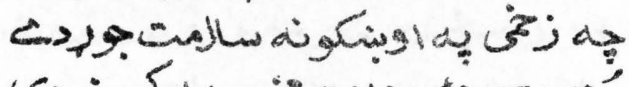

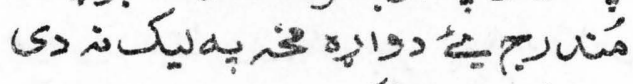
بر

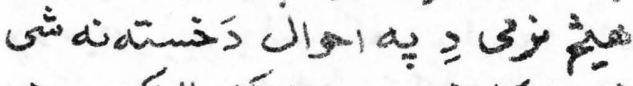
ع نه

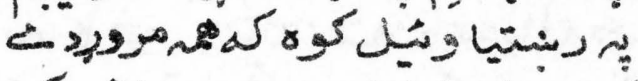

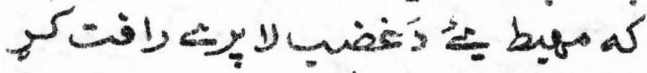

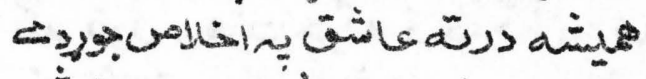

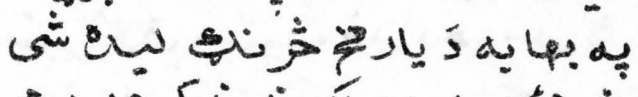
ع مارئه

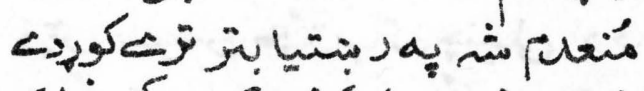
كا

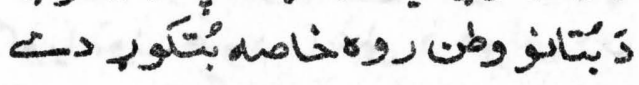

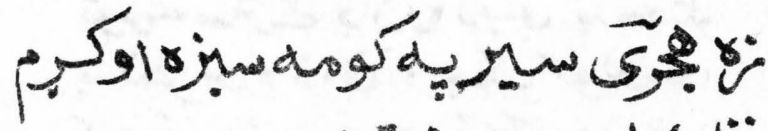
$\Leftrightarrow$ is 


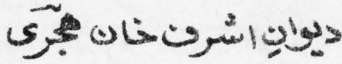

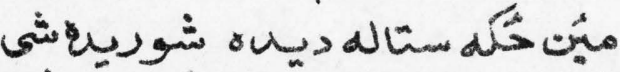

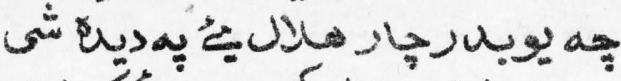

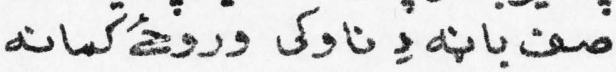

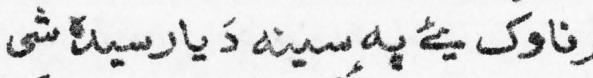

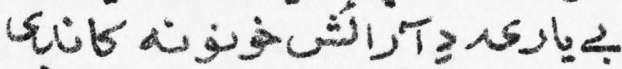
دان

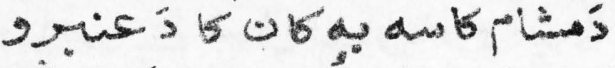

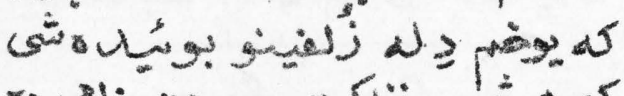
r

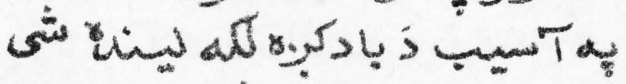

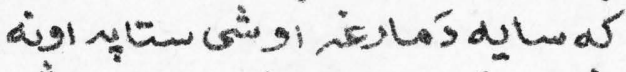
ئم

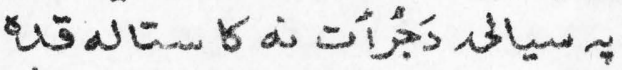

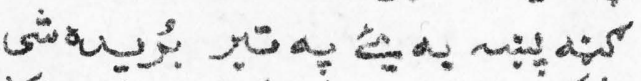

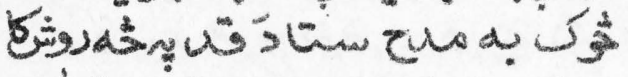

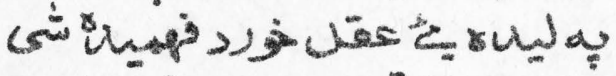

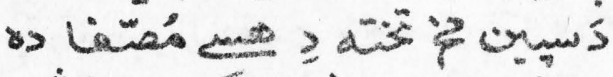

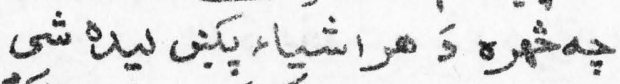
خ خن

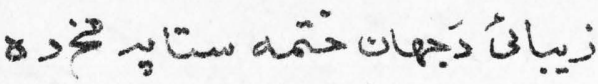

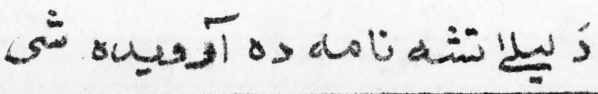




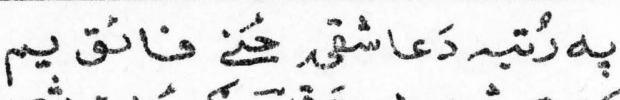

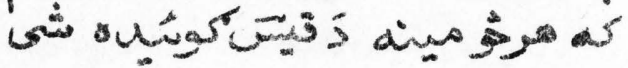

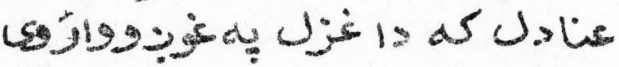

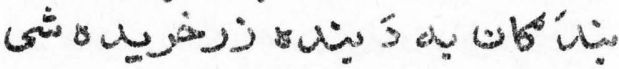

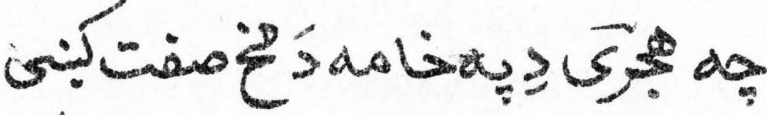

(5)

(4)

ش

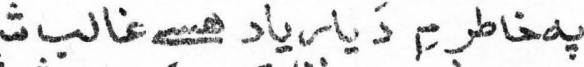

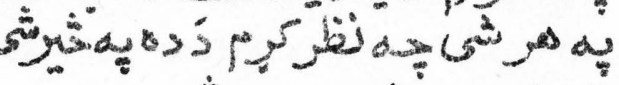

39

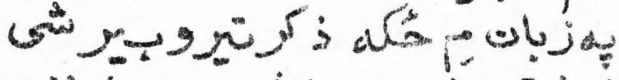

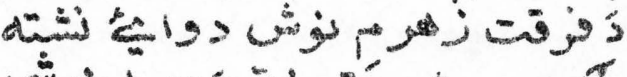

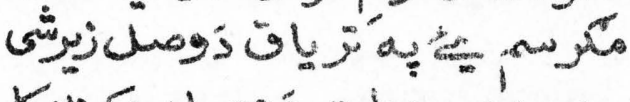

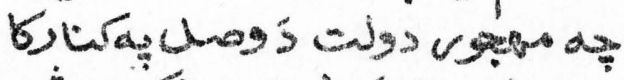

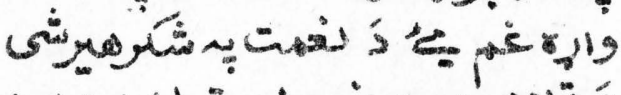

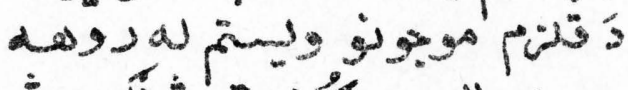

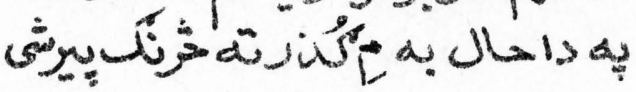

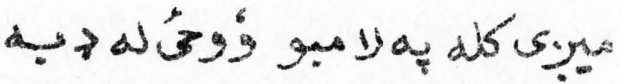

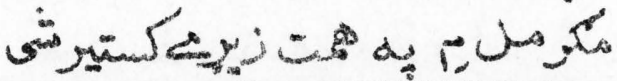




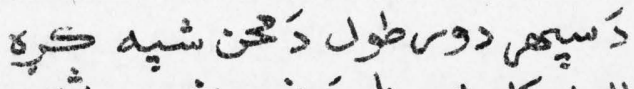

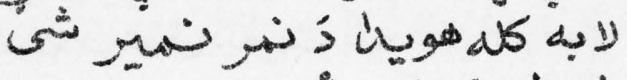
- get ab anás Slis

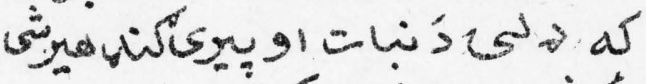

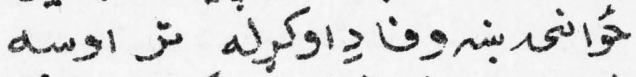
ن I

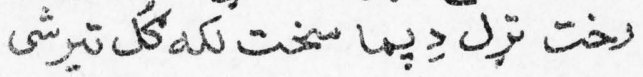

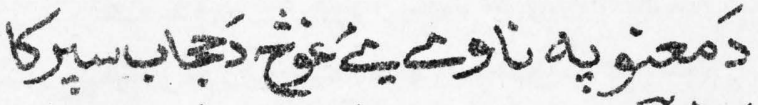

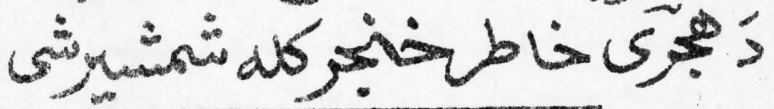

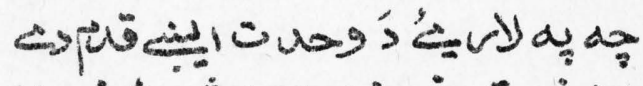

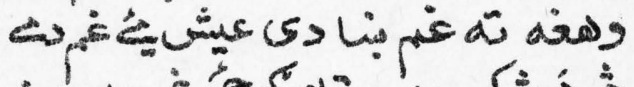

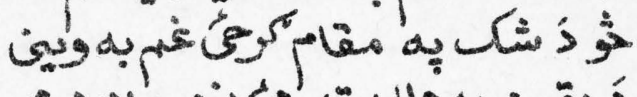

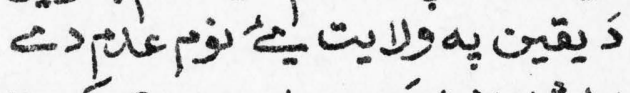

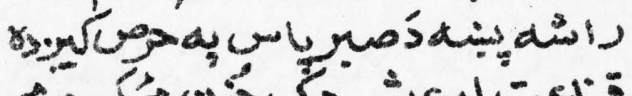

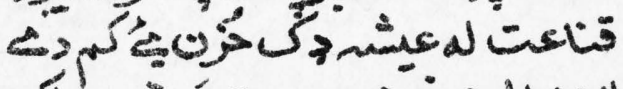

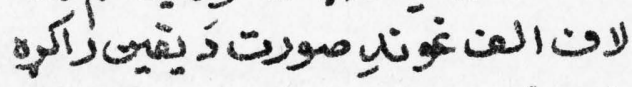

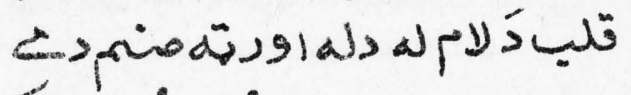

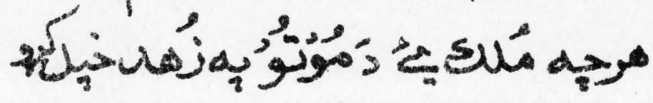

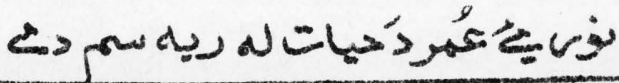




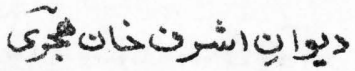

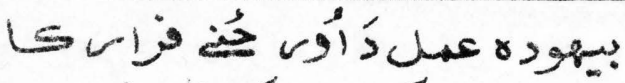

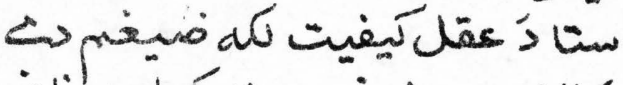
ك' لالهوت مالرغن

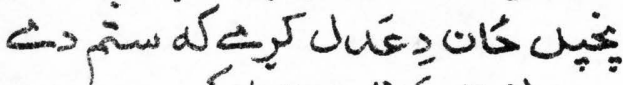

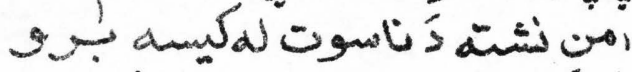

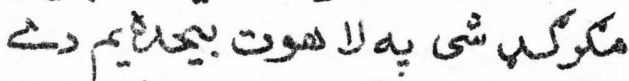

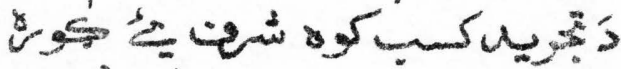

$\Leftrightarrow$ म

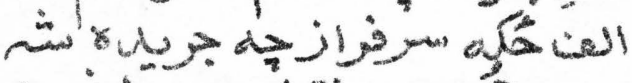
\& م

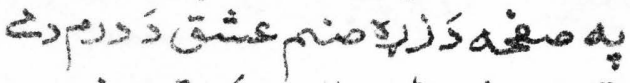
ami

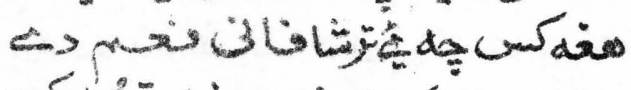
جله

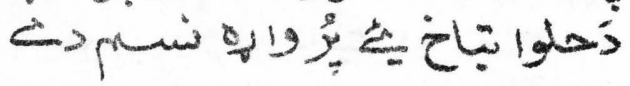

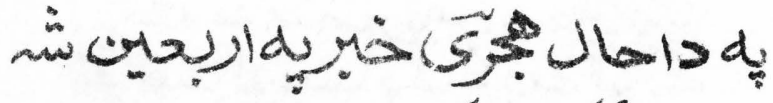

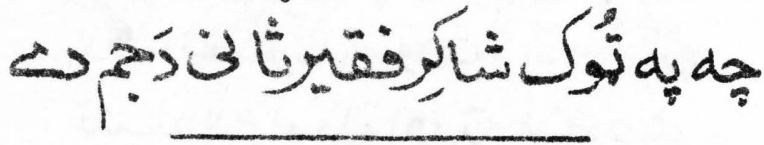

$\Delta I T$ 
يوانِ شروت سنانثئي

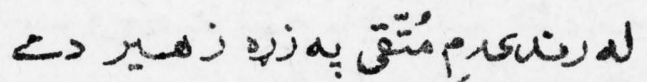

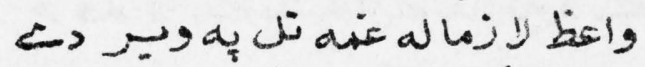

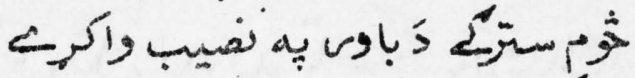

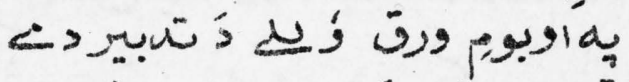

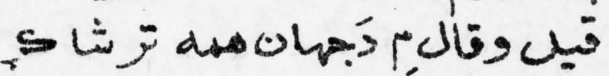

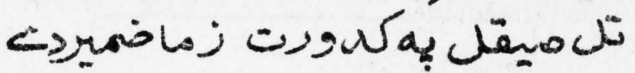

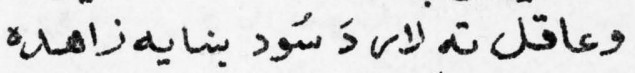

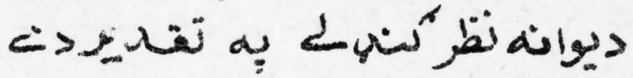

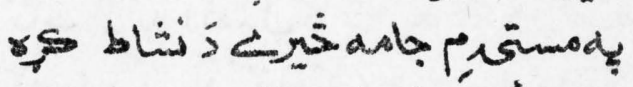

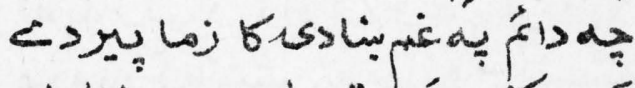

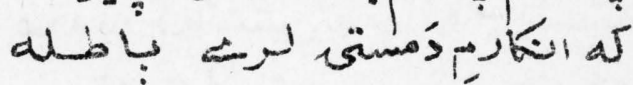

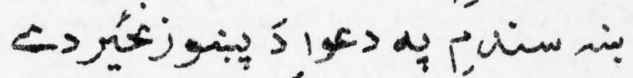

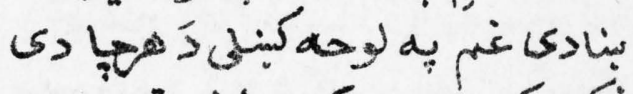

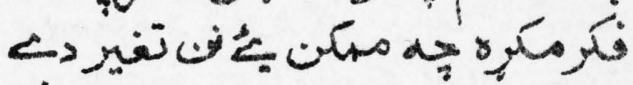

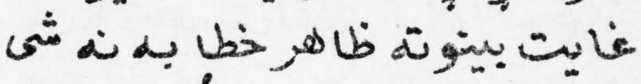

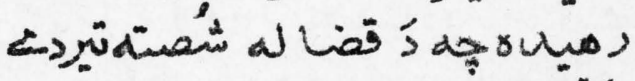

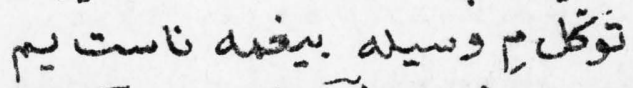

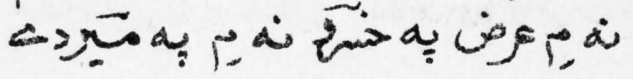

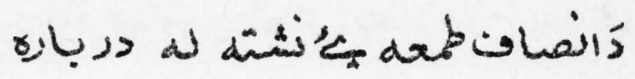

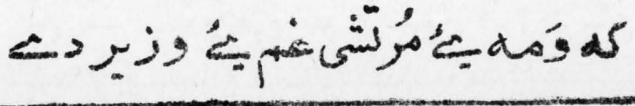


يوإبِاشرتشاسبئى

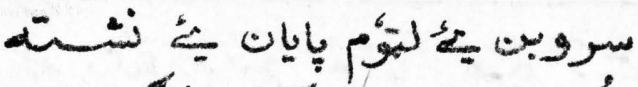
طرونه

S.

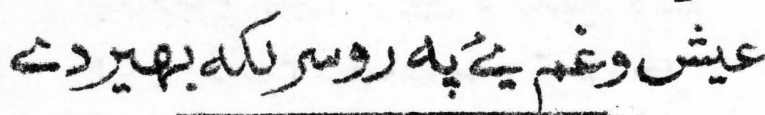

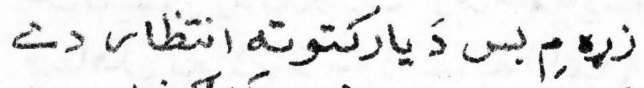

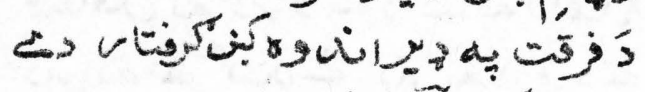

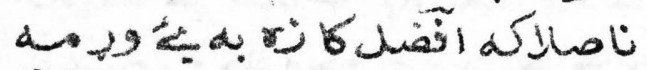

Sulv

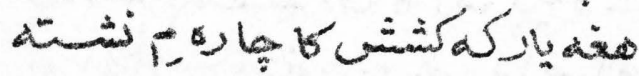

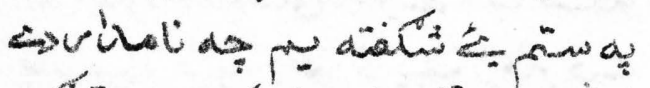

ز

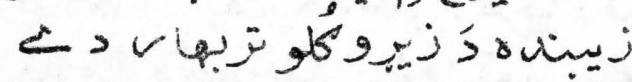

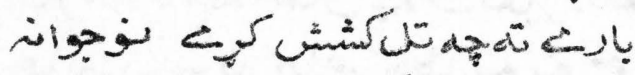

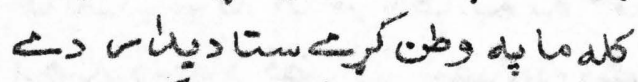

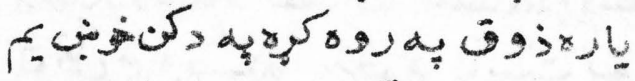

$\Leftrightarrow \sim b_{1} \geqslant a$ a

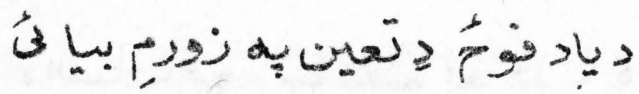

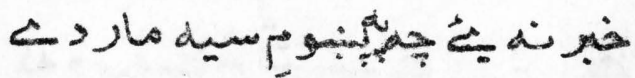

$\Delta 1 \%$ 


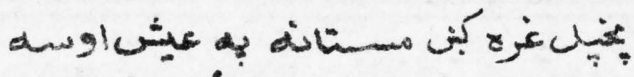

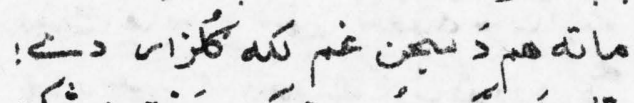

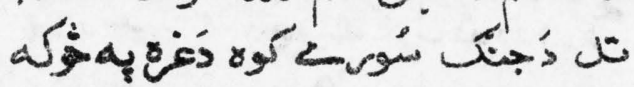

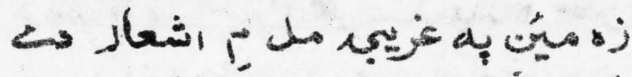

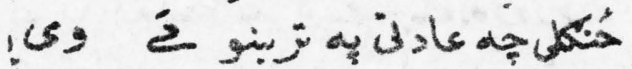

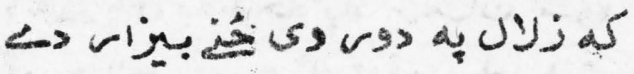
(بs

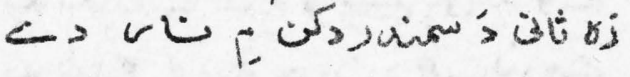

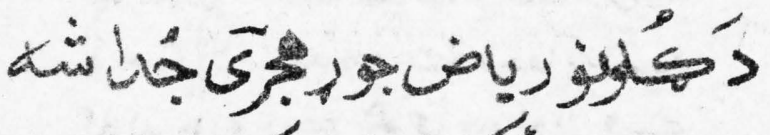

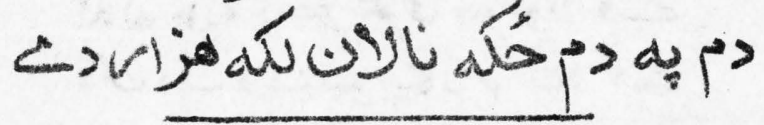
¿

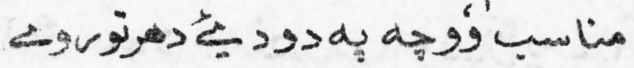

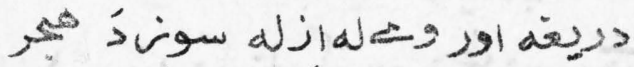
كأ

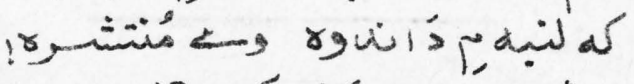

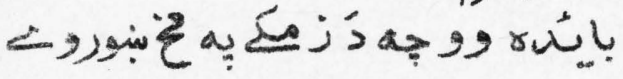

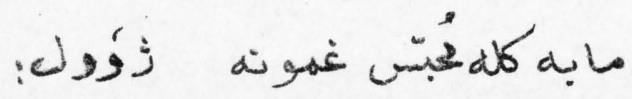

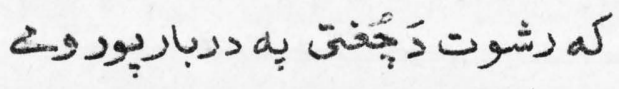




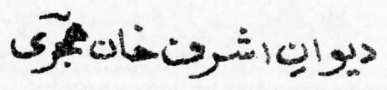

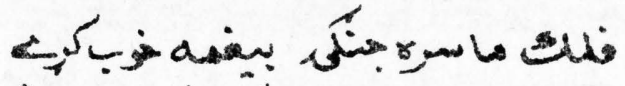

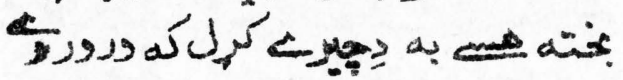

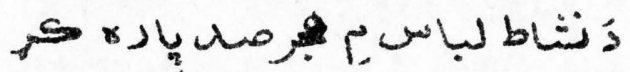

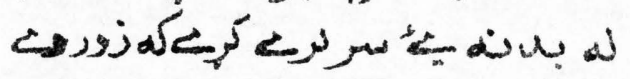

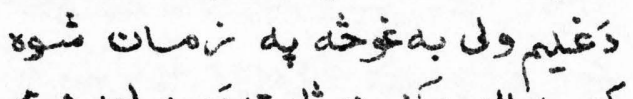

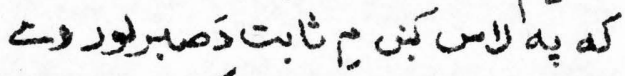
L به

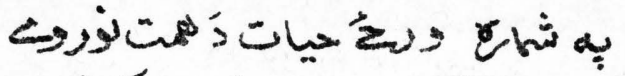

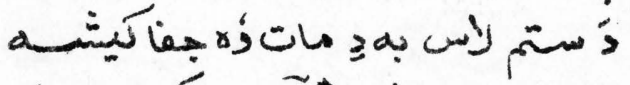
L

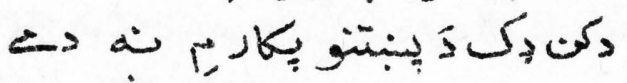

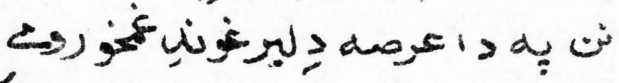

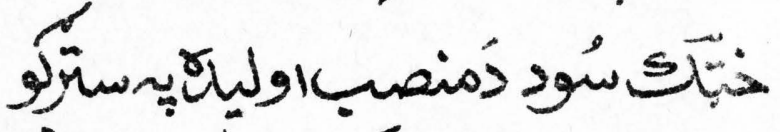

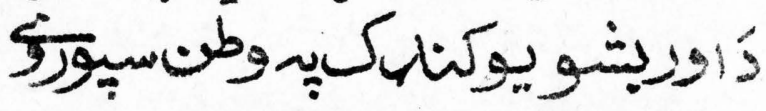

$\Delta 14$ 


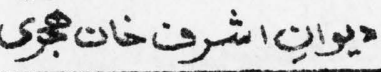

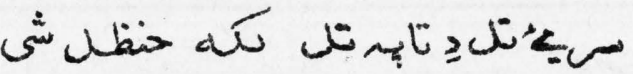

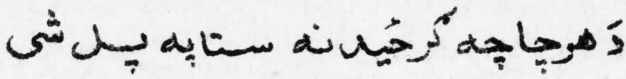

V)

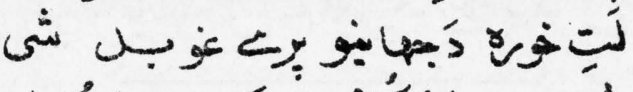

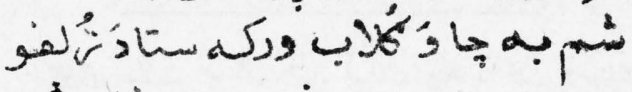

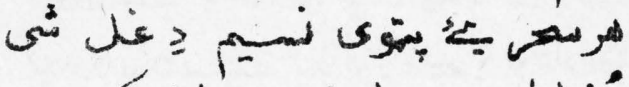
مُشاطرمجه

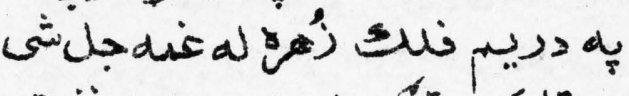

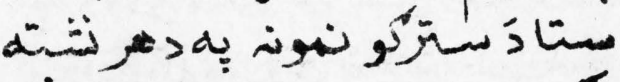

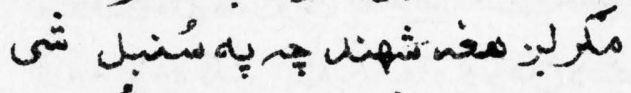
تهمري

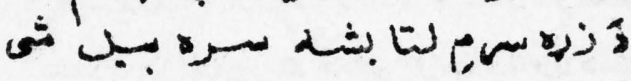

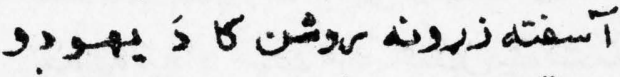

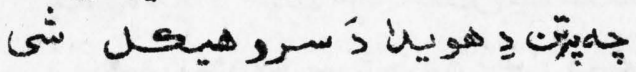

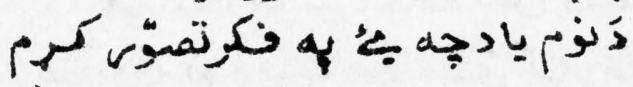

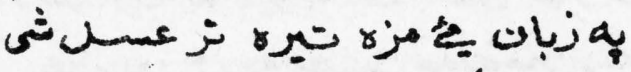

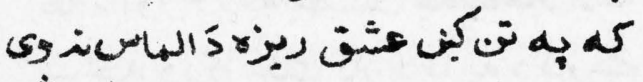

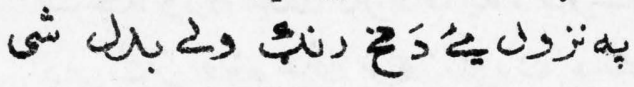

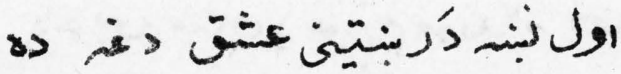

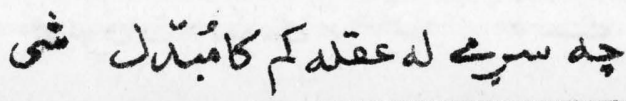


غهن

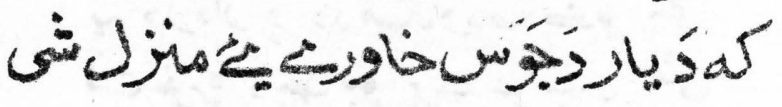

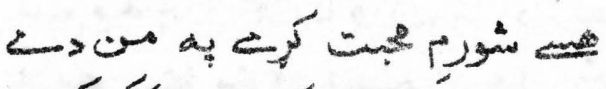
كها

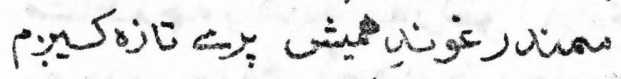

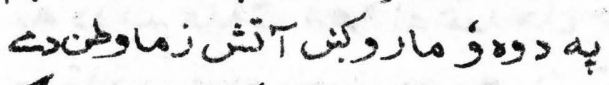

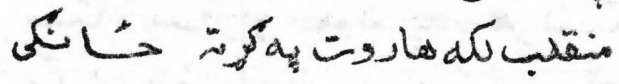

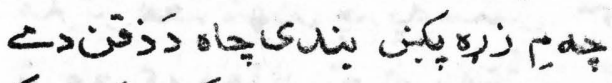

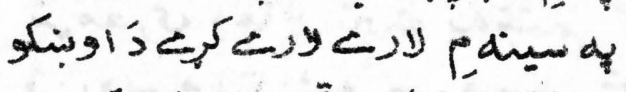
ستاندئنا

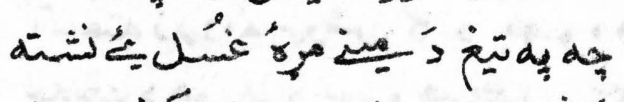

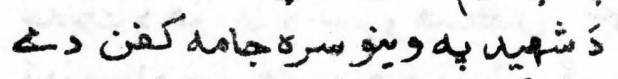

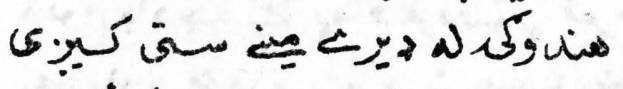

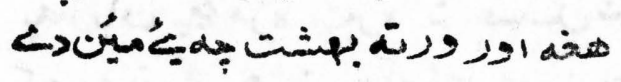

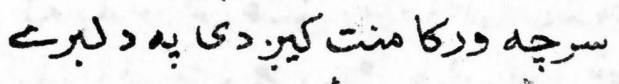

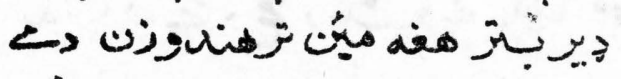

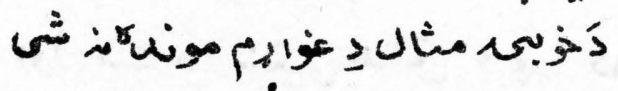

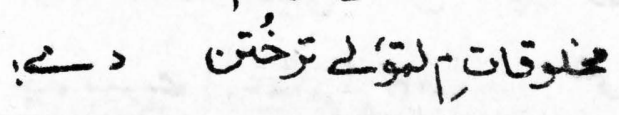




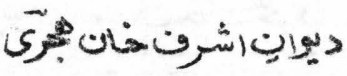

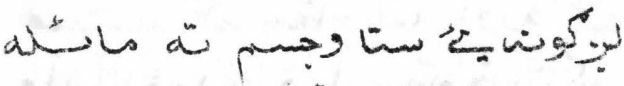

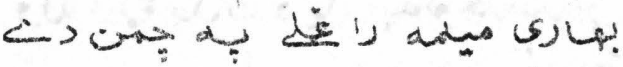
ر)

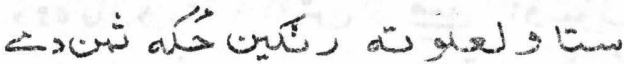

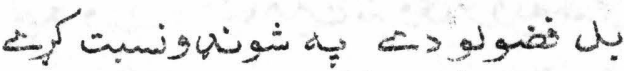

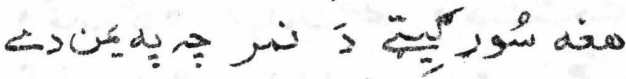

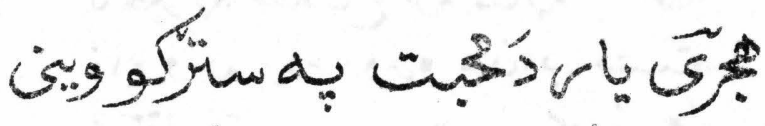

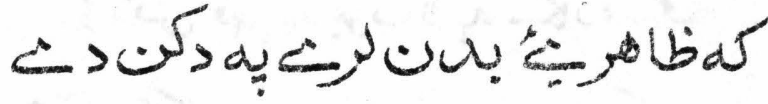

كأق

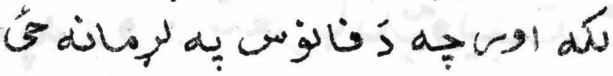

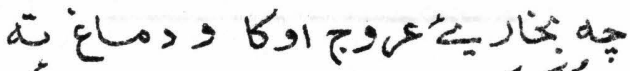

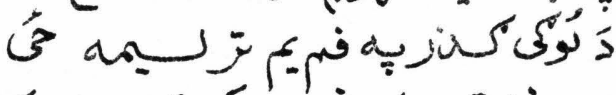

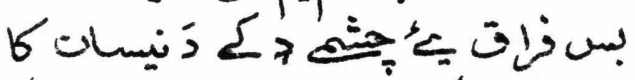

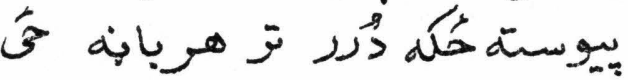

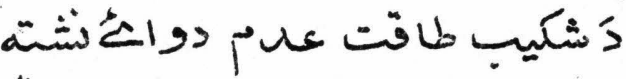
هي

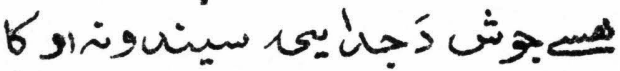

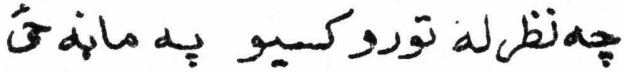

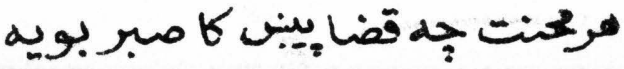




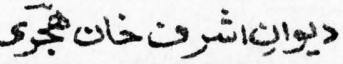

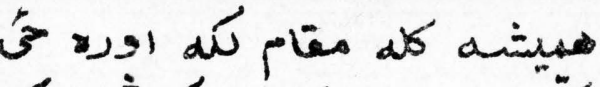

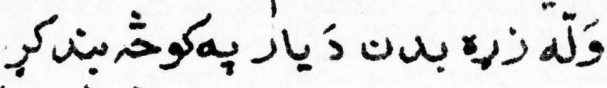

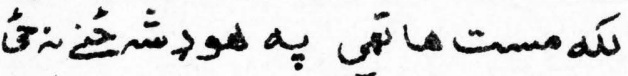

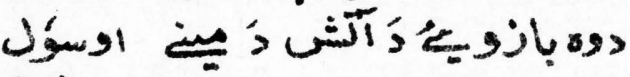

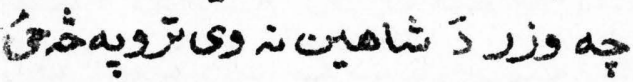
وعلها

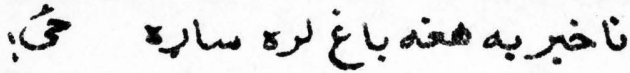

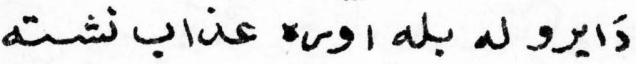

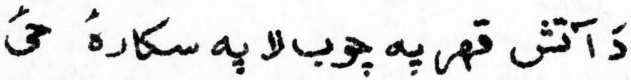

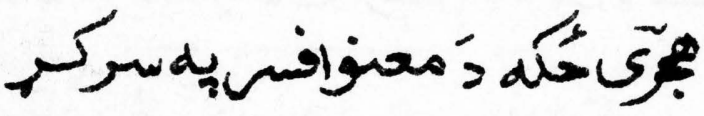

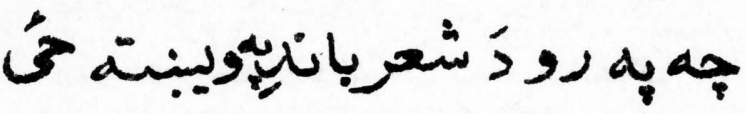




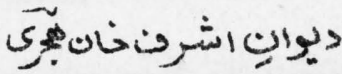

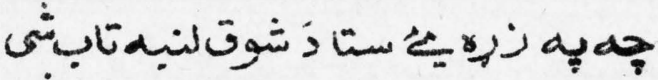

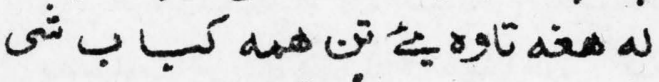

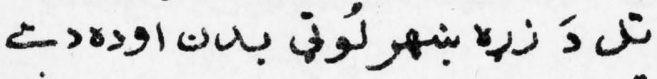

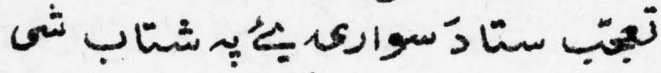

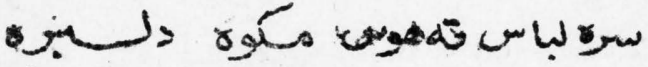

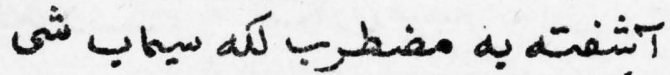

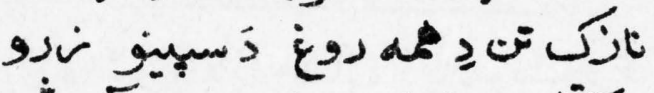

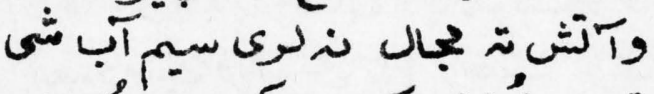

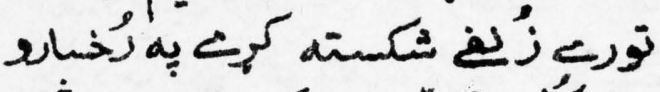

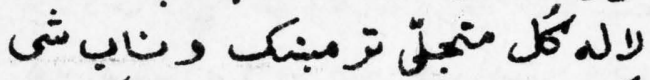

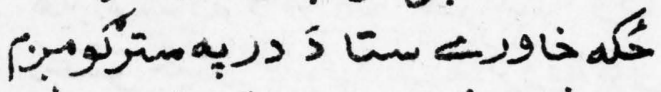

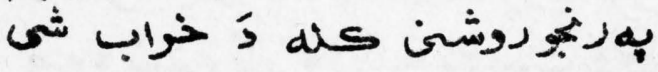

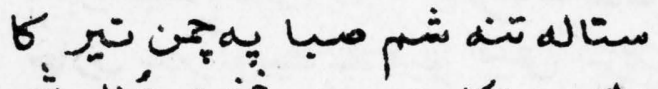

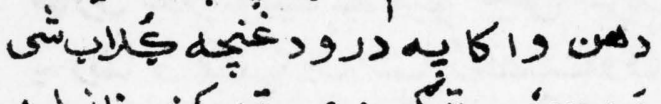

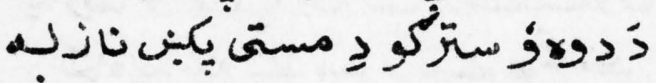

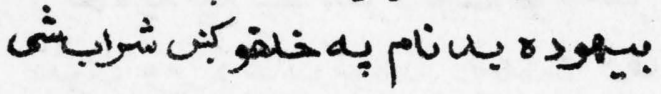
دؤولال وينا هميثىكيح به دروغنه

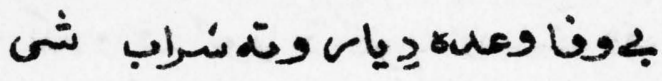

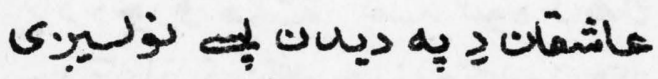

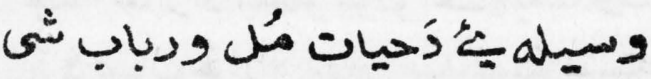


ديوانِاشرتخانهئَ

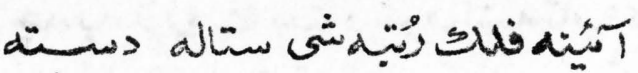
هِ

. به

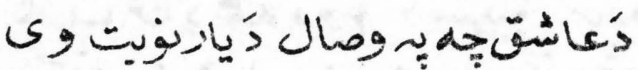

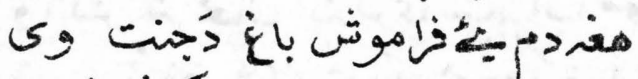
جها

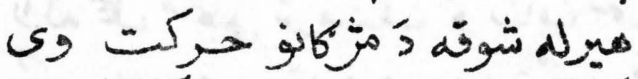

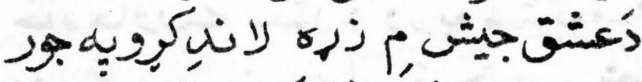

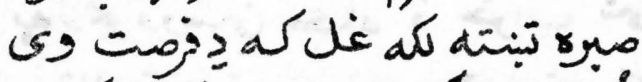

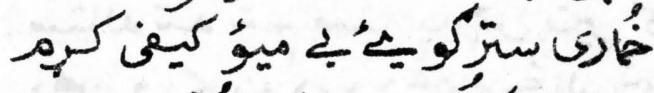

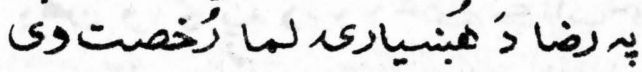

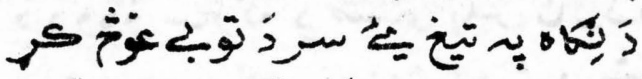

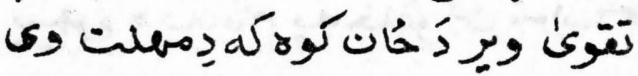

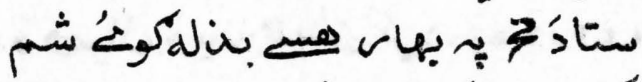

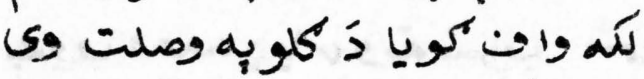

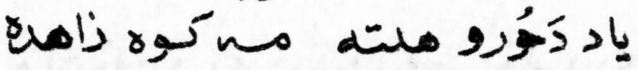

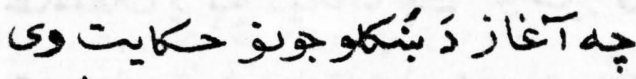

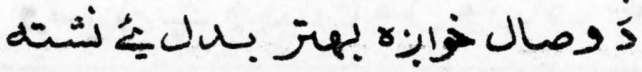

OFP 


\section{يوانِ}

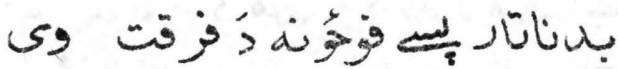

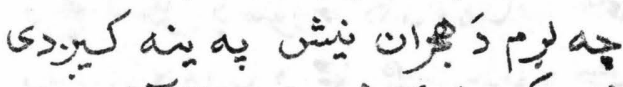

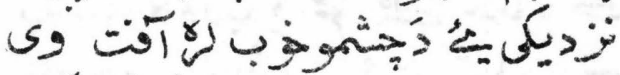

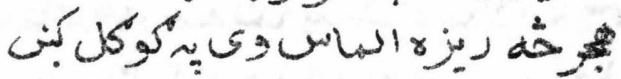

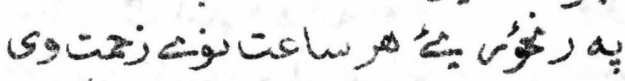

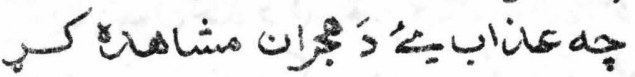

كإد

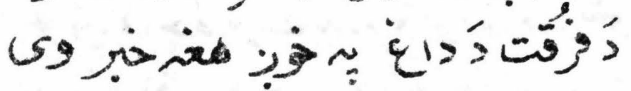

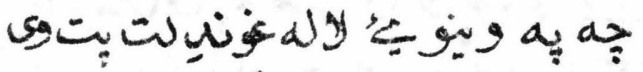

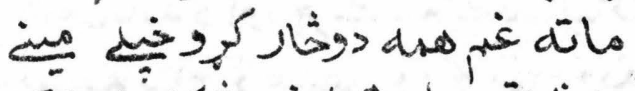

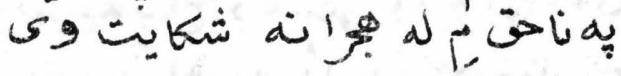

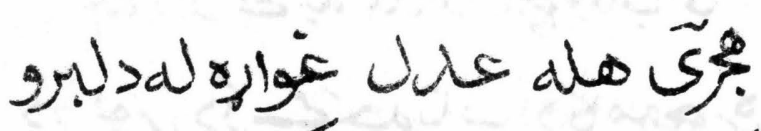

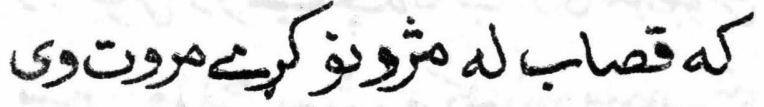

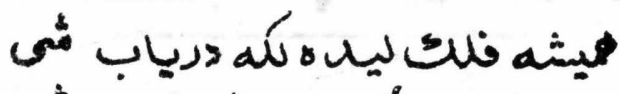

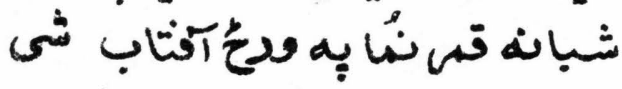

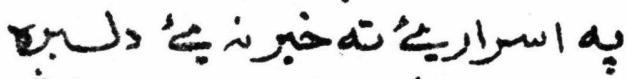

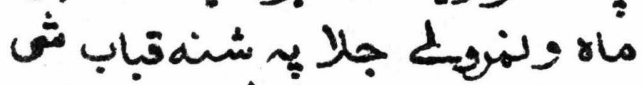

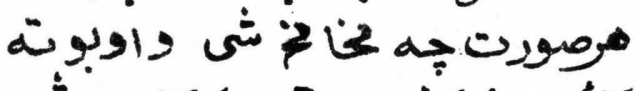

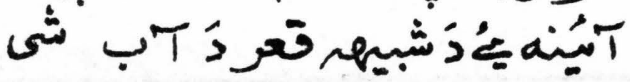




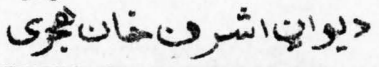

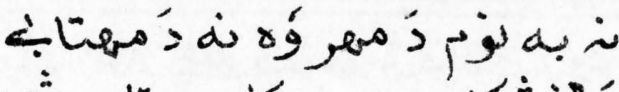

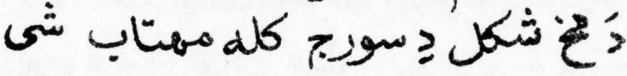

كا

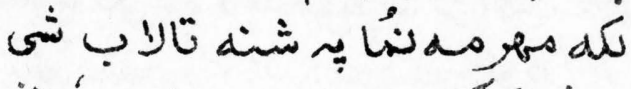

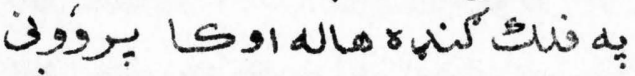

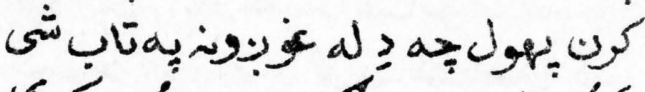

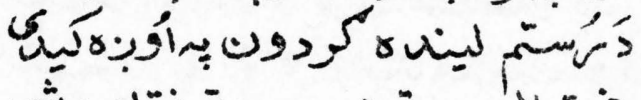

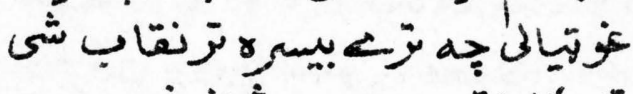

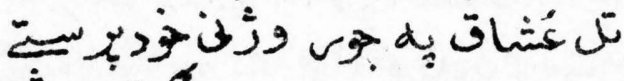

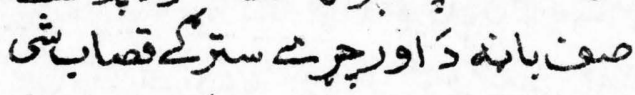

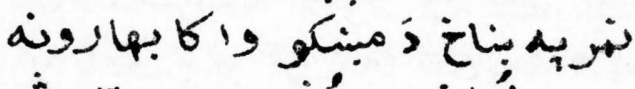
حه

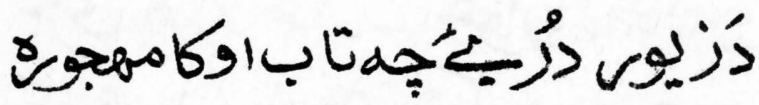

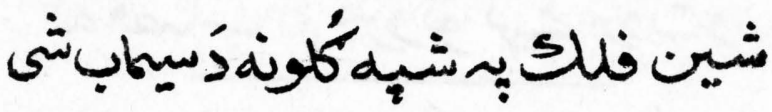




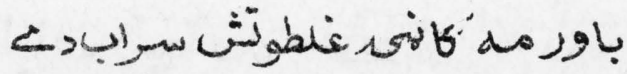

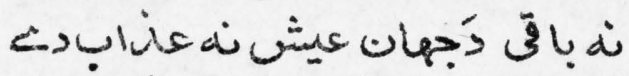

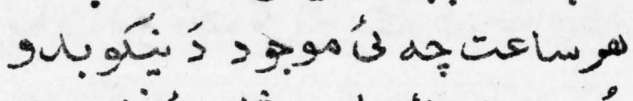

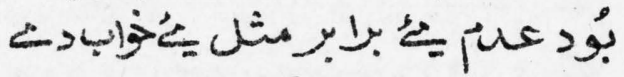

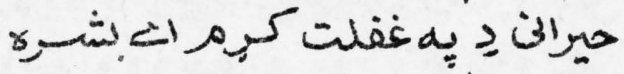

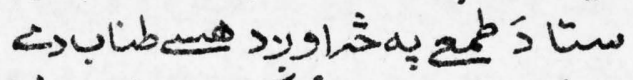

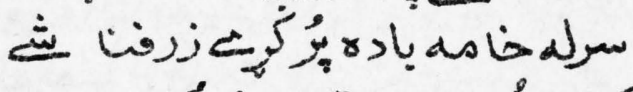

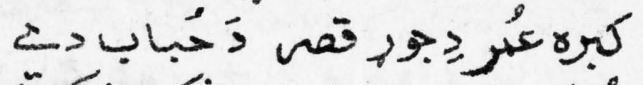

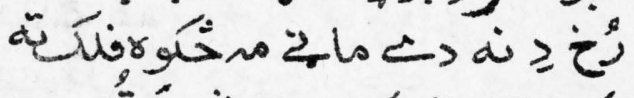

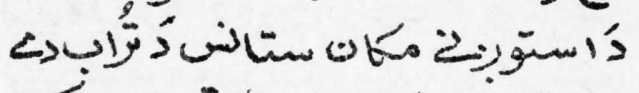

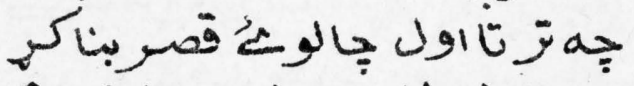

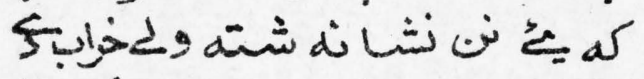

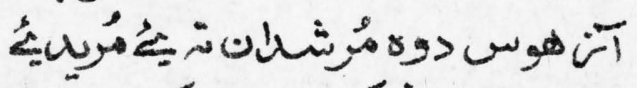

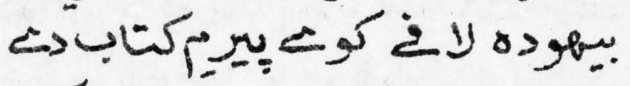

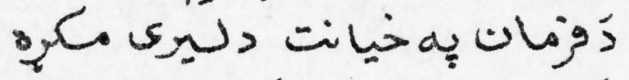

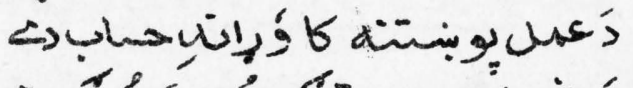
داكلفِ جل

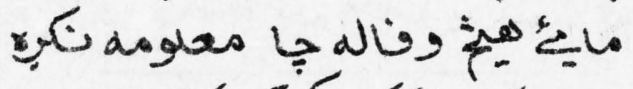

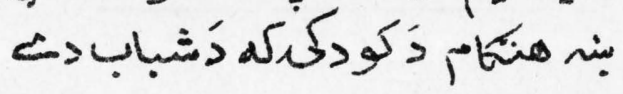




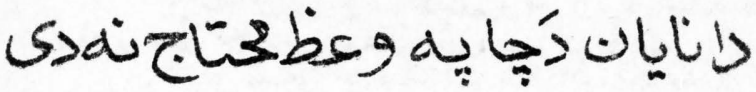

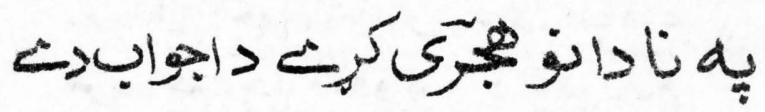

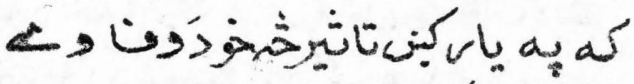

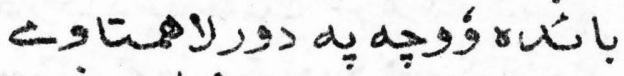

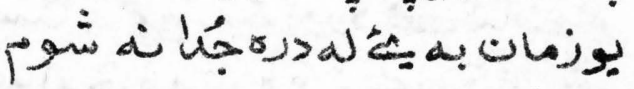

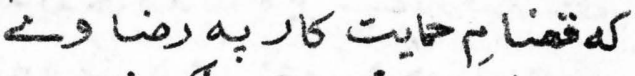

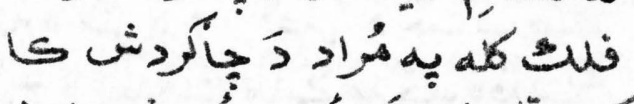

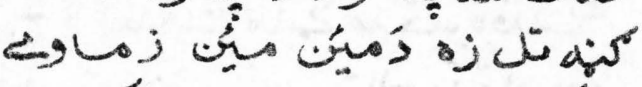

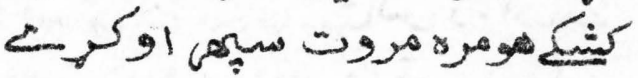

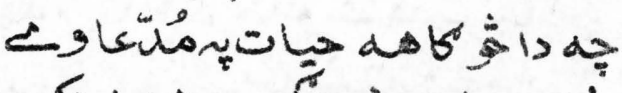

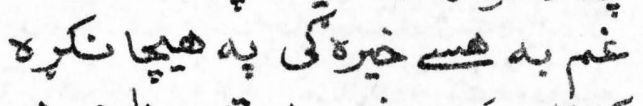

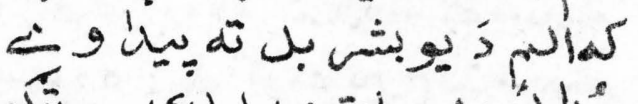

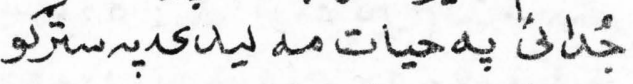

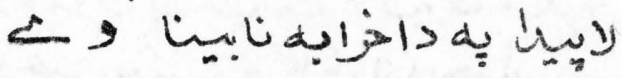

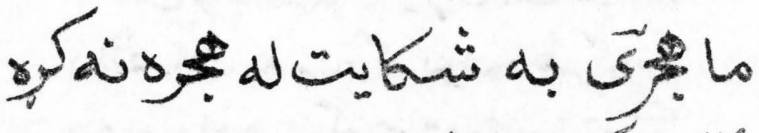

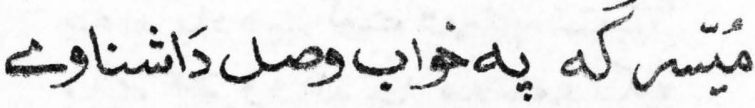




\section{يوانِاشرتخاتبأئى}

د

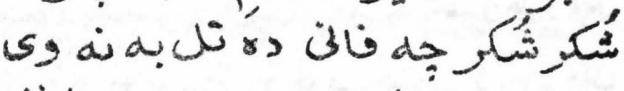

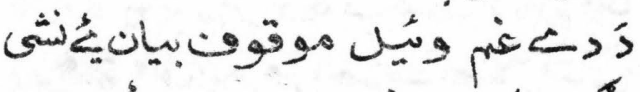

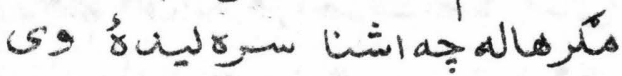

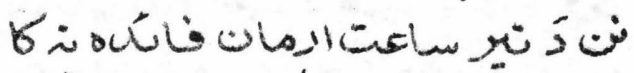

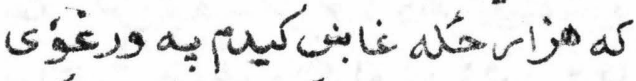

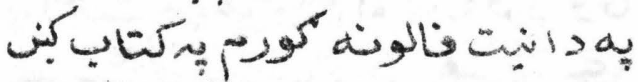

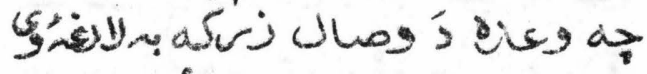

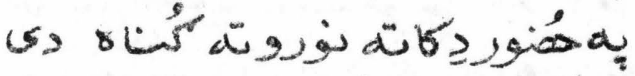

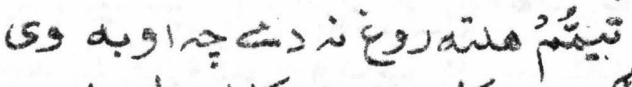

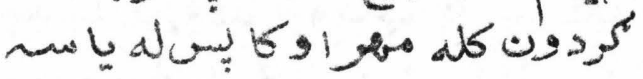

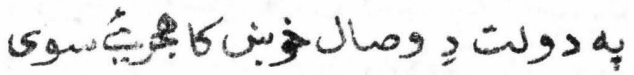

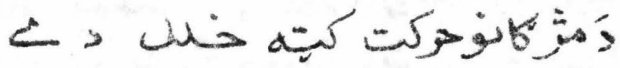

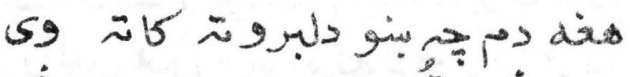

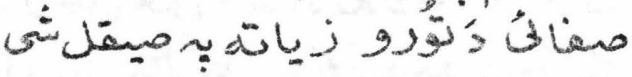

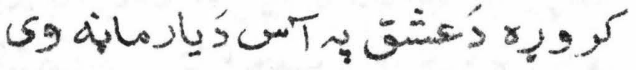
. بن 


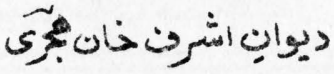

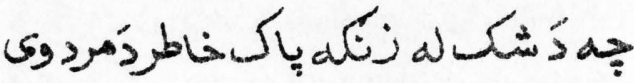

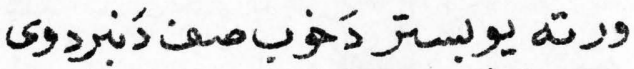
落

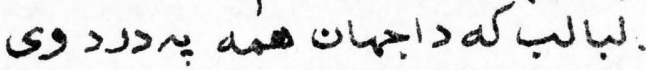

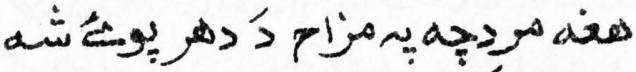

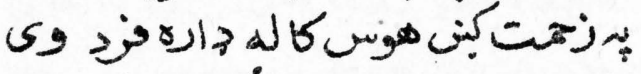

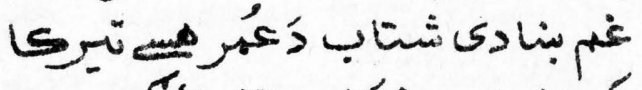

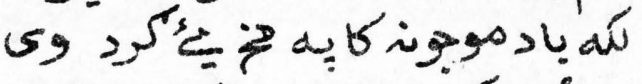

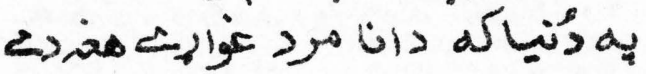

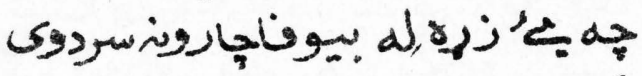
ك'

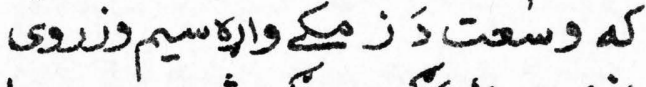
le

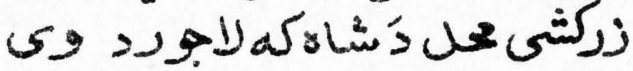

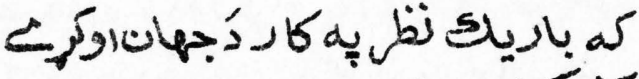

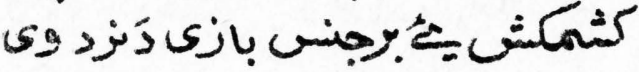

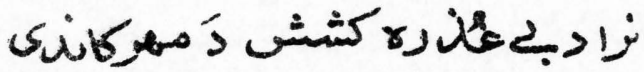

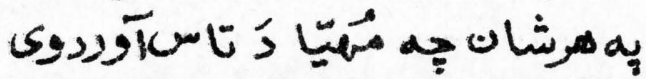

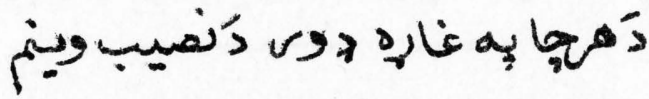

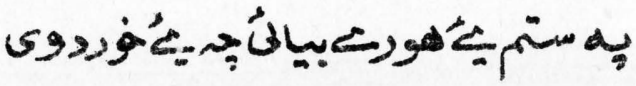




\section{حيوانِاشرنخان بُرئ}

U) تصني ,

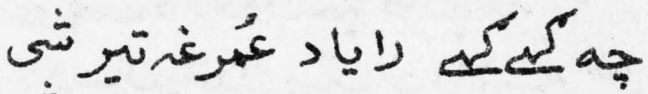
كَّة

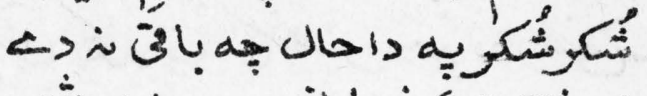

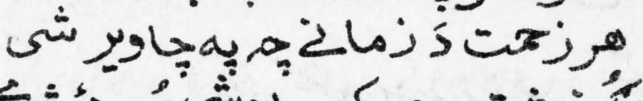

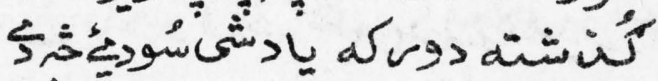
داز

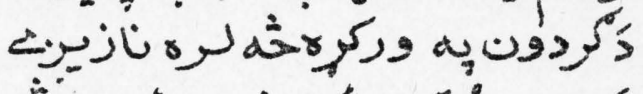

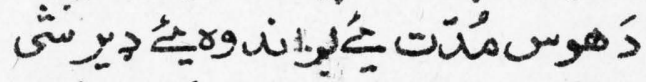

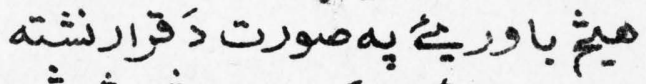

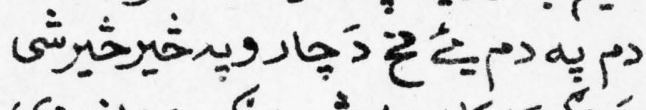

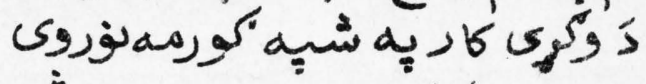

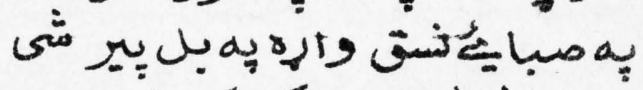

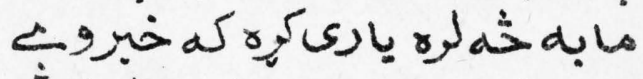

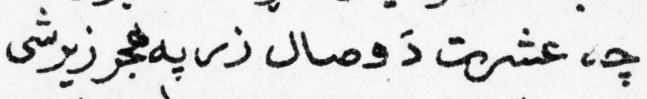

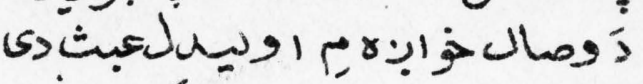

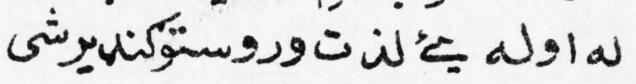

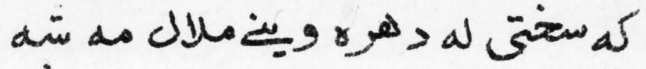

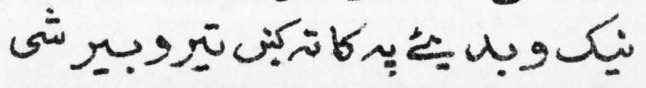


ديوانِاشرنخان برى

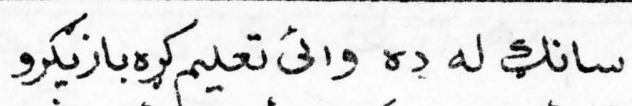
عُ

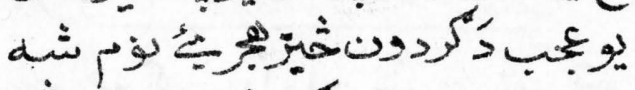

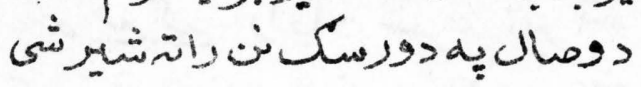

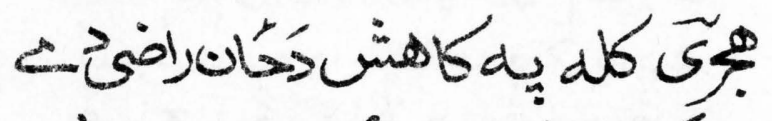

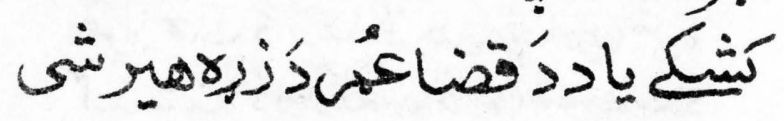

$\Delta r$ 


\section{ديوانِاشرت نان}

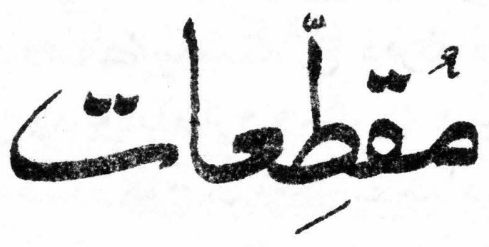




\section{ليوانِاشرنخان ثئى}

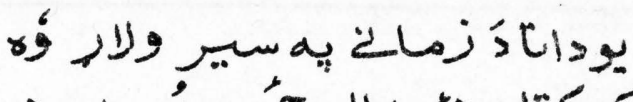

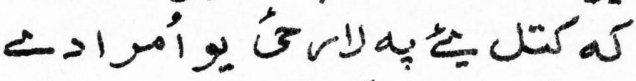

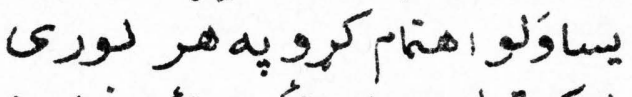

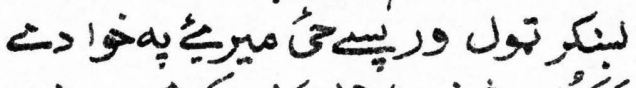

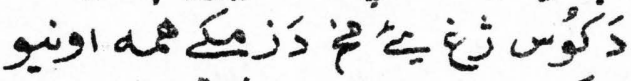

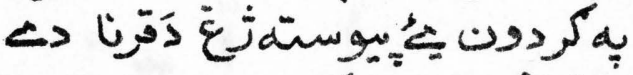
يم" و El

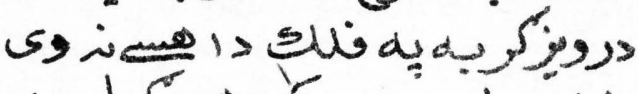

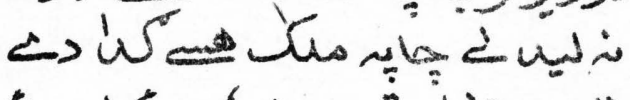
之

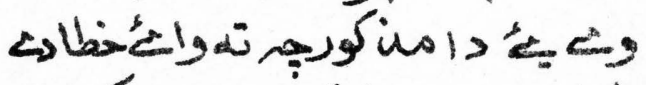

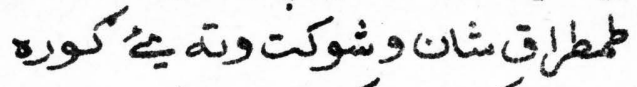

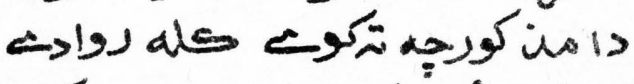

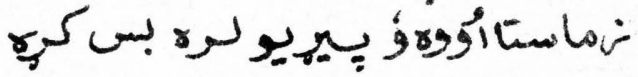

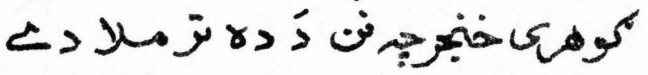

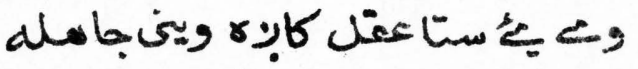

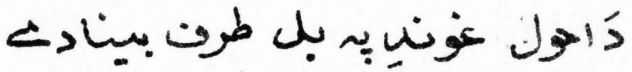

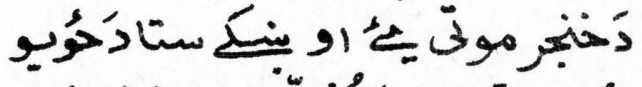

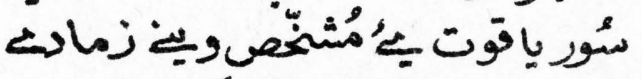

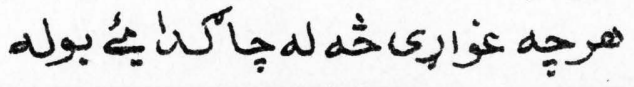


ديوالِنشربنخان ثهرى

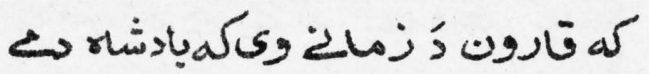

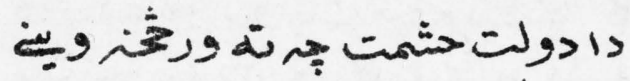

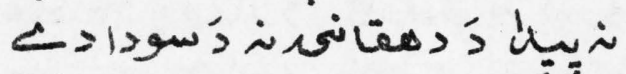

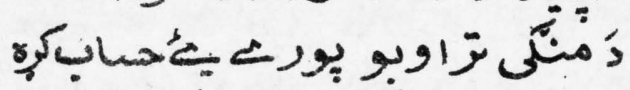

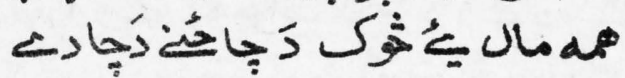

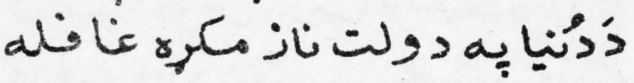

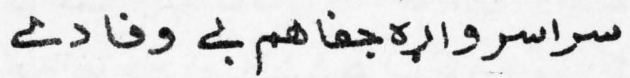

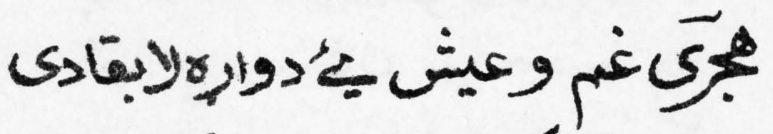

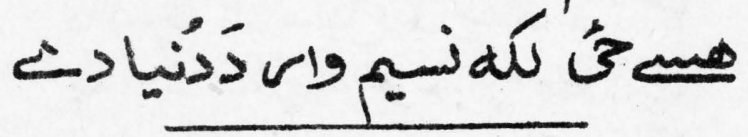

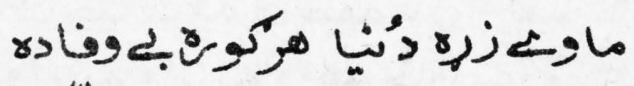

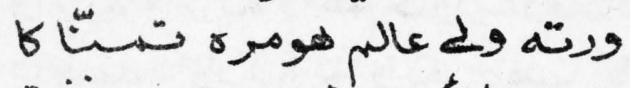

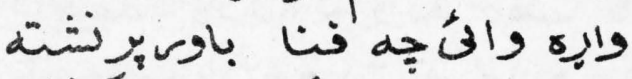

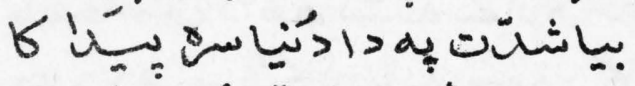

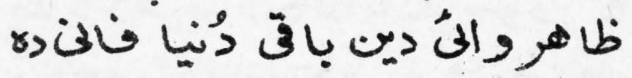

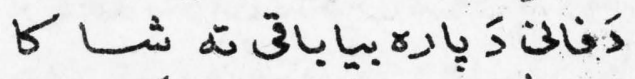

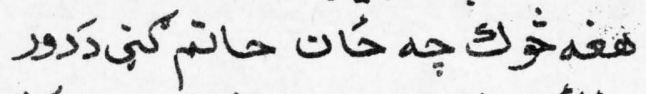

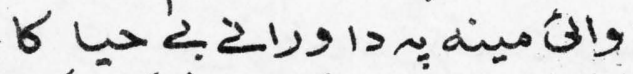

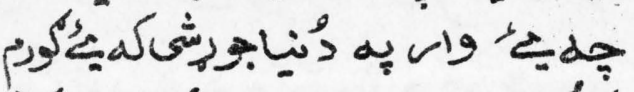
ذَّدُنياحص

$\Delta \mu^{\mu \nu}$ 


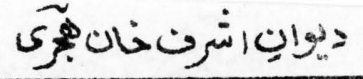

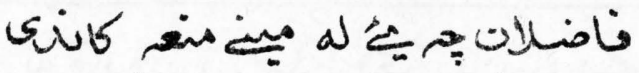

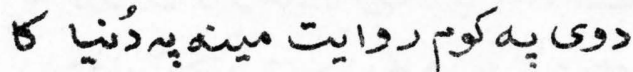

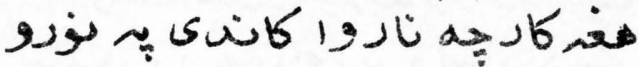

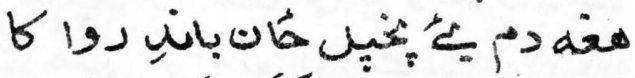
زهر

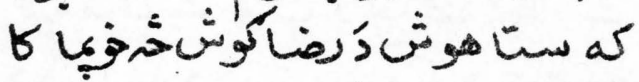

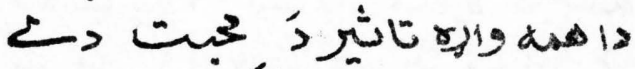

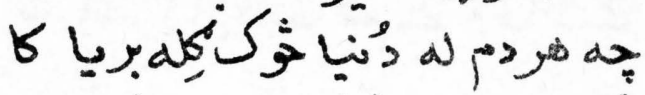

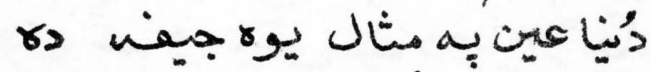

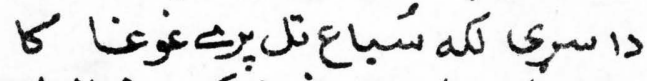

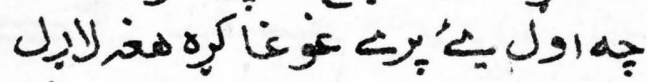

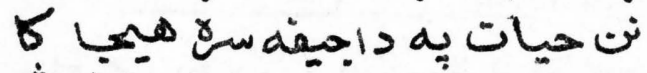

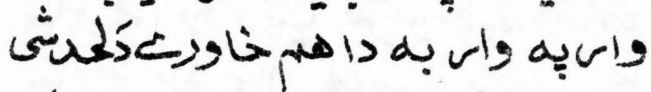

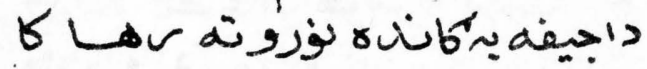

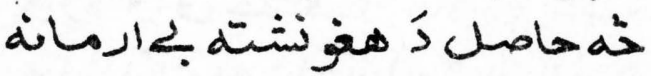

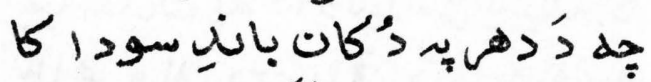

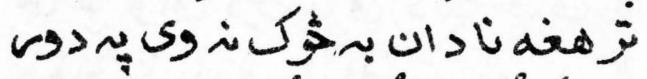

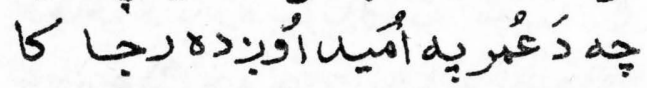

$\Leftrightarrow$ >

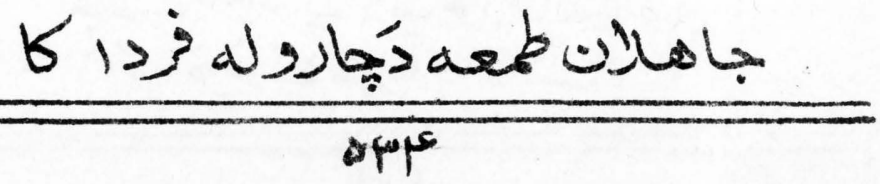




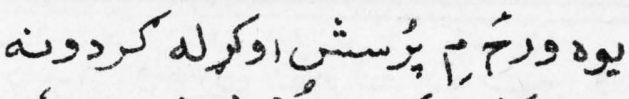

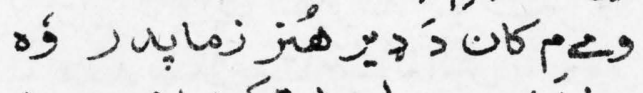
هic

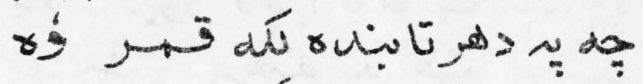

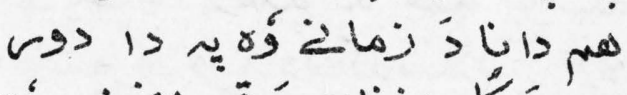

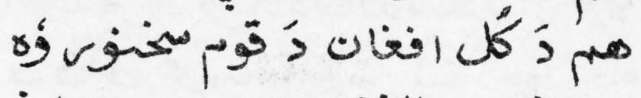

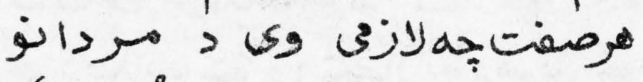

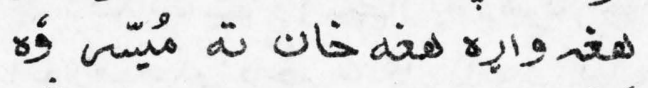

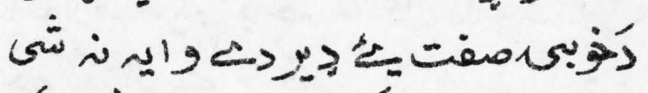

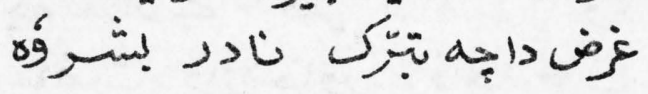

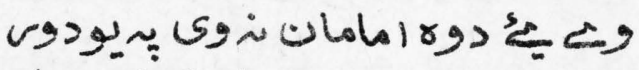

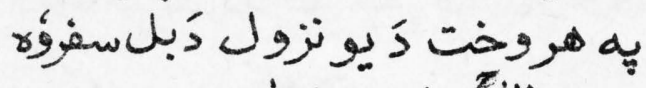

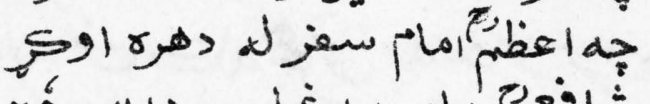

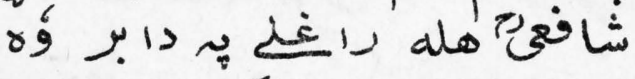
تونيت

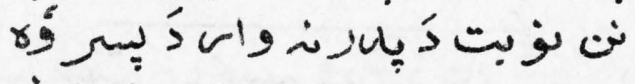

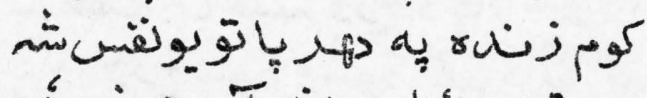

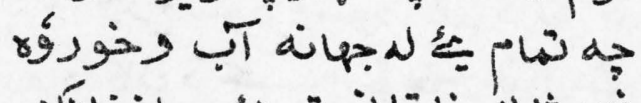

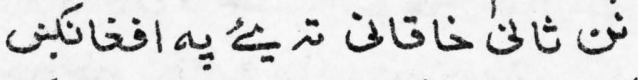

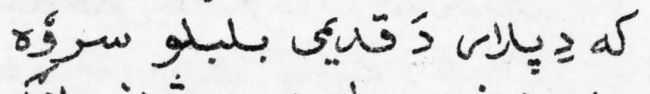
ما كار 


\section{حيوانِاشرت خانه}

تيو

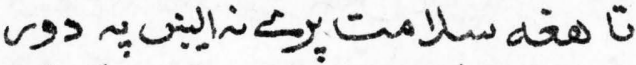

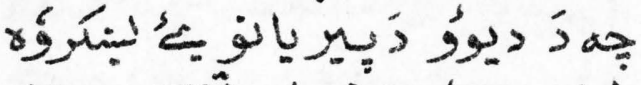

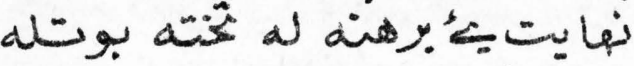

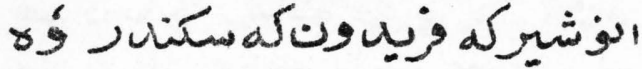

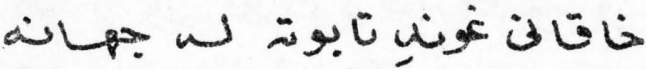

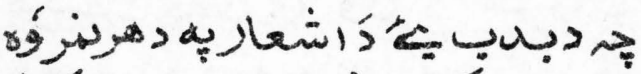
أنوزيكهيم

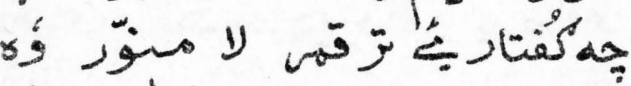
لعاقيت

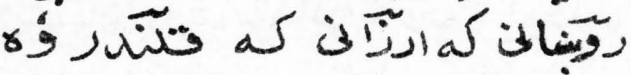

حنه جه آرئ

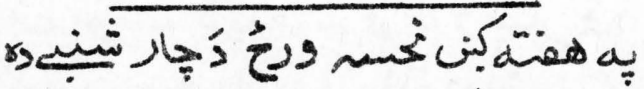

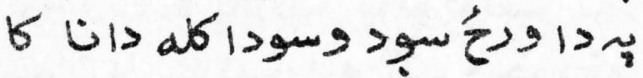

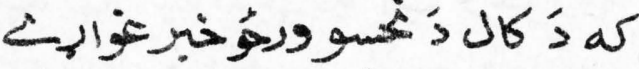

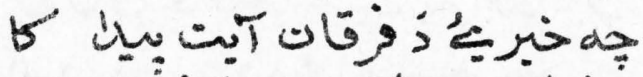
هن كاثل 
ديوانِاشرت خانهيُّى

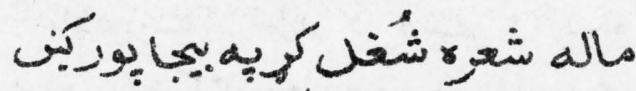

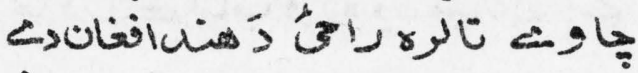

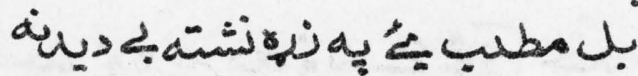

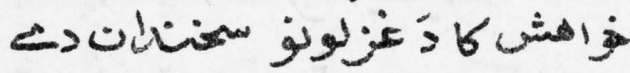

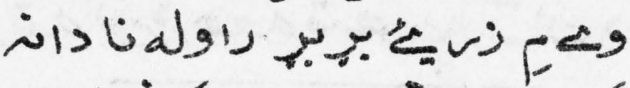

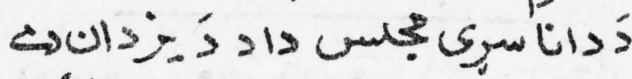

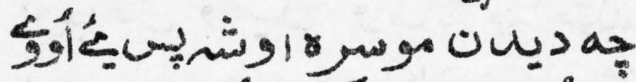
و

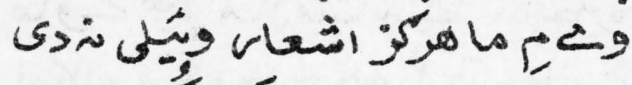

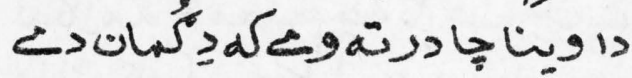

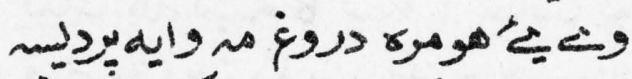

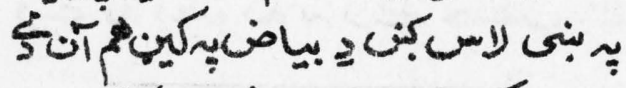

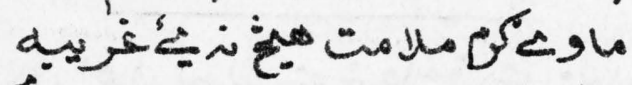

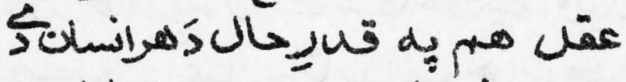

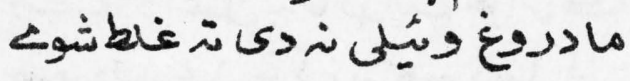

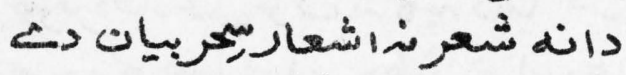

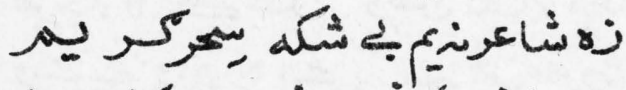

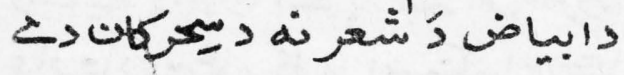

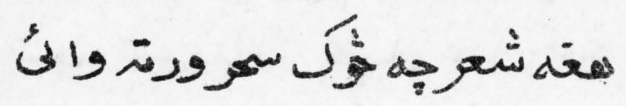

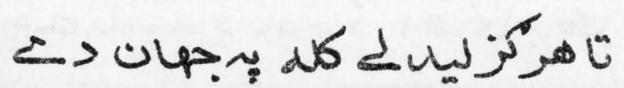




\section{ديوانِشرت خان يرى}

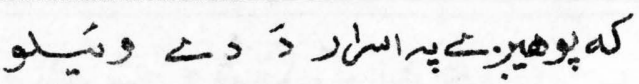

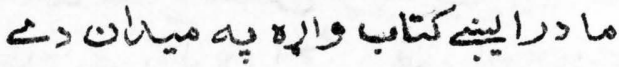
に

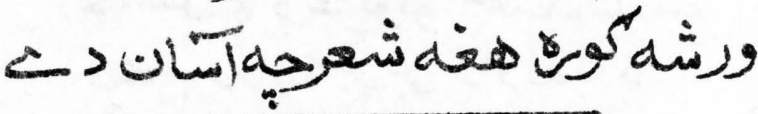

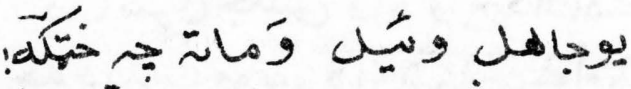

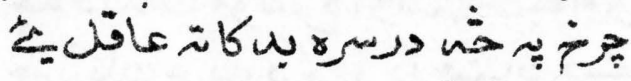

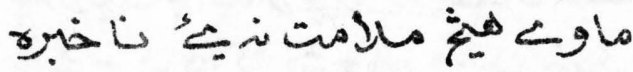

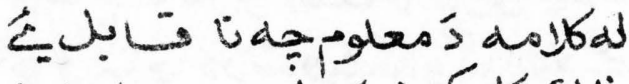
ونا

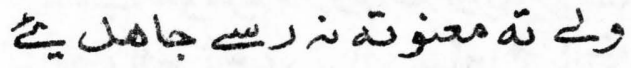

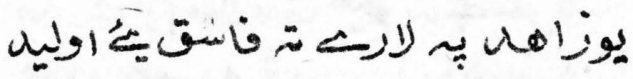

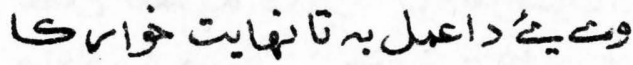

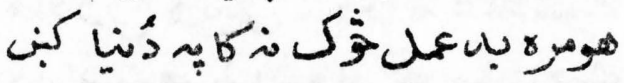

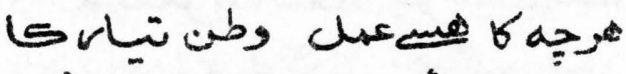

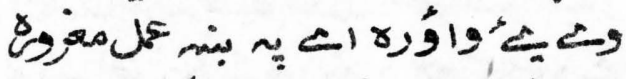

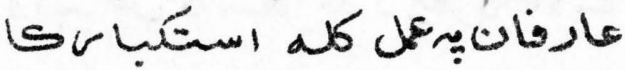

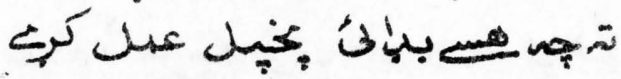

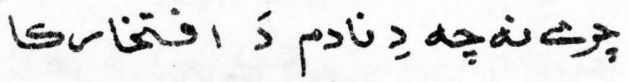




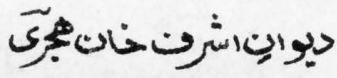

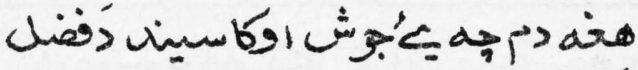

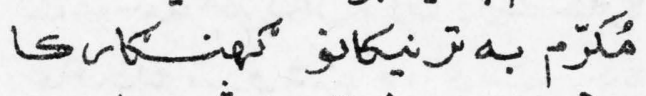

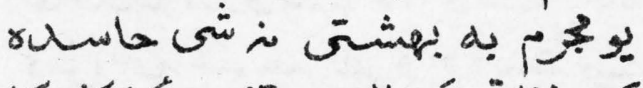

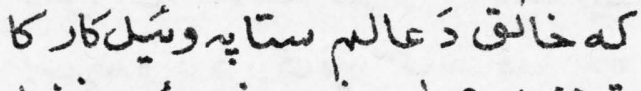

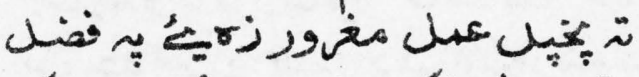

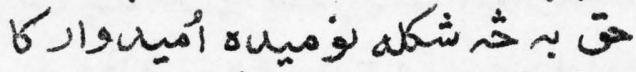

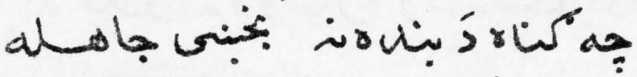

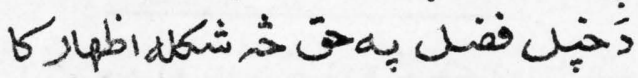

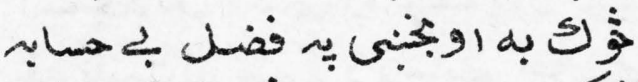

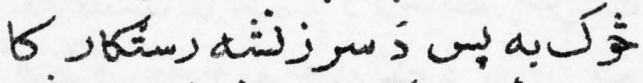

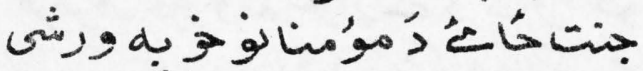

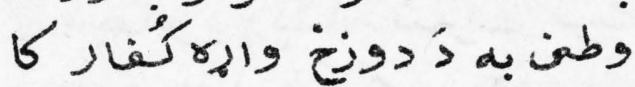

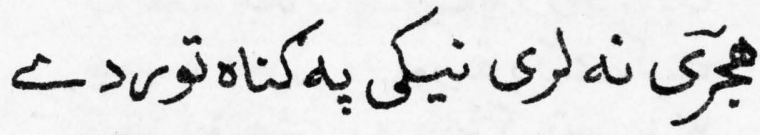

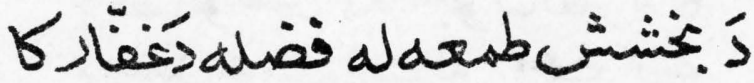


يواينِاشرتشان برجى

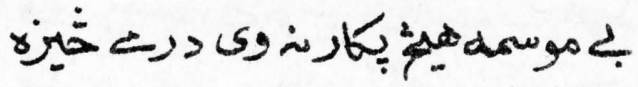

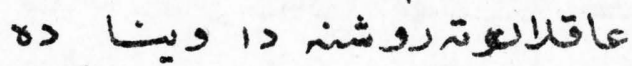

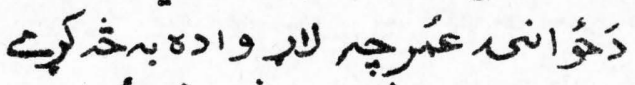

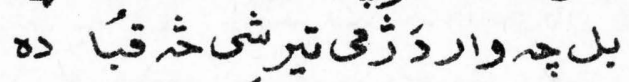

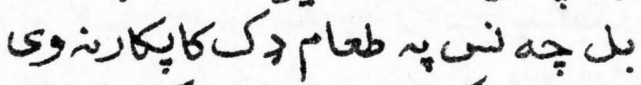

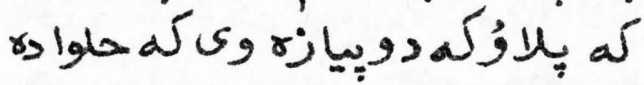

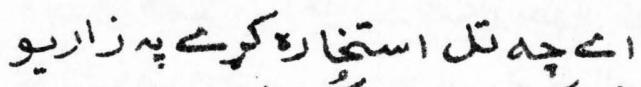

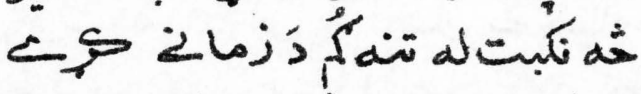

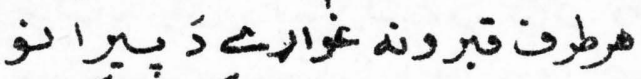

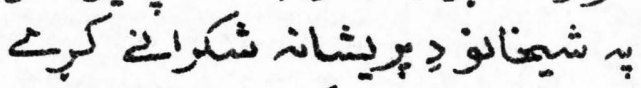

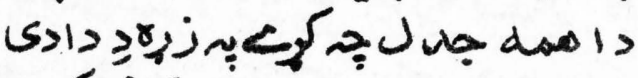

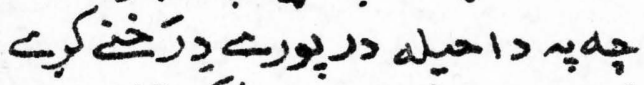

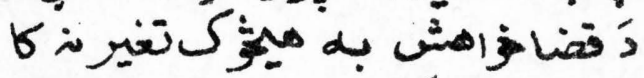

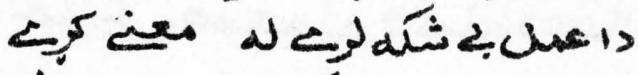

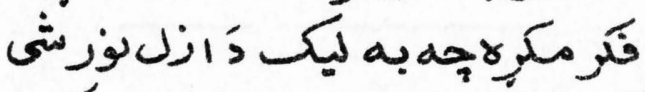

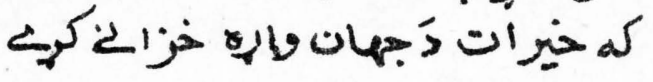

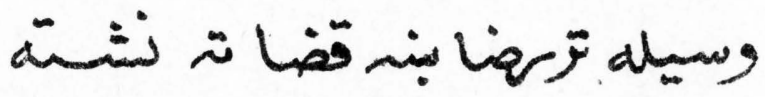

$\Leftrightarrow$ كن

of. 


\section{>يوانِ اشترتخانهيَي}

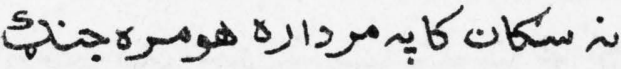

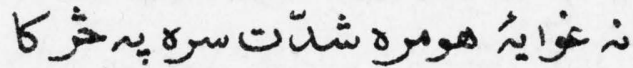

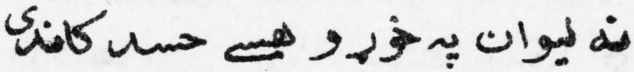

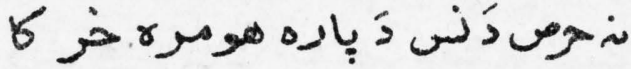

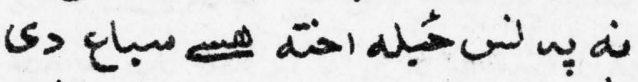

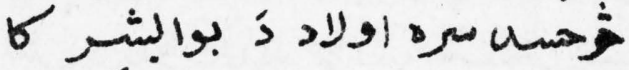

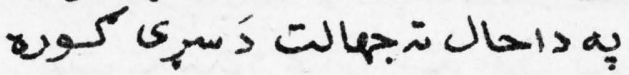

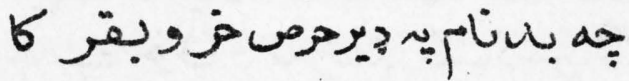

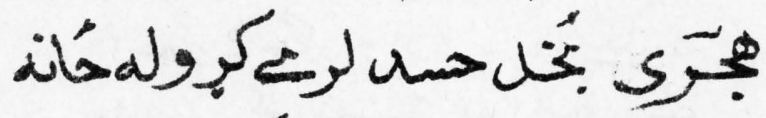
اخصلت به بهانئكن بهن

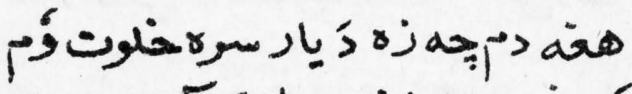

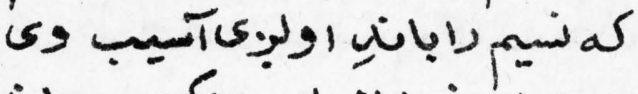

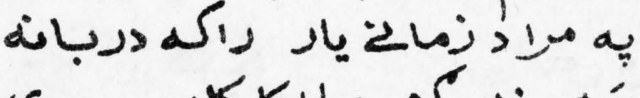

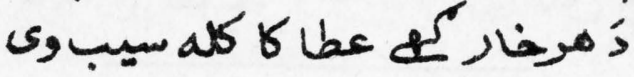

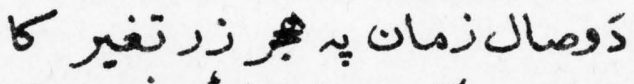

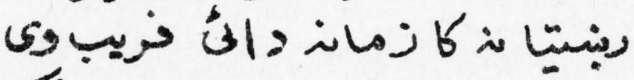

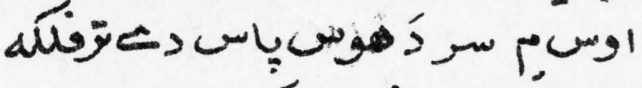

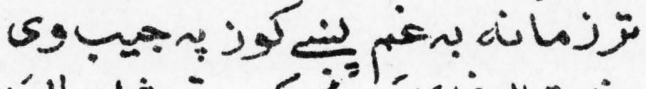

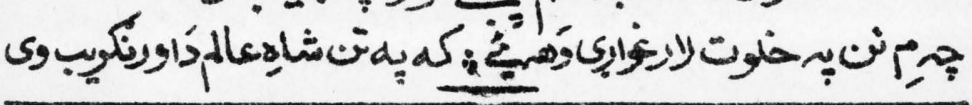




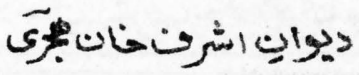

هوح بـ

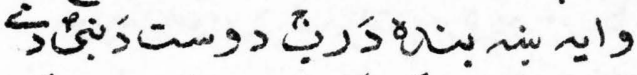

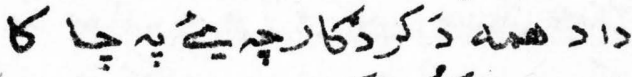

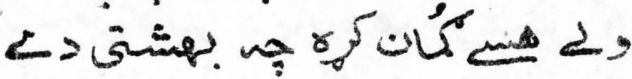

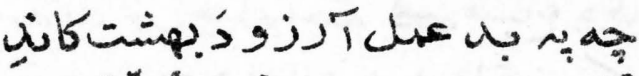
تختى

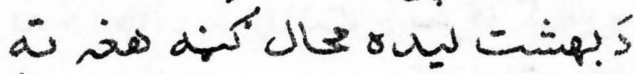
جها 1)

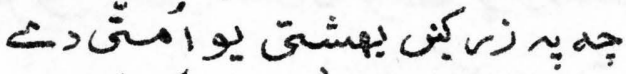

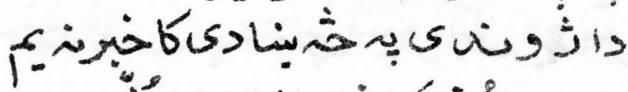
\& بنا

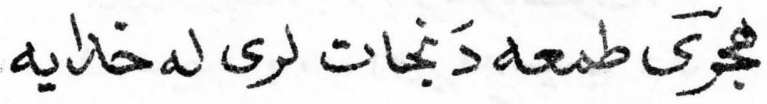
كulsugy 
دواِِاشرت خانهيّى

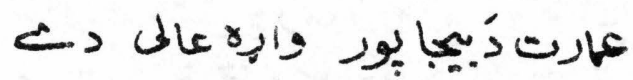

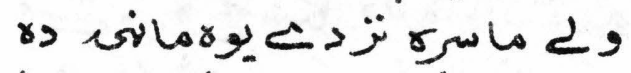

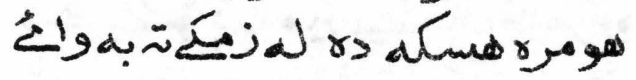

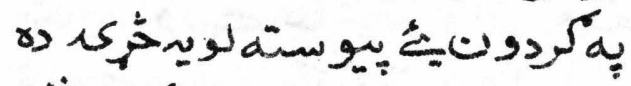

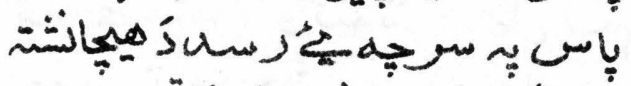

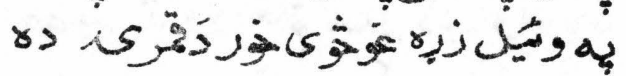

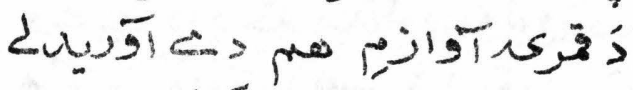
r

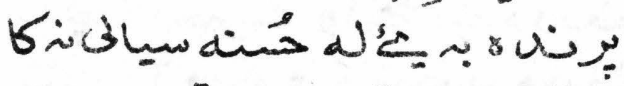

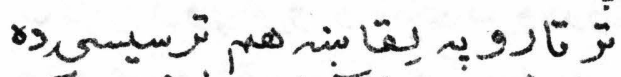

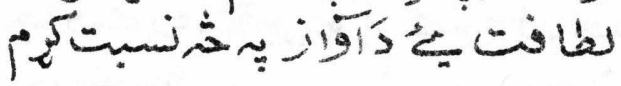

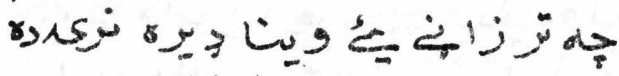

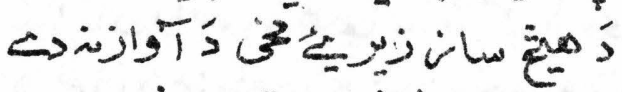

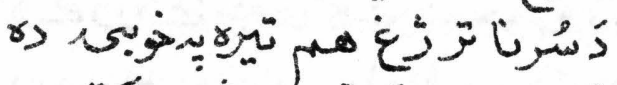

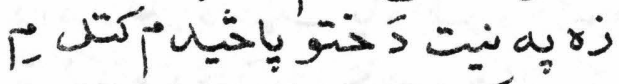

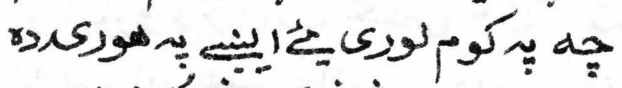
$\Leftrightarrow$ زرجها هغه بروتها

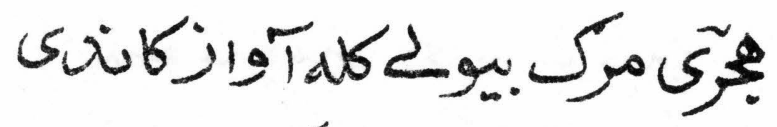

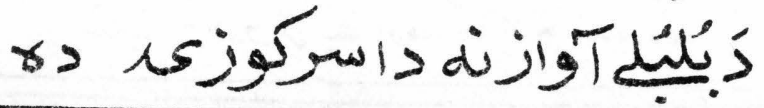
$\Delta \mu r$ 


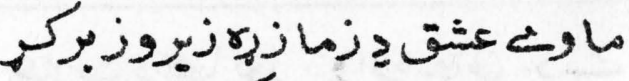

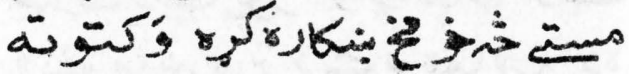

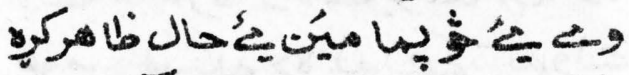

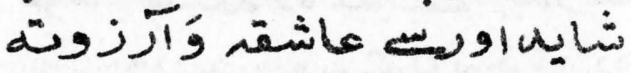

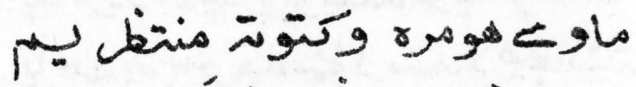

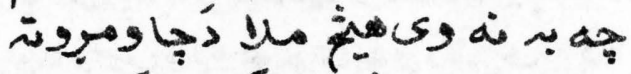
然

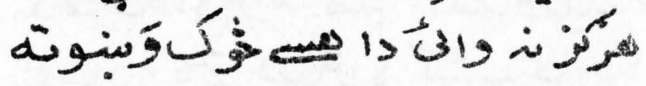
تانه

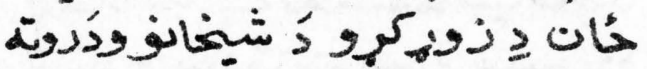
نا

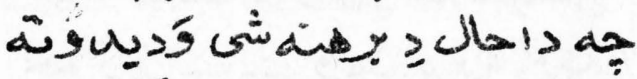

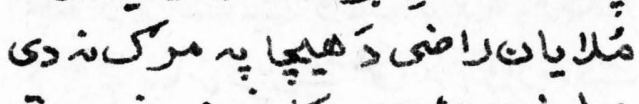

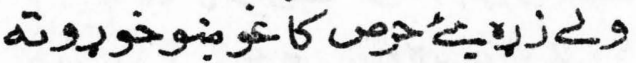

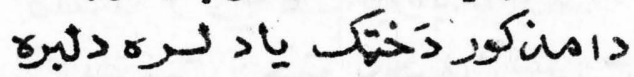

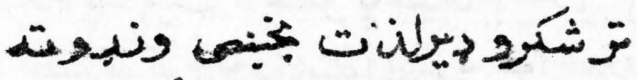

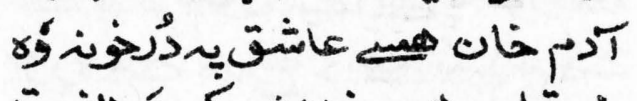

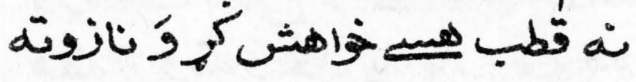

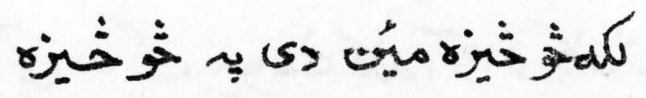

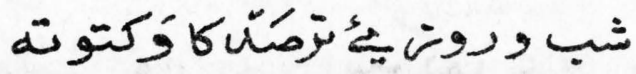




\section{حيوإِ اشرت خانثي}

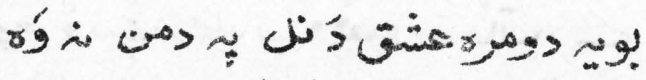

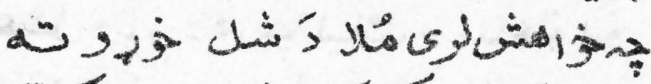

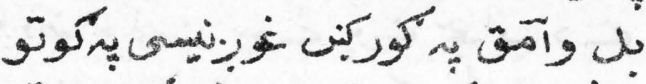

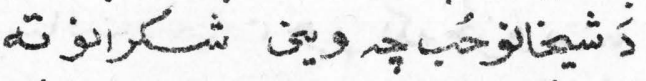

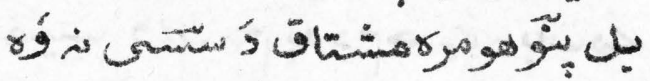

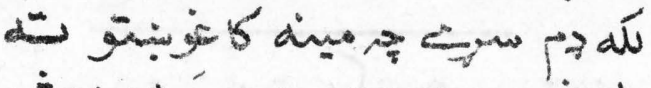

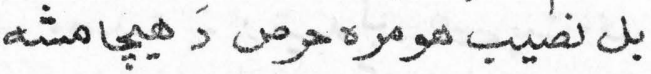
a

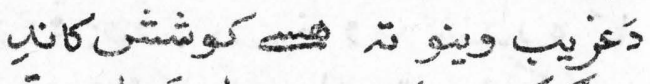

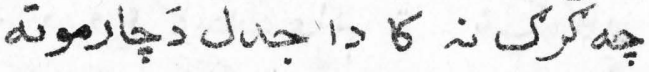

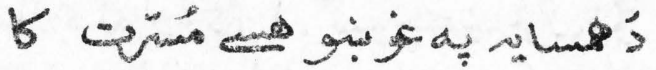

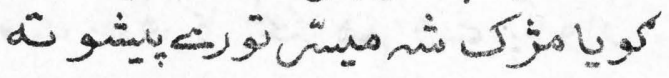

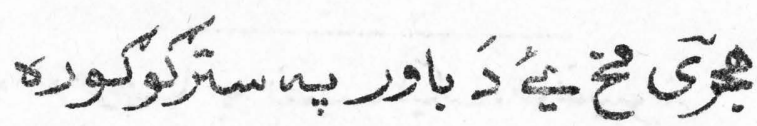

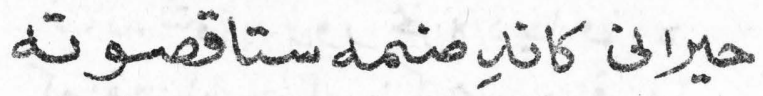

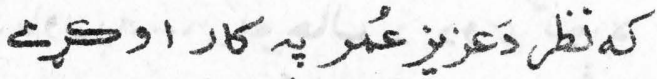
كئis

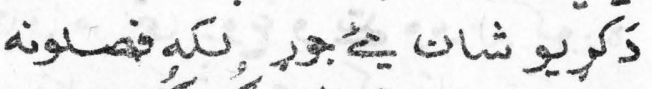

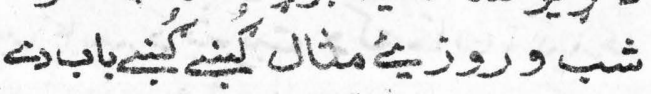
$\checkmark$ dellbo 


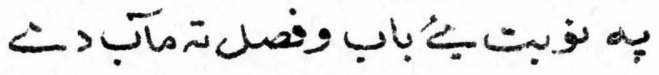

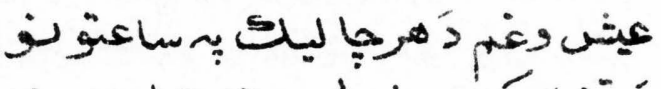

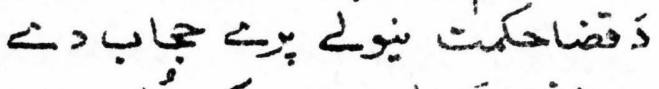

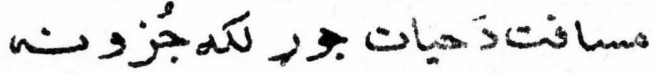

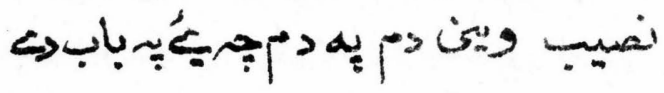

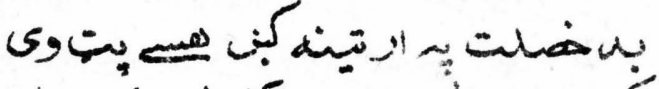

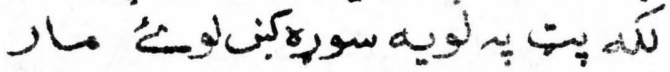

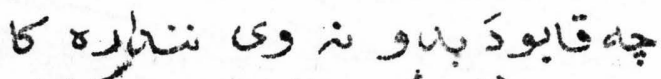
:

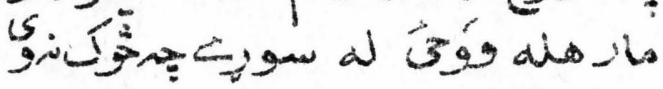

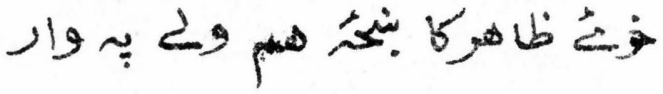

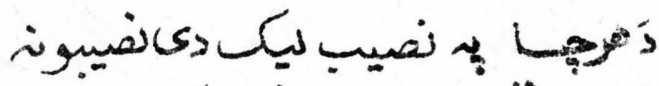

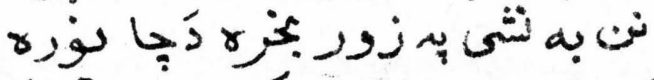

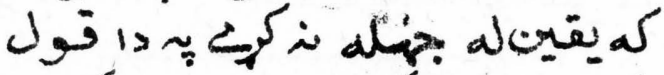

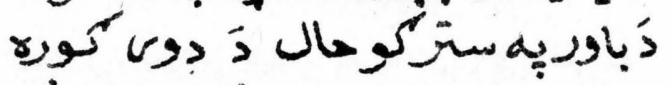

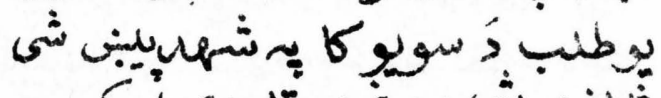

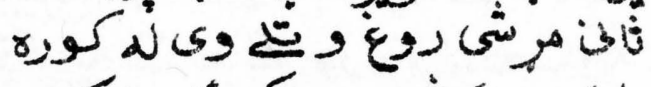

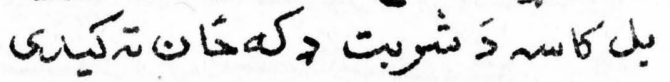

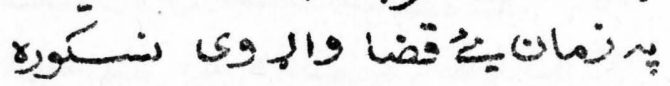




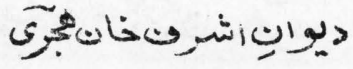

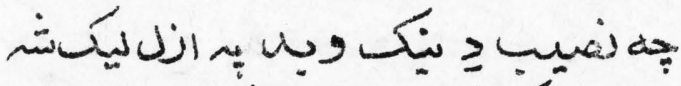

رورو

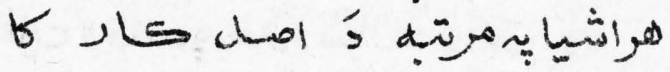

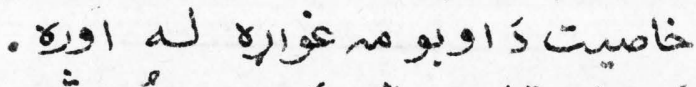

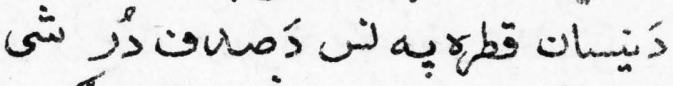

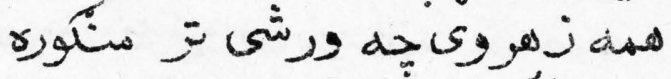
ن

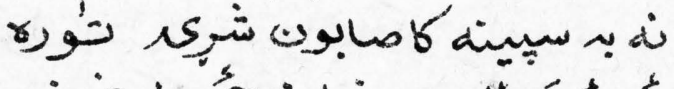

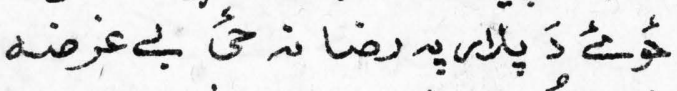

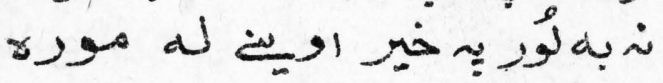
كوان هونة

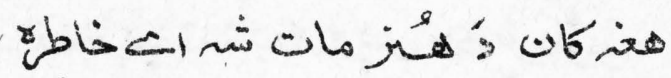
ذَّ ذان

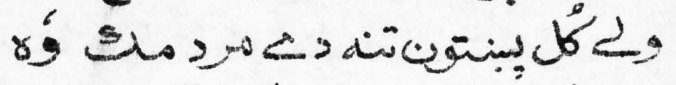
كاونا بو

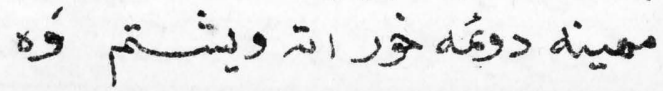




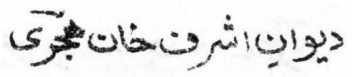

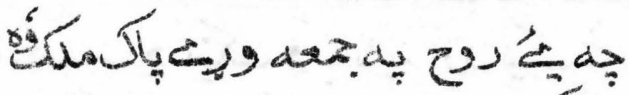
فئكى

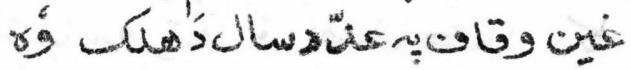

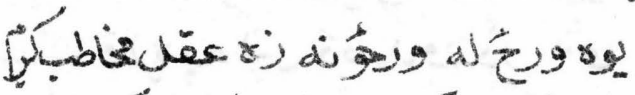

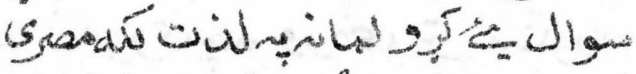
و

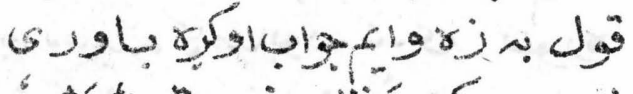
ن

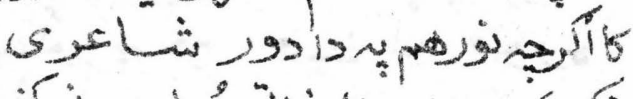

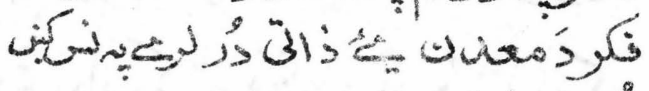

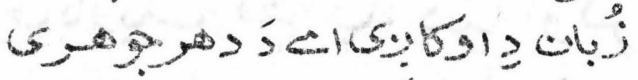

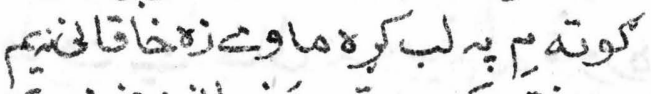

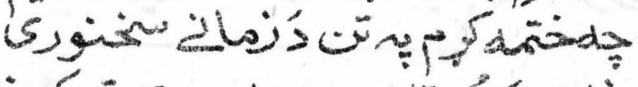

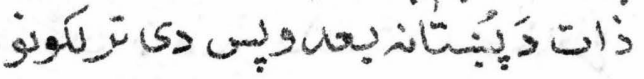
s

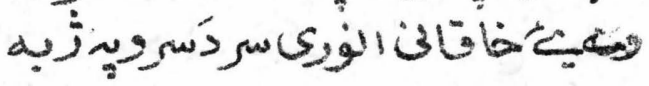
تئئ

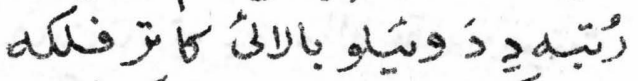

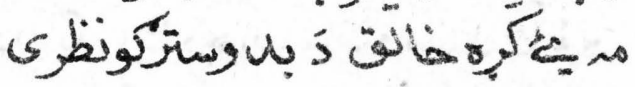

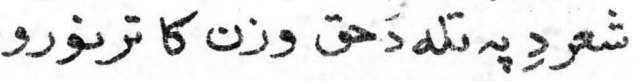




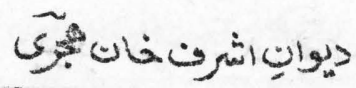

كله مثن

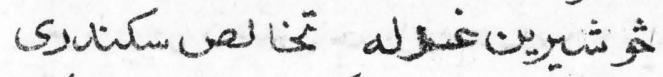

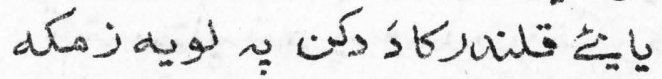

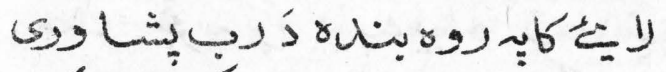

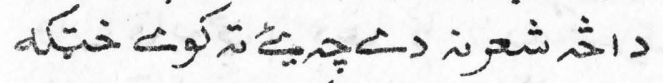

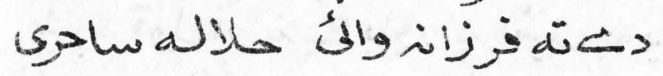

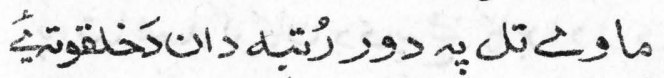

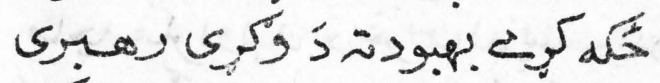
بنه

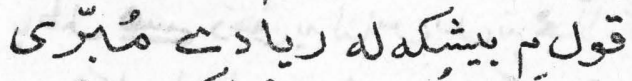
a

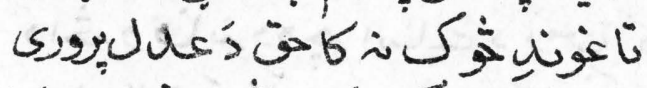

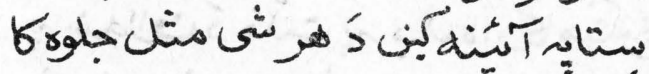
ज) بي 1 منال

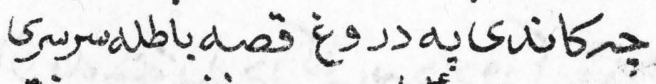

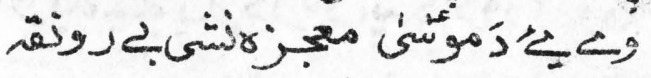

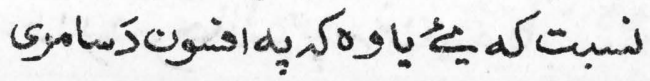




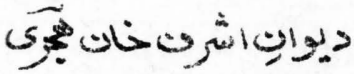

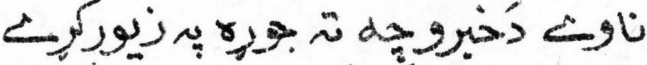
هاك

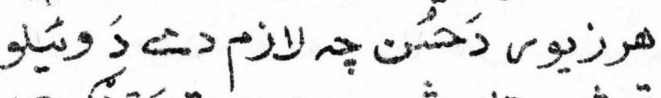

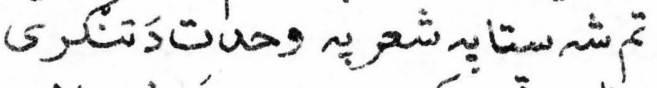

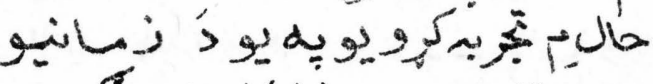

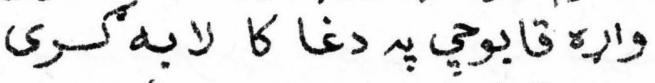

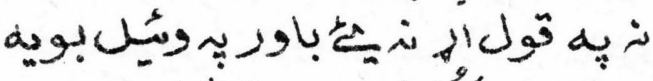

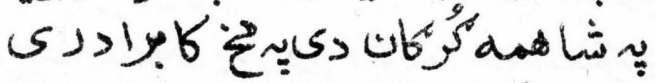

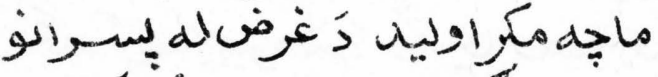

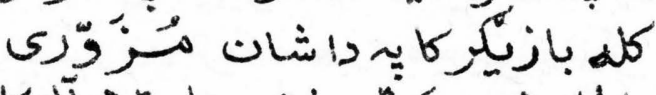

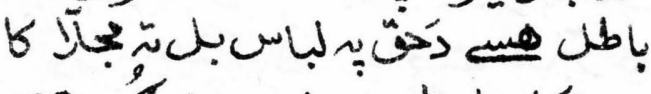

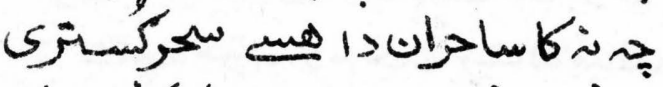

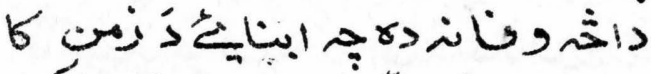

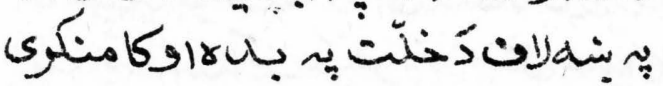

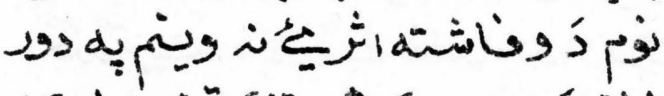

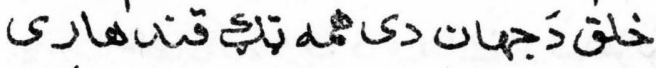

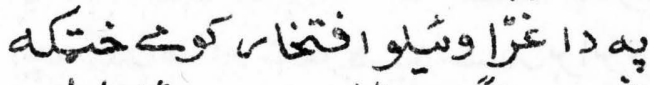

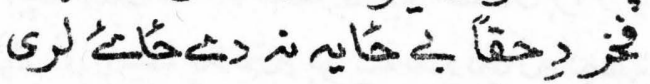

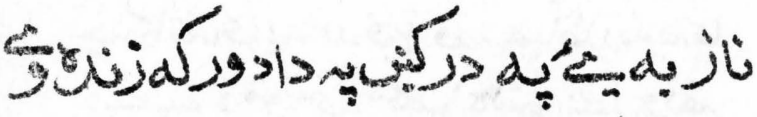
(5) 3. 


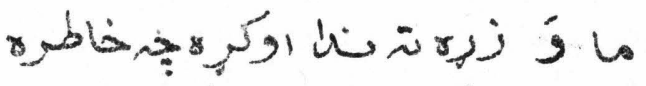

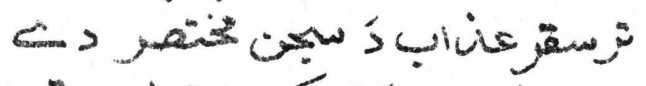
然 Lبوبام

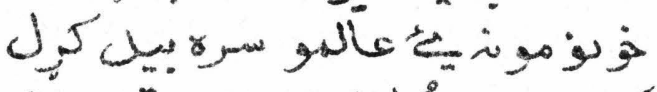

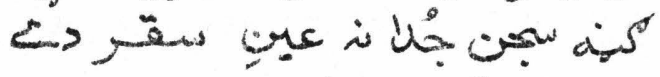

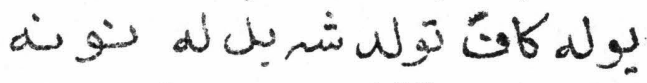
ه ه

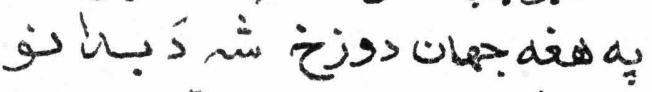

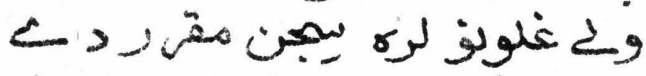

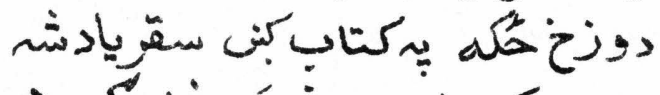

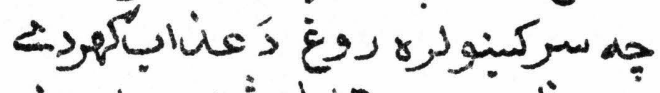

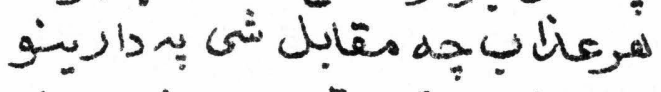

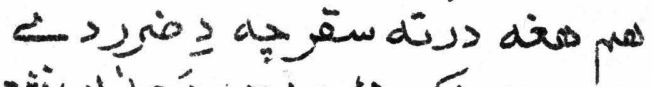

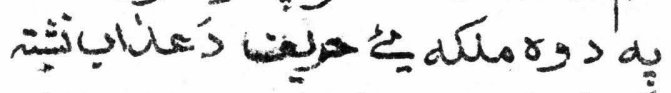

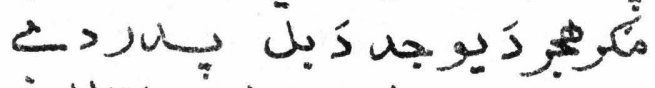

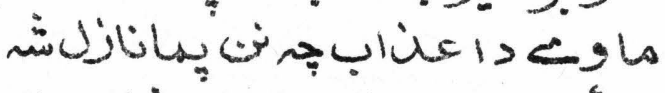

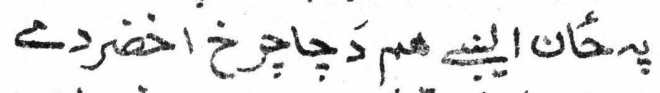
و

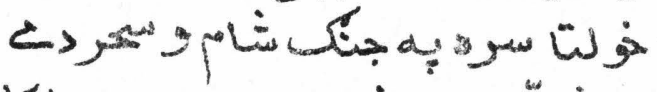

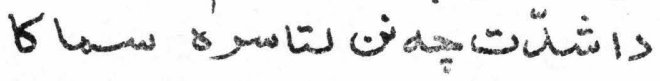




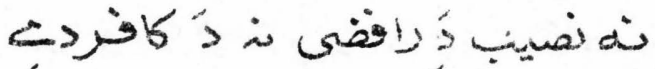

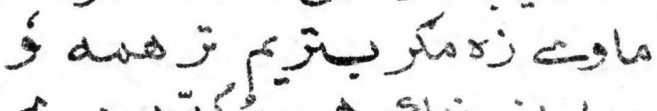
$\Leftrightarrow$ Júl

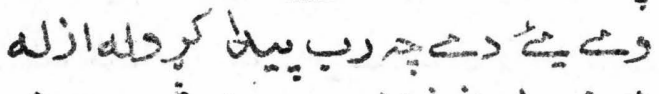
$\Leftrightarrow$

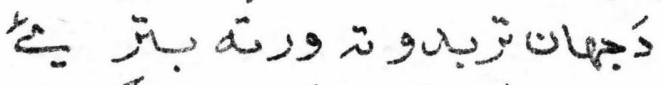

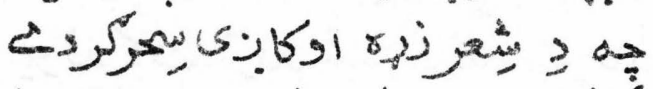

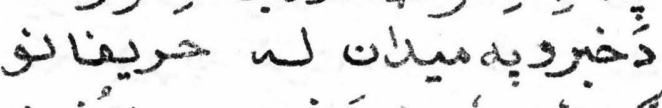

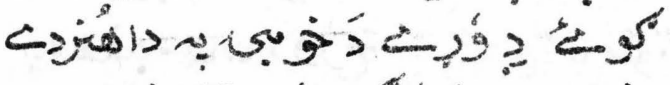
فزان

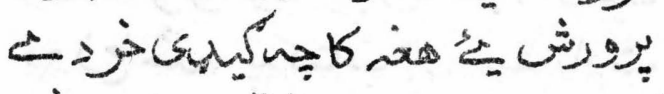

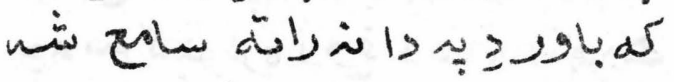

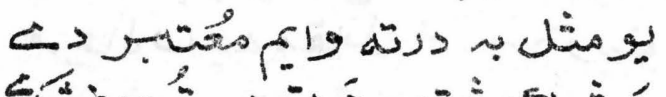

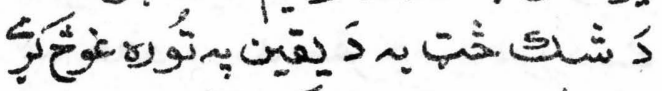

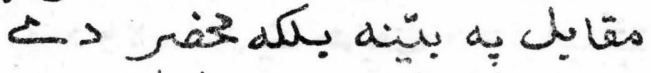

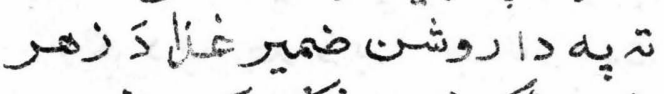

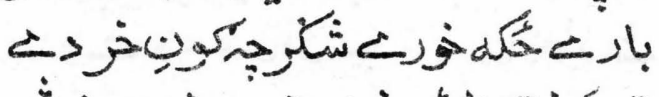

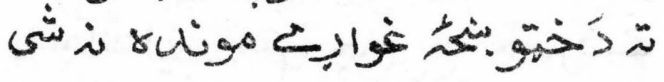

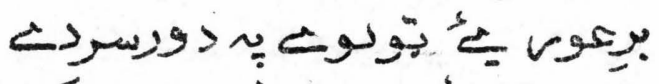

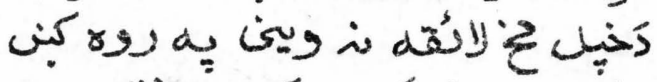
م 


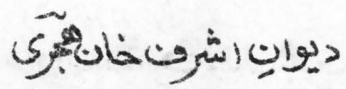

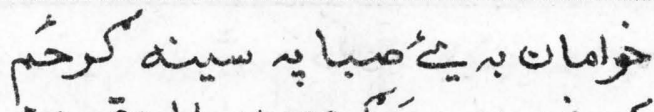

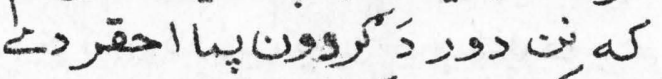

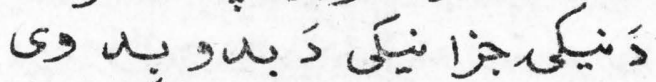

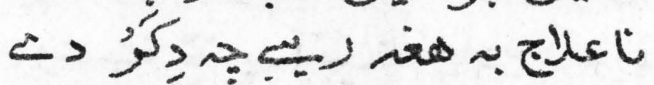

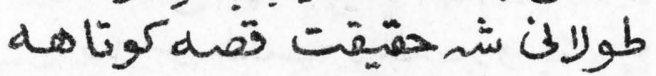

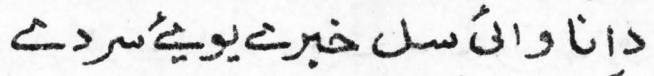

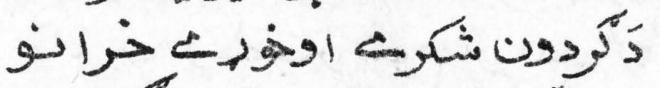

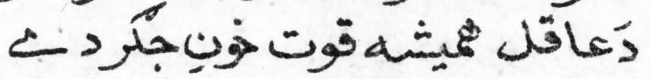

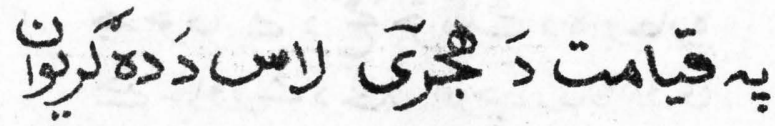
ثر

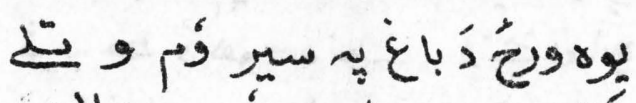

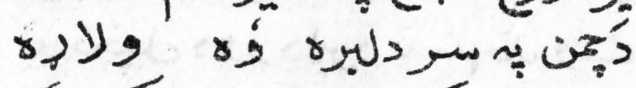

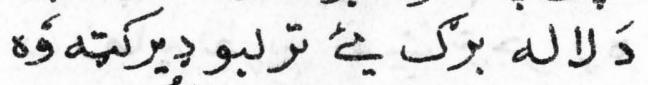
يها

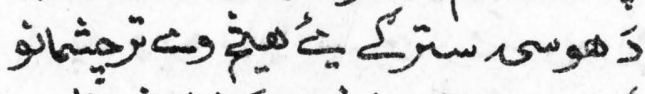

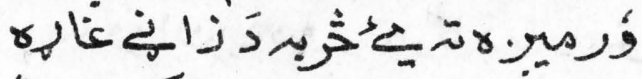

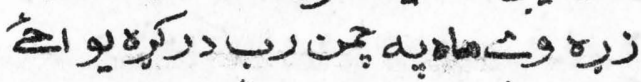

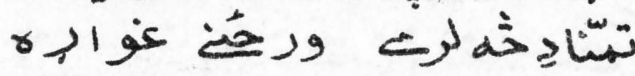

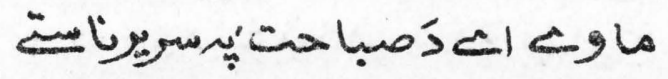

$\Delta \Delta \psi$ 


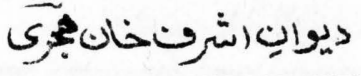

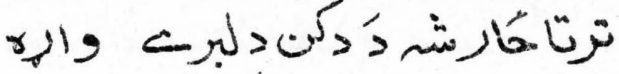

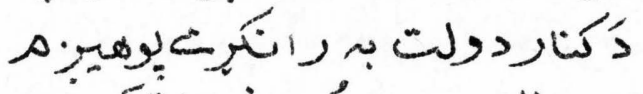

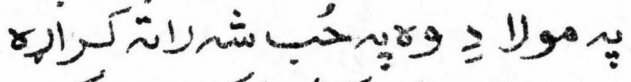
و

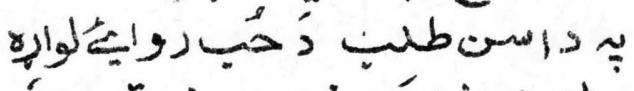

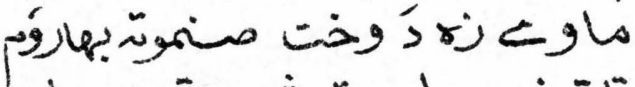

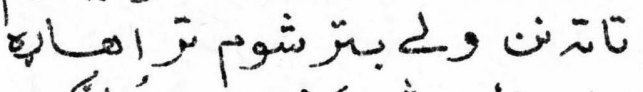

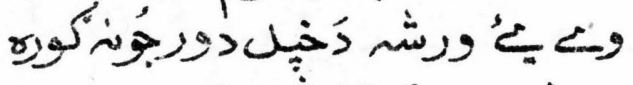

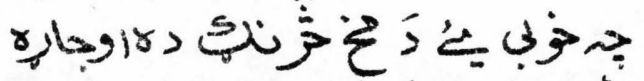

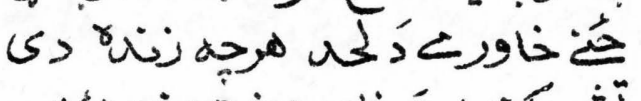

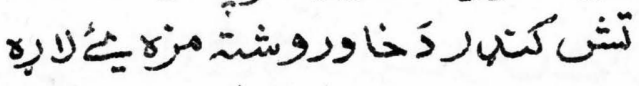

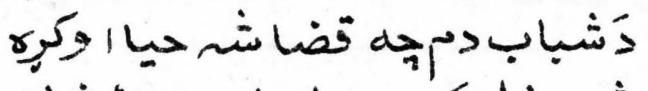

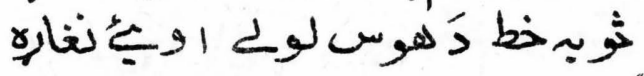

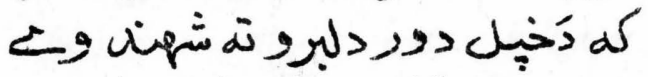

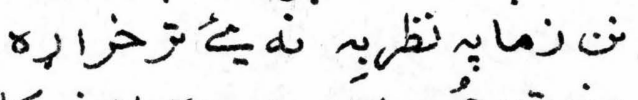

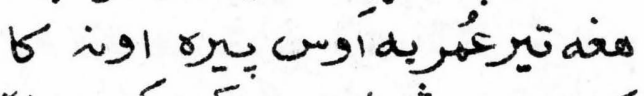

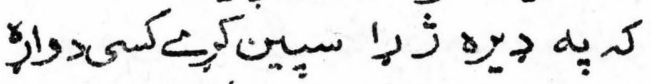
جه نه خهن يه حست ئثة \% 


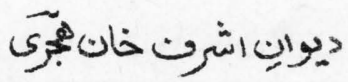

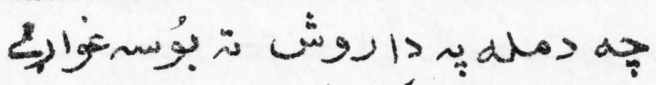

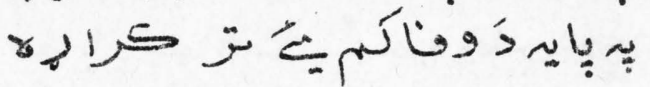

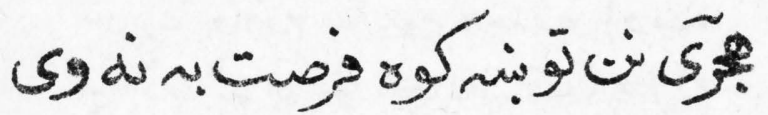

:

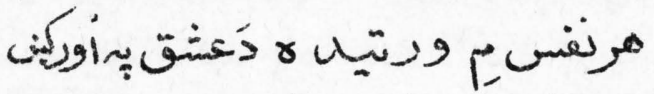

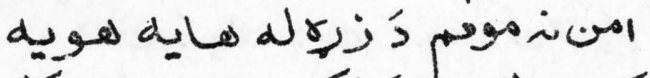

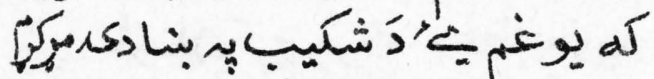

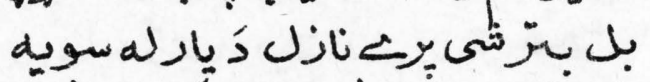

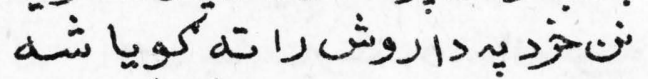

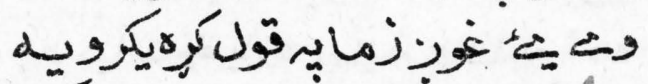

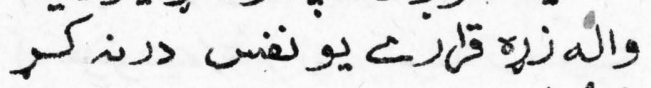

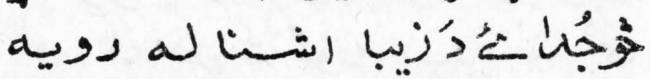

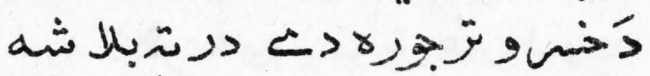
سودي حُخه >

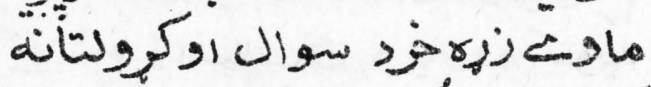

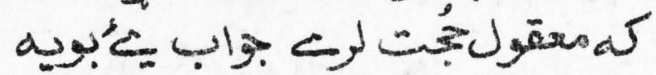

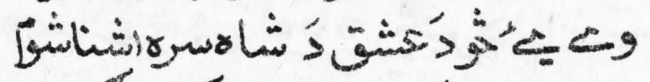

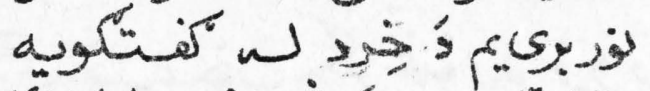

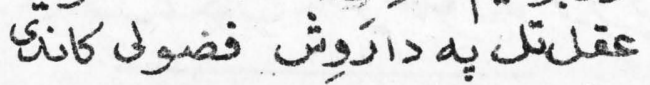

$\triangle \Delta \theta$ 


\section{حيوانِاشرنخان برى)}

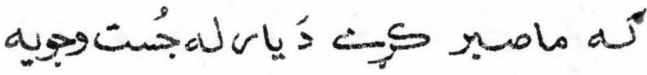

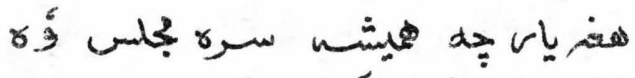

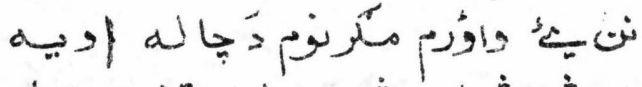
لها

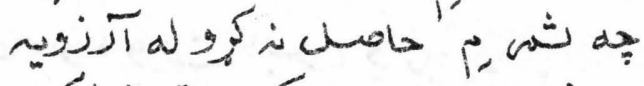

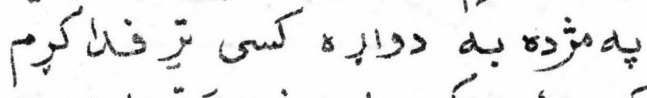

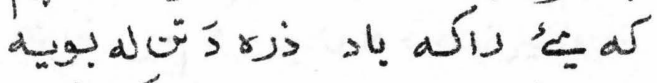

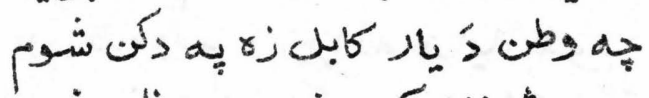

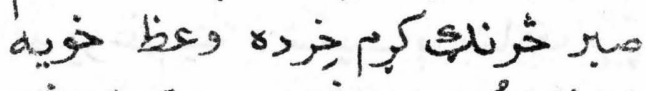

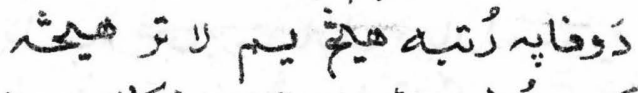


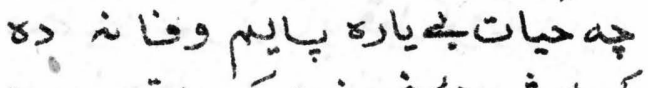

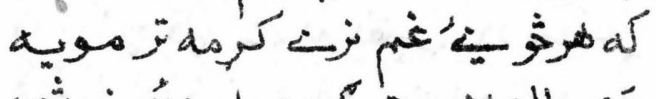

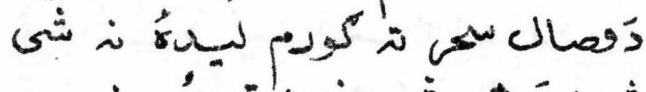

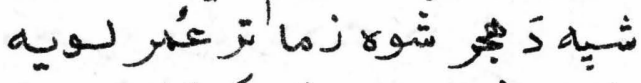

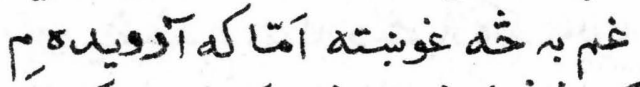

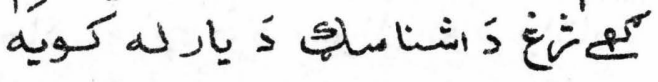



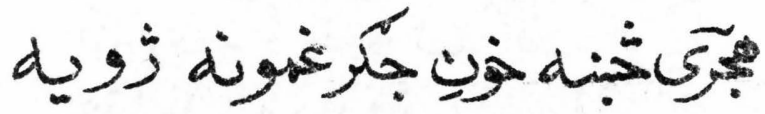




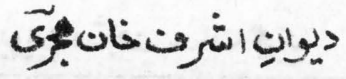

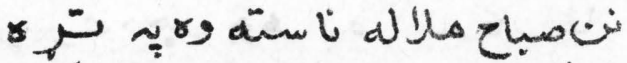

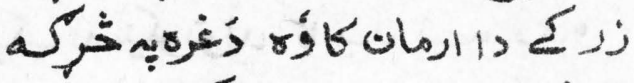

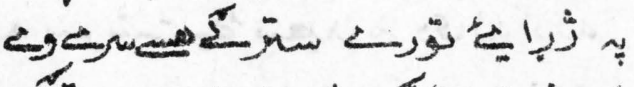

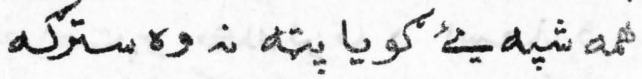
و قبيل

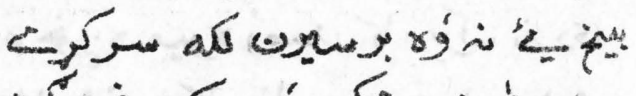

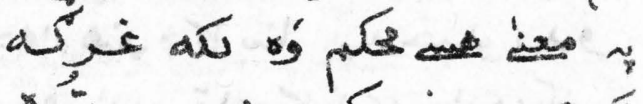

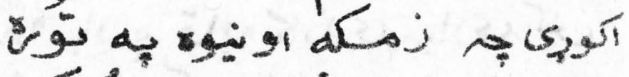

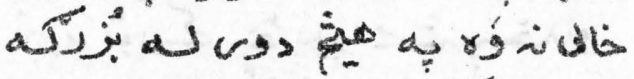
نائهة

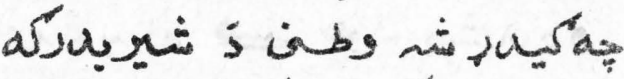
.

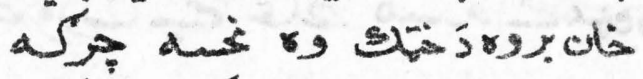

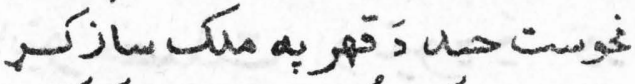

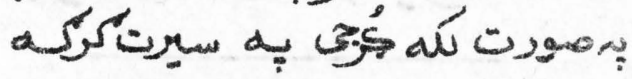

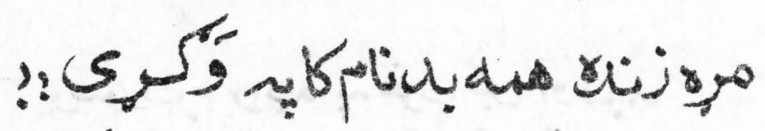

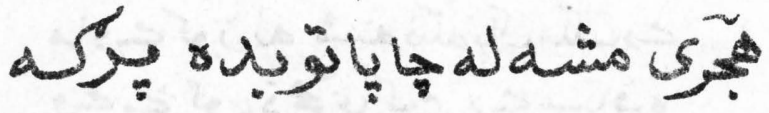




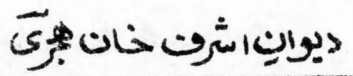

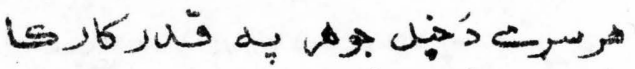

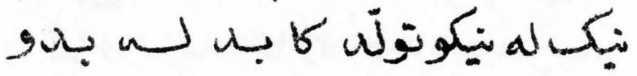

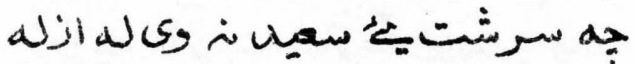
ول ها

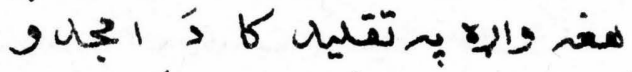
كا

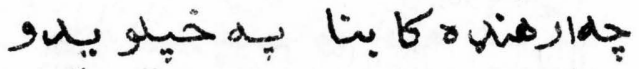

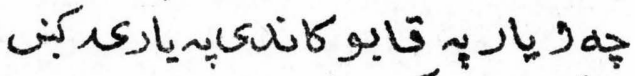

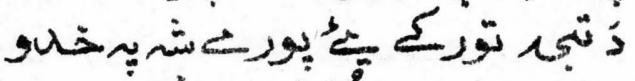

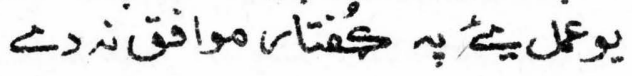

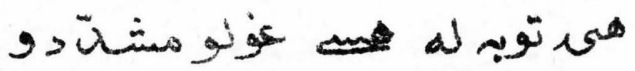

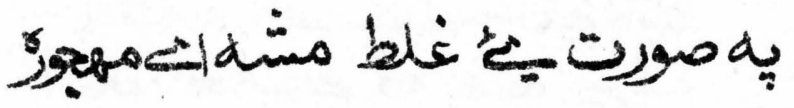

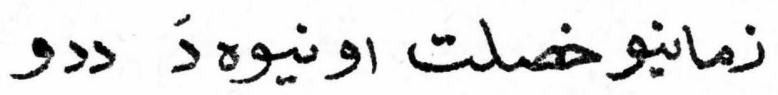

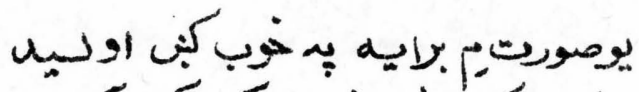

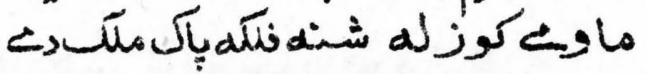

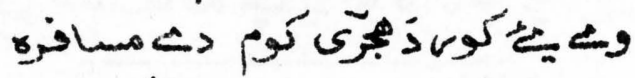

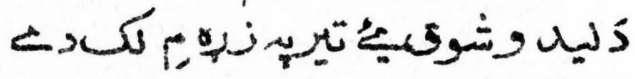




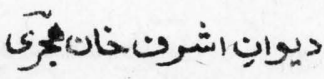

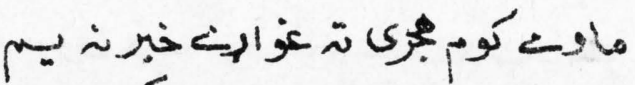

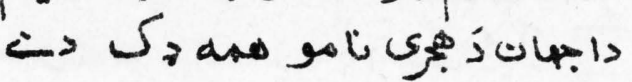

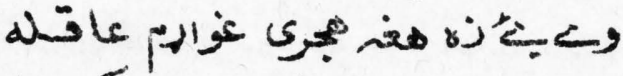
جه

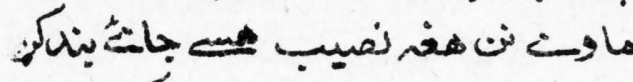
$\Leftrightarrow$ كان

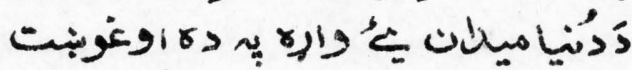

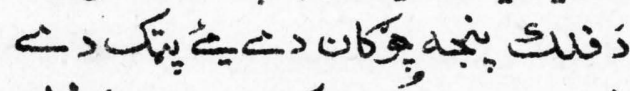

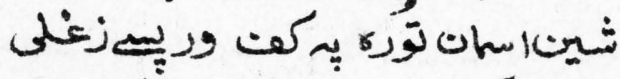

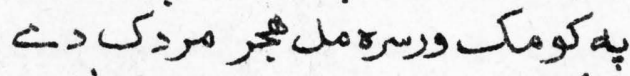

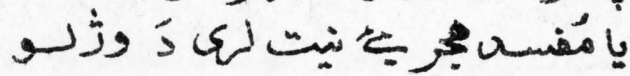

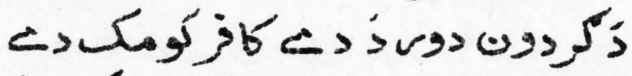

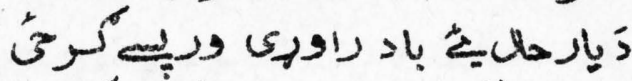

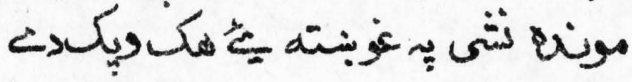

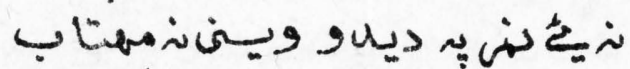

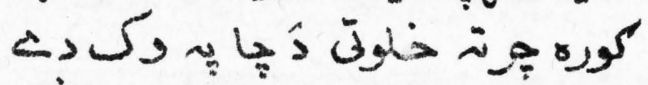

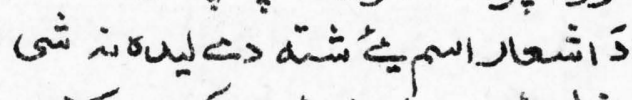

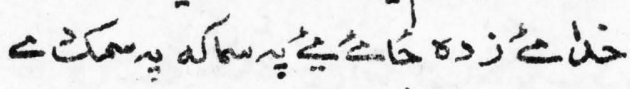
ه $\Leftrightarrow$

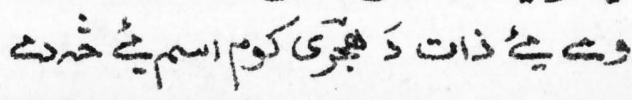




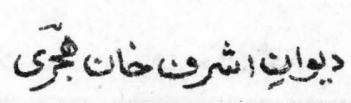

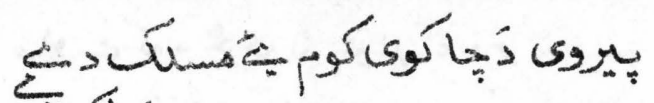

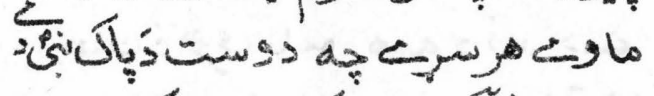

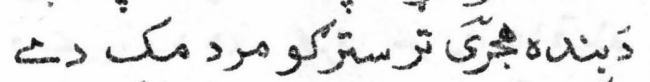

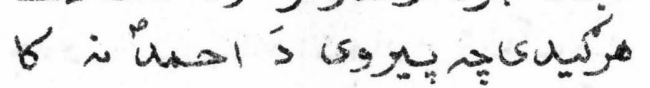

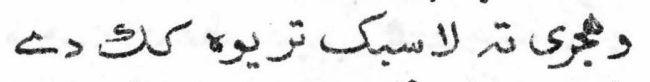

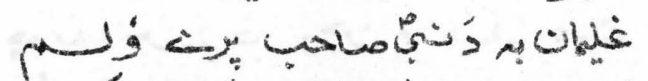

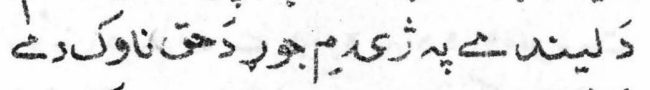

'

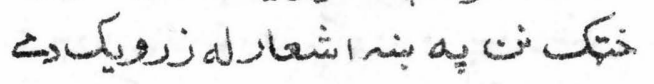

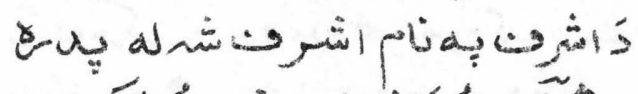

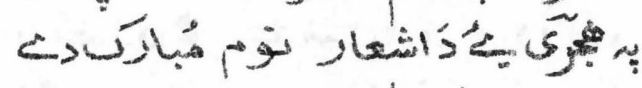

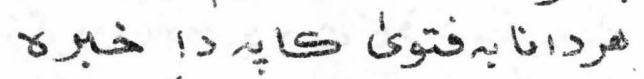

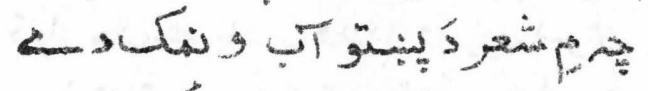

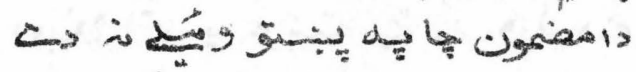

كنيسن

و

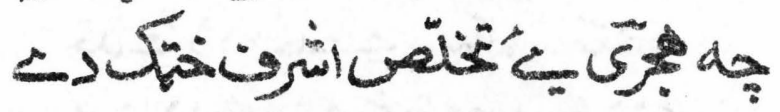

4: 


\section{ديوائاشرتخاتبريَ}

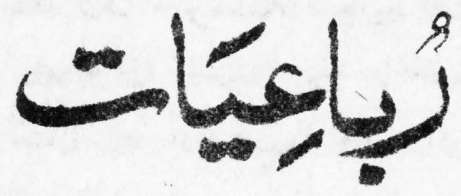




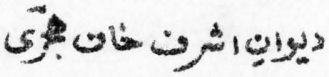

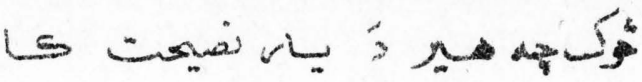

Lom

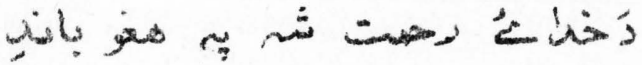

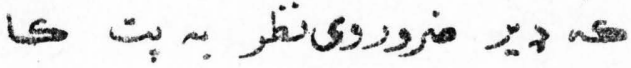

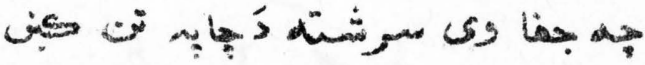

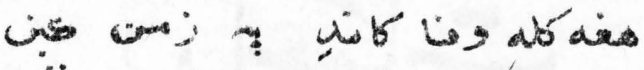

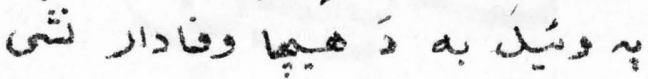

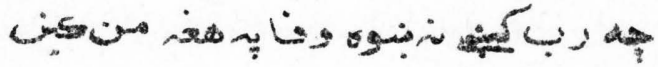

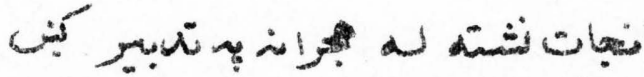

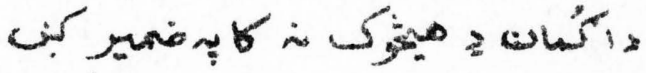

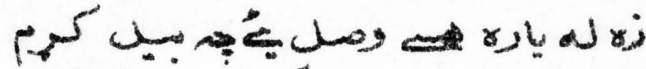

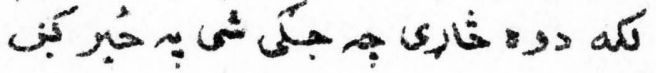

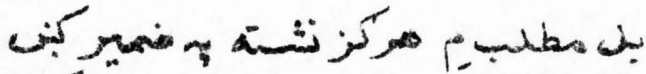

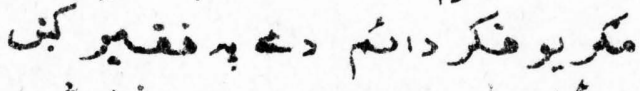

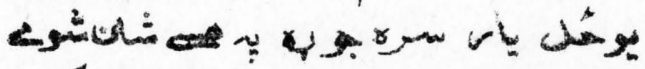

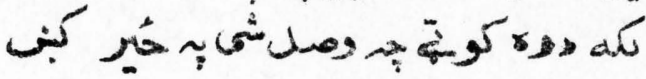




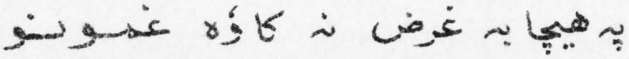

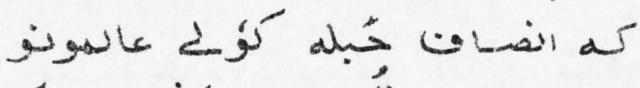
جه

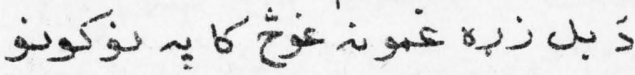

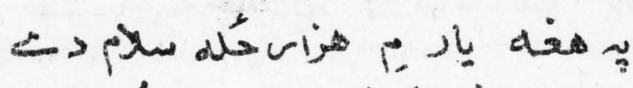

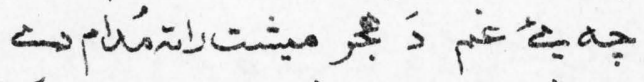

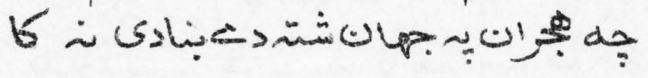

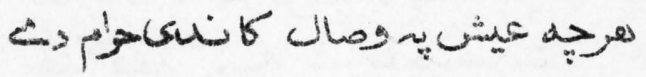

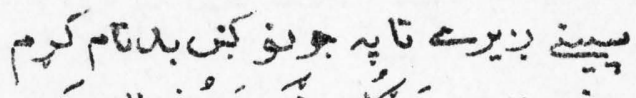

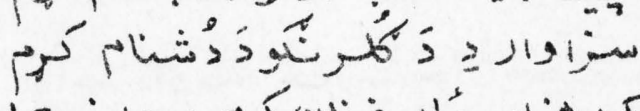
كله هن

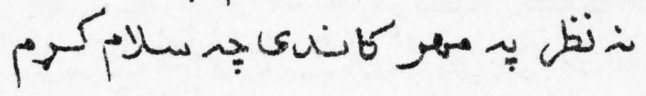

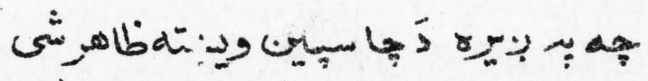

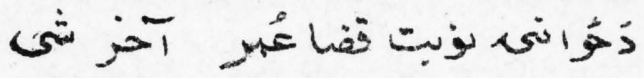

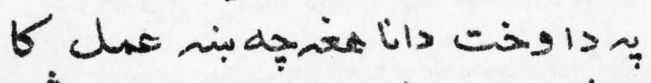

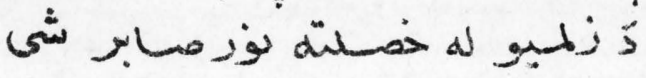


يوانِ

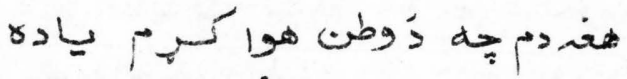

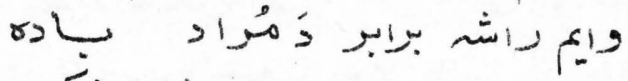

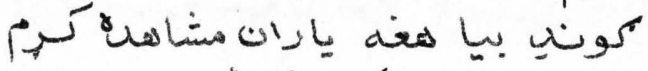

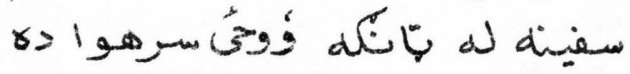

Gs

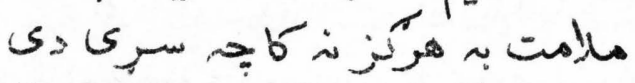

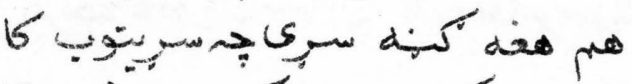

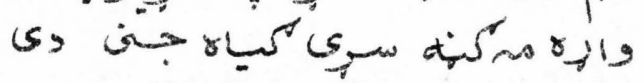

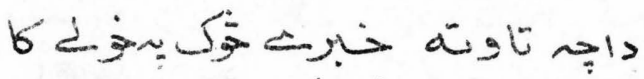

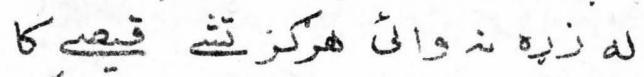

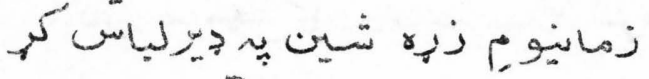

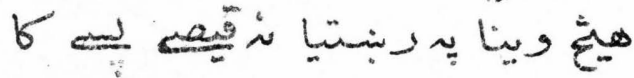

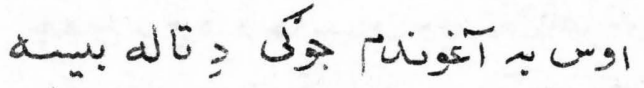

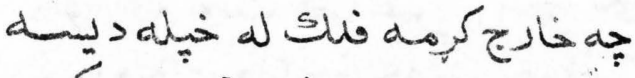

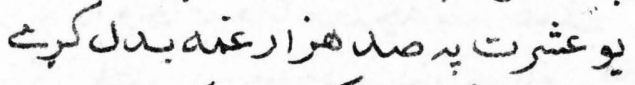

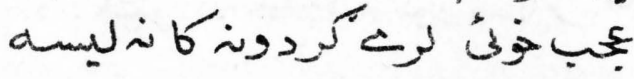

$\Delta 4)^{\circ}$ 
حيوانِ اشربت هات هُرى

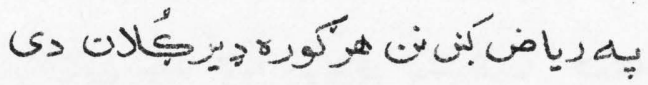

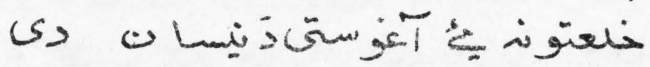

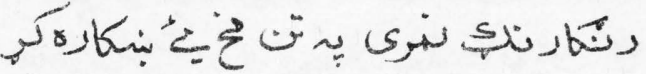

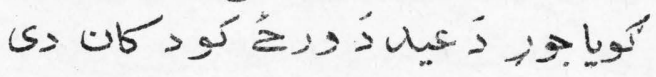

جو

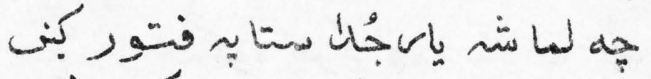

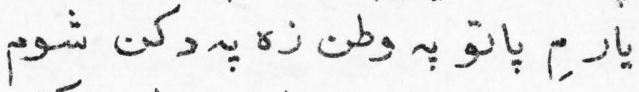

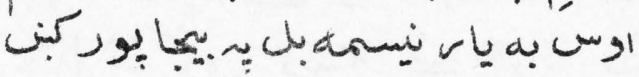

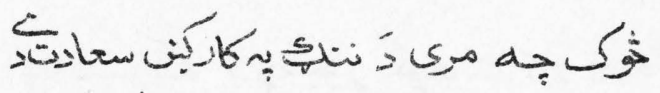

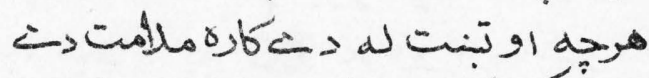

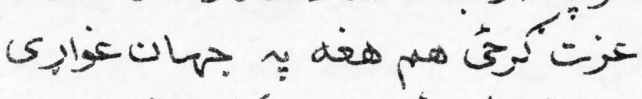

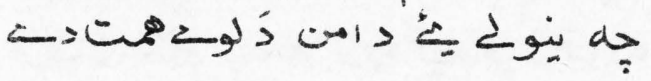

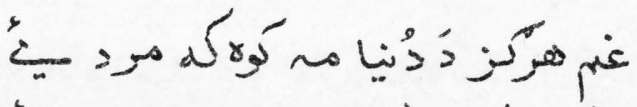

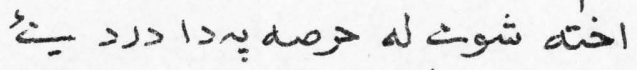

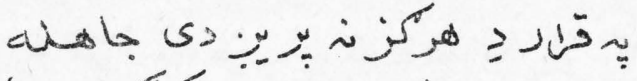
\&

Q 40 


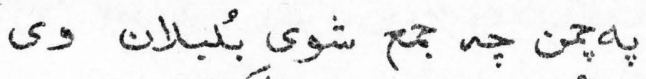

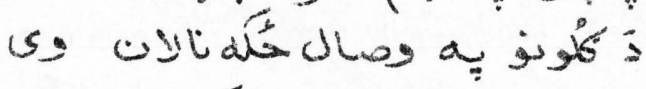
هرز s) وريسية

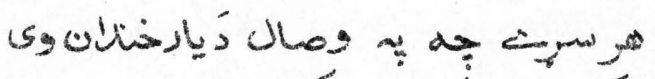

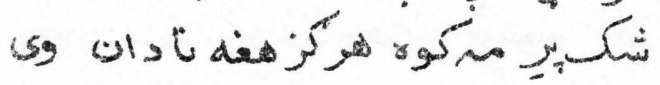

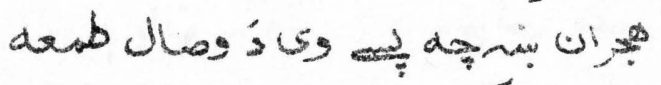
(5)

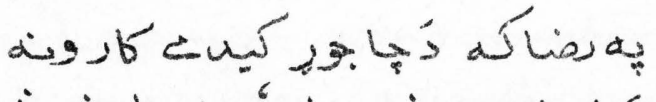
كَ

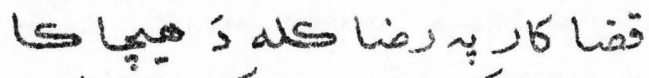

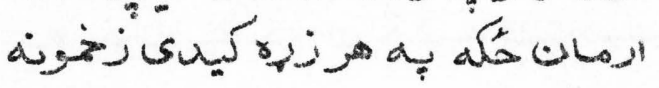

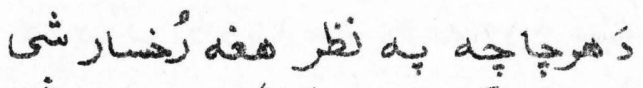

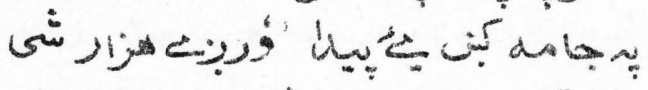

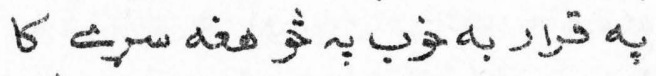
国 


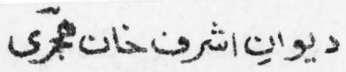

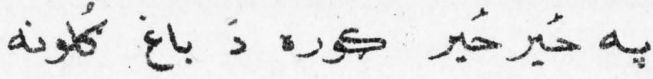
نو

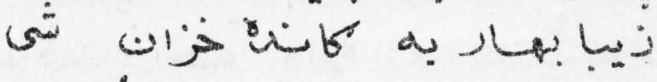
مئم

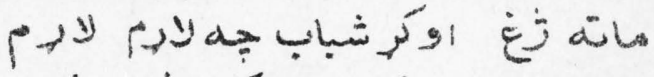
كا دَ

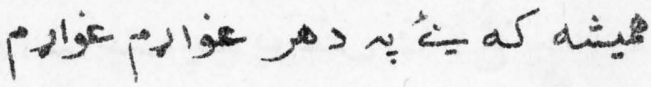

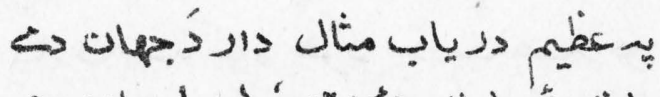

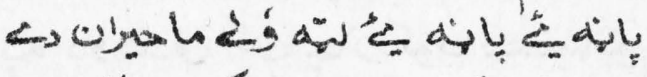

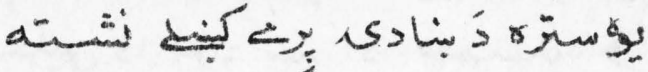

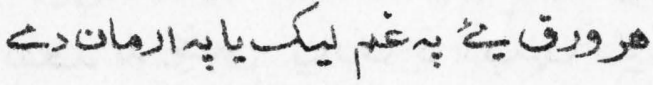

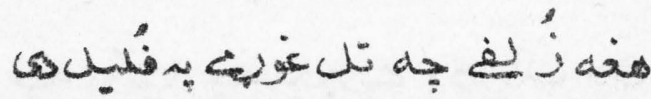

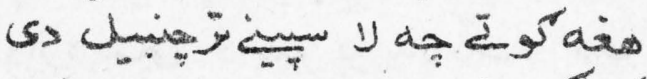

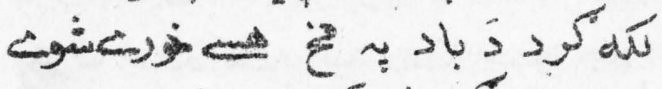
(5) ل 


\section{يوانيخاشرت خلن هيرى}

ڤ

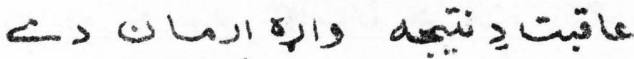

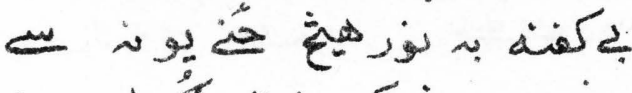

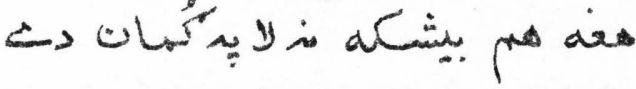

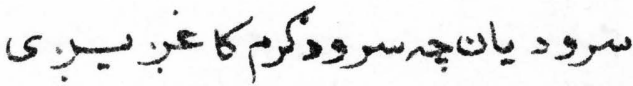

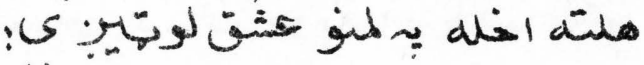

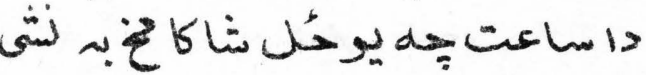
sأlis

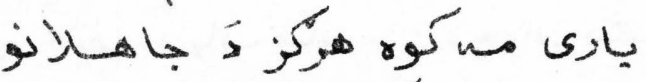

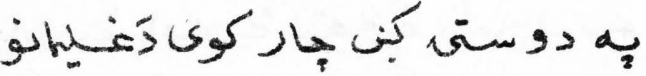

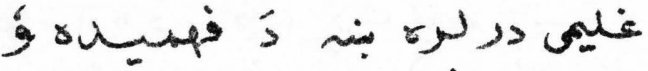

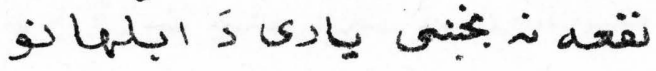

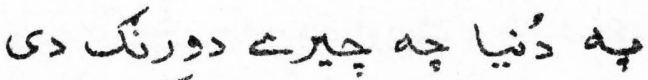

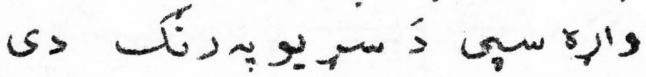
r (s) 


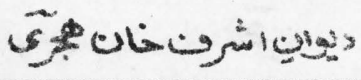

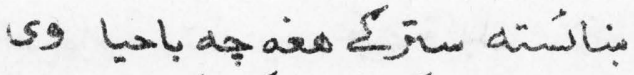

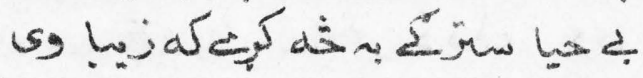

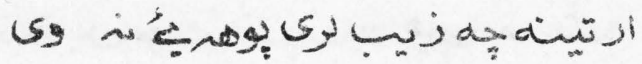

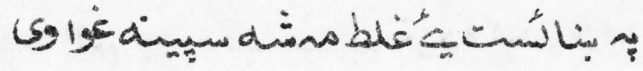

v)

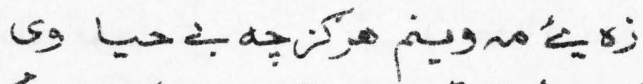

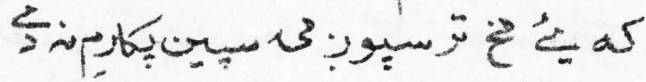

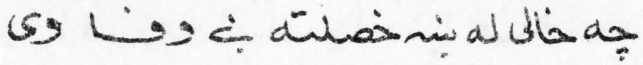

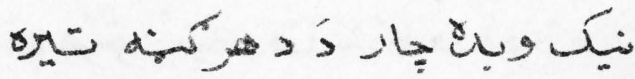

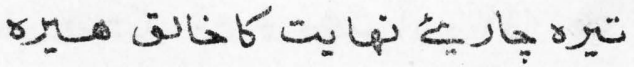

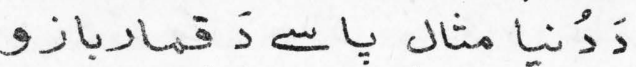

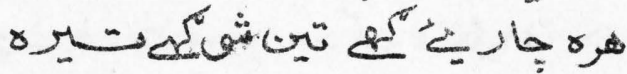

قو

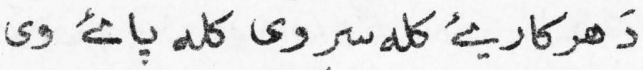

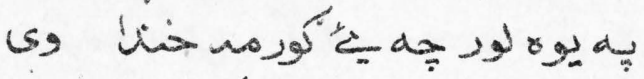

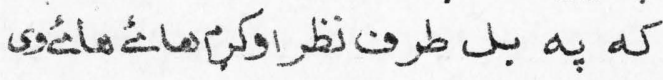




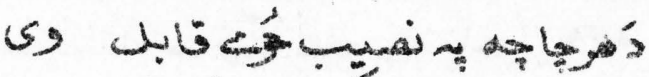

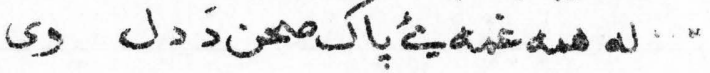

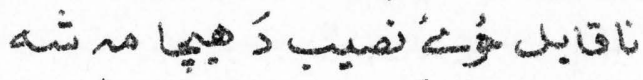

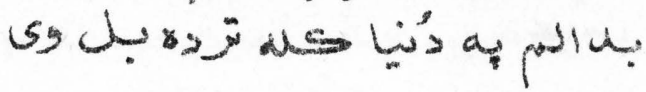

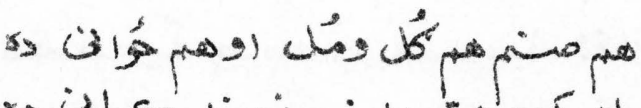

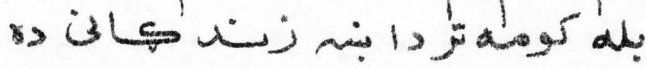

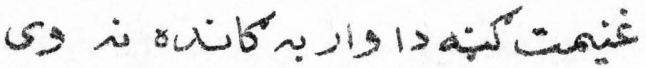

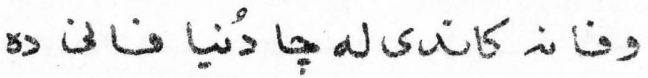

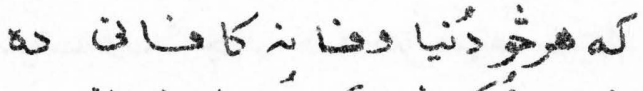
a

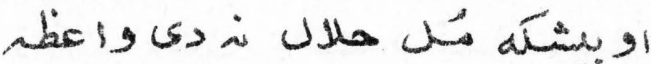

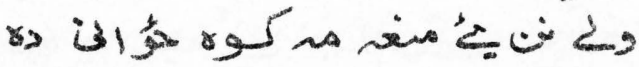

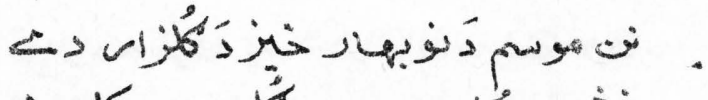

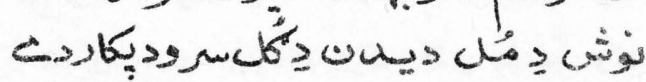
6 a sam

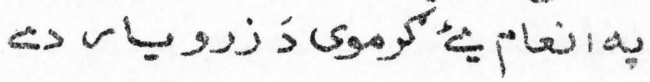




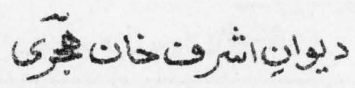

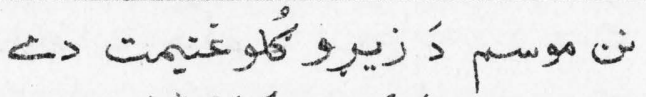

$\Leftrightarrow$ بهارد

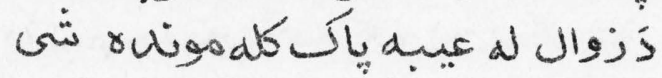

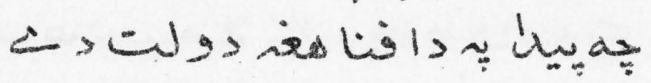

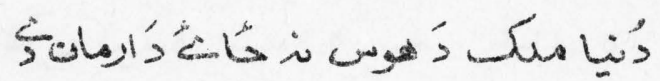

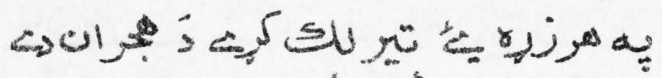

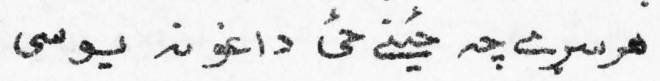

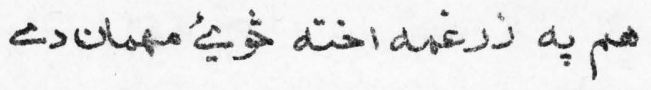

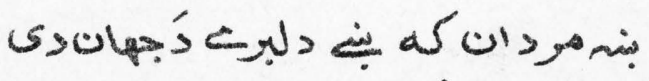

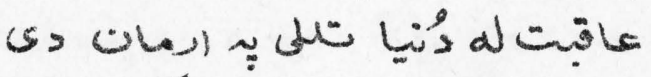

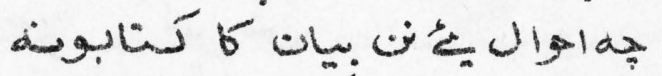

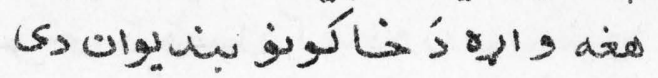

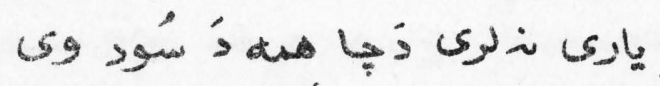
(s) grain's

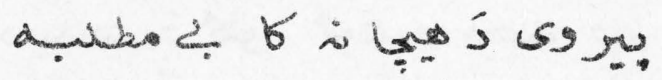
(s)

$\Delta V I$ 


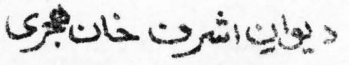

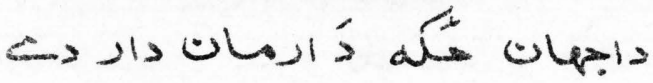

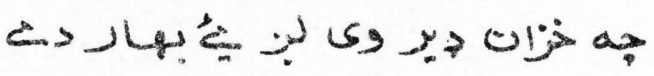

L L

Lد

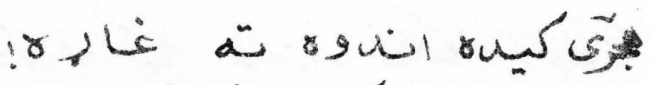

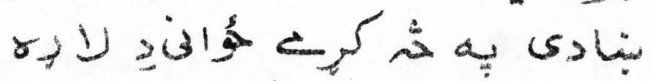

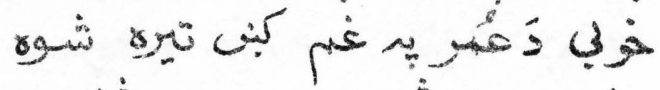

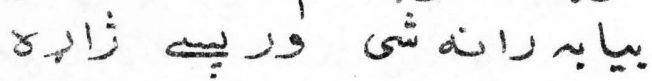

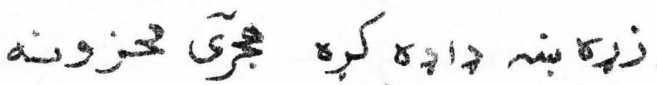

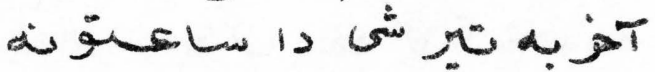
خوشى

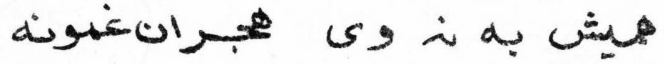

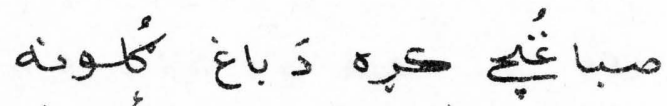

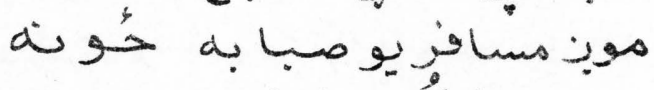
دئل

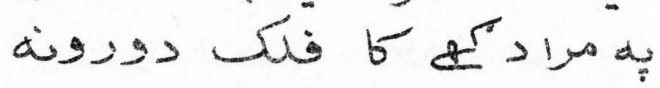

DVP 


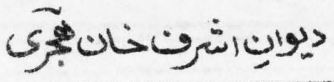

غنيمت شَماره دا بنم وختونة ياركجه وينو سرونه

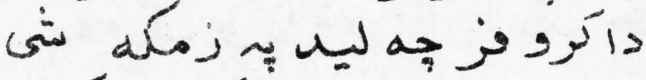

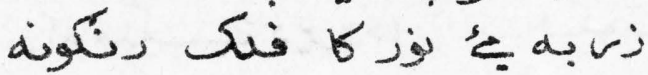

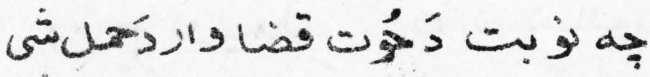

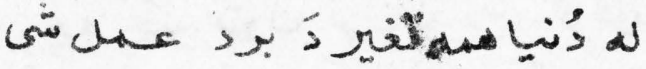

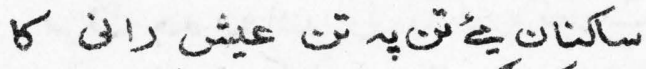

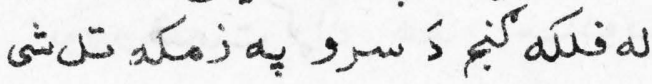

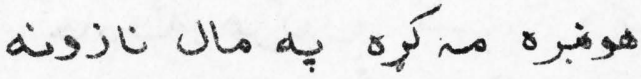

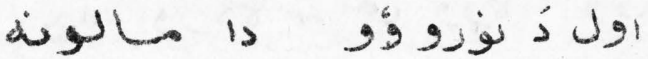
ك الت بـ

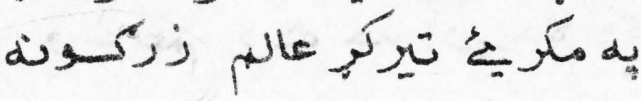

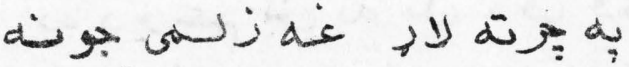

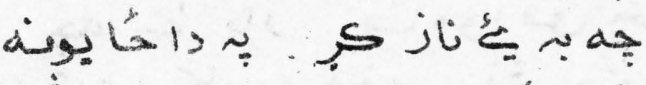

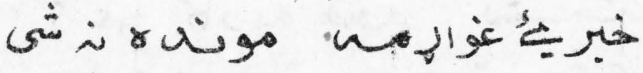

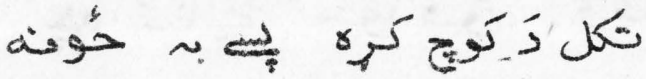




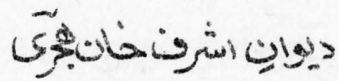

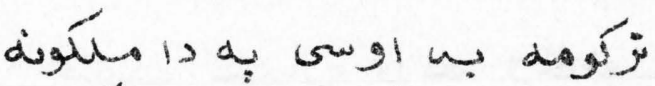

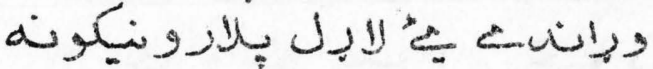

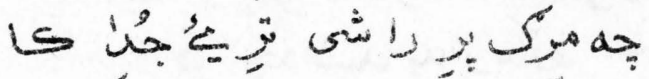

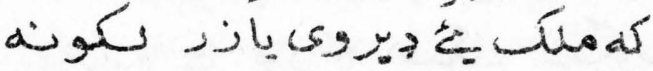

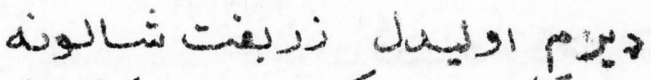

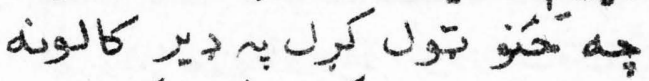

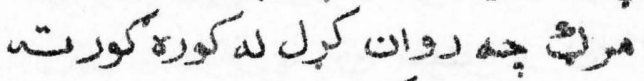

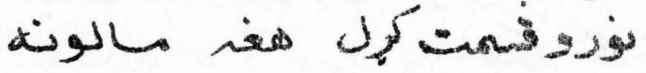

s

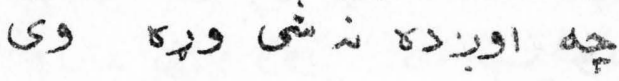

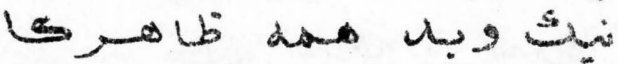

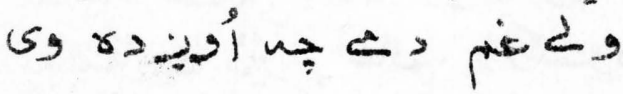

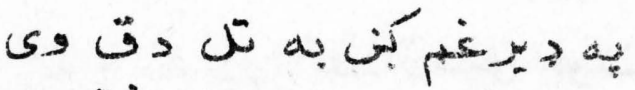
كانه un dis dis os vو

ovis 


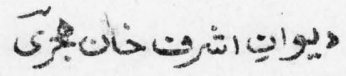

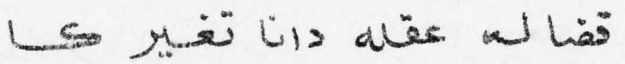

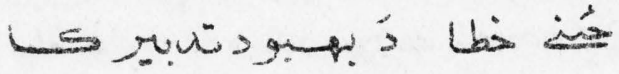

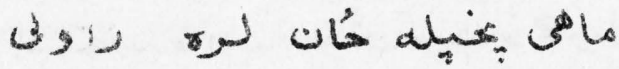

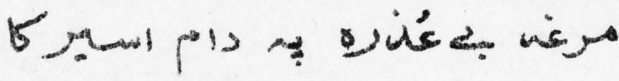

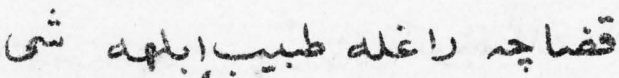

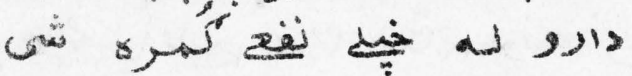
6 كار

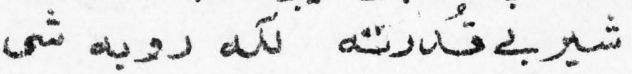

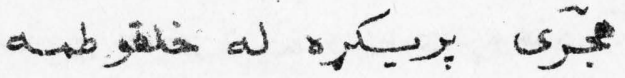

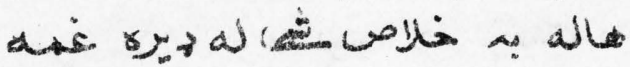
$\Leftrightarrow$ अو davi uglis

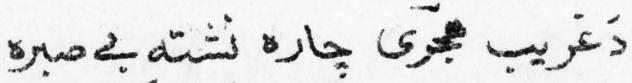

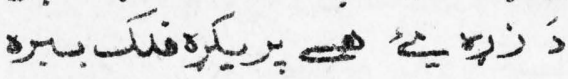

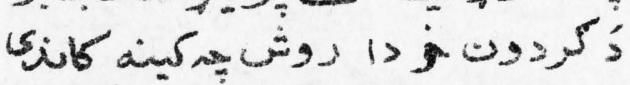
ه

$D \vee 0$ 


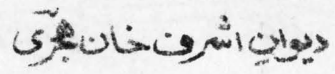

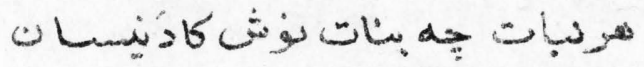

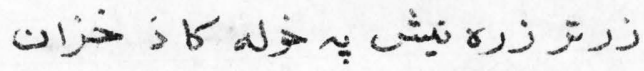

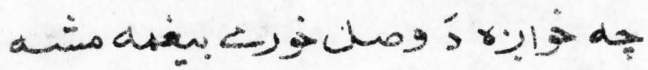

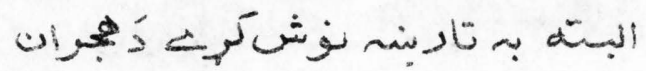

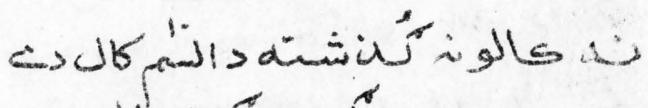
$\Leftrightarrow$ U ل

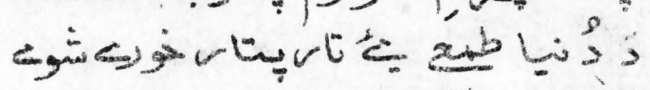

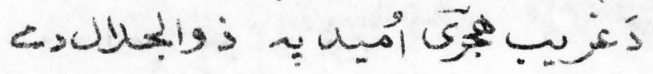

ران

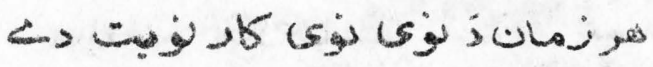

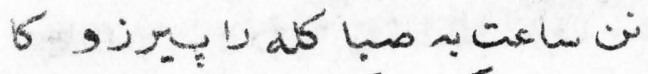

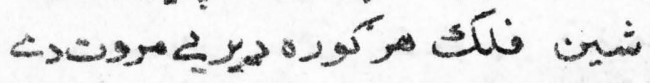

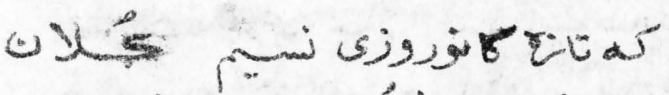

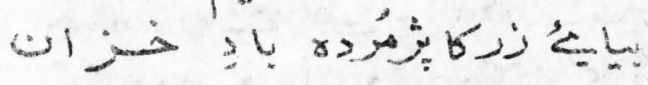
(5) سله لd كال

$\Delta V 4$ 
ديوانِاستونهانبرِ

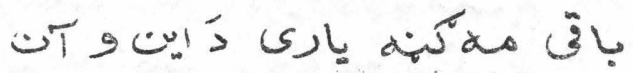

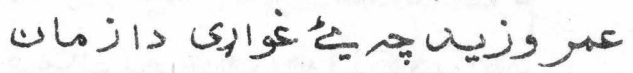

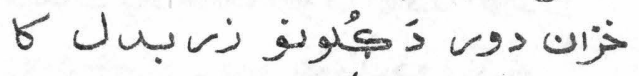

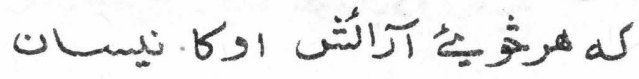

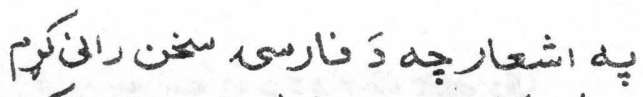

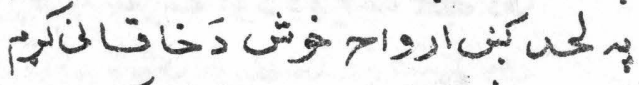

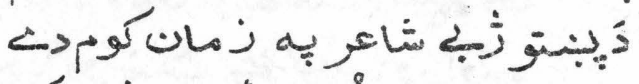

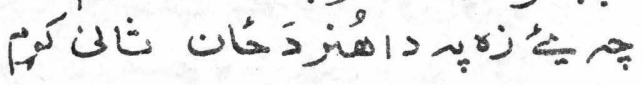

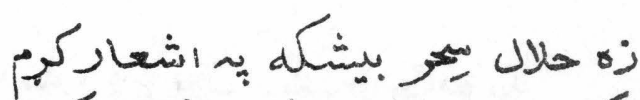

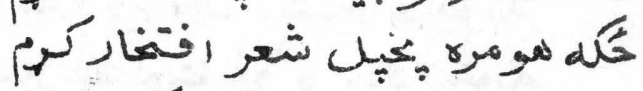

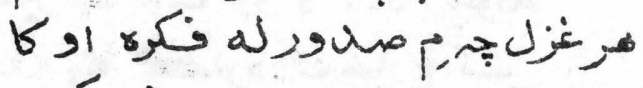

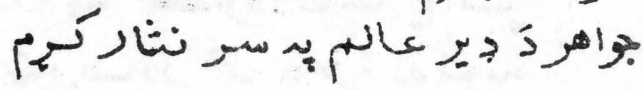

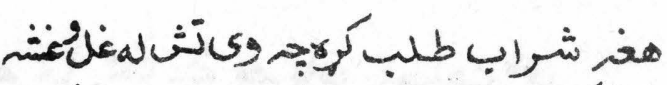

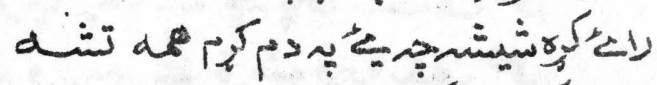

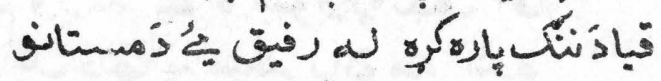

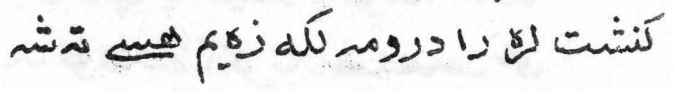

DVV 


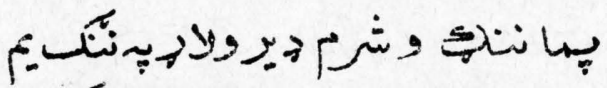

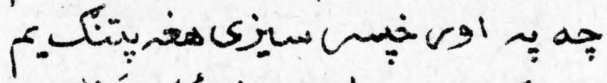

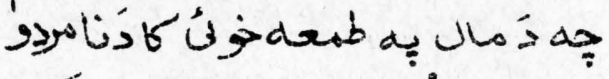

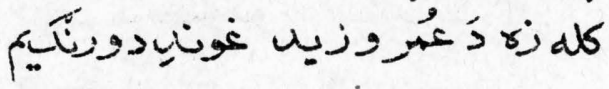

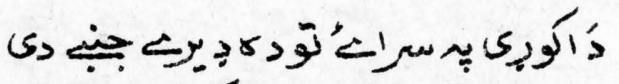

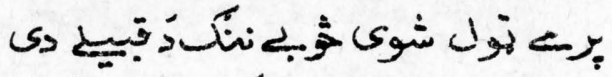

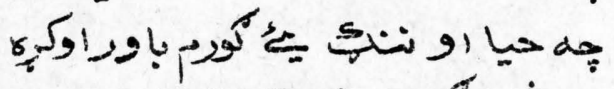

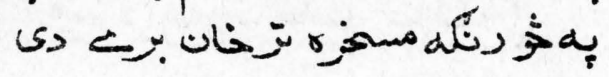

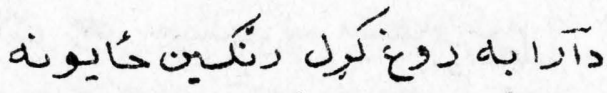

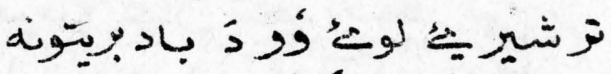
كله

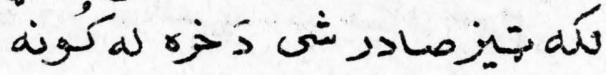

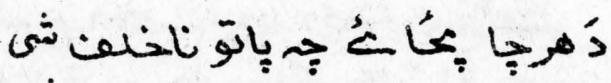

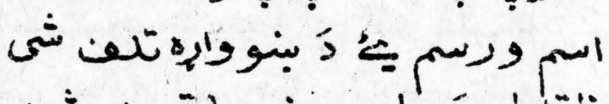

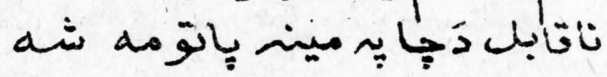

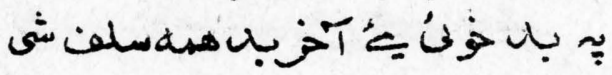




\section{حيوانِاشربخانجئي}

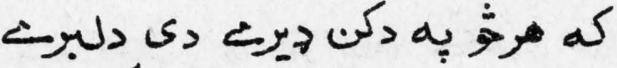

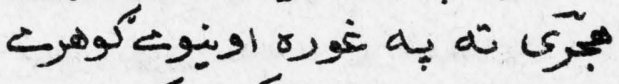

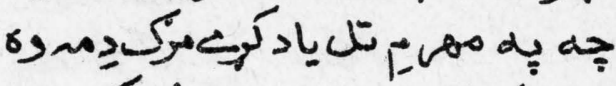

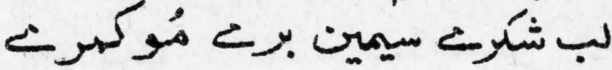

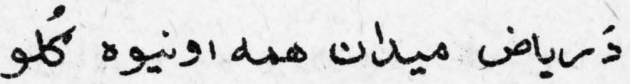

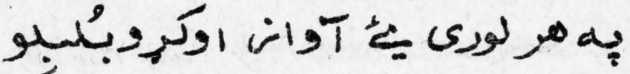

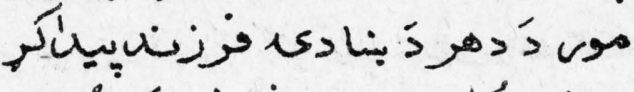

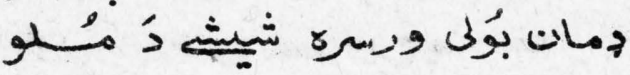

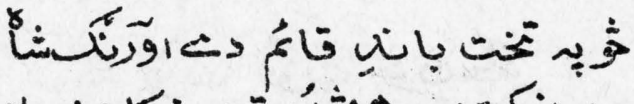

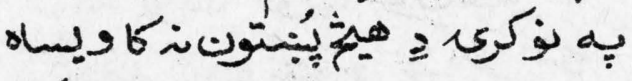

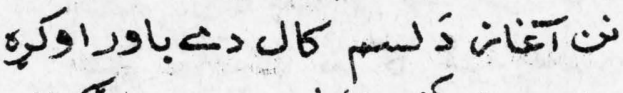

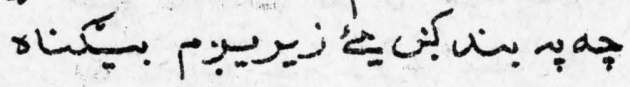

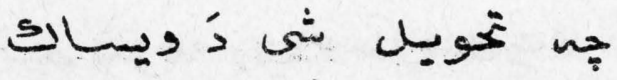

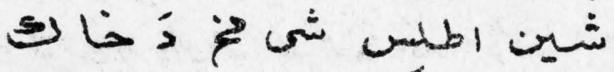

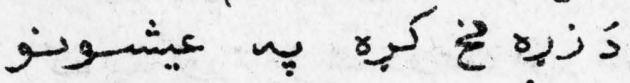

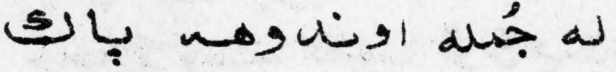




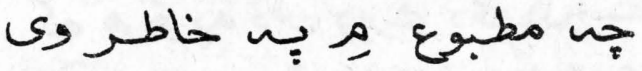

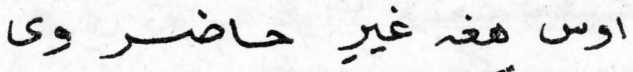
$\Longrightarrow$ i vk

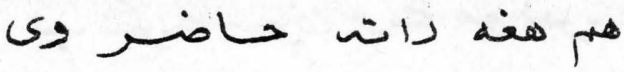

كَ

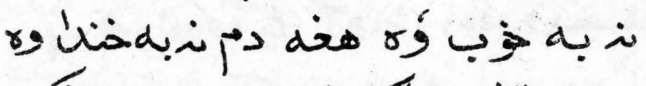

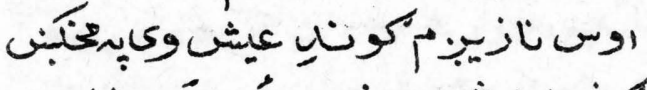

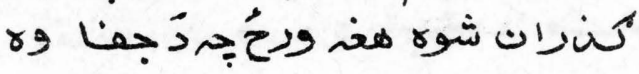

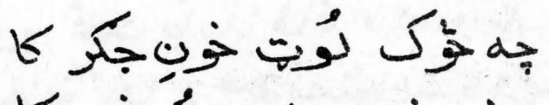

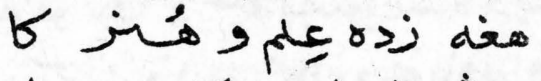

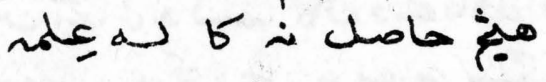

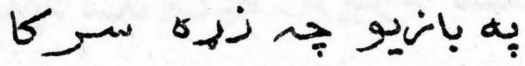

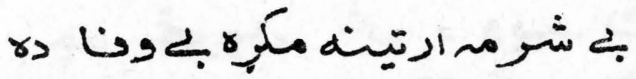

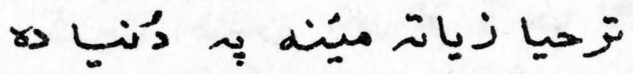

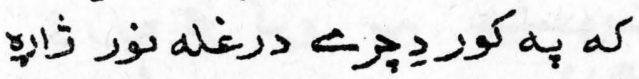
وبيه ر'وستر نضيب تونعا بـلادها 


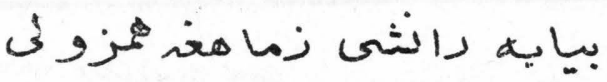

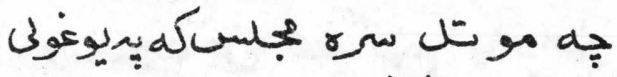

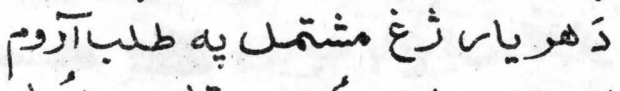

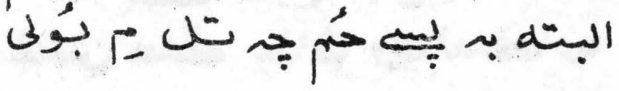

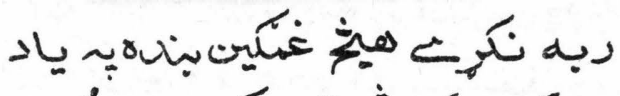

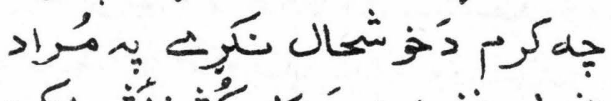

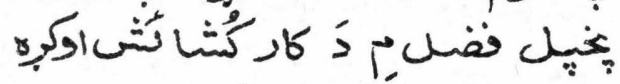

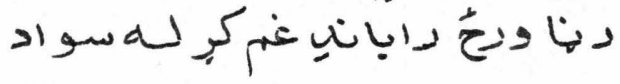

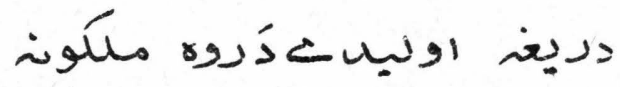

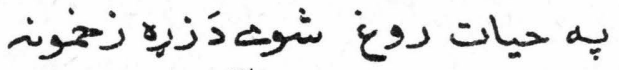

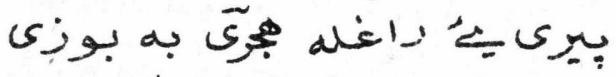

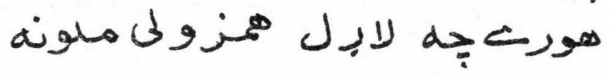

زه"

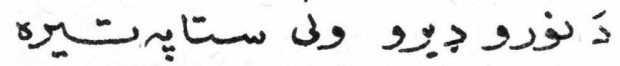

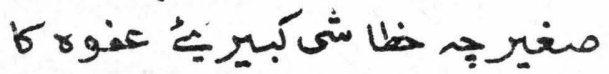

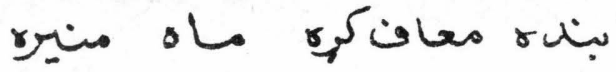




\section{ديوانِاشرتخانجئي}

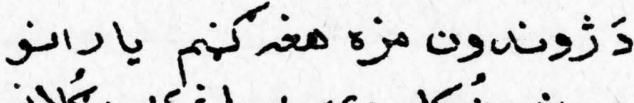

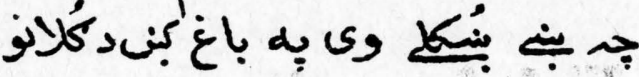

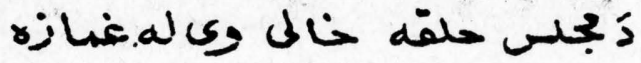

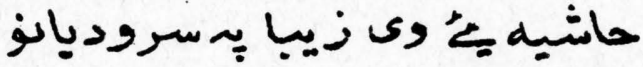



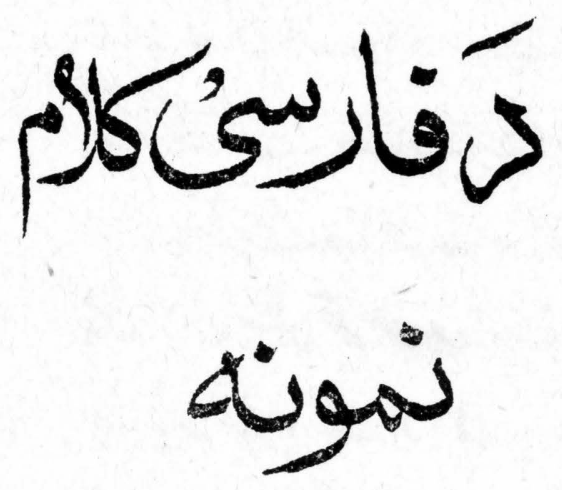

آه

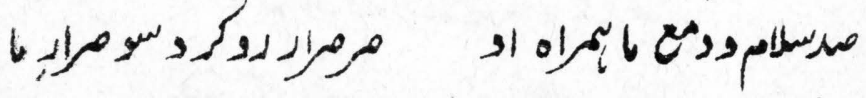

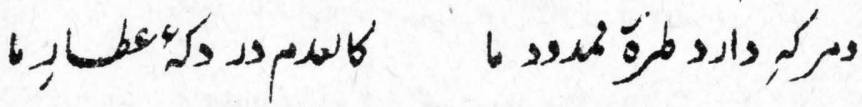

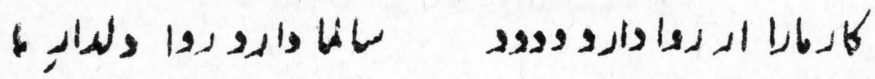

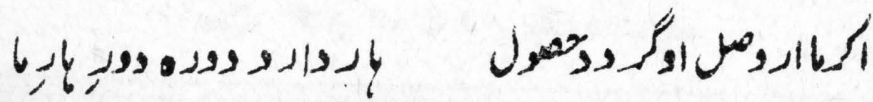




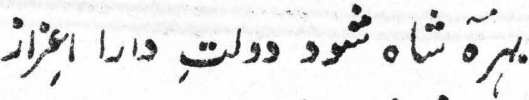

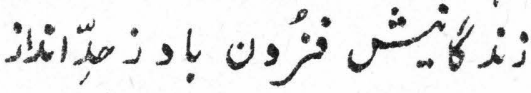

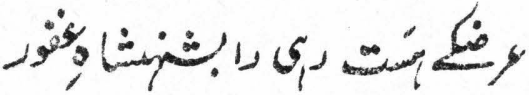

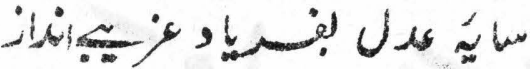

,

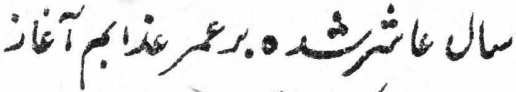

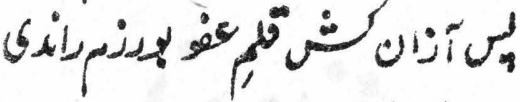

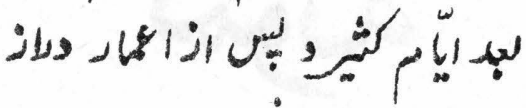

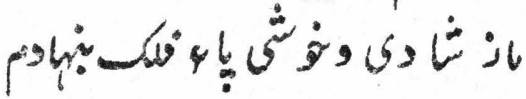

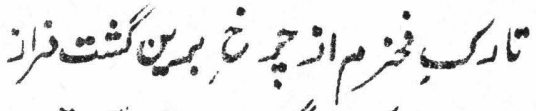

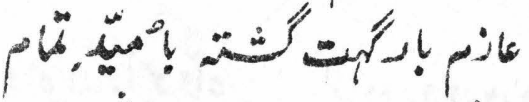

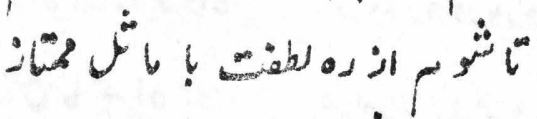

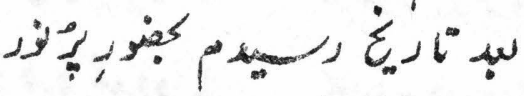

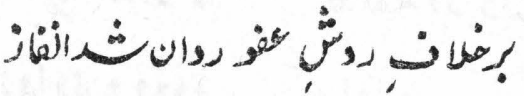

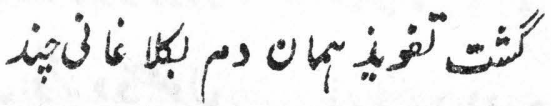




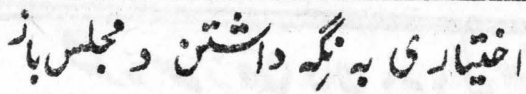

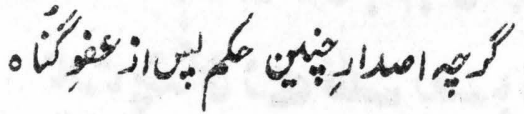

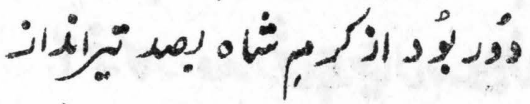

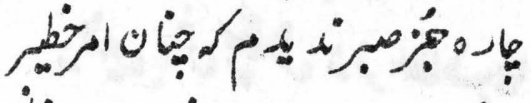

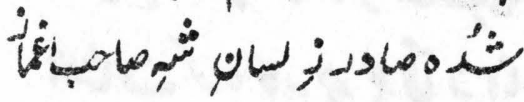

انان

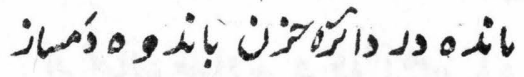

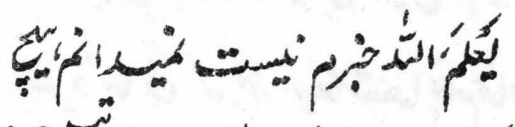

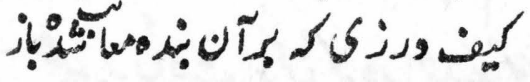

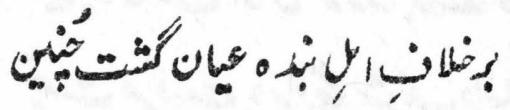

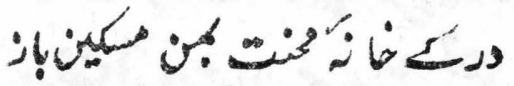

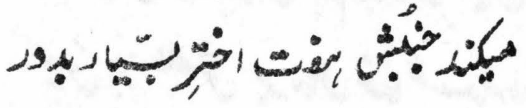

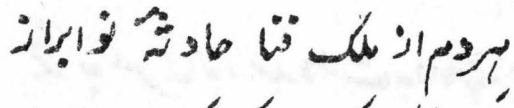

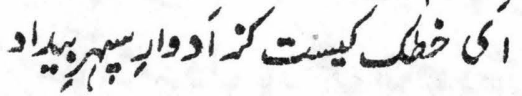

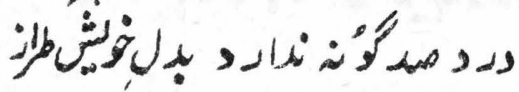




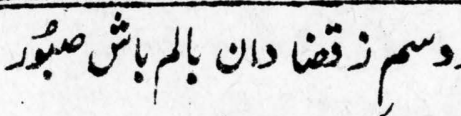

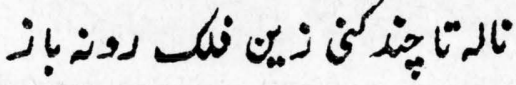

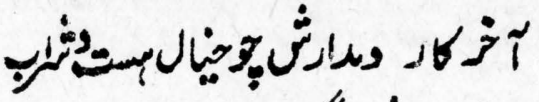

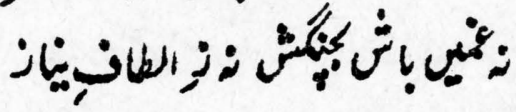

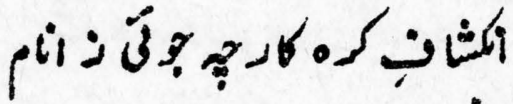

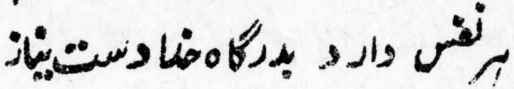

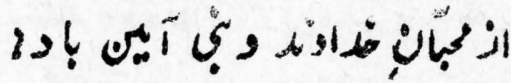

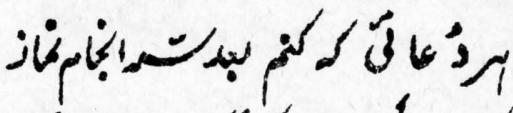

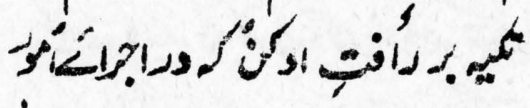

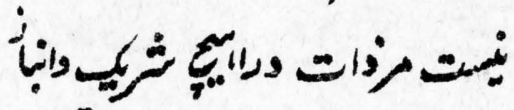

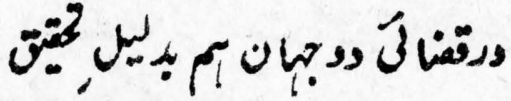

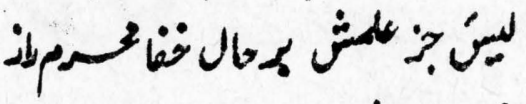

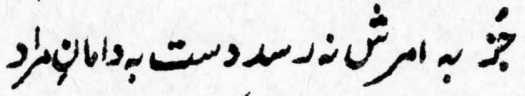

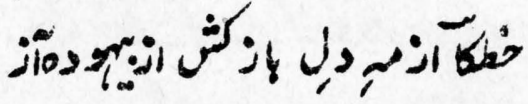




\section{Slis}

\section{cul}

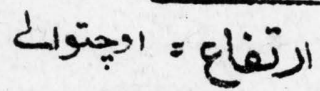

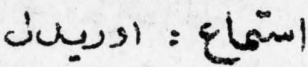

$$
\begin{aligned}
& \text { إنا }
\end{aligned}
$$

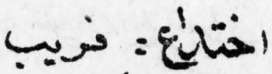

$$
\begin{aligned}
& \text { اودإ = }
\end{aligned}
$$

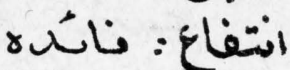

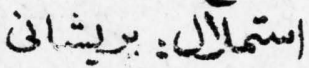

$$
\begin{aligned}
& \text { آختف }
\end{aligned}
$$

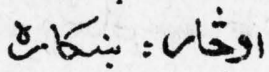

$$
\begin{aligned}
& \text { טو: }
\end{aligned}
$$

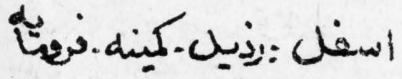

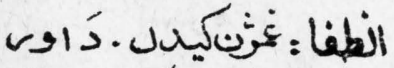
هulis

$$
\begin{aligned}
& \text { كرو }
\end{aligned}
$$

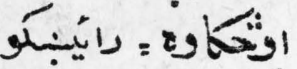

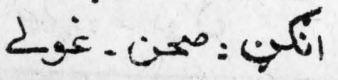

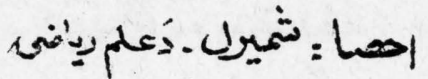

$$
\text { يونة }
$$

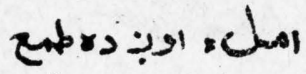

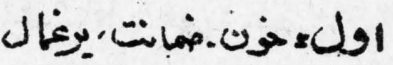

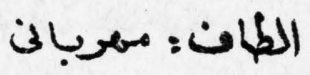

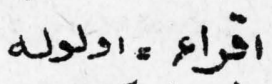

انا

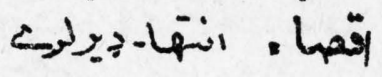

$$
\begin{aligned}
& \text { |جإبا: }
\end{aligned}
$$

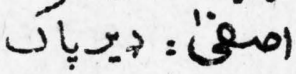

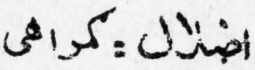

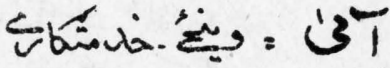

|

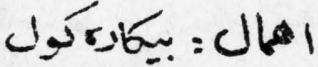

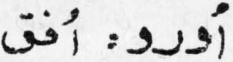

$$
\begin{aligned}
& \text { إن }
\end{aligned}
$$


Juمrap : valpis ل

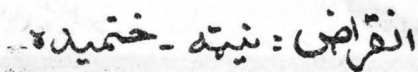

$$
\text { - }
$$

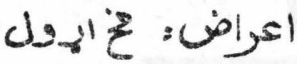

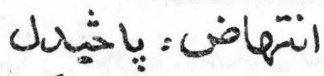

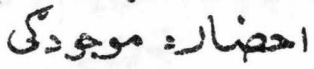

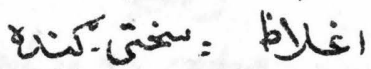

أغ -ble : bاas

ان

$$
\text { alu = غul }
$$

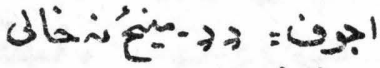

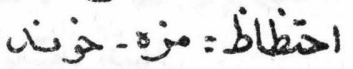

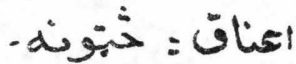

1

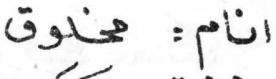

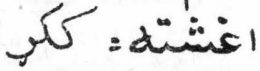

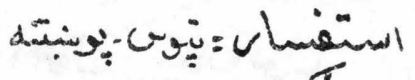
نا

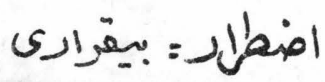

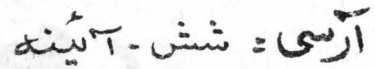

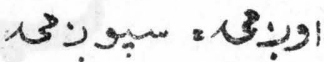

إ.

ا

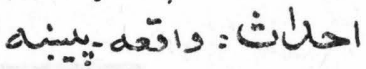

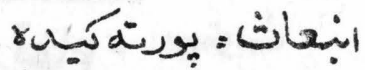

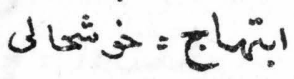

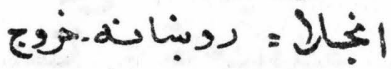

الحاح = سوالمع إسله

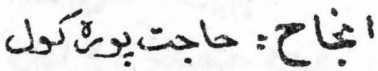

$$
\begin{aligned}
& \text { cuj = }
\end{aligned}
$$

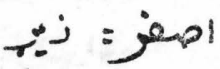

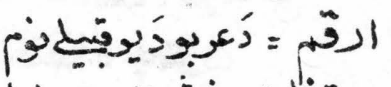

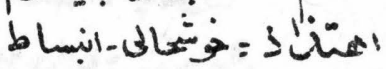

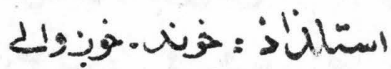

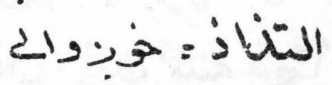

$$
\text { آن }
$$

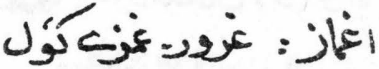

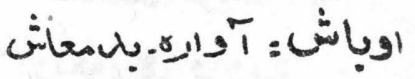

$$
\begin{aligned}
& \text { احمران : بيّـيضانت } \\
& \text { لآل }
\end{aligned}
$$




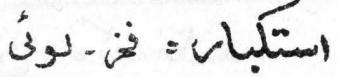

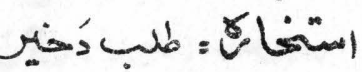

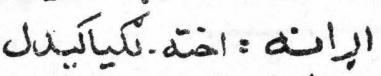

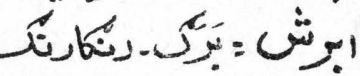

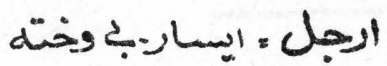

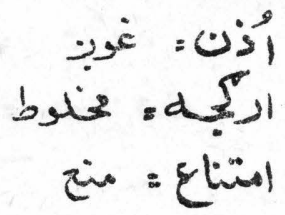

9 هُ

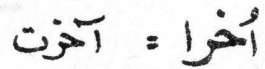

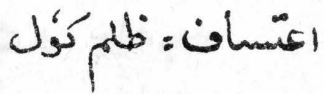

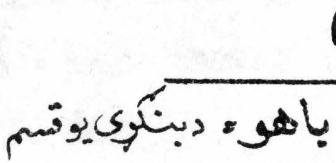
ن :

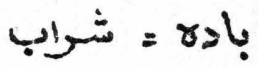

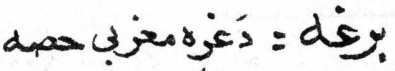

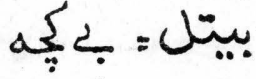

$$
\begin{aligned}
& { }^{\prime}{ }^{\circ}=0 \\
& \text { ds = }
\end{aligned}
$$

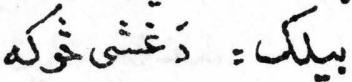
di! = Slb! بإن stris

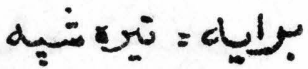
نे

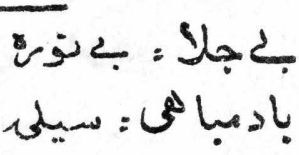

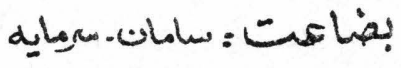

$$
\text { di }
$$$$
\text { . }
$$
رட:

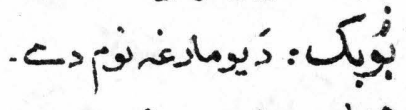

.

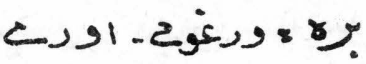

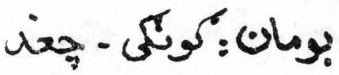
ل

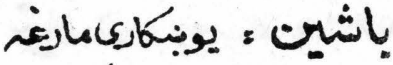

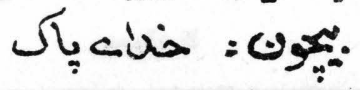




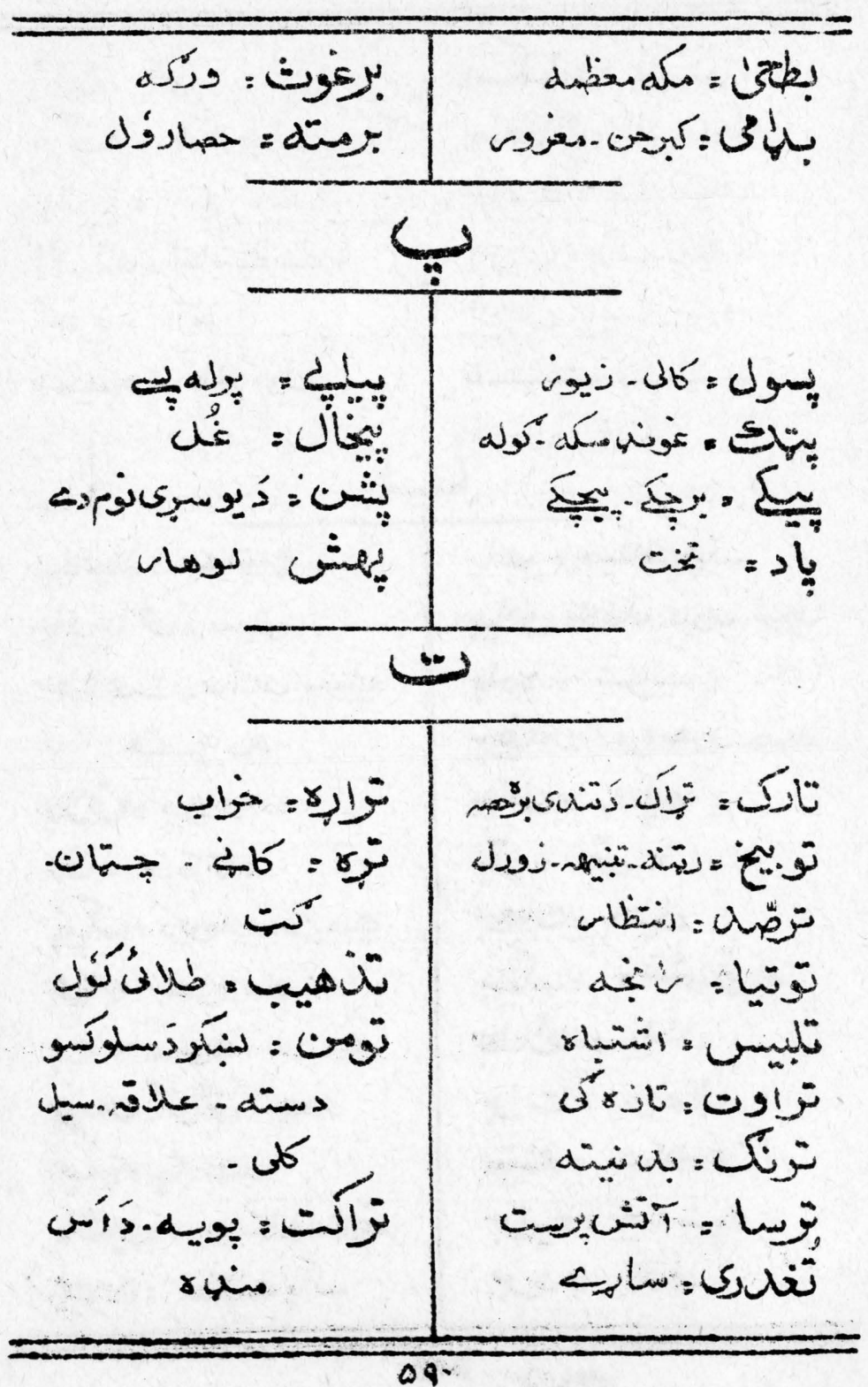




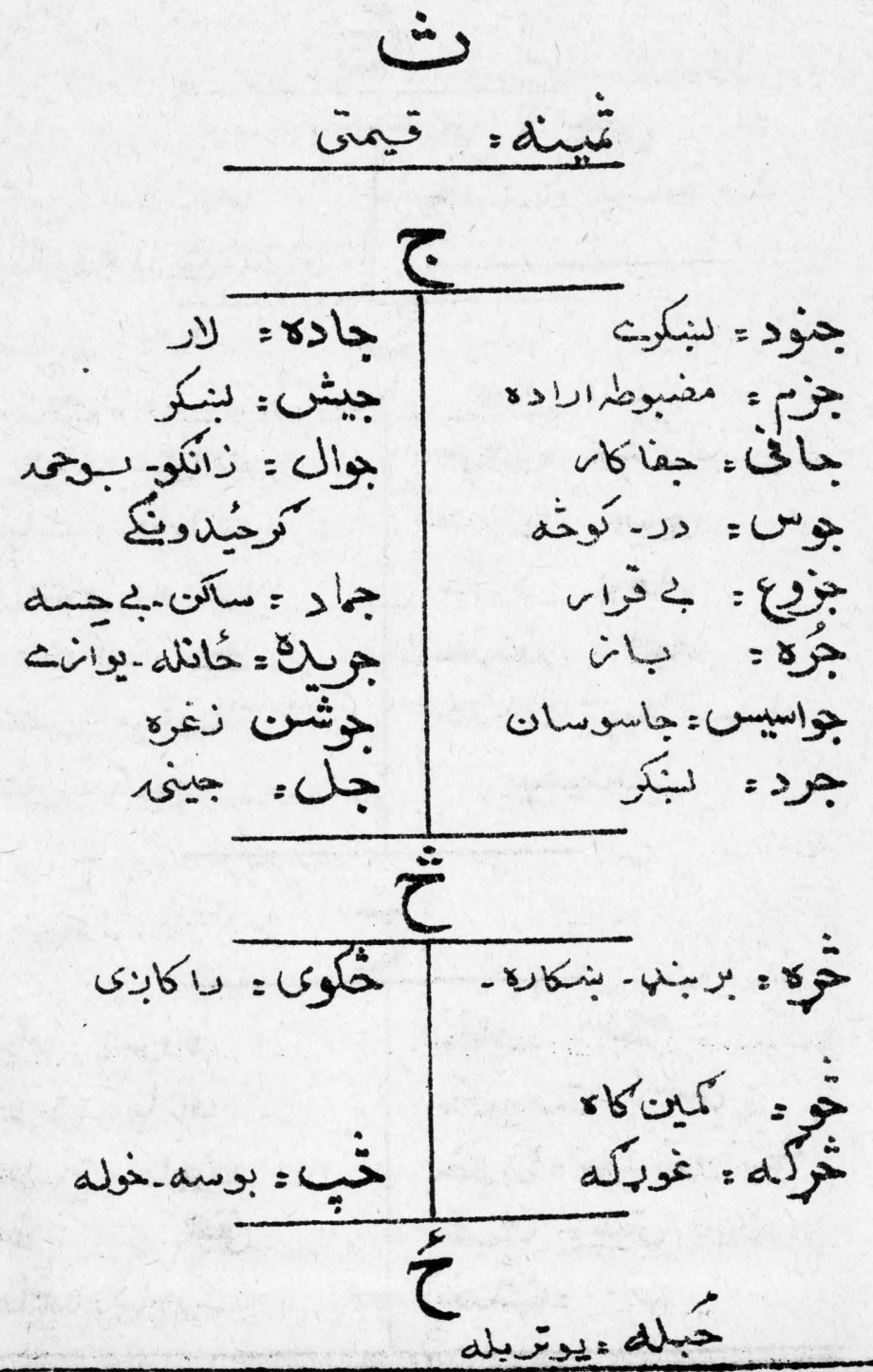




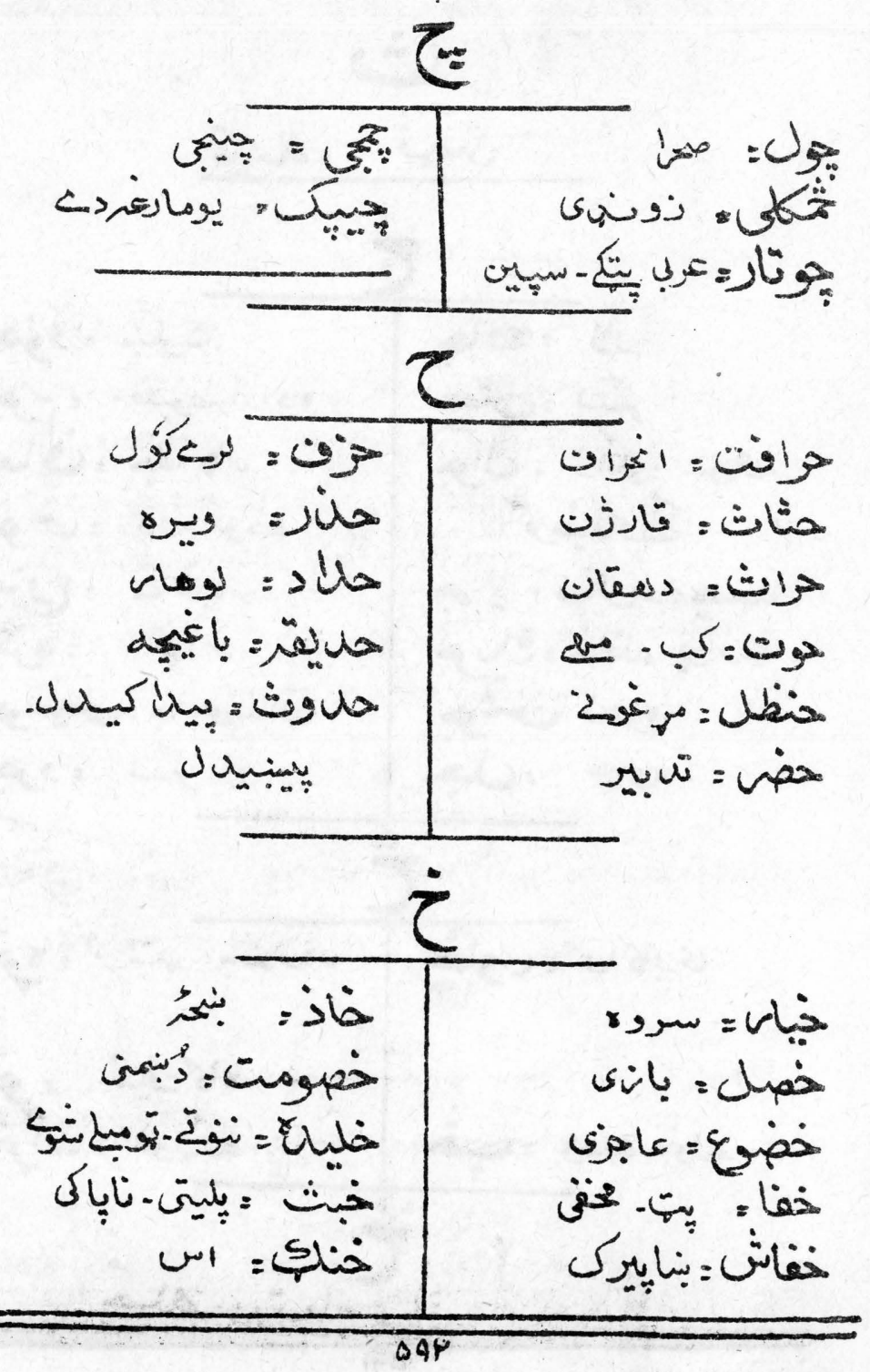




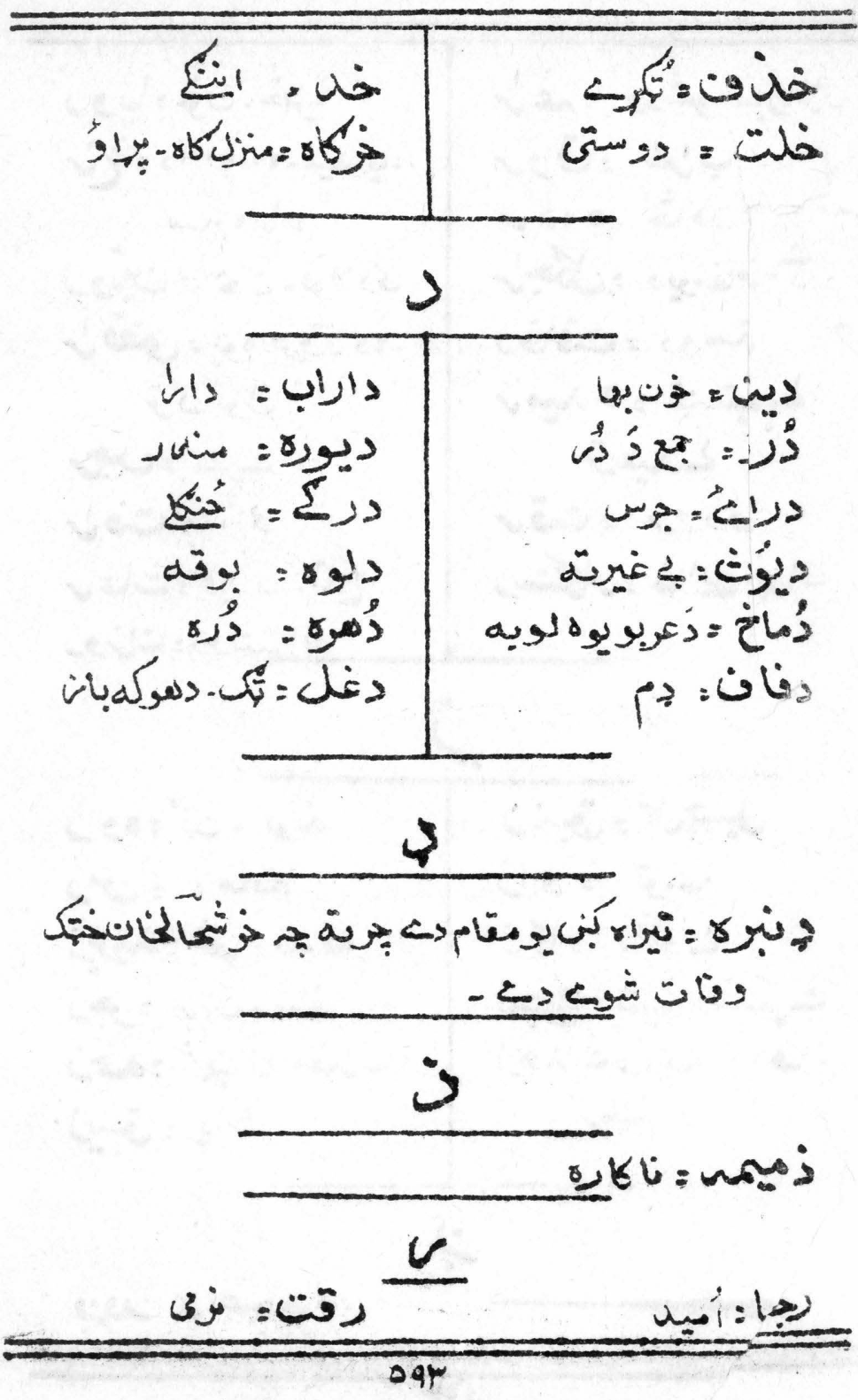




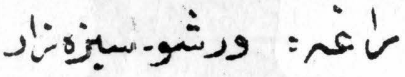

$$
\text { صواثَ = شَّل }
$$

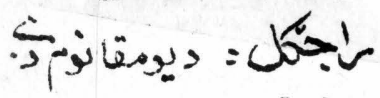

رنافت

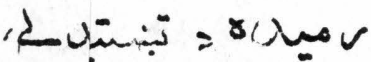

$$
\text { Lut }
$$

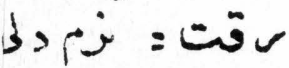

رستَّام = خلايح بنجات

$$
\text { روبا:=زب. خهمر }
$$

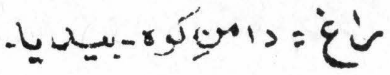

$$
\text { سبرن }
$$

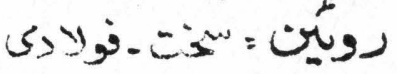

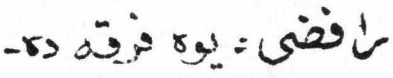

$$
\begin{aligned}
& \text { وَكَكَّل }
\end{aligned}
$$

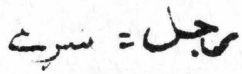

$$
\begin{aligned}
& \text { ن }
\end{aligned}
$$

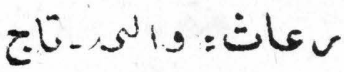

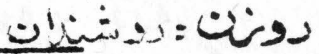

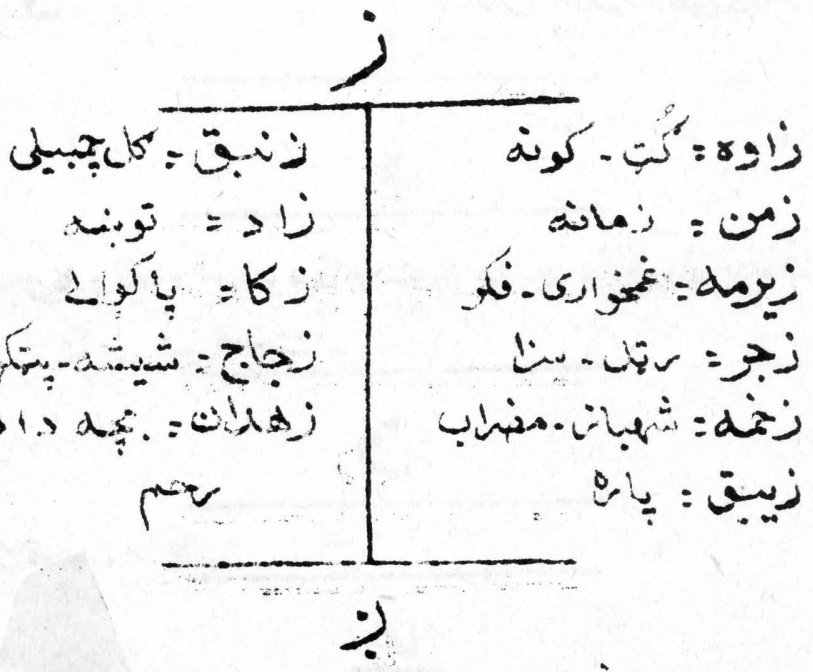

بزدن = عوختن - 


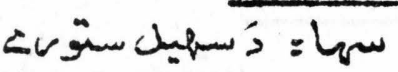

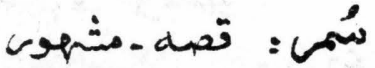

$$
\begin{aligned}
& \text { رغيريقسناحكايتا }
\end{aligned}
$$

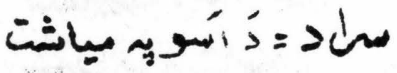

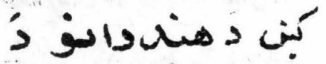

$$
\begin{aligned}
& \text { - مبر } \\
& \dot{y}=\sqrt{\text { us }}
\end{aligned}
$$

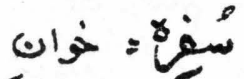

$$
\begin{aligned}
& \text { سمس }
\end{aligned}
$$

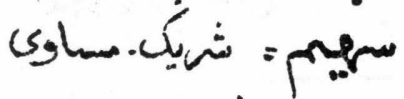

$$
\begin{aligned}
& \text { - }
\end{aligned}
$$

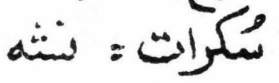

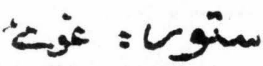

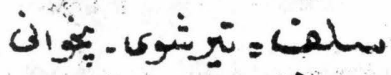

$$
\begin{aligned}
& \text { أس }
\end{aligned}
$$

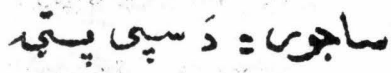

$$
\begin{aligned}
& \text { كودنى } \\
& \text { Uit } \\
& \text { سمأ }
\end{aligned}
$$

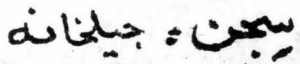

$$
\begin{aligned}
& \text { سماك :كس }
\end{aligned}
$$

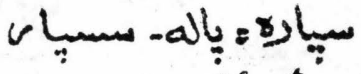

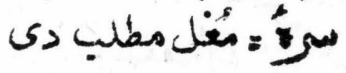

$$
\begin{aligned}
& \text { dolle }
\end{aligned}
$$

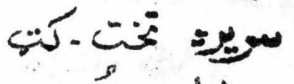

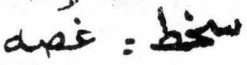

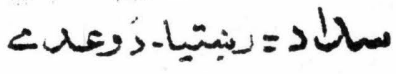

$$
\begin{aligned}
& \text { - vilu }
\end{aligned}
$$

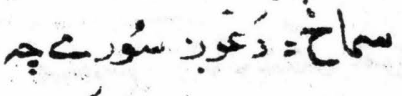

$$
\begin{aligned}
& \text { 1. } \\
& \text { سموا = تون } \\
& \text { من }
\end{aligned}
$$

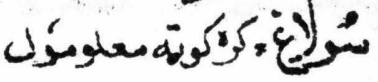

$$
\begin{aligned}
& \text { سف: : }
\end{aligned}
$$

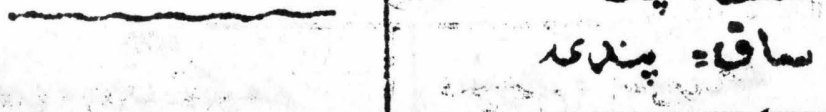




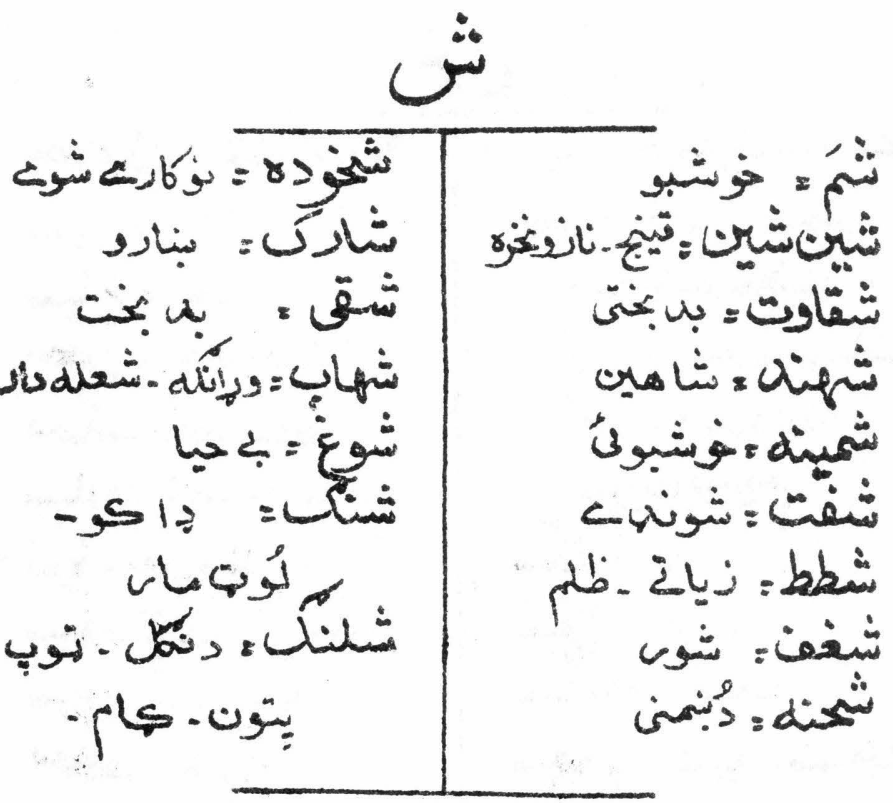

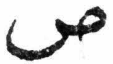

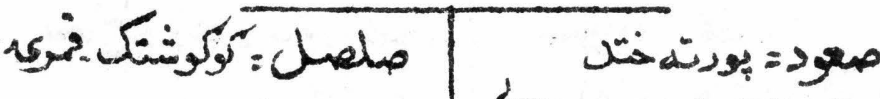

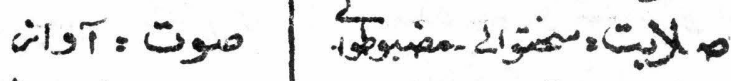

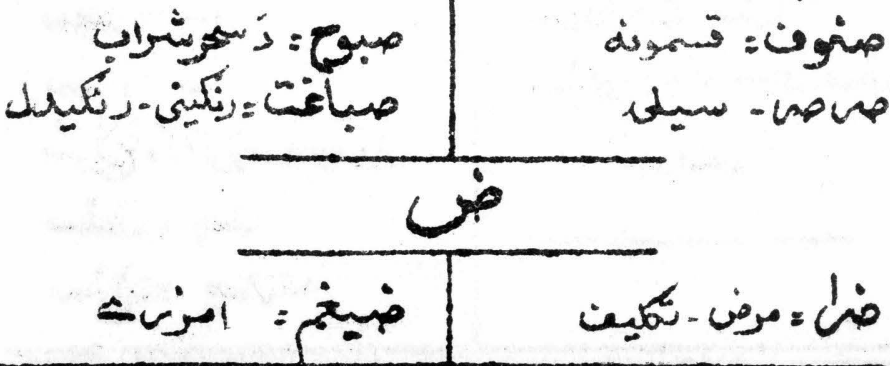




$$
\begin{aligned}
& \text { b }
\end{aligned}
$$

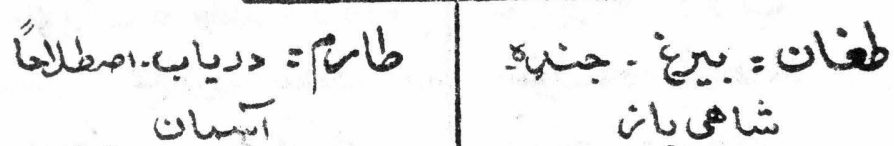

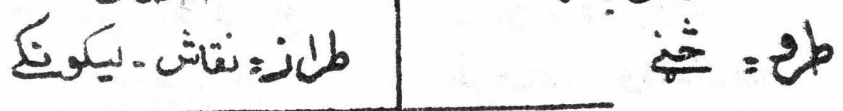

$$
\begin{aligned}
& \breve{b} \\
& \text { לم: } \\
& \varepsilon
\end{aligned}
$$

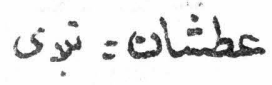

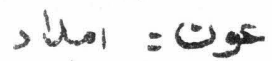

$$
\begin{aligned}
& \text { عارن : انثكى : }
\end{aligned}
$$

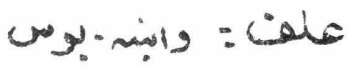

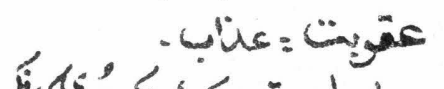

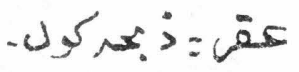

$$
\begin{aligned}
& \text { على = بنركارهون } \\
& \text { ع عان }
\end{aligned}
$$

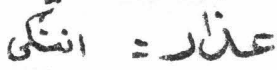

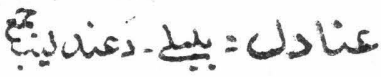

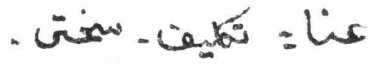

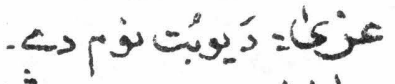

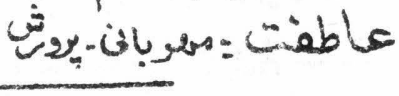

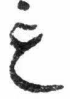




$$
\begin{aligned}
& \text { as = culis } \\
& \rightarrow+5=\omega_{-\infty}^{\infty} \\
& \text { عزوله } \\
& \text { غُخبوان } \\
& \text { كرئها } \\
& \text { تغل }
\end{aligned}
$$

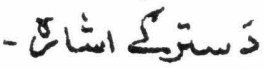

$$
\begin{aligned}
& \text { غنر } \\
& \text { وئل }
\end{aligned}
$$

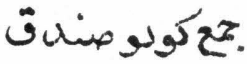

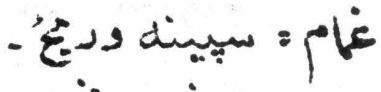

$$
\begin{aligned}
& \text { है - } \\
& 45
\end{aligned}
$$

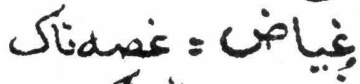

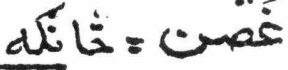

\section{5}

$$
\begin{aligned}
& \text { ثو } \\
& \text { sili } \\
& \text { نे }
\end{aligned}
$$

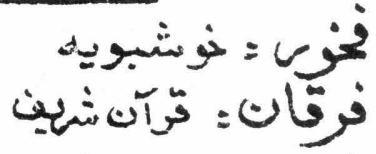

$$
\begin{aligned}
& \text { زو } \\
& \text { كو:كى = ويروكان } \\
& \text { كتاث= = رينيمن } \\
& \text { كبود = آسطان رئن }
\end{aligned}
$$

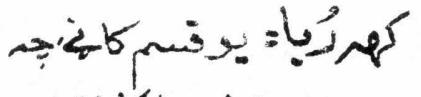

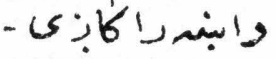

$$
\begin{aligned}
& \text { deisirit = } 6 \\
& \text { كإ } \\
& a_{j} !=0 k 5 \\
& \text { - (1) }
\end{aligned}
$$

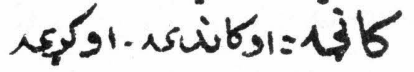




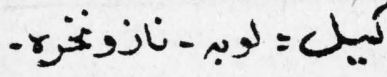

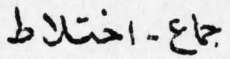

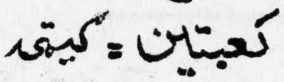

$$
\begin{aligned}
& \text { जा = غ है, }
\end{aligned}
$$

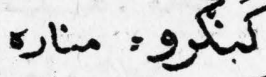

كستبر بوز

كن

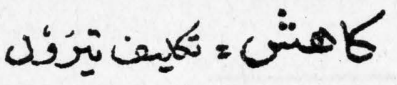

$c \sin _{i=5}$

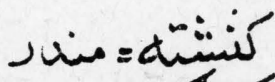
كرئك: זٓ

كور= =يومرين

$\lambda=\dot{r}$

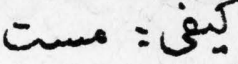

غورت

كوس- زفأك-

كنئ =

$$
\begin{aligned}
& \Leftrightarrow \text { قانَ }
\end{aligned}
$$

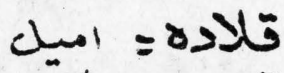

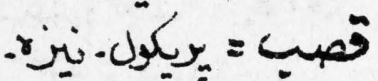

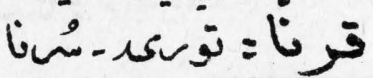

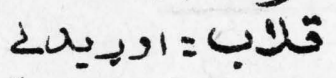

كابوتيا : دربان -كمينه

أخ

كاب =

$$
\text { مونت }
$$

$$
\begin{aligned}
& \stackrel{\sim}{\sim}=60 \\
& \text { ثtgis }=\infty
\end{aligned}
$$

- =

21

$x \rightarrow \alpha^{x}$

जै

تصقاص =امطن

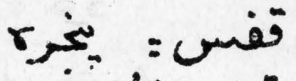

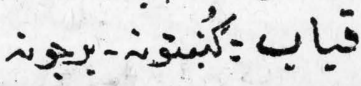




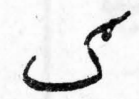

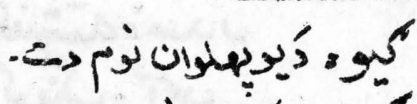

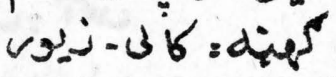

كنيه $8=0$

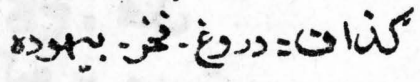

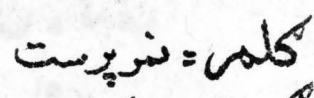

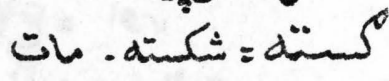

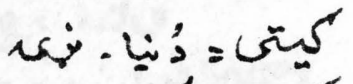

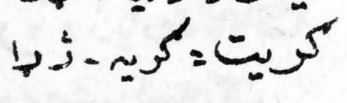

\section{J}

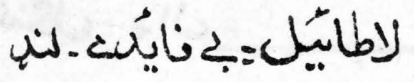

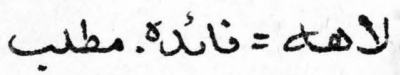

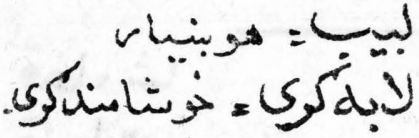

$$
\text { لوزيشه =نوبن }
$$

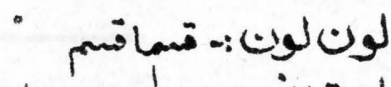

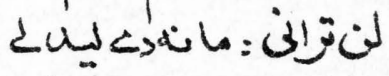

$$
\begin{aligned}
& \text { لن } \\
& \text { كأ }
\end{aligned}
$$

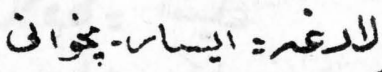

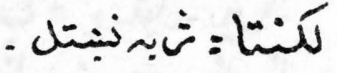

$$
\text { م }
$$

$$
\begin{aligned}
& \text { منيّز = خزكورين }
\end{aligned}
$$

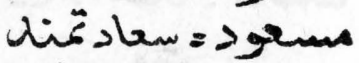

$$
\begin{aligned}
& \text { مليا }
\end{aligned}
$$




\section{منال = سأس}

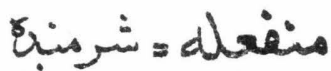

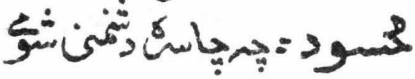

$$
\text { - }
$$

ه广

$$
\text { ماند }
$$

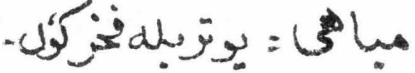
in $=8$ lis

$$
\text { مصديو }
$$

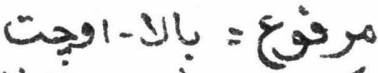

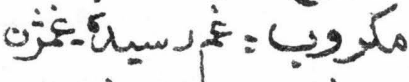

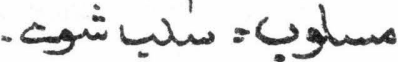

$$
\text { زائل شيون }
$$

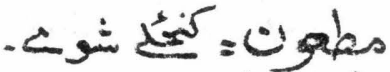
مر ورئة

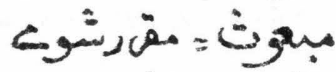
ل

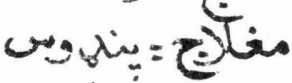

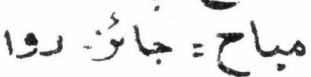

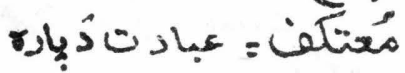

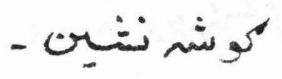

shos =

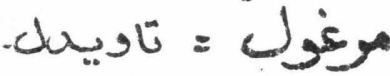

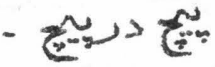

م

ما

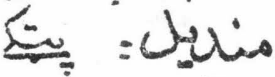

- lim =

U.

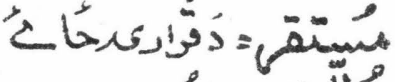

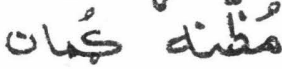

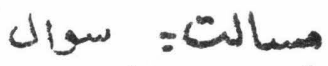

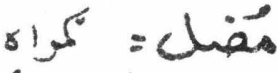

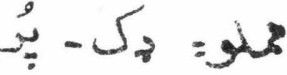

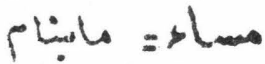

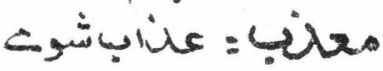

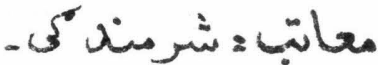

عنابو

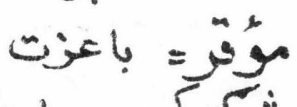

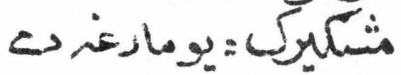

-

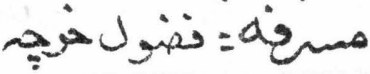




$$
\begin{aligned}
& \dot{3}=120 \\
& \text { مسير }
\end{aligned}
$$

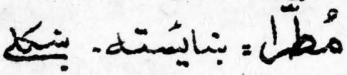

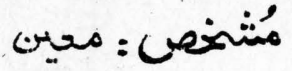

$$
\text { مسزئز }
$$

من

$$
\text { مونس = مرك }
$$

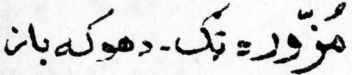

ن

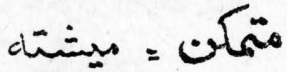

Ul. $=$ Jis .

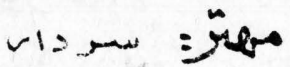

Ul, =

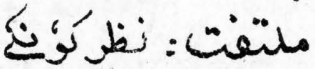

$$
\text { م }
$$

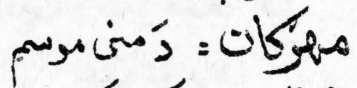

$$
\text { dis }
$$

ables - 0 , s,

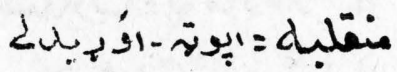

cist $=$ ba
Es

: ه ب

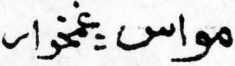

$$
\text { ه }
$$

送,

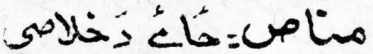

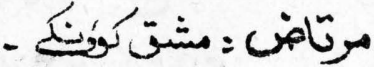
رإن

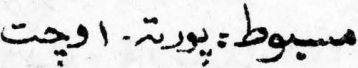

-

كريتي ستون

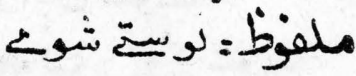
ن using

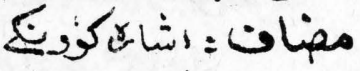

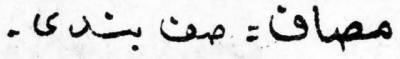
Sid

$$
\text { cos }
$$

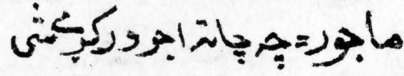


هiligu 

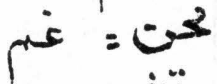

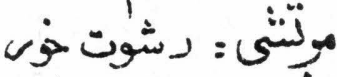

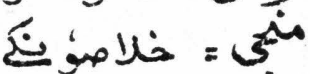
حتى = يهمئ ولائ

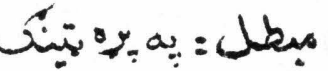
خ

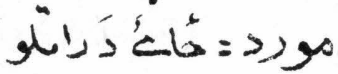

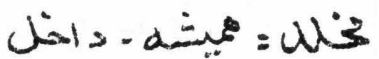

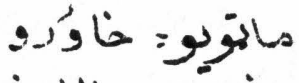
مانو
مُنْبَكل = سوسع سوسع. جالئل منكتَت = بنكاد هات" تبنه

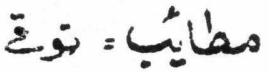

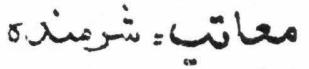

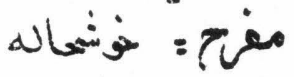
مالrov

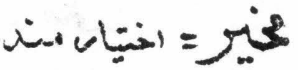

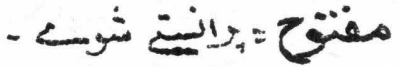

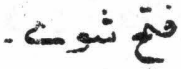

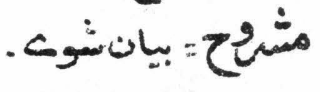

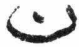

نيسـات = وريمية

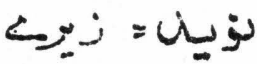

نئ

ناصيه = تسمت - ترأن

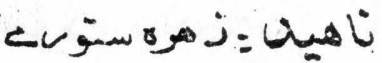

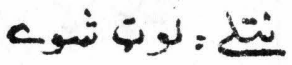

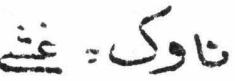

زئت:

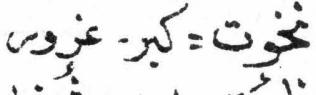

نأك

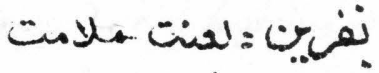

تخس 


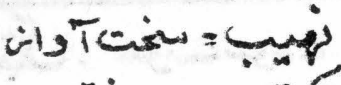

تَّتمَ

نأنها

$$
\text { نا }
$$

$$
\text { كأيه = شيبيلى }
$$

كمستص

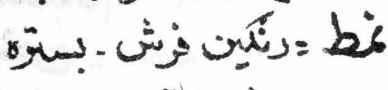

$$
\text { وضع - تضن }
$$

$$
\text { نوإِ = }
$$

$$
\text { ت }
$$

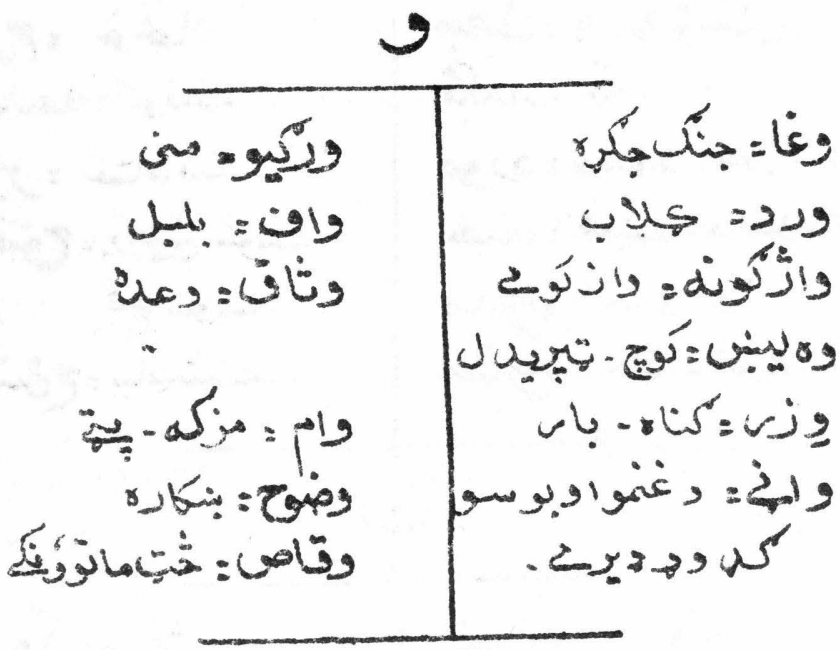

\section{d}

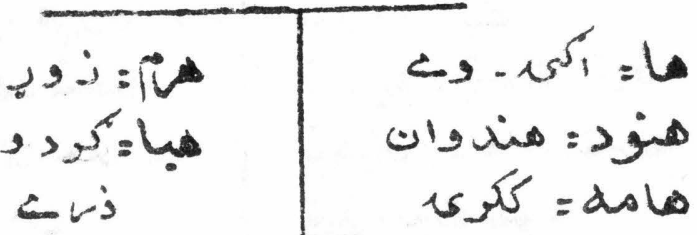




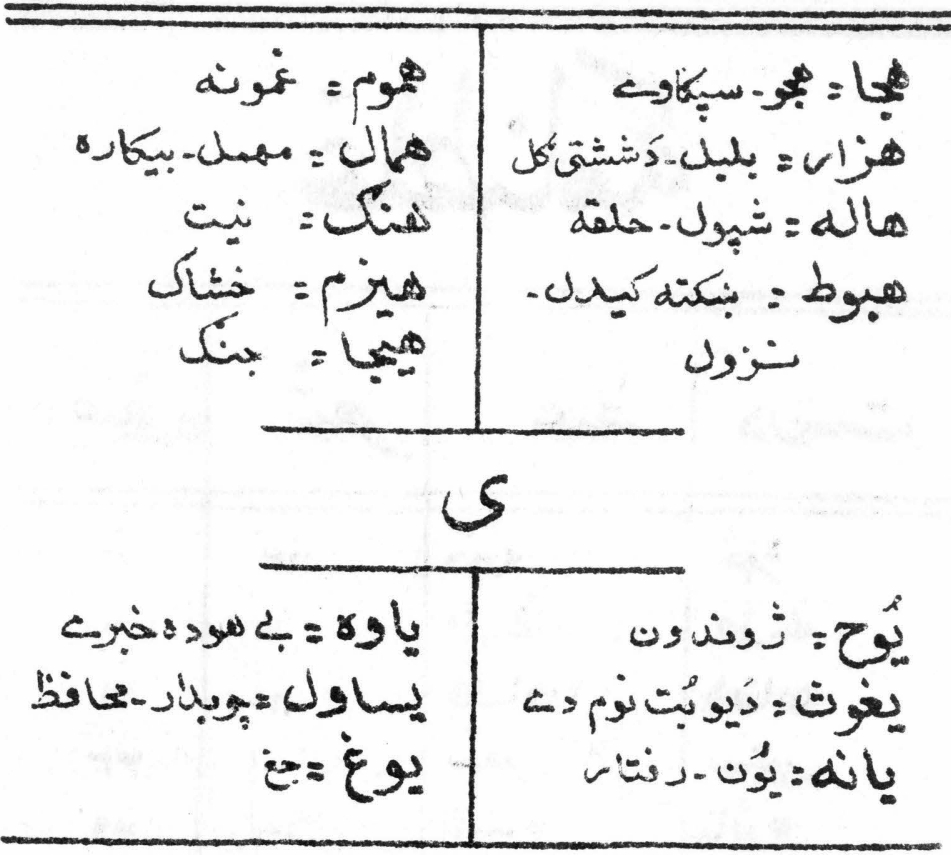

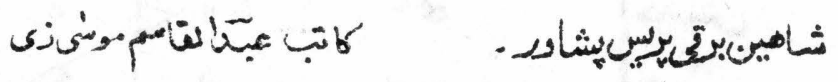



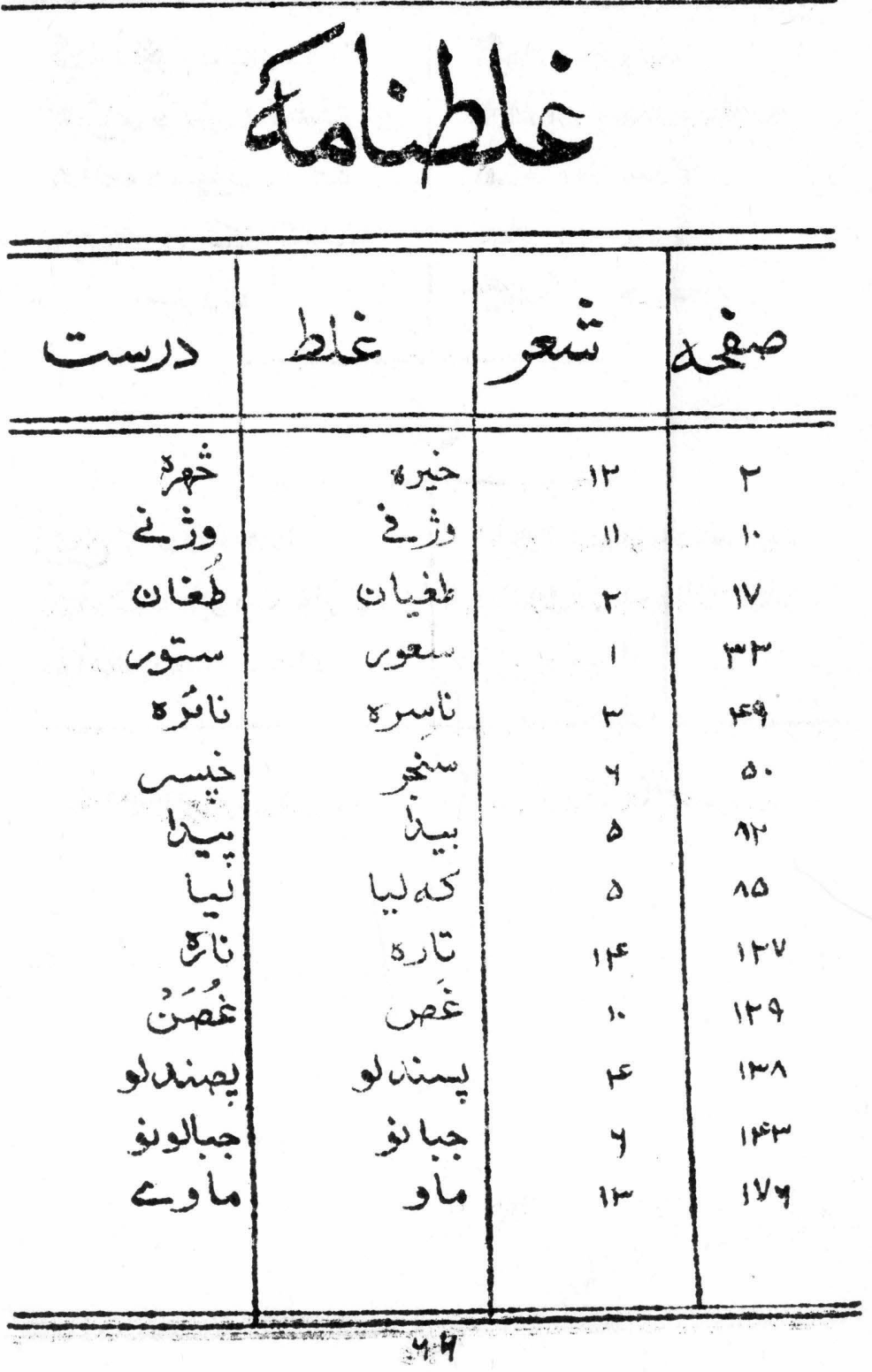


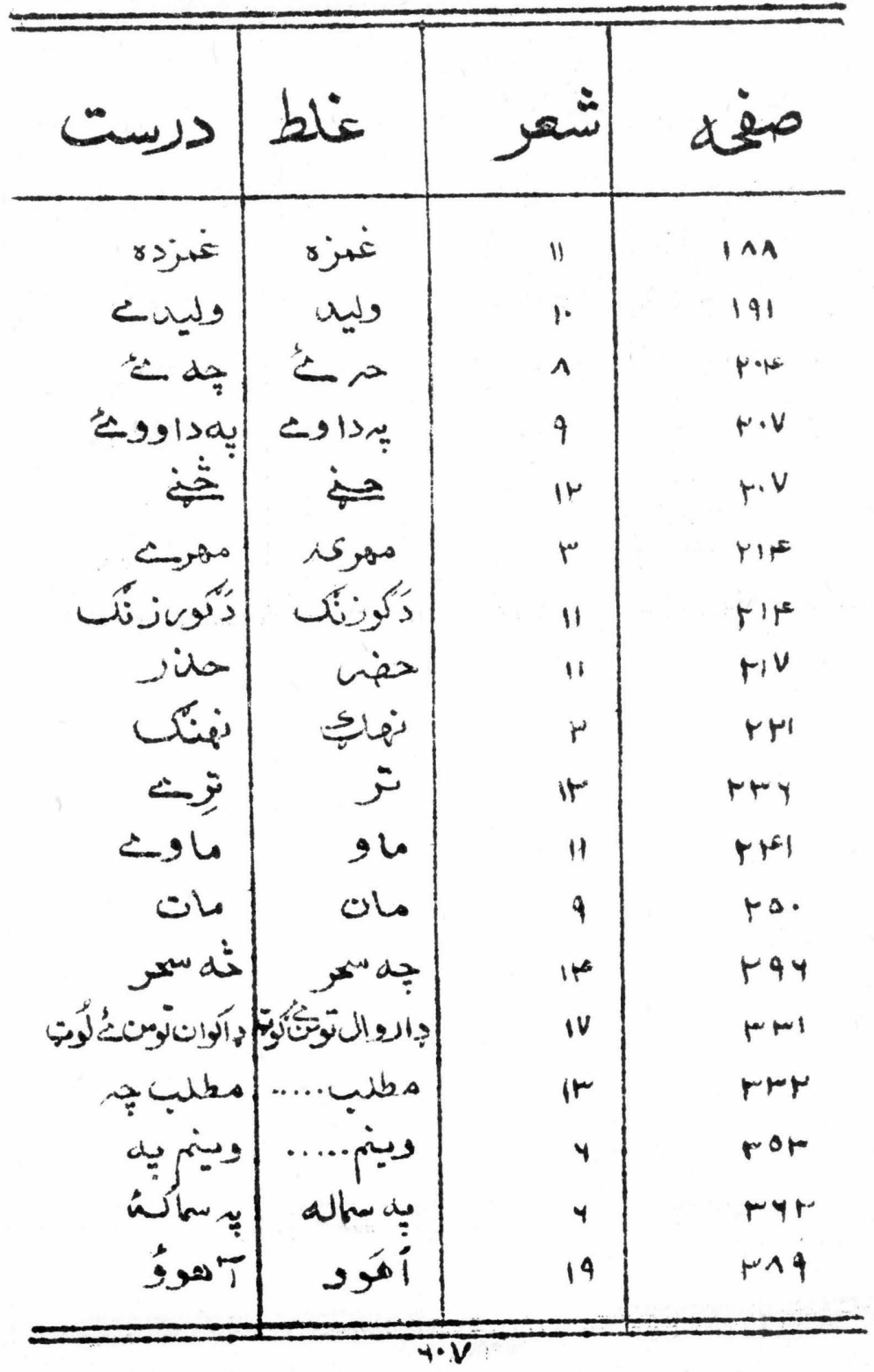




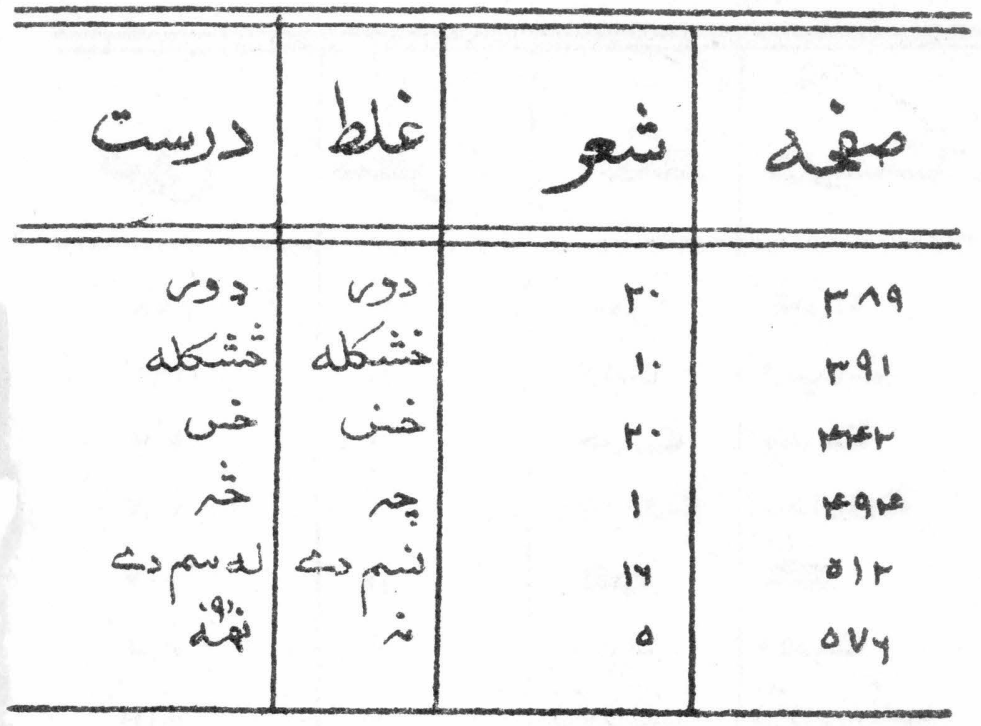

